\title{
The Invasion of the Dutch East Indies
}

Compiled by

The War History Office of the

National Defense College of Japan

Edited and translated by Willem Remmelink 
The Invasion of the Dutch East Indies 

War History Series, Volume 3

\title{
The Invasion of the Dutch East Indies
}

\author{
Compiled by
}

The War History Office of the National Defense College of Japan

Edited and translated by

Willem Remmelink

Leiden University Press 


\author{
Advisory Board \\ Prof. Dr. Ken'ichi Gotō (Professor Emeritus, Waseda University) \\ Prof. Dr. Hisashi Takahashi (Professor Emeritus, Sophia University) \\ Prof. Dr. Ryōichi Tobe (Teikyo University) \\ Prof. Dr. Jirō Mizushima (Chiba University) \\ Dr. Petra Groen (Netherlands Institute for Military History) \\ Dr. Anita van Dissel (Leiden University) \\ Lt. Gen. (ret.) Ad Herweijer (Royal Netherlands Army) (†) \\ Lt. Gen. (ret.) Jan Folmer (Royal Netherlands Army) \\ V. Adm. (ret.) Egmond van Rijn (Royal Netherlands Navy)
}

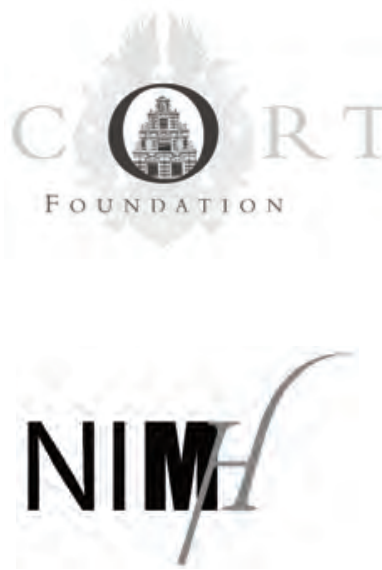

This publication is part of a project of the Corts Foundation (www.cortsfoundation.org) that aims to translate into English several volumes of the Senshi Sōsho series concerning the former Dutch East Indies.

The publication of this volume was made possible by a grant from the Isaac Alfred Ailion Foundation.

The Netherlands Institute of Military History (NIMH)

Original title: 蘭印攻略作戦 [Ran-In Kōryaku Sakusen], published by Asagumo Shimbunsha [Asagumo Newspaper Inc.], Tokyo 1967

(C) National Defense College of Japan [National Institute for Defense Studies], Japan 1967

English translation title: The Invasion of the Dutch East Indies

(C) The Corts Foundation/Leiden University Press, 2015

Cover design: Geert de Koning

ISBN 9789087282370

e-ISBN 9789400602298 (e-pdf)

NUR 686

All rights reserved. Without limiting the rights under copyright reserved above, no part of this book may be reproduced, stored in or introduced into a retrieval system, or transmitted, in any form or by any means (electronic, mechanical, photocopying, recording or otherwise) without the written permission of the publisher and the Corts Foundation, Secretariat, Mozartweg 3, 1323 AV Almere, The Netherlands.

This book is distributed in North America by the University of Chicago Press (www.press.uchicago.edu). 


\section{Contents}

Editor's Note $\quad$ xiii

About the Senshi Sōsho (War History Series) xvii

Foreword $\quad$ xxix

Preface, Explanatory Notes $\quad$ xxxi

Chapter I Outline of the Operation 1

The Southern Operation Plan 4

Characteristics of the Dutch East Indies Operation 6

Scheduling Issues, the Defining Feature of the Execution of the Operation $\quad 7$

Chapter II Situation of the Dutch East Indies 10

$\begin{array}{ll}\text { Topography } & 10\end{array}$

The Dutch East Indies Military Preparations 13

Chapter III Operational Preparations Prior to the War 16

1 Situation Until Summer 1941

2 Preparations in the Summer and Fall of 1941

Start of Full-scale Research; Conception of a Three-division Plan for

[The Situation] After the Decision on the Main Points for the Implementation of Imperial National Policy of Early September $\quad 24$

The Situation in October $\quad 29$

3 Completion of Plans and Issue of Orders by Imperial General Headquarters 36

Completion of Plans on 1 November and Shipping Plan 36

Decision on the Main Points for the Implementation of Imperial
National Policy, and Orders Issued by Imperial General Headquarters

Assessment of the Current Position of the Enemy and the Prospects for the Campaign $\quad 40$

Operation Plan of the Army $\quad 42$ 
Operation Plan of the Navy

The Order Issued by the Army Department of Imperial General Headquarters

to Prepare for Attack, the Instructions Given by the Chief of Army General Staff, and the [Army-Navy] Central Agreement

The Order Issued by the Navy Department of Imperial General Headquarters to

Prepare for Attack, the Instructions Given by the Chief of the Navy General Staff

4 The Southern Army's Plan and Orders 56

The Combined Fleet's Plan and Orders $\quad 58$

The Agreements Between the Southern Army, the Combined Fleet, and the Southern Task Force $\quad 59$

The Order Issued by the Southern Army to Prepare for Attack, and Its Operation Plan 62

The [Navy] Southern Task Force's Plan and Orders 66

$\begin{array}{ll}\text { The Southern Army's Invasion Order } & 67\end{array}$

5 Operational Preparations of the Sixteenth Army $\quad 69$

$\begin{array}{ll}\text { Order of Battle [of the Sixteenth Army] } & 71\end{array}$

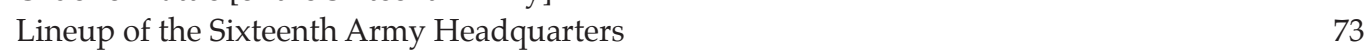

Formation and Personnel of the Divisions and the Infantry Group $\quad 73$

Iwakuni Agreement $\quad 76$

[Lieutenant General Imamura] Takes Command of the Sakaguchi Detachment
and Sends It Off

The [Navy] Philippines (Dutch East Indies) Unit Operation Order No. 1

Operation Plan of the Sixteenth Army 93

Taking Command of the 2d Division and Encouraging the Sakaguchi Detachment 101

Preparation of a Propaganda Group $\quad 101$

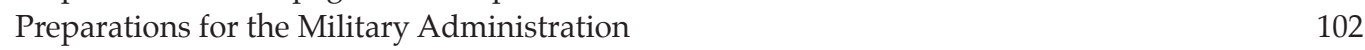

\section{Chapter IV Opening of Hostilities and Capture of the Forward} Advance Bases Davao and Jolo

1 Capture of Davao $\quad 103$

The Arrangements Between the Army and Navy as Presented
[to the Sakaguchi Detachment]

Postponement of the Date for Capturing Davao $\quad 104$

Opening of Hostilities and Advance of the Date to Capture Davao $\quad 105$

The Plan to Capture Davao $\quad 106$

$\begin{array}{ll}\text { Departure, Landing and Occupation } & 108\end{array}$

2 Capture of Jolo Island $\quad 110$

\section{Chapter V Decision to Advance [the Schedule of] the Java Operation} and the Sixteenth Army

1 Decision to Advance [the Date of the Operation] 
2 The Cam Ranh Agreement and Shipping Issues 129

Contents of the Agreement 129

Confusion Caused by Bringing Forward the Java Operation 132

Distinctive Features of the Cam Ranh Agreement 134

Shipping Routes and Ships $\quad 135$

3 The Orders from [the Army Department of] Imperial General Headquarters 138

4 The Southern Army's Operational Direction 141

The Orders to Prepare for the Capture of Java and the Aviation Plan 141

Shipping Operations $\quad 146$

Transfer of the 38th and the 48th Division [to the Sixteenth Army] 152

The Transfer of Other Units $\quad 153$

The Order for Capturing Java 154

5 The [Navy] Southern Task Force's Shift to Phase-Two Operations 155

The Shift to Phase-Two Operations 155

The Dutch East Indies Unit's Phase-Two Mission 157

6 Departure of the Headquarters of the Sixteenth Army and Revision of $\begin{array}{ll}\text { Its Operation Plan } & 160\end{array}$

Issue of the Order to Assemble and Departure of the Headquarters of the Army 160

Makeshift Measures for the 38th Division 161

Reception of the Order to Prepare for the Capture of Java and Making Arrangements
with the Navy

The Southern Army's Dissatisfaction and the Escort Issue 163

Sending off the Eastern Detachment 164

Revision of the Operation Plan $\quad 165$

Chapter VI The Launch of the Dutch East Indies Operation 168

1 The Policy of the [Japanese] Government Towards the Netherlands 168

2 The Launch of the Dutch East Indies Operation 169

3 The Capture of Tarakan $\quad 173$

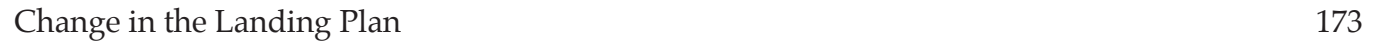

Arrangements with the Navy $\quad 173$

$\begin{array}{ll}\text { The Plan and Order for Capture } & 174\end{array}$

Advance, Landing, and Capture 176

4 The Capture of Menado $\quad 182$

Chapter VII The Capture of Java's Dehors 185

1 [Commander Imamura's] Orders to the 38th Division 185

The Sixteenth Army's Arrangements with the [Navy] Malaya Unit 185 
Army Commander [Imamura] Heads for Gaoxiong After Giving Orders to the 38th Division

2 The Manila Conference and the Arrangements Between the Sixteenth Army and the [Navy] Dutch East Indies Unit

An Unexpected Request from the [Navy] Southern Task Force 190

The General Situation Until Then 191

The Effect on the Malaya Unit and the Order of the Southern Army 203

The Situation in the Eastern Part of the Dutch East Indies 206

The Manila Conference 209

The Banjarmasin Issue $\quad 214$

The Plan of the Sixteenth Army and the Dutch East Indies Unit, and the Arrangement Between Them

The Navy's Shift to Phase-Three Operations and the Decision to Bring in the Carrier Task Force

3 [Army Commander Imamura's] Orders to the 48th Division, the Sakaguchi Detachment and the Main Force of the Army 235

[Army Commander Imamura's] Orders to the 48th Division 236

The Arrangements of the 48th Division with the 4th Destroyer Squadron 237

[Army Commander Imamura's] Order to the Sakaguchi Detachment to Seize Banjarmasin $\quad 240$

The Arrangements of the Main Force of the Army with the 5th Destroyer Squadron 241

[Army Commander Imamura's] Orders to the 2d Division and the Shōji Detachment 244

The Army's Plan and Conduct of the Operation 246

The Situation of the 2d Division 247

Confusion at the Port of Gaoxiong 248

The Army Commander Changes his Departure Date from Gaoxiong 251

4 The Southern Sumatra Invasion Operation 252

The Issue of a Second Postponement of Operation L Arises 252

(1) Preparations for the Southern Sumatra Invasion Operation 254

Start of the Southern Sumatra Operation of the Third Air Force 254

The Situation in Late January 255

Reconsideration of the Employment of the 1st [Paratroop] Raiding Group 257

The Third Air Force Draws up the Outline of the Air Operations [for Operation] L 259

Implementation of the Endau Landing Operation and the Occupation of the Anambas Islands

The Army-Navy Arrangement on the Air Operations [in Operation] L 264

The 38th Division's Operation Plan 267

The [Southern Army's] Decision to Employ the [Paratroop] Raiding Group

Mainly for [the Seizure of] the [Palembang] Airfield; the 38th Division's

Arrangements with the [Navy] Malaya Unit

The [Navy] Malaya Unit's Orders; the Arrangements Made Between the 38th Division and the Navy Escort Force/Navy River-ascending Unit 278

The 38th Division's Order 282

The Operational Preparations of the 1st [Paratroop] Raiding Group 285

(2) Postponement of [Operation] L and H 292 
Second Postponement of [Operation] L (Two Days) 292

The Situation at Ledo Until Then $\quad 294$

Third Postponement of [Operation] L (Four Days) 300

(3) Air Operations and the Sailing of the Convoys 308

The Air Campaign of the 3d Air Division to Destroy the Enemy 308

The Air Operations of the [Navy] Malaya Unit 309

The Judgment on the Enemy Movements, the Sailing of the Convoy and the Fleet, and a Naval Engagement 311

(4) The Paratroop Drop $\quad 316$

[Paratroop] Raiding Group Order 316

The Collaboration of the Different Air Units $\quad 321$

Takeoff, Drop and Occupation $\quad 324$

The Situation from the 15th Onwards 331

(5) The 38th Division's Invasion of Southern Sumatra 333

The Capture of Mentok $\quad 334$

The Landing at Palembang $\quad 335$

The Capture of Tanjungkarang $\quad 337$

Delay in the Upriver Ascent of the Convoy of the Main Force 341

$\begin{array}{ll}\text { The Capture of Bengkulu } & 341\end{array}$

Occupation of the Jambi Oil Fields and Gelumbang 343

Oil and the [Paratroop] Raiding Group 344

5 The Capture of Balikpapan and Kendari 346

(1) The Capture of Balikpapan $\quad 348$

The Scheme to Occupy [Balikpapan] Intact and the Plan for a Surprise Attack 348

The Operation Plan of the Sakaguchi Detachment 351

Dispatch of the Messengers and Guides 354

The Sailing of the Convoy and the Surprise Attacks on the Anchorage 356

Occupation of the Balikpapan Sector $\quad 358$

(2) The Capture of Kendari $\quad 361$

6 The Capture of Ambon $\quad 361$

Changes in the Plan to Capture Ambon $\quad 361$

[The Ambon Operation] in Relation to the Navy's Shift to Phase-Three Operations 362

Departure of the Eastern Detachment from Hong Kong and Its Arrival in Davao 363

$\begin{array}{ll}\text { Operation Plan } & 365\end{array}$

$\begin{array}{ll}\text { Sailing, Landing and Capture } & 368\end{array}$

7 The Capture of Banjarmasin, Makassar, Bali and Timor 373

(1) Politico-Strategic Issues and Phase-Three Operations of the Navy 373

The Strategic Background and the Major Strategic and Tactical Issues 373

The Issue of Seizing Dili $\quad 380$

Phase-Three Operations of the Naval Units 386

(2) The Seizure of Banjarmasin $\quad 391$

Preparations for the Seizure $\quad 391$

The Seizure $\quad 393$

(3) The Seizure of Makassar $\quad 394$

(4) The Capture of Bali $\quad 397$

(5) The Capture of Timor $\quad 403$

Preparations for the Operation 403 
The Carrier Task Force's Air Strike on Port Darwin $\quad 407$

The Seizure of Kupang $\quad 408$

The Seizure of Dili 412

$\begin{array}{ll}\text { Chapter VIII The Invasion of Java } & 417\end{array}$

1 Progress of the Preparations for the Invasion of Java 417

The General Situation Until Mid-February $\quad 418$

The Advance of the Assembly Points 428

The Decision to Include the Sakaguchi Detachment, the Change in the Operation Plan

of the [Sixteenth] Army, and the Paradrop [Operation] Issue 430

2 The Sailing [of the Convoys]

The Situation of the Enemy as Assessed Just Before the Sailing 435

The Start of the Sailing and a Two-Day Postponement of the Landings 437

Another One-Day Postponement of the Date of Landing and Naval Engagements 452

Entry into the Anchorage, Start of the Landings and Naval Engagements 456

3 Operations of the Main Force of the [Sixteenth] Army 459

(1) The Operation Plans $\quad 459$

The Operation Plan of the [Sixteenth] Army $\quad 459$

The Operation Plan of the Shōji Detachment 462

The Operation Plan of the 2d Division 465

The Operation Plan of the Third Air Force 467

(2) The Operations in the Sector of the 2d Division; the Operational Direction
by the [Sixteenth] Army

Landing; the Ship with the [Sixteenth] Army Headquarters Torpedoed 470

Shifting Priority to the Buitenzorg Road 483

The Worries of the [Sixteenth] Army Headquarters 486

The Battle of Leuwiliang $\quad 490$

A Favorable Turn Followed by Setbacks 495

$\begin{array}{ll}\text { A Further Setback } & 502\end{array}$

Report of an Offer of Surrender by the Bandung Garrison 503

(3) The Operations of the Shōji Detachment 505

The Seizure of the Airfield on Day One of the Landing and the Enemy's Assault $\begin{array}{ll}\text { on the Disembarkation Point } & 507\end{array}$

The 2d [of March]: The Detachment Headquarters Overrun and the Advance of the Air Units [of the 3d Air Division] $\quad 509$

The 3d [of March]: [Enemy] Counterattacks at All Fronts 510

The 4th [of March]: Disembarkation Completed 514

Third Air Division Commander [Endō] and Detachment Commander Shōji's
Change of Mind

The Third Air Force's Support of the Ground Operations 518

The 5th [of March]: Heading for the Bandung Stronghold 522

The 6th [of March]: Attack on the [Enemy's] Main Position and Seizure
of the Mountaintop

The 7th [of March]: The Bandung Garrison Offers to Surrender 526

(4) The Surrender of the Dutch East Indies Army 529

The Meeting with the Governor-General and His Party 529 
Broadcast of the Surrender and the Second Meeting

4 The Operations of the Sakaguchi Detachment 537 Operation Plan $\quad 537$

Implementation of the Operation $\quad 540$

5 The Operations of the 48th Division $\quad 548$

$\begin{array}{ll}\text { Terrain and Operation Plan } & 548\end{array}$

$\begin{array}{ll}\text { Operational Preparations } & 551\end{array}$

Landing, and Seizure of Rembang and the Bridges over the Solo River 552

Meeting Engagements at the Banks of the Brantas River 554

$\begin{array}{ll}\text { The Seizure of Porong } & 561\end{array}$

Preparations for Seizing the Surabaya Stronghold $\quad 562$

Surrender of the Eastern Corps of the Dutch East Indies Army 564

6 Conclusion of the Java Invasion Operation and the Operations of the

Allied Forces $\quad 567$

The Troop Strength [Involved in] the Operation and the Military Gains 567

$\begin{array}{ll}\text { The Operations of the Allied Forces } & 570\end{array}$

The Black Clandestine Broadcasts by the Southern Army 574

The Shift to the Military Administration $\quad 585$

$\begin{array}{lr}\text { Conclusion } & 587\end{array}$

$\begin{array}{lr}\text { Notes } & 591\end{array}$

Appendix: List of Units in the Order of Battle of the Sixteenth Army 599

$\begin{array}{ll}\text { Glossary } & 609\end{array}$

Index of Personal Names 615

Index of Place Names 



\section{Editor's Note}

$\mathrm{T}$

he history of Japan's involvement in the Second World War is still a matter of great controversy, not least in Japan itself. There, scholars, the public and politicians cannot even agree on what to call the war, the Pacific War, the Greater East Asia War, the Fifteen Years War, the Asia-Pacific War, to name just a few examples, each with its dedicated partisan following. Successive Japanese governments have avoided the use of any of these names out of context, and the war is usually referred to as "The Late War" (Saki/Konji no Sensō/Taisen). Even though the Imperial Household Agency denies any specific intent, in practice the late Emperor, too, only referred to the war as "the late war," or used expressions such as "that unfortunate war" and "that unfortunate period," unless he was speaking in an international context about the "Second World War." 1

Not surprisingly, the same controversy affected the 102-volume War History Series (Senshi Sōsho), of which The Invasion of the Dutch East Indies forms volume three. Here, a compromise was finally found by allowing the use of the term "Greater East Asia War" in the main text, but avoiding it in titles, forewords and explanatory notes, although this did not prevent the publisher, Asagumo Newspaper Inc., from prominently putting the term on its flyers. ${ }^{2}$ The foreign reader, who is mostly unaware of the enormous controversy still surrounding Japan's involvement in the Second World War and the vigorous, if not acrimonious, debate within Japan, is often left nonplussed by the vague official expressions used in Japan to refer to the war to paper over fundamental differences that all sides seem unable or unwilling to resolve. Moreover, to foreign readers, used to official war histories, as for example in the case of Britain and Australia, that are commissioned and endorsed by the government, or at least commissioned, even if the contents are left to the responsibility of the author, as in the case of the Netherlands, the Japanese example of a war history that is neither commissioned nor endorsed, but nevertheless compiled by a government agency, seems an anomaly and raises the question of whose view it represents.

The foreword to the present book is clear about it: the contents are the sole responsibility of the author and the head of the War History Office. But, as Professor Tobe shows in his introduction, it is not that simple. The text went through a great many study sessions and numerous revisions, and although great care was taken to present the facts and the oral testimonies as objectively as possible, the resulting text does to a large extent represent a view shared by Imperial Army veterans. But even here we should be careful. In the flyer supplied by the publisher, Major Okamura, a former staff officer of Imperial General Headquarters sent out to Singapore to join the invasion of the Dutch East Indies, explicitly denies the claim made in the present book that the war was all about oil. For such a vulgar materialistic

1 Shōji Jun'ichiro, 'What Should the 'Pacific War' be Named? A Study of the Debate in Japan,' NIDS Security Studies, Vol.13, No.3, Mar. 2011, pp. 70-72.

2 Idem, pp. 75-76. 
matter, the Imperial Army did not go to war. It went to war with the idealistic idea of establishing a new order in Asia and freeing the Western colonies of the Western colonizers. This, incidentally, is an argument often heard in Japan to justify Japan's entry into the war. In its most minimal form, it asserts that something good came out of something bad, after all.

When even the name of your subject is a matter of controversy, it becomes very hard to write an authoritative, let alone academically sound, historical narrative. Not being academically trained historians, the authors of the Senshi Sōsho may not be expected to handle their material with all the conventions of the historian's craft regarding primary sources, secondary sources, the literature, references, etc. But in these respects, the Senshi Sōsho do not differ much from most of the older Western military histories. In the official histories compiled by the Allied powers after the war almost simultaneously with the compilation of the Senshi Sossho, the role of the home side is typically emphasized, and they serve to give an account of, if not to account for, the actions of their own forces. A certain bias and one-sidedness is inherent; the Senshi Sōsho are no exception. ${ }^{3}$ The professionalization of the field of military history is a comparatively recent phenomenon. Also the Dutch counterpart, Nederlands-Indië contra Japan, ${ }^{4}$ compiled by the War History Section of the Royal Netherlands Indies Army (KNIL) and completed by the Military History Section of the Royal Netherlands Army, is a case in point. However, there is an interesting difference. The Dutch narrative spends no less than two of its seven volumes on the events leading up to the war. The author of The Invasion of the Dutch East Indies only needs a few pages to hop, step and jump to the opening of hostilities. Regardless of the validity of his argument of why Japan went "inevitably" to war, an argument already disputed in the publisher's flyer, the quick dispatch of this controversial subject is illustrative. It represents a general tendency to skirt controversy and jump as quickly as possible into the nitty-gritty details of the planning and execution of the operation.

It has been remarked that the Senshi Sōsho "... provide a great treasure of data and fact. Yet they often omit discussion of questions of primary interest to the Western historian." ${ }^{5}$ That the Senshi Sōsho and many other Japanese sources are often "maddeningly silent" 6 on such matters, however, does not take away their immense value as a treasure trove of data and fact. As Professor Tobe remarks in his introduction: "It is virtually impossible to examine how Japanese forces fought in the Pacific War without referring to the Senshi Sōsho series."

For the student of the Japanese invasion of the Dutch East Indies, the present translation will fill a large gap in his knowledge, even though he may not find answers to some of his most fundamental questions. There is another limitation. Despite its title, The Invasion of the Dutch East Indies deals mainly with the operations of the Japanese Sixteenth Army until the beginning of March 1942 when the Royal Netherlands Indies Army surrendered. This means that the events in central and northern Sumatra are not dealt with at all, for they mainly took place after that date and, moreover, fell under the responsibility of the Japanese Twenty-fifth

\footnotetext{
3 See also: P.J. Dennis, 'Military History in Australia,' Mededelingen Sectie Militaire Geschiedenis (Vol. 14, 1991) 9-18, pp. 9-10; A.R. Millett, 'The Study of Military History in the United States Since World War II', Idem, 109-129, pp. 122-123.

4 Sectie Krijgsgeschiedenis, Nederlands-Indië contra Japan, 7 Vols., 's-Gravenhage, Staatsdrukkerij, 1949-1961.

5 David C. Evans, Mark R. Peattie, Kaigun: Strategy, Tactics, and Technology in the Imperial Japanese Navy, 1887-1941, Annapolis, Naval Institute Press, 1997, p. xxiii.

6 Idem, p. xxiv.
} 
Army; and events in other areas that fell under the responsibility of the Japanese Navy, e.g. Celebes, are dealt with only very summarily. However, despite these limitations, The Invasion of the Dutch East Indies provides an unparalleled insight into the Japanese military campaign and the men who executed it. Moreover, we hope it will answer some of the questions of those who still wonder how it all could have happened, and who often still bear the scars of defeat and the subsequent years in prison or internment camps. A look over the hill to see what was done and thought in the camp of the former enemy, may not excuse anything, but it may explain many things.

The translation of military terms: Although the organization of the Imperial Japanese Army (IJA) and the Imperial Japanese Navy (IJN) was similar to those of Western armies and navies, there is often no one-to-one correspondence in the names and functions of their constituent parts. Some translators have chosen to emphasize the differences by not translating specific military terms, while others prefer literal translations in some form or another. For example, we might find hiko sentai (飛行戦隊) simply as “sentai" or translated more literally as "air regiment." Others again try to find designations in Western armies and navies that most closely resemble their Japanese counterpart in function, resulting in translations such as "group," "air group," "air combat group," or even "wing." In this book, we have generally followed the third option without being too dogmatic. “Gun" (軍) as in “daijūroku gun" (第 十六軍 [Sixteenth Army]) remains "army," even though "army corps" would be more correct in terms of size and function. At the same time, we have tried to avoid British or Commonwealth terminology and generally followed American usage common in the U.S. Army and Navy during World War II. This limitation precludes the use of terms such as "wing" in the example above because a comparable "wing" did not come into existence in the U.S. (Army) Air Force until after the war. We also tried not to reinvent the wheel and based our translations mainly on the 1944 U.S. Army manual "A Handbook on Japanese Military Forces" [https: / / archive.org/ details/TME30-480] for the IJA, and Japanese Monograph No. 116 for the IJN [http://www.ibiblio.org/hyperwar/Japan/Monos/JM-116/index.html]. As not everyone may agree with our choices, we have made them explicit in the glossary at the end of the book.

Japanese names: The characters used in Japanese names can often be read in more than one way. In the text we have used the readings from the name lists of the IJA and IJN, if given and unless pointed out otherwise by later research. If no reading is given in these lists, we have used readings found in bibliographical dictionaries and other sources. In all other cases, we have adopted the most common reading. In the Index of Personal Names, we have added a question mark behind the family and/or personal name whenever the reading remains open to interpretation. In the translated text, Japanese names are given in Japanese order, i.e. the family name first, followed by the personal name without a comma in between.

Place names: In the Japanese text, foreign place names are either written in characters, as in the case of Chinese place names, or in the Japanese phonetic katakana script. Especially in the latter case, this has led to a great number of hard to identify place names. We think that we managed to identify most of them. With the exception of Hong Kong and Saigon, all place names are given in their modern, local readings, e.g. Guangdong instead of Canton, and 
Gaoxiong instead of Takao. In the case of the Dutch East Indies, colonial era names such as Batavia and Buitenzorg have been preserved, but their modern names, Jakarta and Bogor, have been added in the Index of Place Names. The spelling of Indonesian place names is rather inconsistent and differs from atlas to atlas. We have followed what seems to be the most commonly accepted spelling.

Editorial notes and emendations: Respecting the wishes of the copyright holder, the National Institute for Defense Studies of Japan (NIDS), the translation is full and unabridged. Although the text invites comparison with foreign sources, we have refrained from adding any external material. The editorial emendations and notes within brackets are only meant to make the text more readable, to indicate misprints, contradictory descriptions within the text itself, or occasionally differences with the descriptions in other volumes of the Senshi Sōsho series. Obvious misprints and errata pointed out in the list of errata compiled by NIDS in 2005 have been silently corrected. Parentheses are as used in the Japanese text.

The translation process: Tim Wolput and Satoko Fujino made draft translations of parts of the text, which then were checked against the original text and rewritten by Willem Remmelink and Yumi Miyazaki. The latter also conducted almost all the background research in Japanese sources. We wish that more time could have been given to the solution of remaining problems. However, in the interest of making this translation quickly available to the public, we had to limit ourselves to the most obvious problems. We hope that other researchers will pick up the threads where we left off.

Acknowledgements: I would like to thank the National Institute for Defense Studies for granting us the copyright to publish this translation. Many other institutions and persons helped us with the background research. I would especially like to thank the Military Archives of the National Institute for Defense Studies and the Yasukuni Kaiko Bunko (Yasukuni Archives).

The advisory board read and commented upon the translation. I am grateful to the members of the board for their many helpful comments and suggestions. The final responsibility for the translation, however, rests solely with the editor.

March 2015

Willem G.J. Remmelink 


\section{About the Senshi Sōsho (War History Series)}

\section{TOBE Ryōichi}

$\mathrm{T}$ he Senshi Sōsho is a series of 102 volumes (to which two supplementary volumes were later added) on the military history of the Pacific War (including the Sino-Japanese War). These volumes contain the results of research conducted at the then War History Office (renamed the Military History Department, and later reorganized into the Center for Military History) of the National Defense College (later renamed the National Institute for Defense Studies) of the Defense Agency, or the Ministry of Defense as we know it today. The series was published by Asagumo Shimbunsha [Asagumo Newspaper Inc.] between 1966 and 1980. Although the series is usually called an "official" war history, the fact that it was published by a private publisher and not the government shows the official stance of the government that, although the series contains the results of research conducted by a branch of a governmental institution (i.e. the War History Office of the National Defense College), it does not express the official view of the Japanese government on the Pacific War. As mentioned in the foreword, "the main purpose of the publication of this series is to serve as educational and research material for the Self-Defense Forces," but that "its public use has been taken into consideration as well."

A study of the history of the Pacific War and a compilation of the results by a Japanese governmental institution had been planned since the days of the occupation right after the defeat. However, it was not until 1955, after the end of the occupation, when the War History Office was established within the Defense Agency, that the plan was put into effect in earnest. At the War History Office, dozens of veterans were appointed to compile the materials. They held meeting after meeting to write materials for educational and research purposes, revised these materials based on the discussions in these study meetings, and prepared manuscripts. For the research, the War History Office gathered about 70,000 documents, which were scattered and lost after the defeat, interviewed more than 15,000 veterans, and collected about 10,000 documents transferred from the Ministry of Health and Welfare, which had taken over the demobilization of the Army and the Navy, and about 30,000 documents that had been collected by the occupation forces and were subsequently returned from the United States.

In 1965, the Defense Agency set forth a plan to publish the research results of the War History Office as the Senshi Sōsho series. Publication was started the next year; the study meetings at the War History Office, as many as 3,500 in ten years, and the results of some 240,000 pages of prepared manuscripts provided the basis for the series. The number of authors and researchers who participated in the compilation was 134. The entire 102-volume series can be subdivided in various ways. In one way, they can be divided into seven volumes on the circumstances which led to the opening of hostilities, ten volumes on the Army Department of IGHQ, seven volumes on the Navy Department of IGHQ and the Combined 
Fleet, ten volumes on the military preparations, nine volumes on the invasion operations, ten volumes on the operations in the Solomon Islands and New Guinea, five volumes on the operations in the central Pacific theater, three volumes on the defensive operations in the southwestern theater, four volumes on the operations in Burma, three volumes on the operations in the northeastern theater, three volumes on the operations in Manchuria, fifteen volumes on the operations in China, five volumes on the decisive battles in the Philippines, three volumes on the decisive battles on Okinawa, four volumes on the operations in the homeland, three volumes on the history of special operations (vessel escorting, submarine warfare, etc.) and one volume with a chronological table and a glossary of technical terms. The series can also be subdivided in a different way, e.g. twenty-four volumes on the general conduct of the war, ten volumes on military preparations, sixty-seven volumes on the operations themselves, and one volume on other matters. Finally, the series could be divided into sixty-nine volumes on the Army and thirty-two volumes on the Navy, and one volume common to both (the chronological table). This book, volume 3, is part of the invasion operations of the Army.

The published Senshi Sōsho series was on the whole favorably received by historians of modern and contemporary Japan. It was because the series filled a gap at a time when objective data on the history of the Pacific War were scarce. Also the attitude of the authors who strove to be objective and ideologically unbiased was well thought of.

Needless to say, there was harsh criticism as well. For example, from a historiographical point of view, the series was criticized that its academic level was not necessarily high, which was only natural, for it was written not by academically trained researchers but by veterans. However, at this point I doubt whether there were more suitable persons to write the war history series than these veterans. Even if it had been possible to commission university-level professional researchers to do the writing, without sufficient military knowledge they would not have had the competence to do the work. I should also add that even though there were more than 120,000 historical documents available at the time of publication, their number was limited compared to the current number of available documents.

The authors of the Senshi Sōsho series were consistent in their attitude that they should just convey as faithfully as possible the facts, based on the documents and the oral evidence from the interviews, and leave analyses and interpretation to the reader or the specialist, rather than on the basis of their research results publish their own analyses or interpretations. This is even reflected in the title of the series. By choosing the title "War History Series," they consciously tried to steer clear of the political and ideological controversies that surrounded such titles as "History of the Greater East Asia War," or "History of the Pacific War." As a result, many researchers regarded the series as a kind of primary historical source and tried to utilize the information extracted from the series in their own research. In that sense, even if indices and notes were insufficient, it can be said that the authors successfully achieved in their own way their intention to just convey the facts and the evidence. Moreover, not all of the 102 volumes did necessarily fall short of the required academic level. Of the 102 volumes, quite a few did attain a considerably high research level.

Another criticism was that the authors, as veterans, might be biased towards the organization to which they once belonged and in their evaluation might have become lenient with it or its members. As I mentioned above, the texts of each author were discussed at the study meetings, attended by the whole group, and revised. We cannot tell whether in the reviews 
at the study meetings, any criticism of their fellow soldiers was toned down or actually reinforced. But at least it is clear that the reviews at the study meetings must have put as much restraint as possible on prejudices or feelings of favor or disapproval. In that sense, we may say that objectivity and impartiality were to a large extent guaranteed in the series.

The criticism that the series was written by a group of insiders was also leveled at the fact that the inter-service rivalry between the Army and the Navy sometimes resurfaced in this series. A typical example is the fact that different Army and Navy versions were written, with considerable differences in interpretation, about the circumstances that led to the opening of hostilities. The Senshi Sōsho series can be divided into those volumes of which the Army was in charge and those of which the Navy was in charge. In other words, the parallel tracks that the Army and the Navy had pursued from the time of their foundation in the early Meiji period onwards extended to the issue of who would take charge of certain volumes. However, the difference in interpretation and views between the Army and the Navy mainly occurred in the descriptions of the general conduct of the war; only a few cases show traces of this rivalry in the description of operations. Volume 3, of which the Army was in charge, mainly deals with the history of operations and engagements with a focus on land engagements, and we may say that the influence of the Army-Navy rivalry is almost non-existent.

Another criticism of the Senshi Sōsho series was that it focused on operations, and that the analysis and description of subjects such as the line of communication (logistics), intelligence, and medical matters were extremely few. Other criticism was that the descriptions were too flat and often offered nothing but a list of facts. Many parts of Volume 3 may fall under the latter criticism in particular. However, as I mentioned, this could be the result of the author's effort to just convey the facts or the oral evidence, obtained in the process of his research and writing, while leaving out his subjective judgments as much as possible.

After the publication, a considerable number of misprints and factual mistakes were found. Apart from the misprints, misunderstandings of the facts have been clarified by newly found material and through progress in the research. The Military History Department (or the Center for Military History) is said to be working on an updated list of errata. I am happy to note that these lists of errata have been taken into account in the present translation and that the editors have spent considerable effort to clarify remaining problems and errors in the text.

Despite the above criticisms and shortcomings, there is no doubt that the Senshi Sōsho series is the first basic reference work to turn to when studying the history of the Pacific War; it is a rich and indispensible source for all future research. It is virtually impossible to examine how Japanese forces fought in the Pacific War without referring to the Senshi Sōsho series. Compared to the rudimentary Japanese Monograph series, collected and translated by the Military History Section of General Headquarters, Far East Command, which formed the start of the collection of Japanese war materials and with which foreign researchers generally have to make do, the Senshi Sōsho series represents a quantum leap forward. I do hope that this first full and unabridged translation of a volume of the Senshi Sōsho will be followed by others.

March 2015 


\section{References}

Hara Takeshi, ‘Senshi Sōsho no Raireki oyobi Gaiyō' (原剛「『戦史叢書』の来歴および概要」『防衛研究 所戦史部年報』第1号 (1998年3月) [Takeshi, Hara, 'History and outline of the Senshi Sōsho series,' NIDS Military History Studies Annual Report No. 1, Mar. 1998]).

Shōji Jun'ichirō, 'Senshibu Ryaku-shi'（庄司潤一郎「戦史部略史」『防衛研究所戦史部年報』第1号 (1998 年3月） [Jun'ichirō, Shōji, 'A brief history of the Military History Department,' NIDS Military History Studies Annual Report No. 1, Mar. 1998]).

Id., 'Senshi Sōsho ni okeru Riku-Kaigun Tairitsu ni kansuru Ichi-Kōsatsu — Kaisen Keii o Chūshin to shite' (同「「戦史叢書」における陸海軍対立に関する一考察—「開戦経緯」を中心として一」『戦史研究 年報』第12号 (2009年3月) [Id., 'A study on the rivalry between the Army and the Navy in the Senshi Sōsho series, with a focus on the circumstances which led to the opening of hostilities,' NIDS Military History Studies Annual Report No. 12, Mar. 2009]).

Id., 'Nihon ni okeru Sensō Koshō ni kansuru Mondai no Ichi-Kōsatsu'（同「日本における戦争呼称に 関する問題の一考察」『防衛研究所紀要』第13巻第3号（2011年3月）[Id., ‘What Should the ‘Pacific War' be Named? A Study of the Debate in Japan,' NIDS Security Studies, Vol.13, No.3, Mar. 2011])

Id., 'Shiryō o yomitoku: Taiheiyō Sensō Senshi Kenkyū no Kihon Bunken Senshi Sōsho,' Shūkan Asahi Hyakka vol. 43, 'Shin-Hakken! Nippon no Rekishi-Gendai 3,' (同「史料を読み解く 太平洋戦争戦史 研究の基本文献「戦史叢書」」週刊朝日百科 43 新発見! 日本の歴史 現代3』2014年5月 4 日 $/ 11$ 日 合併号 [Id., 'Interpreting historical materials: Fundamental literature on the military history of the Pacific War, the Senshi Sōsho series,' 'Newly discovered! History of Japan: Contemporary History No. 3,' Weekly Asahi Encyclopedia vol. 43, 4/11 May 2014 issue]).

Senshi Kenkyū Zadankai, 'Senshi-bu ni okeru Senshi Kenkyū no Arikata' (戦史研究座談会「戦史部に おける戦史研究のあり方」『戦史研究年報』第12号(2009年3月) [“A round-table discussion on the study of military history, 'The way military history studies should be at the Military History Department,' NIDS Military History Studies Annual Report No. 12, Mar. 2009].

Kagatani Tadashi, 'Senshi Sōsho Kankō 30 Shūnen ni yosete' (加賀谷貞司「「戦史叢書」刊行30周年に寄 せて」『戦史研究年報』第13号(2010年3月) [Tadashi Kagatani, '[Commemorating] the 30th anniversary of the publication of the Senshi Sōsho series,' NIDS Military History Studies Annual Report No. 13, Mar. 2010]).

Fukushige Hiroshi, ‘Senshi Sōsho Hensan Tōji no Omoide’（福重博「「戦史叢書」編さん当時の思い出」 『戦史研究年報』第13号 (2010年3月) [Fukushige Hiroshi, 'Memories of the time of compiling the Senshi Sōsho series,' NIDS Military History Studies Annual Report No. 13, Mar. 2010]).

Kondō Shinji, ‘Senshi-bu no Kaisō’（近藤新治「戦史部の回想」『戦史研究年報』第13号 (2010年3月) [Kondō Shinji, 'Recollections of the Military History Department,' NIDS Military History Studies Annual Report No. 13, Mar. 2010]) .

Ichiki Toshio, 'Senshi Hensankan no Omoide'（市来俊男「戦史編さん官の思い出」『戦史研究年報』第13 号(2010年3月) [Ichiki Toshio, 'Memories of a war history compiler,' NIDS Military History Studies Annual Report No. 13, Mar. 2010]).

Hatano Sumio, 'Ichigayadai no Senshi-bu to Senshi Sōsho'（波多野澄雄「市ヶ谷台の戦史部と戦史叢書」 『戦史研究年報』第13号 (2010年3月) [Hatano Sumio, ‘The Military History Department at Ichigayadai and the Senshi Sōsho series' NIDS Military History Studies Annual Report No. 13, Mar. 2010]).

Takahashi Hisashi, ‘Senshi-bu Kimmu Jidai o kaerimite’ (高橋久志「戦史部勤務時代を顧みて」『戦史研 究年報』第13号 (2010年3月) [Takahashi Hisashi, 'Looking back my time at the Military History Department,' NIDS Military History Studies Annual Report No. 13, Mar. 2010]). 


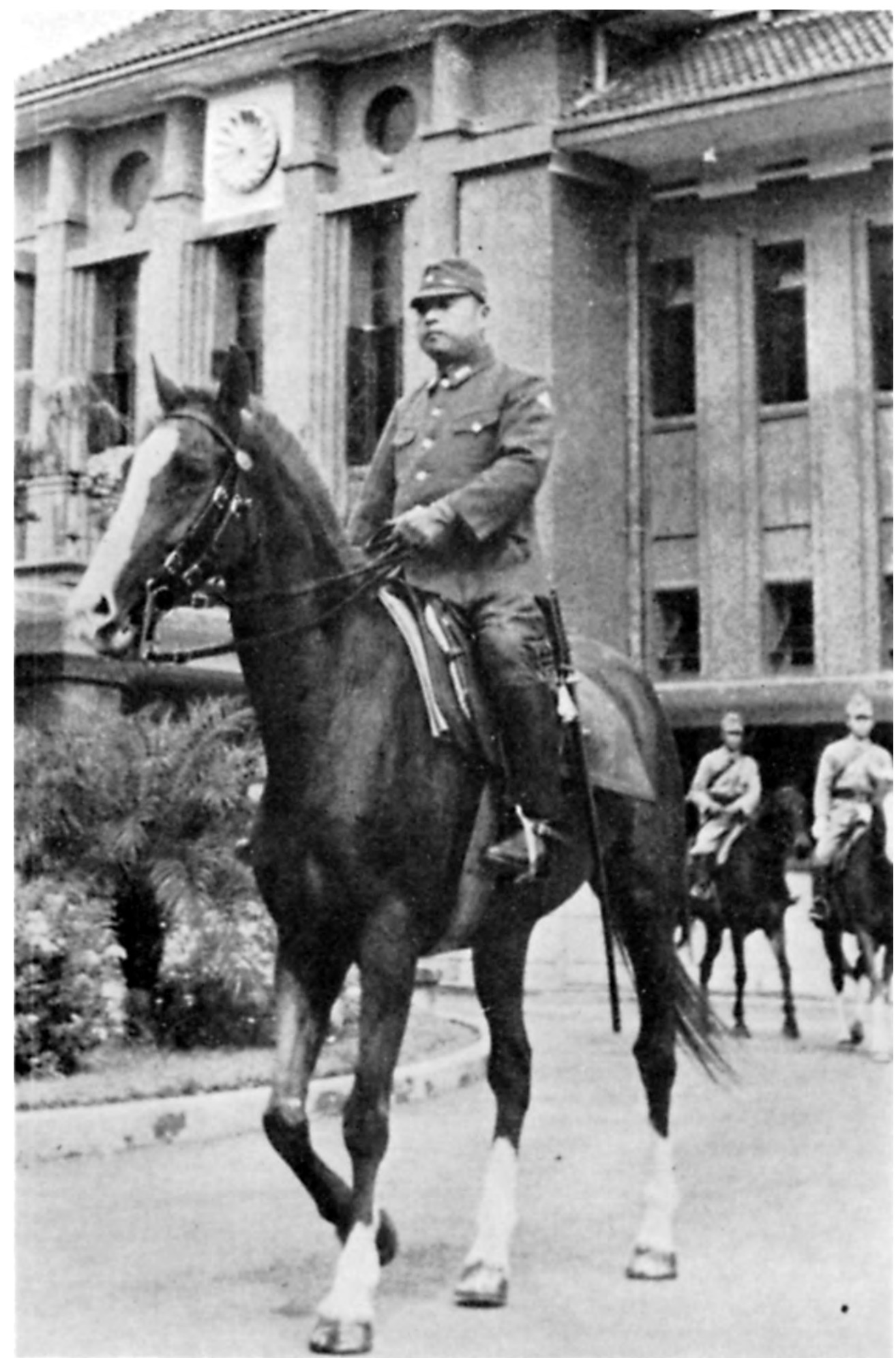

Sixteenth Army Commander Lt. Gen. Imamura Hitoshi (in Front of Army Headquarters in Batavia) 


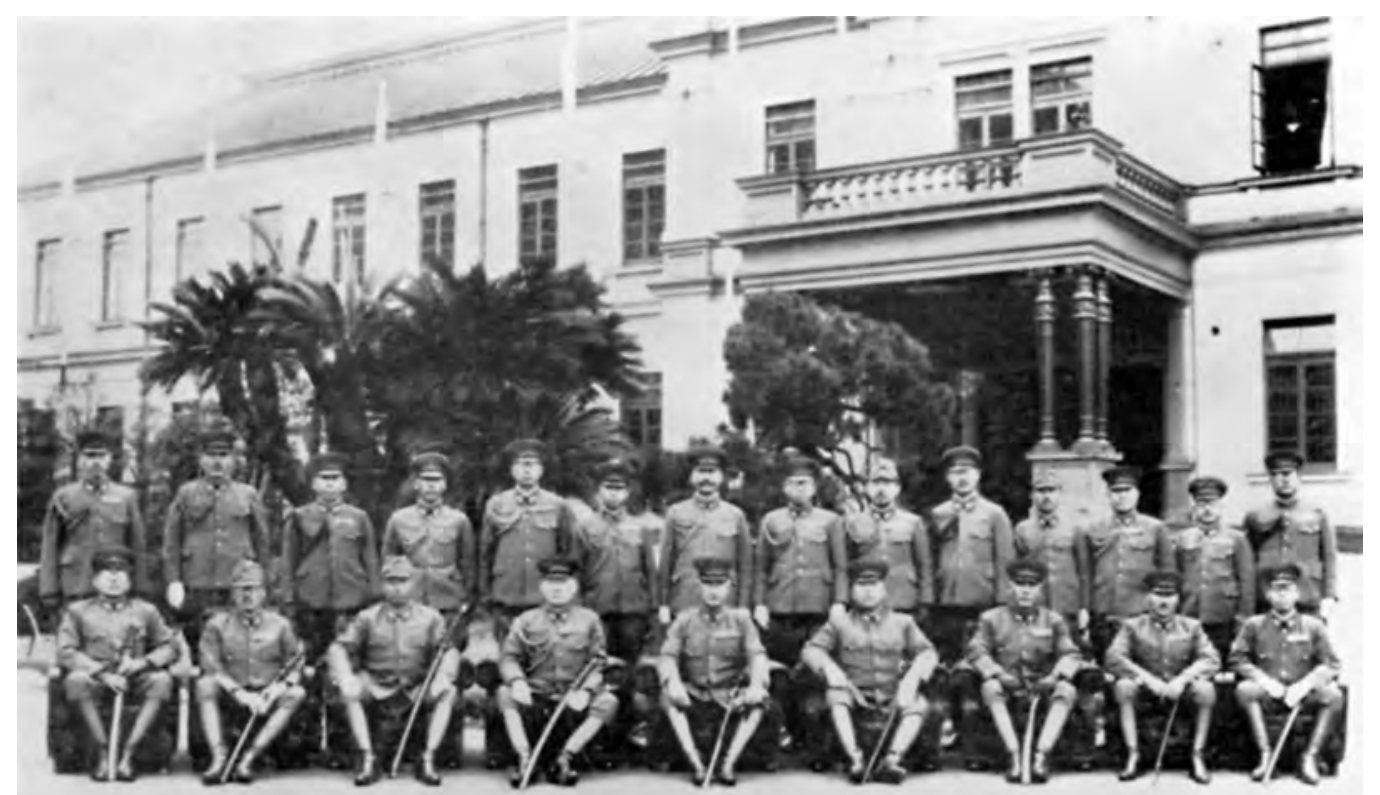

Commanders and Staff of the Central Command and the Southern Army Right After the Issue of the Order of

Battle. From Right to Left in the Front row: Commanders Saeki, Sugawara, Homma, Yamashita, Terauchi, Sugiyama, Imamura, Sakai, and Obata

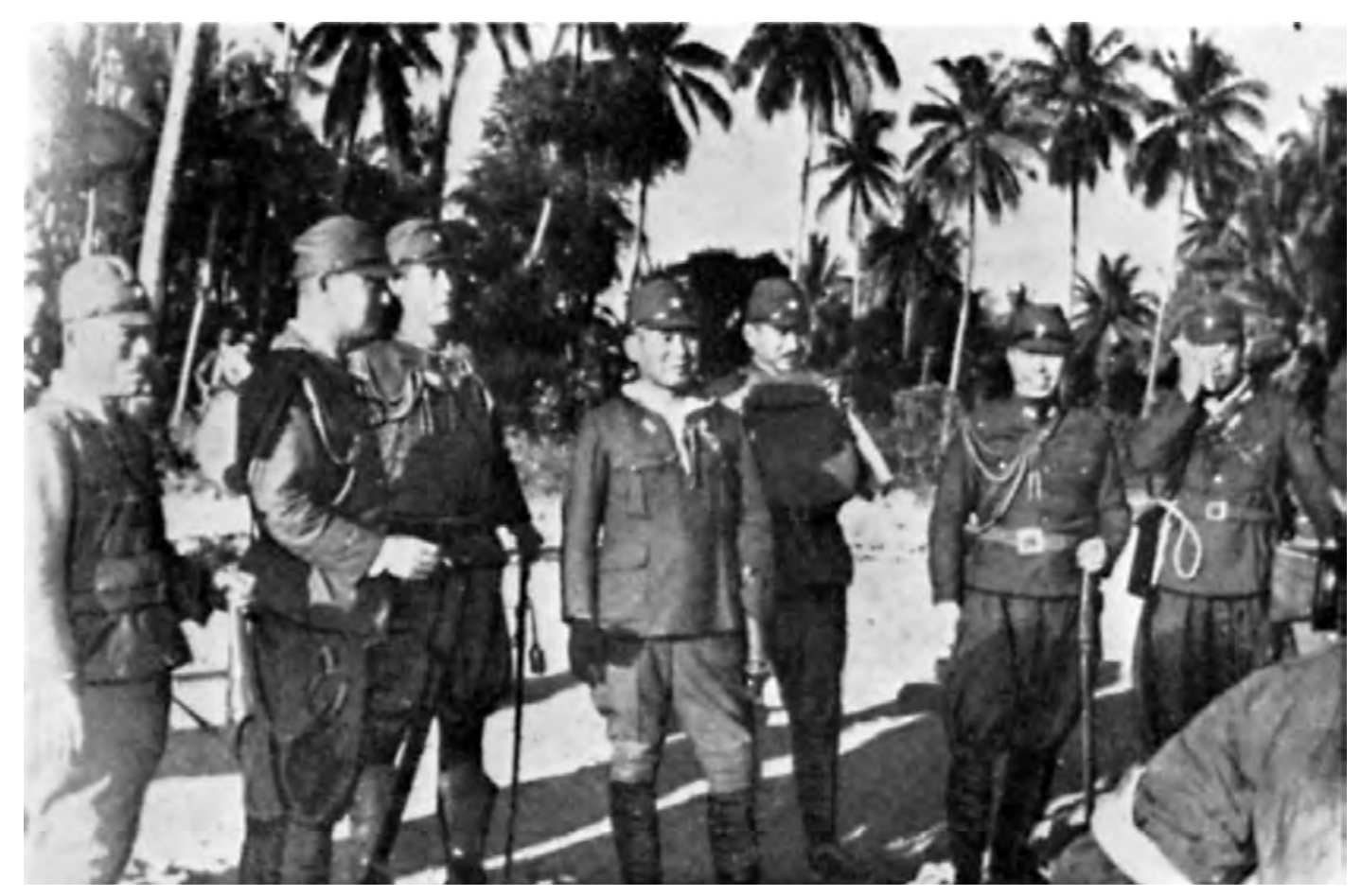

Command Post of the 48th Division at Kragan 


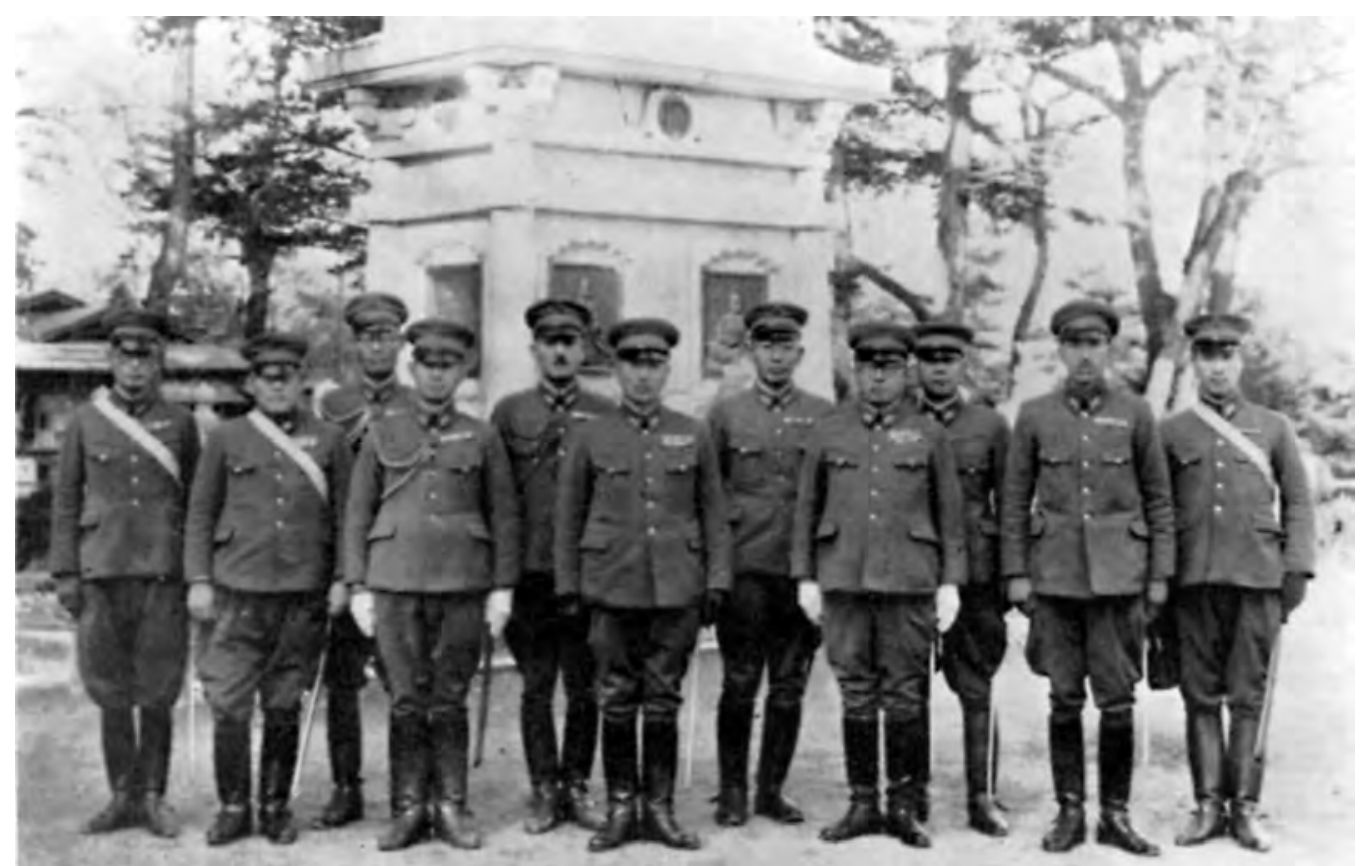

Staff of the $2 d$ Division Headquarters (Right After Mobilization)

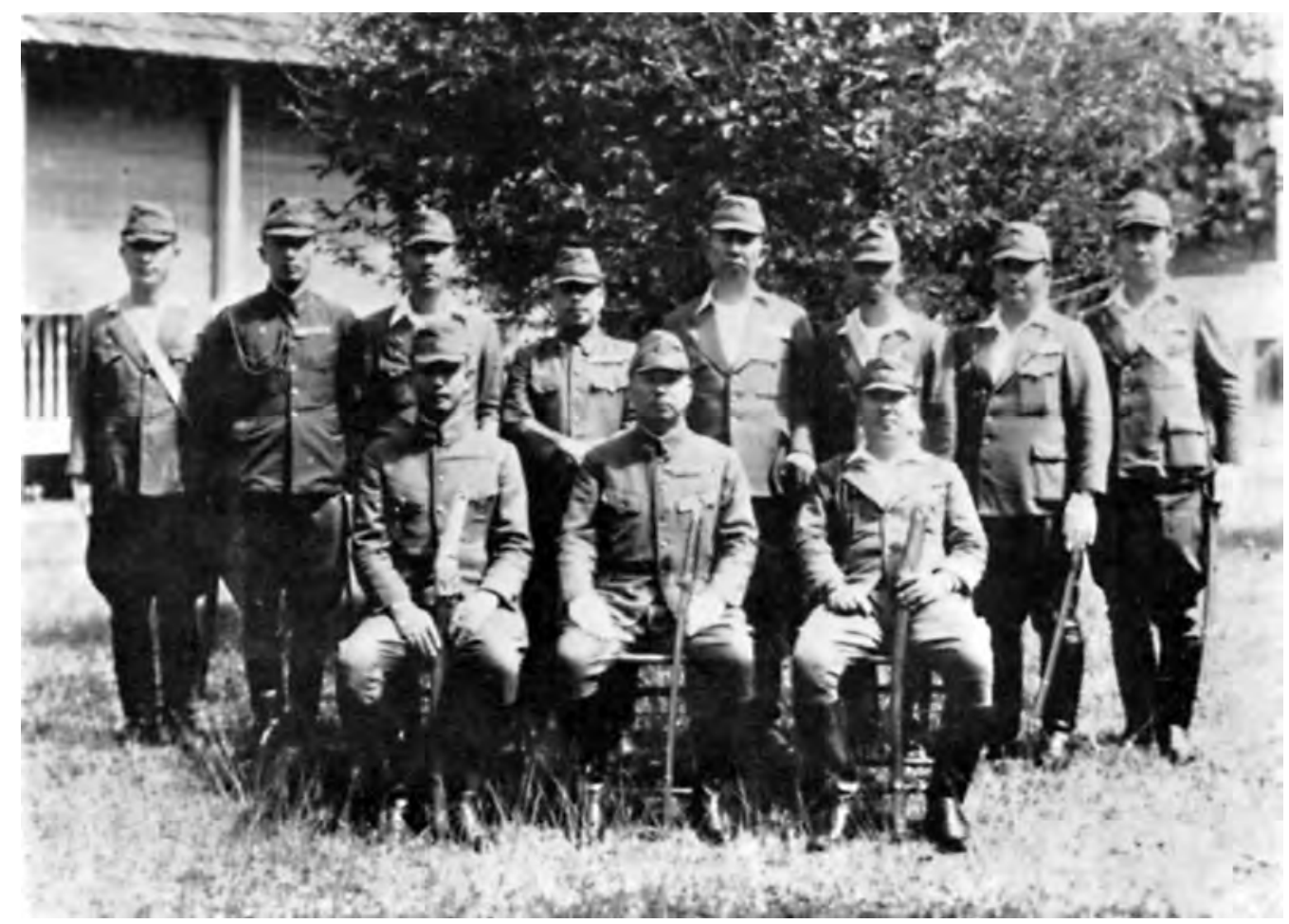




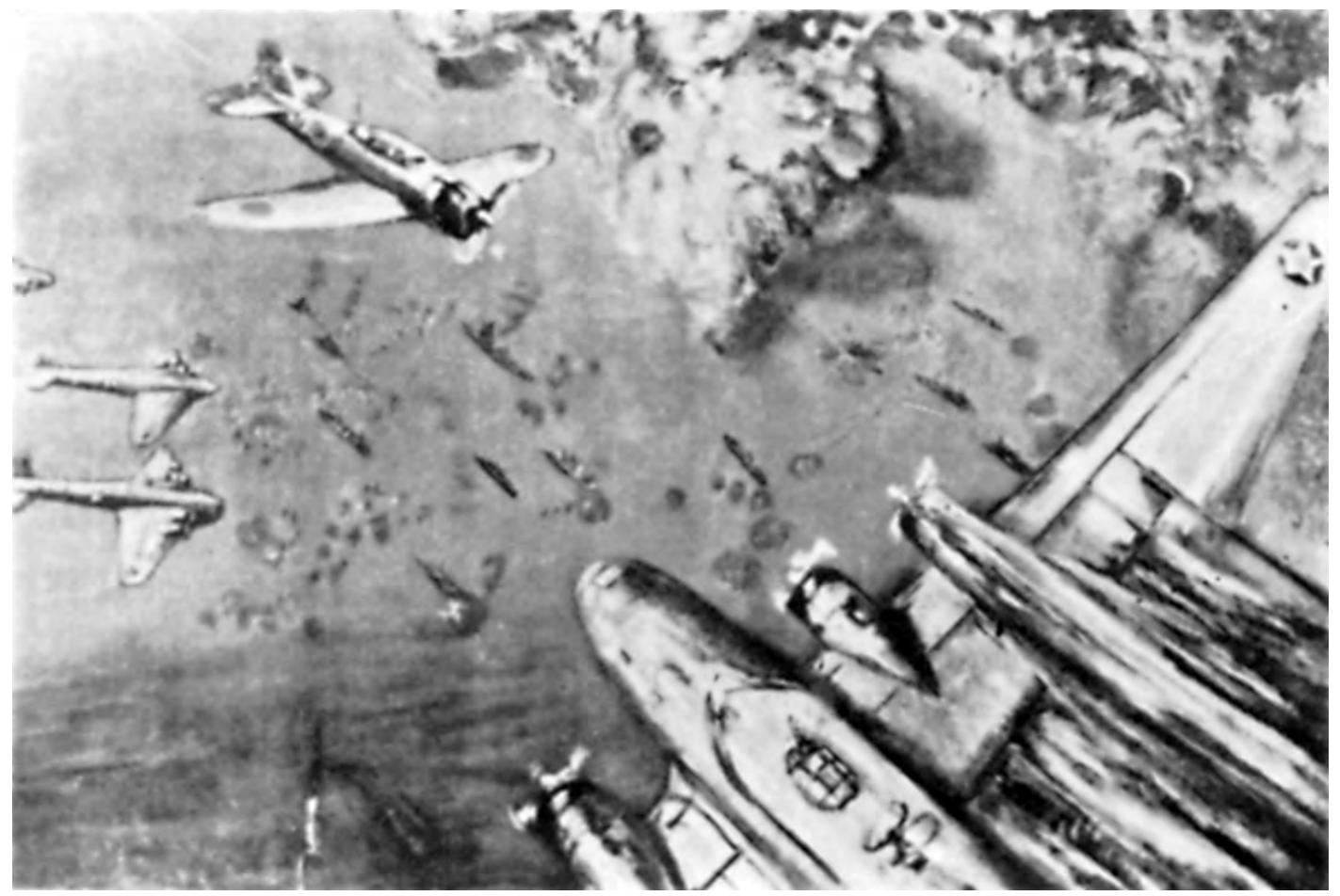

Interception of B-17s by the Takagi Antiaircraft Artillery Battalion and Navy Air Units over Balikpapan (25 January, Day 2 After the Landing)

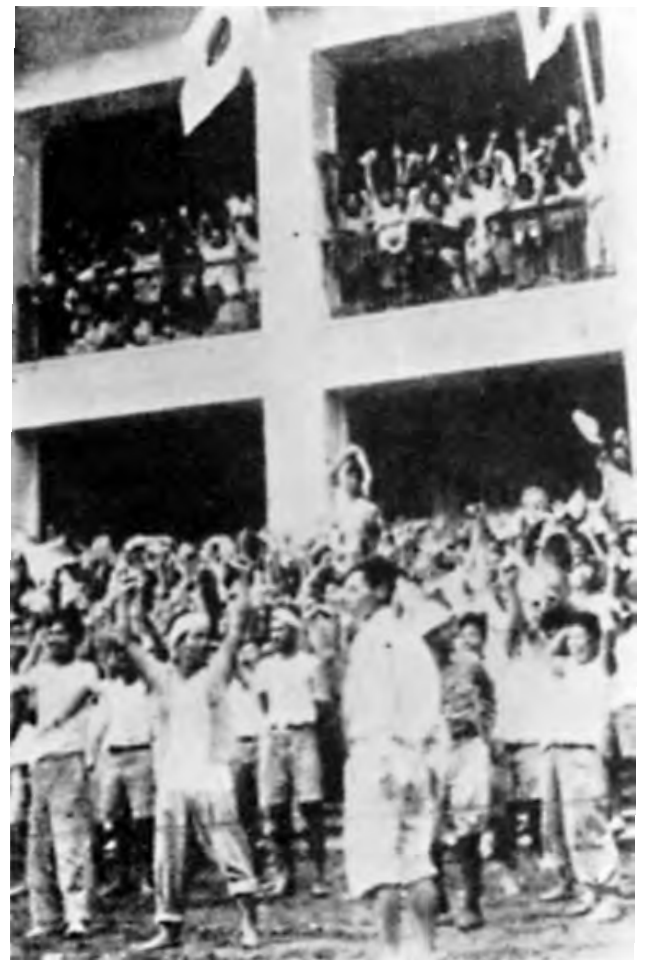

Shouts of Joy from Japanese Residents [on Their Release from] Confinement in Davao

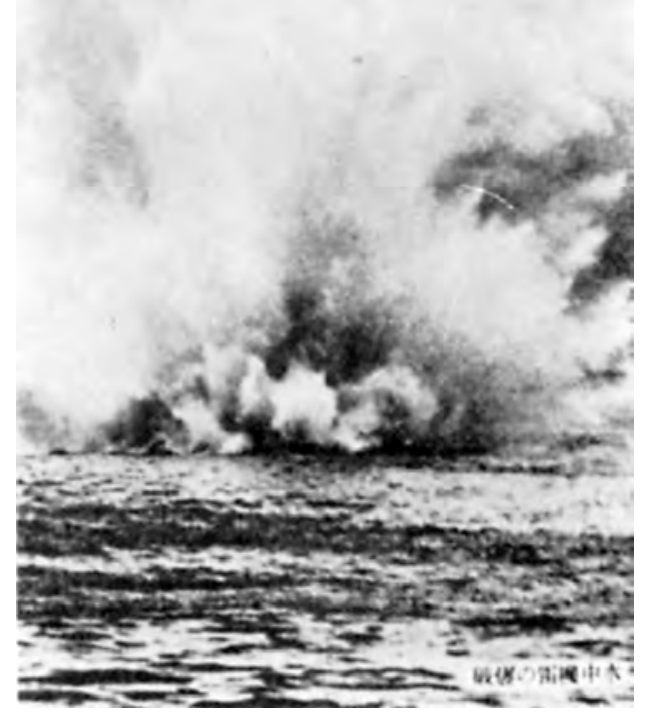

Blowing up Mines in the Musi River 


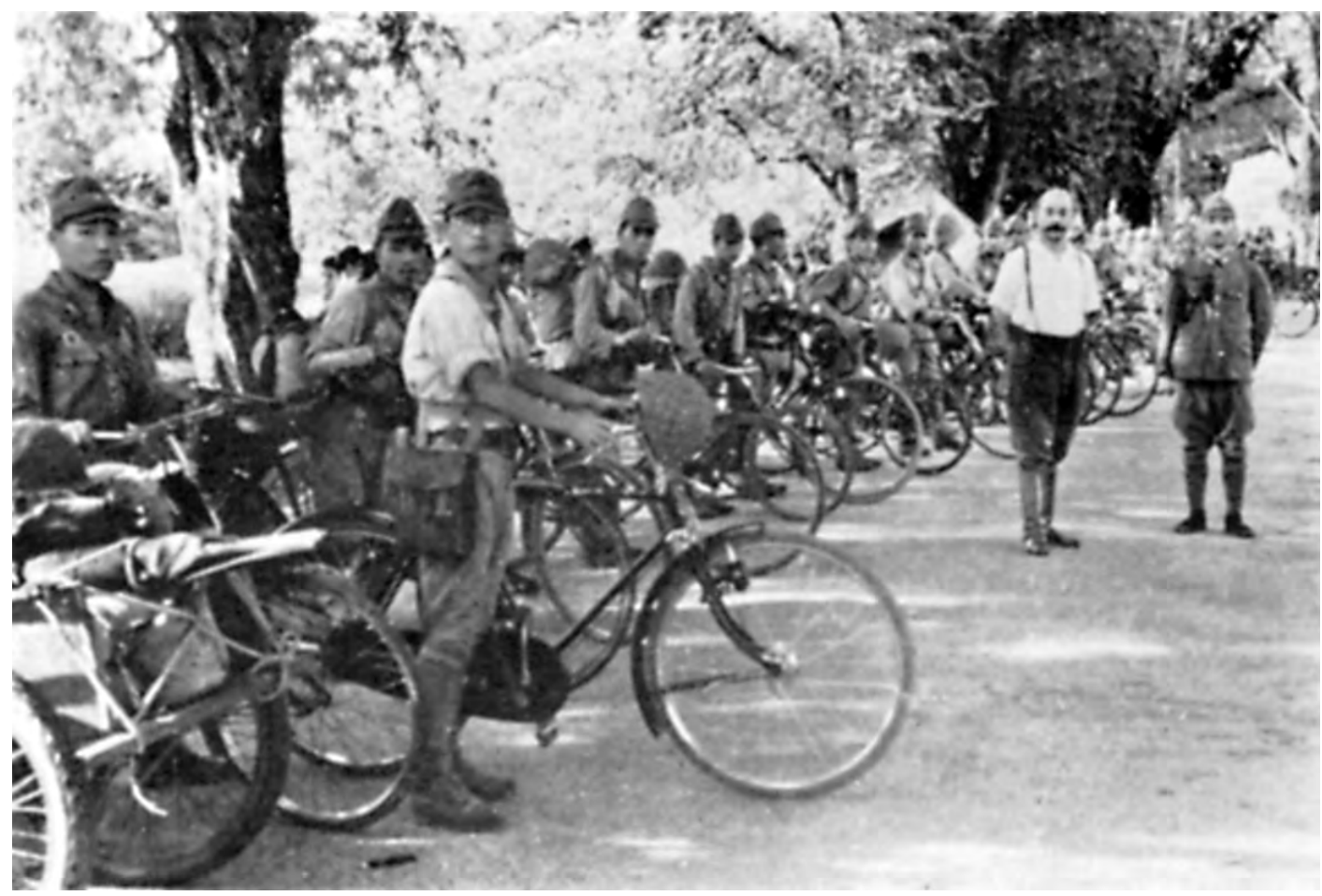

Detachment Commander Kawaguchi and the $2 d$ Company [of the 124th Infantry Regiment] in Singkawang (28 January)

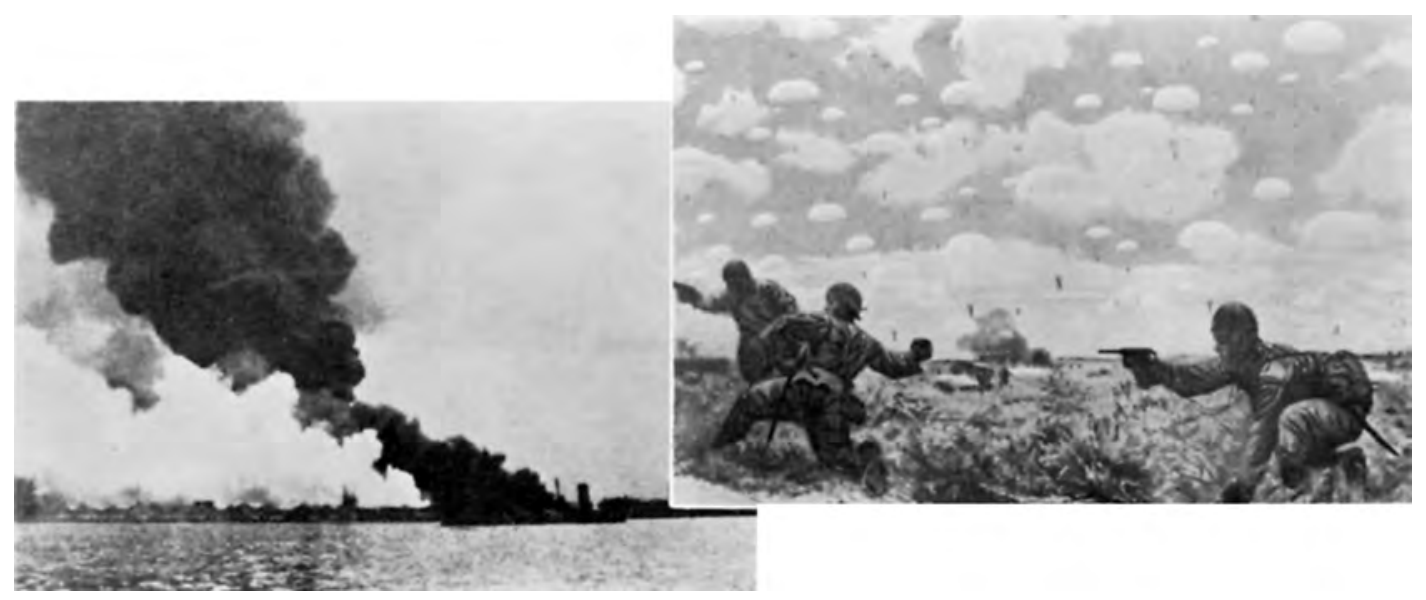

Palembang Oil Refineries in Flames

Drop of the Paratroopers in Palembang 


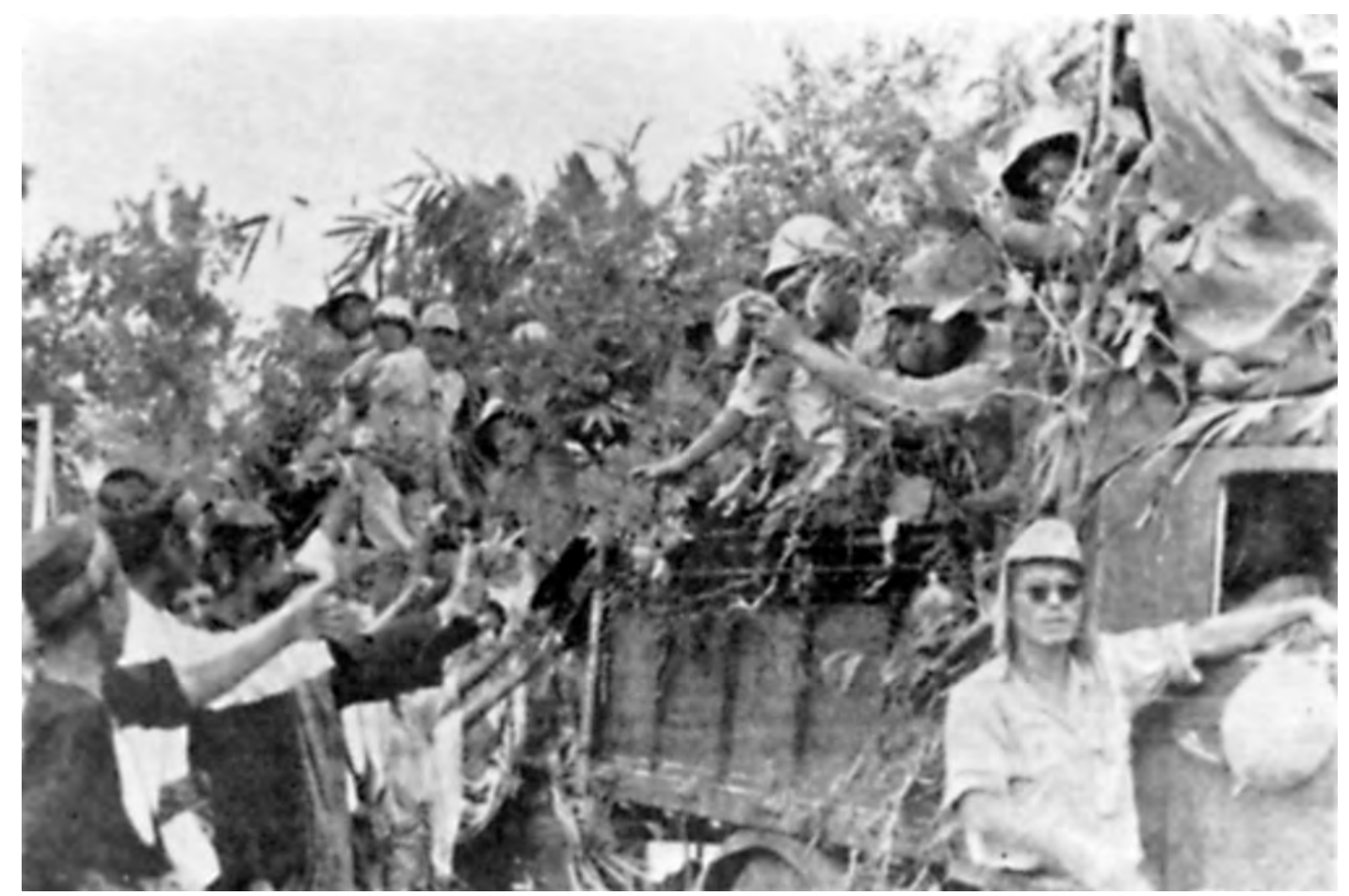

Local People Welcoming with Thumbs Up the Passing of Units of the 48th Division (at Caruban)

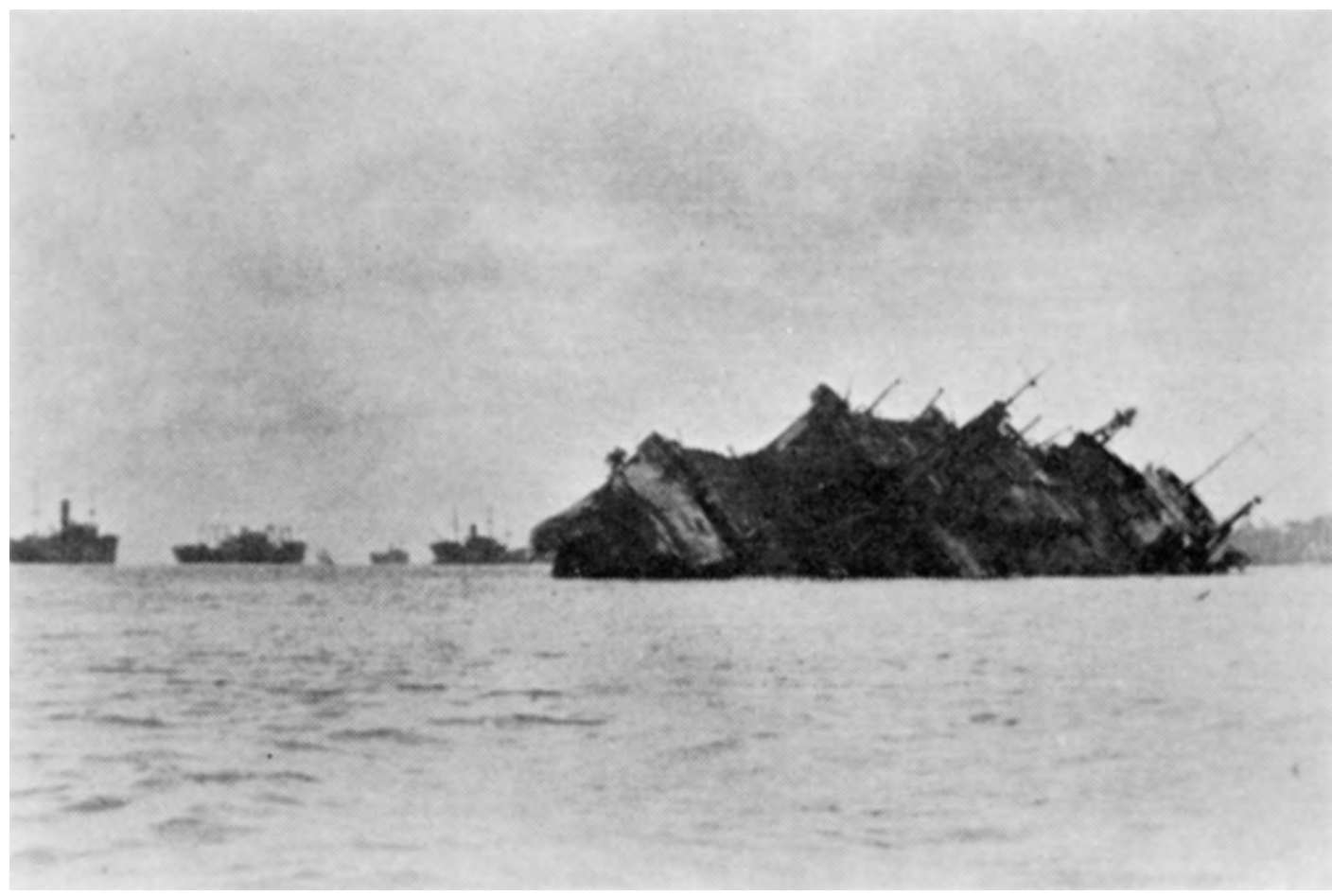

The Stranded Ryūjo-maru (Boarded by the [Sixteenth] Army Commander) 


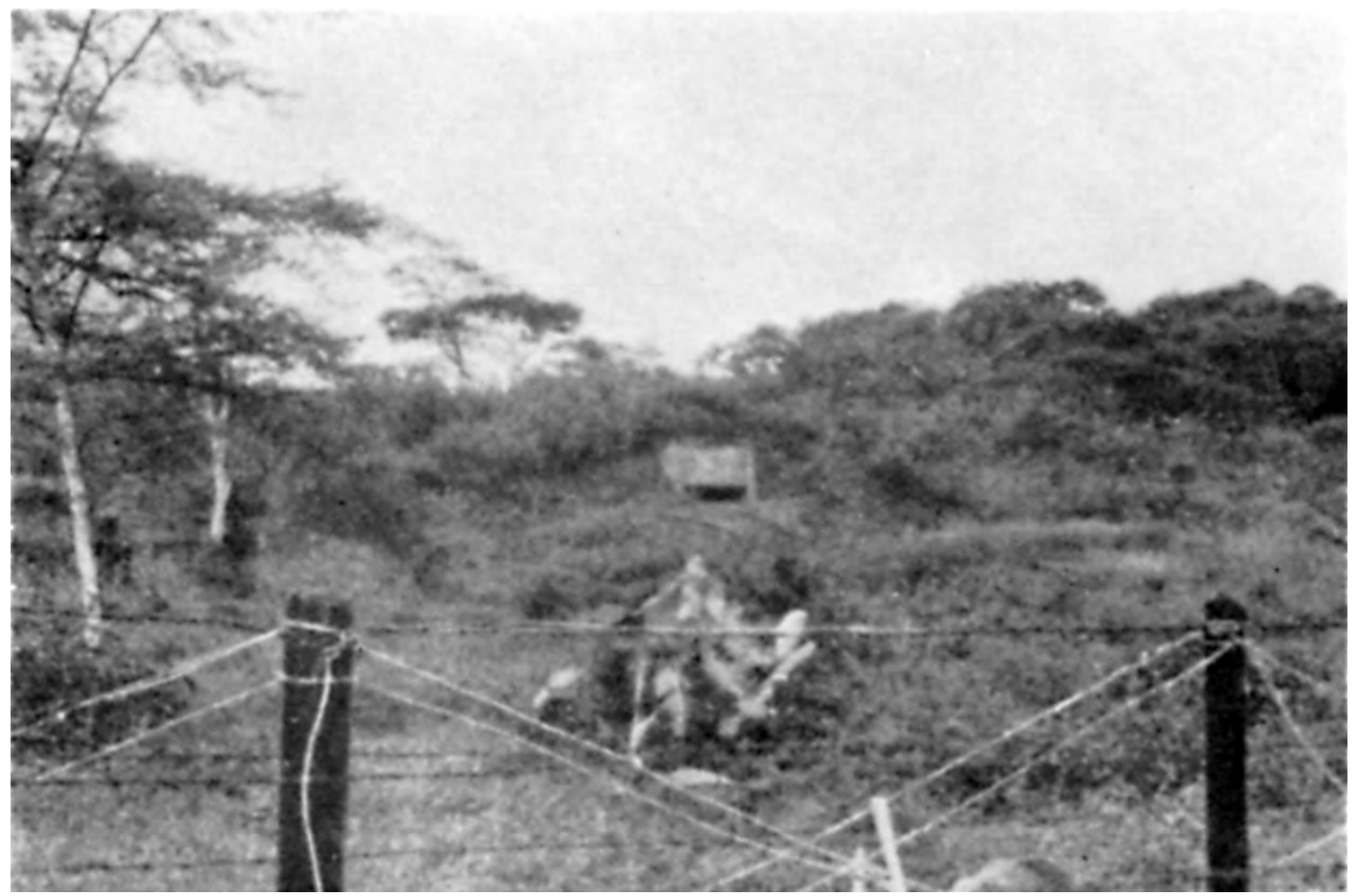

A Pillbox Position and Barbed-Wire Entanglements of the Surabaya Stronghold

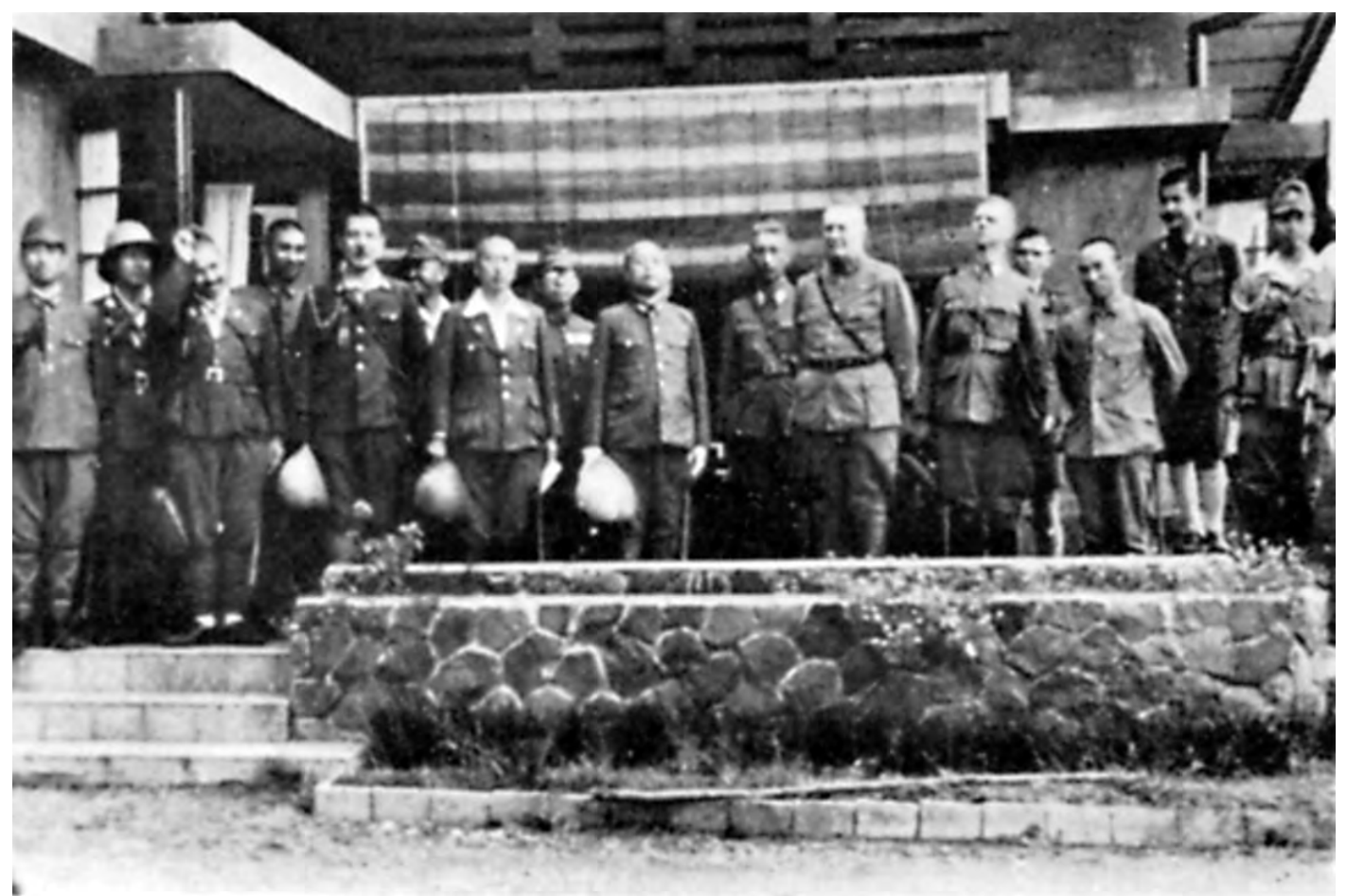

Commemorative Photograph After the Meeting on the Surrender [of the Dutch East Indies Army] 


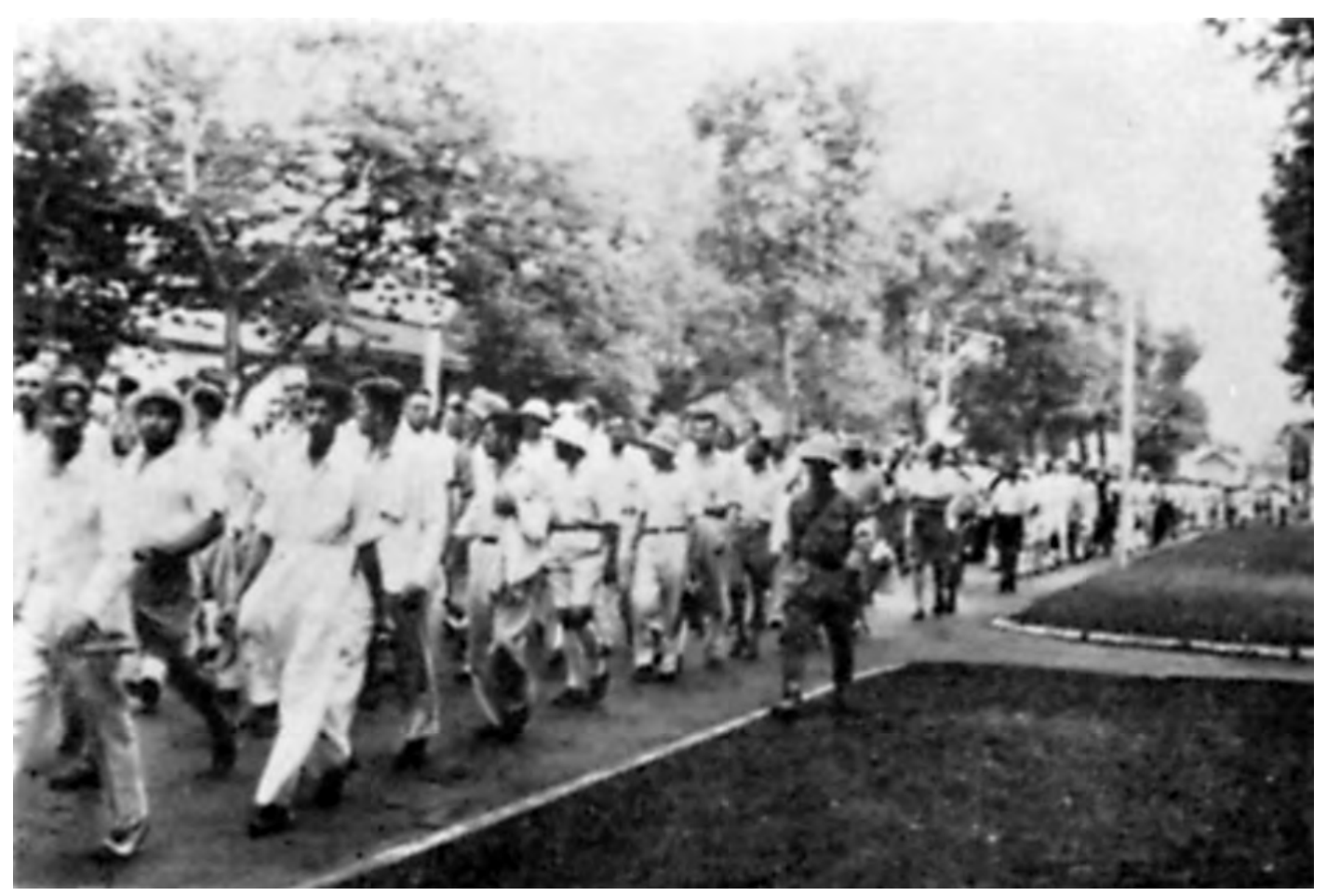

Transport of Prisoners of War 


\section{Foreword}

7 en years after the establishment of the War History Office, we are finally ready to publish some of the results of our research one after another. Following The Invasion of Malaya and The Invasion of the Philippines, we now publish The Invasion of the Dutch East Indies. Although the main purpose of the publication [of this series] is to serve as educational and research material for the Self-Defense Forces, its public use has been taken into consideration as well.

As an enormous quantity of historical documents were destroyed, scattered or lost at the end of the war and, moreover, there was a gap of ten years before the establishment of the War History Office, the difficulties of compiling a history of the war were, compared to past war history compilations, beyond description. Yet fortunately, the understanding of all concerned and the enthusiastic support by a great many veterans helped realize the publication of this work. Here, once again, we would like to express our deep gratitude.

Due to space limitations, not a few parts have been omitted in the account. It is also expected that some parts will need further revision in the future because of newly added collections of historical materials. We earnestly solicit the cooperation and comments of all of you, in or outside the War History Office.

This volume was written by war historiographer Matsuki Hidemitsu.

Further, we would especially like to add that the head of the War History Office and the author are solely responsible for the contents of this volume.

January 1967

National Defense College

Head of the War History Office

Nishiura Susumu 



\section{Preface}

1. This volume focuses on the conduct of the operation by the Sixteenth Army in charge of the Dutch East Indies invasion and on the combat operations of each unit that was based on it. It also deals to a considerable extent with the conduct of the operation by both the Southern Army and [those parts of] the Navy that cooperated in it.

2. The acquisition of oil resources was the primary objective of [Japan's] offensive operations into the South. The operations were executed in such a way that the Fourteenth and the Twenty-fifth Armies, operating respectively in the Philippines and Malaya, should first establish firm footholds, and then, using these as stepping stones, the Sixteenth Army should occupy the vital areas of the Dutch East Indies that contained oil resources. These offensive operations into the South had not [yet] been planned as of the end of July 1941 (about four months before the opening of hostilities), when [on 1 August] the United States, Great Britain and the Netherlands put into effect a total [oil] embargo against Japan. This volume gives an outline of the transition from the beginnings of the southern question to the start of the southern advance.

3. The Dutch East Indies invasion was connected to the surprise attack on Hawaii and the operations in the Philippines, Malaya, British Borneo, Hong Kong, Guam and Rabaul. This volume also touches on its connections with these operations, in addition to the supreme command of Imperial General Headquarters [IGHQ] and that of the Southern Army.

4. The Dutch East Indies invasion was a transoceanic landing operation, unprecedented in its scale in the military history of the world at that time. Moreover, it also included the [Imperial] Japanese Army's first-ever paratroop operation. Accordingly, close cooperation between the Army, the Navy and [their] Air Forces was absolutely necessary. These joint operations are considered to be critically important and are described in considerable detail.

5. As soon as the initial stages of the war produced great military gains, the Southern Army seized the momentum and, ready to push ahead to further military gains, decided to carry out the invasion of the Dutch East Indies about one month ahead of schedule. After receiving the approval of IGHQ and the Navy Southern Task Force, it determinedly strove to realize this. As a result, the allied forces did not succeed in transporting in time two divisions of reinforcements for Java that had been announced, and they had to call off their sailing. Even so, the operations of the Japanese invasion units involved a great deal of strain. These circumstances are also recounted in detail in this volume.

6. On executing the paratroop operation in southern Sumatra, it turned out that the occupation of the Palembang airfield had to be given priority over that of the Palembang oil refineries. Moreover, at the time of the invasion of Java, some confusion was caused when the Shōji Detachment decided to act on its own initiative, although this led to the unex- 
pectedly quick surrender of the enemy. This background is also described in considerable detail.

\section{Explanatory Notes}

1. In general, date and time are indicated in Japan Standard Time [JST].

2. Time of day is expressed using the two following notations: 2:35 p.m. or 1435.

3. [Concerns the original Japanese text. Not relevant to the translation. Omitted by the editor.]

4. [Concerns the original Japanese text. Not relevant to the translation. Omitted by the editor.]

5. The numbers within parentheses refer to the historical source materials. These are shown together at the end of this volume. 


\title{
Chapter I Outline of the Operation
}

\author{
(See Illustration No. 1)
}

$\mathrm{A}$ s a result of World War I, Japan, the United States and Great Britain came to be referred to as the three great powers. The [former German] equatorial Pacific Islands lying between the U.S. territories of the Philippines and Guam and the U.S. mainland became mandated territories of Japan. From way back, Britain had acquired various rights and interests in China with Singapore and Hong Kong serving as its footholds. Seeking Anglo-American support, China subsequently tried to reduce Japan's vested rights in China. Intensification of the confrontation between Japan and the United States and Britain was inevitable. In 1922, the Anglo-Japanese Alliance was annulled and in the same year Japan discontentedly signed the Washington Naval Treaty, followed by the London Naval Treaty of 1930. In 1931, the Manchurian Incident occurred, which led to Japan's withdrawal from the League of Nations in 1933.

These developments were followed by the North China Incident in 1937 (later renamed the China Incident). In the meantime, the Soviet Union and Germany had been building up their national strength and, in November 1936, Japan concluded the Anti-Comintern Pact with Germany. The China Incident steadily assumed more serious proportions, at first particularly through British interference. However, when Germany annexed Austria and occupied Czechoslovakia in 1938, tensions rose in Europe and it now became the United States rather than Britain, which gave active support to China. American anti-Japanese pressure first began with economic measures. In July 1939, the United States gave notice to Japan that it would abrogate the U.S.-Japan Treaty of Commerce and Navigation. Economic pressure dealt a heavy blow, as Japan, poor in resources, had to replenish its resources exhausted in the China Incident. Moreover, it was desperate about its military preparedness to cope with U.S. and Soviet threats. Especially with regard to oil, Japan was almost entirely dependent upon overseas supply. If the United States decided to put an embargo on oil exports, Japan's military preparedness, in particular its sea and air war potential, would simply end up sitting idly, waiting to be rendered powerless. So with the China Incident developing and diplomatic tensions with the Americans and the British rising, the idea of obtaining oil from the nearest and richest oil producing location, i.e. the Dutch East Indies, and securing Japan's national defense became all the more seriously considered. In September 1939, after having concluded the German-Soviet Non-Aggression Pact in the previous month, Germany started its invasion of Poland, which triggered both Britain and France to declare war on Germany, and thus World War II began. During this period, the Netherlands, which held possession of the Dutch East Indies, had become increasingly more on its guard against Japan, but did not display an adverse attitude. In 1934, Japan dispatched a delegation headed by Ambassador Nagaoka Harukazu to Batavia (Jakarta) to promote friendship between [Japan and] the Dutch East In- 
dies. In November 1939, Japan expressed its earnest hope that the European war would not spread to the Netherlands. The Dutch replied that they would be able to avoid that. ${ }^{(12,13)}$

On 2 February 1940, Japan made requests to the Dutch government on matters concerning reciprocal trade, the relaxation or abolition of immigration restrictions, and the granting of facilities for business investment or their enlargement. ${ }^{(12,13)}$ The amount of oil which Japan was importing from the Dutch East Indies at the time had been diminishing year by year from about 870,000 tons in 1937 to about 670,000 tons in 1938 and about 570,000 tons in 1939. ${ }^{12)}$

On 10 April 1940, Germany started a Blitzkrieg operation against Denmark and Norway, and occupied them at a single stroke. Without delay this led to tensions at the Dutch-German border. On 15 April, Foreign Minister Arita proclaimed that it would not be desirable for the stability of East Asia should the war spread to the Dutch East Indies, expressing that Japan was quite concerned about the region. ${ }^{(12,13)}$ In response, the United States immediately made an announcement to check Japan, and then, on 7 May, it announced that it would station its fleet in Honolulu for an indefinite period of time. ${ }^{(13)}$

On 10 May, the Germans launched a major offensive towards the west. The Netherlands immediately declared war on Germany, but were instantly defeated, and on 13 May, the Dutch Queen and her government fled to London. ${ }^{(13)}$ In the meantime, on 11 May, Japan once more formally requested all involved countries to ensure the status quo of the Dutch East Indies. ${ }^{(12,13)}$ On the same day, the [Japanese] Navy unofficially informed the Fourth Fleet that it would be dispatched to Palau. The Dutch East Indies, on the other hand, notified Japan on 12 May of an import licensing system for chemical products, textile yarn, cotton fabrics, etc. ${ }^{(13)}$

Finally on 16 May, in reply to Japan's aforementioned requests of 2 February, the Dutch government-in-exile stated that it had no intention to restrict exports to Japan. [In return] on 20 May, Japan demanded a firm commitment to the export of 1,000,000 tons of oil, 200,000 tons of bauxite and other [items] to Japan. ${ }^{(12)}$ The Netherlands replied on 6 June, but its answer was rather equivocal. ${ }^{(12,13)}$

In June, Italy entered the war and in the same month France surrendered to Germany and Italy.

Along with its support of Britain, the United States adopted a posture of actively containing Japan, which had signed an Anti-Comintern Pact with both Germany and Italy. In June, the United States proclaimed an embargo on the export of machine tools to Japan. ${ }^{(13)}$ In July, it announced a plan to establish a fleet for the Atlantic as well as one for the Pacific. ${ }^{(13)}$ In the same month, the United States designated oil and scrap iron for export to Japan as items requiring an export license. ${ }^{(13)}$

Having forced the British retreat at Dunkirk on 29 May, Germany advanced its best troops to the English Channel and intensified air strikes on Britain, making the collapse of the British Empire seem imminent. ${ }^{(13)}$ Confronted with this sudden change of the [military] situation, on 27 July, the Liaison Conference between IGHQ and the Government decided upon an Outline of the Main Principles for Coping with the Changing World Situation. In this outline, it was decided to "facilitate the settlement of the China Incident and seize a favorable opportunity to settle the southern question," and "with respect to the Dutch East Indies, for the time being to strive to secure its essential resources by diplomatic means." (3)

At that time, the Dutch East Indies position was that it would agree to exporting bauxite, rubber and tin as requested, but concerning oil it wished to have the actual exports of the past three years serve as a basis. Moreover, it specifically wanted to let the oil companies, 
most of which were American or British, handle the agreements. Also, if Japan would not agree to a package-deal import of materials besides the thirteen items Japan had asked for, an increase in oil export would be very difficult. ${ }^{(12)}$ Basing itself on the decisions in the Outline of the Main Principles, the government [of Japan] decided on 24 August to dispatch Minister of Commerce and Industry Kobayashi Ichizō to the Dutch East Indies. ${ }^{(12,13)}$

On 23 September, Japan's armed forces advanced into northern French Indochina, and on the 27th of the same month, Japan, Germany and Italy signed the Tripartite Pact. ${ }^{(13)}$ In reaction to these developments, the United States announced an embargo on [the export of] scrap iron to Japan on the 26th of this month. ${ }^{(13)}$

Fearing that an American oil embargo was not far away, Special Envoy Kobayashi, who had arrived in Java on 12 September, started negotiations and did his best to secure the import of the desired amount of oil, but nonetheless it was as if beating the air. ${ }^{(13)}$ As the China Incident developed, the Netherlands (the Dutch East Indies) had gradually increased its dependence on Britain, but about this time it came more and more to rely on the United States. ${ }^{(13)}$

In October, a meeting was held in Singapore by the United States, Great Britain and the Netherlands. ${ }^{(13)}$

Special Envoy Kobayashi negotiated with the aim of importing 3,150,000 tons or, if possible, 3,800,000 tons of oil. ${ }^{(12)}$ However, with the Netherlands (the Dutch East Indies) caught in a dilemma between the United States and Britain on one side and Japan on the other, an agreement to allow Japan to import its desired quantity remained far from likely. Thus on 17 October, Special Envoy Kobayashi was recalled home. ${ }^{(12)}$

On 11 December, a new ambassador, Yoshizawa Kenkichi, headed from Tokyo to Java. ${ }^{(13)}$ Ambassador Yoshizawa arrived in Batavia (Jakarta) on the 28th of the same month ${ }^{(13)}$ and began negotiations. But as these negotiations were not substantially different from those with the Americans and the British, no progress was made.(13)

In April 1941, Japan concluded the Russo-Japanese Neutrality Pact. ${ }^{(13)}$ The following month, the United States applied the Lend-lease Act to China. ${ }^{(13)}$

Following the outbreak of the Russo-German War in June, Japan began a large-scale mobilization, disguised as an exercise (KANTOKUEN or Special Grand Maneuvers of the Kwantung Army) in July, in order to secretly concentrate its military force in Manchuria and Korea. In addition, Japan advanced into southern French Indochina. On 26 July, the day after the convoy carrying the occupation units left the harbor of Sanya on Hainan Island, the United States announced a firm policy of freezing all Japanese assets in the United States. ${ }^{(13)}$ Britain and the Netherlands immediately followed suit. ${ }^{(13)}$ On 14 June, Ambassador Yoshizawa received an instruction from Tokyo to break off the negotiations and headed home on the 27th of the same month. ${ }^{(13)}$

Japan had already committed large forces to the prosecution of the China Incident and it had to cope with the newly developed Russo-German War. Since April of that year, it had been making every effort to negotiate with the United States in order to avoid war against the latter, but now it found itself at the mercy of a total oil embargo. While renewing its efforts to negotiate with America, it now had to prepare a plan to obtain oil resource areas should the negotiations fail. At that time, a general plan for the southern operation had not yet been drawn up..$^{(10,17)}$

Despite Japan's efforts to steer clear of war with the United States, there was no prospect of successfully completing negotiations with the United States. Finally on 1 December, there 
was no option left but to decide upon war. ${ }^{(10)}$ On 8 December, Japan's armed forces carried out a surprise attack on the U.S. Pacific Fleet in Hawaii and at the same time sudden attacks on Malaya, the Philippines and other locations, thus launching the southern operation. ${ }^{(13)}$

\section{The Southern Operation Plan}

The number of divisions which the Army was able to commit to the southern operation was eleven out of a total of fifty-one divisions. ${ }^{(10)}$

The principal aim of the southern operation lay in getting hold of the Dutch East Indian oil resources. ${ }^{(10,17)}$ The idea of the southern operation was, in short, to make a sudden attack against British Malaya and the U.S.-ruled Philippines in order to set up footholds for a quick conquest of the Dutch East Indies, and while occupying the latter and securing its resources, to establish a defense line along the Sunda Islands.

In Southeast Asia, oil was produced in Miri in British Borneo, Tarakan and Balikpapan in Dutch Borneo, northern and southern Sumatra and eastern Java, of which the largest oil fields were those of Palembang in southern Sumatra, and the nearer locations were the oil fields of Miri and Tarakan. ${ }^{(21)}$

In British Malaya, the British had maintained the stronghold of Singapore as the basis for their rule in East Asia for over a hundred years. Manila was the capital of the U.S.-ruled Philippines. Davao [in southern Mindanao] and Jolo [in the Sulu Islands] were strategic locations dividing the Dutch East Indies and the Philippines, and could serve to launch an attack on the Dutch East Indies. The strategic center of the Dutch East Indies was Java, with the Dutch East Indies Government-General located in Batavia (Jakarta). Kuching in British Borneo was a most suitable location for conducting air operations into southern Sumatra and western Java. In order to occupy the Palembang oil fields, it was preferable to have air support from Malaya and Kuching. Air support from southern Sumatra, Kuching, Banjarmasin (in the south-eastern part of Dutch Borneo), Makassar and Kendari (both on southern Celebes) was required for the conquest of Java. Ambon and Kupang (on Timor Island) in the eastern Dutch East Indies were key locations for covering the left wing of the advance towards Java, and for cutting off reinforcement from Australia. In order to set up air bases in southern Celebes and Banjarmasin, it was necessary to occupy those in Menado, Tarakan and Balikpapan, and get them ready for use as relay fields.

The [Imperial Japanese] Army formed the Southern Army to carry out the southern operation. The Southern Army's operations were planned to be executed roughly as follows:

\section{The Southern Army}

Twenty-fifth Army (consisting of the Imperial Guard Division, the 5th Division and the main force of the 18th and the 56th Divisions as its core): First, the 5th Division will land on the northeast coast of Malaya; then the Imperial Guard Division (under the command of the Fifteenth Army in the initial stage of the operation), starting from French Indochina will pass through Thailand and attack the British forces in Malaya. After breaking through the border, they will dash to Singapore via good roads along the west coast. The main force of the 18th Division (from southern China) will be transported to southern Thailand, and the main force of the 56th Division (from Kyūshū) will be transported to the southeast coast of Malaya to conduct a landing operation at an opportune moment. 
Kawaguchi Detachment (an element of the 18th Division): Starting from French Indochina, it will occupy Miri and then Kuching in British Borneo.

Fourteenth Army (consisting of the 16th and the 48th Divisions, the 65th Brigade, and the 5th Air Force as its core): In the initial stage of the war, advance units will land at northern Luzon, Legaspi and Davao. By about day fifteen, the main force of the army (consisting of the 48th Division's main force as its core) will land at Lingayen Gulf and a part [of the army] (the main force of the 16th Division) will land at Lamon Bay and first will swiftly seize Manila. The 65th Brigade (standing-by in Taiwan) will be in the second transport. After the capture of Manila, the 48th Division will be diverted to the Java invasion, while the Fifth Air Force will be diverted to the Thailand (Burma) area.

Fifteenth Army (consisting of the 33d and the 55th Divisions as its core): It will stabilize Thailand and then head for Burma. In the initial stage, the army will command the Imperial Guard Division. The main force of the 55th Division (standing-by in northern French Indochina) and the 33d Division (from northern China) will be successively transported.

Sixteenth Army: After seizing Jolo Island and vital areas of the Dutch East Indies outside Java, it will capture Java.

One detachment (an element of the 38th Division or the 55th Division was envisioned) will occupy Ambon and then Kupang.

The Sakaguchi Detachment (an element of the 56th Division) will successively seize Jolo Island, Tarakan Island, Balikpapan, and Banjarmasin.

The 38th Division will operate, after the capture of Hong Kong, under the command of the Sixteenth Army, and will capture southern Sumatra with its main force.

The $2 \mathrm{~d}$ Division will proceed from mainland Japan and land on western Java as the division constituting the army's main force.

The 48th Division, after capturing Manila, will operate under the command of the Sixteenth Army and land on eastern Java.

1st [Paratroop] Raiding Group: It will raid and occupy the oil refinery at Palembang. After the drop, it will operate under the command of the Sixteenth Army.

Third Air Force: It will give assistance mainly to the operation of the Twenty-fifth Army; this will be followed by assistance to the Sixteenth Army's operations in southern Sumatra and western Java.

As for the Navy, a Southern Task Force was formed for the southern operation. The Combined Fleet (mainly consisting of the First Fleet through the Sixth Fleet, the Southern Expeditionary Fleet, and the First and the Eleventh Air Fleets), deployed the First Air Fleet (a fleet mainly consisting of aircraft carriers) and the Sixth Fleet (a fleet mainly consisting of submarines) to Hawaii, the Fourth Fleet to the [Japanese] Pacific Islands, the Fifth to the east of mainland Japan and the First to the Inland Sea [of Japan]. Most of the remaining units formed the Southern Task Force. The strength of the Southern Task Force was composed of the Second and the Third Fleet, the Southern Expeditionary Fleet, and the Eleventh Air Fleet (landbased [naval] air units) as the core, while the commander of the Southern Task Force was the commander in chief of the Second Fleet. The Southern Task Force's operations were planned to be executed roughly as follows: 
Main Force of the Southern Task Force (Second Fleet): Its main unit, in the initial stage deployed in the South China Sea, will support overall operations. Afterwards, it will be diverted to Palau, and support the conquest of the Dutch East Indies.

Malaya Unit (Southern Expeditionary Fleet, joined by an element of the Eleventh Air Fleet): It will support the Army operations in Malaya, British Borneo and Sumatra.

Philippines (Dutch East Indies) Unit (Third Fleet): As the unit for the Philippines in the initial stage, it will assist the Fourteenth Army in its operations. During this period, the main unit will operate with Magong as its base. When the Philippines operation is by and large over, it will become the Dutch East Indies Unit. The Navy will capture Menado, Kendari, and Makassar with its own naval forces, while assisting the Sixteenth Army in its operations (except for the Sumatra operation). The main unit, after proceeding from Magong toward Davao, will move south along Celebes.

Air Unit (main force of the Eleventh Air Fleet): After destroying the enemy air power from Taiwan to the Philippines, it will follow the route of the Dutch East Indies Unit, ready to destroy the air power [of the enemy] on Java from the east, while supporting the Sixteenth Army and the Dutch East Indies Unit in their operations.

\section{Characteristics of the Dutch East Indies Operation}

The operation to capture the Dutch East Indies had the following characteristics:

1. It depended on the success or failure of the surprise attack on Hawaii by the Carrier Task Force (the First Air Fleet as its core).

That is to say, the Malaya operation and the Philippines operation were to be pushed through regardless of the result of the Hawaii attack, but the execution of the Dutch East Indies operation largely depended on the success or failure of the Hawaii attack.

2. The operation was designed to strategically use the Philippines, British Borneo and Malaya as stepping stones. Therefore, the progress of operations in these areas, those of the Fourteenth and the Twenty-fifth Armies in particular, would be decisive.

3. As this was a big transoceanic operation over a wide area with long distances to be covered, coordination between different corps and detachments carrying out subdivided operations was imperative.

4. The entire operation required close cooperation between ground, sea and air units.

That is to say, it was necessary to conduct repeated offensive operations to destroy the enemy air power, followed by moving forward a convoy, escorted by navy war vessels under friendly air cover, after which ground units, upon landing ashore, immediately should occupy and equip air bases, then upon the air bases being made ready, the air force units should advance to these bases and engage in their [next] air operations.

Moreover, even though ships and war vessels had been allotted to the southern operation to the fullest extent possible, the ships and escort war vessels were required to be diverted back and forth (north and south), left and right (east and west), because the operation was planned to transport, in a short period of time, an extremely large force of military units, too large compared to the number of available vessels. Therefore the units concerned had to move as an elaborate clockwork of gears and cogwheels. 
5. The Malaya operation and the Philippines operation were to be carried out by means of surprise attacks (or at least sudden attacks). However, the Dutch East Indies operation was to be carried out after a considerable number of days had elapsed. Therefore, the operation had to launch an assault on well-prepared allied forces. Furthermore, it was expected that during that period Java would be provided with U.S. and British reinforcements (from Australia and India), and also be reinforced with forces falling back from the Philippines and Malaya, whereas it was also expected that the Japanese forces would have sustained an accumulated loss of aircraft, ships, etc.

6. The operation would be executed depending on the progress of the Malaya and Philippines operations. Therefore it was an operation that followed the strategic guiding principle of enhancing war achievements, requiring a well-matched momentum of speed and strength.

7. Two out of the three divisions of the Sixteenth Army were divisions that were to join the operation only after the capture of the strongholds of Hong Kong and Manila. There were many other units which were used in two different operations.

8. Attached to the operation was the task of safely occupying oil fields and securing them before their destruction by the allied forces.

\section{Scheduling Issues, the Defining Feature of the Execution of the Operation}

The surprise attack on Hawaii had succeeded. The sudden attacks on Malaya and the Philippines had been successful as well. Great Britain had brought two of its largest battleships, HMS Prince of Wales and HMS Repulse, to Singapore right before the opening of hostilities. For the Southern Task Force, being equipped with only two outdated battleships, the Kong $\bar{o}$ and the Haruna, and cruisers and less powerful war vessels, these [battleships] meant a serious threat. However, on day three after the opening of hostilities, the Japanese forces succeeded in sinking these two British battleships by means of an air attack. The southern operation thus progressed with unexpected speed. The operation was carried out by and large as planned before the opening of hostilities. There had been minor changes of the plan, but they were due to the unexpectedly favorable development of the military situation. A comparison of the actual performance of the southern operation and the planned schedule would be as follows:

\section{Forecast of IGHQ}

Capture of Manila around day 35 after the opening of hostilities

Capture of Singapore

around day 100

Landing at Java around day 103

Surrender of the Dutch East Indies around day 120

\section{Actual result}

day 25 after the opening of hostilities

day 69

day 84

day 92

If a specific remark were to be made on the execution of the operation, it would be about [the changes in] the invasion schedule. Prior to the opening of hostilities, the Southern Army 
had proposed to the Navy's Southern Task Force to shorten the invasion schedule and made an agreement with it on 10 November. However, as the initial stages of the operation developed smoothly, the Army quickly proposed a further shortening of the invasion schedule. Upon obtaining approval from IGHQ, the Army made the Navy's Southern Task Force conform to this, and on 1 January 1942, they agreed on a new schedule, which afterwards the Army obstinately tried to fulfil. The outline of changes in the schedule of the landings on Java, including the initial plan and the actual consequences, was as follows ( $x$ represents the date of the opening of hostilities):

[1941]

5 November

10 November

8 December

10 December

[1942]

1 January

28 January

4 February

6 February

8 February

9 February

10 February

23 February

27 February
IGHQ's plan

around day $x+103$

Internal agreement between the Southern Army and the Southern Task Force

approx. around day $\mathrm{x}+80$

Opening of hostilities (surprise attack accomplished)

Sinking of two large British battleships

Agreement between the Southern Army and the Southern Task Force (approved by IGHQ)

approx. day $x+70$

At the request of the Navy, a postponement with the smallest of margins was decided after consultation [between both forces]

day $x+77$ for eastern Java

day $x+75$ for western Java

The Navy requested the Southern Army for a two-day postponement of the day for the invasion of southern Sumatra

The Navy requested the Southern Army for a further four-day postponement of the invasion of southern Sumatra

The Southern Army unwillingly agreed to the request and postponed the date for the invasion of western Java, but advanced the date for the invasion of eastern Java

day $x+76$ for eastern Java

day $x+81$ for western Java

One-day advance of the invasion of southern Sumatra

Reaching a new agreement, setting the date for the invasion of both eastern and western Java at

day $x+80$

Two-day postponement of the date of the operation due to the appearance of an allied fleet under sail

day $x+82$

Another one-day postponement due to the appearance of an allied fleet under sail

day $x+83$ 
1 March Simultaneous landing operations on both eastern and western Java day $x+83$

The original idea of IGHQ was to render Malaya, the Philippines and British Borneo powerless and to use these locations as bases for successive captures of air bases on territories outside Java, then to move air units forward, and focus their air attacks on Java from [the bases in] southeastern Sumatra, southern Borneo and southern Celebes. When the air attacks showed results, the troops were to cross the sea to Java and carry out the landings. The Southern Army, on the other hand, synchronized the departure time of the convoys with the time of air deployment, and on this basis directed the operation.

The details of each development will be explained one by one.

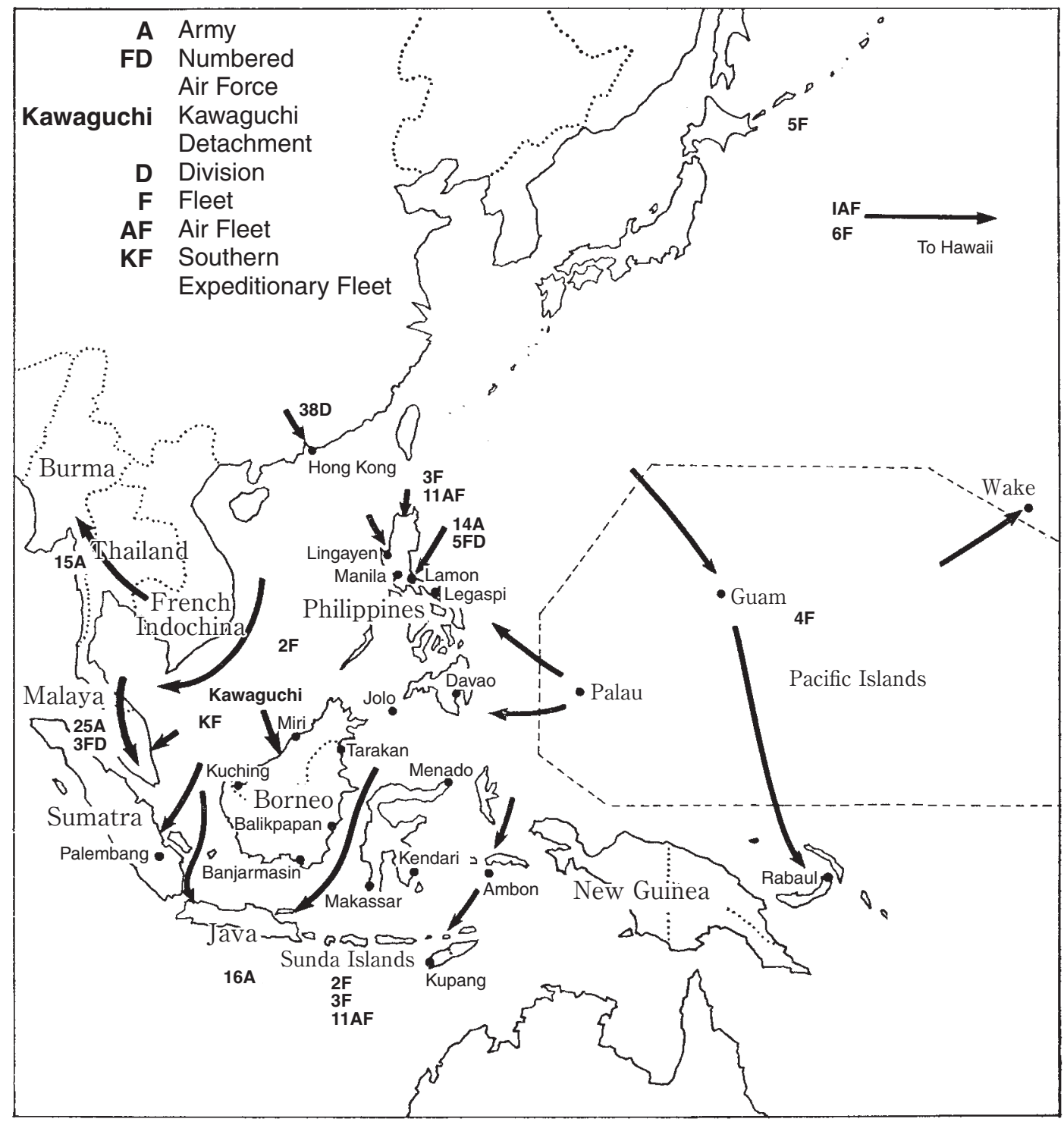

Illustration No. 1-Overview of the Operation Until March 1942 


\section{Chapter II Situation of the Dutch East Indies}

(See Illustrations No. 2 and No. 3)

The situation of the Dutch East Indies was in outline as follows: ${ }^{(21)}$

\section{Topography}

$\mathrm{R}$ anging from latitude $6^{\circ}$ north to $11^{\circ}$ south, and from longitude $95^{\circ}$ to $141^{\circ}$ east, the Dutch East Indies consisted of many islands extending into both the northern and the of Borneo, however, was British territory and the eastern part and a small enclave on the northern coast of [western] Timor were Portuguese.

The total area of the Dutch East Indies covered 1.9 million $\mathrm{km}^{2}$ and its total population amounted to over sixty million. The size of the area was about fifty-eight times that of the Dutch homeland, and about three times that of the total area of Japan at the time, including Korea, Taiwan and Sakhalin. Its length stretching from east to west was approximately 2,700 miles, which was about the same as the distance from Taiwan to Sakhalin.

The population density per square kilometer was 316 for Java (including Madura), 175 for the islands of Bali and Lombok, 26 for the island of Timor, 22 for Celebes, 17 for Sumatra, 4 for Borneo and 2 for the Moluccas. New Guinea was such a primitive place that no survey had [yet] been possible.

The general situation of each island was as follows:(21)

\section{Sumatra and Java}

Sumatra and Java respectively take up about $470,000 \mathrm{~km}^{2}$ and $130,000 \mathrm{~km}^{2}$. From west to east and close to the south coast [of both islands], a mountain range runs like a spinal column as far as the Lesser Sunda Islands. This mountain range is a volcanic chain with many cone-shaped mountains. Whereas the southern coastal areas are steeply inclined, the northern coasts are gently sloped, and have many plains and plateaus. The rivers of Java generally flow along the bottom of V-shaped valleys; their water levels vary greatly depending on the rainfall. The rivers of Sumatra are generally big; some even allow steamship navigation. The lower reaches of the rivers are large wetlands. Entire areas of Palembang and Medan on Sumatra are made up of oil fields.

Although Java occupies no more than one-fourteenth of the total area of the Dutch East Indies, it was crowded with approximately forty million people, two-thirds of the total Dutch East Indies population. Including Batavia (Jakarta), which was the seat of the Dutch East Indies Government-General, with a population of about 600,000 and Surabaya with about 400,000, Java had up to seven cities with a population of 100,000 or more. In Java, the mountains and fields had been developed, as had been the transport facilities 
(both railways and motor roads). Batavia and Surabaya, along with Cilacap on the south coast, constituted strategic military ports as well as commercial ports. Surabaya served as the base of the Dutch East Indies fleet, and had been provided with a stronghold. West of Surabaya were the oil fields of Cepu.

2. Celebes

Celebes is $190,000 \mathrm{~km}^{2}$ in area (more than twice the size of Hokkaidō) with many mountain ranges and gorges. Celebes produced nickel and also had large reserves of iron ore. Key locations on this island were Menado, Makassar and Kendari.

3. Borneo

The island of Borneo is the third largest island in the world with an area of more than $750,000 \mathrm{~km}^{2}$, of which the Dutch territory occupied approximately $540,000 \mathrm{~km}^{2}$. Its border with British Borneo consists of a mountain system. From its centre, mountain ranges branch out to the east, the southeast and the southwest. In between these ranges there are plains and large rivers. With an exceedingly sparse population and many regions yet untrodden by man, most of the island consisted of thick jungle and swamp. The island of Tarakan and the Sanga-Sanga area in Dutch Borneo, along with the area of Miri in British Borneo, were oil-producing locations. The oil gained at Tarakan, being of particularly good quality, was highly valued by the Japanese Navy. The oil of the Sanga-Sanga area was transported by an oil pipeline to Balikpapan, where it was shipped off.

4. Timor

The island of Timor is about the same size as Kyūshū. The eastern part and a small enclave on the northern coast of western Timor were Portuguese territory. It was about the same size as Shikoku. In Dutch Timor was the city of Kupang.

Note: Portuguese Timor had a Portuguese colonial government with a civilian governorgeneral residing in Dili.

5. The Moluccas

Also called the Spice Islands. The city of Ambon on Ambon Island, which had developed of old as a spice trade center, served as the region's center. In the area of Bula in eastern Ceram there was an oil field. The Moluccas had many unexploited places.

6. New Guinea

Being the world's second largest island, it covered an area a little over $800,000 \mathrm{~km}^{2}$, of which the Dutch territory extended from longitude $141^{\circ}$ east onward to the west, occupying an area of a little more than $390,000 \mathrm{~km}^{2}$, which was almost equal to the total area of the main islands of Japan. A central (snow-capped) mountain range like a spinal column linked a series of mountains of 4,000 meters or higher and covered in snow the whole year round. The island had many areas never set foot on by man and consisted of many vast wetlands and dense jungles.

Resources and Industry were in outline as follows: ${ }^{(21)}$

1. The annual production of oil for 1939 was approximately eight million tons (about twenty times that of Japan). The annual quantity needed by Japan at the time was about five million tons, but Japan was not self-sufficient as regards even 10 percent of that amount. The quantities that the Dutch East Indies had been exporting to Japan as well as the quantities 
requested by the Japanese were as previously described. Below is an overview of the production at each location in the Dutch East Indies.
Sumatra
Palembang and surrounding area
3 million tons
Borneo
North Aceh area
1 million tons
$\begin{array}{ll} & \text { Tarakan } \\ \text { Java } & \text { Cepu area } \\ \text { Ceram } & \text { Bula area }\end{array}$
New Guinea and others
1 million tons
0.7 million tons
1 million tons
0.1 million tons
some amount

The Dutch East Indies oil business was for the most part controlled by American or British capital and there also lay the primary cause which complicated the oil issues.

2. Iron ore was undeveloped [at that time] however, it was said that there were deposits of approximately one billion tons in southeastern Borneo and Celebes.

3. Tin was produced on Bangka, Belitung and Singkep, three islands off the coast of Sumatra. Their annual production was between 30,000 and 40,000 tons. This put them into third place in the world.

4. Bauxite was produced on the island of Bintan with an annual production of approximately 400,000 tons.

5. Nickel was mainly produced in Celebes.

6. Manganese was produced in the neighborhoods of Cilacap and Semarang on Java, in Bengkulu on Sumatra, and the islands of Bintan, Bangka and Belitung. The annual production of these areas together reached 12,000 tons.

7. Other than that, coal (with an annual production of 1.5 million tons), sulfur and tungsten were produced.

8. With an annual production of about 450,000 tons, rubber accounted for about one-third of the total annual world production, making the Dutch East Indies the world number two [rubber producer] after Malaya.

9. The production of quinine, a specific medicine for malaria, accounted for 93 percent of the total world production, and the production of kapok amounted to 78 percent of the total world production. It was also said that the Dutch East Indies was one of the world's three biggest producers of sugar.

As many of these resources were indispensible for the self-sufficiency of Japan, in May 1940, Japan requested from the Dutch a firm commitment to the export to Japan of thirteen items, which consisted of the following products (and their quantities): ${ }^{(12)}$

- oil (1 million tons or more)

- rubber (20,000 tons or more)

- manganese ore

- wolfram ore

- chromium pig iron

- castor oil

- molybdenum
- bauxite (200,000 tons or more)

- tin (ore as well, 3,000 tons or more)

- nickel ore

- scrap iron

- industrial salt

- cinchona bark 


\section{Administration and Inhabitants}

After the Japanese troops had landed in the Dutch East Indies, the operation progressed with striking ease through the spontaneous cooperation of the local inhabitants, and the tenor of the administration of the occupied areas turned out to be different from that in the Philippines and Malaya. The [previous] administration of the Dutch East Indies and its inhabitants, however, was in outline as follows: ${ }^{(21)}$

In 1602, the Dutch established the East India Company as a chartered company with Ambon serving as its base. In 1618, the East India Company moved to Jakarta and renamed this [city] Batavia. In 1798, the Dutch government disbanded the East India Company and took direct control over the East Indies.

The Dutch East Indies Government-General had its seat in Batavia and consisted of eight departments. Although the director of each department was appointed by the GovernorGeneral, the chiefs of the army and the navy departments were appointed by the Monarch.

Regional administration was divided into Java (including Madura and called the inner territory) and the outer territories, consisting of the remaining areas. Then further division into residencies was undertaken, resulting in Java being divided into seventeen residencies with the exception of the principalities of Solo and Yogyakarta, Sumatra being divided into ten residencies, etc. Each residency was then further divided into sub-residencies [regencies], and a Dutch official was posted at either level.

In the principalities of Solo (capital Surakarta) and Yogya (capital Yogyakarta) the ruler enjoyed a large measure of self-rule. Living in a royal palace and maintaining a private army, he preserved the old traditions and customs from the feudal age; however, concerning matters of administration, the [native] ruler was supposed to accept the advice and supervision of the Dutch resident.

The Dutch government neglected the education of the indigenous population and avoided the appointment of natives [to colonial government service]. After the Russo-Japanese War, movements for independence arose among the indigenous population, but the Dutch Government-General suppressed them.

According to the national population census of 1930, the total population of the Dutch East Indies was approximately 60,730,000, which could be broken down into an indigenous population of approx. 59,140,000, and about 1,230,000 Chinese, 210,000 Dutch, 7,400 Germans, 7,200 Japanese, 2,400 British, 800 Swiss, 600 Americans, and other nationalities.

While the overseas Chinese used their talents as merchants, the Dutch, the British and the Americans were engaged in the large-scale production of agricultural and forestry products for export, as well as in the exploitation of mineral products. As for the indigenous population, most of them were engaged in a feudal type of subsistence farming. Literate indigenous inhabitants formed only five percent of their population.

\section{The Dutch East Indies Military Preparations}

Holland essentially was a naval power. As previously explained, its homeland was occupied by Germany in May 1940. The land power of the Dutch East Indies was not very great and, after the occupation of the homeland, it was forced to rely on local reinforcements to strengthen its war potential and on reinforcements from the Americans and the British (Australia) to build up its military preparations. 
The intelligence that the [Imperial Japanese] Army General Staff Office had gained by 10 September 1941 was as follows: ${ }^{(23)}$

Strength of the Dutch East Indies Army

Before WW II, its force consisted of an inner territory army of 19,300 men (fifteen infantry battalions, two artillery regiments and others, Europeans accounting for thirty percent), and an outer territory army of 12,000 men (fourteen infantry battalions and others, Europeans accounting for fifteen percent), making a total of 31,300 men. However, at present the inner territory army amounts to 50,000 men (two divisions as its core), the outer territory army 20,000 men (fifteen infantry battalions as its core), reaching a total of 70,000 men, which is a 2.2-times increase in size. At present, preparations are ongoing to consolidate the force, setting 100,000 men [in total] as a goal, however it is very unlikely that this goal will be achieved in this year.

Their disposition is as shown in Illustration No. 3.

Strength of the Dutch East Indies Navy

$\begin{array}{lcccc} & \text { Cruisers } & \text { Destroyers } & \text { Submarines } & \text { Others } \\ \text { Before the war } & 2 & 8 & 12 & 21 \\ \text { At present } & 5 & 8 & 12 & 56\end{array}$

Strength of the Dutch East Indies Air Force

The total number of the aircraft of the army and the navy before the war was about 320 (of which about 150 were front-line aircraft).

However, at present they have about 500 aircraft (of which 300 are front-line aircraft) at their disposal, which means the numbers have approximately been doubled.

Furthermore, there will apparently be another increase of about 150 aircraft in the future. 


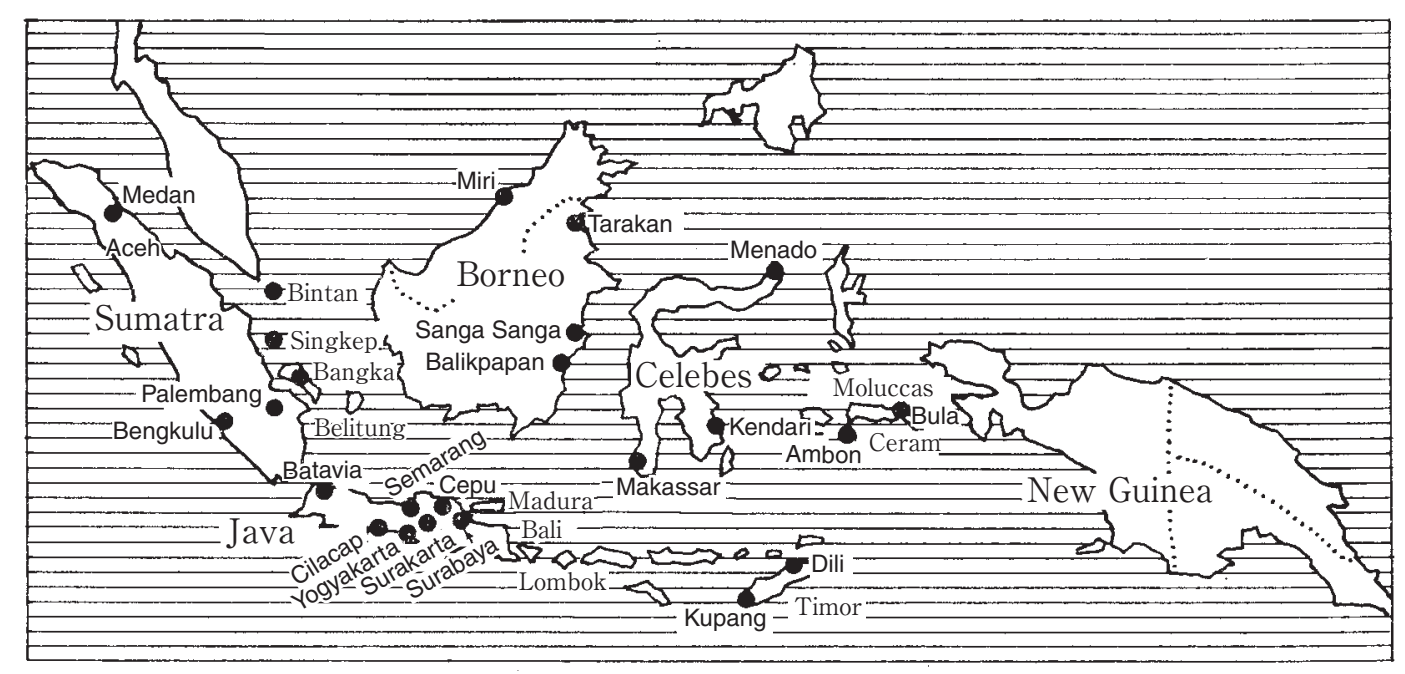

Illustration No. 2-Topographical Map

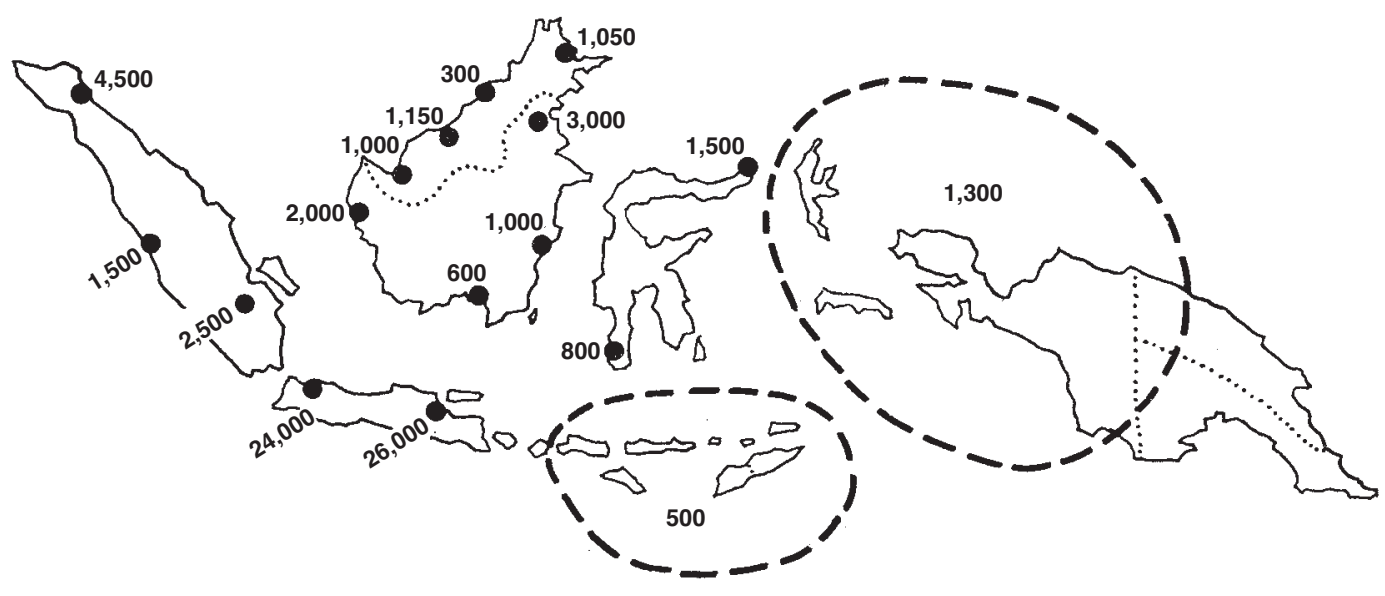

Illustration No. 3-Disposition of the Dutch East Indies Army Strength (Including British Forces in British Borneo). Survey as of 10 September 1941 


\section{Chapter III Operational Preparations Prior to the War}

\section{Situation Until Summer 1941}

$\mathrm{A}$ s stated above, the Dutch government sought refuge in England on 13 May 1940. On 29 May, the British forces retreated from Dunkirk, and in June the French army surrendered to Germany. Now that a German landing on British soil was foreseeable and, like an orphaned child, the Dutch East Indies was left on its own in eastern Asia, IGHQ, for the first time, started research on a southern operation. At that time, as preparation for worst-case scenarios, IGHQ had drawn up operation plans for war against either the Soviet Union, the United States or Britain, or against two or more of them, while handling the China Incident at the same time. However, specific plans were made only for cases of dealing with a single country and, moreover, operations that assumed the Dutch East Indies as an hypothetical enemy had never been considered at all. Therefore, the Army Department of IGHQ assigned personnel to separately study the four areas of the Philippines, Malaya, Hong Kong, and the Dutch East Indies. Maj. Okamura Masayuki, staff officer of Section 2 (Operations Section), was ordered to conduct the investigation into the Dutch East Indies. He took up the assignment from 16 July onwards along with Maj. Shiho Kenkichi, head of the Resources and Materials Group of Section 3 (Organization and Mobilization Section), and Maj. Katō Tsukasa, member of the Economic Mobilization Bureau of the Ministry of War. ${ }^{(17,20)}$ The findings of Staff Officer Okamura's investigations were in outline as follows: ${ }^{(17)}$

The military strength of Java is built around a core of two divisions, but with about two-thirds of the force consisting of indigenous troops, they do not have much of a fighting spirit. Although more and more pillbox positions are built in all areas of the Dutch East Indies, even those along the Bandung stronghold front are perfunctory and of a typical standard type. The barbed-wire entanglements that are being constructed are little more than a poor excuse. If it were possible to land unexpectedly and carry out a surprise attack, we could probably force the surrender of the whole Dutch East Indies Army on Java within a couple of days with only one of our brigades. However, from the point of international good faith we cannot do this. [On the other hand,] if we were to attack a militarily prepared Java, it would come down to an assault. In this case, we would need to deploy two divisions. But once the landing is carried out successfully, Java could be conquered in about one week because of its well-developed grid of good motorways.

In June and July, IGHQ judged that if Japan were to settle things in the southern area, Great Britain, which faced a crisis, and the United States, which was struggling to cope with the drastically changed situation in Europe, could not afford to interfere in the issues between Japan and the Netherlands. ${ }^{(17,18)}$ However, from the beginning of August, the British gradually regained their self-confidence in defending their homeland. As stated above, IGHQ had stud- 
ied the four areas separately, but in the middle of August it made a comprehensive study of these four areas together. ${ }^{(18)}$ In this study, the assessment was made that if Japan were to settle things in the southern area, both the Dutch and the British would put up resistance while maintaining an inseparable relationship; the United States, however, would maintain a cautious attitude in East Asia. ${ }^{(17,18)}$ Thus a plan was conceived which proposed the following: in dealing with the southern area one army with two divisions as its core would deliver a surprise attack on the Dutch East Indies, followed by an attack on Malaya by another army; if the situation should require it, the Dutch East Indies and Malaya were to be attacked simultaneously; when war against the United States was inevitable, again another army would attack the Philippines; the sequence of the attacks on the Dutch East Indies, Malaya and the Philippines was to be determined according to the contingency of a war against the United States. ${ }^{(18)}$

As it was, the German air raids against Britain failed to show the desired results and gradually Britain showed signs of recovery. In the meantime, while actively supporting Britain, the United States showed a willingness to contain Japan. In the Navy Department of IGHQ the view grew stronger that if [Japan] were to resort to military force in order to settle the southern question, war against the United States would be inevitable because the United States and Britain were inseparably tied together. Therefore, on 28 August the Navy Department presented the Army Department with a memo about the interpretation of the Outline of the Main Principles for Coping with the Changing World Situation (as previously explained the decision by the Liaison Conference [between the IGHQ and the Government] on 27 July to "seize a favorable opportunity to settle the southern question") and requested the Army Department to take it into careful consideration. At the time, the Army Department had been entirely preoccupied with the matter of stationing troops in northern French Indochina based on the Outline, and did not have any attention to spare for the Dutch East Indies issue. ${ }^{(17,18)}$ On 23 September, the stationing of troops in northern French Indochina became a fact. $(7,13)$ Then on 26 September, the United States declared an embargo on scrap iron against Japan. ${ }^{(13)}$

Included as members of the (aforementioned) Kobayashi Delegation, which had been dispatched in accordance with the Outline, were Col. Ishimoto Itsuo, chief of the Resource Section of the Ministry of War, and Lt. Col. Nakayama Yasuto, chief of Section 3 of General Affairs of the Army Aviation Headquarters (later in charge of the Military Administration Department of the Dutch East Indies invasion army), along with Navy Capt. Nakahara Yoshimasa and Navy Lt. Cdr. of Engineering Nakasuji Tōichi. ${ }^{(46)}$ The party left Tokyo on 30 August and arrived in Java on 12 September, where they tried to negotiate the import of 3,150,000 or more tons of oil to Japan, but the negotiations were very tough. ${ }^{(12,13)}$ On 17 October, the delegation was recalled. The only result it had achieved was an agreement on the import of $1,800,000$ tons of oil. ${ }^{(12)}$

By advancing into northern French Indochina, Japan tried to shut down the supply route to the Chiang Kai-shek [Jiang Jieshi] regime, but it brought no prospects for settling the China Incident. Furthermore, after having put an embargo on scrap iron, the United States was showing signs of taking measures to put an embargo on oil. And, to top it all, the negotiations between Japan and the Netherlands gave only cause for pessimism. Under these circumstances, the southern question flared up again in October at IGHQ and the Army as well as the Navy Department engaged in another series of studies. The Army Department made the following judgment:(10) "As the German forces are expected to land on the British mainland 
next spring, ${ }^{(10,17)}$ and we may assume that the United States and Britain can be separately [dealt with], we need to take advantage of the favorable opportunity to settle the South (Dutch East Indies and Malaya) in order to settle the China Incident." Subsequently, the Army Department laid down its course of preparing "an operation to first capture the Dutch East Indies by a sudden attack with an army consisting of the 5th and the 48th Divisions as its core, and then to capture Malaya with another army with four divisions as its core, including the Imperial Guard Division and the 18th Division." Accordingly, on 12 October, it issued orders that the 5th Division assemble at Shanghai, and, on the 22d, that the Imperial Guard Division assemble in Shantou [Swatow], the 18th Division in Guangdong [Canton] and the 48th Division on Hainan. ${ }^{(10)}$ The Navy Department initially agreed to this; however, at the end of the month, it stated to the Army Department that "dealing with the South would ultimately come down to war against the United States. If anything, Japan should [face this fact and] be determined to fight the United States from the start." $(7,10)$

On 15 November, the Navy Department put a preparatory fleet mobilization into motion.

It was obvious that putting into motion a southern operation that would entail war with the United States had to be avoided. The above-mentioned plan of the Army Department drawn up in mid-October had already disappeared by the end of October. ${ }^{(7,10)}$ In the meantime, Maj. Kondō Dempachi had taken the place of Staff Officer Okamura as officer in charge of the Dutch East Indies [operation]. ${ }^{(17)}$

Late in November, a discussion arose about mediating the border dispute between French Indochina and Thailand [Franco-Thai War] that had just broken out. If this [situation] could be guided to our advantage, then air bases could be pushed forward into southern French Indochina and Thailand, which would facilitate the [Japanese] transoceanic operations. ${ }^{(7,17)}$ In the previous month, the United States, Britain and the Netherlands had held a [defense] conference in Singapore. On the recall of Special Envoy Kobayashi (he had left Surabaya on 22 October), it had been decided to dispatch again a special envoy, Yoshizawa Kenkichi, who took his departure on 30 November [editor's note: in Chapter I, p. 3, it is said that he left Tokyo on 11 December, which agrees with Yoshizawa's autobiography]. Ambassador Yoshizawa arrived in Batavia (Jakarta) on 28 December, and negotiations started from 2 January 1941. ${ }^{(13)}$

The Army Department of IGHQ followed closely the start of Ambassador Yoshizawa's negotiations and the progress of the mediation of the border dispute between French Indochina and Thailand. ${ }^{(7,17)}$ Earlier, when Special Envoy Kobayashi was to return home, Lt. Col. Nakayama Yasuto had been instructed to stay behind. Col. Ishimoto Itsuo, however, had died of illness on 29 September while in Java. ${ }^{(13)}$ When the new ambassador, Yoshizawa, headed for the Dutch East Indies, he was accompanied by Col. Harada Yoshikazu, staff officer of the Army Department of IGHQ (and later vice chief of staff of the Dutch East Indies invasion army), and Maj. Kuriya Tsugunori, member of the Army General Staff Office (and later staff officer of the Dutch East Indies invasion army), as members of the delegation. ${ }^{(37,42)}$ About two months after the arrival of these two officers, Col. Nakayama Yasuto (promoted to colonel in March) returned home. ${ }^{(46)}$

Until around June or July 1940, the Army Department of IGHQ had thought that Great Britain and the Netherlands could basically be separately [dealt with]. Since about August, it had started considering Britain and the Netherlands as inseparable [when dealing with them], but the United States and Britain as still separable. However, by the end of 1940, it 
had concluded that Britain, the United States and the Netherlands were inseparable. ${ }^{(17)}$ The reason was that the circumstances had changed: Britain had pulled itself together again and a German landing on British soil had become unlikely; the United States had started its active support for Britain, China and the Netherlands; moreover, in Singapore the [defense] conference between the United States, Britain and the Netherlands had [also] been held. The Army Department, considering it imperative to avoid war with the United States, kept a very close watch on the resumption of negotiations with the Dutch and on the [Japanese] mediation between French Indochina and Thailand. ${ }^{(7,17)}$ Nevertheless, it kept implementing the above-mentioned plans made in October when the southern question had resurged. The Thai-French Indochina Border Dispute [Franco-Thai War] was settled through [Japanese] mediation on 11 March 1941, but in the meantime the following measures had been put into effect:

1. In October the 5th Division was ordered to carry out landing operation exercises. Moreover in December, the Imperial Guard Division, the 18th and the 48th Division received orders to carry out exercises for operations in tropical environments, in particular for landing operations. These divisions had been unofficially informed that their area of operation would be Malaya. ${ }^{(1,10)}$

2. In addition, in December the Research Department of the Taiwan Army was established and instructed to carry out investigations, examinations and tests of direct necessity to a southern operation by March 1941. ${ }^{(16)}$

3. Concerning the Dutch East Indies, sorting of information had been started since about December. Lt. Col. Murakami Kimisuke, head of the Southern Group of Department 2 (Intelligence Bureau; and later intelligence staff officer of the Dutch East Indies invasion army), along with Lt. Cols Furuki Shigeyuki, Kadomatsu Shōichi and Ishikawa Susumu, and Maj. Hashida Sei, all of the same department, had been assigned to the study and sorting of data. ${ }^{(19)}$

Lt. Col. Sendō Shunzō, member of the Transport Section of the Economic Mobilization Bureau at the Ministry of War (and later staff officer for shipping of the Dutch East Indies invasion army) had been ordered to examine the data particularly from the standpoint of shipping transport and landing operations. ${ }^{(44)}$

4. In about December, the Inspectorate General of Military Training (whose deputy chief was Lt. Gen. Imamura Hitoshi, and whose chief of its General Affairs Department was Maj. Gen. Okazaki Seizaburō; Lieutenant General Imamura later became commander of the Dutch East Indies invasion army, and Major General Okazaki its chief of staff) conducted a study exercise of bicycle units from Toyohashi City to Kanamarugahara [Kanamaruhara] in Tochigi Prefecture simulating the traversing of Malaya from north to south. ${ }^{(36)}$

5. From January through February 1941, a training trip for staff officers was held in Kyūshū, during which operation rehearsals, mainly for landing operations, were carried out by the relevant staff officers. ${ }^{(17)}$

6. From late March through early April, the Army Department of IGHQ held an exercise of its ground, sea and air units with the 5th division serving as the core, in which after crossing the sea from eastern China and landing at Karatsu in northern Kyūshū, they were supposed to capture Sasebo. The exercise simulated the crossing of the ocean, landing at "the neck" or a narrow part of the Malay Peninsula, and then capturing Singapore. Com- 
mander of the army of this exercise was Lt. Gen. Imamura Hitoshi, the deputy chief of the Inspectorate General of Military Training. ${ }^{(17)}$

As previously explained, the southern question, which had resurged in October of the previous year, outwardly quieted down while the negotiations between Japan and the Netherlands were resumed and the mediation of the border dispute between French Indochina and Thailand went on.

However, as soon as the mediation of the Thai-French Indochina border dispute was concluded on 11 March, Foreign Minister Matsuoka, receiving a magnificent send-off, set out to visit Germany, Italy and the USSR on the following day. On 13 April, the day the SovietJapanese Neutrality Pact was signed, ${ }^{(7)}$ an assembly of army and division commanders was held, which was filled with an unusual air of excitement. ${ }^{(11)}$ During the assembly, $2 \mathrm{~d}$ Division Commander, Lt. Gen. Yoshimoto Teiichi was informally instructed by the chief of Army General Staff to conduct research and training for a southern operation. ${ }^{(56)}$ The $2 \mathrm{~d}$ Division, having returned home from Manchuria in November of the previous year (1940), had earned a reputation for bravery with, among others, the night attack on Gongchangling during the RussoJapanese War. It had also played an active role as the division stationed in Manchuria when the Manchurian Incident had occurred.

On 27 September of the previous year the Tripartite Pact had been signed. (7) On the 12th of the following month, the American President had declared that he would oppose this pact, and in the same month the United States had held the [defense] conference in Singapore with Britain and the Netherlands. ${ }^{(13)}$ [In such circumstances,] Foreign Minister Matsuoka's recent visit to Germany, Italy and the USSR hinted at an important turning point. In the operation plan of the administrative year 1941 (drawn up at the end of 1940), it had been laid down that in a worst-case scenario of war with the United States, the corps in charge of the invasion of the Philippines would be the 7th and the 16th Divisions. The divisions, which had been instructed at the end of 1940 by IGHQ to carry out training while simulating an operation in Malaya, were, as already mentioned, the Imperial Guard Division and the 5th, the 18th and the 48th Divisions. No divisions were mentioned other than these. Now, however, the name of the $2 \mathrm{~d}$ Division appeared, with Java as its target. ${ }^{(17)}$

As a result of Foreign Minister Matsuoka's European visit, the Soviet-Japanese Neutrality Pact, which was of great significance, had been signed in mid-April, ${ }^{(7)}$ and simultaneously Japan had started negotiations with America, ${ }^{(7,10)}$ while on Java, Ambassador Yoshizawa still continued his invariably difficult negotiations.

In May, discussions to station troops in southern French Indochina appeared. However, these did not originate from a scheme to aggressively carry out a southern operation, but rather from the possibility to obtain [military] bases should the worst come to the worst, as continuing efforts were still being made to avoid war between Japan and the United States. ${ }^{(10,}$ ${ }^{17)}$ In the meantime, the $2 d$ Division had been training local tactics in the vicinity of Onahama in Fukushima prefecture while simulating an operation on Java.(56)

On 17 June, the negotiations between Japan and the Netherlands broke down and on the $22 \mathrm{~d}$ of the same month Germany began its eastern campaign against Russia. On 2 July, the Outline of National Policies in View of the Changing Situation (i.e. proceeding with the advance into the South, while settling the northern question in response to the changing situation) was decided upon, after which, on 7 July, a mobilization of military forces directed at the northern 
area (i.e. the Special Grand Maneuvers of the Kwantung Army or KANTOKUEN) was launched. On 25 July, the forces to be stationed in southern French Indochina departed Hainan Island. On the following 26th, the United States officially announced that it had frozen all of Japan's assets in the United States. Britain and the Netherlands immediately followed suit. This sudden turn of events caused the Army and Navy Departments of IGHQ to seriously tackle the planning of operations against the United States, Britain and the Netherlands, as well as an invasion of the southern areas. Before this opportunity arose, definite plans for an invasion of the southern areas had not yet been made, due to the developments mentioned above..$^{(7,10)}$

The Yoshizawa delegation left Java for home on 27 June. ${ }^{(13)}$ Col. Harada Yoshikazu returned home at the same time, while Maj. Kuriya Tsugunori remained in Batavia (Jakarta). ${ }^{37,42)}$ He did not return home until one month prior to the opening of hostilities. ${ }^{(42)}$

\section{Preparations in the Summer and Fall of 1941}

\section{Start of Full-scale Research; Conception of a Three-division Plan for the Dutch East Indies}

When the United States froze all Japanese assets on 26 July and essentially instituted an oil embargo in consequence of Japan's advance into southern French Indochina, the Japanese Army, based on the Outline of National Policies of 2 July, was in the midst of a large-scale mobilization of military forces directed against the North [the Soviets], and the concentrated transport [of troops] to Manchuria and Korea. ${ }^{(10)}$

On 9 August, it was decided to abandon the idea of carrying out a northern operation within the present year, and [instead] to prepare a southern operation scheduled to be ready by the end of November should the negotiations with the United States fail.(10) On this occasion, it was decided that for the time being Maj. Shigeno Nobuo, staff officer of Section 2, and Maj. Nishiura Setsuzō, staff officer of Section 3 of the Army Department of IGHQ, were to exclusively devote themselves to research on the Dutch East Indies operation. ${ }^{(45)}$ Later, Major Nishiura was appointed staff officer for the lines of communication of the Dutch East Indies invasion army.

It spoke for itself that the Navy, which was supposed to play the leading role in a war against the United States, took the lead over the Army in its research. In early mid-August the Navy Department was the first to hold a [tactical] map exercise. ${ }^{(10)}$ This Navy map exercise tentatively scheduled the Army's capture of Singapore to take place about five months after the opening of hostilities because the problem of Thailand also had to be dealt with. Consequently, it advocated a "clockwise advance" (note: advancing via Malaya toward Java was referred to as a "counter-clockwise advance," and advancing via the Philippines toward Java and Sumatra was called a "clockwise advance.") The plan of this exercise was to capture the Philippines from the north in two months, followed by capturing Java sometime between day $x+80$ and day $x+90$ (note: $x$ represents the day of the opening of hostilities), then capturing Singapore through a pincer attack, i.e. by simultaneously attacking from Sumatra in the south and from Malaya in the north. In this map exercise the forces deployed by the Army for the capture of the Philippines consisted of two divisions, and the same number were deployed for the capture of the Dutch East Indies as well. ${ }^{(10)}$ The previous summer, Staff Officer Okamura had judged that two divisions should be deployed for the Dutch East Indies (Java), 
which remained unchanged in this exercise. After handing over his charge of the Dutch East Indies to Staff Officer Kondō, Staff Officer Okamura was sent to inspect the 5th Division's landing exercise in northern Kyūshū (March), the 48th Division's invasion operation in Fuzhou (April) and the Twenty-fifth Army's advance into southern French Indochina (July). ${ }^{(17)}$

Against the Navy Department's clockwise plan, the Army Department advocated a counter-clockwise plan, arguing that a swift advance via Malaya was imperative not only because it was sounder and would lead to an early overthrow of British authority as well as to the blocking of British reinforcements, but also because it might make a shortening of the schedule feasible. ${ }^{(10)}$

After the above-mentioned Navy map exercise, the Army Department carried out its own war game on $14-15$ August, which resulted in the following tentative conclusions: ${ }^{(10)}$

1. The invasion of Malaya and the invasion of the Philippines are to be commenced at the same time. A slight delay in the invasion of Java on account of this will be all right.

2. The 48th Division is to be incorporated into the Philippines invasion army. After the capture of Manila, it is to be diverted to the Dutch East Indies invasion army and to land in Java.

3. After the capture of Hong Kong, the 38th Division is to land in southern Sumatra and occupy Palembang.

4. The $2 \mathrm{~d}$ Division shall be employed for Java in accordance with the plan that has been nursed for a while.

5. Based on the above, the Dutch East Indies invasion army shall be reorganized into a force with three divisions as its core.

6. A paratroop unit shall be dropped at Palembang.

As a result, the following changes were made to the previous deployment plan of the armies:

Malaya invasion army: was to consist of the Imperial Guard Division (stationed in French Indochina at the time), the 5th Division (in eastern China at the time), the 18th Division (in southern China at the time) and the 48th Division (also in southern China at the time) as in the original plan, but the 48th Division was removed.

Philippines invasion army: was originally to consist of the 7th Division (in Hokkaidō at the time) and the 16th Division (in the Kyōto divisional district at the time), but [in the new plan] it was to consist of the 16th and the 48th Division.

Dutch East Indies invasion army: was to be made up of two divisions in the original plan, that is, the $2 d$ Division (in the Sendai divisional district at the time) and another division, but it was now provided with three divisions: the $2 \mathrm{~d}$ Division, the 38th Division (in southern China at the time and to join after the capture of Hong Kong), and the 48th Division (to join after the capture of Manila).

The deployment of a paratroop unit at Palembang was an idea that had been proposed by Staff Officer [Prince] Takeda-no-miya when Staff Officer Okamura Masayuki had presented his report on the outcome of his research on the Dutch East Indies operation in September of the previous year (1940). ${ }^{(17)}$ At that time, the Japanese forces did not have a paratroop unit, but three months later in December, a [Paratroop] Raiding Training Department was established for the first time within the Hamamatsu Army Flying School. The department had 


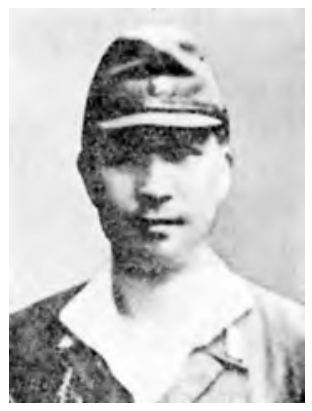

only twelve members. These twelve had started their research by studying written information from the German military and by listening to the experiences of airmen who had to make jumps due to flight accidents. In April of the following year (1941), the [Paratroop] Raiding Training Department became the Baichengzi Army Flying School [Paratroop] Raiding Training Department, and was transferred from Hamamatsu to Baichengzi in Manchuria, where it had started to train several hundred men as paratroop specialists. ${ }^{(93)}$

The 38th Division was stationed in a swampy area in southern China. IGHQ Staff Officer, Maj. This division had been formed following the China Incident, and its in[Prince] Takeda-nomiya fantry regiments carried a regimental number in the two-hundreds. Nevertheless, the division was an elite division with abundant battle experience and highly valued by IGHQ, which was convinced that the division would be able to accomplish the capture of Palembang after capturing the Hong Kong stronghold. In order to capture Palembang, [the division] would have to travel up several rivers for about eighty to ninety kilometers as the crow flies, and carry out the operation on swampy ground. As the 38th Division was well accustomed to rivers and swampy lands in southern China, it was, also in this respect considered to be the most suitable division. ${ }^{(18)}$ The division's troops had been recruited from the Nagoya divisional district.

The 48th Division was a division equipped with motor vehicles and organized in the previous fall. Its core was made up of the Taiwan Mixed Brigade (consisting of two regiments; known as the Hada Detachment, it had earned a reputation for bravery in the China Incident [1937]), and the 47th Infantry Regiment (originally based in Ōita City) of the 6th Division. Almost all of its men were from Kyūshū. As previously explained, since the previous fall the division had held an exercise simulating traversing Malaya lengthwise all the way down to capture Singapore, and it had carried out a landing operation at Fuzhou in the spring [of 1941] as well. The division had assembled on Hainan Island.

IGHQ later (around October) gave the following nicknames to the three divisions that it had decided to assign to the Dutch East Indies invasion in this [new deployment plan]; it may be understood that each of the names reflected the division's history as well as its task at hand:

2d Division:

38th Division:

48th Division:

\author{
Isamu-heidan [the "Braves"] \\ Numa-heidan [the "Swampers"] \\ Umi-heidan [the "Mariners"]
}

On 12 August, [the Army Department of] IGHQ ordered the 48th Division to transfer from Hainan to Taiwan. Following that (on 23 August), it instructed the division to carry out training on the assumption of capturing Surabaya on Java straight after capturing Manila. ${ }^{(1,10)}$ In addition, it ordered the [Paratroop] Raiding Training Department, which was training in Baichengzi, to transfer to Takanabe in Miyazaki Prefecture. ${ }^{(93)}$

In September, the [Paratroop] Raiding Training Department of the Baichengzi Flying School was upgraded and strengthened into the Army [Paratroop] Raiding Training Department under the direct control of the inspector general of Army Aviation, and transferred to Takanabe. Its structure was reorganized into one training regiment (four companies) and one 
training air unit (two squadrons). ${ }^{(39)}$ At the Inspectorate General of Army Aviation, Lt. Col. Itoda Isamu took charge of the department's organization and training. Later he was appointed staff officer of the Dutch East Indies invasion army and, as such, flew in over Palembang along with the raiding units and carried out a belly-landing while the troops parachuted. (39) $^{(39}$

During that period (mid-August) the main concern of the Army Department of IGHQ was whether it was feasible at all to impose double duty on the 38th and the 48th Division and whether the preparation of the paratroop unit would be ready in time. ${ }^{(10)}$ The department was not apprehensive about the operations after the landing on Java; it figured that the 48th Division would swiftly capture the Surabaya stronghold, and that the $2 \mathrm{~d}$ Division, which had earned worldwide fame at Gongchangling, would conquer the Bandung stronghold right after the capture of Batavia. ${ }^{(17)}$

Afterwards, on 23 August, the Army Department conducted another war game on the southern operation. When it had contacted the Navy Department on the previous day, it had been informed that the Navy Department "estimated that there was a probability of one-intwo of having to face east halfway through the execution of the southern operation in order to deal with the U.S. Pacific Fleet; that the Navy estimated that the timing of when it could put the Java invasion army ashore could be set to about ninety days after the opening of hostilities; and that it was working on [the possibility of] conducting an air strike on Hawaii with the full force of its main aircraft carriers right at the opening of hostilities."(10)

Several days before (in mid-August), the Navy Department had made

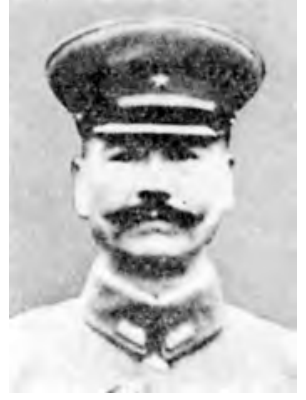

Vice Chief of the Army General Staff Lt. Gen. Tsukada Osamu a request to the Army Department for the Army's cooperation in the capture of Rabaul. ${ }^{(17)}$ However, Vice Chief of the Army General Staff Tsukada Osamu flatly refused, saying, "[the Army] does not have any manpower to waste on such an undertaking." $(10,43)$

The war game of 23 August was conducted with reinforced forces (increased from six to ten divisions), compared to the previous game. While the force for the Philippines and the Dutch East Indies remained the same, the 21st Division (stationed in China), the 55th Division (in Zentsūji), and the 56th Division (in Kurume) were also included for operations in the French Indochina area, along with the Imperial Guard Division, as well as the 5th and the 18th Division. ${ }^{(10)}$

\section{[The Situation] After the Decision on the Main Points for the Implementation of Imperial National Policy of Early September (See Illustration No. 4)}

\section{Report to the Emperor on the Prospects for the Southern Operation}

After the Liaison Conference between IGHQ and the Government on 2 September, an Imperial Conference was held on 6 September, and the Main Points for the Implementation of Imperial National Policy were decided upon; the most important point stated that "... resolved not to flinch from waging war against the United States (and Britain and the Netherlands), war preparations shall be completed approximately by late October."(3)

At this time, Chief of the Army General Staff Sugiyama reported to the Emperor that in [the Army's] estimation, it was possible to complete the southern operation in about five months, including one month and a half for the Philippines, and about one hundred days 
for Malaya, and the Dutch East Indies. The power of the allied forces, relevant to the southern operation, as estimated at that time by IGHQ, was as follows: ${ }^{(2)}$

\begin{tabular}{|c|c|c|c|c|c|c|}
\hline \multicolumn{7}{|l|}{ Air Force } \\
\hline Area & \multicolumn{3}{|c|}{ Current } & \multicolumn{3}{|c|}{ Increase by the end of October } \\
\hline Hong Kong & \multicolumn{3}{|c|}{10 aircraft } & & & \\
\hline Philippines & \multicolumn{3}{|c|}{160 aircraft or more } & \multicolumn{3}{|c|}{100 aircraft } \\
\hline Malaya & \multicolumn{3}{|c|}{200 aircraft or more } & \multicolumn{3}{|c|}{150 aircraft } \\
\hline Burma & \multicolumn{3}{|c|}{50 aircraft } & \multicolumn{3}{|c|}{50 aircraft } \\
\hline Dutch East Indies & \multicolumn{3}{|c|}{300 aircraft } & \multicolumn{3}{|c|}{150 aircraft } \\
\hline In total & \multicolumn{3}{|c|}{720 aircraft or more } & \multicolumn{3}{|c|}{450 aircraft } \\
\hline \multicolumn{7}{|l|}{ Navy } \\
\hline Classification & Aircraf & Carriers & Battleships & Cruisers & Destroyers & Submarines \\
\hline U.S. Asiatic Fleet & & 4 & & 2 & 14 & 17 \\
\hline U.S. Pacific Fleet $(\mathrm{H}$ & Hawaii & 7 & 7 & 18 & 46 & 28 \\
\hline Dutch East Indies F & Fleet & & & 5 & 8 & 19 \\
\hline \multicolumn{7}{|c|}{ British China Fleet and } \\
\hline East Indies F & Fleet & 2 & 2 & 27 & 15 or 16 & 1 \\
\hline In total & & 13 & 9 & 52 & 83 or 84 & 65 \\
\hline
\end{tabular}

(Note by the author: it seems that the "aircraft carriers" [in this chart] include seaplane tenders and flying boat tenders.)

$\begin{array}{lc}\text { Army } & 19,200 \\ \text { Hong Kong } & 35,000 \\ \text { Burma } & 80,000-90,000 \text { (of which } 60,000-70,000 \text { regular army) } \\ \text { Malaya } & 3,500 \\ \text { British Borneo } & 163,000 \text { (of which } 43,000 \text { regular army) } \\ \text { Philippines } & 1,800 \\ \text { Guam } & 70,000 \text { (of which } 50,000 \text { in the inner territory [i.e. Java]) } \\ \text { Dutch East Indies } & \end{array}$

Against this, the [Imperial Japanese] Army was considering to assign ten divisions, two numbered air forces (about 600 aircraft, supplemented by 500 Navy aircraft), and 2.1 million tons of army vessels. More specifically, the plan envisioned one division for French Indochina, five divisions for Malaya (of which one was to have part [of its force] advance into southeastern Burma while securing Thailand with its remaining force) and one numbered air force; two divisions and one numbered air force for the Philippines, and three divisions for the Dutch East Indies (of which one division would have double duty within the southern area).(2)

When Chief of the Army General Staff Sugiyama explained the [Army's] expectation that it would be possible to complete the southern operation in about five months, His Majesty pointed out the erroneous estimate that Chief of Staff Sugiyama had made on the China Incident as war minister, and strongly warned against [too much] optimism. ${ }^{(16)}$ Later (in November) when the headquarters of the Southern Army was organized, the staff of the 
headquarters, hearing about the Emperor's warning, made a resolve to "pledge on the honor of the southern armies to firmly live up to His Majesty's considerations by completing the southern operation within the term scheduled by IGHQ." (24)

\section{Report to the Emperor on the Mobilization of Forces Scheduled for the Southern Operation}

On 8 September, Chief of the Army General Staff Sugiyama reported to the Emperor about the following mobilization: ${ }^{(10)}$

First half of October: The 16th Division (Kyōto Division — to carry out the primary landing in the Philippines together with the 48th Division), the 55th

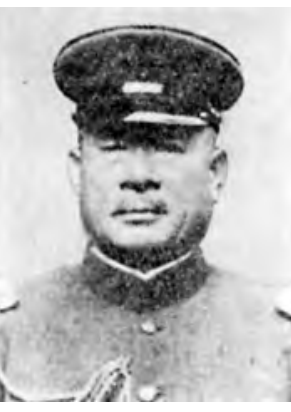

Chief of the Army General Staff General Sugiyama Gen Division (Zentsūji Division - to secure Thailand and occupy the border area of Thailand and Burma), one-third of the 56th Division (Kurume Division), (Sakaguchi Detachment - to capture Guam).

Note: As mentioned previously, in the operation plan for war against the United States., two divisions were assigned to [the operations in] the Philippines and three battalions to [the operations in] Guam. That is to say, the 16th and the 48th Divisions were charged with the Philippines, and the Sakaguchi Detachment with Guam. However, as explained hereinafter, the Army, advocating a counter-clockwise plan, and the Navy, adhering to a clockwise approach, later came to a compromise, in which the Sakaguchi Detachment was directed to the Makassar Strait front and an element of the 55th Division, the Horii Detachment (or South Seas Detachment), was formed for [the operation in] Guam.

Latter half of October: The 2d Division (Sendai Division — to be brought under the Dutch East Indies invasion army and head for west Java), the 65th Brigade ([from] Fukuyama — scheduled for the secondary landing in the Philippines as a reserve for the 48th Division's redeployment).

During his report to the Emperor, Chief of the Army General Staff Sugiyama explained that there was a possibility that by the end of the year, [allied] reinforcements of 50,000 to 60,000 troops from Australia and New Zealand, 100,000 from India, and 10,000 to 20,000 troops from China would be sent to Malaya, Burma and the Dutch East Indies. ${ }^{(2)}$

\section{Continuing Disagreement Between the Army and Navy on the Operation}

On the same day (8 September), the Navy Department was still in favor of a clockwise plan. ${ }^{(9,10)}$ The Army Department, however, had proceeded with its research and considered the counter-clockwise plan a must. Staff Officer Imoto Kumao of Section 2 of the Army Department wrote a memo on that day that "for 'Java,' synchronized landings from the east and the west are more appropriate."

On 10 September, the Navy Department again asked for "support to seize Rabaul," which was flatly turned down as before by Vice Chief of Army General Staff Tsukada. Even when the Navy Department explained that [Rabaul] would "be nothing but an advance position of the Truk Islands," and that it would "have naval guard units take over to return [the Army troops] after the capture," the request was in vain. ${ }^{(9,10)}$ 


\section{Map Exercise at the Naval College}

From the following day, the 11th until the 20th [of the month], the Combined Fleet conducted a map exercise at the Naval College. ${ }^{(105,106,111,113)}$ In the first half, this exercise dealt with general operations, while in the second half the air strike on Hawaii was investigated by only a limited number of staff in the utmost secrecy. The exercise showed that a surprise attack on Hawaii with the full force of all aircraft carriers right at the outset of the war was preferable. On the other hand, concerning the Philippines, the Navy Department wanted to have landings carried out right at the opening of hostilities at Davao as well as in Luzon Island, thereby separating the Philippines from the Dutch East Indies. Furthermore, it also wanted a speedy launch of the Dutch East Indies operation. At the time, the main force of the Philippine Army Air Corps covered the area from the vicinity of Manila to the north. However, as a matter of fact, the flying ranges of the Japanese Navy fighter planes at that time did not allow an attack from Taiwan to Manila and the vicinity, nor did they allow an attack from Palau to Davao and the vicinity (even though their flying range was considerably longer than those of the Army fighter planes). Therefore, if a full-force surprise attack on Hawaii were to be executed with carrier aircraft, then the idea of a landing at Davao right at the opening of hostilities had to be abandoned. So, this war game led to a course of first occupying northern Luzon and after advancing the air bases, occupying the southern Philippines (Davao and Jolo), followed by capturing the Dutch East Indies. ${ }^{(105,106,111,113)}$ The dates for capturing these areas were roughly as follows: northern Luzon on or immediately after the day of the opening of hostilities (day $x$ ), Davao and Jolo approximately between day $x+20$ and day $x+30$, Tarakan and Menado approximately on day $x+50$, Java approximately between day $x+80$ and day $x+90$.

\section{Completion of the First Draft of the Southern Operation Plan and Issue of Summons to Prospective Staff Members}

On 17 September, while the Navy was conducting its map exercise at the Naval College, the Army Department completed its first draft of the southern operation plan. ${ }^{(10)}$

After that, the Army Department summoned the prospective staff officers of the armies for the South and held separate study sessions with the prospective staff officers of each army in the following order: on 25 September with the staff of the Southern Army, on the 26th with the staff of the Philippines invasion army, on the 27th with the staff of the Malaya invasion army, and on the 28th with the staff of the Dutch East Indies invasion army.(23)

The officers summoned as prospective staff for the Dutch East Indies invasion army were the following:(23,36)

Maj. Gen. Okazaki Seizaburō (chief of the General Affairs Department of the Inspectorate General of Military Training; as prospective chief of staff of the army).

Maj. Gen. [Col.] Manaki Takanobu (attached to the Military Affairs Bureau of the Ministry of War; as prospective vice chief of staff).

Lt. Col. Oda Akimitsu (he had been made staff of the Northern District Army since July for the KANTOKUEN [Special Grand Maneuvers of the Kwantung Army] after serving as instructor at the War College; as prospective staff officer in charge of operations).

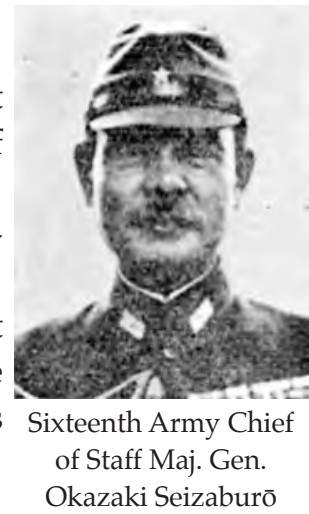


Maj. Yamashita Yutaka (Appointments and Assignment Section of the Ministry of War; as prospective assistant staff officer of operations).

Lt. Col. Murakami Kimisuke (he had been transferred to the Information Department of the Ministry of War after serving as head of the Southern Group of Department 2 of the Army Department of IGHQ; as prospective staff officer of intelligence).

Lt. Col. Itoda Isamu (Inspectorate General of Army Aviation; as prospective staff officer for air operations and the [paratroop] raiding group).

Lt. Col. Saiki Ikuzō (Signal Communications Section of the Office of the Army General Staff; as prospective staff officer for signal communications).

Col. Kitamura Yoshifuto (War College; as prospective senior staff officer of Section 2 of the army).

Lt. Col. Sendō Shunzō (Transport Section of the Ministry of War; as prospective staff officer for shipping).

Maj. Takahashi Mitsuzō (War Preparations Section of the Ministry of War; as prospective staff officer for the lines of communication).

At that time, the Army and the Navy Departments [of IGHQ] were in serious conflict over the counter-clockwise plan versus the clockwise plan. ${ }^{(9,10)}$

The primary causes of the conflict between the counter-clockwise and clockwise plans were: (1) Whereas the Army, considering the state of affairs with the Soviets in the next spring, wanted to ensure the swift capture of the Singapore stronghold, which fell under its responsibility, the Navy, on the contrary, wanted to quickly capture the Philippines and Java, and be ready for the U.S. main fleet to come to the attack; (2) The Army attached more importance to the naval and air forces of the allies around Singapore and their reinforcements coming across the Indian Ocean and from India, while the Navy put a high priority on the U.S. Pacific Fleet in Hawaii; (3) The Army was interested in the oil produced in Palembang, while the Navy was much attracted by the heavy oil produced in Borneo.

The Army had requested the Navy to station part of its air units in the Malaya area, but the Navy, which was strongly focusing on the Philippines, would not comply with the Army's request. ${ }^{(9,10)}$ On the other hand, as mentioned earlier, the Navy had repeatedly asked for the Army's support for the capture of Rabaul, but the Army had refused this. ${ }^{(9,10)}$

Because of this polarity, both were suffering from the following issues: ${ }^{(9,10)}$ There were no major problems with [the operations in] the Philippines and Guam, as they had been prearranged in the operation plan for the [current] administrative year. [However, this was not the case with the following:]

The Navy wanted to occupy the oil fields of Miri on its own account right at the opening of hostilities. Moreover, it also strongly desired to capture Ambon and Kupang at an early point, but was short of the necessary strength [to do so].

The Army had found that the Malaya Operation might be slowed down substantially due to an overland journey of one thousand kilometers and because of the naval and air forces of the allies in Singapore, and that it might end up in a situation where attacks on Java and Sumatra were to be made [only] from the east.

Because of these circumstances, in the joint study sessions on the 28th by the Army Department staff of IGHQ and the prospective staff officers of the Dutch East Indies invasion army, a new plan was conceived to have the detachment, charged with the capture of Guam, 
storm Palembang from the Java Sea after completing the capture of Guam..$^{(10,36)}$ Assessments of the situation of the paratroop unit around that time indicated that 1,500 troops would be ready to be put [into action] at the end of October. ${ }^{(10)}$ The [newly conceived] plan was to have one detachment land in Palembang from the Java Sea and the main force of the army in eastern Java, without [first] destroying the allied air and naval forces in Singapore, Sumatra and western Java. ${ }^{(36)}$ However, it involved great risks. In this study they came to the conclusion that the loss of [Army] vessels at sea by the time that the invasion units were to arrive at the shores of Java and southern Sumatra would amount to 85 out of a total of 500 [Army] vessels (note: this number also includes the transport ships for the Malaya and Philippine invasion units), that is, one sixth [of the total number].(10) The Army Department of IGHQ decided that "[the plan] should be reconsidered as there existed a certain amount of concern about the cover provided by the Navy for the attack on the Dutch East Indies by the Dutch East Indies invasion army," and that "the landing points of the main force of the Malaya invasion army should be changed in a positive way, and that [the date to attack] the Dutch East Indies should be advanced." (Note by the author: this means that by moving the landing points in the Gulf of Thailand as far as possible to the south and, following the development of the operation, by also carrying out landings on the east coast of Malaya, the period [necessary] for the invasion of Malaya should be shortened, so that the landings in southern Sumatra and western Java could be made in a much shorter time frame). ${ }^{(10)}$

As explained above, as of 28 September [1941] the Navy desired: (1) to carry out a surprise attack on Hawaii with its main force of aircraft carriers right at the outset of the war, and also to enable [its unit(s)] to carry out a landing at Davao right at the opening of hostilities as well; and (2) to capture Rabaul, for which operation it absolutely wanted to have the Army's support. The Army, on its part, wanted: (1) to absolutely have the support of Navy air units in order to speed up the Malaya operation as well as to reduce the loss of vessels; (2) to enable the 38th Division to land in Palembang via the South China Sea, as well as to realize the parachute drops [of the paratroop unit]; and (3) to carry out simultaneous landings on Java both from the east and the west.

\section{The Situation in October}

The Army Department [of IGHQ] tried to iron out the differences with the Navy Department. It decided to have the Guam invasion unit, after the capture of the island, proceed all the way down to Rabaul and capture it, which was fervently desired by the Navy, and once Rabaul was captured, have the unit turn round and head all the way back to take part in the Dutch East Indies invasion. In addition, the Army Department also decided to take on the capture of Miri, Kuching, Ambon and Kupang, which the Navy had been at pains [to find a way to capture].

The Army Department performed a war game at the War College from 1 to 5 October. On this occasion, the prospective staff officers of the Dutch East Indies invasion army were completely taken aback to hear that the detachment which was scheduled to head for Palembang after the capture of Guam was also to capture Rabaul after seizing Guam, and that Ambon and Kupang were newly added [to the targets] to capture. ${ }^{(43)}$ 


\section{War Game at the War College}

The outline of the war game held at the War College was as follows:(10)

1. Accommodating the request of the Navy, the Army decided to provide units to invade Rabaul, Ambon, Kupang, Miri and Kuching, to receive in return support from an element of the Navy's land-based air [unit] in the Malaya area in an effort to speed up the pace of the Malaya operation.

2. A surprise attack on Palembang was set to be carried out ten days before the invasion of Singapore, so that the landing on western Java would take place on the same day as the invasion of Singapore. The landing in western Java was set to be executed on day $x+95$. [This date of] landing in Java might be about two weeks later than that of the Navy, which estimated its arrival at eastern Java between day $x+80$ and day $x+90$. However, if the U.S. Pacific Fleet were to launch an offensive [against our forces], the Navy would have to extract and deploy [some of] its air and sea strength [against it]. In such a case, [the Army] would be able to arrive in Java [before the Navy].

3. The strength to be employed was set at ten divisions (Imperial Guard, 5th, 18th, 55th, 56th, 21st, 16th, 48th, 38th and 2d Divisions).

4. The operation was divided into three stages: The first stage would feature a practically simultaneous start of operations in the Philippines, Hong Kong and Malaya, after which Borneo, Celebes and Timor would be promptly captured. As the Malaya operation made progress, key locations in southern Sumatra would be seized. In the second stage Java and northern Sumatra would be captured, and in the third stage key areas would be secured.

5. Regarding the Dutch East Indies territory of Borneo and eastward, the Navy would capture Menado, Tarakan and Kendari on its own account. About Balikpapan, Ambon, Makassar, Banjarmasin and Kupang, a tentative plan to capture them through joint actions by the Army and the Navy had been made. However, the problem of how to share responsibilities with the Navy for the capture of the east coast line of Borneo and the Celebes front still remained unsolved.

6. The [army] troops would be deployed as follows:

The 38th Division would [first] capture Hong Kong, after which its main force would go to central and south Sumatra, while an element of its force (referred to as Detachment B) would [be sent to] capture Ambon and Timor.

One-third of the 55th Division (referred to as the South Seas Detachment or Detachment I) would seize Guam, followed by the capture of Rabaul, after which the detachment would reverse its course and head for the Dutch East Indies.

Note: this detachment was to be organized to replace Detachment A for capturing Guam and other [purposes].

One-third of the 56th Division (referred to as the Sakaguchi Detachment a.k.a. Detachment A) would carry out attacks along the east coastline of Borneo and the Celebes front southward (except for the locations which the Navy would attack on its own account).

Note: The detachment was relieved of the duty to capture Guam.

The 48th Division would have Detachment C carry out advance landings at Aparri, Vigan and Laoag, while the division's main force would land at Lingayen and seize Manila. Afterwards, the division would [be directed to] eastern Java.

The 16th Division would detail Detachment D and Detachment E respectively to head in advance to Davao and Legaspi, while its main force would land in Lamon Bay and head for Manila.

An element of the 18th Division (Detachment $F$ ) and another element of the same division (Detachment G), and an element of the 55th Division (Detachment $\mathrm{H}$ ) would be detailed (sent in 
advance) [respectively] to Miri (followed by Kuching), and the southern and western coasts of the Gulf of Thailand.

The main force of the 5th Division would land in northern Malaya and go southward along its west coast.

The Imperial Guard Division would stabilize Thailand and then head southward along the west coast of Malaya.

The main force of the 55th Division would stabilize Thailand as well as carry out operations in southeastern Burma along with the advance parties, after taking over from the Imperial Guard Division.

The main force of the 18th Division would land on the southwestern coast of the Gulf of Thailand and first head for the Penang stronghold.

The 56th Division (minus Detachment A) would land on the southeastern coast of Malaya.

The 21st Division would secure French Indochina.

7. The schedule of operations was planned as follows: ${ }^{(10)}$

\begin{tabular}{|c|c|}
\hline day $x$ & landing of the advance parties along the Gulf of Thailand \\
\hline day $x+2$ & landings of Detachment $C$ at Aparri, Vigan, Laoag \\
\hline day $x+3$ & landing of Detachment D at Davao \\
\hline day $x+5$ & landing of Detachment E at Legaspi \\
\hline lay $x+10$ & landing of the Detachment I at Guam \\
\hline \multirow[t]{2}{*}{ day $x+25$} & occupation of Hong Kong by the 38th Division \\
\hline & landing of the main force of the Malaya invasion army \\
\hline day $x+35$ & $\begin{array}{l}\text { Malaya invasion army's [possible] battle [with the enemy] at the border [of } \\
\text { Malaya], capture of Manila }\end{array}$ \\
\hline ay $x+45$ & start of concentration of the main force of the Dutch East Indies invasion army \\
\hline day $x+70$ & occupation of key locations in Dutch Borneo and Celebes by Detachment A \\
\hline \multirow{3}{*}{$\begin{array}{l}\text { day } x+85 \\
\text { day } x+95\end{array}$} & occupation of key locations in the southern Sumatra by the 38th Division \\
\hline & occupation of Singapore \\
\hline & $\begin{array}{l}\text { landing of the main force of the Dutch East Indies invasion army (consisting of } \\
\text { the } 2 \mathrm{~d} \text { Division) in western Java }\end{array}$ \\
\hline 1 & preparations for landing in northern Sumatra \\
\hline
\end{tabular}

During the war game, the participants became acutely aware of the fact that the Burma area was a cause for worry. Therefore it was decided to newly add the 33d Division (stationed in China) to the Burma area and to establish a new army with this division and the 55th Division, which would allow the Malaya invasion army to devote itself entirely to the Malay Peninsula. ${ }^{(10)}$ As a result, Maj. Gen. Isayama Haruki, who until now had been considered as prospective chief of staff for the Malaya invasion army, was made the prospective chief of staff of this newly established army, which in turn resulted in the putting forward of Maj. Gen. [Col.] Manaki Takanobu, who had been considered until now the prospective vice chief of staff for the Dutch East Indies invasion army, as prospective vice chief of staff for the Malaya invasion army. ${ }^{(36)}$ [Manaki was promoted to major general on 15 October.]

In this war game, the [role of] commander of the Dutch East Indies army was [played by] Lt. Col. Murakami Kimisuke, the role of commander in chief of the allied naval forces by Col. Kitamura Yoshifuto, and Maj. Kondō Dempachi played the role of the assistant to the leadership of the Dutch East Indies invasion army. ${ }^{(23)}$

Immediately after the war game, the persons concerned in the Office of the Army General Staff, the Ministry of War, and the Army Aviation Department made plans to visit Takanabe in Miyazaki Prefecture. The [Paratroop] Raiding Training Department, which had been trans- 
ferred from Baichengzi in Manchuria to Takanabe in September and had been working hard to establish the unit and provide training to it, was finally ready to hold the first air drop maneuver of the unit in mid-October. ${ }^{(93)}$

\section{Report to the Emperor by the Chief of the Army General Staff}

After the war game, on 10 October, Chief of the Army General Staff Sugiyama reported to the Emperor that operations would be carried out in the Philippines, Malaya, French Indochina, Thailand, Hong Kong, Guam, British Borneo, Dutch Borneo, Celebes, the Bismarck Archipelago (note: Rabaul area), the Moluccas and Timor, followed by invasions of Java and Sumatra; that two divisions (the 16th and the 48th Divisions) as the core would be dispatched to the Philippines, four divisions (Imperial Guard, the 5th, the 18th and the 56th Divisions) as the core to Malaya, three divisions (the $2 \mathrm{~d}$ Division, the 48 th Division, which would be redeployed after the capture of Manila, and the 38th Division, which would be redeployed after the capture of Hong Kong) as the core to the Dutch East Indies, and to Thailand and Burma two divisions (the 55th Division and the 33d Division, the latter being added as a result of the war game) as the core would be deployed; that after a major part of the southern operation was achieved, [the Army] was going to capture Burma at a favorable opportunity (which was decided as a result of the war game); and that it was estimated that in roughly five months it would be possible to occupy most of the key areas in the South. ${ }^{(2)}$

\section{Kanoya Map Exercise [Map exercise at Kanoya Naval Air Base]}

In the meantime, from 4 to 6 October, the Eleventh Air Fleet (the land-based naval air fleet which was to operate in the Philippines and then the Dutch East Indies starting out from Taiwan) had carried out a map exercise at Kanoya, Kyūshū. This map exercise simulated a case where three aircraft carriers would be assigned to the air strikes on Hawaii, while the other carriers would provide support in the southern Philippines, and where the invasion of Davao was to be conducted on the same day as the opening of hostilities (day $x$ ), Legaspi on day $x+2$, Jolo on day $x+14$, and Menado on $x+16$.

\section{The Nagato Map Exercise [Map Exercise on the Battleship Nagato]}

From 9 to 13 October, the Combined Fleet held a map exercise on board the battleship Nagato, which lay off Murozumi in Yamaguchi Prefecture. ${ }^{(9)}$ At that time, no top decision had been made as to the air strike on Hawaii. Concerning the flying ranges of the [naval] fighter aircraft, research had been moving ahead on the possibility of extending their flying range enough to attack Manila and vicinity. It appears that the Combined Fleet carried out this map exercise with the idea of using six aircraft carriers for Hawaii. ${ }^{(112,113)}$ As for the southern operation, the idea was that the Navy was to solely focus its air power on the Philippines and after that on the Dutch East Indies, leaving air operations in Malaya entirely up to the Army; that it would have the Dutch East Indies invasion army land in eastern Java on day $x+70$ via the Makassar Strait, and in western Java on day $x+80$; and that it would capture Singapore via southern Sumatra, synchronizing the attack with "the Army's Malaya invasion army which would come down south through the Malay Peninsula." Even though the Army had decided to provide support of in total [a strength of] about one division for Miri, Ambon, Kupang and Rabaul, the [Navy] plan did not include any air support for the Army in the 
Malaya area. Whereas the Army's plan was to run great risks to finally reach western Java on day $x+95$, the Navy's plan was to arrive in eastern Java on day $x+70$, in western Java on day $x+80$, and southern Sumatra on day $x+83 .{ }^{(9)}$ [The capture of] Davao, which had been set on day $x$ in the Kanoya Map Exercise, was now set on day $x+4$. The reason for this [change] had to do with the idea that part of the air strength, which was to engage in the initial northern Philippines operation, was to be redeployed from Taiwan to Palau. The start of using Menado and Tarakan [as bases] was set even one month earlier than that in the Naval College Map Exercise of mid-September. The schedule of landings was as follows:

$\begin{array}{ll}\text { Malaya (advance parties) } & \text { day } x \\ \text { Advance parties for northern Luzon } & \text { day } x+1 \\ \text { Miri in British Borneo } & \text { day } x+1 \\ \text { Legaspi in Luzon } & \text { day } x+4 \\ \text { Davao } & \text { day } x+4 \\ \text { Main force of Malaya advance corps } & \text { day } x+5 \\ \text { Main force for Luzon } & \\ \text { Kuching in Borneo } & \text { day } x+15 \\ \text { Menado and Ambon } & \text { day } x+20 \\ \text { Tarakan } & \text { day } x+25 \\ \text { Kendari } & \text { day } x+30 \\ \text { Balikpapan } & \text { day } x+35 \\ \text { Makassar } & \text { day } x+40 \\ \text { Main Force for Malaya } & \text { day } x+42 \\ \text { Kupang } & \text { day } x+45 \\ \text { Banjarmasin } & \text { day } x+55 \\ \text { Eastern Java } & \text { day } x+70 \\ \text { Western Java } & \text { day } x+80 \\ \text { Bangka in Southern Sumatra } & \text { day } x+83\end{array}$

Note: no date is given in the original documents for the landing by the main force on Luzon.

On 14 October, the staff officers [Prince] Takeda-no-miya and Kumon, both of whom had observed the Nagato map exercise, returned to the Army Department to give their reports. ${ }^{(9)}$ Further adjustment was necessary ${ }^{(9,10)}$ in order to make simultaneous landings on eastern and western Java possible.

\section{Success of the Paratroop Exercise}

The first general paratroop drop exercise was carried out in Takanabe in mid-October as scheduled. The number of spectators was large enough to make people wonder whether it might even be bigger than the number of troops doing the drop.

\section{Solution of the Navy's Aviation Problem}

On 19 October, Chief of Navy General Staff Nagano decided upon the surprise attack on Hawaii by six aircraft carriers (i.e. the First Air Fleet). It was the day after the Tōjō Cabinet 


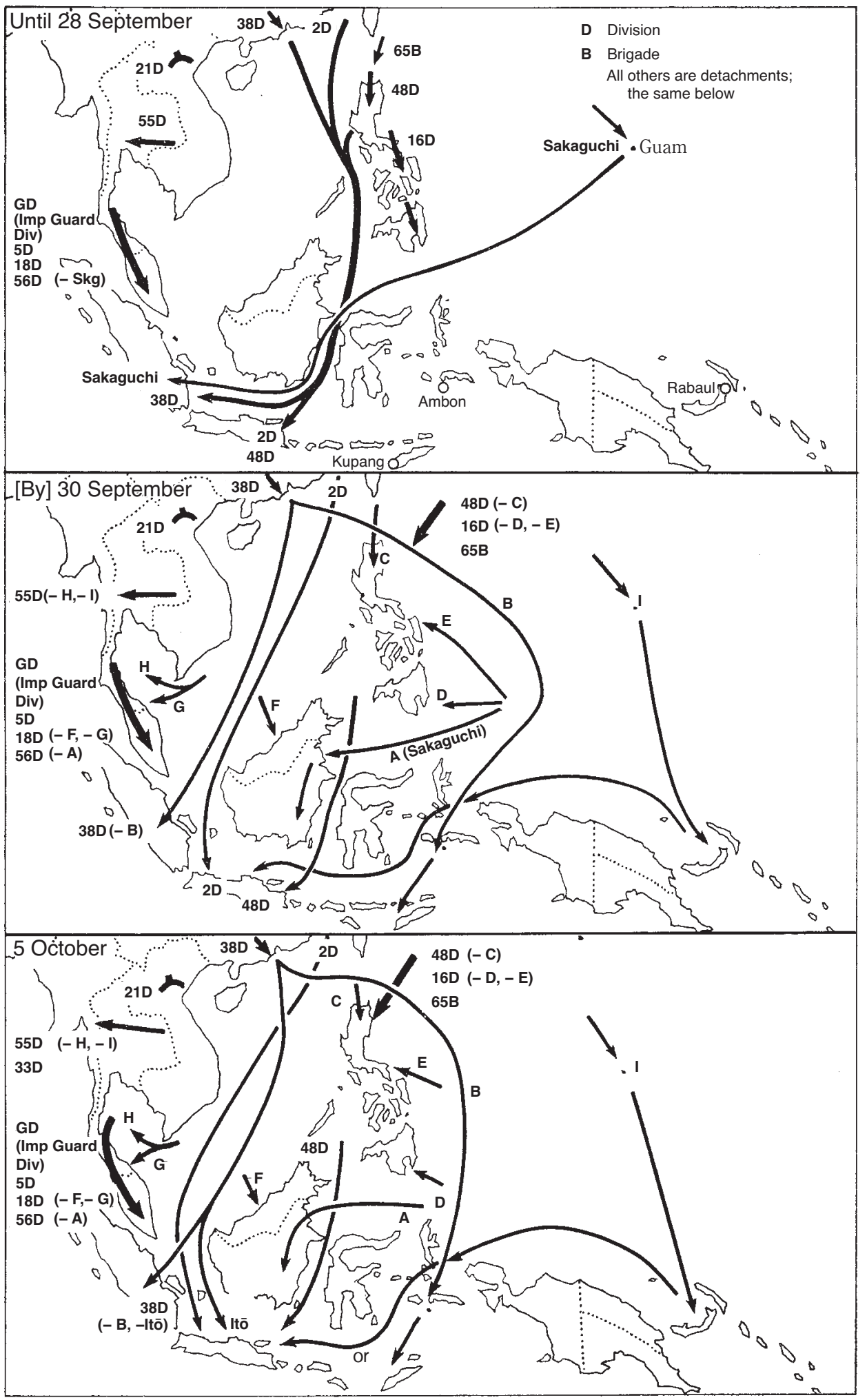

Illustration No. 4-Maps Showing the Changes in Operation Plans from Late September to Early October 


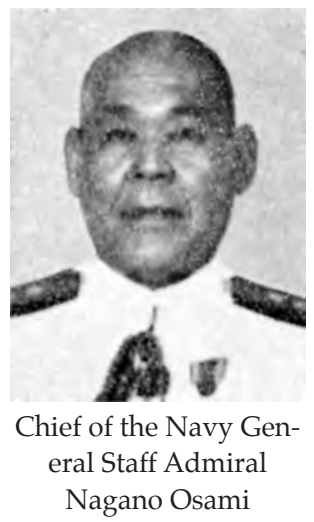

was established. Also around this time the problem of extending the flying range of Navy fighter aircraft (by fitting a disposable tank) was solved. ${ }^{(140)}$ It was decided that the Eleventh Air Fleet (i.e. land-based aircraft), while deploying the strength of its 22d Air Flotilla as the core to Malaya, would have its remaining main force (consisting of the main force of the 21st and the 23d Air Flotilla) operate from Taiwan, and that the aircraft carrier Ryujjo (of the 4th Carrier Division) along with the seaplane tenders Chitose and Mizuho (of the 11th Seaplane Tender Division) would operate from Palau toward Davao and Legaspi.

\section{The Army and the Navy's Completion of the Operation Plans in One Stroke}

From 9 to 10 October, the Army Department had roughly finished a southern operation plan and, from 16 to 18 October, deliberated on an overall operation plan. ${ }^{(10)}$ However, the solution to the Navy's aviation problem enabled it to finalize its operation plan in one stroke. On 20 October, the Navy Department informally decided on the Imperial Japanese Navy Operations Policy. At the end of October, the Army and the Navy Department conferred about a Central Agreement between the Army and Navy and by the 29th [of the month] an agreement on the basic matters was reached. ${ }^{(9)}$ On the 29th, the Navy Department informally informed the Combined Fleet. An assessment made by the Army and the Navy Department estimated that it would be possible to capture Hong Kong in roughly four weeks, Manila in roughly forty to fifty days or more, Singapore in roughly one hundred days or more, and that it would be possible to occupy most of the key areas in the South in roughly five months. ${ }^{(2)}$

\section{Postponement of the Tentative Date for the Opening of Hostilities}

The tentative date for opening hostilities was now being postponed. To be more precise, based on the Main Points for the Implementation of Imperial National Policy, which had been decided upon on 6 September at the Imperial Conference, it had been agreed to finish war preparations by late October, but, unable to decide on war or peace even in mid-October, the [third] Konoe Cabinet resigned. The decision on war or peace was further delayed due to the formation of the Tōjo Cabinet (18 October) and the Emperor's instruction to [abandon the decision on the Main Points of September and] start reconsidering it from scratch. [At the time,] the government was wholly devoting itself to negotiations with the United States in order to avoid war, which led to a situation where a postponement of the date to open hostilities was inevitable.

\section{Situation of the Troops Scheduled to be Deployed for the Invasion of the Dutch East Indies}

From 16 to 21 September, the 2d Division carried out a Divisional B Maneuver, received an Operation A-GŌ [southern operation] training tour from 3 to 4 October, and did tactical research for a southern operation in early October. ${ }^{(58)}$ The division's provisional formation, based on Army Order A No. 63, issued on 16 September, was started sometime between 8 and 16 October, and was completed around 22 October. The division had been unofficially 
informed of the Java operation. ${ }^{(53)}$ The 48th Division, which had received a telegram from IGHQ in mid-August about the change in the division's assignment from the Malaya operation to the Philippines and Java operations and had been transferred from Fuzhou to Taiwan in early September, was presently engaged in training for the Philippine operation. ${ }^{(66)}$ The 38th Division was in the midst of preparing for the invasion of Hong Kong and had not yet been informed about its assignment to participate in the Dutch East Indies operation. The 146th Infantry Regiment, which was to constitute the core force of Detachment A, had been given provisional formation orders on 23 October, and its formation had been completed on 30 October at Ōmura in Kyūshū. ${ }^{(53)}$

\section{Completion of Plans and Issue of Orders by Imperial General Headquarters}

\section{Completion of Plans on 1 November and Shipping Plan \\ (See Illustration No. 5)}

In late October, while Prime Minister Tōjō was reconsidering from scratch the Main Points for the Implementation of Imperial National Policy of 6 September, the Army and Navy Departments of IGHQ concluded the Army-Navy Central Agreement. [Subsequently] on 27 and 28 October, the Army Department assembled the personnel concerned of each army of the Southern Army at Ujina Shipping Transport Command, and conducted studies on shipping. As a result, on 1 November, a shipping transport plan (as in the appended chart of the ArmyNavy Central Agreement) was completed, in which landings on southern Sumatra were to be carried out approximately on day $x+84$, and those on eastern and western Java simultaneously on approximately day $x+103$. The shipping which the Army was going to employ for the southern operation amounted to about two million tons (detailed data will be given later). The shipping transport plan for the Dutch East Indies invasion army was in outline as follows: (23)

56th Mixed Infantry Group (Detachment A or Sakaguchi Detachment, which consists of an element of the 56th Division as its core): After leaving Kyūshū, it shall get ready at Palau and capture Jolo and the east coast of Borneo southward. A tonnage of 50,000 tons shall be allotted to Detachment $A$ for its continuous use from day $x-22$ up to day $x+89$. The ships shall be berthed and loaded at Moji from day $x-22$ to day $x-18$, and stand by at Palau from day $x-7$ to day $x-3$, after which the detachment shall operate in accordance with the arrangements to be made with the Navy.

South Seas Detachment (Detachment I, which consists of one-third of the 55th Division): After leaving Shikoku, it shall get ready at the Ogasawara Islands and join the Dutch East Indies operation after capturing Guam and Rabaul. A tonnage of 50,000 tons shall be allotted to Detachment I for its continuous use from day $x-17$ to day $x+89$. The ships shall be berthed and loaded at Sakaide (in Shikoku) from day $x-17$ to day $x-12$, and the detachment shall prepare for operations at the Ogasawara Islands from day $x-7$ to day $x-3$, after which it shall operate in accordance with the arrangements to be made with the Navy.

\section{8th Division}

The 38th Division shall head from Hong Kong to southern Sumatra via Cam Ranh. The division shall be divided into an advance party, its main force and the Itō Detachment ([at this point] the plan assumed that the South Seas Detachment would be able to capture Ambon and Kupang 


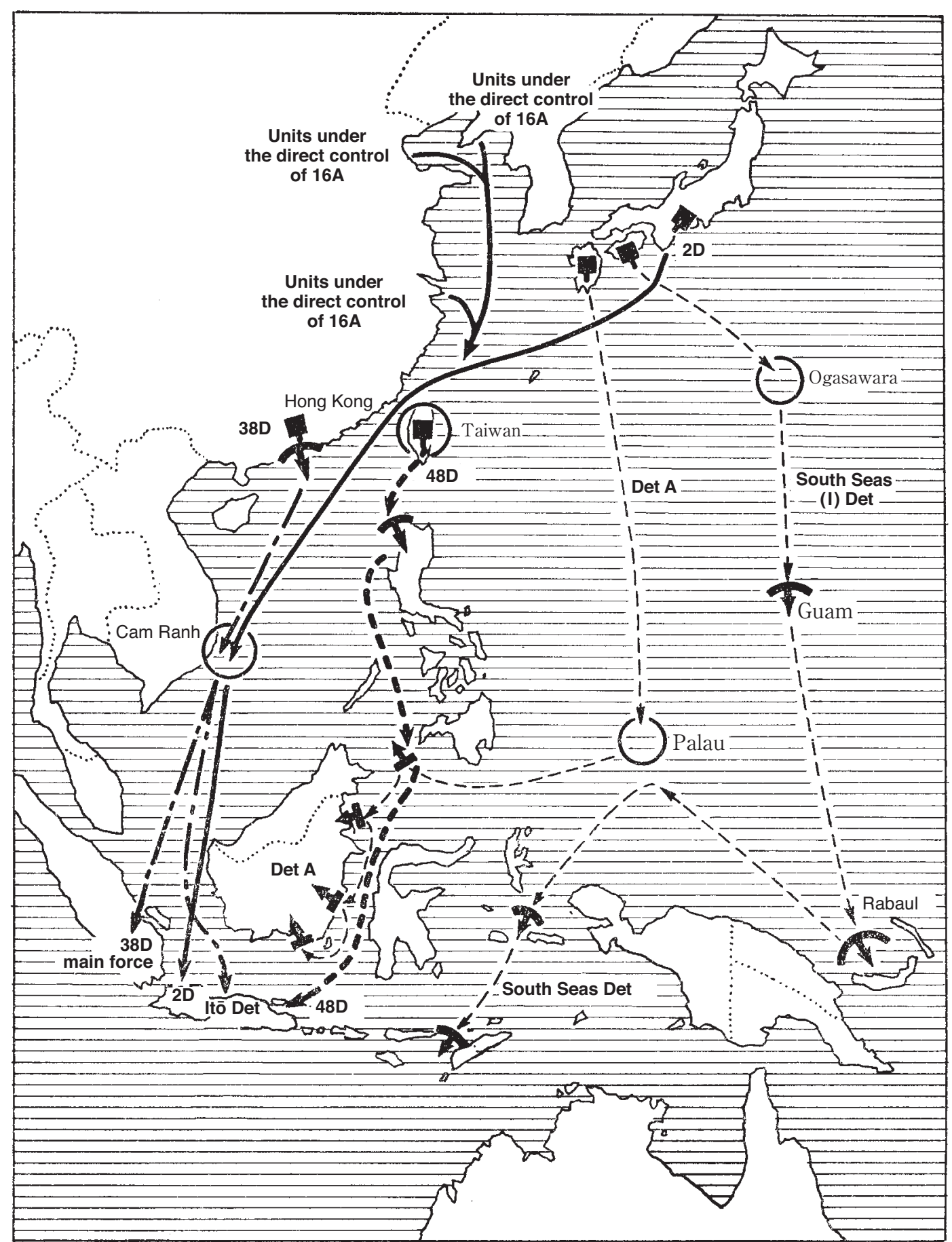

Illustration No. 5-Transportation Plan for the Sixteenth Army, 1 November, 1941

after the capture of Rabaul, and that Detachment B would [remain in the Division] without being dispatched separately). The advance party shall be allotted a tonnage of 30,000 tons. After leaving Hong Kong, it shall rehearse its preparations at Cam Ranh Bay until day $x+64$ before departure from the bay. It shall arrive in southern Sumatra on day $x+78$ and finish disembarka- 
tion on day $x+81$. The main force shall be alloted a tonnage of 120,000 tons. The ships shall be berthed and loaded in Hong Kong from day $x+60$ until day $x+65$. It shall rehearse its preparations at Cam Ranh Bay from day $x+73$ to day $x+78$, arrive in southern Sumatra on day $x+$ 84 and finish disembarking on day $x+89$. The Itō Detachment (one-third of the division) shall be allotted 40,000 tons. The ships shall be berthed and loaded in Hong Kong, from day $x+64$ to day $x+69$. It shall rehearse preparations in Cam Ranh Bay from day $x+93$ to day $x+98$, arrive at the northern coast of central Java on day $x+103$, and complete disembarking on day $x+108$.

[Sixteenth] Army's main force (consisting of the 2d Division as its core)

The $2 \mathrm{~d}$ Division shall be provided with 150,000 tons to cover the distance between the homeland and Taiwan. From day $x+36$ to day $x+41$, the ships shall be berthed and loaded at Tokyo Bay and they shall anchor and stand by in Taiwan from day $x+49$ to day $x+54$. From Taiwan and southward, the division shall be united with the other units under the direct control of the Sixteenth Army. The first transport shall be allotted 260,000 tons. The ships shall anchor in Cam Ranh Bay from day $x+93$ to day $x+98$, arrive in western Java on day $x+103$, and complete disembarking on day $x+108$.

The second transport shall be allotted 170,000 tons. The ships shall anchor in Cam Ranh Bay from day $x+100$ to day $x+105$, arrive in western Java on day $x+110$, and complete disembarking on day $x+115$.

The third transport shall be allotted 130,000 tons. The ships shall anchor in Cam Ranh Bay from day $x+113$ to day $x+118$, arrive in western Java on day $x+123$, and complete disembarking on day $\mathrm{x}+128$.

\section{Core unit of the 48th Division}

Its transportation from the Philippines to eastern Java shall be divided into two stages.

The first transport shall be provided with 170,000 tons. The ships shall be berthed and loaded in Manila Bay from day $x+89$ to day $x+95$, arrive in eastern Java on day $x+103$, and complete disembarking on day $\mathrm{x}+108$.

The second transport shall be allotted 100,000 tons. The ships shall be berthed and loaded in Manila Bay from day $x+96$ to day $x+102$, arrive in eastern Java on day $x+109$, and complete disembarking on day $\mathrm{x}+114$.

Initially, it was planned that Detachment A [the Sakaguchi Detachment] was to take charge of the military administration of Dutch Borneo after its capture. ${ }^{(87,88)}$ Later, it was decided that the Navy was to take on the responsibility for the military administration of the area and that Detachment A was to join the main force of the division in Malaya. ${ }^{\left({ }^{(7)}\right.}$ Either way, the detachment was not scheduled to participate in the invasion of Java. ${ }^{(36,87)}$ In the shipping plan above, it was for the first time that the Itō Detachment's landing on central Java was mentioned. This was decided after the war game at the War College had shown that the Kalijati airfield, which was close to the north coast of central Java, should be attacked and occupied right after the landing and put into use, even if this [action] were to carry a risk. ${ }^{(39)}$

In the plan, the 38th Division [itself] was not to participate in the invasion of Java, as it was assigned to occupy numerous oil fields and airfields situated over a vast area in southern Sumatra. [Furthermore,] the issue of when exactly the South Seas Detachment would be able to join the Dutch East Indies campaign from out of Rabaul became a troublesome item in drawing up the operational plans for the Dutch East Indies invasion army. 


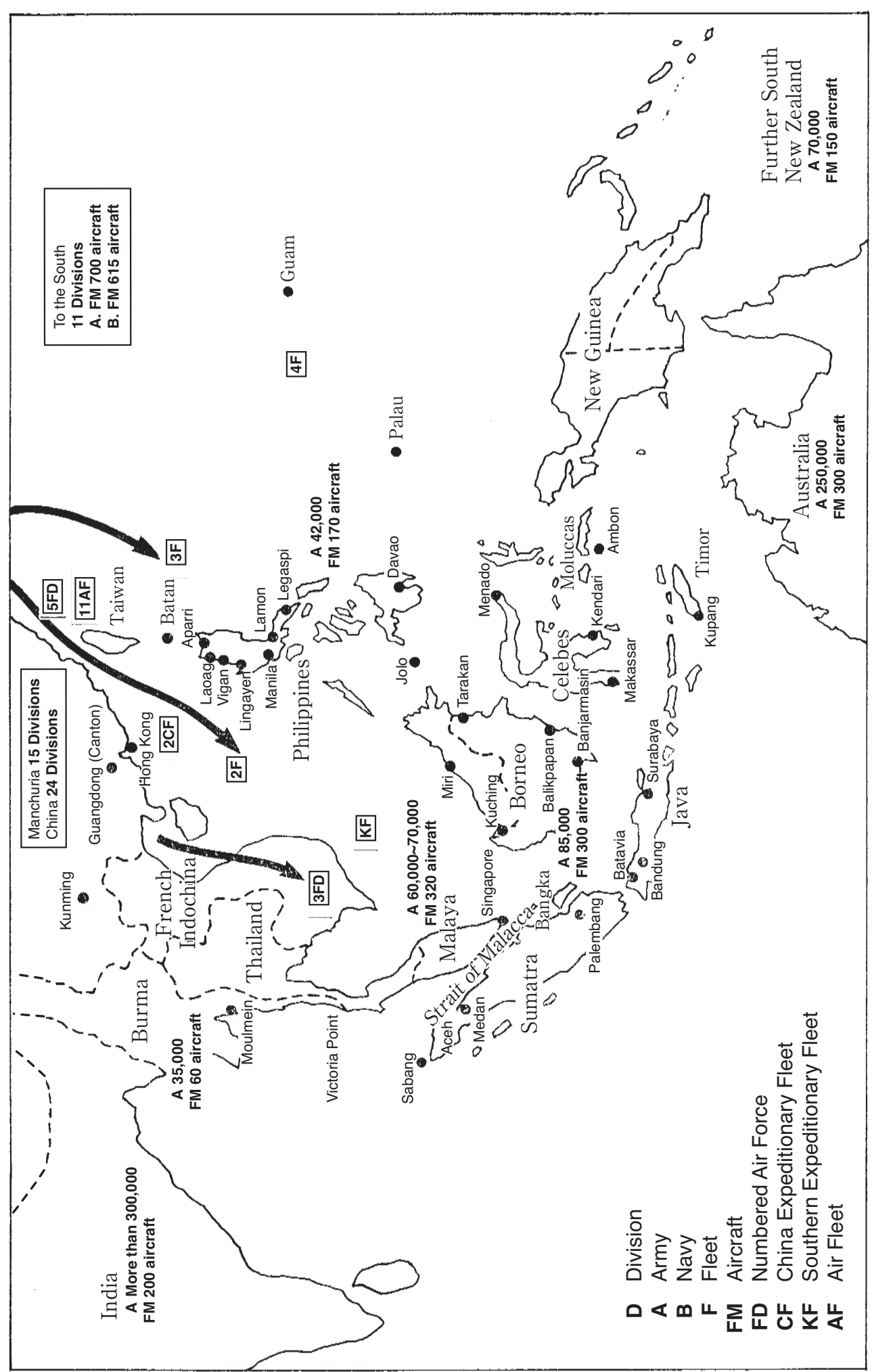

Illustration No. 6-Rough Overview of the Disposition of the Allied and Japanese Forces 


\section{Decision on the Main Points for the Implementation of Imperial National Policy, and Orders Issued by Imperial General Headquarters}

At the Imperial Conference on 5 November, the Main Points for the Implementation of Imperial National Policy were decided upon. While resolved to wage war against the United States, Britain and the Netherlands [if necessary] and setting the time for the start of military actions at the beginning of December and having the Army and the Navy complete their operational preparations [by that time], they stated that the launch of military actions would be aborted should the negotiations with the United States prove successful by 0000 on 1 December. ${ }^{(3,7)}$

Based on the decisions taken at the Imperial Conference, the same day (5 [November]) orders were given for the provisional formation of the Southern Army headquarters and respectively the headquarters of the Fourteenth Army (Philippines), the Fifteenth Army (Thailand and Burma) and the Sixteenth Army (Dutch East Indies). ${ }^{(52)}$ The Malaya area was assigned to the headquarters of the Twenty-fifth Army, which heretofore was stationed in French Indochina, and its formation was revised as well [for the new assignment].

On the following day, the 6th, the order of battle (note: the formation of armies for a campaign, ordered by the Emperor in the incidence of war) for the Southern Army and the South Seas Detachment were issued, and orders were given [to the Southern Army] to prepare to occupy the southern key areas (and to the South Seas Detachment to capture Guam). On the same day, orders were sent to the China Expeditionary Army to prepare to seize Hong Kong. ${ }^{(1)}$ Also the orders of appointment of the commander in chief of the Southern Army and his subordinates were issued on that day.

Meanwhile on the 5th, the Navy ordered the Combined Fleet to implement the necessary preparations for operations against the United States, Britain and the Netherlands. At the same time, in preparation for the above-mentioned operations, the Navy Department of IGHQ instructed the Combined Fleet to have the units involved in the operation proceed to and be at the ready at the positions to be taken before the launch of the operations. ${ }^{(1)}$

Then on 15 November, the Army and the Navy Departments of IGHQ carried out a war game in the presence of the Emperor and explained the plan of the southern operation. ${ }^{(2)} \mathrm{On}$ this day, the Army Department issued the order to the Southern Army for the execution of the invasions of the southern key areas. ${ }^{(1)}$

Needless to say, the date and time of the launch of the invasion operations was put on hold. On 21 November, the Navy Department ordered the Combined Fleet to have the units involved in the operations proceed to their stand-by positions at sea. ${ }^{(1)}$

\section{Assessment of the Current Position of the Enemy and the Prospects for the Campaign}

On 3 and 5 November, Chief of the Army General Staff Sugiyama, alongside Chief of the Navy General Staff Nagano, reported to the Emperor about the operation plan. The position of the enemy at the beginning of September ${ }^{(2,7)}$ has already been related. The Japanese forces to be employed for the operation (compared to the total force), which had been recently determined, were in outline as follows: ${ }^{(2)}$ 


\begin{abstract}
Army
Ground forces: employment of eleven divisions for the southern operation out of a total of fifty-one divisions.

Air forces: two numbered air forces (seventy squadrons, seven hundred aircraft) were to be employed for the southern operation out of a total of five numbered air forces (151 squadrons, 1500 aircraft).
\end{abstract}

Navy

\begin{tabular}{|c|c|c|c|c|c|c|c|c|c|}
\hline & Battleship & $\begin{array}{c}\text { Heavy } \\
\text { cruiser }\end{array}$ & $\begin{array}{c}\text { Light } \\
\text { cruiser }\end{array}$ & $\begin{array}{c}\text { Training } \\
\text { cruiser }\end{array}$ & Destroyer & Submarine & $\begin{array}{c}\text { Aircraft } \\
\text { carrier }\end{array}$ & $\begin{array}{c}\text { Seaplane } \\
\text { tender }\end{array}$ & Aircraft \\
\hline Total & 10 & 18 & 17 & 3 & 112 & 65 & 9 & & 3202 \\
\hline Hawaii & 2 & 2 & 1 & & 11 & 30 & 6 & 382 \\
\hline $\begin{array}{c}\text { Guam, } \\
\text { Wake, } \\
\text { Rabaul }\end{array}$ & 4 & 3 & 1 & 12 & 9 & & 1 & 125 \\
\hline South & 2 & 12 & 8 & 1 & 56 & 16 & 1 & 6 & 615 \\
\hline
\end{tabular}

Note: The number of army aircraft is the approximate number of aircraft of frontline air units (reserve aircraft not included). [On the contrary,] the number of naval aircraft includes training unit aircraft as well as reserve aircraft.

In his explanation to the Emperor, Chief of Army General Staff Sugiyama gave the following account: ${ }^{(2)}$ (See Illustration No. 6)

1. With the outbreak of the Second European War, the conclusion of the Tripartite Pact and in particular our advance towards the southern regions, the military preparedness of the armies of the countries in the southern regions is gradually being built up. Malaya has an army strength of about 60,000 to 70,000 troops and about 320 aircraft. The Philippines has an army strength of about 42,000 troops and about 170 aircraft, the Dutch East Indies of about 85,000 troops and about 300 aircraft, and Burma of about 35,000 troops and about 60 aircraft. Compared to the numbers before the outbreak of the European war, the army strength in Malaya has increased by about eight times, that in the Philippines by about four times, that in the Dutch East Indies by about two-and-a-half times and that in Burma by about five times. At present, the total number amounts to about 200,000 troops and it is expected that the rate of increase will grow even further from now on. When it comes to an opening of hostilities, [further] reinforcements from India, Australia and New Zealand are expected. The current military strength in these areas is estimated to be 300,000 troops or more and about 200 aircraft in India, about 250,000 troops and about 300 aircraft in Australia, and about 70,000 troops and about 150 aircraft in New Zealand. The ground forces of these areas, although there may be regional differences, consist of indigenous troops, each with some 30 percent white soldiers from the homeland as the core. As their military training is insufficient, their fighting power is generally low. However, the fact that they are well accustomed to the tropical climate has to be kept in mind. In addition, due to superior aircraft performance and relatively skilled pilots, their air combat efficiency cannot be viewed lightly, compared to [the combat efficiency of] the ground forces.

2. Presently the Imperial [Japanese] Army consists of fifty-one divisions as its core with approximately two million troops altogether, of which some fifteen divisions are deployed in Manchuria 
and Korea as counterforce against [the Soviets] in the North, and some twenty-four divisions in China as counterforce against the Chinese. The military strength to be put into the southern operation is planned to be formed with one division currently in French Indochina, about five divisions currently in training and standing by in the [Japanese] homeland and Taiwan, and five divisions to be redeployed from China, which make a total of about eleven divisions, ready to be deployed as needed.

3. We would like to set the time of the opening of hostilities at the beginning of December due to the following matters: (1) As time progresses, Japan is put in a less and less favorable position in military preparedness compared to the United States. Especially the disparity in air armaments is expected to increase rapidly. (2) American preparations for war, including the defense of the Philippines, will make fast progress. (3) Defense ties between the United States, Britain and the Netherlands will grow increasingly tighter, and the total defensive strength in the southern regions will be reinforced rapidly. (4) The occurrence of a northern operation has also to be taken into account from next spring onward. (5) Weather conditions in and around the areas of operation [have also to be taken into consideration].

4. Prospects for the operations: The Southern Army, in conjunction with the Combined Fleet, starts operations simultaneously by means of preemptive sudden attacks against the Philippines and Malaya, and swiftly captures southern key areas. Territories to be captured are the Philippines, British Malaya, Burma, the Dutch East Indies, and Timor. Apart from this, the China Expeditionary Army captures Hong Kong with part of its forces. The main constituent of the army operations in the initial period as outlined above are, of course, the landing operations, which are to be carried out against defended strongholds under a scorching heat and after traveling a long distance over sea while clearing away attacks by enemy submarines and aircraft. Therefore, considerable difficulties are to be expected. Yet, seen in a broader perspective, the fighting power of the enemy is dispersed over a wide area and even separated by the sea, which makes it difficult for them to act in conjunction. Also, they are in a context where it is rather difficult to swiftly bring in reinforcements from India and Australia against our sudden attacks. On the contrary, our side will be able to defeat our enemies one by one by using our concentrated fighting power in a sudden offensive. Therefore, by making full use of our organization, equipment, resources, combat tactics and strategy, which have continuously been improved in a creative way, and coupled with a close cooperation between the Army and the Navy, we are convinced of certain victory. We believe that we have definitely all the odds in our favor for the operations after landing, considering the organization, equipment, potential and strength of the enemy and our side. After roughly wrapping up the invasion operations of the southern key areas, every effort is to be made to take the fight out of the enemy through both political and military strategy and to conclude the war as quickly as possible, but it is imperative to anticipate the possibility that the war will extend over a long period. Nevertheless, we can strategically maintain an undefeatable position by occupying and securing the military bases and air bases of the enemy, and by securing sea traffic, which will almost certainly enable us to destroy the enemy plans by employing every possible means.

5. As for the North, the chances of the Soviets advancing and actively taking the offensive are extremely small as long as the Kwantung Army stays in place.

\section{Operation Plan of the Army (See Illustrations No. 7 and No. 8)}

The operation plan drawn up by the Army Department of IGHQ principally concerned the southern operation. The gist of the southern operation was that at the opening of hostilities, the Twenty-fifth Army (consisting of the 5th Division at first, then joined by the Imperial Guard Division, the 18th and the 56th Division one after another in this order) would advance upon Malaya; then, the Fourteenth Army (advance parties at first, then joined by the main 


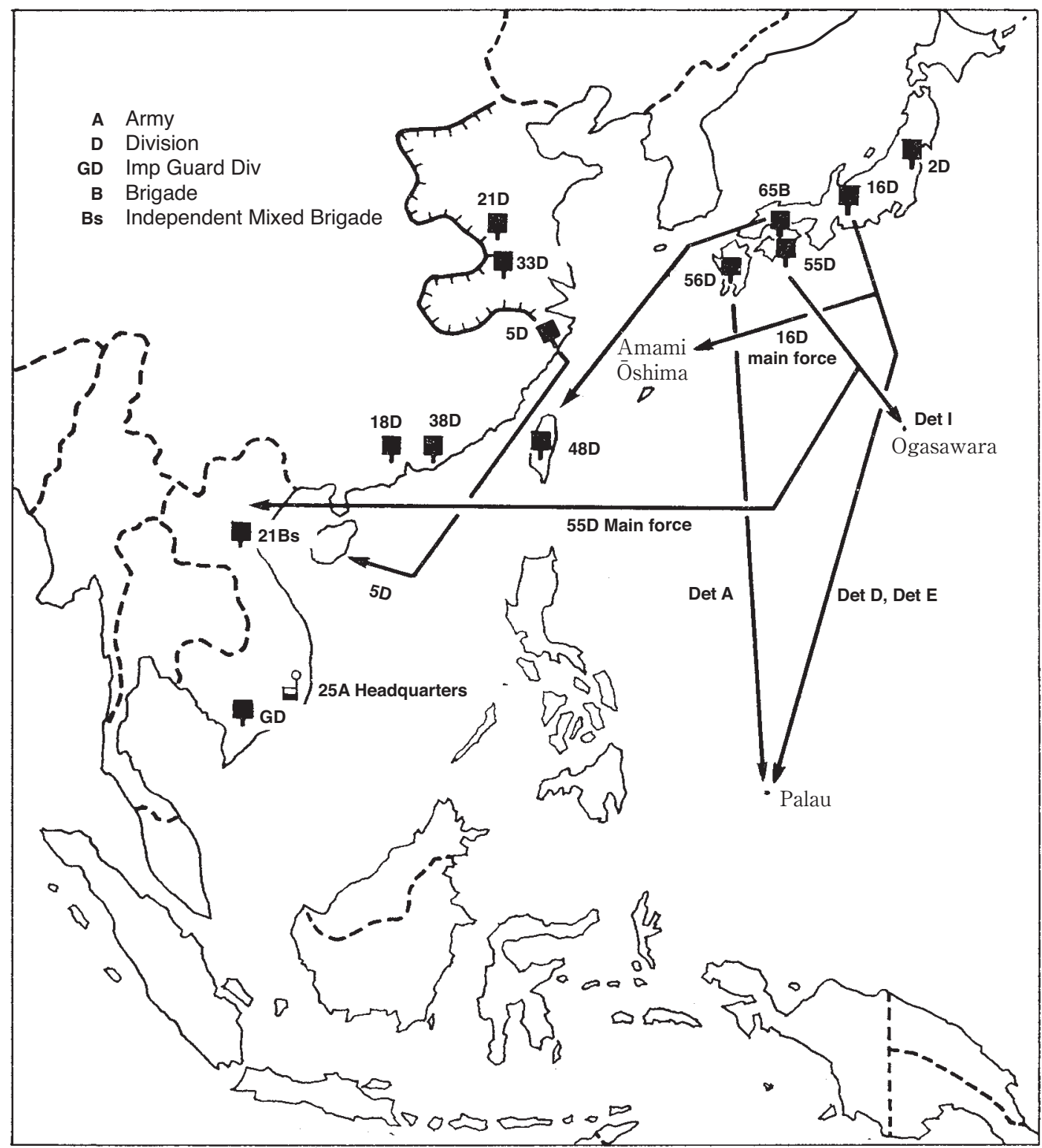

Illustration No. 7-Position as of 6 November 1941 and Operation Schedule Until the End of November

force of the 48th and the 16th Divisions) would advance upon the Philippines; an element of the China Expeditionary Army (i.e. the 38th Division) would advance upon Hong Kong after confirmation of the landings in Malaya; as the invasions of Malaya and the Philippines progressed, the Sixteenth Army (consisting of the $2 \mathrm{~d}$ Division, and joined by the 38th and the 48th Divisions after their captures of Hong Kong and Manila respectively) would advance upon the Dutch East Indies by using the above [places] as bases and occupy the key resource areas [in the Dutch East Indies]; apart from the above, the Fifteenth Army (which in the early stages has the Imperial Guard Division temporarily under its command, and which is joined by the 55th and the 33d Divisions sequentially in this order) would conduct operations in 
Thailand and southeastern Burma; the 21st Division would stabilize and secure French Indochina; the Twenty-fifth Army would capture northern Sumatra after Malaya. As these operations progressed, the overall aim was to completely secure the southern areas. The summary [of the plan] was as follows. Based on the decisions of the Imperial Conference on the 5th [of November], the forces to be deployed in the southern operation were supposed to change their positions by the end of November as shown in Illustration No. 7.

\section{Summary of the General Operation Plan of the Imperial Japanese Army}

\section{Southern Operation}

1. Operational objective: The objective of the southern operation is to destroy the major bases of the United States, Britain and the Dutch East Indies in East Asia and to occupy and secure the key areas of the South. The areas intended to be occupied in this operation are the Philippines, Guam, Hong Kong, British Malaya, Burma, Java, Sumatra, Borneo, Celebes, the Bismarck Archipelago, Dutch Timor, etc.

2. Mission: The Army and Navy, in close cooperation, shall simultaneously start operations in the Philippines and British Malaya, and strive to accomplish the operational objectives as quickly as possible.

3. Operational directives:

(1) The operation shall start with the landing of advance corps in Malaya and air strikes on the Philippines, and taking advantage of the results of the air operations, the main forces [of the armies in charge of each place] shall be put ashore in the Philippines first, then in Malaya, and promptly capture the Philippines and Malaya. Apart from this, in the early stages of the operation, the strategic points of Guam, Hong Kong and British Borneo shall be captured and stability in Thailand and Indochina shall be secured. Meanwhile, the strategic points of the Bismarck Archipelago, Dutch Borneo and Celebes shall be captured as quickly as possible, and, as the Malaya operation progresses, the strategic points in southern Sumatra shall be occupied and the key resource areas secured, while making preparations for operations [to attack] Java. The strategic points of the Moluccas and Timor shall [also] be occupied.

(2) While preparing the air bases to attack Java, superiority shall be gained over the enemy's air power and Java shall be captured. After Singapore has been occupied, strategic areas in northern Sumatra shall be occupied in a timely manner.

(3) Even when the Combined Fleet changes its deployment to an interception position in response to an action of the main U.S. fleet, or when the Soviets join the war during the above operations, the Philippine and Malaya operations shall be continued and the previously-defined objectives of the operation shall be accomplished as quickly as possible.

(4) During the above [operations], air bases in southern Burma shall be seized at favorable opportunities, and when most of the operations are wound up, operations to deal with Burma shall be carried out in as far as the situation permits.

(5) In principle, the landing operations shall be carried out in the face of the enemy while clearing away attacks of its ground, naval and air forces.

(6) Operations in case the British army invades Thailand ahead of us while we are preparing for the operations ... (Omitted by the author.)

(7) If attacked by the enemy while preparing for operations, the units on location shall intercept the enemy at the right moment. If this [attack] should be made after the issue of the order to start the operation, an attack operation shall be launched immediately.

4. Strength employed:

The military strength to be employed for this operation [as a whole] shall consist of 11 divisions, 9 tank regiments, 2 numbered air forces, and other necessary units under the direct 
control of the [Southern] Army as the core. The distribution of these forces and target areas is planned as follows:

The Southern Army

The Fourteenth Army shall consist of 2 divisions as its core and conduct operations in the Philippines area.

The Fifteenth Army shall consist of 2 divisions as its core and conduct operations in the Thailand and Burma areas.

The Sixteenth Army shall consist of 3 divisions (of which 2 divisions shall be diverted from other operations after their completion) as its core and conduct operations in the Dutch East Indies area.

The Twenty-fifth Army shall consist of 4 divisions as its core and conduct operations in the Malaya area.

The unit under the direct control of the Southern Army shall consist of 1 division, 1 mixed brigade, and 2 numbered air forces as its core.

The Twenty-third Army (under the command of the China Expeditionary Army) shall conduct operations in the Hong Kong area with a force of 1 division as its core.

The South Seas Detachment (under the direct control of [the Army Department of] IGHQ) shall consist of 3 infantry battalions as its core and conduct operations in Guam, the Bismarck Archipelago, etc.

5. Launch of the operation:

1. The date to start the operation (the first day of the operation) shall be specified separately... (Omitted by the author.)

6. Outline of the operations:

(1) Operation against the Philippines

The objective of the operation against the Philippines is to defeat the enemy in the Philippines and destroy its major bases. Right at the outset of the war, the air units of the Army and the Navy, in conjunction with each other, shall carry out air strikes against the air power and the naval vessels of the enemy in the Philippines from the direction of Taiwan and Palau as well as from the sea. The Navy units shall make a sudden attack on Batan Island and immediately get the airfield ready for use. Advance parties shall leave the assembly points after the evening of the day before the first air strike against the Philippines, and with the cooperation of the Army and the Navy land in or around Aparri, Vigan (and then Laoag), Legaspi, and Davao, occupy the air bases first and get them ready for use. Then they shall occupy Jolo as quickly as possible, and get the air base ready for use. Hand in hand with the above operations, the air units of the Army and the Navy shall advance the air bases and continue the air operations. Exploiting the results of these operations, the Fourteenth Army shall start landing, by around the 15th day of the operations at the latest, its main force around Lingayen Gulf and part of its force around Lamon Bay escorted by a [naval] unit consisting of the Third Fleet as its core. It shall promptly capture Manila and occupy key places in the islands. After the landing of the main force of the army, a mixed brigade shall advance on Luzon Island at the right moment. When the objective of the operation is almost achieved, the 48th Division shall assemble in or around Manila [to be redeployed] as part of the force for the capture of the Dutch East Indies.

(2) Operation against British Malaya

The objective of the operation against British Malaya is to defeat the enemy in this area, capture its strategic points, Singapore in particular, and destroy the British bases in East Asia. The unit [to attack British Malaya] consisting of the Twenty-fifth Army, the Third Air Force and the Southern Expeditionary Fleet as its core, shall make surprise landings in or around Ban Don, Nakhon, Singora and Pattani with advance corps on the first day 
of the operation, promptly occupy airfields, and get them ready for use, while air units of the Army and the Navy, on and after the first day of the operation, carry out preemptive air strikes against the air power and the naval vessels of the enemy mainly in British Malaya from the direction of southern Indochina. ([The next] part, omitted by the author, concerned operations in case the landings experienced difficulties due to obstruction by the enemy.) Depending on the arrival of some of the ships that have escorted the main force of the Fourteenth Army [for the invasion of the Philippines], the main force of the Twenty-fifth Army shall be put ashore in southern Thailand in quick succession, and expanding on the military gains achieved by the advance landing corps in Malaya, it shall promptly capture Singapore. As the operation progresses, one corps shall seize an opportunity and shall land on the east coast of Malaya at a point as far to the south as possible.

(3) Operation against British Borneo

The objective of the operation against British Borneo is to occupy and secure key resource areas and air bases. Right at the opening of hostilities, an element of the unit under the direct control of the Southern Army shall carry out a sudden attack on Miri, occupy the place, and secure its key resource areas and its air base. Once Miri is occupied, it shall occupy Kuching, secure its air base and get it ready for use in order to let the Navy advance its air units.

(4) Operation against Hong Kong

The objective of the operation against Hong Kong is to defeat the enemy and capture Hong Kong. After confirming the landings of the advance corps or air strikes in Malaya, the unit consisting of a corps of the Twenty-third Army and the Second China Expeditionary Fleet as its core shall start the operation. First, it shall destroy the warships of the enemy on location, break through the enemy's position on Kowloon Peninsula, and then capture Hong Kong Island. After completion of the capture of Hong Kong, the corps concerned shall assemble near Hong Kong [to be redeployed] as [part of] the force for the capture of the Dutch East Indies.

(5) Operation against Guam and the Bismarck Archipelago

The objective of the operation against Guam and the Bismarck Archipelago is to capture Guam first, then occupy air base(s) in the Bismarck Archipelago, and pin down the threat of the enemy in the equatorial Pacific Islands area. At the beginning of the operations, the unit consisting of the South Seas Detachment and the Fourth Fleet as its core shall capture Guam. There the South Seas Detachment turns over [its task of] guarding Guam to the [naval] landing force. [Then] the Army and the Navy in conjunction shall seize an opportunity to occupy Rabaul and secure the air base. After that, the South Seas Detachment shall turn over [its task of] guarding Rabaul to the [naval] landing force as quickly as possible, and move toward the vicinity of Palau.

(6) Operation against the Dutch East Indies

The objective of the operation against the Dutch East Indies is to defeat the enemy in the Dutch East Indies, capture their bases, and occupy and secure key resource areas. While the Philippines operation is underway, the Army and the Navy, in conjunction, shall support an element of the Sixteenth Army to capture Tarakan as quickly as possible. Then, depending on the situation of the Philippines and Malaya operations, they shall successively capture Balikpapan and Banjarmasin, and seizing an opportunity in the course of the above operations or after their completion, capture Ambon and Kupang, get the necessary air bases ready for use, and secure key resource areas as well. Meanwhile about the same time as the capture of Tarakan, the Navy on its own account shall occupy and secure Menado first, then Kendari and Makassar. The guarding of Tarakan and Ambon shall be taken over by the Navy as quickly as possible when the major part of each op- 
eration in these areas is finished. Apart from [this], as the operations in British Malaya progress, another element of the Sixteenth Army shall seize an opportunity to occupy the strategic points of Bangka Island and Palembang, get the air bases ready for use, and secure the key resource areas as well. After having brought the air power of the enemy on Java under control while preparing the air bases, the main force of the Sixteenth Army and a corps diverted from the Philippine Islands shall land in the vicinity of Batavia in western Java and in the vicinity of Surabaya in eastern Java respectively. They shall promptly occupy Batavia, Bandung and Surabaya, and continue to mop up other key areas on Java. Once it becomes possible to take control of the Strait of Malacca after the occupation of Singapore, an element of the Twenty-fifth Army shall land at the right moment in the vicinity of Medan from the direction of the west coast of the Malay Peninsula to occupy key areas in the Aceh region and, seizing an opportunity, Sabang Island.

(7) Operations against Thailand and Burma

The objective of the initial operations against Thailand and Burma is to secure the stability of Thailand, facilitate the operations in Malaya, and prepare for subsequent operations in Burma. Right at the opening of hostilities, the Fifteenth Army shall have an element of its force make its way into central and southern Thailand from southern Indochina by land and by sea, and secure key places in these areas, while occupying with part of this force the vicinity of Victoria Point. One corps of the main force of the Fifteenth Army shall leave Indochina mainly by land right after the opening of hostilities, while another corps shall leave port in northern China after the opening of hostilities. Each corps shall advance toward the vicinity of Bangkok from around the 40th day of the operation, and occupy key places in Thailand. As the main force of the Fifteenth Army arrives, an element of the Twenty-fifth Army shall be diverted toward the area of its main force by land and by sea as soon as possible. The Fifteenth Army shall seize an opportunity to occupy Moulmein and other air bases with a part of its force.

(8) Apart from [the above], a corps under the direct control of the Southern Army shall leave port in northern China in the wake of the reinforcements for the Fifteenth Army, and arriving in Indochina, take charge of securing stability in this area. In particular, it shall be on the watch for an approach of the Chinese Army.

7. Outline of the air operation

(1) Mission: The air units of the Army, in conjunction with those of the Navy, shall carry out preemptive air strikes on enemy air bases right at the outset of the war, gain command of the air and facilitate the landings of the landing troops, after which they shall support ground operations.

(2) Outline

(a) The air operation of the Army shall give priority to the Malaya area.

(b) Before the start of the war, air bases shall be advanced as follows: To southern Taiwan for the attack on the Philippines; To southern Indochina for the attack on Malaya.

(c) Air strike operations shall start on day $x$, i.e. the day of the start of the landings by the ground troops. However, if [our air units] are seriously attacked by the enemy on day $\mathrm{x}$ or before, they shall start advancing at the right moment in conjunction with the Navy. Also, if enemy planes seem to repeatedly reconnoiter our important bases and convoys, they shall be shot down.

(d) The Army air units shall mainly take charge of covering the convoys of the landing troops, to which they are assigned on days $x-1$ and $x-2$.

(e) The operation to advance air units shall start at dawn on day $x$; [the units] shall pin down the enemy's [ability for] action by surprise attacks on their main bases all at once and facilitate the operations of the landing troops. 
For this purpose, the strikes shall be focused on airfields where bombers, torpedo bombers in particular, of the enemy are stationed.

(f) Once the landing troops have landed, [the air units] shall promptly advance their bases to the enemy's territory and closely cooperate with the ground operations. For this, about half of the ground duty units shall accompany the first landing units, occupy the airfields and get them ready for use.

(3) Disposition of the forces:

(a) The Third Air Force (consisting of 5 fighter air groups, 4 light bomber air groups, 4 heavy bomber air groups, and 1 reconnaissance plane air group as its core, including 1 air group each out of the Fifth Air Force's fighter, light bomber, and heavy bomber air groups) shall first create a diversion through a Kunming operation by temporarily deploying in southern China and northern Indochina, and then advance rapidly to deploy in southern Indochina just before the opening of hostilities to take charge of covering the convoy of the advance corps of the Twenty-fifth Army in the Gulf of Thailand. On day $x$, it shall carry out preemptive air strikes on air bases in northern Malaya with its main force and those in southern Thailand with part of its force in order to facilitate the landing operations. After that, the Third Air Force shall promptly advance its main force to Malaya and part of its force to Thailand as rapidly as possible and cooperate directly with the ground operations while continuing to destroy the air power of the enemy.

(b) The Fifth Air Force (consisting of 1 fighter air group, 2 light bomber air groups, 1 heavy bomber air group, and 1 reconnaissance plane air group as its core, minus 1 fighter, light bomber and heavy bomber air group each) shall deploy in southern Taiwan, and in conjunction with Navy air units carry out preemptive air strikes on the air bases located at latitude $16^{\circ}$ north and northward on Luzon Island to facilitate the landing operations. After that, it shall take charge of covering the convoy of the main force of the Fourteenth Army, and advance its main force to Luzon Island as rapidly as possible to cooperate directly with the ground operations while continuing to destroy the air power of the enemy. Just before the opening of hostilities, 1 fighter air group shall be added.

8. Outline of the lines of communication

(1) Southern French Indochina shall be designated as the main lines-of-communication relay point for the southern operation as a whole; Taiwan shall be designated as a supply transfer base, and Guangdong [Canton] as an auxiliary supply transfer base.

(2) Line-of-communicarion units required in the South shall mainly be provided by diverting units from Manchuria, while all the units in China shall be kept in reserve without being diverted.

(3) Based on the principle that most of the military power of the nation shall be committed to the southern operation, operation materials in the homeland as well as in Manchuria shall be gathered and appropriated for the southern operation, and [all] the materiel required by the Southern Army for one campaign shall be sent in the first [transport] simultaneously with the transport for the landing operation or immediately [after] that.

(4) The supply to our armed forces shall be focused on [the forces] in the South. Manchuria and China shall be designated as sources of supply of materials; concerning [the forces] in China in particular, measures to enable them to support themselves on site on their own account shall be stepped up to the limit.

II. Operations against China in the wake of the start of the Southern Operation (Omitted by the author) 
III. Operations against Russia in the wake of the start of the Southern Operation (Omitted by the author)

\section{Operation Plan of the Navy}

The Navy Department of IGHQ drew up the following operation plan, ${ }^{(1)}$ based on which the Combined Fleet made a detailed plan in which from the Combined Fleet the Second Fleet was assigned the southern operation in general, the Eleventh Air Fleet the air operations mainly in the Philippines and subsequently the Dutch East Indies, the Third Fleet the sea operations in these areas, and the Southern Expeditionary Fleet the sea operations in the Malaya area. From way back, the Third Fleet had been the fleet intended for the Philippines operations in the event of an outbreak of war with the United States. The Combined Fleet had been carefully considering a case in which the U.S. Pacific Fleet would come to the attack in the middle of a southern operation.

Mission of the Imperial Japanese Navy for War against the United States, Britain and the Netherlands

\section{Part 1. Mission in Case War against the United States, Britain and the Netherlands Breaks Out During the Operation Against China}

\section{Chapter 1. Summary}

1. The outline of the operational policy of the Imperial Japanese Navy — while continuing [operations] to take control of the Chinese coast and the lower reaches of the Yangzi basin - is to promptly destroy the enemy fleet and air power in the East, to occupy and secure strategic regions in the South, to build up a sustainable and unbeatable position, and [eventually] to destroy [more of] the enemy's fleet and in the end take the fight out of the enemy.

Chapter 2. Mission of the Combined Fleet

Section 1. Stage-one operations

2. The unit consisting of the Second Fleet, the Third Fleet, the Southern Expeditionary Fleet, and the Eleventh Air Fleet as its core shall clear the sea in the Philippines, British Malaya, and the Dutch East Indies of the enemy fleet, destroy them and in conjunction with the Army carry out the following operations:

(1) [The unit] shall launch operations against British Malaya and the Philippines simultaneously, conduct preemptive air strikes on the air and naval forces of the enemy in these areas and [at the same time] put ashore the Army's advance corps in the key areas in Malaya and the Philippines as quickly as possible in order to push ahead the air units and intensify the air operations.

(2) After the above operations [in 2.(1)] produce results, the main force of the Army's invasion force shall be put ashore in the Philippines and then in Malaya to promptly capture the Philippines and British Malaya.

(3) In the early stages of the operations, strategic places in British Borneo shall be occupied, followed by those in Dutch Borneo, the Celebes, and southern Sumatra at the earliest opportunity. Key places in the Moluccas and Timor shall [also] be occupied at favorable opportunities and the air bases there shall be made ready for use.

(4) As soon as the air bases mentioned in the above [2.(3)] have been made ready for use, air units shall be advanced one after another to suppress the air power of the enemy in the Java 
area. After [the operation] gets results, the main force of the Army's invasion force shall be put ashore on Java and capture it.

(5) After capturing Singapore, strategic areas in northern Sumatra shall be occupied and operations against Burma shall be conducted at the right moment in order to block the enemy's supply route to China.

3. The unit with the Fourth Fleet as its core is assigned to defend and patrol the equatorial Pacific Islands and protect the sea-lanes in the area. It shall capture Wake Island right at the opening of hostilities and, in conjunction with the Army, capture Guam and then the strategic places in the Bismarck Archipelago at the right moment.

Further, it shall attack and destroy advance bases of the enemy in the South Pacific at the right moment.

4. The unit consisting of the Fifth Fleet as its core shall patrol the sea to the east of Japan, be ready for surprise attacks of the enemy, and keep watch on the Aleutian Islands area. It shall also defend the Ogasawara Islands and protect sea traffic in the area. At the same time it shall be on its alert for Russia.

5. The unit with the Sixth Fleet as its core shall be dispatched to the Hawaiian Islands and the U.S. West Coast right at the opening of hostilities. It is assigned to reconnoiter and watch on the enemy fleet, conduct surprise attacks on it, and disrupt the sea-lanes [of the enemy] in the area.

6. The unit consisting of the First Air Fleet as its core shall conduct a surprise attack on the enemy fleet in Hawaii right at the outset of the war and strive to degrade its power. After that, it shall mainly be assigned to support the operations of the Fourth Fleet and the southern operation.

7. The main force of the Combined Fleet shall be assigned to support operations as a whole and take action at the right moment according to the movements of the enemy fleet.

8. An element of the Combined Fleet shall be assigned to disrupt the sea-lanes of the enemy in the Pacific and Indian Ocean areas at the right moment.

9. As for Thailand and French Indochina, efforts shall be made to the utmost extent not to arouse the hostility of the people while making them accept our operations. However, if any hostile behavior is observed, armed force shall be used without hesitation so as not to let them hinder our operations.

Section 2. Stage-two operations

(Omitted by the author. [It concerns] operations after the capture of strategic regions in the South.)

Chapter 3. Mission of the China Area Fleet (Omitted by the author)

Chapter 4. Mission of the units stationed at naval stations and strategic ports (Omitted by the author)

\section{Part 2. Mission in Case War Against Russia Breaks Out During the Operations Against the United States, Britain, the Netherlands and China (Omitted by the author)}

The First Fleet (covering the Inland Sea of Japan) consisted of eight battleships as its core, the Second Fleet consisted of thirteen heavy cruisers as its core, the Third and the Fourth Fleet of three (and the Fifth of two) light cruisers as their core. The Sixth Fleet was a submarine fleet, the First Air Fleet was an aircraft carrier [unit], and the Eleventh Air Fleet was a land-based air unit. 
The Order Issued by the Army Department of Imperial General Headquarters to Prepare for Attack, the Instructions Given by the Chief of the Army General Staff, and the [Army-Navy] Central Agreement

The order of battle of the Southern Army, issued on 6 November, was in outline as follows:

Commander in chief of the Southern Army: General Terauchi Hisaichi

General Headquarters of the Southern Army

Fourteenth Army: Army commander, Lt. Gen. Homma Masaharu; [consisting of] the 16th and the 48th Divisions and the 65th Brigade as its core

Fifteenth Army: Army commander, Lt. Gen. Iida Shōjirō; [consisting of] the 33d and the 55th Divisions (minus an element of the division) as its core

Sixteenth Army: Army commander, Lt. Gen. Imamura Hitoshi; [consisting of] the 2d Division and the 56th Mixed Infantry Group as its core

Twenty-fifth Army: Army commander, Lt. Gen. Yamashita Tomoyuki; [consisting of] the Imperial Guard Division, the 5th, the 18th, and the 56th Divisions as its core

21st Division

21st Independent Mixed Brigade

4th Independent Mixed Regiment

Third Air Force: Commander, Lt. Gen. Sugawara Michiō; [consisting of] the 3d, the 7th, and the 12th Air Divisions, and the 81st Air Group as its core

Fifth Air Force: Commander, Lt. Gen. Obata Hideyoshi; [consisting of] the 4th and the 10th Air Divisions as its core

10th, 21st and 83d Independent Air Units

The order of battle of the South Seas Detachment issued on the same day was as follows:

Detachment commander: Maj. Gen. Horii Tomitarō, commander of the 55th Infantry Group; [consisting of] the 55th Division's Infantry Group headquarters and the 144th Infantry Regiment as its core. ${ }^{(23)}$

The order given by the Army Department of IGHQ [Tairikumei] on 6 November to the commander in chief of the Southern Army to prepare for attack read:

(1) IGHQ shall prepare for the seizure of strategic regions in the South. (2) The commander in chief of the Southern Army, in cooperation with the Navy, shall assemble the main force of his army in Indochina, southern China, Taiwan, the Southwest Islands [stretching between the south of Kyūshū and the north of Taiwan], and the equatorial Pacific Islands and prepare to seize strategic areas in the South. Separate orders shall be issued for offensive operations ( ... the rest is omitted [by the author])."(1)

The order given by the Army Department of IGHQ on the same day to the South Seas Detachment commander read: 
(1) (Same as above.). (2) The commander of the South Seas Detachment, in conjunction with the Navy, shall proceed to the Ogasawara Islands and prepare for the capture of Guam. Separate orders shall be issued for offensive operations." ${ }^{\prime 1)}$

On the same day (the 6th), based on the above IGHQ Army Department Order, Chief of the Army General Staff Sugiyama issued an instruction [Tairikushi] to the commander in chief of the Southern Army:

Based on IGHQ Army Department Order No. 556, I instruct you as follows: (1) Summary of the operations of the Southern Army and the Army-Navy Central Agreement for the Southern Operation to which the commander in chief of the Southern Army shall conform in making preparations for the southern operation are specified in the separate volume. (2) The commander in chief of the Southern Army shall finish preparations for the operation by around the end of November (... the rest is omitted by the author)."(1)

The above-mentioned "Summary of the operations of the Southern Army" was an extract of required information from the previously mentioned "Summary of the General Operation Plan of the Imperial Japanese Army." (23) The above-mentioned "Army-Navy Central Agreement" was an agreement made by central command [i.e. the Army and the Navy Department of IGHQ] to establish the cooperation between the two forces, which consisted of: (1) Operational objectives, (2) Mission, (3) Strength employed, (4) Launch of the operation, (5) Outline of the operations, (6) Arrangements about command, (7) Aviation, (8) Sea transportation and communications, (9) Supply and medical affairs, (10) Transport and escort, (11) Time and date of the launch of operations and the time to be used for the operations, (12) Agreement between the Army and the Navy commanders, (13) Information, (14) Operation name and tactical map, (15) Exchange of intelligence, etc. And the separate volume on "The Army-Navy Central Agreement on the air [operations] for the Southern Operation" contained agreements on (1) Strength employed, (2) Outline of the Philippines operations, (3) Outline of Malaya, Burma, British Borneo operations, and (4) Outline of the Dutch East Indies operations. ${ }^{(23)}$

The main points relevant to the Dutch East Indies operations in the Army-Navy central agreement for the southern operation and the Army-Navy central agreement on the air [operations] for the southern operation were in outline as follows:(23)

1. In the southern operation (Operation A-Gō), operations against the Philippines (Operation M), against Malaya (Operation E), against British Borneo (Operation B), and subsequently against the Dutch East Indies (Operation H) shall be carried out. Assigned to the Sixteenth Army charged with the Dutch East Indies operation are the 2d Division, the 38th Division (to be diverted after the Hong Kong operation), and the 48th Division (to be diverted after capturing Manila), the 56th Mixed Infantry Group (Sakaguchi Detachment), South Seas Detachment (to be diverted after the captures of Guam and Rabaul), three tank regiments, five artillery battalions under the direct control of the Army, and eighty-eight antiaircraft guns as the core.

2. The Fourteenth Army shall conduct operations against the Philippines from Taiwan, the Penghu Islands, the Southwest Islands, and Palau; the Twenty-fifth Army shall conduct operations against Malaya from Hainan Island and southern French Indochina; and one detachment under the direct control of the Southern Army (the Kawaguchi Detachment, an element of the 18th Division) shall conduct operations against Miri, and subsequently Kuching in British Borneo from Cam Ranh Bay, and get the air bases there ready for use. Out of the advance parties to attack the Philippines, the unit charged with the capture of Legaspi and Davao shall leave Palau after 


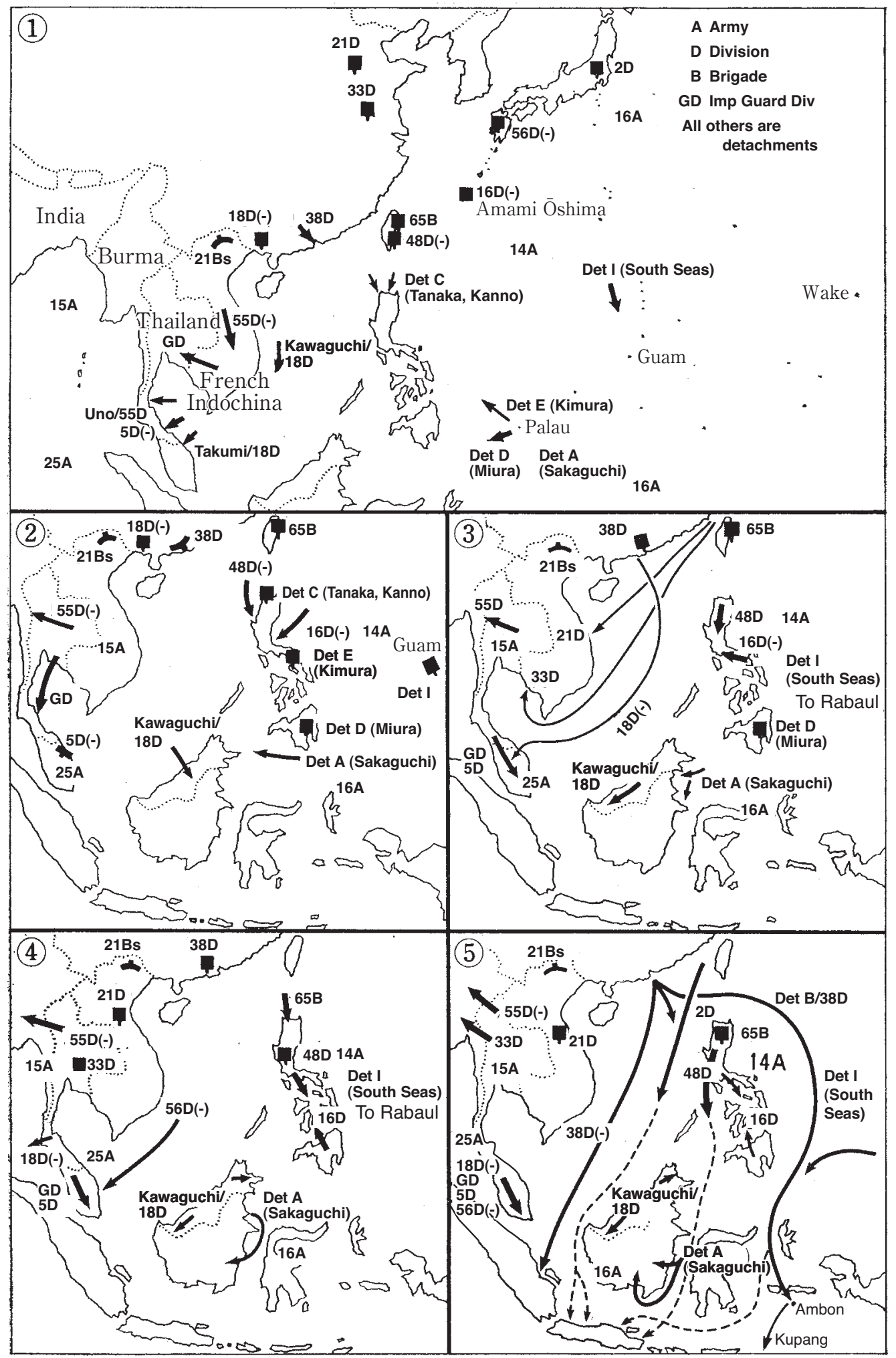

Illustration No. 8-Overview of the Operation Plan of the Army 
the evening of the day before the first air strike against the Philippines, make a landing, and first of all occupy the air bases and get them ready for use. Then, it shall occupy Jolo and set up an air base ready for use as quickly as possible. The guarding of Jolo shall be taken over by naval units.

3. The main points in conducting the Dutch East Indies operation are as described in the "General Operation Plan of the Imperial Japanese Army." However, the assembly points for the attack units are only roughly determined as Palau for the units to capture Borneo and the Moluccas, as Hong Kong for the units to capture Sumatra, as Luzon Island for the units to land in eastern Java, and as Taiwan and Hong Kong for the units to land in western Java.

4. The operations of the Second, the Third, and the Southern Expeditionary Fleets are as described in the above "Mission of the Imperial Japanese Navy." The strength to be employed for the Second Fleet is the 4th, the 5th, and the 7th Cruiser Divisions (heavy cruisers), the $2 \mathrm{~d}$ and the 4 th Destroyer Squadrons, and the $3 \mathrm{~d}$ Battleship Division (depending on the situation). The strength to be employed for the Third Fleet is the 16th Cruiser Division (light cruisers) and the 17th Minelayer Division, the 5th Destroyer Squadron, the 6th Submarine Squadron, the 12th Seaplane Tender Division, and the 1st and the $2 \mathrm{~d}$ Base Forces. The strength to be employed for the Southern Expeditionary Fleet is the Kashii (a training cruiser), the Shimushu (a coastal defense ship), and the 9th Base Force, to which one cruiser division, one destroyer squadron, one aircraft carrier, and two seaplane tenders shall be added in the early stage of the war.

5. The agreement on the air operations was as follows: At the beginning, 279 aircraft of the main force of the Eleventh Air Fleet, 40 reconnaissance seaplanes of the Third Fleet, and 144 aircraft of the Fifth Air Force (apart from this, 30 aircraft are for the air defense of Taiwan) shall start operations in the Philippines area, and 447 aircraft of the Third Air Force, 117 aircraft of the 22d Air Flotilla, and 20 aircraft of the Southern Expeditionary Fleet shall start operations in the Malaya, Burma and British Borneo areas. Air operations in the Burma and Thailand areas are assigned to the Army, those in the Malaya area are mainly the charge of the Army, those in British Borneo are assigned to the Navy, and those in the Philippines shall be conducted jointly by the Army and the Navy. The air cover for the landings of the advance parties in Legaspi and Davao shall be provided by the Navy only. As the Philippines operations make progress, the Eleventh Air Fleet shall proceed to the Dutch East Indies operations by exclusively using airfields in the central and southern Philippines, and the Fifth Air Force shall shift its position toward Thailand. Although air operations against the Dutch East Indies shall be conducted mainly by the Navy, those against northern Sumatra shall be conducted mainly by the Army, and those against southern Sumatra and western Java shall be conducted jointly by the Army and the Navy.

6. An attack schedule shall be made based on the shipping plan completed on 1 November, which sets approximately day $x+85$ for the landing in southern Sumatra and approximately day $x+$ 103 for the landings in (both eastern and western) Java.

7. If a decision shall be made to wage war (note: that is "provided the Main Points for the Implementation of Imperial National Policy are approved at the Imperial Conference on 5 November"), the following commanders are supposed to promptly conclude [specific] arrangements between them:

(1) [The commanders in chief of] the Southern Army and the Combined Fleet and the Second Fleet

(2) [The commanders in chief of] the Southern Army and the Southern Expeditionary Fleet

(3) [The commanders of] the Fourteenth and the Sixteenth Armies and [the commander in chief of] the Third Fleet

(4) [The commanders of] the Fifteenth and the Twenty-fifth Armies and [the commander in chief of] the Southern Expeditionary Fleet 
(5) [The commanders of] the Third and the Fifth Air Force and [the commander of] the Eleventh Air Fleet

(6) [The commander of] the Third Air Force and [the commander in chief of] the Southern Expeditionary Fleet and [the commander of] the 22d Air Flotilla

This central agreement was finally completed after its outline was agreed upon by 29 October and the shipping plan on 1 November. Since the agreement came shortly after the final decision on the Hawaii air strikes and the solution of the problem of extending the flying range of naval fighter aircraft, the result was that much of this agreement was generally based on the Army's draft, which left the agreement with inevitable issues such as discrepancies between central command and the Shipping Transport Command, and the yet unspecified utilization plan of Navy ships.

\section{The Order Issued by the Navy Department of Imperial General Headquarters to Prepare for Attack, the Instructions Given by the Chief of the Navy Gen- eral Staff}

As soon as the Main Points for the Implementation of Imperial National Policy were decided upon on 5 November, the Navy Department of IGHQ transmitted on the same day to the Commander in Chief of the Combined Fleet Yamamoto IGHQ Navy Department Order [Daikairei] No. 1, ordering him to prepare for operations. The order read as follows: ${ }^{(1)}$

1. The Empire [of Japan] has decided to complete all preparations for operations, expecting to wage war against the United States, Britain and the Netherlands in early December for the sake of its self-preservation and self-defense.

2. The commander in chief of the Combined Fleet shall carry out the necessary preparations for the operations.

3. For particulars, the chief of the Navy General Staff is appointed to give instructions.

Following the above Imperial Navy Order, Chief of the Navy General Staff Nagano, on the same day gave the following instruction to the commander in chief of the Combined Fleet:

The Combined Fleet shall have the necessary units advance at the right moment to take their preparatory positions before the launch of operations should the opening of hostilities with the United States, Britain and the Netherlands in early December be inevitable (... the rest is omitted by the author). ${ }^{(1)}$ (Note by the author: [this is] an instruction given by the chief of staff of the Navy Department of IGHQ [Daikaishi].)

\section{Orders for Invasion and Deployment}

The South Seas Detachment charged with the capture of Guam and Rabaul began boarding at Sakaide in Shikoku as early as 10 November, left port on the 13th, and first headed for the Ogasawara Islands. The 56th Mixed Infantry Group charged with capture of the east coast of Borneo was assembling from Kurume divisional district for boarding at Moji due to start from the 17th onwards. ${ }^{(53)}$ 
On 15 November, the Army Department of IGHQ transmitted the following IGHQ Army Department Order to capture strategic regions in the South to the Southern Army. ${ }^{(1)}$ Needless to say, negotiations with the United States were [still] in progress.

1. IGHQ intends to capture the strategic regions of the South for the sake of the Empire's selfpreservation and self-defense and the establishment of a Greater East Asia New Order.

2. The commander in chief of the Southern Army shall in cooperation with the Navy promptly capture the strategic regions in the South in accordance with the following points:

A separate order shall be issued for the start of the attack (advance).

(1) The regions to be occupied shall be the strategic areas of the Philippines, British Malaya and the Dutch East Indies, and a part of Burma, etc.

(2) (Item concerning Thailand and French Indochina. Omitted by the author.)

(3) In implementing the operations, propaganda and disinformation activities shall be carried out mainly in the interest of conducting the prosecution of the operations in our favor.

(4) A military administration shall be established in the occupied areas in order to restore public order and secure important national defense resources as well as means for the Army to maintain itself on its own account (... the rest omitted by the author).

When on 21 November the Navy Department of IGHQ issued its order that "the commander in chief of the Combined Fleet shall start directing the units required for conducting operations at the right moment toward the standby positions at sea," (1) the Carrier Task Force charged with the air strikes on Hawaii had already left the Inland Sea separately in individual ships or in small units from around the 18th onwards and was assembling in Hitokappu Bay in the southern Kuril Islands. ${ }^{(103)}$ The 56th Mixed Infantry Group (i.e. the Sakaguchi Detachment) had left Moji on the 19th for Palau. Detachment E charged with capture of Legaspi and Detachment D charged with capture of Davao, too, had left Nagoya on the 20th for Palau. ${ }^{(53)}$

\section{The Southern Army's Plan and Orders}

(See Illustration No. 9)

On 6 November, General Terauchi Hisaichi was appointed commander in chief of the Southern Army by the Emperor and on the same day received the previously described IGHQ Army Department Order to "prepare for invasion." (23) The principal staff officers, as described above, had been called up by the Army Department of IGHQ from late September onwards as prospective staff personnel of the Southern Army, and since then they had engaged in research side by side with the Army Department.

After receiving the IGHQ Army Department Order to prepare for invasion, the staff of the Southern Army made arrangements with the staff of the Combined Fleet and the Second Fleet on 8 and 9 November. ${ }^{(24)}$ On
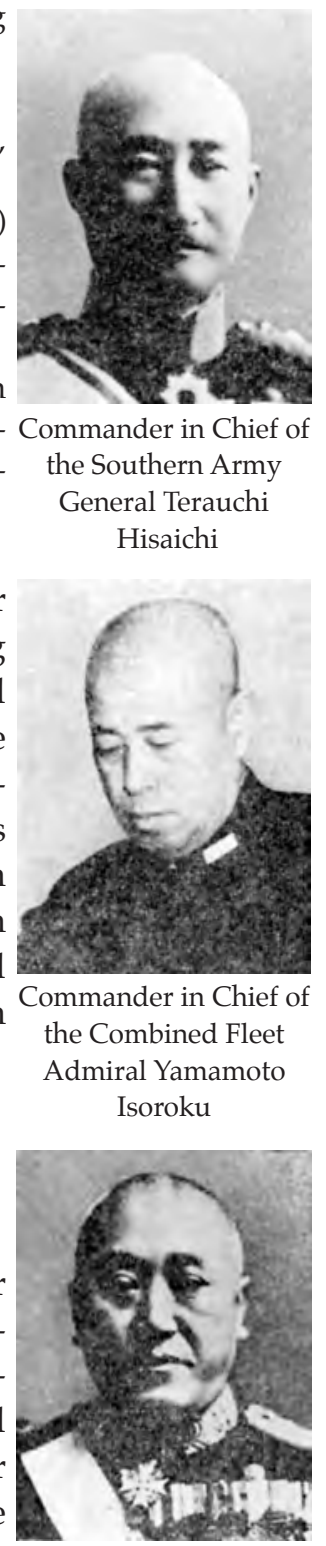

Commander of the Southern Task Force (and Commander in Chief of the Second

Fleet) V. Adm. Kondō Nobutake 
the following day, Commander in Chief Terauchi signed the "Agreement between the Combined Fleet and the Southern Army" and the "Agreement between the commander in chief of the Navy in the Southern Area and the commander in chief of the Southern Army" at the War College with Commander in Chief of the Combined Fleet Admiral Yamamoto Isoroku and Commander in Chief of the Second Fleet (Navy Southern Task Force Commander) V. Adm. Kondō Nobutake. The Southern Army thereafter referred to the first as "General Agreement [Sōkyō] No. 1" (i.e. Agreement between all the forces for the South), and the latter as "General Agreement No. 2."(23,24)

On that day (10 November), Commander in Chief Terauchi finalized the operation plan of the Southern Army and also on the same day summoned all the army commanders under his command to the premises of the Army Department of IGHQ and gave them orders concerning the preparations for the operation. ${ }^{(23)}$

Earlier, upon receiving the previously described IGHQ Navy Department Order on 5 November, the commander in chief of the Combined Fleet released the operation plans to each unit by Operation Order No. 1 of the same date. Subsequently on 7 November, by Operation Order No. 2, he gave orders to "[Execute] the first preparations for the opening of hostilities and set Day Y on 8 December."(107)

As the provisional formation of the headquarters of each army ordered on 5 November had been concluded, the Southern Army's command [over these armies] came into effect on 15 November. ${ }^{(1,23)}$ On the same day, as previously described, the Army Department of IGHQ carried out a war game in the presence of the Emperor and gave the order to invade [the South]. At this time, the armies of the Southern Army, in accordance with the above-mentioned Central Agreement, were drawing up arrangements at Iwakuni in Yamaguchi Prefecture (from 14 to $16 \mathrm{No}$ vember ) and in Saigon (from 15 to 17 November) with the fleets concerned. ${ }^{(23,24)}$ Based on the results of these arrangements, the commander in chief of the Southern Army on 20 November gave the order to invade [the South]. ${ }^{(23,24)}$ [Meanwhile,] Detachment A (i.e. the Sakaguchi Detachment), which was to carry out operational preparations at Palau, had made its departure on the previous day, and Detachments D and E (the Miura and Kimura Detachments), [which] also [were to prepare at Palau], left on this day respectively from Moji and Nagoya. ${ }^{(53)}$

On 15 November, the commander in chief of the Navy in the Southern Area (i.e. the commander of the Navy Southern Task Force), V. Adm. Kondō Nobutake, gave the [Navy] Southern Task Force Operation Order No. 1. On 23 November, the commander of the Philippines ([and later] the Dutch East Indies) Unit (i.e. the commander in chief of the Third Fleet) V. Adm. Takahashi Ibō, gave the [Navy] Philippines Unit Opera-

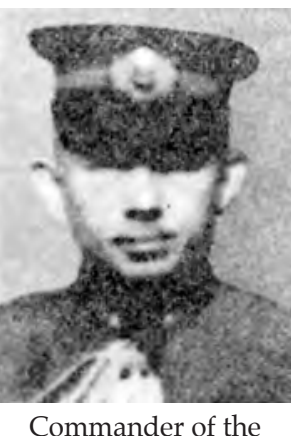

Commander of the Philippines ([and later] the Dutch East Indies) Unit (and Commander in Chief of the Third Fleet) V. Adm. Takahashi Ibō

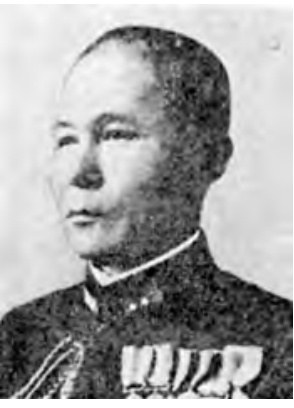

Commander of the Malaya Unit (and Commander in Chief of the Southern Expeditionary Fleet) V. Adm. Ozawa Jisaburō

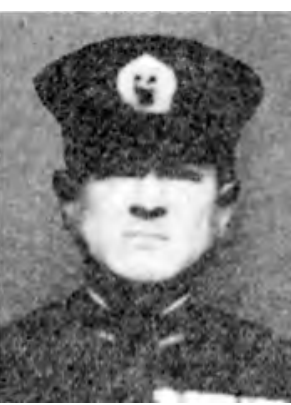

Commander of the Air Unit (Commander in Chief of the Eleventh Air Fleet) V. Adm. Tsukahara Nishizō tion Order No. 1 at the Terashima-suidō [Channel]. On 20 November, the commander of the Malaya Unit (i.e. the commander in chief of the Southern Expeditionary Fleet), V. Adm. 
Ozawa Jisaburō, gave the [Navy] Malaya Unit Operation Order No. $1^{(110)}$ at Saigon. Around 20 November, the commander of the Air Unit (i.e. the commander in chief of the Eleventh Air Fleet), V. Adm. Tsukahara Nishizō, gave the [Navy] Air Unit Operation Order No. $1^{(113)}$ at Gaoxiong, Taiwan.

\section{The Combined Fleet's Plan and Orders}

As stated above, the Combined Fleet issued Operation Order No. 1, dated 5 November. Briefly told, it ran as follows:(107)

1. Stage-one operations shall be divided into three phases:

(1) Phase-one operations: [concerns the period] from the opening of hostilities roughly until the landing of the main force of the Philippines invasion army (approx. until day $x+20$ )

(2) Phase-two operations: [concerns the period] from [the end of] the previous phase roughly until the landing of the main force of the British Malaya invasion army (approx. until day $x$ $+40)$

(3) Phase-three operations: [concerns the period] from [the end of] the previous phase until roughly the completion of the major part of the invasion of the Dutch East Indies.

2. Disposition of forces for phase-one shall be as follows: Main force units (under the direct control of the commander in chief of the Combined Fleet, whose core is the First Fleet, consisting of 6 battleships, 2 aircraft carriers and 2 light cruisers as the core, shall be deployed to the Inland Sea); the Carrier Task Force (whose core is the First Air Fleet, consisting of 6 aircraft carriers, 2 battleships, 2 heavy cruisers and 1 light cruiser as its core, shall be deployed for the air strikes on Hawaii); the Advance Unit (whose core is the Sixth Fleet, consisting of 27 submarines as the core, shall be deployed to the Hawaii area); the South Seas [Pacific Islands] Unit (whose core is the Fourth Fleet, consisting of 4 heavy cruisers, 3 light cruisers, 1 training cruiser and 1 seaplane tender as the core, shall be deployed for the capture of Guam, Wake and Rabaul); the Southern Task Force (to be explained later); the Northern Task Force (whose core is the Fifth Fleet, consisting of 2 light cruisers, 2 auxiliary cruisers and 1 seaplane tender as the core, shall be deployed for patrolling the waters east of Honshū and other tasks); the Supply Unit and others.

3. The Southern Task Force mentioned above, shall have the commander in chief of the Second Fleet as its commander and shall be subdivided as follows:

The Main Unit shall consist of the Second Fleet as its core, with 2 battleships, 2 heavy cruisers, 10 destroyers and 12 carrier-aircraft.

The Philippines Unit shall consist of the Third Fleet as its core, with 1 aircraft carrier, 5 heavy cruisers, 5 light cruisers, 3 seaplane tenders, 29 destroyers, base forces, and 104 carrier-aircraft. The Malaya Unit shall consist of the Southern Expeditionary Fleet as its core, with 5 heavy cruisers, 3 light cruisers, 1 training cruiser, 3 seaplane tenders, 15 destroyers, 21/2 land-based air units, 2 base forces, 191 aircraft.

The Air Unit shall consist of the Eleventh Air Fleet as its core, with 51/2 land-based air units, 2 destroyers, 308 aircraft [of the units].

The Submarine Unit shall consist of the 5th Submarine Squadron as its core with 16 submarines.

4. In phase-one operations, the Southern Task Force shall be responsible for the air operations, the occupation of Batan Island, landing operations at Aparri, Vigan (Laoag), Davao, Legaspi and Jolo, the escort of the main force of the Philippines invasion army, the escort and landing operations of the Malaya invasion advance corps, the Thailand occupation units and the British Borneo invasion units.

5. In phase-two operations, the Southern Task Force shall: (1) continue with phase-one operations, [further] extend military achievements, restructure the forces for the Philippines operation, 
[change focus and] prepare for invasion of the Dutch East Indies, and intensify [operations to] destroy the air and naval war potential of the enemy in Malaya and the Dutch East Indies; (2) escort the main force of the Malaya invasion army; (3) organize the "Dutch East Indies Unit" from almost the same forces that constituted the "Philippines Unit" which engaged in Phase One Operations, while leaving units to defend occupied key areas in the Philippines, whereas the Dutch East Indies Unit shall execute invasion operations in the order of: (1) Menado, Tarakan, (2) Balikpapan, Kendari, (3) Banjarmasin, Makassar, and depending on the situation, Sorong, Ambon and Kupang. The 12th Seaplane Tender Division shall be added to the [Navy] Malaya Unit before the landing of the main force of the Army's Malaya invasion army.

6. In phase-three operations, the Southern Task Force shall: (1) continue with phase-two operations and [further] extend military achievements; (2) escort the invasion army for Sumatra and Java;

(3) destroy sea traffic in the southern areas.

7. Disposition of the forces of the Combined Fleet in phase-two and three operations shall be roughly the same as in phase-one operations. All units except the Southern Task Force shall continue with phase-one operations.

8. Stage-two operations

Areas to be occupied or destroyed are: (1) eastern New Guinea, New Britain, Fiji, Samoa; (2) the Aleutians, Midway; (3) Andaman Islands, and (4) key locations in Australia.

\section{The Agreements Between the Southern Army, the Combined Fleet, and the Southern Task Force}

As previously described, on receiving on 6 November the IGHQ Army Department Order [Tairikumei] to prepare for invasion, the Southern Army concluded agreements with the Combined Fleet and the Southern Task Force [separately] on the 10th [of the month]. In these agreements (General Agreements Nos. 1 and 2) there was a matter that deserves special mention with respect to the Dutch East Indies operation, i.e. the invasion schedule.

The Southern Army, which had heard that the prospect of being able to complete the southern operation within 150 days had been presented to the Emperor, made it a point of honor and became firmly determined to try as hard as possible to shorten the schedule even further. It negotiated with the Navy and obtained an agreement which set the [estimated] landing in Java on "approximately day $x+80$ " instead of "approximately day $x+103$," as indicated in the Central Agreement at IGHQ. ${ }^{(24)}$ As previously described, draft agreements had [already] been reached between the staffs on the 8th and the 9th, and thus [the agreements] were concluded in a short time on the following day at the War College in the presence of both chiefs of the Army and the Navy General Staff. [However, the ceremony] presented an odd sight: Contrary to the Navy Department's quick agreement to this plan to substantially advance the schedule, the Army Department of IGHQ, which should have been most pleased about the advancing of the schedule, looked sullen. The reason why the Navy Department quickly agreed was because it was also eager to shorten the invasion schedule, mindful of an attack by the U.S. main fleet. Moreover, not being fully aware of [the size of] the Army's massive lines of communication units that accompanied it, the Navy took the convoy escorts too lightly. ${ }^{(28)}$ In contrast to the Navy Department, the cause of the Army Department's sullen looks was not simply a matter of losing face because it had been the Army Department that had put forward the Central Agreement schedule which [mentioned] approximately day $x+103$ [as the day to land in Java] ([to be precise,] this schedule was made at Shipping Transport Command). Rather, the reason was that the schedule had been con- 
ceived to operate about two million tons of tonnage so that all ships would move as efficiently as possible between the homeland, Manchuria, China and the southern areas, back and forth (north and south), left and right (east and west) considering the current position and task of each ship for the deployment of over 300,000 troops, and this could not be modified so easily. The Army Department watched the conclusion of the agreements by the Southern Army with a sullen look, hoping that it would turn out to be an impractical idea or wishful thinking. ${ }^{(23,24,105)}$

The "Memorandum of Agreement between the Combined Fleet and the Southern Army (dated 10 November)" signed by General Terauchi and Admiral Yamamoto was a simple document of no more than a few lines. ${ }^{(23)}$ This was because the Combined Fleet had left the specific arrangements to the Southern Task Force.

The "Memorandum of Agreement between the commander in chief of the Navy in the Southern Area and the commander in chief of the Southern Army (dated 10 November),"(23) signed by V. Adm. Kondō Nobutake and General Terauchi Hisaichi was in outline as follows:

1. Policy for joint operations. In conformity with the Central Agreement of 6 November, the objectives of the southern operation shall be accomplished within a short period of time in an atmosphere of immediate and proper cooperation.

2. Launch of the operations (omitted by the author).

3. Standard dates [to implement operations] of capturing. "[In the following chart] are the key areas, which the Army and Navy in cooperation with each other, shall capture, as well as the date of landing (along with assembly points and key areas the Navy shall capture unassisted as well as the date of landing):"

Note: M stands for [operations against] the Philippines, E for Malaya, B for British Borneo and $\mathrm{H}$ for the Dutch East Indies.

\begin{tabular}{|c|c|c|}
\hline Date of start of landing & $\begin{array}{c}\text { Key areas to capture (*stands for the } \\
\text { areas which the Navy will capture } \\
\text { unassisted) }\end{array}$ & Assembly points \\
\hline Day $x$ & $\begin{array}{c}\text { *M: Batan Island, E: Vicinities of } \\
\text { Ban Don, Nakhon, Singora, Pattani }\end{array}$ & M: Magong, E: Sanya \\
\hline Day $x+1$ & $\begin{array}{l}\text { M: Vicinity of Vigan or vicinity of } \\
\text { Laoag and vicinity of Aparri }\end{array}$ & Magong \\
\hline Depending on the proviso of 5.2.a) & E: Vicinity of Kota Bharu & $\begin{array}{l}\text { Sanya (note by the author: "Depend- } \\
\text { ing on the proviso of 5.2.a)" means } \\
\text { that this will be entrusted to the } \\
\text { agreement between the commander } \\
\text { of the Twenty-fifth Army and the } \\
\text { commander of the Malaya Unit) }\end{array}$ \\
\hline By day $x+4$ & M: Vicinity of Legaspi & Palau \\
\hline By day $x+6$ & M: Vicinity of Davao & Palau \\
\hline Around day $x+8$ & E: Vicinities of Singora and Pattani & Cam Ranh Bay \\
\hline Around day $x+8$ & B: Vicinity of Miri & Cam Ranh Bay \\
\hline
\end{tabular}




\begin{tabular}{|c|c|c|}
\hline Around day $x+13$ & B: Vicinity of Kuching & Miri \\
\hline Around day $x+13$ & M: Jolo & Davao \\
\hline By around day $x+14$ & $\begin{array}{l}\text { M: Lingayen Gulf, } \\
\text { Vicinity of Lamon Bay }\end{array}$ & $\begin{array}{c}\text { Penghu Islands [for the unit] for } \\
\text { Lingayen Gulf, Amami Ōshima [for } \\
\text { the unit] for Lamon Bay }\end{array}$ \\
\hline Around day $x+23$ & ${ }^{*} \mathrm{H}$ : Vicinity of Menado & Palau \\
\hline By around. day $x+25$ & $\begin{array}{l}\text { E: South Thailand or East Coast of } \\
\text { Malaya (for the first [landing] of the } \\
\text { main force), H: Vicinity of Tarakan }\end{array}$ & $\begin{array}{l}\text { Penghu Islands (Guangdong) for } \\
\text { Op. E, Palau for Op. H }\end{array}$ \\
\hline Around day $x+35$ & ${ }^{*} \mathrm{H}$ : Vicinity of Kendari & Menado \\
\hline Around day $x+35$ & H: Vicinity of Balikpapan & Tarakan \\
\hline Around day $x+45$ & ${ }^{*} \mathrm{H}$ : Vicinity of Makassar & Kendari \\
\hline By and large around day $x+50$ & H: Vicinity of Banjarmasin & Balikpapan \\
\hline Around day $x+60$ & $\begin{array}{c}\text { E: South Thailand or East Coast of } \\
\text { Malaya (for the second [landing] of } \\
\text { the main force) }\end{array}$ & Cam Ranh Bay (Sanya) \\
\hline By around day $x+60$ & $\begin{array}{l}\mathrm{H} \text { : Ambon and Kupang (as far as } \\
\text { possible) }\end{array}$ & Palau \\
\hline By and large around day $x+80$ & H: Java, Sumatra & $\begin{array}{l}\text { Hong Kong for the capture of Suma- } \\
\text { tra, Manila for eastern Java, Taiwan } \\
\text { and Hong Kong for western Java }\end{array}$ \\
\hline
\end{tabular}

4. Disposition of forces:

Area H: the Sixteenth Army, consisting of the 2d Division ([stationed in the] homeland), the 38th Division ([in] Operation C in the initial stage), the 48th Division ([in] Operation M in the initial stage), the 56th Mixed Infantry Group (i.e. the Sakaguchi Detachment: [in] Palau) and the South Seas Detachment ([in] Operations G and R in the initial stage) as its core, shall occupy Jolo, Tarakan, Balikpapan and Banjarmasin.

Note: C refers to southern China and Hong Kong, G to Guam and R to Rabaul.

Area B: One infantry regiment as its core, under the command of Maj. Gen. Kawaguchi Kiyotake.

(Other areas of which the Southern Army is in charge are omitted by the author.)

The areas of "The Philippines followed by the Dutch East Indies" covered by [the Navy's] Southern Task Force shall be assigned to the Philippines Unit and the Dutch East Indies Unit (the latter shall be organized out of the greater part of the Philippines Unit once the major part of the Philippines operations has been wrapped up), with the commander in chief of the Third Fleet as its commander. Its strength shall consist of most of the Third Fleet, the 5th Cruiser Division, most of the $2 \mathrm{~d}$ and the 4th Destroyer Squadron, the 4th Carrier Division (minus the $2 \mathrm{~d}$ Section), the 11th Seaplane Tender Division, the 12th SeaplaneTender Division (to join later) and 4 battalions of the special naval landing force as its core, with 4 heavy cruisers, 5 light cruisers, 1 aircraft carrier, 3 seaplane tenders, 5 minelayers, 33 destroyers, 12 fighter planes, 18 attack planes, and 40 reconnaissance seaplanes. The disposition at the opening of hostilities is Taiwan and Amami Ōshima for the main force, and Palau for part of the force.

Note: In the early stage of the war, the Southern Task Force was supposed to guard against the allied fleets in Singapore and Manila Bay as well as to be on the alert in the waters east of 
the Philippines in connection with the transport of Detachments A, D, and E, which started their operations from Palau. It roughly decided its initial disposition as follows:

\begin{tabular}{|c|c|c|c|c|c|c|c|}
\hline Units & Battleship & $\begin{array}{l}\text { Heavy } \\
\text { cruiser }\end{array}$ & $\begin{array}{l}\text { Light } \\
\text { cruiser }\end{array}$ & Destroyer & Submarine & $\begin{array}{l}\text { Aircraft } \\
\text { Carrier }\end{array}$ & $\begin{array}{c}\text { Seaplane } \\
\text { Tender }\end{array}$ \\
\hline $\begin{array}{l}\text { Southern } \\
\text { Task Force: } \\
\text { Main units }\end{array}$ & 1 & 2 & & 6 & & & \\
\hline $\begin{array}{c}\text { Southern } \\
\text { Task Force: } \\
\text { Eastern Sup- } \\
\text { port Unit }\end{array}$ & 1 & 1 & & 2 & & & \\
\hline Malaya Unit & & 5 & 2 & 16 & 8 & & \\
\hline $\begin{array}{l}\text { Philippines } \\
\text { Unit }\end{array}$ & & 4 & 5 & 33 & & 1 & 3 \\
\hline
\end{tabular}

5. Outline of the Operations

The take-over of the defense of Jolo shall be arranged between the Sixteenth Army and the Philippines Unit, and that of Tarakan and Ambon shall be arranged between the Sixteenth Army and the Dutch East Indies Unit.

The assembly of the 48th Division around Manila shall be scheduled for approx. day $x+55$, and its departure from the point of assembly for approx. day $x+70$. The [Navy] Philippines (Dutch East Indies) Unit shall provide escort for the redeployment.

The transfer of the corps to capture Bangka Island and southern Sumatra (consisting of an element of the Sixteenth Army) shall be escorted by the [Navy] Malaya Unit.

The transfer (for the capture of Java) of the element of the 38th Division (from Hong Kong), along with the main force of the Sixteenth Army (which shall move from Taiwan and later from southern French Indochina to western Java), shall be escorted by the [Navy] Dutch East Indies Unit.

Escort for the transfer and redeployment (between Palau and Hong Kong, and departure from Palau or Hong Kong) of the units to capture Ambon and Kupang (consisting of elements of Sixteenth Army) shall be arranged between the [Navy] Dutch East Indies Unit and the Sixteenth Army (the rest omitted by the author).

6. About the 40th and the 120th day of operations, meetings shall be held between the commanders concerned of both the Army and the Navy (the rest omitted by the author).

\section{The Order Issued by the Southern Army to Prepare for Attack, and Its Operation Plan}

On 10 November, Commander in Chief Terauchi concluded the previously mentioned agreements (General Agreement Nos. 1 and 2) at the War College, finalized the operation plan of the Southern Army, and in the afternoon at the War Ministry assembled the commanders of the Fourteenth, the Sixteenth and the Twenty-fifth Armies and their respective chiefs of staff, the chief of staff of the Fifteenth Army, the commander and chief of staff of the Third Air Force, and Commander Kawaguchi of the Kawaguchi Detachment (the Twenty-fifth Army commander here was Lieutenant General Yamashita; the newly appointed Fifteenth Army Commander Lt. Gen. Iida Shōjirō was at this time still in French Indochina as commander of the Twenty-fifth Army). Commander in Chief Terauchi gave the following instruction to be handed to all rank and file: 
All officers and men shall fully understand the true meaning of this sacred war, never forget their heavy responsibility, and with an iron will shall be devoted throughout. Firmly united you shall maintain in everything the harmony and cooperation between Army and Navy, and demonstrate the very best of your strength. Trusting in certain victory through our superior valor, you must be determined to achieve the objectives of the expedition in a short period of time. [Moreover,] to innocent officials and common civilians, you must by offering kindness, relief, guidance and encouragement, fully extol the dignity of the Imperial Army and not violate it in the least.

Along with this, he gave the following order to prepare for attack (as well as the operation plan). ${ }^{(23)}$ However, as a [previous] order by IGHQ had set the start of the exercise of command on 15 November, this order bore the date of the 15th even though it was handed down on the 10th.

Southern Army Operation Order A, No. 1.1

\section{Southern Army Order}

Tokyo, 15 November

1. In conjunction with the Navy, I intend to swiftly prepare to invade the strategic areas in the South ... (omitted by the author). The distribution of forces of the Southern Army is as given in the separate volume (omitted by the author).

2. Preparations for the operation shall be completed by approx. [month] [day] (note by the author: left blank in the original document). Excerpts of the operation plan of the Southern Army are as given in the separate volume ... (the rest is omitted by the author).

4. The commanders of the Fourteenth, the Fifteenth, the Sixteenth and the Twenty-fifth Armies, the commander of the Third Air Force and Commander Kawaguchi of the Kawaguchi Detachment shall make arrangements on operations with the Navy commanders concerned, based on the excerpts of the Army-Navy Central Agreement, and the General Agreement No. 2, i.e. the Memorandum of Agreement between the commander in chief of the Navy in the Southern Area and the commander in chief of the Southern Army.

5. The commander of the Fourteenth Army shall prepare for Operation M (note by the author: the Philippines operation).

6. The commander of the Fifteenth Army shall prepare for the operation to enter Thailand while ... (the rest is omitted by author).

7. The commander of the Twenty-fifth Army shall prepare for Operation E (note by the author: the Malaya operation). (Items $8-11$ omitted by the author.)

12. The commander of the Sixteenth Army shall prepare for the occupation of Jolo and Tarakan as well as the subsequent operations against the eastern outer territories of the Dutch East Indies.

13. In the event of an attack by U.S., British and Dutch forces or by any one of these forces, the commanders of the Fourteenth, the Fifteenth, the Sixteenth and the Twenty-fifth Armies and [the commander of] the Third Air Force shall intercept this attack with the forces at their disposal for the purpose of self-defense. However, such a situation as the above should be settled locally with the utmost effort.

Separate orders shall be issued for the execution of the advance.

14. Commander Kawaguchi of the Kawaguchi Detachment shall prepare for Operation B (note by the author: British Borneo operation) ... (the rest omitted by the author).

\section{Separate volume, excerpts of the operation plan of the Southern Army}

Section 1: Operational objective 
Article 1: The objective of the southern operation is to destroy the major bases of the United States, Britain and the Netherlands in East Asia and to occupy and secure the key areas of the South.

Article 2: The areas to be occupied by the Southern Army are the Philippines, British Malaya, Burma, Java and the Islands of Sumatra, Borneo and Timor.

\section{Section 2: Mission}

Article 3: The Southern Army shall, in conjunction with the Combined Fleet, launch the operations in the Philippines and British Malaya simultaneously by means of preemptive air strikes and strive to accomplish the objective of the operations within a short term.

\section{Section 3: Operational directives}

Article 4: The operations shall be conducted in accordance with the previous sections in the following manner:

Phase-one operations

1. Operations shall start with a sudden landing of an advance corps (or a preemptive air strike depending on the situation) against Malaya and a preemptive air strike against the U.S. [forces] in the Philippines. Then taking advantage of the results of the air operations, the main force of each invasion corps shall be put ashore first in the Philippines, then in Malaya, and swiftly capture the Philippines and British Malaya. Apart from this, strategic locations in British Borneo shall be occupied right at the opening of hostilities, and stability in Thailand and Indochina shall be secured.

2. The date for the start of the operations (day 1 of operations) shall be given by [separate] order. Even if the air strikes both in the Philippines and in Malaya on day 1 of operations are impossible to execute due to the weather, the sudden landing in Malaya shall be carried through as long as sea conditions permit. However, the landing of the advance parties in the Philippines shall be postponed depending on the launch of the air operations in the area.

3. During the above [operations], key locations in Dutch Borneo shall be occupied as quickly as possible, followed by key locations in southern Sumatra as the Malaya operation progresses, where vital resource areas shall be secured and preparations for operations against Java shall be made. During or after this, key locations in the Moluccas as well as on Timor shall be occupied at favorable opportunities.

\section{Phase-two operations}

As preparations for the above-mentioned operations make progress, command over enemy air power in the Java area shall be gained swiftly to seize the island. Also, key areas of northern Sumatra shall be occupied at the right moment after the capture of Singapore. During phaseone and phase-two operations, air bases in southern Burma shall be captured at favorable opportunities.

\section{Phase-three operations}

The occupied areas shall be stabilized and secured. Further, as far as circumstances permit, an operation for dealing with Burma shall be carried out. Separate orders shall be issued for implementation of this operation.

Section 4: Outline of the distribution of forces and their mission

Article 5: The outline of the distribution of forces of the Southern Army and their mission for Phase One Operations is as follows: 
The Philippines

The Fourteenth Army (consisting of two divisions as its core), in conjunction with the Navy, shall swiftly capture Manila, and then occupy key locations within the archipelago. After the capture of Manila, a unit with the 48th Division as its core shall be assembled in Manila or its vicinity and prepared so that it is ready to be diverted to the Sixteenth Army.

Malaya

The Twenty-fifth Army (consisting of four divisions as its core), in conjunction with the Navy, shall swiftly capture Singapore.

Thailand and Burma

The Fifteenth Army (consisting of two divisions as its core), in conjunction with the Navy, shall secure the stability of Thailand, facilitate the operations in Malaya, and [at the same time] prepare for subsequent operations against Burma.

The Dutch East Indies

The Sixteenth Army (consisting of three divisions as its core, of which two divisions as the core shall be redeployed from the Fourteenth Army and the Twenty-third Army), in conjunction with the Navy, shall occupy vital resource areas of Dutch Borneo, the Moluccas, Timor and southern Sumatra, secure air bases and make them ready for use.

Units under the direct control of the Southern Army shall consist of one division, two numbered air forces and other units. The division concerned shall be charged to stabilize and secure Indochina.

At the beginning of the operations, an element of the Twenty-fifth Army shall be brought under the direct control [of the Southern Army] to occupy key locations in British Borneo.

The numbered air forces, in conjunction with the Navy air unit, shall first destroy enemy air power in the Philippines, Malaya and Burma, while supporting the operations of the Fourteenth and the Fifteenth Armies with an element of each [air force], and the operations of the Twenty-fifth Army with their main force. Then, they shall support the Sixteenth Army in its operation in southern Sumatra. Furthermore, they shall be charged to cut off the enemy's rear lines of communication as well as to attack locations of strategic (and political) importance at the right moments.

Article 6: The outline of the distribution of forces of the Southern Army and their mission for phase-two operations is planned as follows:

The Philippines

The Fourteenth Army (consisting of one division and one mixed brigade as its core), in conjunction with the Navy, shall stabilize and secure key locations within the Philippine Archipelago. At the arrival of another mixed brigade, the division and other units shall get ready for redeployment.

British Malaya and Northern Sumatra

The Twenty-fifth Army, in conjunction with the Navy, shall secure key locations in Malaya such as Singapore, and Penang, and [at the same time] have a part of its force occupy key areas of northern Sumatra. In the meantime, preparations shall be made so that the unit under the direct control of the Twenty-fifth Army can be diverted to the Sixteenth Army as quickly as possible, and also the extraction of about 1 division shall be prepared.

Java [Editor's note: The original text says "Sixteenth Army." Vol. 34, p. 144 of the War History Series says "Java," which is probably correct.]

The Sixteenth Army, in conjunction with the Navy, shall occupy Java.

The numbered air forces, in conjunction with the Navy air unit, shall support the operations of the Fourteenth, the Fifteenth and the Twenty-fifth Armies with an element of each [air force], and the operations of the Sixteenth Army in Java with a force as large as possible. 
The rest shall largely be the same as in phase-one operations.

Article 7: The outline of the distribution of forces of the Southern Army and their mission for

The Philippines phase-three operations is roughly set as follows:

The mission of the Fourteenth Army (consisting of two mixed brigades as its core) shall be the same as in phase two.

British Malaya

The Twenty-fifth Army (consisting of three divisions as its core) shall stabilize and secure the key areas in British Malaya, British Borneo as well as in northern Sumatra.

The Dutch East Indies

The Sixteenth Army (consisting of two divisions as its core) shall stabilize and secure the key areas of the Dutch East Indies (excluding northern Sumatra).

When implementing the Burma operation, the Fifteenth Army (with part of its strength reinforced), in conjunction with the Navy, shall occupy key areas of Burma.

The numbered air forces, in conjunction with the Navy air unit, shall support the operations of the Fourteenth, the Sixteenth and the Twenty-fifth Armies with an element of each [group], and with a powerful element support the Fifteenth Army in its Burma operation.

\section{The [Navy] Southern Task Force's Plan and Orders}

The [Navy] Southern Task Force received the above-mentioned order of the Combined Fleet dated 5 November (note: although this order bore the date of 5 November, the whole contents were completed only after the 10th) and on 15 November issued its Operation Order No. 1. This order stated that "in conjunction with the Army, the U.S., British and Dutch warships and air power in the Far East shall be completely destroyed, all bases in the Philippines, British Malaya, Burma and the Dutch East Indies shall be demolished, and key areas in these territories shall be captured, while preparations shall be made to intercept attacks by the U.S. mainland fleets and others." [Furthermore] the order described plans to divide the operations [of Stage One] into three phases (until approximately day $x+20$, until approximately day $x+$ 40 , and until the completion of a major part of [the operation into] the South); to start the operations with preemptive air strikes and the swift disembarkation of part [of the force] in Malaya; to support the landing operations of the main force of the Fourteenth Army and then the main force of the Twenty-fifth Army after having supported the landings of the Army advance parties; to make efforts to destroy the allied warships in Singapore with air and naval power, as well as obstructing them with mine and submarine warfare; to make [air bases in] Davao and Jolo ready for use and advance the main force of the Eleventh Air Fleet from Taiwan to start the Dutch East Indies operation; to deploy submarines on the sea-lanes in the southern part of the Celebes Sea and capture Menado, Kendari and Makassar one after another, while capturing Tarakan, Balikpapan, and Banjarmasin one by one in cooperation with the Army, and then at favorable opportunities, to occupy Ambon, followed by Kupang, which is intended as a base for operations against Australia; to have the 22d Air Flotilla divert from the Malaya area to Miri and Kuching, and to advance submarines to the Indian Ocean in order to carry out invasion operations against southern Sumatra and later against Java; and to use paratroop units depending on the situation. It was decided to advance the 6th Submarine Squadron first to Sanya, leaving the Inland Sea on 21 November, the 5th Submarine Squadron first to Palau, leaving the Inland Sea on 25 November, and to advance the 
main force of the Southern Task Force to Magong on 2 December, leaving the Inland Sea on the 29th [of November]. The disposition of forces for the first phase was set as follows: ${ }^{(110)}$

Main Force

Main Unit: under the direct command of the commander in chief of the Second Fleet, [consisting of] the main force of the 4th Cuiser Division ([consisting of] 2 heavy cruisers), part of the 3d Battleship Division ([consisting of] 1 battleship), and 6 destroyers

Eastern Support Unit: [consisting of] 1 battleship of the 3d Battleship Division, 1 heavy cruiser of the 4th Cruiser Division and 2 destroyers ([assigned to] support operations in the eastern waters of the Philippines)

Philippines Unit: under the command of the commander in chief of the Third Fleet, [consisting of] the Third Fleet (minus the 2d Section of the 17th [Minelayer] Division, the 6th Submarine Squadron and the 12th Seaplane Tender Division), the 5th Cruiser Division ([consisting of] 3 heavy cruisers), the main force of the 4 th Carrier Division ([consisting of] 1 aircraft carrier), the main force of the $2 \mathrm{~d}$ Destroyer Squadron, the main force of the 4th Destroyer Squadron, and the 11th Seaplane Tender Division ([consisting of] 2 seaplane tenders)

Malaya Unit: under the command of the commander in chief of the Southern Expeditionary Fleet, [consisting of] the Southern Expeditionary Fleet, 1 heavy cruiser of the 4th Cruiser Division, the 7th Cruiser Division (consisting of 4 heavy cruisers), the 3d Destroyer Squadron, the 4th Submarine Squadron, 1 division of the 6th Submarine Squadron, the 2d Section of the 17th Minelayer Division, the 12th Air Seaplane Tender Division (consisting of seaplane tenders), the 22d Air Flotilla (land-based aircraft), 42 aircraft of the 23d Air Flotilla

Air Unit: under the command of the commander in chief of the Eleventh Air Fleet, [consisting of] the Eleventh Air Fleet (minus the 22d Air Flotilla and 42 aircraft of the 23d Air Flotilla), 2 battalions of the [naval] special landing forces

Submarine Unit: under the command of the commander of the 5th Submarine Squadron, [consisting of] the 5th Submarine Squadron, and the main force of the 6th Submarine Squadron

Note: The basic formation of the Third Fleet consisted of the 16th Cruiser Divison (consisting of 2 light cruisers), the 17th Minelayer Division (consisting of 2 minelayers), the 5th Destroyer Squadron (consisting of 1 light cruiser and 8 destroyers), the 6th Submarine Squadron, the 12th Seaplane Tender Division (consisting of 2 seaplane tenders). The basic formation of the Southern Expeditionary Fleet consisted of 1 training cruiser, 1 escort ship, 1 gunboat and others. ${ }^{(101)}$

\section{The Southern Army's Invasion Order}

The Southern Army, which had passed down the order to prepare to invade the southern key areas, then issued the order to invade the southern key areas (dated 20 November). ${ }^{(23,24)}$ This order prescribed the actions of each army for the next forty to fifty days. ${ }^{(24)}$

With respect to the Dutch East Indies operation, this order contains two points that should be specially mentioned. The first point is that, regardless of previous orders, this order assigned the Sixteenth Army to capture Davao. The reason was that when, in accordance with the above-mentioned General Agreement No. 1, arrangements were made between the Fourteenth and the Sixteenth Armies and the Navy Philippines Unit at Iwakuni, problems arose which will be explained later. The second point is that although the date of issue [of the order] was set as the 20th and it was transmitted to each army on that day, the Sixteenth Army had been given a verbal notification when on the 19th its chief of staff, Okazaki Seizaburō, had 


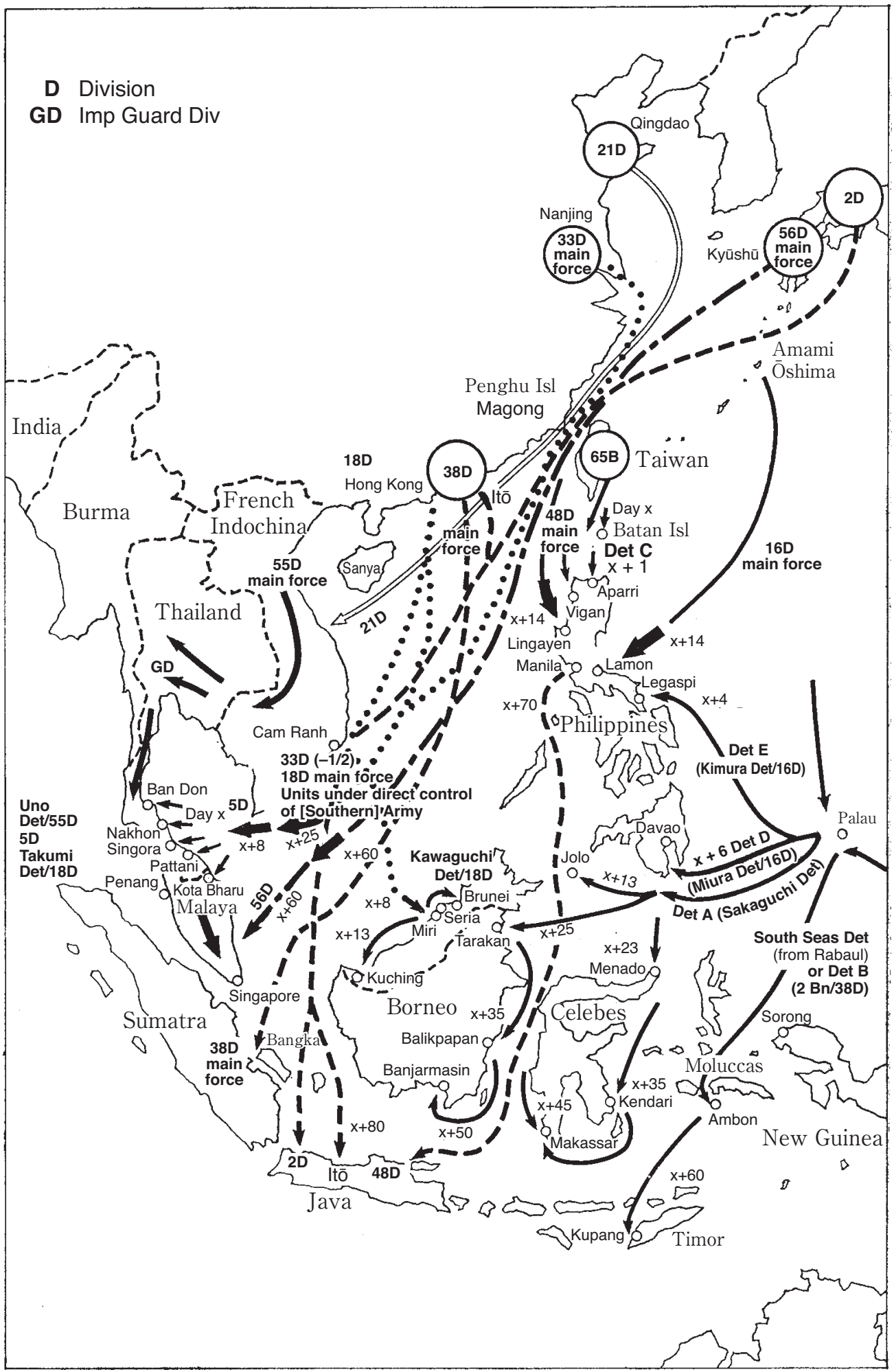

Illustration No. 9-The Southern Army Operation Plan 
been especially summoned. This was because the 56th Mixed Infantry Group [of the Sixteenth Army] (i.e. the Sakaguchi Detachment) was leaving Moji on the night of 19th for Palau. ${ }^{(23,24,36)}$

The excerpt of relevant articles of this Southern Army order (Southern Army Operation Order A, No. 2) is as follows:(23)

1-3. In conjunction with the Navy, I intend to swiftly invade the southern key areas. Separate orders shall be issued for the launch of offensive operations (excerpted by the author).

4. The Fourteenth Army shall swiftly capture the main bases on the Philippines, Manila in particular (summarized by the author).

5. The Twenty-fifth Army shall make a sudden landing in Malaya and make efforts to establish a forward foothold in order to capture Singapore (summarized by the author).

6-10. The Fifteenth Army shall advance into Thailand and secure stability [there] while preparing for the subsequent operations against Burma (summarized and excerpted by the author).

11. The commander of the Sixteenth Army shall swiftly occupy Davao, Jolo, Tarakan and then Balikpapan, Banjarmasin with an element of his force and secure necessary air bases as well as vital resource areas. The commander of the Sixteenth Army shall direct the units, which are under the command of or led by the Fourteenth Army commander, to guard the assembly point of Palau. The unit to occupy Davao shall receive directions from the Fourteenth Army commander as to the date and time to depart from its assembly point. After the capture of Davao, the occupation units in Davao, which were originally under the command of the Fourteenth Army commander (along with the shipping units and part of the materiel), shall be returned to the Fourteenth Army. The defense of Jolo and Tarakan shall be turned over to the Navy swiftly as soon as the major part of each operation in these areas is finished.

12. Commander Kawaguchi of the Kawaguchi Detachment shall depart from the assembly point after the opening of hostilities, carry out a sudden attack, and occupy Miri and Seria first, secure vital resource areas as well as air bases and, immediately after that, occupy the air base near Kuching as quickly as possible. (13-14 are omitted by the author).

15. In order to restore order, obtain resources crucial to national defense and secure the means for the armies to maintain themselves on their own account in the occupied territories, each army commander and Commander Kawaguchi shall take charge of establishing a military administration in each area. Separate orders shall be issued concerning the details of the establishment of a military administration (summarized by the author).

After issuing this order, Commander in Chief Terauchi left Tokyo on 25 November and first headed for Taipei. ${ }^{(23)}$

\section{Operational Preparations of the Sixteenth Army}

Lt. Gen. Imamura Hitoshi had just been transferred to become commander of the Twentythird Army in Guangdong in June after taking part as commander in a maneuver from Shanghai to northern Kyūshū that simulated a transoceanic landing on Malaya to capture Singapore, when, on 6 November, he received a telegram from War Minister Tōjō Hideki that read: "You have been appointed commander of the Sixteenth Army by the Emperor today. Come to Tokyo tomorrow, the 7th, by the airplane specially sent by central command [IGHQ] and turn over your duty to incoming commander Lt. Gen. Sakai Takashi." Lieutenant General Imamura left Guangdong on the 7th with no idea what his new task was, landed at Tachikawa Airfield on the 10th, and was met by Maj. Gen. Okazaki Seizaburō, with whom he had worked 
at the Inspectorate General of Military Training until four months before. The major general informed him that the Sixteenth Army would be dispatched to Java should diplomatic negotiations fail, and that he, Major General Okazaki, had been appointed chief of staff of the army. ${ }^{(35)}$

On 5 [November], the day before Lieutenant General Imamura received the above-mentioned telegram in Guangdong [Canton], the Main Points for the Implementation of Imperial National Policy, which expressed the determination to wage war against the United States, Britain and the Netherlands, had been decided upon at the Imperial Conference in Tokyo. On the same day, outlines for the provisional formation of the headquarters of the Sixteenth and the other armies had been issued by Army Order A, No. 79. ${ }^{(3,52)}$ The detailed regulations of this outline stipulated that the Fourteenth Army, which was to cross the sea and land in the Philippines, would be called "Wataru-shüdan," (Crossing Corps) and that the Sixteenth Army, which was to conquer the Dutch East Indies, would go by the name of "Osamu-shüdan" (Pacifying Corps). ${ }^{(52)}$ When Lieutenant General Imamura read the detailed regulations of this army order, he realized that the completion of the conquest of the Dutch East Indies by the Sixteenth Army meant the completion of the southern operation and that the Sixteenth Army was expected to implement an appropriate military administration in particular. ${ }^{(35)}$ The formation of the Sixteenth Army headquarters was completed on 13 November at the War College under the supervision of the Eastern District Army commander. ${ }^{(32,52)}$

On 6 [November], the day when in Guangdong Lieutenant General Imamura received the above-mentioned telegram from the War Minister, the order of battle of the Southern Army was announced in Tokyo, as well as the Army Department of IGHQ's order to prepare for attack, and the appointment of army commanders and lesser officers. ${ }^{(1,23)}$

On the 10th, when Lieutenant General Imamura arrived in Tokyo, Commander in Chief [of the Southern Army] Terauchi made agreements with Commander in Chief [of the Combined Fleet] Yamamoto Isoroku and Commander in Chief [of the Second Fleet] Kondō Nobutake at the War College. After that, he gathered together Sixteenth Army Commander Imamura and his colleagues at the War Ministry and gave the previously described instruction and the Southern Army Order to prepare for attack. ${ }^{(23)}$

Right after the formation of the [Sixteenth] Army headquarters was completed on 13 November, Army Commander Imamura departed Tokyo on the same day for Iwakuni, where from the 14th to the 16th he made arrangements with the commander in chief of the Third Fleet. $^{(32)}$

In the meantime, as of 0000 on 15 November, the units included in the order of battle of the Sixteenth Army were transferred to the command of Army Commander Imamura. (However, units still in [various distant parts of] homeland Japan, Korea, Manchuria, northern China and eastern China after that time were to be transferred to his command on leaving their respective ports of departure.) Further, an order of the Army Department of IGHQ stipulated that Army Commander Imamura was given authority to give commands concerning preparations for operations to units that were in the order of battle of the army but had not yet been transferred to his command after 0000 on November 15. This day (15 [November]) was the day when IGHQ issued the previously described order of invasion. ${ }^{(1)}$

On concluding the Iwakuni Agreement, Army Commander Imamura on the 16th left Iwakuni for Moji where he took command of the 56th Mixed Infantry Group (Detachment A 
a.k.a. the Sakaguchi Detachment) which was embarking there, gave instructions and encouraged them. The next day on the 17th, he left Moji to fly back to Tokyo. ${ }^{(32,88)}$

On the 18th, Maj. Gen. Harada Yoshikazu, vice chief of staff [of the Sixteenth Army] took up his post. ${ }^{(32)}$ The major general, who worked for the Kwantung Army after his return from Java with Ambassador Yoshizawa Kenkichi, had previously worked in Section 1 of the Army General Staff Office, along with Lieutenant General Imamura and Major General Okazaki. ${ }^{(37)}$ He was posted [vice chief of staff] due to the previously described change in Major General Manaki's task. ${ }^{(36)}$

On the 19th, a formal ceremony was held at the [Sixteenth] Army headquarters [provisionally situated] in the War College where all subordinate officers presented themselves to their commander, after which Army Commander Imamura gave his instructions. ${ }^{(32)}$ In the evening, Chief of Staff Okazaki was summoned to the General Headquarters [of the Southern Army] and unofficially informed of the Southern Army's previously described order of invasion (including the decision that the Sixteenth Army should capture Davao as well). ${ }^{(24,32)}$ The Sakaguchi Detachment left Moji that night and headed for Palau first. ${ }^{(88)}$

From the 24th to the 25th, Army Commander Imamura visited the Sendai divisional district, where the 2d Division Commander Lt. Gen. Maruyama Masao and his subordinates presented themselves to him. He gave them instructions, inspected the division's exercises and encouraged the officers and men. ${ }^{(32)}$

On 1 December, the Imperial Decision to open hostilities was made, which was followed by the issue on the next day, 2 [December], of the Imperial Order of "Exercise of Armed Force on 8 December." ${ }^{(1,3)}$ However on 1 December, the Sakaguchi Detachment was already in Palau (it had arrived in Palau on 28 November ${ }^{(88)}$ ) and the $2 \mathrm{~d}$ Division had started moving to maneuvering grounds in Narashino, Fuji, Toyohashi, etc., in order to vacate its station in the Sendai divisional district and conduct military exercises. ${ }^{(1,53)}$ [Even then,] the Sixteenth Army headquarters was still at the War College in Aoyama, Tokyo, and devoted itself to drawing up its plan of operation. ${ }^{(32)}$

\section{Order of Battle [of the Sixteenth Army] (See the table in the appendix.)}

The order of battle of the Sixteenth Army (issued on 6 November) was in outline as follows; ${ }^{(1,23)}$ details are as shown in the table in the appendix to this volume:

\section{Order of Battle of the Sixteenth Army}

Commander of the Sixteenth Army: Lt. Gen. Imamura Hitoshi

Headquarters of the Sixteenth Army

2d Division

56th Mixed Infantry Group (organization as shown in table No. 1)

8th Tank Regiment, 17th Field Heavy Artillery Regiment (A), 18th Field Antiaircraft Defense Unit headquarters, 44th Field Antiaircraft Artillery Battalion (B), 16th Antiaircraft Artillery Regiment, 1st Independent Engineer Regiment (E), 1st Independent Engineer Company (electricity), 4th Independent Engineer Company ([to facilitate] the river-crossing of heavy equipment), 168th Railway Depot headquarters (B), Sixteenth Army Signal Unit (organization as shown in attached table No. 2), 29th Bridge Building Material Company, Imperial Guard Division River-crossing Material Company, 6th Division Bridge Building Material Company, 3d Field Military Police 
Unit, Line-of-Communication Unit under the direct control of the Sixteenth Army (organization as shown in table No. 3)

\section{Table No. 1}

Organization of the 56th Mixed Infantry Group

Commander: the commander of the 56th Infantry Group, Maj. Gen. Sakaguchi Shizuo

56th Infantry Group headquarters, 146th Infantry Regiment, 56th Infantry Group Armored Car Unit, 56th Field Artillery Regiment 1st Battalion, 56th Engineer Regiment 1st Company, 56th Transport Regiment 2d Company, 56th Infantry Group Medical Unit, and 56th Divisional 1st Field Hospital

\section{Table No. 2}

Organization of the Sixteenth Army Signal Unit

Commander: the commander of the 15th Telegraph Regiment

15th Telegraph Regiment, 3d, 4th, 6th, 7th, 8th, and 13th Independent Radio Platoons (motorized), 60th Radio Telegraph Platoon (horse-carried), 33d, 34th, 45th, 46th, and 55th Fixed Radio Units

\section{Table No. 3}

Line-of-Communication unit under the direct control of the Sixteenth Army 43d and 48th Line-of-Communication Area Units, 2d Field Transport headquarters, 39th and 102d Independent Motor Transport Battalions, 261st Independent Motor Transport Company, 42d and 44th Field Road Units, 5th and 16th Field Well-drilling Companies, 14th Field Duty Unit (commander: 14th Field Duty Unit commander, 14th Field Duty Unit headquarters, 107th and 108th Shore Duty Companies, 45th Sea Duty Company), 61st and 62d Construction Duty Companies, 18th Field Postal Unit, 18th Line-of-Communication Medical Unit (commander: 18th Line-of-Communication Medical Unit commander, 18th Line-of-Communication Medical Unit headquarters, 67th, 115th, 116th, and 121st Line-of-Communication Hospitals), 16th Patient Transport Unit (Commander: the 16th Patient Transport Unit commander, the 16th Patient Transport Unit headquarters, 65th, 66th, and 68th Patient Transport Platoons), 22d Field Water Supply and Purification Department (B), 13th Line-of-Communication Sick Horse Depot, 19th Veterinary Quarantine Depot (B), 24th Field Ordnance Depot, 24th Field Motor Transport Depot, 24th Field Freight Depot

About half of the above units under the direct control of the [Sixteenth] Army, other than the division and the infantry group, were units in Manchuria that had been mobilized for the KANTOKUEN [Special Grand Maneuvers of the Kwantung Army], and those that were stationed in China. They were to be transported to Moji or Gaoxiong to join the 56th Mixed Infantry Group and the main force of the Sixteenth Army. The well-drilling companies were intended to restore and develop oil fields. As mentioned previously, [the Army Department of] IGHQ and the Southern Army planned to divert the 38th and the 48th Divisions, the South Seas Detachment, and many other units under the direct control of other armies to the Sixteenth Army as the capture of Hong Kong, the Philippines, Malaya, Guam, and Rabaul progressed.

The order of battle of the South Seas Detachment, which was scheduled to be put under the command of the Sixteenth Army after the capture of Guam and Rabaul, was as shown in the table in the appendix to this volume. 


\section{Lineup of the Sixteenth Army Headquarters}

Main personnel of the Sixteenth Army headquarters was as follows:

$\begin{array}{ll}\text { Commander of the Army: } & \text { Lt. Gen. Imamura Hitoshi } \\ \text { Chief of Staff: } & \text { Maj. Gen. Okazaki Seizaburō } \\ \text { Vice Chief of Staff: } & \text { Maj. Gen. Harada Yoshikazu } \\ \text { Staff Officers of Section 1 } & \text { Col. Takashima Tatsuhiko } \\ \text { Senior Staff: } & \text { Lt. Col. [Col.] Murakami Kimis } \\ \text { Chief Intelligence Staff: } & \text { Lt. Col. Itoda Isamu } \\ \text { Chief Aviation Staff: } & \text { Lt. Col. Oda Akimitsu } \\ \text { Chief Operations Staff: } & \text { Maj. Kuriya Tsugunori } \\ \text { Staff Officer Intelligence: } & \text { Maj. Yamashita Yutaka } \\ \text { Assistant Operations Staff Officer: } & \\ & \\ \text { Staff Officers of Section 2 } & \text { Col. Kitamura Yoshifuto } \\ \text { Senior Staff: } & \text { Lt. Col. Saiki Ikuzō } \\ \text { Chief Signal Communication Staff: } & \text { Lt. Col. Sendō Shunzō } \\ \text { Chief Shipping Staff: } & \text { Maj. Takahashi Mitsuzō } \\ \text { Staff Officer Line of Communication: } & \text { Maj. Nishiura Setsuzō } \\ \text { Staff Officer Line of Communication: } & \text { Col. Nakayama Yasuto } \\ \text { Attached to the [Sixteenth] Army headquarters: } & \text { Maj. Gen. Yamada Hisamatsu } \\ \text { Ordnance Department Director: } & \text { Maj. Gen. Mukai Kinjirō } \\ \text { Intendance Department Director: } & \text { Maj. Gen. Nakajima Haruhiko } \\ \text { Medical Department Director: } & \text { Col. Kurokawa Sanjirō } \\ \text { Veterinary Department Director: } & \text { Col. Tsumura Mikizō } \\ \text { Legal Department Director: } & \end{array}$

The staff officers of the army headquarters were selected from those who were working at the central offices of the Army in Miyakezaka, or who were teaching at the War College in Aoyama at that time, or from those who had had such careers. This, along with the personality of the army commander and the chief of staff and the previous relationships among the people concerned, might have helped to create an atmosphere where from the beginning the staff got along well and worked harmoniously. Among the staff officers, Colonel Kitamura and Lieutenant Colonel Sendō were experts in shipping who had worked in the Shipping Section of the Army General Staff Office and given lectures on shipping at the War College. Major General Harada, Colonel Nakayama, and Major Kuriya had accompanied the Kobayashi and Yoshizawa delegations to Java, and Colonel Murakami, Lieutenant Colonel Sendō, and Major Nishiura were officers who had studied the Dutch East Indies operation for a long time.

\section{Formation and Personnel of the Divisions and the Infantry Group}

Included in the order of battle of the Sixteenth Army from the very beginning were the $2 \mathrm{~d}$ Division and the 56th Mixed Infantry Group. The 38th and 48th Divisions and the South Seas Detachment were to be added at later stages. The outline of how these units were constituted and composed, and of their main personnel is shown in the table in the appendix. The details of their formation were as follows: 


\section{2d Division ("Isamu-heidan," The Braves)}

Division commander: Lt. Gen. Maruyama Masao

This division was formed by Army Order A, No. 63 on 16 September. However, as will be told later, it was reorganized by Army Order A, No. 5 on 30 January [1942,] because the moving up of the timing of the Java operation caused a shortage of tonnage, and because the results of the Fourteenth and Twenty-fifth Army operations created organizational problems. Consequently, the number of personnel and horses was reduced by respectively 448 men and 1,700 horses, whereas the number of motor vehicles was increased instead. ${ }^{(52,31)}$ After reformation, the regular strength of the division became 13,755 men, 1,335 horses, and 586 motor vehicles. ${ }^{(52)}$ Units integrated into the division and their details were as follows: ${ }^{(52,1,53)}$

2d Division headquarters: 305 men, no horses and 40 motor vehicles.

2d Infantry Group headquarters: 93 men, no horses and 8 motor vehicles. 4th Infantry Regiment: 2,719 men, 203 horses and 36 motor vehicles.

The regiment was [composed of] regimental headquarters, 3 battalions, 1 regimental artillery battery (with 4 mountain guns), 1 antitank gun company (with 4 guns), and 1 signal company.

The battalions were [composed of] 3 companies, 1 machine gun company (with 8 guns), and 1 battalion artillery section (with 2 guns). (Note: According to the action report of the $3 \mathrm{~d}$ Battalion, the actual numbers of men and horses of the battalion were 791 and 51 respectively, and there were no motor vehicles.)

The regiment had sufficient bicycles to cover the needs of one-third of its infantry companies. In addition it was equipped with two-wheeled trail-

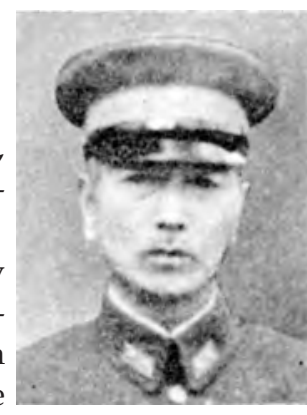

Commander of the $2 \mathrm{~d}$

Division, Lt. Gen. Maruyama Masao ers for heavy firearms.

16th Infantry Regiment: same as above.

29th Infantry Regiment: same as above.

2d Reconnaissance Regiment: regimental headquarters and 4 companies; 439 men, no horses and 59 motor vehicles.

2d Field Artillery Regiment: regimental headquarters and 3 battalions. The battalions were [composed of] their headquarters and 3 batteries (with 4 guns each). The Regiment consisted of 1,738 men, 726 horses and 68 motor vehicles. The 1st Battalion was equipped with motor vehicles; the other battalions were equipped with draft horses.

2d Engineer Regiment: regimental headquarters, 3 companies and 1 equipment platoon; 872 men, no horses and 32 motor vehicles.

2d Transport Regiment: headquarters and 3 companies; 381 men, no horses and 105 motor vehicles.

2d Divisional Signal Unit: unit headquarters and 3 platoons; 182 men, no horses and 18 motor vehicles.

2d Divisional Medical Unit: 491 men, no horses and 36 motor vehicles.

2d Divisional Ordnance Service Unit: 123 men, no horses and 13 motor vehicles.

2d Divisional 1st Field Hospital: 242 men, no horses and 22 motor vehicles.

2d Divisional 2d Field Hospital: same as above.

2d Divisional 4th Field Hospital: 247 men, no horses and 23 motor vehicles.

2d Divisional Water Supply and Purification Department: 196 men, no horses and 25 motor vehicles.

2d Divisional Sick Horse Depot: 47 men, no horses and 7 motor vehicles. 
56th Mixed Infantry Group (Sakaguchi Detachment)

Infantry Group commander: Maj. Gen. Sakaguchi Shizuo

Composition, personnel, etc. were as shown in the table in the appendix. The formation of the unit corresponded to that of the $2 \mathrm{~d}$ Division. The numbers of men, horses, and motor vehicles of the detachment were 5,200, 1,200, and 100 respectively. ${ }^{(24)}$

\section{8th Division ("Numa-heidan" The Swampers)}

Division commander: Lt. Gen. Sano Tadayoshi

The division was scheduled to transfer [to the command of the Sixteenth Army] after the capture of Hong Kong. Composition and main personnel were as shown in the table in the appendix.

Its infantry regiments consisted of regimental headquarters, 3 infantry battalions, [1] infantry artillery unit (with 4 mountain guns) and [1] signal unit. Each infantry battalion consisted of battalion headquarters, 4 companies, and 1 machine gun company. Its mountain artillery regiment consisted of regimental headquarters and 3 battalions, and the battalions consisted of 3 batteries. (Each battery was equipped with 4 mountain guns [Type41 and Type94 mountain guns, 2 for each]). . $^{(1)}$

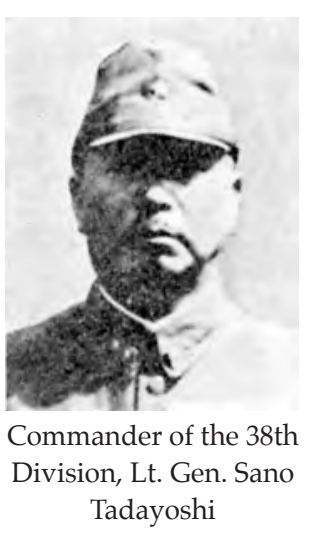

The division was formed for operations against China in 1939, and its formaplanned and prepared to be mobilized for operations against the Soviet Union.

\section{8th Division ("Umi-heidan" The Mariners)}

Division commander: Lt. Gen. Tsuchihashi Yūitsu

Scheduled to transfer [to the command of the Sixteenth Army] after the capture of Manila. Composition and main personnel were as shown in the table in the appendix.

The division had originally been formed in November 1940 and been designed to charge toward Singapore after traversing the whole length of the Malay Peninsula. Accordingly, it was composed of motor-vehicle-based units, which made it different from the $2 \mathrm{~d}$ and 38th Divisions.

The infantry regiments consisted of regimental headquarters, 3 battalions, [1] regimental artillery battery, [1] antitank gun company, [1] signal company, and [1] motor vehicle squad. The regiment had about 2,550 men, 100 trucks, Co 4 passenger cars, 5 sidecars, and 1,000 bicycles. The battalions consisted of their headquarters, 4 companies, [1] machine gun company (with 8 guns),

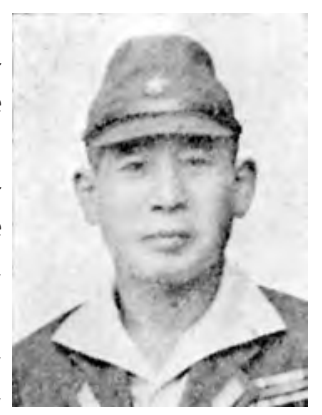

Commander of the 48 th Division, Lt. Gen. Tsuchihashi Yūitsu and [1] battalion artillery section (with 2 guns). The regimental artillery battery and the antitank gun company were equipped with 4 guns each. Basically the mobile strength of the regiment consisted in motor vehicles, bicycles, and marching on foot, about onethird each. Usually, the regimental headquarters, one of the battalions, the regimental artillery battery, the antitank gun company, and the signal company were transported by the 100 trucks, and the other 2 battalions rode bicycles, marched on foot, or were shuttled by motor vehicles. ${ }^{(53,}$ ${ }^{84)}$ However, during the period between the invasion of the Philippines and its departure [from the Philippines] for Java, the regiment increased its number of motor vehicles so that its full force could travel by motor vehicles all together.

The reconnaissance regiment consisted of its headquarters ([equipped with] 7 motor vehicles, 2 sidecars, and 25 bicycles), 1 signal platoon (with 4 vehicles), the 1 st and the $2 \mathrm{~d}$ Companies (with 
8 motor vehicles and a sidecar each), the $3 \mathrm{~d}$ and the 4 th Companies (with 8 light-armored cars, 2 motor vehicles, and a sidecar each), and [1] motorcycle unit (with 60 motorcycles and a van). ${ }^{(86)}$ The mountain artillery regiment consisted of its headquarters and 4 battalions. Each battalion consisted of 2 batteries. In the Philippine operations, the 4th Battalion had [still] used pack horses while the others were equipped with motor vehicles, but the whole regiment became motor-vehicle-based in the Java operations. ${ }^{(80)}$

The engineer regiment consisted of 3 companies and was equipped with motor vehicles. ${ }^{(80)}$ The transport regiment also consisted of 3 companies and was equipped with motor vehicles. ${ }^{\left({ }^{80)}\right.}$ The other units were also equipped with motor vehicles.

Note: The above was [mainly] based on the recollection of the commanders and fragmentary historical materials of the units. Composition and equipment of the 48th Division as designated in Army Order A, No. 57 of 1940 were as follows: ${ }^{(52)}$

$\begin{array}{lrrr}\text { Units integrated [into the Division] } & \text { Personnel } & \text { Horses } & \text { Motor vehicles } \\ \text { 48th Division headquarters } & 300 & 120 & 32 \\ \text { 48th Infantry Group headquarters } & 87 & 0 & 7 \\ \text { 1st Taiwan Infantry Regiment } & 2,580 & 535 & 91 \\ \text { 2d Taiwan Infantry Regiment } & 2,580 & 0 & 91 \\ \text { 47th Infantry Regiment } & 2,580 & 0 & 91 \\ \text { 48th Reconnaissance Regiment } & 418 & 0 & 38 \\ \text { 48th Mountain Artillery Regiment } & 1,783 & 320 & 158 \\ \text { 48th Engineer Regiment } & 759 & 0 & 48 \\ \text { 48th Divisional Signal Unit } & 187 & 0 & 17 \\ \text { 48th Transport Regiment } & 494 & 0 & 124 \\ \text { 48th Divisional Ordnance Service Unit } & 131 & 0 & 15 \\ \text { 48th Divisional Medical Unit } & 533 & 0 & 31 \\ \text { 48th Divisional 1st Field Hospital } & 228 & 0 & 20 \\ \text { 48th Divisional 4th Field Hospital } & 233 & 0 & 21\end{array}$

The 47th Infantry Regiment was equipped with 85 motor vehicles as of 16 January 1941, and 800 bicycles were provided on the same day. ${ }^{(53)}$

\section{South Seas Detachment}

The detachment was scheduled to assemble in Palau after the capture of Guam and Rabaul, and to transfer to the command of the Sixteenth Army. Its composition was as shown in the table in the appendix. The number of men and horses was 4,470 and 1,090 respectively. ${ }^{(5)}$

\section{Iwakuni Agreement (See Illustrations No. 10 to No. 12)}

Having received the order to prepare for the operation to invade the South from Commander in Chief Terauchi on 10 November, Sixteenth Army Commander Imamura, as previously related, left Tokyo on the 13th, on the same day as the formation of the headquarters of the army had been completed, and made arrangements with the Navy at Iwakuni from the 14th through the 16th.

Based on the agreement of the 10th between General Terauchi and Admiral Yamamoto, and [that between General Terauchi] and Vice Admiral Kondō (General Agreement No. 1 and No. 2), this Iwakuni Agreement was supposed to arrange matters between the commanders of the Fourteenth and the Sixteenth Armies and the Fifth Air Force on the one hand 
and the commanders in chief of the Third Fleet and the Eleventh Air Fleet. ${ }^{(23)}$ It was a matter of course that at the time of this agreement the arrangements involving the Sixteenth Army had to wait until later due to the sequence of the invasions.

On 18 [November], at almost the same time as this [Iwakuni] Agreement, specific arrangements were made in Saigon between the Fifteenth and the Twenty-fifth Armies on the one hand and the relevant naval units. ${ }^{(23)}$

Let us first see how arrangements were made to coordinate the operations of the Fourteenth and the Twenty-fifth Armies and the Kawaguchi Detachment (assigned to capture British Borneo) and those of the relevant air and naval units, which preceded the Dutch East Indies operation.

In early November, IGHQ rated the strength of the allied forces as follows: ${ }^{(110)}$

The Philippines Area

Warships: $\quad 2$ heavy cruisers, 1 light cruiser, 14 destroyers and 17 submarines

Aircraft: $\quad 238$ aircraft

Ground troops: $\quad 46,500$ troops, additionally 110,500 troops in mobilization

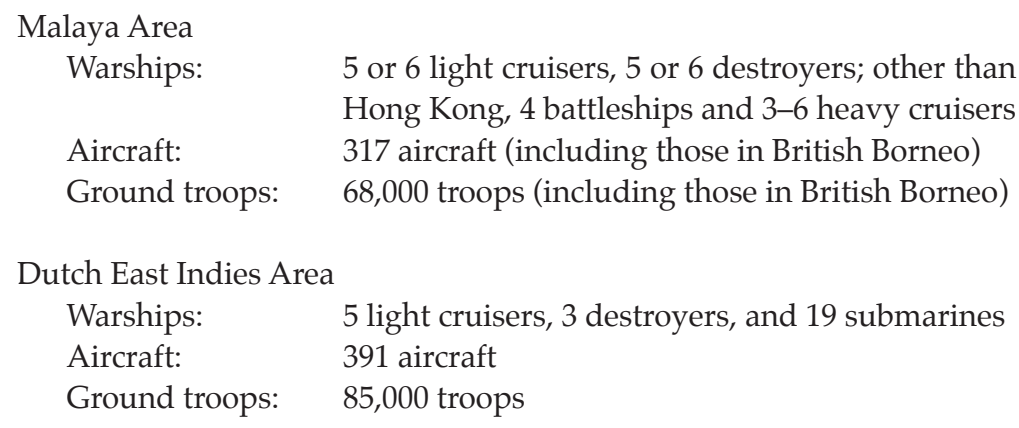

Against these forces, the plan was that the aircraft of the Third Air Force (under the direct control of the Southern Army) and those of the Southern Expeditionary Fleet would conduct preemptive air strikes in Malaya and that those of the Eleventh Air Fleet, the [Navy] Philippines Unit and those of the Fifth Air Force (assigned to the Fourteenth Army) would do likewise in the Philippines; that submarine squadrons would be positioned as far as possible to the south to prevent the allied fleets from coming up north; that other naval units would have destroyer squadrons convoy the advance and other units [of the Army]; and that two battleships, nine heavy cruisers, etc. would be deployed in such a way that they could destroy the allied fleets anywhere should they come up north. An outline of the air and naval forces [to execute the plan] was agreed upon in Iwakuni and Saigon as follows: ${ }^{(23)}$

\footnotetext{
Aircraft The Philippines: 149 army aircraft, 356 navy aircraft Malaya: $\quad 459$ army aircraft, 158 navy aircraft

Warships For general support in the Philippines and Malaya areas: The main unit of the main force of the Southern Task Force, [consisting of] 1 battleship, 2 heavy cruisers, and 4 destroyers The Philippines area:

The main force of the Philippines Unit, [consisting of] 1 heavy cruiser, 3 light cruisers, and 16 destroyers as its core
} 


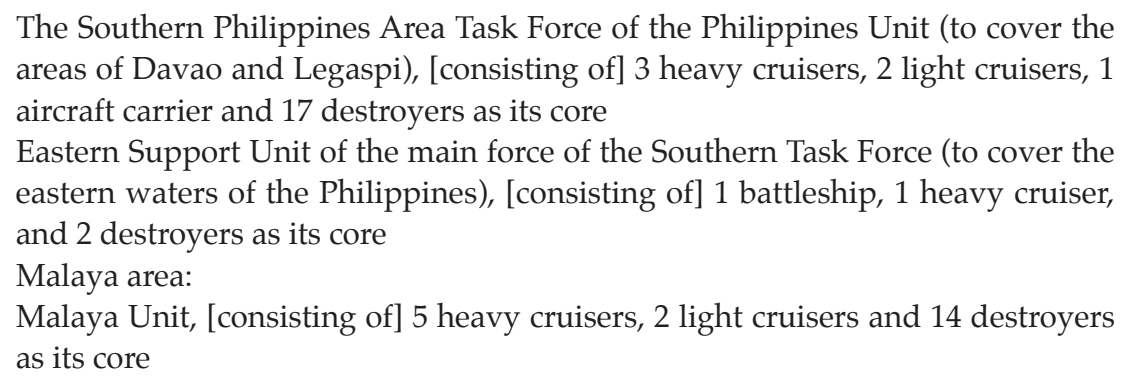

The plan envisioned a sudden attack with an air strength twice as strong as that of the enemy and with an overwhelmingly superior naval strength; and although the priority of the Navy in the initial stages was [the attack on] the Philippines, the main force of the Southern Task Force would consider heading for the eastern waters of Malaya should the British fleet move up north.

The operational arrangements in the Malaya area agreed upon in Saigon on the 18th were in outline as follows: ${ }^{(23)}$

1. A full-scale sudden air attack shall be launched on day $x$.

2. The Twenty-fifth Army headquarters, the main force of the 5th Division ([consisting of] 9 battalions), and 3 battalions of the 18th Division (i.e. the Takumi Detachment) shall leave Sanya on day $x-4$ and land [respectively] in Singora, Pattani and Kota Bharu on day x. Also 3 battalions of the 55th Division (i.e. the Uno Detachment) shall land on the same day in the western part of the Gulf of Thailand.

3. Vehicles and other [equipment] ([loaded on] 44 ships) for the above-mentioned main force of the 5 th Division and the Takumi Detachment shall leave Cam Ranh Bay on day $x+5$ and arrive on day $\mathrm{x}+8$ catching up [with the main force].

4. Three battalions of the 5th Division, the main force of the 18th Division ([consisting of] 6 battalions), and the primary units under the direct control of the Army shall leave Guangdong [ Canton] and/or Taiwan on day $x+18$, and arrive in Singora (and partly in Pattani) on day $x+25$.

5. Three battalions of the Imperial Guard Division (which shall be stationed in Thailand under the command of the Fifteenth Army in the initial stage) shall leave Saigon for Singora on or after day $x+25$.

6. The secondary units under the direct control of the Army shall arrive in Singora around day $x$ +50 .

7. The main force of the 56th Division ([consisting of] 6 battalions) shall arrive in the area between Kuantan and Mersing around day $x+60$.

8. The tertiary units under the direct control of the Twenty-fifth Army shall arrive in Singora and Mersing around day $x+60$.

9. The items from No. 5 through No. 8 in the above are yet to be fixed.

10. The [Navy] Malaya Unit, in Phase One of its operations (until approx. day $x+20$ ), shall start transporting the advance parties of the Twenty-fifth and the Fifteenth Armies each from [Phase One] disposition A, then it shall change to [Phase One] disposition B, and support the Kawaguchi Detachment's operations against British Borneo as well.

Such was the outline of operations and its defining feature was that even though the arrangements for the operations in Malaya up to about day $x+25$ were generally fixed, those after that remained vague and far too vague to mention anything at all concerning Sumatra. 
The arrangements for the operations in the Philippines were made on the 16th (the last day of the Iwakuni meeting) and were in outline as follows: ${ }^{(23)}$

1. A full-scale sudden air attack shall be launched on day $x$.

2. Navy units and army airfield units shall leave Gaoxiong on day $x-1$ and land on Batan Island on day $x$; the Tanaka Detachment ([consisting of] 1 1/2 battalion of the 48th Division) shall leave Magong on day $\mathrm{x}-1$, or day $\mathrm{x}$, and land in Appari on day $\mathrm{x}+2$; the Kanno Detachment ([consisting of] $1 \frac{1}{2}$ battalion of the same division) shall leave Magong on the same [departure] day [as above] and land in Vigan on the same [landing] day [as above]; the Kimura Detachment ([consisting of 2 battalions of the 16th Division) shall leave Palau on day $x$ and land in Legaspi on day $\mathrm{x}+4$, supported by the [Navy] 4th Raid Unit ([consisting of] 1 light cruiser and 8 destroyers); the Miura Detachment ([consisting of] 1 battalion of the same division) shall leave Palau on day $x+3$ and land in Davao on day $x+6$, supported by the [Navy] 5th Raid Unit ([consisting of 1 light cruiser and 8 destroyers). In addition, the Kimura and the Miura Detachment shall also be supported by the [Navy] Southern Philippines Area Task Force of the Philippines Unit (whose strength was previously mentioned,) and the [Navy] Eastern Support Unit from the main force of the Southern Task Force (whose strength was also previously mentioned).

3. The main force of the 48th Division (which comprises the main force of the Fourteenth Army) shall leave Magong, Keelung [Jilong] and Gaoxiong on day $x+10$ (escorted by 2 light cruisers and 16 destroyers), and land around Lingayen Gulf on day $x+14$; the main force of the 16th Division shall leave Amami Ōshima on day $x+10$ escorted by 1 light cruiser and 8 destroyers, and land around Lamon Bay on day $x+16$.

Let us return to the Iwakuni Agreement. On 14 November, scores of top-ranking commanders and staff officers entered the gate of Iwakuni Naval Air Force [Base] in plain clothes. ${ }^{(43)}$ The three-day meeting started with the arrangements between the Fourteenth Army, the Fifth Air Force ([most of] which was under the command of the Fourteenth Army), the Third Fleet, and the Eleventh Air Fleet, and after that the arrangements between the Sixteenth Army and the Third Fleet were taken up. A draft of the latter arrangements had been prepared by the Third Fleet. Whereas the operational arrangements after about day $x+25$ in the arrangements made [in Saigon] between the Southern Expeditionary Fleet and the Twenty-fifth Army remained vague, this draft was quite specific, [and covered] even the period up to [the landing on] Java. This is because the draft was drawn up by the Third Fleet, a leading player of the Navy, which had totally stuck to the "clockwise" plan. The outline of the draft arrangement was as follows: ${ }^{(23)}$ (See Illustrations No. 10 to No.12)

1. The Jolo Detachment ([consisting of] about half a battalion) of the Sakaguchi Detachment ([consisting of] the 56th Mixed Infantry Group as its core) shall sail together with the Miura Detachment of the Fourteenth Army to anchor outside Davao port on day $x+6$ and land on Jolo around day $x+13$; the main force of the Sakaguchi Detachment shall leave Palau around day $x$ +25 and land on Tarakan around day $x+30$; then the Sakaguchi Detachment shall reunite with the Jolo Detachment, turn over [its task of] guarding Tarakan to a Navy unit and land in Balikpapan around day $x+35$; after that, the detachment shall have an element of its force land in Banjarmasin around day $x+54$ and strive to seize Bali around day $x+70$ with [another] element of its force.

2. Detachment B ([consisting of] two battalions of the 38th Division as its core) shall leave Hong Kong around day $x+40$ to assemble in Palau and seize Ambon around day $x+60$, followed by Kupang. 
3. The South Seas Detachment shall assemble in Palau around day $x+40$ and sail to Cam Ranh Bay (the area where the main force of the army is stationed).

4. Depending on the situation, the South Seas Detachment shall capture Ambon and Kupang instead of Detachment B.

5. The 48 th Division shall leave Manila around day $x+71$ and land in eastern Java around day $x$ +80 ; its transport shall be completed in two transports at an interval of 6 days.

6. The main force of the Sixteenth Army ([consisting of] the $2 \mathrm{~d}$ Division and an element of the 38th Division as its core) shall assemble in Taiwan by around day $x+50$ and then head for Cam Ranh Bay; it shall leave the Bay around day $x+75$ and land in western Java around day $x+80$; its transportation and landing shall be completed in four transports at an interval of 7 days.

7. In the capture of Tarakan, a naval landing force shall also make a landing under the command of Detachment Commander Sakaguchi; a naval paratroop unit shall also join in the capture of Balikpapan; depending on the situation, the paratroop unit shall join in the capture of Banjarmasin as well.

8. The main points of the capture of Banjarmasin and Bali shall be discussed and decided upon, based on the situation at the time, by the commander of the Navy Dutch East Indies Unit and Detachment Commander Sakaguchi.

9. Further arrangements concerning corps and detachments other than the Sakaguchi Detachment shall be made around day $x+40$.

The significant main points of this arrangement, whose full text will be discussed later, are as follows:

1. [In this arrangement,] the capture of Ambon and Kupang with Detachment B instead of the South Seas Detachment became the rule.

The war game at the War College in early October had studied the possibility of executing the capture of Ambon and Kupang with the South Seas Detachment after the capture of Guam and Rabaul. The [Army-Navy] Central Agreement on 6 November also followed this idea. However, due to the strong desire for an early termination of the southern operation expressed by the Southern Army on 10 November, it had been changed in such a way that [the capture of Ambon and Kupang would be executed] "by the South Seas Detachment or an element of the 38th Division." Now it was [again] changed to "in principle by an element of the 38th Division (Detachment B)." This was because it was expected that it would take the South Seas Detachment at least forty days to capture Guam and Rabaul and then turn around and head back to the vicinity of Palau, making the whole schedule uncertain.

2. [In this arrangement,] Bali, which had never been brought up in either the Central Agreement or in the agreement between the Southern Army and the [Navy] Southern Task Force, was newly added as a target worth trying to capture.

The [main] reasons were that it was discovered that there was a good airfield on Bali, that the island was small enough to be captured with a small force even though it might involve some risks because it was very close to Java, especially to the [Dutch East Indies] naval port of Surabaya, and that the occupation of Bali would make it possible to cut off support from the United States and Australia and provide effective air support in the capture of Java.

3. The dates to capture each place were scheduled as follows:

Davao:

day $x+6$ (as specified in the General Agreement) 
Jolo: $\quad$ day $x+13$ (as specified in the General Agreement)

Tarakan: $\quad$ around day $x+30$ (specified as "by around day $x+25$ " in the General Agreement)

Balikpapan: around day $x+35$ (as specified in the General Agreement)

Banjarmasin: around day $x+54$ (specified as "around day $x+50$ " in the General Agreement)

Bali: $\quad$ around day $x+70$ (not mentioned at all in the General Agreement)

Java: $\quad$ around day $x+80$ (as specified in the General Agreement)

The date for the capture of Tarakan would automatically become around day $x+30$, when the main force of the [Navy] Philippines Unit would be able to turn around and join after supporting the landing of the main force of the Fourteenth Army in Lingayen Gulf and replenishing its supplies. ${ }^{(9)}$

4. The arrangement concerning the main force of the 38th Division was not included.

This was because this arrangement was supposed to be made between the Sixteenth Army and the [Navy] Malaya Unit.

5. The plan was not realistic.

Due to the fact that the Southern Army strongly requested to shorten the operation period and that the whole arrangement was drafted by the Navy, the plan unrealistically expected that a large slow-moving convoy (sailing at some five or six knots) would cover the distance between Manila and Java (about 1,550 nautical miles) in less than nine days, and the distance between Cam Ranh and Java (about 1,140 nautical miles) in less than five days.

6. The Navy envisioned parachute droppings in Menado and Balikpapan (and depending on the situation, in Banjarmasin as well). [However,] when discussing at the meeting the use of a [naval] paratroop unit in Balikpapan, [Army] Detachment Commander Sakaguchi and the staff officer of the Detachment, Yano Tsuneo, stated that since they intended to land at night and advance to the airfield and into the city at once, they did not hope for a [naval] paratroop unit to drop into the battles during the landing or just after. [Consequently, it was arranged that the [naval] paratroop unit would descend at a suitable moment after the landing of Sakaguchi Detachment. ${ }^{(9)}$

The text of the Iwakuni Agreement concerning the Dutch East Indies Operation was as follows: ${ }^{(23)}$

\section{Arrangement Between the Commander of the Navy Dutch East Indies Unit and the Commander of the Sixteenth Army}

16 November, 1941

V. Adm. Takahashi Ibō, commander of the Navy Dutch East Indies Unit

Lt. Gen. Imamura Hitoshi, commander of the Sixteenth Army

I. Outline of the Operations

1. The Sakaguchi Detachment ([consisting of] 3 infantry battalions and 1 artillery battalion as its core):

[The Sakaguchi Detachment] shall assemble in Palau around day y +23.

The Jolo Detachment shall land on Jolo around day $x+13$ (it sails together with the Davao invasion unit of the Fourteenth Army up to Davao). 
The Sakaguchi Detachment (minus the Jolo Detachment) shall leave Palau around day $\mathrm{x}+$ 25 and land in Tarakan around day $x+30$.

[The Sakaguchi Detachment] shall land in Balikpapan around day $x+35$.

[ditto] in Banjarmasin around day $x+54$.

[ditto] in Bali around day $x+70$ (day $z-10)$.

The day of landing in Java by the main force of the army is indicated as " $z$," which is by and large scheduled for approx. day $x+80$.

2. Detachment $B$ ([consisting of] 2 infantry battalions and 1 artillery battalion as its core):

Shall leave Hong Kong around day $x+40$ and assemble in Palau.

Shall land on Ambon around day $x+60$, followed by Kupang.

3. The South Seas Detachment ([consisting of] 3 infantry battalions and 1 artillery battalion as its core):

Shall assemble in Palau around day $x+40$ and sail to the area of the main force of the army (Cam Ranh Bay) as quickly as possible.

4. Depending on the situation, the South Seas Detachment may land in Ambon and Kupang instead of Detachment B. In such a case, a part of Detachment B's force shall be transported from the area of Detachment B (i.e. Hong Kong) to Palau if required. Which of the above plans should be adopted shall be decided by around day $x+40$, and the Sixteenth Army commander shall inform the commander in chief of the Third Fleet.

5. The 48th Division:

Shall assemble in Manila around day $x+60$.

Shall depart from Manila on day z - 9 (depending on the situation, the division may advance its assembly point to Menado beforehand, and leave there on day $z-5$ ); shall go ashore in eastern Java on day $\mathrm{z}$ after being transported in two transports at an interval of six days.

6. The main force of the army ([consisting of] the $2 \mathrm{~d}$ Division and an element of the 38th Division as its core):

Shall assemble in Taiwan by around day $x+50$, move to southern French Indochina, leave port of the area on day $z-5$, and go ashore in western Java on day $z$ after being transported in four transports at an interval of about seven days.

7. Transportation of part of the army:

During the period from day $x+60$ to day $x+80$, parts of the army shall be transported between Hong Kong, southern French Indochina and Manila.

II. Outline of the arrangements

8. The arrangement concerning the Sakaguchi Detachment is as in the separate volume No. 1.

9. The arrangement on communications is as in the separate volume No. 2 (omitted by the author).

10. [Detailed] arrangements concerning Detachment $B$ and others shall be concluded either in Taipei, Davao, or Palau around day $x+40$. The Army and the Navy shall round off discussions and make decisions by day $\mathrm{x}+35$.

Note: The Eleventh Air Fleet shall also conclude arrangements simultaneously with the above.

Arrangement between the commander of the Navy Dutch East Indies Unit and the commander of the Sixteenth Army: Separate volume No. 1 (Concerning the Sakaguchi Detachment)

16 November, 1941

V. Adm. Takahashi Ibō, commander in chief of the Navy Dutch East Indies Unit

Lt. Gen. Imamura Hitoshi, commander of the Sixteenth Army

(See Illustrations No. 10 and No. 11) 


\section{General Directives}

1. The [Sakaguchi] Detachment shall assemble in Palau around day y +23 .

2. The Jolo Detachment ([consisting of] 1 infantry battalion (minus 2 companies), 1 field field artillery section, and 1 transport squad) shall board the transport ships of the Miura Detachment of the Fourteenth Army (a unit for the capture of Davao), sail together with this detachment and arrive off Davao on day $x+6$. Then it shall land in Jolo around day $x+13$ and capture its air base. After clearing the key areas of Jolo, the detachment shall promptly turn over [its task of] guarding [the island] to the Navy and prepare for transfer towards the area where the main force of the Sakaguchi Detachment [is deployed]. The transfer shall be effected after the Sakaguchi Detachment's landing on Tarakan, which is roughly scheduled for approx. day $x+33$. Depending on the situation of the operations in Davao, that is, if the Jolo Detachment cannot leave for Jolo or a significant delay is expected [in its transfer], the Sakaguchi Detachment may be required to form another unit for capturing Jolo [out of the detachment] and have naval war vessels transport the unit.

3. The Sakaguchi Detachment shall land in Tarakan around day $x+30$, occupy its air base, and secure the oil resources there as well. After clearing the key areas of Tarakan, the detachment shall turn over the guarding [of the area] to the Navy, and land in and around Balikpapan and Samarinda as quickly as possible, occupy air bases, and secure the oil resources [there] as well. Depending on the situation, the capture of Balikpapan shall be carried out ahead of the capture of Samarinda. [The detachment] shall then send its transport ships to Palau for water and coal supply, after which an element of the detachment ([consisting of] approx. 1 infantry battalion and 1 artillery battery as its core) shall land in Banjarmasin and occupy its air base.

4. When the landing of the main force of the army draws near (the first day of the landing [in Java] is indicated as " $z$," which is by and large scheduled for approx. day $x+80$.), [the Sakaguchi Detachment] shall capture Bali ahead of the landing (around day $z-10$ ) with an element of its force ([consisting of] about half an infantry battalion) and strive to facilitate the advancement of [the Army's] air base [to the island].

5. The responsibility for guarding and maintaining security in Balikpapan (including the area in and around Samarinda), Banjarmasin and Bali shall fall on the Army until otherwise ordered.

6. The Sakaguchi Detachment shall be required to set up provisional landing bases in each landing point, and, in addition [to these], to establish a main landing base in Balikpapan during the period of operations of the detachment.

7. Concerning the replenishment of supplies for the Sakaguchi Detachment, the hospitalization and evacuation of its patients and the sending back of mail, the Navy shall provide the necessary support until [the detachment] is able to secure its line of communication with the main force of the army (evacuation locations shall be set either in Taiwan or in Palau). The details [of these arrangements] shall be discussed between the commanders of the Navy and the Army on site.

8. For details of the above, follow the "II. Outline for capturing the [target] areas."

II. Outline for capturing the [target] areas

1. Capture of Jolo

(1) Landing points and their reconnaissance:

$\{1\}$ Landing point: the coast northeast of the town of Jolo. If the landing point needs to be changed depending on the situation, the commander of the escort shall decide after due consultation with the Jolo Detachment commander.

\{2\} Reconnaissance by (Navy) aircraft: If possible, [navy aircraft] shall carry out reconnoitering and provide data necessary for the Jolo landing operation. 
Note: The Eleventh Air Fleet shall conduct the required reconnaissance and provide aerial photographs necessary [for the operations].

(2) Arrival at the assembly point, departure date, and anchorage:

[The detachment] shall assemble in Palau around day y +23 . It shall change ships and board the transport ships of the Fourteenth Army's unit for capturing Davao at an appropriate time before leaving.

It shall leave Palau on day $x+3$. After the Davao Detachment has captured Davao, [the Jolo Detachment] shall leave Davao for Jolo as soon as the situation at the Navy, particularly that of its air operations, shall permit.

(3) Starting date and time of landing and landing schedule:

The landing is scheduled to start before dawn on day $x+13$. Landing shall be completed within one day.

(4) Distribution of the convoy of transport ships, their movements and, if required, the commander's whereabouts:

[The ships are] in the order of the Myōgi and the Yamazuki [Yamatsuki]; the commander of the Jolo Detachment shall board the Myōgi.

The formation of the Jolo Detachment is as follows:

Commander: Lt. Col. Matsumoto Tadasu, commander of the 3d Battalion of the 146th Infantry Regiment

3d Battalion of the 146th Infantry Regiment (minus 2 companies)

1 Field artillery section

1 Transport squad

(5) Escort at sea and course of the convoy:

1. Forces to be employed for the escort: 1 light cruiser and 4 destroyers

Commander of the escort: R. Adm. Tanaka Raizō ([on board] of the Jintsī)

2. Course of the convoy: to be decided by the commander of the escort after due consultation with the detachment commander.

(6) Diversions:

Shall not be executed.

(7) Use of air units:

$\{1\}$ Forces to be employed: part of the Eleventh Air Fleet

\{2\} Main points on cooperation: [Air units] shall cover the convoy under sail as well as at the anchorage, and, at the request of the landing units, support them in their combat.

Note: The Eleventh Air Fleet shall give the above support with an element of both of its land-based attack plane and fighter plane units, while destroying the enemy air power.

(8) Outline of the approach to the anchorage and the time of anchoring:

The anchorage shall be at sea to the northeast of Jolo. [Time] to anchor is at 0100 on the 13th.

Other details shall be decided by the escort commander after due consultation with the detachment commander.

(9) Landing attack and covering fire:

$\{1\}$ [The detachment] shall land on the coast northeast of the town of Jolo, occupy the airfield and the radio station promptly. At the same time it shall search for enemy units on site, and destroy them.

\{2\} Naval warships shall open fire [only] at the request of the landing unit.

(10) Cooperation between the Navy and the Army after landing:

$\{1\}$ Once the key areas in and around Jolo are cleared, the detachment shall promptly turn over [its task of] guarding [the area] to the Navy, assemble in the area of Jolo, 


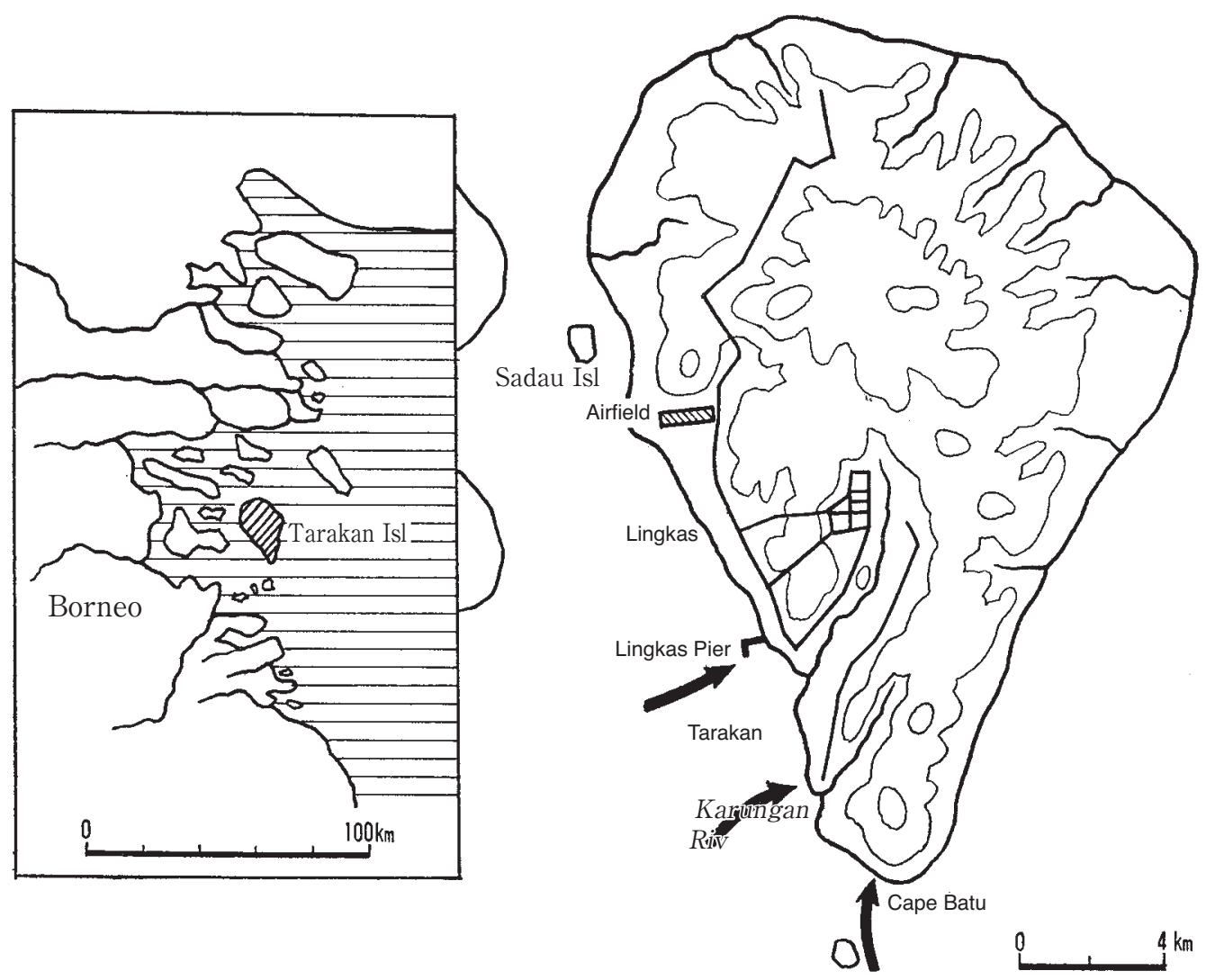

Illustration No. 10 - Overview of Tarakan Island

and as soon as possible join the main force of the Sakaguchi Detachment. Transport ships necessary for this [transfer] shall be brought from the main force of the Sakaguchi Detachment. The details of the escort [of the convoy] shall be decided, based on the situation at the moment, by the escort commander, after due consultation with the Detachment Commander Sakaguchi.

\{2\} Once the landing is completed, the emptied ships (the Myōgi and the Yamazuki [Yamatsuki]) shall be returned to Davao together with the naval vessels.

(11) Communications:

As specified in the separate volume.

2. Capture of Tarakan

(1) Landing points and their reconnaissance

$\{1\}$ Landing points:

The main force [shall land on] the coast from Cape Batu to the Karungan River. Part of the detachment [shall land on] the coast northwest of the Karungan River. Depending on the circumstances, part of the detachment or the main force may land in Lingkas from the beginning or if the situation requires it.

$\{2\}$ Reconnaissance:

In order to keep the tactics secret, no reconnaissance shall be conducted other than specified in the following note:

Note: The Eleventh Air Fleet, while being mindful that the tactics should be kept secret, shall prepare aerial photos of the area including Batu, the oil fields, and 
Sadau, and send them to the Sakaguchi Detachment before its departure from Palau (around day $x+25$ ).

(2) Disposition of landing corps, convoy's arrival at the assembly point, departure date, and anchorage:

$\{1\}$ The detachment shall assemble in Palau around day y +23 , leave Palau as soon as the situation at the Navy permits (which is roughly scheduled for around day $\mathrm{x}+$ 25 ), and arrive at the landing point in a single transport. The detachment is formed as follows:

Commander: Maj. Gen. Sakaguchi Shizuo, commander of the 56th Mixed Infantry Group

56th Mixed Infantry Group (headquarters, 146th Infantry Regiment, armored car unit, 1st Field Artillery Battalion, 1st Engineer Company, 2d Transport Company, medical unit, and 1st Field Hospital)

44th Field Antiaircraft Artillery Battalion

6th and the 7th Independent Radio Platoons, and the 33d Fixed Radio Unit

$\{2\}$ Anchorage at the assembly point is as shown in the attached Illustration No. 1 (omitted by the author).

(3) Starting date and time of landing and landing schedule:

The landing is scheduled to start before dawn on day $x+30$ and shall be completed within two days. The commander of the Navy's Dutch East Indies Unit shall decide the above starting date of landing after due consultation with the Sixteenth Army commander, and both of them shall transmit the date in the form of an order to respectively the escort commander and the detachment commander by the day before [the detachment] leaves Palau at the latest. However, if it suddenly becomes imperative to change the schedule after leaving Palau, the escort commander shall make the decision after due consultation with the detachment commander, and they shall report the decision to respectively the commander of the Navy's Dutch East Indies Unit and the Sixteenth Army commander without delay.

(4) Distribution of the convoy of transport ships, their movements and, if required, the commander's whereabouts:

Shall depend on the arrangements between the escort commander and the detachment commander.

(5) Escort at sea and course of the convoy:

Forces to be employed for the escort: 1 light cruiser, 8 destroyers, and 4 to 6 minesweepers

Commander [of the escort]: R. Adm. Nishimura Shōji (on board of the Naka)

(6) Diversions:

Shall not be executed.

(7) Use of air units:

1. Forces to be employed: part of the Eleventh Air Fleet

2. Main points on cooperation: [Air units] shall cover the convoy under sail as well as at the anchorages, and, on the request of the landing units, support them in their combat.

Note: The Eleventh Air Fleet shall give the above support with an element of both of its land-based attack plane and fighter plane units, while destroying the enemy air power.

(8) Outline of the anchorages, the approach to them, and the time of the convoy's anchorage and the formation at the anchorage: 
The 1st anchorage shall be at sea to the southeast of Cape Batu. Time [to anchor] is $3 \frac{1}{2}$ hours before dawn. Other details shall be decided by the escort commander after due consultation with the detachment commander.

(9) Landing attack, cover and support for the disembarkation operations:

$\{1\}$ The naval landing force shall come under the command of Detachment Commander Sakaguchi with respect to the operations during the period from landing on Tarakan till the completion of clearing the key areas.

\{2\} Directives for the landing attack:

\{a\} Although the landing shall be made as a surprise landing in principle, it shall be carried out by assault if the situation should require it. The change [of plan] shall be ordered by the detachment commander.

$\{b\}$ The detachment shall have its main force land on the coast southeast of the Karungan River, while part [of the detachment] shall land on the coast northwest of the river. They shall promptly seize the Batu battery in the first place. They shall search for the main force of the enemy, wherever it may be, and destroy it and promptly occupy the towns of Tarakan and Lingkas. The naval landing force shall land on the right flank of the Army units.

\{c\} Once the towns of Tarakan and Lingkas have been occupied, the detachment shall have part of its force secure the airfield, the oil fields, and the areas around Sadau without missing any opportunity, while clearing up the remnants of enemy troops with its main force.

$\{d\}$ Each of the above units is supposed to start its advance without waiting for the completion of the landing [of the whole detachment] and strive to quickly achieve battle results.

$\{\mathrm{e}\}$ During the above operations, the Navy shall have some of its warships make efforts to block the enemy fleeing by sea.

\{f\} Although [the attack] is planned as described above, its execution is subject to change due to consultations based on the situation at the moment, between the commanders of the Navy and the Army on the spot.

\{g\} The Navy shall capture Menado with another part [of its units] at about the same time as the detachment's capture of Tarakan.

\{3\} Covering fire for the landing [of the detachment]:

The naval warships shall fire after daybreak at the enemy's fort at Batu and other places, such as the enemy's artillery in particular, at the request of the Army units.

(10) Cooperation between the Navy and the Army after landing:

Once the key areas of Tarakan have been cleared, the detachment shall promptly turn over [its task of] guarding [the area] to the Navy, assemble in the area of [the town of] Tarakan, and prepare for the next operation, i.e. the capture of Balikpapan. Depending on the situation, the Navy and the Army, in conjunction, may occupy key areas, mainly the oil fields in the neighborhood, following the capture of Tarakan. However, it goes against the [original] aim to postpone the capture of Balikpapan for

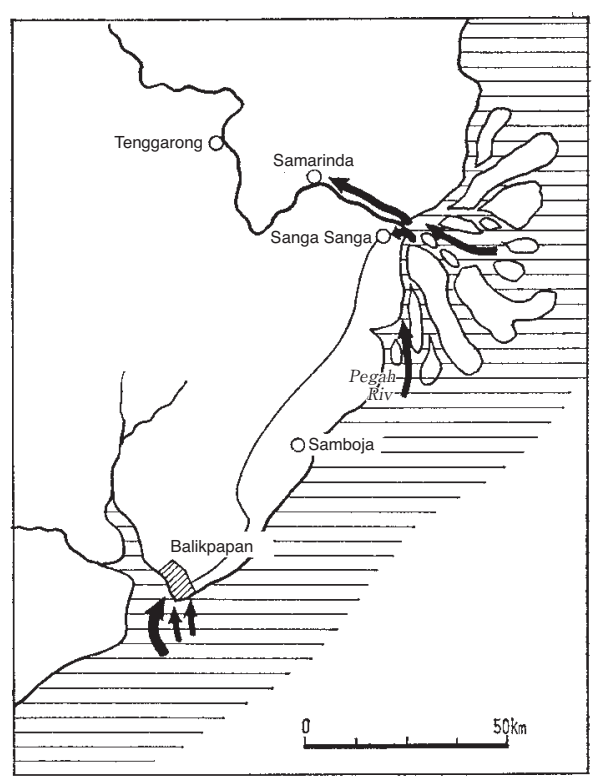

Illustration No. 11 - [Balikpapan] 
this [task]. The Jolo Detachment has to be brought to Tarakan without delay. The details of the escort shall be decided by the escort commander, after due consultation with Detachment Commander Sakaguchi.

(11) Move of the transport ships after the completion of landing:

The transport ships which complete unloading shall be kept on standby on site.

(12) Communications:

As specified in the separate volume (omitted by the author).

3. Capture of Balikpapan, Banjarmasin and Bali

(1) Capture of Balikpapan:

(a) The naval landing force shall come under the command of Detachment Commander Sakaguchi with respect to the operations from the time of landing.

Note: The 1001 Unit (note by the author: [naval] paratroop unit) under the command of the Eleventh Air Fleet commander shall [provisionally] come under the command of Detachment Commander Sakaguchi with respect to the operations during the period after its parachute landing until the clearing of key areas.

(b) Directives for the landing attack:

$\{1\}$ Balikpapan area:

The detachment shall have its main force land near the Balikpapan pier and parts of the detachment near the Baru and Sepuluh batteries (note by the author: supposedly south of Balikpapan), and promptly occupy the oil refineries in particular.

Note: The Navy 1001 Unit shall descend upon key points at the right moment in concert with the Sakaguchi Detachment's landing, and secure these spots.

\{2\} Samarinda area:

For the landings in Samarinda and Sanga Sanga, [units] go [upstream] in landing boats from the mouth of the Pegah River.

\{3\} Once the key areas are cleared, the Army units shall be responsible for the guarding in general, the securing of resources as well as various facilities, and maintaining public order etc., while the Navy units shall be responsible for making the airfields ready for use and securing them.

\{4\} Although [the attack] is planned as described above, its execution is subject to change due to consultations based on the situation at the moment, between the commanders of the Navy and the Army on the spot.

(2) Capture of Banjarmasin:

Shall be decided by the commander of the Navy's Dutch East Indies Unit, based on the situation at the moment, after due consultation with the detachment commander.

Note: The Navy 1001 Unit may cooperate in [the operation].

(3) Capture of Bali:

Shall be decided by the commander of the Navy's Dutch East Indies Unit, based on the situation at the moment, after due consultation with the detachment commander.

On concluding the above arrangement, the following problems occurred:

1. The problem of the responsibility for the capture of Davao.

Davao, along with Jolo Island, was a key place suitable not only for preventing the enemy in the Philippines from fleeing but also to be used as a base for the Dutch East Indies operation. Moreover, there were about twenty thousand Japanese residents in Davao, for whose rescue the Emperor reportedly had a particularly deep concern. ${ }^{(37,87)}$ As mentioned 


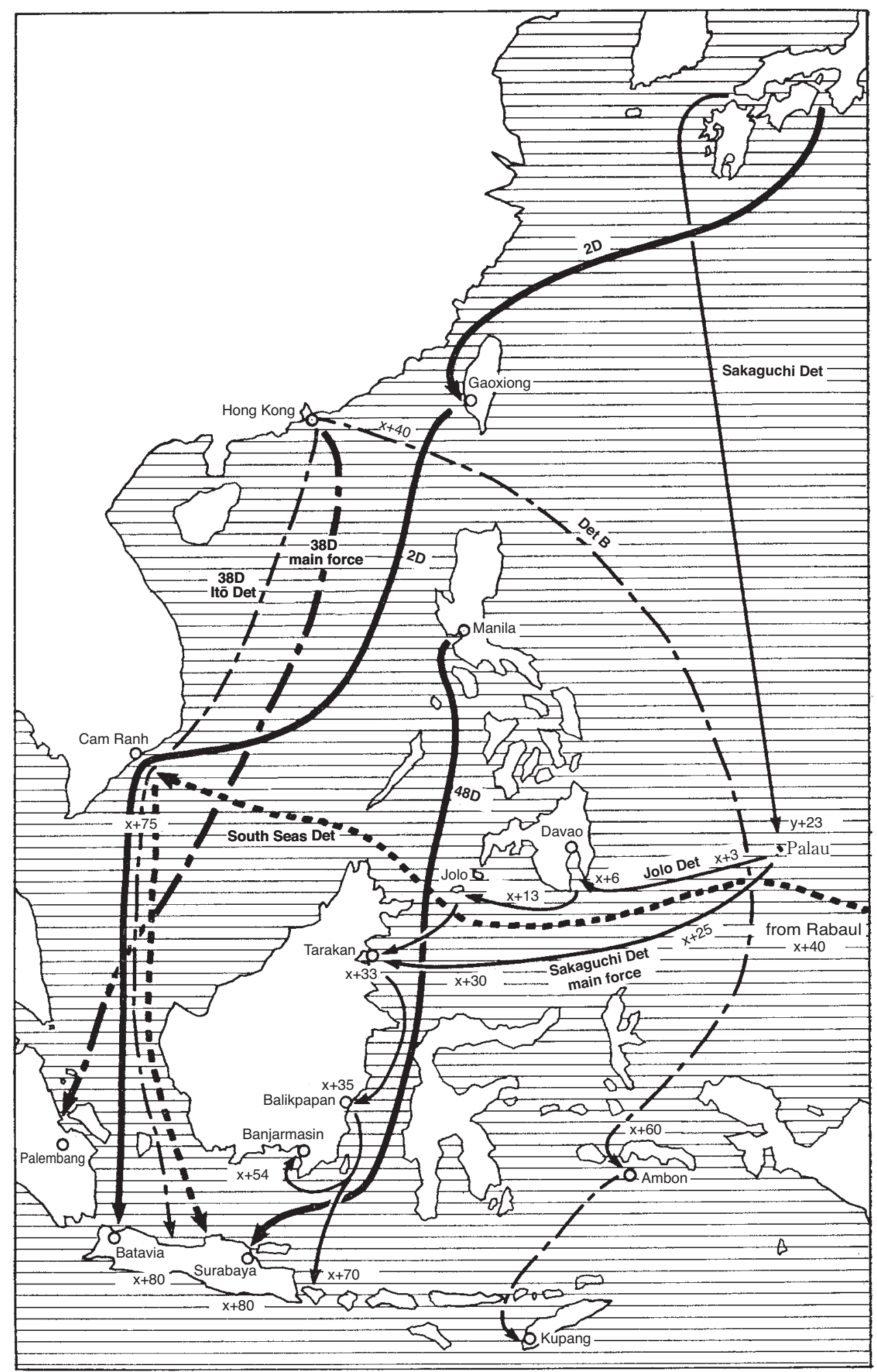

Illustration No. 12 - The Iwakuni Agreement 
previously, the Fourteenth Army planned to have the Miura Detachment (with one battalion as its core) and the Kimura Detachment (with two battalions as its core) of the 16th Division land in Davao and in Legaspi respectively, and have the main force of the 16th Division (with three battalions as its core) land in Lamon Bay. Although it wanted to increase the force for Davao in view of the importance of the place, in relation to other concerns, it had limited the core strength to one battalion. Meanwhile, a draft arrangement between the [Navy] Dutch East Indies Unit and the Sixteenth Army specified that (1) the Jolo Detachment would sail to Davao together with the Miura Detachment, and [from there] head for Jolo Island, while the main force of the Sakaguchi Detachment would leave Palau for Tarakan on the 12th day after the landing of the Jolo Detachment on the island; (2) depending on the situation of the Miura Detachment's operations in the Davao area, that is, if the Jolo Detachment were not able to turn to Jolo or significant delay would be expected in its turn [to Jolo,] the Sakaguchi Detachment might be required to organize another unit for capturing Jolo [out of the detachment]. ${ }^{(23)}$

All of a sudden this became a focus of discussion. Whether the Miura Detachment would be able to capture Davao on its own was a cause for concern. The Third Fleet suggested "the possibility of having the main force of the Sakaguchi Detachment, which had been assigned for capture of Tarakan, stand by at the port of Davao instead of Palau." The Sixteenth Army stated its view that "it did not want a situation where the Sakaguchi Detachment were dragged into war, unable to stand to see the Miura Detachment fighting an uphill battle, which might end up hindering the operations in Tarakan." It added that "if such a situation could be expected, then it might as well have the Sakaguchi Detachment capture Davao from the beginning." Hearing that, the Fourteenth Army made a request for "having the Sakaguchi Detachment under its command during capture of Davao, because the capture of Davao was the Fourteenth Army's task." This led to opposite opinions between the staff officers of the Fourteenth Army and those of the Sixteenth Army over the command of the Sakaguchi Detachment. ${ }^{(9)}$ That night Maeda Masami, chief of staff of the Fourteenth Army visited Imamura, commander of the Sixteenth Army, in his quarters and asked him to agree to putting the Sakaguchi Detachment under the command of the Fourteenth Army during the capture of Davao. Commander Imamura replied that "he would follow the decision of IGHQ." (35) Staff officers of IGHQ and the Southern Army, who attended this [series of] meetings and paid close attention to the progress of the Davao issue, noticed that the Fourteenth Army staff gradually turned to the idea that "it might leave capture of Davao to the Sixteenth Army," and they judged the Fourteenth Army lacking in enthusiasm. ${ }^{(9)}$ In the directive of [the Army Department of] IGHQ and the Southern Army's order, it was specified that "the Fourteenth Army shall capture Davao." But the Miura Detachment was [merely] made up of one battalion as its core and commanded by a lieutenant colonel, whereas, according to sources, the strength of the U.S.-Filipino army in Davao was three thousand troops. ${ }^{(87)}$ [On the other hand,] the Sakaguchi Detachment was made up of one regiment as its core, and commanded by a major general. However, it was the one and only corps that the Sixteenth Army could use for operations for the moment.

After this series of meetings at Iwakuni was over (on the 16th), on the 19th (the day when the Sakaguchi Detachment left Moji) the Southern Army received approval of [the Army Department of] IGHQ to change the plan and have the Sixteenth Army capture 
Davao, and gave the order as specified in the above-mentioned Southern Army Operation Order A, No. 2 on the same day. ${ }^{(9,24)}$

2. The next problem was the description in 2.(9) $\{2\}\{\mathrm{g}\}$ of the draft arrangement concerning the Sakaguchi Detachment. In the Central Agreement, the capture of Menado was agreed upon as "to be carried out about the same time as that of Tarakan," and in the agreement between the Southern Army and the Southern Task Force it was agreed upon as "around day $x+23$ " (note: that of Tarakan as around day $x+25$ ). [However,] the above-mentioned draft [arrangement] prepared by the Third Fleet for this Iwakuni Agreement specified: "[the capture of] Menado on day $x+23$ and that of Tarakan on day $x+30$. . In the meeting the Army insisted that "Menado and Tarakan are the first targets in the Dutch East Indies operation and that these two should be captured on the same day from a political and war strategy viewpoint." In response to this, the Navy made the concession that "Menado shall be captured about the same time as Tarakan." ${ }^{(9)}$

3. The third problem was that, whereas the Southern Army, which desired an early ending of the southern operation, wanted to arrange the concrete details up to capture of Banjarmasin, the Navy insisted that it would make no further arrangements after Tarakan. ${ }^{(9)}$ [In other words,] the Southern Army wanted to give an order to control its actions until about forty days after the start of war and assign the Sixteenth Army missions up to capture of Banjarmasin, ${ }^{(24)}$ whereas the Navy, which regarded operational stages in a different way than the Southern Army, was moreover concerned about changes in the situation such as the U.S. Pacific Fleet coming to the attack.

4. The fourth problem was that the resourceful Staff Officer Yano Tsuneo of the Sakaguchi Detachment, seeing that the plan for the capture of Tarakan and Balikpapan entailed, as previously mentioned, assault landings against the best prepared and strongest front of the enemy, sought "regardless of this arrangement, permission to have a new arrangement based on a surprise attack agreed upon between the units of the Army and the Navy on the spot." $(36,87)$ While the Navy had been interested in this area from early on and made efforts to gather information, the Army had paid little attention to it, so the Sixteenth Army had no materials to criticize the Navy's proposal. Moreover, some showed sympathetic views since the Third Fleet had gone to the trouble to prepare a draft, while others supported the original plan by pointing out the example of the landing that had been made in the face of the enemy at Wusong in the Shanghai Incident. ${ }^{(36)}$ In the end, it came down to a decision that it was permitted to interpret in a broad sense the item that "Although [the attack] is planned as described above, its execution is subject to change due to consultations, based on the situation at the moment, between the commanders of the Navy and the Army on the spot." $(9,36,87)$

How Staff Officer Yano Tsuneo demonstrated his resourcefulness will be described later.

\section{[Lieutenant General Imamura] Takes Command of the Sakaguchi Detachment and Sends It Off}

As soon as the Iwakuni Agreement was concluded on the 16th, Army Commander Imamura went to Moji ${ }^{(32)}$ where he took command of the Sakaguchi Detachment. On the 17 th, he gave instructions [to the detachment] and demanded that, as the vanguard of the Sixteenth Army, the officers and men of the Sakaguchi Detachment should always keep in mind the impor- 
tance of this war and operation, and the duty of the detachment, that they should achieve results in their first campaign with loyalty and bravery, take all possible measures to enhance and maintain their health, military discipline and morals, and extol the dignity of the Imperial Army in and outside the occupied areas. ${ }^{(88)}$

The Sakaguchi Detachment was organized by adding to the 56th Mixed Infantry Group, organized at the Kurume divisional district, the previously mentioned units under the direct control of the army, one of which was the 44th Field Antiaircraft Artillery Battalion (commander: Maj. Takagi Takeo). [This battalion] was put under the command of Detachment Commander Sakaguchi on the 16th on its arrival in Moji after its return from Mudanjiang, Manchuria, by the order of [the Army Department] of IGHQ of 6 November, which had been given soon after their arrival there for the KANTOKUEN [Special Grand Maneuvers of the Kwantung Army]. ${ }^{(88)}$

The Sakaguchi Detachment (5,200 troops, 1,200 horses, 100 motor vehicles, 15 large motorized [landing] craft, and 15 small motorized [landing] craft), embarked on 8 ships, i.e. the Liverpool-maru, the Hankow-maru, the Tsuruga-maru, the Havana-maru, the Kuretake-maru, the Nichiai-maru, the Nissho-maru [Hiteru-maru], and the Teiryu-maru (45,682 gross tons in total) ${ }^{(24)}$ and on 19 November left Moji for the assembly/standby spot in Palau first. Soon after the departure, one of the hawks circling in the blue sky perched on the mast of the Teiry $\bar{u}$ Maru which had the detachment commander on board. ${ }^{(88)}$ All officers and men took this as a good omen and headed straight for the south, confident of their fortunes of war. ${ }^{(88)}$

\section{The [Navy] Philippines (Dutch East Indies) Unit Operation Order No. 1}

V. Adm. Takahashi Ibō (the commander in chief of the Third Fleet and) commander of the Philippines (Dutch East Indies) Unit, which would first operate as the Philippines Unit and then as the Dutch East Indies Unit, issued [Navy] Philippines Unit Operation Order No. 1 at Terashima-suidō [Channel] on 23 November in accordance with the above-mentioned [Navy] Southern Task Force Operation Order No. 1 and the Iwakuni Agreement, ${ }^{(110)}$ left the Channel on the 26th, and advanced to Magong on the 29th. ${ }^{(103)}$

In this order Commander in Chief Takahashi stated the date of landing in Menado, which the Navy was supposed to capture on its own account, as "around day $x+33$ " and that of the landing on Tarakan, which the Army and the Navy were to capture in conjunction, as "around day $x+35 . "$ (110) From a political and war strategy viewpoint, it was desirable that the capture of these two [places] be carried out on the same day, and eventually it happened that way. How it happened will be described later.

The disposition of forces given in the [Navy] Philippines Unit Operation Order No. 1 was in outline as follows. The 5th Raid Unit was charged with the direct escort of the Sakaguchi Detachment and the Southern Philippines Area Task Force was charged with its indirect guard. ${ }^{(110)}$ As mentioned previously, the Southern Task Force organized the Eastern Support Unit (1 battleship, 1 heavy cruiser and 2 destroyers) and assigned it for further indirect guard.

Main unit (from Magong to the waters west of Luzon Island): directly led by the commander in chief [of the Philippines Unit], [consisting of] the heavy cruiser Ashigara and the light cruiser Kuma of the 16th Cruiser Division and 2 destroyers of the 5th Destroyer Squadron.

1st Raid Unit (from Magong to Aparri): [consisting of] the light cruiser Natori and 6 destroyers under the command of the 5th Destroyer Squadron commander. 
2d Raid Unit (from Magong to Vigan): [consisting of] the light cruiser Naka and 7 destroyers under the command of the 4th Destroyer Squadron commander.

3d Raid Unit (from Gaoxiong to Batan Island): [consisting of] 1 destroyer under the command of the $2 \mathrm{~d}$ Base Force commander.

4th Raid Unit (from Palau to Legaspi): [consisting of] the light cruiser Nagara (of the 16th Cruiser Division) and 8 destroyers under the command of the 1st Base Force commander.

5th Raid Unit (from Palau to Davao), [consisting of] the light cruiser Jintsū and 8 destroyers under the command of the $2 \mathrm{~d}$ Destroyer Squadron commander.

Southern Philippines Area Task Force (from Palau): composed of the 5th Cruiser Division ([consisting of] the heavy cruisers Myōkō, Haguro and Nachi), the 4th Carrier Division ([consisting of] the aircraft carrier Ryūjo and 1 destroyer), and the 11th Seaplane Tender Division ([consisting of] the seaplane tenders Chitose and Mizuho) under the command of the 5th Cruiser Division commander.

Minelayer Unit (from Palau): under the command of the 17th Minelayer Division commander.

\section{Operation Plan of the Sixteenth Army (See Illustration No. 13)}

After concluding the arrangement with the Third Fleet at Iwakuni, the Sixteenth Army started to work on its operation plan in earnest.

The operation plan had undergone changes as the IGHQ plan, the Southern Army's plan, the Iwakuni Agreement, and the Southern Army's revised plan (of the 19th) were made successively, and, as of 19 November, the Sixteenth Army was supposed to deploy its forces in the following way:

Sakaguchi Detachment: shall move from Palau to Davao (the detachment shall take control of the Miura Detachment as well) and [further] to Jolo (an element of the detachment), Tarakan (the main force of the detachment), Balikpapan (the full force of the detachment), Banjarmasin (an element of the detachment), and Bali ([the Sixteenth Army] had made an arrangement with the Third Fleet that "the Sakaguchi Detachment would strive to capture Bali with part of its forces," although this was not mentioned in the directive of IGHQ or in the order given by the Southern Army).

Detachment B (two battalions): shall move from Hong Kong to Ambon and Kupang

South Seas Detachment (three battalions): shall move toward Java via Cam Ranh after capturing Rabaul (depending on the situation, it shall move to Ambon and Kupang instead of Detachment B).

38th Division (minus Detachment B and the Itō Detachment): shall move from Hong Kong toward southern Sumatra via Cam Ranh. It shall be divided into an advance party and the main force.

2d Division: shall move toward western Java via Taiwan and Cam Ranh.

Itō Detachment (three battalions): shall move from Hong Kong toward central Java via Cam Ranh.

48th Division: shall move from Luzon toward eastern Java.

At that time, the Sixteenth Army had a rough idea of the following facts in addition to the already mentioned Dutch East Indies topography, military preparedness, etc.: ${ }^{(36)}$

Tarakan and Balikpapan had strong defenses in the cities' coastal areas where oil refinery and storage facilities were located, and where many pillboxes were put in place. Tarakan was particularly [strongly] fortified. At Lingkas there were obstacles along the beach and three lines of 
trenches, while batteries were located at the northwest and southeast ends of the island. In Ambon there were strong defenses in the city and at the mouth of its bay, and also in Kupang. Palembang had many pillboxes in the area of the oil refineries (at the south bank of the Musi River), and Bangka had some defense facilities in and near Mentok.

On Java (See Illustration No. 13) Bandung and Malang were garrison towns. The Bandung stronghold had pillboxes and barbed-wire entanglements on the ridges of the mountains surrounding the city. Especially the areas along the northbound and westbound roads were strongly fortified. The Surabaya stronghold had batteries, pillboxes, and barbed-wire entanglements along the Madura Strait and in the areas of Gresik, the west side of Surabaya, and Wonokromo. As for its land front, the northwest front in particular had strong defenses with three lines of barbed-wire entanglements. Porong, midway between Surabaya and Malang, had fortress-like trenches with pillboxes and barbed-wire entanglements.

Entrenched positions with pillboxes were placed along the perimeter of the capital Batavia. In particular, Tangerang and vicinity in the west of the capital seemed to be a strategic place among the positions along the outer perimeter with entrenched positions with pillboxes in the west and northwest of Tangerang. There was an entrenched position too near Leuwiliang, located to the south of the town. Tangerang and Leuwiliang were meant to serve as bases for offensive and defensive battles in the western Java area. In Cirebon and [near] the ports of Tanjung Priok, Semarang and Cilacap, etc. were entrenched positions with batteries. Furthermore, entrenched positions had been set up everywhere on every promontory or suitable landing spot on the north and northwest coasts of Java.

In the previously mentioned apportioning of shipping, the main force of the 38th Division, which would be used for the operations in southern Sumatra, was further divided into an advance party and the main force. This was based on the idea that, while having the advance group seize the Mentok airfield and, in concert with a paratroop unit, raid the oil refineries in Palembang and seize them, the main force of the division would subsequently come ashore, make sure that the oil resources were securely held, and promptly seize the airfields in Palembang, Tanjungkarang, etc., and make them ready for use. The concept of forming the corps that was to land on Java out of the army's main force consisting of the $2 \mathrm{~d}$ Division as its core, the Itō Detachment ([consisting of] three battalions of the 38th Division as its core), and the core units of the 48th Division, was based on the idea that the main force of the army consisting of the $2 \mathrm{~d}$ Division as its core should land in western Java and seize the capital Batavia, while the Itō Detachment should land on the north coast of central Java, raid the Kalijati airfield, secure the place, and act in concert with the main force of the army in capturing Batavia, after which both of them should capture the Bandung stronghold, and that [in the meantime] the core units of the 48th Division should land in eastern Java and capture the Surabaya stronghold. ${ }^{(36)}$

Originally, the Java operation was to be carried out by landing only the $2 \mathrm{~d}$ and the 48 th Divisions in western and eastern Java [respectively]. However, the Itō Detachment was added, because soon after the war game held at the War College in early October, Lt. Col. Itoda Isamu had suggested that "air operations against western Java can be conducted from southern Sumatra and Kuching and those against eastern Java can be done from southern Celebes and Banjarmasin, but south-central Java will be left as a blind spot, which makes it seem appropriate to me to raid, occupy, and use the Kalijati airfield. This unit will also be effective in connecting the corps in eastern and western [Java]." Thus it was decided to put this idea into practice even though considerable risks were anticipated. ${ }^{(39)}$ 
The Sixteenth Army's operation plan, which had been worked on in earnest after the conclusion of the Iwakuni Agreement (on 16 November), was finished around the 21st of the following month. On 21 December, Col. Kume Seiichi, commander of the 1st [Paratroop] Raiding Group visited the Sixteenth Army headquarters and studied it. ${ }^{(33)}$ The lines-of communication plan of the Sixteenth Army was completed on 25 December. ${ }^{(5)}$

A remarkable change had occurred in the period between the Iwakuni Agreement and the completion of the Sixteenth Army's operation plan. Amazingly successful battle results were achieved in various regions just after the opening of hostilities on 8 December, and the 38th Division had already landed in Hong Kong (on the 18th). On the other hand, the Fourth Fleet [still] failed to capture Wake Island, which conse-

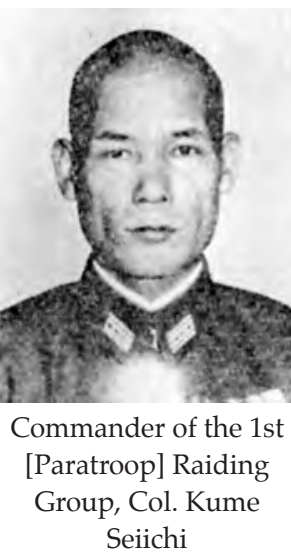
quently meant a postponement of the capture of Rabaul by the South Seas Detachment. That is to say, the responsibility for the capture of Ambon and Kupang would inevitably have to be settled on Detachment B. However, this change in the situation was reflected neither in the Sixteenth Army's operation plan of around 21 December nor in its lines-ofcommunication plan of 25 December. On the day when the lines-of-communication plan was completed, the British army in Hong Kong surrendered, and the South Seas Detachment was still in Guam, but this was not reflected in the lines-of-communication plan, either.

The Sixteenth Army's operation plan, completed around 21 December, was in outline as follows: ${ }^{(5,36)}$ (See Illustration No. 13)

\section{Sixteenth Army's Operation Plan}

\section{Mission:}

The Sixteenth Army (97,800 men once the 38th and the 48th Division, the South Seas Detachment and others are attached (excluding the 10,000 ground personnel of the air units), and 11,750 horses) shall, in conjunction with the Navy, capture Davao, Jolo, then Tarakan and Balikpapan with the Sakaguchi Detachment (5,980 men and 860 horses), and further capture Banjarmasin and Bali with part of this detachment. [The Army] shall also capture Ambon and Kupang with Detachment B (2 battalions of the 38th Division as its core, 3,300 men and 560 horses) and, in conjunction with the army air unit and the navy unit, capture Bangka, Palembang, and other key locations in southern Sumatra with the main force of the 38th Division (4 battalions as its core, i.e. 12,360 men, and 1,910 horses, excluding the 10,000 personnel of the air units), secure resources and air bases, and at the same time make preparations for the capture of Java which shall be carried out by the main force of the army. Concerning Davao, Jolo, Tarakan and Ambon, the guarding of these places shall be turned over to the Navy units once they are seized.

As soon as the main force of the army has been concentrated, it shall, almost simultaneously and in concert, put ashore in western Java the main force consisting of the $2 \mathrm{~d}$ Division as its core (27,730 men and 4,970 horses) and the units under the direct control of the army, in the north of central Java the Itō Detachment (1 regiment as its core, commanded by the commander of the 38th Division's Infantry Group, consisting of 5,910 men and 910 horses), and in eastern Java the unit consisting of the 48th Division as its core (24,600 men and 1,210 horses). They shall capture Batavia, Surabaya, and Bandung, and then pacify the entire island.

The South Seas Detachment (4,470 men and 1,090 horses) is scheduled to be used [in the capture of] the mainland of Java. However, depending on the situation, it may [also] be assigned to capture Ambon and Kupang instead of Detachment B. 
As for the transport [of the army], the unit with the main force of the 38th Division as its core, which is responsible for capturing southern Sumatra, shall be divided into an advance party and the main force, and be transported in one transport each. The [unit for] eastern Java shall be divided into two transports. As for the units for western Java, the troops shall be divided into three transports and the military supplies into four transports. Others shall be transported in one transport each.

2. Southern Sumatra Operations:

The outline of the southern Sumatra operations by the main force of the 38th Division ([consisting of] 4 battalions as its core) is as follows:

(1) It shall have an advance party ([consisting of] 2 battalions as its core) proceed under air and naval cover, and raid and capture Mentok with an element of the party, and have the main force of the party go up the Musi and other rivers by boat, capture Palembang in concert with the paratroop unit, and secure the oil resources.

(2) The main force shall follow the advance party and make sure that the oil resources and the airfield in Palembang area are securely held, then promptly occupy the Tanjungkarang airfield, get it ready for use, and after that mop up [the enemy] in southern Sumatra.

3. The operations of the Sakaguchi Detachment:

Shall be executed in accordznce with the arrangement between the Sixteenth Army and the [Navy] Dutch East Indies Unit in Iwakuni, and in accordance with the one to be concluded between the Sakaguchi Detachment and the naval unit on site.

4. Ambon and Kupang Operations:

(1) Shall be carried out by Detachment B (or by the South Seas Detachment depending on the situation).

(2) In the operations for capturing Ambon, [the detachment concerned] shall land on the eastern coast of the island and head for the city of Ambon and the Laha airfield. In the operations for capturing Kupang, [the detachment concerned] shall land on the south coast and head for the city of Kupang and the airfield.

5. Java Operations:

(1) Batavia, Surabaya and Bandung shall be promptly captured and subsequently the entire island shall be pacified.

(2) The 48th Division shall land in the area of Rembang. Using Rembang as its base, it shall promptly capture Surabaya, and then, using Surabaya as its base, act in concert with the operations of the main force of the army.

(3) The main force of the army shall promptly capture Batavia, and then, using this city as its base, capture the Bandung stronghold. In order [to realize this]:

\{1\} The first landing units shall be divided into the Noguchi Detachment ([consisting of] the 2d Reconnaissance Regiment as its core, 2,700 men and 100 horses), the $2 \mathrm{~d}$ Division (minus the Noguchi Detachment, 18,880 men and 1,870 horses), and the Itō Detachment ([consisting of] the 38th Infantry Group headquarters and 1 infantry regiment of the 38th Division as its core, 5,910 men and 910 horses).

\{2\} The Noguchi Detachment shall land around Carita, charge toward Buitenzorg [Bogor], facilitate the capture of Batavia by the main force of the $2 \mathrm{~d}$ Division, and take action so as to gain advantage for the next operation.

The 2d Division shall land its main force near Merak and Anyer-Lor, and part of its force near Mauk, and then promptly occupy Batavia and the port of Tanjung Priok.

The Itō Detachment shall land near Cilamaya and then secure the Kalijati airfield. Further, it shall facilitate the capture of Batavia by the main force of the army and gain advantage for subsequent operations.

\{3\} Next, the 2d Division shall advance its main force to Buitenzorg [Bogor] and part of the division to Cikampek from Batavia in concert with the Itō Detachment. 


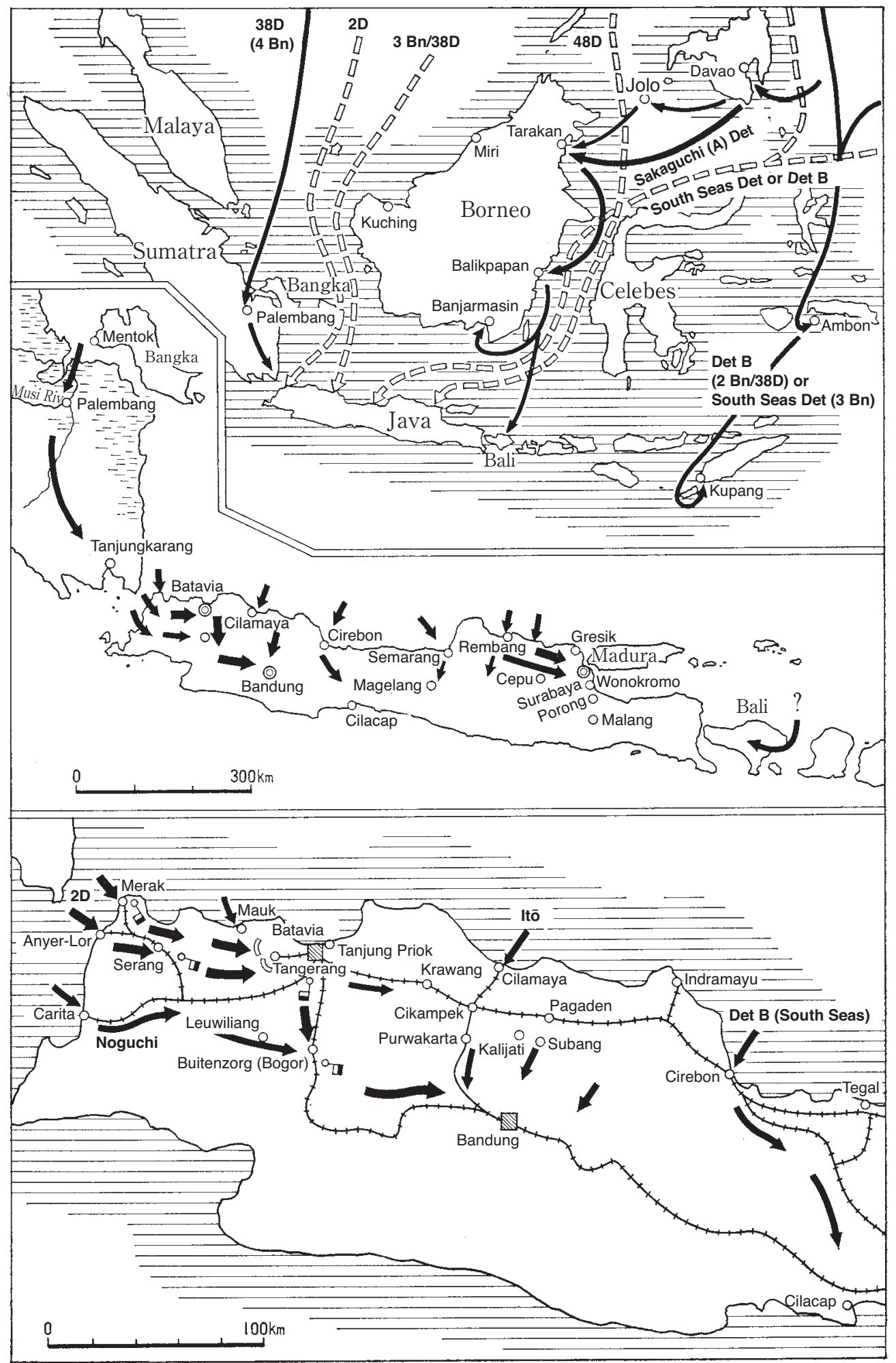

Illustration No. 13 - The Operation Plan of the Sixteenth Army as of 21 December 1941 
\{4\} Next, the main force of the army shall make preparations for the attack [on the Bandung stronghold] along the line connecting Buitenzorg [Bogor], Purwakarta and Subang (i.e. the line which stretches from the west front to the north front of the stronghold), and attack it from the direction of Buitenzorg [Bogor] with the main force. Depending on the situation [the army] shall attack the stronghold southward from the direction of Subang with its main force. (Note: an attack from the west front was anticipated to be difficult because the force had to cross several steep gorges, but [this course was supported] particularly by the staff in charge of the line of communication, who held that in any event it would be superior in safety and certainty. ${ }^{(36)}$ )

\{5\} Detachment D (i.e. the South Seas Detachment, if the South Seas Detachment shall be charged with the capture of Ambon and Kupang, this operation shall be assigned to Detachment B of the 38th Division) shall land in Cirebon, dash forward to Cilacap, cut off the allied forces' route for reinforcements from, or escape to, the Indian Ocean, and give the army an advantage in its operations.

\{6\} The second landing units (6,150 men and 3,000 horses) of the $2 \mathrm{~d}$ Division and other units shall join the operations of the main force of the army after landing. The 48th Division, after its capture of Surabaya, shall use the town as a base and turn toward central Java. In line with the situation, it shall act in concert with the main force of the army in its operations.

\{7\} The main line of communication of the main force of the army shall be established initially from Merak to Batavia and later from Tanjung Priok to Batavia, Buitenzorg [Bogor], and Bandung.

$\{8\}$ Following the capture of the Bandung stronghold, the entire island shall be pacified.

The amount of arms and equipment to be provided to the Sixteenth Army ([consisting of] the $2 \mathrm{~d}$, the 38 th, and the 48th Divisions, the Sakaguchi and the South Seas Detachment as its core) was planned as follows: ${ }^{(5)}$

48,411 rifles, 1,147 light machine guns, 88 vehicle-mounted light machine guns, 362 heavy machine guns, 247 vehicle-mounted heavy machine guns, 10 antiaircraft heavy machine guns, 1,156 Type89 heavy grenade launchers, 52 Type10 light grenade launchers, 20 Type97 antitank rifles, 66 Type92 infantry guns, 4 Type11 infantry mortars, 70 Type94 37-mm. guns, 169 TypeRa [Rheinmetall-model] 37-mm. antitank guns, 112 Type4 37-mm. tank guns, 44 Type 90 57-mm. tank guns, 57 Type41 mountain guns (regimental guns), 21 converted Type38 field guns, 74 Type94 mountain guns, 24 Type $9110-\mathrm{cm}$. howitzers, 24 Type $9615-\mathrm{cm}$. howitzers, 92 Type $887-\mathrm{cm}$. antiaircraft guns, 36 Type 94 light trench mortars, 16 Type89 mortars, 4,898 motor vehicles (5,898 motor vehicles in total, when combined with airfield units), 11 Type94 tankettes, 40 Type97 tankettes, 98 Type95 light tanks, and 44 Type89 medium tanks.

As mentioned previously, the Sixteenth Army completed its line-of-communication plan on 25 December based on its operation plan and the line-of-communication plan of the Southern Army. The most noteworthy points of the plan were as follows: ${ }^{(5)}$

1. The main supply points for the [Sixteenth] Army were set by the Southern Army at Batavia, Surabaya and Palembang.

2. Twenty-four units from mainland Japan, eight units from Manchuria, one unit from southern China, four units from the Philippines, and two units from Malaya were supposed to be incorporated into the line-of-communication units of the army sometime between day $x+25$ and day $x+80$. The army decided to apportion necessary line-of-communication units to each corps and 
detachment, organize the line-of-communication department of the army with the main force of the remaining units, and have Vice Chief of Staff Harada serve also as director of the lines-ofcommunication department of the army. It also decided to attach the Sumatra oil-drilling unit (commander: head of the oil-drilling group of the 21st Field Ordnance Depot) to the 38th Division and the Java oil-drilling unit of the Army to the 48th Division for the Cepu and other oil fields.

3. In the plan it was decided that the main supplies to be delivered to the army would be for about the first six months of operations, that is, ammunition for about one campaign, fuel, provisions and fodder for about three months, and medical supplies, veterinary goods etc. for about six months, and that, after that, ammunition and some other supplies would be delivered roughly every six months.

4. In the plan, the base supply point for the 48th Division was initially set at Rembang and later at Surabaya. The main force of the army would initially be supplied through the first landing point, and later through Batavia, the main line-of-communication center.

5. It was decided that the signal communication center of the army would be moved, following the developments of the operations, to Saigon, a signal ship, [a point] near Merak, Batavia and, if necessary, Serang and Tangerang one after another.

6. The use of the railway unit of the army ([consisting of] the main force of the 6th Railway Regiment and the 168th Railway Depot headquarters as its core, and assigned to the area of the main force of the army) was roughly planned as follows:

(1) The army railway unit shall have parts of the unit land in Merak, Mauk, Carita and Cilamaya along with the first landing units, seize the existing railways quickly and, by operating them, temporarily carry out the transport of units and munitions toward Batavia, and make its way into the city without delay. After entering into the city, it shall restore the railway between Tanjung Priok and Buitenzorg [Bogor] via Batavia.

(2) The main force of the army railway unit shall land near Batavia or Merak ahead of each of the second and the third landing units. While also directing the parts of the unit that had landed earlier, it shall restore in the first place the railway between Tanjung Priok and Buitenzorg [Bogor] via Batavia with a part of the unit or with its main force, get it ready for conducting the transport through close cooperation with the logistics unit or, if necessary, by assigning part of the unit to the army line-of-communication unit. Meanwhile, the unit shall have its main force, or a part of the unit, handle the mobile transport of Detachment D to Cilacap via Cirebon, and plan for railway combats. The use of the railway unit of the army after the capture of key locations shall depend on the situation at that time.

(3) During the period from the landings in Merak, Anyer-Lor, Carita, Mauk, and Cilamaya to [entering into] Batavia, the railway unit of the army shall not do repairs except minor ones. It should first of all advance into Batavia by quickly seizing the existing railways. Depending on the degree of destruction of the railways, it shall be expected to promptly advance into Batavia by motor vehicles without repairing the railways.

(4) The railway between Tanjung Priok and Buitenzorg [Bogor] via Batavia has to be quickly restored and maintained to the extent that one hundred tons [of transport] per day can be dealt with, and the necessary disembarkation facilities have to be equipped. The railway between Batavia and Cilacap via Cirebon has to be repaired so as to move Detachment D forward as much as possible. If necessary, motor vehicles can be used to go forward first in order to restore [the railway].

(5) During the initial stages after landings, the railway unit of the army shall provide makeshift armored trains and operate them to advance toward Cirebon from Batavia.

How long did those involved at the time estimate the time required for capturing Java? Before the opening of hostilities, it seemed to be roughly estimated at twenty to sixty days, though 
the estimation differed from person to person depending on their judgment of the strength, capability, equipment, and defense facilities of the Dutch East Indies Army, their judgment of our damage during sea transportation, and their judgment of the reinforcements provided by the British, U.S. and Australian forces. Some among the staff [of the Army Department] of IGHQ, who were well-informed of [the strength of] the enemy and ourselves, took it relatively easy, but those who [were charged to] execute the operation were cautious. It seems that [the Army Department of] IGHQ unofficially announced to the staff of the Southern Army that "it expected the landing on Java to be on day $x+103$ and the completion of the conquest of Java on day $x+120$, ,"(23) but Staff Officer Yamashita Yutaka (an up-and-coming major), who was appointed staff (assistant operations staff officer) of the Sixteenth Army from being a member of a section of the War Ministry, recalls: "I estimated [the time required for the conquest of Java] to be two months." After the opening of hostilities, everyone came to change their estimation of the time necessary to capture Java as they were hearing more and more about the military gains in the Philippines, Malaya, and other areas and became aware that the date of the Java operation could be advanced. [Intelligence] Staff Officer Kuriya Tsugunori (who had returned to Japan from Java in the month before the opening of hostilities) recalled that when he had been asked about his judgment [on the necessary time] by Staff Officer Arao Okikatsu, chief of operations of the Southern Army some time before the convoy for capturing Java had left Cam Ranh Bay, his answer had been that it could be captured in the time required [for the army] to march and travel through [the land], that is, a week, or ten days including contingency time. However, Army Commander Imamura described the judgment he had formed at almost the same time as Staff Officer Kuriya above, as follows: "At the end of early February, the chief of the Operations Bureau of the Army Department of IGHQ, Tanaka Shin'ichi, came to Saigon and asked me whether it was possible to dispose of the entire Java invasion within fourteen days (two weeks). I answered that at that moment I could not tell how many ships would be able to arrive and disembark while braving enemy torpedoes, and that, though I wished in my mind that we could make the enemy surrender within a month, my conscience did not allow me to declare that we could [promise to] make it happen." (Note: Will be described later [p. 427].)

As mentioned previously, the Sixteenth Army headquarters [temporarily] situated in the War College completed its operation plan with Commander Kume of the [Paratroop] Raiding Group on 21 December. However the next day, on the 22d, Col. Takashima Tatsuhiko, senior staff officer of Section 1 [of the headquarters] went to IGHQ and requested the following matters: ${ }^{(9)}$

1. The staff of the Sixteenth Army should be increased so that all of its detachments would have their own staff officers attached.

2. The capture of Rabaul by the South Seas Detachment should be carried out promptly so that the detachment could be diverted to the Sixteenth Army soon.

3. Ways to capture both Palembang and Balikpapan simultaneously should be sought out [at the Army Department]. (Note: at that moment, the operation in the Malaya area was unexpectedly making sudden progress. Nevertheless, there were no arrangements yet on the Palembang operation between the Sixteenth Army and the Southern Expeditionary Fleet.)

4. The capture of Ambon should be [re]scheduled for around 10 January. (Note: the 38th Division had already landed on Hong Kong Island on 18 December, which ensured the likelihood of an early redeployment of Detachment B.) 
5. The Davao unit (note: the Sakaguchi Detachment had already landed in Davao on the 20th) should be promptly replenished because of the serious damage incurred.

6. Ex-ante reinforcement (note: [increased] assignment of supernumerary personnel for filling vacancies before launching the operations) to the $2 \mathrm{~d}$ Division should be approved.

On this day (the 22d), Staff Officer Oda Akimitsu, chief of operations [of the Sixteenth Army headquarters], took off from Tokyo for the Southern Army headquarters in Saigon with the operation plan that had just been completed. ${ }^{(40)}$ At that time, the Sixteenth Army headquarters assumed that it would still have about another month before its departure from Tokyo. ${ }^{(35,36,38)}$ For this reason, Staff Officer Oda Akimitsu had intended to return to Tokyo as soon as he finished briefing the Southern Army. However, when on the next day, the 23d, Staff Officer Oda reported to the headquarters [of the Southern Army] in Saigon, he received an entirely unexpected command to stay in Saigon, being told that it was doing a study of advancing the Java operations by about one month from the [original] plan of IGHQ. ${ }^{(40)}$

\section{Taking Command of the 2d Division and Encouraging the Sakaguchi Detachment}

Army Commander Imamura, who had taken command of the Sakaguchi Detachment and sent it off at Moji, dispatched his Vice Chief of Staff Harada Yoshikazu (accompanied by Staff Officer Itoda Isamu) to Palau upon the safe arrival of the detachment there on 28 November, to inspect the detachment and give directions as to the final preparation for the operations as well as to encourage the officers and men. ${ }^{(37,39)}$

Army Commander Imamura also visited the Sendai divisional district from 24 to 25 November, where, after the cadre of the $2 \mathrm{~d}$ Division presented themselves before him, he gave instructions, inspected its maneuvers, and gave directions. ${ }^{(32)}$ The $2 \mathrm{~d}$ Division left Sendai, Wakamatsu and Shibata one after another from 1 to 16 December, arrived at the maneuver areas in Narashino, at the foot of Mt. Fuji, in Toyohashi, and Inuyama from 1 to 17 December, and continued training. ${ }^{(1,53)}$ Before the opening of hostilities, the $2 \mathrm{~d}$ Division [was ordered to] pretend to "be off to the Kunming operations." (55, 59) Division Commander Maruyama Masao reported to the [Sixteenth] Army headquarters on 9 December and after that stayed at the Narashino maneuver area. ${ }^{(32)}$

\section{Preparation of a Propaganda Group}

The propaganda group of the Sixteenth Army was formed as an agency supervised by Staff Section 1, and was making preparations to be dispatched. ${ }^{(38,48)}$ Its mission mainly consisted in counterpropaganda and the breaking of the enemy's fighting spirit; at the same time, considering the special characteristics of the Dutch East Indies, it also included the prevention of the destruction of resources, the heightening of the morale of the officers and men of the Imperial Army, the news coverage sent to the homeland, the conducting of pacification activities to stabilize popular feeling right after occupation, etc. The propaganda group of the army was granted three million yen as expenses for its formation and equipment before leaving for the front. The group, led by Lt. Col. Machida Keiji, consisted of eleven officers, twentysix noncommissioned officers, seventy-three men, eighty-seven drafted personnel, and forty eight employed personnel. The drafted personnel included men such as Ōya Sōichi, Matsui 
Suisei, Abe Tomoji, Tomizawa Uio, Kitahara Takeo, Ōe Kenji, Takeda Rintarō, Ōki Atsuo, Asano Akira, Ono Saseo, Yokoyama Ryūichi, Iida Nobuo, Ishimoto Tōkichi, Kurata Fumindo, Kōno Takashi, Ōchi Hiroshi, Minami Masayoshi, and Shimizu Hitoshi, who represented various professions such as writer, painter, musician, movie director, printer, stenographer and advertising balloon manufacturer. The drafted personnel had been given military training for about ten days ${ }^{(48)}$ and each of them was making preparations for the propaganda activities; painters and printers were creating posters, propaganda leaflets, etc., while writers were drafting advertisement copy. ${ }^{(38,48)}$

\section{Preparations for the Military Administration}

A military administration department was formed within the organization of the headquarters of the army. Maj. Gen. Harada Yoshikazu, vice chief of staff, was concurrently assigned director to the department, while Col. Nakayama Yasuto was head of the department, and some twenty personnel of senior official class, some 150 clerical staff and others were assigned to it. But it was kept on a small scale with the intention of making use of the local administrative structure and personnel as much as possible. ${ }^{(37,46)}$ IGHQ had issued "Directives for implementing an administration in the southern occupied areas" on 26 November. ${ }^{(1)}$ In the previously-mentioned "Transportation, Lines-of-communication and Signal Communications Plan of the Sixteenth Army," the army had specified: "In the early stages of the operation, the administration of the occupied areas shall focus on promptly securing public order and acquiring important national defense resources, liquid fuel in particular, as well as on enabling the army that conducts the operation to support itself on site; when implementing the administration, it shall use the remaining [administrative] structures as much as possible and run them while especially respecting the traditional organizations and ethnic customs in order to reduce the burden of the army in achieving its aims; the currency used in the area of operations shall be a military scrip for the time being, etc."(5) Based on these rules, it proceeded with research on and preparations for the military administration. ${ }^{(37,46)}$ 


\section{Chapter IV Opening of Hostilities and Capture of the Forward Advance Bases Davao and Jolo}

\section{Capture of Davao (See Illustrations No. 14 and No. 15)}

The Arrangements Between the Army and Navy as Presented [to the Sakaguchi Detachment]

$\Delta$

s previously related, the responsibility for the capture of Davao had been an issue at the time of the Iwakuni Agreement (concluded on 16 November). On 19 November, it had finally been decided to assign this responsibility to the Sixteenth Army, and on the same day the Sakaguchi Detachment had departed from Moji. On arrival in Palau on the 28th, the detachment started planning an operation to take the allied forces by surprise, and immediately began hard training by practicing cutting paths through the dense roots of [tidewater] mangrove forests. ${ }^{(87)}$ At the end of the month, Vice Chief of Staff [of the Sixteenth Army] Harada flew in, ${ }^{(37,39)}$ and on 1 and 2 December, the 5th Cruiser Division, the $2 \mathrm{~d}$ Destroyer Squadron and other naval units sailed into port. ${ }^{(114,117)}$ Vice Chief of Staff Harada passed down the order of the Sixteenth Army, which was based on the Southern Army's order of 20 [November] (in which the capture of Davao was added to the assignments [of the Sixteenth Army]), as well as the revised operation arrangements between the [Navy] Dutch East Indies Unit and the Sixteenth Army. These arrangements provided how the Sakaguchi Detachment and cooperating air and navy units should capture Davao, Jolo, Tarakan, Balikpapan, Samarinda, Banjarmasin and Bali. [The items concerning] the capture of Davao had been modified so that Detachment Commander Sakaguchi would take command of the Miura Detachment in the capture. [Also included] in the arrangements [regarding the capture of Davao] were that the Miura Detachment and the [naval] landing force should take the credit for the capture, and that the strength of the Sakaguchi Detachment should be retained. As for the capture of Tarakan and Balikpapan, a frontal attack was still in the plan, and Davao was also planned to be captured from the direction that the U.S.-Filipino Army seemed to expect. ${ }^{(88)}$ As will be described later point by point, the Sakaguchi Detachment, which was training to force its way through areas densely covered with mangroves, would drastically change the entire approach of the presented operation outline.

[However,] the outline of the proposed operations in Davao and Jolo was as follows: ${ }^{(88)}$

\section{Davao}

The unit [consisting of] the main force of the Sakaguchi Detachment and the Miura Detachment as its core shall leave Palau on day $x+2$. Before dawn on day $x+6$, the Miura Detachment shall land around Talomo bay, the main force of the Sakaguchi Detachment 
in Santa Cruz, one company on Samal Island, and the naval landing force in Kaganjan (probably the same as Kaganjuan in Illustration No. 14), all about the same time, and each of them shall capture key locations and airfields in the neighborhood at one stroke. After mopping up the landing points and their vicinity, an element of the unit shall be dispatched toward Cotabato (160 kilometers west of Davao) and seize its airfield. Once each place has been cleared of the enemy, the Sakaguchi Detachment shall turn over the [task of] guarding to the Miura Detachment and the naval units, assemble in Davao, and instruct and train the troops in preparation for the next operation. The assembly of the third echelon, the departure of the Jolo Detachment, and the water and coal supply to the ships shall depend on the situation. Elements of both of the [naval] land-based attack plane and fighter plane units shall cooperate [in the operations]. The strength of the escort shall be specified separately.

2. Jolo

The detachment [consisting of] the $3 \mathrm{~d}$ battalion (minus two companies) of the 146th Infantry Regiment under the command of Lt. Col. Matsumoto Tadasu as the core shall make a surprise landing on the coast northeast of the town of Jolo on day $x+13$ and seize the airfield and the radio station at one stroke. The detachment shall have independent engineers and disembarkation equipment diverted from the Miura Detachment after its capture of Davao and send these back with the ships to Davao after the capture of Jolo. After the capture, it shall turn over the [task of] guarding to the Navy and join the main force of the Sakaguchi Detachment. One light cruiser, four destroyers, and elements of both of the [naval] land-based attack plane and fighter plane units shall cooperate [in the operation].

\section{Postponement of the Date for Capturing Davao}

As for the waters east of the Philippines, the Navy Philippines Unit had decided to have the 4th Raid Unit ([consisting of] one light cruiser and eight destroyers) cooperate with the Kimura Detachment scheduled to land in Legaspi on day $x+4$, and the 5th Raid Unit ([also consisting of] one light cruiser and eight destroyers) with the Sakaguchi Detachment scheduled to land in Davao on day $x+6$ and, apart from these, deploy the Southern Philippines Area Task Force ([consisting of] three heavy cruisers, one aircraft carrier, two seaplane tenders, and one destroyer), and position its main unit ([consisting of] one heavy cruiser, one light cruiser, and two destroyers) on the waters northwest of Luzon (south of Magong). The Navy Southern Task Force had decided to deploy its main unit ([consisting of] one battleship, two heavy cruisers, and four destroyers) in the South China Sea and the Eastern Support Unit ([consisting of] one battleship, one heavy cruiser, and two destroyers) on the waters east of the Philippines. ${ }^{(110)}$ In addition, the naval aviation unit (i.e. the Eleventh Air Fleet) had planned to deploy strong air units in Palau. However, a report came in that the new and powerful British battleships, HMS Prince of Wales, HMS Repulse and other ships had been brought to Malaya. As previously related, the [Navy] Malaya Unit mainly consisted of [just] five heavy cruisers and one light cruiser. Because of this, on 28 November, the deployment of the Eastern Support Unit [which should have been] on the [sea] east of the Philippines had to be cancelled, and [further] twenty-seven planes of the air unit (i.e. the Eleventh Air Fleet) had to be diverted to the Southern Expeditionary Fleet on 2 December. ${ }^{(102)}$ About the 
same time, another element of the Philippines Unit in the eastern [waters] of the Philippines was also diverted to the west.

V. Adm. Takahashi Ibō, commander of the Philippines Unit had no choice but to give an order to postpone the capture of Davao scheduled on day $x+6$ to day $x+14 .^{(114,117)}$

From a report from the Fourteenth Army, the Southern Army learned on the next day, the 4th [of December], that the [Navy] Philippines Unit intended to postpone the date of the capture of Davao. After consulting with all parties concerned, it sent a telegram on 6 December to central command [i.e. the Army Department of IGHQ], the Fourteenth Army and the Sixteenth Army that "in view of the new disposition of the fleets, the date of landing in Davao shall be changed to day $x+13$ (order issued on behalf of a higher authority)."(22,24)

\section{Opening of Hostilities and Advance of the Date to Capture Davao}

Hostilities were opened on 8 December. In the Imperial Rescript on the Declaration of War, war was declared [only] on the United States and Britain, the Netherlands were left out. ${ }^{(13)}$

The Carrier Task Force succeeded in making a surprise attack on Hawaii on the 8th.

In the Philippines area, the air power of the allied forces was destroyed at a stroke on the 8th. On the 10th, the Tanaka Detachment (under cover of the 5th Destroyer Squadron) and the Kanno Detachment (under cover of the 4th Destroyer Squadron) landed in Aparri and Vigan respectively. ${ }^{(119,}{ }^{120)}$ Both the air and landing operations in Malaya also made a good start. On the 10th, HMS Prince of Wales and HMS Repulse were sunk. ${ }^{(104)}$ It seemed that [the U.S.] warships from the Philippines had withdrawn toward the Dutch East Indies. ${ }^{(110)}$

In the east coast area of the Philippines (more precisely, east coast area of the central and southern Philippines), R. Adm. Takagi Takeo, commander of the [Navy] Southern Philippines Area Task Force (and commander of the 5th Cruiser Division), was supposed to carry out air strikes on Davao and support the capture of Legaspi (in conjunction with the Army's Kimura Detachment and the [Navy] 4th Raid Unit under the command of the commander of the [Navy] 1st Base Force), but due to the diversion of the selected force [to the west] and the postponement of the date of capture of Davao, he decided to [alter the plan and] have the 11th Seaplane Tender Division ([consisting of] the seaplane tenders Chitose and Mizuho) support the unit to capture Legaspi from the beginning, and he left Palau at 1300 on 6 December with the remaining force (i.e. the 5th Cruiser Division ([consisting of] heavy cruisers, the Myōko, the Haguro, and the Nachi), the 4th Carrier Division ([consisting of] one aircraft carrier, the $R y \bar{u} j \bar{o}$ ), and the $2 \mathrm{~d}$ Destroyer Squadron ([consisting of] one light cruiser, the Jintsu, the 15th Destroyer Division and the Amatsukaze and the Hatsukaze of the 16th Destroyer Division), and carried out air strikes on Davao and Malalag Bay on the 8th by launching an attack plane unit from the carrier on the sea, but no aircraft of the allied forces were found. ${ }^{102,114,117,124)}$ After the air strikes on Davao, the [Navy] Southern Philippines Area Task Force changed its course and on the early morning of the 9th joined the unit [to support] the capture of Legaspi ([consisting of] one light cruiser, the Nagara, and the Yukikaze and the Tokitsukaze of the 16th Destroyer Division, which had left Palau for the attack on the 8th), and headed for Legaspi. ${ }^{(14,}$ 117) The landing in Legaspi was scheduled before dawn on the 12th.

In these circumstances, Rear Admiral Takagi had been sounding out the view of R. Adm. Tanaka Raizō, commander of the $2 \mathrm{~d}$ Destroyer Squadron, since the 11th, and following the success of the landing in Legaspi on the 12th, he proposed to the commander of the Philip- 
pines Unit (V. Adm. Takahashi Ibō) to advance the date of the capture of Davao. ${ }^{(114,117)}$ Vice Admiral Takahashi consulted V. Adm. Tsukahara Nishizō, commander in chief of the Eleventh Air Fleet, and gave the order "to capture Davao as soon as possible if the situation permitted, regardless of the date specified in the Classified Order of the Philippines Unit No. $1 .{ }^{\prime(117)}$

\section{The Plan to Capture Davao}

The 2d Destroyer Squadron ([under] Commander R. Adm. Tanaka Raizō), which returned to Palau on the morning of the 14th after finishing supporting the landing operations in Legaspi, immediately made arrangements with the Sakaguchi Detachment and reported on the 15th that "it had made arrangements with the Army's Sakaguchi Detachment to advance [the date of] the 5th Raid Unit's attack on Davao by two days." ${ }^{\prime 117)}$ The 5th Cruiser Division ([under] Commander R. Adm. Takagi Takeo) returned to Palau on the 16th, and reported that, because the enemy's movements in the areas to the south of Luzon and in the Molucca Sea were unknown, it wanted to continuously use the 4th Carrier Division (the aircraft carrier $R y \bar{u} \bar{j} \overline{0}$ ) in these areas up to and including the attack on Jolo, and that it had made arrangements with the Sakaguchi Detachment to tentatively set [the date of] the capture of Jolo on the 25th. ${ }^{(114,117)}$ The 4 th and the 5th Destroyer Squadrons and the 1st and the $2 \mathrm{~d}$ Base Forces, which had escorted the advance units and put them ashore in northern Luzon, were on their way to [their next duty of] escorting the main force of the Fourteenth Army and the main force of the 16th Division, which should land in Lingayen Gulf on the 22d, and in Lamon Bay on the 24th respectively, while the Malaya Unit was escorting the 5th Division, etc. and the Kawaguchi Detachment, which should land around the Gulf of Thailand and in British Borneo respectively. [This unit] was subsequently scheduled to escort the transport of the main force of the Twenty-fifth Army. ${ }^{(102)}$

The Sakaguchi Detachment had obtained information that "some twenty thousand Japanese nationals had been confined [in Davao] upon the declaration of war." (87) Also, it had obtained information that "the strength of the U.S.-Filipino Army in Davao, which had consisted of only about two companies before, had been gradually reinforced and reached some three thousand troops." $(87,50)$

As mentioned previously, the Sakaguchi Detachment had made arrangements with its navy counterparts on the 14th-15th to draw up an operation plan. While drafting it, special consideration was given to such points as that [the detachment] would adopt a method which might take the U.S.-Filipino Army by surprise regardless of the proposed outline of attack arranged between the [Navy] Philippines Unit and the Sixteenth Army, that it would try to safely rescue the resident Japanese nationals, that it would let the Miura Detachment of the Fourteenth Army take the credit for the capture, and that it would avoid damage to the Matsumoto Battalion which was assigned to capture Jolo right after the capture of Davao. Adopting the ideas of his staff officer, Yano Tsuneo, the detachment commander [Sakaguchi] drew up a plan in which, regardless of the presented outline of attack, the main force would take a detour all the way around Samal Island and be put ashore at the rear of Davao, while part of the force would be put ashore on the coast of Talomo Bay, and by occupying the airfield at a stroke, [the detachment would] make the U.S.-Filipino Army in Davao beat a hasty retreat, allowing [the detachment] to safely rescue the Japanese nationals as well as to keep 
the facilities in Davao intact. He requested the Navy not to directly shell Davao from the sea for the safety of the Japanese nationals. He also planned to let the Miura Detachment and the naval landing force have the honor of the capture of Davao, and [for this purpose,] particularly made sure that the regimental commander would stay with the colors at sea, because especially the movement of the colors would become a news story. Many officers and men of the 146th Infantry Regiment were dissatisfied with this plan because this operation was the opening battle of the war [and they craved the honor], but the detachment commander kept them under control. ${ }^{(87)}$

The operation plan of the Sakaguchi Detachment was in outline as follows: ${ }^{(89,90)}$

\section{Right Wing Unit:}

Commander: Lt. Col. Miura Toshio; consisting of the whole of the Miura Detachment, the 7th Company of the 146th Infantry Regiment, and [1] armored car unit (minus 1 platoon) as the core;

Shall land in the mouth of the Panacan River, attack the Sasa airfield at night, subsequently capture the city of Davao, in hot pursuit chase the U.S.-Filipino Army toward the Davao River, and, in concert with the left wing unit, capture and destroy the defeated enemies on the right bank of the Davao River.

Left Wing Unit:

Commander: Maj. Kanauji Ken'ichi; consisting of the 2d Battalion (minus the 7th Company) of the 146 Infantry Regiment, half of the regimental artillery unit, half of the regiment's antitank gun unit, and 1 armored car platoon as the core;

Shall land on the coast of Talomo Bay, keep guard over the southwest with part of the unit, occupy Talomo and its vicinity with the main force, and, in concert with the right wing unit, capture and destroy the defeated enemies on the right bank of the Davao River. After that, [it] shall conquer Malagos (2 kilometers northwest of Talomo) and Malalag (95 kilometers southwest of Davao). [Editor's note: Malagos is actually $20 \mathrm{~km}$. from Talomo, and Malalag $75 \mathrm{~km}$. from Davao.]

Rear Base Unit:

Commander: Lt. Col. Matsumoto Tadasu; consisting of the $3 \mathrm{~d}$ Battalion (minus the 10th and the 12th Companies) of the 146th Infantry Regiment and 1 field artillery section as the core;

Shall be positioned at the rear of the right wing unit. After the right wing unit advances into the city of Davao, [it] shall secure key locations and function as a rear base for the right wing unit mopping up the city of Davao and its vicinity.

1st Field Artillery Battalion (minus the 1st and 3d Battery and the battalion supply train):

The main force of the battalion headquarters shall accompany the Miura Detachment and be charged with reconnoitering the enemy's movements and the terrain. If it seems to meet resistance from the U.S.-Filipino Army, it shall put the battalion under single control and cooperate with the right wing unit in its battle.

Headquarters of the Detachment (minus an element):

After landing on the coast of Tibungco, shall advance into the city of Davao.

3d Battery of the 44th Field Antiaircraft Artillery Battalion:

Shall be assigned to the aerial defense around the anchorage, while staying on board.

146th Infantry Regiment (minus the main force of both of the $2 \mathrm{~d}$ and the $3 \mathrm{~d}$ Battalion):

Shall remain on board as reserve.

Note: The Miura Detachment consisted of the 1st Battalion of the 33d Infantry Regiment (Battalion commander: Maj. Tsunoda Isamu), 1 engineer platoon and 1 independent engineer platoon as the core and was under the command of Lt. Col. Miura Toshio, who was attached to the 33d Infantry Regiment of the 16th Division. ${ }^{(89,90)}$ 


\section{Departure, Landing and Occupation}

After 1600 on 16 December, the Sakaguchi Detachment and the Miura Detachment left Palau for Davao one after another in respectively eight and four transport ships. ${ }^{(117)}$ The convoy was escorted by the 5th Raid Unit (consisting of one light cruiser and six destroyers) commanded by R. Adm. Tanaka Raizō, commander of the 2d Destroyer Squadron. A fleet which included the 5th Cruiser Division (consisting of three heavy cruisers), the 4th Carrier Division (consisting of one aircraft carrier, the Ryūjo, and a destroyer, the Shiokaze), and the 11th Seaplane Tender Division (consisting of the seaplane tenders Chitose and Mizuho) and others, under the command of R. Adm. Takagi Takeo, commander of the 5th Cruiser Division was assigned to give direct support. ${ }^{102,114,117)}$

Although the convoy came under a torpedo attack by an allied submarine on the morning of the 17th, it sustained no damage. ${ }^{(102,117)}$ Coming under no further attacks after that, it entered anchorage on the night of the 19th. A very strict blackout had been enforced over the city of Davao, its vicinity and the areas to the south of the city, while many lookout posts had been set up as well. However, there were scattered lights along the coast where the main force of the Sakaguchi Detachment came to anchor after taking a detour around Samal Island, [which meant that] it had taken the enemy by complete surprise. ${ }^{(87)}$

The Miura Detachment, assigned to seize the airfield in a night attack and then capture the city of Davao, and the naval landing force, assigned to capture the oil storage facilities at Lanang in a night attack, each reported that they had successfully made surprise landings at 0400. ${ }^{(87,89,90)}$ When Detachment Commander Sakaguchi came ashore in the second transport and advanced toward the airfield believing that the airfield had been secured in the night attack by the Miura Detachment, he only found that the Miura Detachment had not been able to launch a predawn attack, that some fifty soldiers had been killed when our naval planes mistakenly bombed them while they were preparing for an attack after daybreak, and that this had put the detachment in a difficult position for carrying out the attack. He also found that the naval landing force, which should have captured the oil storage facilities at Lanang in a night attack, had not been able to carry that out either and was moving toward the airfield. ${ }^{(87)}$

Detachment Commander Sakaguchi had hoped to quickly seize the airfield as well as Davao City and rescue the resident Japanese nationals before sunset, so he had been pressing the Miura Detachment to attack. However, when he found the detachment in a situation too difficult from which to launch an attack, he at last decided to bring the Matsumoto Battalion into play. He had intended to deploy it in the capture of Jolo planned right after [this operation], which was one of the reasons why he wished to avoid committing the battalion [in Davao], but there was no other option. ${ }^{(87)}$ Around 1000, he ordered the Matsumoto Battalion to capture Davao from the direction of the coast. ${ }^{(87,89,90)}$ The battalion immediately attacked and advanced, defeated the U.S.-Filipino Army, and stormed into Davao around 1500. After the advance of the Matsumoto Battalion, the Miura Detachment moved into the airfield and then into Davao. The U.S.-Filipino Army on the airfield and in and around Davao fled to the mountains in the west. ${ }^{(87)}$

Earlier, the left wing unit had landed near Talomo at 0500 without meeting with resistance from the U.S.-Filipino Army and immediately advanced towards the line of the Davao River. [However,] the U.S.-Filipino Army put up considerable resistance at the line of the Talomo River. Finally after daybreak, the left wing unit succeeded in beating back the U.S.-Filipino 
Army and advanced eastward. However, its advance was difficult because the U.S.-Filipino Army had set up several lines of permanent positions on Matina Hill, where the sources of the [city's] water supply were located, and counterattacked from there using these positions as strongholds. ${ }^{(87)}$

Detachment Commander Sakaguchi, who had moved into Davao just after 1500, learned that a considerable number of the U.S.-Filipino Army troops were on the other side of the Davao River and that the left wing unit was engaged in a hard battle. He had ordered the Miura Detachment to cross the river and attack [the enemy], but then, in view of the condition of the detachment, he newly ordered the Ezaki Engineer Company to cross the Davao River and attack the enemy. The company immediately started its advance and together with the left wing unit made a frontal attack on the U.S.-Filipino Army from both sides. The U.S.-Filipino Army retreated northwestwards along the Davao River valley. The Ezaki Company and the left wing unit were able to make contact after sunset. ${ }^{(87)}$

As soon as the Sakaguchi Detachment had entered Davao, it had started the operation to rescue resident Japanese nationals. They were detained in a junior high school in the northwest end of the city, at the wharf of Davao, in Mintal (six kilometers west of Davao), in Daliao (six kilometers west-southwest of Davao), and other places on the eastern coast opposite Davao, and in the area in the north of Davao in groups of some two thousand people each. Influential people were detained in a prison in Beruna Colony, located fifty kilometers northwest of Davao. ${ }^{(50,87)}$ [Editor's note: the distances and directions are not all correct; "Beruna" Colony is probably a corruption of "(Davao) Penal Colony."] The detachment was able to successfully rescue the Japanese nationals detained in warehouse(s) at the Davao wharf by breaking down the walls [of the building(s)] just before raging fires (which had been caused by the shelling of the Navy) spread to the warehouse(s). After rescuing the Japanese nationals in Davao, the Sakaguchi Detachment rushed in all directions to rescue Japanese nationals in various places throughout the area where the defeated enemy was still rampant. ${ }^{(87)}$ It was on the morning of the 24th that the detachment rescued the Japanese residents detained in 'Beruna' Colony. Dramatic scenes abounded: a [Japanese] elementary school principal got on top of an armored car of the Sakaguchi Detachment on its way to rescue [Japanese residents] to lead the way; a Japanese civilian jumped on a machine gunner of the U.S.-Filipino Army who was firing at the officer and men of the Sakaguchi Detachment when they approached the detention camp, etc. ${ }^{(50,87)}$

Upon the capture of Davao, the Miura Detachment started constructing defensive works by piling sandbags. The Sakaguchi Detachment had the unit charged with the capture of Jolo under the command of Lieutenant Colonel Matsumoto prepare for the subsequent operation and, with the rest of its troops, he mopped up the remaining enemies in and around Davao. A number of the resident Japanese formed a volunteer corps to cooperate in this operation. ${ }^{(87)}$

It had been agreed that the Navy would not shell the city from its ships when capturing Davao. ${ }^{(87)}$ However, on the early morning of the 20th, when a motor launch of the destroyer Amatsukaze guarding the anchorage in Talomo Bay approached the Davao wharf to capture small boats and came under fire of the U.S.-Filipino Army, the Amatsukaze opened a protective bombardment at 0715 . Some shells hit the oil tanks in Davao City and caused a big fire.

The 4th Carrier Division (consisting of the aircraft carrier Ryūjō and a destroyer, the Shiokaze) had conducted reconnoitering attacks on Davao with six carrier-based attack planes on the 19th. On the next day, the 20th, it provided cover for the landing, and after that until the 
22d, it took charge of direct air support over the anchorage. The 5th Cruiser Division (consisting of the heavy cruisers Myōko, Haguro and Nachi) acted practically in concert with the 4th Carrier Division. The 11th Seaplane Tender Division (with only the seaplane carrier the Chitose) moved westward on the waters north of the [Army] attack units. On the 20th, it cooperated in their landing attacks with its on-board reconnaissance seaplanes, set up a floating air base in Talomo Bay as early as the same evening, and started conducting aerial patrols and reconnoitering attacks on [enemy] bases on Mindanao. On the 20th, R. Adm. Irifune Naosaburō, commander of the $32 \mathrm{~d}$ [Special] Base Force, hoisted his standard in Davao. ${ }^{(102)}$

The losses of the 146 Infantry Regiment (formed in Ōmura, Kyūshū) consisted of twentytwo men (amongst whom were four officers, four noncommissioned officers, and fourteen soldiers), including those killed in the Jolo operations which will be described later. ${ }^{(53)}$ This shows that the officers led from the front and fought bravely, but at the same time, it raises a question as to what the previously mentioned visit of Takashima, senior staff of Section 1 of the Sixteenth Army, to IGHQ on the $22 \mathrm{~d}$ and his request that the Davao unit be promptly replenished because of the serious damage incurred, was all about. In fact, it shows that the damage to the Miura Detachment, when our naval planes mistakenly bombed it, was really serious. At the time of landing, Detachment Commander Miura deployed the main force of the 1st Battalion of the 33d Infantry Regiment (with Maj. Tsunoda Isamu as the battalion commander) in the front line, and put [other] elements of it and the 7th Company of the 146th Infantry Regiment under his direct control. The battle of the Tsunoda Battalion went as follows: ${ }^{(89,90)}$

\begin{abstract}
Arrival at the shore at 0400 . With no beach/underwater obstacles nor shore-side pillboxes found, we made a successful landing, straightaway gathered near the Panacan Bridge, and cut the telephone lines above the roads. The left front line company reached the southern end of the airfield around 0630. Then our naval air units unleashed a fierce aerial bombardment. Sunrise was at 0640. Battalion Commander Tsunoda had reinforcements of one platoon of the 1st Company and the 7th Company of the 146th Infantry Regiment (minus one squad) sent by Detachment Commander Miura, and decided "to advance towards the barracks and launch a frontal attack on the enemy."
\end{abstract}

Although Detachment Commander Sakaguchi had intended to let the Miura Detachment take the credit for the capture of Davao, he regretted the unexpected turn of events. He had no other choice but to order the Matsumoto Detachment, assigned to the capture of Jolo, to charge [into Davao] at short notice, because the Miura Detachment had incurred [too much] unforeseen damage, and the large fires that had broken out in the city made him concerned about the imminent danger to which the Japanese residents were exposed.

\title{
2. Capture of Jolo Island (See Illustration No. 15)
}

As previously explained, the main points of the operation for the capture of Jolo were presented in the Iwakuni Agreement and in the subsequent arrangement between the [Navy] Dutch East Indies Unit and the Sixteenth Army (which was brought by its Vice Chief of Staff Harada [to Palau]); they were further adjusted in the arrangement between Detachment Commander Sakaguchi and R. Adm. Tanaka Raizō, commander of the [Navy] 5th Raid Unit 


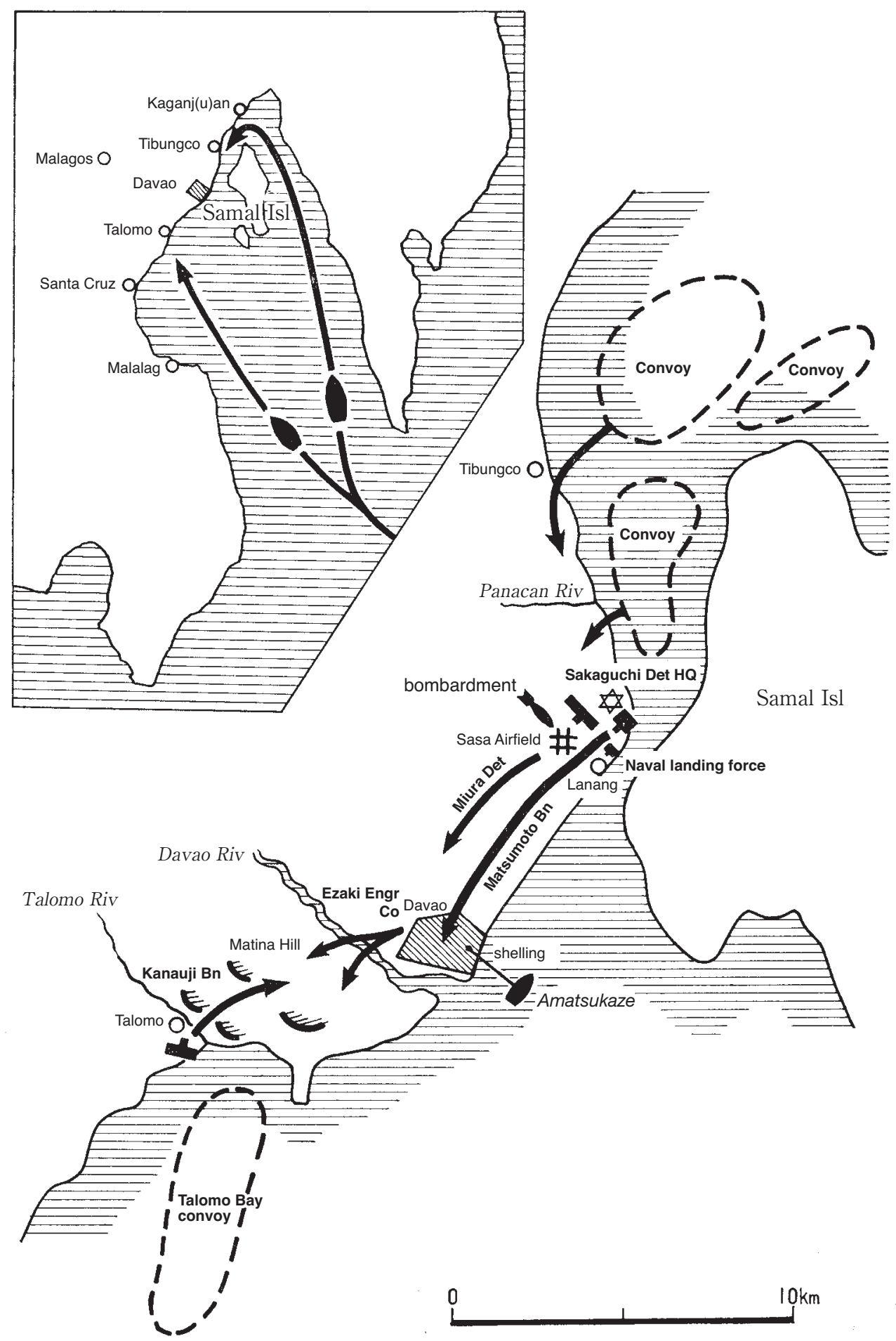

Illustration No.14-The Capture of Davao 

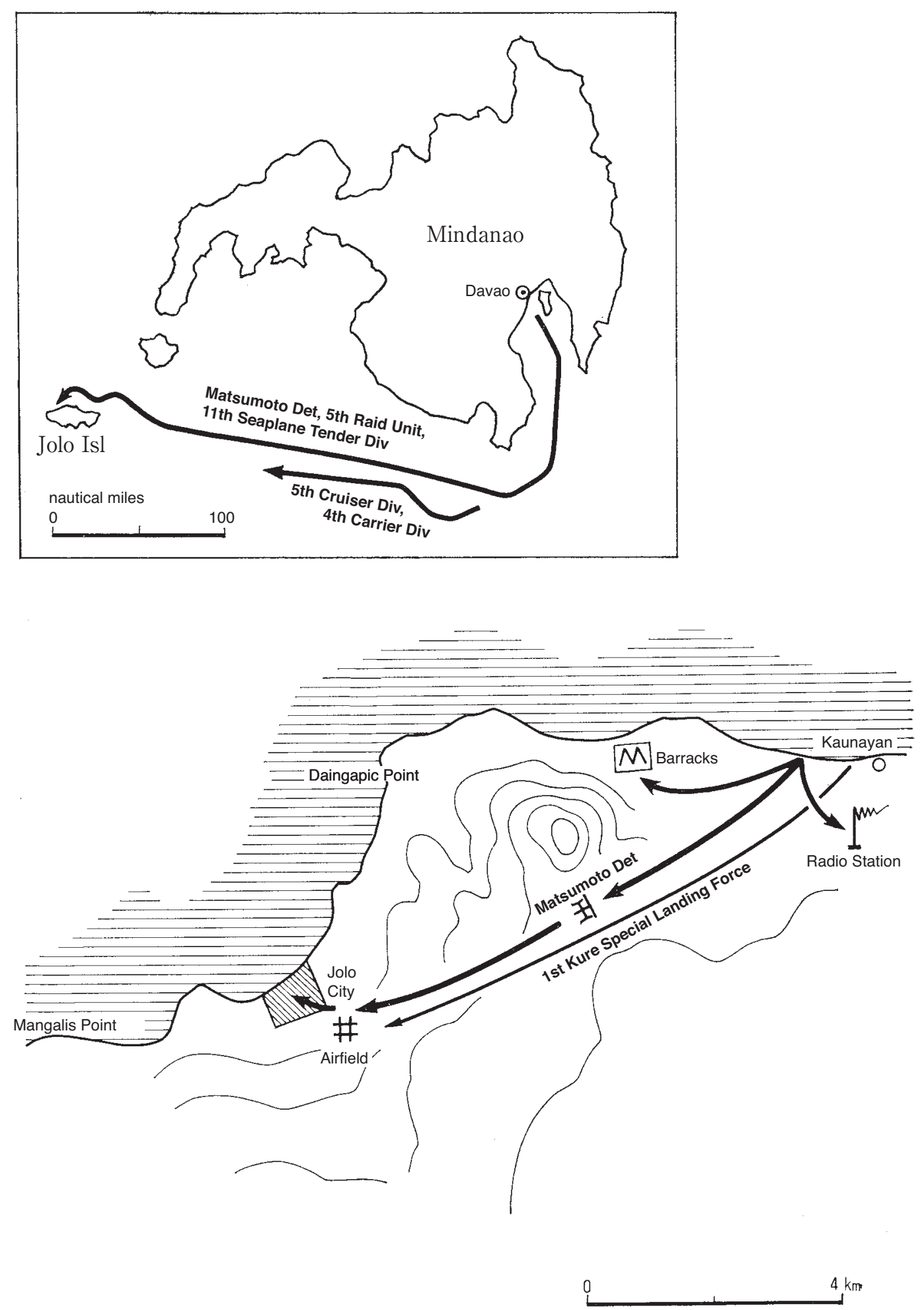

Illustration No. 15-The Capture of Jolo 
(and commander of the 2d Destroyer Squadron) in Palau on 15 December, along with the main points of the operation for the capture of Davao.

In the above-mentioned arrangement of 15 December, it was specified that the landing [on Jolo] should be around 25 December; that the [Jolo] unit should sail along with the unit for the capture of Davao [up to Davao], from where it should separately advance [toward Jolo]; that the Army Jolo Detachment, consisting of the 3d Battalion of the 146th Infantry Regiment (minus two companies) and one field artillery section as the core, under the command of the battalion commander, Lt. Col. Matsumoto Tadasu, should board the Yamazuki-maru [Yamatsuki-maru]; that two [naval] ships with a naval construction unit on board should go along with it; that they should be directly escorted by the [Navy] 5th Raid Unit (consisting of the Jintsu and the 15th Destroyer Division as the core under the command of Rear Admiral Tanaka, commander of the 2d Destroyer Squadron); that the Jolo Detachment should land on the coast to the west of Kaunayan (depending on the situation, on the coast between Daingapic Point and Mangalis Point), and first seize the airfield, the radio station, and the center of [Jolo] town; that naval bombardments should be conducted [only] on request; that emptied ships and the [Navy] 5th Raid Unit should return to Davao after completion of the disembarkation; that the [Navy] Southern Philippines Area Task Force (made up of the 5th Cruiser Division (consisting of three heavy cruisers), the 4th Carrier Division (consisting of one aircraft carrier and one destroyer) and the 11th Seaplane Tender Division (consisting of one seaplane carrier)) should support [the operation], etc. ${ }^{(114,117)}$

The headquarters of the 21st Air Flotilla, a land-based [naval] air unit, advanced [its base] to Palau on 19 December, and an element of the land-based air flotilla advanced [its base] to Davao from the 22d. ${ }^{(102)}$

On 22 December, it was decided that the landing on Jolo would be conducted on the 25th. (117) As mentioned previously, the Matsumoto Battalion (i.e. the Jolo Detachment), which had been dragged into unexpected battles in Davao on the 20th, rapidly made preparations after that, embarked on the Yamazuki-maru [Yamatsuki-maru], and left Davao at 1200 on the 23d. Two naval transport ships and ships of the [Navy] 5th Raid Unit and the Southern Philippines Area Task Force left Davao from the evening of the $22 \mathrm{~d}$ to the $23 \mathrm{~d} .{ }^{(114,117)}$ On the $23 \mathrm{~d}$ in the morning, a heavy bomber of the allied forces raided Davao, and in the afternoon, a flying boat of the allied forces came reconnoitering the convoy. On the 24th, there was a report that "an enemy light cruiser was seen," but it did not result in any engagement, ${ }^{(117)}$ and there were no raids [either] by allied planes on this day. ${ }^{(117)}$

The Matsumoto Detachment began landing [operations] at 0040 on the 25th and reached the coast west of Kaunayan at 0120.(117) Although it succeeded in landing secretly as scheduled, it could not launch a night attack mainly due to the inaccuracy of its maps and its unfamiliarity with the terrain. ${ }^{(15,87)}$ After dawn, it eliminated some slight resistance from the U.S.-Filipino Army and seized the airfield around 0600, the barracks around 0700, the town of Jolo around 0800 , and the radio station around 1030.(117) The airfield was fit for immediate use, and four land-based aircraft were advanced from Taiwan to Jolo airfield as early as the [same] afternoon. ${ }^{(102)}$

After occupying the whole area of the town of Jolo, the Matsumoto Detachment started mopping up the U.S.-Filipino Army (about three hundred troops), which had fled toward the mountain forests on the eastern coast. Not understanding the intention [of the Detachment], the [local] Moro people put up stubborn resistance with bamboo spears and hunting 
guns. However, once the Matsumoto Detachment had succeeded in winning over the chief of the tribe to its side, they began to cooperate with the detachment, which made the capture of the remaining defeated troops in the island so easy that it completed clearing the island in a few days. ${ }^{(15,87)}$ The losses that the Matsumoto Detachment incurred in the battle for Jolo were only two men. ${ }^{(53)}$

[In the meantime,] only one allied plane came flying over on the 25th, and not a plane came to raid on the 26th. ${ }^{(102)}$

The 4th Carrier Division ([consisting of] one aircraft carrier, the Ryūjō, and one destroyer, the Shiokaze), which had provided direct air cover until the 24th, returned to Palau on the 26th. The 11th Seaplane Tender Division (the seaplane carrier Chitose), which had taken charge of the direct air cover until the fighter planes of air units (i.e. the Eleventh Air Fleet) advanced to the Jolo base on the 26th, returned to Davao on the 28th. ${ }^{(102,103)}$ The 5th Cruiser Division (consisting of the heavy cruisers Myōkō, Haguro, and Nachi) advanced to a spot one hundred nautical miles southeast of Jolo and turned around to return to Palau on the 28th. ${ }^{(114)}$

The air unit (i.e. the Eleventh Air Fleet) advanced the whole force of its Tainan Air Group (about fifty fighter planes) to Jolo by 2 January. ${ }^{(102)}$ The Matsumoto Detachment turned over the guarding of Jolo to the Navy, departed from Jolo at 1200 on 13 January, and arrived in Tarakan on the morning of the next day as will be described later. 


\section{Chapter V Decision to Advance [the Schedule of] the Java Operation and the Sixteenth Army}

\section{Decision to Advance [the Date of the Operation]}

(See Illustration No. 16)

$\mathrm{O}$ n 19 December, the Southern Army Operations Section (more precisely, Senior Staff Col. Ishii Masayoshi and Chief of Operations Lt. Col. Arao Okikatsu, both in Section 1 of the Southern Army Staff) in Saigon set their minds on bringing forward the Java operation by about one month (note: about one month earlier than planned by IGHQ).(24) It was two days before the Sixteenth Army headquarters [still located] at the War College completed its operation plan, six days before it made its line-of-communication plan, and one day before the Sakaguchi Detachment landed in Davao.

The reason that they set their minds on moving up the Java operation was [the fact that] since the opening of hostilities, the war situation had developed quite favorably, which made them conclude that "most of the goals of Operation A-GŌ [i.e. the southern operation] should be attained by making use of the current war momentum and by conducting the operation on the concept of strategic pursuit." (24) Section 1 of the Southern Army Staff considered that "it was of vital importance for Japan to establish its sphere of self-preservation and self-defense before the enemy was fully ready to destroy its commerce; that allowing the U.S. and British naval forces to unite [in a counterattack] would result in restricting the operations of our Navy and prevent it from gaining independent command of the seas in the Indian Ocean as well as in the West Pacific, which [the staff] feared would cause the Dutch East Indies operation to be conducted under anxiety and strain."(24) Although the staff judged that an additional tonnage of some half a million tons would be necessary to attain this end, ${ }^{(24)}$ they determinedly planned to accelerate the operation.

The war situation up to the day before [they started planning] (the 18th) was in outline as follows:

Huge achievements had been made in the first engagements, which dispelled the worries about the eastern waters for the present. The Twenty-fifth Army, which had succeeded in carrying out a surprise landing in Malaya, had shifted to chasing the enemy after breaking through the Jitra line by as early as 13 December, which the British Indian Army had boasted could check the advance of the Japanese Army for at least three months. By 17 December, the command post in Alor Setar had revised the operation plan as follows:

The Imperial Guard Division and the 5th Division shall charge toward Singapore along the west coast, while the Takumi Detachment ([which] came ashore in Kota Bharu and is going southward along the eastern coast) shall advance toward Kuala Lumpur or Gemas from the direction 


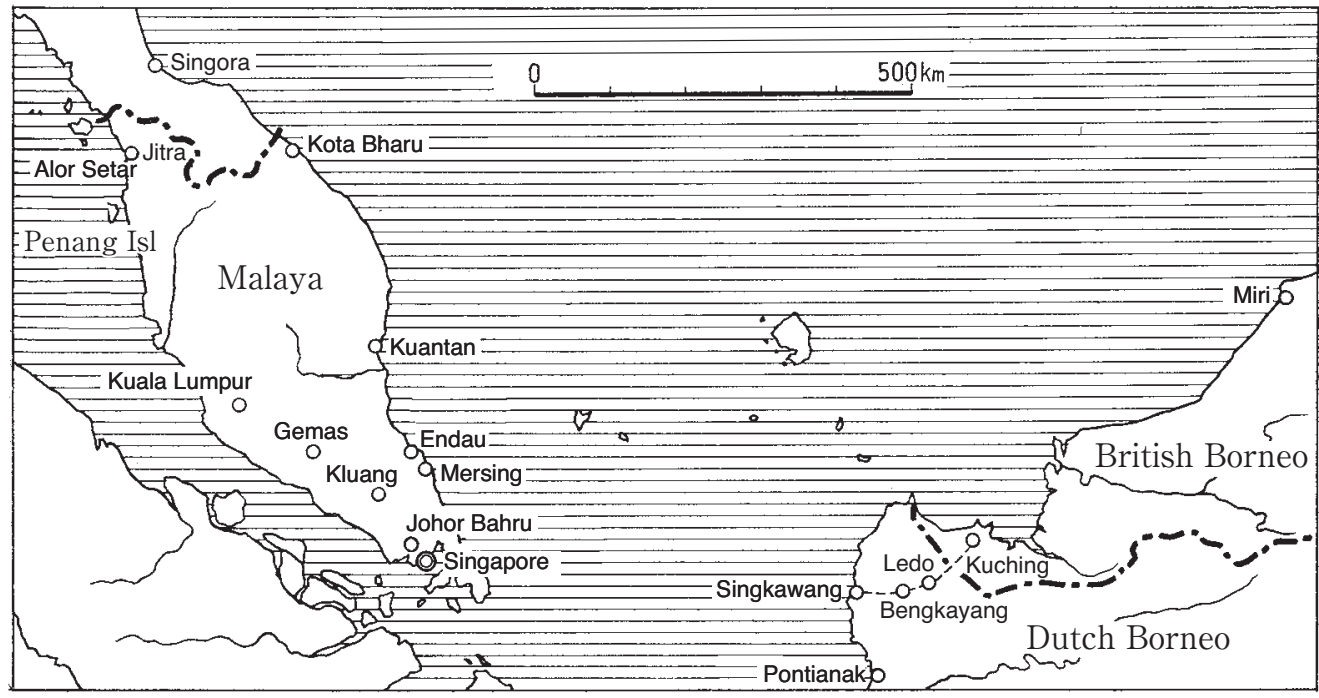

Illustration No. 16 - Map of Relevant Places in Malaya and Western Borneo

of Kuantan, and facilitate the operations of the main force of the army. [On the other hand,] the 18th Division, which will be transported to Singora in the third transport, will after arrival temporarily remain there on standby and, taking an opportunity, land in or near Mersing and charge toward Kluang and Johor Bahru.

The 56th Division, which had been scheduled for transport and landing in or near Mersing as the last corps of the Twenty-fifth Army, was now considered unnecessary for the capture of the Malay Peninsula. The 38th Division assigned to the capture of Hong Kong broke through the stronghold around Tai Mo Shan [Damaoshan] with unexpected swiftness, completely seized the whole of the Kowloon [Jiulong] Peninsula by 14 December, and was about to go ahead with the landing on Hong Kong [Island]. As for the Philippines, after succeeding in destroying the enemy air power right at the outset of the war, operations of the advance units progressed as scheduled. The landing of the main force of the Fourteenth Army around Lingayen Gulf and Lamon Bay scheduled for 22 and 24 December respectively and the subsequent operations could be looked forward to with confidence, while the prospect that the redeployment of the 48th Division to the Java operation could be carried out ahead of schedule looked very good. The Kawaguchi Detachment (consisting of three battalions of the 18th Division as its core) had made a successful landing near Miri on 16 December and the Sakaguchi Detachment had departed from Palau on the 17th for the capture of Davao. The success of the subsequent operations of these detachments was [also] judged unquestionable. The $2 \mathrm{~d}$ Division stood by on the mainland [of Japan] fully prepared, while the 1st [Paratroop] Raiding Group was preparing for departure in Kyūshū, following the instruction issued by the chief of the Army General Staff of IGHQ on 8 December. ${ }^{(1)}$ The only concern was the delay in the schedule of capturing Rabaul by the South Seas Detachment and the [resultant] delay in it making a U-turn to join the Dutch East Indies operation, which had been caused by the Fourth Fleet's failure to capture Wake Island (on 10 December). The South Seas Detachment, which [was expected to] to capture Guam and then Rabaul, and then join the Dutch East Indies operation, had to wait in Guam to no purpose, even though it had captured the island as early as 10 December, because the Fourth Fleet was in the middle of preparations to retry 
capturing Wake Island. However, the operations of the Twenty-fifth Army went so smoothly that the 56th Division, which were to be transferred along with the 18th Division, was now considered unnecessary for the operations in the Malay Peninsula, so the delay in the operations of the South Seas Detachment was not really worth bothering about.

What is more, that night (the night of the 18th), the 38th Division succeeded in landing on Hong Kong Island. As described previously, the division [was among those] planned to be redeployed to the Dutch East Indies operation. The Southern Army judged it was time to concretize its phase-two operations (the operations for the capture of Java).

On the 19th, the Operations Section of the Southern Army, as previously described, set its mind on advancing [the schedule of] the Java operation and on the same day informed the staff of the Second Fleet that it wanted to conclude further arrangements between the Army and the Navy (the arrangements for phase-two operations, i.e. the operations for the capture of Java, which followed those concluded on 10 November) and that it was considering as subjects of the arrangements the schedule for the capture of the Dutch East Indies, the outlines of the capture of Palembang (about [the use of] the paratroop unit and the cover provided by the ships), matters concerning anti-submarine [measures] and shipping, etc. ${ }^{(24)}$

The Operations Section of the Southern Army set its mind on having the acceleration of the Java operation agreed and tried to promptly conclude agreements for phase-two operations, which had been expected around day $x+40$ (i.e. 17 January), ahead of schedule. As to the reasons [why it hastened the conclusion of agreements], it has to be pointed out that apart from the already-described general situation, and with the exception of eastern Borneo [and further east] (which the previous arrangements already covered up to the outline for the capture of Bali), the outlines for the capture of key areas outside Java, e.g. west of Borneo and southern Sumatra, had yet to be covered. However, now the stage had been reached where specific arrangements for the operations to capture southern Sumatra could be concluded. The first arrangement [necessary] concerned the operations on the west coast of Borneo, where the Kawaguchi Detachment, which had landed in Miri on the 16th, was going to land in Kuching on the 21st. ${ }^{(118)}$ Naval planes were supposed to advance into Kuching and launch air operations against Sumatra and western Java as soon as the Kuching airfield became ready for use. The second arrangement [necessary] was that preparations for a Kuantan landing operation were taking shape. By seizing Kuantan, air support from its airfield for the southern Sumatra operation would become possible. The value of the Kuantan airfield had been mentioned for the first time in Saigon on 10 December by Kumon Aribumi, a staff officer of IGHQ. ${ }^{(24)}$ The next day, the 11th, when IGHQ Staff Officer Kondō Dempachi returned to Tokyo from Saigon, the Southern Army told him: "We are currently studying a speedup of the operations, and [more precisely]we are considering advancing [the schedule of] the capture of Singapore by seizing Kuantan and [also] landing in Mersing and Bangka on approximately day $x+60$. We would like [IGHQ] to consider an increase in tonnage of 150,000 tons in total: 50,000 tons each for the new operations, for replenishment, and for matériel."(24) Landing in Kuantan at this time [of the operations] had not been included in the previous plans. The next day, the 12th, the Southern Army settled on an outline for the operations on the east coast of Malaya. ${ }^{(23)}$ In the previous plans, the 5th and the Imperial Guard Division would advance southward along the west coast of Malaya, while the 18th Division was scheduled to land in Singora around day $x+25$ (12 January) and would head for Penang, while the 56th Division in the subsequent transport would come ashore in Kuantan and 
Mersing around day $x+60$ (6 February). In the [new] plan, this was changed: now the 18th Division, expected to arrive first, would be used for the east coast of Malaya. [To be exact,] two battalions of the 18 th Division as the core would be put ashore in Kuantan on day $x+17$ (25 December), while the main force of the 18th Division (four battalions as its core) would be put ashore on day $x+40$ (17 January) in Endau and Mersing. ${ }^{(23,24)}$ The Twenty-fifth Army had on the whole no objection to this plan and, on the 15th, ordered the Takumi Detachment (going southward from Kota Bharu along the east coast) to go [further] southward and act in concert with the units landing in Kuantan. On the 17th, it unofficially disclosed the army's intention to the staff officers of the 18th Division, while revising its operation plan in accordance with [the outline] mentioned above. ${ }^{(53)}$ [Meanwhile,] on this day (the 17th), the Southern Army explained the Kuantan operation to the staff of the Third Air Force, the [Navy] Malaya Unit, and the 22d Air Flotilla. ${ }^{(23,24)}$ At this time, [ the operations to] capture Davao (on the 20th) and Jolo (on the 25th) had not yet been executed. Since the start of the study on the southern operation in 1940, it had been consistently taken for granted that the operations via the east of Borneo would proceed more quickly than those conducted via Malaya. However, the sinking of two large British battleships and the smooth progress in the Malaya and British Borneo operations had brought about these alterations [in the plans].

On this day (the 19th [when the Southern Army contacted the Navy Southern Task Force]), out of the three land-based air flotillas of the Southern Task Force, the 21st Air Flotilla headquarters had moved to Palau from Taiwan. ${ }^{(102,104)}$ This flotilla was supposed to move to Davao without delay when the Sakaguchi Detachment had captured Davao (on 20th). The 23d Air Flotilla was still in southern Taiwan together with the Eleventh Air Fleet headquarters, ${ }^{(102,104)}$ while the 22d Air Flotilla (assigned to the [Navy] Malaya Unit) was in southern French Indochina. ${ }^{(102,104)}$ As mentioned previously, right before the opening of hostilities, the [Navy] Southern Task Force attached great importance to the movements of the British fleet and considered the possibility of having to advance the 23d Air Flotilla to Kuching (scheduled to be captured on the 21st) after the Philippines operations. However, after the sinking of the two large British battleships, it decided to have the air flotilla advance to Jolo (scheduled to be captured on the 25th) and then go southward along the east coast of Borneo.

The next day, the 20th, Section 1 of the Staff of the Southern Army made a proposal to advance [the schedule of] the operations for capturing Java at the staff meeting of the headquarters [of the Southern Army]. (24) A staff officer of the Shipping Transport Command stationed at the Saigon command post made a comment that "provided that the ships currently allocated [to the army] are not returned, it seems possible," but Section 1 judged that "it will probably be necessary to assign an additional 150,000 to 300,000 tons of tonnage."(24) On this day, the Southern Army sent a telegram to the Army Department of IGHQ to inform it that it was considering a plan to complete the Java operation by and large by day $\mathrm{x}+90$ and requested central command's considerations. ${ }^{(23,24)}$ [Also] on this day, Vice Admiral Kondō, commander of the Southern Task Force, left Cam Ranh Bay and headed northeastward with his main unit for the support of the landing of the 48th Division, etc. around Lingayen Gulf (scheduled for the 22d). ${ }^{(118)}$

On the next day, the 21st, Col. Hattori Takushirō, chief of Section 2 (Operations Section) of the Army Department of IGHQ, arrived in Saigon with a draft outline for operations against Burma and to transmit the arrangements for subsequent operations. ${ }^{(24)}$ While the tasks of the Fifteenth Army (with the 33d and 55th Divisions as its core) remained the same 
as mentioned previously, IGHQ would later on divert the 56th Division (from the order of battle of the Twenty-fifth Army) to the Fifteenth Army to have it join the Burma operation. The Southern Army told Colonel Hattori on his arrival that the operations were making favorable progress; that it was necessary to accomplish the Java operation quickly; that for this purpose it wanted an additional tonnage of about 150,000 tons; and that the South Seas Detachment did not have to be incorporated in the Sixteenth Army, and so on. ${ }^{(24)}$ Colonel Hattori agreed, and the next day, the $22 \mathrm{~d}$, he sent the following telegram to the chief of Department 1 (the chief of the Operations Bureau) of the Army Department of IGHQ:(23)

(Preliminaries omitted by the author)

1. The arrangements for the Malaya area operations are currently concluded between the [Southern] Army and the Southern Expeditionary Fleet in Cam Ranh Bay as specified in the Southern Army Staff Section 1 Telegram No. 166 and will be completed today. On completion of the arrangements, these will be passed down as an order to the Twenty-fifth Army. As for the use of the 56th Division, it seems that the [Southern] Army is presently considering to have it land in or around Singora at the predetermined time, and later use it for the northern Sumatra operations at the right moment.

2. The [Southern] Army is currently studying together with the shipping staff [the possibility] of accelerating as much as possible the completion of all the operations including the Dutch East Indies operation (which is hoped to be completed by around day $x+90$ ). Various [details] have to be considered concerning these arrangements, however it is [at least] necessary to additionally requisition about 150,000 tons of tonnage. I will bring back the definite plan of these [arrangements], and I would like IGHQ to go ahead with the research.

3. The [Southern] Army is studying the Burma operations based on the IGHQ plan. However, these operations shall need to be studied in connection with Item 2 above as they involve ships transporting the reinforcements for the Fifteenth Army.

4. Please inform me urgently whether it is possible to embark about four battalions of the 38th Division as the core from about day $x+25$ to day $x+30$, as these are necessary around day $x+50$ for the quick capture of Bangka Island and southern Sumatra. Furthermore, also from the viewpoint of the above, it would be better that the unit to be diverted from Hong Kong to the Sixteenth Army should be transferred to the order of battle of the Sixteenth Army as soon as possible.

5. The [Southern] Army considers it acceptable that the South Seas Detachment will not be transferred to the Southern Army if [the detachment] is needed [otherwise] in terms of general operations.

As of that day (the 22d), the Navy Southern Task Force had not yet thought about advancing the Java operation. As previously described, in the eastern area, Davao was captured six days behind schedule. The Southern Task Force was also critical of the Southern Army's intention of conducting a Kuantan landing operation, which had not been in the plan. On this day, the Southern Task Force (the Second Fleet) sent the following telegram to the Malaya Unit (the Southern Expeditionary Fleet): ${ }^{(23)}$

\section{Dated 22 [December], from Chief of Staff, Second Fleet}

\section{To Chief of Staff, Southern Expeditionary Fleet}

We have no objection to the plan to accelerate the operations for capturing Malaya so as to promptly gain control of the fate of Singapore. However, we would need more careful consid- 
eration if this purpose requires more reinforcement of the naval strength than [initially] planned. Above all, we think that changing the schedule of just one area to rush forward to capture Sumatra should better be avoided, unless the operations in Malaya progress very smoothly. In our opinion, the priority is to destroy the enemy's sea power as much as possible before pulling our decisive battle strength from the southern area. For this reason, in regard to capturing the South, we want to accelerate the operations in Malaya and the eastern part of the Dutch East Indies as simultaneously as possible, while taking into account the progress in both areas, and coupled with advancing submarine units into the Indian Ocean, destroy the enemy and its key areas by encirclement.

On the next day, the 23d, the Southern Army concluded arrangements with the [Navy] Malaya Unit (Southern Expeditionary Fleet) in Cam Ranh Bay on the previously mentioned Kuantan and Mersing operations, etc. (which were called "General Agreement No. 3" by the Southern Army). They were in outline as follows: ${ }^{(23)}$

Operation Q (operation to capture Kuantan)

A unit consisting of two battalions of the 18th Division as its core shall assemble at Cap Saint Jacques (note: south of Saigon) no later than day $x+15$, depart on day $x+18$, and assemble at Singora no later than day $x+20$. It shall [again] depart on day $x+21$ (29 December), land in Kuantan around the 31st under the direct escort of an element of the 3d Destroyer Squadron, and seize the airfield near Kuantan in cooperation with the Takumi Detachment coming down south along the east coast of Malaya.

Note: The [pronunciation of] letter ' $Q$ ' is equivalent to [a Japanese word with the meaning of] "quick, rapid, or hurry." It expresses the Southern Army's intention at that time.

Operation S (operations against Endau and Mersing)

The main force of the 18th Division (with four infantry battalions as its core) shall depart from Humen in southern China around day $x+31$, arrive in Cam Ranh Bay no later than day $x+33$. It shall depart from Cam Ranh Bay around day $x+36$ (13 January), and be put ashore in or near Endau or Mersing under the direct escort of a unit consisting of the 3d Destroyer Squadron as its core.

\section{Transport of Part of the Twenty-fifth and the Fifteenth Armies}

A unit under the direct control of the Twenty-fifth Army (in the 1st transport) and three infantry battalions and others of the 5th Division, and [also] a unit under the direct control of the Fifteenth Army and half of the 33d Division (55 ships in total) shall leave Magong on day $x+23$. The former shall land at Singora around day $x+30$ (7 January) escorted by the 5th Destroyer Squadron (which belongs to the Philippines Unit and which provided cover for the landing of the Tanaka Detachment at Aparri and that of the main force of the 48th Division at Lingayen Gulf). The latter shall land in Cap Saint Jacques or Saigon around day $x+28$ under cover of the Kashii (a training cruiser), the Shimushu (a coastal defense ship), and others.

On that day (the 23d), Staff Officer Oda Akimitsu of the Sixteenth Army arrived in Saigon with "the Sixteenth Army operation plan which had just been finalized on the 21st" in hand in order to report [the plan to the Southern Army]. ${ }^{(24)}$ Having thought that the Sixteenth Army headquarters would not leave [Tokyo] for another month or more, he was surprised to hear about the advancement of [the schedule of] the Java operation. He decided to stay in Saigon with only the barest necessities [he had brought with him] and sent a telegram to the head- 
quarters of the army in Tokyo, advising that the command post [of the army] be advanced to Saigon immediately. ${ }^{(40)}$

[Also] on that day (the 23d), the main force of the [Navy Hawaii] Task Force returned to Hashirajima in the Inland Sea. ${ }^{(103)}$ However, the $2 \mathrm{~d}$ Carrier Division was to return later due to its cooperation in the second attack on Wake Island (which was captured on the 23d). ${ }^{(103)}$

On receipt of the previously mentioned telegram from [Colonel] Hattori, chief of Section 2, at the Army Department of IGHQ, Staff Officer Okamura Masayuki went to liaise with the Navy Department on the next day, the 24th. On the same day, he reported the following results: ${ }^{(9)}$

1. The Combined Fleet wants to capture Ambon around day $x+30$. The reasons are that it wants to capture the island before the enemy reinforces it, and also that it wants to dispose of Ambon quickly in order to make aircraft carriers available for [the operation to] capture Java (around day $x+80$ ), etc. On the other hand, Commander Yamamoto of the Navy Department wants to have the $2 \mathrm{~d}$ Carrier Division depart from Moji around 10 January (day $\mathrm{x}+33$ ) and capture Ambon around day $x+55$.

2. The Navy Department wants an increase in the strength of Detachment B assigned to capture Ambon to three battalions if the Southern Army does not need the 56th Division for the Malaya operation.

3. The Navy Department wants Pontianak to be captured by the Kawaguchi Detachment around day $x+40$ (17 January) so that the air operations against southern Sumatra and western Java can be more favorably conducted.

4. The Navy Department wants the 38th Division to leave Hong Kong on day $x+40$ (17 January) and land in southern Sumatra around day $x+60$ (6 February), because it will be impossible to [carry out the operations to] capture Palembang on day $x+50$ (27 January) due to [issues of] escort.

5. The Navy Department wants the capture of Singapore to precede that of Medan in northern Sumatra.

Let me add a little more explanation to the above report of Staff Officer Okamura. The first point concerns Ambon. In the original plan, Ambon was scheduled "to be captured by the South Seas Detachment." Then it was changed to "to be captured by the South Seas Detachment (or depending on the situation, by Detachment B)." In IGHQ's plan it was supposed "to be captured while seizing an opportunity." (23) The Southern Army did not seem much interested in capturing Ambon either, because it attached more importance to the line of operations directed straight toward Java. However, the unexpected battle results achieved in various regions in the initial operations gave the Combined Fleet hope to capture Ambon at an early moment. Ambon was a strategically important place against the U.S. and Australian forces, and there was also a report that the Australian Army had moved into Ambon. ${ }^{(23)}$ In the meantime, as the South Seas Detachment was still in Guam waiting for the opportunity to start for Rabaul, it was decided that Detachment B should be used [for the capture of Ambon] instead of the South Seas Detachment (with three battalions as its core). This led [the Navy Department] to request the reinforcement of Detachment B, originally set to consist of two battalions as its core, to three battalions as the core. The second point is that the Naval General Staff and the Combined Fleet considered using the strength of the First Air Fleet (an aircraft carrier fleet) for capturing Java (around 26 February). The third point concerns the fact that a naval plane had found a large airfield at Ledo (in the hinterland of Pontianak). ${ }^{(23)}$ 
This led the Navy Department to plan this new [operation] of capturing it in order to enhance the support for the air operations against Sumatra and western Java. [However,] on that day (the 24th), the Kawaguchi Detachment had not yet seized the Kuching airfield. The fourth point concerns the plan of the Southern Army to use the 18th Division, which would arrive first, instead of the 56th Division for the east coast of Malaya, and to change the task of the 56th Division to the capture of northern Sumatra. When the Navy tried to reschedule the escorts for the 18th Division from southern China to Malaya, those for the previously mentioned units of the Twenty-fifth and the Fifteenth Armies from Magong to Singora and to Saigon, those for the 38th Division from southern China to southern Sumatra, and those for the main force of the Sixteenth Army from Taiwan to Cam Ranh Bay, it came to the conclusion that for reasons of escort capacity it was impossible to let the 38th Division capture Bangka and Palembang around day $x+50$ (27 January), and that the operations for capturing northern Sumatra should be executed after the capture of Singapore. [The Navy] then wondered why the division assigned to capture Singapore could not be used for the capture of northern Sumatra as well, and it questioned the need for the 56th Division in the northern Sumatra operation.

As previously described, the [Navy] Southern Task Force was not exactly pleased with the Southern Army's changes in the plan. On that day (the 24th), however, the Navy Department of IGHQ held a meeting with the Combined Fleet and the First Air Fleet, where they reached the conclusions as indicated in the previously cited report of Staff Officer Okamura, so on that day, the chief of staff of the Combined Fleet sent the following telegram to the Southern Task Force:(23)

\section{Dated 24 [December] from Chief of Staff, Combined Fleet}

\section{To Chief of Staff, Second Fleet}

1. The Army asked our opinion about advancing [the schedule of] the southern operation. The Combined Fleet replied that it agreed to the idea in principle and asked [the Army] to discuss details with the Second Fleet. So you should consult with the Southern Army so as to shorten the schedule of this operation as much as possible in view of the current war momentum.

2. The $2 \mathrm{~d}$ Carrier Division is expected to be transferred to the Southern Task Force in the next phase and be able to advance to Palau in early January.

3. In relation to the recent situation of enemy reinforcements coming from Australia, it is at present necessary to promptly conquer the line from Ambon to Kupang. We would like you to study a plan to capture Ambon as well as Tarakan and Menado simultaneously around day $x+30$.

As will be explained later, from the standpoint of the Southern Task Force, it was totally unthinkable to seize Ambon along with Tarakan and Menado at the same time in terms of escort strength, the situation of the Sixteenth Army and the 38th Division, etc. The Combined Fleet, however, was very keen on the capture of Ambon.

The next day, the 25th, the Southern Task Force replied to the above-cited telegram as follows: ${ }^{(23,117)}$

1. As for conducting the current operations in the area of the Dutch East Indies Unit, the following plan is under consideration with due regard to the Combined Fleet classified telegram No. 929.

a) Standard schedule of capturing 
[Capture of] Tarakan around 10 January, Balikpapan and Kendari around 20 January, Ambon around 25 January, and Timor Island around 15 February. However, [the capture of] Kendari could be after [the capture of] Ambon depending on the situation.

b) Forces to be employed for escorting

[The escort on] the line between Tarakan and Balikpapan will be a force consisting of the 4th Destroyer Squadron as the core, and the others a force consisting of the $2 \mathrm{~d}$ Destroyer Squadron as the core.

2. Concerning the preparation and use of the army forces to be employed for the capture of Ambon and Kupang, we will promptly discuss the matter with the Southern Army. However, in view of the situation in those areas, we would like to request a favor of central command as well in that it will consider pushing the Army to prepare particularly strong forces.

This telegram raises the question of why Menado was omitted. Concerning this matter, "landing in Menado was arranged approximately day $x+23$, and in Tarakan by approximately day $x+25$ " in the Agreement between the Southern Army and the Southern Task Force of 10 November. However, in the meetings for the Iwakuni Agreement on 16 November, the Navy had [presented] a plan in which the capture of Menado was scheduled a week earlier than that of Tarakan, which made the Army demand that "both should be captured at the same time because [these places] were the first points to be captured in the Dutch East Indies." [At that time,] the Navy promised to state for the record that "Menado will be captured about the same time as Tarakan." Still, in Operation Order No. 1 of the Philippines (Dutch East Indies) Unit issued on 23 November, which should have been based on the [Iwakuni] Agreement, it stated that "Menado [shall be captured] around day $x+33$, and Tarakan around day $x+35 . "$ After that, the issue remained undecided.

In the above telegram, a plan of how to employ the $2 \mathrm{~d}$ and the 4 th Destroyer Squadron was mentioned. Actually, the destroyer squadrons [assigned to] the Southern Task Force were the $2 \mathrm{~d}$ to the 5th Squadrons ([according to] the standard formation, a destroyer squadron consisted of a light cruiser and four destroyer divisions (although the 5th Destroyer Squadron had [only] two divisions); a destroyer division consisted of two sections, and a section consisted of two destroyers). They were employed as follows: ${ }^{(117,118,119,120)}$

The $2 \mathrm{~d}$ Destroyer Squadron (the [light cruiser] Jints $\bar{u}$ and the 8th, the 15th, and the 16th Destroyer Division): was assigned to the Philippines Unit and, with its main force, charged with the escort of the transport convoy of the unit for capturing Legaspi, Davao, Jolo, etc.

Note: The 18th Destroyer Division was also included in the squadron formation, but it was transferred to the [Hawaii] Task Force.

The 3d Destroyer Squadron (the [light cruiser] Sendai and the 11th, the 12th, the 19th and the 20th Destroyer Divisions): was assigned to the Malaya Unit and charged with the escort of the transport convoy in the Malaya, British Borneo and Sumatra areas.

The 4th Destroyer Squadron (the [light cruiser] Naka and the 2d, the 4th, the 9th and the 24th Destroyer Divisions): was assigned to the Philippines Unit and, with its main force, charged with the escort of the Kanno Detachment to Vigan and the main force of the army to Lingayen. The 5th Destroyer Squadron (the [light cruiser] Natori and the 5th and the 22d Destroyer Division): was assigned to the Philippines Unit and, with its main force, charged with the escort of the Tanaka Detachment to Aparri and the main force of the Fourteenth Army to Lingayen Gulf. After that, it was temporarily charged with the escort of the transport convoy of the main force of the Twenty-fifth Army and an element of the Fifteenth Army under the command of the 
Malaya Unit. Next, it was supposed to return to the Dutch East Indies Unit to escort the main force of the Sixteenth Army to western Java.

The escort for the transport of the main force of the 16th Division from Amami Ōshima to Lamon Bay was conducted by the Commander of the 1st Base Force who had an element of the 4 th Destroyer Squadron assigned to his command. ${ }^{(124)}$

The Malaya Unit, which provided cover to the first landing (launched on the 8th) and the second landing (launched on the 16th) of the Malaya advance corps and also to the Kawaguchi Detachment's British Borneo operations (its landing was launched on the 16th at Miri), had announced the shift of the disposition of forces to phase-two dispositions on the previous day (the 24th). ${ }^{(120)}$ Also, on the same day, the unit passed down [as an order] the outline of Operation Q. ${ }^{(118)}$ [In the meantime,] after the landing at Miri on the 16th, the Kawaguchi Detachment had postponed its departure for capturing Kuching scheduled for the 20th, because it came under attack from a flying boat and three or four bombers three times on the 17th, from two or three bombers from the direction of Kuching several times on the 18th, and from a total of six bombers from the direction of Tarakan twice on the 19th. However, as eighteen planes of the Malaya Unit advanced to the Miri airfield from French Indochina on the 22d, [the detachment] departed from Miri at 1500 on the same day. It came ashore at Kuching on the morning of the 24th (which is three days behind schedule), and seized the Kuching airfield at 1640 on the 25th. ${ }^{(91,92,118,130)}$ The main unit of the Philippines Unit, which had supported the main force of the Fourteenth Army to land around Lingayen Gulf, returned to Magong on the 23d. (103) The main unit of the Southern Task Force, which also had supported the landing of the main force of the Fourteenth Army around Lingayen Gulf, formed the Eastern Support Unit with the battleship Haruna and lesser vessels on the $23 \mathrm{~d}$, and sent it separately toward the waters east of Mindanao, while the main force returned to Cam Ranh Bay on the 24th. ${ }^{(103)}$ The landings in Davao and Jolo were successfully carried out on the 20th and the 25 th respectively. ${ }^{(114,117)}$

[Taking advantage of] the momentum to advance the Java operation and of the situation described above, the Combined Fleet transmitted a preliminary order on this day (the 25th) that "it would shift the disposition of forces to phase-two dispositions as of 1200 on the 26th," which was two days ahead of schedule, and officially announced the order on the next day, the 26th. ${ }^{(117)}$

Upon receiving the above order (on the 26th), the Southern Task Force immediately issued an order to shift the disposition of forces to phase-two dispositions. ${ }^{(119)}$ At that time, the Southern Task Force judged that the surface ships of the allied forces had retreated mainly to the Dutch East Indies and decided in outline on the following operational policy for phase two. ${ }^{(110)}$

1. As the Philippines operations are for the most part finished, the Philippines Unit (i.e. the Third Fleet) will divert most of its fleet to the Dutch East Indies operation, leaving [only] an element of small warships in the Philippines.

2. The land-based unit (i.e. the Eleventh Air Fleet, whose main force is [still] in Taiwan, and whose 21st Air Flotilla Headquarters has advanced to Palau on the 19th) will continuously have an element of its force cooperate with the Army in its operations against Luzon from Taiwan, while having the main force of the unit advance to Davao and Jolo to employ it in the Dutch East Indies operation. 
3. In the Malaya area, the main force of the Twenty-fifth Army shall promptly be put ashore in order to try to capture Singapore at an early date, while an air unit (the 22d Air Flotilla) shall be advanced to western Borneo and northern Malaya to carry out air operations over the Java Sea and the Malacca Strait in cooperation with the unit advanced into the eastern regions [i.e. in eastern Borneo and further east].

4. The 5th Submarine Squadron deployed in the Malaya area shall come under the direct command of the Southern Task Force and be advanced to Penang and further toward the Indian Ocean, the 6th Submarine Squadron shall be advanced toward the direction of Australia, and the 4th Submarine Squadron, while still assigned to the Malaya Unit, shall be advanced to the Java Sea to engage in submarine warfare.

5. The [Navy] paratroop unit (i.e. the 1st and the $3 \mathrm{~d}$ Yokosuka Special Landing Force assigned to the Eleventh Air Fleet) shall be first employed for Tarakan (or depending on the situation, Menado).

6. The $2 \mathrm{~d}$ Carrier Division (consisting of two aircraft carriers), which shall be newly assigned (note: expected be transferred to the Eleventh Air Fleet around 16 January), shall first of all cooperate in the capture of Ambon.

The [Army Department of] IGHQ, which had received the previously mentioned telegram from Colonel Hattori on the $22 \mathrm{~d}$, studied [the possibility of] increasing the shipping tonnage by 150,000 tons as requested by the Southern Army, only to reply to the army on the 27th that it could not afford to provide additional ships. ${ }^{(23,24)}$ On receiving this telegram, the Southern Army simultaneously learned that the Army Department of IGHQ had ordered the Shipping Transport Command to prepare the return of some 300,000 tons from the South to the homeland by the end of February. ${ }^{(23,24)}$ The Southern Army took this matter very seriously, and immediately on the same day sent the following telegram: ${ }^{(23,24)}$

\section{Dated 27 [December] from Chief of Staff, Southern Army}

\section{To Vice Chief of Army General Staff}

1. I received Army General Staff Telegram No. 43. It is extremely disappointing that there is no likelihood of an additional requisition of ships. Now that it has come to this, we will study [the matter] and do our best to manage [the necessary transportation] with the currently allocated ships. As you are fully aware, in order to bring forward the Java operation, the [Southern] Army is rearranging the entire [shipping plan] by calling off or putting off [some of] the transportation of other armies, and it cannot be managed by [only] rearranging the shipping [plan] of one area. Therefore, it would be appreciated if you understand that it cannot be decided solely by the opinion of the Sisteenth Army as suggested in your reply.

2. Also, according to Central Shipping Transport Telegram No. 308, an order was transmitted to the captain general of Shipping Transport Command to prepare the return of some 300,000 tons to the mainland from January until the end of February, just when the shipping for our operations will be at its peak. As this will affect the foundation of our operation plan, we would like to be informed of the actual situation immediately.

On that day (the 27th), the Southern Army decided to cancel Operation Q. ${ }^{(23,24)}$ This came about as follows: ${ }^{(23,24)}$

On completing the previously mentioned arrangements with the Malaya Unit on the $23 \mathrm{~d}$, the Southern Army had passed down an order [for Operation Q] to the Twenty-fifth Army and the 
Third Air Force on the same day. The Southern Task Force also gave an order the next day, the 24th. However, even though the [Navy] Malaya Unit, the Twenty-fifth Army and the Third Air Force had for the time being consented to the Kuantan landing operation at the strong insistence of the Southern Army and made arrangements and passed down the orders for it as previously described, all three still had misgivings and in the end came to regard it as unsuitable.

The [Navy] Malaya Unit was annoyed because [the operation] had not been included in the original plan and came suddenly out of the blue. Moreover, it felt that [the operation] was risky unless it gained control over the allied air power in Singapore.

The Third Air Force thought it odd that it had to gain air control over Singapore in advance in order to capture Kuantan for its own sake, instead of [the original idea of] capturing Kuantan for the purpose of attacking the allied air forces in Singapore [and other places].

The Twenty-fifth Army felt that it had better not conduct the risky Kuantan landing operation, because the Takumi Detachment was coming south at a good speed along the east coast toward Kuantan.

Nevertheless, arrangements were made and the order was passed down. Despite the efforts of the Third Air Force and the Malaya Unit, little progress was made with the preparation and implementation [of attacks] for gaining air control over Singapore.

The Koba Detachment (consisting of two battalions of the 18th Division as its core), charged with the capture of Kuantan, left Guangdong on the 20th, entered the port of Cap Saint Jacques on the 23d, [again] left it on the 25th under cover of the 3d Destroyer Squadron and arrived in Singora on the morning of 27th. By this time, the judgment was that the Takumi Detachment would be able to seize Kuantan by around the 31st at the latest.

On this day, both the Twenty-fifth Army and the Third Air Force offered their opinion that the Kuantan landing operation should be called off. The Malaya Unit also informed the Southern Army on this day that it was not confident [about the operation]. That evening, the Southern Army unwillingly decided to call off Operation Q. [In the altered plan,] the Koba Detachment was to land in Kota Bharu and rush toward Kuantan by land.

As for western Borneo, on the previous day (the 26th), the Southern Army had sent a telegram to the commander of the Kawaguchi Detachment (in Kuching) to "investigate and report immediately on [the possibility] to seize airfields near Bara or Ledo by either land or sea as quickly as possible in further cooperation with the Navy. The results of reconnaissance by the air units will be forwarded later."(23) However, on the 28th [the Southern Army] received information from [the Army Department of] IGHQ about a road between Kuching and Singkawang, and on the same day, ordered the detachment to prepare for the capture of Ledo as follows: ${ }^{(23)}$

\section{Dated 28 [December] from Chief of Staff, Southern Army}

\section{To Detachment Commander Kawaguchi}

1. The road between Kuching and Singkawang seems [good enough] to be used by motor vehicles.

2. We would like the Kawaguchi Detachment to be ready to seize, without missing an opportunity, airfields near Bengkayang or, depending on the situation, a port (Singkawang or Pontianak), which leads to these [airfields].

The 21st Air Flotilla headquarters had advanced into Davao from Palau on the previous day (the 27th). The Sakaguchi Detachment had landed in Davao on the 20th, and the Matsumoto Detachment had landed in Jolo on the 25 th, as previously described. The 48 th and the 16th 
Divisions were rushing to Manila from Lingayen Gulf and Lamon Bay respectively. The Eleventh Air Fleet headquarters and the 23d Air Flotilla headquarters were still in Taiwan. On that day (the 28th), the commander of the [Navy] Southern Task Force, estimating that the start of [the operations for] capturing Tarakan and Menado would be around 10 January, gave an order to his Eastern Support Unit to leave Magong at a suitable moment and advance to the waters between Mindanao and Palau. He also indicated that the main unit of the Southern Task Force should leave Cam Ranh Bay on 9 January and Magong on the 14th to advance to Palau. ${ }^{(120)}$ On this day (the 28th), the Dutch East Indies Unit (the former Philippines Unit, presently in Magong) issued [an order to shift to] phase-two dispositions. ${ }^{(117)}$ The Sixteenth Army headquarters was still located in Tokyo.

On the next day, the 29th, General Terauchi, commander in chief of the Southern Army had a meeting with Vice Admiral Kondō, commander of the Southern Task Force, on the heavy cruiser Atago, the flagship of the Southern Task Force, in Cam Ranh Bay to discuss advancing [the schedule of] the Java operation and informally reached an agreement. ${ }^{(23)}$ This means that they had the meeting nineteen days ahead of schedule, despite the fact that the [previous] agreement on 10 November specified that "[a meeting for] the next agreement will be around day $x+40 . "$ [In the meeting,] it was informally agreed that the capture of Bangka and Palembang would be around day $x+60$ and that of Java around day $x+70$ (16 February). ${ }^{(23)}$ As previously mentioned, the capture of Java had been scheduled for around day $x+103$ in the IGHQ plan. On the same day (the 29th) as the above agreement was reached, Vice Admiral Takahashi, commander of the Dutch East Indies Unit (the [former] Philippines Unit), issued his orders concerning the Dutch East Indies operation by way of the Dutch East Indies (Philippines) Unit Classified Order No. 3. ${ }^{(110)}$

The next day, the 30th, Chief of the Army General Staff Sugiyama had a talk with Chief of the Navy General Staff Nagano and requested the cooperation of the Navy in the acceleration of the Java operation in the following terms. ${ }^{(2)}$ [Meanwhile] the Combined Fleet, which had captured Wake Island in the second attack on the $23 \mathrm{~d}$, was going to capture Rabaul in cooperation with the South Seas Detachment in late January, and along with this [progress], had become enthusiastic about [attacking] areas of northeastern Australia.

Needless to say, the Java operation is very difficult. [In fact,] in the light of the results of previous studies such as war games and others, the operations against Malaya and Java were deemed the most difficult. This can be said in particular about the air operations. As it is, in the Malaya operation, owing to divine aid and the close cooperation between the Army and the Navy, we were able to achieve brilliant military gains by conducting a surprise attack on the enemy. However, as for the Java operation that we will conduct shortly, we must expect that it will be extremely difficult compared to the Malaya operation, owing to the facts that the enemy has rapidly been reinforcing its defense in the area these days, that it is more difficult to make a surprise attack on Java than on Malaya, and that the enemy is getting familiar with our ways of conducting landing operations, and so on. In view of these characteristics of the Java operation, the Army is determined to accomplish the operation after thorough preparations. We sincerely hope that the Navy will also closely cooperate [with the Army] in various operations, in air operations in particular, so that we can fully demonstrate the essence of cooperation between the Army and the Navy in the final stage of the southern operation. 
After obtaining the approval of central command and the Combined Fleet, on 1 January (1942), the commander in chief of the Southern Army and the commander of the Southern Task Force signed the draft agreement of the 29th on bringing forward the Java operation. ${ }^{(23)}$ On 4 January when the New Year functions of the Imperial Court were over, Chief of the Army General Staff Sugiyama offered the Emperor the following report on the advance of [the schedule of] the Java operation:(2)

Allow me to humbly offer my report on the conduct of our future operations in the southern area. As I have often reported, the operations in the southern areas have on the whole been developing quite favorably. Enemy bases such as Hong Kong and Manila have already been seized in land battles, and now we have come to the conclusion that the capture of Singapore will also come about in just over one month. In sea battles, we delivered fatal blows to the U.S. and British naval forces in the Pacific Ocean. I know that at this very moment the Imperial Army and Navy are in full-scale pursuit of the enemy on land, at sea and in the air in the southwest Pacific. Of course, we realize that we must stay on our guard even more so after victory and that we must strictly guard against any failure or setback caused by negligence or carelessness. However, we consider it appropriate to use this momentum of the war, take advantage of the fact that the enemy has yet to recover his whole posture and promptly finish the capture of predetermined areas such as Hong Kong, the Philippines, Malaya, Burma and the Dutch East Indies. The swift completion of the capture of the above predetermined areas is not only advantageous for pursuing the southern operation itself, I also believe it is all the more imperative when considering the conduct of the Empire's war from a political and military strategic point of view, especially in view of the changing state of affairs in the northern area. That is, I think that it is appropriate to carry out the Dutch East Indies operation ahead of the initially conceived [schedule] and conduct the Burma operation as soon as possible. Hereafter, I will relate the details of how to bring forward the Dutch East Indies operation and implement the Burma operation.

1. The conduct of the Dutch East Indies operation

Based on the above-mentioned judgment of the situation, the commander in chief of the Southern Army made the following agreement with the commander in chief of the Second Fleet on this operation.

Although the outline of the operations against the Dutch East Indies is the same as that which was already shown to you along with the war games, etc., the dates of conducting the operations have been advanced in all areas ahead of schedule in the light of the present situation where the enemy army as well as navy in the Dutch East Indies is being reinforced. That is, [we will first] set the landing of the main force of the Sixteenth Army on Java about day $x+70$ (16 February, about one month ahead of schedule) as the standard, and accordingly set the landings in or around Bangka and Palembang, which have to precede the landing in Java, around day $x$ +60 (6 February), the landing in Ambon around day $x+48$ (25 January), and in Kupang about day $x+65$ (11 February), and all operations will be directed [on this basis].

For this purpose, the 38th Division, which was charged with the capture of Hong Kong and performed brilliantly, has quickly replaced its losses after the fall of Hong Kong, and has already started boarding the ships in order for its main force to operate in Bangka and Palembang, and for an element of it to operate in Ambon and Kupang as the Eastern Detachment. Likewise, the 48th Division, which was charged with the operations against the Philippines, has turned over the remaining operations in Bataan Peninsula to other corps and is gradually assembling in order to prepare for the Dutch East Indies operation. The commander of the Sixteenth Army, who was standing by on the mainland, has already gone to Saigon, and the $2 \mathrm{~d}$ Division will successively depart from the mainland in the second half of this month. 
As this advancement of the Dutch East Indies operation changes the scheduled dates, some tightness in shipping, escort, etc. may occur. It is also expected that the early transfer of the 48th Division may cause to some extent a delay in destroying the enemy on Bataan Peninsula. It may, perhaps, also somewhat delay the transportation of the 56th Division. However, from the point of view of conducting the whole operation as we first explained, we consider [the advancing of the schedule] appropriate. Moreover, as it is within the task you assigned to the commander in chief of the Southern Army, the Army Department [of IGHQ], in complete unity with the Navy Department has been providing directions to the best of its ability in order to facilitate the army on site to accomplish the plan. In this regard, I would like you to give an order to incorporate the 38th Division into the order of battle of the Sixteenth Army today, and later an order to incorporate [other] units under the direct control of other armies into the order of battle of the Sixteenth Army.

2. The Burma operation

We have studied how to conduct the Burma operation for a long time and after doing research with the army on site as well, for the most part completed a final draft, which I would like to bring to your attention.

(Omitted by the author. This part explains [the Army's plan] that, with the objective to secure key areas in Burma after destroying the British Army as well as tightening the blockade against China, the Fifteenth Army will advance along the line of the Salween River near Moulmein as quickly as possible, make preparations for [subsequent] operations, and with its main force promptly occupy key areas in central Burma from the area along the road between Moulmein and Pegu, and that the force to be employed will be the 33d Division and the 55th Division as its core, possibly reinforced with the 56th Division and others.)

Concerning the full-scale operations against Burma as described above, and after further communication with the Navy, I would like to ask your favor of giving an Imperial Order to the commander in chief of the Southern Army [to execute the operations].

In short, I have reported on the advancement of [the schedule of] the Dutch East Indies operation and the implementation of the Burma operation in regard to the conduct of subsequent operations in the southern area. Furthermore, the South Seas Detachment is expected to land on the Bismarck Archipelago on the 23d of this month. If these operations progress smoothly from now on, we expect to be able to complete the capture of the predetermined areas by around the end of March. We will even more try not to make mistakes in the operation plans and thereby promptly accomplish the original objectives. Herewith I conclude my report.

\section{The Cam Ranh Agreement and Shipping Issues}

\section{Contents of the Agreement}

The memorandum of agreement informally reached on 29 December in Cam Ranh Bay and signed on 1 January was as follows: ${ }^{(23,95)}$

General Agreement No. 4

Memorandum of Agreement Between the Commander in Chief of the Navy in the Southern Area and the Commander in Chief of the Southern Army

1 January 1942

General Terauchi Hisaichi, commander in chief, Southern Army

V. Adm. Kondō Nobutake, commander in chief, Second Fleet 
In view of the current progress of the southern operations, the following revisions and additions were made to the agreement of 10 November 1941:

1. Standard dates [to implement operations] of capturing

[Based on] the following standard schedule, implementation [of each operation] is to be arranged between the relevant commanders:

\begin{tabular}{|c|c|c|c|}
\hline Date of start of landing & $\begin{array}{c}\text { Key areas to capture } \\
\left({ }^{*} \text { stands for the areas }\right. \\
\text { which the Navy will cap- } \\
\text { ture unassisted })\end{array}$ & Assembly points & $\begin{array}{l}\text { Commanders between } \\
\text { whom an arrangement } \\
\text { should be made }\end{array}$ \\
\hline Day $x+33$ & $\begin{array}{l}\text { * Menado and vicinity } \\
\text { Tarakan and vicinity }\end{array}$ & Davao or Jolo & \multirow{4}{*}{$\begin{array}{l}\text { Commander in chief of the } \\
\text { Third Fleet } \\
\text { Commander of the } \\
\text { Sixteenth Army }\end{array}$} \\
\hline Day $x+43$ & $\begin{array}{l}\text { * Kendari and vicinity } \\
\text { Balikpapan and vicinity }\end{array}$ & Menado and Tarakan & \\
\hline Day $x+48$ & Ambon & Davao & \\
\hline Day $x+53$ & $\begin{array}{l}\text { * Makassar and vicinity } \\
\text { Banjarmasin and vicinity }\end{array}$ & Kendari and Balikpapan & \\
\hline Roughly day $x+60$ & Bangka and Palembang & Cam Ranh & $\begin{array}{l}\text { Commander in chief of the } \\
\text { Southern Expeditionary } \\
\text { Fleet } \\
\text { Commander of the } \\
\text { Sixteenth Army }\end{array}$ \\
\hline Roughly day $x+65$ & Kupang & Ambon & $\begin{array}{l}\text { Commander in chief of the } \\
\text { Third Fleet } \\
\text { Commander of the } \\
\text { Sixteenth Army }\end{array}$ \\
\hline Roughly day $x+70$ & Java & $\begin{array}{l}\text { Luzon Island for eastern } \\
\text { Java } \\
\text { Gaoxiong for western Java }\end{array}$ & Same as above \\
\hline Roughly day $x+80$ & Northern Sumatra & Penang & $\begin{array}{l}\text { Commander in chief of the } \\
\text { Southern Expeditionary } \\
\text { Fleet } \\
\text { Commander of the } \\
\text { Twenty-fifth Army }\end{array}$ \\
\hline For others, the arrar & $\begin{array}{r}\text { ents between the supreme } \\
\text { will }\end{array}$ & $\begin{array}{l}\text { ommanders of the Army a } \\
\text { oply }\end{array}$ & the Navy in each area \\
\hline
\end{tabular}

2. [The Army's] Sea transport and assignment of escort [by the Navy]

A summary of the transport [plan] of the Army and the escort to be provided [by the Navy] are as shown in the attached chart. (Omitted by the author.)

A comparison of dates in the plan and the actual [dates of] implementation [of the operations] concerning the places already captured is as follows: 


\begin{tabular}{|c|c|c|c|}
\hline Key areas captured & $\begin{array}{l}\text { Agreement between the } \\
\text { Southern Army and the } \\
\text { Navy on } 10 \text { November } \\
\text { (General Agreement No. 2) }\end{array}$ & $\begin{array}{l}\text { Arrangements between the } \\
\text { Fourteenth and the } \\
\text { Sixteenth Army and the } \\
\text { Navy on } 16 \text { November and } \\
\text { those between the Twenty- } \\
\text { fifth Army and the Navy on } \\
18 \text { November }\end{array}$ & Implementation \\
\hline $\begin{array}{l}\text { Batan Island, Ban Don, } \\
\text { Nakhon, Singora, and } \\
\text { Pattani }\end{array}$ & Day x (8 December) & Same as on the left & 8 December \\
\hline Vigan and Aparri & $\begin{array}{c}\text { Day } x+1 \\
\text { (9 December) }\end{array}$ & Day x + 2 (10 December) & 10 December \\
\hline Legaspi & $\begin{array}{l}\text { No later than day } x+4 \\
\text { (12 December) }\end{array}$ & Day x + 4 (12 December) & 12 December \\
\hline Davao & $\begin{array}{l}\text { No later than day } x+6 \\
\text { (14 December) }\end{array}$ & Day x + 6 (14 December) & 20 December \\
\hline $\begin{array}{c}\text { Singora, Pattani and their } \\
\text { vicinities }\end{array}$ & $\begin{array}{l}\text { Around day } x+8 \\
\text { (16 December) }\end{array}$ & & 16 December \\
\hline Miri and its vicinity & $\begin{array}{l}\text { Around day } x+8 \\
\text { (16 December) }\end{array}$ & & 16 December \\
\hline Kuching & $\begin{array}{l}\text { Around day } x+13 \\
\text { (21 December) }\end{array}$ & & 24 December \\
\hline Jolo & $\begin{array}{l}\text { Around day } x+13 \\
\text { (21 December) }\end{array}$ & & 25 December \\
\hline Lingayen Gulf & $\begin{array}{l}\text { By around day } x+14 \\
\text { (22 December) }\end{array}$ & $\begin{array}{c}\text { Day } x+14 \\
(22 \text { December })\end{array}$ & 22 December \\
\hline Lamon Bay & Same as above & $\begin{array}{c}\text { Day } x+16 \\
\text { (24 December) }\end{array}$ & 24 December \\
\hline
\end{tabular}

A comparison of the schedule to capture targets yet to be captured in the agreements and arrangements made so far and in the agreement made this time is as follows:

\begin{tabular}{|c|c|c|c|c|}
\hline Target to be captured & $\begin{array}{c}\text { Central Agreement, } \\
5 \text { November }\end{array}$ & $\begin{array}{c}\text { General Agreement } \\
\text { No. 2, 10 November }\end{array}$ & $\begin{array}{c}\text { Iwakuni Agreement, } \\
16 \text { November }\end{array}$ & $\begin{array}{c}\text { General Agreement } \\
\text { No. 4, } 1 \text { January }\end{array}$ \\
\hline Menado & Around day $x+23$ & $\begin{array}{c}\text { About the same time } \\
\text { as Tarakan }\end{array}$ & Day $x+33$ \\
\hline Tarakan & Around day $x+25$ & Day $x+30$ & Day $x+33$ \\
\hline Kendari & & Around day $x+35$ & & Day $x+43$ \\
\hline
\end{tabular}




\begin{tabular}{|c|c|c|c|c|}
\hline Balikpapan & & Around day $x+35$ & Day $x+35$ & Day $x+43$ \\
\hline Makassar & & Around day $x+45$ & Day $x+54$ & Day $x+53$ \\
\hline Banjarmasin & & $\begin{array}{c}\text { By and large around } \\
\text { day } x+50\end{array}$ & Day $x+54$ & Day $x+53$ \\
\hline Ambon & By around day $x+60$ & Day $x+60$ & Day $x+48$ \\
\hline Kupang & & By around day $x+60$ & Roughly day $x+65$ \\
\hline Bali & Day $x+85$ & $\begin{array}{c}\text { By and large around } \\
\text { day } x+80\end{array}$ & Day $x+70$ & Roughly day $x+60$ \\
\hline $\begin{array}{c}\text { Bangka and } \\
\text { Palembang }\end{array}$ & Day $x+103$ & $\begin{array}{c}\text { By and large around } \\
\text { day } x+80\end{array}$ & & Roughly day $x+70$ \\
\hline Java & & Roughly day $x+80$ \\
\hline Northern Sumatra & & & & \\
\hline
\end{tabular}

\section{Confusion Caused by Bringing Forward the Java Operation}

After the war, Army Commander Imamura and staff officers of the Sixteenth Army unanimously recalled that "the headquarters of the army were scheduled to leave Tokyo in midJanuary and we were preparing the operations; then, around 23 December, all of a sudden the request came to advance to the South in quick order, which was followed by telegrams urging us to come to the South. We had to wait for planes to be arranged and left Tokyo on the 30th." As described previously, Staff Officer Oda, who had left [Tokyo] around the 22d to liaise with [the Southern Army], ended up remaining in Saigon. On the other hand, Lt. Col. Ueno Shigeru, staff officer of Shipping Transport Command, who was working at its Saigon command post and was also posted to the Southern Army, recalled the situation as follows:

Around 20 December, the captain general of the Shipping Transport Command sent his chief of the staff and Staff Officer Mabuchi back home to Ujina to prepare the Java operation based on the prearranged plan, and ordered them to prepare the transport for the $2 \mathrm{~d}$ Division, the transport ships for the landing on Java, and matériel for small boats. However, in Saigon, it was suddenly decided to advance [the schedule of] the Java operation by one month based on the intention of the Southern Army. We fundamentally changed the original plan, and started to handle the shipping according to a new plan, which was in outline as follows:

1. The transportation of units under the direct control of the Twenty-fifth Army scheduled in and after January will be slightly delayed and the transport ships will be changed.

2. The transportation of the 21st Division will be postponed so as to land in Haiphong in February.

3. The transportation of the 33d Division and the units under the direct control of the Fifteenth Army will be postponed and the transport ships will be changed. 
By the above arrangements, some 90,000 tons, consisting of eighteen transport ships, for the main force of the 38th Division will be moved to Hong Kong around 10 January, some 210,000 tons, consisting of forty transport ships, for the $2 \mathrm{~d}$ Division and the unit under the direct control of the Sixteenth Army will be moved to Gaoxiong, and some 170,000 tons, consisting of thirtyfive transport ships, for the 48 th Division will be moved to Lingayen, both by the scheduled date.

Although the above arrangements were, of course, immediately communicated to [the headquarters in] Ujina, they had no way of knowing the intention of the Southern Army, and it seems that no information concerning the advancement of the landings on Java was provided at that moment by IGHQ [either]. This caused unexpected trouble. The transport ships, which left Japan's mainland, Dalian and Shanghai, acted against the intention of [the command post in] Saigon. It seems that the transport ships and shipping units were confused by different instructions from Saigon and Ujina. Although it was just for one or two days, the whole shipping situation was thrown into total confusion.

The above recollections raise the question of what brought about the confusion despite the fact that the schedule in General Agreement No. 2 (the agreement between the Southern Army and the Navy Southern Task Force concluded at the War College on 10 November, [which set the capture of] Java on day $x+80$ ) did not much differ from that in General Agreement No. 4 (the agreement between the Southern Army and the Navy Southern Task Force concluded at Cam Ranh Bay on 1 January, [which set the capture of] Java on day $x+70$ ), the fact that General Agreement No. 2 was given as an instruction in the separate volume of Southern Army Operation Order No. 1 (dated 15 November), and the fact that the Saigon command post of the Shipping Transport Command (captain general: Lieutenant General Saeki) was attached to the Southern Army. Furthermore, it raises the question of how the situation could develop in the above-mentioned way even though the Chief of the Army General Staff Sugiyama and other staff of the Army Department of IGHQ had been present at the conclusion of General Agreement No. 2 at the War College on 10 November and had been informed of Southern Army Operation Order No. 1.

The reason was that the Southern Army in Southern Army Operation Order No. 1 only ordered the commanders of the armies, the air force, and the commander of the Kawaguchi Detachment to make arrangements on operations with the Navy commanders concerned, based on the excerpts of the Army-Navy Central Agreement, and the General Agreement No. 2 (see the previous description for the original text), but the order lacked [directives concerning] the shipping arrangements to back up [the above arrangements].

Most of the ships were operated under the direct control of IGHQ. (Note: For example, in December 1942, when the southern operation was over and fierce battles were fought in the Solomons, out of an Army tonnage of 1.26 million tons, 200,000 tons were allotted to the Southern Army, 20,000 tons to the China Expeditionary Army, but 1.04 million tons were employed under the direct control of IGHQ.)

More specifically, in the Army Department [of IGHQ], the chief of transport and communications (the director of Department 3) under the command of the inspector general of lines of communication (i.e. the vice chief of the Army General Staff [Lt. Gen. Tanabe Moritake]) planned the operation of ships under the direct control of IGHQ and gave instructions to the captain general of the Shipping Transport Command (who was under the command of the chief of Army General Staff) to operate the ships according to plan. This means that the commander in chief of the Southern Army had no discretion to operate ships that were under 
the direct control of central command, nor was the captain general of the Shipping Transport Command (Lt. Gen. Saeki Bunrō) allowed to operate such ships by order of the Southern Army even though he was posted to the commander in chief of the Southern Army with regard to the southern operation.

Although the previously mentioned Southern Army Operations Order No.1 was distributed to the Shipping Transport Command (more precisely its command post), it believed that the order had been distributed just for reference and paid no attention to it. Moreover, with respect to shipping, it considered the Sixteenth Army as so-called "passengers." Furthermore, it assumed that the shipping plan indicated in the instruction issued by the chief of the Army General Staff of the Army Department of IGHQ (i.e. the Central Agreement [which was attached as a separate volume]) was the only one in force. Still more, as described previously, IGHQ ([particularly] the Inspectorate General of Lines of Communication and the Bureau of the Chief of Transportation and Communication) considered General Agreement No. 2 of 10 November as an impractical idea or wishful thinking.

Whatever the case, the Southern Army was well aware of the authority of each agency concerning such shipping operations. In this respect, the agreement between the Southern Army and the Southern Task Force of 10 November (i.e. General Agreement No. 2) was concluded to set the target they were striving after and it was something that demanded serious consideration from the Army Department of IGHQ (and should it prove feasible, measures for implementation).

\section{Distinctive Features of the Cam Ranh Agreement}

The main points, which might also be called the distinctive features, of the agreement signed on 1 January are the following:

1. [The schedule of] the landing on Java was set thirty-three days ahead of that in the Central Agreement of 5 November, and ten days ahead of the General Agreement No. 2 of 10 November.

2. Judging that the capture of Singapore would be possible in early February, about one month ahead of the originally estimated date of about day $x+100$, it was decided to advance bases to southern Sumatra, while skipping over Singapore before completing its capture. It was also decided to advance a base to Ledo in western Borneo, so that naval planes could be advanced there.

Note: Although the Southern Army insisted that Bangka and Palembang should be captured on day $x+50$, it turned out that [the Navy] could not manage to provide escort forces at sea, and that it would take days to seize the airfield at Ledo and make it ready for use, so the date [to capture these places] was set around day $x+60 .{ }^{(9,23,24,119)}$ On 6 January, the Southern Army ordered the Kawaguchi Detachment to capture Ledo. ${ }^{(23)}$

3. As previously described, setting the capture of Tarakan and Menado on different days had been an issue, but it was agreed to set the date to capture both places on the same day [in this agreement]. [However,] it was put off by about three days due to the delay in the capture of Davao and Jolo, etc.

4. [The date to] capture Ambon was set on day $x+48$ because, as previously mentioned, the Combined Fleet strongly demanded its capture at an early date. It was decided to use Detachment $B$ for the capture instead of the South Seas Detachment and the force to be employed for Detachment B was increased to three battalions as requested by the Navy. ${ }^{(9,24)}$ It was [also] decided to return the South Seas Detachment [to the control of the Army Department of IGHQ]. 
5. The starting point of the operations to capture Tarakan, Menado and Ambon [editor's note: the text mistakenly says Palau] was changed from Palau to Davao, ${ }^{(119)}$ for reasons that Davao was already seized and that the city was advantageous from a geographical point of view and the capacity of its base.

6. The capture of Bali was not included [in the agreement], for reasons that not sufficient time for its capture was expected any longer due to the extremely shortened schedule, that, unlike at the time of the Iwakuni Agreement, [the operations to] capture Southern Sumatra, Ledo and Kupang were set before the capture [of Java], and that an increase in lines of operation would cause a shortage of forces to be employed for escort.

7. The cooperation of an element of the Carrier Task Force (i.e. the $2 \mathrm{~d}$ Carrier Division with the aircraft carriers, Sōry $\bar{u}$ and Hiry $\bar{u}$ ) in capturing Ambon was included in the plan. ${ }^{(110)}$ [However,] at the time of the conclusion of this agreement, it was not [yet] determined whether or not the main force of the Carrier Task Force would cooperate in the operation to capture Java.

8. It was planned that the Navy air unit would advance into Borneo (including Ledo) and further east, and with a part also into Malaya and southern Sumatra, whereas the army air unit would advance into southern Sumatra from Malaya. ${ }^{(23,24)}$

9. It was [also] planned that the Twenty-fifth Army would capture Malaya only with the 5th Division, the Imperial Guard Division, and the 18th Division, and that, after the capture of Singapore, a part of the army was to capture northern Sumatra; the 56th Division was given up so that [the division could join] the Burma operation. ${ }^{(23,100)}$

\section{Shipping Routes and Ships}

The tonnage allotted to the Sixteenth Army for the invasion of the Dutch East Indies in the Cam Ranh Agreement was a total of 910,000 tons, in about 178 ships. ${ }^{(23)}$ The breakdown was as follows: ${ }^{(23)}$

Until the first landing in Java:

610,000 tons in about 118 ships

The second landing in Java and thereafter: $\quad 300,000$ tons in about 60 ships

Note: The number of ships and tonnage are those specified in General Agreement No. 4. The same applies hereinafter.

The amount of tonnage, the shipping routes and the schedules for each corps, detachment, etc. were planned as follows: ${ }^{(23)}$

Sakaguchi Detachment: [shall be provided with] about 46,000 tons in total in eight ships.

[The detachment] shall leave Jolo or Davao on 8 January (day $x+31$ ), sail under the direct escort of the Navy, land in Tarakan on 10 January (day $x+33$ ); shall leave Tarakan on 17 January $($ day $x+40)$, sail under the direct escort of the Navy, land in Balikpapan on 20 January (day $x+43$ ); shall leave Balikpapan on 27 January (day $x+50)$, sail under the direct escort of the Navy, and land in Banjarmasin on 30 January (day $x+53$ ).

Eastern Detachment (Detachment B, consisting of three battalions of the 38th Division): [shall be provided with] about 40,000 tons in total in about seven ships.

[The detachment] shall leave Hong Kong on 9 January (day $x+32$ ), sail under the direct escort of the Navy, stay at Davao from 16 January (day $x+39$ ) to 18 January (day $x+41$ ); shall leave Davao on 19 January (day $x+42$ ), sail under the direct escort of the Navy, land in Ambon on 25 January (day $x+48$ ); shall leave Ambon on 7 February (day $x+61$ ), sail under the direct escort of the Navy, land in Kupang on 11 February (day $x+65)$. The ships shall stay at Kupang for debarkation until 12 February (day $\mathrm{x}+66$ ). 
Main force of the 38th Division (consisting of four battalions as its core): [shall be provided with] about 90,000 tons in total in about 18 ships.

[The unit] shall board in Hong Kong in the period from 11 January (day $x+34$ ) to 19 January $($ day $x+42)$, leave Hong Kong on 20 January (day $x+43)$, sail under a light direct escort or under an indirect escort, stay in Cam Ranh Bay [for the period] from 25 January (day $x+48$ ) to 29 January (day $x+52$ ); shall leave Cam Ranh Bay on 30 January (day $x+53$ ), sail under the direct escort of the Navy, land in Bangka and Palembang on 6 February (day $x+60)$. Disembarkation shall be completed on 7 February (day $x+61$ ) and on 10 February (day $x+$ 64) in Bangka and Palembang respectively.

Core unit of the 48th Division: [shall be provided with] about 220,000 tons in total in about 45 ships.

[The unit] shall board in Luzon Island in the period from 1 February (day $x+55)$ to 7 February (day $x+61$ ), leave Luzon on 8 February (day $x+62$ ), sail under the direct escort of the Navy, land in the vicinity of Surabaya on 16 February (day $x+70$ ). Disembarkation shall be completed on 19 February (day $x+73$ ). Of these ships, a tonnage of 170,000 tons in total in 35 ships shall comprise those which shall gather in Gaoxiong from the 21st to the 27th of January, and a tonnage of 50,000 tons in total in about 10 ships shall comprise those which shall gather in Gaoxiong from 3 December to 27 January from the mainland, Manchuria and Korea, China, etc.

Core unit of the $2 \mathrm{~d}$ Division: [shall be provided with] 160,000 tons in total in about 30 ships.

[The unit] shall board in Osaka in the period from 11 January (day $x+34)$ to 19 January (day $x+42)$, sail under the indirect escort of the Navy, and stay at Gaoxiong during the period from 29 January (day $x+52$ ) to 5 February (day $x+59$ ); shall leave Gaoxiong on 6 February $($ day $x+60)$, sail under the direct escort of the Navy, and land in the vicinity of Batavia on 16 February (day $x+70$ ). Disembarkation shall be completed on 19 February.

Unit under the direct control of the [Sixteenth] Army, which shall land in western Java: [shall be provided with] 50,000 tons in total in about 10 ships.

[The unit] shall board in China in the period from 23 January (day $x+46)$ to 27 January (day $x+50$ ), leave on 28 January (day $x+51$ ), stay at Gaoxiong from 2 February (day $x+56$ ) to 5 February; shall leave on the next day, the 6 th $($ day $x+60)$, sail under the direct escort of the Navy, land in western Java on 16 February (day $x+70$ ). Disembarkation shall be completed on 19 February.

The Army started the war with a tonnage of about 2.1 million tons, ${ }^{(23)}$ of which about 1.75 million tons was used for the southern operation as of 25 November. The breakdown was: about 1.5 million tons in troopships, about 150,000 tons in military supply ships, and about 100,000 tons in special purpose ships. Out of the troopships, about 1.45 million tons was in use and about 50,000 tons was held in reserve. ${ }^{(23)}$

Around the time of the Cam Ranh Agreement, the main shipping related to the southern operation was as follows: ${ }^{(23)}$ Transportation of the main force of the Fourteenth Army to the Philippines was completed ([more precisely, the transport of] the 48th Division to Lingayen [was completed] on 22 December, and that of the 16th Division to Lamon Bay on 24 December), and the first and the second landing of the Malaya advance corps (consisting of the main force of the 5th Division, etc.) had [also] been completed ([respectively] on 8 December and on 16 December). ${ }^{(118,119,120,124,125)}$ 


\section{Units on Board [and in Transit Around the Time of the Cam Ranh Agreement]}

Main force of the 33d Division and an element of the unit under the direct control of the Fifteenth Army (about 70,000 tons [in total]): After departing from eastern China, [the unit] left Magong on 31 December and arrived in Bangkok on 10 January.

Three battalions of the 5th Division and the first unit of the unit under the direct control of Twenty-fifth Army (about 330,000 tons [in total]): [The unit] left Magong on 31 December and arrived in Singora on 8 January.

Main force of the 18th Division and part of the unit under the direct control of the Twenty-fifth Army (about 170,000 tons [in total]): [The unit] was supposed to land in Endau and Mersing, and left the area of Guangdong on 7 January and arrived in Cam Ranh on 10 January.

Second unit under the control of the Twenty-fifth Army (210,000 tons [in total]): [The unit] was supposed to head for Malaya from China, [but] that seems to have been changed.

65th Brigade (50,000 tons [in total]): [The unit] was heading for the Philippines from Taiwan, leaving Gaoxiong on 30 December. It arrived in Lingayen on 1 January.

Sakaguchi Detachment (46,000 tons [in total]): [The unit] was using the ships for operations in Davao and Jolo.

Note: The tonnage was as specified in the Central Agreement. The same applies hereinafter.

\section{Units in the Middle of Embarking and Those About to Embark Shortly}

An element of the Imperial Guard Division and others (170,000 tons [in total]): [The unit] was supposed to head for Malaya from French Indochina and Thailand.

Main force of the 21st Division (about 100,000 tons [in total]): [The unit] was supposed to head for French Indochina from northern China. (Its transportation was postponed, and [consequently] it left Qingdao on 20 January and arrived in Haiphong on 3 February.)

Main force of the 56th Division (about 100,000 tons [in total]): [The unit] was supposed to head for Malaya from Kyūshū.

The Twenty-fifth Army had arranged with the [Navy] Malaya Unit on 18 November to "land near Endau and Mersing around 6 February." (This was also postponed. [The unit eventually] started assembling in Moji on 11 February and left Moji on the 16th to be transported to Burma.)

2d Division (160,000 tons [in total]): [The division] was heading for Taiwan from the mainland (and later for Java [as its destination]).

Fifth Air Force (100,000 tons [in total]): As the Philippines operations were almost over, [the group] was heading for Thailand.

\section{Units Embarking in the Beginning or Middle of January}

Half of the 33d Division (70,000 tons [in total]): [The unit] will head for Thailand from eastern China.

Part of the 21st Division (50,000 tons [in total]): [The unit] will head for French Indochina from northern China.

Third unit of the unit under the direct control of the Twenty-fifth Army (110,000 tons): [The unit] will head for Malaya from southern China.

\section{Units Embarking in Late January}

38th Division (190,000 tons [in total]): [The division] will head for the Dutch East Indies from Hong Kong. 


\section{Units Embarking from Mid-February Onward}

Units for capturing Java consisting of the $2 \mathrm{~d}$ and the 48 th Division as its core $(830,000$ tons [in total]): [The units] will head for Java from Taiwan, French Indochina and the Philippines.

As described previously, in order to meet the advanced schedule of the Java operation, the Saigon command post (attached to the Southern Army) of the Shipping Transport Command allotted the ships it managed to make available for transporting the units for the Java operation by such arrangements as putting off the transportation of the 21st, the 33d, and the 56th Divisions and the units under the direct control of the Twenty-fifth and the Fifteenth Armies, or by transporting them in smaller units at a time over a longer period. ${ }^{(27)}$ Fortunately, the damage and loss of ships since the opening of hostilities was smaller than expected. According to a report of the Shipping Transport Command, the damage and loss for fifty-five days from 4 December to 27 January was as follows: ${ }^{(23)}$
Sunk:
20 ships $(115,000$ tons [in total])
Too damaged to be used:
8 ships $(48,000$ tons [in total])
In total:
28 ships $(163,000$ tons [in total])

The shipping situation at the time of the Cam Ranh Agreement was as described above. Later, on 15 January, ships to be used by the Sixteenth Army for the operations against Java (excluding ships for the Sakaguchi and the Eastern Detachment) were determined as follows: ${ }^{(24)}$

\section{Transport ships}

First transport: 220,000 tons for the main force of the army, 210,000 tons for the 48th Division, and 130,000 tons for the 38th Division, making a total of 560,000 tons.
Second transport:
150,000 tons
Third transport:
100,000 tons
In total:
810,000 tons

Ten extra-large [motorized landing] craft, 170 large-sized motorized [landing craft], 170 smallsized motorized [landing] craft, 5 armored craft, 5 Type-A high-speed craft, 6 Type-B highspeed craft, 80 boats with Yanmar engines, and 20 small lighters.

\section{The Orders from [the Army Department of] Imperial General Headquarters}

The 38th Division captured Hong Kong on 25 December and made a triumphal entry into the city on the 28th. ${ }^{(53)}$ The 48th Division, which had landed at Lingayen Gulf on 22 December, occupied Manila on 2 January in concert with the 16th Division, which had landed at Lamon Bay on 24 December. ${ }^{(53)}$ The Twenty-fifth Army kept on advancing southward, setting itself the goal to complete the capture of Singapore by 11 February (Empire Day). ${ }^{(53)}$

As previously described, on 4 January, Chief of the Army General Staff Sugiyama presented a report about advancing [the schedule of] the Java operation to the Emperor. ${ }^{(2)}$ [Accordingly, the Army Department of] IGHQ issued the following orders to transfer units for the Dutch East Indies operation: ${ }^{(1)}$ 


\section{Chapter V / Decision to Advance the Java Operation and the Sixteenth Army}

\section{IGHQ Army Department Order No. 585 of 4 January ${ }^{(1)}$}

Units to be transferred from the order of battle of the Twenty-third Army in southern China to the order of battle of the Sixteenth Army as of 1200 on 4 January:

\section{8th Division}

2d Independent Antitank Gun Battalion (under the supervision of the 3d Division)

5th Independent Antitank Gun Battalion (under the supervision of the 16th Division)

One element of the 14th Telegraph Regiment (under the supervision of Southern China Area Army)

5th Field Gas Company B (under the supervision of the 2d Division)

18th Field Gas Company B (under the supervision of the 7th Division)

17th Water Supply and Purification Department (under the supervision of the 1st Division)

Note 1: "Supervision" means that, for example, when "under the supervision of the 3d Division," the mobilization or formation of this unit was supervised by the 3d Division.

Note 2: On this day, by IGHQ Army Department Order No. 584, [the Army Department of] IGHQ transmitted to the South Seas Detachment (in Guam) an order "to capture Rabaul as quickly as possible after about mid-January in cooperation with the Navy." (1)

\section{IGHQ Army Department Order No. 588 of 14 January ${ }^{(1)}$}

The 48th Division shall be removed from the order of battle of the Fourteenth Army to be incorporated into that of the Sixteenth Army. The transfer of command [to the Sixteenth Army] shall take effect when it departs from a port in Luzon. However, the commander of the Sixteenth Army is allowed to give commands concerning preparations for operations prior to this [transfer].

On 29 January, the Twenty-fifth Army was pressing on Johor Bahru. ${ }^{(23)}$ The implementation of the Java operation was finally taking concrete shape. However, as previously described, the Southern Army's request for an additional allotment of 150,000 tons of shipping was refused and the tonnage would not be enough however hard it tried to juggle the ships. ${ }^{(23,24)}$ [As a result, the Army Department of] IGHQ decided to cancel the transfer of the units which on 6 November had been ordered to join the order of battle of the Sixteenth Army but which might not be able to make it from Manchuria in time. Instead, in order to reinforce the Sixteenth Army, it decided to divert some units of the Fourteenth Army and the Southern Army, etc. in the Philippines and other areas to the Sixteenth Army, and issued the following order: ${ }^{(1)}$

\section{IGHQ Army Department Order No. 594 of 29 January}

The following units shall be removed from the order of battle of the Southern Army, the Fourteenth, and the Twenty-fifth Armies to be incorporated into that of the Sixteenth Army. The transfer of command [to the Sixteenth Army] shall take effect when the unit leaves port at its current location for the Dutch East Indies operation.

1. Units to be diverted from the order of battle of the Southern Army to that of the Sixteenth Army 23d Antiaircraft Artillery Regiment (minus the Antiaircraft Searchlight Company): (Twenty-first Army)

138th Railway Depot headquarters (B): (Home unit, 5th Division)

2. Units to be diverted from the order of battle of the Fourteenth Army to that of the Sixteenth Army 
8th Independent Antitank Gun Company: (16th Division)

10th Independent Antitank Gun Company: (Home unit, 4th Division)

4th Tank Regiment: (Fifth Army)

45th Field Antiaircraft Artillery Battalion (B): (Home unit, 6th Division)

48th Field Antiaircraft Artillery Battalion (B): (20th Division)

30th and 31st Independent Field Antiaircraft Artillery Battery: (Home unit, 3d Division)

3d Independent Engineer Regiment (A), (horse-carried): (2d Division)

One battalion of the 6th Railway Regiment and one element of its Material Depot (Northern

China Area Army)

5th Independent Radio Platoon (motorized): (China Expeditionary Army)

51st and 52d Independent Radio Platoon (motorized): (Home unit, 5th Division)

40th Fixed Radio Unit: (Home unit, 5th Division)

26th Bridge Building Material Company: (Home unit, 3d Division)

13th River-crossing Material Company: (Home unit, 51st Division)

14th River-crossing Material Company: (53d Division)

209th Independent Motor Transport Company: (Home unit, Imperial Guard Division)

258th and 259th Independent Motor Transport Company: (Home unit, 4th Division)

38th Patient Transport Platoon: (2d Division)

8th Water Supply and Purification Department: (1st Division)

3. Units to be diverted from the order of battle of the Twenty-fifth Army to that of the Sixteenth

Army

2d Tank Regiment (minus one light tank squadron): (Home unit, Imperial Guard Division)

34th Field Antiaircraft Artillery Battalion (B) (Home unit, Imperial Guard Division)

35th Field Antiaircraft Artillery Battalion (minus an element) (B): (Home unit, Imperial Guard

Division)

28th Motor Transport Regiment: (Home unit, 51st Division)

45th Independent Motor Transport Battalion: (Home unit, 3d Division)

212th Independent Motor Transport Company: (Home unit, Imperial Guard Division)

307th and 308th Independent Motor Transport Company: (Taiwan Army)

4. Unit to be diverted from the order of battle of the Sixteenth Army to [that of] the Kwantung Army

8th Tank Regiment: (Eastern District Army)

5. Units to be diverted from the order of battle of the Sixteenth Army to [that of] the Fifth Army in

Manchuria

42d Field Road Unit: (56th Division)

44th Field Road Unit: (Home unit, 57th Division)

6. Unit to be diverted from the order of battle of the Sixteenth Army to [that of] the Twentieth

Army in Manchuria

16th Field Well-drilling Company: (52d Division)

Note: The [organization] in parentheses above is the unit that supervised the mobilization or formation of the units.

After a course of events, which will be described later, the convoy of the main force of the Sixteenth Army would leave Cam Ranh Bay for Java on 18 February. Just before that day, on the 16th, [the Army Department of] IGHQ issued the following order increasing units: ${ }^{(1)}$

\section{IGHQ Army Department Order No. 600 of 16 February}

The following [unit] shall be incorporated into the order of battle of the Sixteenth Army as of its departure from a port in the mainland:

5th Fixed Radio Unit: (under the supervision of the Northern District Army) 
[Consequently,] just before landing on Java, the main units of the Sixteenth Army were the following:

\author{
2d Division \\ 38th Division \\ 48th Division \\ 56th Mixed Infantry Group \\ 4th Tank Regiment and 2d Tank Regiment (minus [one] light tank squadron) \\ 17th Field Heavy Artillery Regiment (A) \\ 2d and 5th Independent Antitank Gun Battalion, and the 8th and the 10th Independent Antitank \\ Gun Company \\ 16th Antiaircraft Artillery Regiment and 23d Antiaircraft Artillery Regiment (minus the Anti- \\ aircraft Searchlight Company); 44th, 45th and 34th Field Antiaircraft Artillery Battalion (B), 35th \\ Field Antiaircraft Artillery Battalion (B) (minus an element); 30th and 31st Independent Field \\ Antiaircraft Artillery Battery \\ (Engineer units and others are omitted. The details are as shown in the appended table.)
}

\title{
4. The Southern Army's Operational Direction
}

\section{The Orders to Prepare for the Capture of Java and the Aviation Plan}

From the start of its research on the southern operation in the summer of 1940 until the decision to open hostilities, the Southern Army had consistently thought that the operations heading for Java via the east of Borneo would make faster progress than those heading for Java via Malaya. However, the reality was that after the opening of hostilities, with two British battleships sunk and the Twenty-fifth Army starting to charge [southward] at a good speed in Malaya, the capture of Davao was, as previously described, six days behind schedule in the eastern area. [Consequently,] the Southern Army gave the following order to the Twenty-fifth Army as early as 23 December: ${ }^{(23)}$

\section{Southern Army Order}

Saigon, 23 December

1. The overall operations of the Southern Army are progressing as scheduled.

2. In conjunction with the Navy, I intend to swiftly capture Singapore.

3. The commander of the Twenty-fifth Army shall promptly seize Singapore in the following manner:

a) He shall expand the military gains attained so far, and swiftly capture Singapore from the direction of the west coast of Malaya.

b) By and large by day $x+23$, he shall raid and secure the enemy airfield near Kuantan with a part [of the army]. Furthermore, he shall have a corps land in or near Endau or Mersing at a favorable opportunity to facilitate the operations of the main force of the army. The cooperation with the Navy for the above operations will be based on General Agreement No. 3.

Around the time of passing down the above order, the Southern Army expected that the operations in Malaya would progress faster than those in the east of Borneo theater. It planned to sharply accelerate the operations in Malaya and in western Borneo, and by [speeding up and] synchronizing the operations in the east of Borneo theater with those in west, carry out the landing operations in both eastern and in western Java simultaneously at an early date. 
On 28 December, the Southern Army ordered the Kawaguchi Detachment to prepare for capturing Ledo. ${ }^{(23)}$

On 3 January, Lieutenant General Imamura, commander of the Sixteenth Army, arrived in Saigon with his chief of staff, Okazaki, and other personnel of the command post [of the army]. ${ }^{(32)}$ The next day, the 4 th, the Southern Army showed the Sixteenth Army what it intended to do, explained General Agreement No. 4 signed on 1 January, and gave its views on the operations of the Navy, its plan of how to use the [transport] ships, its operation schedule and their relation to the air operations, etc. ${ }^{(24)}$ Army Commander Imamura firmly stated that he "fully agreed to bringing forward the Java operation."(24)

Although, as previously described, the Kuantan landing operation ordered by the Southern Army order of 23 December had been called off on the 27th, ${ }^{(23)}$ the Takumi Detachment seized [the town of] Kuantan on the 31st and the Kuantan airfield on 3 January, and from the 4 th onwards it put its all into making the airfield ready for use. ${ }^{(23,53)}$

Now the problem to be immediately addressed in the western theater was the capture of Ledo. As for the Endau and Mersing landing operations ordered by the Southern Army order of 23 December, the departure [of the units in charge] from Cam Ranh Bay was scheduled for day $x+36$ (13 January), and the main force of the 18th Division was preparing for boarding in Humen, southern China. (It left Humen on 7 January and arrived in Cam Ranh on 10 January. ${ }^{(53)}$ )

On 5 January, the Southern Army ordered the Sixteenth Army to prepare for capturing Java and the next day, the 6th, it ordered the Kawaguchi Detachment to capture the airfield in Ledo. ${ }^{(23)}$ The reason why these orders were issued in reverse order was that the preparations of the Kawaguchi Detachment for capturing Ledo were delayed, ${ }^{(23)}$ as will later be described in detail. The order given to the Sixteenth Army was as follows: ${ }^{(23)}$

\section{Southern Army Operation Order A, No. 32}

\section{Southern Army Order Saigon, 5 January}

1. The overall operations of the Southern Army are progressing as scheduled.

2. In conjunction with the Navy, I intend to swiftly prepare for capturing Java. The cooperation with the Navy shall be based on General Agreements No. 2 and No. 4.

3. The commander of the Sixteenth Army shall prepare for capturing Java in the following manner:

a. By and large around day $x+60$, he shall secure key resource areas in Bangka Island and southern Sumatra with part [of the army], and promptly make air bases [there] ready for use.

b. He shall seize Ambon and Kupang as quickly as possible. When the major part of the operation in Ambon is achieved, he shall turn over the guarding [of the place] to the Navy.

4. The Third Air Force shall closely cooperate in the Sixteenth Army's operation against Bangka Island and southern Sumatra, while continuing its previous mission. It shall destroy the air power of the enemy in Sumatra in a timely manner.

5. The captain general of the Shipping Transport Command shall closely cooperate in the operations conducted by the commanders of the Sixteenth Army and the Third Air Force.

6. I will [command from] Saigon.

Count Terauchi Hisaichi, commander in chief of the Southern Army 
The order given to the Kawaguchi Detachment [by the Southern Army] on the 6th was as follows: ${ }^{(23)}$

\title{
Southern Army Operation Order A, No. 34
}

\author{
Southern Army Order Saigon, 6 January
}

Detachment Commander Kawaguchi shall promptly seize, mainly by land, the airfields near Bengkayang and the ports in Dutch Borneo, which lead to these [airfields].

From the start, the Southern Army had the idea to divert the Fifth Air Force, assigned to the Fourteenth Army, to the operations in Thailand [and neighboring areas] when the Philippines operations were for the most part over and assign it mainly to the Burma operation. Now, as Manila was completely occupied on 2 January and the [Army Department of] IGHQ had recently revealed its concept for the Burma operations, the Southern Army issued an order on 8 January to put the Fifth Air Force under the direct control of the army mainly to conduct air operations in Burma in direct cooperation with the operations of the Fifteenth Army, but also to cooperate with the Third Air Force with heavy bomber units when required at the time of the attack on Singapore. ${ }^{(23)}$ On 10 January, the Southern Army drew up a supplementary plan for its air operations, including a concretization of the preparations for the Java operation. ${ }^{(2)}$ The following is an excerpt from this plan of items concerning the Java operation:

\section{Supplement to the Southern Army's Air Operation Plan}

Southern Army Staff, Section 4, 10 January

\section{Mission}

1. In quick response to the rapid progress in the overall operations, the air units of the Southern Army, in conjunction with the Navy air units, shall extend the military gains achieved since the opening of hostilities, fiercely pursue and destroy the British and Dutch air forces so as not to give them opportunities for reinforcement, and closely cooperate with operations of each army.

3. For the frequent and rapid advancement of bases and the continuous air operations we expect the lines of communication to be beyond reproach.

II. Outline of Operations

5. For the period of capturing Singapore and destroying the enemy air power in Sumatra (from around 1 January to around 5 February)

(1) The Third Air Force shall have its main force attack key military facilities of the enemy near Singapore, while at the same time destroying the enemy air power in Malaya and northern Sumatra, and with an element of its force directly cooperate in the operations of the Twenty-fifth Army. It shall anticipate the possibility that it may temporarily have to cooperate with its full force in the Twenty-fifth Army's attack on Singapore.

(4) The Navy air unit is supposed to promptly advance its main force to the bases in western Borneo near Kuching or Ledo and an element of its force to northern Malaya and strive to destroy the enemy warships near Singapore and the enemy air power in Singapore, eastern Sumatra and Java. The details shall be arranged separately.

6. For the period of capturing Sumatra and Java (from around 1 February to around 25 February)

(1) The Third Air Force shall promptly destroy the enemy air power in Sumatra and cooperate with an element of the Sixteenth Army in its attack on Bangka and Palembang. 
When air bases on Bangka Island and in southern Sumatra become ready for use, it shall, without missing any opportunity, move forward as much strength as possible to swiftly destroy the enemy air power in western Java. At the same time it shall closely and directly cooperate in the landing operation of the main force of the Sixteenth Army. It shall cooperate in subsequent operations [as well] while advancing its bases into Java one after another.

(3) (a)The Navy air unit shall still have its main force in western Borneo and an element of it in northern Malaya and is supposed to try to destroy the enemy warships and air power in western Sumatra and Java.

(b) Concerning the air operations in the operation for capturing southern Sumatra, arrangements shall be directly made between the Sixteenth Army, the First Southern Expeditionary Fleet (note by the author: the Southern Expeditionary Fleet was renamed the First Southern Expeditionary Fleet on 3 January), and the Third Air Force.

(c) The Eleventh Air Fleet is supposed to advance its bases into Celebes and southern Borneo to try to destroy the enemy warships and air power in eastern Java and [also] cooperate in the landing operations of part of the Sixteenth Army in eastern Java.

(d) The arrangements for the air operation to support the Sixteenth Army's operation in western Java shall be directly made between the Third Air Force and the 22d Air Flotilla, those in the landing operations in eastern Java shall be directly made between the Sixteenth Army and the Eleventh Air Fleet.

7. For the period of the northern Burma operations (about 25 February onwards)

(1) The Third Air Force shall cooperate with the army in securing stability in Sumatra and Java with an element of its force for each area, and also cooperate with an element or the main force of its fighter plane and heavy bomber units in the Fifth Air Force's operations when required. At the same time, it shall prepare for subsequent operations.

9. From March onwards we shall carry out the operations while preparing for sudden changes in [the state of affairs in] the north at any time and [also] gradually change our position so that it will be easier to secure a long-lasting stability of the key areas in the South as well as to carry out air operations in Burma.

III. Disposition of forces to be employed and summary of the operations

10. For the period of capturing Singapore and destroying the enemy air power in Sumatra

(1) In order to destroy the enemy air power in and around Singapore, airfields in Ipoh and Kuantan shall be ready for use by around 10 January.

(2) When required, two heavy bomber air groups of the Fifth Air Force shall be diverted to cooperate in the attack on key places in Singapore.

(3) When required, the Third Air Force shall cooperate with its full strength in the Twentyfifth Army's crossing of the Johor Strait.

(4) In consideration of the next operations, transport units and Type- 1 fighter plane units shall at the right moments be scheduled for maintenance in order to keep up military strength.

(5) Just after the capture of Singapore, the following transfer shall be arranged:

a. The 73d Independent Squadron and one-third of the 84th Airfield Battalion of the Twenty-fifth Army shall prepare to be transferred to the Sixteenth Army.

b. (Omitted by the author.)

(6) The preparation of Kluang and Kahang airfields for the southern Sumatra operation shall be completed by around 31 January.

(7) The transfer of the main force of the Fifth Air Force from the Philippines to Thailand shall be completed by and large by 25 January.

11. For the period of capturing Sumatra and Java 


\section{Chapter V / Decision to Advance the Java Operation and the Sixteenth Army}

(1) Main points of cooperation with part of the Sixteenth Army in capturing southern Sumatra

(a) By 31 January the deployment of fighter plane units in Kluang, Kahang and Batu Pahat, light bomber air groups in Ipoh and Kuala Lumpur, and heavy bomber air groups in Ketil, Alor Setar and Ayer Tawar shall be completed.

(b) Force to be employed: 9 command reconnaissance planes, 40 Type- 1 fighter planes, 30 Type-97 planes, 9 assault planes, 20 twin-engine light bombers, and 30 heavy bombers.

(c) The units mentioned in the previous item, except for the heavy bomber unit, shall be pushed forward when airfields in southern Sumatra are ready for use.

(d) Air ground support units that have landed in Sumatra under the command of the Sixteenth Army shall be transferred to the Third Air Force when they have completed the preparation of the airfields.

(e) Detailed arrangements with the Navy shall be made between the Sixteenth Army, the First Southern Expeditionary Fleet, and the Third Air Force.

(2) Main points of cooperation with the main force of the Sixteenth Army in capturing Java

(a) Mentok, Palembang and Tanjungkarang, which are to be used as bases, shall be promptly seized and made ready for use.

(b) Forces to be employed: same as mentioned in the previous item.

(c) As soon as air bases on Java are ready for use, air units shall advance their bases one after another. At that time, air ground support units under the command of the Sixteenth Army shall be transferred to the Third Air Force.

(d) For this period, the 73d Independent Squadron and one-third of the 84th Airfield Battalion of the Twenty-fifth Army shall be transferred to the Sixteenth Army.

(e) The arrangements for the air operations in western Java shall be directly made by the end of January between the Third Air Force and the [Navy] 22d Air Flotilla.

(f) The Eleventh Air Fleet and the Third Fleet shall cooperate in the air cover for the landing operations in eastern Java. Arrangements in detail shall be directly made between the Sixteenth Army and the above Navy units.

(g) Subsequent operations to destroy the enemy air power on the Australian front shall be carried out under the responsibility of the Navy by using bases in eastern Java and the Lesser Sunda Islands.

(3) Cooperation in the capture of northern Sumatra by an element of the Twenty-fifth Army

(4) Main points of cooperation with the Fifteenth Army in the Burma operation (omitted by the author)

12. Main points of cooperation in air operations in the final stages of the Burma operation (omitted by the author)

13. As for the use of XX Units (note by the author: paratroop raiding units), although the main goal is to let them cooperate in the operation to capture Palembang, their exact use shall be decided depending on the situation of the enemy air [power], the timing of the arrival of the units, and the situation of our bases, etc.

14. The disposition of air units in the final phase of Operation A-Gō [southern operation] is planned as follows:

(The rest omitted by the author.)

The outline of the cooperation of the air units in the Java operation was arranged in the following way: the Army shall let the Third Air Force support the operation by advancing the force from Malaya via southern Sumatra to western Java; [it shall also] put an element of the ground support units of the Third Air Force under the command of the Sixteenth Army and have it seize airfields upon landing and make them ready for use; the Navy shall let the 22d 
Air Flotilla (which shall [temporarily] be transferred from the command of the Eleventh Air Fleet to the control of the [Navy] Malaya Unit) support the operation from the west coast of Borneo with its main force and from Malaya with an element; [it shall also] let its air unit (i.e. the Eleventh Air Fleet) advance the 21st Air Flotilla southward from Davao to Celebes and the 23d Air Flotilla from Jolo to eastern Borneo, and have them support [the army's] landings in Java from [the bases in] southern Celebes and southeastern Borneo [respectively].

The 1st [Paratroop] Raiding Group (consisting of its headquarters led by Col. Kume Seiichi, the 1st [Paratroop] Raiding Regiment led by Maj. Takeda Takeo, the 2d [Paratroop] Raiding Regiment led by Maj. Kōmura Takeo, and its air unit led by Maj. Niihara Sueto), which had been given the order for provisional formation on 1 December, completed its formation on the 5th at Nyūtabaru, Miyazaki [Prefecture]. ${ }^{(93)}$ Then, on the 8th, it received an instruction issued by the chief of the Army General Staff of the Army Department of IGHQ, which read, "[the group] shall successively proceed to the South and place itself under the command of the commander in chief of the Southern Army,"(1) and, on the 19th, first of all the 1st Regiment left Moji on the Meikō-maru. ${ }^{(93)}$ On 1 January, Lt. Col. Kinoshita Hideaki, attached to the Group, reported to the headquarters of the Southern Army and informed them that "the [Paratroop] Raiding Group consists of an air unit of three squadrons and two regiments of ground troops, making a total of 1,500 men. It is going to assemble either in Saigon or Phnom Penh. Assembling is expected to be complete in mid-January." ${ }^{(23)}$ However, an unexpected accident happened just after this. The Meikō-maru, which transported the 1st [Paratroop] Raiding Regiment sank on 3 January at $15^{\circ} 15^{\prime}$ north $112^{\circ} 55^{\prime}$ east due to a spontaneous combustion of incendiary bombs. ${ }^{(23)}$ Although it was fortunate that all the officers and men were rescued by the escorting destroyers, because they had foreseen [the explosion] just before it happened and jumped into the sea, they suffered an outbreak of paratyphoid fever, which dealt them a mental as well as physical blow. ${ }^{(23)}$ Group Commander Kume, after arranging a hasty dispatch of the $2 \mathrm{~d}$ [Paratroop] Raiding Regiment, left Takanabe ahead by air on 8 January, put himself under the command of the Southern Army on the same day, and went ahead to Phnom Penh. ${ }^{(23)}$

\section{Shipping Operations}

As soon as it was decided to bring the Java operation forward, Lt. Gen. Saeki Bunrō, captain general of Shipping Transport Command, drew up a plan that (1) the transport of troops of units unrelated to the Java operation should generally be postponed by ten to twenty days, (2) the allotment of ships for units scheduled to be transported after January should be completely changed, and (3) ships scheduled to be in dock [for repair] but which were still usable should be assigned for short-distance transport, and their docking should be postponed for the present. He generally decided to operate the ships in the previously described way, but worked it out as follows: ${ }^{(27)}$

Operations related to the Eastern Detachment (Detachment B)

An element of the 5th Anchorage headquarters and one half platoon of the 104th Sea Duty Company were moved from Cam Ranh Bay to Hong Kong, and put under the command of the Eastern Detachment Commander on 5 January in Hong Kong. In addition, one company of the 14th 
Independent Engineer Regiment was put under the command of the Eastern Detachment Commander on 5 January in Hong Kong.

Five transport ships, 40,000 tons in total, were allotted to the Eastern Detachment: the Miike-maru, the Zen'yō-maru, the Ryōō-maru, the Yamaura-maru, and the Africa-maru. They were scheduled to leave Hong Kong around 12 January and assemble in Davao around 20 January.

Operations related to the main force of the 38th Division

The main force of the 5th Anchorage headquarters, the headquarters and one company of the 14th Independent Engineer Regiment, one company of the 26th Independent Engineer Regiment, and one and a half platoon of the 104th Sea Duty Company were put on standby in Cam Ranh until the arrival of the main force of the 38th Division (from Hong Kong), and were put under the

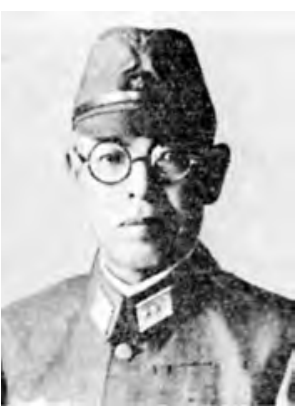

Captain General of the Shipping Transport Command

Lt. Gen. Saeki Bunrō command of the commander of the 38th Division in Cam Ranh on 20 January. The 65th Construction Duty Company was moved from the mainland to Hong Kong, and put under the command of the commander of the 38th Division in Hong Kong on 12 January.

Eighteen transport ships, 120,000 tons in total, were allotted to the main force of the 38th Division: the $A n^{\prime} y \bar{o}-m a r u$, the Tajima-maru, the Ōyo-maru, the Tacoma-maru, the Mansei-maru, the Alaska-maru, the Shinkyō-maru, the Gin'yō-maru, the Rakuyō-maru, the Makassar-maru, the Shinsei-maru No. 1, the Toyofuku-maru [Hōfuku-maru], the Argun-maru, the Lima-maru, the Buyō-maru, the Boston-maru, the Meigen-maru, and the Singapore-maru. The force was scheduled to board in Hong Kong on 18 January, complete assembling in Cam Ranh Bay on 24 January and finish changing ships by 31 January.

The Shōji Detachment (two battalions of the 38th Division as its core, [scheduled for] Java)

Six transport ships, 40,000 tons in total, were allotted to the detachment: the Taigen-maru No. 3, the Naples-maru, the Calcutta-maru, the Suwa-maru, the Kōzan-maru, and the Glasgow-maru. The detachment was scheduled to board in Hong Kong, leave [there] on 30 January, and assemble in Cam Ranh Bay.

The main force of the Sixteenth Army (the 2d Division as its core)

The 40th Anchorage headquarters, the 120th Shore Duty Company and the 67th Construction Company embarked from the mainland on 10 January and were seconded to the Sixteenth Army commander in Gaoxiong. The main force of the 6th Independent Engineer Regiment, two platoons of the 10th Independent Engineer Regiment, and the 59th Sea Duty Company were moved to Gaoxiong, and seconded to the Sixteenth Army commander in Gaoxiung on 27 January.

Forty [editor's note: only 39 are mentioned in the text] transport ships, 220,000 tons in total, were allotted to the force, and after the boarding at Ujina and other ports in the mainland, they were scheduled to sail successively to Gaoxiong under the direct escort of the 9th Cruiser Division to assemble there. (Five ships were boarded and left on 15 January, six ships on the 16th, twenty-one ships on the 18th and the 19th, and, other than these, seven other ships were boarded and left from [other] ports on the mainland. Apart from these, one other ship joined in Gaoxiong by 4 February.) Most of the ships were scheduled to finish assembling by 25 January and then start the changing of ships and other [preparations].

The [allotted] transport ships were: the Aden-maru, the Biyo-maru, the Tsurushima-maru, the Tōho-maru [A], the Dainichi-maru, the Brazil-maru, the Tófuku-maru, the Taihei-maru, the Akagisanmaru, the Hōeisan-maru, the Taiei-maru, the Shinshi-maru, the Colombia-maru, the Pacific-maru, the Heian-maru, the Tōsei-maru, the Zuishō-maru, the Taizan-maru, the Haridono-maru [Somedono- 
maru?] the Fushimi-maru, the Erii-maru, the Uchide-maru, the Nichiwa-maru, the Suwa-maru, the Shinanogawa-maru, the Genoa-maru, the Toyooka-maru, the Tempei-maru, the Maebashi-maru, the Taketoyo-maru, the Teikai-maru, the Tatsuno-maru, the Atsuta-maru, the Sydney-maru, the Kaimeimaru, the Toyama-maru, the Ryōga-maru, the Kōyō-maru, and the Reiyō-maru. The hospital ships the Horrai-maru and the Mizuho-maru, and the air defense ships, the Ayato[san]-maru and the Ryūjo-maru were [also] included in the convoy.

\section{Operations related to the 48th Division}

The 45th Anchorage headquarters and the 121st Shore Duty Company were moved from Osaka to Gaoxiong. They boarded the transport ships for the 48th Division at Gaoxiong on 20 January [along with the division], and were seconded to the 48th Division commander in Lingayen. The 26th Independent Engineer Regiment, the 39th Sea Duty Company and the 68th Construction Duty Company were [also] made to board the transport ships for the 48th Division at Lingayen on 30 January.

Thirty-six transport ships, 210,000 tons in total were allotted to the division: the Yamagikumaru, the Kenkon-maru, the Hague-maru, the Nankō-maru, the Aden-maru, the Kōnan-maru, the Johore-maru, the Takaoka-maru, the Holland-maru, the Hokko-maru, the Kyokusei-maru, the Taiei-maru [Daiei-maru], the Kenzan-maru, the Anzan-maru, the Himalaya-maru, the Havre-maru, the Arizonamaru, the Chōkō-maru, the Nisshü-maru [Nichihide-maru], the Biyō-maru, the Italy-maru, the Asakamaru, the Kashu-maru, the Yoneyama-maru, the Hakuroku-maru [Hakushika-maru], the Teiyō-maru, the Hamburg-maru, the Denmark-maru, the Arabia-maru, the Tokushima-maru, the Miyadono-maru, the Jinsan-maru [Jinzan-maru], the Wales-maru, the Suez-maru, the Tamon-maru, and the Yasukawamaru. Apart from these, the Satsuma-maru, the Minryō-maru and the Hozugawa-maru were also assigned. Most of these ships were made to assemble by 31 January, and four ships by 4 February in Lingayen. Other than these, the faster ships, the Sasako-maru and the Sagami-maru, were made to leave Saigon on 31 January to arrive at Lingayen Gulf on 5 February. (The background of this will be described later.)

The transport convoys were assigned the following armed protection: ${ }^{(27)}$

[The convoy of] the 38th Division (including the Eastern Detachment and the Shōji Detachment) Three air defense ships were included, which mounted twenty-one antiaircraft guns, seven field guns and some antiaircraft machine guns. Since the number of transport ships for the 38th Division was twenty-nine ships in total, this meant one gun per transport ship on average.

[The convoy of] the 48th Division

To the total of thirty-six transport ships two air defense ships were added, which mounted twenty-four antiaircraft guns, thirty field guns and twenty-two machine guns, which meant two guns per transport ship on average.

[The convoy of] the main force of the Sixteenth Army

Forty transport ships were joined by two air defense ships, the Ayatosan-maru and the Ryūjomaru, which mounted forty-four antiaircraft guns, twenty-four field guns and twenty machine guns, which meant two guns per transport ship on average.

The reason why the captain general of the Shipping Transport Command arranged the shipping transport in the above-mentioned way was that he had received the following order from the commander in chief of the Southern Army on 30 December: ${ }^{(23)}$ 
Southern Army Operation Order A, No. 24

\section{Southern Army Order}

Saigon, 30 December

1. I intend to prepare for Operation $\mathrm{H}$ (note by the author: this indicates the Dutch East Indies operation in a broad sense and the Java operation in a narrow sense).

2. The captain general of the Shipping Transport Command shall conduct the preparatory transportation of the Sixteenth Army for Operation H. From now on, the 1st and the 2d Debarkation Group commanders shall be seconded to him in regard to the operation of ships allotted to the Southern Army and the shipping in preparation of Operation $\mathrm{H}$.

3. The following units shall be put under the command of the Sixteenth Army commander:

1st Debarkation Group headquarters ([from] the Fourteenth Army)

6th Independent Engineer Regiment (minus one company (minus two platoons)) ([from] the Fourteenth Army)

28th Independent Engineer Regiment ([from] the Fourteenth Army)

10th Independent Engineer Regiment (minus two companies (minus one platoon)) ([from] the Fourteenth Army)

14th Independent Engineer Regiment headquarters and one company ([from] the Twenty-fifth Army)

One company of the 26th Independent Engineer Regiment ([from] the Twenty-fifth Army)

Main force of the 5th Anchorage headquarters ([from] the Shipping Transport Command)

39th Sea Duty Company ([from] the Fourteenth Army)

59th Sea Duty Company ([from] the Twenty-fifth Army)

104th Sea Duty Company (minus one platoon) ([from] the Shipping Transport Command)

68th Construction Duty Company

The commanders of the Fourteenth and the Twenty-fifth Armies and the captain general of the Shipping Transport Command shall put the units which are listed above and which are under their command under the command of the Sixteenth Army commander. The transfer of command will start at 0000 on 10 January for the units to be transferred from the Fourteenth Army and at 0000 on 3 January for the units to be transferred from the Twenty-fifth Army and the Shipping Transport Command.

4. (Omitted by the author)

5. The commanders of the Fourteenth and the Twenty-fifth Armies shall put the following units under the command of the captain general of the Shipping Transport Command:

Main force of the 1st On-board Antiaircraft Artillery Regiment ([from] the Twenty-fifth Army) 2d On-board Antiaircraft Artillery Regiment (Its main force [from] the Twenty-fifth Army; an element [from] the Fourteenth Army)

1st Ship Repair Depot ([from] the Fourteenth Army)

2d Ship Repair Depot ([from] the Twenty-fifth Army)

Shipping Signal Regiment (Its main force [from] the Twenty-fifth Army; an element [from] the Fourteenth Army)

Vessel Launching Unit ([from] the Twenty-fifth Army)

Transfer of command will start at 0000 on 10 January.

(The rest omitted by the author.)

Based on this order from the Southern Army, the captain general of the Shipping Transport Command, Lt. Gen. Saeki Bunrō, issued on 1 January the following order and took the following measures:(23) 


\section{Chapter V / Decision to Advance the Java Operation and the Sixteenth Army}

\section{Order}

1 January

1. The Southern Army is preparing for Operation H. For that purpose, the units listed in Separate Volume No. 1 shall be newly put under the command of the Sixteenth Army commander and the units listed in Separate Volume No. 2 shall come back under my command. Further, from now on the 1st and the $2 \mathrm{~d}$ Disembarkation Group commanders shall be seconded to me in regard to the operation of ships allotted to the Southern Army and the shipping in preparation of Operation $\mathrm{H}$.

2. I intend to arrange the shipping for Operation $\mathrm{H}$.

3. The 1st Disembarkation Group commander [Maj. Gen. Itō Shinobu] shall handle the ship units (including boats, matériel, fuel; the same applies hereinafter.) to be newly put under the command of the Sixteenth Army commander based on Separate Volume No. 3 and prepare the shipping for Operation $\mathrm{H}$.

4. The $2 \mathrm{~d}$ Disembarkation Group commander [Maj. Gen. Tanabe Suketomo] shall closely cooperate with the 1st Disembarkation Group commander in regard to the transfer of the ship units listed in Separate Volume No. 3 that shall be removed from the command of the Twenty-fifth Army commander and put under the command of the Sixteenth Army commander.

5. The commanders of the 1st and the 2d On-board Antiaircraft Artillery Regiments shall be located in Saigon and in Gaoxiong respectively, and mainly prepare for antiaircraft and antisubmarine self-defense related to the shipping for Operation H based on Separate Volume No. 4, while continuing their current tasks. When the operation is conducted, they are supposed to directly take part in it as shall be instructed separately.

6. The commander of the Shipping Signal Regiment shall be located in Saigon, and mainly prepare for communications related to the shipping for Operation $\mathrm{H}$ according to Separate Volume No. 5 , while continuing his current tasks.

7. The commander of the 1st Ship Repair Depot shall still continue his current tasks in Singora. The commander of the 2d Ship Repair Depot shall visit Cam Ranh and Gaoxiong, repair broken or damaged vessels, and arrange matériel related to the shipping for Operation S (note by the author: the Endau and Mersing operation) and Operation $\mathrm{H}$, while preparing for subsequent actions.

8. The commander of the Vessel Launching Unit shall conduct the move involved in the transfer of the ship units listed in item 4. After that, he shall prepare the movement of ships for Operation $\mathrm{H}$.

9. Colonel Yoshimura in Ujina shall be assigned to prepare the shipping for Operation $\mathrm{H}$, in particular, to make a plan and arrange the shipping of the $2 \mathrm{~d}$ Division, the units attached to the division, and the units under the direct control of the [Sixteenth] Army that accompany the division.

10. The commander of the Southern China Shipping Unit shall prepare the shipping for Operation $\mathrm{H}$ in Guangdong and Hong Kong. In particular, he shall arrange the embarkation of the 38th Division.

11. The 1st Anchorage superintendent shall prepare the shipping for Operation $\mathrm{H}$ in Saigon and Cam Ranh. In particular, he shall facilitate the arrangements at the assembly spot of the transport ships in Cam Ranh.

12. The commander of the Gaoxiong Anchorage shall prepare the shipping for Operation $\mathrm{H}$ in Taiwan. In particular, he shall facilitate the arrangements at the assembly spot of the transport ships.

13. Colonel Yoshimura in Ujina, the commander of the Southern China Shipping Unit, the 1st Anchorage superintendent and the commander of the Gaoxiong Anchorage shall cooperate with each unit concerned in regard to the shipping in items 3 to 8 above.

14. I shall be in Saigon. 
(Separate Volume No. 1) (Omitted by the author. Southern Army Operation Order A, No. 24-3) (Separate Volume No. 2) (Omitted by the author. Same as above No. 24-5)

(Separate Volume No. 3)

Operation H, Ship Units Allotment Plan

Detachment B (with two battalions of the 38th Division as its core):

An element of the 5th Anchorage headquarters

One company of the 14th Independent Engineer Regiment

One half platoon of the 104th Sea Duty Company

Boats: 2 extra-large [motorized landing] craft, 20 large motorized [landing] craft, 20 small motorized [landing] craft, 1 armored craft, 1 Type-A high-speed craft, and 1 Type-B high-speed craft.

Main force of the 38th Division:

Main force of the 5th Anchorage headquarters

Headquarters and one company of the 14th Independent Engineer Regiment

One company of the 26th Independent Engineer Regiment

104th Sea Duty Company (minus one and a half platoon)

67th Construction Duty Company (from the mainland)

Boats: 8 extra-large [motorized landing] craft, 35 large motorized [landing] craft, 35 small motorized [landing] craft, 1 armored craft, 1 Type-A high-speed craft, and 1 Type-B high-speed craft, and 20 boats with Yanmar engines.

48th Division:

45th Anchorage headquarters

28th Independent Engineer Regiment

121st Shore Duty Company (from the mainland)

39th Sea Duty Company (minus one platoon)

50th Construction Duty Company

Boats: 10 extra-large [motorized landing] craft, 60 large motorized [landing] craft, 60 small motorized [landing] craft, 2 armored craft, 2 Type-A high-speed craft, and 2 Type-B high-speed craft, 30 boats with Yanmar engines, and 10 small lighters

\section{2d Division:}

40th Anchorage headquarters

Headquarters, two companies, and two platoons of the 6th Independent Engineer Regiment

Two platoons of the 10th Independent Engineer Regiment

120th Shore Duty Company

One platoon of the 39th Sea Duty Company

59th Sea Duty Company

65th Construction Duty Company

Boats: 10 extra-large [motorized landing] craft, 60 large motorized [landing] craft, 60 small motorized [landing] craft, 2 armored craft, 2 Type-A high-speed craft, and 2 Type-B high-speed craft, 30 boats with Yanmar engines, and 10 small lighters

As previously described, the sudden advancement of [the schedule of] the Java operation brought absolute chaos to the shipping operations. On the night of 31 December, Lieutenant General Saeki, captain general of the Shipping Transport Command, sent from the Saigon command post the following classified military telegram (note: classified military telegrams are sent by priority) in order to unify the transport: ${ }^{(23,27)}$ 
The situation has changed. From now on, all ships involved in the southern operation shall be operated under the orders of Saigon regardless of the original plan or the directions from Ujina.

With this telegram, [control of] the movements of the transport ships was changed and taken over by Saigon. By 2 January, it succeeded in bringing everything under the sole command of Saigon. ${ }^{(27)}$

As previously described, the Southern Army issued an order to transfer the 1st Disembarkation Group to the Sixteenth Army on 30 [December], when the 1st Disembarkation Group was assembling in Gaoxiong after the Philippines operation. On 5 January, Maj. Gen. Itō Shinobu, commander of the group flew from Gaoxiong to Saigon, where he re-

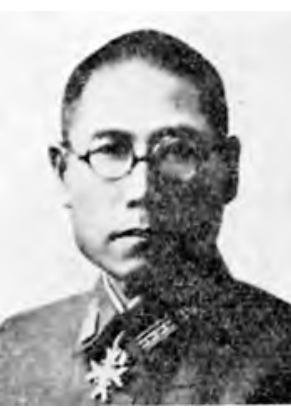

1st Disembarkation Group Commander Maj. Gen. Itō Shinobu ceived orders from the headquarters of the Southern Army and the command post of the Shipping Transport Command, and returned to Gaoxiong. [He] came under the command of the commander of the Sixteenth Army on 10 January. ${ }^{(94)}$

\section{Transfer of the 38th and the 48th Divisions [to the Sixteenth Army]}

As previously told, IGHQ ordered the change in the order of battle of the 38th and the 48th Divisions on 4 January and 14 January respectively. For the 38th Division, which had held a triumphal entry into Hong Kong on 28 December, and was assembling to prepare for its next operation, ${ }^{(53)}$ this posed no problems. However, the 48th Division, which had seized Manila on 2 January, was [still] facing the U.S.-Filipino Army on the Bataan Peninsula and the situation in Bataan was rather precarious. At that time, the Southern Army was considering to divert the 48th Division and many other ground units to the Java operation and to divert the Fifth Air Force to the Burma operation; in fact, it had already ordered the air unit on 1 January to prepare itself. ${ }^{(23)}$ In order to discuss the diversion of forces [with the Fourteenth Army] and arrange it to their mutual satisfaction, Commander in Chief of the Southern Army Terauchi dispatched Aoki Shigemasa, vice chief of staff of the Southern Army, [to the Philippines]. Lieutenant General Aoki dropped by the headquarters of the Fourteenth Army in Cabanatuan on 4 January and went on to Manila on 5 [January], where he conferred with the chief of staff of the [Fourteenth] Army, Lt. Gen. Maeda Masami, and other officers. ${ }^{(23,53)}$ The Fourteenth Army agreed on the whole, but made the following requests: ${ }^{(53)}$

1. It would like the extraction of the Independent Engineer Regiment (A) and the Railway Regiment to be reconsidered because [many] roads and railways on Luzon Island had been destroyed.

2. The extraction of the 48 th Division from the Bataan front required that the 65 th Infantry Brigade (which had started landing around Lingayen on 1 January) would take its place. In addition, [the army] would like to hold a memorial service in Manila around 15 January before the diversion of troops to other theaters. Therefore, it would like the diversion to be implemented after that date.

3. It would like the heavy bomber air groups and fighter plane air groups to remain [in the Philippines].

In response to [these requests], Lieutenant General Aoki stated that leaving the Railway Regiment was reasonable, but that the 48th Division should be assembled in Lingayen in time 
for boarding the ships between 1 and 7 February for the Java operation, and that leaving the air unit [in the Philippines] would be very difficult. ${ }^{(53)}$ He returned to Saigon on the 8th, ${ }^{(24)}$ where it was decided that the diversion of the 48th Division would be implemented as discussed with the Fourteenth Army; that, regrettably, from the railway regiment one battalion would be transferred to the Sixteenth Army, while its main force (consisting of two battalions) would be kept [in the Philippines]; that the heavy field artillery [units] which the 48th Division requested to keep under its command would not be extracted from the Fourteenth Army and that those for the Sixteenth Army would be transferred from the Twenty-fifth Army (note: the heavy field artillery [units] to be transferred from the Twenty-fifth Army were still in Manchuria), and that all of the Fifth Air Force would be diverted to the Thailand theater, etc. ${ }^{(24)}$ On the same day, the Southern Army immediately issued an order to divert the Fifth Air Force, ${ }^{(23)}$ and also issued orders to successively divert the ground units to the Sixteenth Army, as will be explained later.

The diversion of the 48th Division, which after seizing Manila was spearheading the attack on Bataan, should have been a matter of careful consideration. However, at that time, the thought of bringing forward the Java operation was dominant, and the staff officers of the IGHQ who accompanied Lieutenant General Aoki as observers also held the same view as the Southern Army. [So] on 9 January, the 48th Division was relieved on the front line by the 65th Brigade. ${ }^{(80)}$

\section{The Transfer of Other Units}

Along with the decision to bring forward the Java operation, the Southern Army issued the following orders for the transfer of units to the Sixteenth Army: ${ }^{(23)}$

Southern Army Operation Order A, No. 24 of 30 December:(23)

The 1st Disembarkation Group headquarters and other units related to shipping, eleven units in total (described above)

Southern Army Operation Order A, No. 25 of 1 January:(23)

One company of the 14th Independent Engineer Regiment (D)

This unit handled the shipping of the Eastern Detachment, which [the Army Department of] IGHQ had transferred from the Twenty-third Army to the Southern Army.

Southern Army Operation Order A, No. 27 of 3 January: ${ }^{(23)}$

The 23d Antiaircraft Artillery Regiment (minus the Antiaircraft Searchlight Company)

This unit was ordered to transfer from the Imperial Guard Infantry Group in Saigon to the command of the Sixteenth Army.

Southern Army Operation Order A, No. 29 of 4 January:(23)

The 50th Construction Duty Company

This unit was transferred from the Fourteenth Army to the command of the Sixteenth Army, and simultaneously the 68th Construction Duty Company, which was delayed, was put under the command of the Fourteenth Army [instead].

Southern Army Operation Order A, No. 30 of 4 January:(23)

The 2d Tank Regiment (minus [one] light tank squadron), the 45th Independent Motor Transport Battalion, and the 212th, the 307th, and the 308th Independent Motor Transport Company

These units were under the command of the Twenty-fifth Army, but still were stuck north of Taiwan due to transport delays.

Southern Army Operation Order A, No. 33 of 5 January:(23) 
The 34th Field Antiaircraft Artillery Battalion (B) and the 35th Field Antiaircraft Artillery Battalion (minus one battery) (B)

These were also under the command of the Twenty-fifth Army.

Southern Army Operation Order A, No. 37 of 15 January:(23)

An element of the 25th Air Signal Unit (i.e. two radio squads), an element of the 2d Meteorological Company (two weather observation details), and the 7th and the 33d Airfield Companies

These units were transferred from the air unit of the Southern Army to the command of the Sixteenth Army in Cam Ranh, and were expected to accompany the 38th Division's units in the capture of Sumatra to repair and make the air bases ready for use.

Southern Army Operation Order A, No. 38 of 15 January: ${ }^{(23)}$

The 4th Air Ground Support headquarters, the 24th Airfield Battalion, the 28th Airfield Battalion, an element of the 1st Air Signal Regiment, the 9th Field Airfield Construction Unit, an element of the 9th Field Aircraft Repair Depot, the 298th Independent Motor Transport Company, the 123d Ground Duty Company, and the 4th Meteorological Company

These units were engaged in the Philippines operation under the orders and command of the Fifth Air Force. Aiming to transfer these units to the Sixteenth Army to have them promptly repair air bases upon seizing them, the Southern Army, already on 1 January, had ordered that "[the units] shall prepare for redeployment to take part in the Dutch East Indies operation under the command of the Sixteenth Army." (23)

The 8th and 10th Independent Antitank Gun Companies, the 4th Tank Regiment, the 45th and the 48th Field Antiaircraft Artillery Battalions (B), the 30th and the 31st Independent Field Antiaircraft Artillery Batteries, the 3d Independent Engineer Regiment (A), one battalion of the 6th Railway Regiment and an element of the Material Depot, the 5th, the 51st, and the 52d Independent Radio Platoons (motorized), the 40th Fixed Radio Unit, the 26th Bridge Building Material Company, the 13th and the 14th River-crossing Material Companies, the 209th, the 258th, and the 259th Independent Motor Transport Companies, the 38th Patient Transport Platoon, and the 8th Water Supply and Purification Department

These units were engaged in the Philippines operations. As previously described, their transfer from the Fourteenth Army was decided upon as a result of the conference with the vice chief of staff [of the Southern Army], Aoki.

The 138th Railway Depot Headquarters (B)

This unit was expected to move from French Indochina to Gaoxiong, come under the command of the Sixteenth Army, and conduct works related to the capture of the railway [system] in Java.

Southern Army Operation Order A, No. 41 of 18 January:(23)

The 28th Motor Transport Regiment

This unit used to be under the command of the Twenty-fifth Army and was in Gaoxiong at that time.

As previously mentioned, the transfer of the majority of the above units was later ordered by [the Army Department of] IGHQ in the form of a change in the order of battle.

\section{The Order for Capturing Java}

Due to developments that will be explained later, the capture of Tarakan and Menado was carried out on 11 January, a day behind schedule ([as specified in] the Cam Ranh Agreement, i.e. General Agreement No. 4). 
After that, the Navy met with difficulties and found it increasingly impossible to keep to the schedule of the Cam Ranh Agreement. On 19 January, the Southern Army received a telegram from the Navy Southern Task Force in which it requested a delay of about ten days in the schedule. However, the Southern Army was firmly determined to carry out the operation as specified in the Cam Ranh Agreement. Knowing that the Sixteenth Army had yielded to the request of the Navy Dutch East Indies Unit and postponed the capture of Tarakan by one day (from 10 to 11 January), the scheduled date of the capture of Balikpapan by four days (from 20 to 24 January) and that of Ambon by 6 days (from 25 to 31 January, the details of which will be described later), the Southern Army was displeased about this and the next day, the 20th, it resolutely issued the following order to carry out the capture of Java: ${ }^{(23,24)}$

\section{Southern Army Order}

Saigon, 20 January

1. The overall operations of the Southern Army are progressing as scheduled.

2. In conjunction with the Navy, I intend to swiftly capture Java. The cooperation with the Navy shall be based on General Agreement No. 2 and No. 4.

3. The commander of the Sixteenth Army shall swiftly capture Java in the following manner:

(a) Exploiting the results of having gained command of the air over Java, he shall land his main force in western Java and almost simultaneously an element [of his army] in eastern Java. When conducting the landing operations, he should expect interference from the naval and air forces of the enemy.

(b) After the landing, he shall defeat the enemy and promptly seize Batavia, Surabaya and Bandung.

(c) He shall swiftly make air bases in Java ready for use.

4. The commander of the Third Air Force shall assist in the Sixteenth Army's operation in the following manner:

(a) As soon as the airfields on Bangka Island and southern Sumatra have been made ready for use, he shall advance there, without missing an opportunity, as much strength as possible, swiftly destroy the enemy air power in western Java, and directly and closely assist in the landing operations of the main force of the Sixteenth Army.

(b) As soon as the air bases in Java are ready for use, he shall swiftly advance an element of his group.

5. The captain general of the Shipping Transport Command shall closely assist in the operations conducted by the commanders of the Sixteenth Army and the Third Air Force.

6. I shall [command from] Saigon.

Count Terauchi Hisaichi, commander in chief of the Southern Army

\section{The [Navy] Southern Task Force's Shift to Phase-Two Operations}

\section{The Shift to Phase-Two Operations}

As previously told, the Southern Army had divided the southern operation into three stages, and set the capture of the Philippines, Malaya and British Borneo as the first stage and the capture of Java as the second stage. On the other hand, as previously mentioned, the Navy Southern Task Force had divided the southern operation into four stages, and set the period up to the completion of covering the landing of the main force of the Fourteenth Army in 
the Philippines as the first stage, the period up to the completion of covering the landing of the main force of the Twenty-fifth Army in Malaya as the second stage, and the Java operation as the third stage.

As already mentioned, the Navy's shift to phase-two operations was implemented first by the Malaya Unit (the Southern Expeditionary Fleet), then by the Combined Fleet, then by the Southern Task Force (the Second Fleet), then by the Philippines (Dutch East Indies) Unit (the Third Fleet), and then by the Air Unit (the Eleventh Air Fleet), in that order.

The Malaya Unit: On having completed the escort of the first transport of the Malaya advance corps (consisting of the main force of the 5th Division, the Takumi Detachment, etc.) and the covering of its landing (on 8 December), the covering of the landing (on 16 December) of the second transport of the Malaya advance corps (the horse trailers of the units in the first transport, etc.), the escort and the covering of the landing of the British Borneo Unit (the Kawaguchi Detachment) (in Miri on 16 December and in Kuching on the 24th, which on the 20th was rescheduled from the 21st to the 24th), and moreover on having concluded an arrangement (General Agreement No. 3) with the Southern Army on the escort for subsequent transports (such as those of the three battalions of the 5th Division, and the main force of the 18th and the 33d Divisions, etc.), the Malaya Unit issued an order to shift to second phase dispositions on the $23 \mathrm{~d}$ and implemented it on the $24 \mathrm{th} .{ }^{(118)}$ The contents of the arrangement concluded on the $23 \mathrm{~d}$ were as follows: ${ }^{(23)}$

1. The Koba Detachment, which would leave Cap Saint Jacques on 26 December and land in Kuantan on 31 December via Singora, would be directly escorted by an element of the 3d Destroyer Squadron.

2. The three battalions of the 5th Division, the first [transport] units under the direct control of the Twenty-fifth Army, the main force of the 33d Division, and the units under the direct control of the Fifteenth Army, which were to assemble in Magong from the mainland, Manchuria and Korea, Taiwan and China, would be directly escorted by the core unit of the 5th Destroyer Squadron, temporarily transferred from the Philippines (Dutch East Indies) Unit. They were scheduled to leave Magong on 31 December, and land in Singora and southern French Indochina on 7 and 5 January respectively.

3. The main force of the 18th Division, which was scheduled to leave Guangdong on 7 January, arrive in Cam Ranh on the 10th, leave the bay on the 13th, and land in Endau and Mersing on the 17th, would be directly escorted by the $3 \mathrm{~d}$ Destroyer Squadron.

The Combined Fleet: Despite the fact that the Southern Task Force was critical of bringing forward the Java operation, the Combined Fleet discussed it with the Navy General Staff, and sent a telegram on the 24th that it agreed to the idea of bringing forward the Java operation, that it was hoping in particular for an early seizure of Ambon, and that it was [also] considering letting the $2 \mathrm{~d}$ Carrier Division take part in the operation. It transmitted a preliminary order on the next day (the 25th) that it would shift to phase-two dispositions two days ahead of schedule, and implemented the shift as of 1200 on the next day, the 26 th. $^{(117,119)}$

The commander of the Southern Task Force had departed from Cam Ranh Bay on the 20th with his main unit to provide cover for the landing of the main force of the Fourteenth Army around Lingayen Gulf (expected to start on 22 December). The landing of the Fourteenth Army went smoothly, and since on the other hand the moment to launch the Dutch East Indies operation was drawing near, he issued an order on the $23 \mathrm{~d}$ to form and dispatch 
the Eastern Support Unit (note: the Eastern Support Unit reached Magong on the same day, then headed for the waters southeast of Mindanao), while he himself returned to Cam Ranh Bay with the rest of his main unit on the 24th. There he received the order of the Combined Fleet to shift to phase-two dispositions, and on the 26th he gave orders to shift to phase-two dispositions. At the same time, he decided to have the 5th Destroyer Squadron, which had been diverted to the Malaya Unit from the Philippines (Dutch East Indies) Unit, rejoin the Philippines (Dutch East Indies) Unit upon completion of its escort duties from Magong to French Indochina and Malaya. ${ }^{(117,118,119,120)}$ As for himself, partly due to the cancellation on the 27th of the Kuantan landing operation, he decided to leave Cam Ranh Bay after concluding agreements with the Southern Army (on and after the 29th [of December]) with his main unit on 9 January, sail to Magong for replenishments, and leave Magong on the 14th to advance to Palau. He gave his orders on 28 [December] and advanced to Palau on 18 January. ${ }^{(103,}$ ${ }^{120)}$ The phase-two operational policy of the Southern Task Force was as previously described.

The commander of the Philippines (Dutch East Indies Unit) had sallied forth from Magong on the 19th with his main unit to support the landing of the main force of the Fourteenth Army around Lingayen. As the landing seemed to go smoothly, he returned to Magong on the 23d, where, when learning that the landings in Davao on the 20th had been successful, that the Southern Task Force had issued an order to form and dispatch the Eastern Support Unit on the 23d, that the landing by the main force of the 16th Division around the Lamon Bay on the 24th had started smoothly, that the landing in Jolo on the 25th had been successful, that on the 26th, the Southern Task Force had ordered the shift to phase-two dispositions, and that on the 28th, the Southern Task Force had ordered that its main unit should change course toward Palau, he [also] ordered the Philippines (Dutch East Indies) Unit on the 28th to shift the disposition of its forces to phase-two dispositions. [Then] on 2 January, he left Gaoxiong with his main unit, and advanced to Davao on 6 January. ${ }^{(102,103,117)}$

All this had come about in the following way: First, the Southern Army had proposed the Kuantan, Endau and Mersing operations (on 12 December) and urged the [Navy] Malaya Unit to shift to phase two at an earlier date; then it proposed the advancement of [the schedule of] Java operations to [the Army Department of] IGHQ and the [Navy] Southern Task Force (19-21 December); this was supported by IGHQ and the Combined Fleet (on the 24th); the Combined Fleet urged the Southern Task Force, which then ordered the Philippines (Dutch East Indies) Unit to shift to phase-two dispositions. [At that time,] the air unit (the Eleventh Air Fleet) had not yet shifted to phase two. The chief of staff of the Combined Fleet, Rear Admiral Ugaki, considered the situation and concluded that "[at least things were] carried out as scheduled in the Central Agreement of November." (108) On 2 January, the air unit issued an order to shift the disposition of its forces to phase-two dispositions. ${ }^{(17)}$ The Eleventh Air Fleet headquarters [finally] advanced from Gaoxiong to Davao on 7 January. The 23d and the 21st Air Flotilla headquarters advanced from Gaoxiong and Palau to Jolo and Davao on 3 January and 27 December respectively. ${ }^{(102,104)}$

\section{The Dutch East Indies Unit's Phase-Two Mission}

On 3 January, [the Navy Department of] IGHQ organized the Third Southern Expeditionary Fleet [for operations] in the Philippines, and changed the name of the Southern Expeditionary Fleet into the First Southern Expeditionary Fleet on the same day. ${ }^{(1,101)}$ The [Navy] Philippines 
(Dutch East Indies) Unit, which started operations as the Philippines Unit at the opening of hostilities, became the Dutch East Indies (Philippines) Unit as of [the start of] phase-two dispositions on 28 December, and started preparing for the Dutch East Indies operation with its main force, while leaving behind an element for the Philippines operations. [With the establishment of the Third Southern Expeditionary Fleet], it fully became the Dutch East Indies Unit on 3 January.

On 29 December (the day when the Cam Ranh Agreement was concluded), Commander in Chief of the Third Fleet V. Adm. Takahashi Ibō issued in Magong the phase-two operation plan by means of the Dutch East Indies (Philippines) Unit Order No. 3, Classified. Its main points are in extract as follows: ${ }^{(10)}$

\section{Information on the Enemy and the Situation of Friendly Forces}

(1) The U.S. Pacific Fleet was almost completely destroyed at a stroke at the opening of hostilities, and for the present there is no possibility of a transoceanic attack by its main force. (2) Although the movements of the U.S. Asiatic Fleet are unknown since the opening of hostilities, it is almost certain that it has already pulled back into or south of the Celebes Sea. The movements of the British Far East Fleet are also unknown after its main force was completely destroyed. However, it is highly likely that the U.S. and British fleets in the East will join the Dutch fleet and come out in an allied defensive battle chiefly in the waters of the Dutch East Indies and Australia. (3) Although the U.S., British and Dutch submarines have incurred some losses, most of them still frequently appear everywhere, and it is expected that from now on many will be active especially in the Dutch East Indies waters. (4) Although the U.S. air units in the Philippines were almost completely destroyed, some of them have fled to the Dutch East Indies area and it seems that they are planning to counterattack along with the British and the Dutch air forces. (5) Judging from geographical features and the armaments of the Dutch forces, it is necessary to be on the alert for enemy mines in the Java Sea and the southern part of the South China Sea. (6) The air unit of the Southern Task Force has already advanced some elements into Davao and Jolo and been conducting operations against area $\mathrm{H}$ (note by the author: the Dutch East Indies). Their deployment is expected to be complete around 5 January. (7) The $2 \mathrm{~d}$ Carrier Division is scheduled to be incorporated in the air unit of the Southern Task Force around 16 January. (The rest omitted by the author.)

\section{The Plan}

Based on the mission [stated in] the Philippines Unit Order No. 1, Classified, the Dutch East Indies Unit shall, in cooperation with the air unit of the Southern Task Force and the Sixteenth Army, capture Tarakan and Menado first, and one after another seize and advance into strategic points in the Makassar Strait, the Molucca Sea and the Banda Sea. At the same time, acting in concert with friendly forces [such as] the Southern Expeditionary Fleet and the Malaya invasion army, it shall push forward with the encirclement of Java to swiftly capture Java at the center.

\section{Operational outline}

1. By securing close cooperation and contact with friendly air units, we expect to sally forth while having command of the air as much as possible.

2. Against enemy submarines and mines strong direct escort forces shall be employed, and by having them closely cooperate with the base forces and the air unit, we are determined to maintain a perfect surface escort and landing cover.

3. Against the enemy surface forces, first of all sufficient forces shall be employed so that such an enemy force can be destroyed [just] by the escort forces on site. In addition to this, efforts shall 
be made to catch and destroy such [an enemy surface force], in concert with the search and attack [operations] of strong support units and friendly air units.

4. As for the capture of strategic points in the Dutch East Indies, the destruction and seizure of the enemy's important air bases shall be the principal objective, and we aim to advance simultaneously in the east and the west by and large in the following order and schedule:

(a) The areas in eastern Celebes, to the east of it, and the Banda Sea

Solely by the Navy: Menado (around 10 January) $\rightarrow$ Kendari (around 20 January) $\rightarrow$ Makassar (to be captured around 25 January - 14 February, seizing a favorable opportunity.)

Solely by the Army: Ambon (around 25 January) $\rightarrow$ Kupang (around 5 February)

(b) The area of the Makassar Strait and eastern Java

In conjunction with the Army: Tarakan (around 10 January) $\rightarrow$ Balikpapan (around 20 January) $\rightarrow$ Banjarmasin (around 30 January) $\rightarrow$ Surabaya area (around 16 February)

Depending on the situation, in conjunction with the Army: capture of Makassar around 5 February, and also Bali almost simultaneously with the capture of Surabaya.

(c) Western Java

In conjunction with the Army: Batavia area (around 16 February)

Distribution of Forces (summarized by the author)

Main unit: the main force of the 16th Cruiser Division

Western Attack Unit:

1st Escort Unit: the main force of the 4th Destroyer Squadron as its core

$2 \mathrm{~d}$ Base Unit: the main force of the $2 \mathrm{~d}$ Base Force as its core

1st Air Unit: the auxiliary seaplane tenders the San'yō-maru and the Sanuki-maru as its core

3d Escort Unit: the 5th Destroyer Squadron (after rejoining [the Dutch East Indies Unit])

Eastern Attack Unit:

Support Unit: the 5th Cruiser Division as its core

2d Escort Unit: the main force of the 2d Destroyer Squadron as its core

1st Base Unit: the main force of the 1st Base Force as its core

2d Air Unit: the 11th Seaplane Tender Division as its core

Eastern Philippines Unit: the 32d Special Base Force as its core

Western Philippines Unit: the 17th Minelayer Division as its core

Mission of Each Unit (summarized by the author)

The main unit shall stay on the alert in Malalag Bay (note: inside Davao Gulf); depending on the information on the enemy, it shall sail towards Celebes and the Makassar Strait. It mainly covers the Western-Attack Unit.

The 1st Escort Unit shall escort the Sakaguchi Detachment, leave Davao around 7 January, anchor at sea east of Cape Batu on Tarakan Island before daybreak on 10 January, put the detachment ashore, join the invasion and secure the air base to advance a unit of the Eleventh Air Fleet. [Then] it shall have the 2d Kure Special Landing Force replace the Army unit, escort the Sakaguchi Detachment, leaving Tarakan around 18 January, put the detachment ashore in Balikpapan before daybreak around 20 January, join them in seizing the air base and resource areas, and advance the air unit of the Eleventh Air Fleet. Next, it shall escort an element of the Sakaguchi Detachment, leaving Balikpapan around 28 January, invade Banjarmasin before daybreak around 30 January, and secure the enemy's air base. In the event that the 1001st Unit (a paratroop unit) shall cooperate in the operation, a special order shall be issued.

The 2d Base Unit shall take on the defense of Tarakan and Balikpapan, and other related tasks.

The 1st Air Unit shall cooperate with the 1st Escort Unit by providing guard against submarines and support in the landing attacks. 
The 3d Escort Unit shall sail to Gaoxiong after rejoining from the Malaya Unit, escort the main force of the Sixteenth Army from there, leave Gaoxiong (Magong for part of the army) on 30 January, sail to Cam Ranh Bay, leave the bay on 11 February, and put the army ashore in Batavia and the vicinity on 16 February. An element of the Southern Expeditionary Fleet shall cooperate with the unit.

The Support Unit of the Eastern Attack Unit shall provide cover and support in the capture of Menado, Kendari, Ambon, Makassar and Kupang, etc. and [also] be on the watch for the direction of Australia.

The 2d Escort Unit shall leave Davao on 8 January, and capture Menado in a raid on 10 January to advance a unit of the Eleventh Air Fleet. Then it shall have an element of the force participate in a predawn raid on Kendari under the command of the 1st Base Force commander around 20 January, and provide cover [for the operation] with most of its force. After that, it shall escort Detachment B of the Army from Menado to Ambon (Detachment B is to be escorted from Davao to Menado beforehand by an element of the 2d Escort Unit after the capture of Menado), capture Ambon around 25 January, and secure its airfield. Then, it shall further escort Detachment B (depending on the situation, an element of its force shall be left behind in Ambon), and in conjunction with the detachment, prepare for the capture of $\mathrm{Ku}$ pang [to be carried out] around 5 February. [Possible] use of the 1001st Unit (the paratroop unit) shall be determined by a later order.

The 1st Base Unit shall guard the anchorage in Bangka (note: north of Menado) after the capture of Menado. Then it shall conduct a sudden predawn attack on Kendari with most of the unit and an element of the $2 \mathrm{~d}$ Escort Unit under its command around 20 January under the cover of the $2 \mathrm{~d}$ Escort Unit, and secure the air base [there] to advance an air unit of the Eleventh Air Fleet. Depending on the situation, it shall capture Makassar.

The 2d Air Unit shall cooperate with the 2d Escort Unit by providing guard against submarines and support in the landing attacks.

The Eastern Philippines Unit, the Western Philippines Unit (omitted by the author)

The Dutch East Indies Unit issued the above orders, but compared with the Cam Ranh Agreement (i.e. General Agreement No. 4 of 1 January) the following differences appear:

1. The schedule and the outline of the capture of Makassar were not fixed due to a shortage of strength.

2. Complying with the strong wish of the Combined Fleet, the capture of Kupang was scheduled six days ahead of the plan specified in the Cam Ranh Agreement.

3. Complying with the strong wish of the Eleventh Air Fleet, the capture of Bali (airfield) was [also] included in [this] plan, which was not the case in the Cam Ranh Agreement. And so, due to the tight schedule and a shortage of strength, it was decided to conduct it as a detached operation of the Java landing operation.

\section{Departure of the Headquarters of the Sixteenth Army and Revision of Its Operation Plan}

\section{Issue of the Order to Assemble and Departure of the Headquarters of the Army}

As previously described, the Sixteenth Army headquarters ([still] at the War College) had planned "to depart from the mainland after the New Year, around mid-January," when out of the blue a telegram came from Staff Officer Oda, who had arrived in Saigon on 23 Decem- 
ber, saying: "[the idea of] bringing forward the Java operation by about one month is being studied, and the presence of the army commander and the chief of staff is urgently requested," which was followed by a telegram from the Southern Army pressing [the headquarters] to come over. ${ }^{(35,36,38)}$

On the 25th, Army Commander Imamura decided "to advance the command post of the army from Tokyo to Saigon on the 29th and its headquarters to Gaoxiong," and he issued an order on the 27th to the $2 \mathrm{~d}$ Division and the units under the direct control of the army to assemble in Gaoxiong, Taiwan, to prepare for the subsequent operations. ${ }^{(32,33)}$ At that time, the $2 \mathrm{~d}$ Division headquarters was in barracks on the Narashino Maneuvering Grounds.

Where to set up the headquarters of the army was a problem. Gaoxiong was a wellequipped major shipping base where not only the $2 \mathrm{~d}$ Division, but also various other units of the Sixteenth Army transported from the mainland, Manchuria and Korea, and China would assemble, complete preparations for the operations, sort out the order of embarkation, etc. On the other hand, Saigon was the place where the headquarters of the Southern Army and the command post of the Shipping Transport Command were located, and it was [also] close to Cam Ranh Bay, which was the base of the Navy and the transit point for the 38th Division. But then again, Taipei was the seat of the Taiwan Army headquarters and the transport and communications hub in Taiwan. Considering the advantages and disadvantages of each place, the army commander decided to [first] set up his command post in Saigon, his headquarters in Gaoxiong, and his liaison office in Taipei, and [later] close the command post and the liaison office as the situation changed. ${ }^{(35,36,38)} \mathrm{He}$ also decided that he would go ahead to Saigon by plane, accompanied by his chief of staff, both senior staff officers, his [chief of] aviation staff, Itoda, his [chief of] signal communications staff, Saiki, and his intelligence staff, Murakami and Kuriya, and a communication code officer to set up the command post, while he would have his vice chief of staff, Harada, fly to Gaoxiong beforehand in another plane accompanied by other staff officers, to wait for the arrival of the army headquarters coming in by ship and simultaneously conduct other tasks in Gaoxiong and Taipei as well. ${ }^{(35,36,38)}$ As a result, before being reunited with his army headquarters on 17 February, the army commander and his chief of staff were only present at the army headquarters from 19 to 21 January and from 25 January to 3 February. In this period, the staff of the army headquarters in Gaoxiong, the shipping staff in particular, had to rack their brains [to coordinate the situation]. ${ }^{(32,44)}$

Due to a lack of available flights, Army Commander Imamura finally took off together with the personnel of the command post at 1500 on the 30th. He stopped over at Akeno, offered a prayer for victory at the Ise Shrine, and left Yamada on the next day, the 31st, for Shanghai first. However, due to trouble with the aircraft, the plane made an emergency landing on Cheju Island. ${ }^{(32,33,34)}$

\section{Makeshift Measures for the 38th Division}

The army commander and his group, who were forced to start the year 1942 on an isolated island in southern Korea, left Jeju Island at 1700 on 1 January (the day when the Cam Ranh Agreement was signed), spent the night in Shanghai, flew from Shanghai to Taipei on the next day, the $2 \mathrm{~d}$, and arrived at Taipei airfield at 1100. At the headquarters of the Taiwan Army they received telegrams notifying them of "the advancement of the schedule of the 
[Java] operation," "Detachment B's embarkation on 6 January and its departure from Hong Kong on 9 January," and other matters. ${ }^{(34)}$ Learning that Detachment B would head for Ambon after calling at Davao, they immediately sent a telegram to order the Sakaguchi Detachment in Davao to transfer an antiaircraft artillery battery to Detachment B at Davao. ${ }^{(36)}$ Staff Officer [of the Army Department] of IGHQ Sejima Ryūzō, who was visiting Taipei after attending the Cam Ranh Agreement, informed them that "military radio [units] required for Detachment B will be transferred from the Twenty-third Army ([in] southern China)," and also shared with them lessons learned in the Malaya operation. ${ }^{(34)}$ After that, the Army commander and his group left Taipei for Guangdong at $1330 .{ }^{(34)}$ On the next day, the $3 \mathrm{~d}$, they hurriedly gave the necessary briefings at Guangdong airfield to the chief of staff of the 38th Division, Col. Abe Yoshimitsu, its chief of operations staff, Maj. Oyadomari Chōsei, and Maj. Tosaka Susumu, staff officer of the 38th Division assigned to the Eastern Detachment (Detachment B), and [finally] arrived in Saigon via Tourane that evening. ${ }^{(32,34,36)}$

Note: According to documents [kept by] Staff Officer Tosaka, the 38th Division had been given the order on 30 December by the Twenty-third Army commander "to form a detachment, consisting of one infantry regiment and one artillery battalion under the command of the infantry group commander as its core, so as to be suitable for an operation on an isolated island, and be ready for embarkation in Hong Kong on 6 January and departure on 9 January."

\section{Reception of the Order to Prepare for the Capture of Java and Making Arrangements with the Navy}

The [Sixteenth] Army commander and his officers received a report from Staff Officer Oda, and were [further] given details on the advancement of [the schedule of] the Dutch East Indies operation at the Southern Army headquarters the next day, the 4 th. ${ }^{(24,36)}$ On that day, [the Army Department of] IGHQ issued the order for the transfer of the 38th Division. ${ }^{(1)}$ The place where the army commander should station himself became an issue again that night, but it was decided that both he and his chief of staff would station themselves in Saigon. (36)

The next day, the 5th, Army Commander Imamura received the previously described order of the Southern Army to prepare for capturing Java (that is, to capture Bangka, southern Sumatra, Ambon and Kupang, and be ready for capturing Java). ${ }^{(23,24)}$

On the next day, the 6th, the Sixteenth Army received a telegram from the Dutch East Indies Unit, which proposed the following contents for the arrangement [between the army and the unit], and wired back its approval. ${ }^{(117)}$ The main unit of the Dutch East Indies Unit advanced to Davao on this day. ${ }^{(103)}$

1. Detachment B (i.e. the Itō Detachment on four transport ships) shall leave Hong Kong on 12 January under the escort of the 8th Destroyer Division, and arrive in Davao on 18 January. It shall subsequently capture Ambon on 25 January and Kupang on 5 February under the direct escort of a force with the $2 \mathrm{~d}$ Destroyer Squadron as its core.

2. The Sakaguchi Detachment shall capture Tarakan on 11 January, Balikpapan on 21 January, and Banjarmasin on 31 January [starting] from Davao escorted by a force with the 4th Destroyer Squadron as its core.

3. The main force of the Sixteenth Army shall assemble in Gaoxiong between 29 January and 5 February, and land in Batavia or its vicinity around 16 February under the direct escort of the 
5th Destroyer Squadron. Details shall be arranged between the commanders of the 5th Destroyer Squadron and the Sixteenth Army on 26 January in Gaoxiong.

4. The 48th Division shall leave Manila on 7 February and land in Surabaya or its vicinity around 16 February escorted by a force with the 4th Destroyer Squadron as its core. Details shall be arranged between commanders of the 4th Destroyer Squadron and the 48th Division on 4 February in Manila.

\section{The Southern Army's Dissatisfaction and the Escort Issue}

There are three noteworthy points with regard to the arrangement above. The first is the delay in making the arrangement. The delay in the advance of the command post [of the Sixteenth Army] to Saigon via Taiwan on account of plane trouble was one reason, but [what was worse,] Vice Chief of Staff Harada and the rest of the personnel of the army headquarters to be stationed in Gaoxiong also were forced to start the new year on Kakamigahara airfield in Gifu prefecture due to a plane accident. The commander of the Navy Dutch East Indies Unit had planned to advance to Davao on his flagship, the Ashigara, on 2 January after concluding arrangements with the Sixteenth Army commander on 29 December in Gaoxiong ([according to] the telegram of 28 December from the Third Fleet). ${ }^{(117)}$ However, as of the 29th, [chief of] Shipping Staff Sendō was the only staff of the army in Taiwan while Army Commander Imamura and other officers were still in Tokyo, which gave the main unit of the Dutch East Indies Unit no choice but to leave Gaoxiong [without an arrangement] on 2 January to advance to Davao on the 6th. (Army Commander Imamura and his group made it to Taipei on their way to Saigon on the day that Commander in Chief of the Third Fleet Takahashi departed from Gaoxiong.) The second point was that the schedule of the capture of Tarakan and other places was set one day later than specified in the Cam Ranh Agreement. This was due to the fact that the captures of Davao and Jolo were conducted behind the schedule [arranged in November] as previously mentioned, and that fixing the airfields of Davao and Jolo was making slow progress because of their bad condition. Particularly, the slow progress in fixing the bases [became the primary cause of the delay], as a large force of the 23d Air Flotilla was expected to advance into Jolo after the change in the air operation plan. [Thus a postponement] was requested by the Navy and approved by the Sixteenth Army. ${ }^{(119)}$ Upon receiving the approval of the Sixteenth Army on 6 January, the commander of the [Navy] Dutch East Indies Unit issued an order for the postponement the next day, the 7th. The third point is the comment made by the 5th Destroyer Squadron Commander R. Adm. Hara Kenzaburō, that "although the Dutch East Indies Unit has planned and ordered that the 5th Destroyer Squadron shall escort the main force of the Sixteenth Army in fifty-six ships to Batavia, I am not confident at all that I can carry out the escort only with the force of my squadron of one cruiser and eight destroyers." (35) At that time, the Southern Task Force had four destroyer squadrons, of which the 3d Destroyer Squadron was assigned to the Malaya Unit to be employed for the Bangka and Palembang operations. The other three destroyer squadrons were assigned to the Dutch East Indies Unit: the 2d Destroyer Squadron ([consisting of] three destroyer divisions) was planned and ordered to be employed for [the escort of] the [Army] Eastern Detachment, the 4th Destroyer Squadron ([consisting of] three destroyer divisions) for [the escort of] the Sakaguchi Detachment and the 48th Division, and the 5th Destroyer Squadron ([consisting of] two destroyer divisions) for the main force of the Sixteenth Army, as mentioned above. ${ }^{(117,118,119,120)}$ As previously pointed out, the [Navy] Dutch 
East Indies Unit, which would also conduct operations on the Celebes front, was not even in a position to decide on the outline of the capture of Makassar due to a shortage of strength, let alone to increase the strength of [the squadron of] Rear Admiral Hara.

On 9 January, Army Commander Imamura sent his Chief of Operations Staff Oda to the headquarters of the Southern Army to request that (1) the Navy's strength for the escort be increased and (2) the date of landing in Java be postponed. ${ }^{(24,35)}$ The Southern Army was firmly determined to achieve a swift capture of Java and its chief of staff, Lt. Gen. Tsukada Osamu, who was dissatisfied with the Sixteenth Army's delay in advancing its command post and its postponement of the schedule for capturing Tarakan and other [places], [just] answered that (1) the Navy's escort capability should be trusted and (2) the landing on Java should definitely be carried out on day $x+70$ as specified in the Cam Ranh Agreement. ${ }^{(24,35)}$ Army Commander Imamura thought: "It is not the Army but the Navy itself, particularly the 5th Destroyer Squadron commander and the Dutch East Indies commander (the commander in chief of the Third Fleet) responsible for the task, who are worried about the escort. If things go wrong, whether the Navy is to be blamed or not, it will be my men, the Emperor's subjects and their elders' beloved sons who will be sunk to the bottom of the sea by the enemy navy." He decided to immediately meet Commander in Chief Terauchi in person to request his considerations. However, before doing so, he thought it necessary to check the fighting power of [the squadron of] Rear Admiral Hara and visited the commander of the Malaya Unit (the First Southern Expeditionary Fleet), V. Adm. Ozawa Jisaburō, at his headquarters in Saigon to ask him about it. ${ }^{(35)}$ [Editor's note: According to the description on p. 185 and 188, this meeting took place in Cam Ranh.] Vice Admiral Ozawa told Lieutenant General Imamura his expectation that "by the time the main force of the Sixteenth Army heads for Java, the Malaya Unit will be able to support [the escort]; you may count on it," which made Lieutenant General Imamura feel extremely grateful [and relieved]. ${ }^{(35)}$

\section{Sending off the Eastern Detachment}

As soon as he had wired the Dutch East Indies Unit on 6 January his approval of the arrangement, Army Commander Imamura ordered Senior Staff Officers Takashima, of Section 1, and Kitamura, of Section 2, to leave Saigon immediately (on the 6th) for Hong Kong (for the 38th Division and the Eastern Detachment), and then head for Gaoxiong; and he had them depart on that very day. ${ }^{(33,36,43)}$ As previously told, the 38th Division had come under the command of the army commander two days before, on the 4th, and the Eastern Detachment had started embarking on that very day, the 6th. The army commander very much wanted to see and encourage Maj. Gen. Itō Takeo, commander of the 38th Infantry Group, who at the decision to form the detachment was appointed commander of the Eastern Detachment, but he could not leave Saigon ${ }^{(36)}$ When he had met with the staff of the 38th Division for a brief moment at Guangdong airfield previously on 3 January under the described circumstances, the details of the Eastern Detachment had not yet been decided, and thus he had not met with Major General Itō. ${ }^{(36)}$ Senior Staff Officers Takashima and Kitamura left Saigon and arrived in Guangdong on the 6th, reached Hong Kong on the 7th, passed down the army's order to the 38th Division, encouraged the Eastern Detachment, and flew from Guangdong to Taiwan on the 8 th. ${ }^{(33,43)}$ 
The Eastern Detachment concluded arrangements with the 8th Destroyer Division commander in Hong Kong on the 11th, departed from Hong Kong on the 12th, and headed for Davao first (where it arrived on the 18th). ${ }^{(117)}$ Details of the Eastern Detachment will be given later.

\section{Revision of the Operation Plan}

As previously described, immediately after the conclusion of the arrangement with the Dutch East Indies Unit, Senior Staff Officers Takashima and Kitamura went to the headquarters of the [Sixteenth] Army in Gaoxiong via Hong Kong. Staff Officers Murakami and Kuriya departed to gather information from the Kawaguchi Detachment in British Borneo and the Twenty-fifth Army in Malaya respectively. Staff Officer Itoda left to liaise with the Third Air Force and the 1st [Paratroop] Raiding Group. ${ }^{(36,39,42)}$ Staff Officer Saiki flew from Saigon to Hong Kong on the 6th, to give directions and support for the departure of the Eastern Detachment, together with Staff Officer Nishiura, who arrived in Guangdong from Gaoxiong on the 8 th. ${ }^{(34)}$

Ever since the advancement of [the schedule of] the Java operation became an issue, Staff Officer Oda had been working on a revision of the operation plan, which he substantially finished by the 6th. Before this, the chief of Section 2 of the Army Department of IGHQ, Hattori, had visited Saigon and sent the following telegram to Tokyo on 30 December: ${ }^{(23)}$

\section{To Vice Chief of Army General Staff}

Dated 30 December

I have returned to Cam Ranh Bay. The Southern Army has worked out the following final draft regarding the conduct of subsequent operations:

1. The situation in the Malaya area is as already reported. However, due to the Takumi Detachment's advance to Kuantan and vicinity, etc., Operation $Q$ has been called off and Operation $S$ will be conducted around day $x+40$.

2. The whole Operation $\mathrm{H}$ will be brought forward so that landing operations in Java of the main force will be carried out around day $x+70$. Detachment $B$ ([consisting of] three battalions of the 38th Division) will embark around day $x+40$, assemble in Palau, and conduct operations against Ambon around day $x+50$, and then against Kupang. The main force of the 38th Division will embark around day $x+35$ and conduct operations against Mentok and Palembang around day $x+60$. The $2 d$ Division (including the units under the direct control of the [Sixteenth] Army) and the 48th Division ([also] including the units under the direct control of the army) will embark around day $x+33$ and day $x+55$ respectively, and both will land in Java around day $x+$ 70. The operations in the Makassar Strait will be conducted on the whole according to the prearranged plan. [However,] as an increase in the total tonnage for the above [operations] cannot be expected, non-urgent transportation will be called off or postponed, and the formation of the force for the Sixteenth Army will be reduced to a minimum as well.

3. The main force of the 21st Division will embark around day $x+36$ and an element of it around day $x+48$ respectively, and [both] will be moved to northern French Indochina. The 56th Division will embark around day $x+57$ and be moved to southern French Indochina or Thailand as reserve for the [Southern] Army.

The above items were discussed between the [Southern] Army and the Second Fleet yesterday in Cam Ranh, and they reached an agreement.

4. Regarding the Burma operation, the [Southern Army] on the whole shared our view, except the part of the draft of the operational guidelines which was revised as a result of various kinds of 
research. Further, by around the end of January first of all the Moulmein operation will be conducted.

Note: Q indicates the Kuantan landing operations (which [would] have been carried out by the Koba Detachment), S indicates the Endau and Mersing landing operations (to be carried out by the main force of the 18th Division), and H the Dutch East Indies operation.

\section{To Chief, Department 1}

Dated 30 December

In view of the results of observations mainly of the Malaya operations, items to be considered in regard to the disposition of forces for Operation $\mathrm{H}$, in particular the order of embarkation, are as follows. It would be appreciated if you shared them with the Sixteenth Army.

1. The strength, the formation and the composition of the army should be as light as possible. However, the commitment of army engineers and military police should be raised as much as possible. Heavy artillery and medium tanks would require much time to unload and may destroy roads.

2. Operations against an area along one road in one direction should be conducted with a combat group consisting of three infantry battalions, one artillery battery (or two batteries), one light tank squadron, one engineer company, a motor transport company, a mobile repair squad, and a signal unit, by having the group charge [into the area].

3. After landing, broken bridges rather than enemy resistance will hinder our advance most. Although there may be various countermeasures against this, the most effective way, in short, is to have a unit consisting of an elite infantry battalion as its core charge ahead while keeping close proximity to the enemy. The order of embarkation should be decided after due consideration of this fact.

4. The following units shall be put ashore at the earliest moment:

Engineer units, river-crossing material units, an element of the supply depot to collect and supervise supplies of materials, and military police units.

5. Further, as mentioned in the previous telegram, in view of the purpose of this war and the actual situation of public order right behind the front lines, it is urgently required to promptly advance agencies for implementing a military administration into site so that a [time] gap between the operations and the [beginning of] governing the occupied area will not be created.

6. I will head for Hong Kong next.

The reasons why the Sixteenth Army decided to revise at this time the previously described operation plan of 21 December generally can be inferred from the above telegram. They are roughly as follows: ${ }^{(36,40)}$

1. While the army was made to give up the South Seas Detachment, it had [the strength of] Detachment B (the Eastern Detachment) with two battalions as its core increased to three battalions as the core [instead].

2. As the real fighting power of the allied forces was becoming more or less clear, bold operations came to be considered appropriate.

3. It came to be considered appropriate to employ a combat group with three infantry battalions as its core and combined with various [kinds of] troops as a unit in the operations.

4. The advancement of [the schedule of] the Java operation reduced fears of large troop reinforcements in Java by the U.S., British and Australian forces.

The Sixteenth Army revised its operation plan roughly as follows. The details will be described later one by one: 
1. Detachment B shall consist of three battalions commanded by the infantry group commander of the 38th Division as its core, and renamed the Eastern Detachment.

2. [Previous] plans concerning the South Seas Detachment shall be deleted.

3. The Sakaguchi Detachment shall [operate] as previously planned.

4. The force to join the central Java operations from the 38th Division (other than the Eastern Detachment) shall consist of two battalions as its core. (In the previous plan, [a unit of] three battalions commanded by the infantry group commander as its core was considered for this task. This unit should preferably have three battalions as its core, as it would take the risk of making a landing on its own in front of the Bandung stronghold. However, now that the Eastern Detachment was [increased to] three battalions, and also in terms of the main force of the 38th Division, [the strength of] this unit had to be [limited to] two battalions as its core.) The use of this detachment and the main force of the 38th Division (consisting of four battalions as its core) shall remain as previously planned.

5. The 48th Division shall additionally be given the task of seizing Cilacap at a favorable opportunity. (This was caused by the fact that [the army] had to give up the South Seas Detachment.)

6. The $2 \mathrm{~d}$ Division shall form a powerful unit to head for Buitenzorg [Bogor] along the road at the foot of the mountains in the south [of Java] with one infantry regiment (minus one battalion) and one reconnaissance regiment, commanded by the infantry group commander, as its core. (In the previous plan [this unit] was to consist of two infantry battalions, commanded by the reconnaissance regiment commander, as its core.) This unit shall anticipate the possibility that it may have to charge toward Bandung following the seizure of Buitenzorg [Bogor]. 


\section{Chapter VI The Launch of the Dutch East Indies Operation}

\section{The Policy of the [Japanese] Government Towards the Netherlands}

$\mathrm{O}$ n 1 December, the government decided to go to war with the United States and Great Britain, and at the same time also with the Netherlands. However, with respect to the Netherlands, it was decided that until the first military actions against the Netherlands were launched (i.e. the landings in Tarakan and Menado in the Dutch East Indies, scheduled to take place about one month after the opening of hostilities), Japanese initiatives to enter into a state of war should be avoided. More precisely, on 4 December, the following decisions were made on how to deal with the Netherlands: ${ }^{(3)}$

\section{The Treatment of the Netherlands}

1. Until a state of war with the Netherlands [actually] breaks out, the Netherlands will be treated as a quasi-enemy country; the [Dutch] minister and his staff shall be put under close watch and protection [within their embassy] and the use of codes shall be prohibited. (Consequently, also all communications with the enemy countries shall be absolutely forbidden.)

2. In the event war is declared by the Netherlands, Japan shall announce its entry into a state of war with the Netherlands. Also, in the event a state of war with the Netherlands breaks out before the latter declares war, Japan shall announce its entry into a state of war with the Netherlands as specified above, and thereafter treat the country as an enemy country under international law.

As previously described, on 8 December, the Imperial Rescript on the Declaration of War was proclaimed, but the Netherlands was left out of the [list of] belligerent nations.

Right after the opening of hostilities, [Japan was] notified by the Dutch government on 10 December that "as Japan has opened hostilities with the United States and Great Britain, with both of whom the Netherlands maintains close and inseparable relations, the Netherlands considers that it is now in a state of war with Japan." However, regardless of the previous decisions, the Japanese government ignored this [notification]. ${ }^{(12)}$ Instead, against the background of better-than-expected military gains since the opening of hostilities, [the government] wished to effect as much as possible a so-called bloodless occupation of the Dutch East Indies. On 13 December, the following policy was decided upon at the Liaison Conference between IGHQ and the Government: ${ }^{(3)}$ 


\section{Directives for War against the Dutch East Indies Following the Changes in the War Situation}

With due regard to the developments of the situation, efforts shall be made based on the following points, so that the objectives of the occupation as determined according to the prearranged plan shall be attained as much as possible without resorting to force:

1. Efforts shall be made to conduct negotiations at an appropriate moment by the end of this year with the Government General of the Dutch East Indies by and large on the following conditions:

(1) The Dutch East Indies shall abandon all hostile acts against the Empire [of Japan], and implement measures to prevent disturbances as well as the destruction of infrastructure and resources following the occupation of vital areas of the Dutch East Indies by the Imperial Japanese Army.

(2) The Empire [of Japan] shall respect the existing Dutch East Indies administrative structure, and also strictly protect the life and property of all inhabitants.

2. Operations shall be executed based on the prearranged plan, regardless of a shift in the negotiations. Provided that the negotiations are successful, the occupation shall be carried out without resorting to force.

3. A declaration of entering into a state of war with the Netherlands shall not be made during negotiations.

4. The future territorial status of the Dutch East Indies and other matters shall not be touched upon during the negotiations.

These [diplomatic] maneuvers were conducted through the intermediary of Switzerland, but ended in failure. In fact, their chance of success had been considered extremely small from the very start.

As will be explained later, the Sakaguchi Detachment landed in Tarakan on 11 January, and on the same day landings and paratroop droppings of Navy units were also carried out in Menado. On the next day, the 12th, the [Japanese] government issued the following declaration: $(3,13)$

\section{Declaration by the Imperial Japanese Government}

Even though the Empire [of Japan] has recently opened hostilities with the United States and Great Britain, it has refrained from taking hostile measures against the Dutch East Indies out of consideration to spare the inhabitants as much as possible the ravages of war. Nevertheless, the Dutch Government has not only given notice to the Empire [of Japan] that it regarded the fact that Japan had opened hostilities with the United States and Britain, with both of whom the Netherlands maintains close and inseparable relations, had brought about a state of war between the Netherlands and Japan, but since then, its forces have also actually engaged in all forms of hostile acts against the [Japanese] Empire. Moreover, it has recently turned the Dutch East Indies into a base for U.S., British and Dutch forces to put up resistance against Japan.

Although the Empire [of Japan] feels no enmity towards the innocent civilians of the Dutch East Indies, the Imperial Army and Navy have finally come to open hostilities on 11 January against the Dutch forces in order to crush the Dutch hostile acts as well as to protect the lives and property of the Empire's subjects.

\section{The Launch of the Dutch East Indies Operation}

As already told, on 28 December, the [Navy] Dutch East Indies (Philippines) Unit Commander Vice Admiral Takahashi gave the following orders concerning the disposition of 
forces and the immediate schedule: (On this day, Army Commander Imamura was still in Tokyo.)

Western Attack Unit (commander: commander in chief of the Third Fleet) 1st Escort Unit ([consisting of] the main force of the 4th Destroyer Squadron and the $2 \mathrm{~d}$ Kure Special Landing Force as its core) in conjunction with the Sakaguchi Detachment: shall seize Tarakan, Balikpapan and Banjarmasin.

$2 d$ Base Unit ([consisting of] the main force of the $2 d$ Base Force as its core): shall cooperate with the 1st Escort Unit.

1st Air Unit ([with] the auxiliary seaplane tenders the San'yō-maru and the Sanuki-maru as its core): shall cooperate with the 1st Escort Unit. [Editor's note: the Japanese text says "2d Air Unit," which is a misprint.]

Eastern Attack Unit (commander: commander of the 5th Cruiser Division)

$2 \mathrm{~d}$ Escort Unit ([consisting of] the main force of the 2d Destroyer Squadron, the Sasebo Combined Special Landing Force, and the 1st Kure Special Landing Force as its core): shall seize Menado, Kendari and Makassar.

1st Base Unit ([consisting of] the main force of the 1st Base Force): shall cooperate with the force above.

2d Air Unit ([consisting of] the 11th Seaplane Tender Division with the seaplane tenders the Chitose and the Mizuho as its core): shall also cooperate with the 2d Escort Unit.

Support Unit ([with] the 5th Cruiser Division as its core): shall support the Eastern Attack Unit's operations.

Main unit ([consisting of] the main force of the 16th Cruiser Division): shall support all operations and cover the Western Attack Unit.

Landings in Tarakan and Menado are scheduled for 10 January.

On 2 January, the main force of the 4th Destroyer Squadron (which had provided cover for the landing of the main force of the 48th Division around Lingayen) advanced into Davao, where its commander, Nishimura, immediately held a preliminary meeting with the commander of the Sakaguchi Detachment. ${ }^{(119)}$ On this day, Army Commander Imamura and his group made a stop at Taipei between 1100 and 1330 on their way from Shanghai to Guangdong, while the commander in chief [of the Navy Dutch East Indies Unit], Takahashi, left Gaoxiong with his main unit. On the previous day (1 January), the 65th Brigade had landed around Lingayen Gulf. ${ }^{(23)}$ The $2 \mathrm{~d}$ Destroyer Squadron, which would newly comprise [part of] the Eastern Attack Unit, and the 5th Cruiser Division, which would support that unit, had been charged with operations in Davao and Jolo, and thus remained in Davao. ${ }^{(114,117)}$ Further on this day, the $2 \mathrm{~d}$, the commander in chief of the Eleventh Air Fleet, Tsukahara (stationed in Taiwan) implemented the phase-two disposition of forces, and directed the 1st Air Raid Unit (the 21st Air Flotilla) to carry out operations in the Celebes area from Davao, and the $2 \mathrm{~d}$ Air Raid Unit (the $23 \mathrm{~d}$ Air Flotilla) in the east coast area of Borneo from Jolo. ${ }^{(117,141)}$ The Combined Fleet issued an order on the same day "to incorporate the 2d Carrier Division into the Southern Task Force on 7 January." The Southern Task Force and its air unit (the Eleventh Air Fleet) planned to use this [division] for support in seizing Ambon. ${ }^{(107,110)}$ On this day (2 January), the Eleventh Air Fleet headquarters and the 23d Air Flotilla headquarters were still based in Takao. The air unit stationed 97 aircraft in Gaoxiong, 89 in Davao, 18 in Peleliu, 41 in Jolo and 9 in Legaspi. ${ }^{(143)}$ [However,] the airfields of Davao and Jolo were in such an extremely poor condition that Commander in Chief Tsukahara had to send a 
telegram to all parties concerned that "as for Jolo, a runway of $50 \mathrm{~m}$ wide and about $1000 \mathrm{~m}$ long is expected to be completed and ready for use by 5 January. Concerning the Davao landbase, a runway of $1200 \mathrm{~m}$ long is supposed to be completed by 6 January, however, due to soft soil and many squalls, the rolling and compaction work of the parking area has not progressed satisfactorily." (117) From 22 December, land-based aircraft had started to advance into Davao and on the 27th the 21st Air Flotilla had advanced its headquarters from Palau to Davao. ${ }^{(143)}$ The air unit which had proceeded to Davao started reconnaissance of the Menado area from 24 December and began attacking its airfield from the 26th. Land-based aircraft had started to move into Jolo since the 26th and they delivered their first strike on Tarakan on 30 December. $^{(104)}$

On the next day, the 3d, the formation of the Third Southern Expeditionary Fleet (Philippines) was announced, which allowed Vice Admiral Takahashi to concentrate on the Dutch East Indies operation from that time onwards..$^{(1)}$ In the late afternoon of this day, Commander Imamura and his group arrived in Saigon. ${ }^{(32)}$ Commander Takahashi's flagship the Ashigara was on its way to Davao. ${ }^{(103)}$

On the next day, the 4 th, Commander Imamura received an explanation on bringing forward the schedule of the Java operation from the Southern Army in Saigon. ${ }^{(24)}$ Also on this day, the 38th Division was incorporated into the order of battle of the Sixteenth Army, ${ }^{(1)}$ while Vice Chief of Staff of the Southern Army Aoki Shigemasa, arrived at the Fourteenth Army headquarters and started negotiations for the transfer of the 48 th Division, ${ }^{(23,80)}$ while the rest of the Sakaguchi Detachment left Palau for Davao. ${ }^{(88)}$

On January 5, the Southern Army gave Commander Imamura orders to prepare for capturing Java as well as to carry out the seizure of Bangka, Palembang, Ambon and Kupang. ${ }^{(23,24)}$ [At this moment] Commander in Chief [of the Navy Dutch East Indies Unit] Takahashi was still on his way to Davao. [Also] on this day, the senior staff officer of the Third Fleet, Capt. Yamaki Akira (who left Gaoxiong on 2 January by air and arrived in Davao on the afternoon of the 4th), assembled the senior staff officers of each division, squadron and others on board the Nachi, the flagship of the 5th Cruiser Division, explained the order given on the 29th, and discussed the arrangements. ${ }^{(113)}$ After the meeting, the 4th Destroyer Squadron commander, R. Adm. Nishimura Shōji, made an operational arrangement with Detachment Commander Sakaguchi, and immediately on the same day (the 5th) the latter gave the order to capture Tarakan. ${ }^{\left({ }^{88}\right)}$ Rear Admiral Nishimura and the 2d Destroyer Squadron commander, R. Adm. Tanaka Raizō, respectively issued orders to the 1st Escort Unit to prepare for the capture of Tarakan, ${ }^{(119)}$ and to the $2 \mathrm{~d}$ Escort Unit to prepare for the capture of Menado. ${ }^{(117)}$

On the next day, the 6th, Commander in Chief Takahashi (on board the heavy cruiser Ashigara) entered the port of Davao. ${ }^{(103)}$ On the same day, the Eastern Support Unit of the Southern Task Force (the battleship Haruna and the heavy cruiser Maya) left Magong to head for the southeastern waters of Mindanao. ${ }^{(103)}$ With the arrival of the reinforcements of the Sakaguchi Detachment on that day, now the entire force of the detachment (except its Matsumoto Detachment at Jolo) was completely assembled off Daliao (southwest of Davao). ${ }^{(88)}$ While the headquarters of the 23d Air Flotilla had proceeded from Gaoxiong to Jolo on the $3 \mathrm{~d}$, the Eleventh Air Fleet headquarters was still stationed in Taiwan. ${ }^{(143)}$ As already described, Commander in Chief Takahashi sent to Army Commander Imamura (in Saigon) on that day a telegram concerning the arrangements, and also requested that the start of the capture of Tarakan and other places be delayed by one day. 
At 0030 on the following day, the 7th, Commander in Chief Takahashi sent the following order by telegram: ${ }^{(119)}$

The Dutch East Indies Unit Order No. 3, Classified, shall be revised as follows:

The [date of] capture of Menado and Tarakan shall be changed to 11 January and consequently the schedule of operations of each [relevant] unit shall roughly be delayed by one day.

On this day (the 7th), the Eleventh Air Fleet headquarters advanced from Gaoxiong to Davao. ${ }^{(143)}$ Also on the same day, in accordance with the Combined Fleet order (dated 2 January), the Southern Task Force (based in Cam Ranh) ordered the incorporation of the 2d Carrier Division (with the aircraft carriers Sōryu and Hiryū) into the air unit (the Eleventh Air Fleet). ${ }^{(117)}$ After the operations at Hawaii and Wake Island, the $2 \mathrm{~d}$ Carrier Division had returned to base in Kure on 29 December. ${ }^{(103)}$ The commander of the [Navy] Dutch East Indies Unit reported on this day (the 7th) the following:(117)

1. With the arrival of the main unit on 6 January, which left Gaoxiong on 2 January, the assembly of the Dutch East Indies invasion unit at Davao is completed.

2. -5 . (Omitted by the author)

6. The airfields in both Legaspi and Jolo have been made ready for use and each base force is preparing for transfer. Public order has already been secured at Legaspi. Even though the Special Landing Force is preparing for transfer, except for one element to be left behind, the situation at Jolo still requires a considerable degree of caution. As for Davao, although the demands of the air unit have not yet been fulfilled due to poor airfield conditions and continuous hindrance by the weather, efforts are being made day and night to get it ready.

7. The Dutch East Indies invasion unit shall start its scheduled operations as of today.

The Sakaguchi Detachment had [originally] been scheduled to depart from Davao on the 6th, but, following the one-day postponement, the detachment left at 1100 on the 7th, and headed for Tarakan. ${ }^{(8)}$ The 21st Air Flotilla had made a fierce attack on Ambon on the previous night. ${ }^{(103)}$ Although the flotilla had been delivering strikes on Menado from 26 December onwards, and the 23d Air Flotilla on Tarakan from 30 December onwards, they hardly encountered enemy aircraft. ${ }^{(103)}$ On that day (the 7th), the commander in chief of the Eleventh Air Fleet, Tsukahara, gave the 21st Air Flotilla commander [R. Adm. Tada Takeo] orders to raid and seize the air base of Menado on 11 January, employing the 1001st Unit (minus the 3d Yokosuka Naval District Special Landing Force; note: a paratroop unit) and the necessary air force. ${ }^{(117)}$

Note: As previously told, the [first] use of the paratroop unit of the Navy (the 1001st Unit) had been changed to Tarakan (or depending on the situation, Menado). On 31 December, its use was decided as follows: ${ }^{(110)}$

Employment of the 1001st Unit

1. In capturing Menado, about 300 men shall be dropped on the airfield on the day of landing of the invasion unit, and seize the airfield.

2. The unit shall not be used for the capture of Tarakan due to the bad condition of the Jolo Air Base.

3. Against Balikpapan, 600 men shall depart from Tarakan and be dropped on the airfield of Balikpapan in two groups one day prior to landing [of the invasion unit] in order to secure the airfield and provide support for the landing. 
The air unit (the Eleventh Air Fleet) started operations with the following disposition of forces: 114 aircraft for the 1st Air Raid Unit ([consisting of] the 21st Air Flotilla) (for the Menado area), 105 aircraft for the 2d Air Raid Unit ([consisting of] the 23d Air Flotilla) (for the Tarakan area), and 18 aircraft (flying boats) for reconnaissance. ${ }^{(110)}$

\section{The Capture of Tarakan (See Illustration No. 17)}

\section{Change in the Landing Plan}

As already described, the arrangement between the commanders of the Navy Dutch East Indies Unit and the Sixteenth Army (drafted by the Dutch East Indies Unit) signed on 16 November, specified that the landing on Tarakan Island would be made on the strongly [fortified] front on both banks of the Karungan River. And as already told, Staff Officer Yano Tsuneo of the Sakaguchi Detachment had at that time insisted that he wanted "to execute the operation in a modified way regardless of the [original] plan." When he received "no objections," he began training for passing through the jungle as soon as the detachment had arrived in Palau. However, in the Detachment Order handed down on 17 November, and even in those handed down on 25 November and 12 December, which followed the additional assignment of tasks to capture Davao, the Sakaguchi Detachment still described its landing points as both banks of the Karungan River. ${ }^{(88)}$ This came from the idea of deceiving your own forces [in order to deceive the enemy]. As a matter of fact, Chief of Staff [of the Sixteenth Army] Okazaki had found out about a certain Katsuyama, who had returned to Japan after twenty-odd years of doing business in Tarakan. Hearing that "there is a road from Tarakan City to the east coast through the jungle which Dutch forces also use during maneuvers," he had sent this person immediately around the end of November from the homeland to the Sakaguchi Detachment (in Palau at the time) in order to serve as guide. ${ }^{(36)}$ Thus the detachment commander's intention to land on the east coast [of the island] became firmer and more resolute than ever.

\section{Arrangements with the Navy}

Upon the arrival of the 4th Destroyer Squadron in Davao on 2 January, Detachment Commander Sakaguchi on the same day made a preliminary arrangement with Squadron Commander Nishimura Shōji. On the following day, the 5th, they [officially] concluded an "Arrangement between the Navy 1st Escort Unit and the Army Sakaguchi Detachment,"(119) which was in outline as follows: ${ }^{(88)}$

Landing points: The main force of the Sakaguchi Detachment shall land on the east coast of Tarakan, one element of the detachment on the southeastern end of the island, and the $2 \mathrm{~d}$ Kure Special Landing Force also on the east coast of the island.

Disposition of forces for the landing: (1) One and a half army battalion shall land in the central part of the east coast of Tarakan and seize the oil fields and Lingkas. (2) One army battalion shall land on the southeastern end of the island and, after seizing the battery at Mengacu, seize Lingkas. (3) One battalion of the [naval] 2d Kure Special Landing Force shall, after landing on the central part of the east coast of the island, seize the airfield.

No special reconnaissance of the landing points shall be conducted. 
The transport convoy shall leave Daliao (note: $15 \mathrm{~km}$ southwest of Davao) at 1100 on 6 January, drop anchor at 1930 on 9 January at anchorage no. 1 and 0000 on 10 January at anchorage no. 2. The first landing shall be launched (from anchorage no. 1) at 2130 on the 9th and the second landing (from anchorage no. 2) at 0200 on the 10th.

Distribution of ships:

Right Wing Unit (the 1st Party): the Tsuruga-maru, the Liverpool-maru (with the right wing unit commander on board), the Nissho-maru [Hiteru-maru], the Hankow-maru, the Ehime-maru, the Kunikawa-maru (with the 2d Kure Special Landing Force on board) and the Kano-maru.

Left Wing Unit (the 2d Party): the Havana-maru (with the left wing unit commander on board), the Teiryu-maru (with the detachment commander on board), the Kuretake-maru, the Nichiaimaru, the Kagu-maru, the Kunitsu-maru, and the the Rakutō-maru.

Note: The Kunikawa, the Kano, the Kagu, the Kunitsu and the Rakuto belonged to the Navy.

Forces employed for the escort: One cruiser (the Naka), ten destroyers, three submarine chasers and three patrol boats under the command of 4th Destroyer Squadron Commander Rear Admiral Nishimura.

Forces employed for support: The auxiliary seaplane tenders the San'yō-maru and the Sanukimaru, and one element of the 23d Air Flotilla.

The landings are to be made as surprise landings.

Covering fire for the landings shall be provided by the Navy warships [only] upon request by the commanders of the landing forces.

Transport ships shall move their anchorage one by one to the Lingkas anchorage when ordered after the landings.

When ordered, the Kuretake-maru shall sail to Jolo under the escort of a destroyer and return the Jolo operation unit of the Sakaguchi Detachment to [its parent unit] in Tarakan.

\section{The Plan and Order for Capture}

Based on the preliminary arrangements previously made (on the $2 \mathrm{~d}$ ), Detachment Commander Sakaguchi issued the following order: ${ }^{(119)}$

\section{Sakaguchi Detachment Order}

Daliao, 0800, 5 January

1. The Imperial Army has completed its occupation of Manila on 3 January, and is further engaged in destroying the defeated enemy. The key areas of Davao and vicinity are practically cleared; public order has largely been restored and the local Japanese nationals have for the most part returned to their present residences.

The Jolo Detachment, which is still stationed in Jolo Island, has largely completed the mopping up of the enemy there, and is now being relieved of its guard duty by the naval landing force. The Dutch East Indies government, which has foreseen our attacks and proclaimed total resistance, has had its warships and aircraft conduct repeated attacks on our forces.

2. The detachment shall leave the port of Davao at 1100 tomorrow on the 6 th, go ashore at Tarakan on the night of the 9th, and capture the island to seize its airfield, as well as to secure the oil resources.

3. The 1st Field Antiaircraft Artillery Battery shall come under the command of Detachment B after the departure of the [Sakaguchi] Detachment from Davao. The command shall be transferred when Detachment B enters the port of Davao.

4. Both [left and right] wing units as well as the units under the direct control of the detachment shall be charged with the capture of Tarakan in conformity with Separate Volume No.1: Main points of the capture of Tarakan and Separate Volume No. 2: Tarakan Landing Plan of the Sakaguchi Detachment. 
5. The particulars [of the operation] shall be given through the staff officers.

6. I am in Daliao and shall board the Teiry $\bar{u}$-maru at 1000 tomorrow on the 6th.

Separate sheets: Distribution of Forces (note: excerpted by the author)

Right Wing Unit

Commander: Regimental Commander Col. Yamamoto Kyōhei

146th Infantry Regiment (minus 2d Battalion, 3d Battalion (minus two companies), half of [both] regimental artillery and antitank gun units)

1st Engineer Company (minus one platoon)

Medical Unit (minus half of the unit), Radio [Unit]

Left Wing Unit

Commander: Battalion Commander Maj. Kanauji Ken'ichi

2d Infantry Battalion (minus 6th Company), half of [both] regimental artillery and antitank gun units

One engineer platoon, Radio [Unit]

Squad for Collecting Cast-off Articles

Commander: Capt. Tajima Toshitsugu

Units under the direct control [of the Detachment]

Detachment headquarters (minus three mark-3 radio squads), 6th Infantry Company, armored car unit, 1st Field Artillery Battalion (minus one platoon), 44th Field Antiaircraft Artillery Battalion (minus one battery), $2 \mathrm{~d}$ Transport Company (minus one squad), half of the medical unit, 1st Field Hospital, 6th and 7th Independent Radio Platoon, 33d Fixed Radio Unit, 1st Independent Engineer Company (minus two platoons), one element of the 45th Anchorage headquarters, 16th Shipping Signal Platoon, attached military police unit (minus one element).

\section{Separate Volume No. 1: Outline of the Capture of Tarakan}

I. Mission

1. The detachment shall make surprise landings on the shore at Amal and on the shore at [Cape] Batu. Then taking advantage of the darkness of the night, it shall seize at a stroke the oil fields of Tarakan as well as the Lingkas area with its main force, and all batteries along the Karungan [River] with one element [of the detachment], after which it shall capture the airfield.

2. After the landing at Tarakan, the Jolo Detachment shall be brought back [from Jolo]. When the whole island [of Tarakan] has been cleared [of the enemy], the main force of the detachment shall turn over guard duty to the naval landing force and assemble in or near Tarakan to make preparations for the capture of Balikpapan.

II. Directives

3. The detachment shall leave the port of Davao on day $x+30$. Escorted by Navy warships and aircraft, the detachment shall head straight for the island of Tarakan in Dutch Borneo, while closely guarding itself against [enemy] aircraft and submarines, and enter the waters south of the Adat Reef (note by the author: $25 \mathrm{~km}$ east of Tarakan) off Amal in the evening of day $x+33$, for temporary anchoring.

4. The right wing unit shall swiftly transfer to [landing] boats in the waters south of the Adat Reef, carry out a surprise landing on the shore at Amal, catch and destroy the enemy surveillance units in and around Amal. Without waiting for the completion of the landing, the unit shall swiftly work its way through the swamps and jungle, carefully so as to keep its purpose hidden, launch a sudden attack on the Pamusian oil field and seize it. While having one element secure the site, the main force shall seize the river-head area, barracks, radio 
station, main plants and the Lingkas pier at one fell swoop, by which it shall crush the enemy's demolition plans, and catch and destroy the enemy forces by daybreak.

5. The transport ships of the left wing unit shall leave the waters south of the Adat Reef at the appropriate time and temporarily anchor east off [Cape] Batu. Before dawn on day $x+34$, the unit shall land in or near Batu, and raid and seize all batteries east of the Pamusian River and secure them by daybreak.

6. The Makiuchi Unit of the Naval Landing Force (which from the moment of landing till the clearing of the key areas of Tarakan shall be put under the command of Detachment Commander Sakaguchi during the operation) shall land in or near Amal before dawn following the right wing unit, get itself ready [for the operation], start toward the airfield via Tarakan, seize it, and secure the airfield and the Batu Dua oil field. Depending on the circumstances, the landing shall be made in the vicinity of the Lingkas Pier.

7. The right wing unit shall have a unit, consisting of about two companies led by the battalion commander as its core, advance behind the naval landing force, and after the latter's seizure of the airfield and the Batu Dua oil field, secure both the Juwata and Gunung Cangkol oil fields, while staying in very close contact with the [naval] force and being particularly on the alert for aerial warnings.

8. The armored car unit shall land in or near Batu and, as long as the situation permits, cooperate with the naval landing force in its attack on the airfield. Then the unit shall cooperate with the battalion assigned to capture the Juwata oil field in capturing the oil field, after which the unit shall be on standby at Tarakan. Depending on the circumstances, the landing shall be made in the vicinity of the Lingkas Pier.

9. The detachment headquarters and the 6th Infantry Company shall land in or near Batu after dawn and go to the BPM office. Depending on the circumstances, the landing shall be made at or near the Lingkas Pier.

10. The Squad for Collecting Cast-off Articles shall land along with the right wing unit, and from there on it shall accompany the right wing unit as it advances, to collect and sort weapons, ammunition and other matériel.

11. The right wing unit shall have its engineer unit make efforts to find and remove the enemy's demolition devices as well as to prevent fires during the period of the capture [operation] of the whole island.

12. When the capture of Tarakan Island makes progress, and as far as the situation permits, the Kuretake-maru shall be swiftly dispatched to Jolo for the return transport of the Jolo detachment.

13. When the key areas of Tarakan Island have been cleared, guard duty shall be turned over to the Navy, and the main force shall be assembled in Tarakan and its vicinity to prepare for the capture of Balikpapan.

14. During the capture of Tarakan Island, the Navy shall have its aircraft strike the enemy positions in Juwata at daybreak, and, along with its warships, cut off the enemy's retreat to the north from Juwata and vicinity.

15. "Yama" [Mountain] and "Kawa" [River] have been set as nighttime passwords.

\section{Advance, Landing and Capture}

As already told, a "one-day postponement" was announced [past] midnight on 6 January, and at 0800 on the 7th, first of all a clearing unit (of seven destroyers) left Malalag Bay (note: southwest of Davao). [Then] the transport convoy ([consisting of] nine ships of the Sakaguchi Detachment, two ships of the 2d Kure Special Landing Force, three ships of the Construction and Defense Squads, two ships of the Eleventh Air Fleet, sixteen ships in total) left the anchorage of Daliao at 1100. ${ }^{(119)}$ One light cruiser (the Naka), ten destroyers, six minesweepers, 
three submarine chasers, one converted auxiliary gunboat and other warships [for escort] and the sixteen transport ships comprised a total of forty ships; they sailed at a speed of 8.5 knots. ${ }^{(119)}$ It was calm on 7 January. ${ }^{(119)}$ On the 8 th, there was a report of (an) allied submarine(s) but no attack was made. ${ }^{(119)}$ On the afternoon of the 9th, aircraft of the 23d Air Flotilla spotted one merchant vessel and one gunboat in the port of Lingkas; they bombed them and caused a fire. ${ }^{(119)}$ The convoy continued to sail calmly. Although it came under attack from three allied bombers and two allied fighter planes at 1750 on the 10th and again from three bombers at 1818, it sustained no loss and anchored at anchorage No. 1 at 1900.(88) [Another] report of submarine(s) came in the evening, but there was no attack. First of all, at 2130 the first landing unit of the right wing unit of the Sakaguchi Detachment, followed by troops of the $2 \mathrm{~d}$ Kure Special Landing Force at 2200, left Anchorage No. 1 by their own landing boats. ${ }^{(119)}$ Just before that, at around 2100, fires broke out at two locations on Tarakan Island. ${ }^{(119)}$ The convoy of the left wing unit left Anchorage No. 1 at 0030 on the 11th, and reached anchorage No. 2 at 0110. At 0220 it completed changing to the landing craft and departed. ${ }^{(119)}$

The sky above Tarakan was burning red from the oil field fires set by the Dutch East Indies forces. ${ }^{(87)}$ Although the [landing boats] were expected to sail in the dark night for about 15 nautical miles from Anchorage No. 1 to the shore, the silhouette of the island was clearly visible. ${ }^{(87)}$ The right wing unit and the $2 \mathrm{~d}$ Kure Special Landing Force successfully went ashore at 0000 and at 0030 on the 11 th respectively. ${ }^{(119)}$ However, as they had mistaken the fire at the Gunung Cangkol oil field for that of the Lingkas oil field located to its south, they had landed four to six km north of their intended landing point, the mouth of the Amal River. ${ }^{(87)}$ The commander of the right wing unit only noticed this after the landing craft had gone back for another transport. ${ }^{(87)}$ They had no choice but to head south for the mouth of the Amal River on foot. ${ }^{(87)}$ When they reached the mouth of the Amal River, the day had [already] broken. ${ }^{(87)}$ The right wing unit made a sudden attack on the pillbox position(s) located there, defeated the guards, captured several of Indonesian soldiers and, by interrogating them, learned the rough disposition of the Dutch East Indies forces. Breaking through the jungle, the right wing unit advanced to the north side of the Tarakan oil field. ${ }^{\left({ }^{87}\right)}$ It was around 1100 on the 11th. ${ }^{\left({ }^{(8)}\right.}$ The moment the right wing unit advanced to the north side of the oil field, it came under fierce gunfire from a Dutch East Indies unit, which made it difficult to move forward. ${ }^{\left({ }^{87}\right)}$ When night fell, a counterattack was launched by the Dutch East Indies unit, whereupon [the Japanese troops] attempted a night assault. Although some elements successfully seized both barracks No. 1 and No. 2, [the attempt] was not an entire success, as the regimental headquarters and another element ended up [being pushed] back to their original position. ${ }^{(87)}$

Meanwhile at 1700, Detachment Commander Sakaguchi (still on board) sent the Navy escort unit the following wire: (1) Although the right wing unit and the $2 \mathrm{~d}$ Kure Special Landing Force have advanced as far as the highlands east of Tarakan, they are blocked by a strong enemy artillery position, and their advance is delayed. They intend to break through the position tonight by means of night raids. (2) The situation of the left wing unit is unknown. (3) Bombing is requested on the battery position to the east of the foreign residential area of the town of Tarakan as well as on the batteries of Juwata at the northern end of the island and on the little island of Sadau (at the high-angled gun artillery position). The air unit decided to carry out the bombing in the early morning of the 12th, as it was [already] too late for bombing on the 11th. ${ }^{(119)}$ However, after the start of attacks at daybreak on the 12th, a bearer of a flag of truce dispatched by the [Dutch] garrison commander [Lt. Col. S. de Waal] came 
to announce the surrender. ${ }^{(87)}$ The right wing unit commander, Colonel Yamamoto, sent a wire to Detachment Commander Sakaguchi, stating: "The [Dutch] commander and his men have announced surrender at 0820. Therefore, the prompt landing of the detachment commander by way of the Lingkas Pier is requested." (88)

It was known that the left wing unit had departed from anchorage No. 2 at 0220 on the 11th and succeeded in landing at 0400 , but as of 1700 on the 11th [the wire stated that] "the situation of the left wing unit is unknown." [Furthermore,] as of 2030 on the same day [it was said that] "the actions and the military gains of the left wing unit after landing are unknown, but [it is certain that] the Mengacu Battery is not yet seized because it occasionally fires at [our] boats operating near the port entrance."(119) Nevertheless, Colonel Yamamoto's telegram asked for the landing [of the detachment commander] at the Lingkas Pier since the [Dutch] garrison commander and all his men had surrendered. At 1100, 4th Destroyer Squadron Commander Nishimura ordered the commander of the $2 \mathrm{~d}$ Base Force to sweep the sea for mines. ${ }^{(119)}$ Four minesweepers promptly set out and approached the Mengacu Channel around 1200, when suddenly they came under fire from the battery at Karungan. By 1215, the first two ships had been sunk ${ }^{(119)}$ and so had one large-sized motorized [landing] craft of the Army. ${ }^{(88)}$ At 1252, the 4th Destroyer Squadron commander ordered by telegram the remaining two sweepers to "stop firing and head back." (119)

What had happened to the left wing unit? And what did Detachment Commander Sakaguchi do? After completing its landing at the landing point at Cape Batu at 0400 on the 11th as scheduled, the left wing unit tried to advance in the jungle towards the rear of the western battery. However, due to the extremely dense vegetation and the steep terrain in the jungle, it was only able to move forward by about 100 meters per hour, and got disoriented again and again. When it [finally] reached the rear of the battery, it was about noon on the 12th. ${ }^{(87)}$ Detachment Commander Sakaguchi, with no reports at all either from the left wing unit after its landing, or from his liaison officer dispatched to the left wing unit, had absolutely no clue about the situation [of the unit] until the night of the 11th. At midnight on the 11th, he had the 56th Field Artillery Regiment 1st Battalion Commander Lt. Col. Namekata Shōichi take command of one infantry company, go ashore at the point where the left wing unit had landed and, taking advantage of the darkness of the night, advance along the coast to seize the battery. ${ }^{(87)}$ At 0430 on the 12th, the Namekata Unit went ashore on the coast to the southeast of the Mengacu Battery, and around daybreak reached the front of the battery. However, the terrain blocked its progress. Although the left wing unit reached the rear of the Karungan Battery by noon of the 12th as mentioned above, not knowing the [exact] position of the battery, and also due to the poor condition of communications and having a hard time to move, it [finally] seized the battery at 1710 on the following day the 13th. ${ }^{(87,119)}$

In the final analysis, because of the three [following] reasons, that is, (1) insufficient enforcement of the order of the Dutch East Indies garrison commander, (2) the left wing unit's delay in seizing the battery, and (3) hasty minesweeping, Minesweepers No. 13 and No. 14 and one army [landing] craft were sunk in broad daylight right in front of their fellow warships. The situation at that time was recorded as follows by the 44th Field Antiaircraft Artillery Battalion: ${ }^{(88)}$

The brisk attack by the frontline unit of the right wing unit, carried out by means of night raids, finally made the enemy commander surrender on the morning of the following day, the 12th. 
Our Navy immediately started minesweeping in the southern waters of Tarakan Island, after which it was intended that the detachment commander would land at the shore of Lingkas in front of Tarakan for a meeting of both commanders, when all of a sudden, by fierce fire of the enemy's coastal artillery, two of the Navy's minesweepers and one army large-sized motorized [landing] craft were sunk in the blink of an eye. The detachment commander had no choice but to enter the town of Tarakan from the direction of the mouth of Amal River from which the main force of the landing unit had [started] its advance, and accept the enemy's unconditional surrender. Thus, the firing of the above-mentioned coastal artillery was the result of the fact that the enemy's order had not been fully enforced.

Having changed plans and entering [the town of] Tarakan after landing at the mouth of Amal River, the Sakaguchi Detachment headquarters ([more precisely] Staff Officer Yano) sent a telegram at 2100 on the 12th with the following content: "(1) The detachment commander entered Tarakan at 1930 via Amal. (2) At 0830 the commander of the right wing unit ordered the enemy in talks to suspend hostilities in the area, [in particular] to cease hostile operations of the Karungan Battery, but when he tried to reach the battery, it opened fire on our ships which was extremely regrettable. (3) At present, all enemy troops as far [north] as the airfield (seized by the naval landing force) have been completely disarmed. Disarmament of enemy troops north of the airfield will be carried out tomorrow on the 13th. (4) The Karungan Battery will be dealt with tomorrow morning on the 13th. Accordingly, we will notify when [it will be safe enough to] start the minesweeping [operation] ... [omitted by the author]. (7) The Lingkas defense is heavily fortified; should we have attempted to carry out a landing at this location as in the army agreement, then the landing troops would have been totally destroyed." (119) On the morning of the following day, the 13th, Detachment Commander Sakaguchi received a visit from the Dutch East Indies garrison commander, and officially accepted the latter's surrender. ${ }^{(87)}$ The mopping up of the enemy on the whole island was completed on the same day. ${ }^{(87)}$ Prior to this, on the 12th, the destroyer Yamakaze discovered a Dutch minelayer attempting to get away at night to the north of the Island, and together with patrol boat No. 38 sank the ship. ${ }^{(119)}$ Further, as soon as the Kuretake-maru had completed its handling of cargo at 2000 of the 11th, the destroyer Suzukaze escorted the Kuretake-maru to pick up the Matsumoto Detachment in Jolo. ${ }^{(119)}$

On the 14th the Sakaguchi Detachment turned over its guard duty [of the island] to the Navy. ${ }^{(119)}$

The strength of the Dutch East Indies Army at Tarakan Island at the opening of hostilities had been 1,400 men, including 800 infantry, 400 artillery and 70 engineers, which, with three $120-\mathrm{mm}$. guns and twelve field guns as the core, had [also] been well equipped with numerous machine guns. [After the battle,] 871 [men] were made prisoner of war. ${ }^{(100)}$ The only loss sustained by the Sakaguchi Detachment was just seven men killed in action. ${ }^{(53)}$ By contrast, the Navy sustained heavy casualties; 156 men were killed when two of its minesweepers were sunk, and 15 men were killed and 27 injured when they were bombed at the airfield on the 13th. ${ }^{(119)}$

The Sakaguchi Detachment suffered enemy air strikes from the 10th until the13th; no more strikes were made after that. ${ }^{(88)}$ The number of the [enemy] aircraft which came for strikes $^{(88)}$ and the military gains of the 44th Field Antiaircraft Artillery Battalion (consisting of two batteries) was reported as follows: ${ }^{(88)}$ 


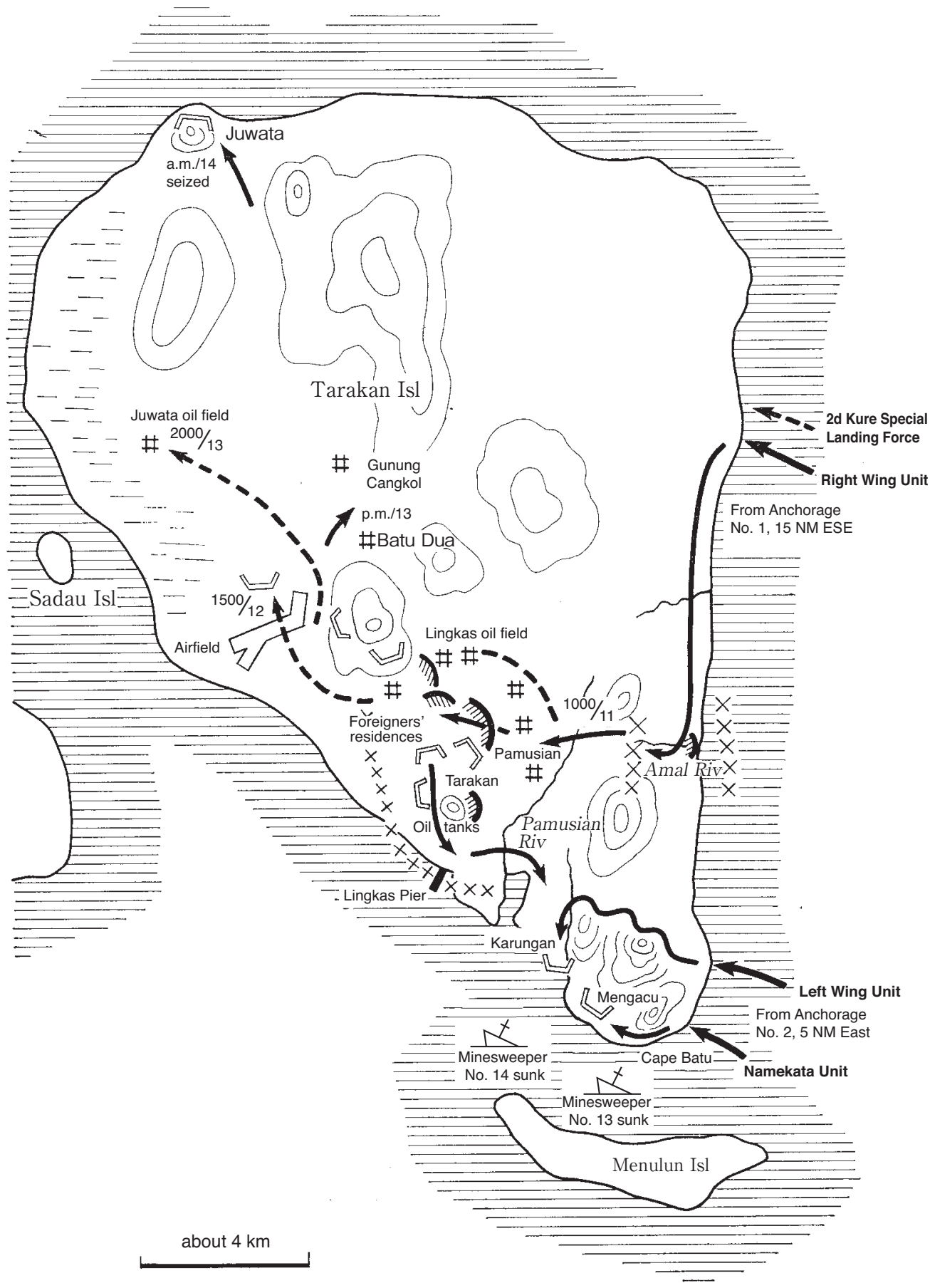

Illustration No. 17-The Capture of Tarakan 


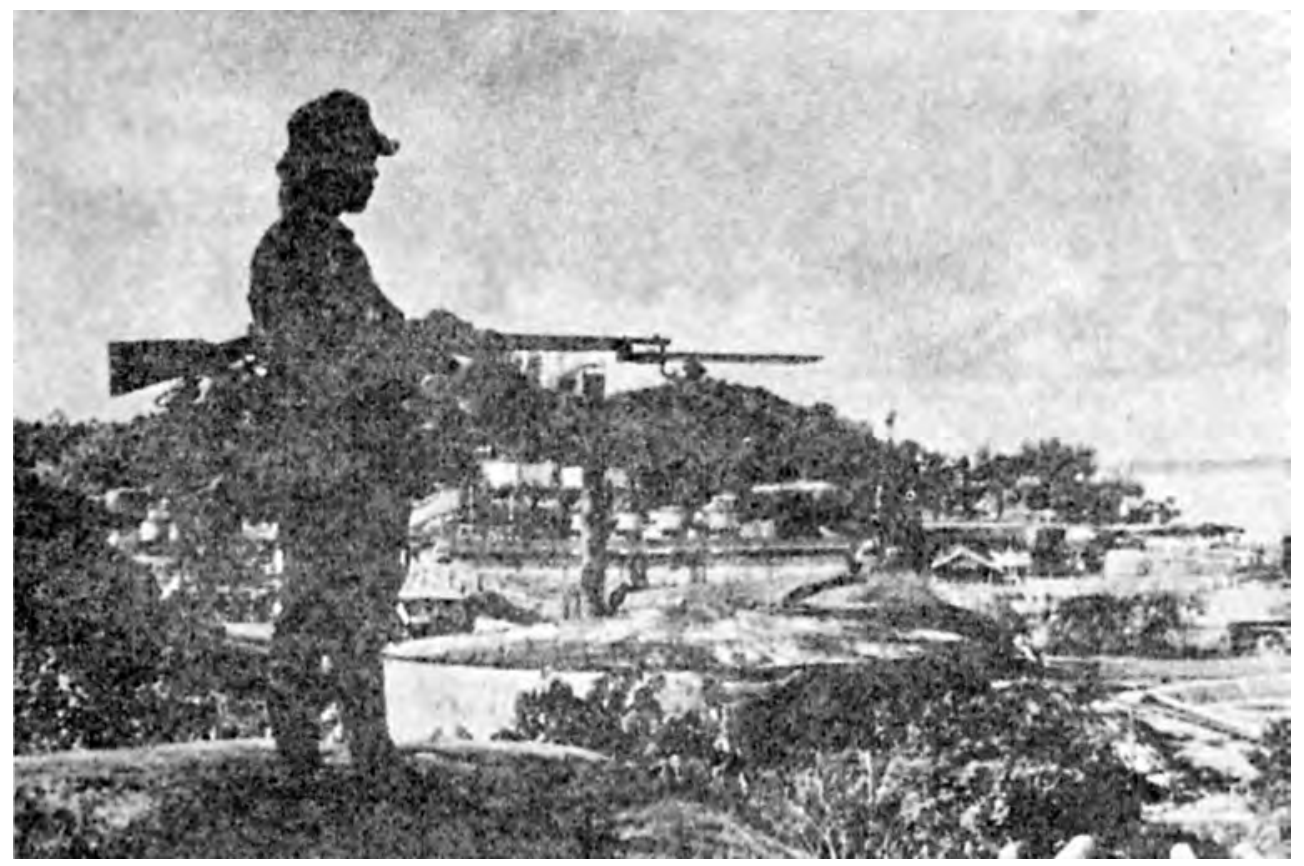

Right After the Capture of Tarakan

[January]

10th: 3 aircraft came flying in at 17406 bombs dropped

4 aircraft came flying in at 18126 bombs dropped

11th: $1 \mathrm{~B}-17$ came flying in at 12553 bombs dropped

12th: 3 aircraft came flying in at 12559 bombs dropped

3 aircraft came flying in at 18329 bombs dropped

13th: 3 aircraft came flying in at 11106 bombs dropped

3 aircraft came flying in at 14005 bombs dropped

1 aircraft downed

Total number of fired [antiaircraft] shells: 339 shots; military gains: 3 aircraft brought down

Note: The three aircraft reported to have been downed, apparently included planes shot down by Navy fighter planes.

The oil facilities had been substantially destroyed. In Lingkas, oil had for a large part been consumed by fire, but there was [still] 12,300 tons of heavy oil left in the surviving tanks, and [also] 120 oil drums of heavy oil.(119)

Tarakan's airfield was much narrower than expected. A thirty meter wide and about seven-hundred meter long runway was finally ready for use on the 16th, and nine fighter planes and two land-based reconnaissance planes advanced from Jolo on the same day. ${ }^{(119)}$ [However, it required considerable effort to get the facility ready for [the Navy land-based] medium-sized attack plane units to advance. As the Dutch East Indies forces had laid submarine mines all over the waterway, it was impossible for [the Japanese forces] to bring in matériel. The total number of swept mines had reached 77 by the 17 th, and 173 by the 24th. .119) $^{(19}$ 


\section{The Capture of Menado (See Illustration No. 18)}

On the day the Sakaguchi Detachment landed on Tarakan Island, the Navy carried out landings and parachute droppings in Menado. The force employed from the Dutch East Indies Unit and the tasks assigned to this operation were as follows: ${ }^{(14)}$

Eastern Attack Unit (commander: the 5th Cruiser Division commander)

Support Unit

Main force of the 5th Cruiser Division (heavy cruisers the Haguro and the Nachi; the Myōkō was damaged on 4 January and sent back to the mainland for repair) as its core: shall support all operations.

2d Escort Unit

Main force of the 2d Destroyer Squadron (consisting of the light cruiser Jints $\bar{u}$, the 15th and the 16th Destroyer Division), and the Sasebo Combined Special Landing Force (minus two platoons) as its core: shall directly escort the convoy, capture Menado, secure its air base and make it ready for use.

1st Base Unit

1st Base Force as its core (with the light cruiser Nagara (which belongs to the 16th Cruiser Division), and others): shall support the $2 \mathrm{~d}$ Escort Unit, defend the Bangka anchorage and protect the sea transport.

2d Air Unit

11th Seaplane Tender Division (with seaplane tenders the Chitose and the Mizuho) as its core: shall provide guard against submarines and support in the landing attacks.

The 2d Escort Unit commander laid down the course of action, in which he would have the main force of the Sasebo Combined Special Landing Force go ashore at the town of Menado on the west coast and an element at Kema on the east coast to carry out a pincer attack against the Dutch East Indies forces to seize the airfield in the Langoan area. On 5 January, he passed down his orders at Davao. ${ }^{(117)}$

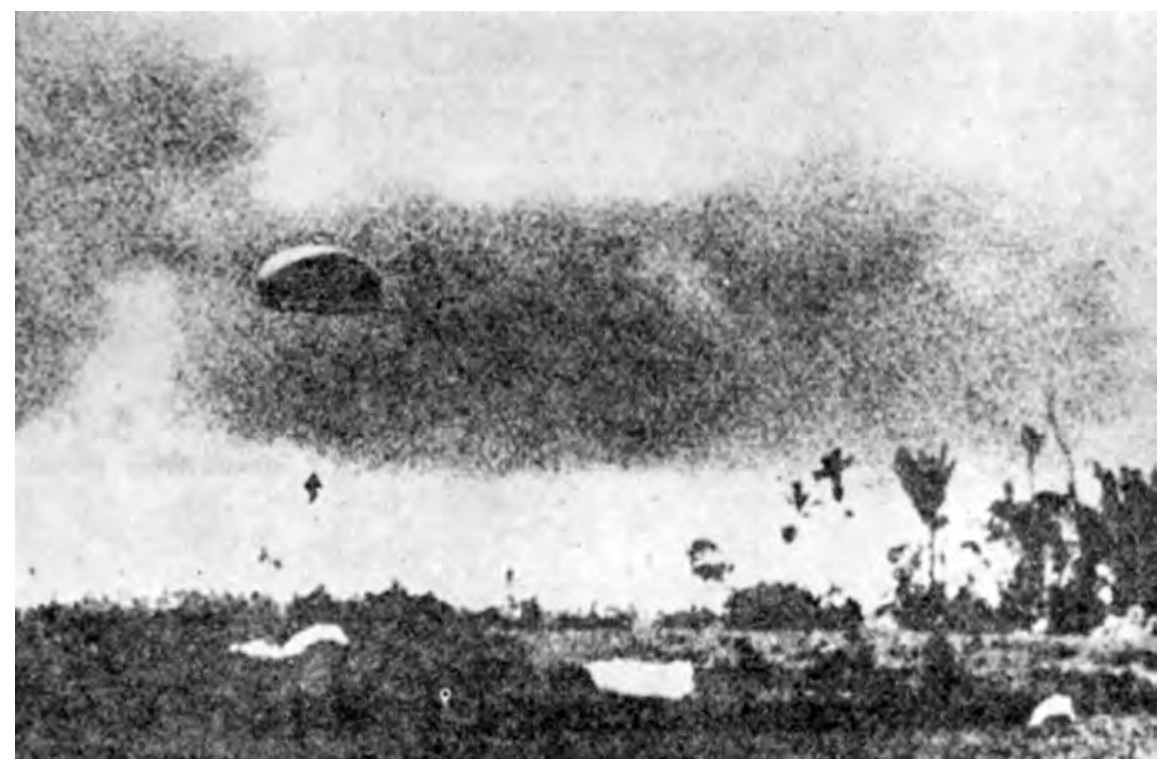

Naval Paratroop Unit Drop at Menado 


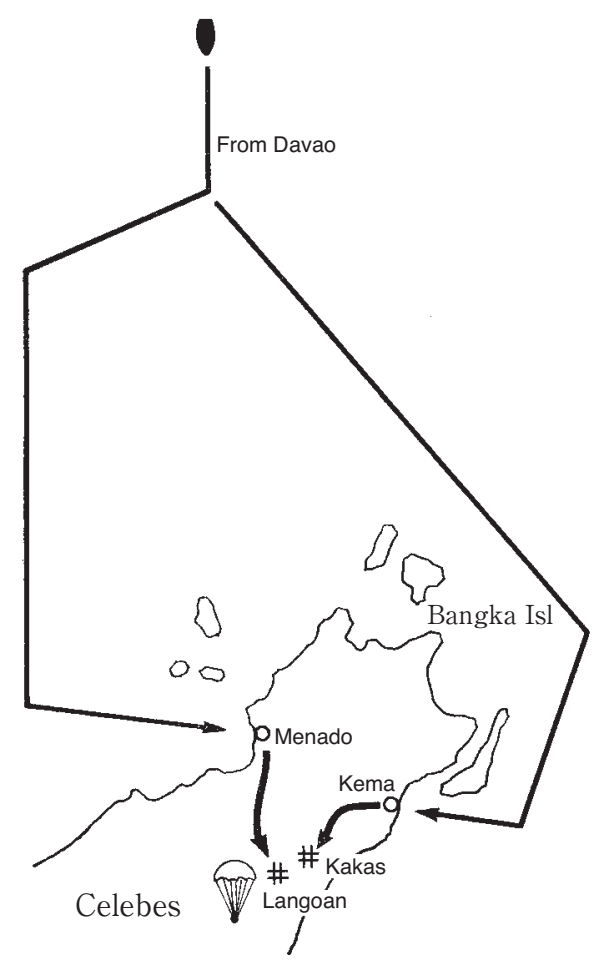

Illustration No. 18 - The $\{$ Navy $\}$ Operation to Capture Menado

The 1001st Unit ([consisting of] the 1st Yokosuka Special Landing Force) under the command of the commander in chief of the Eleventh Air Fleet would carry out the paratroop drop. On 7 January, Commander in Chief [of the Fleet] Tsukahara ordered that "the unit be put under the command of the 1st Air Raid Unit (i.e. the 21st Air Flotilla) until the drop, which shall be executed on 11 January."(144) It was decided that, in cooperation with the 1st Air Raid Unit, the 1001st Unit would drop two companies (334 men) on 11 January and one company (74 men) on 12 January at Langoan to seize the Langoan airfield and the Kakas Sea [plane] Base. ${ }^{(144)}$

On 9 January, the convoy of ten ships and its escort ships sailed from Davao. ${ }^{(117)}$ On this day, an allied plane flew close to reconnoiter and another three heavy bombers came to drop bombs, but no damage was sustained At 1400 on the 10th, the convoy separated into those heading for Menado and those for Kema. ${ }^{(117)}$ At 1830, three flying boats came and dropped bombs but no damage was sustained' No allied surface vessels appeared ei-

ther. On the following day, the 11th, the Menado unit (about 1,800 men) and the Kema Unit (about 1,400 men) successfully landed at 0400 and 0420 respectively. Repulsing a small number of Dutch East Indies troops, the units headed for the airfield. ${ }^{(117)}$ Six enemy planes came to attack and dropped bombs [on the Japanese troops] in Menado at 0635, followed by six planes at 0650, and three planes at 1540; four planes came to attack in Kema at 0620, followed by three planes at 0700 , five planes at 1430 and four planes at 1628 , but no major damage was sustained in either area. ${ }^{(117)}$

On this day, two companies commanded by the 1001st Unit's battalion commander, consisting of 334 men in total, had boarded twenty-eight planes and left Davao at 0630. At 0952 they parachuted in, and completely seized the Langoan airfield at 1130 and the Kakas Sea [plane] Base at $1800 .{ }^{(144)}$

On the following day, the 12th, one company of reinforcements (74 men) also parachuted in at 0952, and the paratroop unit, the Menado landing unit and the Kema landing unit each succeeded in making contact. ${ }^{(144)}$ On this day eight [enemy] planes flew in to drop bombs [on the Japanese troops] in Kema at 0815, followed by three planes at 0835, and also four planes flew in to drop bombs in Menado at 1030, which caused little damage. ${ }^{(17)}$ On this afternoon, ten fighter planes and one reconnaissance plane of the 21st Air Flotilla advanced into Kakas Airfield. ${ }^{(134)}$ From then on, no more air raids by allied planes were seen.

This paratroop operation at Menado was the first ever paratroop operation carried out by Japanese forces. The Army, which was planning to employ the 1st [Paratroop] Raiding 
Group for a surprise attack on Palembang, requested [the Navy] to delay the announcement about the paratroop operation at Menado. The Navy approved this request, and delayed its announcement until the droppings at Palembang. Thus on 15 February the following communiqués were released:(13)

\section{IGHQ Communiqué (1700 on 15 February)}

The Imperial Navy Paratroop Unit took part in the battle to capture Celebes on 11 January and achieved splendid results.

\section{IGHQ Communiqué (1710 on 15 February)}

The powerful Imperial Army Paratroop Unit succeeded in executing a surprise dropping at Palembang on Sumatra, the largest oil field area in the Dutch East Indies, at 1126 on 14 February, and while destroying the enemy and securing the airfield and other vital locations, it is further expanding military gains. 


\section{Chapter VII The Capture of Java's Dehors}

\section{1. [Commander Imamura's] Orders to the 38th Division}

\section{The Sixteenth Army's Arrangements with the [Navy] Malaya Unit}

$\mathrm{O}$ n 9 January, a meeting was held at the command post of the Sixteenth Army in Saigon with the staff officers Oyadomari Chōsei of the 38th Division and Akatsuka Kazuo of the 48th Division, who [both] had flown in on the day before. ${ }^{(32)}$ On the afternoon of the next day, the 10th, Army Commander [Imamura], Chief of Staff Okazaki, and Staff Officer Oda left for Cam Ranh Bay, where they had a meeting with the [Navy] Malaya Unit (the First Southern Expeditionary Fleet) on the flagship, the Chōkai, on both the 11th and the 12th, and also with the commander and staff officer(s) of the 5th Destroyer Squadron, after which they returned to Saigon on the night of the 12th. ${ }^{(32,120)}$

The general situation at that time was as follows:

1. Anticipating the seizure of Kuala Lumpur (seized on the 11th), the Twenty-fifth Army had given the following order in Ipoh on 10 January:(53) "(1) The enemy in central Malaya is [for the most part] destroyed near Slim, [after] being severely attacked and closely pursued by the 5th Division, and part of the remnants are retreating southward. [Meanwhile,] the 18th Division will land in Mersing shortly. (2) The army shall closely pursue the enemy toward Singapore." The main force of the 18th Division had left Humen in southern China on the 7th and had arrived in Cam Ranh Bay on the 10th. ${ }^{(53)}$ The Southern Army had held talks with the [Navy] Malaya Unit at Cam Ranh Bay on the 11th with the 18th Division also participating, where they agreed on [the plan] that the main force of the 18th Division ([consisting of] four battalions as its core) would land in Mersing on 17 January, and they signed [the arrangement] on the 12th. ${ }^{(23)}$ In Kuan$\tan$, the airfield had been made ready for use on the 10th. ${ }^{(53)}$ [Previously] on 6 January, the Southern Army had ordered the Kawaguchi Detachment to seize the airfields in Ledo. ${ }^{(23)}$ [Editor's note: Called Singkawang II and Singkawang III in Dutch sources. The latter was just an emergency landing strip.] The Southern Army had completed the previously mentioned "Supplement to the Southern Army's Air Operation Plan" on 10 January. ${ }^{(2)}$ The main force of the 33d Division had arrived in Bangkok from eastern China [also] on 10 January. ${ }^{(23,120)}$ The Sakaguchi Detachment had landed in Tarakan on 11 January, ${ }^{(119)}$ and the Eastern Detachment had left Hong Kong in southern China on 12 January to head first for Davao. ${ }^{(118)}$

2. The information on the allied forces, obtained by 8 January, was in outline as follows: ${ }^{(23)}$

(1) In Burma, the enemy was making every effort to build up its preparations against our offensive: It seemed that two divisions extracted from the northwest of India had arrived in Rangoon around 23 December, and the Chinese Army was also continuing its advance into Burma. 
(2) In Malaya, the British Indian Army was planning to hold out by having the units, which were previously deployed in several lines along the west coast, and the front line division of the Indian Army fight as a rearguard. Some 1,000 British Indian troops had been stationed in groups over the whole area of Kuantan on the east coast, but their main force had retreated westward on the 5 th due to the attacks by our army. There was information that an element of Australian troops had arrived in or near Singapore, but it seems that large corps had yet to arrive for support. In Singapore, some 70 allied aircraft were found on 3 January, which was [increased to] 114 aircraft on 7 January. It is certain that [the air force] had been reinforced [with aircraft] from the Dutch East Indies and Australia.

(3) In Sumatra, sixteen aircraft were found in Palembang, seven in Pekanbaru, and two in Medan on 3 January.

(4) Some 800 British Indian troops, who had been stationed in or near Kuching in British Borneo, had retreated in the direction of Siluas (note: southwest of Kuching) in Dutch [Borneo] at the end of December.

As previously described, the Southern Army had planned "landings in Bangka and Palembang around day $x+60$ (6 February)" with the aim of (1) seizing the oil resources in Palembang and its environs, the area with the richest oil field of the Dutch East Indies, (2) cutting off reinforcements for the allied forces in Singapore as well as blocking the retreat of the forces from the area, and (3) obtaining an air base for [the operation to] capture Java. It [also] intended to use the 1st [Paratroop] Raiding Group for seizing the oil resources in Palembang. However, the 1st [Paratroop] Raiding Regiment, which had been shipwrecked on 3 January, had reached Bangkok on the 11th with almost nothing more than the clothes on its back, and the $2 \mathrm{~d}$ [Paratroop] Raiding Regiment had not yet left the mainland. (It departed from Moji on the 15th. ${ }^{(23,93)}$ ) The Southern Army had come to think that it was impossible to use the [paratroop] raiding group for Palembang, because of the material and moral shock which the 1st [Paratroop] Raiding Regiment had sustained and the actual condition of the $2 \mathrm{~d}$ [Paratroop] Raiding Regiment with its insufficient level of training. ${ }^{(28)}$

Due to the fact that the [paratroop] raiding group was in the above-described condition, and the fact that the immediate concern of the [Navy] Malaya Unit was focused on the Mersing landing operation, which was expected to involve great risks, and the fact that the 38th Division would advance its assembly point to Cam Ranh and from then on work on preparing for the southern Sumatra operation, etc., the arrangements between the Sixteenth Army and the [Navy] Malaya Unit were somewhat less specific. In outline they can be imagined as having been as follows:

1. The Sixteenth Army shall have the main force of the 38th Division (with four battalions as its core) leave Hong Kong around 20 January, advance to Cam Ranh Bay around 24 January, and prepare for Operation L (i.e. the Bangka and Palembang landing operations).

2. The [Navy] Malaya Unit shall prepare for Operation L, while carrying out the Mersing landing operation ([of] the main force of the 18th Division, scheduled to land on 17 January), the seizure of the base on the Anambas [islands] (on the sea east of Singapore), and the operations against the coast west of Ledo.

3. The Sixteenth Army shall have the Operation L unit leave Cam Ranh around 31 January and have its advance party land in Bangka and Palembang on day L (6 February).

4. The Malaya Unit shall support these operations with the main force of its air and naval capacity. 
5. The droppings of the 1st [Paratroop] Raiding Group in Palembang shall be tentatively scheduled for the day before day L. The Southern Army shall be pressed for the execution [of the operation].

6. At a later date, the [Navy] Malaya Unit shall make further arrangements with the 38th Division about its escort and with the Third Air Force about its air cooperation.

At that time, the $3 \mathrm{~d}$ Destroyer Squadron was the only destroyer squadron in the Malaya Unit and it had been decided that its commander, R. Adm. Hashimoto Shintarō, leading the light cruiser Sendai, and the 11th and the 20th Destroyer Divisions, would provide the direct escort of the Mersing landing unit, while the 12th and the 19th Destroyer Divisions, each respectively incorporated in the main unit of the Malaya Unit and the main escort unit ([consisting of] the 7th Cruiser Division as its core), would provide the indirect escort of the Mersing landing unit. ${ }^{(118)}$ The 5th Destroyer Squadron under the command of R. Adm. Hara Kenzaburō ([consisting of] the Natori and the 5th and the 22d Destroyer Division, i.e. one light cruiser and eight destroyers), which had [temporarily] been transferred from the Philippines (Dutch East Indies) Unit to the Malaya Unit to escort the main force of the 33d Division, one regiment of the 5th Division, and others from Magong to Singora and Bangkok, was returned from the Malaya Unit to the Dutch East Indies Unit after finishing escorting the transport convoy on 9 January, and it was in the middle of changing course in order to escort the main force of the Sixteenth Army from Gaoxiong to Java. On its way, it made a call at Cam Ranh Bay for about five hours on the 12th, and had talks with the Sixteenth Army as well as with the Malaya Unit as previously told. ${ }^{(120)}$ Due to the Southern Army's acceleration of the Java operation, it had been decided that the 5th Destroyer Squadron would escort the main force of the Sixteenth Army straight to Java from Gaoxiong (without calling at Cam Ranh). At that time, the 5th Destroyer Squadron had received the following telegram from the [Navy] Dutch East Indies Unit: ${ }^{(120)}$

\section{Dated 6 January at 2030, from Chief of Staff, Third Fleet}

The following matters have been decided in the arrangement between the Sixteenth Army and the Third Fleet:

1. The escort of Detachment B has been changed and assigned to the 8th Destroyer Division.

2. The main force of the Sixteenth Army shall assemble in Gaoxiong from 29 January to 5 February and directly go [to the waters] close to Batavia without calling at Cam Ranh Bay. The details shall be specified in the arrangement between the 5th Destroyer Squadron commander and the [Sixteenth] Army commander.

\section{Dated 6 January at 2100, from Chief of Staff, Third Fleet}

The Third Fleet and the Sixteenth Army made a preliminary arrangement in Gaoxiong on 29 December and then concluded the formal arrangement by telegram. Therefore, no further faceto-face meetings will be held. A summary of the arrangement is as follows:

1. Army Detachment B (or the Itō Detachment, in four transport ships) shall leave Hong Kong on 12 January and arrive in Davao on 18 January under the escort of the 8th Destroyer Division. After that, it shall capture Ambon on 25 January and Kupang on 5 February under the escort of a force consisting of the $2 \mathrm{~d}$ Destroyer Squadron as its core.

2. The Sakaguchi Detachment shall be escorted by a force consisting of the 4th Destroyer Squadron as its core, and is scheduled to capture Tarakan on 11 January, Balikpapan on 21 January, and Banjarmasin on 31 January. (Accordingly, part of the operation to capture Menado is also set on 11 January.) 
3. The main force of the Sixteenth Army shall be escorted by a force which consists of the 5th Destroyer Squadron as its core. It shall depart from Gaoxiong during the period from 29 January to 5 February and land in or near Batavia around 16 February. The details shall be specified between the commanders of the 5th Destroyer Squadron and the Sixteenth Army in Gaoxiong on 26 January.

4. The 48th Division shall leave Manila on 7 February [under the escort of] a force consisting of the 4th Destroyer Squadron as its core and land in or near Surabaya around 16 February. The details shall be specified between the commanders of the 4th Destroyer Squadron and the 48th Division in Manila on 4 February.

The 8th Destroyer Division, which would escort the Itō Detachment, belonged to the $2 \mathrm{~d}$ Destroyer Squadron. As previously explained, because the operation schedule was quite tight and the forces employed for escorting were extremely limited, the [Navy] Southern Task Force (including the Dutch East Indies Unit, the Malaya Unit, and others) had no extra strength to spare for the rear. On 14 January, the Navy Department of the IGHQ [even] passed down an order that "the second transport convoy of the unit under the direct control of the Twenty-fifth Army (in twenty-four transport ships) from Magong to Singora shall be provided by the Second China Expeditionary Fleet."(1) It was during these meetings [in Cam Ranh] on the 11th and 12th that, before directly reporting his concerns to [Southern Army] Commander in Chief Terauchi, [Sixteenth] Army Commander Imamura had sought the opinion of [First Southern Expeditionary Fleet] Commander in Chief Ozawa, who had given him a reassuring response. (See the previous description [p.164].)

\section{Army Commander [Imamura] Heads for Gaoxiong After Giving Orders to the 38th Division}

On 14 January, the 48th Division ([in] the Philippines) was added to the order of battle of the Sixteenth Army by order of [the Army Department of] IGHQ. ${ }^{(1)}$

On the next day, the 15th, the previously mentioned preliminary arrangement made between the Sixteenth Army and the [Navy] Malaya Unit in Cam Ranh on the 12th was [officially] signed. ${ }^{(120)}$

The $2 \mathrm{~d}$ Division was supposed to start leaving Moji from that day (the 15th) and come to Gaoxiong first. ${ }^{(53)}$

Army Commander Imamura left Saigon at 0900 on the next day, the 16th, along with Chief of Staff Okazaki, leaving [Chief of] Operations Staff Oda and others in Saigon. He arrived in Guangdong at 1700 via Sanya on Hainan Island, made a courtesy call on the Twenty-third Army commander, and left Guangdong at 1300 on the next day, the 17th, for Hong Kong, where, after the commander and cadre of the 38th Division had presented themselves before him, he gave instructions and took command of the division. ${ }^{(32)}$ Division Commander Sano Tadayoshi reported that (1) the damage that the division had sustained through the capture of Hong Kong was not so serious, and that the valuable experiences gained through fighting against a European army was rather a big advantage for them; that (2) the Itō Detachment (or the Eastern Detachment), which had embarked with the help of Staff Officers Saiki Ikuzō and Nishiura Setsuzō dispatched from Saigon and Taiwan respectively, had been sent off by Senior Staff Officers Takashima Tatsuhiko and Kitamura Yoshifuto, who had come from 
Saigon representing the army commander, and that it had left Hong Kong on the 12th, under the escort of the 8th Destroyer Division, and was heading first for Davao. ${ }^{(35,36)}$

At 0900 on the next day, the 18 th, ${ }^{(32)}$ Army Commander [Imamura] gave the 38 th Division commander in outline the following order: ${ }^{(66)}$

1. The main force of the 38th Division (minus the Eastern Detachment and the Shōji Detachment) shall advance first to Cam Ranh Bay by late January and leave the bay around 31 January under a naval escort, pass through [the waters] off the coast of Singapore, and put ashore an element on Bangka Island around 6 February to seize Mentok airfield. On the same day, the main force shall go upstream on the Musi River, rush to Palembang, secure the place, relieve the paratroopers, and at the same time have a powerful unit advance as swiftly as possible to Telukbetung, which faces the Sunda Strait, and seize the airfield there.

2. The Shōji Detachment ([consisting of] the main force of the 230th Infantry Regiment as its core) shall be put under the direct command of the [Sixteenth] Army and shall advance to Gaoxiong first.

Incidentally, Chief of Staff Okazaki considered that motorization [of the army] was absolutely essential in order to accomplish a blitzkrieg-like operation against the Dutch East Indies where the roads were considerably developed, and he had sent in advance a telegram to the 38th Division to instruct them to equip [its units] with motor vehicles seized in the war. ${ }^{(36)}$ However, according to the report from the division, the Twenty-third Army had not allowed it. Understanding the Twenty-third Army's position, Chief of Staff Okazaki then borrowed eighty motor vehicles [from the Twenty-third Army] by handing in exchange a bond of borrowing to its chief of staff, Major General Kuribayashi, and equipped [the division] with them. ${ }^{(36)}$ Later, the Shōji Detachment achieved great results in seizing at a stroke the Kalijati airfield on the day of its landing by using these motor vehicles, and thereby enabling the advance of the 3d Air Division under the command of Major General Endō as early as the next day.

After issuing the above orders to the 38th Division on the 18th, Army Commander Imamura left Hong Kong for Gaoxiong at 1000 on the same day, where, after a long absence, he took command of the headquarters of the army. ${ }^{(32)}$ Vice Chief of Staff Harada and Staff Officers Takahashi, Nishiura, Yamashita and others had left Tokyo on 2 January, arrived in Taipei on the 5th, then [first] stationed [the army headquarters] at [the facility of] the Taiwan Army headquarters in Taipei. After welcoming Staff Officers Takashima and Kitamura from Saigon on the 8th, they had moved from Taipei and set up the army headquarters in Gaoxiong on the 12 th. ${ }^{(45,33,34)}$

After mostly finishing what he had to do in Gaoxiong, the army commander was considering departing for the Philippines to take command of the 48th Division there, when the [Navy] Dutch East Indies Unit (the Third Fleet), which had [once] stated in its order that "it would hold no further face-to-face meetings with the Sixteenth Army, and that, from now on the commanders of the 4th and the 5th Destroyer Squadrons should arrange matters respectively with the commanders of the 48th Division and the Sixteenth Army," notified its "wish to make operational arrangements with the Sixteenth Army in Manila from the 21st onward." So the army commander flew from Gaoxiong to Manila on the 21st, ahead of schedule. ${ }^{(32)}$ On the previous day (the 20th), the Southern Army had given the Sixteenth Army the previously mentioned order to carry out the operation to capture Java. ${ }^{(23,24)}$ 


\section{The Manila Conference and the Arrangements Between the Sixteenth Army and the [Navy] Dutch East Indies Unit}

\section{An Unexpected Request from the [Navy] Southern Task Force}

On 19 January, the Southern Army received a telegram from the [Navy] Southern Task Force (i.e. the Second Fleet), which explained the totally unexpected situation in the eastern part of the Dutch East Indies, and requested postponement of the landings on Java due to this [situation]. ${ }^{(23,24)}$ At that time, the 38th Division had finished its embarkation and was to leave Hong Kong and head southward on the next day, the 20th. Furthermore, the 2d Division was due to arrive in Gaoxiong from the day after next, the 21st, and the 48th Division had been preparing for the Java operation since the 8th, while the Twenty-fifth Army had given an order on the 10th to pursue the enemy toward Singapore and, though behind schedule, was going to carry out a landing in Mersing on the 26th. ${ }^{(53)}$ [Actually,] it was the postponement from 17 to 26 January of the date of landing in Mersing (though it was decided that only the unloading of plane fuel and ammunition would do and that the landing of the main force of the 18th Division was no longer necessary), and the delay in capturing the Ledo airfield by the Kawaguchi Detachment that the Southern Army really worried about. It had never dreamed of a delay in the operations on the east coast of Borneo [and further east]. Three days before (on the 16th), it had [even] recorded in its journal: "Directives for Operation $\mathrm{H}$ (note by the author: the Java operation): Although the principle is to carry out simultaneous landings in eastern and western Java, the landing in eastern Java may have to be carried out on its own [first], should by any chance Operation L (note by the author: the Bangka and Palembang operations) be delayed."(24) And so it stuck to its conviction that it should land on Java on day $x+70$ (16 February) in any case. ${ }^{(23,24)}$

\section{Dated 19 January at 0000 from Chief of Staff, Second Fleet \\ To Chief of Staff, Southern Army}

Regarding the schedule for capturing the Dutch East Indies, the bases seized in the eastern part of the Dutch East Indies are in an unexpectedly bad condition, and even though we are trying by every possible means to expand them and make them ready for use, the fact remains that the advance and deployment of [our] air force is gradually getting delayed, whereas the enemy has been launching counterattacks from the many bases [still under its control]. In addition, if we consider the situation at Tarakan, where [submarine] mines were laid over extensive areas, it becomes inevitable to postpone the scheduled dates of landing in Banjarmasin, Makassar, Timor and Java by about ten days in order to proceed with the coming capture operations without serious problems. Therefore, in order to arrange the details, we will send the senior staff officer of our fleet to the meeting to be held in Manila from 21 to 23 January between the Sixteenth Army, the Third Fleet, and the Eleventh Air Fleet. We would like you to especially see to it that also from your headquarters a staff officer will be dispatched.

The Southern Army took the situation seriously and decided to dispatch Col. Ishii Masayoshi, senior staff officer of Section 1, Col. Tanikawa Kazuo, senior staff officer of Section 4, and [Navy] Capt. Ishihara Itsu, staff officer of the Second Fleet seconded to the Southern Army, to Manila. At the same time, it sent the [Navy] Southern Task Force and the Army Department of IGHQ the following telegrams: ${ }^{(23)}$ 


\section{To Chief of Staff, Second Fleet (dated 19 January at 1730)}

We have taken note of the Second Fleet Telegram Classified No. 702 regarding the schedule for the capture of $\mathrm{H}$. The [Southern] Army considers that it is essential that the schedule should not be postponed even if it entails some risks, as it is highly likely that allowing the enemy time to increase its preparations step by step would rather make the capture operations more difficult. Therefore, it has asked the corps under its command for full support not only for the air units of the Army but also for those of the Navy in respect to seizing airfields and making them ready for use, and replenishing fuel and ammunition [for their aircraft]. We would like to ask your understanding of the above in advance. We shall send Staff Officers Ishihara, Ishii, and Tanikawa to Manila.

\section{Dated 19 January from Chief of Staff [Southern Army]}

\section{To Vice Chief of Army General Staff}

Southern Army Staff Section 1 Telegram No. 557

1. We have received a telegram from the Second Fleet, which is summarized as follows: (The following part omitted by the author.)

2. In response, we wired back, stressing that the [Southern] Army wants to keep the invasion schedule specified in General Agreement No. 4 as standard at all costs, as it is apparent that postponement of the date of capture would rather result in the enemy's reinforcement of its defense (naval and air [defense] in particular) and cause further delay in our advance, and we informed [the fleet] that we would provide full support for the Navy air units as well by seizing airfields and making them ready for use, and replenishing fuel and ammunition [for their aircraft], in order to increase the fleet's confidence.

3. However, regarding Operation H (note by the author: the Java operation), our operational policy was originally based on the assumption that we would resolutely carry out the policy by applying overwhelming results against the enemy air power, as the air power of both the enemy and us is evenly matched. Now that the enemy's air power in $\mathrm{H}$ has been slightly increased, and, moreover, a reinforcement of enemy naval vessels seems to be arriving soon, it is perfectly clear that a postponement of several days will rather cause a delay of more than a dozen days. Therefore, we judge that it is too late to hesitate in carrying out the plan of operations.

4. We [provided] the above [information] just in case a proposal [would be made to you] by the Navy General Staff.

\section{The General Situation Until Then}

\section{Information on allied forces}

Southern Army Special Report No. 5 (from 9 to 20 January) $)^{(23)}$

1. General situation

(1) The allied forces of the enemy in the Southwest Pacific seem to be preparing for a protracted [war] by making every effort to strengthen the line between Burma and Australia via the Dutch East Indies (Sumatra and Java), while continuing resistance in Malaya and the Philippines. Although it is not yet known for certain how much Britain and the United States have reinforced their military strength since around the time of the opening of hostilities, it is roughly estimated as follows:

\{1\} Burma

One Indian Army division and about fifty aircraft.

\{2\} Malaya

About one Indian Army brigade and about one Australian Army brigade. 
Some U.S. and Dutch aircraft.

It seems that Britain is dispatching more warships from the Indian Ocean to reconstruct its Eastern Fleet, but the details are unknown.

\{3\} The Dutch East Indies

Whereas the details of ground troops and aircraft are unknown, the main force of the U.S. Asiatic Fleet seems to have fled to this area. Regarding their route of transport, it is almost certain that Britain for sure but also the United States is using the Indian Ocean route. (The rest omitted by the author.)

II. Operation S (the Endau and Mersing landing operation) has up to now progressed as follows:

As previously mentioned, the Southern Army drew up plans for Operation Q (the Kuantan landing operation) and Operation S on 13 December, concluded General Agreement No. 3 at Cam Ranh on 23 December, and on the same day ordered by means of Southern Army Operation Order A, No. 20 that Operation Q [would be carried out by a force of] two battalions of the 18th Division as its core, which would land in Kuantan around 31 December, and that Operation S [would be carried out by] the main force of the 18th Division ([consisting of] four battalions as its core), which would land in Mersing around 7 January. However, it cancelled Operation Q on 27 December and had the unit supposed to conduct the operation (i.e. the Koba Detachment) land in Singora [instead] and go southward along the east coast. [Meanwhile] the Takumi Detachment, which had gone ahead southward along the east coast, occupied Kuantan on 31 December, and the airfield there was made ready for use on 10 January. ${ }^{(23)}$ As previously told, the Southern Army unwillingly called off Operation Q for four reasons: the opinions offered by the Twenty-fifth Army and the Third Air Force, the opinion of the Navy, and the swift advance of the Takumi Detachment. Instead, it poured great enthusiasm in conducting Operation $S$ and insisted on its definite implementation. ${ }^{(23)}$ As for the Twenty-fifth Army, it had great expectations for the Mersing landing operation because the progress of its operations since its advance to the banks of the Perak River had not been very good. The main force of the 18th Division charged with the Mersing operation was [also] extremely enthusiastic, partly because the units formed out of this division and commanded by Detachment Commanders Takumi, Koba and Kawaguchi had been achieving brilliant military gains on the east coast of Malaya and the west coast of Borneo. ${ }^{(23)}$ The air [support] arrangements for Operation $S$ were made on 3 January (the day when [Sixteenth] Army Commander Imamura moved to Saigon). ${ }^{(23)}$ Anticipating that a landing close to Singapore would trigger fierce counterattacks by the allied air and naval forces, it was decided that the air operation should be absolutely perfect. This resulted in a plan for an unusually massive air operation since the opening of hostilities, in which a total of more than 300 aircraft, consisting of about 110 fighter planes, about 80 heavy bombers of the Third Air Force of the Army and about 20 fighter planes and about 100 land-based attack planes of the 1st Air Unit (the 22d Air Flotilla) of the Navy would be employed. Also, it was decided that almost all airfields in Malaya would be used, among which those in Kota Bharu and Sungai Petani would be shared by the Army and the Navy, and that the Army would advance about 60 Type-97 fighter planes to the Kuantan airfield to provide perfect cover for the convoy. ${ }^{(23)}$ Furthermore, it was decided that the air operation should 
be launched as soon as possible from 10 January onwards to destroy the allied air power in and around Singapore. ${ }^{(23)}$ Subsequently, on 11 January, the Southern Army conferred about the operational arrangements for Operation S in Cam Ranh and concluded them on the next day, the 12th. ${ }^{(23)}$ (On that day, the Sixteenth Army had a preliminary meeting with the [Navy] Malaya Unit in Cam Ranh on the operations against Bangka and Palembang. ${ }^{(32)}$ ) The top echelon of the 18th Division (who arrived at Cam Ranh Bay on 10 January) also participated in the arrangement. ${ }^{(23)}$ In this arrangement, it was decided to roughly set the landing date as 17 January, and if a change [in the date] were necessary, both parties should discuss and determine [a new date] by noon three days prior [to the landing date]. The point of landing should be the coast of Endau, and the landings should take place for two days in eleven fast ships, which would leave Cam Ranh Bay on 14 January under the direct escort of the Navy 3d Destroyer Squadron (of about six destroyers) with the Sendai as flagship as its core, and under the indirect escort of almost the whole force of the Malaya Unit. ${ }^{(23)}$ In concluding this arrangement, heated arguments were exchanged over the schedule between the Southern Army and the Navy; the former insisted on carrying out the operations against Bangka, Palembang and Java as scheduled in General Agreement No. 4 (the agreement concluded on 1 January), while the latter would like to carry out secure surface escort operations after [first] gaining command of the air. ${ }^{(23)}$ Although the operation to destroy the enemy air power based on the above-mentioned arrangement of 3 January was started on 12 January, the start on the Navy side [was delayed to] the following day, the 13th, due to bad weather on the east coast of Malaya. ${ }^{(23)}$ What was more, it did not produce the expected results: repeated attacks by our forces ended in vain as the allied air forces escaped from Singapore. Instead, the allied air forces came to attack the anchorage in Singora on the 12th and the 13th and in Sungai Petani on the 15th, and it seemed from observation that they were also being reinforced. ${ }^{(23)}$ Around this time, the Twenty-fifth Army's offensive was regaining its momentum; on 11 January it stormed into Kuala Lumpur, a place of strategic importance, and its leading group closed in on Gemas on the 14th. It was now expected that [the Twenty-fifth Army] would be able to advance to the Straits of Johor around 25 January. ${ }^{(23)}$ On 14 January (two days before the [Sixteenth] Army Commander Imamura left Saigon for Hong Kong and Gaoxiong), the chief of staff of the Twenty-fifth Army [Lt. Gen. Suzuki Sōsaku] sent the following telegram to the chief of General Staff of the Southern Army:(23)

\section{ToMI [Twenty-fifth Army] Staff Section 1 Telegram No. 723 (dated 14 January)}

The operations of the [Twenty-fifth] Army are making more progress than expected. In view of the current situation, where most of the immediate enemy has been destroyed and so has its morale, we have come to the conclusion that Operation S does not need to be carried out in order to [facilitate] the capture of Singapore. Instead, the army would like to promptly launch the Sumatra operation following the capture of Singapore. Therefore, although we appreciate the special consideration of [the Army Department of] IGHQ and the Navy [for Operation S], we would like to propose that Operation S be cancelled for the above reason, and that the main force of the 18th Division will be put ashore in Singora and assemble on the coast opposite of Penang. 
The Southern Army received the above telegram on the same day (the 14th). It was [also] the day when the 18th Division was supposed to leave Cam Ranh Bay for Operation S. ${ }^{(23)}$ The above telegram of the Twenty-fifth Army had been sent to [the Army Department of] IGHQ as well, and also to the Navy by its liaison officer. ${ }^{(23)}$ [Meanwhile] the [Navy] Malaya Unit had wired the Southern Army on the same day (the 14th) that "it would postpone the landing date of Operation S (by two days [in total]) to the 19th in view of the insufficient results of the air operations to destroy the enemy in the Malaya theater." (23) The 18th Division, however, which wanted to be engaged in the operations of the war as soon as possible, wired the chief of staff [of the Southern Army] under the name of Division Commander Lt. Gen. Mutaguchi Ren'ya, on the same day (the 14th) the following telegram: ${ }^{(23)}$

\section{KIKU [18th Division] Staff Telegram No. 25 (dated 14 January)}

Even though the division hoped and tried every way to persuade [the Navy] to depart as soon as possible [for Operation S], the Navy did not agree to our departure because of the less-than-expected results of the air operation to destroy the enemy air power, and it even further postponed [the departure] by one day, which eventually forced us to [just] watch the situation. Although it has made efforts to improve its air operation by changing the methods, the timing and other [factors], the Navy seems to think that [even] departure under a blackout will probably be difficult depending on the results [of the air operation] from tomorrow onwards. We really would like to have the [Southern] Army's help as well, so that this operation [of ours] will be swiftly accomplished.

At that time, the results of the massive air operations launched from 12 January onwards to destroy the enemy air power were not as anticipated: the allied air forces had fled to Sumatra, and [their] aircraft still kept on making occasional guerrilla-like attacks. ${ }^{(23)}$ [However,] the Southern Army headquarters had no accurate knowledge of the insufficient results of these air operations. ${ }^{(23)}$ Furthermore, there was also the precedent of Operation Q, when the Southern Army, though deploring the Navy's proposal to postpone the operation, had reluctantly accepted it, because it had been formally consulted. ${ }^{(23)}$ However, it did not approve the Twenty-fifth Army's proposal to cancel Operation S and turned it down. ${ }^{(23)}$ While the Southern Army found the [Navy] Malaya Unit's proposal cowardly, it felt obliged to agree to the proposal as it had been formally consulted, and it sent on the same day the following telegram to the chief and vice chief of staff of the Malaya Unit under the name of the chief of staff [of the Southern Army]:(23)

\section{Southern Army Staff Section 1 Telegram No. 504 (dated 14 January)}

Although the results [of the damage] caused to the enemy warships in the air operation against Singapore are not clear, we completely overwhelmed the enemy air forces and not more than about fifty [enemy] aircraft are left. As the enemy aircraft are only vainly trying to escape to preserve themselves, the [Southern] Army judges that the cover of the convoys under sail and at the anchorages may be expected to be perfect. In view of the progress of the operations along the west coast of Malaya, we are very much afraid that further delay in implementing Operation $S$ at this moment in order to await [further] results in the air operations will mean that we will not only lose a battle opportunity but also delay the launch 
of Operation H. We would appreciate your understanding that when the [Southern] Army concluded the agreement on the air operations we counted on carrying out the operations under such results as attained up to today. And we would like you to understand that also concerning the implementation of Operation L our view remains the same as the above.

Note: Operation H means the Java [operation], and L means the Bangka and Palembang operations.

Thus, on 16 January, the day of the operation convoy's departure after the two-day delay came at last, but the Southern Army received another telegram from the Malaya Unit: ${ }^{(23)}$

On the 14th, an Army reconnaissance plane scouting [the enemy around] Singapore spotted one aircraft carrier and seven warships in its naval port, and six or seven ships which seemed to be battleships or cruisers on the sea south of [Kampung Sungai] Buntu. On the 15th, we identified on reconnaissance photos by a Navy reconnaissance plane, one battleship (apparently Renown-class) and five destroyers anchored in the naval port. Others are unidentified due to clouds. Our unit plans to destroy these enemy [ships] first. We would like to request a postponement of Operation $S$ for the time being.

The same day (the 16th), the Southern Army received yet another telegram from the Malaya Unit to the effect that the latter wanted to postpone Operation S until the 21st, to which the army reluctantly sent a reply of approval. Then again on the same day (the 16th) the army received the following consultative telegram, this time from the Southern Task Force (the Second Fleet): ${ }^{(23)}$

In view of the enemy's movements in the Singapore area and the present progress of the Army operations in the E area, we [propose to] cancel Operation S. The Navy's cooperation in the sea transport and debarkation of matériel for the Army air bases to the Endau and Mersing areas shall be arranged between the commander in chief of the Southern Army and the commander of the Malaya Unit.

Note: E indicates Malaya.

On this day (the 16th), the judgement of Section 1 of the Southern Army Staff was [still]

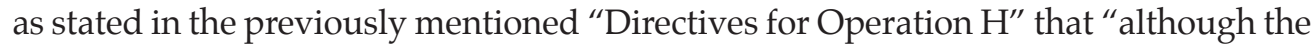
principle is to carry out simultaneous landings in eastern and western Java, the landing in eastern Java may have to be carried out on its own [first], should by any chance Operation L be delayed." (24) On the previous day (the 15th), after receiving the information about the allied fleet in the Singapore area, the commander of the Malaya Unit (and commander in chief of the First Southern Expeditionary Fleet), Vice Admiral Ozawa, had left Cam Ranh Bay with his main unit and was sailing southward, ${ }^{(103)}$ while the commander of the Southern Task Force (and commander in chief of the Second Fleet), Vice Admiral Kondō, who had left Magong on the 14th and was on his way [with his fleet] to Palau, ${ }^{(103)}$ had sent the Southern Army the above-mentioned proposal to discuss cancelling the operation. It was [also] the day when [Sixteenth] Army Commander Imamura left Saigon for Hong Kong and Gaoxiong. ${ }^{(32)}$

The Southern Army headquarters finally recognized the fact that the results [of the air operation] to destroy the enemy air power were insufficient. ${ }^{(23)}$ At that time, the 
front line of the Twenty-fifth Army was closing in on Gemas, but the actions of the allied air forces were still brisk. ${ }^{(23)}$ The next day, the 17th, in reply to telegram No. 153 sent by the Southern Army on the 16th (the telegram concerning the postponement [of operation S] until the 21st), the Malaya Unit (in the middle of its mission) expressed its views as follows: ${ }^{(23)}$

\section{To Chief of Staff, Southern Army}

\section{From Chief of Staff, First Southern Expeditionary Fleet}

Concerning Southern Army Staff Section 1 Telegram No. 153, we have the following views: The Southern Expeditionary Fleet considers the main objective of Operation $S$ to be the acceleration of the operations of the Twenty-fifth Army. By maintaining close contact and working together with the army we are familiar with the progress of its operations in detail. At the same time, in the light of the circumstances surrounding the cancellation of Operation $\mathrm{Q}$, we are very concerned about the delay of day S, and through the departments concerned both in the Army and the Navy, we have often signaled to the [Southern] Army as well our intention regarding stepping-up the air operation. Whereas the operations of the Twentyfifth Army are developing more rapidly than expected, the progress of the air operations, which had been delayed and were finally launched on the 12th, has failed to live up to our expectations, partly due to bad weather. As of the 14th, it seems that we have been able to practically overwhelm the enemy fighter planes, but most of the enemy torpedo bombers are yet to be destroyed. We judged that it was highly possible that in carrying out Operation $\mathrm{S}$ as scheduled under such circumstances [our] transport fleet would sustain serious damage, and thus we postponed [the operation]. You may understand from the above that we consider the enemy attack planes as the main object of our air operation. We would like you to understand that our view is significantly different from yours. Because it would be unpleasant to carry out under these circumstances in cooperation [with you] Operation L hereafter, we would like to have a full discussion on another occasion.

Unlike the Twenty-fifth Army, the Southern Army not only focused on the operations in Malaya, but also in particular on the implementation of the Bangka, Palembang and Java operations, and thus [the Southern Army considered] it urgently necessary to promptly make airfields ready for use. [In other words,] even if it were [no longer] necessary to put ashore forces for the capture of Singapore, it was still necessary to disembark the forces and the matériel for making the airfields near Kluang and Kahang ready for use. [Consequently,] instead of giving full approval to the cancellation of Operation S, the [Southern] Army sent on the same day (the 17th) the following reply for a conditional cancellation [of Operation $S$ ]:(23)

\section{To Chiefs of Staff, Second Fleet and First Southern Expeditionary Fleet}

\section{From Chief of Staff [Southern Army]}

We have no objection to your proposal concerning Operation $S$ on the following conditions: The sea transport to Endau or Mersing shall be conducted in two ships by 26 January at the latest. The Navy shall take charge of the mine sweeping of and near the landing points and the cover of the ships under sail and at the anchorages; whereas the Army shall take charge of the air defense. The time required for disembarkation will be a whole day and a night. Further, the units on stand-by in Cam Ranh Bay shall be put ashore in Singora and Bangkok. 
After receiving replies from the Southern Task Force and the Malaya Unit that [both] had no objections to the above telegram, the Southern Army ordered the cancellation of Operation S on 19 January, and at the same time gave an order to the Third Air Force to "transport and land [the ground units of] the air units (including the matériel), presently on stand-by in Cam Ranh Bay, near Endau or Mersing by 26 January at the latest in cooperation with the [Navy] Malaya Unit."'(23) On the previous day (the 18th), the main unit of the Southern Task Force ([under the command of] Vice Admiral Kondō) had arrived in Palau to support the Dutch East Indies operation. ${ }^{(103)}$ Also on this day (the 19th), the main unit of the Malaya Unit returned to Cam Ranh Bay, ${ }^{(103)}$ because there were not as many enemy warships in Singapore as reported, and the allied fleet had not appeared either. ${ }^{(118)}$ Meanwhile, Sixteenth Army Commander Imamura, who had ordered the main force of the 38th Division to first advance to Cam Ran Bay, had arrived in Gaoxiong on the previous day (the 18th). ${ }^{(32)}$

It was on this [very] day (the 19th) and under the above-mentioned circumstances that the Southern Army received the telegram mentioned in the beginning [of this section] from the Southern Task Force, that is, the telegram to the effect that the forward push of the bases in the eastern part of the Dutch East Indies could not be carried out as scheduled, and that it would like to request that the landings on Java scheduled for 16 February be postponed by about ten days. For the Southern Army the two messages [the delay in the forward push and the postponement of the Java landings] contained in the telegram came totally unexpected.

III. The Ledo airfields issue (See Illustration No. 19)

At that time, one of the concerns of the Southern Army was [the progress of the operation to] seize the airfields in Ledo and make them ready for use. The issue was in outline as follows:

As previously described, [in preparation] for conducting the southern Sumatra and Java operations, the plan was that the Army air units would go southward along the Malay Peninsula, while the main force of the land-based aircraft of the [Navy] Malaya Unit would advance into western Borneo (i.e. Kuching) to carry out further operations [from there].

The Kawaguchi Detachment had seized the airfield in Kuching on 25 December. ${ }^{(23)}$ However, the Kuching airfield was against expectations in such a bad condition that it was judged too difficult to be fixed for use. ${ }^{(23)}$ On learning that the airfield in Ledo found on 20 December was quite vast, the Southern Army sent a telegram to Detachment Commander Kawaguchi on 26 December that for the sake of the [Navy] Malaya Unit it "wanted him to investigate and report immediately on [the possibility] of seizing the airfields near Bara or Ledo by either land or sea as quickly as possible in further cooperation with the Navy." It was followed by another telegram on 28 December, saying: "The road between Kuching and Singkawang seems [good enough] to be used by motor vehicles. We would like the Kawaguchi Detachment to be ready to seize, without missing an opportunity, the airfields near Bengkayang or, depending on the situation, a port (Singkawang or Pontianak), which

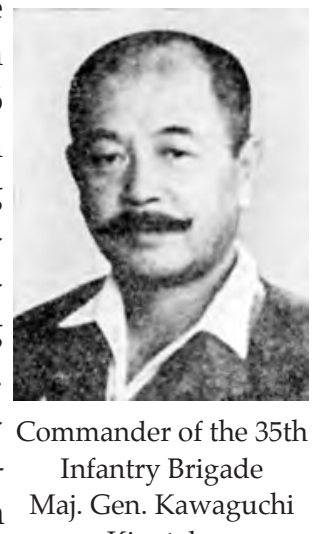

Kiyotake 
leads to these [airfields]."(23) On concluding General Agreement No. 4 ([about] bringing forward the Java operations) on 1 January, the Southern Army directed the [coming] operations with great enthusiasm, and as previously mentioned, on 6 January, ordered the Kawaguchi Detachment to capture Ledo. However, Detachment Commander Kawaguchi was away from Kuching, having gone to the north from 27 December to 12 January, doing things like having an audience with the Sultan of Brunei. [His absence] worried and irritated the Southern Army, and [so did the fact that] preparations for seizing Ledo had not much progressed. ${ }^{(23,92)}$

Detachment Commander Kawaguchi was away from Kuching for the following reasons. The mission assigned to the detachment on 20 November ([by] Southern Army order) was that "the [commander of the] Kawaguchi Detachment shall depart from the assembly point after the opening of hostilities, attack Miri and Seria first, secure vital resource areas as well as air bases and, immediately after that, occupy the air base near Kuching as quickly as possible. In the occupied territories, he shall [also] assume the task of establishing a military administration." (23) Furthermore, the Southern Army order he received on 6 January was a simple one, which read, "Detachment Commander Kawaguchi shall promptly seize, mainly by land, airfields near Bengkayang, and ports in Dutch Borneo which lead to these [airfields]." (23) No change in the basic mission of establishing a military administration, which had been stated in the Southern Army order of 20 November, was mentioned, nor was the intention of the Southern Army conveyed adequately. Furthermore, the detachment commander had enough confidence in his regimental commander to let [the latter] duly make preparations for [the seizure of] Ledo. He also felt that it was not totally impossible to expand and make the Kuching airfield ready for use. ${ }^{(23,92)}$

After the operations to seize Miri, the Kawaguchi Detachment ([consisting of] the 35th Infantry Brigade headquarters and the 124th Infantry Regiment of the 18th Division as its core) left [an element of] its forces consisting of one infantry battalion and one company as the core in Miri and Seria, and seized Kuching with the rest. After the seizure of Kuching, Detachment Commander (Brigade Commander) Maj. Gen. Kawaguchi Kiyotake left Kuching with one infantry battalion (minus two companies) and others on 27 December, and returned to Miri, leaving in Kuching a unit consisting of five infantry companies as its core under the command of the commander of the 124th Infantry Regiment, Col. Oka Akinosuke. [Commander Kawaguchi] stationed himself in Brunei and Labuan on 31 December and 1 January, and in Jesselton from 8 to 11 January. ${ }^{(23,92)}$ On 28 December, Detachment Commander Kawaguchi received a telegram from the Southern Army with an order to prepare for seizing Ledo, as to which, on the 29th, he wired back to the Southern Army from Miri, that (1) in view of the activities of enemy aircraft and submarines, he considered it appropriate to advance by land, and that (2) because he thought it necessary to reinforce the troops [in Kuching] from Miri, he would like to request ships to be sent. [This] was followed by another telegram on the next day, the 30th, from Miri to the effect that "[the commander] would dispatch Maj. Shiraishi Michinori, the 18th Division staff officer attached to the detachment, for discussing future operations." ${ }^{(23)}$ At that time, the rainfall in Kuching was getting heavier and heavier. The impatient Southern Army read this telegram from Miri and as a last resort wired back that "As [our] Staff Officer Satō is 
at your location, we request you to postpone the dispatch of [your] Staff Officer Shiraishi until after the seizure of Ledo." (23) On the next day, the 31st, Detachment Commander Kawaguchi sent the Southern Army a telegram that "the road leading to Ledo is in an extremely bad condition: no bridges [were found] across the rivers, and there is no prospect of obtaining provisions and fodder on the way there. Besides, the airfields in Ledo, Bengkayang, Pontianak and others have already been destroyed by the attacks of [our] naval aircraft. On the other hand, Kuching airfield has good soil, and we expect that part of the airfield will be ready in a few days, and it will be available from around 1 January. I recommend you to consider giving up the Ledo operation and using the Kuching airfield [instead]." However, the Southern Army paid no attention to it because it was wired from Miri. ${ }^{(23)}$ On 2 January, the Kawaguchi Detachment reported on the situation in Kuching. The main point was that at the Kuching airfield extension work was in progress, aiming at making [a field of] 300 meters wide and 800 meters long, and that an extension of its length to 1,000 meters was expected to require about ten days, and to 1,200 meters another fifty days, and to 1,500 meters another sixty days. ${ }^{(23)}$ It was absolutely out of the question because [a runway of] 1,200 meters long was required for the Navy land-based attack planes. ${ }^{(23)}$ On the next day, 3 January (the day [Sixteenth] Army Commander Imamura advanced to Saigon), the Southern Army sent a telegram under the name of Senior Staff Officer of Section 1 Col. Ishii Masayoshi to Staff Officer Shiraishi [attached to the Kawaguchi Detachment], which read "Report the progress of the preparations for the operation by return telegram" and implicitly pressed him for action. ${ }^{(23)}$ On this day (the 3d), the Southern Army held talks about the already-mentioned air [support] arrangement for Operation S and others with the [Navy] Malaya Unit, where they deliberated [the issue] and decided that "Ledo shall be captured by land. Seizure by sea shall be conducted when possible without strain." (23) At that time, the Southern Army felt that Regimental Commander Oka Akinosuke and Detachment Commander Kawaguchi Kiyotake were hesitating to prepare for the Ledo operation. ${ }^{(23)}$ On the next day, the 4th, the Southern Army inquired of the Navy about its eagerness to use the Ledo airfield, ${ }^{(23)}$ and learned that the Malaya Unit had the intention to advance almost all of its air units to Ledo. ${ }^{(23)}$ Just then (on the 5th), the Kawaguchi Detachment (whose commander was still in Miri at that time), sent in the following report on the state of preparation for the Ledo operation: ${ }^{(23)}$

Telegram sent on 5 January

1. Regarding the new operations, the detachment has been taking action as shown in the separately sent telegram No. 255.

2. The progress of preparation and the situation known as of yesterday, the 4th

(1) The enemy troops who retreated from the neighborhood of Kuching consist of some 800 men and seem to be demoralized.

(2) The stretch of eighty kilometers of road between Bau and Siluas in Dutch [Borneo] is a narrow defile. There are many streams with suspension bridges and log bridges. A construction unit has been sent in advance to repair them.

(3) The progress of establishing an overland line of communication is as shown in the separately sent telegram No. 256. An infantry company is scheduled to be sent to Siluas in advance.

3. The units diverted from Miri are assembling in Kuching in about four seized small cargo ships, of which the first ship will be arriving on the 6th. 
4. It is expected that the unit in Kuching will be able to launch the new operation from the 8th onwards.

Having received the above telegram, the Southern Army issued its Operation Order A, No. 34 on the next day, the 6th, which read: "Detachment Commander Kawaguchi shall promptly seize, mainly by land, enemy airfields near Bengkayang and ports in Dutch Borneo which lead to these [airfields]." ${ }^{(23)}$ [Editor's note: The orders concerning the Kawaguchi Detachment are quoted in slightly different redactions on pp. 143, 198, 299.]

The Kawaguchi Detachment (with its commander in Miri) received the above Southern Army order and drew up the outline of the Ledo operations roughly as follows: ${ }^{(23,91)}$

\section{Outline of the Ledo Operation by the Kawaguchi Detachment}

1. Operational Objective

(1) [The detachment] shall promptly seize the enemy airfields near Bengkayang and the ports in northwestern Borneo which lead to these [airfields].

2. Mission

(2) The detachment shall promptly seize the airfields near Bengkayang and the ports which lead to these [airfields] with its main force both by land and by sea.

3. Operational Directives

(3) An element of the Kuching guard unit shall be advanced to the area of the upper reaches of the Sarawak River near the border to set up a line-of-communication route.

(4) The 1st Unit ([consisting of] five companies under the command of the regimental commander) shall assemble near the upper reaches of the Sarawak River to attack the airfields by land.

(5) The 2d Unit ([consisting of] three companies under the command of the battalion commander) shall land in or near Pemangkat by sea and then capture Singkawang and Pontianak. An element of the unit shall directly cooperate with the 1st Unit in its attack on the Ledo airfields.

(6) The timing of the landing of the $2 \mathrm{~d}$ Unit shall be decided depending on the progress of the preparation for the operations of the 1st Unit.

Then, on 8 January, the Kawaguchi Detachment reported to the Southern Army that "the completion of the line of communication will be delayed by a few days from the scheduled date, the 9th, because fragile log bridges were found at several places near the border, and in some places streams flow over thirty meters [wide]," and that "on the path leading to Siluas in Dutch [Borneo] there are dozens of log bridges and suspension bridges that are so [flimsy] that they barely allow a single native to cross; it would take about two weeks [for us to repair them] so that military forces can consecutively cross them." Further, on the 11th, it reported that the "the advance party from Kuching attacked some 500 enemy troops in or near [Jagui]babang (about 115 kilometers southwest of Kuching) in Dutch Borneo on 10 January," and the same day, it reported on the state of the Kuching airfield as follows: ${ }^{(23)}$

The state of the Kuching airfield

1. A runway of 100 meters wide and 800 meters long was completed on 3 January. The extension work is still in progress, and we expect to extend it to 100 meters wide and 1,000 meters long by 20 January. 
2. The extension plan is [to construct a runway of] 300 meters wide and 1,000 meters long from east to west, and [another of] 300 meters wide and 1,500 meters long from north to south.

3. There are 57 holes caused by explosions of land mines.

In the meantime, on 10 January, the Southern Army completed its air operation plan based on the air [support] arrangement concluded with the [Navy] Malaya Unit on the $3 \mathrm{~d}$. It stated that "the Navy air unit shall promptly advance its main force to the bases in western Borneo near Kuching or Ledo, and an element of its force to northern Malaya, and strive to destroy the enemy warships near Singapore and the enemy air power in Singapore, eastern Sumatra and Java." (2)

Detachment Commander Kawaguchi, who, positioning himself in Miri, had pursued [the task of] seizing Sandakan and other vital places in northeastern British Borneo, and rescuing Japanese nationals there, returned from Jesselton to Miri on 11 January, and arrived in Kuching on the evening of 14 January. ${ }^{(23,92)}$ During this period, the Southern Army was worried and irritated to the highest degree. ${ }^{(23)}$

On the next day, the 15th, Detachment Commander Kawaguchi wired to the Southern Army from Kuching to report on the progress of assembling the detachment for the Ledo operation: "(1) Three infantry companies under the command of the battalion commander and one machine gun company [have assembled] in the area between Risau (eight kilometers northeast of Siluas), and [Jagui]babang (twelve kilometers northeast of Siluas) by 13 January, one infantry battalion and one artillery section by the 14th, and further, the regimental headquarters, one infantry company, and one antitank gun company by the 15th. (2) The detachment headquarters, one infantry battalion (minus one company), and one engineer platoon have assembled in Kuching by the 15th. (3) Machine gun units and others [will join] on and after the 16th." He also added: "We have given instructions to launch an attack on Siluas, after the main force of the regiment, which is now assembling to attack the immediate enemy, advances to [Jagui]babang (scheduled for the 15th)."(23)

Three days later, on the evening (of the 18th), Staff Major Shiraishi of the [Kawaguchi] Detachment unexpectedly turned up at the Southern Army headquarters. The headquarters thought that he had come to report the seizure of the Ledo airfield and the [current] situation, only to be greatly disappointed to hear to their surprise that he [only] had come to make an interim report. [The headquarters] explained to him in no uncertain terms that "the seizure of the Ledo airfield would determine the success of the next operations, those against Bangka and Palembang in particular." The 38th Division charged with the Bangka and Palembang operations was in the middle of embarkation at Hong Kong, and scheduled to depart from the port in two days (on the 20th) to head southward. On the next day, the 19th, Staff Officer Shiraishi sent the following telegram to Detachment Commander Kawaguchi in Kuching:(23)

1. I contacted the headquarters. The [Southern] Army recognized the activities of the detachment and expressed appreciation.

2. The [Southern] Army has high expectations [of us], as it considers that the detachment's rapid seizure of airfields in and near Ledo, Singkawang and Pontianak would decide the success of the coming operations. 


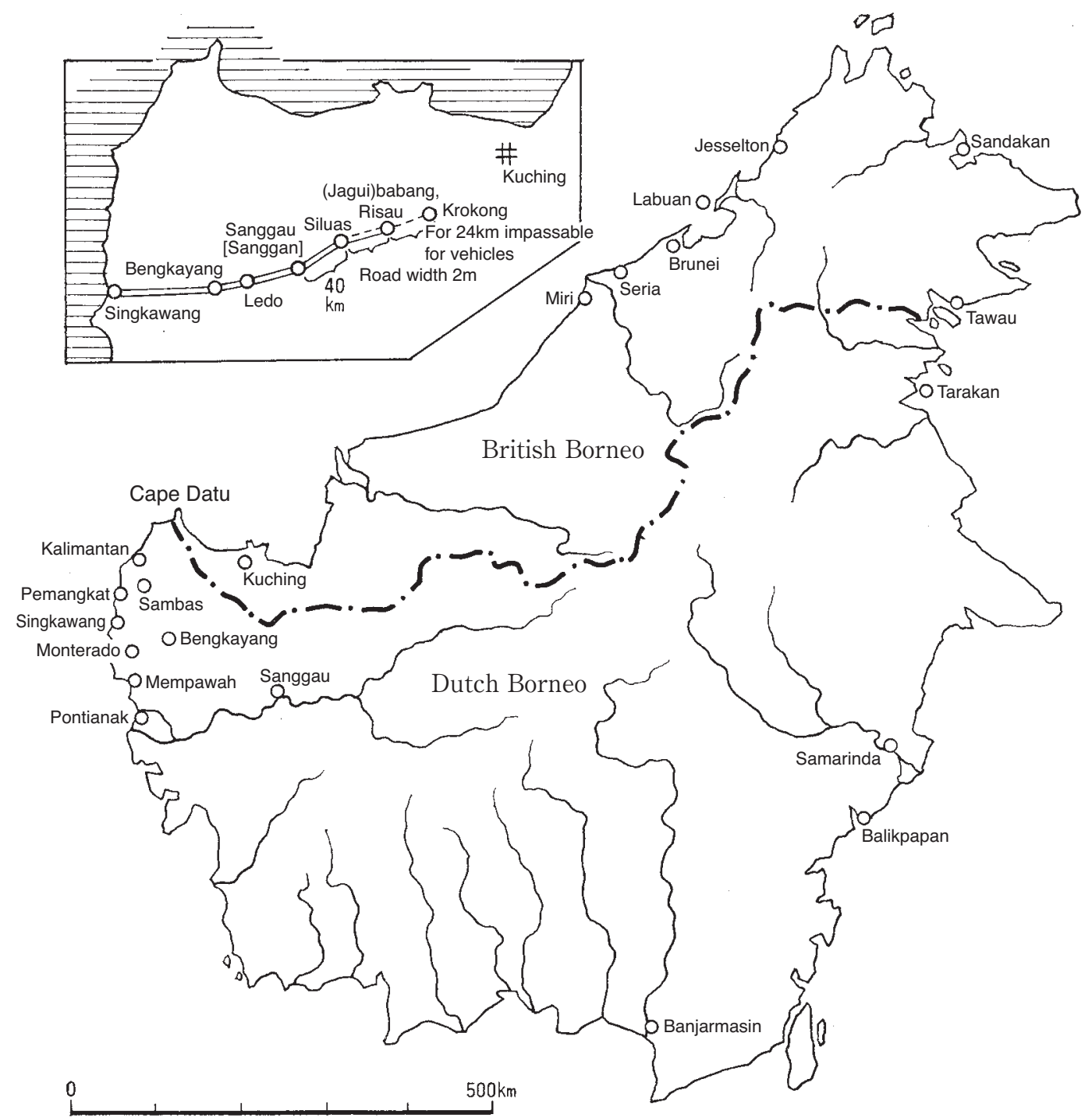

Illustration No. 19-Map of Ledo and Borneo

3. In view of the important position [the detachment was given] to decide the [success] of the operations, it is considered necessary for the detachment to seize [the airfield in] Ledo by all means and make it ready for use by the end of January at the latest. Navy planes will use the airfield in Ledo.

Then, the Southern Army received the following telegram sent on 18 January from the Kawaguchi Detachment: ${ }^{(23)}$

1. Five infantry companies under the command of the regimental commander ([hereafter] called the 1st Dutch Borneo Unit) have assembled in and near Dobare [Tebarau?] without trouble.

2. Three infantry companies under the command of the battalion commander ([hereafter] called the $2 \mathrm{~d}$ Dutch Borneo Unit) have assembled in Kuching today, the 18th. 
3. The Siluas unit is scheduled to launch an attack on the 19th. Accordingly, we are urging it to destroy the enemy in and near Sanggau [Sanggan] to [swiftly] advance to Ledo, but it is expected to take a few days. We are making inquiries as to [the progress] of the regiment, and we will report to you as soon as we know.

Then, the Southern Army received another telegram from the Kawaguchi Detachment sent on the 19th to the effect that "Kuching and vicinity was suffering from the heaviest rainfall in the past twenty years, and that the condition of the roads in the border area had become so bad that the mud was knee-deep." The Army further received the following telegram sent on the same day: ${ }^{(23)}$

The overland attack to complete the mission to seize the Bengkayang airfield has not progressed as planned due to natural and geographical [factors], and enemy resistance; all forms of transport are interrupted, and provisions and fodder sent in advance are gradually decreasing. Thus, we cannot exclude the possibility of total failure and we are preparing an attack by advancing [a unit] by sea under XX (note by the author: the two characters in the original text are illegible) to land near Pemangkat. The plan is as follows:

1. The first echelon shall consist of about two infantry companies under the command of the battalion commander equipped with a machine gun, a battalion [Type92] gun, and a regimental [75-mm. Type41 mountain] gun in six large-sized motorized [landing] craft, six smallsized motorized [landing] craft and four fishing boats. It shall leave Kuching on the night of the $22 \mathrm{~d}$, reach the bay south of Cape Datu on the morning of the $23 \mathrm{~d}$, leave there around noon on the same day, and land in or near Pemangkat at dawn on the 24th.

2. The second echelon shall consist of one infantry platoon equipped with two machine guns, and one battalion gun in two seized motorized sailing boats. It shall leave Kuching on the morning of the $23 \mathrm{~d}$ and land in Pemangkat.

3. The third echelon (accompanied by the detachment commander) shall consist of two infantry platoons equipped with one machine gun and one battalion gun in a passenger boat ([of] 173 tons) seized on the coast. It shall leave around noon on the $23 \mathrm{~d}$, and land in Babakappa [?] on the morning of the 24th.

4. After landing, an element shall seize Sambas and the main force shall seize Singkawang and advance towards Bengkayang, though [the operation] shall depend on the enemy's movements.

5. We would like the Navy to provide cover against enemy aircraft and surface warships from morning till sunset on the $23 \mathrm{~d}$ and during the morning from daybreak [on the 24th], but if it is impossible, we shall carry out the attack on our own.

The above was the situation concerning Ledo until the day (the 19th) when the Southern Army received the already-mentioned telegram from the Southern Task Force, which wished "to postpone the date of [the operation to] capture Java by about ten days [due to] the difficulty in advancing its bases to eastern Borneo [and further east]."

\section{The Effect on the Malaya Unit and the Order of the Southern Army}

The telegram of the Southern Task Force (the Second Fleet) on the 19th, which proposed the postponement [of the Java operation] by ten days, [also] affected the Malaya Unit.

As previously mentioned, the Southern Army immediately wired back to the Southern Task Force concerning the latter's telegram of the 19th, and [also] sent a telegram to the Army 
Department of IGHQ on the same day. On the next day, the 20th, the senior staff officer of Section 1 of the Southern Army, Ishii Masayoshi, along with the senior staff officer of Section 4, Tanikawa Kazuo, and the Navy staff officer with the Southern Army, Ishihara Itsu, left Saigon and first made a stopover at Cam Ranh on their way to Manila. There Ishii made the arrangement relating to Operation $S$ (the arrangement about the operation to put ashore the units connected with the air units and their matériel in Endau in two transport ships on the 26th) with the chief of staff and others of the First Southern Expeditionary Fleet (the Malaya Unit). He also held talks on the subsequent operations. At the meeting, [the Navy Malaya Unit] shocked Ishii and his group by bringing up [a request] to the effect that "we would like you to agree to a delay of Operation L (the operations against Bangka and Palembang) by two weeks, because the Kuching airfield is in bad condition with no prospect of [when it will be] ready for use due to the heavy rainfall, and there is no prospect of when the Ledo airfield will be seized and made ready for use either." (23) (Note: Col. Tanikawa Kazuo wrote in his diary for this day, "I left Saigon in the morning, arrived in Cam Ranh, and contacted the [First] Southern Expeditionary Fleet. It tabled a bombshell motion to change the timing of Operation L.")

Although Colonel Ishii found "[the time frame] far too leisurely and the argument containing many objectionable points," he firmly determined, "there is no need to agree to such a preposterous proposal. Anyway, let's argue the case in Manila." (23)

Staff Officer Shiraishi of the Kawaguchi Detachment, who accompanied the group, "looked greatly impressed, seemingly taken aback by the significance of the Ledo operation [he was reminded of] anew." (23) After the meeting was over, he sent the following telegrams: ${ }^{(23)}$

\section{To Detachment Commander Kawaguchi}

\section{From Staff Officer Shiraishi (dated 21 January)}

Yesterday, the 20th, we had talks with the Southern Expeditionary Fleet at Cam Ranh Bay.

1. In the wake of the Army, the Navy will transport fuel and ammunition to Singkawang by sea. The $2 \mathrm{~d}$ Unit shall seize as many trucks as possible in and near Singkawang in order to facilitate the transport of fuel and ammunition by land. It shall further take actions necessary to go up the Sambas River, and unload them near Ledo.

2. In order for the Navy to transport the fuel and ammunition, I would like you to let the Navy use the two small cargo ships (or motorized sailing boats, if unavailable) which the Army seized, and instruct them to advance right after the Army's boat units.

3. [According to the Navy] it will shortly advance its base to the Anambas (note by the author: [a group of islands] located halfway between Singapore and Ledo), and there are no mines laid by the enemy in the waters north of Cape Datu.

4. The cooperation of Navy aircraft while we are sailing cannot be expected due to [the location of] their bases.

5. The [Southern] Army from the commander in chief down has high hopes that the detachment will put up a good fight. Besides, I paid a call to the division commander at Cam Ranh Bay. He expressed satisfaction with the detachment's service.

\section{To Detachment Commander Kawaguchi}

\section{From Staff Officer Shiraishi (dated 22 January)}

Please pass on [the following information] to the commander of the 1st Dutch Borneo Unit (note by the author: Regimental Commander Oka). 
1. The situation in Tarakan has failed to come up to expectations. Delay in progress [of the operations] through the area is unavoidable. Right now, the value of the Ledo airfield has become immense and the operation of the 1st Unit will give the Navy a tacit prod.

2. I reported that the 1st Unit has been fighting bravely in spite of the bad weather, which pleased the [Southern] Army. However, in view of the fact that [the Army Department] of IGHQ and others pin their hopes on the ongoing operation as a key to the success of the coming operations, the Southern Army earnestly hopes for swift success at all costs.

The plan which the Malaya Unit presented at the above-mentioned meeting on the 20th was that Operation S [would be conducted] up to 28 January, the Ledo operation from 31 January to 5 February, and Operation L (the Bangka and Palembang operations) from 11 to 18 February, and the landing in Bangka and Palembang on 18 February. ${ }^{(24)}$

Staff Officer Shiraishi reported to [18th] Division Commander Mutaguchi as mentioned in the above telegram. Due to the change of the outline of Operation $S$ which the Southern Army was forced to make on 17 January, the main force of the 18th Division left Cam Ranh on 20 January escorted by the 3d Destroyer Squadron, landed in Singora on 22 January, ${ }^{(118)}$ and then headed for Singapore by land along the west coast. ${ }^{(53)}$

As previously told, the Southern Army was shocked by the proposal from the Southern Task Force to postpone the capture of Java by ten days, which was followed by the "bombshell motion"(25) on the next day, the 20th, by the Malaya Unit to postpone the capture of Bangka and Palembang for about two weeks. The Southern Army highhandedly issued the following order on the same day. ${ }^{(23,24)}$ It was an order that the Sixteenth Army, a corps under the command of the commander in chief of the Southern Army, should carry out the Java operations as had been agreed with the commander in chief of the Navy in the Southern Area.

\section{Southern Army Order}

Saigon, 20 January

1. The overall operations of the Southern Army are progressing as scheduled.

2. In conjunction with the Navy, I intend to swiftly capture Java. The cooperation with the Navy shall be based on General Agreement No. 2 and No. 4.

3. The commander of the Sixteenth Army shall swiftly capture Java in the following manner:

(a) Exploiting the results of having gained command of the air over Java, he shall land his main force in western Java and almost simultaneously an element [of his army] in eastern Java. When conducting the landing operations, he should expect interference from the naval and air forces of the enemy.

(b) After the landing, he shall defeat the enemy and promptly seize Batavia, Surabaya and Bandung.

(c) He shall swiftly make air bases in Java ready for use.

(Note by the author: Item No. 4 and No. 5 refer to the tasks of the Third Air Force commander and the captain general of the Shipping Transport Command. See the previous description [p. 155].)

6. I shall [command from] Saigon.

Count Terauchi Hisaichi, commander in chief of the Southern Army 


\section{The Situation in the Eastern Part of the Dutch East Indies}

In the eastern part of the Dutch East Indies, under the already-described circumstances, the Dutch East Indies Unit (the Third Fleet) Commander V. Adm. Takahashi Ibō, who had advanced to Davao on 6 January, the same night issued an order to "postpone the capture of Tarakan and Menado by one day, and also the subsequent schedule by one day." [Consequently,] the landings in Tarakan and Menado were carried out on 11 January, one day behind the schedule specified in the Cam Ranh Agreement (General Agreement No. 4).

However, in conducting the next operations against Balikpapan and Kendari, other problems came up. (General Agreement No. 4 had scheduled the date of landing [in these places] for 20 January.)

First, the airfield in Tarakan was smaller than expected, and therefore it needed to be extended and made ready for use, while fuel and ammunition also needed to be accumulated there. However, the sweeping of mines laid all over the waterway was not making much progress, partly because two out of the four [available] minesweepers had been shelled and sunk. ${ }^{(119)}$ As for the progress of the minesweeping, twenty-seven mines had been disposed of on 15 January, nineteen mines on the 16th, eighteen mines on the 17th, and a total of seventy-seven mines by the 17 th; by the 24 th, a total of 173 mines were disposed of. ${ }^{(119)}$ As for the airfield, on the 16th, they barely managed to extend the runway to 30 meters wide and 700 meters long, which made the commander of the 1st Escort Unit (R. Adm. Nishimura Shojji, commander of the 4th Destroyer Squadron) wire on the 16th to the commander of the $2 \mathrm{~d}$ Kure Special Landing Force and the leader of the construction squad that "if the Tarakan airfield cannot be made ready [in time] for the advance of [the Navy] land-based mediumsized attack planes, it will greatly hinder the coming operations. As the scheduled date to launch the next operations is getting close, you shall make the airfield ready for use at any cost as soon as possible so that the land-based medium-sized attack planes can use [the airfield]." On the 18th, the situation [didn't seem to have changed] so he again wired to the commander of the $2 \mathrm{~d}$ Kure Special Landing Force that "the task of guarding [is important but] all possible efforts shall be devoted to transporting the unloaded matériel and getting the airfield ready at any cost, as making the airfield ready is at present the most important [matter] for the [coming] operations." (119) Such was the situation as of the 18th, despite the fact that the landing in Balikpapan was set for 20 January, and accordingly departure from Tarakan on 17 January in the Cam Ranh Agreement (General Agreement No. 4).

Secondly, the 1st Air Raid Unit (i.e. the 21st Air Flotilla in Davao), charged with the support of the operations in the east of Celebes, had sent the following telegram [to the commander of the Dutch East Indies Unit] on 14 January:

According to the reconnaissance of our land-based reconnaissance planes conducted today on the 14th, some thirty enemy submarines were going underwater dispersed between Labuha and the west point of the Sula Islands about 1650 . They can be calculated to reach the vicinity of Menado tomorrow morning. In addition, in Ambon, about twenty-five enemy aircraft have gathered and one mid-sized cruiser [was also spotted]. Tomorrow, the 15th, our unit will attack Ambon with all of our land-based medium-sized attack planes and fighter planes, and search for enemy submarines and attack them with all of our flying boats (ten available at most). Further, we will postpone advancing our headquarters to Menado scheduled for tomorrow, the 15th. 
For the above reasons, about 0900 on 15 January Vice Admiral Takahashi, commander of the Dutch East Indies Unit, ordered R. Adm. Takagi Takeo, commander of the Eastern Attack Unit ([and] commander of the 5th Cruiser Division) to attack the enemy submarines in the Molucca Sea, and also issued an order "to delay the date of [the operations to] seize Kendari and Ambon to 24 January and to 29 January respectively. The [new] dates for the subsequent invasion schedule will be announced after they are determined depending on the construction units' preparations for departure, and on the progress in making the bases ready." (117) At that time, the Tokyo-maru and the Ken'yō-maru, which were supposed to transport the 1st Construction Squad to be redeployed from Legaspi, had left the [Japanese] mainland behind schedule, and were expected to reach Legaspi no sooner than 15 January. ${ }^{(117,145)}$

Just on this day (the 15th), the following report came to the Dutch East Indies Unit (i.e. the Third Fleet) from Tarakan:(119)

\section{Sent by the 1st Escort Unit at 2300 on the 15th}

The seizure of Balikpapan was scheduled to start on the 21st, and we were proceeding with the preparations. Then the army changed its operation outline in the light of the course of things during the Tarakan operation, among which is that the Tarakan airfield needs to be made fully ready. We discussed [these matters] with Detachment Commander Sakaguchi and decided to conduct the operation in tandem with the Kendari operation on the 24th.

In summary, when the 4th Destroyer Squadron, which had carried out the landing operation in Tarakan on the 11th, considered it difficult to conduct the coming [operation to] seize Balikpapan as scheduled due to [the condition of] the Tarakan airfield and the [presence of] mines, the 21st Air Flotilla [stationed] in Davao had just reported on the state of the allied warships in the Molucca Sea on the 14th. This was followed by the order on the 15th, issued by the Third Fleet [also stationed] in Davao to the Eastern Attack Unit ([consisting of] the 5th Cruiser Division, the 2d Destroyer Squadron, and others), to postpone [the operations to] seize Kendari and Ambon. With the underlying facts that [the operations to] seize Balikpapan and Kendari were originally planned to be conducted simultaneously, and that Yano Tsuneo, staff officer of the Sakaguchi Detachment, again showing his resourcefulness, had proposed new "Operational outline for seizing in the coming operation the oil resources in Balikpapan intact, in the light of the fact that the oil resources in Tarakan had been destroyed in advance," the 1st Escort Unit saw in the order to postpone [the operation to] seize Kendari an opportunity to report its decision to "also postpone [the operation to] seize Balikpapan until the 24th."

The commander of the Dutch East Indies Unit ([and] commander in chief of the Third Fleet) approved this telegram from the 1st Escort Unit, and issued the following order by telegram on the 16th: ${ }^{(119)}$

\section{Sent by the Dutch East Indies Unit at 2400 on the 16th}

In view of the readiness of the Tarakan base and other [factors], the [date of] advancing into Balikpapan will on account of these [factors] be changed to about 24 January.

At that time, the 2d Carrier Division ([consisting of] the aircraft carriers Sōry $\bar{u}$ and Hiry $\bar{u}$ ), had been transferred from the Combined Fleet to the Southern Task Force by the order of 8 
January; it had left the Bungo Channel at 0600 on 13 January, and was sailing southward, heading first for Palau. ${ }^{(117)}$ The [Army] Eastern Detachment charged with seizure of Ambon had left Hong Kong on 12 January and was under way, heading first for Davao. ${ }^{(117)}$

While the [Navy] Dutch East Indies Unit (i.e. the Third Fleet [stationed] in Davao) and the [Navy] air unit (i.e. the Eleventh Air Fleet, whose commander in chief had advanced into Davao on 7 January one day behind the commander in chief of the Third Fleet) were in the above situation, Commander of the Southern Task Force ([and] Commander in Chief of the Second Fleet) Vice Admiral Kondō advanced into Palau on 18 January and took command of the Eastern Support Unit, which he had organized and dispatched previously (on 23 December). ${ }^{(103)}$ The main unit of the Southern Task Force ([under the command of] Vice Admiral Kondō) had left Cam Ranh Bay on 8 January after signing the Cam Ranh Agreement on 1 January, and advanced to Palau on 18 January via Magong (which he left on the 14th), because the Malaya area operations had passed the critical point, and the time [to conduct] the Dutch East Indies operations was approaching. ${ }^{(103,109)}$ On advancing into Palau, the Southern Task Force immediately invited Capt. Yamaki Akira, senior staff officer of the Third Fleet, and Capt. Takahashi Chihaya, senior staff officer of the Eleventh Air Fleet, to meet and started talks with them. ${ }^{(113,136)}$ At the meeting, Captain Yamaki strongly demanded a two-week postponement of the schedule of the subsequent Dutch East Indies operation: ${ }^{(113)}$

1. The seized airfields in Davao, Jolo, Tarakan and Menado are all in such an unexpectedly bad condition that [several] days will be required to extend and make them ready for use, and that two weeks would be required after their seizure before land-based attack plane units could use them.

2. It is impossible to arrange the escort ships, if the invasion [were to be conducted] according to the schedule specified in the Cam Ranh Agreement.

3. The current schedule has put us in a situation where the [operations to] gain command of the air by the land-based air units are started almost simultaneously with the departure of the invasion units from their bases. [Consequently,] the latter will [have to] rush headlong into the points to be seized before [the air operations] have brought about sufficient results, which we fear may increase the damage to the invasion units.

4. In Tarakan, the mines laid by the enemy gave us a lot of trouble and much time was spent on minesweeping, which, as a result, caused a delay in the operation schedule. It may be expected that the [farther] we go southward from now on, the more minefields [will be encountered], which means that it is necessary to allow more time for sweeping mines.

5. In the current schedule, escort ships cannot afford to take time off for maintenance; their engines cannot be maintained because they have to be ready all the time for sailing at high speed, and [they] break down one after another. [Moreover,] the officers and crew are exhausted because they cannot take time off [either], which makes us worry about the prospect [for the coming operations] if the operations continue [in this way].

6. In the current circumstances, it will be difficult to provide escort forces at the time of [the operation to] seize Banjarmasin. Even if escort can be provided, it will be dangerous to pass in front of Java with the enemy on your flank.

The staff officer of the Eleventh Air Fleet (the [land-based] air unit), Takahashi Chihaya, also requested a postponement of the invasion date(s): ${ }^{(136)}$

1. It has taken more days than expected to make the airfields ready for use, which has resulted in a successive delay in the forward deployment of the air units. I am of the same opinion as the Dutch East Indies Unit on the postponement of the schedule. 
2. As for the air operations prior to the invasion of Java, it is all right to conduct those against eastern Java from Balikpapan and Makassar, and call off [the seizure] of Banjarmasin.

3. Among the recently seized documents in Tarakan, detailed materials were found on the airfield on Bali. As the airfield on Bali seems far better than we expected, we really want this airfield to be seized before the landing in Java.

In response to these views, the Southern Task Force stated that a postponement of the invasion schedule would be awkward both from the point of view of the general conduct of the operations and from the point of view of good faith towards the Southern Army and demanded [more] effort [to keep to the original schedule]. In the end, however, it accepted that [a postponement] was unavoidable, but consolidated the views on a two-week postponement into a ten-day postponement and, as previously told, sent the telegram to the Southern Army.

\section{The Manila Conference}

In accordance with the Cam Ranh Agreement (the agreement of 1 January between the Southern Army and the [Navy] Southern Task Force), the Manila Conference had been prepared as the place where the Sixteenth Army and the [Navy] Dutch East Indies Unit were to make arrangements [for the Java operation], but putting aside the Sixteenth Army, the Southern Army turned it into a scene of dispute with the Southern Task Force [about the invasion schedule].

On the 21st, Col. Ishii Masayoshi, senior staff officer of Section 1, Col. Tanikawa Kazuo, senior staff officer of Section 4, [both] from the staff of the Southern Army, Lt. Col. Miyashi Minoru, chief of operations staff of the Third Air Force, [Navy] Capt. Ishihara Itsu, staff officer [of the Second Fleet] seconded to the Southern Army, and [Navy] Capt. Tomari Mitsuyoshi, senior staff officer of the First Southern Expeditionary Fleet, directly flew to Manila across the South China Sea by a naval land-based attack plane. ${ }^{(23)}$

Colonel Ishii felt confident because when he had already gone to bed in Cam Ranh the night before, Staff Officer Arao [of the Southern Army] had visited him from Saigon, bringing the following telegram [from Tokyo]:(23)

\section{To Chief of Staff, Southern Army}

\section{From Vice Chief, Army General Staff}

I acknowledge Southern Army Staff Section 1 Telegram No. 557.

As a result of our contact with the Navy, [we learned that] the Navy General Staff is of the same opinion as the Army, and that it does not wish to postpone the operation schedule. Further, it very well understands the sentiments of the Army. In addition, according to the telegram(s) from the Combined Fleet to the Second and the Third Fleets, the former demands [an explanation of] the reasons [to request] the postponement of the operation schedule. As this is the situation [at the Navy], the Navy General Staff, according to the above communication, may be expected to send a telegram to the Combined Fleet, the Second and the Third Fleets that "keeping in mind that the postponement of the operation schedule may have a significant impact on all parties, [they should] prudently deal with it." [This] XX (note by the author: two characters in the original text are illegible) situation is for you to keep in mind in your negotiations with the Navy side. 
On the Navy side, Senior Staff Officer Capt. Yanagisawa Kuranosuke and Gunnery Staff Officer Cdr. Fujita Masamichi, [both] of the Second Fleet, Capt. Yamaki Akira, senior staff officer of the Third Fleet, and Capt. Takahashi Chihaya, senior staff officer of the Eleventh Air Fleet, four in total, flew from Palau on the night of the 19th to Manila. From Gaoxiong, Cdr. Yoshikawa Shūkichi, senior staff officer of the 5th Destroyer Squadron also joined them. From Saigon, [Navy] Lt. Cdr. Iguchi, liaison staff officer with the Third Air Force, and Cdr. Kimura Kenji, senior staff officer of the 12th Seaplane Tender Division (who was to be transferred and attached to the Third Fleet headquarters), came accompanying [Navy] Capt. Tomari Mitsuyoshi, senior staff officer of the First Southern Expeditionary Fleet. As for the Sixteenth Army, Commander Lieutenant General Imamura, Chief of Staff Major General Okazaki, and Senior Staff Officer of Section 1 Colonel Takashima had arrived in Manila at 1330 (on the 21st) from Taiwan. ${ }^{(32,33)}$ Staff Officer Oda had arrived from Saigon. ${ }^{(40)}$

On arriving at the Manila Hotel, Staff Officer Ishii of the Southern Army requested the holding of immediate talks (on the 21st) between Colonel Tanikawa of the Southern Army, [Navy] Captain Yanagisawa of the Second Fleet, [Navy] Captain Takahashi of the Eleventh Air Fleet, [Navy] Captain Tomari of the First Southern Expeditionary Fleet, [Navy] Captain Yamaki of the Third Fleet, and himself only, excluding the presence of the personnel of the Sixteenth Army, who had been put up at the same hotel. ${ }^{(23)}$ The meeting was held as requested and on that day, following [Navy] Captain Yamaki's explanation, they discussed [the matter] until 0130. ${ }^{(23)}$ [Navy] Captain Yamaki explained that he had "visited the Second Fleet and earnestly requested a postponement of [Operations] $\mathrm{L}$ and $\mathrm{H}$ for two weeks, but that Commander in Chief Kondō had sternly demanded to reduce the number of days [of the postponement]." And he requested, "I would like you to accept a postponement of ten days, that is, to set $\mathrm{H}$ on day $\mathrm{x}+80$, as there is no other way." (23) [Navy] Captain Yamaki gave the following grounds [for his request]: "The airfields occupied so far are in an unexpectedly bad condition and they require at least two weeks before allowing the [naval] land-based medium-sized attack planes to use them; a [naval] land-based medium-sized attack plane weighs twelve tons fully-loaded, which imposes particular requirements; from now on the Third Fleet has to seize a number of airfields such as those in Balikpapan, Kendari, Makassar, etc. one after another, and the details of [their condition] are [still] unclear; what is more, [the farther] the Third Fleet proceeds southward, the vaster the minefields will become, and sweeping them is not easily done; furthermore, the above-mentioned schedule with a tenday postponement of the operation has already dropped the whole [operation against] Banjarmasin, and included instead the seizure of the airfield on Bali just before day $\mathrm{H}$ (the date of landing in Java) ([because] the capture of Banjarmasin is out of the question in the light of the enemy movements and the time required, because the seaway leading there [passes] just in front of Surabaya, and because it is difficult to arrange warships for the [Banjarmasin] convoy); furthermore, if the [main] convoy leaves Lingayen on 8 February, and sails at a speed of eight knots, it will arrive in Java no sooner than the 19th, [which means] it cannot be on time if $\mathrm{H}$ (the date of landing in Java) is set on day $\mathrm{x}+70$, i.e. 16 February, [and thus] setting $\mathrm{H}$ on day $\mathrm{x}+70$ is totally out of the question." (23)

On the next day, the 22d, the negotiations with the First Southern Expeditionary Fleet were conducted from morning onwards with the staff officers of the Sixteenth Army taking part, too. ${ }^{(23)}$ Senior Staff Officer Captain Tomari of the First Southern Expeditionary Fleet for the present insisted on the proposal of a two-week postponement which the Fleet had pre- 
sented to the Southern Army at Cam Ranh Bay. ${ }^{(23)}$ The Southern Army firmly opposed it, arguing that the Navy should try and use airfields in Malaya as its base if the Kuching airfield was in bad condition and [the usefulness of] the airfields in Ledo was unknown, and that attacks against L (Bangka and Palembang) and $\mathrm{H}$ (Java) would not be totally impossible if the airfields in Kluang and Kahang in Malaya were seized, which was regarded as certain judging from the progress of the operations of the Twenty-fifth Army, and thus the heated negotiations went on and on. ${ }^{(23)}$ The staff officers of the Sixteenth Army considered the attitude of the staff officers of the Southern Army incomprehensible, wondering why a postponement of a mere ten days had to be so stubbornly refused, and spoke for the Fleet. ${ }^{(23,38,40)}$ In the end, they decided to [first] settle on a compromise proposed by Captain Yanagisawa of the Second Fleet, and, at 1500, [Senior] Staff Officer Ishii of the Southern Army sent the following telegram to Saigon: ${ }^{(23)}$ [Editor's note: According to the description on p. 222, the final compromise was proposed by Colonel Kawagoe, chief of staff of the 48th Division.]

\section{To Chief of Staff, Southern Army, sent at 1500 on 22 January}

Since yesterday, the 21st, we have negotiated the dates of $\mathrm{L}$ and $\mathrm{H}$ with the fleets as best as we could. The Navy has also made the utmost efforts to reduce the days [of the postponement], but it turned out that they could not be reduced any further than the following schedule:

L was set on day $x+64$. (Note by the author: originally set on day $x+60$ )

Western part of $\mathrm{H}$ was set on day $x+75$. (Ditto: originally set on day $x+70$ )

Eastern part of $\mathrm{H}$ was set on day $x+77$. (Ditto: originally set on day $x+70$ )

Makassar was set on day $x+63$.

Kupang was set on day $x+74$. (Note by the author: originally set on day $x+65$ )

The seizure of Banjarmasin shall be omitted in order to shorten the [delayed] schedule, and air operations against $\mathrm{H}$ will be conducted from Makassar and Balikpapan. However, if possible, the airfield on Bali will be seized around day $x+75$. Furthermore, OSAMU-SHŪDAN (note by the author: the Sixteenth Army) wishes to conduct the landings on eastern and western $\mathrm{H}$ almost simultaneously on day $x+77$ for reasons of control of the army.

Please [inform me of] your ideas and give your instructions about the above as soon as possible.

Although the Sixteenth Army's wish for landings both in eastern and in western Java on day $x+77$ was mentioned in the above telegram, Colonel Ishii rejected it because he thought that "the [Navy] Dutch East Indies Unit would probably have much more difficulties in proceeding with its operations than the Malaya Unit had, which means that the schedule would be pushed back more and more if simultaneous landings were laid down as a principle." (23) The headquarters of the Southern Army in Saigon sent the following reply: ${ }^{(23)}$

\section{From Chief of Staff, [Southern Army]}

\section{To Staff Officer Ishii}

Although the postponement of the invasion schedule was extremely disappointing, we will adopt the shortest schedule indicated in your report as the new invasion schedule. From now on, through even closer cooperation between the Army and the Navy, we are determined to successfully carry out Operation $\mathrm{H}$, firmly keeping to the new invasion schedule. Finally, we appreciate the great efforts you and the other [officers] have made. Meanwhile, according to the OSAMU [Sixteenth Army] Staff Section 1 Telegram No. 43, it seems that [the army] accepted the 
Third Fleet's proposal concerning a significant change in the schedule of [the operation to] seize Ambon. However, this is a matter to be decided between the [Southern] Army and the Second Fleet, and as this applies to subsequent operations as well, you must warn [the army] about it.

As the above telegram reached Manila on the 23d, Staff Officer Ishii and his group and the staff officers of the Sixteenth Army took it as [approval] that "the new schedule was decided," and discussed concrete arrangements with the Navy based on it. The same evening, [Sixteenth] Army Commander Imamura invited the staff officers of the Southern Army and the naval staff officers, Captain Yanagisawa, Captain Yamaki, Captain Tomari and Captain Takahashi, to thank them for their efforts, and asked for their continuous support and cooperation. ${ }^{(32)}$

Colonel Ishii and his group left Manila at 1000 on the next day, the 24th, and returned to Saigon. ${ }^{(23)}$ Colonel Ishii reported: "So far as it goes, agreement was reached by suppressing the requests from the units under the control of the Second Fleet. However, the invasion schedule was curtailed to the limit. In particular, this was achieved based on the idea that [the convoys] should depart when the air units were ready for deployment, and not on the idea that the convoy should depart after the enemy air power was totally destroyed. The airfields in Ledo will be pivotal as they will enable us to bombard as far as Surabaya, but if they cannot be prepared in time for the operations against Bangka and Palembang, the airfields in Malaya will be used to launch [bombardments] instead. Such was the way in which we worked out [the schedule]." (24) Naval Staff Officer Ishihara stated: "We would like the Army not to force on us unreasonable [operations], as this schedule is [shortened] to the limit."(24)

Soon [the proposal for] the agreement (dated 25 January) on the standard schedule for landings based on the results of the Manila Conference got to the commander in chief of the Southern Army in Saigon from the commander in chief of the Second Fleet in Palau. ${ }^{(23)}$ However, in this agreement, the word "around" had been added to each of five [newly-scheduled] landing dates, which provoked controversy again. ${ }^{(23)}$ Some argued that it was necessary to determine the exact dates [and remind the Navy of the sense of exactness] by having it delete the word "around." ${ }^{(23)}$ However, the sender was the commander in chief of the Navy in the South, and besides, it was also forwarded to the commanders in chief of fleets. Consequently, [the Army] reluctantly settled [the matter] by letting [Navy] Captain Ishihara send the following telegram to the chief of staff of the Second Fleet [R. Adm. Shiraishi Kazutaka]:(23)

\section{From Staff Officer Ishihara}

\section{To Chief of Staff, Second Fleet}

The [Southern] Army received the $2 \mathrm{~F}$ (note by the author: the Second Fleet) Classified Telegram No. 750, and found it regrettable that the word "around" appeared in front of the scheduled dates of invasion. The army considered the fact that the word "around" was added despite the serious negotiations at the Manila Conference, which were primarily about deciding the dates, would make the decisions at Manila meaningless. [The army] wanted the deletion of the word "around" from the [formal] agreement so desperately that it would have requested [another] discussion on this issue. However, in the light of the fact that this was formally [proposed as an] agreement by the [commander in] chief of your fleet, I managed to convince the army at last after various negotiations, and succeeded in bringing [the situation to a point] where after waiting a while, the return telegram from [the Army General Staff in] Tokyo with the reply of no objection was received [from them as well]. Such being the case, it is hoped that, in view of 
the difficult circumstances of the Manila Conference, you will consider this invasion schedule as the standard, regardless of the word "around," and do your very best to seriously keep to this [schedule.]

The above-mentioned telegram of the official [proposal for the] agreement sent by the commander in chief of the Second Fleet was as follows:(119)

\section{To Commander in Chief, Southern Army}

\section{From Commander in Chief, Second Fleet}

\section{Combined Fleet, Southern Task Force, Chief of Navy General Staff}

Second Fleet Classified Telegram No. 750, 2100, 25 January

We would like to make the following additions and revisions to the agreement of 1 January, 1942, between the commander in chief of the Southern Army and the commander in chief of the Navy in the South, and [would like to] discuss these [with you].

1. Standard dates [to implement operations] of capturing (areas to be seized, the dates to start landing [operations])

(a) Makassar, around day $x+63$; (b) Bangka and Palembang, around day $x+64$; (c) Kupang, around day $x+74$; (d) Western Java, around day $x+75$; (e) Eastern Java, around day $x+77$

2. The seizure of Banjarmasin shall be conducted overland from Balikpapan as quickly as possible. However, depending upon the circumstances, the operation may be launched after consultations between the commander of the Sixteenth Army and the commander in chief of the Third Fleet.

3. The air base on Bali shall be seized in conjunction by the Army and the Navy around day $x+$ 75 , so that it can be used as an air base at the time of [the operations to] capture eastern Java. The details of the implementation of the above operation shall be arranged between the commander of the Sixteenth Army, the commander in chief of the Third Fleet, the commander of the Third Air Force and the commander in chief of the Eleventh Air Fleet.

4. The commander of the Third Air Force and the commander in chief of the Eleventh Air Fleet shall be included in the [number of] commanders with whom the arrangements for the operations to capture Java shall be made.

\section{Schedule for $L$ and the western part of $H$}

The schedule for the landings in Bangka and Palembang (L) and western Java (H) was arranged on the $22 \mathrm{~d}$ as follows: ${ }^{(23)}$

1. The airfields in Kluang and Kahang shall be seized by around 25, or 26 January (day $x+48$, or day $x+49)$ at the latest.

2. The army aircraft shall be ready in Malaya by 3 February (day $x+57$ ). The Navy shall make efforts to have those of its aircraft which are to be deployed in Malaya ready by the same day as well.

3. The deployment of the naval [land-based] medium-sized attack planes to the airfield in Ledo shall be completed by 6 February.

4. The advance party of the units for seizing Bangka and Palembang ([consisting of] two battalions of the 38th Division as its core, in seven transport ships) shall leave Cam Ranh on 4 February (day $x+58$ ) and come ashore in Bangka and Palembang on the night of 10 February (day $x+$ 64). The 3d Destroyer Squadron (reinforced with four destroyers and four minesweepers) shall leave Cam Ranh on 5 February [editor's note: the text says "March," which clearly is a misprint] $($ day $x+59)$ to escort them. 
5. The main force of the 38th Division (in twelve transport ships) shall leave Cam Ranh on 6 February (day $x+60$ ), and come ashore in Palembang on the night of 11 February (day $x+65$ ). The cruiser the Yura, four destroyers, and a few minesweepers shall leave Cam Ranh on 7 February (day $\mathrm{x}+61$ ) to escort them.

6. The convoy of the main force of the Sixteenth Army ([consisting of] the 2d Division and the Shōji Detachment as its core) shall leave Cam Ranh Bay on the night of 12 February (day x + 66), and come ashore in western Java on the morning of 21 February (day $x+75$ ). The 5th Destroyer Squadron ([consisting of] eight destroyers, if possible, reinforced with two destroyers of the 4th Destroyer Squadron) shall accompany and escort them. The ships to be charged with the escort of the main force of the 38th Division shall join the 5th Destroyer Squadron at sea on the night of 17 February (day $x+71$ ), after replenishing at Anambas on 16 February (day $x+$ 70).

[Thus, the increase of forces to escort the convoy of the main force of the Sixteenth Army, an issue about which Commander Imamura of the [Sixteenth] Army was worried, and about which Commander in Chief Ozawa [of the First Southern Expeditionary Fleet] had given him kind assurances, was taken up.

\section{The Issue of the Eastern Part of $\mathrm{H}$ and Bali}

The postponement of the schedule [for the operation against] eastern Java gave time, which was welcomed by those in the Shipping Transport Command, the Sixteenth Army and the 48th Division. However, the sudden decision to capture Bali disconcerted the people concerned. The capture of Bali was included neither in the central agreement nor in the Tokyo agreement of the Southern Army. Although it had come up in the arrangement between the [Navy] Dutch East Indies Unit and the Sixteenth Army at the Iwakuni Conference, it was [again] completely ignored in the Cam Ranh Agreement of the Southern Army. Consequently, it had fallen out of the scope of both the Southern Army and the Shipping Transport Command. In the end, however, it was decided that one battalion of the 48th Division would be assigned [for its capture]. In order to rush headlong toward [the island] under circumstances where control of the air as well as of the sea was yet to be gained, faster ships had to be allocated. [Chief] Shipping Staff Sendō Shunzō of the Sixteenth Army was quite at loss considering that "[most of] the faster ships are already badly damaged in [previous operations in] various areas. If the ships have to be arranged out of those already allocated to the Sixteenth Army, it will be depressingly [difficult]." "(44) Staff Officer Ueno Shigeru of the Shipping Transport Command painstakingly made inquiries, found two faster ships, the Sasako-maru and the Sagami-maru in the middle of unloading in Singora, and arranged for them immediately (on 25 January). ${ }^{(27)}$ Both ships quickly completed unloading, left Singora, entered port at Cap Saint Jacques on 28 January and left the port on the 31st after hasty preparations to hurry to Lingayen. ${ }^{(27)}$

\section{The Banjarmasin Issue}

As previously mentioned, Colonel Ishii had wired at 1500 on 22 January that "the seizure of Banjarmasin shall be omitted in order to shorten the [delayed] schedule," (23) because the Navy had stated that the air operations against Java would be conducted from southern Celebes and Balikpapan [first], and then also from Bali once the island had been captured. However, 
the seizure of Banjarmasin before [the operation to] capture Java had been reported to the Emperor and included in the orders issued by the Army and the Navy Departments of IGHQ to the Southern Army and the Southern Task Force. [Consequently,] previously in Tokyo, the Southern Army had ordered the Sixteenth Army to capture [Banjarmasin] by the order of 20 November. Also, the Southern Task Force had given an order to capture the place, as mentioned previously. Neither the staff officers of the Southern Army nor those of the Southern Task Force could ignore the IGHQ order (of 6 November), and sent on the $23 \mathrm{~d}$ the following lame telegrams: ${ }^{(23)}$

\section{To Vice Chief of Army General Staff}

\section{From Chief of Staff, Southern Army, 23 January}

Southern Army Staff Section 1 Telegram No. 604

1. According to the current study of the invasion schedule conducted in Manila, the [rapid] progress of the entire $\mathrm{H}$ (note by the author: the Java operation) is hoped for by omitting the seizure of Banjarmasin.

2. We request your understanding [of the above] in advance, as its seizure is among the items in the central agreement.

3. However, we expect to seize Banjarmasin almost at the same time as [the operation against] eastern Java or when the opportunity arises afterwards.

\section{To Navy Department of the IGHQ}

\section{From Senior Staff Officer of the Second Fleet at Manila}

\section{Classified Telegram No. 175 of the 23d}

As a result of research and discussions with the [Southern] Army headquarters and other parties concerned (the Third Fleet, the First Southern Expeditionary Fleet, the Eleventh Air Fleet, the Sixteenth Army and the Third Air Force), an agreement was reached and the following definite plan was worked out. We would like you to urgently let us know your view. Further, we would like the Navy General Staff to pass on the contents of this telegram to the Army General Staff, too.

1. Standard dates [to implement operations] of capture
(a) Ambon: day $x+54$, 31 January
(b) Makassar: day $x+63,9$ February
(c) Bangka and Palembang: day $x+64,10$ February
(d) Kupang: day $x+74,20$ February
(e) Western Java: day $x+75$, 21 February
(f) Eastern Java: day $x+77,23$ February

2. In order to put [the entire operation] within the invasion schedule of the preceding item, it was decided to call off the surface escort of the Sakaguchi Detachment, and to plan an overland seizure of Banjarmasin from Balikpapan [instead]. In addition, as an air base [to be used] at the time of landing in eastern Java, Bali shall be captured. It is scheduled for day $x+75$ (21 February).

3. In order to use the Ledo airfield for the air operation at the time of [the operations to] seize Bangka and Palembang, both the Army and the Navy shall cooperate with each other as much as possible. Also, the naval air forces shall be advanced to the seized bases in southern Malaya.

4. The reinforcement of the army forces for mopping up [enemy remnants] in Mindanao shall be considered at the [Southern] Army headquarters. 
The Army Department of IGHQ sent the following reply telegram on the next day, the 24th (the day the participants of the Manila Conference headed back). ${ }^{(23)}$

\section{From Vice Chief of Army General Staff, sent at 1440 on 24 January To Chief of Staff, [Southern Army]}

Army General Staff Telegram No. 551

We respectfully acknowledge Southern Army Staff Section 1 Telegram No. 604.

The key to the operations to capture Java lies in the success or failure of the air operations, for which, as you are well aware, the seizure of Banjarmasin is invaluable. Thus, the operation plan approved by the Emperor as well as the central agreement paid particular attention to it. Furthermore, in view of the fact that the enemy efforts to strengthen the defense of Java [have progressed so much that] they cannot be taken lightly, we are deeply concerned about the results of air operations in a situation where the cooperation of the aircraft carriers cannot necessarily be expected. If there are difficulties in conducting the operation from the sea, are there no other ways, such as an overland seizure or maneuvering along the coast in small boats? [Furthermore,] even if there is not enough time after the seizure to make the base ready for use before the launch of operations to capture Java, may it not be better to occupy [Banjarmasin] in order to ensure [the success of] subsequent operations? Please pay further attention to these points.

While feeling that the telegram was "very considerate," (23) the Southern Army was [more] concerned about the delay in the agreement with the Second Fleet (the Southern Task Force) and sent the following telegram to [the Army Department of] IGHQ on the next day, the 25th: ${ }^{(23)}$

\section{To Vice Chief of Army General Staff}

\section{From Chief of Staff, Southern Army, sent on the 25th}

Southern Army Staff Section 1 Telegram No. 622

1. We respectfully acknowledge Army General Staff Telegram No. 551.

2. We are absolutely of the same opinion about the value of Banjarmasin. However, we omitted [the operation] from the new plan because the seizure [of the place] in conjunction by the Army and the Navy might cause a significant delay in the invasion of Java.

3. Nevertheless, in order to securely carry out the invasion of Java, we decided to seize Banjarmasin by land as well as by the sea, and took [the necessary] steps.

4. Further, we intend to capture Bali with two faster ships together with the Navy no later than day $x+75$.

The Southern Army eagerly awaited the reply telegram from [the Army Department of] IGHQ, but since no reply came, it lost patience ${ }^{(23)}$ and sent the next day, the 26th, another telegram to [the Army Department] of IGHQ: ${ }^{(23)}$

\section{To Vice Chief of Army General Staff}

\section{From Chief of Staff, Southern Army, sent on the 26th}

Southern Army Staff Section 1 Telegram No. 632

Concerning the omission of Banjarmasin [from the new plan], mentioned in Southern Army Staff Section 1 Telegram No. 604, your urgent reply is requested because of [the time required 
for] the revision of the agreement between the Army and the Navy. In this regard, we would like you to refer to Southern Army Staff Section 1 Telegram No. 622.

In response to this telegram, the Army Department of IGHQ sent the following reply: (23)

From Vice Chief of Army General Staff, sent on the 26th

To Chief of Staff, [Southern Army]

Army General Staff Telegram No. 591

We respectfully acknowledge Southern Army Staff Section 1 Telegram No. 632. I am contacting you again, praying for certain success in the operation [to] capture Java.

We have also been negotiating about the cooperation from aircraft carriers in the Java operation. However, at present it cannot be expected for sure, as the Navy is extremely cautious about sending them to a sea where the enemy air force is [still] strong. Although the value of seizing Banjarmasin for the air operations against Java remains to our mind unquestionable, we would like to know the status of the discussions between the Army and the Navy on the prospects for success of the air operations at your end. As to your view that the capture of Java might be significantly delayed if the Army and the Navy in conjunction should capture [Banjarmasin], the Navy General Staff has doubts, too. Although it thinks that it might represent the view of the Navy on site, we want to know the true state of affairs. For your information, the Navy General Staff also fully recognizes the necessity of seizing Banjarmasin, and has already ordered [the units] on site that the place needs to be seized and made ready for use before the landings on Java.

When the staff officers of Section 1 of the Southern Army Staff read the telegram, they felt "worse than ever."(23) Chief of Staff Lt. Gen. Tsukada Osamu, who had orchestrated the southern operation plan as vice chief of Army General Staff until just before he was transferred as chief of staff [of the Southern Army], was also disgusted with the attitude of [the Army Department] of IGHQ, and gave vent to his frustration by saying: "[The Army Department of] IGHQ got it wrong. At the beginning of the preliminary study on the southern operation, the original plan was that [the airfield in] Banjarmasin would be used by army aircraft for the attack on Java. Despite the fact that the Navy is now in charge of this area, they must be saying all these things out of recollections from that time. Why do they keep on grumbling about such trivial things when the Navy says it won't use [the airfield]?"(23) The Southern Army wired [again] the following telegram on the next day, the 27th: ${ }^{(23)}$

\section{To Vice Chief of Army General Staff}

\section{From Chief of Staff, [Southern Army], dated 27 January}

Southern Army Staff Section 4, Telegram No. 658

We are deeply aware of the significance of the seizure of Banjarmasin, which was mentioned in Army General Staff Telegram No. 591 (in which you requested reconsideration of our decision regarding its seizure). The Army and the Navy on site have been studying [the feasibility] of carrying out [the seizure] according to plan as best as possible. However, as a result of a detailed study of matters related to the escort to be provided by Navy warships, the [possible] dates of seizing air bases, the setting up [of our bases] and making them ready for use, and to other [factors] in the entire Java operation, we regrettably came to the conclusion that conducting the seizure of Banjarmasin as planned would cause another delay of about two weeks in the capture 
of eastern Java. Although both the Army and the Navy fully realize that the air operations in the Java invasion operation will never be easy, they do not believe that the tactical value of seizing Banjarmasin as planned can compensate for the strategic disadvantage of a two-week delay in the invasion schedule. Thus, in order to make up for the disadvantage of revising the [prepared] plan, the decision was made to capture Bali as well as swiftly seize Banjarmasin by land and by maneuvering small boats along the coast, of which you were already informed in the previous telegrams.

The reference in the above telegram to "Southern Army Staff Section 4" indicates that this telegram was drafted by Section 4 of the Southern Army Staff, that is, the section in charge of air-related matters of the Southern Army. Seven days of exchanging telegrams had not yet settled the matter, and without a settlement, the Southern Army and the Southern Task Force could not conclude the Manila Agreement.

How did [the Army Department of] IGHQ, which had stated in its report to the Throne that the seizure of Banjarmasin would take place ahead of [the Java operation] and had given orders accordingly, view the strength of the allied air and naval forces? Col. Tanikawa Kazuo, senior staff officer of Section 4 of the Southern Army wrote in his diary for 3 February as follows:

The state of reinforcement of [enemy] air forces in the Far East ([source:] Army General Staff)

1. [number of aircraft] already sent in:

100 aircraft in Burma, 110 aircraft in Malaya, 10 aircraft in the Dutch East Indies, 100 aircraft in India, which make a total of 320 aircraft (40 aircraft from Chongqing included).

2. [number of aircraft] diverted within the East Asia:

40 aircraft to Burma from India, 40 aircraft to Malaya from the Dutch East Indies, 50 aircraft to Malaya from Australia, 30 aircraft to the Dutch East Indies from Australia.

3. [number of aircraft] to be sent to East Asia shortly:

245 aircraft from the British mainland and Egypt ([consisting of] 64 bombers and 181 fighter planes), 40 aircraft to the Dutch East Indies from the United States (fighter planes), 80 Australian Air Force aircraft returning from the British mainland and north Africa ([consisting of] three bomber squadrons and two fighter plane squadrons), which make a total of 365 aircraft.

4. 240 aircraft to Egypt from the British mainland.

5. The increase of U.S. aircraft in the above:

Already increased: 90 aircraft to Malaya, 10 aircraft to Dutch East Indies, which make a total of 100 aircraft ([consisting of] 60 fighter planes and 40 super heavy bombers).

To be sent in shortly: 40 aircraft to the Dutch East Indies.

As for the allied naval power, the U.S. Far East Fleet in the Philippines had retreated to the Dutch East Indies without a fight, and the British Fleet in Malaya was also expected to retreat to the Dutch East Indies. On 20 January, the Southern Army submitted the Southern Army Special Report No. 5, in which it stated: "Lieutenant General MacArthur still seems to remain in Corregidor Island. Java now serves as the operational command center of the allied forces, replacing Singapore. In fact, the General Headquarters of the allied forces of the Southwestern Pacific has been set up in Surabaya, and the commander in chief of the U.S. Asiatic Fleet, Hart, also seems to have stationed himself there. It seems that the U.S. Fleet based on Surabaya and Ambon has taken charge of the waters of Celebes and further east."(23) 
The Southern Army had never thought that the concept of [strategic] pursuit was easy [to implement], either. As previously mentioned, [Sixteenth] Army Commander Imamura had considered directly requesting Commander in Chief [of the Southern Army] Terauchi for an increase in warships to escort [his army]. Also Colonel Tanikawa, senior staff officer of Section 4 of the Staff Department of the Southern Army headquarters, who was responsible for planning and directing the air operations of the Southern Army, held a grim but determined view and wrote in his diary for 2 February as follows:

My beliefs regarding the Bangka, Palembang and Java operations

The time has really come for the final stage of the southern operation, the Bangka, Palembang, and Java operations. While various studies and discussions have been conducted about [the prospects for] success or failure in these operations, my beliefs are as follows:

1. We shall definitely succeed in the Bangka, Palembang and Java operations. However, the degree of risk and damage involved will be the most serious in the whole southern operation, and we must be fully prepared for that in advance.

2. Some elements in the operational environment of the Bangka, Palembang and Java operations, such as the movements of the enemy and the terrain, may of course make the operations incomparably more difficult than those in the initial stages of the Malaya landing operations. However, what makes me believe in our certain success is based on the nature [of the enemy], which is essentially a colonial army. When the high command of the German Eastern Army started doubting the success of its operations in the middle of the Battle of Tannenberg, only Hoffmann, who alone grasped the nature of the Russian Army, was not shaken, believing in the success [of the operation]. My belief is just like that.

3. That we have to carry out the Bangka, Palembang and Java operations without waiting for the results of the air operation to destroy the enemy power, nay, because we are unable to afford to wait, simply cannot be helped. After all, if we do not conduct the operations this way, we will remain unable to estimate when to conduct the operations and, moreover, a great strategic disadvantage will be the result. It simply is the inevitable fate of the Southern Army to swiftly carry out the risky operations against Bangka, Palembang and Java. We did expect the risks from the beginning. Nevertheless, I believe that we will be absolutely successful. The most important thing is to be mentally prepared not to waver in the middle of the operations.

Incidentally, on the next day, the 28th, the issue of the seizure of Banjarmasin came to an abrupt end. The Southern Army received the following telegram from [the Army Department of] IGHQ on the 28th: ${ }^{(23)}$

\section{From Chief of Army General Staff, sent at 1130 on the 28th}

\section{To Commander in Chief, Southern Army}

Army General Staff Telegram No. 611

Reply to Southern Army Staff Section 1 Telegram No. 604

Although there were various arguments about the seizure of Banjarmasin, we learned from Sixteenth Army Operation Order A, No. 119 ([sent to us in] OsAmu [Sixteenth Army] Staff Section 1 Telegram No. 84) that the army planned to seize the airfield on its own and make it ready for use by early February. Since it became clear to us that you also intended to attach great importance to the place for the Java operation, we approved everything. 
The staff officers of the Southern Army looked at each other in dumb surprise. ${ }^{(23)}$ Sixteenth Army Operation Order A, No. 119 was a surprise, but the attitude of [the Army Department of] IGHQ was [even] more of a surprise.

Now at last, the commander in chief of the Southern Army and the commander in chief of the Navy in the South were able to sign the Manila Agreement. It was actually [already] 28 January. ${ }^{(119)}$

What on earth was stated in Sixteenth Army Operation Order A, No. 119 mentioned in the above telegram from the chief of Army General Staff, and how had it come about? Things had gone as follows: after the discussions on the 21st and on the morning of the $22 \mathrm{~d}$ in Manila, Colonel Ishii had sent a telegram to the Southern Army in the afternoon of the 22d that "[the seizure of] Banjarmasin will be omitted," and [likewise] [Navy] Captain Yanagisawa had sent a telegram to the Navy General Staff, the Southern Army and others that "an overland attack [will be made]." ${ }^{(23)}$ On the next day, the 23d, the Southern Army had wired [the Army Department of] IGHQ that "the seizure [of Banjarmasin] in advance [of the Java operation] will [reluctantly] be omitted. However, we expect to seize [Banjarmasin] about the same time as the landings in Java or when the opportunity arises afterwards,"(23) [in reply] to which, the Army Department of [IGHQ] had wired the Southern Army on the next day, the 24th, to the effect that "We want you to seize it in advance by all possible means." (23) At that time, the Sakaguchi Detachment had left port in Tarakan at 1700 on the 21st, started landing in Balikpapan before daybreak of that day (the 24th), and was in the middle of a fight to seize the city [and surrounding] areas. ${ }^{(119)}$ However, that morning, some destroyers of the allied forces came to attack the anchorage of the convoy of the Sakaguchi Detachment, and some damage was caused. ${ }^{(116)}$ On learning the intention of the Army Department of IGHQ, the Southern Army immediately (about the night of the 24th) wired the Sixteenth Army to order "the Sakaguchi Detachment to take charge of guarding Balikpapan and make the airfield ready for use once the place was seized, and also capture Banjarmasin by land and by sea on their own." In this order, [the Southern Army] demanded that the Sakaguchi Detachment make every effort, while giving as example the operation of the Kawaguchi Detachment in western Borneo when it sailed the distance of some four hundred kilometers in small boats. ${ }^{(23)}$ After the Manila Conference, the Sixteenth Army headquarters returned from Manila to Gaoxiong on the 24th, where it received the above Southern Army order and, on the 25 th, issued the following order: ${ }^{(22)}$

\section{Osamu [Sixteenth Army] Operation Order A, No. 119}

Sixteenth Army Order, Gaoxiong, 25 January

1. Based on the requirements of the general situation, it has been decided that there will be no direct escort provided by Navy warships for the seizure of Banjarmasin.

2. After the seizure of Balikpapan, the detachment shall leave [part of] its force with the required strength to take charge of guarding the place and cooperate in making the Balikpapan airfield ready for use. Then (by early February at the latest), it shall promptly seize the Banjarmasin airfield on its own in the way described below, so that the Navy can advance its air base there. It shall keep in mind that the rapid seizure of the airfield and making it ready for use is of extremely great significance, as [the airfield] will be the one and only base for the fighter plane units charged in particular with the air operations to destroy the air power of the enemy, [which is essential to] the conduct of the entire operation of the army. 
(a) An element of [the detachment] will seize Banjarmasin and its airfield by land.

(b) Another element of [the detachment] will take core personnel of the Navy Airfield XX (note by the author: the two characters in the original text are illegible) and as much fuel and ammunition for fighter planes as possible from Balikpapan in motorized boats, and fishing boats and others in possession of the Navy, and by maneuvering along the coast seize Banjarmasin and make its airfield ready for use.

(c) In cooperation with the naval core personnel, the army will mainly take charge of making the airfield ready for use. For that purpose, [the army] shall make efforts to draft local people.

3. Sanga Sanga and Samarinda shall be seized mainly by land with another element of the force.

In other words, whereas [the Army Department of] IGHQ sent the already-mentioned telegram on the 26th and for two days, the 26th and the 27th, made the Southern Army feel "worse than ever," (23) the Sixteenth Army had simply given an order on the 25th based on the talks with the Third Fleet and the Eleventh Air Fleet at the Manila Conference, to seize [Banjarmasin] no later than 10 February, thirteen days ahead of the date of landing in eastern Java (day $x+77$, i.e. 23 February), and had [already] settled the issue on the 25 th. Ultimately, [the confusion] was caused for the following three reasons:

1. Staff Officer Ishii had gathered from [the discussions in] Manila that "the seizure of the [Banjarmasin] airfield, which had been intended for the Navy's use, was no longer necessary if the Navy wouldn't use it," and the Southern Army had assumed that the Sixteenth Army had shared the impression.

2. The Southern Army had not thought that the Sakaguchi Detachment could attack Banjarmasin so soon. However, the Sakaguchi Detachment, which had come ashore on the morning of the 24th despite the fact that its anchorage had been raided by several [enemy] destroyers, had [already] advanced its headquarters to the city of Balikpapan before daybreak on the 25th, and had started operations to mop up [the enemy] on the 26th.

3. As mentioned previously, the Sixteenth Army gave the order to the Sakaguchi Detachment on the 25th, but it was not until one day later that it reported the full text of the order to [the Army Department] of IGHQ and the Southern Army by OsAMu [Sixteenth Army] Staff Section 1 Telegram No. 84 sent at 1545 on the 26th. Then again, it was not before the 28th that the signal section of both [the Army Department] of IGHQ and the Southern Army belatedly decoded [the telegram].

The Sixteenth Army did not know that the Southern Army and [the Army Department of] IGHQ had been exchanging telegrams [over the seizure of Banjarmasin], or that this issue had been delaying the conclusion of the Manila Agreement until the 28th, either. ${ }^{(36,40)}$

After signing [the Manila Agreement] on the 28th, the commander in chief of the Second Fleet gave the following order: ${ }^{(119)}$

\section{Southern Task Force Telegraphic Order No. 78 (at 1700, 28 January)}

The supplemented and revised agreement on Operation $\mathrm{H}$ with the commander in chief of the Southern Army has come into effect as Second Fleet Classified Telegram No. 750 (note by the 
author: the already-described telegram of 25 January). Each unit shall conduct operations in conjunction with the relevant army units conform to the above agreement.

As seen in Army General Staff Telegram No. 591 of the 26th, the Navy Department of IGHQ, too, strongly felt the necessity of seizing Banjarmasin and had sent telegram(s) to the units on site to reaffirm the necessity of seizing [the airfield of] the town and making it ready for use ahead of the Java landings. However, ultimately, the units on site could not give what they did not have, and the Dutch East Indies Unit (the Third Fleet) sent the following telegram to the 1st Escort Unit (the 4th Destroyer Squadron) on 28 January. ${ }^{(119)}$ [Consequently, ] two days later, the 30th, the 4th Destroyer Squadron left Balikpapan for Lingayen Gulf in order to escort the 48th Division from the Philippines to Java. ${ }^{(119)}$

We will cancel [the task of] the 1st Escort Unit to provide an escort to Banjarmasin. It has been decided that the Sakaguchi Detachment will seize Banjarmasin by land as well as by boat by maneuvering them along the coast. The $2 \mathrm{~d}$ Base Unit shall have an element with fishing boats as its main [force] transport the base matériel, fuel, etc. of the Eleventh Air Fleet, and cooperate with the Sakaguchi Detachment.

\section{The Plan of the Sixteenth Army and the Dutch East Indies Unit, and the Arrangement Between Them}

As already described, at the Manila Conference, [the entire meeting] on 21 January was spent on discussions between the Southern Army and the Navy, and although the Sixteenth Army was included in the conference on the $22 \mathrm{~d}$, the Southern Army kept on taking the lead. The chief of staff of the 48th Division, Col. Kawagoe Moriji, who attended the conference on that day, recalled the situation as follows:

In the meeting on the $22 \mathrm{~d}$, the Navy insisted that the seizure and preparation of airfields had not progressed as planned, and that, in eastern Borneo, [the whole operation of] seizing the Banjarmasin [airfield], making it ready and accumulating fuel and ammunition [there] would be completed around the date set in the plan before the opening of hostilities [at the earliest], and could not be done as scheduled in the recent Cam Ranh Agreement, and such was the case in Celebes. On the other hand, the Southern Army insisted that what had been decided at the recent Cam Ranh Agreement could not be changed because it had been reported to [the Army Department of] IGHQ. Both would not yield a bit, strongly insisting that they would not mind arguing their points all night that night. The argument was broken off once at my

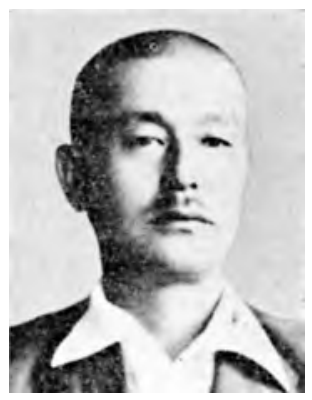

Chief of Staff of the 48th Division, Col. Kawagoe Moriji suggestion, and resumed in the afternoon, but once again became so heated that you could not imagine when it would come to an end. Explaining that [actually] the 48th Division would be in the biggest trouble, I presented a compromise adopting half of each argument. The Navy agreed with it right away, but the Southern Army did not give an inch. [Then,] in response to that, the Navy argued that it was the airfields for fighter planes that were the biggest problem. (Note by the author: Staff Officer Ishii's telegram of 1500 already mentioned in the above was sent at this juncture.) As the arguments did not come to an end, I spoke again and suggested seizing Bali ahead of the Java landing operations and conducting airstrikes on Java from Bali. [The reason for my suggestion was that] while the main force of the Sixteenth Army was supposed to come ashore in western Java under cover of the Army 
air units (and of part of the Navy air units as well), my division was expected to come ashore in eastern Java under cover of the Navy air units only. My words greatly changed the direction of the discussion. The Southern Army staff officers asked me which units [I had in mind] to capture Bali and when, to which I answered that the 48th Division shall capture it with a force consisting of one infantry battalion, one mountain artillery battery, one engineer platoon and one medical platoon as its core, and the best timing would be about one week prior to the landing in Java. They all immediately agreed, and told me that I should go to Davao and make arrangements with the Eleventh Air Fleet, as the Dutch East Indies Unit [the Third Fleet] was in the middle of the operations to seize Balikpapan and Kendari at that time, and that the Third Fleet would abide by the results. That was how the difficult agreement was reached at last. (Note by the author: [Navy] Staff Officer Yanagisawa's telegram of the 22d already mentioned in the above was sent at this juncture.)

On the next day, the 23d, the staff officers of the Sixteenth Army held preliminary talks with the Navy in Manila, ${ }^{(32)}$ and Chief of Staff of the 48th Division Kawagoe flew to Davao accompanied by Staff Officer Akatsuka Kazuo. ${ }^{(80)}$ The airfield in Davao was rough and bumpy, crudely made with wire netting laid out [over the runway], on which they barely managed to land. ${ }^{(80)}$ Chief of Staff Kawagoe felt that he [now] understood the trouble the Navy had in constructing airfields. He had talks with Commander in Chief of the Eleventh Air Fleet V. Adm. Tsukahara Nishizō and his chief of staff, Ōnishi Takijirō, in which it was decided that the landing location would be the narrow sandy beach on the southeast coast of Bali, and detailed arrangements were made. ${ }^{\left({ }^{80}\right)}$ Commander in Chief Tsukahara shocked Chief of Staff Kawagoe by saying: “Two fast transport ships with a speed of over seventeen knots will be necessary. We would like the Army to arrange them. If impossible, we will look into the [possibility that] the Navy arrange them." (80) This led to the already-described search for faster ships and the choosing of the Sasako-maru and the Sagami-maru. Chief of Staff Kawagoe and his companion returned to Manila the next day, the 24th. ${ }^{\left({ }^{80}\right)}$ On that day (the 24th), the participants of the Manila Conference returned [to their units]. ${ }^{(23,32)}$ It was also the day that the landings in Balikpapan and Kendari were carried out, which will be described later. ${ }^{(117,119)}$

\section{The Situation of the Sixteenth Army and its Operation Plan}

The situation as of the $23 \mathrm{~d}$, when the Sixteenth Army held talks with the Dutch East Indies Unit in Manila, was roughly as follows:

1. The Sakaguchi Detachment was sailing southward from Tarakan in order to land in Balikpapan before daybreak of the next day, the 24th. ${ }^{(119)}$

2. The Eastern Detachment had arrived in Davao on the 18th, and was preparing for the seizure of Ambon. ${ }^{(117)}$ Although the landing in Ambon was scheduled for 25 January in the Cam Ranh Agreement, on 15 January it was postponed by the Dutch East Indies Unit until the 29th, and [again] on 19 January further postponed until the 31st. ${ }^{(117)}$

3. The 38th Division, which had left Hong Kong on 20 January, was approaching Cam Ranh Bay. ${ }^{(66)}$ (It reached the bay on the 24th.)

4. The 48th Division, whose task at the battlefront in Bataan had been taken over by the 65th Brigade on 8 January, was preparing for the Java operation in Manila. ${ }^{(79)}$

5. As for the 2d Division, following the IGHQ Army Department Instruction No. 1037 ${ }^{(1)}$ of 24 November, the headquarters of the division had arrived [at the maneuvering 
grounds] in Narashino from 7 to 8 December, the 4th Infantry Regiment at the foot of Mt. Fuji from the 11th to the 17th, the 16th Infantry Regiment [also] in Narashino from the $3 \mathrm{~d}$ to the 6 th, the 29 th Infantry Regiment in Toyohashi from the 1 st to the 4 th, while the other units had also arrived by train generally in the same way, and [all of them] had started training at the maneuvering grounds. ${ }^{(53)}$ Later on 27 December, they were ordered by the Sixteenth Army (in Tokyo at that time) to advance to Gaoxiong. However on 3 January, while preparing for the move, 448 personnel, 1,700 horses, and some matériel were transferred to units on the mainland, ${ }^{(31)}$ which was followed by the order that some of the men and horses of the 16th Infantry Regiment (197 men and 178 horses) and the $3 \mathrm{~d}$ Battalion of the $2 \mathrm{~d}$ Field Artillery Regiment would be transported in the second and later transports and follow on. ${ }^{(31)}$ The Division embarked during the period of 15 to 23 January at Ujina left the port, and [its ships] arrived in Gaoxiong one after another from 21 January onwards (the arrival [of the ships] was completed on the 26th). ${ }^{(31)}$ On 14 January, the Navy Department of IGHQ had ordered by Instruction No. 40 that "the commander in chief of the Combined Fleet shall provide the convoy transporting the Army $2 \mathrm{~d}$ Division (in about thirty-three transport ships), which will leave Moji on 18 January, with direct escort from Moji to Gaoxiong. The commander in chief of the Chinkai Guard District shall put the 32d Destroyer Division under the command of the commander in chief of the Combined Fleet regarding the above escort."(1) On 15 January, by Telegraphic Operation Order No. 43, the commander in chief of the Combined Fleet gave the order that "the 9th Cruiser Division commander shall provide the escort to the Army transport convoy [mentioned] in IGHQ Navy Department Instruction No. 40. The force to be employed for the escort shall consist of the 9th Cruiser Division, the 1st Section of the 27th Destroyer Division, and the 32d Destroyer Division." ${ }^{(129)}$ The 9th Cruiser Division consisted of the light cruisers $\mathrm{Oi}$ and Kitakami and its commander was R. Adm. Kishi Fukuji. ${ }^{(129)}$

As already described, in the operation plan of the Sixteenth Army (which was the revision of the previous operation plan after [the army] had on 5 January received the Southern Army's order to prepare for the invasion of Java) as well as in the recent Manila Conference, three issues had arisen: (1) the issue of capturing Bali with an element of the 48th Division ahead of [the Java operation], (2) the issue of the seizure of Banjarmasin, and (3) the issue of a shortage of naval forces to provide [sufficient] escort. At that time (as of the 23d), the forces which [the Navy] could afford to employ for the escort of the large convoy of fifty-six ships with the main force of the Sixteenth Army aboard to western and central Java was just one light cruiser and eight destroyers (i.e. the Natori under the command of Rear Admiral Hara, commander of the 5th Destroyer Squadron with the 5th and the 22d Destroyer Divisions) ([as seen in] the order of the Southern Task Force of 4 January). [Therefore,] the Navy was reluctant to separately land the Shōji Detachment (in Patrol), which was rather close to the naval port of Surabaya. It also stated that it would not be able to fully guarantee the safety [of the army] against a threat from the Indian Ocean if the main force of the army landed in Merak. So, the strengthening of the escort force by bringing in part of the [Navy] Malaya Unit and others became the topic of this conference. 


\section{The Situation of the [Navy] Dutch East Indies Unit and its Operation Plan}

As of 23 January, the situation of the [Navy] Dutch East Indies Unit was roughly as follows:

1. The South China Sea: Of the 5th Destroyer Squadron ([consisting of] one light cruiser and eight destroyers) that had finished escorting the main force of the 33d Division, one regiment of the 5th Division, and others to Bangkok and Singora, the flagship the Natori and the four destroyers of the 22d Destroyer Division had left Singora on 9 January, arrived in Magong on 16 January, left port on the 21st, and arrived in Gaoxiong on the same day, where they had stayed since then. The four destroyers of the 5th Destroyer Division [of the 5th Squadron] had left Singora on the 12th and arrived in Magong on the 18th. Thereafter, they had joined the main force, and were also in Gaoxiong. ${ }^{(120)}$

2. The Makassar Strait: The Western Attack Unit was escorting the Sakaguchi Detachment for the landing operations in Balikpapan which would be conducted on the next day, the 24th. ${ }^{(119)}$ The Western Attack Unit consisted of the 1st Escort Unit (the main force of the 4th Destroyer Squadron), the $2 \mathrm{~d}$ Base Force, and the 1st Air Unit ([consisting of] the auxiliary seaplane tenders the San'yō-maru and the Sanuki-maru), and they were under the direct control of the Dutch East Indies Unit commander. ${ }^{(119)}$ Leaving Davao on this day (the 23d), the Dutch East Indies Unit commander was sailing southward, leading the main force [of the unit] (the 16th Cruiser Division) to support [the operation to] seize Balikpapan. ${ }^{(119)}$

3. The Molucca Sea: The Eastern Attack Unit under the command of the 5th Cruiser Division commander was sailing southward to go ashore in Kendari on the next day, the 24th. The Eastern Attack Unit consisted of the Support Unit (the 5th Cruiser Division), the 1st Base Unit (with the 1st Base Force as its core), the $2 \mathrm{~d}$ Escort Unit ([made up of] the main force of the $2 \mathrm{~d}$ Destroyer Squadron), and the $2 \mathrm{~d}$ Air Unit (i.e. the 11th Seaplane Tender Division with the seaplane tenders Chitose and Mizuho). .117) $^{-1}$

4. Tarakan and Menado had been captured on the 11th, one day behind the schedule set in the Cam Ranh Agreement. The upcoming operations against Balikpapan and Kendari were to be conducted on the 24th, four days behind the schedule of the Cam Ranh Agreement. The operation to seize Ambon was also changed and to be conducted on the 31st, six days behind the schedule of the Cam Ranh Agreement. ${ }^{(117,119)}$

While this was the situation of the Dutch East Indies Unit, the plan for its [coming operations] was that its Eastern Attack Unit would have to head eastward to seize Ambon right after the seizure of Kendari, then head westward to seize Makassar, and again head eastward to seize Kupang, while its Western Attack Unit would seize Balikpapan [first], then cooperate in the seizure of Makassar while conducting the operation to seize Banjarmasin at the same time, and on top of that, escort the 48th Division from the Philippines to Java. [For the Dutch East Indies Unit,] it was absolutely impossible to strictly keep to the schedule of the Cam Ranh Agreement, and [the unit] was also painfully aware that it had a serious shortage of destroyers. In these circumstances, the cancellation of the escort in the operation to seize Banjarmasin was of help in terms of both the schedule and the scarcity of destroyers. However, if the reason to omit [the operation against] Banjarmasin had been "the danger of sailing immediately north of Surabaya and exposing the flank [of the convoy to the enemy naval port]," then the previously described arguments for an attack on Bali [naturally] raise the question: "Then what about Bali? Would that not be all the more dangerous?" Ultimately, [the tight schedule and the shortage of forces brought about that] the commander of the 4th Destroyer Squadron would leave Balikpapan (on 30 January), about two weeks before the seizure of Makassar 
(12 February), for the Philippines with his main force escort to the 48th Division; that the element left behind [in Makassar] to support the seizure of the place would be withdrawn immediately after its cooperation; and that the dangerous [operation] to capture Bali would be supported by just a small force commanded by the 1st Base Force commander [R. Adm. Kubo Kyūji]. The details will be described later along with the issue of the escort of the main force of the Sixteenth Army.

\section{The Arrangements between the Sixteenth Army and the Air and Naval Units}

(See Illustration No. 20)

With all the above-mentioned problems involved, the Sixteenth Army concluded the following arrangements on 23 January in Manila with the air and naval units concerned:

Memorandum of the Arrangements for Operation $\mathrm{H}$ between the Sixteenth Army, the Third Air Force, the Third Fleet and the Eleventh Air Fleet

I. Distribution of the landing forces, landing points, names for landing sectors and their reconnaissance

1. Landing points and names for landing sectors

(1) Units in the first transport

$\{1\}$ Area No. 1 ([assigned to] the 2d Division and the main force of the units under the direct control of the army)

Sector A Landing Unit ([consisting of] 2 infantry battalions and 1 reconnaissance regiment as its core): on the south side of Merak

Sector B Landing Unit ([consisting of] 2 infantry battalions as its core): on the north side of Merak

Sector C Landing Unit ([consisting of] the main force of the [2d] Division and the main force of the units under the direct control of the army): along Bantam Bay

Note by the author: Although Lt. Col. Sendō Shunzō, chief shipping staff of the Sixteenth Army, explained in detail and stressed the unsuitableness of the coast of Bantam Bay and the advantages of the coast of Merak, the Navy emphasized the threat from the Indian Ocean and finally overcame [the opposition of] the army. ${ }^{(44)}$

\{2\} Area No. 2 ([assigned to] the Shōji Detachment, [consisting of] 2 infantry battalions as its core): [on the coast near] Patrol

Note by the author: The Navy expressed disapproval of the idea of separately [landing] the Shōji Detachment, particularly of putting it ashore closer to the naval port of Surabaya, but this time the army had its way. ${ }^{(44)}$

\{3\} Area No. 3 ([assigned to] the 48th Division as its core)

Sector D: Right Wing Unit ([consisting of] 3 infantry battalions as its core): on the north side of Kragan

Sector E: Left Wing Unit ([consisting of] the main force of the division): on the south side of Kragan

Note by the author: Although the Sixteenth Army initially planned to put Sector D and Sector $\mathrm{E}$ at a considerable distance [from each other], the 48th Division opposed this. ${ }^{(80)}$

(2) Units in the second transport Area No. 1: Batavia (or Bantam) about 100,000 tons

Area No. 3 Surabaya (or Kragan) about 50,000 tons

(3) Units in the third transport

Area No. 1: Batavia (or Bantam) about 100,000 tons 
2. Reconnaissance of the landing points

(1) Reconnaissance by aircraft

Army: Thirty copies of the photomaps on a scale of about 1 to 25,000 of the landing coasts of Areas No. 1 and 2 shall be delivered to the [Sixteenth] Army headquarters in Saigon by around 10 February (three copies of which shall be delivered to the 12th Seaplane Tender Division (the Kamikawa-maru) in Cam Ranh).

Navy: Thirty copies of the photomaps on a scale of about 1 to 25,000 of the landing coast of Area No. 3 shall be delivered to the 48th Division in Jolo (the Pata anchorage) by around 10 February.

(2) Other prior reconnaissance, if necessary, shall be conducted by arrangement between the commanders of the landing corps, escort units and air units.

II. Assembly points, arrival and departure dates of the transport ships

\begin{tabular}{|c|c|c|c|c|}
\hline Transports & Areas & Assembly Points & Dates of Arrival & Dates of Departure \\
\hline \multirow{2}{*}{ First } & Areas No. 1 and No. 2 & $\begin{array}{l}\text { Gaoxiong, then } \\
\text { Cam Ranh }\end{array}$ & $\begin{array}{l}\text { Leave Gaoxiong dur- } \\
\text { ing the period from } \\
\text { the beginning till } 6 \\
\text { February one after an- } \\
\text { other, and assemble in } \\
\text { Cam Ranh }\end{array}$ & $\mathrm{H}-8$ \\
\hline & Area No. 3 & $\begin{array}{l}\text { Lingayen, then the } \\
\text { Jolo/Pata } \\
\text { anchorage }\end{array}$ & $\begin{array}{c}\text { Complete embarka- } \\
\text { tion by } 7 \text { February, } \\
\text { leave on } 8 \text { February, } \\
\text { and assemble at the } \\
\text { Pata anchorage on } \\
12 \text { February }\end{array}$ & $\mathrm{I}-7$ \\
\hline \multirow{2}{*}{ Second } & Area No. 1 & \multicolumn{3}{|c|}{$\begin{array}{l}\text { Advance from mainland Japan to Cam Ranh first, and then go } \\
\text { ashore in Batavia (or Bantam) }\end{array}$} \\
\hline & Area No. 3 & \multicolumn{3}{|c|}{$\begin{array}{l}\text { Advance from Lingayen to Jolo or Davao, and then go ashore in } \\
\text { Surabaya (or Kragan) }\end{array}$} \\
\hline Remarks & \multicolumn{4}{|c|}{$\begin{array}{l}\text { The Sixteenth Army commander shall determine the second and later transports after due } \\
\text { consultation with the commanders of the } 4 \text { th and } 5 \text { th Destroyer Squadrons }\end{array}$} \\
\hline
\end{tabular}

Note by the author: " $\mathrm{H}$ " indicates the date of landing on western Java, which was 21 February, and "I" that on eastern Java, which was 23 February. At the Manila Conference, the dates of landing in western and eastern Java were respectively set five days and seven days behind those specified in the Cam Ranh Agreement, which allowed [the units concerned] to call at Cam Ranh and Jolo respectively.

III. Starting date and time of the landings and the schedule

1. Starting dates of landings

The first day of the landings are set as follows:

Eastern Java: on day I

Western Java: on day $\mathrm{H}$

Although day I and day H are scheduled for "XX," the Sixteenth Army commander shall fix [them] after due consultation with the commander in chief of the Third Fleet by 1200 on day $\mathrm{H}-9$. However, if further changes [to these dates] become necessary after the departure [of the units], [new dates] shall be decided upon through consultations each time.

Note by the author: " $X X$ " had been set as day $x+75$, and day $x+77$, that is, 21 and 23

February. However, on 10 February, both of them were changed to day $x+80$, that is, 26 February. This had come about in the following way: 
On 21 January at the Manila Conference, it was agreed that the dates [of the landings] would be set as day $x+75$ and day $x+77$, and that the Third Air Force commander and the commander in chief of the Eleventh Air Fleet would be included in those with whom arrangements on $\mathrm{H}$ would be made. On 23 January, staff officers of the Sixteenth Army, the Third Fleet, the Third Air Force and the Eleventh Air Fleet made a draft of this memorandum of the arrangement for Operation $\mathrm{H}$ in Manila.

On 25 January, the Second Fleet sent the formal [proposal for the] agreement to the Southern Army. On 28 January, the agreement between the Second Fleet and the Southern Army came into effect.

On the 30th, this memorandum of the arrangement for Operation $\mathrm{H}$ officially came into effect.

On 4 February, a postponement of [Operation] L for four days came up as an issue. On the 6th, a postponement of [Operation] L for another two days came up.

On the 10th, the Southern Army and the Second Fleet reached an agreement to set the schedule of both $\mathrm{H}$ and I on day $\mathrm{x}+80$.

2. Start of the landings

Entry into the anchorage shall be made around 0000 for both day $\mathrm{H}$ and day I. Although the start of the landings is set at 0200 for both day $\mathrm{H}$ and day I, [the landings] in each area shall be started as soon as [the units] in the area are ready.

3. Landing schedule

(1) Units in the first transport

Area No. 1: [shall be completed] in about seven days.

Area No. 2: [shall be completed] in about five days. Depending on the circumstances, on day $\mathrm{H}+2$ and onwards, units yet to be debarked may be [again] transported and put ashore at Area No. 1. The decision of whether to implement [this] shall be made by the Sixteenth Army commander after due consultation with the 5th Destroyer Squadron commander.

Note by the author: The sentence after the phrase "depending on the circumstances" was added reflecting the Navy's opinion. ${ }^{(4)}$

Area No. 3: [shall be completed] in about five days.

(2) Units in the second transport

Area No. 1: [shall be completed] in about five days.

Area No. 3: [shall be completed] in about five days.

IV. Distribution of the convoy of transport ships, the commander's whereabouts, and the escort forces:

Note by the author: Of the ships in the table below, the Natori was the flagship of the 5th Destroyer Squadron, the Yura was the flagship of the 5th Submarine Squadron, and the Sendai was the flagship of the 3d Destroyer Squadron. The Yura and the Sendai belonged to the Malaya Unit. As of 23 January, only the 5th Destroyer Squadron had been decided as the force to escort [the transport ships] to Areas No. 1 and No. 2 , and [its task] was planned as shown in this table. However, a reinforcement with two destroyers from the air unit (the Eleventh Air Fleet) was announced on 28 January, which was followed by a reinforcement with the Yura and five destroyers from the Malaya Unit on 17 February. "No. 333" is unknown. 


\begin{tabular}{|c|c|c|c|c|c|c|c|}
\hline \multirow{2}{*}{ Transport } & \multirow{2}{*}{\multicolumn{2}{|c|}{$\begin{array}{l}\text { Areas and } \\
\text { Convoys }\end{array}$}} & \multirow{2}{*}{ Units } & \multirow{2}{*}{$\begin{array}{l}\text { Number of } \\
\text { Ships }\end{array}$} & \multicolumn{2}{|c|}{ Commander's whereabouts } & \multirow{2}{*}{$\begin{array}{l}\text { Escort } \\
\text { Forces }\end{array}$} \\
\hline & & & & & Army & Navy & \\
\hline \multirow{6}{*}{ First } & & 1st convoy & $\begin{array}{c}\text { Sector A } \\
\text { landing unit }\end{array}$ & 8 & $\begin{array}{l}\text { Infantry group } \\
\text { commander/ } \\
\text { the Kōyo-maru }\end{array}$ & & \multirow{6}{*}{$\begin{array}{c}\text { 5th } \\
\text { Destroyer } \\
\text { Squadron } \\
\text { and } \\
6 \text { destroyers, } \\
1 \text { light } \\
\text { cruiser, and } \\
5 \\
\text { minesweep- } \\
\text { ers of the } \\
\text { First South- } \\
\text { ern Expedi- } \\
\text { tionary Fleet } \\
\text { as the core }\end{array}$} \\
\hline & & $2 \mathrm{~d}$ convoy & $\begin{array}{c}\text { Sector B } \\
\text { landing unit }\end{array}$ & 6 & $\begin{array}{c}\text { Regimental } \\
\text { commander / } \\
\text { the Reiyō-maru } \\
\end{array}$ & & \\
\hline & Area No. 1 & $3 d$ convoy & $\begin{array}{c}\text { Sector C } \\
\text { landing unit } \\
\text { (main force of } \\
\text { the division } \\
\text { and main force } \\
\text { of the unit } \\
\text { under the di- } \\
\text { rect control of } \\
\text { the [Sixteenth] } \\
\text { Army) }\end{array}$ & \begin{tabular}{|c|}
27 \\
2 munitions \\
ships \\
1 No. 333 \\
1 water supply \\
ship \\
1 coaling ship \\
1 repair ship
\end{tabular} & $\begin{array}{l}\text { Army com- } \\
\text { mander/the } \\
\text { Sakura-maru } \\
\text { Division com- } \\
\text { mander/the } \\
\text { Ayatosan-maru }\end{array}$ & The Natori & \\
\hline & Area No. 2 & 4th convoy & $\begin{array}{c}\text { Shōji } \\
\text { Detachment }\end{array}$ & 7 & $\begin{array}{c}\text { Regimental } \\
\text { commander/ } \\
\text { the Suwa-maru }\end{array}$ & $\begin{array}{l}\text { The Yura or } \\
\text { the Sendai } \\
\text { (depending } \\
\text { on situation) }\end{array}$ & \\
\hline & & 5th convoy & $\begin{array}{c}\text { Right Wing } \\
\text { Unit }\end{array}$ & 6 & $\begin{array}{c}\text { Regimental } \\
\text { commander/ } \\
\text { the Aden-maru }\end{array}$ & & \\
\hline & Area No. 3 & 6th convoy & $\begin{array}{l}\text { Left Wing Unit } \\
\text { (main force of } \\
\text { the division) }\end{array}$ & $\begin{array}{c}19 \\
2 \text { munitions } \\
\text { ships } \\
1 \text { water supply } \\
\text { ship } \\
1 \text { coaling ship } \\
1 \text { hospital ship } \\
1 \text { repair ship }\end{array}$ & $\begin{array}{c}\text { Division com- } \\
\text { mander / the } \\
\text { Teiyō-maru } \\
\text { Infantry group } \\
\text { commander/ } \\
\text { the Tonegawa- } \\
\text { maru }\end{array}$ & The Naka & \\
\hline Second & $\begin{array}{c}\text { Areas No. } 1 \\
\text { and No. } 3\end{array}$ & \multicolumn{6}{|c|}{ To be determined depending on the situation at the time } \\
\hline
\end{tabular}

V. Route of the convoys

As shown in Supplement No. 1 (omitted by the author)

VI. Reconnaissance and diversions

The Navy air units shall conduct feint bombings of enemy naval bases and others in the Probolinggo area (note by the author: southeast of Surabaya).

VII. Anchorage and the formation at the anchorage:

Anchorages and the convoy's formation at the anchorage shall be determined by the commander of the landing corps after due consultation with the commander of the escort.

VIII. Outline of landing attack

Although [the landing shall be made] as a surprise landing in principle, it shall be carried out by assault if the situation should require it. 
IX. Use of air units

1. Forces to be employed

(1) The Eleventh Air Fleet

About 80 Type-1 land-based attack planes, about 35 Type-96 land-based attack planes, about 70 Type-0 fighter planes, and about 5 land-based reconnaissance planes.

(2) The Third Fleet About 50 reconnaissance seaplanes

(3) The Third Air Force

About 15 command reconnaissance planes, about 4 army reconnaissance planes, about 40 Type- 1 fighter planes, about 50 Type- 97 fighter planes, about 20 assault planes, about 20 twin-engine light bombers, and about 30 heavy bombers.

The above forces may slightly be increased or decreased depending on the situation.

2. Bases to be used

(1) [Bases] in Sumatra, Borneo and others

$\{1\}$ The Palembang [airfield] shall be made ready and used by the Army. The Navy may use this [base] by advancing some land-based attack planes, or as a relay base for about thirty-six land-based attack planes when attacks on enemy surface forces in the Indian Ocean are necessary.

\{2\} The Mentok [airfield] shall be made ready for use mainly by the Army, but with the cooperation of the Navy. The Army and the Navy shall share the airfield and each shall advance thirty fighter planes. However, when the Army starts using the Tanjungkarang airfield, the Navy shall exclusively use the Mentok airfield.

\{3\} The Ledo [airfield] shall be used by the Navy. However, the Army may advance some command reconnaissance planes there.

\{4\} As for the airfields other than the above, those in Sumatra shall be used by the Army, and those in Borneo by the Navy.

(2) [Bases] in Java

$\{1\}$ [The airfields in] Batavia and Cililitan (note by the author: east of Batavia [editor's note: south of Batavia; the civil airfield, Kemayoran, was east of the city]) shall be made ready for use by the Army and shared by the Army and the Navy in the following way:

The Navy: about 36 land-based attack planes and about 27 fighter planes.

The Army: about 20 twin-engine light bombers and about 15 command reconnaissance planes.

\{2\} The Buitenzorg [Bogor] and Kalijati [airfields] shall be made ready and used by the Army. However, if the Batavia or Cililitan airfields cannot be used or if it takes more time than expected to make them ready, the Navy shall advance about 27 fighter planes to the Kalijati [airfield].

3. Outline of operations

(1) [We shall] promptly destroy the enemy air power in Java. The areas assigned [to the Army or the Navy] in particular are as follows:

\{1\} The areas assigned [to the Army and the Navy] after the advance of the Army air units to Palembang are roughly decided as follows:

The Navy: [the area] east of $108^{\circ}$ east

The Army: [the area] west of $108^{\circ}$ east

$\{2\}$ In general the Navy shall mainly take charge of destroying the remnants of the enemy air power after the Army has gone ashore.

(2) The attack on enemy warships shall be mainly assigned to the Navy.

(3) Covering of the convoy under sail and at anchorage

\{1\} The main force of the Sixteenth Army 
(a) The Navy shall be charged with the cover before and on day $\mathrm{H}-2$.

Note: The cover in the area northward of $5^{\circ}$ north shall be provided by the First Southern Expeditionary Fleet.

(b) The cover of the convoy up to the point of separation of the Shōji Detachment from the main force of the army (indicated as point " $\mathrm{j}$ " in Supplement No. 1) on day $\mathrm{H}-1$ shall be charged to the Navy. After that, the Navy shall take charge of the cover of the Shōji Detachment, and the Army of the cover of the rest of the main force of the army. However, guarding against [enemy] submarines shall be wholly assigned to the Navy.

$\{2\}$ The 48th Division

Along with guarding against [enemy] submarines, the Third Fleet shall take charge of guarding the sky [over the anchorage] as well, from the time when the convoy enters the anchorage until the advance of the fighter planes of the Eleventh Air Fleet there. After that, the Eleventh Air Fleet shall take over [the task of] guarding.

\{3\} The guarding of the sky over the anchorage

The guarding of the sky shall be provided by the Army all the time until sunset on day $\mathrm{H}+2$ over the anchorage for the units landing in Bantam, and on day $\mathrm{H}+1$ over that for the units landing in Merak. After that, it shall provide air cover as needed depending on the situation.

(4) Support of the ground operations

\{1\} The area of the main force of the Sixteenth Army

(a) The Army shall be in charge of the direct support of the ground operations.

(b) The Navy shall be in charge of cutting off the transport routes of the enemy in the Cilacap area. It shall [also] be in charge of attacking enemy reinforcements or forces in retreat when requested by the Army.

$\{2\}$ The area of the 48th Division

The Third Fleet shall be in charge of direct support of the ground operations and the Eleventh Air Fleet shall provide appropriately provide support at the request of the Army. The Army shall join in [the direct support] if possible.

\section{Information}

(1) Military gains of [the operation] to destroy the enemy air power

The results of reconnaissance of enemy airfields, weather information and others shall promptly be shared between the Army and the Navy air units.

(2) Other information concerning enemy movements and others shall be exchanged every time [it is obtained].

5. Allotment [of facilities] and rules about the use of the shared airfields

The allotment [of facilities] and rules about the use of the airfields shared by the Army and the Navy shall be arranged between senior commanding officers of the Army and the Navy [units] which [actually] use the airfield.

6. Identification of friends

Conforms to the agreement between the Southern Army and the Combined Fleet.

$X$. Defense facilities of landing bases

1. The landing bases shall be set up as follows:

For Areas No. 1 and No. 2: Batavia (Bantam shall be used at the beginning.)

For Area No. 3: Surabaya (Kragan shall be used at the beginning).

2. The Navy shall take charge of the sea defense, the Army of the defense on land, and both shall jointly take charge of the air defense.

XI. Move of the transport ships after the completion of disembarkation After completing disembarkation, [the transport ships] shall be moved to the required areas under the direct or indirect cover of the escort unit in the area. 


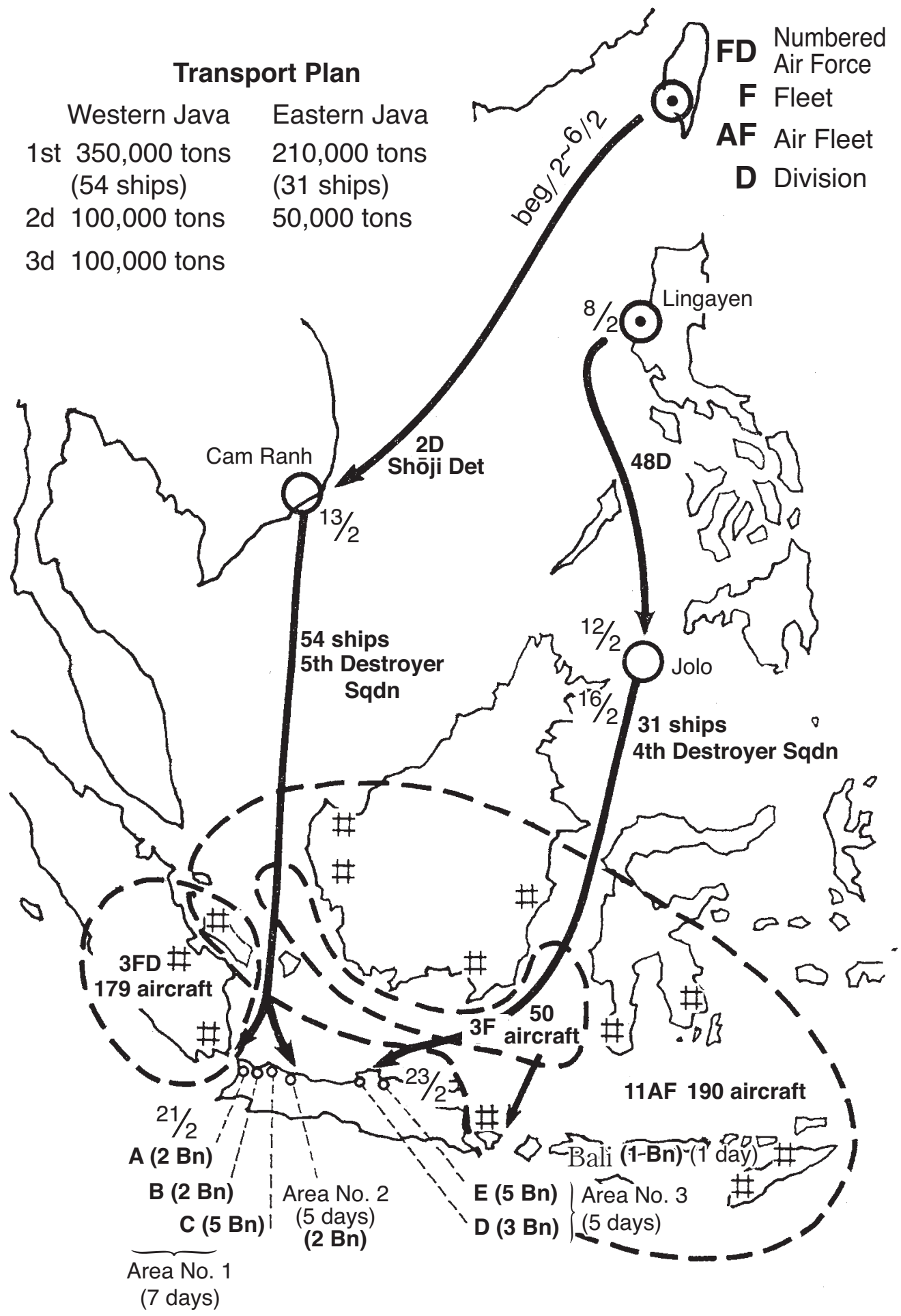

Illustration No. 20-Overview of the Arrangements for Operation $H$ 
XII. Signal Communications As specified in the signal communication arrangement in the separate volume (omitted by the author).

XIII. Others

1. The 48th Division shall have an element seize the Bali airfield in conjunction with the Navy no later than day I - 2 to make it ready for use, with the aim of advancing a naval air base. Note by the author: On 28 January, when the cancellation of the seizure of Banjarmasin by sea and the [implementation of] the new [plan of] capturing Bali was decided, the Southern Task Force issued the order to "capture Bali around 21 February (day I - 2)." However, the Dutch East Indies Unit changed the order to "capture Bali on 18 February (day I - 5)." This shall be described later.

2. The Navy, in concert with the ground operations, shall take control of the waters south of Java, and block the enemy's retreat.

3. Details other than the above shall be discussed and decided between the commanders of the landing corps, escort forces and air units concerned.

As mentioned earlier, while the Manila Agreement had officially become effective on 28 January, this draft of the arrangement on Operation $\mathrm{H}$ (of 23 January), [officially] came into effect on 30 January. ${ }^{(135)}$ [Later] on 10 February, only the dates of "day $\mathrm{H}$ and day I" were modified. ${ }^{(96)}$

\section{The Navy's Shift to Phase-Three Operations and the Decision to Bring in the Carrier Task Force}

The above arrangements on Operation $\mathrm{H}$ stated that the Navy would take control of the waters south of Java, and block the enemy's retreat. This was a critical matter when considering the fact that the allied forces, which had retreated from the Philippines and Malaya after the opening of hostilities, and those reinforced from the United States, Britain and Australia, had been concentrated in Java. However, on 23 January, when this preliminary arrangement for Operation $\mathrm{H}$ was made, the participation of the First Air Fleet (the Carrier Task Force), the Sixth Fleet (the Submarine Fleet) and others in the Java operation had not yet been decided.

On 23 January, when this preliminary arrangement for Operation $\mathrm{H}$ was made, the South Seas Detachment with the cooperation of the Fourth Fleet, was in the middle of its landing operation on Rabaul, which was also supported by the First Air Fleet. ${ }^{(116)}$

At that time, the Combined Fleet, which had supported the Rabaul landing operation, was also interested in implementing Carrier Task Force operations on the northeast coast of Australia, following the Rabaul operations.

The reason why the Army Department of the IGHQ repeatedly requested the Southern Army during the time after the Manila Conference until 27 January to seize Banjarmasin ahead [of the Java operation] was that it intended to tell [the army] that the latter should seize Banjarmasin before landing on Java just to be on the safe side, as it was difficult to expect the cooperation from the Carrier Task Force.

Because of the Army's request to have the Carrier Task Force participate in the Java operation, the concern of the Combined Fleet about the risky operation to capture Bali, and the [possible] military gains for the Carrier Task Force when it participated in the Java operation compared to conducting operations against the northeast coast of Australia, the Navy de- 
cided on 30 January to have part of both the Carrier Task Force and the Sixth Fleet join the Java operation. The details will be described later.

Regarding the Navy's shift to phase-three operations (the operation to capture Java), the Combined Fleet ordered the shift to take effect as of 1200 on 24 January. ${ }^{(17)}$ [The shift to phasethree operations] was ordered by the Southern Task Force on the same day (the 24th), ${ }^{(117)}$ and by the Dutch East Indies Unit on 28 January when the issues of Banjarmasin and Bali were settled. . 117,119$)^{-1}$

The most distinctive feature of the phase-three disposition of the Dutch East Indies Unit was that [the task of] escorting the convoy of the main force of the Sixteenth Army ([to be conducted by] the 3d Escort Unit, [consisting of] the 5th Destroyer Squadron as its core) in the South China Sea was newly added to the current [tasks of providing] escorts along the Makassar Strait front ([provided by] the 1st Escort Unit, [consisting of] the 4th Destroyer Squadron), and in the Molucca Sea ([provided by] the 2d Escort Unit, [consisting of] the 2d Destroyer Squadron). The second distinctive feature was that the escort of the Sakaguchi Detachment would be provided no farther than Balikpapan, and that the [forces for the cancelled part of the escort] would be diverted to the escort of the 48th Division, and that the Celebes front was extended from Kendari to Bali via Makassar. The phase-three disposition of the Dutch East Indies Unit (ordered on 28 January) was supposed to be as follows after the ongoing operation to seize Ambon (on 31 January):

Main Unit [consisting of] the 16th Cruiser Division (minus the Nagara, which left the heavy cruiser Ashigara as its only component), one section of one destroyer division of the 4th Destroyer Squadron: Shall support the entire operation mainly in the eastern part of the Java Sea, [sailing] from Davao, to the Makassar Strait and Surabaya.

1st Escort Unit [consisting of] the main force of the 4th Destroyer Squadron: Shall escort the 48th Division from Lingayen Gulf to Surabaya.

2d Base Unit: Shall work in conjunction with the Sakaguchi Detachment's [operation to] seize Banjarmasin, [the operation of] the Eleventh Air Fleet to prepare the Banjarmasin air base, and [the operation of] the 1st Base Force to seize Makassar. After that, it shall join the escort of the 48th Division.

2d Air Unit [consisting of] the 11th Seaplane Tender Division ([made up of] the seaplane tenders, Chitose, and Mizuho): After cooperating in the seizure of Ambon and Makassar, it shall cooperate with the 1st Escort Unit and the 2d Base Unit.

3d Escort Unit [consisting of] the 5th Destroyer Squadron (which was reinforced with one section of the 6th Destroyer Division, and also with the light cruiser Yura, the 11th and the 12th Destroyer Division of the Malaya Unit): Shall escort the main force of the Sixteenth Army from Gaoxiong to western Java.

1st Air Unit [with] the auxiliary seaplane tenders Kamikawa-maru and San'yō-maru: Shall cooperate with the 3d Escort Unit.

Eastern Support Unit [of the Dutch East Indies Unit, consisting of] the 5th Cruiser Division (minus the Myōko under repair in the mainland; namely, the heavy cruisers Haguro and Nachi) and one and a half destroyer divisions: Shall support the 2d Escort Unit and the 1st Base Unit.

$2 d$ Escort Unit [consisting of] the main force of the $2 \mathrm{~d}$ Destroyer Squadron: Shall escort the Eastern Detachment and [take part in] the operations to seize Kupang.

1st Base Unit [consisting of] the light cruiser Nagara and the 21st Destroyer Division, but reinforced with two destroyer divisions for [the operation to] seize Makassar [till its completion] and (one destroyer division for Bali [till its completion]): Shall take part in the Makassar and Bali invasion operations. 
Celebes Guard Unit

Ambon Guard Unit

The destroyers employed in the Dutch East Indies Unit were insufficient as already described, and consisted of eight destroyer divisions, that is, the 8th, the 15th, and the 16th Destroyer Divisions of the 2d Destroyer Squadron (note: the 18th Destroyer Division initially included in the squadron was transferred to the Carrier Task Force), the $2 \mathrm{~d}$, the 9th and the 24th Destroyer Divisions of the 4th Destroyer Squadron (note: the 4th Destroyer Division initially included in the squadron was transferred to the main force of the Southern Task Force, and later to the carrier-based air units), the 5th and the 22d Destroyer Divisions of the 5th Destroyer Squadron. [Because of the insufficient strength,] it was decided to newly add the following four and a half destroyer divisions as reinforcements:

In [the order] issued on 21 January, the 21st Destroyer Division (with four destroyers) was transferred from the main-force unit, ${ }^{(114)}$ and participated in [the operations] to seize Kendari and Makassar, and in the operation of the Kanemura Detachment to capture Bali.

In [the order] issued on 28 January, the 7th Destroyer Division (with three destroyers) was transferred from the Carrier Task Force (the First Air Fleet), ${ }^{(114)}$ and participated in [the operations] of the Eastern Detachment to seize Ambon and Timor.

In [the order] issued on 28 January, the 1st Section of the 6th Destroyer Division (with two destroyers) was transferred from the Air Unit (the Eleventh Air Fleet) ${ }^{(114,120)}$ and joined the escort of the main force of the Sixteenth Army, which headed from Cam Ranh Bay to western Java.

In [the order] issued on 17 February (though it was informally decided at the Manila Conference), the 11th Destroyer Division (with three destroyers) and the 12th Destroyer Division (with one destroyer) were transferred from the Malaya Unit (the 3d Destroyer Squadron) ${ }^{(120)}$ and joined the escort of the convoy of the main force of the Sixteenth Army from Anambas southwards.

In this way, the number of destroyers to escort the convoy of the main force of the Sixteenth Army, which [Sixteenth] Army Commander Imamura had been concerned about, was increased from the eight destroyers of the 5th Destroyer Squadron ([consisting of] the 5th and the 22d Destroyer Division) to fifteen destroyers.

\section{3. [Army Commander Imamura's] Orders to the 48th Division, the Sakaguchi Detachment, and the Main Force of the Army}

After completing the arrangements with the Third Fleet, the Third Air Force, and the Eleventh Air Fleet on 23 January, [Sixteenth] Army Commander Imamura, in Manila on the next day, the 24th, gave the 48th Division the orders regarding the Java operations and returned to Taiwan on the same day. ${ }^{(32)}$ On the next day, the 25th, in Gaoxiong, Army Commander [Imamura] wired the Sakaguchi Detachment the order regarding [the operation to] seize Banjarmasin. ${ }^{(22)}$ On the day after the next day, the 27th, the leadership of the [Sixteenth] Army made arrangements about the Java operation with the commander of the 5th Destroyer Squadron in Gaoxiong. ${ }^{(120)}$ After completing these arrangements, [Sixteenth] Army Com- 
mander Imamura passed down his order regarding the Java operation to the main force of the army ([consisting of] the 2d Division, the Shōji Detachment, and others) in Gaoxiong on 30 January. ${ }^{(31)}$ Then the army commander gave instructions about the assembly and embarkation of the main force of the army and flew from Gaoxiong to Saigon on 3 February, ${ }^{(32)}$ which was the day before the date, the 4th, when the 38th Division was to start leaving Cam Ranh Bay for the Bangka and Palembang operations (in the renewed schedule set at the Manila Conference). On the 4 th, the following day in Manila, the 48th Division commander made arrangements for the Java operation with the 4th Destroyer Squadron commander, who had sailed in from Balikpapan. ${ }^{(119)}$

\section{[Army Commander Imamura's] Orders to the 48th Division}

(See Illustration No. 21)

As previously mentioned, the army commander had given his orders to the 48th Division on 24 January. In the afternoon two days before this (the 22d) in Manila, the [48th] Division Commander Lieutenant General Tsuchihashi and his staff and commanding officers had presented themselves before Army Commander [Imamura.] [Commander Imamura] gave instructions and invited the commanding officers of the division in the evening, where he thanked them for their service in the invasion of the Philippines over dinner, and requested them to put up a good fight in the Java operation. ${ }^{(32)}$ As previously described, Chief of Staff Kawagoe and Staff Officer Akatsuka [of the 48th Division] had flown to Davao on the previous day (the 23d) to make arrangements about [the operation to] capture Bali with the Eleventh Air Fleet, and they had returned on that day (the 24th). ${ }^{\left({ }^{0}\right)}$ Staff Officer Akatsuka had previously (on 8 January) reported to the [Sixteenth] Army command post in Saigon by order of Division Commander Tsuchihashi, but, due to the circumstances at that time, he had returned with no particular instructions given. ${ }^{\left({ }^{(0)}\right.}$

The order of the Sixteenth Army passed down on the 24th was roughly as follows: ${ }^{(31)}$

1. The transfer of command of the units currently in the Philippines and to be brought under the control of the 48th Division shall take effect at the time of their departure from the ports in the Philippines, and for the others at the time of their arrival at ports in the Philippines. However, the division commander was given authority to give the necessary commands concerning preparations for operations to the former before the specified time.

2. [The 48th Division shall] embark at Lingayen during the period from 1 to 7 February and leave the gulf about 8 February to advance to the anchorage at Jolo (Pata).

3. With the aim of advancing a naval air base, the division shall have an element ([consisting of] about one infantry battalion and one mountain artillery section as its core) capture the Bali airfield in conjunction with the Navy no later than day I-2, and swiftly make it ready together with the Navy air base ground crew.

4. The division shall come ashore in the areas south and north of Kragan before dawn on day I, and have part of its force promptly secure the crossing point of the Solo River and the oil resources in Cepu.

About the same time, the main force of the army shall land in western Java.

Day I is tentatively set on 23 February, and the exact date shall be announced later. Even if day I should be delayed, [the division] shall leave Lingayen more or less as scheduled, stand by in Jolo, and decide the time for leaving Jolo so that it shall be able to land in or near Kragan before dawn on day I. 
5. Next, while destroying the enemy, the division shall promptly seize Surabaya, and at the same time when a good opportunity arises, have a powerful element [of the division] dash toward Cilacap to block the enemy's retreat. After [successfully] seizing Surabaya, [the division] shall promptly set up a landing base there.

6. After that, [the division] shall act in concert with the main force of the army and mop up [the enemy] in eastern Java. During the action, it shall make efforts to prevent the destruction of the existing resources and to secure airfields.

\section{The Arrangements of the 48th Division with the 4th Destroyer Squadron}

The 4th Destroyer Squadron (under the command of R. Adm. Nishimura Shōji) originally consisted of its flagship the Naka and the $2 \mathrm{~d}$, the 4th, the 9th, and the 24th Destroyer Division (each of which was made up of four destroyers). When the commander escorted the Sakaguchi Detachment and was engaged in the Balikpapan landing operation on 24 January by leading the Naka, the 24th Destroyer Division, the 9th Destroyer Division (minus the Yamagumo), the 2d Destroyer Division (minus the Murasame) as the 1st Escort Unit, he received an order from the Dutch East Indies Unit on 29 January, and left Balikpapan on the 30th with the Naka and the $2 \mathrm{~d}$ Destroyer Division (with three destroyers) to hurry to Manila. ${ }^{(119)}$ The 9th Destroyer Division and two destroyers of the 24th Destroyer Division would rejoin his formation at Jolo after supporting the seizure of Makassar. ${ }^{(119)}$ During this [operation], the other two destroyers of the 24th Destroyer Division had been transferred to the main unit of the Dutch East Indies Unit, ${ }^{(119)}$ while the 4th Destroyer Division had remained part of the main force of the Southern Task Force. ${ }^{(119)}$ As soon as Rear Admiral Nishimura arrived in Manila, 48th Division Commander Tsuchihashi immediately made arrangements with him (on 4 February), which were in outline as follows: ${ }^{(119)}$

\section{Summary of the Arrangements Between the 48th Division and the 4th Destroyer Squadron}

1. Outline of action:

[The division] shall leave Lingayen Gulf on 8 February, arrive in Jolo on 12 or 13 February, from where it shall depart on day I - 7, and enter the anchorage in Kragan on the night of day I - 1.

2. Tasks [to be discharged] at the assembly points:

7 February: arrangement of signal communications between the ships' captains at Lingayen Gulf

14 February: arrangements between the escort unit, the transport convoy and the ships' captains in Jolo.

3. Outline of the transport from Lingayen Gulf to Jolo: (omitted by the author)

4. Distribution of the convoy:

1st Section [consisting of] six ships: (1) the Yamagiku-maru, (2) the Kenkon-maru, (3) the Haguemaru, (4) the Nankō-maru, (5) the Aden-maru (with Regimental Commander Imai on board), and (6) the Kōnan-maru.

2d Section [consisting of] six ships: (21) the Johore-maru, (22) the Takaoka-maru, (23) the Hollandmaru, (24) the Hokkō-maru, (25) the Kyokusei-maru, and (26) the Taiei-maru [Daiei-maru].

3d Section [consisting of] six ships: (31) the Kenzan-maru, (32) the Himalaya-maru, (33) the Havremaru, (34) the Arizona-maru (with Division Commander Tsuchihashi on board), (35) the Anzan-maru, and (36) the Chōkō-maru.

4th Section [consisting of] six ships: (41) the Nisshu-maru [Nichihide-maru], (42) the Biyō-maru, (43) the Italy-maru, (44) the Asaka-maru, (45) the Kashu-maru, and (46) the Yoneyama-maru. 
5th Section [consisting of] six ships: (51) the Hakuroku-maru [Hakushika-maru], (52) the Teiyo-maru (with Infantry Group Commander Abe on board), (53) the Hamburg-maru, (54) the Denmarkmaru, (55) the Arabia-maru, and (56) the Tokushima-maru.

6th Section [consisting of] six ships: (61) the Miyadono-maru, (62) the Jinsan-maru [Jinzan-maru], (63) the Wales-maru, (64) the Suez-maru, (65) the Tamon-maru, and (66) the Yasukawa-maru.

7th Section [consisting of] three ships: (71) the Satsuma-maru, (72) the Minryō-maru, and (73) the Hozugawa-maru.

Other than the above: (two ships) the Sagami-maru and the Sasako-maru.

Total (excluding the two ships above): thirty-nine ships

Note: The Sagami-maru and the Sasako-maru carrying the units for the surprise attack on Bali shall join the main convoy at the Makassar Strait and sail along with it. The number before the name of each ship indicates her number in each section [of the convoy].

5. Landing points and distribution of forces:

The Imai Unit ([consisting of] two infantry battalions and one mountain artillery battalion, under the command of Col. Imai Kazufumi, commander of the 1st Taiwan Infantry Regiment, as its core) shall come ashore in sector (B) of Kragan. After landing, it shall advance to Sedan and Mazeran." (Note by the author: "Sedan" seems to be in the vicinity of the Serang River. "Mazeran" is taken as Magelang. Whether the word "advance" above meant an advance in a strict sense or not is unclear.) [Editor's note: Sedan is actually located about ten kilometers south-southwest of Kragan at the foot of Mount Lasem. "Mazeran" could not be identified. It is unlikely to be Magelang, which is more than two hundred kilometers to the southwest in central Java and was not reached by the Japanese forces until a week after the landings. The author shows his doubts about the identification with Magelang by his remark on "advance in a strict sense." However, "Mazeran" might be a corruption of "Semarang."]

The Kitamura Unit (the 48th Reconnaissance Regiment under the command of Lt. Col. Kitamura Kurō, commander of the regiment) shall [also] come ashore in sector (B) of Kragan. After landing, it shall advance to Bojonegoro.

The Abe Unit ([consisting of] three infantry battalions, two tank squadrons, and two mountain artillery battalions, under the command of Maj. Gen. Abe Kōichi, commander of the 48th Infantry Group, as its core) shall come ashore in sector (A) of Kragan. After landing, it shall advance into Ponjōru (Bulūjaku) (note by the author: these seem to be located several kilometers south of Kragan). [Editor's note: "Ponjōru" is almost certainly "Bancar," and "Bulūjaku" is a corruption of "Bulujowo." Both are located on the coast southeast of Kragan. See also Illustration No. 63, p. 556.]

The Tanaka Unit ([consisting of] two infantry battalions and one mountain artillery battalion, under the command of Col. Tanaka Tōru, commander of the 2d Taiwan Infantry Regiment, as its core) shall [also] come ashore in sector (A) of Kragan. After landing, it shall advance to Cepu.

6. Landing date and time, and the schedule:

(1) Day I, the starting date of the landings, is [tentatively] scheduled for day $x+77$ (23 February); [the division] shall leave Jolo on day I - 7, anchor at 0100 on day I, and start the landing [operation] at 0200 on the same day. However, if mines are found at the anchorage and need to be removed, it may wait for the completion [of the minesweeping] before entering the anchorage.

(2) The landing shall be completed in five days. For the disembarkation of munitions, the anchorage shall be changed to the area east of Cape Bendo.

7. Outline of the escort:

(1) Sea route plan: as shown on separate sheet (omitted by the author).

(2) Navigation speed: eight knots normal speed.

(3) Direct escort shall be provided. 


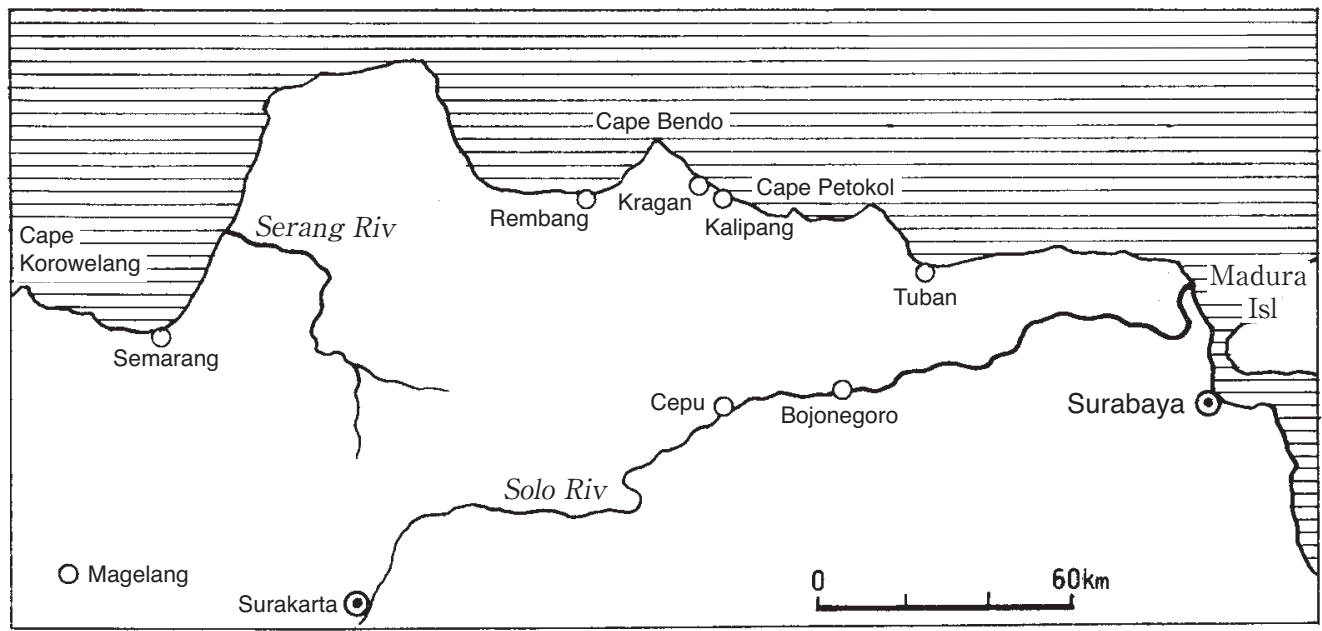

Illustration No. 21-The Area of the 48th Division

Forces [to be employed for the escort] are:

One cruiser and four destroyers [for the route] between Lingayen and Jolo, however, three submarine chasers and one minelayer shall be added as far as the Apo [Reef] Channel. And one cruiser, nine destroyers, two minesweepers, six submarine chasers and one minelayer shall be employed for [the route] between Jolo and Kragan.

Note by the author: At the time of this arrangement (4 February), the 2d Destroyer Division, (three destroyers of) the 9th Destroyer Division, one section (two destroyers) of the 24th Destroyer Division and two minesweepers of the $2 \mathrm{~d}$ Base Force were to be employed as the destroyers and the minesweepers in the escort force. However, when the operation was actually conducted, one destroyer of the 24th Destroyer Division was removed and two minesweepers of the $2 \mathrm{~d}$ Base Force were added instead.

(4) Formation to be adopted when sailing during an alert: (omitted by the author)

8. Entry into the anchorage, landing under combat conditions, and cover:

(1) The commander of the escort [unit] shall give the command to "get into formation to enter the anchorage" at an appropriate moment before entering the anchorage. The formation is as shown in the separate drawing (omitted by the author).

(2) Anchoring formation is as shown in the separate drawing (omitted by the author).

(3) Although the landing shall be made as a surprise landing in principle, it shall be expected that it may be carried out by assault.

(4) Covering fire at the landing front by the Navy warships shall [only] be provided upon request of the division commander and the wing commanders. However, naval bombardments of the area west of Cape Bendo (inclusive) and the area east of Cape Petokol (inclusive) shall be provided at the discretion of the naval commander.

(5) Guarding in [and from] the sky shall be assigned to the Third Fleet and the Eleventh Air Fleet.

9. Actions of the transport ships after disembarkation:

(1) After completing the disembarkation, the transport ships shall return to the designated ports under direct or indirect escort of the escort units.

(2) If possible, the escort unit may make a feint by leading transport ships on their return to the vicinity of the mouth of the Kuto River (located eight nautical miles west of Cape Korowelang). [Editor's note: About thirty kilometers west of Semarang.]

10. Others: 
(1) By the time of departure from Jolo, the naval air unit shall prepare aerial photographs of the vicinity of the landing points and send them to the 48th Division.

(2) The actions of the commanding officers after landing The 48th Division commander shall land in area (A) in the $3 \mathrm{~d}$ landing on day I, and position himself in Kalipang (three kilometers southeast of Kragan).

The commander of the 1st Escort Unit shall be on board the Naka, and timely take action near the anchorage [when necessary].

(3) A seaplane base shall be set up near the landing points by the seaplane tenders Chitose and Mizuho of the Third Fleet.

(4) With the aim of removing [obstacles] from the Surabaya Strait [and securing the waterway there], the stronghold on Madura Island shall be captured as swiftly as possible after the seizure of Surabaya. For that purpose, the landing forces shall [start] from the vicinity of Kragan or Tuban [and] go ashore on Madura Island by maneuvering along the coast using boats. The minesweeping and cover necessary for this operation shall be separately arranged with the naval units concerned.

(5) Signal communication and exchange of information (omitted by the author).

\section{[Army Commander Imamura's] Order to the Sakaguchi Detachment to Seize Banjarmasin}

As already described, [Sixteenth] Army Commander Imamura, who ordered the 48th Division to capture eastern Java after the Manila Conference and returned to the army headquarters in Gaoxiong on the 24th, simply gave the Sakaguchi Detachment the order to seize Banjarmasin by 10 February on the 25th, when the Southern Army and the [Army Department of] IGHQ were in the middle of exchanging telegrams, both of them feeling frustrated and worried the whole time. The reasons have already been touched upon, but in detail they were as follows:

1. The Southern Army thought that the Sakaguchi Detachment was in a difficult situation because, firstly, the detachment, which started [the operation to] land in Balikpapan before daybreak on the day before (the 24th), was reported to have four transport ships (the Tsuruga-maru, the Kuretake-maru, the Sumanoura-maru and the Tatsugami-maru) sunk, and two transport ships (the Kumagawa-maru and the Asahisan-maru) and one patrol boat seriously damaged by several destroyers of the allied forces which had devastated the anchorage in the middle [of the operation]; and secondly, [the Southern Army] judged it impossible for the Sakaguchi Detachment to be ready to seize Banjarmasin by land and that it would be difficult to seize the place overland before the Java landing [operation] due to the terrain and the distance. [The Southern Army] also judged it difficult to seize [the place] even by sea before the Java landing [operation], because of the previously described situation at sea, and the fact that the cooperation of the Navy could not be expected. ${ }^{(23)}$

2. In contrast to this, the Sixteenth Army and the Sakaguchi Detachment had no doubts at all because they had been ordered to seize Banjarmasin by the Southern Army's order of 20 November of the previous year. ${ }^{(40,87)}$ The detachment's resourceful staff officer, Lieutenant Colonel Yano, had already worked out a plan to carry out surprise attacks both overland and by landing craft, even if the Navy did provide an escort. ${ }^{(87)}$ On receiving a telegram of the Sixteenth Army from Manila (to the effect that cooperation from Navy warships could not be expected), the Sakaguchi Detachment immediately informed the Sixteenth Army that it definitely reckoned on seizing [Banjarmasin] both by land and by landing craft before 10 February; moreover, that the loss [sustained due to] the sinking of the transport ships was no more than thirty-nine men, and that 
the operation to seize Balikpapan had progressed [so] favorably [that] its headquarters had [already] entered the city before dawn on the $25 \mathrm{th} .{ }^{\left({ }^{87}\right)}$ Accordingly, on the night of the 25 th as already described, the Sixteenth Army gave the Sakaguchi Detachment the order to seize Banjarmasin and on the morning of the next day, the 26th, wired a copy of the order to the [Army Department] of IGHQ and the Southern Army. ${ }^{(22)}$ Both the Sixteenth Army and the Sakaguchi Detachment never even dreamed that until the 28th, IGHQ and the Southern Army would have a heated argument [about Banjarmasin]. ${ }^{(40,87)}$

\section{The Arrangements of the Main Force of the Army with the 5th Destroyer Squadron (See Illustration No. 22)}

Two days later, on the 27th, the Sixteenth Army, along with the 2d Division and the Shöji Detachment, made arrangements with the 5th Destroyer Squadron in Gaoxiong for the western Java invasion operation. ${ }^{(120)}$ The situation at that time was as follows:

Eastern Detachment: left Davao on that day (the 27th), with the intention to land in Ambon on 31 January. ${ }^{(119)}$

Sakaguchi Detachment: was preparing for the [operation to] seize Banjarmasin after having landed in Balikpapan on the 24th and completed mopping up [the enemy] on the 26th. ${ }^{(88)}$

38th Division: having arrived in Cam Ranh on the 24th, it was preparing for the Bangka and Palembang operations and was scheduled to leave port on 4 February. ${ }^{(66)}$

48th Division: was in Manila waiting for the arrival of the 4th Destroyer Squadron commander from Balikpapan following the army's order of the 24th. ${ }^{(36)}$

2d Division: had been arriving in Gaoxiong one after another from the 21st onward, and had completed its arrival the previous day, the 26th. ${ }^{(53)}$

Shōji Detachment: its convoy was scheduled to leave Hong Kong on the 29th and arrive in Gaoxiong on the 31st. The detachment commander had flown in ahead on the 25th. ${ }^{(75)}$

5th Destroyer Squadron: its main force had arrived in Magong from Singora on 16 January and the remainder on the 18 th. ${ }^{(120)}$

1st Base Unit: had landed in Kendari with the support of the 5th Cruiser Division and the $2 \mathrm{~d}$ Destroyer Squadron on the same day as the Sakaguchi Detachment [in Balikpapan] (24 January), and was preparing for the operation to seize Makassar. ${ }^{(120)}$

The contents of the arrangements were roughly as follows:

A Summary of the Arrangements Between the Commanders of the Sixteenth Army, the 2d Division, the Shōji Detachment, and the 5th Destroyer Squadron for the Western Java Landing Operations

1. Assembly point(s) and tasks [to be discharged] there:

(1) The transport ships shall arrive in Gaoxiong one after another by 5 February and then gather in Cam Ranh Bay by 10 February according to the following schedule:

Eleven transport ships (under the escort of the Nagatsuki and the Minazuki) shall leave Gaoxiong at 1000 on 1 February. 
Seventeen transport ships (under the escort of the Harukaze and the Hatakaze) shall leave Gaoxiong at 1000 on 3 February.

Eighteen transport ships (under the escort of the Fumizuki and the Satsuki) shall leave Gaoxiong at 1000 on 5 February.

Eight transport ships (under the escort of the Asakaze and the Matsukaze) shall leave Gaoxiong at 1000 on 6 February.

Note by the author: the names within parentheses are of the destroyers belonging to the 5 th Destroyer Squadron.

(2) Tasks [to be discharged] at Cam Ranh Bay

11 February: Arrangements between the landing units within each sector, those between the escort units within each area, those between the ship captains, and those for signal communications

12 February: Training of the army itself

2. Distribution of the Convoy:

1st Convoy: [consisting of] eight ships; the Kōyo-maru (with Infantry Group Commander Nasu [on board]), the Nichiwa-maru, the Hokumei-maru, the Shinshi-maru, the Colombiamaru, the Atlas-maru, the Ryūnan-maru, and the Genkai-maru.

2d Convoy: [consisting of] seven ships; the Akitsu-maru, the Momoyama-maru, the Pacific-maru, the Kizan-maru, the Reiyō-maru (with the commander of the 4th Infantry Regiment, Fukushima, [on board]), the Tsuyama-maru, and the Sydney-maru.

3d Convoy: [consisting of] thirty-two ships

1st Section: [consisting of] six ships; the Tatsuno-maru, the Haridono-maru [Somedono-maru?], the Takesato-maru [Taketoyo-maru?], the Heian-maru, the Akagisan-maru, and the Hōrai-maru.

2d Section: [consisting of] five ships; the Atsuta-maru (with Division Commander Maruyama [on board]), the Ryūjō-maru (with Army Commander Imamura [on board]), the Fushimi-maru, the Shinanogawa-maru, and the Ayatosan-maru.

3d Section: [consisting of] six ships; the Taizan-maru, the Dainichi-maru, the Hōeizan-maru, the Tōsei-maru, the Taihei-maru, and the Genoa-maru.

4th Section: [consisting of] five ships; the Brazil-maru, the Toffuku-maru, the Toyooka-maru, the Mizuho-maru, and the Sakura-maru.

5th Section: [consisting of] five ships; the Maebashi-maru, the Tokiwa-maru, the Tempei-maru, the Miikesan-maru, and one munitions ship.

6th Section: [consisting of] five ships; the Erii-maru, the Zuishō-maru, the Tōhō-maru [B], the Gifu-maru, and one munitions ship.

4th Convoy: [consisting of] seven ships; the Daigen-maru No. 3 [Taigen-maru?], the Naples-maru, the Calcutta-maru, the Glasgow-maru, the Suwa-maru (with Detachment Commander Shōji [on board]), the Kōzan-maru, and the Yamazuki-maru [Yamatsuki-maru].

Fifty-four ships in total.

3. Landing points and distribution of forces:

Area No. 1

Sector A (south of Merak): the unit [consisting of] two infantry battalions and reconnaissance regiment as its core, under the command of Maj. Gen. Nasu Yumio, the 2d Infantry Group commander, which shall be [transported] in the first convoy (in eight ships).

Sector B (north of Merak): the unit [consisting of] two infantry battalions as its core, under the command of Col. Fukushima Kyūsaku, the 4th Infantry Regiment commander, which shall be [transported] in the second convoy (in seven ships).

Sector C (western part of Bantam Bay): the main force of the $2 \mathrm{~d}$ Division and that of the unit under the direct control of the Sixteenth Army, which shall be [transported] in the 
third convoy (in thirty-two ships). The transport shall be under the command of Col. Satō Hanshichi, the 29th Infantry Regiment commander.

Area No. 2

The Patrol coast: the unit [consisting of] two infantry battalions as its core, under the command of Col. Shōji Toshishige, the 230th Infantry Regiment commander, which shall be [transported] in the fourth convoy (in seven ships).

4. Date and time of the landings and the schedule:

(1) Day H, the starting date of the landings, is [tentatively] scheduled for day $x+75$ (21 February). It shall be fixed by 1200 on day $\mathrm{H}-9$.

(2) Departure from Cam Ranh Bay shall be at 1000 on day $\mathrm{H}-8$.

(3) Scheduled time for anchoring is around 0000 on day $\mathrm{H}$ (for every area).

(4) Scheduled time to start landing is around 0200 on the same day ([landings] shall be launched as soon as [the units] are ready).

(5) Landing schedule Sectors A and B (Merak): about five days.

Sector C (Bantam Bay): about seven days.

Area No. 2 (Patrol): about five days.

(6) Depending on circumstances, on day $\mathrm{H}+2$ and onwards, the units supposed to be put ashore in Area No. 2 may be taken to Area No. 1 for debarkation. The implementation shall be discussed and decided by the commanders of the Sixteenth Army and the 5th Destroyer Squadron.

Note by the author: the 5th Destroyer Squadron considered it dangerous to carry out landing [operations] in Patrol.

5. Outline of escort:

(1) Scheduled route: as shown in the separate drawing (omitted by the author)

(2) Navigation speed: eight knots normal speed

(3) Direct escort shall be provided. Forces [to be employed for the escort] consist of the Natori, the Yura, sixteen destroyers, five minesweepers, and another ship, of which the Yura, six destroyers, and five minesweepers shall join later.

Note by the author: As for destroyers, the 5 th and the $22 \mathrm{~d}$ Destroyer Division of the 5th Destroyer Squadron participated from the beginning, the 6th Destroyer Division of the 1st Destroyer Squadron joined at Cam Ranh Bay, and the 11th and the 12th Destroyer Division of the 3d Destroyer Squadron joined from Anambas.

(4) Formation to be adopted when sailing during an alert: as shown in the separate drawing (omitted by the author).

6. Entry into the anchorage, landing under combat conditions, and cover:

(1) The commander of escort [unit] for [each landing sector] shall give the command to "get into formation to enter the anchorage" at an appropriate moment before entering the anchorage. The formation is as shown in the separate drawing (omitted by the author).

(2) Anchoring formation is as shown in the separate drawing (omitted by the author).

(3) Although the landings shall be made as surprise landings in principle, they shall be carried out by assault depending upon the situation.

(4) In Area No. 1, an element of the 1st landing unit shall raid and seize Merak Island and Panjang Island.

(5) Covering fire at the landing front by the Navy warships shall [only] be provided upon request of the landing unit (detachment) commander of each landing sector.

7. Actions of the transport ships after debarkation and the succeeding transport ships:

(1) After completing the disembarkation, the transport ships shall return appropriately. In principle indirect escort shall be provided on the way back; however, depending on the move- 
ments of the enemy, they might be escorted as far as the vicinity of the Karimata Strait (note by the author: about 500 kilometers northwest of Batavia).

(2) The ships of the second transport ([consisting of] about twenty-five ships) for Area No.1 shall leave Cam Ranh Bay around day $\mathrm{H}+14$, and enter [the anchorage of] Bantam (or Batavia) for debarkation around day $\mathrm{H}+22$ under the escort of the Navy.

8. Others:

(1) The actions of the commanding officers after landing

The Sixteenth Army commander: shall go ashore in Sector $\mathrm{C}$ before dawn on day $\mathrm{H}$, and advance his command post to Serdang [editor's note: "Sedan" in the Japanese text here is probably a corruption of "Serdang"].

The $2 \mathrm{~d}$ Division commander: shall land along with the units of the second landing on day $\mathrm{H}$, and advance toward Serdang first.

The Shōji Detachment commander: shall land in or near Patrol along with the units of the second landing on day $\mathrm{H}$, and thereafter advance along the Batavia Highway.

The 5th Destroyer Squadron commander: shall directly escort the transport convoy. After arriving in Sector $C$, he shall generally positioned himself on the waters outward of the sector and adopt an appropriate guarding posture.

(2) Signal communications (omitted by the author)

(3) Exchange of information (omitted by the author)

In [making] this arrangement, the Navy again opposed [the idea of] separately putting the Shōji Detachment ashore in Patrol out of concern about the escort. ${ }^{(44,138)}$ However, as this [plan] had become fixed since the studies conducted at [the Army Department of] IGHQ before the opening of hostilities, the Sixteenth Army did not listen to the Navy's [advice]. ${ }^{(4)}$ The Navy decided to leave fate to Heaven and agreed to it. ${ }^{(138)}$ When [making] this arrangement, the Navy side asked, "Which ship are you going to take, Commander?" (138) to which Army Com-

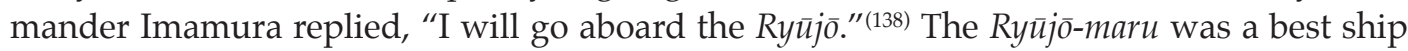
along with the Akitsu-maru. It was able to carry thirty to forty large-sized motorized [landing] craft and more small-sized ones; it was also equipped with a deck to carry and launch aircraft, and had a unique appearance. ${ }^{(94)}$ The Navy tentatively suggested with a laugh: "We think it better for you, Commander, to go on board the poorest ship because [the Ryūjō-maru] will inevitably come under attack from the enemy once you enter the Java Sea." However, [the Navy] left it at that, presuming that he had intentionally chosen [it] for its convenience of com-

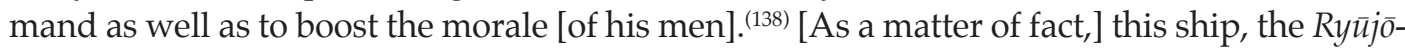
maru, was torpedoed in Bantam Bay, and the army commander ended up swimming in the sea which was covered with fuel oil; however, this indeed boosted the morale of the army.

\section{[Army Commander Imamura's] Orders to the 2d Division and the Shōji Detachment}

When Army Commander Imamura had given the order on the 25th to the Sakaguchi Detachment to seize Banjarmasin, he had also ordered the main force of the army to advance its assembly point to Cam Ranh Bay, and on the 30th, as soon as the above-mentioned arrangements with Rear Admiral Hara, the 3d Escort Unit commander (and the 5th Destroyer Squadron commander) had been completed on the 27th, he gave the main force of the army the following order concerning the Java invasion operation: ${ }^{(31)}$ 


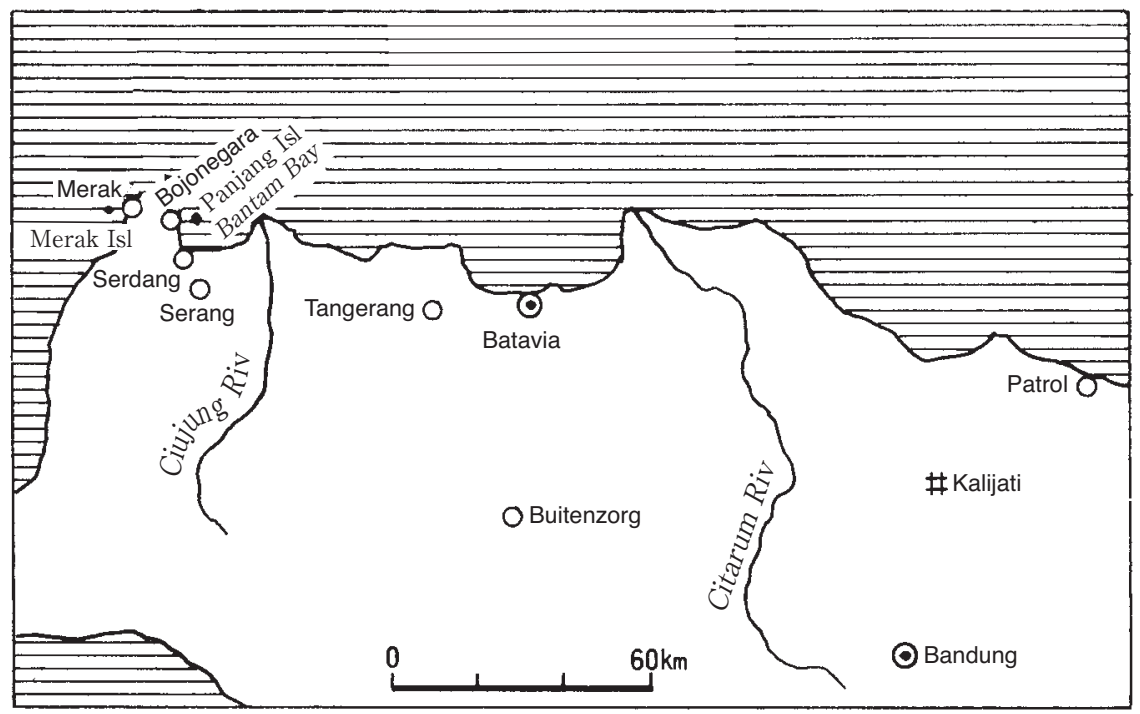

Illustration No. 22-The Area of the Main Force of the Army

\section{Sixteenth Army Order}

1. The army, in conjunction with the 5th Destroyer Squadron, shall have the units of the first transport ([consisting of] the 2d Division (minus one artillery battalion) and the Shōji Detachment as its core) leave Cam Ranh Bay on day H - 6, go ashore on western Java before dawn on day H, and destroy the enemy to promptly seize Batavia first and then Bandung.

Day $\mathrm{H}$ indicates the first day of landing and the date shall be given later by an order.

About the same time, the 48th Division shall land in eastern Java, and promptly seize Surabaya first. The Third Air Force and the air units under the command of the First Southern Expeditionary Fleet shall closely and directly cooperate in the operations of the main force of the army. The main force of the First Southern Expeditionary Fleet shall be charged with the indirect escort for the main force of the army.

2. The $2 \mathrm{~d}$ Division shall promptly seize Batavia first in the following manner:

(1) Part of the army shall land in or near Merak and the main force near Bojonegara before dawn on Day H, and they shall promptly advance to the Ciujung River line first.

(2) A powerful element of the army shall rush to Buitenzorg [Bogor] in order to divide the enemy into those in the Batavia area and those in the Bandung area, to cut off their escape and reinforcement routes, and to secure a foothold as far forward as possible for the army's subsequent seizure of Bandung.

(3) The main force of the division shall advance through the areas along the road between Serang - Tangerang - Batavia towards Batavia and the area to its south, and promptly seize them.

(4) [The division] shall give the air units as much support as possible in making the airfields ready for use and in transporting fuel and ammunition.

3. The Shōji Detachment shall land in or near Patrol before dawn on day H, promptly seize and secure the Kalijati airfield, and also gain control of the crossing point over the Citarum River in order to divide the enemy in the Bandung and the Batavia areas, and to cut off their escape and reinforcement routes. Depending on the situation, the detachment shall have one element prepare for participating in seizing Batavia. The air units shall be provided with as much support as possible in making the airfields ready for use; moreover, the detachment shall also be responsible for arranging their quarters, supplies, guarding, etc. 


\section{The Army's Plan and Conduct of the Operation}

The enemy position on Java as far as it was known to IGHQ before the opening of hostilities has already been described. Since then, the Sakaguchi Detachment, which had landed in Tarakan on 11 January, had reported in mid-January, as information obtained from prisoners, the following deployment of the Dutch East Indies Army: ${ }^{(24)}$

In Java, one division had been deployed in each of the eastern and western parts, and later an additional division was established in central Java. The army commander was Lieutenant General Ter Poorten, who was positioned in Bandung. In eastern Java, a unit [consisting] of three infantry battalions as its core was stationed in Malang and another [consisting] of one infantry battalion as its core in Surabaya. In central Java, a unit [consisting] of three infantry battalions as its core was stationed in Magelang, and one [consisting] of one infantry battalion as its core in Surakarta and Cilacap. In western Java, a unit [consisting] of three infantry battalions as its core was stationed in Bandung and another [consisting] of three infantry battalions as its core in Batavia.

Since before the opening of hostilities the Government-General in Batavia had reportedly been moving to Bandung one [department] after another. It was only natural to expect that the allied forces would put up strong resistance by taking advantage of the pillbox positions set on the steep mountainsides surrounding the four fronts of Bandung, turning the Bandung stronghold into a bastion. However, it was unlikely that from the outset they would abandon Batavia, which was the capital and the center of politics, the economy, communications, transport, etc., and which, on top of that, had the good harbor of Tanjung Priok.

What made it even more unlikely that the allied forces would abandon Batavia from the outset, but on the contrary might be expected to launch aggressive counterattacks near Tangerang, was the consideration that reportedly there were a considerable number of pillbox positions around the perimeter of Batavia, especially in the west and northwest of Tangerang, and also waterside obstacles and defense facilities all along the north coast, and that according to successive reports after the opening of hostilities, the Dutch East Indies Army had been further enlisting troops, that the British Indian Army in Malaya was being reinforced and so was the Australian Army in the Dutch East Indies, that the forces repelled from the Philippines and Malaya had been gathering in Java, and that the reinforcements intended for Malaya had been redirected to Java. As previously described, when Army Commander Imamura advanced to Saigon in early January, he revised the operation plan which had been drawn up in Tokyo in early mid-December. Even in late January the plan remained unchanged. If anything, he had become rather more cautious than in early January. [After all,] the Sakaguchi Detachment had sustained the loss of four transport ships and serious damage to two ships in Balikpapan, which was merely an advance base of the allied forces. The Southern Army, on the other hand, insisted that the departure of the convoy for the Java invasion should be synchronized with the occupation of air bases in Sumatra, Borneo and Celebes, and that the air operation should be launched at the same time as the departure of the convoy. However, only a couple of destroyers of the U.S., British and Dutch fleets had been sunk other than the Prince of Wales and the Repulse. Although the number of the destroyers to escort the large convoy of fifty-four ships was increased from eight to sixteen (in reality, fifteen) at his request, he was worried about how many ships of the convoy would be able to arrive in- 
tact. After due consideration of these matters, the army commander set the initial mission of the $2 \mathrm{~d}$ Division. His idea was that [the division] should first seize Batavia, and then the Bandung stronghold, but to [decide later] how to carry it out depending on the subsequent situation. ${ }^{(36)}$

Army Commander Imamura was the most concerned about the Shōji Detachment. First of all, for various reasons, in particular those related to the distribution of forces among the Shōji Detachment, the main force of the 38th Division, and the Eastern Detachment, he had been forced to limit the strength of the Shōji Detachment to only two battalions as its core. Secondly, both the [Navy] Dutch East Indies Unit and the 5th Destroyer Squadron objected to the landing point due to its riskiness. Thirdly, the Kalijati airfield, which the detachment was to seize, was also of great importance to the allied forces and, what is more, it was very close to the Bandung stronghold (in the vicinity of which the main division of the Dutch East Indies Army should be expected). Moreover, it was also close to Cilacap, where British and Australian reinforcements were expected to land. [The detachment] was definitely short of strength. [However,] Chief of Staff Okazaki set his eyes on Lt. Col. Ōno Takeo, commander of the $2 \mathrm{~d}$ Independent Antitank Gun Battalion, whose companies had been separately assigned to other corps in different areas. ${ }^{(36)}$ He right away assigned the latter to the Shōji Detachment, and put him in charge of the command at the landing point (note: the disembarkation of the detachment was scheduled to take five days), so that Detachment Commander Shojji would be able to rush toward Kalijati and the bridge over the Citarum River, free of worry about his rear. ${ }^{(36)}$ As the operations of the Shōji Detachment were not only highly risky but also closely and inseparably linked to the operations of the 2d Division, Army Commander Imamura decided to specially assign his Assistant Operations Staff Officer (Maj.) Yamashita Yutaka to the Shojji Detachment. ${ }^{(36)}$ Prior to this (when he attended the Manila Conference and assigned the 48th Division its mission), Army Commander Imamura had assigned Intelligence Staff Officer Maj. Kuriya Tsugunori, and Line-of-Communication Staff Officer Maj. Nishiura Setsuzō to the 48th Division. ${ }^{(36)}$

\section{The Situation of the $2 \mathrm{~d}$ Division}

The $2 \mathrm{~d}$ Division had left Ujina during the period from 15 to 23 January, and arrived in Gaoxiong from 21 to 26 January. After it had concluded arrangements with the 5th Destroyer Squadron on the 27th, and received the order of the army on the 30th, it left Gaoxiong for Cam Ranh Bay during the period from 1 to 6 February. We may illustrate the movements of the division from its time in the Japanese mainland onwards by citing the following records of the $3 \mathrm{~d}$ Battalion of the 4 th Infantry Regiment, which boarded the Tokiwa-maru: ${ }^{(60)}$

16 - 21 September 1941: Landing training of the 4th Infantry Regiment on the coast of Ishinomaki

9 October: Given the order of mobilization

16 October: The first day of the mobilization

29 October: Completion of the mobilization

4 November onwards: Joint training with transport ships near Matsushima

17 December: Arrival of the regiment at the barracks at the foot of Mt. Fuji

12 January 1942: Departure from Gotemba

13 January: Arrival in Hiroshima 
15 January: Embarkation of the main force of the regiment and lessons in the Indonesian language

18 January: Finished loading the Tokiwa-maru (with a mixed shipment of the main force of the $3 \mathrm{~d}$ Battalion, one transport platoon, half a sick horse depot, and one bridge building material platoon), and departure from Ujina to assemble in Shimonoseki

21 January at 1000: Departure from Shimonoseki for Magong (?). We were told that we would arrive around the 27th. We were also told that [the ship] would call at Magong (?) for a few days, and that it would take about two weeks to sail to the Dutch East Indies.

22 January: Naval aircraft came flying over twice; the course followed the line of the Goto Islands - the Dan'jo Archipelago - Magong.

26 January: Entry into the port of Magong

28 January: It was decided that we would "leave the current place at 0700 on the 31st and call at Gaoxiong." We were told that as a divisional reserve battalion, we would be in charge of the disembarkation of some two thousand and several hundred cases of military supplies at the time of landing.

29 January: Water filters were distributed.

30 January: It was decided that we would leave Magong the next morning and advance to Gaoxiong; the final landing place shall be decided in Gaoxiong.

31 January: Departure from Magong at 0700; arrival in the port of Gaoxiong at 1600

1 February: In order to receive the divisional orders, only the commander went ashore in Gaoxiong and learned the plan for the landing in Java.

2 February: We were told that the landing at the northwest tip of Java was scheduled for the $23 \mathrm{~d}$ of the month. We were also told that [due to the schedule], [the ship] would call at Cam Ranh Bay and depart from there on the 15th.

3 February: From today or tomorrow, bombing raids on Java and Australia are supposed to start. [The ship] came alongside the quay at Gaoxiong. The officers and men were sent ashore to bathe for the first time since Hiroshima. We should depart on the 5th.

4 February: An ordnance unit, an army signal unit, a tank unit, an independent engineer unit, an antiaircraft artillery unit, and others were additionally loaded onto the Tokiwa-maru.

5 February: Departure from Gaoxiong for Cam Ranh Bay at 1000 under direct escort of the Navy

From 15 January onwards, the officers and men of this battalion sailed for forty-five days on dangerous waters far beyond the equator, packed in the small space of a ship without bathing.

\section{Confusion at the Port of Gaoxiong}

What can be observed based on the above-related movements of the Tokiwa-maru is that on the basis of the Cam Ranh Agreement of 1 January, she and the other ships hastily left Shimonoseki; that according to the plan at that time she was supposed to head [straight] for Java with a stop at Magong only for a supply of coal and water, but that the Manila Agreement, which became officially effective on 28 January, gave five extra days to spare, so she changed her route from Magong to also call at Gaoxiong; but that there she ended up being crammed with many more fighting units.

As already mentioned, bringing forward the Java operation necessitated an increase in shipping tonnage of about 300,000 tons. But as the Southern Army understood the predicament of the [Army Department] of IGHQ, it requested an increase of only 150,000 tons. Because the [Army Department of] IGHQ did not even approve this increase of 150,000 tons, ${ }^{(24)}$ the Southern Army had to make do [with what it had] and drew up a plan for the period from 16 January onwards based on the following shipping volume:(24) 
First transport: $\quad 130,000$ tons for the 38th Division 210,000 tons for the 48th Division 220,000 tons for the main force of the army

Subtotal: 560,000 tons Second transport: 150,000 tons Third transport: 100,000 tons Total 810,000 tons

Because of the unexpected advance of the operation schedule, the movements and the cargoes of ships hurriedly coming from the Japanese mainland, Manchuria, Korea and China varied from ship to ship. Because the absolute number of ships was too small, and because they had to be loaded in a way to meet [the requirements] of the operation plan, some units had to disembark to be transported later and even units in the first transport had to be switched to other ships. The port of Gaoxiong was in chaos. [Chief] Shipping Officer Sendō of the Sixteenth Army described the situation at that time as follows: ${ }^{(44)}$

At the assembly point in Gaoxiong, I was swamped by a dizzying amount of all kinds of tasks: taking control of units unexpectedly arriving from all areas without notice, sorting them by area and arranging transportation for them, replenishing a huge number of ships with coal and water, the distribution of landing craft, loading war matériel, changing the ships of the units, and so on. In addition, the cramped wharf was so overflowing with departing, incoming and waiting ships that the anchorage was extended as far as the exposed open sea. Moreover, due to the [limited] tonnage, a considerable quantity of forces, equipment and materiel of the units in the first transport had to be left behind at the assembly point. It remains a painful memory of that time that instead of sympathizing with the feelings of those who were not able to join the glorious front line after having left for the war in high spirits, or imagining the feelings of the unit commanders who left while leaving behind even their weapons and matériel, which they regarded as indispensable for accomplishing their tasks, and the men in charge of this equipment, I steeled myself against taking pity in order to persuade [the commanders] that considering the characteristics of the operations of our army, they should be firmly determined to accomplish their tasks without regret, even if their forces were decimated on the sea.

Similar problems also occurred in Lingayen Gulf. No matter what, the Japanese were short of ships. According to the transportation plan sent to the 48th Division from the Southern Army ([to be precise,] the Saigon command post of the Shipping Transport Command) in mid-January, the 48th Division was divided into three transports:

(See the previously described plan of the Southern Army of 16 January.)

First transport: Division headquarters, two infantry regiments, two mountain artillery battalions, one engineer regiment, one bridge building material company, and one transport company.

Second transport: The other fighting units of the 48th Division, and the 4th Tank Regiment and the units of the 17th Field Heavy Artillery Regiment.

Third transport: The other units.

That is to say, it would take three months to complete all the transportation. ${ }^{\left({ }^{(0)}\right)}$ Chief of Staff Kawagoe [of the 48th Division] ordered his staff members: "Though we [calculated accom- 
modation] on the basis of seven people per 3.3 square meters in the Philippines invasion operation, try and make a plan this time on a basis of ten people [per 3.3 square-meters]."(80) The plan was completed the next morning. When he reported it to Division Commander Tsuchihashi, the latter ordered: "Re-plan it so that all the fighting units will be transported in the first transport." ${ }^{(80)}$ Although Chief of Staff Kawagoe and his staff reviewed it for three days and nights, ${ }^{\left({ }^{(0)}\right)}$ the tonnage was still insufficient. Calculation on a basis of fifteen people per 3.3 square meters did not work, either. Lying in his bed, feeling that he had exhausted every possible means, Chief of Staff Kawagoe looked at the entire ship allocation plan of the Southern Army. ${ }^{(80)}$ By chance he noticed that about fifteen ships were to call at Gaoxiong from Dalian, Dagu and Shanghai with bridge building material companies, field hospitals and others on board. He immediately roused all staff members from their beds, and ordered them to work out [a new calculation] on the assumption that these ships would be emptied in Gaoxiong and moved to Lingayen Gulf. The next morning, it turned out that the rear units of the division, the 4th Tank Regiment, and the units of the 17th Field Heavy Artillery Regiment would be able to go on board, not to mention the fighting units of the division. Maj. Tanabe Masaki, chief staff officer for the line of communication with the rear, was immediately sent to the branch office of the Shipping Transport Command to make arrangements to cancel the assignment of the previously mentioned units from the Kwantung Army and the China Expeditionary Army to the division, disembark them at Gaoxiong, and have the empty ships hurry from Gaoxiong to Lingayen. This proposal was approved by the Southern Army (the command post of the Shipping Transport Command), which enabled Division Commander Tsuchihashi to go ashore in Java with all the fighting units he had in the Philippines. On the other hand, however, the units forced to disembark at Gaoxiong were not able to participate in the Java operation after all and cursed their luck. ${ }^{\left({ }^{(0)}\right.}$

Note: The required tonnage of "three tons per person and nine tons per horse" was the standard in the China operations for military transport ships (cargo ships), and in principle, freight belonging to the units was not specifically included in the count and loaded in vacant spaces. Three tons per person was equivalent to three people per 3.3 square meters. As the southern operation would take place in a tropical region, it was considered [preferable] that more space be allocated than in the case of the above-mentioned China operations. This standard of "three tons per person (three people per 3.3 square meters)" was a calculation based on the premise that double or triple bunks could be used.(148)

Especially, I would like to add that the military horses of the 2d Division, mainly bred in Hokkaidō, sailed southward beyond the equator without being allowed to "disembark for bathing," unlike the people [on board]. Whether they would endure sailing in the tropical zone was a matter of great concern. However, the result came as a surprise. The officers and men from the Tōhoku district were solid, familiar with handling horses, and they really loved horses. During the sailing, [even] the officers voluntarily took the initiative to live in the horse stalls at the bottom of the ships and treated them with tender care day and night. Out of more than 1,000 military horses, only three succumbed during the sailing. ${ }^{(94)}$ 


\section{The Army Commander Changes his Departure Date from Gaoxiong}

After concluding the arrangements with the 5th Destroyer Squadron on the 27th, Army Commander Imamura paid a visit to the Taiwan Army headquarters and the Government-General of Taiwan in Taipei with Chief of Staff Okazaki on the 28th to express his appreciation and asked them to look after affairs while he was away. The next morning, he returned to Gaoxiong by train, and gave orders to the $2 \mathrm{~d}$ Division and others on the 30th as already described, ${ }^{(32)}$ which put an end to the main administrative work he had to do in Gaoxiong. In Cam Ranh Bay, the 38th Division was supposed to make arrangements with the Malaya Unit (the First Southern Expeditionary Fleet) on the next day, the 31st, with the 3d Destroyer Squadron and the 9th Base Force on the day after next, 1 February, and leave for Bangka and Palembang on the evening of the 4 th. ${ }^{(118)}$ (Before the Manila Conference, it was supposed to leave Cam Ranh Bay on 31 January.) While concerned about the 38th Division in Cam Ranh Bay, Army Commander Imamura had planned to leave Gaoxiong by aircraft on 1 February, after observing in person the arrival of the convoy of the Shōji Detachment (from Hong Kong; though the detachment commander had already flown ahead to Gaoxiong on the 25th) and the arrival of part of the convoy of the $2 \mathrm{~d}$ Division (from Magong), both expected to arrive in Gaoxiong on the 31st, the passing down of orders to the $2 \mathrm{~d}$ Division and to the Shōji Detachment, and the change of ships of men and freight. However, there was a pile of problems in Gaoxiong. Amid the chaos in Gaoxiong, which has been described, the commanders of the units, who were ordered to disembark and remain in Gaoxiong, pestered the shipping staff, insisting that their men would not be convinced unless they were brought back in the first transport unit, or they would be too ashamed to face [people] at home. Also, he [Imamura] thought it necessary to give all possible instructions to the Shōji Detachment, which was going to put its head into the lion's mouth, so to speak. Originally, when Army Commander Imamura was still an officer attached to a company of the 4th Sendai Infantry Regiment, Colonel Shōji had joined the company as a probationary officer, and was directly trained by him. Then, when Army Commander Imamura graduated from the War College and returned as a company commander of the regiment, Shōji served as a senior officer of the company. Furthermore, when Army Commander Imamura was the commander of the Twenty-third Army, Shōji served as the regimental commander of a division under the control of the army. Only a few companies in infantry regiments had a probationary officer (1 person) assigned to it, and the officers who trained probationary officers and the latter were usually bound by deep comradeship. Apart from the relationship from the time when Shōji was a probationary officer, Army Commander Imamura and Colonel Shōji also had the other connections mentioned above.

Army Commander Imamura had asked Lt. Gen. Sano Tadayoshi, commander of the 38th Division, to specifically appoint Colonel Shōji as commander of the unit to seize Kalijati. It was partly because the regiment under the command of Colonel Shōji, who was trained in the 4th Infantry Regiment of the $2 \mathrm{~d}$ Division, would be the most suitable for the joint operations with the $2 \mathrm{~d}$ Division. However, the main reason was that he expected that with Colonel Shōji as the commander of the detachment, which not only had to cope with difficult circumstances but also conduct its operations in close and inseparable connection with the main force of the army, he would have a detachment commander who would be of one mind with him as army commander and that even if he was unable to communicate with [the detachment] as he wished, [Shōji] would take the appropriate actions. 
Because of all the many problems [listed] above, the army commander decided for the time being to postpone his departure, which was scheduled for the 31st. ${ }^{(32)}$ On that day, the army commander learned that the Eastern Detachment had successfully landed in Ambon that morning, which left Bangka, Palembang, Banjarmasin Bali, and Kupang [as places to be seized]. On the next day, 1 February, the first convoy left Gaoxiong. ${ }^{(120)}$ The second, the third and the fourth (the last) convoys were scheduled to leave Gaoxiong for Cam Ranh on the 3d, the 5th, and the 6th respectively. ${ }^{(120)}$ The army commander had continuously been directing various units, but receiving a telegram on the next day, the $2 \mathrm{~d}$, which will be described later, he left Gaoxiong for Cam Ranh Bay on the $3 \mathrm{~d}$, parting from $2 \mathrm{~d}$ Division Commander Maruyama, 1st Disembarkation Group Commander Itō Shinobu, and Detachment Commander Shōji. He stayed in Sanya that night for aircraft availability reasons. ${ }^{(32)}$

\section{The Southern Sumatra Invasion Operation}

\section{The Issue of a Second Postponement of Operation L Arises}

Army Commander Imamura had put off his departure from Gaoxiong scheduled for 31 January because of the postponement of the invasion schedule (a decision made on 28 January) and the actual situation at Gaoxiong. Then on 2 February he received a telegram from the Malaya Unit (the First Southern Expeditionary Fleet) requesting "a postponement of the operations against Bangka and Palembang." ${ }^{(33)}$ Considering that "this is a serious matter which may affect the schedule of the landing operation in Java," (33) [the commander] hastily left Gaoxiong on the following day, the $3 \mathrm{~d}$, and flew to Sanya on Hainan Island on the same day. ${ }^{(32)}$ As previously described, the 38th Division (which had left Hong Kong on 20 January and arrived in Cam Ranh on the 24th) had postponed its departure scheduled for 31 January till 4 February as a result of the official conclusion of the Manila Agreement on 28 January and was about to leave Cam Ranh on the evening of 4 February to head for Bangka and Palembang.

Chief of Staff Okazaki, Senior Staff Officers Takashima and Kitamura, Staff Officer Oda and others accompanied Army Commander Imamura, while Staff Officers Kuriya and Nishiura, and Staff Officer Yamashita had been attached to the 48th Division and the Shōji Detachment respectively. Vice Chief of Staff Harada, Staff Officer Sendō and others remained in Gaoxiong to take care of remaining affairs. Earlier, as soon as the outline of the Mersing landing operation had been changed on 19 January (in such a way that the landing operation of the main force of the 18th Division was called off, and that air unit(s) and their matériel were to be put ashore in Endau on the 26th in two transport ships instead), and the arrangements between the [Navy] Malaya Unit and the [Army] Third Air Force had been concluded on the same day based on the [new] outline, [Chief Aviation] Staff Itoda, who had been left in Sagion, had returned to Gaoxiong on the same day (the 19th) to report on the situation. ${ }^{(32)}$ Then he had immediately flown back again to French Indochina, working busily between the Southern Army, the Third Air Force and the 1st [Paratroop] Raiding Group in an effort to realize the Palembang paradrop operation. ${ }^{(39)}$ By around 22 January, the Southern Army had abandoned the idea of dropping the [paratroop] raiding unit at Palembang for three reasons: the fact that the 1st [Paratroop] Raiding Regiment had been shipwrecked, the $2 \mathrm{~d}$ [Paratroop] Raiding Regiment's insufficient level of training and the delay of its departure from 
the [Japanese] homeland, and the moving up of the operation schedule. Nonetheless, Staff Officer Itoda zealously persuaded all parties, and by the 25th had convinced them to implement the parachute raid. ${ }^{(24,39)}$ After that, he stayed on in Saigon to proceed with the preparation of the specifics of the Palembang paratroop operation. ${ }^{(39)}$ In addition, the Sixteenth Army had also dispatched Staff Officer Saiki to French Indochina in order to prepare for the Bangka and Palembang operations. ${ }^{(34)}$ He had left Taiwan on 23 January and arrived in Saigon on the 25th, where at the Southern Army headquarters he learned about the [decision in] the Manila Agreement to change the schedule (the departure of the 38th Division from Saigon, which had been set on 31 January in the Cam Ranh Agreement, was changed to 4 February in the Manila Agreement). Arriving in Cam Ranh Bay on the 27th, he visited 38th Division Commander Sano on board the Gin'yō-maru to pay his respects and then headed for the Chōkai, the flagship of the First Southern Expeditionary Fleet commander in chief, Vice Admiral Ozawa. There, along with Staff Officer Itoda he took part in making preliminary arrangements for the Bangka and Palembang operations between the Sixteenth Army, the [Navy] Malaya Unit (the First Southern Expeditionary Fleet) and the Third Air Force, and returned to Saigon on the 28th. On the 31st, he once again left Saigon for Cam Ranh Bay, this time along with Southern Army Staff Officers Arao and Matsumae, and Sixteenth Army Staff Officer Itoda, to complete the "Arrangements for the air [operations] of the Bangka and Palembang operations between the Sixteenth Army, the First Southern Expeditionary Fleet, and the Third Air Force" on board the Chōkai, the flagship of the Malaya Unit, with all parties concerned. Then he attended the conclusion of the "Arrangements for the Bangka and Palembang operations between the 38th Division and the First Southern Expeditionary Fleet," and returned to Saigon on the next day, 1 February. While dealing with these, he [also] worked on, among other things, accommodating the 38th Division's request for an increase in the number of small cargo ships. ${ }^{(34)}$

While such was the situation at Cam Ranh Bay, the [Sixteenth] Army commander and his group arrived in Sanya on Hainan Island on the $3 \mathrm{~d}$, and then, via the Nha Trang airfield in French Indochina, reached Cam Ranh Bay at 1230 on the 4 th. They were met by 38 th Division Commander Sano, and paid a visit to [Navy] Commander in Chief Ozawa. ${ }^{(32,33)}$ The [Navy] commander in chief and his officers requested Army Commander Imamura that "due to the current condition of the Ledo airfield and other [matters], it is not possible to let the 38th Division start from Cam Ranh Bay tonight. I would like you to agree to postpone the schedule for at least two days." (36) Earlier on that day (the 4th), [Sixteenth] Staff Officer Saiki in Saigon had already sent a military classified telegram to [the army commander arriving in] Cam Ranh, signaling the intention of the Southern Army that "it would definitely not agree to a change of schedule." (34) Nevertheless, the army commander and his officers shared the feeling that the request of the [Navy] Malaya Unit was inevitable under the circumstances. ${ }^{\left(36,{ }^{39)}\right.}$ In the evening, the army commander and his group arrived from Cam Ranh in Saigon, where four of them, i.e. Senior Staff Officers Takashima and Kitamura, Staff Officer Oda and Navy Staff Officer Wakatsuki (staff officer of the Third Fleet seconded to the Sixteenth Army) went straight to the Southern Army Staff Office to make a "request for consent to a postponement of the schedule." (23) The Southern Army staff turned red with anger as they saw "the Sixteenth Army coming in a body, having sided with the Malaya Unit."(23) Once again a heated exchange concerning the issue of a postponement of the schedule started. ${ }^{(23)}$ 


\section{(1) Preparations for the Southern Sumatra Invasion Operation}

To what extent had the preparations for the Southern Sumatra invasion operation been making progress by this time?

We have already related that as soon as the Cam Ranh Agreement to move up the Java operation had formally become effective (on 1 January), the Southern Army had ordered the Sixteenth Army on 5 January "to prepare for [the operation] to capture Java as well as to carry out [the operations] to seize Bangka, Palembang, Ambon and Kupang," that as soon as the formal arrangement with the Malaya Unit had been concluded on 15 January, [Sixteenth] Army Commander Imamura had given orders to the 38th Division commander on 18 January in Hong Kong to carry out the Bangka and Palembang operations; that the 38th Division had departed from Hong Kong on 20 January and advanced to Cam Ranh Bay on the 24th, but that its departure from Cam Ranh Bay scheduled for the 31st had been postponed to 4 February according to the [decisions] made at the Manila Conference which had been held in the meantime; and that just before the Manila Conference, the change in the outline of the Mersing landing operation, the delay in the Kawaguchi Detachment's [operation to] seize the Ledo [airfields], and the regrettable shipwreck of the 1st [Paratroop] Raiding Group had occurred.

\section{Start of the Southern Sumatra Operation of the Third Air Force}

While assisting the Twenty-fifth Army with its operations in Malaya, the Third Air Force had already started preparations for the coming Sumatra operation as early as mid-December. To be concrete, it had had the 81st Air Group reconnoiter the Medan airfield since 11 December, and the airfields of Pekanbaru, Palembang and Mentok since the 17th, while having the 7th Air Division investigate the general situation of [the enemy] air [forces and fields] in Northern Sumatra. [Further,] from the beginning of January, it had the 81st Air Group to continuously watch the Medan and Pekanbaru airfields, while having an element advance and attack these airfields in the following way: ${ }^{(96)}$

28 December: The 3d Air Division ([consisting of] the 59th and the 75th Air Groups, from the Sungai Petani base) attacked the Medan airfield with twenty-five aircraft (seven fighter planes and eighteen light bombers), and blew up or set fire to four aircraft on the ground, hangar(s) and powder magazine(s).

16 January: The 3d Air Division ([consisting of] the 59th, the 75th and the 90th Air Group, from the Sungai Petani and Ipoh bases) attacked the Medan airfield with its main force, set fire to one aircraft on the ground and blew up the runway.

17 January: The 7th Air Division ([consisting of] the 64th and the 12th Air Groups, from the Alor Setar and Ipoh bases) attacked the Pekanbaru airfield with forty-one aircraft (nine fighter planes and thirty-two heavy bombers), set fire to five aircraft on the ground and warehouse(s), and blew up seven aircraft and the runway.

23 January: The 7th Air Division ([consisting of] the 98th Air Group, from the Ketil base) attacked the Palembang airfield with its twenty-seven aircraft (heavy bombers), set fire to one aircraft on the ground, fought against fifteen enemy aircraft which came to intercept, and shot down five of them. Our loss was fourteen aircraft moderately or slightly damaged. 


\section{The Situation in Late January}

The British Indian Army in Malaya, in expectation of reinforcements being sent in, was seen to put up resistance by taking up successive in-depth positions over a very long distance. In particular, in early and mid-December it put up resistance by taking up strong positions in the Jitra line sector, and from late December to early January in the sector south of the Perak River (the Kampar and Slim sectors), during which time it also strengthened [the defense of] the whole sector of Gemas, Bakri and their vicinities in the south of the peninsula. ${ }^{(23)}$ In midJanuary, the Twenty-fifth Army, while getting one after another reports such as "on 15 January, a battleship carrying 1,600 men arrived in Singapore; on 16 January more reinforcements arrived; fifty pursuit aircraft and B-17 bombers arrived [as well]," had carried out attacks on the strong [enemy] positions in the vicinities of Gemas and Bakri with the Imperial Guard Division and the 5th Division. ${ }^{(23)}$ Around that time the 18 th Division had been on standby at Cam Ranh Bay since 10 January for the landing operation near Endau and Mersing. ${ }^{(23)}$ The 5th Division had seized the strong position near Gemas [in an engagement] from around the 14th until the 19th, ${ }^{(23)}$ and the Imperial Guard Division those near Bakri [in an engagement] from around the 18th until the $22 \mathrm{~d} .{ }^{(23)}$ In the meantime, on the 15th, acting on reports that "enemy battleships and an aircraft carrier [had been] spotted at Singapore," the [Navy] Malaya Unit had departed from Cam Ranh Bay and headed south, which, on the 17th, had resulted in the decision to change the outline of the Endau and Mersing landing operations. The Southern Army had ordered this [change] on the 19th, and the 18th Division left Cam Ranh Bay on the 20th, arrived at Singora on the $22 \mathrm{~d}$, and started the landing [operation]. ${ }^{(23,}$ 118) As the information concerning the battleships and an aircraft carrier in Singapore had proved false, the main unit of the [Navy] Malaya Unit had returned to Cam Ranh Bay on the 19th. ${ }^{(103)}$ The Third Air Force, while successively advancing its air bases, had continued its battle to destroy the enemy air power in conjunction with the naval air units of the Malaya Unit, and also assisted the Twenty-fifth Army in its ground operations. ${ }^{(23)}$ Command of the air above the battlefronts and their vicinities was largely in Japanese hands. ${ }^{(23)}$ Nevertheless, the British Air Force still possessed about 150 to 160 aircraft and kept carrying out guerillalike attacks against our air bases from its base in Singapore. ${ }^{(23)}$ The Twenty-fifth Army's operation became a high-speed pursuit battle after it had destroyed the British Indian Army near Gemas and Bakri. ${ }^{(23)}$ The 5th Division, which had advanced to Labis on the 21st, to Yong Peng on the 24th, and to Kluang on the 25th, [finally] made a long-awaited charge into Johor Bahru at 1530 on the 31st. ${ }^{(23)}$ The Imperial Guard Division advanced to Batu Pahat on the 25th, and to the Strait of Johor line on the 31st. ${ }^{(23)}$ As for the [Navy] Malaya Unit, after calling off the mid-January operation to lure out the battleships and the carrier [believed to be] in Singapore (both of which turned out to be false reports), it provided escort for the transport of the 18th Division between Cam Ranh Bay and Singora from 20 to 22 January, and from the 24th onwards, [the unit] shifted [its operation] to provide escort for the disembarkation operation at Endau (in which [the ground units of] the air units and their matériel transported in two ships were disembarked instead of the cancelled landing operation of 18th Division) and [subsequently] to occupy the Anambas base, both of which were realized on the 26th. ${ }^{(23,}$ 118, 126) With the advance of the Twenty-fifth Army and the gradual approach of Japanese air bases, the British air forces fled to Sumatra one after another. ${ }^{(23)}$ Now the Dutch East Indies Air Force became the main constituent [of the enemy]. ${ }^{(23)}$ The Dutch East Indies Air Force had been gradually reinforced with U.S. air forces, and at the beginning of February, its 
strength was estimated at about one hundred aircraft in Sumatra and some three hundred aircraft in Java, including the aircraft of the British air forces which had escaped [the Japanese attacks]. ${ }^{(23)}$ Reconnaissance of the general state of the [enemy] air forces and fields in Sumatra and the attack operations against the island had progressed as previously described. As for the U.S., British and Dutch warships, few had sustained any significant damage apart from the Prince of Wales and the Repulse [which had been sunk].

\section{The Enemy Position at the End of January}

The information which the Southern Army had obtained by the end of January on the allied army and air force reinforcements since the opening of hostilities was as follows: ${ }^{(23)}$

\section{Burma area}

Apart from reinforcements of at least one division and other technical units of the [British] Indian Army, also Chiang [Kai-shek]'s Sixth Army has been moved up close to the border, of which two corps have [already] entered Burma for certain. It appears that the remainder is also taking the route to enter [Burma]. This information is mainly based on the following sources (omitted by the author).

It appears that the air force has been increased by some fifty aircraft.

This information is mainly based on the following sources (omitted by the author).

2. Malaya area

An increase of one brigade of Indian troops [is known] for sure, apart from [this], an increase of about one division of Indian troops as well as elements of British and Australian troops must be assumed. This information is mainly based on the following:

(1) On 8 January, a brigade of Indian troops had newly assembled at Malacca. As a result of an engagement, it was identified as the 45th Independent Brigade of the [British] Indian Army, which had newly arrived (degree of certainty A).

(2) Australian reinforcements have successively been sent in, and their strength is said to be seventy thousand something (intelligence from A; degree of certainty B-).

(3) On the morning of 15 January, 1,600 men (mostly British, but also including some U.S. Air Force personnel) arrived in Singapore in four transport ships (intelligence from A; degree of certainty B).

Apart from the above, the following active movements of convoys have been [observed] recently:

(a) On 16 January, reinforcements in five transport ships arrived (18 January, intelligence from A).

(b) At 1250 on 23 January, ten transport ships were heading northward off Cape Jabung (about one hundred kilometers northeast of Jambi) (aircraft reconnaissance).

(c) On 28 January four 8,000-ton-class transport ships, led by warships, were heading southwestward through the Singapore Strait (reported by the Sugawara Group).

Also on the same day five transport ships under [naval] escort were heading northward through the Bangka Strait (reported by a naval air unit).

Concerning the above, it is by and large certain that these are reinforcements of the [British] Indian Army, as seen in the following [reference] information:

[Reference] information

According to the intelligence from A (Jiemin), it seems that two brigades of the British 18 th Division were those in Singapore on the 28th, and one brigade of the division (the 53d Brigade) was apparently the one which had been in Singapore before that [day] (Army General Staff Office Report). 
Further, the increase in air [forces] should be over two hundred aircraft (however, some [of them] must have been deployed in Sumatra). This information is mainly based on the following:

\{1\} Both on 20 and 24 December, one [air] squadron each heading for East Asia waited for its turn to get aboard at Basra (Army Report from Italy; degree of certainty B).

\{2\} On 8 January, a reinforcement of a dozen or more twin-engine bombers arrived from Egypt (intelligence from A and Jiemin report; degree of certainty B).

\{3\} On 12 January, aircraft arrived from Australia (though their number was unclear) (intelligence from A and Jiemin report; degree of certainty B).

\{4\} Reinforcements sent to Malaya from the Dutch East Indies right after the opening of hostilities consisted of fifteen bombers (statement of (a) Dutch POW; degree of certainty A).

$\{5\}$ On 16 January, fifty U.S. aircraft (P-40) arrived (intelligence from A, Jiemin report, and monitored broadcast; degree of certainty $\mathrm{B})$.

\{6\} On 28 January, fifty Hurricanes and fifty-one Spitfires will be transported to XX (note by the author: the two characters in the original text are illegible) via Batavia (intelligence from A passed on by Army General Staff; degree of certainty C).

\{7\} On 20 January, two Indian [air] squadrons were transported to Singapore from Iraq (information from a military attaché in Italy; degree of certainty $\mathrm{C}$ ).

3. Dutch East Indies area

Apart from a reinforcement of an estimated two ([or] three) battalions to Sumatra, [the situation] is still unknown. However, up to now the arrival of large troop numbers is unthinkable. This information is based on the following:

(1) From 25 to 26 January, eighteen transport ships (about a total of 80,000 tons) were anchored in and around the port of Padang on Sumatra (naval air unit information; degree of certainty A).

(2) Recently, units of allied forces have arrived in a certain port of the Dutch East Indies (broadcast monitored on 27 January; degree of certainty B).

(3) On 28 January, six U.S. Army regiments arrived in Surabaya (intelligence from A and Jiemin report; degree of certainty C).

Further, as for air force units, U.S. equipment and training personnel must have arrived in considerable numbers, but [details] remain unknown. However, the current number of aircraft is estimated to have reached about five hundred.

This information is based on the following:

$\{1\}$ Three thousand U.S. air personnel arrived in Java (information of 28 January and Cheng Jiemin report, degree of certainty $C$ ).

\{2\} According to the statement of a Dutch East Indies POW pilot, the current number of aircraft in the Dutch East Indies is some seven hundred, and they are dispersed over every airfield (degree of certainty C).

[Editor's note: Cheng Jiemin could not be identified with any certainty. He might have been Chiang Kai-shek's spymaster, whose report the Japanese somehow got hold of, cf. http:/ / en.wikipedia.org/wiki/National_Security_Bureau_(Republic_of_China).]

\section{Reconsideration of the Employment of the 1st [Paratroop] Raiding Group}

The general condition of the shipwrecked 1st [Paratroop] Raiding Regiment and the $2 \mathrm{~d}$ [Paratroop] Raiding Regiment has already been mentioned, but in detail their state was as follows: When the 1st [Paratroop] Raiding Regiment was sailing south from Magong along with the main force of the 33d Division, the ship which was carrying the regiment, the Meiko-maru, sank due to a spontaneous combustion of its cargo on 3 January. ${ }^{(23)}$ Although [the regiment's] men were rescued by escorting destroyers, all of its weapons and matériel were lost. ${ }^{(23)}$ On 
the 7th, Lt. Col. Kinoshita Hideaki, who was attached to the 1st [Paratroop] Raiding Group, sent a telegram from Bangkok to the Southern Army to say that "the regiment will arrive in Bangkok on the 9th. Upon arranging clothes and personal effects for the present, the regiment will leave Bangkok by train on the 12th. I request you to arrange the whole set of paratroop clothing, parachutes, weapons, equipment, supply containers, medical supplies and matériel [sufficient to equip] one regiment to be immediately sent from the Inspectorate General of Aviation." (23) Then on the 9th, Lieutenant Colonel Kinoshita [again] sent the Southern Army a telegram from Bangkok that ${ }^{(23)}$ "I fear that it is highly likely that the 1st [Paratroop] Raiding Regiment cannot be [ready] in time for the date of the operation because of its heavy loss. I request you to keep in close contact with the Inspectorate General [of Aviation for the information] about the date and time of arrival of items subsequently dispatched from the homeland. In my humble opinion, it is faster and more certain to employ the $2 \mathrm{~d}$ Regiment as an emergency expedient. Therefore, I believe a swift additional assignment of the $2 \mathrm{~d}$ Regiment as well as resupply of sunken equipment and matériel for the [paratroop] air unit should be given top priority. I would like you to also give consideration to the employment of the 1st Regiment once its re-equipment is completed."(23) It meant that it was impossible for the time being to assign the 1st [Paratroop] Raiding Regiment difficult missions even if the regiment were re-equipped. In a following telegram sent on the 11th, the lieutenant colonel reported: "The bulk of the 1st [Paratroop] Raiding Regiment has come ashore at Bangkok on the morning of the 11th. All arrived with only the clothes they were wearing, but their morale is high."(23) [From this telegram] the Southern Army got the impression that the men had been rescued separately and were coming ashore in small groups. On 15 January, the 1st [Paratroop] Raiding Group Commander, Col. Kume Seiichi, arrived in Guangdong, southern China, with the main force of the [Paratroop] Raiding Air Unit. ${ }^{(23)}$ On the 17th the Inspectorate General of Aviation wired the Southern Army:(23) "The 2d [Paratroop] Raiding Regiment left Moji on the 15th, heading for Haiphong in French Indochina; the regiment brings along weapons, clothes and matériel to be handed over to the 1st [Paratroop] Raiding Regiment, with which, in our expectation, the loss sustained by the 1st [Paratroop] Raiding Regiment in the shipwreck of the Meiko-maru can be completely replaced; special operational training for about one week was provided to Lieutenant Tokunaga, 2d [Paratroop] Raiding Regiment 1st Company commander, and his men, a total of sixty-four personnel; the [Paratroop] Raiding Air Unit 3d Squadron is scheduled to depart around 20 January."

As already described, the scheduled date for the Palembang landing set forth in General Agreement No. 4 (Cam Ranh Agreement) was 6 February. Accordingly, the drop of the paratroops at Palembang had been scheduled for 5 February. However, taking into account the physical and mental blow which the 1st [Paratroop] Raiding Regiment had suffered as well as the $2 \mathrm{~d}$ [Paratroop] Raiding Regiment's insufficient level of training and the shortness of time allowed to prepare for the operation, the Southern Army abandoned the idea of conducting the Palembang [paratroop] raiding operation, for which it had had high hopes since before the opening of hostilities. On 22 January, the Southern Army drew up the following plan concerning the deployment of the 1st [Paratroop] Raiding Group: ${ }^{(24)}$

First Deployment: $\quad$ About day $x+60$ (6 February)

Pekanbaru or Jambi in central Sumatra

Second Deployment: About day $x+80$ (26 February) 
Third Deployment:

Sabang, Pangkalan Susu, or Pangkalan Brandan in northern Sumatra, and the Andamans in the waters northwest of Sumatra

About day $x+90$ (8 March)

Yenangyaung in Burma

As a matter of fact, on the day when the Southern Army drew up the above plan at Saigon, Staff Officer Ishii unofficially concluded [an agreement] on a four-day postponement of the Palembang [operation] at Manila. ${ }^{(23)}$ It gave an extra four days to spare. Sixteenth Army Staff Officer Lt. Col. Itoda Isamu, who had been involved in the establishment and training of the paratroop raiding group at the Inspectorate General of Aviation, now was staff officer of the Sixteenth Army, which was going to conduct the Palembang landing operation. Staff Officer Itoda passionately advocated the employment [of the paratroop raiding group] at Palembang. ${ }^{(39)}$ Also 1st [Paratroop] Raiding Group Commander Colonel Kume, who had just then arrived, made a strong request for conducting the Palembang paratroop operation. Thus, on the 24th (the day when the 38th Division advanced to Cam Ranh Bay), the Southern Army changed its mind to conduct the Palembang paratroop operation.

\section{The Third Air Force Draws up the Outline of the Air Operations [for Operation] L}

After the employment of the 1st [Paratroop] Raiding Group (under the direct control of the Southern Army) for the Palembang [operation] was decided (for which operation the raiding group was to be brought under the control of the Third Air Force), the Third Air Force ([led by] Lt. Gen. Sugawara Michiō) drew up the "Outline of the Air Operations [for Operation] $\mathrm{L}^{\prime \prime}{ }^{(96)}$ on the 25th, based on the "Supplement to the Southern Army's Air Operation Plan" of 10 January. ${ }^{(2)} \mathrm{L}$ refers to Bangka and Palembang in a narrow sense, and in a broader sense to Southern Sumatra. Here it is used in the broader sense.

\section{Outline of the Air Operations [for Operation] L}

I. Mission

1. [We shall] expand the military gains in the Singapore operation and while constraining the Dutch East Indies Air Force from reinforcing or gathering strength in Southern Sumatra, closely cooperate with the Sixteenth Army in its Bangka and Palembang operations.

2. While conducting this operation, [we shall] at the right moment launch the air operations against western Java and prepare [to give] direct cooperation in the landing operation of the main force of the Sixteenth Army in western Java.

II. Directives

1. For the period of the capture of Singapore

(1) Prior to the landing (or disembarkation) operation in or near Endau, a Singapore air operation shall be conducted, [in which] the remaining enemy air power shall be destroyed, and through attacks on vital targets in the Singapore area, efforts shall be made to crush the enemy's will to resist.

(2) At the time of the Twenty-fifth Army's [operation to] capture Singapore, we shall speed up the capture by bombing vital points on the island along with the bombardment by the army.

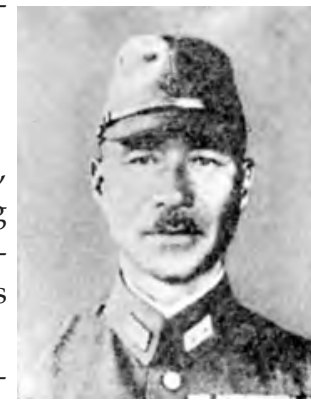

Third Air Force Commander Lt. Gen. Sugawara Michiō 
(3) When the Kluang, Kahang and Batu Pahat airfields are seized and made ready for use, preparations for the capture of Singapore and Operation L shall be swiftly completed. The deployment plan of the forces is as shown in Supplement No. 1 (note by the author: the contents of Supplement No. 1 is roughly the same as Illustration No. 23).

(4) During this period, [forces shall be] assigned to timely conduct attacks on the airfields in Sumatra, cut off the line of retreat of the enemy air power in the Singapore area, pursue them, and constrain the Dutch East Indies Air Force from reinforcing or gathering strength, so that the [operation to] capture Singapore as well as the execution of Operation $\mathrm{L}$ will be facilitated.

2. For the period of the capture of southern Sumatra

(1) [Forces shall be] assigned to support the operations of the Sixteenth Army's Bangka and Palembang landing units, in conjunction with Navy air units.

(2) Between day $L-4$ and day $L-2$, the chief concern of the fighter plane units of the $3 \mathrm{~d}$ Air Division shall be to destroy the enemy air power in Palembang.

(3) On day L-1, the [Paratroop] Raiding Group shall be dropped in Palembang. On this occasion one element will facilitate this action.

(4) When the airfields in Southern Sumatra are seized and made ready for use, a powerful element shall be advanced [there] without missing an opportunity. Most of the element shall swiftly destroy the enemy air power in western Java, while an element of it shall support the Sixteenth Army's operation to mop up southern Sumatra. Meanwhile, in order to give direct support to the main force of the Sixteenth Army in the western Java landing operation, preparation of the Tanjungkarang airfield shall be accelerated.

(5) The outline of the cooperation between the Army and Navy air units in Operation L shall be arranged separately.

(6) Before and after the capture of Singapore and right at the launch of Operation L, the remaining force of the [Third] Air Force may also conduct [operations to] search for enemy ships near Singapore and in the Malacca Strait and attack them.

3. Others

(1) Forces not involved in Operation L and the Java operation shall directly cooperate with an element of the Twenty-fifth Army in northern Sumatra. The details shall be planned separately.

(2) An element of the fighter plane [unit] may be charged with the air defense of the Singapore area.

III. Disposition of forces to be employed and outline of operations

1. The Attack on Singapore

(1) The outline of the attack before the capture of Singapore by the Twenty-fifth Army is as shown in Third Air Force Operation Order A, No. 174 Supplement "Outline of Air Operation Po." [Editor's note: the text has "Bo," which is a mistake for "Po" (Singapore), see Vol. 34 of the War History Series.]

(2) Once the Kluang, Kahang and Batu Pahat airfields are seized, the 15th Air Ground Support Unit shall be advanced to southern Malaya with the aim of accelerating the [set-up of] air bases and the accumulation of matériel for Operation L.

(3) Prior to the start of Operation L, the distribution of air units shall be changed as follows: [Units] under the direct control of the [Third] Air Force: 81st Air Group, 98th Air Group, and 1st [Paratroop] Raiding Group.

3d Air Division: 15th Independent Air Unit (minus the 51st Independent Squadron), 59th Air Group, 64th Air Group, 75th Air Group, 90th Air Group, and 27th Air Group.

7th Air Division: 51st Independent Squadron, 12th Air Group, and 60th Air Group. 12th Air Division: 1st Air Group, 11th Air Group, and 47th Independent Squadron.

(4) Missions of each unit based on the distribution above are as follows: 


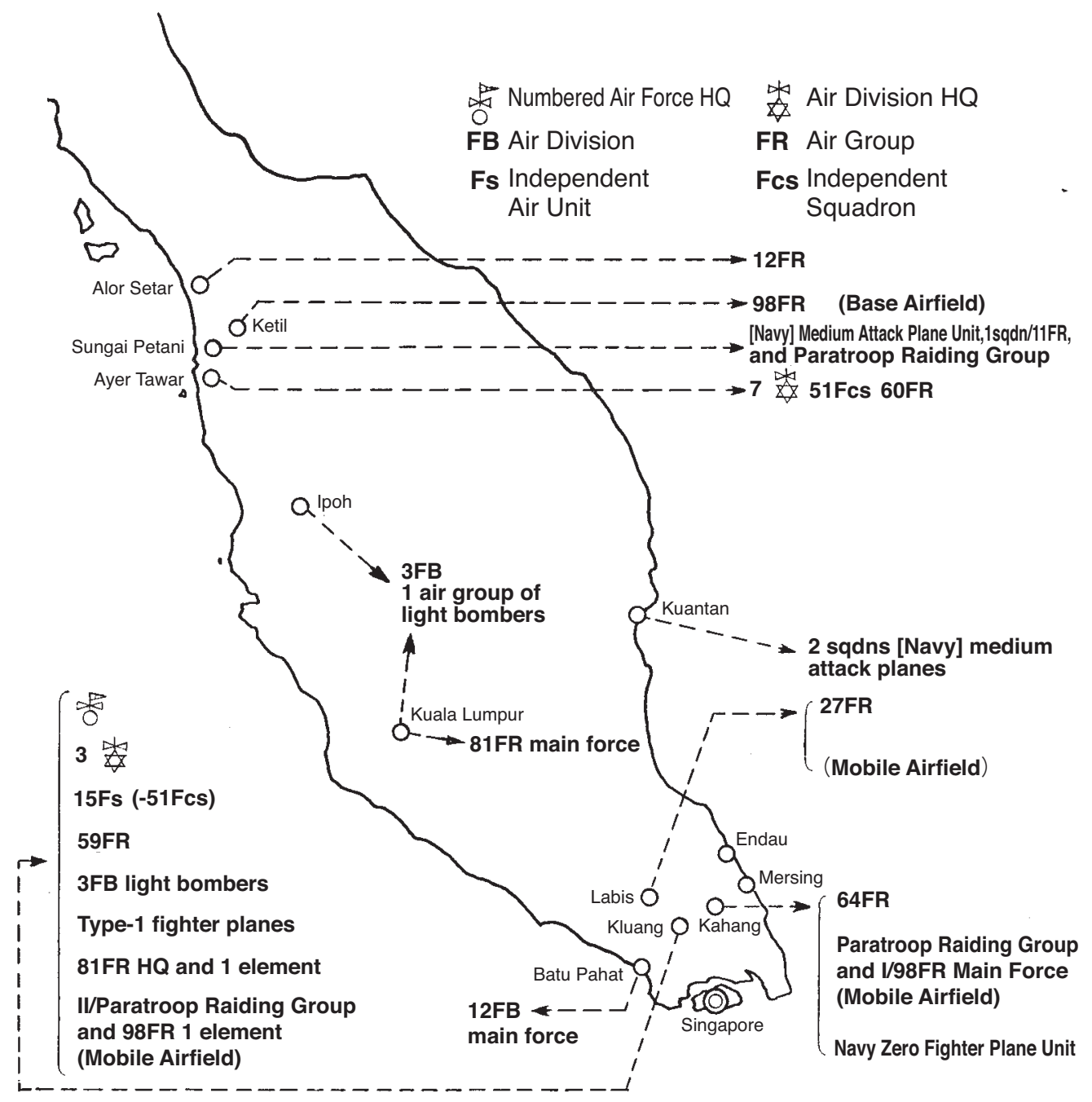

Illustration No. 23 - Scheduled Disposition of Air Units (25 January, 1942)

(a) 81st Air Group (note by the author: Command Reconnaissance):

Shall undertake general reconnaissance in Sumatra, Java and other locations, especially reconnaissance that will serve as preparation for the invasion of Java. For this purpose, the airfields in Kuching or Ledo in Borneo may be used temporarily. One element of the group shall directly support the [paratroop] raiding group in its operation.

(b) 3d Air Division:

Shall support the Twenty-fifth Army and also cooperate in Operation L.

(c) 7th Air Division:

Shall cooperate in the operation to capture Singapore. If required, it shall be employed as reinforcement in Operation L (in preparation for the northern Sumatra operation).

(d) 12th Air Division:

In cooperation with the $3 \mathrm{~d}$ Air Division, shall take charge of gaining command of the air in and around Singapore, conducting surveillance of the Pekanbaru airfield. It shall [also] destroy [the enemy] when opportunities arise. If possible, it shall provide 
the air defense of the anchorage of the units for Operation L, and [also] make preparations for cooperation in the Java operations.

2. Direct Support in Operation L

(1) From 1700 until the evening of the day before day L (scheduled for 10 February) an element of the fighter [planes] of the $3 \mathrm{~d}$ Air Division shall be charged with covering the sailing transport convoy of Operation L.

(2) Concurrently with Item (1), support shall be provided to the [Paratroop] Raiding Group's execution of its raiding mission. For this purpose, the reconnaissance unit shall be charged with reconnaissance of the drop point in Palembang and vicinity before and after the drop. [Further,] Type-1 fighter plane units shall be charged with direct cover of the [Paratroop] Raiding Air (Transport) Unit.

(3) After the drop of the [Paratroop] Raiding Group until the arrival of the landing units of Operation L, its fighting power, where necessary, shall be maintained and nurtured [with supplies provided] by descending (landing) airborne (transport) units or by airdrops. Along with this, direct support shall [also] be given to the [Paratroop] Raiding Group during its ground combat, if required.

(4) When the Palembang airfield is seized and made ready for use, an element of the 12th Air Division and the $3 \mathrm{~d}$ Air Division each will swiftly advance to the airfield to provide direct support for the landing units of Operation L (including the [Paratroop] Raiding Group) in their ground operations. Further, at an opportune moment, the air operations for the Java [operation] shall be launched. For this purpose, preparation of the Tanjungkarang airfield shall be accelerated so that assault [plane] units and Type-97 fighter [plane] units can be advanced.

At that time, the operation to land air units, fuel and ammunition at Endau was to be carried out on the following day, the 26th. ${ }^{(23)}$ The 18th Division, whose landing [operation in] Endau and Mersing had been cancelled, had left Cam Ranh Bay on the 20th under escort of the 3d Destroyer Squadron, landed in Singora on the 22d, and was now moving south along the west coast of Malaya. ${ }^{(23)}$ The 5th Division had seized Kluang on the 24th, while the Imperial Guard Division was in the middle of attacking the British Indian Army near Batu Pahat. ${ }^{(23)}$ The Twenty-fifth Army wished to capture Singapore by Empire Day (11 February), whereas the Southern Army, for its part, wished to seize Palembang right before that. ${ }^{(23,24)}$ Based on these circumstances (the Manila Agreement was to be formally concluded on 28 January), the plan as of that day (the 25th) was that the 38th Division would depart from Cam Ranh on 4 February and land in Palembang on 10 February, and that the 1st [Paratroop] Raiding Group would be dropped on Palembang the day before the landing [operation], namely on 9 February. ${ }^{(23,24)}$ The Southern Army had framed a plan to bring the 1st [Paratroop] Raiding Group under the control of the Third Air Force for executing the paradrop operation, and it had unofficially notified [both units]. ${ }^{(23,24)}$

The types and the rough number of aircraft kept under the air groups were as follows:(23)

59th Air Group: twenty-four fighter planes

1st, 11th, and 64th Air Group: thirty-six fighter planes each

27th Air Group: thirty-six assault planes

75th and 90th Air Group: twenty-seven light bombers each

12th, 60th and 98th Air Group: twenty-seven heavy bombers each

81st Air Group: eighteen command reconnaissance planes 


\section{Implementation of the Endau Landing Operation and the Occupation of the Anambas Islands}

On the 26th, the day after the Third Air Force had decided on the previously explained "Outline of Air Operations [in Operation] L," the Endau debarkation operation and the operation to occupy Anambas (note by the author: islands in the waters east of Singapore) were carried out. ${ }^{(118,126)}$ The landing operations in Endau and Mersing had been planned in order to secure with the main force of the 18th Division air bases for Operation L, as well as to capture and destroy the British Indian Army in the northern part of Johor, which was directly in front of the main force of the Twenty-fifth Army. However, as already explained, on 17 January the plan had been changed to [just] putting ashore air units, fuel, ammunition and matériel in two transport ships. The operation to occupy the Anambas islands, [on the other hand], was to be conducted so that the [Navy] Malaya Unit could advance [air] bases for conducting the southern Sumatra and Java operations. ${ }^{(102)}$ While the Malaya Unit had been considering the risks and was carefully making preparations for the Endau and Mersing operations that were to be carried out with the main force of the 18th Division, it had from 15 January onwards been engaged in an operation to lure the [enemy] fleet out of Singapore, as previously described ([for this purpose] its main unit had left Cam Ranh Bay on the 15th). However, on the 17th, air reconnaissance had made clear that "no warships other than one cruiser, five destroyers and seven transport ships were found in Singapore naval port." The operation was canceled and its main unit had returned to Cam Ranh Bay on the 19th. ${ }^{(118)}$

Note: At 0230 on the 16th, the Malaya Unit had wired all units: "According to photo reconnaissance by naval aircraft on the 15th, [enemy] battleships are anchored at Singapore. It appears that they are accompanying an aircraft carrier. It is likely that the enemy aircraft carrier will conduct an air raid on Cam Ranh Bay." (118)

Following the cancelation of the [original] Endau and Mersing operations, the Malaya Unit (Vice Admiral Ozawa), who had returned to Cam Ranh Bay, assembled the senior staff officers of all units on his flagship, the Chōkai, in the bay on the 20th. ${ }^{(118)}$ The $3 \mathrm{~d}$ Destroyer Squadron was assigned to escort "the two transport ships leaving Singora on the 24th to put ashore [personnel and matériel] at Endau on the 26th," after providing escort to "the 18th Division leaving Cam Ranh Bay on the 20th to arrive in Singora on the 22d."(118) The 9th Base Force was set to leave the bay of Puolo Condore (note: southwest of Saigon) on the 24th to conduct [the operation to] occupy the Anambas Islands on the 26th. ${ }^{(126)}$ The 7th Cruiser Division was set to support both of these operations. ${ }^{(115,118,126)}$

The two transport ships carrying the 20th Independent Engineer Battalion and other units, aviation fuel and ammunition left Singora on 24 January and reached the Endau anchorage on the morning of the 26th. ${ }^{(23)}$ They came under attack from about thirty [enemy] aircraft around 1630, about twenty aircraft around 1900 and [again] about six aircraft around 2000 on the same day, but the [enemy aircraft] were defeated by our 12th Air Division. ${ }^{(118)}$ The transport ships completed debarkation around 1200 on the 28th, sustaining no damage, and headed back [to their base]. ${ }^{(23)}$ Meanwhile on the night of the 26th, two allied destroyers attacked the anchorage, but the 3d Destroyer Squadron sank one of them and put the other to flight. ${ }^{(118)}$

The 9th Base Force occupied the Anambas on the 26th as planned. ${ }^{(126)}$ 
As previously described, the landing operations in Endau and Mersing with the main force of the 18th Division had been changed after, on the 14th, the Twenty-fifth Army had proposed to cancel them and the Malaya Unit had proposed to postpone them, which had been followed by the Malaya Unit's launch of its operation (to lure out and destroy the battleships and the aircraft carrier which were reported to be found in Singapore) on the 15th. Due to the telegrams from the [Navy] Southern Task Force and the Malaya Unit, and the [reported] progress of the operation of the Twenty-fifth Army on the 16th and the 17th, it was decided to change [the operation plan] (by calling off the employment of the 18th Division and replacing it with the transportation [of personnel and matériel] in two ships), and on the 19th the order was given [to change the operation]. But how did this change actually work out? The situation around the time when the operation [plan] was changed was that "the Twenty-fifth Army [had] charged into Kuala Lumpur on 11 January, the van of the army [had] closed in on Gemas on the 14th, and seized the town on the 16th, while it [was] expected to reach Johor Strait around the 25th." However, after that, the war had not progressed very smoothly for the Twenty-fifth Army. It was not able to seize the airfield in Kluang until the 25th, and that in Kahang until the 27th. ${ }^{(23)}$ On the 22d, Southern Army Staff Officer Saitō Tomoo sent the following telegram to the [Southern] Army headquarters from Gemas, which left the Southern Army with the impression that "the fact that it had to shift the 18th Division, which should have been assembling on the coast opposite Penang [in preparation] for the northern Sumatra operation, to the Singapore front had effectually been a wasteful detour, and that the Endau and Mersing operations should have been carried out as planned, even if they had to be implemented a couple of days behind schedule."(23)

We arrived in Gemas on the late night of yesterday, the 21st. Although the Twenty-fifth Army has been planning to dispatch a detachment from Kluang to the Mersing area and is making the greatest efforts to clear supply route(s) for the air [unit(s)], [my] estimation of the progress of the next operations is that the Kahang and Kluang airfields will not be ready until around 4 or 5 February at the very best, due to transportation and other [factors] in preparation for the capture of Singapore. It is expected that the use of these airfields as bases to cooperate in Operation $\mathrm{L}$ from the 5 th or the 6th will lead to terrible confusion. Furthermore, in view of the fact that tenacious resistance from the enemy may be expected in the capture of Singapore, and in view of the present state of its defense facilities, the reality is that it will be necessary [for the Twenty-fifth Army] to request cooperation of the air units of XX (note by the author: the two characters [in the original text] are illegible), heavy bombers in particular. Due to the above matters, I believe that it is highly necessary to re-examine when to launch operation $\mathrm{L}$. In the light of this situation, I also believe that it is necessary for the chief of operations, if possible, the chief or vice chief of staff to get into direct contact with the Twenty-fifth Army headquarters.

Note: On the day that Staff Officer Saitō wired the above, an informal agreement was reached at Manila on a four-day postponement of Operation L.

\section{The Army-Navy Arrangement on the Air Operations [in Operation] L}

(See Illustration No. 24)

As explained above, the 38th Division had advanced to Cam Ranh Bay on the 24th, the Third Air Force's operation plan, including the parachuting operation of the [Paratroop] Raiding Group, was completed on the 25th, and the [operations to] disembark [personnel and matériel] at Endau and to occupy the Anambas were carried out on the 26th, which was followed by 
the occupation of the Ledo airfield on the 27th. ${ }^{(23)}$ (As for the latter, the seizure was [successfully] carried out but things would not go smoothly at all afterwards, as will be explained later). On the following day, the 28th, the air [operation] arrangement for Operation L was concluded on board the flagship of the Malaya Unit, the Chōkai, at Cam Ranh Bay. ${ }^{(34)}$ Staff Officers Saiki and Itoda participated from the Sixteenth Army. ${ }^{(34,39)}$ The arrangement read as follows: ${ }^{(96)}$

\section{Arrangement on the Air [Operation in] Operation L between the First Southern Expeditionary Fleet Commander in Chief, the Sixteenth Army Commander and the Third Air Force Commander}

First Southern Expeditionary Fleet Commander in Chief, V. Adm. Ozawa Jisaburō

Sixteenth Army Commander, Lt. Gen. Imamura Hitoshi

Third Air Force Commander, Lt. Gen. Sugawara Michiō

I. Name of Operation and Basic Dates

1. The Operations in Bangka Island and Palembang shall be called Operation L.

2. The day when the advance party of the 38th Division lands in Mentok shall be indicated as day $\mathrm{L}$, and is scheduled for 10 February. In case a change of date for day $\mathrm{L}$ is required due to the progress of the air operations, weather conditions or enemy movements, a decision shall be made by 1200 on day L -6 upon deliberation between the First Southern Expeditionary Fleet commander in chief and the Sixteenth Army commander. However, regarding [matters involving] air operations, the Sixteenth Army commander shall consult the Third Air Force commander.

II. Forces to be employed

1. Navy

1st Air Unit: About 100 land-based attack planes, about 30 fighter planes, and 6 land-based reconnaissance planes.

Malaya Unit: About 40 seaplanes.

2. Army

About 9 command reconnaissance planes*, about 40 Type-1 fighter planes*, about 30 Type97 fighter planes*, about 9 assault planes*, about 20 twin-engine light bombers*, and about 30 heavy bombers.

*Indicates aircraft to be advanced to the airfields in southern Sumatra.

Depending on the condition of the airfields, the above number of aircraft shall be slightly changed.

III. [Air] bases to be used and distribution of forces

1. Navy

(a) When the Ledo [airfield] is fit for use:

Ledo and Kuching [airfields]: 2 air units of land-based attack planes, about 30 fighter planes, and 6 land-based reconnaissance planes.

Kuantan: about 30 land-based attack planes.

Sungai Petani: about 10 planes.

(b) When [the airfields in] Ledo and Kuching are unusable, [aircraft] shall be advanced in the following way:

Kuantan: about 60 land-based attack planes, and some of the fighter planes.

Kahang: about 30 fighter planes.

About 30 land-based attack planes may use [the airfield] as an advance base for refueling. If the XX Unit (note by the author: the [paratroop] raiding unit) should use the airfield, [the use by the land-based attack planes] shall be only until and including day $\mathrm{L}-3$ or on day $L+7$ and onwards. 
Sungai Petani: about 10 landbased attack planes.

Kota Bharu: about 40 land-based attack planes.

\section{Army}

Kahang: about 25 Type-1 fighter planes, about 45 transport planes. The remaining units to be used for Operation L shall use the Kluang, Batu Pahat, Kuala Lumpur, Ipoh, Ketil and other airfields. Depending on the readi- ness and other circumstances of the airfields, the above disposition and the forces deployed will be changed.

3. The Army shall be charged with making the Mentok and Palembang [air] bases ready for use. In the preparation of Mentok, the Navy shall cooperate. In the initial days after the seizure of the Mentok and Palembang [air] bases, Mentok shall be shared by the Army and the Navy in the following way, whereas Palembang shall be used by the Army: Navy fighter planes and others: about 30 planes.

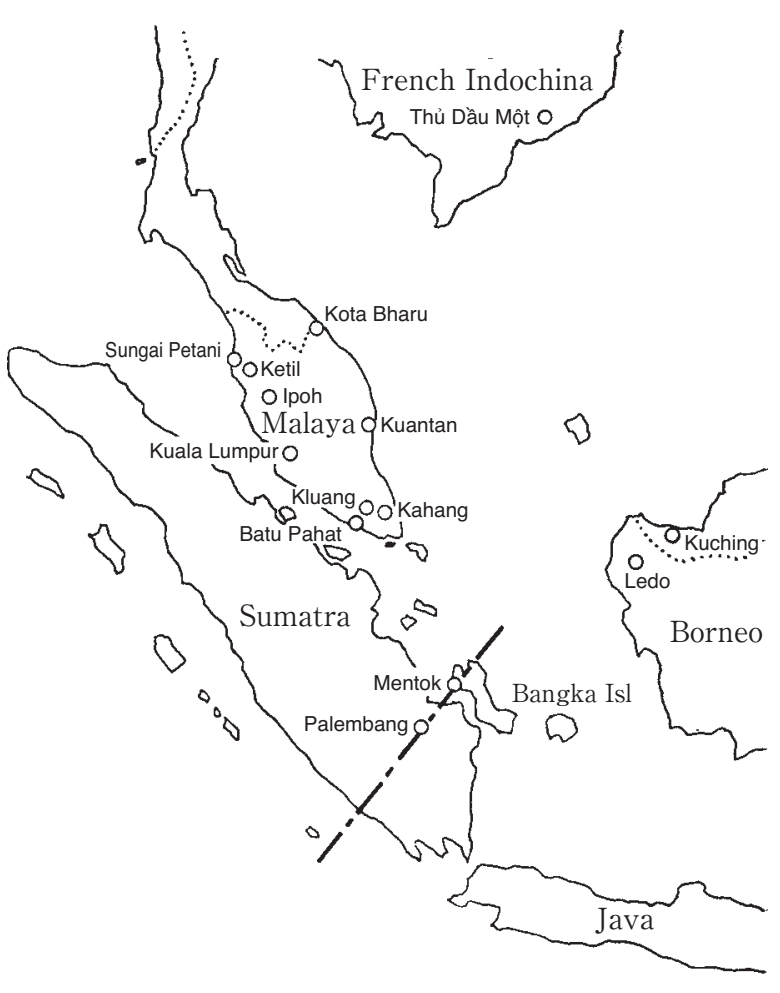

Illustration No. 24 - The Points Mentioned in the Arrangement on the Air [Operation in] Operation L

Army fighter planes: about 30 planes.

When possible, the Army shall assist the Navy in the transport of its aviation fuel. After that, the use of this [air] base shall be newly arranged between the Army and the Navy commanders concerned.

IV. Outline of the operation

1. We shall be determined to swiftly destroy the enemy air power in Sumatra as well as suppress the enemy air power in Java. The areas assigned to [the Army and the Navy] are roughly decided as follows. However, [both] shall attack the enemy in the other's area as occasion may require.

Navy: [the area] east of the line connecting Mentok and Palembang ([the line] included).

Army: [the area] west of the above-mentioned line ([the line] included).

2. The attack on enemy warships shall be charged to the Navy.

3. Covering of the convoy

(1) Under sail

(a) Direct cover provided on day L -1 by [both] the Army and the Navy fighter planes in conjunction shall be as follows:

Until 1400: the Navy.

From 1400 onwards: the Army. In case XX Unit (note by the author: the [paratroop] raiding group) is used, its cover [will be started] roughly from 1700 onwards.

In case XX Unit (note by the author: the [paratroop] raiding group) is used, the Navy fighter planes shall provide cover [for the convoy] on its own as much as possible.

(b) The guarding under sail other than the above shall be charged to the Navy. 
(2) At the anchorages for the Mentok and Palembang [operations], and while sailing upstream

The guarding against enemy aircraft after both the Army and the Navy fighter planes are advanced in the area shall be provided by both forces in conjunction; the guarding other than the above shall be assigned to the Navy.

(3) Support for ground operations and the operations to sail upstream

Support for the operations to sail upstream to Palembang shall mainly be assigned to the Navy. Support for ground operations after that shall be assigned to the Army. However, the Navy shall be charged with this [task] until the Army aircraft are advanced to the area.

V. Exchange of Information

The Army shall make efforts to reconnoiter the movements of the enemy air forces in the Batavia area and provide the Navy with the information.

\section{The 38th Division's Operation Plan}

As we have seen, the Sixteenth Army had received orders from the Southern Army to capture Southern Sumatra on 5 January, concluded a formal arrangement with the [Navy] Malaya Unit on 15 January, and had given its orders to the 38th Division on the 18th. The last had left Hong Kong on the 20th and reached Cam Ranh Bay on the 24th. Although the [original] schedule of its departure from Cam Ranh Bay had been set for 31 January, the departure had been postponed to 4 February as a result of the Manila Agreement (effective on the 28th).

We have also mentioned that [the Army Department of] IGHQ rated the military potential of the 38th Division very highly, ${ }^{(18)}$ but that at the same time it was deeply concerned about the loss the division might sustain during the [operation to] capture Hong Kong. ${ }^{(18)}$ Because of these concerns, IGHQ had never shown its intention of imposing a double duty on the division until after the capture of Hong Kong, even though it had already decided to impose the double duty on the 38th Division for both the capture of Hong Kong and the invasion of Java [as early as in] the summer of 1941 and ever since had strongly adhered to this fixed course of action. ${ }^{(18)}$ After the opening of hostilities, when the 38th Division had been about to cross over to Hong Kong Island on 17 December, after clearing away the strongholds on the Kowloon Peninsula, Staff Officer Takayama Shinobu had suggested at IGHQ that "the 38th Division should be given instructions about training for the next duty,"(9) but without giving any instructions, IGHQ had [only] closely watched the 38th Division's progress in its capture of Hong Kong. ${ }^{(18)}$ The division had taken control of Hong Kong on 25 December, grandly made a triumphal entry into Hong Kong on the 28th, and after that taken up the task of guarding, when suddenly on the 30th, the division had received orders to organize and dispatch the Eastern Detachment, which was followed by orders to have the Shōji Detachment join the Java operation and the main force of the division the Sumatra operation. ${ }^{(66)}$ By contrast, the 48th Division, which was another powerful division with a long history and brilliant military achievements, consisting of the 1st and 2d Taiwan Infantry Regiment, and the 47th Infantry Regiments (originally stationed in Ōita, Kyūshū), had been notified in the summer of 1941 that the division was scheduled to be "charged with [the duty to] invade Java, subsequent to the invasion of the Philippines." ${ }^{(80)}$ The different treatment of these divisions, i.e. whether they were informally notified or not, after all originated from the different expectations [which IGHQ had] of the capture of the Hong Kong stronghold and the field operations in the Philippines. ${ }^{(18)}$ 
The loss sustained by the 38th Division in the operation to capture Hong Kong was unexpectedly small; four hundred men were killed (among whom were thirty-five officers), and eight hundred men were wounded (among whom were fifty officers). ${ }^{(24)}$ The proportion of officers among the casualties was high; nevertheless, morale had risen even more. The ranks were replenished with men from the 104th Division [stationed] in the Guangdong sector. ${ }^{(24)}$

Having handed over the Eastern Detachment and the Shōji Detachment, a total of five infantry battalions as the core, that is, the 38th Infantry Group headquarters, the 228th Infantry Regiment, the 230th Infantry Regiment (minus the 3d Battalion), one battalion and one company of the 38th Mountain Artillery Regiment, one company of the 38th Engineer Regiment, one company of the 38th Transport Regiment, one-third of the medical unit, and one element of one field hospital, the force kept by Division Commander Sano consisted of four battalions as the core. ${ }^{(6)}$ [Additionally,] one independent motor transport battalion, one shipping engineer regiment, one anchorage headquarters, one sea transport unit, one oil-drilling unit, one railway unit platoon and one shore duty company were brought under the control of the division. ${ }^{(66)}$

Regarding the allied forces in Sumatra, the following intelligence had been acquired: "It appears that about ten thousand troops of the Dutch East Indies Army have been deployed in Sumatra and stationed by about one battalion in each vital location. It also appears that elements of British and Australian forces have entered the island;" "Ground forces in southern Sumatra are estimated at about three thousand men;" "In Palembang and its vicinity, there seems to be the Palembang-Jambi territorial headquarters (commanded by a colonel), [one] infantry battalion (commanded by a lieutenant colonel and made up of two to three companies), machine gun(s), some infantry artillery, four to five light tanks, antiaircraft artillery and some aircraft." $(23,24)$

As for maps and charts, a map on a scale of 1 to 1,000,000, a map of southern Sumatra on a scale of 1 to 500,000, a map of Palembang and its vicinity on a scale of 1 to 50,000, a hydrographical chart of the Musi River, aerial photographs of Palembang and others had been distributed. ${ }^{(66)}$ Regarding the topography, the 38th Division possessed more or less the following information:(66)

There are many swamps and woods in the vicinity of Palembang, which in general makes offroad passing not easy. Railways have been laid between Palembang and Telukbetung, and between Palembang and Lubuklinggau, but their capacity is unknown. There is a railroad workshop in Lahat.

A motorway runs alongside the railroad from Palembang to Martapura and Tanjungkarang, and another runs between Palembang, Lahat and Lubuklinggau. Other motorways than the above are unknown.

The Musi River allows 5,000 to 6,000-ton-class ships to navigate up to the vicinity of Palembang. However, it is difficult unless around high tide as there are shoals around its estuary. The current is slow. The Saleh River is navigable for landing boats up to [the point] near Martapura, and the Telang River up to [the point where] it joins the Musi River.

There are motor vehicles and boats available in Palembang and its vicinity, but their numbers are unclear. Oil sources are located in Jambi, Sekayu, Tebatagung, and Lahat, and oil is conveyed to Palembang through iron pipes.

The main facilities of Palembang include barracks (northwest of the city of Palembang), the Sungaigerong oil refinery (about five kilometers east of the city), the Plaju oil refinery (about five kilometers east of the city) [editor's note: the Japanese text has an unidentifiable place name, which is probably a misreading for "Plaju"], the north Palembang airfield (about ten kilometers 
northwest of the city) and the new Palembang airfield (somewhere in the middle between the city and the north airfield, but its exact location is unknown).

\section{The 38th Division's Tough Job}

As previously explained, it is no exaggeration to say that the Greater East Asian War was launched for the oil in Palembang. It was one of the main missions of the Southern Army to occupy Palembang at an early stage before [the facilities] were destroyed by the allied forces. However, as the Palembang airfield was a superior airfield, the Palembang [operation] also became inextricably linked to [wider] strategic factors, which chiefly concerned the advancement of the Java operation. [As a result, the Palembang operation] became entwined in a tangle of desiderata: ${ }^{(28)}(1)$ the wish to safely get hold of the oil resources at an early stage, for which purpose the location should be securely seized in a surprise attack prior to the capture of Singapore; (2) the wish to carry out the landing operation of Operation L safely and soundly by seizing the Palembang airfield in a surprise attack beforehand; (3) the wish to facilitate [the operation to] capture Singapore as well as to cut off the allied forces' retreat from the city by seizing the Palembang airfield before the capture of Singapore and isolating the latter, and at the same time, the wish to quickly launch air operations against Java by seizing this airfield. However, the following matters also greatly affected [the planning]:(28) (1) as there was a limit to the capacity of the [Paratroop] Raiding Group, the unit could not be left isolated in enemy territory for a long time; (2) and yet, early departure of the convoy of the 38th Division would give a clue to the plan beforehand; (3) and still more, beyond reason or logic, there was the wish to make Singapore fall by Empire Day, i.e. 11 February. The Southern Army had painstakingly drawn up the following plan: ${ }^{(28)}$

4 February Departure of the advance party of the 38th Division from Cam Ranh Bay. 5 February

6 February Departure of the main force of the 38th Division from Cam Ranh Bay.

7 February The Twenty-fifth Army's ([consisting of] the Imperial Guard Division, the 5th, and the 18th Divisions) crossing at night of the Johor Strait and landing [on Singapore Island].

8 February Day 1 of the attack on the Singapore stronghold.

9 February Day 2 of the attack on the Singapore stronghold; drop of the 1st [Paratroop] Raiding Group on Palembang.

10 February Arrival of the advance party of the 38th Division in Palembang at night; day 3 of the attack on the Singapore stronghold; surrender of the British Forces.

11 February Empire Day; arrival of the main force of the 38th Division in Palembang.

As of 30 January, the Southern Army was worrying about the issue of how it should divide the limited strength of the 1st [Paratroop] Raiding Group between the oil resources of Palembang and the airfield. ${ }^{(28)}$ Commander in Chief [of the Southern Army] Terauchi also expressed his feelings that "the paratroop unit must not be made to fight until death." (30)

Whereas the Southern Army was having a hard time with strategic issues, the 38th Division, the unit to implement the [operation], had tactical issues to rack its brain over. Since before the opening of hostilities, the Dutch East Indies authorities had boasted: "We have 
500,000 tons of oil in storage in Palembang. If the Japanese forces should come up the river, we will release 10,000 ton of oil per day into the river, and burn up the convoy coming up the river." (36) [However,] there was no other way conceivable [to get to Palembang] than to ascend the river. Even if fire should not be set to released oil, it would still be easy [for the enemy] to position artillery and transfix the limited rivers leading to Palembang, or to install obstacles and blockade the waterway. Together with the Shipping Transport Command and others, the 38th Division conducted studies on the allied forces' [possible use of] illumination, ground fire, underwater obstacles, setting fire to released oil and attacks by small warships or torpedo boats, [and also on] treacherous tidal currents, changes of water depth due to the tides, waves and whirlpools, reefs, shoals, narrowing waterways, branching waterways, mazes and all other kinds of inhibitory factors, and prepared countermeasures. ${ }^{(27)}$ It was decided to first send forward the advance party, which operated more lightly, so that the exposure to the allied forces of the convoy sailing from Cam Ranh Bay was minimized. ${ }^{(66)}$ [Also,] in order not to leave the Paratroop Raiding Group, which was to seize the refineries and the airfield in Palembang before they were destroyed and burned by the allied forces, isolated too long in enemy territory, [the 38th Division] wanted to plan the operation in such a way that [the division] could conduct it lightly and swiftly by seizing Mentok, the eye of the estuary, in a sudden attack, and keep the ascent to Palembang concealed as long as possible. Consequently, assuming that the paratroop unit would parachute down in Palembang at 1130 on day $\mathrm{L}-1$, a plan was drawn up in which the convoy of the advance party would enter the anchorage off Mentok and off the estuary on that night, and that before dawn on the following day (day L) an element would go ashore in Mentok by making a surprise attack, while by about the same time, the main force would reach the mouths of all (three) usable rivers, start navigating up these three rivers by motorized boats at daybreak, reach Palembang by the evening of the same day and support the paratroop unit. ${ }^{(66)}$

The 38th Division planned the operation in outline as follows: ${ }^{(96)}$ (See Illustrations No. 29 and No. 30)

1. Disposition of forces

Advance party (in 8 transport ships)

Commander: Col. Tanaka Ryōsaburō, 229th Infantry Regiment commander.

Mentok Landing Unit

Commander: Capt. Orita Masaru, 229th Infantry Regiment 1st Battalion commander, [consisting of] one half infantry battalion as its core.

Musi River Ascending Unit

Commander: Col. Tanaka Ryōsaburō, 229th Infantry Regiment commander, [consisting of] one infantry battalion and one battery as its core.

Saleh River Ascending Unit

Commander: Lt. Col. Iwabuchi Tsuneo, 38th Engineer Regiment commander, [consisting of] one infantry company, one battery and one engineer company as its core.

Telang River Ascending Unit

Commander: Maj. Miyazawa Shigezō, 229th Regiment 2d Battalion commander, [consisting of] one half infantry battalion and one artillery section as its core.

Main force of the division (in 14 transport ships)

[Consisting of] two infantry battalions, one artillery battalion and one engineer company as its core.

2. Outline of the conduct of the operation 
(1) The Mentok landing unit shall carry out a surprise landing on the shore south of the Mentok airfield at around 0300 on day L. It shall first seize the airfield and make it ready for use, after which it shall seize strategic points on Bangka Island.

(2) Units to go upstream to Palembang (the Musi, the Saleh and the Telang Ascending Units) After transferring to boats at the Mentok anchorage, the main force of the advance party shall start going upstream around 0700 on day L, [divided into] the Musi, the Saleh and the Telang Ascending Units. In cooperation with the [Paratroop] Raiding Group, they shall first seize resources and important facilities in Palembang and its vicinity.

(The Navy shall be charged with clearing the waterway of the Musi River up to three [nautical] miles upstream of the Palembang railway wharf, using one large-sized motorized [landing] craft and ten small-sized motorized [landing] craft. When the waterway is cleared, six transport ships shall ascend the Musi River to Palembang.)

After that, the Martapura and the Tanjungkarang airfields as well as the oil producing regions around [Talang] Abab and Limau shall be swiftly seized, and also preparation for [the operations] to mop up enemy naval bases in Lampung and Semangka Bays shall be made. The seizure of Martapura and Tanjungkarang are scheduled for day L +6 and day L +9 respectively.

(3) The main force of the division shall reach the mouth of the Musi River on day L +2 , ascend the Musi River in its [transport] ships as they are, go ashore in Palembang and vicinity and extend the military gains of the advance party.

3. The airfield units and aviation matériel that will accompany the 38th Division shall be as shown in Separate Sheet No. 1.

4. The sailing route plan of the 38th Division is as shown in Separate Sheet No. 2. (Omitted by the author.)

Separate Sheet No. 1: The deployment plan of air ground support units for Operation L

\begin{tabular}{|c|c|c|}
\hline Units & Mentok & Palembang \\
\hline $\begin{array}{c}\text { 7th Airfield Company } \\
\text { (heavy bombers) }\end{array}$ & entire force \\
\hline $\begin{array}{c}\text { 33d Air[field] Company } \\
\text { (fighter planes) }\end{array}$ & onout two-thirds & about one-third \\
\hline $\begin{array}{c}\text { Elements of the } \\
\text { 25th Air Signal Unit }\end{array}$ & $\begin{array}{c}\text { one meteorological } \\
\text { observation detail }\end{array}$ & one squad \\
\hline $\begin{array}{c}\text { Elements of the } \\
\text { 2d Field Meteorological Company }\end{array}$ & $\begin{array}{c}\text { 1. In case it is difficult to use the Mentok airfield, a part or the greater part } \\
\text { of the force may be transferred to Palembang. } \\
\text { 2. Aside from [units indicated in] this table, about 1,800 coolies will be trans- } \\
\text { ported, of which 1,000 will be posted in Mentok and 2,000 in Palembang } \\
\text { (note by the author: the numbers, which do not tally, are true to the orig- } \\
\text { inal document). }\end{array}$ \\
\hline
\end{tabular}




\section{The [Southern Army's] Decision to Employ the [Paratroop] Raiding Group Mainly for [the Seizure of] the [Palembang] Airfield; the 38th Division's Arrangements with the [Navy] Malaya Unit}

On 31 January, the Southern Army Staff Officers Arao Okikatsu (lieutenant colonel, chief of operations) and Matsumae Misoo (lieutenant colonel, aviation staff), and the Sixteenth Army Staff Officers Itoda Osamu (lieutenant colonel, chief of aviation) and Saiki Ikuzō (lieutenant colonel, chief of signal communications) went from Saigon to Cam Ranh Bay, where in the morning, on board the flagship of the First Southern Expeditionary Fleet, the Chōkai, they concluded arrangements on the air [operations] for Operation L, and also in the afternoon on the same ship attended the [conclusion of] the arrangement between the 38th Division and the First Southern Expeditionary Fleet. ${ }^{(34)}$

In the arrangements for the air [operations] made in the morning, the deployment of the 1st [Paratroop] Raiding Group was decided upon. As mentioned earlier, the Southern Army had been thinking hard about the problem of where it should mainly use the 1st [Paratroop] Raiding Group, as the latter's strength and capacity were limited: for the seizure of the airfield or for the seizure of the oil refineries. Staff Officer Arao, in line with the thinking of Commander in Chief Terauchi, stressed that the group should mainly be employed for the seizure of the airfield. ${ }^{(28)}$ That night the Southern Army gave orders to the Third Air Force and the 1st [Paratroop] Raiding Group, by which it brought the 1st [Paratroop] Raiding Group (which had formerly been under the direct command of the Southern Army) under the command of the Third Air Force commander, and ordered the Third Air Force commander to carry out the parachute drop operation on Palembang, giving priority to the seizure of the airfield. Staff Officer Arao recorded it in his journal as follows: ${ }^{(24)}$

Attended the preliminary arrangement between the First Southern Expeditionary Fleet and the 38th Division in Cam Ranh.

1. I stressed that the seizure of the airfield was the primary operational objective, and that the seizure of the Palembang oil field came next (as the landings will [probably] overrun their schedule).

2. Advance Party: Two battalions of the 229th Infantry [Regiment]. The Orita Battalion ([consisting of] two companies) [will be assigned] to occupy Mentok. The main force will depart at 0330 on day L in large- and small-sized motorized [landing] craft. In ascending the Musi River, [the unit] shall be divided in three groups [to go up different routes] and advance to Palembang at daybreak on day $\mathrm{L}+1$. [This operations will be conducted in] twelve extra-large-sized motorized [landing] craft, twenty-five large-sized motorized [landing] craft, eighteen small-sized motorized [landing] craft, and for use by the Navy two large- and thirteen small-sized motorized [landing] craft. In total: twelve extra-large-sized motorized [landing] craft, twenty-seven largesized motorized [landing] craft, and thirty-one small-sized motorized [landing] craft.

3. Main force: in eight extra-large-sized motorized [landing] craft

4. Five small cargo ships: [shall] assemble at Cap Saint Jacques at noon on 1 February, and arrive at the Mentok [anchorage] around 1200 on day L via the Anambas.

5. Sixty to seventy fishing boats [shall] leave Cap Saint Jacques on 5 February, and arrive on 15 February. Ship captains need to be given training to ascend rivers. The 38th Division has [already] considered which unit will handle the emergency when the waterway is blocked.

Success is imperative. We have to expect [some] loss of transport ships.

6. [The Southern Army] shall clearly state in its Operation Order A, No. 47 that in the use of the [Paratroop] Raiding Group priority should be given to the seizure of the airfield. 
The order, which the Southern Army issued on this day, specifying the seizure of the airfield as the priority for the [Paratroop] Raiding Group, read as follows: ${ }^{(96)}$

Southern Army Operation Order A, No. 48

\section{Southern Army Order}

Saigon, 31 January

1. Hereafter the 1st [Paratroop] Raiding Group shall be put under the command of the Third Air Force commander.

2. The Third Air Force commander shall employ the 1st [Paratroop] Raiding Group for the purpose of Operation L in the following way:

(1) The 1st [Paratroop] Raiding Group shall seize the Palembang airfield in order to facilitate Operations $\mathrm{L}$ and $\mathrm{H}$, and if possible, it shall [further] seize and secure the oil refineries in Palembang before the enemy destroys them.

(2) Time of execution of the first drop and/or landing shall be the morning of day L - 1. If weather conditions do not allow this, execution shall be aborted.

(3) The parachute unit and/or landing unit shall be put under the command of the Sixteenth Army commander on the arrival of the main force of the 38th Division in Palembang.

(4) When Operation L is completed, the 1st [Paratroop] Raiding Group (with the exception of the parachute and/ or landing unit) shall be returned to the unit to which it originally belongs without separate orders.

It is no exaggeration to say that the Greater East Asia War broke out with oil as the main cause. In order to seize Palembang, the biggest oil resources in the Dutch East Indies, the Army had [specifically] started to prepare the employment of the 1st [Paratroop] Raiding Group, which was the only one of its kind. And, in order to make the surprise parachute drop a success, the announcement of the Navy's earlier employment of its paratroop unit in Menado (11 January) had been suppressed. Why then did it give the order to "seize the airfield first, and the oil refineries [only] if possible"? The [main] reasons were the following:(28)

1. Due to circumstances that will be explained later, the Southern Army considered the seizure of the Palembang airfield absolutely imperative for strategic and tactical reasons. Furthermore, following the wishes of IGHQ, the army had also decided that it definitely had to seize the oil refineries in Palembang as well. However, due to the timing [of the operation], the air power and the military capacity of the [paratroop] raiding group had their limits. This led to the decision to carry out paradrops on both the airfield and the oil refineries, but with priority on the airfield.

2. The Palembang airfield was large to the extent that one could say that no other airfield in central or southern Sumatra could match it in size, and thus the Southern Army approached the seizure of this airfield with grim Chief of the Army General Staff Sugiyama disembarking at determination.

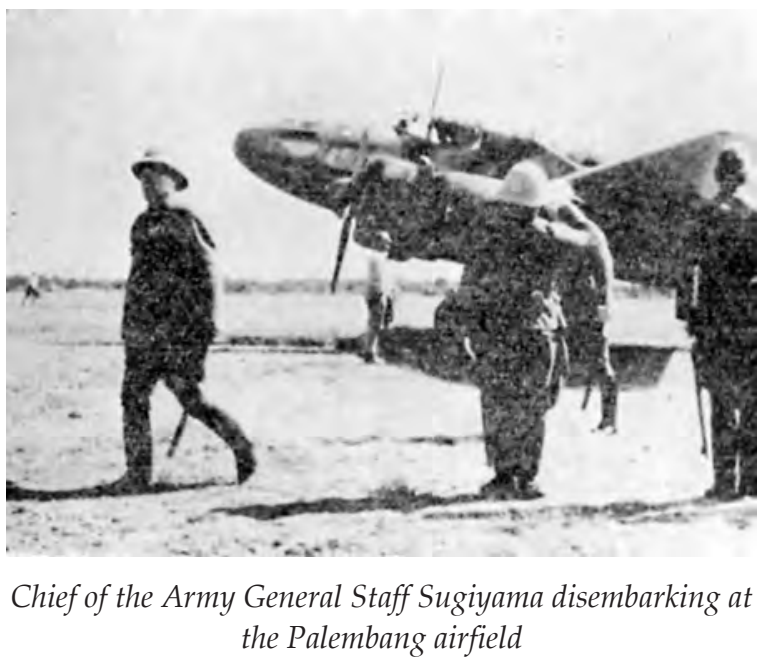


The words recorded in the aforementioned journal of [Staff Officer] Arao that "We have to expect [some] loss of transport ships," reflect how keenly the Southern Army at that time actually felt about [the operation to seize] the Palembang airfield.

In the study that the Southern Army had conducted on the southern operation with the Second Fleet in early November of the previous year, it had realized that "whereas brazen transports in large convoys and bold landings may be possible in the surprise (sudden) attack operations in the Philippines and northern Malaya in the early stages after the opening of hostilities, around the time of the Bangka and Palembang operations, the allied forces will probably have recovered themselves and launch a counteroffensive with superior power. At that time, advancing in convoys may be impossible, and it is imaginable that [attack operations] will have to be made in large- and small-sized motorized [landing] craft."

Now, the Southern Army felt that it faced a situation similar to the one described above, and about which it had been worried [since] before the opening of hostilities. As mentioned previously, the Southern Army judged that about five-hundred aircraft were currently [deployed] in the Dutch East Indies, among which were dozens of B-17s and B-24s. On top of that, also one hundred and some dozen British aircraft were present. It goes without saying that it worried about the fact that the allied forces still had many aircraft, but the Southern Army was especially deeply concerned about the B-17s and B-24s, for it had learned that in the Celebes theater the [Navy] Type-0 fighter planes had been powerless against the B-17 and B-24 flying fortresses.

On 17 January three B-24s and two B-17s had flown in for an attack over Menado (the northern tip of Celebes), which [Japan] had seized on 11 January. Seven [Navy] Type0 fighter planes had intercepted them but failed to bring them down. The Eleventh Air Fleet reported the following points as lessons [learned in] combat: ${ }^{(134,141)}$

(1) The B-24 and B-17 models that have newly appeared are both very strong in their armored protection. Each Type-0 fighter plane fired all the bullets it had at close range, but failed to bring them down. It is necessary to increase as quickly as possible the power of our fighter planes' armor-piercing ammunition and also to increase the amount of 20-mm. ammunition loaded on each aircraft.

(2) It is conceivable that from now on the allied forces will fly these models to Australia to reinforce their strength. It is necessary to intensify our operations to intercept them.

(3) Judging from the circumstances when the Type-0 fighter planes pursued [the enemy aircraft] for two hundred nautical miles, we consider that the allied forces are using [bases in] Java, Timor and other areas.

(4) In order not to be attacked out of range (i.e. from [bases] whose distances exceed our flying range) it is necessary for us to have large attack planes ready.

The Southern Army was deeply concerned that allied aircraft, including the dozens of "fortresses of the sky," against which the Japanese fighter planes had been powerless, would conduct furious attacks from Palembang. Moreover, [if seized and used,] the Palembang airfield would enable [the Army] to forestall the retreat of the allied forces in the Singapore area as well as to conduct attacks on Java. From a strategic and tactical [viewpoint], the Southern Army regarded it as absolutely necessary to make a surprise attack and seize this airfield. 
As for the oil refineries, in view of the earlier examples of Tarakan, Balikpapan and others, the Southern Army expected a certain degree of destruction [of facilities] by the allied forces. However, the Army [also] knew that it was impossible [for the allied forces] to completely destroy [these oil facilities].

Taking these characteristics of the airfield and the oil refineries, and the capacity of the [Paratroop] Raiding Group into account, the Southern Army issued the aforementioned order.

3. Another reason was the fact that the [Japanese] air units and the [paratroop] raiding group had limits to their capacity due to the factor of timing.

Although the Southern Army had the Third and the Fifth Air Forces under its command, the army had to simultaneously carry out Operation L, the Singapore operations and the operations in the Burma area. In particular, it was difficult to carry out Operation $\mathrm{L}$ and the capture of the Singapore stronghold at the same time. The state of [progress of preparation of the seized] airfields was [delayed] as Staff Officer Saitō had described in his above-mentioned telegram. And also for the [Navy] Malaya Unit, the state of the airfields in Kuching and Ledo was [deplorable] as has been explained before. If Japan had had enough aircraft and airfields available, and if it had been an operation to be conducted after the Palembang [airfield] was rendered powerless, it could have focused on [the operation to seize] the oil refineries. However, that was not the case.

The 1st Raiding Group was also in a difficult situation. The shipwreck of the 1st Raiding Regiment and its subsequent state was as described before, and it turned out to be impossible to use [the regiment for the operation] after all. The decision was made to employ the 2d [Paratroop] Raiding Regiment [instead]. However, as mentioned above, the regiment had just arrived, and its level of training was insufficient. [So,] Colonel Kume, commander of [the 1st Paratroop] Raiding Group and Sixteenth Army Staff Officer Lieutenant Colonel Itoda resolved to accompany the 2d [Paratroop] Raiding Regiment, and perform a belly-landing [with their aircraft] at the time of the parachute drop of the regiment (neither officer had parachute experience). Because of these limits to the capacity of the [Paratroop] Raiding Group, the Southern Army had made the decision that the oil refineries should be "seized and secured, [only] if possible."

4. The factor which fundamentally affected the employment of the [Paratroop] Raiding Group this time was the timing [of the operation].

The prime factor in the timing [of the operation] was the Southern Army's firm determination to "resolutely carry out [the operations] according to the schedule set in the Manila Agreement." At the root of this determination of the Southern Army were its sense of duty that "the schedule set in the Manila Agreement should be accomplished by all means because the schedule had been reported to IGHQ;" its judgment of the situation that "Java should be taken in strategic pursuit, while taking advantage of the state of the war;" its philosophy regarding the Army and the Navy's joint operations that "these should be carried through with unshakeable faith;" and its faith as supreme commander in the units under its command.

The second factor was the [timing of the operation] in relation to the Singapore [operation], that is, the parachute drop had to be carried out right before the fall of Singapore, and the 38th Division had to be put ashore in connection with the drop. These aims and their relation to the schedule have already been explained. 
The Southern Army approached the [Navy] Malaya Unit and the Sixteenth Army with the unshakeable faith that the operations demanded such timing.

[On the other hand,] the Malaya Unit looked at it in a way quite different from the Southern Army. That is, whereas the Southern Army's point of view was that "the timing must not be delayed, and for that, we will move on as soon as the airfields are ready for use," the [Navy] Malaya Unit's point of view was "to [first] beat the enemy before moving on." As described earlier, on 31 January the arrangements on the air [operations in] Operation $\mathrm{L}$ as well as "the arrangements for Operation L between the 38th Division and the [Navy] Malaya Unit" were concluded. On the same day, the Southern Army gave order(s) concerning the [Paratroop] Raiding operation. However, the Classified [Navy] Malaya Unit Operation Order No. 17 (note: the order to execute the Bangka and Palembang operations), which Malaya Unit Commander Vice Admiral Ozawa passed down on the next day (1 February) read as follows:

This operation shall be swiftly launched the moment the enemy air power in the Malaya area, eastern Sumatra, western Borneo and western Java has generally been brought under control. ${ }^{(130)}$

Earlier (just before the opening of hostilities), when the issue had arisen whether the landing of an element of the Twenty-fifth Army in Kota Bharu should be carried out simultaneously with the landings in Singora and other points in Thai territory, and the Navy Department of IGHQ and the Combined Fleet had shown disapproval because of the risks involved, Commander in Chief Ozawa had nevertheless, once it became his decision to make, resolutely and clearly supported the plan and thereby deeply impressed the Twenty-fifth Army, the Southern Army and the Army Department of IGHQ. Even though this very man, this very Commander in Chief Ozawa, [now] showed a [more cautious] way of thinking, as seen in the above-mentioned order, the Southern Army would not hear of any delay at all in the timing [of the operation].

Also, [Sixteenth] Army Commander Imamura, who was widely known for his bravery as a commander with a resolute and indomitable fighting spirit, and who was particularly famous for the great authority he had shown on the battlefield in Nanning, southern China, as commander of the 5th Division, [had shown his concern] when he had a proposal submitted to the Southern Army staff to reinforce the escort strength. But the Southern Army staff [had dismissed the proposal even from such a man] by simply saying that he should trust the strength of the escort of the Navy, as we have seen.

All this was based on the Southern Army's belief that "No postponement of the timing [of the operation], nor [too much] cautiousness should be allowed."

5. In short, in relation to the timing of the attack on Singapore, [factors such as] the current superiority of the allied air forces, in particular the threat of the "Fortresses in the Sky," progress in the reinforcement of the allied forces in the Sunda Islands, and the current progress in the preparations for the attack on Singapore made [the Southern Army] think that it was imperative to seize the Palembang airfield without delay in a sudden attack. On the other hand, in view of the specific character of the southern operation and of the intentions of IGHQ, [also] the Palembang oil refineries were targets, which had to be seized in a paratroop operation. Because of the demands of the timing [of the operation], the Japanese air operations had to make do with insufficient operational forces and in- 
sufficient preliminary attacks, and they also had to be conducted with insufficient paratrooper strength. It was highly risky to let the convoy of the 38th Division proceed under insufficient air support, and although resigned "to expect [some] loss of transport ships," this [again] made [the Southern Army] attach all the more importance to the necessity of seizing the Palembang airfield in a paradrop raid. The judgment regarding the oil refineries was as previously explained. All this resulted in the decision to drop the [Paratroop] Raiding Group on both the Palembang airfield and the oil refineries on day L - 1, with the airfield as the primary objective.

Note: The convoy of the 38th Division consisted of eight ships for the advance party and fourteen ships for the main force, a total of twenty-two ships. Further, anticipating the difficulties of sailing upstream and landing, seventy motorized [landing] craft as well as sixty to seventy fishing boats or small cargo ships were made ready. In order to have the convoy safely reach [the waters of] southern Sumatra and [successfully] carry out the upriver sailing, the landing, and the disembarkation while removing underwater obstacles, it was a matter of course to deny the allied forces the use of the Palembang airfield, but it was also necessary to swiftly have Japanese air units advance to the airfield.

\section{The Arrangements Between the 38th Division and the [Navy] Malaya Unit}

Following the arrangements on the air operations between the Southern Army and the [Navy] Malaya Unit (the First Southern Expeditionary Fleet) on the morning of the 31st, in the afternoon, arrangements were made between the 38th Division and the Malaya Unit, which were roughly as follows: ${ }^{(96,118)}$

\section{Forces}

(1) The Army: 38th Division

(a) Advance party: two infantry battalions and two batteries as the core, [in] eight ships. Mentok landing unit: one-half infantry battalion as the core.

River-ascending Unit [toward] Palembang: one-and-one-half infantry battalion and two batteries as the core.

(b) Main force: two infantry battalions and one artillery battalion as the core, [in] fourteen ships

(2) The Navy

(a) Forces to escort the advance party: the 3d Destroyer Squadron ([consisting of] one light cruiser (the Sendai) and four destroyers), a few minesweepers and submarine chasers.

(b) Forces to escort the main force: the Yura (light cruiser), the Shimushu (coastal defense vessel), four destroyers of the $3 \mathrm{~d}$ Destroyer Squadron and other small warships.

(c) Supporting surface forces: the main force of the surface unit of the Malaya Unit ([consisting of] five heavy cruisers (its flagship, the Chōkai, and [the cruisers] Kumano, Suzuya, Mikuma and Mogami of the 7th Cruiser Division), one aircraft carrier (the Ryūjō), two auxiliary seaplane tenders (the Kamikawa-maru and the Sagara-maru), six destroyers and others).

(d) Air force: the whole force of the 22d Air Flotilla.

(e) River-ascending Unit [toward] Palembang: the main force of the 9th Base Force ([consisting of] auxiliary minesweeper(s), guard ship(s), fishing boat(s) and others).

2. Schedule for the departure of the transport ships from the assembly point and the start of the landing (going upstream)

Advance party: 
Mentok Landing Unit ([in] two ships): shall depart from the assembly point in the evening of day L -6 , arrive at the Mentok [anchorage] before daybreak, and swiftly go ashore at Mentok.

River-ascending Unit [toward] Palembang ([in] six ships): shall depart from the assembly point in the evening of day $\mathrm{L}-6$, arrive at the Mentok [anchorage] before daybreak and, after changing to [landing] craft and reaching the mouths of the Musi, the Telang and the Saleh rivers, start going upstream early in the morning.

Main force ([in] fourteen ships): shall depart from the assembly point in the evening of day $\mathrm{L}-4$, and reach the mouth of the Musi River before daybreak on day $\mathrm{L}+2$.

Landing and debarkation is expected to take about ten days for the Mentok landing unit, and about two weeks for the River-ascending Unit [toward] Palembang and the main force of the division.

3. Support for the landing and disembarkation, and cooperation concerning the waterway of the Musi river

(1) A small Navy vessel shall lead the way when the advance party maneuvers craft from the Mentok anchorage to the mouth of [each] river to go upstream.

(2) Members of the Navy Special Minesweeping Unit shall borrow fifteen large- and small-sized motorized [landing] craft from the Army at the Mentok anchorage in which they shall clear the waterway of the Musi River and sweep the river sailing upstream from the river mouth up to Palembang.

4. Others

Details such as escort at sea, entry into the anchorage, guarding at the anchorage and the waterway shall be arranged between the 38th Division commander and the 3d Destroyer Squadron commander/9th Base Force commander.

\section{The [Navy] Malaya Unit's Orders; the Arrangements Made Between the 38th Division and the Navy Escort Force/ Navy River-ascending Unit}

In conformity with the arrangements made on the 31st, Malaya Unit Commander Vice Admiral Ozawa released the Plan for Operation L by means of [Malaya Unit] Operation Order No. 17 on the next day, 1 February, and ordered its execution. ${ }^{(115,118)}$ In this operation plan, Items 1 and 2 read:

1. Operational objective:

Consists in assisting the 38th Division to swiftly land in Bangka and Palembang and their vicinities, and seizing the key locations in these areas.

2. Mission:

(1) The operation shall be started swiftly when the enemy air power in the Malaya area, eastern Sumatra, western Borneo and western Java has largely been brought under control.

(2) The transport convoy shall be on standby in Cam Ranh Bay and at the right opportunity depart under the escort of the Escort Unit.

The distribution of forces, outlines of the tasks of each unit, signal communications, replenishment and the arrangements between the Navy and the Army were specified in Item 3 and below. ${ }^{(115,118)}$

The outline of the disposition of forces was as follows: ${ }^{(115,118)}$

Main Unit, under the direct command of the First Southern Expeditionary Fleet commander in chief: the Chōkai (heavy cruiser), the 7th Cruiser Division (four heavy cruisers), and five de- 
stroyers of the 3d Destroyer Squadron, [shall be charged with] support for the entire operation.

Escort Unit, led by the 3d Destroyer Squadron commander:

1st Escort Unit: [consisting of] the 3d Destroyer Squadron under the direct command of the $3 \mathrm{~d}$ Destroyer Squadron commander (minus eight destroyers) as the core, [shall be charged with] the direct escort of the advance party.

$2 \mathrm{~d}$ Escort Unit, led by the captain of the Yura: [consisting of] the Yura (light cruiser), two destroyers of the 3d Destroyer Squadron, the Shimushu (coast defense vessel) as the core, [shall be charged with] the direct escort of the transport convoy of the main force.

1st Air Unit, led by the 22d Air Flotilla commander: [consisting of] the 22d Air Flotilla, and the Kanoya Air Group (minus half of its strength) as the core, [shall be charged with] (1) destroying enemy warships, (2) destroying the enemy air power in the area east of Bangka and Palembang in Sumatra, western Borneo and suppressing the [enemy] air power in western Java, (3) escorting the transport convoy(s), (4) conducting the guarding over sea, and (5) preparing air base(s) in Malaya for use.

2d Air Unit, led by the captain of the Kamikawa-maru: [consisting of] the auxiliary seaplane tenders Kamikawa-maru and Sagara-maru as the core, [shall be charged with] (1) escort of the transport convoy(s), (2) conducting the guarding at the anchorages [for] the Bangka and Palembang [operations] and support for the operation to ascend the rivers [to] Palembang.

3d Air Unit, led by the 4th Carrier Division commander: [consisting of] the 4th Carrier Division (the aircraft carrier $R y \bar{u} j \bar{j}$ ), and one destroyer, [shall be charged with] attacking enemy warships.

River-ascending Unit [toward] Palembang, led by the 9th Base Force commander: [consisting of] the Hatsutaka, the Eikō-maru, the 91st Guard Unit, element of the 91st Signal Unit, the Special Minesweeping Unit ([made up of] the Rumoi-maru, the Otowa-maru, eight auxiliary guard ships, and four fishing boats), the Shimushu (after completion of its task in the 2d Escort Unit), [shall be charged with] (1) the operation to ascend the rivers up to Palembang, (2) minesweeping and guarding at anchorages [off] Bangka and at the mouth of the Musi River, depending on the circumstances.

(The rest omitted by the author)

\section{Arrangements Between the 38th Division, the Escort Unit and the Navy River-ascending Unit}

On 1 February, the 38th Division commander made arrangements on the details [of the operation] at Cam Ranh Bay with R. Adm. Hashimoto Shintarō, commander of the Escort Unit ([and also] 3d Destroyer Squadron commander), and R. Adm. Hiraoka Kumeichi, commander of the [Navy] River-ascending Unit ([and also] 9th Base Force commander). The outline was as follows: ${ }^{(118)}$

1. Distribution of the transport convoy and the commanders whereabouts

Advance Party:

1st Section: (1)(2) the Tajima-maru (with 38th Engineer Regiment Commander Iwabuchi on board), (2)(3) the Tacoma-maru, (3)(4) the Mansei-maru, and (4)(5) the Ōyō-maru (with Battalion Commander Miyazawa on board).

2d Section: (5)(?) the $A n^{\prime} y \bar{o}-m a r u$ (with Battalion Commander Orita on board), (6)(?) the Alaska-maru, (7)(1) the Kinugawa-maru (with 229th Infantry Regiment Commander Tanaka on board), and (8)(6) the Sado-maru (air defense ship).

1st Escort Unit Commander Rear Admiral Hashimoto will be on board of the Sendai, and [Navy] River-ascending Unit Commander Rear Admiral Hiraoka on the Hatsutaka. 
Main Force:

3d Section: (9)(1) the Argun-maru, (10)(2) the Singapore-maru, (11)(3) the Shinkyo-maru, (12)(4) the Rakuyō-maru, (13)(5) the Lima-maru, (14)(6) the Gin'yō-maru (with Division Commander Sano on board), and (15)(7) the Tsushima-maru.

4th Section: (16)(8) the Meigen-maru, (17)(9) the Taketsu-maru [Buyō-maru?], (18)(10) the Kenzui-maru, (19)(11) the Makassar-maru, (20)(12) the Shinsei-maru No. 1, (21)(13) the Fusōmaru (hospital ship), and (22)(14) the Hirokawa-maru (air defense ship).

2d Escort Unit Commander [Navy] Captain Miyoshi will be on board the Yura.

Note: The first parentheses ( ) represent the ship's number, and the second parentheses ( ) the order of ships in ascending the Musi River.

2. Disposition of forces of the Landing Units

Advance Party (Commander: Colonel Tanaka)

Mentok Landing Unit: [consisting of] one half of infantry battalion, led by Captain Orita (on board the $A n^{\prime} y \bar{o}-m a r u$ ).

Musi River Ascending Unit: [consisting of] one infantry battalion and one battery, led by Colonel Tanaka (on board the Kinugawa-maru).

Saleh River Ascending Unit: [consisting of] one infantry company, one battery, and one engineer company, led by Lieutenant Colonel Iwabuchi (on board the Tajima-maru).

Telang River Ascending Unit: one-half infantry battalion, and one artillery section, led by Major Miyazawa (on board the Ōyō-maru).

Debarkation Operation Unit: [consisting of] twenty-seven large-sized motorized [landing] craft, thirty small-sized motorized [landing] craft, and four extra-large motorized [landing] craft, led by Lieutenant Colonel Morimoto.

Main Force (Commander: the 38th Division commander)

[Consisting of] two infantry battalions, one artillery battalion, and one engineer company

3. Date of the transport convoy's departure from the assembly point, date and time to start landing (going upstream) and the landing schedule

Advance Party

Mentok Landing Unit ([in] two ships): [shall] depart from Cam Ranh Bay at 1900 on day $\mathrm{L}-6$, arrive at the Mentok [anchorage] at 0000 on day L, and start landing around 0200 on day L. The landing shall be complete in about ten days.

River-ascending Unit [toward] Palembang ([in] six ships): The same as the above for the time of departure from Cam Ranh Bay and arrival at the Mentok [anchorage]. After arriving at the Mentok [anchorage], the units shall reach the mouths of the Musi, the Telang and the Saleh Rivers around 0700 on day L by maneuvering [landing] craft, and each start ascending the rivers. The transport ships shall change their anchorages to the mouth of the Musi River at an appropriate time and sail upstream to Palembang, as soon as the waterway of that river is cleared. The landing shall be completed in about two weeks.

Main Force ([in] fourteen ships)

[Shall] depart from Cam Ranh Bay at 1800 on day L - 4, and arrive at the mouth of the Musi River about day $\mathrm{L}+2$. The landing shall be completed in about two weeks.

4. Reconnaissance of the landing points and the rivers to ascend

No reconnaissance shall be undertaken other than covert aerial photo-reconnaissance by Army and Navy aircraft.

5. Escort at sea

(1) Forces to be employed for escort

(a) Forces to be employed for direct escort

1st Escort Unit: the 3d Destroyer Squadron ([made up of] the Sendai, the 11th Destroyer Division, and the Asagiri), 1st Minesweeper Division, 11th Subchaser Division (minus 
Subchaser No. 9). [Editor's note: The text says "Minesweeper No. 9," which is a mistake. See also under 2d Escort Unit below.]

2d Escort Unit: the Yura, the Shimushu, the 20th Destroyer Division (minus the Asagiri), the Shonan-maru No. 7, the Shonan-maru No. 12, and the Subchaser No. 9.

(b) Forces to be employed for indirect escort: the Hatsutaka and the Eikō-maru

(2) Navigation

(a) Navigation route: as shown on the separate drawing (omitted by the author).

(b) Navigation speed: eight knots normal speed.

(c) Navigation formation: as shown on the separate drawing (omitted by the author).

(3) Outline of escort

6. Entry into the anchorage

(1) Anchorages and the formation at the anchorage: as shown in the separate drawing (omitted by the author).

(2) Outline of entry into the anchorages

(a) Formation to enter the anchorage: as shown in the separate drawing (omitted by the author).

(b) The command to "get into formation to enter the anchorage" shall be given two hours before anchoring, and the minesweepers shall start clearing the route ahead as soon as they are ready. When sailing at a very low speed, the transport ships shall navigate while steering clear of mines.

7. Landing under combat conditions and cover

(1) The landing attack in Mentok [shall be made] as a surprise landing in principle. However, it will be carried out by assault while eliminating attacks of enemy army, naval and air forces, if the situation should require it.

(2) Landing cover: No naval bombardment shall be conducted.

(3) Support for debarkation operations

(a) The Navy

At [the anchorages of] Mentok and at the mouth of the Musi River, subchasers and auxiliary minesweepers shall provide guarding and relief in the waters in and around the transport convoy anchorage.

At the Mentok [anchorage] on the early morning of day L, the transport ships will change anchoring spots, and minesweeping shall be conducted.

When the river-ascending unit [toward] Palembang of the advance party maneuvers its [landing] craft towards the Musi, the Telang and Saleh Rivers from the Mentok [anchorage], two small warships shall lead the way up to the mouths of the rivers above.

Assembly points for the [landing] craft units shall be [the side of] the Kinugawa-maru for the craft heading for the mouths of the Musi and the Telang Rivers, and [the side of] the Tajima-maru for those heading for the mouth of the Saleh River.

The expected time of departure from the assembly points (along the ships' side) shall be about 0300 .

(b) The Army

The Army shall assist the debarkation of seaplane base equipment from the Eiko-maru at Mentok.

8. Coordination between the Army and the Navy in the Musi River waterway

(1) After anchoring at the Mentok [anchorage], the Eikó-maru shall promptly dispatch crew for nine small-sized motorized [landing] craft to the Kinugawa-maru, and those for one largeand one small-sized motorized [landing] craft to the Ōyo-maru, to receive [a total of] one large-sized motorized [landing] craft (including engine operators) and ten small-sized motorized [landing] craft from the Army. These landing craft will be returned to the Army near the station pier of Palembang once the clearing of the waterway is completed. 
(2) Zone to be cleared: The naval river-ascending unit shall clear the waterway from the mouth of the Musi River to three nautical miles upstream of the Palembang railway wharf.

(3) Waterway guidance: Although no waterway guidance for the transport ships will be provided in the mouth of the Musi River in principle, the Navy shall provide guidance in dangerous areas as the occasion may demand.

(4) The naval river-ascending unit shall report the progress of [its operation to] clear the waterway to the Kinugawa-maru.

9. Signal communications (the rest omitted by the author.)

\section{The 38th Division's Order}

On 1 February, 38th Division Commander Sano concluded the above detailed arrangements, and on the next day, the $2 \mathrm{~d}$, he issued the following divisional order concerning Operation $\mathrm{L}:(69)$

Numa [38th Division] Operation Order A, No. 101

38th Division Order

Gin'yō-maru, Cam Ranh, 1800, 2 February

1. The [Sixteenth] Army shall destroy the enemy in the Dutch East Indies, seize its bases, and also secure key military locations and vital resource areas.

2. The division, in conjunction with the First Southern Expeditionary Fleet, shall capture southern Sumatra to secure oil resources. Further, it shall swiftly seize air bases in Bangka Island, Palembang, Martapura, and Tanjungkarang and their vicinities, make them ready for use, and also destroy enemy naval bases in Lampung Bay and Semangka Bay, to facilitate the army's subsequent operations.

The Third Air Force will closely cooperate with the division in executing the operation.

The memorandum of arrangements with the [Navy] 9th Base Force and the 3d Destroyer Squadron are as shown in the separate volume.

Five small cargo ships and about seventy fishing boats are expected to be newly allocated [to the division].

3. The advance party shall depart from Cam Ranh Bay on a date to be given in a separate order, and arrive [on the waters] south of Mentok on Bangka Island around 0000 on day L. About two infantry companies, led by the battalion commander, shall land on the island, first seize the Mentok airfield and make it ready for use, and seize Pangkalpinang and other strategic points on Bangka as well. The main force [of the advance party] shall switch to [landing] craft on or around the waters [off Mentok], and go up the Telang, Musi and Saleh River roughly in the disposition detailed below, to seize Palembang. In cooperation with the airborne [paratroop] raiding unit, which is scheduled to have already arrived there, it shall first seize the Palembang airfield and make it ready for use. Also, it shall secure the oil refineries, the power station, and other vital facilities of the city as well as the oil fields in and around [Talang] Abab and Limau. Further, it shall prepare to seize the air bases in Martapura and Tanjungkarang as well as to destroy the enemy naval bases in Lampung and Semangka Bay.

The 3d Destroyer Squadron and the 9th Base Force of the First Southern Expeditionary Fleet shall assist [the advance party] in its landing attack on Bangka Island as well as in its ascent of the rivers to Palembang.

[The details of the disposition]

(1) Telang River ascending unit

About two infantry companies, and about one artillery section as the core, led by the battalion commander. 
(2) Musi River ascending unit

About three infantry companies, and about one battery as the core, led by the advance party commander.

(3) Saleh River ascending unit

About one infantry company, and about one battery as the core, led by the engineer regiment commander.

4. Staff Officer Hosokawa shall accompany the advance party and direct the operations.

5. The Ordnance Department director shall have the main force of the Ordnance Department accompany the advance party, together with one element of the Ordnance Service Unit, to facilitate the operation [of the advance party].

6. The Intendance Department director shall have the main force of the Intendance Department accompany the advance party, to facilitate the operations [of the latter].

7. The Medical Department director shall have one element of the Medical Department accompany the advance party, to facilitate the medical needs [of the latter].

8. The commander of the disembarkation working unit shall have one element assist the advance party in the landing attacks at Bangka Island, and have the main force cooperate [with the river-ascending units] in going up the Telang, Musi and Saleh Rivers. Also, [the commander] shall put [his unit] in charge of the disembarkation operations of the advance party as well as the main force of the division in or near Mentok and Palembang. In addition, one powerful element shall seize shipping matériel in and around Mentok and Palembang, and secure loading/ unloading facilities. Five small cargo ships and about seventy fishing boats shall be allocated in or near the Mentok [anchorage].

9. Having been put at the disposal of the advance party commander, the 7th Airfield Company commander shall cooperate in seizing the Palembang airfield and making it ready for use, and in making preparations for seizing the Martapura and Tanjungkarang airfields and others. About six hundred coolies will be allocated for the construction of the airfields.

10. Having been put at the disposal of the advance party commander, the 33d Airfield Company commander shall first cooperate in seizing the Mentok airfield and making it ready for use. Following the advance party's seizure of Palembang, he shall cooperate [with the party] in securing the airfield and making it ready for use, as well as in making preparations for seizing the Martapura and Tanjungkarang airfields and others. About nine hundred coolies will be allocated for the construction of the airfields.

11. Having been put at the disposal of the advance party commander, one element each of the 25th Air Signal Unit and of the 2d Field Meteorological Company shall respectively have a part of them stationed in Mentok and their main force in Palembang, in order to provide assistance in securing the airfields and making them ready, and to make preparations for seizing the airfields mentioned in Items 9 and 10.

12. The $2 d$ Company of the Shipping Signal Regiment shall have its main force accompany the advance party and one element the main force [of the 38th Division]. It shall be charged with the signal communications within the convoy during sailing, and with those between the landing units of the convoy and the disembarkation working unit at the time of the advance party's landing attack, and the disembarkation of the advance party and the main force.

13. The oil-drilling unit shall have its main force accompany the advance party, take charge of taking possession of the oil resources, and also make preparations so that [the unit] can start operating [the oil production facilities] as soon as possible.

14. The units which shall constitute the main force shall depart from Cam Ranh Bay on a date to be given in a separate order, arrive at the mouth of the Musi River before daybreak on day $\mathrm{L}+2$, and go up the river toward Palembang.

15. The $3 \mathrm{~d}$ Battalion of the 229th Infantry Regiment shall be prepared to promptly come under the command of the advance party commander upon its arrival in Palembang. 
16. The Mitsuoka Unit of the 4th Tank Regiment shall be prepared to promptly come under the command of the advance party commander upon its arrival in Palembang.

17. The 23d Antiaircraft Artillery Regiment (minus two batteries and the Antiaircraft Searchlight Company) shall be charged with the air defense during sailing and when entering the anchorage.

18. The 45th Independent Motor Transport Battalion (minus two companies) shall be prepared to promptly come under the command of the advance party commander upon its arrival in Palembang.

19. The director of the Military Administration Department shall put part [of the department] at the disposal of the advance party commander and have it prepare for introducing a military administration, while having the main force [of the department] still continue its current duties as before.

20. The head of the Propaganda Group shall put part [of the group] at the disposal of the advance party commander, and assign it propaganda activities in the division's areas of operation, while having the main force [of the group] still continue its current duties as before.

21. From the time of departure from Cam Ranh Bay until entry into the anchorage, all radio [contact] between the advance party and the main force shall be strictly sealed off other than the Mark-7 radio of the Shipping Signal Unit.

22. In particular, each unit shall do everything possible to enhance the reputation of the Imperial Army at home and abroad by acting in the great founding spirit of our nation.

23. I shall be on board the Gin'yō-maru, and shall on day L + 2 leave Cam Ranh Bay along with the main force to head for Palembang.

Division Commander Sano Tadayoshi

\section{The Oil-drilling Unit}

I will add some explanations about the oil-drilling unit mentioned in the above order.

In September 1941, the oil-drilling group was formed on site within the 21st Field Ordnance Depot in Saigon. First, Maj. Ōkubo Tōru, accompanied by two personnel drafted from Nippon Oil Corporation, arrived by air in Saigon to prepare the formation. ${ }^{(49)}$ Then in October, the main force of the oil-drilling group ([consisting of] about eight commissioned officers including the group commander Lt. Col. Nagahata Yoshinobu, about ten noncommissioned officers, and about 150 drafted oil engineers) arrived in Saigon by sea to complete the formation. In November, in order to restore the oil fields in the Miri and Seria sectors in British northern Borneo, the oildrilling group was first put under the control of the Kawaguchi Detachment, and the group assembled at Cam Ranh Bay. On 13 December, it departed from Cam Ranh Bay along with the Kawaguchi Detachment, and went ashore in the Miri and Seria sector on the 16th, where it worked on the restoration of the oil fields when the latter were seized. ${ }^{(49)}$ This time [however], the 38th Division was to seize the oil fields in southern Sumatra, but the Twenty-fifth Army also was to seize the oil fields in northern Sumatra, following the capture of Singapore. Therefore, arrangements were made to have the Miri oil-drilling group operate in the following way: ${ }^{(49)}$

The main force, directly led by Group Commander Lieutenant Colonel Nagahata, was brought under the control of the 38th Division, which would seize the oil fields in southern Sumatra (Palembang [in particular]), and was transferred from the Miri and Seria sector.

The oil-drilling unit led by Maj. Katō Shunji, who was attached to the group, was brought under the control of the Twenty-fifth Army, which would seize the oil fields in northern Sumatra, and was transferred from the Miri and Seria sector.

The Borneo oil-drilling unit led by Maj. Ōkubo Tōru, who was [also] attached to the group, remained in the Miri and Seria sector. 


\section{The Operational Preparations of the 1st [Paratroop] Raiding Group}

As described earlier, around 22 January the Southern Army had abandoned the idea of using the 1st [Paratroop] Raiding Group in [the operation against] Palembang. However, by the 25th it had changed this [policy], and on the 31st, gave the order [to employ the group in the Palembang operation]. Col. Kume Seiichi, commander of the 1st [Paratroop] Raiding Group, along with the main force of the [Paratroop] Raiding Air Unit ([consisting of] eighteen aircraft), had reached Guangdong in southern China on 15 January, left there on the 18th and arrived in Sanya, Hainan [on the same day], from where they departed on the 19th, to arrive in Phnom Penh in French Indochina. ${ }^{(23)}$ On 22 January, the Southern Army had shown him the [new] policy on the use of the [Paratroop] Raiding Group, ${ }^{(24)}$ and on 26 January at Phnom Penh he had passed down Operation Order A, No. 22,(96) and had his units make preparations according to the following plan. Although the Southern Army had already changed its mind by that day, it had not yet notified Colonel Kume [about it]. As we have seen, the 1st [Paratroop] Raiding Group consisted of the 1st [Paratroop] Raiding Regiment ([which had been] shipwrecked), the 2d [Paratroop] Raiding Regiment ([which had] left the port of Moji on 15 January) and the [Paratroop] Raiding Air Group. The [Paratroop] Raiding Regiments were made up of four companies with 160 men each, and the [Paratroop] Raiding Air Group was made up of four squadrons (of nine aircraft) and one airfield company. ${ }^{(93)}$

\section{Outline of the Operation Plan of the [Paratroop] Raiding Group ${ }^{(96)}$}

First [Operation] (in early February)

Pekanbaru (note: central Sumatra) [paradrop] raiding operation: The objective is to seize the airfield and suppress enemy aircraft activity. Forces to be employed are 180 men led by a company commander of the $2 \mathrm{~d}$ [Paratroop] Raiding Regiment. The operation shall be launched from the Taiping base.

Jambi (note: central Sumatra) [paradrop] raiding operation: The objective is to seize the airfield in order to advance Japanese Type-97 fighter plane unit(s), and at the same time, to try to carry out a sudden attack on Palembang by using seized motor vehicles. Forces to be employed are 270 men led by the $2 \mathrm{~d}$ [Paratroop] Raiding Regiment commander. The operation shall be launched from the Kluang base.

Second [Operation] (in late February)

Sabang (note: an island northwest of Sumatra) [paradrop] raiding operation: The objective is to seize and secure this important island, which is a maritime strategic point. Forces to be employed are 270 men, led by a [paratroop] raiding regiment commander. The operation shall be launched from the Ayer Tawar base.

The Andamans (note: an archipelago west of the Malay peninsula) [paradrop] raiding operation: The objective is to seize and secure the archipelago, a major maritime strategic point. Forces to be employed are 180 men, led by a [paratroop] raiding regiment commander. The operation shall be launched from the Tavoy base.

Third [Operation] (in early March)

Yenangyaung (note: Burma) [paradrop] raiding operation: The objective is to seize and secure a large oil field area. Forces to be employed are three companies, led by a [paratroop] raiding regiment commander. The operation shall be launched from the Lampang base.

As the above plan shows, there was no outlook yet for when it would be possible to use the shipwrecked 1st [Paratroop] Raiding Regiment. 
As explained earlier, because of the postponement of Operations $\mathrm{L}$ and $\mathrm{H}$, decided at the Manila Conference, and the opinions expressed by the people concerned, the Southern Army had from about the 24th strengthened its resolution to use [the Paratroop Raiding Group] against Palembang, and on the 31st it passed down the order for the drop on the Palembang airfield (the chief aim), and on the oil refineries (a part of them). ${ }^{(96)}$ Based on this Southern Army order of the 31st, the Third Air Force Commander Lt. Gen. Sugawara Michiō on the same day gave the following order: ${ }^{(96)}$

Third Air Force Operation Order A, No. 244

Third Air Force Order

Sungai Petani, 2000, 31 January

1. The 1st [Paratroop] Raiding Group shall be newly brought under my command.

2. A part of the [Third] Air Force shall make preparations for the [Paradrop] Raiding Operation [in Operation] L. The outline of preparatory training for the [Paradrop] Raiding Operation [in Operation] L is as shown in the separate volume (omitted by the author).

3. The 7th Air Division commander [Maj. Gen. Yamamoto Kenji] shall temporarily put the 98th Air Group commander under my direct command.

4. In preparation for the [Paradrop] Raiding Operation [in Operation] L, the 98th Air Group commander shall, based on the outline in the separate volume, have the required force engage in joint training with the 1st [Paratroop] Raiding Group in Phnom Penh, Sungai Petani and Ketil and their vicinities. The commander shall also give assistance to the 1st [Paratroop] Raiding Group with its shift of position to Malaya. He shall arrange the particulars with the 1st [Paratroop] Raiding Group commander. The Southern Army is expected to take care of the ground duties, quartering and supplies in Phnom Penh.

5. The 1st [Paratroop] Raiding Group commander shall conduct joint training with the 98th Air Group according to the outline in the separate volume. Further, he shall rapidly advance the personnel and matériel for the first and the second [Paradrop] Raiding Operation [in Operation] L to Sungai Petani and have [the unit(s)] make preparations for the subsequent operations. When rapidly advancing personnel and matériel to Sungai Petani, the commander shall have the assistance of the 98th Air Group.

6. The 18th Air Ground Support commander shall be charged with the ground duties as well as quartering and supplies for the units mentioned in the previous item(s).

7. I am in Sungai Petani, and shall advance toward [Kluang] or its vicinity when the Kluang airfield is ready for use.

In accordance with the above order, 1st [Paratroop] Raiding Group Commander Colonel Kume on the same day (the 31st) at Phnom Penh issued Operation Order A, No. 25, released the following outline of the operational preparation plan and prepared for the operation. ${ }^{(96)}$

1. (Assisted by twenty-seven aircraft of the [Paratroop] Raiding Air Unit, and about nineteen heavy bombers of the 98th Air Group), 260 men led by the 2d [Paratroop] Raiding Regiment Commander Maj. Kōmura Takeo, shall carry out a sudden attack on the Palembang airfield and seize it, after which they will seize and secure [the city of] Palembang. [In the meantime,] 130 men led by a company commander of the regiment (assisted by thirteen aircraft of the [Paratroop] Raiding Air Unit, and about eight heavy bombers of the 98th Air Group), shall carry out a sudden attack on the Palembang oil refineries and seize them.

Note: One [Paratroop] Raiding Air Unit aircraft was able to carry ten paratroopers. The reason that the number of the aircraft and that of the paratroopers [allocated for the attack] on the Palembang airfield did not match is due to the fact that one aircraft was 
to carry out a belly-landing, and twenty-six aircraft were to be employed for the paratroopers.

2. Schedule of Preparations for the Operation

2 till 4 February [inclusive]: Joint training with heavy bombers at Phnom Penh

5 till 6 February [inclusive]: Rapid advance to Sungai Petani

7 February: Preparation for the operation at Sungai Petani

8 February: $\quad$ Rapid advance to the Kluang or the Kahang airfield

9 February: $\quad$ Execution of [paradrop] raiding [operation]

On 4 February (the day when the advance party of the 38th Division was scheduled to leave Cam Ranh Bay), Third Air Force Commander Lieutenant General Sugawara passed down the following order concerning the execution of Operation L. ${ }^{(96)}$

Third Air Force Operation Order A, No. 257

\section{Third Air Force Order}

Sungai Petani, 0800, 4 February

1. Information on Palembang and its vicinity is as shown in Information Record No. 67 in the separate volume (note by the author: original document missing).

2. The [Third] Air Force shall continue to cooperate with the Twenty-fifth Army and at the same time execute Operation L in cooperation with the Sixteenth Army and the Navy. The start of [the operation to] capture Singapore has been scheduled for the night of 7 February, and day L for 10 February; for both separate orders shall be issued. The outline of the cooperation with the Twenty-fifth Army in the operation to capture Singapore is shown in separate volume No. 1 (omitted by the author); the outline of the air operations [in Operation] L in separate volume No. 2 (note by the author: described earlier); the memorandum of the arrangement on air [operations] between the Army and the Navy regarding Operation L in separate volume No. 3 (note of author: described earlier); and the outline of the [Paradrop] Raiding Operation [in Operation] L in separate volume No. 4.

3. The 7th Air Division commander shall in conformity with separate volume No. 1 mainly cooperate in the Twenty-fifth Army's operation to capture Singapore. He may use the Kluang airfield as an advance base for an element of his force except on day L - 1. Further, from 2400 on 5 February onwards, he shall temporarily put the 64th Air Group under the command of the $3 \mathrm{~d}$ Air Division commander at Kahang.

4. The 3d Air Division commander shall discharge the duties stated below:

(1) Continue his cooperation with the Twenty-fifth Army in its operation.

(2) Search for enemy aircraft in Palembang and its vicinity and destroy them, mainly with his fighter plane unit(s) between day $\mathrm{L}-4$ and day $\mathrm{L}-2$.

(3) Carry out the [paradrop] raiding operation against Palembang and its vicinity in conformity with separate volume No. 4.

(4) Provide cover for the convoy of the 38th Division under sail, with an element of his fighter plane unit(s) from 1700 of day $\mathrm{L}-1$ until about the evening [of the same day].

(5) Make preparations to advance an element of his force to the Palembang airfield when it is seized and ready for use in order to cooperate with the Sixteenth Army.

[Also,] he shall temporarily put the 64th Air Group under his command at Kahang at 2400 on 5 February.

5. The 12th Air Division commander shall discharge the duties stated below:

(1) Continue the tasks stated in Item 5 of Third Air Force Operation Order A, No. 230, particularly the cooperation with the $3 \mathrm{~d}$ and the 7 th Air Divisions in their combat in the air above the Singapore sector between day $\mathrm{L}-4$ and day $\mathrm{L}-2$. 
(2) Keep watch on the Pekanbaru airfield during Operation L and seize the opportunity to search for enemy aircraft appearing at the airfield and destroy them.

(3) Make preparations to advance an element to the Palembang airfield on day L and onwards, so that it can take charge of the air defense of the place and its vicinity.

The 1st Squadron of the 11th Air Group shall be returned to its original command after providing cover for the [Paratroop] Raiding Air Unit during its rapid advance to the Kluang and the Kahang airfields.

6. The 1st Raiding Group commander shall, in conformity with separate volume No. 4, carry out a paratroop raid on or around the Palembang airfield and the oil refineries at 1130 on day $\mathrm{L}-1$, seize and secure these surroundings, while facilitating the attacks of the [Third] Air Force and the 38th Division.

[The commander] shall temporarily put the 12th Transport Squadron under his command and have the 3d Air Division, the 81st and the 98th Air Group cooperate in the execution of the [paradrop] raiding [operation] until the completion of Raiding Operation L. However, he shall give instructions to the 98th Air Group commander regarding the details of the raiding operation.

The parachuting and landing units shall come under the command of the Sixteenth Army commander from the moment of the landing of the 38th Division at Palembang. After completion of Operation L, the other units under [the command of] the group shall, without separate orders, be returned to their original command.

7. The 81st and the 98th Air Groups, in conformity with separate volume No. 4, shall be charged with the raiding operation, along with the units mentioned in the previous item. The 98th Air Group commander shall receive instructions from the 1st [Paratroop] Raiding Group commander regarding the details of the raiding operation.

8. The 1st Squadron of the 11th Air Group shall return to its original command on day L-2, after [covering] the rapid advance of the [Paratroop] Raiding Air Unit to the Kluang and the Kahang airfields.

9. I shall be in Kluang.

Note by the author: Outline of the Third Air Force's disposition of forces at that time

[Units] under the direct control of the [Third] Air Force: the 81st (command reconnaissance), and the 98th (heavy bombers) Air Groups, 1st [Paratroop] Raiding Group

3d Air Division: the 27th (light bombers), the 75th (light bombers), the 90th (light bombers), and the 59th (fighter planes) Air Groups, and the 50th Independent Squadron (command reconnaissance)

7th Air Division: the 64th (fighter planes), the 12th (heavy bombers), and the 60th (heavy bombers) Air Groups, and the 51st Independent Squadron (command reconnaissance)

12th Air Division: the 1st (fighter planes), and the 11th (fighter planes) Air Groups, and the 47th Independent Squadron (fighter planes)

\section{Separate volume No. 4 Outline of [Paradrop] Raiding Operation [in Operation] L}

\section{Mission}

[We shall] seize the Palembang airfield to facilitate Operations L and H, and [also] seize and secure the oil refineries in Palembang before the enemy destroys them.

2. Outline of the Operations

(1) Prior to day L - 1, the 3d Air Division (including the units [temporarily] attached) shall destroy the enemy air power in Palembang.

(2) The first (paradrop) raid shall be set at 1130 on day $\mathrm{L}-1$. 
However, the execution shall be aborted by separate order(s) if inevitable due to weather or other conditions.

(3) By the evening of day L - 2, the first echelon shall be deployed to Kahang, the second echelon and one air group of light bombers of the $3 \mathrm{~d}$ Air Division to Kluang, to be ready for the launch of the raiding [operation].

(4) The first and the second echelons shall operate separately. The first echelon shall execute the parachuting [operation] on the Palembang airfield and its vicinity, and the second echelon on the Palembang oil refineries and their vicinity. Each shall mop up the enemy in the surroundings, seize and secure the objectives of their respective operations until the arrival of the 38th Division. The paratrooper unit of the first echelon shall [also] attack Palembang barracks, circumstances permitting.

(5) The air groups of light bombers of the $3 \mathrm{~d}$ Air Division shall in general accompany the first or the second echelon, and attack the barracks in Palembang city right before the parachuting [operation].

(6) [Some aircraft of] the reconnaissance unit(s) under the direct control of the [Third] Air Force shall fly ahead of the echelons while others shall accompany them, to conduct surveillance of the battle site.

(7) After the execution of the paradrop [operation], the first and the second echelon as well as the air groups of light bombers shall assemble and return as quickly as possible. The air groups of heavy bombers shall return to their bases, while the [Paratroop] Raiding ([paratrooper] transport) Air Unit shall return to its after refueling at the Kluang or the Kahang airfield. However, units that can directly return to their bases shall not conduct the above-mentioned refueling.

(8) After providing the cover for the execution of the first [paradrop] raiding operation, one element of the fighter plane units of the $3 \mathrm{~d}$ Air Division shall provide air cover [also] for the convoy roughly from 1700 onwards. Further, if required, it shall support the ground battle, while making sure of the progress of the Japanese troops.

(9) The 3d Air Division will timely have its command reconnaissance unit conduct surveillance of the combat site of the paratroopers unit.

(10) The second [paradrop] raid shall be prepared, set for 1500 on the day after that of the first raid. The forces to be employed in [the second] paradrop (and landing) [raid] shall be about two squadrons of the air transport unit as the standard, and its drop zone shall be set at the Palembang airfield.

3. The disposition of the forces to be employed and the operation schedule are as shown on Separate Sheet No. 1.

4. The 1st [Paratroop] Raiding Group commander shall decide on the details of the basic standard for the joint operations, the drop zones of the echelons, and the dispositions during the flight.

\section{Separate Sheet No. 1}




\begin{tabular}{|c|c|c|c|}
\hline \multicolumn{4}{|c|}{$\begin{array}{l}\text { Rough overview of disposition of forces to be employed and } \\
\text { the schedule of Palembang [paradrop] raiding operation }\end{array}$} \\
\hline Date & Disposition of forces & Operation objectives (tasks) & Outline of actions \\
\hline \multirow{2}{*}{$\begin{array}{l}\text { Day L }-4 \\
\text { through } \\
\text { Day L }-1\end{array}$} & $\begin{array}{l}\text { Fighter planes of the } 3 d \\
\text { Air Division (including } \\
\text { units brought under the } \\
\text { command of the divi- } \\
\text { sion) }\end{array}$ & $\begin{array}{l}\text { To destroy enemy aircraft on } \\
\text { the Palembang airfield. }\end{array}$ & $\begin{array}{l}\text { Attacks shall be made at a good op- } \\
\text { portunity. The launching bases will } \\
\text { be the Kluang and Kahang airfields. }\end{array}$ \\
\hline & $\begin{array}{l}\text { Required forces of the } \\
\text { 12th Air Division }\end{array}$ & $\begin{array}{l}\text { To take command of the air } \\
\text { over the Singapore sector; to } \\
\text { watch on the Pekanbaru air- } \\
\text { field; and to destroy enemy air- } \\
\text { craft on this airfield, if required. }\end{array}$ & $\begin{array}{l}\text { Attacks shall be made at a good op- } \\
\text { portunity. The launching base will be } \\
\text { Batu Pahat. }\end{array}$ \\
\hline Day L - 2 & $\begin{array}{l}\text { The first raiding unit of } \\
\text { the [Paratroop] Raiding } \\
\text { Group, the 98th, the 59th, } \\
\text { the 64th Air Group, three } \\
\text { aircraft of the } 81 \text { st Air } \\
\text { Group, one air group of } \\
\text { light bombers of the } 3 \mathrm{~d} \\
\text { Air Division }\end{array}$ & $\begin{array}{l}\text { For the first [paradrop] raid, } \\
\text { each echelon will assemble by } \\
\text { the evening at the Kluang or } \\
\text { the Kahang [airfield], to pre- } \\
\text { pare for departing on day L }-1 \text {. }\end{array}$ & $\begin{array}{l}\text { 1. The first raiding unit of the [Para- } \\
\text { troop] Raiding Group will depart } \\
\text { from Sungai Petani and advance to } \\
\text { the Kluang or the Kahang [air- } \\
\text { field]. } \\
\text { 2. The 98th Air Group shall depart } \\
\text { from the Ketil [airfield], assemble } \\
\text { two squadrons at the Kahang [air- } \\
\text { field], and another at the Kluang } \\
\text { [airfield]. }\end{array}$ \\
\hline Day L - 1 & $\begin{array}{l}\text { 1st Echelon: } \\
\text { One element of the 2d } \\
\text { [Paratroop] Raiding } \\
\text { Regiment [transported } \\
\text { by] about two } \\
\text { squadrons of the [Para- } \\
\text { troop] Raiding Air Unit. } \\
\text { About two squadrons of } \\
\text { the 98th Air Group, the } \\
\text { 64th Air Group, one air- } \\
\text { craft of the 81st Air } \\
\text { Group (accompanying). } \\
\text { 2d Echelon: } \\
\text { One element of the 2d } \\
\text { [Paratroop] Raiding } \\
\text { Regiment [transported } \\
\text { by] about two } \\
\text { squadrons of the [Air] } \\
\text { Transport [Unit]. } \\
\text { One squadron of the } \\
\text { 98th Air Group, the 59th } \\
\text { Air Group, one aircraft } \\
\text { of the 81st Air Group } \\
\text { (accompanying). } \\
\text { Another aircraft of the } \\
\text { 81st Air Group (to go in } \\
\text { advance). }\end{array}$ & $\begin{array}{l}\text { 1. 1st Echelon: To execute the } \\
\text { [paradrop] raid at the Palem- } \\
\text { bang airfield and its vicinity, } \\
\text { secure the airfield, and } \\
\text { quickly make it ready for use } \\
\text { by Type-97 fighter planes. } \\
\text { 2. 2d Echelon: To execute the } \\
\text { [paradrop] raid at the oil re- } \\
\text { fineries in Palembang and } \\
\text { their vicinity, seize and se- } \\
\text { cure these refineries before } \\
\text { destruction by the enemy. } \\
\text { 3. The } 98 \text { th Air Group shall } \\
\text { transport the weaponry and } \\
\text { matériel respectively for each } \\
\text { transport squadron of both } \\
\text { echelons, and [also] provide } \\
\text { cover fire against antiaircraft } \\
\text { fire at the rear of the trans- } \\
\text { port squadrons. } \\
\text { 4. The air groups of fighter } \\
\text { planes shall provide the di- } \\
\text { rect cover for each echelon } \\
\text { respectively. } \\
\text { 5. The command reconnais- } \\
\text { sance planes shall conduct re- } \\
\text { connaissance just before and } \\
\text { during the time of the opera- } \\
\text { tion, and provide guidance. }\end{array}$ & $\begin{array}{l}\text { 1. Execution of the [paradrop] raid } \\
\text { shall be at } 1130 \text {. } \\
\text { 2. The 1st echelon will depart from } \\
\text { the Kahang, and the } 2 \mathrm{~d} \text { from the } \\
\text { Kluang base. } \\
\text { 3. [All units] shall return to their ad- } \\
\text { vance base(s). However, units that } \\
\text { have sufficient flight range shall di- } \\
\text { rectly return to their original base. } \\
\text { 4. If it is impossible to operate in this } \\
\text { [way] due to the situation of the } \\
\text { transport aircraft, the number of } \\
\text { units shall not be reduced even if a } \\
\text { reduction in the number of men } \\
\text { should be necessary. }\end{array}$ \\
\hline
\end{tabular}




\begin{tabular}{|c|c|c|c|}
\hline \multirow{2}{*}{$\begin{array}{l}\text { Day L }-1 \\
\text { [cont.] }\end{array}$} & $\begin{array}{l}\text { One element of the light } \\
\text { bomber unit(s) of the } 3 \mathrm{~d} \\
\text { Air Division }\end{array}$ & $\begin{array}{l}\text { Attacks against the barracks in } \\
\text { the city of Palembang. }\end{array}$ & $\begin{array}{l}\text { 1. [The operation] shall be conducted } \\
\text { right before the execution of the } \\
\text { first [paradrop] raid. [The element] } \\
\text { shall operate along with one of the } \\
\text { echelons as long as it can. } \\
\text { 2. [It] shall depart from the Kluang } \\
\text { base. }\end{array}$ \\
\hline & $\begin{array}{l}\text { One element of the } \\
\text { fighter plane unit(s) of } \\
\text { the 3d Air Division (in- } \\
\text { cluding units brought } \\
\text { under the control of the } \\
\text { division) }\end{array}$ & $\begin{array}{l}\text { Air cover for the convoy of the } \\
\text { 38th Division }\end{array}$ & $\begin{array}{l}\text { 1. After returning from [the task] to } \\
\text { cover the first [paradrop] raid, it } \\
\text { shall swiftly go to the air above the } \\
\text { convoy, to provide cover from } \\
\text { roughly } 1700 \text { onwards. } \\
\text { 2. This [operation] shall be sus- } \\
\text { pended so that [the unit] can return } \\
\text { and land at dusk. }\end{array}$ \\
\hline \multirow[t]{3}{*}{ Day L } & $\begin{array}{l}\text { 3d Echelon: } \\
\text { One element of the } 2 \mathrm{~d} \\
\text { [Paratroop] Raiding } \\
\text { Regiment [transported } \\
\text { by] about two } \\
\text { squadrons of [Air] } \\
\text { Transport [Unit]. About } \\
1 \text { squadron of the 98th } \\
\text { Air Group, about one- } \\
\text { half of fighter plane } \\
\text { unit(s) of the 3d Air Di- } \\
\text { vision (including the } \\
\text { units brought under the } \\
\text { control of the division), } \\
\text { one aircraft of the } 81 \mathrm{st} \\
\text { Air Group }\end{array}$ & $\begin{array}{l}\text { 1. To execute the [paradrop] } \\
\text { raid at the Palembang airfield } \\
\text { and its vicinity, to reinforce } \\
\text { [the first raiding unit]. } \\
\text { 2. The tasks for the air units to } \\
\text { cooperate [in the above oper- } \\
\text { ation] shall be the same as on } \\
\text { the previous day. }\end{array}$ & $\begin{array}{l}\text { 1. The Kluang airfield shall be used } \\
\text { as the base to launch [the opera- } \\
\text { tions]. } \\
\text { 2. Execution of the [paradrop] raid is } \\
\text { scheduled at } 1500 \text {. The launching } \\
\text { [of the operation] shall be given in } \\
\text { separate order(s). }\end{array}$ \\
\hline & $\begin{array}{l}\text { Elements of the } 3 \mathrm{~d} \text { and } \\
\text { the } 7 \text { th Air Division }\end{array}$ & $\begin{array}{l}\text { To support the ground combat } \\
\text { in Palembang and its vicinity, if } \\
\text { required. }\end{array}$ & \\
\hline & $\begin{array}{l}\text { An Element of the } 12 \text { th } \\
\text { Air Division }\end{array}$ & $\begin{array}{l}\text { To prepare to advance to the } \\
\text { Palembang airfield and under- } \\
\text { take the task of the air defense } \\
\text { of Palembang and vicinity, as } \\
\text { soon as the airfield has been } \\
\text { provisionally made ready. }\end{array}$ & \\
\hline $\begin{array}{l}\text { Day L - } 1 \\
\text { Day L }\end{array}$ & $\begin{array}{l}\text { Command Reconnais- } \\
\text { sance Unit of the } 3 \mathrm{~d} \text { Air } \\
\text { Division }\end{array}$ & $\begin{array}{l}\text { To conduct surveillance of the } \\
\text { battle site at the appropriate mo- } \\
\text { ments after the drop of the } \\
\text { [paratroop] raiding group. }\end{array}$ & \\
\hline Comments & \multicolumn{3}{|c|}{$\begin{array}{l}\text { 1. The advancement of forces on day L onwards shall be announced by separate order(s). } \\
\text { 2. This table shall in part be subject to change depending on the situation. }\end{array}$} \\
\hline
\end{tabular}




\section{(2) Postponement of [Operation] $\mathrm{L}$ and $\mathrm{H}$}

\section{Second Postponement of [Operation] L (Two Days)}

As we have seen, on 1 February the [Navy] Malaya Unit (First Southern Expeditionary Fleet), the naval escort unit and the naval river-ascending unit had already passed down orders regarding the execution of Operation L; the 38th Division had done so on 2 February, and the Third Air Force on 4 February. And the time of departure [of the advance party] from Cam Ranh Bay had been set at 1900 on 4 February.

However, just before the time of departure (on the evening of the 4th), Colonel Takashima and Colonel Kitamura, senior staff officers of Section 1 and Section 2 of the Sixteenth Army, Chief of Operations of the Sixteenth Army Lieutenant Colonel Oda, and [Navy] Commander Wakatsuki, staff officer of the Third Fleet seconded to the Sixteenth Army, came to the staff office of the Southern Army, where Staff Officer Wakatsuki requested Colonel Ishii, senior staff of Section 1 of the Southern Army, "to postpone the execution of Operation L for just two days, because not much progress has been made in making the Ledo airfield ready for use."(23)

In fact, this was exactly what the Southern Army had been wary of, because [for one thing,] such an atmosphere [of favoring postponement] had [indeed] been detected on the 31st during the previously described visit of the [Southern Army] Staff Officers Arao and Matsumae to Cam Ranh Bay, [and for another,] because [the Southern Army] knew that the [Navy] Malaya Unit had sent a telegram on the $2 d$ to the Sixteenth Army headquarters in Gaoxiong about its wish to postpone the operation, ${ }^{(33)}$ and that on this very day (the 4 th) Sixteenth Army Commander Imamura and his party were visiting Cam Ranh Bay to have talks with the Malaya Unit about it. ${ }^{(34)}$ Thus, on the early morning of the 4th, the Southern Army had let Sixteenth Army Staff Officer Saiki, who stayed in Saigon, send a military classified telegram (note: which was sent with priority) [to the Sixteen Army commander at] Cam Ranh Bay, to notify them that "the Southern Army would definitely not agree to a change of schedule of day L."'(34)

The Southern Army staff office was disgusted that the Sixteenth Army staff officers had joined the Navy staff officer en bloc, and that the Navy again requested another postponement just as at the time of the Kuantan, Endau and Mersing operations, or at the Manila Conference. ${ }^{(23)}$ Colonel Ishii mainly argued with [Navy] Commander Wakatsuki and insisted: “It has been mutually agreed at the Manila [Conference] that in the event the Ledo airfields were unusable, because [at that time] the seizure of the Ledo airfields was still uncertain, [other] airfields in the Malaya area would be used [instead] for conducting the air campaign; as the arrangements have been settled that way, the fact that the Ledo airfields cannot be used does at this late date not constitute a reason for a postponement." (23) Navy Commander Wakatsuki explained: "The 22d Air Flotilla has started moving its forces to the Ledo area, judging that it could use the airfields, even though it wondered whether it was the right thing to do because the situation in Ledo was still unclear; subsequently, the Flotilla learned that it would take longer than expected to make the airfields ready for use, but that it is now too late to redirect the forces to the Malaya area."(23) The staff officers of the Sixteenth Army made comments implying that they rather supported Commander Wakatsuki of the Navy, as they had done at the Manila Conference, ${ }^{(23,40)}$ and the discussion went on for about one hour. ${ }^{(23)} \mathrm{Navy}$ Commander Wakatsuki repeated time and again that "this is the last time to request a postponement and there will be no such requests again from now on." (23) Colonel Ishii did not 
yield, but when breaking up [the meeting], he felt that "a two-day postponement would probably be inevitable." (23) After receiving approval, Staff Officer Ishii sent the following telegram to the Southern Task Force (i.e. the Second Fleet). ${ }^{(23)}$

1. At the talks, which the OsAMU-SHŪDAN (note by the author: the Sixteenth Army) had with the First Southern Expeditionary Fleet at Cam Ranh Bay today, a request for a two-day postponement of the launch of Operation L was made by the First Southern Expeditionary Fleet because the airfields had not yet been made ready for use.

2. Presently, we have completed all our preparations and scheduled the start of our ground attacks against Singapore from the 7th onwards. As the surrender [of Singapore] is imminent, we would like to seize an opportune moment ahead [of the fall of Singapore] to carry out [Operation] L. We would like your consideration for the realization of the above.

In reply to this telegram, the Southern Task Force (the Second Fleet) wired back as follows: ${ }^{(23)}$

[We] would like a one- or two-day postponement be [decided] in talks between the Sixteenth Army and the First Southern Expeditionary Fleet.

The date to launch [Operation] L, which had been set on "roughly day $x+60$ " at the suggestion of the Southern Army ([in the] Cam Ranh Agreement) on 1 January and postponed to "day $x+64$ " on 28 January ([in the] Manila Agreement), now had to be postponed once again to "day $x+66$." Having received the reply from the [Navy] Southern Task Force, the Southern Army, while sending the following telegram to seek the approval of the Army Department of IGHQ on the same day (the 5th), issued an order to postpone [Operation] L by two days, setting it on 12 February. ${ }^{(23)}$

\section{From: Chief of Staff, Southern Army, sent on 5 February}

\section{To: Vice Chief, Army General Staff}

1. On the 4th, a request for a two-day postponement of [Operation] L came from the First Southern Expeditionary Fleet to the OSAMU-SHŪDAN.

2. The reason for this was a delay in providing the Ledo airfields with fuel and ammunition. Despite the arrangement that the airfields in Malaya should be used if there was no prospect for using the Ledo airfield for [Operation] L, the Navy had focused itself on the Ledo airfield, which it said resulted in another delay in providing other airfields in Malaya with fuel and ammunition.

3. As for the Army, the Twenty-fifth Army has seized Kluang on 25 January, as agreed with the Navy. The Third Air Force and the OsAMU-SHŪDAN have both completed their preparations.

At 1022 on the 4th, the [Navy] Malaya Unit, under the name of the senior staff officer, notified its subordinate units that "Day L is expected to be postponed by two days; the decision will be made after consultation with the Sixteenth Army commander around noon today." It was followed by a telegram sent at 1530 on the same day under the name of the chief of staff [of the unit], which read: "For the present moment the date [of Operation] L is expected to be postponed by two days." (130) 


\section{The Situation at Ledo Until Then}

The Kawaguchi Detachment had seized the Ledo airfield on 27 January and from the 28th until the end of the month provisionally repaired a 50-meter wide and 1,000-meter long runway. However, for the deployment of the Navy land-based medium-sized attack planes, the runway had to be extended to a length of 1,300 meters. The detachment was working at full stretch day and night in an area right below the equator on the rebuilding of the roads and the airfield, allowing its officers and men only a few hours of sleep per day. ${ }^{(23)}$ Moreover, Ledo was located far into the interior, and the roads leading to the area from the coast had in places been destroyed, and also more than a dozen bridges had been demolished. On 3 February, an element of the [Navy] land-based medium-sized attack planes took the risk and performed a landing (note by the author: although the number of planes is unknown, it was apparently a trial landing performed by just a few aircraft). However, even on 4 February, the fuel accumulated in Ledo was just a mere total of two hundred drums. The matter was that the supplies were [first] transported upriver for about forty-five kilometers by motorized [landing] craft from Pemangkat on the west coast to Sambas, taking as much as sixteen hours, and then with great difficulty from Sambas to Ledo for about eighty kilometers along a destroyed road. ${ }^{(23)}$

Previously, the Ledo situation has been described up to the point that on 19 January the Kawaguchi Detachment reported to the Southern Army its plan (1) to have the 1st unit led by Regimental Commander Oka ([consisting of] five infantry companies as the core) seize Ledo by way of the Kuching - Ledo road, and (2) to have the $2 \mathrm{~d}$ unit under the direct command of Detachment Commander Kawaguchi ([consisting of] three companies led by a battalion commander as the core) depart from Kuching by sea on the night of the $22 \mathrm{~d}$ until noon on the $23 \mathrm{~d}$ in three echelons and land on the shore west of Ledo; and I have described that (3) on the 20th the bombshell motion of a two-week postponement of [Operation] L tabled at Cam Ranh Bay had led to heated arguments between Staff Officer Ishii and Malaya Unit Staff Officer Tomari, which had made [Kawaguchi Detachment] Staff Officer Shiraishi so acutely aware of the significance of Ledo that he had immediately sent a telegram to Detachment Commander Kawaguchi. Since then, the following developments had occurred in Ledo.

\section{The Seizure of Ledo}

On 23 January, Detachment Commander Kawaguchi had wired to the Southern Army from Kuching about the situation at the Kuching airfield: "At the Kuching airfield, it is easy to take off and land when the weather is fine, but in rainy weather, even experienced pilots will need extra caution when flying small aircraft. Although [the runway of] the airfield runs 1,000 meters from north to south, the northernmost 100 meters are not usable at present, because the ground level is being raised." However on the same day, having received the previously mentioned telegram sent by Staff Officer Shiraishi from Saigon ("that [the Army Department] of IGHQ and others pin their hopes on the ongoing operation"), Commander Kawaguchi sent the following telegram to the Southern Army: ${ }^{(23)}$

\section{Kawaguchi Detachment Telegram No. 73 (sent on 23 January)}

1. The weekly precipitation in Kuching until yesterday the 21st amounted to about forty inches, which is one-fourth of the annual precipitation; it was a heavy rainfall rarely seen in recent years. 
2. The Siluas River and streams in its vicinity have flooded and turned the whole place into a sea. Nevertheless, it is impossible to cross the water because not a single dugout canoe was found around the place, and making a raft will not do because neither the bamboo nor the wood is buoyant.

3. There are three-meter high plunging breakers at sea, and even during daytime there is a risk that boats will capsize. As enemy flying boats frequently come flying over Kuching and its vicinity, our intentions will be discovered if we do not sail at night in the dark. Consequently, we must wait until the day that sailing by night becomes possible.

4. As the situation on land and at sea is as such, we cannot do anything no matter how impatient we are, and thus we request your understanding.

On the following day, the 24th, Detachment Commander Kawaguchi (at Kuching) again sent the Southern Army the following telegram. ${ }^{(23)}$ The [Navy] Malaya Unit, meanwhile, had launched [the operation to provide] cover for the disembarkation operations at Endau as well as the Anambas landing operations with this day (the 24th) as day 1 (both the debarkation and the landing operations were executed on the 26th). ${ }^{(118,126)}$

\section{Kawaguchi Detachment Telegram No. 80 (sent on 24 January)}

1. Even though the waves are finally subsiding, they are still two and a half meters high, and it is [still] difficult to sail in boats. Consequently, I have decided to postpone [the operation] for another day.

2. According to a telegram sent to the [naval] landing force, the Navy's fighter planes and the Kamikawa-maru (an auxiliary seaplane tender) should arrive in Kuching around the 27th.

3. If it were possible to have the Navy aircraft arrive tomorrow on the 25th, they would be able to assist in the actions of our unit from the 25th onwards.

On the following day, the 25th, Detachment Commander Kawaguchi wired the Southern Army: "As the waves have subsided to two meters high, the first echelon ([consisting of] large- and small-sized motorized [landing] craft and fishing boats) shall leave Kuching this evening, the second and the third echelons ([consisting of] seized small steamships) on the morning of tomorrow the 26th, and all of them are expected to land in and around Pemangkat around daybreak on the 27th."(23) Then on the same day, the detachment commander wired the following by means of Kawaguchi Detachment Field Telegram No. 88: ${ }^{(23)}$ "(1) On the 23d and the 24th the weather has improved, and the weather is fine today too. The airfield was bombed yesterday, the 24th, but nevertheless it was made ready; (2) According to a report from the 1st unit, it expects to seize the Ledo [airfield] on the 29th; (3) I express my sincere gratitude for the concern you have shown to Staff Officer Shiraishi while he was in Saigon." Simultaneously, Sixteenth Army Staff Officer Murakami, who was attached to the detachment, also wired the following to the Southern Army by means of Kawaguchi Detachment Field Telegram No. 89: ${ }^{(23)}$

The departure of the $2 \mathrm{~d}$ unit of the Kawaguchi Detachment was delayed due to high waves, but its first echelon is scheduled to depart on the evening of the 25th. Although the detachment commander persistently insists on sailing without support, [I am of] the opinion that it is better if the detachment be provided with air cover while moving southward on the afternoon of the 26th if possible. 
The 1st unit, led by Col. Oka Akinosuke, had started its operations on 24 January, driven away forty to fifty enemy soldiers in Siluas and its vicinity on the morning of the same day, after which the unit had defeated about one thousand enemy troops at Sanggau [Sanggan], and seized the Ledo airfield at 1000 on the 27th. ${ }^{(23,91)}$

The $2 \mathrm{~d}$ Unit, under the direct command of Maj. Gen. Kawaguchi Kiyotake, had departed from Kuching between 1930 on the 25th and 1100 on the 26th in three echelons (with Detachment Commander Kawaguchi accompanying the third echelon). The unit successfully made a surprise landing in Pemangkat at 0700 on the 27th. After sending a telegram to Commander in Chief Terauchi [of the Southern Army]: "Although it is the august virtue of His Majesty the Emperor that enabled us to accomplish without cover the above important task (note by the author: maneuvering the boats at sea along the coast and landing at Pemangkat), we owe it [also] to your constant guidance for which we are deeply grateful" (Kawaguchi Detachment Field Telegram No. 96 sent on the 27th), the unit continued to closely pursue the allied forces, which were taking flight both by land and by sea, and on the same day successfully seized Sambas at 1500, followed by Singkawang at 2100. ${ }^{(23)}$ Detachment Commander Kawaguchi reported to the Southern Army by telegram: "We will continue our operation to first mop up the main forces of the enemy in the Pontianak area, [then] turn around and charge toward the Ledo area; while advancing northward to the Siluas area, we shall swiftly seize the airfields and make them ready for use." However, the Southern Army had already learned from a report by 1st unit Commander Oka that the 1st unit had [already] seized the Ledo airfield. Having received a telegram from the Southern Army which told him to "report the actual situation of the Ledo airfields by return," the detachment commander wired on the morning of the 28th the following Detachment Telegram No. 101:(23)

1. While overcoming repeated stiff resistance and dealing with blown up bridges, an element of the detachment has reached Singkawang at 2100 on the 27th. However, in pursuing [the enemy], the detachment has no other means but to do it mainly on bicycles and on foot.

2. Gathering from the talk of the natives, it appears that the Ledo airfields have been destroyed to a considerable degree.

3. Recognizing that repair of the airfields is the most urgent matter in view of the overall operations of the Southern Army, the detachment shall change its plan. On the early morning of the 28th it shall leave Singkawang; while having one element undertake the above-mentioned seizure and preparation [of the airfields], it shall engage with the main force in hot pursuit of the enemy in Pontianak to mop them up.

Then, on the 28th, Detachment Commander Kawaguchi wired by means of Detachment Field Telegram No. 104 from Singkawang to the Southern Army that "measured with the eye, the [main] Ledo airfield is 300 meters wide and 1,000 meters long, and has been blasted in fourteen or fifteen places." (23) Meanwhile on the evening of the same day, 1st unit Commander Oka wired by means of Detachment Telegram No. 399 to the Southern Army from Ledo that "[repair] work at the [main] Ledo airfield has finally started since the afternoon of the 28th, and with the [available] strength, the repair of the 50-meter wide and 1,000-meter long runway will be done in a couple of days."(23)

In the meantime, the Navy Malaya Unit had been providing support for the Southern Army's disembarkation operation at Endau (carried out in two transport ships), and had also been conducting the operation to occupy the [enemy] base on the Anambas Islands. ${ }^{(118,}{ }^{126)}$ The 
forces had in outline been deployed as follows: the 3d Destroyer Squadron (minus the 12th and the 19th Destroyer Divisions) had provided the direct escort for the two Army transport ships which left Singora on the 24th and entered the anchorage and engaged in the debarkation [operation] at Endau on the 26th; the 9th Base Force had left Puolo Condore on the 24th and occupied Anambas Islands on the 26th; the 7th Cruiser Division (with the 19th Destroyer Division attached), the 4th Carrier Division ([with] the aircraft carrier Ryūjō), the 12th Seaplane Tender Division ([with the ] auxiliary seaplane tenders Kamikawa-maru and Sagaramaru) and the 22d Air Flotilla ([consisting of] land-based planes) had provided support for the above, while the main unit (the Chokki and the 12th Destroyer Division) had provided overall support. ${ }^{(115,118)}$ The units had operated as scheduled. The disembarkation operation at Endau was completed on the 28th. ${ }^{(118)}$ Although two allied destroyers came to attack [the transport ships] at Endau on the 27th, one was sunk and the other was put to flight. ${ }^{(118)}$

As previously described, when on the 20th Malaya Unit Staff Officer Tomari had presented his bombshell motion of a two-week postponement of [Operation] L at Cam Ranh Bay, Staff Officer Ishii had insisted that "if the Ledo [airfield] were unusable, [the Navy] should use base(s) in Malaya," and he again maintained this argument in the Manila Conference held from the 21st through the 23d. While acceding to this idea and considering that it might have to use the base(s) in Malaya if the Ledo [airfield] was not ready in time, the Malaya Unit put all efforts into making Ledo ready, and had its Ledo contingent of the 4th Construction Squad leave Kuching on the $22 \mathrm{~d}$ and follow the Oka Unit toward Ledo. ${ }^{(145)} \mathrm{Hav}-$ ing been informed about the arrival of the Endau disembarkation unit and the Anambas occupation unit at their respective destinations on the 26th, as well as the Oka Unit's seizure of Ledo on the 27th, [the Malaya Unit] had ordered the 4th Submarine Squadron commander by Telegraphic Operation Order No. 103 on that day (the 27th) to escort the Fujikawa-maru (carrying personnel and base matériel for the Genzan Air Group), and the Tatsumiya-maru (carrying the Kanoya Air Group's advance personnel and matériel for the Ledo Base).(122)

\section{Little Progress in the Preparation and Repair of the Ledo Base}

As previously mentioned, on the next day, the 28th, the staff officers of the First Southern Expeditionary Fleet, the Sixteenth Army and the Third Air Force had held a conference at Cam Ranh Bay, where they made arrangements on the air [operations] in Operation L. ${ }^{(34)}$ The Navy had agreed to deploy two land-based attack plane units, about thirty fighter planes and six land-based reconnaissance planes to Ledo and Kuching, about thirty land-based attack planes to Kuantan, and about ten planes to Sungai Petani, provided that Ledo was fit for use. It was also decided upon in the arrangements that if Ledo and Kuching were not fit for use, the [Navy] aircraft would be deployed to [airfields] in Kuantan, Kahang, Sungai Petani and Kota Bharu. ${ }^{(96)}$

After participating in the above-mentioned Anambas operation, three aircraft of the auxiliary seaplane tender Kamikawa-maru had advanced to Kuching on the 27th, and reported the following result of their reconnaissance of Ledo:(130)

\section{Telegram sent on 28 January}

1. Spotted a small number of Japanese ground troops in the town of Ledo.

2. The [main] Ledo airfield has been seriously destroyed by landmines. No human figure was spotted [on the airfield]. The airfield appears unpaved, and [the surface] seems to be red clay. 
3. The bridges on the road from Pemangkat to Singkawang and Ledo have largely been destroyed. No Japanese troops were spotted on the road.

\section{Telegram sent on 29 January}

1. The [main] Ledo airfield is located about five kilometers east of Ledo, with three runways; one which runs from north to south is about 2,500 meters long, another which runs from east to west is about 1,200 meters long, and the other which runs in between is about 1,200 meters long. There are about seventy-nine large and small holes blasted by landmines, which are currently being repaired by army units. The soil [appears] to be red clay, with some patches of grass; the ground appears to be in comparatively good condition. No obstacles were found in the perimeter.

2. A dozen or more bridges on the road from Singkawang to Ledo have been destroyed. Also a dozen or more holes probably blasted by landmines were spotted on the road.

3. No Japanese forces were spotted other than large-sized motorized [landing] craft in Pemangkat and the army in Ledo.

So, on this day (the 29th), First Southern Expeditionary Fleet Staff Officer Terasaki Takaji immediately visited the Southern Army headquarters to request "the cooperation of engineers, as the road to the Ledo airfields is destroyed."(23) The Southern Army readily consented and dispatched Staff Officer Watanabe Tarō together with Second Lieutenant Inagaki (engineer) to assist in making the Ledo airfield ready for use, in repairing the transportation roads, and for the operational communications. At the same time, [the Southern Army] also arranged to dispatch [to Ledo] the Engineer Company of the 4th Independent Mixed Regiment, which was in northern French Indochina. ${ }^{(23)}$ Further, the army sent on the same day (the 29th) a telegram to Detachment Commander Kawaguchi, in which it requested a report on the situation of the roads and transportation facilities to be used by the Navy for the transport of fuel and ammunition to the Ledo airfield, and also suggested that the working party companies in Miri and Seria be transferred to the Ledo area to be temporarily used as engineers. ${ }^{(23)}$

However, despite the instructions given to Staff Officer Shiraishi on the 19th and the 20th, and the telegrams sent to the Kawaguchi Detachment on the 27th and the 29th, Detachment Commander Kawaguchi had thought in quite an opposite way and took different actions. That is to say, on the 28th, he advanced to Singkawang from Pemangkat, and ordered the $2 \mathrm{~d}$ unit to closely pursue with one element the allied units to Bengkayang and with its main force to Pontianak. The main force of the $2 \mathrm{~d}$ unit (accompanied by Commander Kawaguchi) went southward on thoroughly destroyed roads, seized Mempawah at 2000 on the 28th, and the equatorial city of Pontianak, at 2000 on the 29th, from where on the 30th the detachment commander sent the following telegram to Commander in Chief Terauchi: ${ }^{(23)}$

\section{Kawaguchi Detachment Field Telegram No. 122 (30 January)}

1. The detachment is ready to join Operations $\mathrm{L}$ and $\mathrm{H}$ any time, having made its boats ready as well, so that the main force of about two battalions will be able to assemble in Pontianak and vicinity by 1 February [at the latest]. The morale of officers and men is high. I would like your consideration of the above in the employment of the detachment hereafter.

2. The remaining forces will be sufficient for the present to keep public order in British Borneo.

3. I humbly offer the above as my opinion. 
Note: The order the Southern Army had given to Detachment Commander Kawaguchi was Southern Army Operation Order A, No. 34 of 6 January, which read, "Detachment Commander Kawaguchi shall promptly seize, mainly by land, the airfields near Bengkayang and ports in Dutch Borneo which lead to these [airfields]." Since then, no exact orders had been given, only staff[-level] communications had been wired, and those moreover in the form of suggestions.

On receiving the telegram from Detachment Commander Kawaguchi, the Southern Army staff felt that he had totally ignored the situation. In reply, the Southern Army returned the following telegram: ${ }^{(23)}$

\section{From: Chief of Staff, [Southern Army,] sent on 30 January}

\section{To: Detachment Commander Kawaguchi}

We received your telegram No. 122.

We are deeply impressed by the fact that you have fully achieved the objectives of the operation despite the difficult conditions, and that further you are determined to request a new task now. Nevertheless, all we expect from your detachment at present is to make the airfields in Ledo and vicinity ready for use and to complete the accumulation of Navy aviation fuel and ammunition. Therefore, we earnestly hope that first of all you do everything in your power with all your forces and boats to achieve this objective.

Note: The battalion left in British Borneo at that time had made efforts to achieve stability and introduce a military administration over a vast area. One element of the force had sailed a great distance by boat and seized Tawau (which had many Japanese residents) on the northeast coast of Borneo on 1 February.

[The Southern Army was impatient because] in five days, the 38th Division would depart from Cam Ranh Bay and head to Palembang. On that day (the 30th), Southern Army Staff Officer Watanabe had flown from Saigon to Kuching, and Sixteenth Army Staff Officer Murakami from Kuching to Pontianak by seaplane, while the Fujikawa-maru and the Tatsumiyamaru, which carried part of the base personnel (advance party) and matériel of the 22d Air Flotilla, had left Cap Saint Jacques ([in] French Indochina) at 2000. ${ }^{(119,130)}$

On the following day, the 31st, Southern Army Staff Officer Watanabe had flown from Kuching to Pontianak via Pemangkat by seaplane. Both units of the Kawaguchi Detachment had begun reconnaissance and repair work, with the $2 \mathrm{~d}$ unit from the west coast and the 1 st unit from Ledo.

Staff Officers Murakami and Watanabe, along with the officers of the Navy, carried out a broad and thorough reconnaissance of the transportation routes, from the air (seaplane) as well as on the ground, and from the 30th onward, every day frequently reported to the Southern Army, the [Navy] Malaya Unit and others by telegram. ${ }^{(130)}$ The bridges on the main roads had been blown up very thoroughly and it was extremely difficult to repair the other roads so that automobiles could use them for the transport of aviation fuel and ammunition. The main routes to Ledo were (1) the Pemangkat - Sambas - Ledo Route, (2) the Singkawang Monterado - Bengkayang - Ledo Route, (3) the Mempawah - Monterado - Bengkayang Route, (4) the Mempawah - Sungai Penuh - Tunang - Bengkayang Route, (5) the Pontianak - Sungai Penuh - Tunang - Bengkayang Route, and (6) the Sambas River (by water up to Sanggau [Sanggan]) - Ledo Route. In the end, route (2) was being repaired, and route (6) 
was being reconstructed. As for route (2), i.e. the Singkawang - Ledo Route, more than a dozen bridges had been destroyed, and on 2 February, Staff Officer Watanabe reported that it was expected to take fifteen days to repair them, while concerning route (6), i.e. the Sambas River - Sanggau [Sanggan] - Ledo Route, the Kawaguchi Detachment reported on 1 February that "it is expected to take one week to repair [the road] between Sanggau [Sanggan] and Ledo." $(23,122,130)$

For reasons that this route was good, or that one was better, the Fujikawa-maru and the Tatsumiya-maru (both of which had left Cap Saint Jacques in French Indochina on the 30th) were sent around from one destination to another. When the Fujikawa-maru arrived in Kuching on 1 February, following the order on the 31st of the [Navy] Malaya Unit to "head for Kuching," she was on the same afternoon again ordered to "sail to Pemangkat." ${ }^{(122,130)}$ As for the Tatsumiya-maru, when she arrived in Pemangkat at 0845 on 2 February following the order of the Malaya Unit to "go to Pemangkat," her destination was changed to Pontianak. Accordingly, she left Pemangkat at 2333 on the same day for Pontianak, where on 4 February her destination was once again changed to Pemangkat. She left Pontianak at 1200 on the very day (the 4th) and finally arrived in Pemangkat at $1845 .{ }^{(122,130)}$ On that day, the warship Kashii with the above-mentioned Engineer Company of the 4th Independent Mixed Regiment on board departed from Cap Saint Jacques in French Indochina for Pemangkat. This was also the day the 38th Division's Convoy was to set out from Cam Ranh Bay. ${ }^{(122,130)}$ These were the circumstances when on the same day Staff Officer Watanabe sent the headquarters [of the Southern Army] a telegram in which he reported that "the Kawaguchi Detachment is [fully] engaged in the road repair work, putting everything available into it, allowing the officers and men merely a few hour sleep a day." (23) While putting its best efforts into repairing the roads, the Kawaguchi Detachment was [also] cooperating in transporting [matériel] by sailing upriver from Pemangkat to Sanggau [Sanggan] with the steamer and motorized sailing boats it had brought from Kuching to Pemangkat, and with all of its large- and small-sized motorized [landing] craft. ${ }^{(23)}$ Although on 3 February some Navy medium-sized attack planes had advanced to Ledo (which was apparently a trial landing; see the previous description), the amount of fuel they had been able to accumulate in Ledo by 4 February was only two hundred drums, as mentioned earlier. It was on the evening of that day (the 4th) that the three staff officers of the Sixteenth Army and [Navy] Staff Officer Wakatsuki went to the Southern Army headquarters to request a two-day postponement of [Operation] L. Staff Officer Wakatsuki was a [Navy] staff officer of the Third Fleet (i.e. the Dutch East Indies Unit) seconded to the Sixteenth Army and not a staff officer of the First Southern Expeditionary Fleet (i.e. the Malaya Unit). In other words, the staff officers of the Sixteenth Army and the Third Fleet sympathized with the First Southern Expeditionary Fleet.

\section{Third Postponement of [Operation] L (Four Days)}

Just when the Southern Army had unwillingly ordered a two-day postponement of [Operation] L because of the request of Staff Officer Wakatsuki and his party on 4 February and the telegram of the [Navy] Southern Task Force of the following day, the 5th, a telegram arrived from the Malaya Unit, which read: "We will dispatch our Chief of Staff R. Adm. Sawada Torao (accompanied by Senior Staff Officer Captain Tomari) to Saigon on 6 February to discuss Operation L." Even though the Southern Army Staff assumed that "[the Navy] could 
not possibly request another postponement on top of [the two-day postponement]," it inwardly feared that this would be the case. ${ }^{(23)}$

On the afternoon of the following day, the 6th, the Malaya Unit's Chief of Staff Sawada and Senior Staff Officer Tomari visited the [Southern Army] headquarters. ${ }^{(23)}$ When asked about the purpose of their visit, they made a request: "Yesterday on the 5th when [landbased] medium-sized attack planes and fighter planes landed on [the] Kuching [airfield], four aircraft were damaged because of bomb craters. We were informed that the repair [of the airfield] should be completed on the 7th, which we consider very doubtful. As for the Ledo airfield, on the other hand, the transport routes are long and poor, and the accumulation of fuel and ammunition has yet to be completed. Furthermore, the Kuantan airfield in Malaya, to which the [Navy land-based] medium-sized attack planes have advanced, is surrounded by a tall forest, and the trees in an area of two hundred meters wide and three hundred meters deep need to be cut down. However, we have managed to clear only twenty meters in two days, as many of the trees are enormous. We fear that it will take as much as ten days [if we continue] at this pace. As the Navy [has decided to] have aircraft maintenance personnel as well engage in the work of felling the trees, we would like you to approve at least another four days, that is, in total a postponement of six-days." Showing deep regret, Chief of Staff Sawada said, "I am very sorry to make such a request now at [such a late] moment, but I would like you to somehow understand the situation." He was so polite that it made the staff officers of the Southern Army feel sorry. ${ }^{(23)}$ After letting Chief of Staff Sawada withdraw, Colonel Ishii, Colonel Tanikawa, Lieutenant Colonel Arao and others of the Southern Army discussed matters with Captain Tomari and 22d Air Flotilla Staff Officer Commander Kōma Masayoshi. Colonel Takashima, senior staff officer of Section 1 of the Sixteenth Army was [also] present. It was a serious discussion, which continued until about 2200. The Southern Army mainly accused the Navy of insufficient preparation. ${ }^{(23)}$ It frankly pointed out: "When you manage to clear only forty [sic; above it says "twenty"] meters of forest in two days, and you have 260 meters to go, how can you finish it within a postponement of four days?" "When you have arrangements in which the Navy is to advance to both the Kuantan and the Kahang airfields for Operation L if the Kuching and the Ledo airfields are not fit for use, why have you been neglecting to make [the required] preparations?" "[Don't you remember] that in the Memorandum of the Arrangements between the commander in chief of the First Southern Expeditionary Fleet, the commander of the Sixteenth Army, and the commander of the Third Air Force of January 28, it was agreed that:

When the airfields in Ledo and Kuching are unusable, [aircraft] shall be advanced in the following way:

Kuantan: about 60 land-based attack planes, and part of the fighter planes.

Kahang: about 30 fighter planes; about 30 land-based attack planes may use the airfield as an advance base for refueling. If the [paratroop] raiding unit should use the airfield, [the Navy planes shall use the airfield] only until and including day $L-3$ or on day $L+1$ and onwards. [Editor's note: $\mathrm{L}+1$ is a mistake. The arrangement quoted on p. 265 has $\mathrm{L}+7$, as does Vol. 34, p. 470.]

Sungai Petani: about 10 land-based attack planes.

Kota Bharu: about 40 land-based attack planes." 
"Having concluded this arrangement, the Navy should in any case have conducted sufficient research on the Kuantan and the Kahang airfields, yet how dare you say now that trees are obstructing their use?" "If you had told us earlier that the trees would be a hindrance, wouldn't we have dispatched engineers or other troops?" "As a matter of fact, when we received your request concerning Ledo, didn't we immediately give orders to dispatch an engineer company of the 4th Independent Mixed Regiment?" Then [the army] proposed: "As a way to deal with the situation, since there is fuel at the [Kahang] airfield, how about having the landbased attack planes take off only with bombs, refuel at the Kahang [airfield] and then head south?" But when the reply was: "We have not inspected the Kahang [airfield] yet," the talks sure enough turned ugly. When Colonel Tanikawa reproached Colonel Takashima, senior staff officer of Section 1 of the Sixteenth Army, the latter retorted, "It's all because Ledo was supposed to be ready for use" [editor's note: the seizure and preparation of Ledo by the Kawaguchi Detachment was under the direct command of the Southern Army, not the Sixteenth Army], and the atmosphere instantly turned from bad to worse to such a degree that Colonel Ishii had to smooth things over. ${ }^{(23)}$ Although in this way no agreement was reached after all, the Southern Army consented to a postponement for only one day ([to be precise,] delayed the departure of the convoy of the 38th Division scheduled for the evening of that day, the 6th, to the evening of the next day, the 7th), while it checked up on the situation at Ledo. Moreover, they agreed that in any case the clearing of the trees [at Kuantan] had to be accelerated as quickly as possible. Fortunately, they found a company of the 20th Independent Engineer Regiment, which was assembling at Kahang and vicinity after it had finished the disembarkation operation at Endau and been assigned to the Third Air Force. It was decided to have about fifty members, mainly consisting of the cadre of this company, transported by [Navy land-based] medium-sized attack planes to Kuantan on the following day the 7th, and have them assist in clearing the trees. Meanwhile, the Navy would arrange to immediately send approximately three tons of dynamite from Saigon to Kuantan. Thus, the meeting broke up at 2200, and immediately after that, the Southern Army sent the following telegram to the Army Department of IGHQ:(23)

\section{From: Chief of Staff, Southern Army, sent on 6 February}

\section{To: Vice Chief of Staff}

1. Today, we received another request for a further postponement of four days from the First Southern Expeditionary Fleet. The main reason for this was that trees in (some) place(s) around the Kuantan airfield needed to be cut down, and even though the work had been started two days ago, the amount of work was too much to tell when it would be finished.

2. Although we were frustrated by this request, as it was made after such a long time since the conclusion of the arrangements for Operation L, we immediately arranged the assistance of [army] engineers, and [at the same time] based on the concluded arrangements, urged [the Navy] to use the Kahang airfield and took measures to let [the Navy aircraft] use army fuel, etc. However, it was decided to determine a new date for day $\mathrm{L}$ by tomorrow, the 7 th, upon careful examination of all the factors that the Navy said were still unclear. ${ }^{(23)}$

The telegram that the Southern Army sent on this night to the Third Air Force, concerning its assistance in felling the trees around the Kuantan airfield with its engineers, read as follows: ${ }^{(23)}$ 
Southern Army Staff Section 4 Telegram No. 817 (sent on 6 February from Chief of Staff)

In order to assist [the Navy] in clearing the forest (of about three hectares with many large trees) surrounding the Kuantan airfield, which the Navy air units have already been working on, we request you to urgently dispatch to Kuantan about fifty personnel, mainly [consisting of] commissioned and noncommissioned officers of the 20th Independent Engineer Regiment (with equipment to cut down trees and explosives as well). The above is [passed down] by order [of the commander in chief]. For the purpose of airlifting the personnel and the equipment, about ten [Navy land-based] medium-sized attack planes shall [be sent and] land at the Kahang airfield on the afternoon of tomorrow the 7th. We request your urgent preparations [for the dispatch].

In order to have the engineer company commander fully recognize the urgency of the situation as well as to survey the capacity of the Kahang airfield, Southern Army Section 4 Senior Staff Officer Colonel Tanikawa left Saigon on the early morning of the following day, the 7th, and headed for Kluang. In Kluang, he went to the Third Air Force headquarters, where he was surprised to find that they had received only the [last] part from "The above is [passed down] by order [of the commander in chief]" onwards of the above-mentioned telegram, which was sent the previous evening. Consequently, not knowing what to do at all, the Third Air Force had made no preparations. Colonel Tanikawa immediately explained the situation and gave instructions as to the preparations to be made. However, in the meantime, the majority of the Navy medium-sized attack planes, which had come from Kuantan to pick up the engineer company at Kahang, just went back as there was no sign that the engineer company would appear. [In the end], about fifteen personnel were transported on the last five aircraft, and the remainder were transported on the following day, the 8th. ${ }^{(23)}$ On the 7 th, Colonel Tanikawa wired the chief of staff [of the Southern Army] from Kluang as follows: ${ }^{(23)}$

Third Air Force Staff Telegram No. 62 (Sent on the 7th by the Third Air Force commander)

From Colonel Tanikawa

1. I have dealt with the dispatch of engineers to Kuantan.

2. Kahang is perfectly fit for use as an advance base for [Navy land-based] medium-sized attack planes. Also the Navy officers dispatched [to the airfield] share this judgment.

3. Preparations have been made in advance so that refueling, use of the airfield and other various facilities at Kahang will be provided by the Army. Continuous advancement [of forces] will cause no problems.

4. Based on the above, I find no reason at all to delay the landing [operations] at L any further, and [consider] it appropriate to issue an order to immediately launch [the operation].

5. I will return on the afternoon of tomorrow, the 8th.

In the meantime, on the 6th, the Combined Fleet headquarters on Hashirajima in the Seto Inland Sea had learned that the Malaya Unit (First Southern Expeditionary Fleet) and the Southern Task Force (the Second Fleet) were of different opinions; whereas the former insisted that there was no option but to delay Operation L until around 18 February because of the delays in making the air bases in Kuantan, Kuching and Ledo ready for use, the latter demanded that the operation be executed for the sake of the whole operation, no matter what loss be sustained. The Combined Fleet headquarters had wired them: "After also contacting central command [the Navy Department of IGHQ], we are of the opinion that it would be better not to make so much haste."(108) 
On the 7th, the Southern Army received an official inquiry from the [Navy] Malaya Unit, which stated: "We would like to postpone Operation L for another four days. However, we would like to start as soon as preparations for the air operations are complete." ${ }^{(23)}$ At that time, the situation of each corps was as follows:

1. The Twenty-fifth Army (the Imperial Guard Division, the 5th and the 18th Divisions) was about to go ashore in Singapore at 2400 on the following day, the 8 th. (Note: due to the postponement of [Operation] L and the preparation of the Twenty-fifth Army, the date was postponed on the 6th from the 7 th to the 8 th.)

2. The [Navy] air unit (the Eleventh Air Fleet) had been carrying out attacks against eastern Java from Balikpapan and Kendari since 3 February.

3. A powerful element of the Sakaguchi Detachment had departed from Balikpapan on 30 January, and was closing in on Banjarmasin (which was occupied on the 10th [of February]).

4. The Makassar invasion unit of the eastern attack unit ([consisting of] the 1st Base Force as the core) had departed from Kendari on 6 February, and was approaching Makassar (the landing was conducted on the 9th).

5. The Eastern Detachment (which would be covered by the [Navy] eastern attack unit after the latter's capture of Makassar) was preparing for the landing at Timor scheduled for 20 February, leaving Ambon on 17 and 18 February.

6. The Kanemura Detachment, which was set to capture Bali, left Lingayen Gulf on 7 February. [Meanwhile,] the 48th Division was scheduled to depart from the Gulf on the 8th.

7. The convoy of the $2 \mathrm{~d}$ Division and the Shōji Detachment had left Gaoxiong in four echelons on 1, 3, 5 and 6 February, and had begun to arrive in Cam Ranh Bay from the 6th onwards.

8. The 38th Division's scheduled departure date from Cam Ranh Bay had been changed from 31 January to 4 February, then to 6 February, and it was now again being postponed.

The Malaya Unit, [too,] had wired each unit covering the 38th Division at 1022 on 4 February that "Day L is expected to be postponed for two days. [The postponement] will be decided today around noon upon deliberation with the Sixteenth Army commander," which was followed by a telegram at 1530 on the same day (4 February), announcing that "Day L is expected to be postponed for two days," and again at 0800 on 6 February, that "Day L shall be postponed until specifically ordered otherwise." $(130,133)$

As the strength of the allied forces was gradually being increased, and it had been considered advantageous to conduct Operation L before the completion of the capture of Singapore, the Southern Army felt it extremely regrettable to postpone Day L now to 16 February (the departure from Cam Ranh would then be on 10 February). However, it wired back its approval, "trusting the sincerity of the Navy." (24) At 1925 on this day (the 7th), the Malaya Unit wired the following order: ${ }^{(115)}$

On the 7th, the following arrangement was made with the [Southern] Army:

Day L will be postponed for another four days. However, [the operation shall be] launched as soon as the preparations for the air operations are complete.

Then on the following day, the 8th, the Southern Army received a telegram from the [Navy] Southern Task Force, requesting the following change of schedule: ${ }^{(23)}$

L: $\operatorname{day} x+70$

H: day $x+81$

I: no later than day $x+81$ (to be arranged between the Third Fleet and the Sixteenth Army) 
Note: Before the opening of hostilities, the advance [to Java] along the east side of Borneo was believed to be faster than that along the west side of Borneo. After the two British battleships were sunk (on 10 December), the advance from the west came to be considered faster. But now, the advance from the east was again thought faster. The previously indicated factors may be considered as the causes for this latest change; however, we [also] need to give special attention to the following circumstances: While the [Navy] Dutch East Indies Unit was in charge of the attack along the east [side of Borneo] all the way to Java, the Malaya Unit was in charge of the attack along the west [side of Borneo] up to Sumatra, and would turn over [the attack on] western Java to the Dutch East Indies Unit. Whereas the main force of the Eleventh Air Fleet had consistently carried out the operations along the eastern route, with some reinforcements from the $2 \mathrm{~d}$ Carrier Division (the carrier unit which had executed the surprise attack on Hawaii), only the units of the 22d Air Flotilla as the core had carried out the operations along the western route and, what is more, the forward push of its airfields had been limited. [Moreover,] since the end of January, the 22d Air Flotilla had focused on advancing [its units] to Kuching and Ledo, taking into account the coming operation (the Java operation) and the future command disposition (the flotilla was expected to return under the direct command of the Eleventh Air Fleet), and it had paid no heed at all to the airfields in Malaya.

The Southern Army had no other option but to accede to this request as well. ${ }^{(23)}$

The [Navy] Malaya Unit made an earnest effort, which the Southern Army also sincerely supported. On the afternoon of the 9th, the prospects for the air operations were clear. Deciding to shorten the delay by one day, the Malaya Unit issued the following order at 1400 on the 9th, and that evening the units for Operation L departed from Cam Ranh Bay. ${ }^{(130)}$

\section{Malaya Unit Signal [?] Telegraphic Operation Order No. 18 (1400, 9 February)}

1. The date of $\mathrm{L}$ is set for 15 February.

2. Each unit shall operate as planned.

As day $\mathrm{L}$ was advanced by one day, it must have been possible to likewise advance days $\mathrm{H}$ and I as well. Nevertheless, the Southern Task Force, which had already obtained the consent of the Southern Army and also understood the views of the Combined Fleet, that night issued the following order by telegram, in spite of this [possibility]:(117)

\section{Southern Task Force Telegraphic Order No. 96 (2040, 9 February)}

The following amendments were made in the target dates for the invasions in the Dutch East Indies operation:

1. Western Java: day $x+81$

2. Eastern Java: no later than day $x+81$, depending on the arrangements between the commander in chief of the Third Fleet and the Sixteenth Army commander.

But how did this all affect the connection between [operations against] Singapore and [Operation] L? Colonel Tanikawa wrote in his journal at that time as follows:

9 February: Successfully crossed Johor Strait. The date of L was fixed: the landing was finally set for 15 February, and [the units] will depart tonight. 
10 February: The capture of Singapore is making progress hour by hour. From the viewpoint of strategic exquisiteness, the delay of L was really regrettable.

14 February: Not yet reached the city of Singapore, because of persistent resistance in the area. With the landing of Operation $\mathrm{L}$ a day ahead, it has become the tensest moment of the southern operation. The [Paratroop] Raiding Group set out at 0900 today, and successfully parachuted down at 1126 . When considered together with [Operation] L, it might be said that the delay in the capture of Singapore has rather created a strategic advantage.

On the 14th, the [Paratroop] Raiding Group parachuted down on the oil refineries and the airfield of Palembang. On the following day, the 15th, the advance party of the 38th Division arrived at Palembang. On the same day, the British forces in Singapore raised the flag of surrender.

\section{The Subsequent [Situation of] the Airfields and the Land-based Air Units}

In the end, the Kuantan airfield was quickly fixed and used, but it was impossible after all to make use of the Ledo airfield for Operation L, despite the enormous amount of labor and effort that had been put into it.

As of 17 February, when the 38th Division commander came ashore at Palembang following the landing of the advance party (on the 15th), the following effort had been spent on the Ledo airfield, ${ }^{(23)}$ but during that time the airfield was only used by three heavily-shot aircraft, which had made emergency landings on 15 February. ${ }^{(104)}$

\section{Outline of the progress to ready the Ledo airfield: ${ }^{(23)}$}

1. The work force committed to the airfield work: a total of 8,091 men since 28 January.

2. The number of days they were deployed: 21 days from 28 January to 17 February.

3. The accumulation of fuel and ammunition (as of 1200, 17 February): 1,058 [drums] of 92-octane gasoline, 1,099 [drums] of 87-octane gasoline, 36 [drums] of mineral oil, 10 No. 25 [250kg] bombs, 680 No. 6 [60kg] bombs, and 30 units of oxygen ([in stock] at the airfield).

276 [drums] of 92-octane gasoline, 128 [drums] of 87-octane gasoline, 120 [drums] of mineral oil, 320 of No. 6 [60kg] bombs, and 144 units of oxygen ([in stock] at Momong).

The land-based air units of the Malaya Unit for Operation L consisted of (1) the Genzan Air Group (thirty-six land-based attack planes), (2) the Mihoro Air Group (thirty-six land-based attack planes), (3) the Yamada Unit (thirty fighter planes and six land-based reconnaissance planes), and (4) the Kanoya Air Group (twenty-seven land-based attack planes), led by the commander of the 22d Air Flotilla [R. Adm. Matsunaga Sadaichi], of which the Flotilla commander, the Genzan Air Group and the Yamada Unit launched operations from the Kuching airfield, the Mihoro Air Group from the Kuantan airfield and the Kanoya Air Group from the Thủ Dâu Một airfield in French Indochina. ${ }^{(104)}$

On 12 February, the advance party of the 38th Division was heading south halfway between Cam Ranh Bay and Palembang. That night, Regimental Commander Oka [of the Kawaguchi Detachment] sent the Southern Army the following telegram from Sanggau [Sanggan]. It described that it would take another week to complete a runway with a length of 1,300 meters, which was necessary for a [Navy] land-based attack plane, and [also] about one week each for the work to [re-]build the bridge(s) over the Ledo River and those to the 
south of Pemangkat, as well as the road from Ledo to Singkawang. It was on 6 February that the Engineer Company of the 4th Independent Mixed Regiment had arrived at Pemangkat in the warship Kashii. ${ }^{122)}$

1. As of today, the 12 th, in addition to the two runways of 1,100 meters long, a taxiway of 30 meters wide and 500 meters long, which connects the runways ([and] which was constructed at the request of the staff of the $22 \mathrm{~d}$ Air Flotilla) was completed on the airfield. We are extremely determined to extend one of the runways to 1,300 meters, to be completed in a week from tomorrow, the 13th, in order to make the airfield ready for the advance of the Kanoya Air Group. I understand that if this extension work is completed, [this airfield] would be [sufficient] enough to serve as a base for two units of medium-sized land-based attack planes and one Type- 1 attack plane unit, [in total] about ninety aircraft.

2. The bridge building materials sent by the [Southern] Army in Saigon, to the amount of three trucks, have arrived in Pemangkat. I have arranged that they will be debarked at Sambas, and distributed in such a way that spikes, etc. will be used by the bridge construction units, and the engineering tools in the extension work of the airfield. ${ }^{(23)}$

3. (The rest, concerning the current situation and the outlook for the repair of the roads and bridges, has been omitted by the author).

\section{The Military Gains of the Kawaguchi Detachment}

Despite the tremendous effort made by the Kawaguchi Detachment, the Ledo airfields were never put into use before the end of the Java invasion. The military achievements of the Kawaguchi Detachment during its operation in Dutch Borneo (up to 19 February) were as follows: ${ }^{(23)}$

\section{Operations:}

27 January: Seizure of Sanggau [Sanggan], the Ledo airfields, Pemangkat, and Sambas.

28 January: Seizure of Singkawang.

29 January: Seizure of Bengkayang and Pontianak.

16 February: Seizure of Sintang.

2. Military gains: (1) 270 abandoned dead bodies; 182 prisoners of war; (2) Seized [weaponry and vehicles]: 4 tanks, 2 armored vehicles, 47 motor trucks, 133 passenger cars, 2 trench mortars, 7 heavy machine guns, 5 light machine guns, 12 (semi-)automatic rifles, 416 rifles, 35 pistols and others.

3. Losses: 19 killed in action; 2 died of wounds; 31 wounded in action. 


\section{(3) Air Operations and the Sailing of the Convoys}

\section{The Air Campaign of the 3d Air Division to Destroy the Enemy}

I have already described the air campaign of the Third Air Force over Sumatra conducted until the 23d [inclusive] of January, and the Army-Navy arrangement on the air operations in [Operation] L (preliminarily arranged on 28 January, and concluded on the 30th), as well as the Third Air Force order ([issued on] 4 February).

As mentioned earlier, on 5 February, Operation L was postponed for two days. However, the Third Air Force decided to launch the air operations [for Operation] L from 6 February onwards in accordance with the plan for [Operation] L that had been passed down in the order of 4 February, and issued the following order on the 6 th: ${ }^{(96)}$

Third Air Force Operation Order A, No. 262

\section{Third Air Force Order}

Kluang, 1000, 6 February

1. Day $x$ (note by the author: the date to start [the operation to] capture Singapore, previously [scheduled for] the 7th [of February]) set forth in Third Air Force Operation Order A, No. 257 (note by the author: [issued on] 4 February) and day L have been set respectively on 8 and 12 February. The actions of the Twenty-fifth Army, given in separate volume No. 1: The outline of the cooperation with the Twenty-fifth Army in the operation to capture Singapore will be changed as set forth in the separate sheet.

2. The commanders of all units involved shall arrange their actions in accordance with the above changes. However, the $3 \mathrm{~d}$ Air Division commander shall spot and destroy enemy aircraft in Palembang and vicinity as soon as possible, regardless of Third Air Force Operation Order A, No. 257.

\section{Separate Sheet}

1. The launch of [the operation to] capture [Singapore] is set for 8 February (day $\mathrm{x}$ ).

2. On the night of day $x-1$, while continuing its diversionary action as before, the Imperial Guard Division shall have one element make a surprise attack on the western part of Ubin Island (in the eastern end of Johor Strait) and secure it.

3. On day $x$ at 2300 , the 5 th and the 18 th Division shall have their 1st landing units go ashore all at once.

Within the Third Air Force, the 3d Air Division was charged with the air operation of Operation L, which was to be executed simultaneously with the capture of Singapore. On 6 February, the division started its campaign to destroy the enemy air power in the Palembang sector based on the above two orders. During the period up to the 8th, the campaign was carried out three times, and [the division successfully] destroyed the major part of the allied air forces in this sector. The outline [of the attack] was as follows: ${ }^{(96)}$

[February]

6th: The aircraft of the 59th, the 64th, the 75th and the 90th Air Groups, sixty-six in total, took off from the Kluang and the Kahang airfields, attacked the Palembang [airfield] with their main force, and the Mentok airfield with an element. After bringing down fifteen [enemy] aircraft and destroying eleven on the ground, all aircraft returned to their bases. 
7th: The aircraft of the 59th, the 64th and the 90th Air Groups, thirty-seven in total, attacked the Palembang airfield, destroyed twenty [enemy] aircraft on the ground, and brought down most of the dozen or more which fought back. Two Japanese aircraft did not return to their base.

8th: The aircraft of the 59th, the 64th and the 90th Air Groups, forty-two in total, attacked the Palembang airfield, brought down two [enemy] aircraft and destroyed nine on the ground.

On 9 February, when the major part of the [enemy] air forces in the Palembang area was destroyed as detailed above, the date of $\mathrm{L}$ was changed to the $15 \mathrm{th}$. Therefore, on the 10 th, the Third Air Force commander passed down the following order: ${ }^{(96)}$

Third Air Force Operation Order A, No. 268

\title{
Third Air Force Order
}

\author{
Kluang, 0930, 10 February
}

1. Day L was again changed, and set for 15 February. The outline of actions of the 38th Division as well as its scheduled sailing route is as shown in the separate volume. (Omitted by the author)

2. The commanders of all units involved shall arrange their actions in accordance with the date set in the previous item, regardless of Third Air Force Operation Order A, No. 262.

3. The 3d Air Division commander shall keep watch on the Palembang airfield and destroy enemy aircraft at a good opportunity. He shall bring the 64th Air Group under his command from 2000, 11 February onwards.

4. The 7th Air Division commander shall put the 64th Air Group under the command of the 3d Air Division commander from 2000, 11 February onwards.

5. The 1st [Paratroop] Raiding Group commander and the 98th Air Group commander shall use the Kahang and the Kluang airfields for the [Paratroop] Raiding Air Unit and the 98th Air Group respectively as the first takeoff base, regardless of Third Air Force Operation Order A, No. 257 separate volume No. 4.

Accordingly, on the 13th (one day prior to the drop of the paratroopers), the $3 \mathrm{~d}$ Air Division ([consisting of] the 59th, the 64th, the 75th and the 90th Air Groups) attacked Palembang with thirty-five aircraft, brought down five [enemy] aircraft, and destroyed another four. On the Japanese side three aircraft did not return to their base. ${ }^{(96)}$

\section{The Air Operations of the [Navy] Malaya Unit}

The air unit of the Malaya Unit (the First Southern Expeditionary Fleet) consisted of the 1st Air Unit (a land-based air unit, [consisting of] the 22d Air Flotilla as the core), the $2 \mathrm{~d}$ Air Unit (the auxiliary seaplane tenders Kamikawa-maru and Sagara-maru, from 1 February onwards), and the $3 \mathrm{~d}$ air unit (the aircraft carrier Ryuj $\bar{j} \overline{0}) .{ }^{(110)}$ In early February, the Sagara-maru took up position at the Anambas Islands, while the Kamikawa-maru and the Ryūjō were in Cam Ranh Bay, and [both] mainly carried out patrolling and guarding [duties] against submarines in the Anambas Islands and the Ledo areas. ${ }^{(130,133)}$

On concluding the already mentioned arrangement for the air operations [in Operation] L, on 31 January, the Malaya Unit had passed down the following order to the commander of the 1st Air Unit (the commander of the 22d Air Flotilla). ${ }^{(104)}$

1. Advance the Genzan Air Group and the Yamada Unit to the Kuching [airfield] on 3 and 5 February respectively, and further advance them to the Ledo [airfield] when it is ready for use. 
2. Advance the Mihoro Air Group to the Kuantan [airfield] on 6 February.

3. Swiftly advance the Kanoya Air Group to the Kuantan [airfield], and to the Ledo [airfield], as it is made ready for use.

The aforementioned Fujikawa-maru and the Tatsumiya-maru had left Cap Saint Jacques on 30 January, with the Fujikawa-maru arriving at Kuching on 1 February, and the Tatsumiya-maru at Pemangkat, the port finally decided as its destination, on the night of 4 February. ${ }^{(122)}$ The Genzan Air Group and the Yamada Unit had advanced to the Kuching [airfield] as ordered, but they could not advance [further] from Kuching, because not much progress had been made in the preparation of the Ledo base. ${ }^{(104)}$

The Mihoro Air Group had [also] advanced to the Kuantan [airfield] on 6 February as ordered. However, the trees surrounding [the airfield] had prevented aircraft with a full load of fuel and ammunition from taking off. [For this reason,] on the same day, First Southern Expeditionary Fleet Chief of Staff Sawada and Captain Tomari had hurriedly visited the Southern Army headquarters to request a four-day postponement of [Operation] L. When the Southern Army had suggested the idea of "How about [the Navy aircraft] using the Kahang [airfield], one of the airfields [mentioned] in the arrangement for the air operation [in Operation] L, as a relay base, and having them fill up [their fuel tanks] there," the 22d Air Flotilla staff officer had answered, "We have not inspected the Kahang [airfield] yet," which had infuriated the Southern Army, as previously described. ${ }^{(23)}$ On the same day, the [Army] Third Air Force had launched its air campaign [in Operation] L to destroy the enemy air power. ${ }^{(96)}$

Because of the state of affairs at the Ledo, Kuantan and Kahang airfields, the Kanoya Air Group had no opportunity to advance from its base in Thủ Dâu Một in French Indochina. ${ }^{(104)}$

On 8 February, the previously mentioned reinforcements from the 20th Independent Engineer Regiment began their work of blowing up the dense forest surrounding the Kuantan [airfield]. ${ }^{(104)}$ Also on this day, the $22 \mathrm{~d}$ Air Flotilla advanced its headquarters from Saigon to Kuching. ${ }^{(104)}$

On 9 February, it became feasible to put into practice the idea of having aircraft take off light [i.e. without a full load of fuel] from the Kuantan [airfield], rushing to the Kahang [airfield] to fill up [their fuel tanks] and carrying out the attack, as the Southern Army had suggested. Consequently, the date for $\mathrm{L}$ was set for the 15th, and the convoy [of the advance party] departed from Cam Ranh Bay on the evening of the 9th. The Kuching unit [i.e. the air unit which used the Kuching airfield, also] began its attack operations [in Operation] L on the same day.

On 10 February, the Kuantan unit (the Mihoro Air Group) advanced to the Kahang [airfield] and started its attack operations on the 11th, taking off from there. However, as it became possible to take off with a full load of fuel from the Kuantan [airfield] from 12 February onwards, the unit conducted the attacks from Kuantan from then on.

[However,] as the Ledo airfields were eventually of no use at all for the whole period of Operation L, and the state of the Kuantan [airfield] was as previously described, the Genzan Air Group and the Yamada Unit ended up operating from Kuching, the Mihoro Air Group from Kuantan (except for the two days when it used Kahang as a relay base), and the Kanoya Air Group from Thủ Dâu Một from beginning to end. ${ }^{(104)}$

Note: Even though it might be [correct to] say that the Kuching airfield was used, due to the difficulties in getting the airfield ready for use, the aircraft had throughout to limit the amount of fuel to half [a tank], when taking off from the airfield. 
The attack targets were mainly enemy aircraft in western Java and enemy warships in the waters off Singapore, Sumatra and western Java. ${ }^{(104)}$ An outline of the attacks was as follows: ${ }^{(103,104)}$

[February]

1st: Reconnaissance and attack with eleven aircraft; one [enemy] merchant ship sunk.

2d: Search and attack with sixteen aircraft.

3d: Search and attack with twenty-seven aircraft; three [enemy] merchant ships sunk.

4th: Search and attack with sixteen aircraft; one [enemy] merchant ship and one [enemy] small escort warship sunk.

5th: Search and attack with fourteen aircraft.

6th: The Army launched its air operation [in Operation] L, but the Navy not [yet].

7th: Same as above.

8th: Search and attack with seven aircraft; one [enemy] merchant ship sunk.

9th: Attack mainly on Batavia with twenty-four aircraft; twelve [enemy] aircraft brought down,

10th: eight aircraft destroyed on the ground.

11th: Attack with forty-three aircraft; one [enemy] light cruiser hit directly and two [enemy] merchant ships destroyed.

12th: Attack with approximately eighty to ninety aircraft; eight [enemy] aircraft in the Batavia area brought down, one [enemy] cruiser and one [enemy] auxiliary ship hit directly, and one [enemy] merchant ship heavily damaged.

13th: Attack with ninety-five aircraft; one [enemy] merchant ship sunk.

The above was the general situation until the day before the paradrop operation on Palembang.

\section{The Judgment on the Enemy Movements, the Sailing of the Convoy and the Fleet, and a Naval Engagement}

On February 9 at noon the Malaya Unit decided and issued the order "to start this evening." The judgment on the enemy movements made at that time was in summary as follows:(115)

1. The [sea] traffic of allied warships and transport ships between Singapore and Java was most frequent during the period after the capture of Johor Bahru ([on] 31 January) until about the 5th of February [inclusive]. Although it has gradually become less frequent since the 6th, the coming and going of transport ships escorted by light cruisers, destroyers and others still continues. As two warships, supposedly battleships, were spotted at Batavia on the 8th, there is a very high probability of encountering allied surface units in the Bangka area.

2. As the Twenty-fifth Army has landed on Singapore Island this morning, it is likely that we can capture units trying to flee from the island.

3. Counter offensives by the allied air forces are expected to be small.

4. It is highly necessary to be on guard against the allied submarines.

5. It is necessary to be on a strict alert against the underwater mines in the whole Bangka and Palembang area.

6. Whereas strong resistance is not expected [during the operation to] capture Bangka Island, it is expected that the operation to go upriver toward Palembang for dozens of nautical miles will meet with considerable resistance. 


\section{The 38th Division's Marching Order and Departure}

After its arrival in Cam Ranh Bay on 24 January, the departure date of the 38th Division had been successively changed from 31 January to 4 February, then to the 6th and then again to the 10th, but it [finally received the order] to "depart on the evening of today, the 9th." Accordingly, the division issued the following order: ${ }^{(69)}$

Numa [38th Division] Operation Order A, No. 110

\section{8th Division Order}

1. The date for L, set forth in NumA [38th Division] Operation Order A No. 101, is set for 15 February.

2. The advance party, based on the memorandum of arrangements with the First Southern Expeditionary Fleet and the 3d Destroyer Squadron, shall depart from Cam Ranh Bay at 1900 today, the 9 th, and advance in convoy according to the distribution set forth in the separate sheet.

3. The main force of the division, based on the memorandum of arrangements with the First Southern Expeditionary Fleet and the 3d Destroyer Squadron, shall depart from Cam Ranh Bay at 1800 two days later on the day of celebration of the founding of the state, the 11th, and advance in convoy according to the distribution set forth in the separate sheet.

4. This is the time to demonstrate the ability of the division as well as the true form of the Imperial Army. All officers and men must make a great and determined effort.

5. I shall be on board the Gin'yo-maru. [I shall] depart from Cam Ranh Bay along with the main force in the evening of 11 February, and advance toward Palembang.

The advance party set off at 1900 on the 9 th. The distribution of the convoy was as follows: ${ }^{(69)}$

1st Section: the Tajima-maru (6,995 tons, Lieutenant Colonel Iwabuchi), the Tacoma-maru (5,772 tons, Lieutenant Colonel Nagahata), the Mansei-maru (7,770 tons, Lieutenant Colonel Satō), the Ōyō-maru (5,458 tons, Major Miyazawa)

2d Section: the An'yō-maru (9,256 tons, Captain Orita), the Alaska-maru (7,378 tons, Captain Sumihara), the Kinugawa-maru (6,936 tons, Colonel Tanaka), the Sado-maru (7,180 tons, air defense ship, Lieutenant Colonel Fujimoto)

The main force of the division set off at 1800 on the 11th. The distribution of the convoy was as follows: ${ }^{(69)}$

3d Section: the Alpen-maru [Argun-maru?] (6,661 tons, First Lieutenant Okada), the Singaporemaru (5,859 tons, Lieutenant Colonel Yabuta), the Shinkyō-maru (5,139 tons, Major Kemmotsu), the Rakuyo-maru (9,418 tons, Colonel Kanki), the Lima-maru (6,989 tons, Lieutenant Colonel Furushō), the Gin'yō-maru (8,613 tons, Lieutenant Colonel Endō), the Tsushima-maru (6,754 tons, Major Kashiwabara)

4th Section: the Meigen-maru (5,435 tons, First Lieutenant Hirano), the Buyō-maru (5,446 tons, Captain Koide), the Kenzui-maru (4,156 tons, First Lieutenant Narihira), the Makassar-maru (4,026 tons, Captain Kusakabe), the Shinsei-maru No. 1 (5,879 tons, Major Ōneda), the Fusōmaru (8,196 tons, hospital ship), the Hirokawa-maru (6,872 tons, air defense ship, Lieutenant Colonel Okuzaki)

Note: the officers whose names are given within parentheses were the transport commanders. 


\section{Departure of the Malaya Unit and its Engagements (See Illustration No. 25)}

As we have seen, the outline of the disposition of the forces of the Malaya Unit for Operation L was the main unit ([consisting of] the Chōkai, the 7th Cruiser Division, five destroyers of the $3 \mathrm{~d}$ Destroyer Squadron), the 1st escort unit ([consisting of] the 3d Destroyer Squadron (minus eight destroyers) as the core), the $2 \mathrm{~d}$ escort unit ([consisting of] the Yura, the Shimushu, two destroyers of the 3d Destroyer Squadron as the core), the 1st Air Unit (land-based air [unit]), the $2 \mathrm{~d}$ air unit ([consisting of] the auxiliary seaplane tenders Kamikawa-maru and Sagara-maru), the $3 \mathrm{~d}$ air unit ([consisting of] the aircraft carrier Ryūjō, one destroyer of $3 \mathrm{~d}$ Destroyer Squadron), the river-ascending unit [toward] Palembang (the 9th Base Force with the Hatsutaka as the core), and others.

On 9 February, the Sendai (light cruiser), the flagship of the 3d Destroyer Squadron ([led by] R. Adm. Hashimoto Shintarō), and four destroyers (the Hatsuyuki, the Shirayuki, the Fubuki and the Asagiri) departed from Cam Ranh Bay at 1900, escorting the advance party. ${ }^{(118)}$

On the following day, the 10th, Commander in Chief Ozawa sallied forth from Cam Ranh Bay with the main unit, ${ }^{(102)}$ accompanied by the $3 \mathrm{~d}$ Air Unit. In the main unit were the flagship Chōkai (heavy cruiser), the Kumano, the Suzuya, the Mikuma and the Mogami (all heavy cruisers) of the 7th Cruiser Division, the flagship of the 5th Submarine Squadron the Yura (light cruiser), and the Ayanami, the Isonami and the Shirakumo (all destroyers) of the 3d Destroyer Squadron. The destroyers the Uranami and the Murakumo, which on the 9th had discontinued their support for the transport to Ledo, were [also] to join [the main unit] near the Anambas Islands on the 12th. On the 8th, Commander in Chief Ozawa had decided to reassign the Yura (light cruiser) to the main unit [from the 2d escort unit] and the Kashii (training cruiser) of the Anambas base unit to the $2 \mathrm{~d}$ escort unit instead, considering that there was a strong probability in this operation that [the main unit] would encounter a powerful allied fleet. The destroyer Shikinami of the 3d Destroyer Squadron was attached to the 4th Carrier Division (the $R y \bar{u} j \bar{o})$ of the $3 \mathrm{~d}$ air unit, and accompanied it. ${ }^{(102)}$

At 1800 on the following day, the 11th, the Kashii (training cruiser), the Shimushu (coastal defense ship), and the Yügiri and the Amagiri (both of which were destroyers of the $3 \mathrm{~d}$ Destroyer Squadron) departed, escorting the main force of the 38th Division. ${ }^{(102)}$

The 1st Air Unit (the 22d Air Flotilla) was conducting the [air] campaign from the Kuching, the Kuantan (the Kahang) and the Thủ Dâu Một [airfields], and the 2d Air Unit ([seaplanes of] the auxiliary seaplane tenders) was carrying out patrols with the Kamikawa-maru at Cam Ranh Bay and the Sagara-maru at the Anambas Islands. ${ }^{(130,133)}$

On the following day, the 12th, the convoy continued to advance southward, while the destroyers with a short cruising distance alternately refueled at the Anambas [base]. ${ }^{(102)} \mathrm{Hav}$ ing learned that allied warships were fleeing from Singapore, Commander in Chief Ozawa on that day at 1630 gave orders to catch and destroy them. ${ }^{(118)}$ On that day, the Hatsutaka, the flagship of the commander of the 9th Base Force, which had been reassigned from the Anambas base unit to the river-ascending unit [towards] Palembang, joined [the main unit] from Anambas and headed southward. ${ }^{(102)}$

On the next day, the 13th, the main unit crossed the equator at 0600. Acting in concert with the aircraft, the units engaged in the campaign to catch and destroy the warships fleeing from Singapore in the sector east of Lingga Island. ${ }^{(102,115,118)}$ The 3d Destroyer Squadron sank one ship, which seemed to be an auxiliary cruiser, and also one minelayer and one commercial ship, etc., with its flagship the Sendai, and others. ${ }^{(118)}$ [Meanwhile,] the convoy of the ad- 
vance party continued to advance southward under the escort of minesweepers and others. ${ }^{(118)}$ On the same day, one allied aircraft came close for scouting and five for an attack, but no loss was sustained on the Japanese side. ${ }^{(118)}$

On the following day, the 14th (the day of the first drop of the paratroopers), the $3 \mathrm{~d}$ Destroyer Squadron headed southward while intensifying its direct escort. The squadron as well as the other units still successfully caught and destroyed the allied ships fleeing [from Singapore]. ${ }^{(102)}$ At 0830 the convoy of the advance party came under attack from three allied aircraft, but no loss was sustained. Japanese fighter planes provided air cover between about 1000 and 1545, during which period six allied aircraft came for an attack at approximately 1230, another four at approximately 1450, but they caused no loss on the Japanese side. At 2100 the convoy of the advance party began its entry into the Mentok anchorage. ${ }^{(118)}$

Between 0010 and 0100 on the next day, the 15th, the ships entered the Mentok anchorage and moved to prepare for the landing operation at Mentok and the river-ascending operation toward Palembang. ${ }^{(118)}$ However, at 0938, a reconnaissance seaplane of the Chōkai transmitted that "three enemy cruisers and five destroyers are heading northward through the Gaspar Strait," and then at 0950, "the enemy seems to have six destroyers as direct escort accompanying one battleship." At that time, the convoy of the main force of the 38th Division was sailing [the waters] northeast of Lingga Island, heading southward. ${ }^{(118)}$ At 1240, Commander in Chief Ozawa judged that "the main force of the enemy [must] consist of one battleship, three cruisers and eight destroyers." ${ }^{(104)}$ At that point, the 1st Air Unit (the 22d Air Flotilla) was still based in Kuantan, Kuching and Thủ Dâu Một. As for the 2d Air Unit, the Sagaramaru was still at its base in Anambas Island, while the Kamikawa-maru, which had departed from Cam Ranh Bay on the 14th, was steaming southward. ${ }^{(104,130,133)}$ Commander in Chief Ozawa made up his mind to first direct a concentrated air attack, while having the convoy temporarily evacuate from the area, and then attack the allied fleet with all the warships he could employ. At 1035, he ordered the 1st Air Unit to prepare for an attack with the full force of its land-based attack planes. Then he successively gave the following orders: at 1045, he ordered: "(1) The main unit shall advance to the southeastern waters to destroy the enemy fleet; (2) the 1st and the $3 \mathrm{~d}$ Air Units shall repeatedly attack the enemy with full force; and (3) the $2 d$ Air Unit shall get close to the enemy fleet for scouting." (118) Then at 1125: "The 2d escort unit ([and] the convoy of the main force of the 38th Division) shall temporarily evacuate to the north." ${ }^{(118)}$ Further at 1330: "The main unit shall try to engage the main force of the enemy in a decisive battle, after the attacks by the 1st and the $3 \mathrm{~d}$ air units on the latter." And at 1330: "[(1)] The Sendai, the Yura, the 11th Destroyer Division (note by the author: the Hatsuyuki, the Shirayuki and the Fubuki) and the Asagiri shall join the main unit; (2) the main unit shall sail to the waters southeast of Cape Jang; (3) the remaining element of the 1st escort unit (note by the author: [the element and] the convoy of the advance party of the 38th Division) shall enter into the anchorage in the mouth of the Musi River." ${ }^{(118)}$ However, as the allied fleet reversed its course at 1417, the $2 \mathrm{~d}$ escort unit (and the convoy of the main force of the 38th Division) [also] turned around at 1700, and headed for the mouth of the Musi River. ${ }^{(118)}$ At 1700 [the commander in chief] ordered the 1st escort unit that "the commander of the 1st escort unit shall return to his original mission when convenient." At 1710, Commander in Chief Ozawa reported to the Combined Fleet and the Southern Task Force: "Against one Malaya-type battleship, seven cruisers and five destroyers heading northward, I had the air units start their attack around 1330 and onwards, intending to conduct a decisive battle after 
having the air units destroy the enemy main force. But around 1400 the allied fleet reversed its course."(118) The engagement had ended with no enemy ships sunk by the air attacks and no [direct] encounters between the surface units.

\section{The Sailing of the Advance Party}

The conditions during the passage of the $A n^{\prime} y \overline{0}-m a r u$, which was the head of the left file of the advance party ([sailing in] double file, with four ships each) were as follows: ${ }^{(69)}$

[February]

9th: Departed from Cam Ranh at 1900. Everything all right.

10th: Clear. Spotted something that looked like an allied submarine on the port bow.

11th: Clear. Everything all right.

12th: Spotted something that looked like an allied submarine on the port bow at 0730. At 0915, strict alert against submarines. At 1000, (an) escort ship opens fire on the port bow.

13th: Clear. Everything all right.

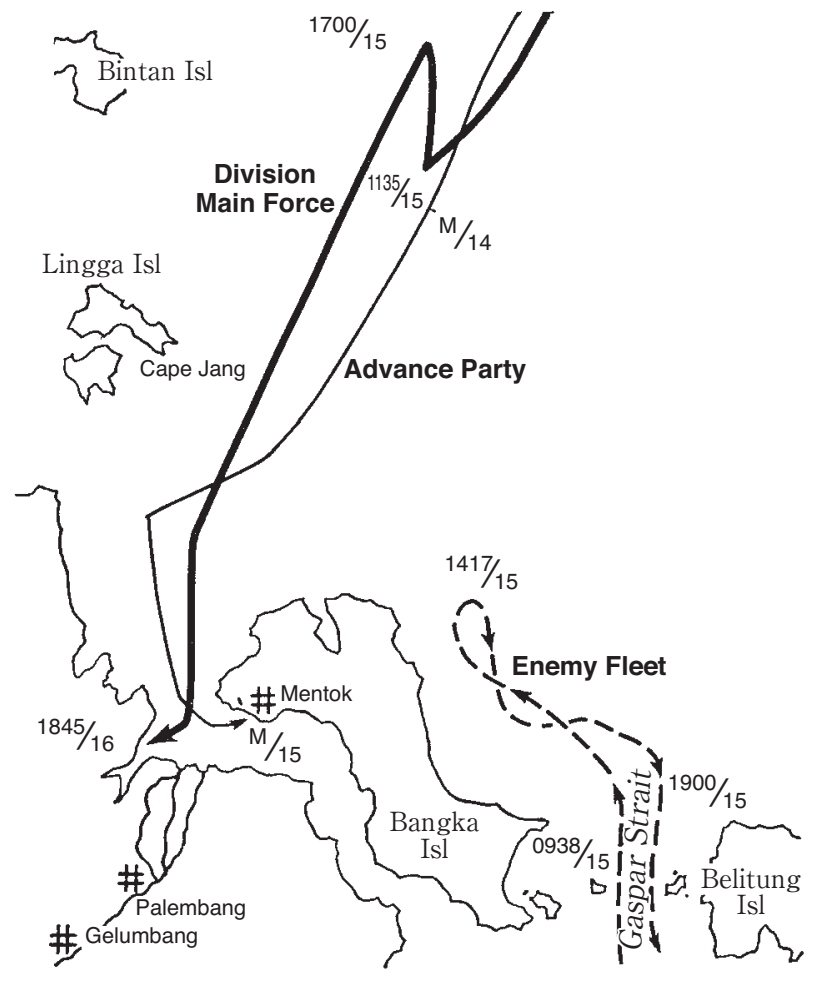

Illustration No. 25-Routes of Sailing and Entry into Anchorage of Operation $L$ Advance party: safely entered anchorage.

Main force of the division: entered anchorage after once having reversed its course at the approach of the enemy fleet coming for an attack.

14th: Clear. At 0845, one allied aircraft approached, but was repelled. Next, some more approached, but were repelled. Then, strict alert against floating mines. At 1230, (an) escort ship destroyed mines ahead. At 1245, five allied aircraft approached, were intercepted by two Japanese aircraft, which brought down two of the allied aircraft at 1250. At 1330, three allied aircraft approached, [but] were repelled. At 1920, twelve allied aircraft approached, [but] were repelled. At 2330, entered the Mentok anchorage, dropped anchor at 2435 , started transferring to landing craft at 2445 , which was completed at 0200 . 


\section{(4) The Paratroop Drop}

\section{[Paratroop] Raiding Group Order}

Having on 4 February received the aforementioned Third Air Force Order, Colonel Kume, the commander of the 1st [Paratroop] Raiding Group, drew up an attack plan as well as an outline of the raid, and on the 11th he passed down the following order:(96)

\section{1st [Paratroop] Raiding Group Operation Order A, No. 32}

\section{1st [Paratroop] Raiding Group Order}

\section{February}

1. Details concerning the enemy movements and the situation of our own troops will be provided separately.

2. Based on the attack plan in the separate volume, at 1130 on day $\mathrm{L}-1$ as the set time and date, the 1st [Paratroop] Raiding Group shall execute a raid against the airfield and the oil refineries of Palembang and their vicinity, seize and secure them, while facilitating the operations of the Third Air Force and the 38th Division as well. The 12th Transport Squadron shall temporarily be put under my command until the completion of Raiding Operation L. The 3d Air Division and the 81st and the 98th Air Groups shall provide cooperation when the [paradrop] raid is carried out, of which the 98th Air Group shall follow my command with respect to the details of the raiding operation. The paratroop as well as the [crash-] landing units shall come under the command of the Sixteenth Army commander when the main force of the 38th Division arrives in Palembang. The remaining units under the command of the group shall return to their original command on completion of Operation L without separate orders.

3. The airfield raiding unit shall act as follows:

(1) The main force shall parachute down in a sector southeast of the airfield and one element in a sector west of the airfield, attack and seize the airfield. While having the necessary forces secure the airfield, the main force shall attack and seize [the city of] Palembang. Particular attention must be paid to keeping an eye on the main road to Jambi. After the drop and until the troops have collected and readied their equipment, [air] cover by means of ground attacks by [our] fighter planes shall be provided. In the attack on the airfield, it is necessary to stay in close contact with aircraft that performs an emergency or crash-landing.

(2) Upon seizing the airfield, [the unit] shall start to work on repairing the airfield, so that it will first of all be fit for use by fighter plane units, and secondly by large aircraft.

(3) Once Palembang is seized, [the unit] shall make efforts to get hold of facilities related to the oil refineries, and to seize as many means of transport as possible for the sake of the main force of the 38th Division.

(4) After the drop, [the unit] shall take the oil refineries raiding unit under its command.

(5) The advance party of the 38th Division, consisting of one and a half infantry battalions as the core and led by Colonel Tanaka, is scheduled to sail upriver to Palembang on day L.

4. The oil refineries raiding unit shall parachute down in the vicinity of the location, and first seize key parts of the refineries by means of a sudden attack. It shall try to frustrate the enemy's plan to destroy [the facilities] and secure the premises upon seizing them. [The unit] shall need to be particularly on guard against enemy maneuvers conducted from the west or from upriver. After the drop, the unit shall return under the command of the regimental commander, and therefore shall swiftly establish radio contact.

5. The $2 \mathrm{~d}$ [Paratroop] Raiding Regiment commander shall secure the targets to be seized until the arrival of the main force of the 38th Division (scheduled for day L + 2).

6. The [Paratroop] Raiding Air Unit shall enplane the paratroop units, and raid Palembang and vicinity at 1130 on day $L-1$ as the set time and date. 
7. The cooperating heavy bomber group shall take on board important arms and matériel, and fly ahead to Palembang and vicinity while providing cover against antiaircraft fire for the [Paratroop] Raiding Air Unit. The outline of cooperation to be provided by the 81st, the 64th, the 59th and the 90th Air Groups shall be arranged separately.

8. The outline of the paradrop raid conducted by the [Paratroop] Raiding Air Unit and the cooperating air group of heavy bombers shall be given in separate order(s).

9. The ground units of the second raiding unit shall be in Sungai Petani and make preparations so that the [2d paradrop] raid can be executed on day $\mathrm{L}$, which shall be separately ordered.

10. As for quartering, provisions and medical supplies after the drop, you must depend on what you can get from the enemy, [nevertheless] you must be fully determined to carry on. [Only] indispensable matériel may be supplied by air transport.

11. I shall be with the $2 \mathrm{~d}$ [Paratroop] Raiding Regiment.

\section{Separate volume: $\quad$ Palembang [Paratroop] Attack [Operation] Plan}

4 February 1942, 1st [Paratroop] Raiding Group Headquarters

\section{Mission}

On day L-1 (9 February), the first [paradrop] raid shall be executed. The paradrop shall be conducted at 1130 of the same day the main force shall make a sudden attack on the Palembang airfield, seize and secure it, after which [the force] shall attack and seize [the city of] Palembang. Simultaneously, an element shall parachute down in the vicinity of the oil refineries, make a sudden attack [on the facilities], seize and secure them.

On day L, a second [paradrop] raid shall be executed to reinforce our fighting power. By acting in close connection with the cooperating air units, we expect to carry out an integrated air and ground [attack] and maintain perfect security [to keep the enemy unaware].

2. Outline

(1) The cooperation in the operations and the raiding operation schedule of the air units (except that of the air groups that drop equipment) are as shown in Attachment 1.

(2) Deployment to the launching bases:

By the evening of day L - 2 (8 February), the airfield raiding unit and the cooperating air units shall be deployed to the Kahang [airfield], and the oil refineries raiding unit and its cooperating air units to the Kluang [airfield]. [Both] shall complete the preparations for the raid.

(3) Outline of the flight

(a) The departure from the launching bases shall be set at such a time that the paradrop can be executed at 1130 on day $\mathrm{L}-1$.

(b) The [Paratroop] Raiding Group commander shall decide the details of the flight formation, after consulting the commanders of the $2 \mathrm{~d}$ [Paratroop] Raiding Regiment, the [Paratroop] Raiding Air Unit, and the 98th Air Group.

(c) If during the flight and before the execution of the drop it becomes by any means inevitable to change decisions due to the situation in the air, the [Paratroop] Raiding Group commander shall make that decision.

(4) Execution of the paradrop operation

(a) The [Paratroop] Raiding Group commander shall decide upon the direction of approach, the formation, the altitude of the paradrop and the mid-air assembling, after consulting the commanders of the [Paratroop] Raiding Air Unit, the 2d [Paratroop] Raiding Regiment and the 98th Air Group.

(b) Although the air units will signal the moment to conduct the paradrop, the paratroop units shall decide on the execution of the paradrop. 
(c) Even if the direction of the first approach or other factors should prevent the drops, the flight shall be resumed for the next attempt as long as circumstances permit.

(5) Launching of the attack

(a) The paratroop unit [to be dropped near] the airfield shall have its main force parachute down on the sector east of the airfield, and one element on the sector west of the airfield. [The unit] shall carry out a sudden attack on the airfield and seize it, and while securing it with the necessary forces, have its main force attack and seize [the city of] Palembang. [Meanwhile, the unit] shall stay in close contact with aircraft that perform a forced landing. In particular it is necessary to keep an eye on the main road to Jambi. Once Palembang is seized, it shall try to seize as many means of transport as possible, and simultaneously it shall repair the airfield so that it will first of all be fit for use by fighter plane units, and secondly by large aircraft. The advance party of the 38th Division, consisting of one and a half infantry battalions as the core and led by Colonel Tanaka, is scheduled to sail upriver to Palembang on day L.

(b) The paratroop unit [to be dropped near] the oil refineries shall, [after] parachuting down in the vicinity of the location, first seize the key parts of the oil refineries by means of a sudden attack, try as much as possible to frustrate the enemy's plan to destroy [the facilities], and secure the premises upon seizing them.

(c) The two [paratroop] raiding units shall try to maintain contact with each other. After the drop, the oil refineries raiding unit shall come under the command of the regimental commander.

(d) Both units shall secure the targets to be seized until the arrival of the main force of the division. They shall be put under the command of the Sixteenth Army commander upon arrival of the main force of the 38th Division. The arrival of the main force of the 38th Division in Palembang is scheduled for day $\mathrm{L}+2$.

(6) Actions of the air units after the execution of the paradrop

[They shall] assemble and return to their bases as soon as possible; the 98th Air Group shall [directly] head back to its base, and the [Paratroop] Raiding Air Units shall head back to their base after refueling at the Kluang or Kahang airfields.

(7) Execution of the second [paradrop] raiding [operation]

(a) The second [paradrop] raiding operation shall be executed at 1500 on day L. The forces to parachute down shall be one hundred men led by a company commander. [The unit] shall depart from the Sungai Petani [airfield] and refuel at the Kluang or the Kahang airfield, after which it shall carry out the paradrop. It shall have the main force [of the unit] parachute down on the airfield and the sector along the Palembang Road, and about one platoon on the oil refineries and their vicinity. The units on the ground shall mark the drop zones.

(b) If the 12th Transport Squadron is available for employment, [only] the preparation for this [paradrop] operation shall be conducted, and the launching [of the operation] shall be ordered separately.

3. The disposition of the forces (the number of men given in parentheses applies in the event the 12th Transport Squadron is employed)

Ground units of the first raiding unit

Airfield raiding unit:

Commanding officer: 2d [Paratroop] Raiding Regiment Commander Maj. Kōmura Takeo

[Consisting of] 1 [paratroop] infantry company (minus 1 platoon and 1 element), 1 [paratroop] engineer company (minus 1 platoon and 1 element), 180 men in total

Oil refineries raiding unit:

Commanding officer: First Lieutenant Hirose 
[Consisting of] 1 [paratroop] infantry company (minus 1 platoon and 1 element), a small number of specialists, 1 element of a signal unit, 70 men in total

Ground units of the second raiding unit

Commanding officer: First Lieutenant Morisawa

[Consisting of] 1 [paratroop] infantry company (minus 1 element), 100 men in total [Paratroop] Raiding Air Unit

Commanding officer: [Paratroop] Raiding Air Unit Commander Maj. Niihara Sueto

[Consisting of] the [Paratroop] Raiding Air Unit

98th Air Group (unit under command)

Commanding officer: 98th Air Group Commander Lt. Col. Ōsaka Junji

[Consisting of] the 98th Air Group

4. Signal communications

The rules for signal communications regarding the [paradrop] operation are as shown in separate volume. (Omitted by the author.)

5. Supplies for the paratroop units

Supplies of weapons, ammunition and other matériel necessary after the drop shall be provided by air transport upon request.

\section{Attachment 1}

\begin{tabular}{|c|c|c|c|}
\hline \multicolumn{4}{|c|}{$\begin{array}{l}\text { Rough overview of the scheduled actions of cooperating air units in the } \\
\text { Palembang [paradrop] raiding operation }\end{array}$} \\
\hline Date & Outline of forces & Operational objectives (tasks) & Outline of actions \\
\hline \multirow{2}{*}{$\begin{array}{l}\text { Day L-4 } \\
\text { through } \\
\text { Day L-2 }\end{array}$} & $\begin{array}{l}\text { Fighter planes of the } 3 \mathrm{~d} \text { Air Di- } \\
\text { vision (including units brought } \\
\text { under the command of the divi- } \\
\text { sion) }\end{array}$ & $\begin{array}{l}\text { To destroy enemy aircraft on } \\
\text { the Palembang airfield. }\end{array}$ & $\begin{array}{l}\text { Attacks shall be made at a good } \\
\text { opportunity. The launching } \\
\text { bases will be the Kluang and } \\
\text { Kahang airfields. }\end{array}$ \\
\hline & $\begin{array}{l}\text { The necessary forces of the 12th } \\
\text { Air Division }\end{array}$ & $\begin{array}{l}\text { To take command of the air } \\
\text { over the Singapore sector; to } \\
\text { watch on the Pekanbaru air- } \\
\text { field; and to destroy enemy air- } \\
\text { craft on the airfields, if } \\
\text { required. }\end{array}$ & $\begin{array}{l}\text { Attacks shall be made at a good } \\
\text { opportunity. The launching } \\
\text { base will be Batu Pahat. }\end{array}$ \\
\hline Day L - 2 & $\begin{array}{l}\text { The first operation unit of the } \\
\text { [Paratroop] Raiding Group, the } \\
\text { 98th, the 59th, the 64th Air } \\
\text { Group } \\
\text { Three aircraft of the 81st Air } \\
\text { Group } \\
\text { One air group of light bombers } \\
\text { of the 3d Air Division }\end{array}$ & $\begin{array}{l}\text { For the first [paradrop] raid, } \\
\text { each echelon will assemble by } \\
\text { evening at the Kluang or the } \\
\text { Kahang [airfield], to prepare for } \\
\text { departing on day } L-1 \text {. }\end{array}$ & $\begin{array}{l}\text { 1. The first raiding unit of the } \\
\text { [Paratroop] Raiding Group } \\
\text { will depart from Sungai } \\
\text { Petani and advance to the } \\
\text { Kluang and the Kahang [air- } \\
\text { field]. } \\
\text { 2. The 98th Air Group shall de- } \\
\text { part from the Ketil [airfield], } \\
\text { assemble two squadrons at } \\
\text { the Kahang [airfield], and an- } \\
\text { other at the Kluang [airfield]. }\end{array}$ \\
\hline
\end{tabular}




\begin{tabular}{|c|c|c|c|}
\hline \multirow[t]{3}{*}{$\begin{array}{l}\text { Day L }-1 \\
(9 \text { Feb. })\end{array}$} & $\begin{array}{l}\text { First raiding unit } \\
\text {-Airfield raiding unit: } 180 \text { men } \\
\text { ( } 260 \text { men) of the 2d [Para- } \\
\text { troop] Raiding Regiment } \\
\text { [transported by] about two } \\
\text { squadrons of the [Paratroop] } \\
\text { Raiding Air Unit (20 aircraft). } \\
\text { About two squadrons of the } \\
\text { 98th Air Group } \\
\text { The 64th Air Group } \\
\text { One aircraft of the } 81 \text { st Air } \\
\text { Group (accompanying). } \\
\text {-Oil refineries raiding unit: } 70 \\
\text { men (130 men) of the 2d } \\
\text { [Paratroop] Raiding Regiment } \\
\text { [transported by] about one } \\
\text { squadron of the [Paratroop] } \\
\text { Raiding Air Unit (7 aircraft). } \\
\text { One squadron of the } 98 \text { th Air } \\
\text { Group } \\
\text { The 59th Air Group } \\
\text { One aircraft of the } 81 \text { st Air } \\
\text { Group (accompanying). } \\
\text { Separately: Another aircraft of } \\
\text { the 81st Air Group (to go in } \\
\text { advance) }\end{array}$ & $\begin{array}{l}\text { 1. Airfield raiding Unit: To exe- } \\
\text { cute the [paradrop] raid at } \\
\text { the Palembang airfield and } \\
\text { its vicinity, secure the air- } \\
\text { field, and quickly make it } \\
\text { ready for use by Type-97 } \\
\text { fighter planes; after that at- } \\
\text { tack [the city of] Palembang. } \\
\text { 2. Oil refineries raiding unit: To } \\
\text { execute the [paradrop] raid } \\
\text { at the oil refineries in Palem- } \\
\text { bang and their vicinity, seize } \\
\text { and secure these refineries } \\
\text { before destruction by the } \\
\text { enemy. } \\
\text { 3. The 98th Air Group shall } \\
\text { transport the weaponry and } \\
\text { matériel respectively for } \\
\text { each transport squadron of } \\
\text { both raiding units, and [also] } \\
\text { provide cover against anti- } \\
\text { aircraft fire at the rear of the } \\
\text { transport squadrons. } \\
\text { 4. The air groups of fighter } \\
\text { planes shall provide the di- } \\
\text { rect cover for each, and also } \\
\text { attack the airfield facilities } \\
\text { while the Paratrooper units } \\
\text { are [collecting and] putting } \\
\text { on their equipment ([for] } 5 \text { to } \\
\text { 10 minutes). } \\
\text { 5. The command reconnais- } \\
\text { sance units shall conduct re- } \\
\text { connaissance just before and } \\
\text { during the time of operation, } \\
\text { and provide guidance. }\end{array}$ & $\begin{array}{l}\text { 1. Execution of the [paradrop] } \\
\text { raid shall be at } 1130 . \\
\text { 2. The airfield raiding unit will } \\
\text { depart from the Kahang, and } \\
\text { the oil refineries raiding unit } \\
\text { from the Kluang base. } \\
\text { 3. [All units] shall return to } \\
\text { their advance base(s). How- } \\
\text { ever, units that have suffi- } \\
\text { cient flight range shall } \\
\text { directly return to their origi- } \\
\text { nal base. } \\
\text { 4. The transport aircraft are } \\
\text { planned based on the as- } \\
\text { sumption that the } 12 \text { th } \\
\text { Transport Squadron will not } \\
\text { be employed. }\end{array}$ \\
\hline & $\begin{array}{l}\text { One element of the light } \\
\text { bomber unit(s) of the } 3 \mathrm{~d} \text { Air } \\
\text { Division }\end{array}$ & $\begin{array}{l}\text { Attacks against the barracks in } \\
\text { the city of Palembang. }\end{array}$ & $\begin{array}{l}\text { 1. [The operation] shall be con- } \\
\text { ducted right before the exe- } \\
\text { cution of the first [paradrop] } \\
\text { raid. [The element] shall op- } \\
\text { erate along with one of the } \\
\text { raiding units as long as it } \\
\text { can. } \\
\text { 2. [It] shall depart from the } \\
\text { Kluang base. }\end{array}$ \\
\hline & $\begin{array}{l}\text { One element of the fighter } \\
\text { plane unit(s) of the } 3 \mathrm{~d} \text { Air Divi- } \\
\text { sion (including units brought } \\
\text { under the control of the divi- } \\
\text { sion) }\end{array}$ & $\begin{array}{l}\text { Air cover for the convoy of the } \\
\text { 38th Division. }\end{array}$ & $\begin{array}{l}\text { After returning from [the task] } \\
\text { to cover the first [paradrop] } \\
\text { raid, it shall swiftly go to the } \\
\text { air above the convoy, to pro- } \\
\text { vide cover from roughly } 1700 \\
\text { onwards. }\end{array}$ \\
\hline
\end{tabular}




\begin{tabular}{|c|c|c|c|}
\hline \multirow[t]{3}{*}{ Day L } & $\begin{array}{l}\text { Second raiding unit } \\
100 \text { men of the } 2 \mathrm{~d} \text { [Paratroop] } \\
\text { Raiding Regiment [transported } \\
\text { by] about one squadron of the } \\
\text { [Paratroop] Raiding Air Unit. } \\
\text { About one squadron of the } \\
98 \text { th Air Group, half of the } \\
\text { fighter plane units of the } 3 \mathrm{~d} \text { Air } \\
\text { Division (including those } \\
\text { brought under the control of } \\
\text { the division) } \\
\text { One aircraft of the } 81 \text { st Air } \\
\text { Group }\end{array}$ & $\begin{array}{l}\text { 1. To execute the [paradrop] } \\
\text { raid at the airfield and oil re- } \\
\text { fineries of Palembang and } \\
\text { their vicinities, to reinforce } \\
\text { the first raiding unit. } \\
\text { 2. The tasks for the air units to } \\
\text { cooperate [in the above oper- } \\
\text { ation] shall be the same as on } \\
\text { the previous day. }\end{array}$ & $\begin{array}{l}\text { 1. The Kluang airfield shall be } \\
\text { used as the launching base. } \\
\text { 2. Execution of the [paradrop] } \\
\text { raid is scheduled at } 1500 \text {. } \\
\text { 3. If the 12th Transport } \\
\text { Squadron is available for } \\
\text { use, [only] the preparation } \\
\text { for this [paradrop] operation } \\
\text { shall be conducted, and the } \\
\text { launching [of the operation] } \\
\text { shall be given by separate } \\
\text { order. }\end{array}$ \\
\hline & $\begin{array}{l}\text { Elements of the } 3 \mathrm{~d} \text { and the } 7 \text { th } \\
\text { Air Division }\end{array}$ & $\begin{array}{l}\text { Support the ground combat in } \\
\text { Palembang and its vicinity, if } \\
\text { required. }\end{array}$ & \\
\hline & $\begin{array}{l}\text { An Element of the 12th Air Di- } \\
\text { vision }\end{array}$ & $\begin{array}{l}\text { Advance to the Palembang air- } \\
\text { field as the airfield is [tem- } \\
\text { porarily] made ready, and } \\
\text { prepare to undertake [the tasks } \\
\text { of] the air defense of Palem- } \\
\text { bang and its vicinity. }\end{array}$ & $\begin{array}{l}\text { Batu Pahat will be used as the } \\
\text { launching base. }\end{array}$ \\
\hline $\begin{array}{l}\text { Day L-1 } \\
\text { Day L }\end{array}$ & $\begin{array}{l}\text { Command Reconnaissance } \\
\text { Unit of the } 3 d \text { Air Division }\end{array}$ & $\begin{array}{l}\text { To conduct surveillance of the } \\
\text { battle site at appropriate mo- } \\
\text { ments after the drop of the } \\
\text { [paratroop] raiding group }\end{array}$ & \\
\hline Comments & \multicolumn{3}{|c|}{ The advancement of forces from day L onwards shall be announced by separate order(s). } \\
\hline
\end{tabular}

\section{The Collaboration of the Different Air Units}

At noon on 9 February, as we have seen, it was finally decided to "set day L for 15 February." Having learned this on the night of the 9th, Third Air Force Commander Lieutenant General Sugawara, as previously told, issued at 0930 on the following day, the 10th, the order regarding the execution of Operation L by which he reassigned the 64th Air Group to the 3d Air Division from the 11th onwards. Meanwhile, the Twenty-fifth Army, which had landed on Singapore Island on the night of the 8th, was in the middle of a fierce battle, while the advance party of the 38th Division had departed from Cam Ranh Bay on the 9th, and its main force on the 11th. It is an old rule in war that when the enemy is having a hard time, we are as well. When the allied forces were desperately putting up resistance in Singapore, the Twenty-fifth Army was [also] having a hard time sustaining its attack. And then right in the middle of all this, Operation L was about to be executed. As complaints were heard from the Twenty-fifth Army, the Southern Army ([to be precise] the Third Air Force) for its part [knew it needed to] rack its brains to determine the distribution of forces. For this very reason, and prior to the execution of Operation L, Commander in Chief Terauchi had specifically dispatched Chief of Operations Arao to the Twenty-fifth Army. ${ }^{(28)}$ In the end, the following distribution of [air] forces between Operation L and the Singapore operation was made. ${ }^{(96,103,104)}$ 
Navy (about 180 aircraft)

Shall operate on and to the east of the line connecting Palembang and Mentok.

1st Air Unit (22d Air Flotilla)

[Shall operate from the airfields in] Kuantan (Kahang), Kuching and Thủ Dâu Một in

French Indochina (as explained previously).

2d Air Unit (the Kamikawa-maru, and the Sagara-maru)

[Shall operate from] the Anambas Islands and Cam Ranh (as explained previously).

3d Air Unit (the Rȳujō)

Shall basically accompany the convoy(s).

Army (Third Air Force)

Units under the direct command of the Third Air Force

81st Air Group (command reconnaissance): shall cooperate in Operation L with one element (reconnoitering).

98th Air Group (heavy bombers): shall accompany the [Paratroop] Raiding Group and drop equipment.

1st [Paratroop] Raiding Group

Group headquarters, the 2d [Paratroop] Raiding Regiment and the [Paratroop] Raiding Air Unit shall participate in Operation L. (About three companies shall descend on day 1, and about one company on day 2.)

7th Air Division (a bomber division, consisting of the 12th and the 60th Air Groups and the 51st Independent Squadron): shall cooperate in the capture of Singapore.

12th Air Division (a fighter plane division, consisting of the 1st and the 11th Air Groups and the 47th Independent Squadron): shall cooperate in the capture of Singapore. However, one squadron of the 11th Air Group shall escort the 1st [Paratroop] Raiding Group's advance from Sungai Petani to Kluang, and Kahang.

3d Air Division: shall cooperate in Operation L with its main force, and in the capture of Singapore with one element.

So, the question arises how 3d Air Division Commander Major General Endō allocated his forces between Palembang and Singapore. Major General Endō allocated his forces in the following way (from the 11th onwards): ${ }^{(96)}$

15th Independent Air Unit (headquarters and one reconnaissance squadron): shall mainly cooperate in Operation L from Kluang.

59th Air Group (fighter planes): shall participate in Operation L with its main force (two squadrons) from Kluang.

64th Air Group (fighter planes): shall participate in Operation L with its full force from Kahang.

75th Air Group (light bombers): [shall engage in] the Singapore operation.

90th Air Group (light bombers): shall participate in Operation L from Kluang.

27th Air Group (light bombers): [shall engage in] the Singapore operation.

Third Air Division Commander Endō cooperated in the fierce battles in Singapore to such an extent that the Twenty-fifth Army, which was fighting a hard battle, was deeply grateful. ${ }^{(98)}$ In fact, as previously described, after having conducted an air campaign for [Operation] L from the 6th through the 8th of February, Major General Endō carried out air strikes for [Operation] L for only one day on the 13th, one day prior to the drop of paratroopers.

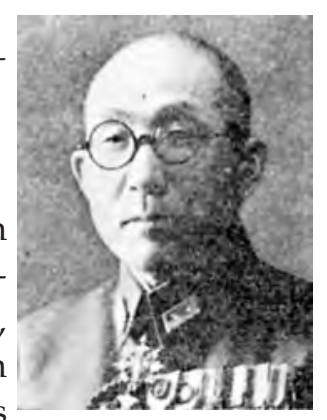

3d Air Division Commander, Maj. Gen. Endō Saburō 
On the 1st day of the drop of the 1st [Paratroop] Raiding Group, the number of aircraft which took off with paratroopers or equipment on board was sixty-one [in total] ([consisting of] twenty-five transport aircraft of the [Paratroop] Raiding Air Unit, nine MC aircraft of the transport squadron, and twenty-seven heavy bombers of the 98th Air Group). They were supported by the aforementioned 3d Air Division's forces for Operation L, which made a total of more than one hundred aircraft when they took off. ${ }^{(39,96)}$

The 1st [Paratroop] Raiding Group, in accordance with the aforementioned Third Air Force order of the 10th of January [editor's note: probably the order of 10 February is meant (p. 309)], concluded the "Outline of raiding [operations] of the [Paratroop] Raiding Air Unit and cooperating air groups," and at 1700 on the 11th passed it down as a written instruction at Sungai Petani. ${ }^{(96)}$ In summary the contents were as follows: ${ }^{(96)}$

1. The [Paratroop] Raiding Air Unit shall advance from Sungai Petani to Kahang by 1900 of day $\mathrm{L}-2$. The 98th Air Group shall advance to Kluang.

2. Takeoff shall start at 0830 on day L - 1. At 0900, the [Paratroop] Raiding Air Unit and the 64th Air Group shall depart from Kahang and join the 58th [editor's note: misprint for 59th] and the 98th Air Groups in the skies over Kluang. At 0920, they shall put the formation in order over Batu Pahat, and fly ahead at an altitude of 3,000 meters.

3. The aircraft carrying paratroopers and those carrying their equipment (the [Paratroop] Raiding Air Unit and the 98th Air Group) shall fly in [the following] formations, with the number of aircraft [in each formation] from the front as nine - nine - nine - seven - nine - nine - nine (sixtyone aircraft in total).

4. Three plans shall be prepared, with an approach from the mouth of the Musi River and along [the river] as plan No. 1 .

5. The drop will be set at 1130, and shall be executed as follows:

[On a zone] between the airfield and the city of Palembang: the aircraft with the group commander on board shall make a belly landing.

[On a zone] 1,200 meters southeast of the airfield: eighteen aircraft carrying paratroopers and fifteen aircraft carrying equipment.

[On a zone] 200 meters southwest of the airfield: six aircraft carrying paratroopers and three aircraft carrying equipment.

[On a zone] 700 meters south of the oil refineries: three aircraft carrying paratroopers and three aircraft carrying equipment.

[On a zone] 500 meters southwest of the oil refineries: six aircraft carrying paratroopers and six aircraft carrying equipment.

6. The fighter plane unit (the 59th and the 64th Air Group) shall provide direct escort during the flight and while [the paratroop units] are descending and collecting their equipment. After that, one element shall continue providing direct escort for the units in the air.

7. The light bomber unit shall make bombing raids against ground fire from the airfield, the barracks and other [targets].

8. On day $\mathrm{L}-1$ the command reconnaissance unit (the 81st Air Group) shall conduct reconnaissance prior to the drop with one aircraft, and with another two aircraft provide guidance and reconnoiter the situation after the drop. 


\section{Takeoff, Drop and Occupation}

\section{The Units to be Dropped and their Strength}

In the end, it was decided to employ the $2 \mathrm{~d}$ [Paratroop] Raiding Regiment for the drop. The final deployment was set as follows: ${ }^{(96)}$

First unit to be dropped and its strength ([execution] on the 14th)

Aircraft to make a belly landing (one aircraft): [Paratroop] Raiding Group Commander Kume, Sixteenth Army Staff Officer Itoda, Captain Ueda (signal communications), Group Adjutant Inagaki, interpreter Saitō, press corps member Araki, and one antitank gun.

Southeast side of the airfield: seventeen men of the 2d [Paratroop] Raiding Regiment headquarters (i.e. Regimental Commander Kōmura and his men), thirty men of the signal squad, ninety-seven men of the 4th Company (Company Commander First Lieutenant Mitani and his men), thirty-six men of the $3 \mathrm{~d}$ Platoon of the $2 \mathrm{~d}$ Company, a total of 180 men.

Southwest side of the airfield: sixty men of the $2 \mathrm{~d}$ Company (Company Commander First Lieutenant Hirose and his men).

South side of the east oil refinery: Second Lieutenant Hasebe and his men, thirty-nine men [in total].

West side of the west oil refinery: sixty men of the 1st Company (Company Commander First Lieutenant Nakao and his men).

Second unit to be dropped and its strength ([execution] on the 15th): ninety men of the 3d

Company (Company Commander First Lieutenant Morisawa and his men).

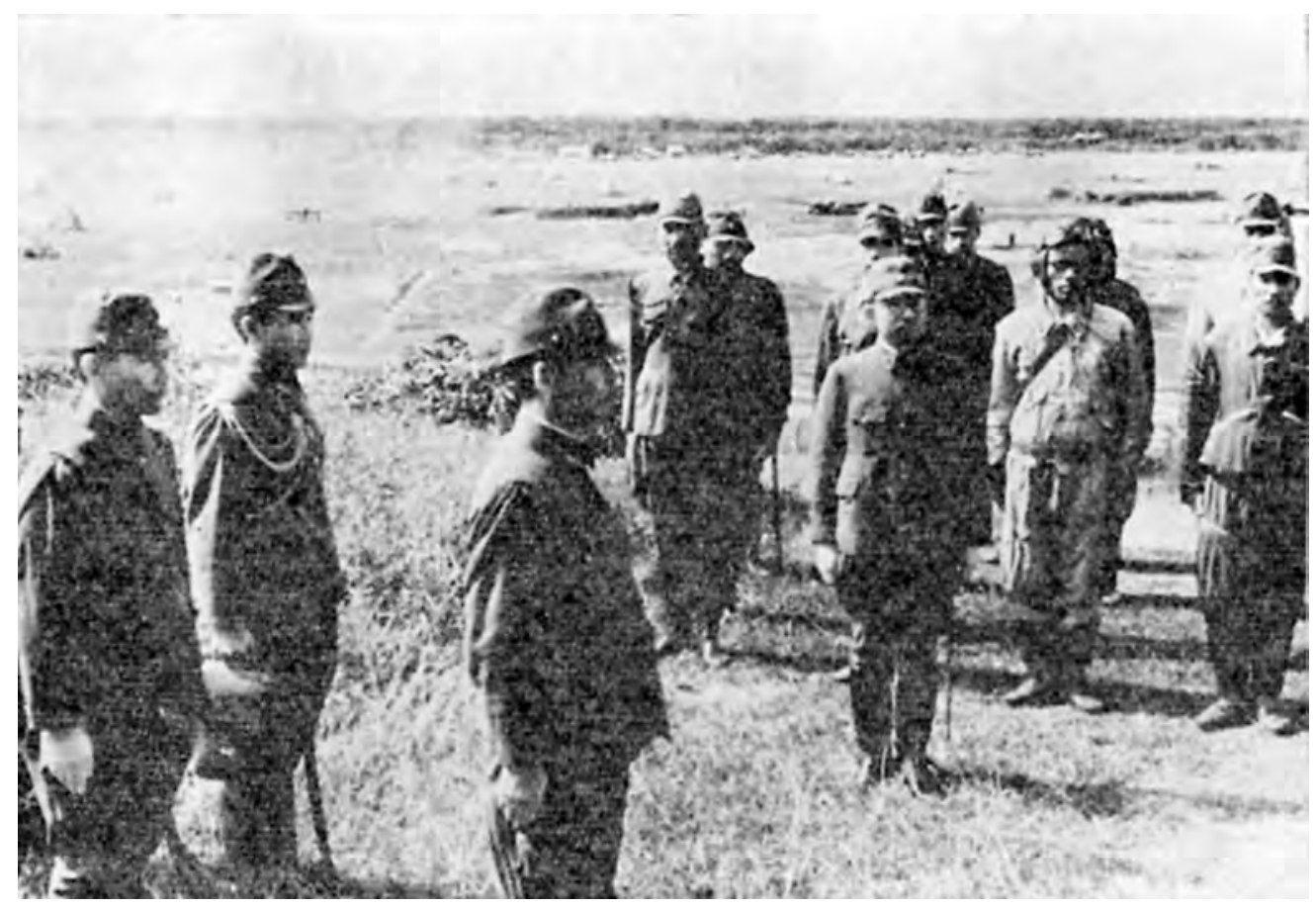

Instructions Right Before the Launch of the Palembang Paratroop Operation

(at the Kluang Airfield) 


\section{Takeoff}

On the 13th at 1500, the first raiding unit completed its deployment to the Kahang and the Kluang airfields, and it stood ready for action in the following way. The second raiding unit stood by at Sungai Petani.

Kahang airfield: [Paratroop] Raiding Group headquarters, 330 men of the 2d [Paratroop] Raiding Regiment, two transport squadrons (thirty-four Lockheed-type aircraft), the 64th Air Group (three squadrons of Type-1 fighter planes).

Kluang airfield: 98th Air Group (aircraft to carry equipment; two squadrons of Model-II aircraft), the 90th Air Group (one squadron of light bombers), the 59th Air Group (two squadrons of fighter planes), the 15th Independent Air Unit (one squadron of reconnaissance planes), the 81st Air Group (three command reconnaissance planes).

At 1700, Third Air Force Commander Sugawara gave instructions, which were attended by the Southern Army Vice Chief of Staff Sakaguchi Yoshitarō and others. On that day, the 3d Air Division had attacked Palembang with its main force for the first time in five days, while cooperating with the Twenty-fifth Army in its attack on Singapore, as mentioned previously.

On the following day, the 14th in Malaya, it was clear or lightly clouded with a slight wind, a cloud ceiling of 1,000 meters, and visibility of 10 to 20 kilometers. The first raiding unit left the Kluang and the Kahang airfields at 0830, assembled above Batu Pahat, and flew straight toward the Musi River at an altitude of 3,000 meters, in the order of the first and the second echelons under the direct escort of the fighter plane unit. At that time, the advance party of the 38th Division, which had left Cam Ranh Bay in the evening of the 9th, was heading southward, aiming to reach the Mentok anchorage that night. The main force of the division, which had left [the bay] on the 11th, followed in its wake. ${ }^{(96,118)}$

One element of the reconnaissance unit had flown ahead of the raiding unit, and reconnoitered the weather, the atmospheric conditions and the enemy movements in Palembang and the vicinity. The command reconnaissance [element], which had flown ahead, reported the presence of ten large and thirty small aircraft on the Palembang airfield. In the Sumatra area, there were signs that the weather was gradually worsening; Palembang was covered with thick cloud with a ceiling of 200 meters. Further, due to the fires at Singapore, a sooty smoke was hanging over the mouth of the Musi River, and rendered the visibility extremely poor. These adverse weather conditions made the flight of the raiding unit difficult, but they [also] helped the unit to carry out a surprise attack. ${ }^{(96)}$

\section{The Drop (See Illustration No. 26)}

Around 1120, the unit reached the sky over the mouth of the Musi River, where it divided [into echelons] to head toward their own drop zones; the first echelon approached the airspace above the airfield and the second echelon the airspace above the oil refineries. The allied forces opened fire simultaneously with antiaircraft guns, antiaircraft machine guns and other [arms]. However, the [paratroop] raiding units defied the fire and started parachuting down. The airfield raiding unit completed its drop at 1126, and the oil refineries raiding unit at $1130 .{ }^{(96)}$

Without missing an opportunity, the 98th Air Group dropped weapons, ammunition and other equipment, while strafing [the sources of] the antiaircraft fire. Meanwhile, the 90th Air 
Group (light bombers) bombed the [enemy] ground units, suppressed them, and so helped the paratroopers to collect their weapons and ammunition and, after that, fight the enemy. In this fight, one aircraft of the 90th Air Group crashed itself [editor's note: according to Vol. 34 , p. 500, it was a plane of the 98th Air Group]. When providing cover for the paratroop units about 800 meters above the airfield, the 64th Air Group spotted five allied fighter planes which came to attack the air group of heavy bombers dropping equipment. It brought down one [allied] aircraft and drove back the others. Then, at 1205, when providing cover at an altitude of about 2,000 meters, the group spotted about ten allied fighter planes approaching from the direction of Palembang, intercepted them, brought down one, and drove back the others. It was 1217. The 59th Air Group [at first] had been charged with the cover for the paratroop unit above the refineries, but seeing no allied aircraft it [changed the plan and] strafed the antiaircraft positions in the oil refineries, suppressed them, and provided support to the paratroop unit in its operation. From around 1210 onwards, and after confirming the situation of the paratroop units, these supporting air units started leaving the battle site one after another to head back to their bases. ${ }^{(96)}$

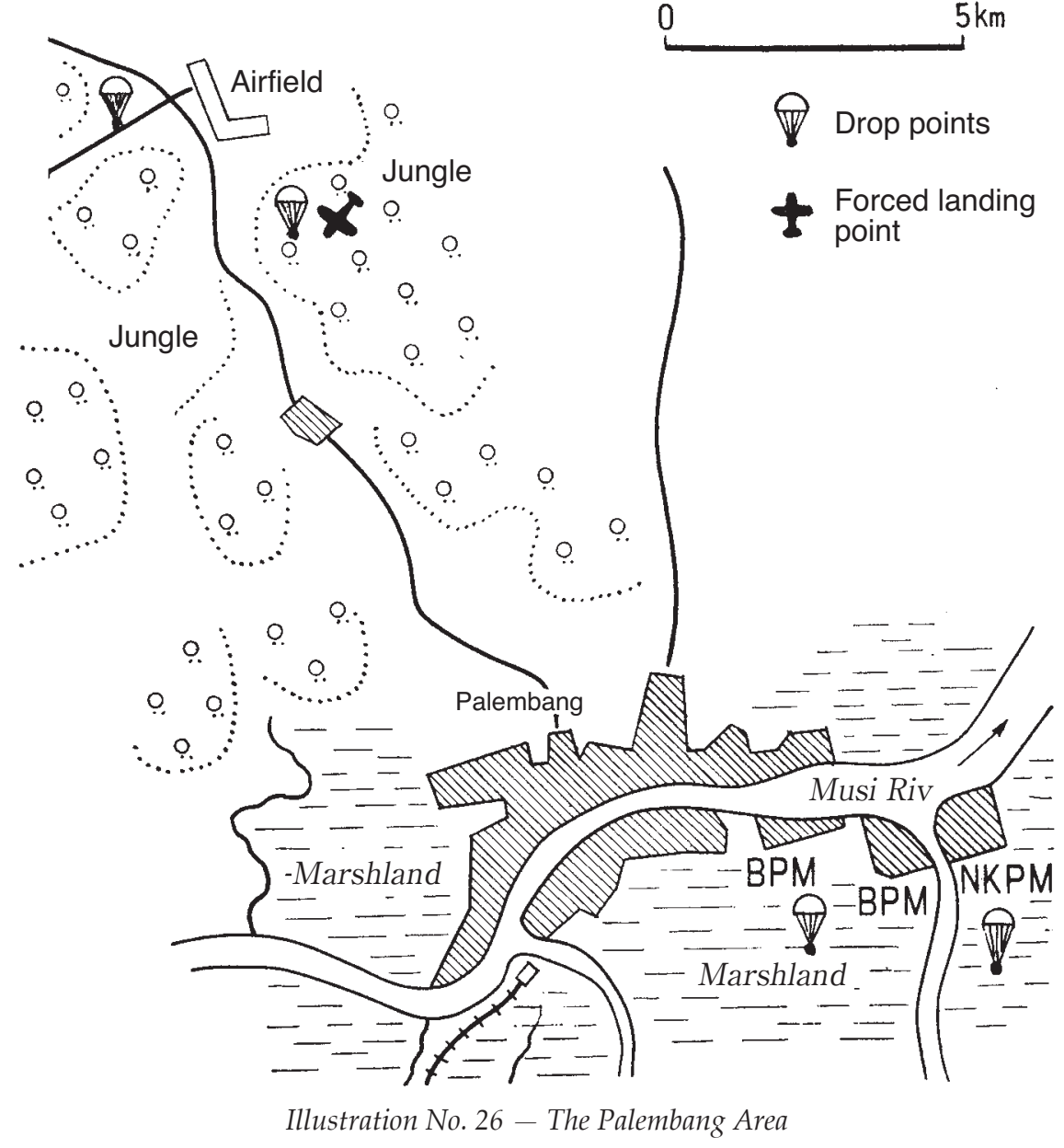




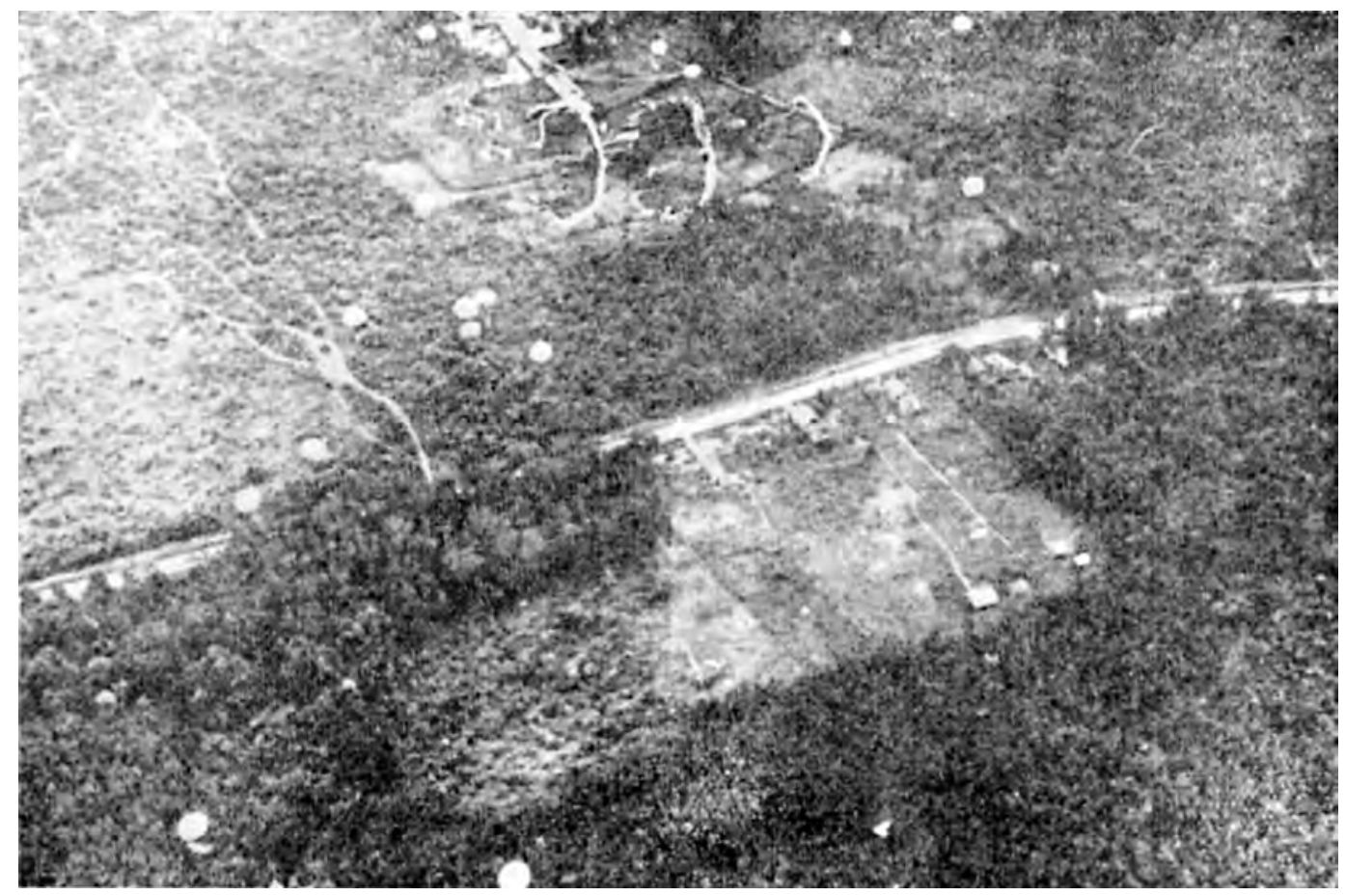

Actual Situation of the Palembang Paradrop Operation (Taken from a Hayabusa [Type-1 Fighter Plane])

\section{Operations of the Unit Dropped near the Airfield (See Illustration No. 27)}

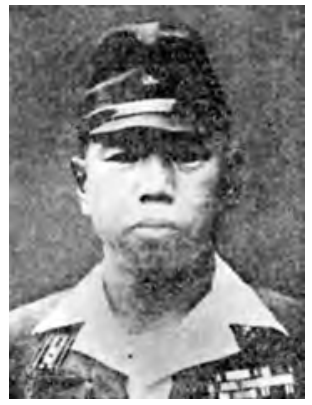

2d [Paratroop] Raiding Regiment Commander Maj. Kōmura Takeo

The airfield raiding unit carried out the drop as scheduled, with the main force ([consisting of] two platoons of the $2 \mathrm{~d}$ Company and the 4 th Company (minus one platoon) of the $2 \mathrm{~d}$ [Paratroop] Raiding Regiment as the core (180 men, including and led by Regimental Commander Kōmura)) at 1126 [on a zone] some three kilometers southeast of the airfield, and with one element ([consisting of] the $2 \mathrm{~d}$ Company (minus two platoons) as the core (sixty men including and led by Company Commander Hirose)) at 1130 on the southwestern side of the airfield. Striving to bring the unit back under command, the airfield raiding unit began its actions and advanced toward the airfield under cover of the supporting air units. After the drop, Regimental Commander Kōmura immediately headed toward the southeastern corner of the airfield. Around 1200, taking command of ten men of his [unit], he pushed his way through the dense jungle, to find around 1330, in a hollow about two kilometers southeast of the airfield, 4th Company Commander First Lieutenant Mitani and his men, twenty-four in total, who were reconnoitering the enemy, and brought them under his command. On this occasion he also learned about the actions of First Lieutenant Okumoto and his men (which will be described later). Fearing that allied reinforcements from Palembang city to the airfield might arrive quicker than expected, Regimental Commander Kōmura decided to swiftly advance to the Jambi Road and cut off the allied reinforcements. He put five of his men under the command of First Lieu- 


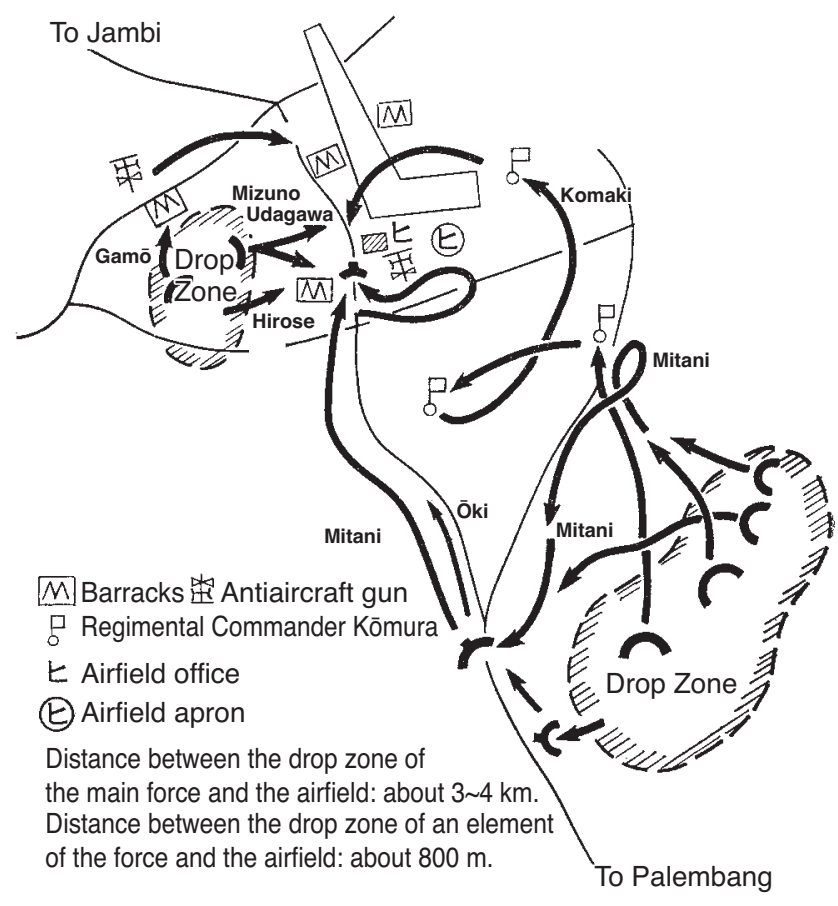

Illustration No. 27 - The Engagements at the Airfield tenant Mitani, and ordered them to go to the road connecting Palembang city and the airfield, attack and advance along the road toward the airfield office. First Lieutenant Mitani put an advance party of twenty men, led by Platoon Commander First Lieutenant Ōki, in the armored cars which First Lieutenant Okumoto had seized earlier, but while they advanced, they encountered an allied unit of some three hundred men approaching from the airfield. After a fierce battle they defeated the allied unit, and at 1820 occupied the airfield office. However, First Lieutenant Ōki was severely injured in this battle. [Meanwhile,] Regimental Commander Kōmura, leading five men, had set out after Company Commander Mitani, but due to the thick jungle, [Kōmura] finally lost contact with the company. After engaging in battle with an al-

lied unit of about 100 men around 1400, [Kōmura and his men] reached the east side of the airfield at 1800. There, the regimental commander found and took command of a total of twenty-five men, including First Lieutenant Komaki. At 2100 they reached the airfield office, where [Commander Kōmura] took command of the units which had already assembled, as well as the officers and men, who were coming in one after another. ${ }^{(93)}$

Prior to this, First Lieutenant Okumoto, platoon commander of the 4th Company, and four men, who had landed in the zone along the road connecting the airfield and Palembang city, had engaged around 1200 an allied unit of some two hundred men with two light-armored cars, seized one armored car and three trucks, and cut off reinforcements to the airfield. ${ }^{(93)}$

In the meantime, First Lieutenant Hirose, commander of the $2 \mathrm{~d}$ Company, who had landed in the zone west of the airfield, advanced with the two men he had brought under his command. Around 1400 he approached the front of the barracks on the west side of the airfield, where he discovered an allied unit of about 350 men. The first lieutenant withdrew for the moment, brought another man under his command, and at 1700 he stormed the barracks along with two of his men, and seized them. Earlier, First Lieutenant Gamō, platoon commander of the $2 \mathrm{~d}$ Company, had brought sixteen men under his command right after the drop. However, [he and his men] were not able to collect their weapons and ammunition as they had expected, and what is more, they came under point-blank fire of antiaircraft guns and machine guns of an antiaircraft position near the barracks. Intending to suppress the enemy fire, they moved forward with [only] hand grenades and pistols, set fire to the bar- 
racks and burned them down. However, [during the action] First Lieutenant Gamō was killed by a direct hit from an antiaircraft machine gun that had suddenly opened up. After this, Sergeant Major Yoshinaga took over the command of the platoon, and at 1820 [Sergeant Major Yoshinaga and his men] advanced to [the area at] the northwest end of the airfield. ${ }^{(93)}$

Thus, the Kōmura Unit occupied the airfield, and with all the forces that had assembled by midnight kept a strict guard until morning. Despite hearing some intermittent rifle reports, there was no counterattack from allied units that night. ${ }^{(93)}$

\section{The Occupation of the Oil Refineries (See Illustration No. 28)}

At 1130, the oil refineries raiding unit had its main force ([consisting of] the 1st Company of the $2 \mathrm{~d}$ [Paratroop] Raiding Regiment as the core (sixty men including and led by First Lieutenant Nakao)) descend on the west side of the west oil refinery, and one element (thirtynine men including and led by Second Lieutenant Hasebe) on the south side of the east oil refinery, as scheduled. Under cover of the air units, [both] strove to collect their weapons and ammunition, while trying to assemble the troops. ${ }^{(93)}$

First Lieutenant Tokunaga, a platoon commander of the 1st Company, who had landed at the west side of the west oil refinery, launched an attack against a pillbox position at the southwest side of the refinery at 1140, leading the six men he had gathered. They daringly charged the pillbox position, seized it, and further headed north along the road lined by company houses, where they encountered an allied unit of some sixty men with two light machine guns and one heavy machine gun. [First Lieutenant Tokunaga and his men] immediately attacked them and, at the same time, he ordered the Ogawa and the Yoshioka Squads (each [made up of] six men including the commanders), both of whom had just then caught up [with Tokunaga], to pursue the defeated enemy and charge into the premises of the refinery to secure all distillation units. Both squads entered the premises, secured the central distillation unit, and flew the flag of the Rising Sun on its tower. It was 1330. In the meantime, with only a small number of men at his disposal, First Lieutenant Tokunaga had defeated the garrison that had put up a fierce resistance. On seeing the Rising Sun flag being raised on the central distillation tower at 1310, he immediately started moving toward the distillation unit. At that moment, Company Commander Nakao showed up and assumed command. While defeating an allied unit of some thirty men armed with two light machine guns on their way, they entered the central distillation unit at 1410. Bringing the Ogawa and the Yoshioka Squads back under his command, Commander Nakao and his men closed the pipe cocks in the oil refinery, and put out the fire in the boilers in order to prevent destruction of the facilities by fire. The allied units, taking advantage of the fact that the Japanese troops were few in number, launched a fierce counterattack and approached as close as forty to fifty meters. As the bullets of both sides flew all over the place, oil began to gush out of the tanks and pipes. Company Commander Nakao ordered the Tokunaga Platoon to make a counterattack, which drove back the enemy, and [the platoon] advanced to an area northeast of the company houses. [Meanwhile,] the allied unit opened fire with mortars; the pipes directly hit by the shells caught fire and black smoke filled the air. The company commander assembled the unit, and took shelter in an air-raid shelter fifty meters south of the distillation unit. When night fell, an allied unit of some two hundred men closed in [on the Japanese] from three sides, threw hand grenades, and persistently repeated their counterattacks all night. But every time, [Commander Nakao's] company beat them back. ${ }^{(93)}$ 
In the meantime, the Hasebe Platoon, which had descended on the zone south of the east oil refinery, began its advance at 1230 towards the refinery, after collecting its weapons and ammunition. Two men, Corporal Ikeno and Private First Class Yamashita, who had dropped right in front of an outpost position and came under fierce fire from the allied troops, bravely fought back only with their hand grenades and pistols and defeated eight men. They further advanced in pursuit of the defeated enemy, but heavy fire from somewhere near the barracks injured Private Yamashita. Carrying the private on his back, Corporal Ikeno pulled back, joined the main force of the platoon, and reported the immediate situation of the enemy to Platoon Commander Hasebe. Learning that the only way through was the road leading through the barracks, the platoon commander began to move ahead along both sides of this road, while making it passable. Despite the fierce fire [from the enemy], at 1500 [he and his men] closed in to a point about one hundred meters from the enemy, where Second Lieutenant Hasebe was killed. Sergeant Major Niwa took his place and led the platoon. With the casualties gradually increasing and the advance getting difficult, at 1600 the sergeant major dispatched a scout in an effort to find an alternative route, but without success. He came to a decision to carry out a night attack, and made preparation for it, while fortifying his position. At 2300 the platoon executed a night attack on a pillbox position at the southeast of the barracks, [successfully] seized it, and continued its attack to occupy all the distillation units at 0100 on the 15 th. ${ }^{(93)}$

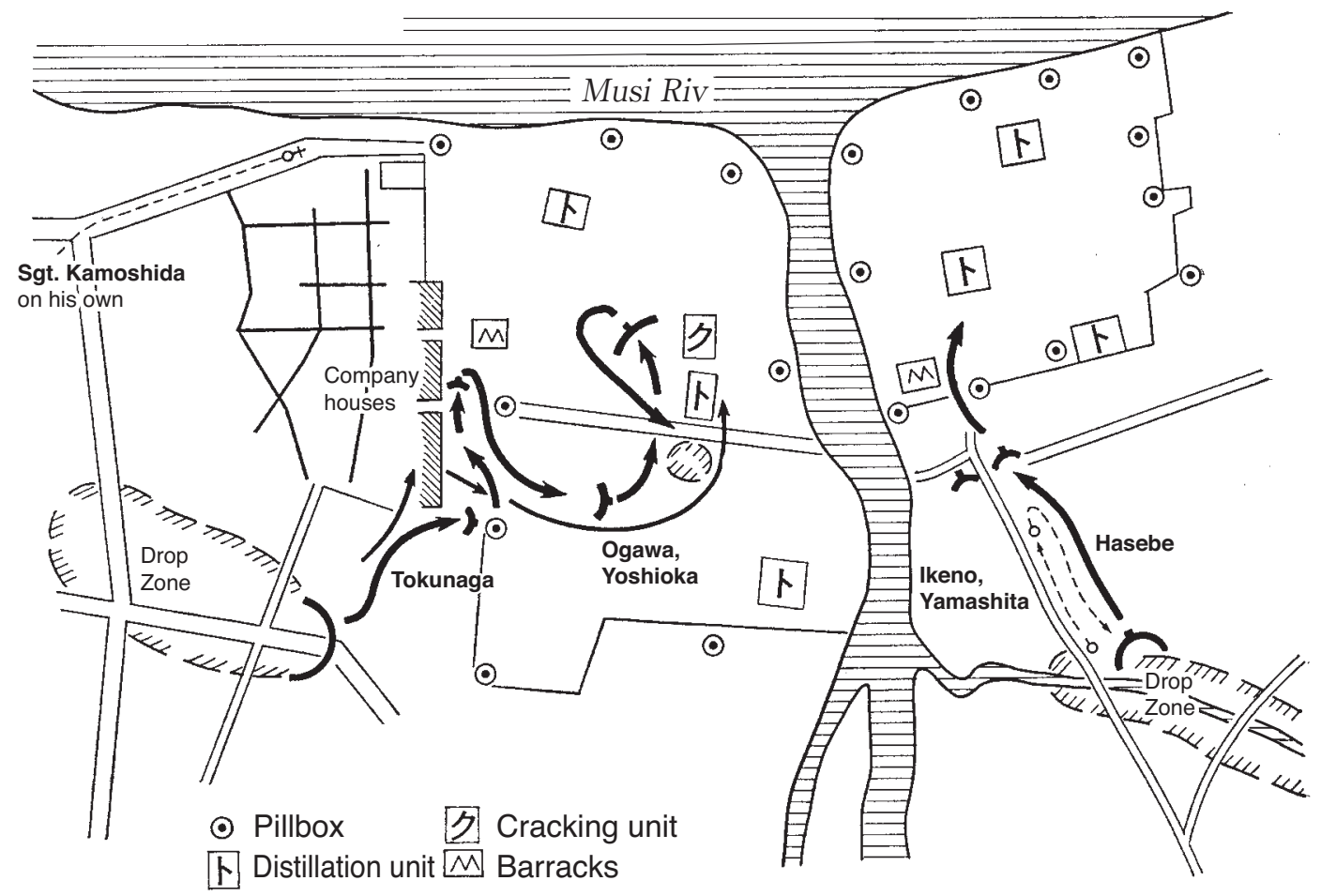

Illustration No. 28 - The Engagements at the Oil Refineries 


\section{The Situation from the 15th Onwards}

\section{The Airfield}

As one aircraft of the reconnaissance unit (15th Independent Air Unit Commander Lt. Col. Nakahama Gosuke) had landed [at the airfield] at 1030 on the 15th, it communicated the situation including the fact that most of the dropped weapons and ammunition were yet to be collected. Third Air Force Commander Sugawara immediately dispatched by transport aircraft personnel, weapons and ammunition which belonged to the airfield battalion stationed at the Kahang airfield, and simultaneously had one element of a fighter plane unit rapidly advance to the Palembang airfield and charged it with the task of providing cover for the raiding unit. At 1130, [Paratroop] Raiding Group Commander Colonel Kume reached the airfield and assumed overall command from then on. The fact was that the colonel had executed a forced landing at 1130 on the 14th about ten kilometers south of the airfield and attempted to move toward the location of the $2 \mathrm{~d}$ [Paratroop] Raiding Regiment headquarters, but he had been obstructed by the allied forces and the terrain, and been unable to advance as planned. At 1300, all men of the third echelon (the second raiding unit), that is, the $3 \mathrm{~d}$ Company (ninety men including First Lieutenant Morisawa) descended safely on the airfield, reinforcing the [raiding unit's] fighting strength. At 1600, the raiding group commander ordered the Adachi Platoon of the Morisawa Company to scout the city of Palembang. At 1730, the platoon entered the barracks in the city of Palembang without meeting any resistance, spotted allied armored craft going down the Musi River, fired at them, and caused one of them to run aground. At 1930, learning the situation of the Adachi Platoon, the raiding group commander immediately advanced into the city of Palembang, and started mopping up [the enemy]. On the following day, the 16th, contact was established with the oil refineries raiding

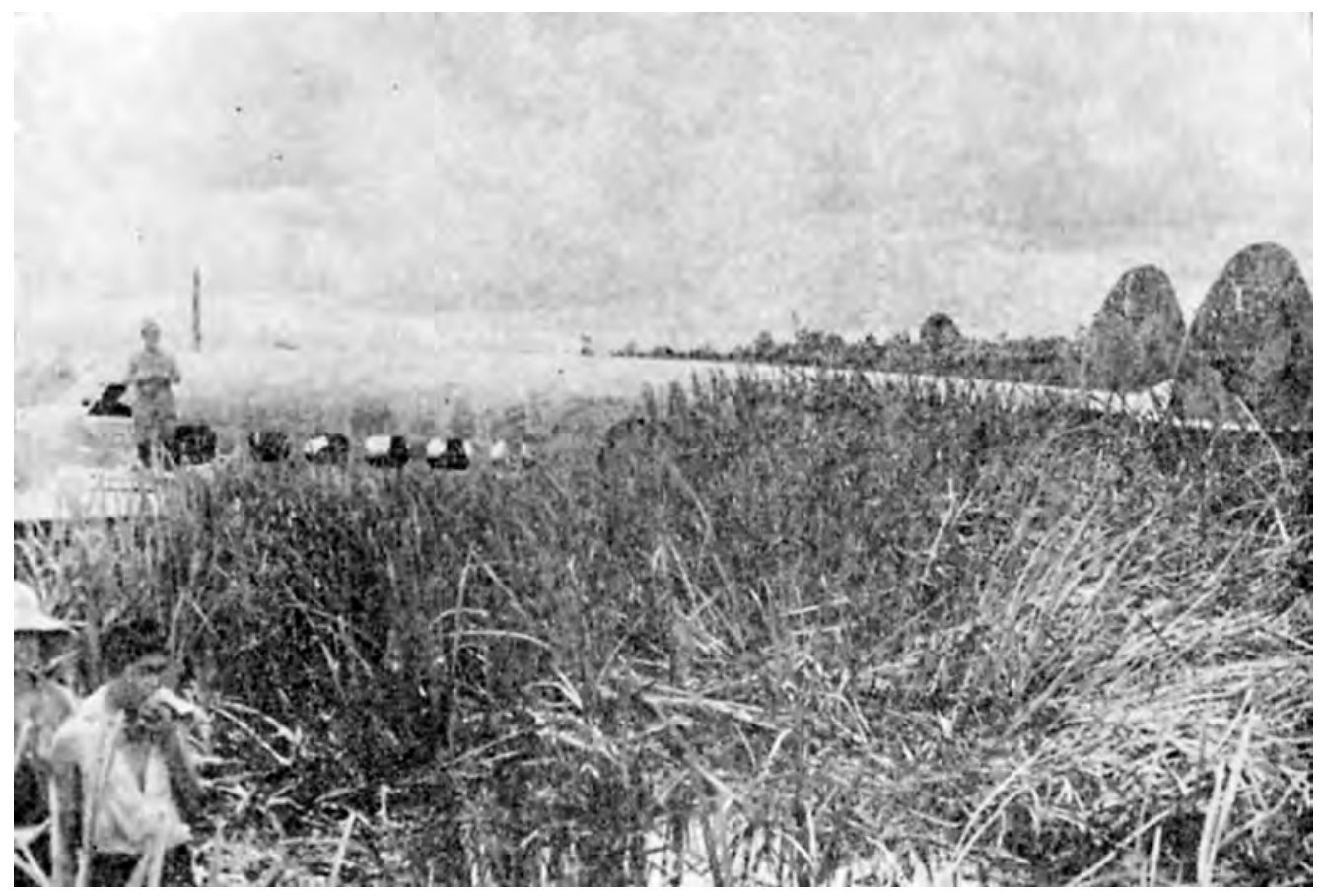

The Aircraft of the [Paratroop] Raiding Group Commander After its Forced Landing (14 February) 
unit. From around 2100 on the same day, in joint action with the Tanaka Advance Party of the 38th Division (which had started to arrive in Palembang one after another from 1900 onwards on the 15th), [the group] secured the airfield and the city of Palembang. On the 20th, guard duty [of the places] was taken over by a unit of the 38th Division.

After the battle it was found that the [enemy] unit which had defended the airfield had consisted of British, Dutch and Australian soldiers, some 530 men in total, led by a Dutch colonel, and that it had possessed a large number of trucks and light-armored cars. Further, it had set up a small number of pillbox positions around the airfield, where it had installed thirteen antiaircraft guns and five antiaircraft machine guns. ${ }^{(93,96)}$

\section{The Operations at the Oil Refineries}

As the counterattacks of the allied unit had gradually become sluggish toward daybreak on the 15th, the west oil refinery attack unit, after having returned to the drop zone and collected equipment, assembled at the company office in three trucks at 0830. Meanwhile, at the east oil refinery, [the attack unit] secured the distillation facilities all through the night, and mopped up [the enemy in] the neighborhood at dawn on the 15th. At 0600, there was a sudden explosion at the NKPM oil refinery with a deafening sound (which was [later] judged to be caused by a time bomb), and [the refinery] was instantly enveloped in flames, but no [further] damage was found to the distillation and the cracking facilities. Around noon of the 15th, the oil refinery raiding unit had completed mopping up [the enemy] and secured the premises. On the 20th, their guard duty was taken over by an element of the 38th Division. ${ }^{(93)}$

After the battle it was found that the [enemy] unit that had defended the oil refineries had been some 550 men in total, led by a captain. It had set up a small number of pillbox positions, where it had installed ten antiaircraft guns and five antiaircraft machine guns. ${ }^{(93,96)}$

\section{Results}

As we have seen, the Army's first ever paratroop unit had occupied Palembang and seized 250,000 tons of oil, a small number of British and U.S. aircraft, and various types of weapons and matériel. ${ }^{(23)}$

The number of casualties sustained on the 14th among the 329 men dropped was as follows: ${ }^{(23)}$

Killed in action: two officers, seventeen noncommissioned officers and twenty soldiers, a total of thirty-nine men.

Wounded and hospitalized: three officers, eighteen noncommissioned officers and sixteen soldiers, a total of thirty-seven men.

Wounded but remaining in the unit: four noncommissioned officers and seven soldiers, in total eleven men.

Note: Also included in the number of those killed in action are two men whose parachute did not open.

Commander in Chief Terauchi conferred a citation of merit on the Kume Paratroop Unit and the units that had directly cooperated, which read: "As the vanguard of the Southern Army, you have skillfully taken advantage of the opportunity for battle, and divided the Dutch East 
Indies and Malaya areas, as well as secured the key for the coming operations of the entire army." ${ }^{(13,93)}$

Third Air Force Commander Sugawara [also] conferred a citation of merit on five men: First Lieutenant Okumoto Minoru, Sergeant Kawahara Masao, Senior Private Katano Saburō, Senior Private Tsushima Shūsuke and Paymaster Sergeant Major Kikuchi Kiyoji. The citation of merit read as follows: ${ }^{(13,93)}$ "Right after descending, you encountered a motor vehicle unit, which suddenly appeared, speeding ahead from the direction of the airfield, boldly attacked and disarmed it, during which you happened to spot an enemy unit of some 150 men in four trucks with a light-armored car in front, heading northward to reinforce the airfield from the city of Palembang in response to an emergency. [Immediately] shifting your position and without missing an opportunity, you attacked [these trucks] with pistols and hand grenades. Once [you saw] the enemy step out of the vehicles, you bravely rushed the enemy without fearing death or injury, and finally put the enemy to rout, leaving many weapons and dead bodies behind. [You] aggressively and steadfastly forestalled the enemy with a small number of men by cutting off the reinforcement to the airfield at the critical moment when the main force of our unit was not yet fully prepared, and frustrated the intention of the enemy, which brought about the success of this operation."

An outline of the organization of the [Paratroop] Raiding Regiment has already been given, but a more detailed description would run as follows. ${ }^{(93)}$ Due to the limitation on the number of aircraft in this operation, however, not all [of the regiment] was able to participate.

The regiment consisted of the regimental headquarters and four companies.

The 1 st, the $2 \mathrm{~d}$ and the $3 \mathrm{~d}$ Companies consisted of a command team, three platoons and one machine gun platoon. [Each] platoon consists of three rifle squads ([equipped] with one light machine gun for each) and one grenade squad ([equipped] with two to three grenade launchers). The machinegun platoon was equipped, in addition to two heavy machine guns, with either a 37-mm. antitank gun, a 20-mm. antitank rifle, or a Type11 infantry gun.

The 4 th Company was organized in the same way as the 1 st, the $2 \mathrm{~d}$ and the $3 \mathrm{~d}$ Companies, but the rifle platoons [also] possessed engineer skills, and were equipped with two flamethrowers. Each company consisted of some 160 men, and each platoon about 34 men.

\section{(5) The 38th Division's Invasion of Southern Sumatra}

The convoy of the advance party entered the Mentok anchorage on the night of 14 February. The main force of the advance party headed for the mouth of the Musi, the Telang and the Saleh Rivers in landing craft, while the Orita Battalion headed for Bangka Island. On the morning of the 15th, the battalion went ashore at Mentok, seized the airfield, and by the 18th it had occupied the entire island of Bangka. [Meanwhile,] on the morning of the 15th the advance party had set out to ascend the three rivers [mentioned], and on the evening of the same day, the center column unit reached Palembang. The left column unit seized the Martapura airfield on the morning of the 19th. The main force of the division got to the mouth of the Musi River on the evening of the 16th, and reached Palembang on the evening of the 20th. The division commander had arrived in Palembang on the afternoon of the 17th ahead of [the main force], and sent the main force of the advance party, designated as the Tanaka Detachment, southward. This detachment seized Tanjungkarang on the 20th. Furthermore, 
after assigning the Tanaka Detachment, he assigned the Kanki Detachment to rush westward. This detachment seized Lahat on the $22 \mathrm{~d}$ and Bengkulu on the 24th. Having dealt with the dispatch of the Tanaka and the Kanki Detachments, he diverted the main force of the Orita Battalion from Bangka Island and sent it northward. This battalion and other units seized Jambi on 4 March, which completed [the operation to] occupy all key locations in southern Sumatra. In the meantime, the disembarkations at Mentok and at Palembang had been completed respectively on 21 February and on 28 February.

Although the main force of the [Paratroop] Raiding Group had parachuted down at midday on the 14th and one element on the morning of the 15th, it was not until the night of the 15th that they shook hands with the advance party of the 38th Division. On the afternoon of the 17th, the [Paratroop] Raiding Group came under the command of the 38th Division Commander. The air units of the Third Air Force advanced one after another to the Palembang airfield without missing an opportunity: the $2 \mathrm{~d}$ Squadron of the 11th Air Group (fighter planes) of the 12th Air Division had advanced to the Palembang [airfield] on the morning of the 15th, the headquarters and the 1st Squadron of the air group and one squadron of fighter planes of the 3d Air Division in the afternoon, the 3d Squadron of the 11th Air Group on the 16th, the headquarters of the 3d Air Division, the 27th Air Group (the headquarters and the 1st Squadron), as well as the $2 \mathrm{~d}$ Squadron of the 64th Air Group on the 17th. It was followed by the remaining units of the $3 \mathrm{~d}$ Air Division, the headquarters of the 12th Air Division, and also the 3d Squadron of the 1st Air Group on the 19th. [These units] took charge of the air defense over Palembang and carried out air campaigns over Java, while cooperating with the 38th Division in its operation. ${ }^{(96)}$

Judging on 18 February [according to p. 439, 16 February] that Operation L had for the most part been completed, [Navy] Malaya Unit Commander Ozawa started on his way back on the morning of the same day with his main unit. It was decided that the unit would transfer one of its elements to the Dutch East Indies Unit for the Java operation, while having another element take charge of the sweeping of the sea off Singapore and in the Strait of Malacca. ${ }^{(118)}$ The Hatsutaka, the flagship of the river-ascending unit commander (9th Base Force commander), started on the 18th for the Singapore area, while the Sendai, the flagship of the escort unit commander (3d Destroyer Squadron commander), left the Mentok anchorage on the 25 th. ${ }^{(118,126)}$

\section{The Capture of Mentok (See Illustration No. 29)}

The advance party consisted of the 229th Infantry Regiment (minus the 3d Battalion), led by Regimental Commander Col. Tanaka Ryōsaburō, the divisional armored car company, the 2d Battalion (minus one battery) of the 38th Mountain Artillery Regiment, the 38th Engineer Regiment (minus one company and one platoon), one divisional radio platoon, and the main force of the divisional medical unit. ${ }^{(68)}$ At 0100 on the 15th, the convoy ([consisting of] the previously-mentioned eight ships) completed its entry into the Mentok anchorage, after which the main force of the advance party and the Orita Unit started switching to their landing craft, respectively for going upriver and for going ashore at Mentok. ${ }^{(69)}$ The Orita Unit included the 1st Battalion of the 229th Infantry Regiment ([with] the 1st and the 2d Companyies of the regiment as its core), led by Battalion Commander Capt. Orita Masaru, one platoon each of the regimental artillery and engineers, one antiaircraft battery, and the $33 \mathrm{~d}$ 
Airfield Company. ${ }^{(69)}$ The operation plan of the unit (the Bangka invasion unit) made by the division was that ${ }^{(66)}$ "The Bangka invasion unit shall have one platoon land near the Mentok pier around 0300 and simultaneously the main force shall go ashore two kilometers southeast of Mentok. After the landing, the main force shall immediately attack the Mentok airfield from the east, and one element from the direction of the city. [Once it is seized, the unit] shall mop up [the enemy] in the neighborhood, after which the battalion shall move on to Palembang, leaving one company behind. The company that stays behind shall swiftly seize Pangkalpinang."(66) At 0225, the [Orita] Unit reached the shore, with the main force in four large and one small-sized motorized [landing] craft and one element in two small-sized motorized [landing] craft. At 0730 the unit seized the lighthouse and at 0830 the city and the airfield of Mentok. ${ }^{(69)}$ At the shore there were no obstacles nor were there any gun positions. Although there were some 2,500 people, officers and men of the allied forces as well as citizens of enemy countries, who had fled from Singapore, they were taken prisoner without resistance. ${ }^{(69)}$ The battalion occupied Pangkalpinang on the 18th, and by the 19th it had completely cleaned up the entire island. ${ }^{(66)}$ The landing of the Orita Battalion was followed by the disembarkation of the 33d Airfield Company, and airfield-related matériel from the ships that carried the [Orita] Unit. Of the two ships, the $A n^{\prime} y \bar{o}$-maru finished disembarkation on the 20th, and the Alaska-maru on the 21st. ${ }^{(69)}$ Then, in conformity with the division order, which will be mentioned later, Battalion Commander Orita left 1st Company Commander Takeuchi and his men behind on Bangka Island and successively departed with the rest of his unit from Mentok and headed for Palembang from 23 February onwards. ${ }^{(69)}$

As for the Mentok airfield, on 19 February it was reported: "As of 1800 on the 18th, [the airfield is] 200 meters wide and 800 meters long. [With] the disembarkation of matériel completed, [the airfield will be] expanded to a width of 200 meters and a length of 1,020 meters by the 21st." (118)

\section{The Landing at Palembang (See Illustration No. 29)}

The ascent of the rivers by the main force of the advance party and its subsequent operations had been planned as follows: (66) "After switching to the landing craft at the Mentok anchorage, the party shall be divided into the right column unit (the Telang River ascending unit: [consisting of] one half infantry battalion as the core, led by Maj. Miyazawa Shigezō, commander of the $2 d$ Battalion of the 229th Infantry Regiment), the center column unit (the Musi River ascending unit: [consisting of] three companies and one platoon as the core, led by 229th Infantry Regimental Commander Col. Tanaka Ryōsaburō), and the left column unit (the Saleh River ascending unit: [consisting of] the main force of the 38th Engineer Regiment and one infantry company as the core, led by Regimental Commander Lt. Col. Iwabuchi Tsuneo). Around 0300 they shall depart from the anchorage to go upriver. The right column unit shall ascend the Telang River and in cooperation with the main force (the center column unit) advance toward Palembang, where, in joint action with the [Paratroop] Raiding Unit, they shall capture the city. The left column unit shall move toward the rear of Palembang to facilitate the advance of the main force. If the city has already been captured [by then], the left column, without moving into Palembang, shall swiftly move on to Martapura to cut off the escape route of the allied forces. After the capture of Palembang, the advance party shall make preparation for heading south towards Tanjungkarang." 


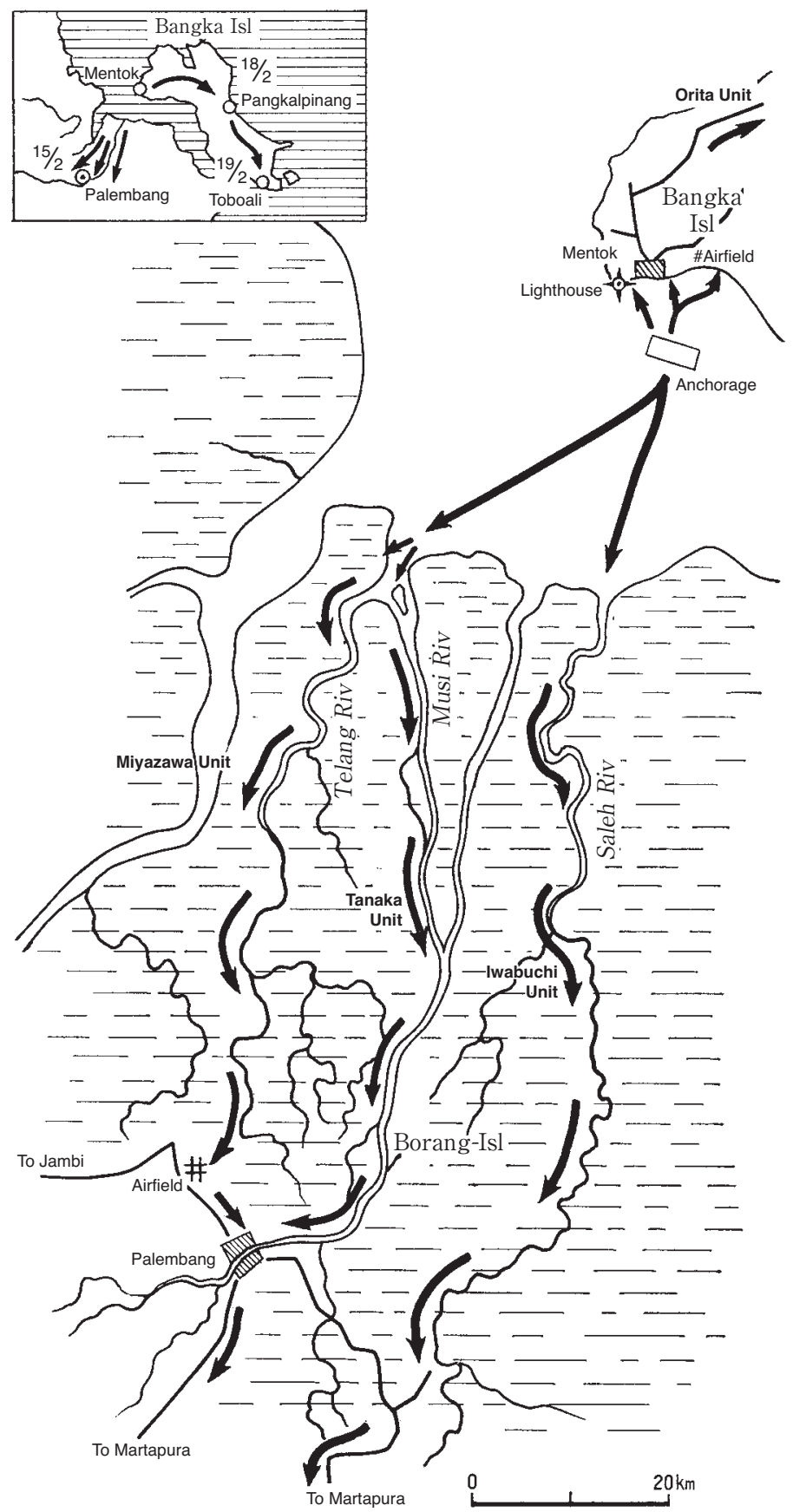

Illustration No. 29 - The Bangka and Palembang Operations of the Tanaka Advance Party
Around 0300 (on the 15th), after confirming that the Orita unit had successfully landed on Mentok, advance party commander Colonel Tanaka ordered each ascending unit to set out. ${ }^{(68)}$ Around 0600 (0640 for the left column unit), the river ascending units each reached the mouths of their [respective] rivers under the guidance of Navy warships. ${ }^{(69)}$ Around 0800, each of the units left the mouths of their rivers, and started going upstream. ${ }^{(68)}$ They dashed up the rivers which had yet to be cleared [of mines] by the Navy. Because on this day, as explained earlier, the Malaya Unit was focusing on its operation against the allied fleet and the Third Air Force was in the middle of the second paradrop operation on Palembang, no support by Japanese aircraft during their ascent could be given. However, despite suffering five successive attacks by allied aircraft during the ascent, the ascending units fortunately sustained only minor losses. ${ }^{(68)}$

From the evening of the 15th onwards, the right column unit moved into the vicinity of the Palembang airfield and estab-

lished contact with the paratroop unit. On the early morning of the following day, the 16th, [the unit] left the neighborhood of the airfield to join the main force in the city of Palembang. It then crossed the Musi River to assemble in preparation to head southward. ${ }^{(68)}$ 
The left column unit, without entering Palembang, headed for Martapura from midnight of the 15th onwards by landing craft and further by marching on foot. ${ }^{(68)}$

[Meanwhile,] from 1900 on the 15th onwards, the center column unit had started disembarkation in the Palembang area ([to be precise,] the 4th Company at the western end of the urban area on the south bank of the Musi River, the 6th Company at the eastern end of the urban area on the south bank of the Musi River, and the main force ([consisting of] the $3 \mathrm{~d}$ Company as the core) at the eastern part of the urban area on the north bank of the Musi River). Colonel Tanaka disembarked on the pier at $2000,{ }^{(68)}$ and was immediately able to contact [Paratroop] Raiding

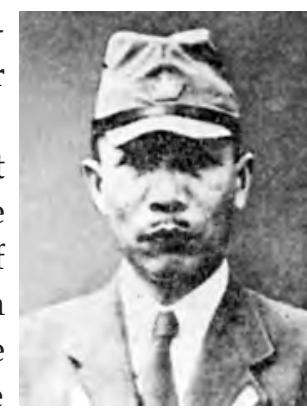

229th Infantry Regiment Commander, Col. Tanaka Ryōsaburō Group Commander Kume on the north bank (note: a unit of the [Paratroop] Raiding Group, which had advanced south from the airfield, had been entering the city from 1730 onwards). ${ }^{(93)}$ However, he did not succeed in making contact with the paratroop units which had occupied the oil refineries on the south bank. It was only around 1100 on the following day, the 16th, that the 6th Company, which had landed on the south bank near the eastern end near the oil refinery, [finally] established contact with the paratroop units that had seized the oil refineries. ${ }^{(68)}$

As soon as he had established contact with the [Paratroop] Raiding Group, Colonel Tanaka secured Palembang without missing an opportunity and at the same time decided to make preparations for the advance southward. First, he had one infantry platoon on bicycles leave Palembang southward to reconnoiter, and next around 1700 he had the 4th Company (minus one platoon) [also] head southward in motor vehicles, which had been collected. ${ }^{(68)}$

\section{The Capture of Tanjungkarang (See Illustration No. 30)}

\section{The [38th] Division's Order}

At precisely that time, the convoy of the main force of the division was entering the mouth of the Musi River. ${ }^{(118)}$ Prior to this, at 1320 on the previous day (the 15th), [Navy] Commander in Chief Ozawa, who had intended to fight a decisive battle with the allied fleet as mentioned earlier, had given the order that "the convoy of the advance party shall evacuate and anchor at the mouth of the Musi River." In conformity with the order, leaving three ships, i.e. the Tajima-maru, the An'yō-maru and the Alaska-maru, behind at the Mentok anchorage, the remaining five ships of the convoy [of the advance party] had weighed anchor at the Mentok anchorage at 1500 of the same day (the 15th), and entered the anchorage at the mouth of the Musi River at 1740, where they had waited for the Navy to finish the clearing of the river. ${ }^{(69)}$ The convoy of the main force of the division entered the anchorage at the mouth of the Musi river at 1845 on the 16th. ${ }^{(118)}$ Right before that, Division Commander Sano had issued the following order:(69)

\section{8th Division Order}

Gin'yō-maru on the waters east of Sumatra, 1600, 16 February

1. Yesterday, on the 15 th at 0235 , one element of the advance party successfully landed on Bangka Island and seized the Mentok airfield at 0640 . The main force of the party had its left river ascending unit at 0640 , and its right and center river ascending units ... advance to the mouth of 
the Musi river, where each unit respectively started ascending the [designated] river. In the meantime, at 1126 of the day before yesterday, the airborne [Paratroop] Raiding Group completed its drop on the Palembang airfield, the oil refineries and their vicinities. Further, around 1300 yesterday, the 15th, one squadron of the fighter planes of the Third Air Force rapidly advanced to the Palembang airfield. It seems that the convoy of the advance party and the river ascending units came under repeated attacks from formations of enemy aircraft.

2. The plan of the division remains the same as it was. The 1st [Paratroop] Raiding Group shall be newly put under my command upon the arrival of the division in Palembang, and the $2 \mathrm{~d}$ Sea Transport Supervisory Unit upon its arrival in Mentok.

3. The advance party shall henceforth become the Tanaka Detachment and, in cooperation with the 1st [Paratroop] Raiding Group, leave one element in the vicinities of Palembang, Limau and [Talang] Abab, and send the main force forward toward the south as swiftly as possible to seize the airbases of Martapura and Tanjungkarang and make them ready for use, while mopping up the enemy naval bases along Lampung Bay in order to facilitate the Java invasion of the army. In this operation, it is required to have an especially powerful unit ascend the river(s) between Palembang and Martapura by landing craft to quickly advance to the latter to capture the enemy. The following person(s) and units shall newly be put under the command of the detachment commander upon their arrival in Palembang (the rest omitted by the author).

Staff Officer Oyadomari

3d Battalion of the 229th Infantry Regiment

2d Squadron of the 4th Tank Regiment (with one-third of the regimental train attached) 45th Independent Motor Transport Battalion (minus two companies)

4. The Chief of Staff, Staff Officer Oyadomari, Adjutant Yamamoto and part of the division headquarters shall ascend the Musi River in extra-large motorized [landing] craft this evening, when the convoy of the main force arrives at the mouth of the river, ahead [of the rest of the force] to Palembang. The ascending [of the river] and the disembarkation [of this party] shall be assigned to the disembarkation working unit. (The rest [of this item] and items 5 to 8 are omitted by the author.)

9. The 1st [Paratroop] Raiding Group shall secure the airfield and the oil refineries of Palembang. The Tanaka Detachment shall cooperate with the group in these tasks.

10. The Orita Unit shall henceforth come under my direct command and still continue its present tasks (the rest omitted by author).

11. The 3d Battalion of the 229th Infantry Regiment (note by the author: with Maj. Kemmotsu Heishichi as battalion commander) shall come under the command of Detachment Commander Tanaka upon its arrival in Palembang. For this purpose, the battalion headquarters and about one company shall advance to Palembang in extra-large motorized [landing] craft on this evening when the convoy of the main force arrives at the mouth of the Musi River (the rest omitted by the author).

12. The $2 \mathrm{~d}$ Squadron of the 4 th Tank Regiment (with one-third of the regimental train attached) shall come under the command of Detachment Commander Tanaka upon its arrival in Palembang. For this purpose, about six light tanks shall advance to Palembang in extra-large motorized [landing] craft on this evening when the convoy of the main force arrives at the mouth of the Musi River.

13. The 45th Independent Motor Transport Battalion (minus two companies) shall, upon its arrival in Palembang, come under the command of the advance party commander.

14. The Disembarkation Working Unit shall still continue its present tasks, in such a way that the unit shall this evening take charge of the river ascending operation of most of the division headquarters, the Kemmotsu Battalion and one element of the tank squadron from the mouth of the Musi River to Palembang in the six extra-large motorized [landing] craft that accompanied the convoy of the main force. [The unit] shall [also] take charge of the disembarkation work at Palem- 
bang and, by means of the required number of large- and small-sized motorized [landing] craft, small cargo ships and fishing boats, simultaneously take charge of the river ascending operation of the necessary units in the convoy of the main force, which are to go upstream ahead [of the other units].

15. - 21. (Omitted by the author.)

22. I shall this evening leave the mouth of the Musi River and advance toward Palembang along with part of the division headquarters in extra-large motorized [landing] craft.

As previously mentioned, on the afternoon of the 16th, Commander Tanaka of the advance party had already sent the 4th Company southward. Following the aforementioned division order, he [then] assigned two companies to stay behind to guard Palembang, reassigned the main force of the remaining unit as the Tanaka Detachment and ordered it to charge toward Tanjungkarang. First, on the afternoon of the 17th, the Miyazawa Battalion (the former right column unit) departed from Palembang by collected vehicles (busses, trucks, and automobiles). ${ }^{(68)}$ Sixteenth Army Staff Officer Itoda, and 38th Division Staff Officer Oyadomari accompanied the unit. ${ }^{(68,39)}$ After having seized the Talang Jimar oil field [editor's note: the text has Talang Jur, which is a misreading], the Miyazawa Battalion had one element [stay and] keep a watch on the direction of Lahat, and advanced southward with its main force. When a non-commissioned officer and his underling (both with a railroad background and capable of operating locomotives), who were under the direct command of the detachment commander and accompanied the advance party, found a serviceable switch engine at the Talang Jimar station [editor's note: probably a station near Talang Jimar is meant], [the battalion commander] immediately put this to use, created a temporary armored train unit with one infantry platoon and one regimental gun, and had [the unit] pursue the enemy. ${ }^{(68)}$ Detachment Commander Tanaka had been fretting about the fact that there were no motor vehicles available for the main force of the detachment, but at 1200 on the 18th, the motor vehicles of the 45th Independent Motor Transport Battalion were finally unloaded. Losing no time, the detachment instantly left Palembang and reached the Martapura airfield at 0500 on the 19th. ${ }^{(68)}$ Earlier, the left column unit, which had headed to Martapura [partly] in landing craft, and [partly] on foot from midnight of the 15th [editor's note: apparently by way of the Komering River], had reached the Martapura airfield a little after 0400 on this morning (of the 19th), and had seized the airfield after a minor engagement. This was followed by the arrival of the Miyazawa Battalion in Martapura. ${ }^{(68)}$ At 0600 (on the 19th) the Miyazawa Battalion left Martapura, which was followed by the main force of the detachment (including the former left column unit, and the armored car unit of the division, which had caught up [with the main force]). It left Martapura at 0200 the next day (the 20th). Both rushed ahead, crossing rivers at Kutoraja [editor's note: probably a misreading for Kotabumi] and Mandah by using improvised materials because the bridges there had been destroyed by the allied forces. By dawn on the 20th, [the battalion] reached Tanjungkarang (the main force at 1000), after which it further advanced to the coast. At 1200, while briskly shooting at the [Japanese] troops with two gunboats, the rear guard of the allied unit left the jetty of Telukbetung. As the artillery had not yet caught up with the detachment, it had to vainly let [the enemy] escape. The total distance the detachment had covered in these two days and nights was some 500 kilometers. ${ }^{(67,68)}$

On the following day, the 21st, with considerable effort, Sixteenth Army Staff Officer Itoda found the Tanjungkarang airfield. ${ }^{(39)}$ Against all expectations, the airfield was far from complete, with [a runway of] a mere 700 meters. The Tanaka Detachment immediately began 
construction work. Working around the clock, it completed a runway of 25 meters wide and 800 meters long by the 25th. ${ }^{(39,68)}$ On the afternoon of the same day, the fighter planes of the $3 \mathrm{~d}$ Air Division rapidly advanced to the airfield and launched the operation against Java on the opposite shore. ${ }^{(96)}$

After having made a belly landing together with [Paratroop] Raiding Group Commander Kume on a clearing within a stretch of swampy jungle four kilometers [according to p. 331, ten kilometers] southeast of the Palembang airfield, Sixteenth Army Staff Officer Itoda directed [operations] in the Palembang sector and the preparation of Tanjungkarang airfield. On the 17th, he had reported the following from Palembang to the Sixteenth Army: (23)

1. As of 2100 on the 15 th, the right and the center column units of the advance party of the 38th Division have been working hard policing and restoring public order in key

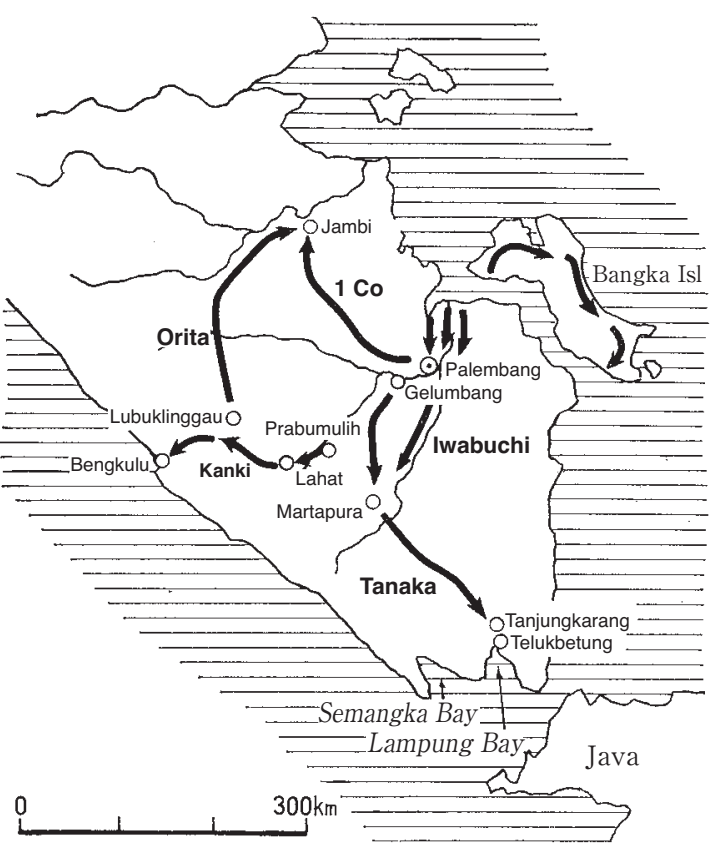

Illustration No. 30 - The 38th Division's Southern Sumatra Operations locations at Palembang. Around 1700 on the 16th, about one company [of the party] was sent off towards Tanjungkarang. The left column unit departed from [a place] east of Palembang at 0900 on the 16th for Martapura. At 2400 on the 16th, part of the aviation fuel arrived. There are no impediments to the operations of the fighter planes based in Palembang.

2. Policing and the restoration of public order in Palembang are appropriately carried out under the unified command of Colonel Kume. There are a few defeated troops in the vicinity, but the people mostly remain [in their places]. Electricity and water is supplied as usual; only the telephone is out of service.

3. Although I chose a landing spot slightly far from the airfield where enemy [troops] were sparsely deployed, due to the difficult terrain, I arrived at my present position [only] at 1800 on the 15th. I [hereby] apologize for the delay in sending my report. I will give the necessary instructions to the commander of the airfield company which arrived on the 17th, and advance to Tanjungkarang.

4. The brave and hard fighting of all the officers and men of the [Paratroop] Raiding Group in this operation cannot be related without tears. Those who did not participate in this battle make up no more than a [small] part of each company of the $2 \mathrm{~d}$ Regiment, [which means that] if one intends to use [the paratroopers] for the Cilacap [operation], one will have no choice but to rely on those who fought in Palembang. Having seen the battle with my own eyes, I do not have the heart to drive them into another hardship, and I offer as my opinion that [the idea of] using the [Paratroop] Raiding Group in the Cilacap [operation] should be given up. 


\section{Delay in the Upriver Ascent of the Convoy of the Main Force}

Earlier, on the 15th, the Tanaka advance party had started ascending the rivers in motorized landing craft at 0830, but it was not until two hours later at 1030 that the Navy started clearing the Musi River. ${ }^{(102)}$ At 1030 the Navy river-ascending unit commander (i.e. the 9th Base Force commander) had his units start going upriver, in the order of: (1) the 1st Explosives Sweeper Unit ([consisting of] nine large and small motorized [landing] craft), the $2 \mathrm{~d}$ Explosives Sweeper Unit ([consisting of] eight auxiliary cutters), and the 3d Explosives Sweeper Unit ([consisting of] four fishing boats) (the units above were generically referred to as the Explosives Sweeper Units); (2) the Minesweeper Unit ([consisting of] the Otowa-maru and the Rumoi-maru); and (3) the main unit (the Hatsutaka). ${ }^{(102)}$ However, due to twelve bombing raids and strafes by an aggregate number of thirty-nine allied aircraft, and the frequent parting of the minesweeping ropes caused by the many obstacles on the sea/[river]bed, the mine sweeping operation was given up at 1300 after sweeping only ten nautical miles. The units returned to the mouth of the river at 1500. ${ }^{(102)}$ Commander in Chief Ozawa then transferred three minesweepers from the Escort Unit to the river-ascending unit. ${ }^{(102)}$ On the same day (the 15th), the five ships of the convoy of the advance party, which had been ordered to change their anchorage [in preparation] for the aforementioned decisive fleet battle, had left the Mentok anchorage for the anchorage at the mouth of the Musi River, and arrived there at $1740 .{ }^{(118)}$ At 0800 on the following day, the 16th, the Navy river-ascending unit [again] began clearing the river while sailing upstream reinforced by the three minesweepers mentioned earlier, and by 2030 roughly finished clearing [the river] up to Palembang. ${ }^{(102)}$ At 1845 of that day, the fourteen ships of the convoy of the main force of the 38th Division arrived at the mouth of the Musi River, and entered the anchorage. ${ }^{(118)}$

On the following day, the 17th (the day when the Miyazawa Battalion started its advance to the south), the Shimushu (a coastal defense ship of 400 tons) started ascending the [Musi] river with the 38th Division headquarters on board, which had been transferred from the Gin'yo-maru. [Editor's note: the Shimushu-class coastal defense ships had a displacement of 860 tons; the 400 tons mentioned here are presumably gross registry tons.] Following [the Shimushu], the army convoy of nineteen ships ([of which] five belonged to the former advance party and fourteen to the main force of the division) left the anchorage at the mouth of the Musi River. ${ }^{(102)}$ However, at [a point] three nautical miles upriver from Borang Island, [the convoy] encountered a mine barrier that was yet to be cleared and was forced to anchor temporarily . Only the Shimushu kept sailing on alone, reached Palembang at 1435 (on the 17th), and disembarked the division headquarters. ${ }^{(102)}$

At 1830 on the 19th, [the operation of] clearing the river was completed; twenty-eight mines were dealt with. At 0800 on the 20 th, the convoy departed from its temporary anchorage guided by the Shimushu, and arrived in Palembang around 1500 on the same day, where it started disembarkation. The disembarkation was completed on the 28th. ${ }^{(102)}$

\section{The Capture of Bengkulu}

Division Commander Lt. Gen. Sano Tadayoshi, who had arrived in Palembang at 1435 on the 17th on the Shimushu ahead [of the rest of the convoy] as mentioned previously, on the night of the 19th issued the following order concerning the preparation for the seizure of Lahat and Bengkulu. ${ }^{(69)}$ [At that time] the convoy was [still] stuck near Borang Island. ${ }^{(102)}$ 
Numa [38th Division] Operation Order A, No. 114

38th Division Order

Palembang, 2400, 19 February

1. As of 0850 today the 19th, the Tanaka Detachment has seized Martapura driving off weak enemy forces and continues its dash towards Tanjungkarang. The Orita Battalion completed the capture of Bangka Island on the 18th. The 3d Air Division has been supporting the offensive of the Tanaka Detachment with the Palembang airfield as its base. The people of Yukasuka (a place approximately 130 kilometers west of Palembang) have come to show their allegiance to us. [Editor's note: "Yukasuka" could not be identified. It might be a misspelling/misreading for Bungamas, between Lahat and Tebingtinggi.] The convoy of the main force is expected to come to Palembang and start disembarking here tomorrow the 20th.

2. The plan of the division remains the same as it was.

3. The Ōneda Unit (note by the author: 3d Battalion, 230th Infantry Regiment) shall put its Obata Platoon under my direct control at Palembang, let its main force first advance to Prabumulih (a three-forked railroad junction southwest of Palembang) and vicinity, seize the location, and prepare for the advance toward Lahat and Bengkulu. [The unit] shall come under the command of unit commander Kanki (note by the author: the artillery regiment commander) upon his arrival at Prabumulih. Further, [the Ōneda Unit] shall put the 10th Company (minus one platoon) under the command of Lieutenant Colonel Nagahata, the commander of the Division Oil-drilling Unit, upon his arrival at the location.

4. The Obata Platoon shall advance to Sekayu and vicinity, and secure the location, after which it shall prepare for the advance against Jambi. [The platoon] shall also investigate the condition of the oil fields in the vicinity.

5. The Orita Unit shall assign a unit consisting of about one infantry company and one machine gun platoon as the core for guarding the entire island of Bangka, and assemble its main force in the vicinity of Mentok, so that it can be redeployed to Palembang at any time (the rest omitted by the author).

6. After disembarkation, the Kanki Detachment shall successively advance to Prabumulih and prepare for the capture of Lahat and Bengkulu (the rest and item 7 omitted by the author).

8. The 1st [Paratroop] Raiding Group shall assemble in the Palembang barracks and prepare for the next operation. The group shall turn over the guard duty of the oil refineries and their vicinity to the disembarkation working unit at 0900 on the 20th (the rest omitted by the author).

When the disembarkation started, Division Commander Sano ordered Col. Kanki Takekichi to seize the oil fields and the airfield in Lahat, and [the towns of] Lubuklinggau and Bengkulu. ${ }^{(66)}$

On 21 February, the Kanki detachment ([consisting of] the 38th Mountain Artillery Regiment headquarters and one mountain battery with Colonel Kanki as regimental commander, the main force of the $3 \mathrm{~d}$ Battalion of the 230th Infantry Regiment with Maj. Ōneda Yasuhei as battalion commander, one squadron of the 4th Tank Regiment, one element of the divisional signals unit, one element of the divisional medical unit and others), left Palembang and advanced while commandeering motor vehicles. The detachment captured Lahat on the $22 \mathrm{~d}$, Lubuklinggau on the $23 \mathrm{~d}$ and, after crossing a mountain range, Bengkulu on the west coast on the 24 th. ${ }^{(70,71,72)}$ No allied units were seen in this area, and the locals lent their active cooperation to the operation of the detachment. ${ }^{(70,71,72)} \mathrm{Col}$. Abe Yoshimitsu, chief of staff of the division, who accompanied the detachment, gave directions particularly concerning the occupation of the oil fields in Lahat and the disposition of the oil production unit. ${ }^{(66)}$ 


\section{Occupation of the Jambi Oil Fields and Gelumbang}

Following the assignments concerning the operations in Tanjungkarang (the Tanaka Detachment) and in Bengkulu (the Kanki Detachment), Division Commander Sano decided to redeploy the main force of the Orita Battalion, which was still in Bangka, for carrying out the operation to occupy the oil fields in Jambi, and on the evening of the 21st he passed down the following order: ${ }^{(69)}$

Numa [the 38th Division] Operation Order A, No. 119

38th Division Order

Palembang, 1800, 21 February

1. Yesterday the 20th, the Tanaka Detachment completely occupied Tanjungkarang and Telukbetung and destroyed the enemy naval base(s) in Lampung Bay. [Editor's note: Tanjungkarang and Telukbetung are now together known as Bandar Lampung.] The rear guard unit of the enemy escaped from Lampung Bay on a gunboat at 1200 yesterday the 20th. Without a break, the Tanaka Detachment mopped up the enemy along Semangka Bay and is now making the Tanjungkarang airfield ready for use. The Orita Unit has completed its capture of Bangka Island.

2. The plan of the division remains the same as it was.

3. The Tanaka Detachment shall send Staff Officer Oyadomari back to Palembang to return him to my command.

4. The Orita Unit shall put [a unit consisting of] about one company and one machine gun platoon as the core under my direct control as the Bangka Island occupation unit, turn over its current duty to this unit, and head for Palembang with the main force of the remaining unit. The disembarkation unit commander shall be in charge of the transport.

5. The Bangka Island occupation unit shall hereafter come under my direct control and take over the current duty of the Orita Unit (the rest omitted by author).

The redeployed element of the Orita Unit consisted of the battalion headquarters, the $2 \mathrm{~d}$ Company, one machine gun company and one regimental gun section as the core and departed from Mentok [one after another] by small cargo ships between 23 February and 1 March ${ }^{(69)}$ During that time, Mentok suffered a number of air strikes: [one air strike] by one aircraft on the $22 \mathrm{~d}$, two strikes by one aircraft each time on the $23 \mathrm{~d}$, again two by one aircraft each time on the 26th, then two strikes by one aircraft and one by four aircraft on the 27th. ${ }^{699}$

As mentioned previously, the division commander had earlier (on the 19th) dispatched the Obata Platoon to Sekayu, partly in preparation for the operation against Jambi. Also, in order to occupy the oil fields in Jambi and the vicinity, at the time of the redeployment of the Orita Battalion he gave the order to a unit consisting of one infantry company and one artillery section as the core, led by Battalion Commander Captain Orita, to prepare at Lubuklinggau and capture Jambi. He also had Colonel Abe, the chief of staff of the division, accompany the unit and give directions to it. Separately, [the division commander] had one infantry company head for Jambi from Palembang (in northwesterly direction). ${ }^{(66)}$ The Orita Unit, which [had been redeployed] from Bangka Island to assemble in Lubuklinggau via Palembang and made preparations for further advance, departed from the city on 23 February and headed for Jambi. On its way, the unit had two minor engagements with the enemy and [was held up] at a bridge that had been destroyed. Nevertheless, [the unit] dashed [toward Jambi] and, on 4 March, seized the place without engaging in combat. In the meantime, 
the company that had headed for Jambi from Palembang was delayed by the bad condition of the road and finally arrived in Jambi on the following day, the 5th. ${ }^{(66)}$

With the occupation of the Jambi oil fields, the main part of the southern and central Sumatra operations of the 38th Division was completed.

[In the meantime,] it was decided that the Navy would use the airfield of Gelumbang (fifty kilometers southwest of Palembang; discovered on 16 February) for the Java operation. On 23 February, the Southern Army sent a telegram to the 38th Division to instantly give full support to the Navy's preparation of the Gelumbang airfield (including the transport of fuel and ammunition). ${ }^{(23)}$ Thanks to the cooperation of the 38th Division, from the 24th onwards, a powerful unit of the $22 \mathrm{~d}$ Air Flotilla was deployed at this airfield, which will be mentioned later in detail.

\section{Oil and the [Paratroop] Raiding Group}

Whereas about eighty percent of the eastern oil refinery of Palembang (NKPM) had been lost due to deliberate detonation by the allied forces on the early morning of the 15th, only four gasoline tanks had been destroyed by fire at the western oil refinery (BPM) at the time right after the seizure. [Editor's note: NKPM, or Nederlandsche Koloniale Petroleum Maatschappij, was a subsidiary of the American Standard Vacuum Oil Company; BPM, or Bataafsche Petroleum Maatschappij was a subsidiary of Royal Dutch Shell.] The situation until 18 February was as described in the following [telegrams]: ${ }^{(23)}$

\section{From: 1st [Paratroop] Raiding Group Commander, at Palembang, on 18 February}

The situation of the refineries according to the subsequent investigation conducted by [Southern] Army Staff Officer Satō Hiroo, and his comments:

1. As it is expected that at least approximately 150,000 tons of crude oil and approximately 400,000 tons of refined oil (the precise breakdown of the contents is still under investigation) that remained at the BPM Oil Refinery can be secured, I request that tankers be allocated and that preparations be made so that [the oil] can successively be sent to the homeland.

2. At the BPM Refinery, only about three fires are still burning. Although one tank has already been destroyed by fire (each tank contains 10,000 tons), the others remain intact with almost no fear that the fire will spread.

3. It is required to urgently dispatch a large number of engineers who can handle the distillation and cracking installations because all the main Dutch engineers have fled.

4. The NKPM Refinery is still on fire to such an extent that there is no prospect of when the fire will be extinguished. There are more or less ten tanks, which are in lesser danger of catching fire; it is expected that 70,000 to 80,000 tons of refined oil can be secured.

5. The two tankers seized at the refineries belong to the 300-ton class. We are searching for more [tankers] to the best of our abilities.

6. As such is the situation, I am of the opinion that it would be better if fuel for operations and other needs during the southern operation be supplied from Palembang as a base, so that the supply [of oil] from the homeland can be reduced as much as possible.

\section{From: Chief of Staff, 38th Division, at Mentok, on 20 February}

1. Apart from the oil tanks and pipes destroyed by fire, the BPM Refinery is for the most part intact. Further, it has a facility to process gasoline for aviation as well. Its loading facility is also 
intact. The capacity of the remaining oil tanks (excluding smaller processing oil tanks) is some 500,000 tons.

2. The NKPM Refinery was blown up at the time of our occupation and is difficult to repair.

Note: this telegram was sent on the 20th, but reports the situation on the 18th.

However, allied aircraft, which infiltrated [the area] from the 19th onwards, brought an unexpectedly heavy loss.

As mentioned previously, [Japanese] fighter plane unit(s) had started to arrive from 15 February onwards at the Palembang airfield. These were followed by the $3 \mathrm{~d}$ Air Division headquarters, which had advanced on the 17th, and by the 12th Air Division headquarters, which had advanced on the 19th. From the 19th onwards, [these units] launched air strikes against Java. However, the allied air forces managed to infiltrate the area with a small number of aircraft in the way described below: ${ }^{(99)}$

[February]

15th: Three attacks were made on the airfield by a total of four aircraft. [The Japanese] brought down two of them. [The enemy aircraft] did not come to the refineries.

16th: Five attacks were made on the airfield by a total of nine aircraft. [The Japanese] forced one of them to make an emergency landing. No attacks were made on the oil refineries.

17th: More than dozen aircraft came to attack the airfield. [The Japanese] brought down three of them. No attacks were made on the oil refineries.

18th: No attacks were made on the airfield or the oil refineries.

19th: Three attacks were made on the airfield by a total of three aircraft. There was also an attack on the oil refineries, which set fire to the tanks of the BPM plant.

20th: One aircraft came for an attack on the refineries, and enlarged the number of tanks destroyed by fire.

21st: One aircraft came for an attack on the refineries, and destroyed one distillation and one cracking installation. This aircraft was brought down by [Japanese] fighter plane(s).

Since its seizure, they had worked all day and night until finally the fire was extinguished on the night of the 17th, and the refinery was brought in the condition of the 18th described in the telegrams above, but then this refinery was [again] enveloped in flames from the 19th onwards as related above, which moreover not only destroyed nearly thirty tanks, including all of the most important 100-octane gasoline tanks, but also put one each of the distillation and cracking installations out of commission. This could happen because [the Japanese] had been taken off guard during their air attack operation against Java and because the antiaircraft artillery had arrived late due to the mine barrier which had held up the convoy [at a point] three nautical miles upriver from Borang Island until the 20th. ${ }^{(99,102)}$

For the [Paratroop] Raiding Group, which had occupied the refineries, this was a bitter pill to swallow.

By Southern Army Order of 22 February, the 1st [Paratroop] Raiding Group returned from the Sixteenth Army (the 38th Division) command to the command of the Third Air Force commander. Then, at 2400 on 1 March, it was brought back under the direct control of the Southern Army from the command of the Third Air Force commander. ${ }^{(23)}$ 


\section{The Capture of Balikpapan and Kendari (See Illustration No. 31)}

The Balikpapan and Kendari landing operations were launched on the day (24 January) when the participants of the Manila Conference went on their way back after the conference, which had been held between the Southern Army and the [Navy] Southern Task Force to discuss the invasion schedule, and between the Sixteenth Army and the [Navy] Dutch East Indies Unit to make arrangements for the Java operation.

Balikpapan was a key resource location: oil, which was transported through pipelines from the oil fields in the Samarinda and Sanga Sanga areas located northwest of Balikpapan, was stored and refined there, and shipped from there as well. Besides, [the city] had an airfield, from which air attacks against eastern Java could be conducted. Kendari, on the other hand, was a strategic place, which would enable [Japanese] naval aircraft to conduct air attacks on eastern Java, while gaining command of the air over a vast area in the east and southeast, stretching from Ambon and Kupang to Bali Island. At the same time, it was an ideal place for establishing a naval base.

Whereas the capture of Balikpapan was to be conducted by both the Army and the Navy in conjunction, that of Kendari was to be carried out solely by the Navy. ${ }^{(1)}$

In accordance with the Southern Army order of 20 November, the Sixteenth Army had ordered the Sakaguchi Detachment to capture Balikpapan. ${ }^{(36)}$

The [Navy] Southern Task Force (i.e. the Second Fleet) had issued the order to shift to phase-two operations on 26 December, and [thereby] ordered the Dutch East Indies Unit to carry out the operations to capture Balikpapan and Kendari (which belonged to the phasetwo operations of the Southern Task Force). It had also ordered its air unit (i.e. the Eleventh Air Fleet) to cooperate [in the operations]. ${ }^{(110)}$ The chief task of the Southern Task Force in the phase-two operations was the escort of the transport of the main force of the Twenty-fifth Army [to Malaya]. ${ }^{(102)}$ [To that end,] after the escort of the transport of the main force of the Fourteenth Army [to the Philippines], the Southern Task Force had diverted the 5th Destroyer Squadron and others from the Philippines Unit (Dutch East Indies Unit, i.e. the Third Fleet) to the Malaya Unit (the Southern Expeditionary Fleet) and positioned the main force of the Southern Task Force in Cam Ranh Bay. ${ }^{(102)}$ As support for the Dutch East Indies Unit, Southern Task Force Commander Vice Admiral Kondō had formed the Eastern Support Unit ([consisting of] the battleship Haruna, the heavy cruiser Maya and two destroyers) with an element of the main force (the order was given on 23 December), and separately sent the unit to the waters southeast of Davao. ${ }^{(102)}$ As soon as the outlook for [the completion of] the escort of the main force of the Twenty-fifth Army became clear, Vice Admiral Kondō left Cam Ranh Bay on 8 January with the main unit of the Southern Task Force, advanced to Palau on 18 January, and took command of the Eastern Support Unit. ${ }^{(102)}$

[Meanwhile,] on 28 December, Vice Admiral Takahashi, commander of the Dutch East Indies Unit, had in outline made the following disposition of forces (for the phase-two operations):(110) [In this disposition,] the Western Attack Unit (after carrying out the landing operation on Tarakan on 11 January) would conduct the Balikpapan operation, and the Eastern Attack Unit (after conducting the operation to capture Menado on 11 January) would conduct the Kendari operation, while the main unit remained positioned in Davao. ${ }^{(102)}$

Main Unit: directly led by the Vice Admiral Takahashi; the main force of the 16th Cruiser Division (the heavy cruiser Ashigara). 


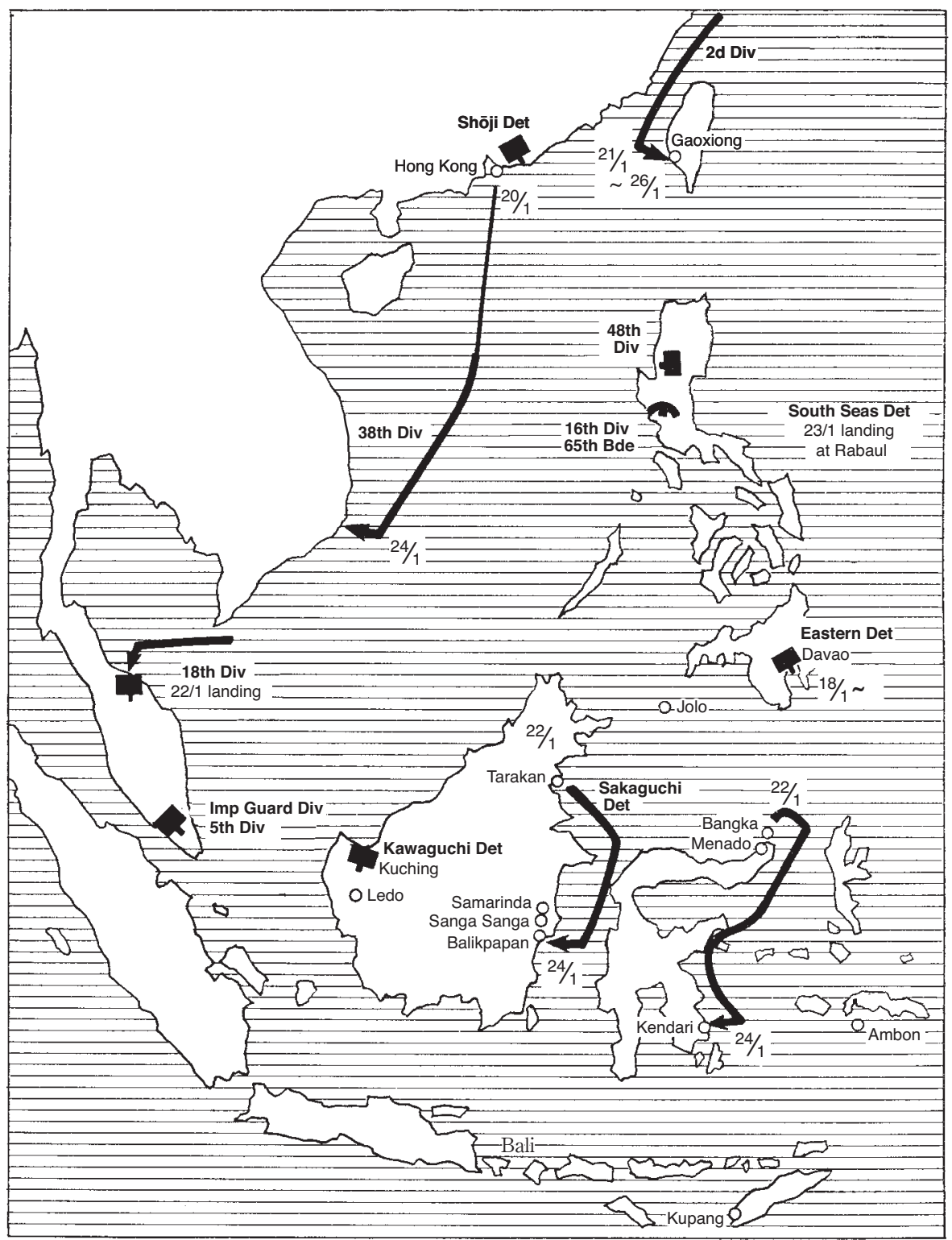

Illustration No. 31 - Balikpapan and Kendari Operations, and the General Situation at that Time

Western Attack Unit:

1st Escort Unit: the 4th Destroyer Squadron (minus the 4th Destroyer Division) as its core

$2 \mathrm{~d}$ Base Unit: the light cruiser Kuma (note: she belonged to the 16th Cruiser Division [at that time] and was transferred to the Third Southern Expeditionary Fleet on 3 January) and most of the $2 \mathrm{~d}$ Base Force.

1st Air Unit: the auxiliary seaplane tenders San'yō-maru and Sanuki-maru as the core. [Editor's note: the Japanese text says " $2 \mathrm{~d}$ Air Unit," which is a misprint.]

Eastern Attack Unit:

Support Unit: the 5th Cruiser Division (the heavy cruisers Myōkō, Haguro and Nachi (note: the Myōkō was damaged on 4 January and moved to the mainland for repair)) and two destroyers. 
2d Escort Unit: the 2d Destroyer Squadron (minus the 18th Destroyer Division) as its core.

1st Base Unit: the light cruiser Nagara (note: she belonged to the 16th Cruiser Division) and most of the 1st Base Force.

2d Air Unit: the 11th Seaplane Tender Division (the seaplane tenders Chitose and Mizuho).

Of the [naval] air unit (i.e. the Eleventh Air Fleet), the 23d Air Flotilla (the 2d Air Raid Unit) headquarters had advanced to Jolo Island on 3 January, and the 21st Air Flotilla (the 1st Air Raid Unit) headquarters to Menado on 16 January. ${ }^{(102)}$ The headquarters of the Eleventh Air Fleet (V. Adm. Tsukahara Nishizō) had been positioned in Davao since 7 January. ${ }^{(102)}$ The disposition of forces of the Eleventh Air Fleet as of 31 December was as already described, however, as of 20 January the disposition of forces of the $23 \mathrm{~d}$ Air Flotilla was that it had its headquarters and twenty-four aircraft in Tarakan, fifty-five in Jolo, and twenty in Gaoxiong. ${ }^{(143)}$

The attacks on Balikpapan and Kendari were to be launched from Tarakan and Menado respectively. ${ }^{(110)}$

Although [the operations to] capture Balikpapan and Kendari had been scheduled for day $x+43$ (20 January) in the Cam Ran Agreement (on 1 January), they were postponed on 6 January for one day due to the delay in the capture of Davao and Jolo Island, the bad condition of the airfields, and the fact that the Philippines Unit (the Dutch East Indies Unit) as well as the air unit had been late in shifting to the Dutch East Indies operation. Then, on 16 January after the capture of Tarakan and Menado, [the operations] were [again] postponed for another three days, due to the mines laid in [the waterways of] Tarakan, the condition of its airfield, and information on [enemy] submarines in the Molucca Sea, finally resulting in a postponement of four days in total, and [the operations] came to be carried out on 24 January, as mentioned previously.

\section{(1) The Capture of Balikpapan}

\section{The Scheme to Occupy [Balikpapan] Intact and the Plan for a Surprise}

Attack (See Illustrations No. 32 and No. 33)

As we have seen, the arrangement of 16 November between the [Navy] Dutch East Indies Unit and the Sixteenth Army stipulated: "The Sakaguchi Detachment shall have its main force land near the Balikpapan pier and parts of the detachment near the Baru and Sepuluh batteries each (note by the author: the specific locations are unclear)." [Editor's note: the Baru battery was located north of the harbor front, the Sepuluh battery south of the harbor front near the residential area of Klandasan.] Also the contents of the arrangement between the Army and the Navy, which [Sixteenth Army] Vice Chief of Staff Harada Yoshikazu had conveyed when he had flown into Palau at the end of November, stipulated the same. ${ }^{(88)}$ Having left Palau and captured Davao, the Sakaguchi Detachment held a preliminary meeting with the 4 th Destroyer Squadron on [the operations to] capture Tarakan and Balikpapan on 2 January, as soon as the squadron had advanced to Davao on that day, ${ }^{(119)}$ after completing its escort of the main force of the Fourteenth Army. At the meeting, Yano Tsuneo, staff officer of the detachment, made a proposal, after pointing out that an assault on the strongest front where the enemy was well prepared should be avoided. On 5 January, the 4 th Destroyer Squadron (led by R. Adm. Nishimura Shōji) prepared, based on this proposal, [a draft] "Arrangement between the 1st Escort Unit of the Navy and the Sakaguchi Detachment of 
the Army," which both commanders signed the same day. The arrangement stated in outline the following:(88)

Landing points: Plan No. 1 was to have the main force land in the area north of the Balikpapan airfield and one element in the area south of the airfield. Plan No. 2 was to have the main force land in the area south of the Balikpapan airfield and one element in the area north of the airfield.

Disposition of the landing forces: the main force shall consist of two battalions, and an element of one battalion (minus two companies).

No particular reconnaissance of the landing points will be made; a surprise landing will be conducted at 2200 on 19 January. A naval bombardment shall be provided at the request of the landing unit commander(s).

The Sakaguchi Detachment had landed on Tarakan Island before dawn on 11 January and made the commander of the Dutch garrison on the island surrender the next day, the 12th. The fierce firepower concentrated like hail at the front and the destruction of the oil resources by fire in that operation had taught Detachment Commander Sakaguchi and Staff Officer Yano a big lesson, which they applied in [planning] the coming operation to seize Balikpapan. ${ }^{(87)}$

On 15 January, the Matsumoto Battalion arrived in Tarakan after completing the capture of Jolo Island. ${ }^{(119)}$ At 1800 on that day, Detachment Commander Sakaguchi passed down orders to start the embarkation and the changing of ships the next day, the 16th, and complete it on the morning of the 17th. He also announced that he would board the Teiry $\bar{u}$-maru at 1800 on the 16th. ${ }^{(88)}$ At that time, the plan was that the detachment would leave Tarakan on the 18th. ${ }^{(88)}$ [However,] the preparation of the Tarakan airfield was terribly delayed, and it was not ready for use for either the 23d Air Flotilla or the Navy 1001 Unit (the naval paratroop unit that was to parachute down on Balikpapan). ${ }^{(119)}$ On that day (the 15th), after conferring with Detachment Commander Sakaguchi, Rear Admiral Nishimura wired the [Navy] Dutch East Indies Unit commander that an arrangement had been made to "postpone the landing in Balikpapan scheduled for the 21st until the 24th." (See the previous description.) On the next day, the 16th, the [Navy] Dutch East Indies Unit commander, Vice Admiral Takahashi, approved the wired report from Rear Admiral Nishimura, and ordered by telegram to "change the date of landing in Balikpapan from the 21st to the 24th." ${ }^{\text {(119) }}$ However, about the [progress of] readying the Tarakan airfield one could only be pessimistic. Although the Asama-maru carrying the officers and men of the Navy 1001 Unit had arrived in Tarakan at 0930 on that day (the 16th), due to the judgment that the three-day postponement would not be sufficient to make the airfield ready for use by the transport plane unit (twenty-eight to thirty-nine planes) required for the 1001 Unit to take off and land, it was decided to cancel the parachute drop [of the unit] on Balikpapan and to use [the unit] for Banjarmasin instead. ${ }^{(103)}$

The Sakaguchi Detachment had continued the operation to mop up [the enemy] until the 14 th, and on the 15th it passed down the order of embarkation in conformity with the previously mentioned arrangement of 5 January, while hurriedly carrying out various measures, reorganizations, and the transfer of control. ${ }^{(88)}$ Then, [the detachment] faced two new situations: (1) the three-day postponement of the schedule, and (2) the cancellation of the paradrop of the paratroop unit. 
Lieutenant Colonel Yano, staff officer of the detachment, immediately shaped some clever plans. One of them was a way to keep the Dutch East Indies forces from destroying and burning down the oil resource facilities, and another was a way to occupy Balikpapan by completely taking the Dutch East Indies forces by surprise. ${ }^{(87)}$

Prior to that, the 44th Field Antiaircraft Artillery Battalion Commander Maj. Takagi Takeo had offered an idea of sending Captain Colijn, son of the former Governor-General of the Dutch East Indies, manager of BPM, and adjutant of the Tarakan garrison, and Captain Reinderhoff, staff officer of the garrison (both of whom had been taken prisoner at the time of the capture of Tarakan), to the Balikpapan garrison headquarters to have them transmit the message that the resources and equipment in the whole area of Balikpapan should not be destroyed. ${ }^{(88)}$ [Editor's note: Captain Colijn was the son of the prewar prime minister and minister of the colonies Hendrik Colijn, who has never been Governor-General.] Staff Officer Yano had [once] turned down the idea. However, being allowed three extra days [before the Balikpapan operation], he began considering its implementation. At once, [Staff Officer Yano] drew up a plan to infiltrate [two] guides along with those military messengers, have a powerful unit led by a battalion commander secretly ascend the river in front of the city of Balikpapan to deeply advance into the rear of the city after landing at a point far upriver from the urban area under the guidance of the guides, take control of the weak points of the Balikpapan garrison at a stroke by seizing the water supply area, cutting off the escape route, and surrounding the shelter for Dutch noncombatants (families of the troops in particular), etc., and make the garrison surrender at an early stage. ${ }^{\left({ }^{87}\right)}$ Although Regimental Commander Yamamoto and three battalion commanders were against the proposal to detach a battalion to secretly ascend the river, Detachment Commander Sakaguchi approved Staff Officer Yano's entire plan. ${ }^{(87)}$

On the next day, the 17th, the detachment proposed it at the meeting with the Navy. As the Navy agreed with it, the arrangement of 5 January was nullified, and the new plan was arranged. ${ }^{(119)}$

The next day, the 18th, the military messengers together with the guides left the port [of Tarakan]. ${ }^{(88)}$

The following day, the 19th, Detachment Commander Sakaguchi assembled the commanders of each unit on the Teiry $\bar{u}$-maru to give them instructions and explain the new operation plan, the scheme [to send the messengers], etc. He [also] carried out test maneuvers in cooperation with the Navy that night. ${ }^{(88)}$ The test maneuvers were for verifying whether the aforementioned secret unit led by a battalion commander would be able to go upriver in front of the city of Balikpapan [even] in the beams of the searchlights of the Dutch East Indies forces. The experiment was carried out by navigating a camouflaged [landing] craft at a distance of 500 meters from the side of a destroyer, which turned a searchlight on the craft. [The result] was reassuring. ${ }^{(87)}$

A summary of the instructions given by Detachment Commander Sakaguchi on that day was as follows: ${ }^{(88)}$ "The detachment's operations have made steady progress and [the detachment] is just about to cross the equator to advance further southward. (Part omitted by the author.) (1) Consider carefully once again the peculiarity of the coming operation. The main purpose of the coming operation is to secure resources. (Part omitted by the author.) (2) Make good use of your experience in the past battles. As shown in the history of war, errors will occur in battles one after another. What lets you turn these errors and mistakes into achieving 
a brilliant victory is actually nothing but the unflagging, diehard effort and the strong spirit of unanimous cooperation shown by the commanding officers and their men. All units are required to maintain an ever closer contact with each other, push forward with their tasks with high morale, always foster a fresh and keen sense for opportunities, and have the grit to turn even mistakes into a key to victory. (3) Military discipline and morals: As the areas of the coming operations are places where the detachment will itself establish a military administration after the battles, it also makes both the method and the spirit of conducting the operations different from the traditional battles so far. Officers and men are required to ever more firmly stick to their principles, and exercise further self-control and self-discipline. (4) Preparation for the subsequent operations: The capture of Balikpapan does not mean that the detachment will stop at that place. The transport ships shall be replenished with water and coal, and part of [the detachment] will depart to further attack Banjarmasin. (Part omitted by the author.) (5) Provisions. (Part omitted by the author.) (6) Reporting. (Part omitted by the author.) Concluding remarks."

On the next day, the 20th, Detachment Commander Sakaguchi issued the following SAKA [Sakaguchi Detachment] Operation Order A, No. 19. ${ }^{(88)}$

\section{Sakaguchi Detachment Order}

Teiryū-maru, 0800, 20 January

1. The enemy in Balikpapan is a unit consisting of the 6th Infantry Battalion as the core, led by Lieutenant Colonel Van Den Hoogenband. It has not yet destroyed resources, plants and other facilities in the area. Our Navy air unit shall cooperate in our operation with its main force using the Jolo airfield as its base, and one element of fighter planes using the Tarakan airfield as its base.

2. At 1700 tomorrow, the 21st, the detachment shall leave the port of Tarakan, go ashore in Balikpapan and vicinity under the escort of naval vessels and air units, mop up [the enemy] in Balikpapan and key areas in the neighborhood, and secure the air base and the oil resource plants.

3. All units involved shall be charged with the capture of Balikpapan, the airfield, and other key locations, in accordance with separate volume No. 1 "Outline of the capture of Balikpapan," and separate volume No. 2 "Balikpapan landing plan."

At 1700 on the next day, the 21st, the convoy left the port of Tarakan, and headed for Balikpapan.

\section{The Operation Plan of the Sakaguchi Detachment (See Illustration No. 32)}

The Sakaguchi Detachment was to make its way from Tarakan under escort of the Western Attack Unit and the 23d Air Flotilla to occupy the Balikpapan sector.

The Western Attack Unit consisted of the following strength, while it was supported by the main unit ([with] the heavy cruiser Ashigara) directly led by the commander of the Dutch East Indies Unit with Davao as its base:(118)

1st Escort Unit: the light cruiser Naka, the 24th Destroyer Division, the 9th Destroyer Division (minus the Yamagumo), and the 2d Destroyer Division (minus the Murasame) of the 4th Destroyer Squadron as the core, led by the squadron commander.

$2 \mathrm{~d}$ Base Unit: most of the $2 \mathrm{~d}$ Base Force. 
1st Air Unit: the auxiliary seaplane tenders the San'yō-maru and the Sanuki-maru with about twenty planes in total. [Editor's note: the Japanese text has "2d Air Unit," which is a misprint.]

The 23d Air Flotilla was going to provide support with its main force from Jolo, and with one element from Tarakan. ${ }^{(104)}$

The Sakaguchi Detachment had made a plan in which it would sail ahead supported by the air and naval forces mentioned above, enter the anchorage on the afternoon of the 23d, and have one element of the detachment (a unit led by Battalion Commander Kanauji) ascend the river in front of Balikpapan after sunset, make a detour and raid [the city] from the north; at the same time it would have the main force [of the detachment] make a surprise landing on the coast to the north and the south of the airfield located on the coast northeast of Balikpapan; [then] one element of the main force (a unit led by Battalion Commander Kume) would make a sudden attack on the airfield as well as Samboja, while the main force ([consisting of] the Matsumoto Battalion led by Regimental Commander Yamamoto, and later joined by the main force of the Kume Battalion) would assault Balikpapan from the east and capture [the city]. ${ }^{(88)}$

The disposition of forces was determined as follows: ${ }^{(88)}$

Raid Unit

Commanding officer: 2d Battalion Commander Maj. Kanauji Ken'ichi

$2 \mathrm{~d}$ Battalion (minus the 7th Company)

One regimental gun squad

Three radio squads

One engineer platoon

One element of the medical unit

Airfield Seizure Unit

Commanding officer: 1st Battalion Commander Lt. Col. Kume Motozō

1st Battalion (minus the $2 \mathrm{~d}$ and the 4th Companies)

One radio squad

One armored car platoon (until the seizure of the airfield)

One field artillery battery (one section will be removed after the seizure of the airfield)

Assault Unit

Commanding officer: 146th Infantry Regiment Commander Col. Yamamoto Kyōhei

146th Infantry Regiment (minus the 1st Battalion \{minus the 4th Company\}, the 2d Battalion, one regimental gun squad, and four radio squads)

Armored car unit (minus one platoon)

1st Field Artillery Battalion (minus one battery)

One engineer platoon

One platoon each from the airfield seizure unit and the Samboja seizure unit shall be additionally attached after the seizure of the airfield and Samboja respectively.

Samboja Seizure Unit

2d Infantry Company (one armored car platoon and one artillery section shall be attached after the seizure of the airfield.)

Battlefield Resources Salvage Unit

Units under the direct command: headquarters, the 7th Company, the antiaircraft artillery battalion, and others 
The outline for the capture of Balikpapan (Separate volume No. 1 of the SAKA [Sakaguchi Detachment] Operation Order A, No. 19) was as follows: ${ }^{(88)}$

\section{Outline for the Capture of Balikpapan}

19 January, 1942

1. Mission

(1) The detachment shall have one element make an unexpected surprise attack from the area north of Balikpapan and have the main force go ashore on the coast to the east and west of the airfield and advance while destroying the [enemy] positions east of Balikpapan one by one to occupy the urban area.

(2) After the capture of Balikpapan, [the detachment] shall salvage the resources, set up a base, and prepare for subsequent operations while maintaining a strict antiaircraft guard.

2. Directives

(3) At 1700 on 21 January, the detachment shall leave the port of Tarakan and head straight to the sea off the coast of Balikpapan in Dutch Borneo under the escort of naval vessels and aircraft while itself maintaining a strict watch on [enemy] submarines in particular.

(4) After sunset on 23 January, the Raid Unit shall transfer to [landing] craft at the anchorage south of the [coral] reef fifteen kilometers southwest of Balikpapan and, while hiding the scheme in every possible way, thread its way camouflaged through the enemy searchlights along the coast and secretly go up the Wain River at high tide. After seizing and securing the water-pumping station, it shall storm, without missing an opportunity, at a stroke the headquarters of the command center of the Balikpapan garrison by way of the enemy's evacuation shelter while using the vehicles on site. Then, it shall launch surprise attacks on every barracks and battery to throw the enemy into confusion and prevent the destruction by fire of the resources.

(5) Before daybreak on 24 January, the Airfield Seizure Unit shall transfer to [landing] craft at the anchorage east of the airfield and go ashore in the area about eight kilometers northeast of the airfield. At daybreak, following closely on the heels of the artillery bombardment, it shall storm into the airfield, seize and secure [the facility], after which [the unit] shall come under the command of the Assault Unit commander and leave a force of about one platoon at the airfield in charge of guarding [the facility].

(6) The Assault Unit shall transfer to [landing] craft at the anchorage east of the airfield and go ashore about four kilometers southwest of the mouth of the Manggar River. While cooperating in the seizure of the airfield with one element of its force, its main force shall, after getting ready near the landing point [for the assault], storm and break through the [enemy] positions on the way to Balikpapan and rush into [the city]. [There] it shall assume the command of the Raid Unit as well and secure the resources and guard Balikpapan. Once the airfield is seized, it shall also bring the Airfield Seizure Unit under its command.

(7) The Samboja Seizure Unit shall [also] go ashore at the [same] landing point as the Airfield Seizure Unit. After the seizure of the airfield, it shall advance toward Samboja through the areas along the coastal road and promptly seize and secure Samboja. After that, its main force shall return to its original command, leaving about one platoon there behind.

(8) The Battlefield Resources Salvage Unit shall ... (the rest omitted by the author).

(9) The detachment headquarters shall act along with the Assault Unit.

(10) The Prisoner Internment Unit shall ... (the rest omitted by the author).

(11) After the seizure of Balikpapan and Samboja, the Armored Car Unit shall assemble in one place, and ... (the rest omitted by the author).

(12) After the seizure of Balikpapan, the artillery unit shall assemble ... (the rest omitted by the author).

(13) (Omitted by the author.) 
(14) The engineer unit shall be in charge of repairing the disembarkation facilities for heavy materials near the airfield and the road and the bridges between the airfield and Balikpapan and make them ready for use. After that, it shall assemble in Balikpapan. (Part omitted by the author.)

(15) - (19) (Omitted by the author.)

(20) After completing [the operation] to mop up [the enemy] in Balikpapan and vicinity, the Samarinda Seizure Unit ([consisting of] about one infantry battalion, one armored car platoon and one artillery battery as the core) shall be sent to mop up [the enemy] in Sanga Sanga, Samarinda, and Tenggarong and vicinity.

In the Balikpapan landing plan (separate volume No. 2 of the SAKA [Sakaguchi Detachment] Operation Order A, No. 19 drawn up on 20 January), which the Sakaguchi Detachment had arranged with the 4 th Destroyer Squadron commander, the noteworthy points were roughly as follows: ${ }^{(88)}$

1. No reconnaissance of the landing points shall be conducted in advance.

2. The Raid Unit shall drop anchor at the $2 \mathrm{~d}$ anchorage at 2100 on the $23 \mathrm{~d}$, and start ascending the river at 2230 .

The main force of the detachment shall drop anchor at the 1st anchorage at 0230 [0100, see Vol. 26, p. 190] on the 24th and start landing at 0230.

3 Division of the Convoy (notes: B [in front of the name of ships] indicates a Navy transport ship.) 1st Section: Tsuruga-maru, Liverpool-maru ([with] the regimental commander [on board]), Nisshō-maru [Hiteru-maru], Ehime-maru, B Asahisan-maru, B Nittei-maru, [B] Kumagawa-maru, and B Sumanoura-maru

2d Section: Havana-maru, Hankow-maru, Teiryū-maru ([with] the detachment commander [on board]), Kuretake-maru, B Kanayamasan-maru [Kayamasan-maru], B Tōei-maru, B Tatsugami-maru, B Nan'a-maru (note: the Havana-maru and the Hankow-maru shall use the $2 \mathrm{~d}$ anchorage.)

4. The Naval Landing Force ([consisting of] two platoons) shall come under the command of Detachment Commander Sakaguchi as far as ground operations are concerned from the time of landing until [the completion of] the operation to mop up [the enemy] in key areas of Balikpapan and guard the airfield after its seizure.

5. [Landing] craft to be used at the start of landing.

The Assault Unit: five large and five small motorized [landing] craft.

The Raid Unit: four large and six small motorized [landing] craft.

The Airfield Seizure Unit: five large and five small motorized [landing] craft.

\section{Dispatch of the Messengers and Guides (See Illustration No. 34)}

In order to prevent the oil and other resource facilities in Balikpapan from being destroyed and burnt down, Detachment Commander Sakaguchi had decided to send Captain Reinderhoff, a staff officer of the Tarakan garrison, and Captain Colijn, the adjutant of the garrison, and had them take a written notice addressed to the Balikpapan garrison commander, as mentioned previously. ${ }^{(88)}$

Also, he had selected two indigenous police officers, who had been transferred from Balikpapan to Tarakan about two months before, as guides for the Kanauji Raid Unit, which would go upriver and come ashore [at a point] north of Balikpapan. He then added three Japanese interpreters to the above party of four, and had them leave Tarakan at 1535 on 18 January by a seized small gasoline boat to go southward. ${ }^{(87,139)}$ 


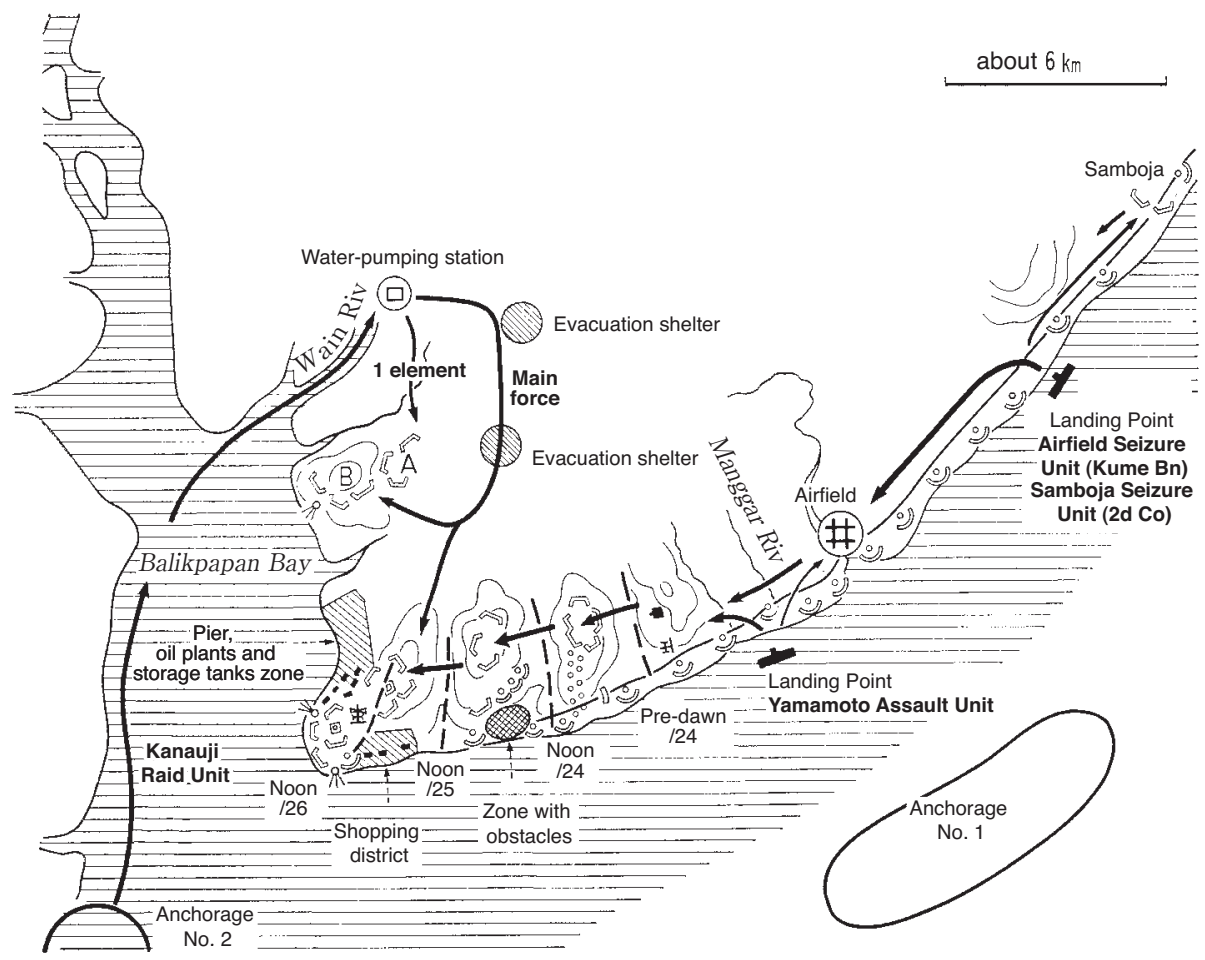

Illustration No. 32 - Information on Balikpapan, and Schematic Map of the Capture [Operation]

On the morning of the 20th [at a point] off Samarinda, the party was spotted by a Dutch flying boat, which picked up the two [Dutch] captains, [sent as] messengers, and left. ${ }^{(87,139)}$

The remaining five members of the party kept going southward and reached [a point] off Samboja around 1600 on the same day, where they temporarily anchored to wait for the reply from the commander of Balikpapan [garrison]. Around 1800, a messenger came to the boat displaying a flag of truce with a letter from the Balikpapan [garrison] commander, which read: "The key facilities have already been burned down on the 18th before the message from the Japanese army was delivered." The scheme to prevent the destruction [of the facilities] by fire before the fact came too late. While the two indigenous police officers, who acted as guides and the interpreters went ashore near Samboja by canoe at 0200 on the 21st, the gasoline boat headed back. Around noon on the 22d it met the convoy of the Sakaguchi Detachment, and returned to Tarakan on the evening of the 23d. On the 21st, the party of the guides and the others, who had landed near Samboja, headed for [the area] north of Balikpapan while crossing the mountains on foot. They passed through the minefields in the northern suburbs of Balikpapan on the morning of the next day, the $22 \mathrm{~d}$, and reached the Sumber River around 1500, where they rented a boat for fifty yen and went down the river. They stood by at the mouth of the river until the evening of the $23 \mathrm{~d}$. From around 2130 that night with their lamps lit, they waited for the Kanauji Raid Unit to appear at the mouth of the river. ${ }^{(87,139)}$ 
The Sailing of the Convoy and the Surprise Attacks on the Anchorage

(See Illustrations No. 33 and No. 34)

The convoy of a total of sixteen ships, [consisting of] eight ships with the Sakaguchi Detachment [on board] and eight transport ships of the Navy, had left the port of Tarakan at 1700 on the 21st and headed southward under the escort of one light cruiser (the Naka), nine destroyers, four minesweepers, three submarine chasers, and three patrol boats, led by 1st Escort Unit Commander ([and also] the 4th Destroyer Squadron Commander) Rear Admiral Nishimura. ${ }^{(119)}$

What was known about the situation in the air and at sea at that time was roughly as follows:(119)

1. Whereas the allied naval surface forces have been moving southward one after another out of reach of our air power and are staying in the Java Sea showing little fight, one element of the force seems to be maneuvering in the Makassar Strait.

2. A couple of submarines are spotted between Tarakan and Balikpapan every day, in addition to those that constantly appear off Tarakan.

3. There seem to be some destroyers, patrol vessels, minelayers, and torpedo boats in Balikpapan.

4. Dutch planes have been launching fairly aggressive counterattacks from airfields in various places, especially from secret airfields unknown [to us]. [Editor's note: The airfield Samarinda II, which the Japanese did not discover until 24 January and did not occupy until early March after the Dutch capitulation.]

5. Our reconnaissance from the air on the 20th spotted fires and explosions everywhere at Balikpapan, Samarinda and other places.

On the 21st, nothing happened at sea. ${ }^{(119)}$

On the $22 \mathrm{~d}$, nothing happened during the morning. Around noon, the detachment encountered the boat that was (on its way back) [from] having taken the previously mentioned messengers and guides, and was briefed [on the situation]. Around 1800, the Havana-maru and the Hankow-maru with the Kanauji Raid Unit on board were separated [from the convoy] 
and started advancing [ahead of the other ships] under the escort of two destroyers. Around 2300 the convoy crossed the equator. ${ }^{(119)}$

At 0005 on the 23d, the convoy of the Kanauji Raid Unit came under torpedo attack from an [enemy] submarine (four torpedoes [were launched]). At 1050, three allied aircraft flew in above the main convoy. From 1220 onwards, one allied aircraft reconnoitered the main convoy. [Then] at 1625, nine heavy and four light bombers of the allied forces came for an attack on the main convoy and did minor damage to the Tatsugami-maru (a naval munitions ship). In the meantime, at 1602 nine heavy and six light bombers strafed the Kanauji Raid Unit. At 1720, Rear Admiral Nishimura ordered minesweeping. However, around that time, one twin-engine aircraft came for an attack and caused a fire on the Nan'a-maru (a transport ship of the Eleventh Air Fleet), which [eventually] stalled the ship. At 2045, the convoy of the Kanauji Raid Unit (the Havana-maru and the Hankow-maru) completed entering into the anchorage. At 2230, the Raid Unit left the anchorage and started ascending the river in [landing] craft ([to be precise] four large and six small motorized [landing] craft, camouflaged with mangroves). As already described, the guides, consisting of the [two] indigenous police officers and others, were waiting [for them] from around 2130 with their lamp(s) lit. The Havana-maru and the Hankow-maru left the anchorage along with the two destroyers to join the main convoy (which was expected at 0900 on the 24th). Meanwhile, the main convoy also came under attack from [enemy] submarine(s) at 2040, but [the convoy] completed entering the anchorage at 2330. ${ }^{(119)}$

On the 24th at 0030, one small allied naval vessel appeared in the [anchorage] of the main force, and at 0040 the Tsuruga-maru (6,987 tons; with the Field Artillery Battalion headquarters, one field artillery battery, the Antiaircraft Artillery Battalion headquarters, the main force of the $2 \mathrm{~d}$ Battery of the Antiaircraft Artillery Battalion, the main force of the medical unit, etc. on board ${ }^{(88)}$ ) was sunk by torpedo(es). ${ }^{(119)}$ At that time, the transport ships were anchored in the following order:(119)

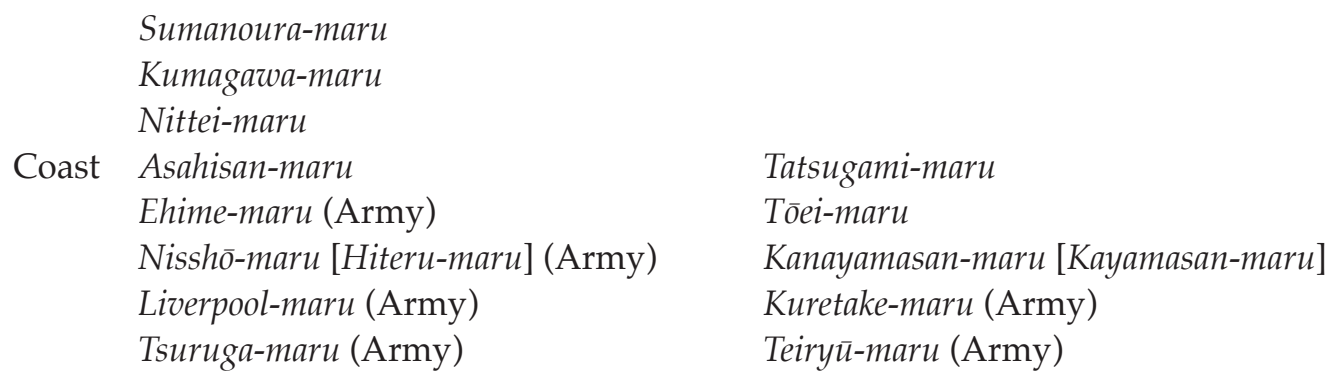

After a little while at 0140, Detachment Commander Sakaguchi ordered "the departure of the units to seize the airfield and the bridges." ${ }^{(119)}$ The Kume Battalion (the Airfield Seizure Unit, in five large and five small motorized [landing] craft) and the main force of the Yamamoto Regiment (the Assault Unit, in five large and five small motorized [landing] craft) launched the landing [operations] all at once, and the first wave succeeded in landing at 0240. ${ }^{(88,119)}$ Following them, the shuttle operation to land [the rest of the troops] was started. However, between 0420 and 0500, in the middle of the operation, allied naval vessels, which were judged to be three or four destroyers and one or two cruisers, appeared out of nowhere 
like phantom killers, wreaked havoc in the dark, and disappeared like the wind. ${ }^{(119)}$ In an instant, the following loss was caused on our [Japanese] side: ${ }^{(119)}$

Sunk:

The Sumanoura-maru (auxiliary torpedo- and submarine-net layer and mine layer/oiler) The Tatsugami-maru (munitions ship)

The Kuretake-maru (5,175 tons; with the 3d Battalion headquarters, the 12th Company, the 3d Machine Gun Company, and others on board)

Badly damaged:

Patrol boat No. 37

The Asahisan-maru

Slightly damaged:

The Kumagawa-maru

Note: The raiding [allied] naval vessels were four U.S. destroyers (the USS [John D.] Ford, Pope, Parrott and Paul Jones). On the 20th, having learned that the convoy of the Sakaguchi Detachment was heading southward, the joint headquarters of the United States, Britain, the Netherlands and Australia had six U.S. submarines and two Dutch submarines advance to the waters of Balikpapan from Surabaya as well as from the South China Sea, and [also] dispatched a task force ([consisting of] two light cruisers and four destroyers), which was refueling at Timor Island, to carry out a hit-and-run mission. Of this task force, the two light cruisers had troubles on the way, and [the remaining] four destroyers carried out the hit-and-run attack. ${ }^{(51, \text { etc.) }}$ For the four stealthily approaching destroyers, [the Japanese] convoy in the middle of the disembarkation operation against the backdrop of the land blazing with oil fires was of course an easy target.

At that time, the 1st Air Unit's San'yō-maru (with six Type-0 Observation Seaplanes and two Type-0 Reconnaissance Seaplanes) had left Tarakan on the $23 \mathrm{~d}$ and was scheduled to reach Balikpapan on the 26th, while the Sanuki-maru (with six Type-0 Observation Seaplanes and two reconnaissance seaplanes) was to leave Tarakan on the 24th to reach Balikpapan on the 27th. ${ }^{(131,132)}$ Furthermore, the main force of the 23d Air Flotilla (the 2d Air Raid Unit) was [still] in Jolo Island because the Tarakan airfield was not yet ready. ${ }^{(104,132)}$ In the meantime, the operation to capture Kendari was going on in the east, simultaneously with the operation to capture Balikpapan. At 0930, Rear Admiral Nishimura received a telegram from the commander of the Dutch East Indies Unit, which said: "The main unit is hurrying to Balikpapan and will arrive there on the evening of the 24th."(119)

\section{Occupation of the Balikpapan Sector}

(See Illustration No. 34)

Although the Sakaguchi Detachment had two of its ships, the Kuretake-maru and the Tsurugamaru, torpedoed and sunk as mentioned previously, no more than thirty-nine men were killed in the sinking. ${ }^{(53)}$ At 0240, the Kume and the Yamamoto Units succeeded in landing without meeting any resistance, seized the airfield and the bridges at daybreak as planned, and went on with their subsequent operations as scheduled. ${ }^{(87,119)}$ The southwestward advance of the Yamamoto Unit (the Assault Unit) was hindered by the destroyed bridge(s) on the coastal road, but [the unit] managed to reach the north end of the city of Balikpapan at night. ${ }^{\left({ }^{87}\right)}$ As the Dutch East Indies garrison had already retreated from their positions, the Assault Unit 
entered the city of Balikpapan at 0400 on the 25th with no engagements at all. ${ }^{(87,119)}$

The Raid Unit led by Battalion Commander Kanauji left its anchorage at 2230, and headed toward the prearranged waterway, keeping a distance of about 500 meters between its craft. ${ }^{(87,119)}$ When passing in front of the Balikpapan stronghold, they were illuminated by searchlights as bright as daylight, but they managed [to pass] without being found out after all. ${ }^{(87)}$ At 0330 on the 24th, the Raid Unit [successfully] got to the mouth of the Wain River, where the indigenous police officers were holding up signal lamp(s). One large motorized [landing] craft ran aground there, which threw the formation in disorder, and the vessels ascended the Wain River in disorderly fashion. However, at 1730 on the 24th, the main force reached the predetermined landing point under the guidance of the indigenous police officers. ${ }^{(119)}$ Early on the morning of the 25th, the Raid Unit Commander Kanauji sent one element of the force to seize 190

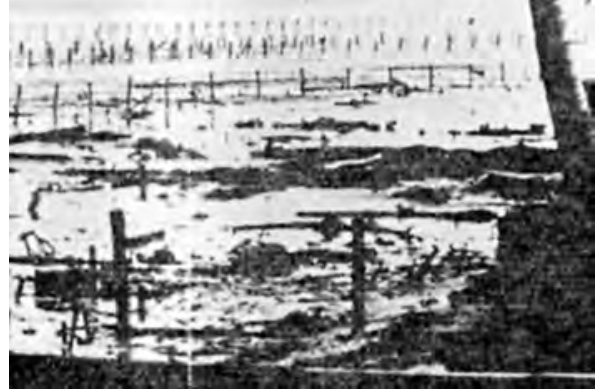
Obstacles Along the Coast in Front of Balikpapan the water-pumping station, had another powerful element advance toward Balikpapan on a path along the water pipeline, and had the rest of the main force advance on the road between Batu Ampar and Balikpapan. ${ }^{(87)}$ At 1440 when the main force of the Raid Unit advanced into Batu Ampar and was about to go on southward, it encountered the Dutch East Indies garrison commander and his men moving towards them in about one hundred vehicles with an armored car in front. ${ }^{(87)}$ The Kanauji Unit defeated them, went [on] southward, and entered the city of Balikpapan. ${ }^{(87)}$ By an investigation of the prisoners, it was learned that the Dutch East Indies garrison had had no idea at all about the detour of the Kanauji Raid Unit. ${ }^{(87)}$

The detachment headquarters had landed after the Assault Unit and advanced behind the unit to enter Balikpapan on the morning of the 25th. ${ }^{(119)}$

On the 25th, the Sakaguchi Detachment completed occupying the whole urban area of the city. On the 26th, it started mopping up [the enemy] in the whole neighborhood and established a military administration. At the same time, it cooperated with the Navy in setting up the airfield. ${ }^{(87)}$ Lt. Col. Kume Motozō became commander of the Kume Detachment, commanding the 1st Battalion and others. Having one element advance on the road between Balikpapan, Batu Ampar and Samarinda, and his main force on the road between Balikpapan, Samboja and Samarinda, he seized the oil fields in the whole area of Sanga Sanga and vicinity. ${ }^{(87)}$

The loss sustained by the Sakaguchi Detachment in the operation to capture Balikpapan was eight men killed on land and thirty-nine at sea (most of the latter were missing). ${ }^{(53)}$

After that, the Sakaguchi Detachment had its main force stationed in Balikpapan and vicinity, and the Kume Detachment in the Sanga Sanga area; while implementing the military administration, it also gathered information for the capture of Banjarmasin. ${ }^{(88)}$ 


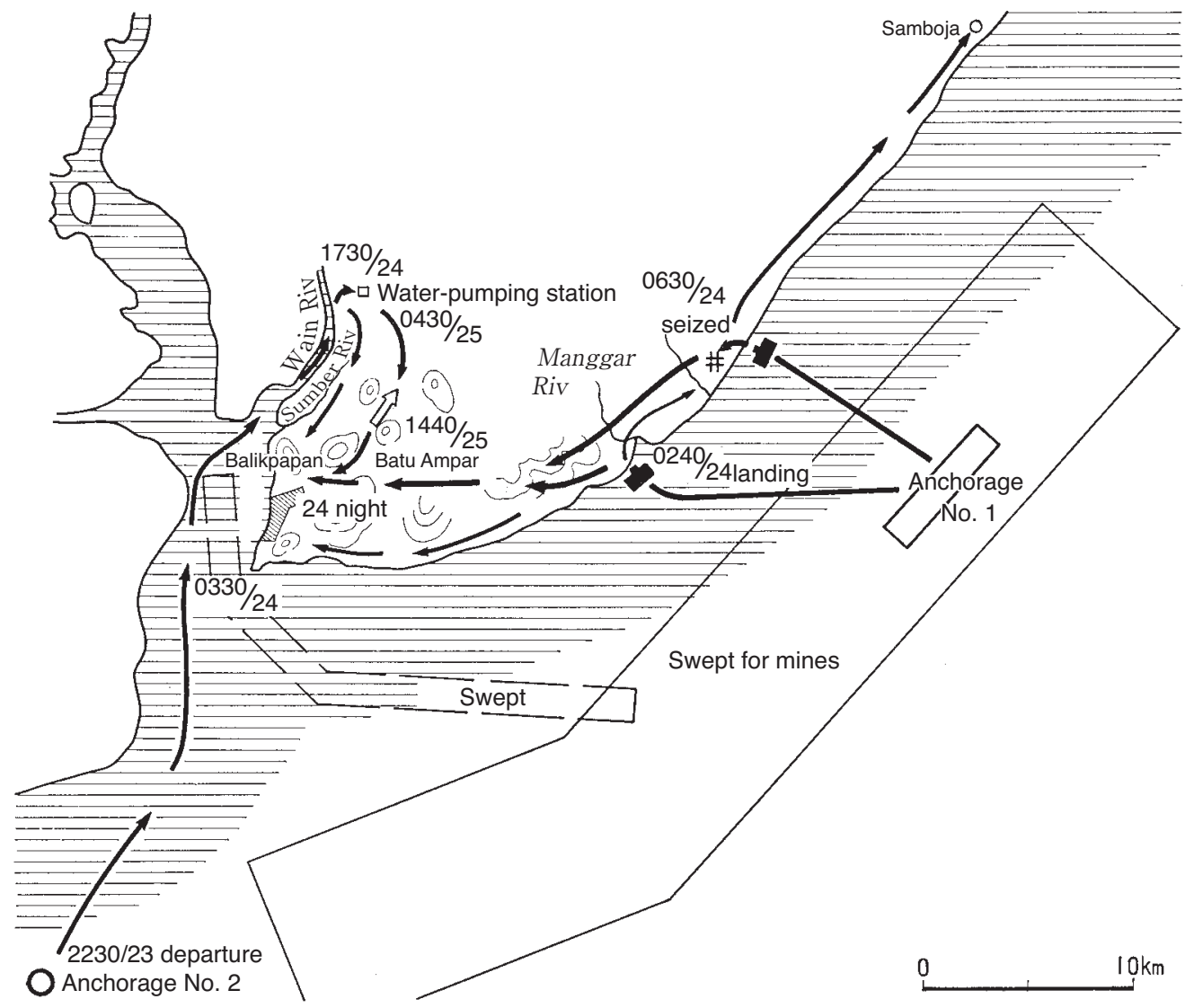

Illustration No. 34 - The Sakaguchi Detachment's Operation to Capture Balikpapan

As for the anchorage, on the 24th after the allied destroyers had gone, one [allied] heavy bomber came for an attack at 0812, which was followed by one [allied] flying boat at 0925, ten [allied] heavy bombers at 0950, seven [allied] heavy bombers at 1040, one [allied] flying boat at 1205 , and eleven [allied] heavy bombers at 1710 . On the next day, the 25th, ten [allied] heavy bombers came for an attack at 1000, which was [again] followed by seven [allied] heavy bombers at 1305 , but they caused little damage. ${ }^{(88,119)}$ The 1st Air Unit (the auxiliary seaplane tenders San'yo-maru and Sanuki-maru) arrived in Balikpapan on the 26th, and on the same day, the $2 \mathrm{~d}$ Base Force (which had left Tarakan on the 24th), arrived as well. ${ }^{(125,131,}$ 132) On the 28th, nine fighter planes of the 23d Air Flotilla advanced [to Balikpapan] and its headquarters [also] advanced there on the 30th. ${ }^{(104,143)}$ The $2 \mathrm{~d}$ Base Force removed fifty-seven mines by 5 February. ${ }^{(125)}$ The main unit of the Dutch East Indies Unit turned around on the evening of the 25th and returned to Davao on the evening of the 26th. ${ }^{(103)}$

The 44th Field Antiaircraft Artillery Battalion ([consisting of] two batteries) reported that it had fired 180 shells from its ship at fifty-two Douglas B-18A and forty-six Boeing B-17 bombers during the period from 23 January to 3 February and caused damage to three planes. ${ }^{(88)}$ 


\section{(2) The Capture of Kendari}

Simultaneously with the operation to capture Balikpapan, the operation to capture Kendari was carried out independently by the Navy. The strategic significance of Kendari and the change in the invasion schedule have previously been related.

The operation to capture Kendari was carried out by R. Adm. Takagi Takeo, commander of the Eastern Attack Unit ([and] the 5th Cruiser Division), with the following disposition of the forces: ${ }^{(114)}$

Support unit: [consisting of] the 5th Cruiser Division ([with] the heavy cruisers Haguro and Nachi) and one section of the 6th Destroyer Division; assigned for general support.

1st Base Unit: led by the 1st Base Force commander; [consisting of] the light cruiser Nagara, the 15th and the 16th Destroyer Divisions, the main force of the 1st Base Force, and the main force of the Sasebo Combined Special Landing Force as the core; assigned for the capture of Kendari.

2d Escort Unit: [consisting of] the light cruiser Jints $\bar{u}$ and the 8th Destroyer Division, led by the $2 \mathrm{~d}$ Destroyer Squadron commander, assigned to cooperate with the 1st Base Unit.

2d Air Unit: [consisting of] the 11th Seaplane Tender Division (the seaplane tenders Chitose and Mizuho), assigned to cooperate with the 1st Base Force in its antisubmarine guarding and its landing operation.

The invasion unit departed from the Bangka anchorage on 21 January, came ashore in Kendari at 0428 on the 24 th, and seized the airfield at 1700 on the same day. ${ }^{(117)}$ The support unit, which had departed from Davao on the 22d, kept guard [against enemy]. However there were no counterattacks by the allied navy, and it returned to Davao on the 26th. . $^{(14)}$

The 21st Air Flotilla (the 1st Air Raid Unit) had supported the operation from Menado, and as early as on the 25th, thirty planes advanced to the Kendari airfield. ${ }^{(143)}$

The Chitose and the Mizuho had left the Bangka anchorage on the 21st and advanced to Salabangka Channel (north of Kendari) on the 24th [for the operation], but the Chitose left there on the 26th and returned to the Bangka anchorage on the 27th. ${ }^{(117)}$

\section{The Capture of Ambon}

\section{Changes in the Plan to Capture Ambon}

The Eastern Detachment landed on Ambon Island on 31 January in conjunction with the Navy. Being a historically famous place, Ambon was of strategic importance as well. Ambon was the foremost island of the Spice Islands (the Moluccas) and had served as the center of politics, the economy, and military affairs of the northeastern waters of the East Indies ever since the Dutch built their base in Ambon in 1599. The port, being [originally] a volcanic crater, was a deep-water inlet with deeply inward curving shorelines, while the peninsulas on both sides formed a natural stronghold, which made it a natural naval port. With the port as its center, further fortifications had been built. Added to that, there was a good air base. Together with Kupang, Ambon was an outpost of the Australian forces and it was an area that could become an offensive base for the U.S. and Australian forces. 
As related previously, before the opening of hostilities, the plan to capture Ambon was very vague due to many uncertain factors. However, after the opening of hostilities, the decisive conditions [for the operation] were all of a sudden satisfied in less than a few days. The first was the success in the surprise attack on Hawaii, the second was the results in the battle off the coast of Malaya (in which two British battleships were sunk), and the third was the progress in the Hong Kong operation. The Eleventh Air Fleet, which had paid close attention to the British fleet (in the Malaya area), now could turn its attention to Ambon and so did the Combined Fleet. [The fleet] issued an order to dispatch the $2 \mathrm{~d}$ Carrier Division ([consisting of] the aircraft careers Sōry $\bar{u}$ and Hiry $\bar{u}$ ), which had returned from the air strikes on Hawaii [to the area]). In concert [with the Navy], the Southern Army, for its part, decided to employ Detachment B instead of the South Seas Detachment and also increased the strength [of the detachment] from two battalions to three. Then, in the Cam Ranh Agreement (of 1 January), it was stipulated to "capture [Ambon] on 25 January."

However, due to the delay in the [Navy's] shift from the Philippines operation to the Dutch East Indies operation, the schedule was postponed for one day on 6 January, then for another three days on 15 January due to reports on [enemy] submarines in the Molucca Sea, and [again] for another two days on 19 January. In the end, it was decided to carry out [the operation] to capture [the island] on 31 January. The reasons for the two-day postponement on 19 January were related to the redeployment of the forces assigned to the capture of Kendari, the transport of the 1st Kure Special Landing Force and the 6th [3d on p. 367] Construction Squad, which were to advance into Ambon, [the situation of] the transport ship(s) for the air base materials of the Eleventh Air Fleet, the current situation of the air raids against Ambon, and others. The change in the schedule was decided in such a way that the Sixteenth Army [simply] agreed to the proposals made by the [Navy] Dutch East Indies Unit. Having learned about the change, the Southern Army admonished the Sixteenth Army that the latter "must obtain the approval of the Southern Army before making such a significant change."(23, 24)

\section{[The Ambon Operation] in Relation to the Navy's Shift to Phase-Three Operations}

As we have seen, in the operational phases of the Navy, phase-two operations covered basically the period until the moment [the Navy] put ashore the main force of the Malaya invasion army.

The Combined Fleet had issued the order that "the shift to phase-three operations shall take effect as of 1200 on 24 January." (117) What was so significant about 24 January? It was the day when the staff officers of the Southern Army and the Southern Task Force, and the officers concerned of the Sixteenth Army and the Dutch East Indies Unit started on their way back from Manila, where the former had discussed the changes in the invasion schedule, and the latter had made arrangements for the Dutch East Indies operation. It was also the day when the landing [operations] in Balikpapan and Kendari were carried out. And, one week earlier (on 17 January), the Endau and Mersing landing operation (which was assigned to the 56th Division in the original plan, but which was later reassigned to the 18th Division instead) had been cancelled, and two days before that day (on 22 January), the 18th Division had launched its operation to land in Singora. ${ }^{(23)}$ 
Although the Combined Fleet had passed down the order to shift to phase-three operations on 24 January, the units on site were still in confusion. This was first of all because of the already described issue that the word "around" was attached to the dates in the invasion schedule; secondly because of the previously mentioned issue of the capture of Banjarmasin; and thirdly because of the fact that changes were made in the schedule of the operations currently under way. Above all, the Banjarmasin issue was the biggest issue. Whether the operation to capture the city was to be conducted [both] by the Army and the Navy in conjunction or not would affect the employment of the fleet. As we have seen, the schedule informally set at the Manila Conference was officially fixed on the day when the Banjarmasin issue was settled, which was 28 January. Consequently, the employment of the fleet was not fixed until after that date.

It was in such a period of transition [from one operational phase to the other] that the unit [assigned] to capture Ambon left Davao and carried out the landing in Ambon.

\section{Departure of the Eastern Detachment from Hong Kong and Its Arrival in Davao}

On the 30th [of December], Lt. Gen. Sano Tadayoshi, commander of the 38th Division, who had launched the attack on Hong Kong on 8 December, forced its surrender on the 25th, and had a triumphal entry on the 28th, received the order of the Twenty-third Army to organize the Eastern Detachment and prepare for its dispatch. ${ }^{(76)}$ As already described, the Cam Ranh Agreement was [informally] reached between the Southern Army and the Southern Task Force the day before (on the 29th).

As mentioned previously, on 3 January at Guangdong, Sixteenth Army Commander Imamura met the staff officers of the 38th Division which, on the next day, the 4th, was transferred to the order of battle of the Sixteenth Army. The next day, the 5th, the Southern Army ordered the Sixteenth Army to capture Bangka, Palembang, Ambon and Kupang. Sixteenth Army Commander Imamura (i.e. 38th Division Commander Sano) had organized the Eastern Detachment, which was assigned to capture Ambon and Kupang, as follows: ${ }^{(76)}$

\section{Eastern Detachment}

Commander: 38th Infantry Group Commander Maj. Gen. Itō Takeo

38th Infantry Group headquarters

228th Infantry Regiment

Light-armored Car Unit

2d Battalion of the 38th Mountain Artillery Regiment

3d Company of the 38th Engineer Regiment (minus one platoon)

One element of the 38th Divisional Signal Unit

One platoon of the 38th Transport Regiment

One element of the 38th Divisional Medical Unit

38th Divisional 1st Field Hospital (minus one half)

One element of the 38th Divisional Sick Horse Depot

3d Battery of the 23d Antiaircraft Artillery Regiment

1st Battery of the 44th Field Antiaircraft Artillery Battalion

$2 \mathrm{~d}$ Battery of the 2d Independent Antitank Gun Battalion

One independent engineer company

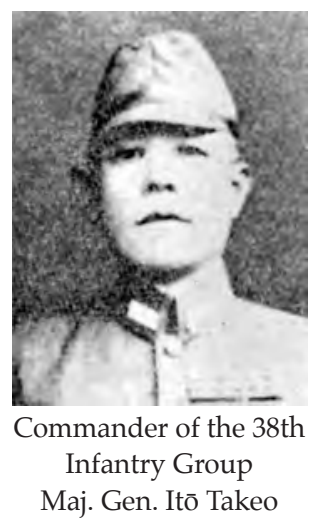


Water supply and purification department

One element of the anchorage headquarters

Maj. Tosaka Susumu, staff officer of the 38th Division, was attached to the detachment. The detachment, which was expected to depend mainly on packhorses but also to use motor vehicles, consisted of 5,300 men, 400 horses, and 110 motor vehicles, and for the operation carried ammunition for about half a campaign, and provisions and fodder, and other supplies for about half a year. ${ }^{(76)}$

On 30 December, the Southern Task Force (the Second Fleet) issued an order to escort the Eastern Detachment to Davao with one section of the 8th Destroyer Division (of the 2d Destroyer Squadron; it had originally been assigned to the main unit of the Southern Task Force and then transferred to the Malaya Unit to escort [the units of] the second landing of the Fifteenth Army in southern Thailand). ${ }^{(17)}$ The section arrived in Hong Kong on 4 January. On that day, the Southern Task Force gave an order to also commit the $2 \mathrm{~d}$ section of the destroyer division [to the task]. ${ }^{(117)}$

However, the arrival of the army radio unit and others, which were being brought together from afar to be transferred to the Eastern Detachment, had been delayed and so had the preparation of matériel, about which Sixteenth Army Staff Officers Saiki, Nishiura and others had racked their brains, as previously described. [Editor's note: Apart from the general description of the shipping problems in Chapter V, no specific description concerning the Eastern Detachment was found.] [Eventually,] the [scheduled] departure date (of 9 January) was inevitably postponed until the 12th. On 6 January, in conformity to the arrangements between the Dutch East Indies Unit and the Sixteenth Army of that day (which was mentioned earlier), Dutch East Indies Unit Commander Vice Admiral Takahashi transmitted an order that "the 8th Destroyer Division commander shall escort the Itō Detachment to Davao by 18 January, leaving Hong Kong on 12 January; arrangements shall be made with Detachment Commander Itō at Hong Kong on the 11th."(117)

The situation at the time of the arrangements was as described previously. Being sent off by Colonels Takashima Tatsuhiko and Kitamura Yoshifuto, who were specially dispatched [there] by [Sixteenth] Army Commander Imamura, the Eastern Detachment departed from Hong Kong on the 12th and first headed for Davao under escort of the 1st Section of the 8th Destroyer Division (the Öshio and the Asashio). ${ }^{(34,117)}$ The $2 \mathrm{~d}$ Section (the Michishio and the Arashio) left Magong on the 13th and joined the convoy [at a point] south of Taiwan on the same day. ${ }^{(117)}$ The Eastern Detachment had embarked on the following ships: ${ }^{(76)}$

Miike-maru (12,000 tons): headquarters, and the units under direct control.

Africa-maru (9,000 tons): regimental headquarters, and the 3d Battalion.

Ryōyō-maru (6,000 tons): main force of the Artillery Battalion and one element of infantry. Zen'yo-maru (6,000 tons): 1st Battalion as the core.

Yamaura-maru (6,000 tons): $2 \mathrm{~d}$ Battalion as the core.

Apart from the Ryōyo-maru, the other four ships arrived in Davao at 1115 on 18 January under the escort of the Öshio and the Michishio, as they were fast ships and could sail at a speed of twelve knots or over. The Ryōyo-maru arrived in Davao at 1930 on the next day, the 19th, under the escort of the Asashio and the Arashio. ${ }^{(117)}$ 


\section{Operation Plan (See Illustrations No. 35 and No. 36)}

Detachment Commander Itō, who arrived in Davao on 18 January, put under his command the antiaircraft artillery battery which had been left there by Detachment Commander Sakaguchi, ${ }^{(88)}$ and immediately set about making arrangements with the Navy side.

At that time, the situation in the eastern area of the Dutch East Indies was roughly as follows: On the 11th, the Sakaguchi Detachment and the Western Attack Unit had conducted the landing operation in Tarakan, and the Eastern Attack Unit in Menado, while the commander of the $2 \mathrm{~d}$ Destroyer Squadron had returned to Davao the day before (on the 17th), after having completed its support of the Menado landing operation. While the Western Attack Unit was making preparations to carry out the coming Balikpapan landing operation (on the 24th) in conjunction with the Sakaguchi Detachment, the Eastern Attack Unit was preparing for the coming operation to capture Kendari (on the 24th), which would mainly be conducted by the 1st Base Unit. [The Eastern Attack Unit] was also about to start preparations for the subsequent operation to capture Ambon, which would mainly be carried out by the $2 \mathrm{~d}$ Destroyer Squadron ([though the operation] which had been scheduled for the 29th, was on the 19th postponed until the 31st). ${ }^{(102)}$ The headquarters of the 21st Air Flotilla (the 1st Air Raid Unit) had advanced from Davao to Menado on the 16th. ${ }^{(104)}$ The main unit of the Dutch East Indies Unit was positioned in Davao to support the operation to capture Balikpapan. ${ }^{(103)}$ The main unit of the Southern Task Force, which had shifted its position from Cam Ranh Bay via Magong to support the operations in the eastern area of the Dutch East Indies, arrived in Palau that day (the 18th). ${ }^{(103)}$ The $2 \mathrm{~d}$ Carrier Division (the aircraft carriers Sōry $\bar{u}$ and Hiry $\bar{u}$ ) assigned to support the Ambon invasion operation had left the Bungo Channel on the 13th and were heading southward. ${ }^{(103)}$

Considerable difficulties were expected in the operations to capture Kendari (landing to be executed on 24 January) and Ambon (on 31 January), in view both of their location and the situation of the allied forces. Eventually, it was decided that those operations should be conducted in the following way: ${ }^{(114)}$

Eastern Attack Unit (led by the 5th Cruiser Division commander)

Support Unit: 5th Cruiser Division (the heavy cruisers Haguro and Nachi), and the $2 \mathrm{~d}$ Section of the 6th Destroyer Division, assigned to support [the operations to] capture Kendari and then Ambon.

1st Base Unit: the light cruiser Nagara, the 15th and the 16th Destroyer Divisions, and the 1st Base Force shall capture Kendari from Bangka. After the capture, the 16th and the 15th Destroyer Divisions shall head for Ambon, the 16th Destroyer Division from the Bangka anchorage after [once] returning there, and the 15th [directly] from Kendari.

2d Escort Unit: The commander, [i.e.] the 2d Destroyer Squadron commander, shall support the 1st Base Unit in [the operation to] capture Kendari with the light cruiser Jintsu and the 8th Destroyer Division (which had returned to his command after escorting the Eastern Detachment from Hong Kong to Davao) while preparing for the capture of Ambon. After completing the operation to capture Kendari, he shall execute [the operation to] capture Ambon also employing the 16th Destroyer Division ([which will join from] the Bangka anchorage) and the 15th Destroyer Division ([from] Kendari), both of which will have returned to his command as mentioned above.

2d Air Unit (the 11th Seaplane Tender Division): After supporting the operation to capture Kendari, the seaplane carrier Chitose shall return to the Bangka anchorage, and the Mizuho 
to the Salabangka Channel (north of Kendari), and both shall take part in the operation to capture Ambon from these anchorages.

On the 18th, when Detachment Commander Itō arrived in Davao, and on the next day, the 19th, the staff officers of the Southern Task Force and the Dutch East Indies Unit held meetings with the commanders and staff officers of the 5 th Cruiser Division and the $2 \mathrm{~d}$ Destroyer Squadron to discuss the plans. ${ }^{(114,117)}$ On that day, the 19th, the operation to capture Ambon scheduled for the 29th was postponed until the 31st for the reasons previously described. On the next day, the 20th, Detachment Commander Itō and R. Adm. Tanaka Raizō, commander of the $2 \mathrm{~d}$ Destroyer Squadron, made a [draft] arrangement, which was signed on the next day, the 21st. ${ }^{(117)}$ On that day (the 21st), Rear Admiral Tanaka [also] made arrangements with the 21st Air Flotilla, and on the following day, the 22d, he gathered his commanding officers in Davao and passed down the $2 \mathrm{~d}$ Escort Unit order. ${ }^{(117)}$ Around the same time, Detachment Commander Itō also issued his detachment order.

At that time, the situation known about Ambon Island was roughly as follows:(128)

1. The strength of the Dutch East Indies garrison guarding Ambon Island was estimated at about one thousand troops, but it seems that it has recently been reinforced by about two thousand Australian troops.

2. Mines are laid at the entrance of Ambon Bay and at Baguala Bay.

3. There seem to be coastal batteries on the shores both north and south of the entrance to Ambon Bay. It is certain that there are antiaircraft battery positions [around] the sea[plane] base in Halong as well as at the Laha airfield.

4. Taking all information into account, it seems that the whole of Ambon Island has been turned into a stronghold, and that particularly strong defense facilities have been built in the neighborhood of the city of Ambon and to the west of the Laha airfield with the area of Ambon Bay serving as the front gate defense and the Baguala Bay area as the back gate defense.

The Eastern Detachment was merely provided with several maps that were no better than rough sketches apparently taken from intelligence survey maps. ${ }^{(78)}$ Although it was [also] provided with some aerial photographs taken by navy aircraft, needless to say, these could never clearly show the terrain and the disposition of the [enemy] garrison in detail. ${ }^{(78)}$ Judging that the allied forces on the island would defensively try to secure strategic points near the city of Ambon, the Eastern Detachment decided to land on the east coast of the southeastern peninsula, where the defense was considered weak, so that it could catch and destroy the main force [of the enemy] on the southeastern peninsula and promptly seize the strategic points on Ambon. ${ }^{(78)}$ It was decided that ammunition, provisions and fodder required in the early operations after the landing should be carried along, and that the rest should be unloaded and supplied by the transport ships which would be brought around to Ambon Bay after the capture of Ambon. And it was [also] decided that the landing should be carried out before daybreak on 31 January from the drifting transport ships. ${ }^{(78)}$ [Editor's note: The sea was apparently too deep to anchor.] [Further] it was decided that the Navy should have the 1st Kure Special Landing Force go ashore from the Hitu-lama anchorage and head for the Laha airfield. ${ }^{(128)}$ From the Army, 1st Lt. Wakabayashi Tōichi's company was attached to the [naval] landing force, ${ }^{(78)}$ making the force a total of 745 men. ${ }^{(128)}$ 


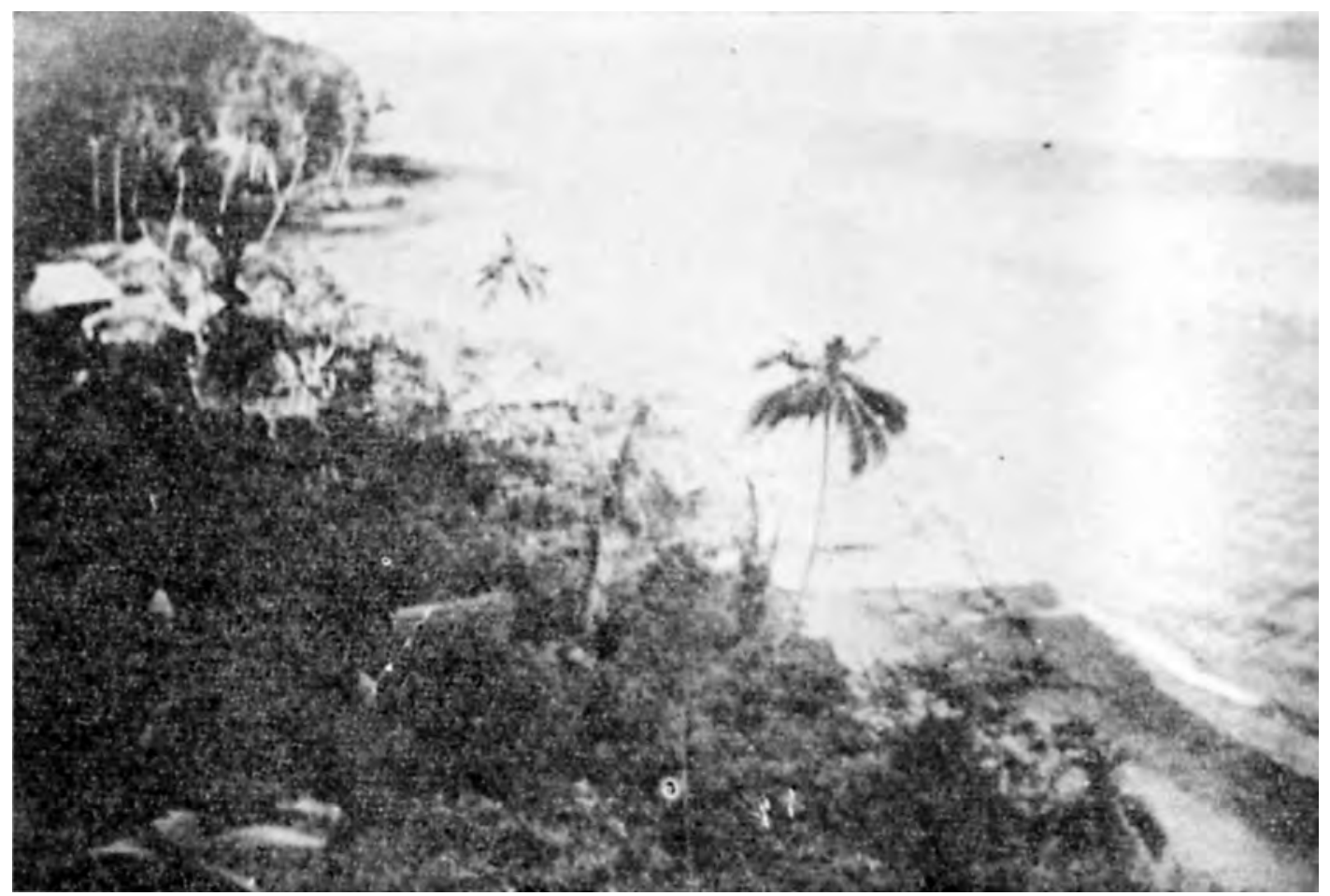

A View of the Landing Beach on Ambon

R. Adm. Takagi Takeo, commander of the Eastern Attack Unit ([and] 5th Cruiser Division commander), deployed his force in the following way: ${ }^{(114)}$ The $2 \mathrm{~d}$ Destroyer Squadron properly consisted of the Jintsu (a light cruiser), and the 8th, the 15th, the 16th and the 18th Destroyer Divisions (four destroyers each), but the 18th Destroyer Division had been assigned to the Carrier Task Force. ${ }^{(117)}$

Support Unit: [consisting of] the 5th Cruiser Division (the heavy cruisers Haguro and Nachi) and the Ikazuchi of the 6th Destroyer Division; [assigned to] support all the operations.

2d Escort Unit: [consisting of] the light cruiser Jintsū, the 8th, the 15th, and the 16th Destroyer Division, the main force of the 1st Kure Special Landing Force, and the 3d [6th on p. 362] Construction Squad as the core, led by the $2 \mathrm{~d}$ Destroyer Squadron commander; [assigned to] (1) escort the units to capture Ambon, (2) capture Ambon in conjunction with the Army, and (3) seize the Ambon air base and make [the airfield] ready for use.

1st Base Unit: [consisting of] the main force of the 1st Base Force, the Nagara (a light cruiser of the 16th Cruiser Division), the 21st Destroyer Division (minus the Hatsuharu), and the Sasebo Combined Special Landing Force as the core; [assigned to] prepare for the capture of Makassar, and other tasks.

The 2d Air Unit: [consisting of] the 11th Seaplane Tender Division (with the seaplane tenders Chitose and Mizuho) as the core; [assigned to] (1) support the 2d Escort Unit, (2) guard against [enemy] submarines and aircraft, while supporting the ground combat.

It was decided that the $2 \mathrm{~d}$ Escort Unit commander should escort the 1st echelon ([consisting of] the Itō Detachment) from Davao to Ambon with the [Navy] 1st detachment ([consisting of] the 8th Destroyer Division as the core), and the 2d echelon ([consisting of] the landing 
force, construction squad and other units) from the Bangka anchorage to Ambon with the [Navy] 2d detachment (i.e. the 2d Section of the 16th Destroyer Division); that he should have the cover unit ([consisting of] the 15th Destroyer Division) advance eastward from Kendari for the cover [operation], and that he himself would form the main unit, directly leading the light cruiser Jints $\bar{u}$ and the 1st Section of the 16th Destroyer Division and depart from the Bangka anchorage. ${ }^{(117)}$

\section{Sailing, Landing and Capture (See Illustration No. 36)}

As already described, on 21 January, the units to capture Balikpapan and Kendari departed from Tarakan and Menado respectively and started landing on the 24th. On that day (the 24th), the 2d Carrier Division (the Sōry $\bar{u}$ and the Hiry $\bar{u}$, which had departed from the Bungo Channel on the 13th and been brought under the command of the commander in chief of the Eleventh Air Fleet) conducted an [air] strike on Ambon Island with their carrier aircraft, but having found no allied naval vessels or aircraft they mainly made the batteries and [military] facilities their target. ${ }^{(103)}$ On the next day, the 25th, the 1st Air Raid Unit (the 21st Air Flotilla) had already advanced thirty aircraft to Kendari. The 21st Air Flotilla headquarters also advanced there from Menado on the $27 \mathrm{th},{ }^{(143)}$ which completed [Japanese] preparations. Although the allied naval surface forces seemed to have escaped to the south of Timor Island and to the west of Makassar, [enemy] submarines were judged to be in the Molucca Sea. ${ }^{(117)}$

At 1530 on the 27th, the Eastern Detachment (the 1st echelon, [consisting of] the previously-mentioned five ships) departed from Davao under the escort of the [Navy] 1st detachment ([consisting of] the 8th Destroyer Division and minesweepers). ${ }^{(117)}$

On the 28th, the 1st Section of the 15th Destroyer Division departed from Kendari and headed for the east, while the Jints $\bar{u}$ and the $2 \mathrm{~d}$ Section of the 15th Destroyer Division left the Bangka anchorage. ${ }^{(117)}$

On the 29th, the $2 \mathrm{~d}$ echelon ([consisting of] six navy transport ships) left the Bangka anchorage under escort of the 16th Destroyer Division. ${ }^{(117)}$ On that day, the seaplane tender Chitose left the Bangka anchorage, while the Mizuho left the Salabangka Channel. ${ }^{(103)}$ On the same day, the 1st echelon detected allied submarine(s) for the first time, but they were not attacked. ${ }^{(117)}$

On the 30th, the Support Unit (which had departed from Davao on the 29th) advanced to the Bangka anchorage. ${ }^{(14)}$ One [enemy] bomber approached the convoy at 0745 and [another] at 1320 , but they conducted no air attacks. ${ }^{(117)}$ The $2 \mathrm{~d}$ echelon came under a torpedo attack of [enemy] submarine(s) at 2216, but sustained no damage. It entered the Hitu-lama anchorage at 2300. ${ }^{(117)}$ The 1st echelon entered the Rutung anchorage in the middle of the night (at 0020 on the 31st) without being attacked by [enemy] submarine(s) at all. ${ }^{(117)}$ Command of the air and the sea was in [Japanese] hands.

At 0030 on the 31st, the Eastern Detachment completed its entrance into the anchorage, and at 0215 completed its shift to the [landing] craft. Without encountering major resistance, the detachment successfully came ashore in the area east of Rutung in front of the enemy. The right attack unit ([consisting of] the $2 \mathrm{~d}$ Battalion (minus the 7th Company) of the 228th Infantry Regiment as the core) landed at 0240, and the left attack unit ([consisting of] the 228th Infantry Regiment (minus the $2 \mathrm{~d}$ Battalion and the 10th Company), an antitank gun unit, and a light-armored car unit) landed at 0250. ${ }^{(76)}$ Major General Itō sent a telegram [to 
the Navy] to express his gratitude, saying, "Thanks to your support, we have succeeded in landing. We sincerely appreciate the escort which you so devotedly provided."(117)

Following the landing, both attack units of the Eastern Detachment single-mindedly pushed ahead and advanced toward the city of Ambon braving the heavy rains and steep mountains. ${ }^{(76)}$ The right attack unit ([with] 2d Battalion Commander Maj. Kimura Eijirō as its commander) seized the strong position near Paso, which was fortified with several lines of obstacles and pillboxes, after which it charged into the city with one element at 2030, and into Halong with its main force at 0500 on 1 February. ${ }^{(76)}$ The main force of the left attack unit ([with] Regimental Commander Col. Doi Sadashichi as its commander) defeated some scattered allied units and charged into the city of Ambon at 1700 on the 31st. ${ }^{(76)}$ The allied units positioned in the Paso and the Halong area got hemmed in between the [Japanese] right attack unit, which had been ad-

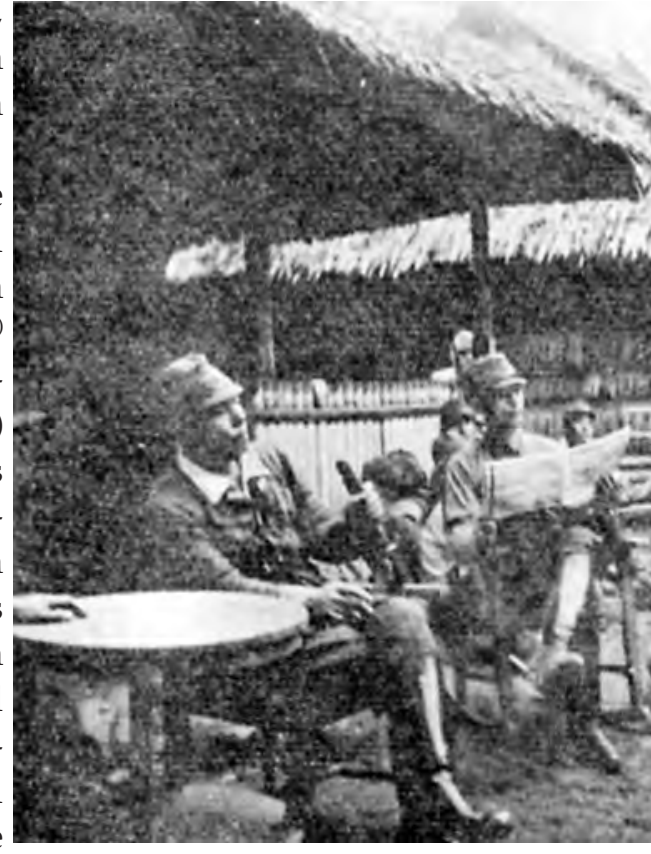

Detachment Commander Itō and Staff Officer Tosaka [at] the Eastern Detachment Headquarters Right After the Landing on Ambon vancing [into Paso and Halong], and the left attack unit, which had captured the city of Ambon. First of all, Lieutenant Colonel Kapitz, the Dutch East Indies garrison commander and his men, about 800 in total (including indigenous troops), laid down their arms at 0230 on 1 February. ${ }^{(76)}$

In the Hitu-lama area, the 1st Kure Special Naval Landing Force had departed in its [landing] craft at 0120 and tried to go ashore around 0200, but it encountered fierce resistance from allied units and did not succeed in landing until 0320. Following the seizure of Hitu-lama, it rushed toward the Laha airfield, advanced to the front of the airfield at 1530, and launched an attack at 1600 . However, it could not move at all due to concentrated mortar fire. At nightfall, the commander of the landing force requested bombardments on the next day, the 1st. ${ }^{(128)}$ [Then,] 1st Lt. Wakabayashi Tōichi, commander of the 10th Company of the 228th Infantry Regiment, which was attached to the [naval] landing force (he had graduated from the Imperial Japanese Military Academy with distinction and received citations of merit for [his contribution in] the previous Hong Kong operation and the subsequent Guadalcanal operation; Detachment Commander Itō and Regimental Commander Doi had expressly selected his company to be attached to the Navy) proposed [to outflank the enemy]. He went into the jungle with his company in the dark night (at 2100 on the 31st) in order to seize the highlands north of the Laha airfield in a surprise attack by making a detour through the jungle. ${ }^{(76,128)}$

On 1 February, the naval landing forces in front of the Laha airfield repeatedly wired requests for air strikes at around 0600, around 0900 and around 1200.(117) The telegrams said: “There are four rows of barbed wire entanglements, and twenty or more pillboxes at the front; besides the mortar fire from the front, [we are] exposed to lateral shelling, fired from the battery in front of the Doi Regiment; [what is more] the Wakabayashi Company's move- 
ments are unknown; we request air strikes."(117) [Editor's note: the socalled Nona battery, a coastal battery to the southeast of Ambon city, could not be turned to the direction of Ambon but was employed to fire by the map across the bay at the Laha airfield and the road leading to it.]

Because he had split the allied forces in a northern and southern group through his seizure of [the city] of Ambon on the previous evening (the 31st), and moreover had forced the surrender of the commander of the Dutch East Indies garrison at Halong at daybreak the following morning, Detachment Commander Ito expected that he could seize the stronghold in the southern part of the peninsula by the end of the day. So, from early morning, he sent the left attack unit southward and had

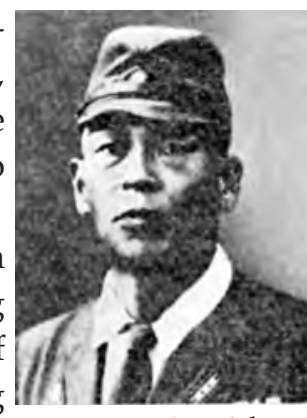

Commander of the 228th Regiment, Col. Doi Sadashichi the right attack unit mop up [the enemy] in Halong and Paso. ${ }^{(76)}$ On seizing the highlands east of Ambon at 0800 that day (the 1st), the left attack unit commander, Col. Doi Sadashichi, immediately headed southward and launched an attack at 1100, positioning the $3 \mathrm{~d}$ Battalion (commander: Maj. Nishiyama Haruka) and the 1st Battalion (commander: Maj. Hayakawa Kikuo) at the right and the left front lines respectively. ${ }^{(76)}$ However, the [enemy] unit they were facing was a strong Australian force, and [what is more,] apart from several lines of barbed wire entanglements and many pillboxes, there was a gun battery and the terrain was steep. The [Japanese] attack had made little progress by the time night fell. Detachment Commander Itō wired the Navy: "The enemy is putting up stubborn resistance with [only] one small caliber gun. [As] we intend to seize Highland [of] 514 [meters high] tonight, we request air strikes and shelling of the southern side of Highland 514 (exclusive of the highland itself) tomorrow, the $2 \mathrm{~d} . .^{\prime(117)}$

On the next day, the $2 \mathrm{~d}$, at the Laha airfield, the naval landing force charged into a corner of the airfield at dawn. However, the attack made little progress after that, and it seemed that the commander of the force, Cdr. Ieki Kōnosuke, had been killed as well. ${ }^{(117)}$ Requests for air strikes were repeated by the landing force. ${ }^{(117)}$ At 1030, 2d Destroyer Squadron Commander Rear Admiral Tanaka requested Major General Itō to send Army reinforcements. ${ }^{(117)}$ They tried to bring [landing] craft [into Halong] and take [the reinforcements] across Ambon Bay from Halong to the Laha airfield and put them ashore, but it was impossible to bring the [landing] craft into Halong. ${ }^{(117)}$ At 0800 on that day, Rear Admiral Tanaka ordered to sweep mines in the bay for the first time, and under cover of the 15th Destroyer Division, which, at 1045, had begun firing (eighty shells) at the [enemy] battery and the airfield, the 21st Minesweeper Division ([consisting of] five minesweepers) started minesweeping. However, between 1330 and 1400, one of them was sunk and two of them were heavily damaged, which led to the order to suspend the minesweeping at 1445. ${ }^{(117)}$ Major Kimura, commander of the right attack unit, who had been mopping up [the enemy] in the Halong and the Paso areas, had assembled the $2 \mathrm{~d}$ Battalion (minus two companies) and waited for the [landing] craft to arrive. However, having learned that the craft would not come, he left Halong at 1600, and headed for Laha on the road along the inner edge of the bay. ${ }^{(76)}$ [In the meantime,] at 1230 on that day, the Wakabayashi Company was heading southward after repelling some twenty enemy troops carrying machine guns in the highlands north of Laha, and was preparing to make a surprise attack on the airfield in the early morning of the next day, the $3 \mathrm{~d} .{ }^{(76)}$ On that day, the 11th Seaplane Tender Division ([with] the seaplane tenders Chitose and Mizuho) sup- 
ported the ground combat with their full force. ${ }^{(117)}$

On the next day, the $3 d$, at 0600 , the Wakabayashi Company charged into the airfield from the rear. ${ }^{(76)}$ At 0630, the garrison unit in Laha raised the white flag. The 1st Kure Special Landing Force reported to Rear Admiral Tanaka: "At 0630 on the 3d, we charged into the airfield again and completely seized it. The Laha airfield [has a runway of] 1,300 meters long and 60 meters wide, and ... will be completely ready for Type-0 fighter planes and land-based medium-sized attack planes to land this morning." ${ }^{(117)}$ At the time of charging into the airfield, Company Commander Wakabayashi had sent one element of his force to the river in the west in order to cut off the [enemy's] escape route. ${ }^{(76)}$ In the afternoon, the naval landing force reported: "The

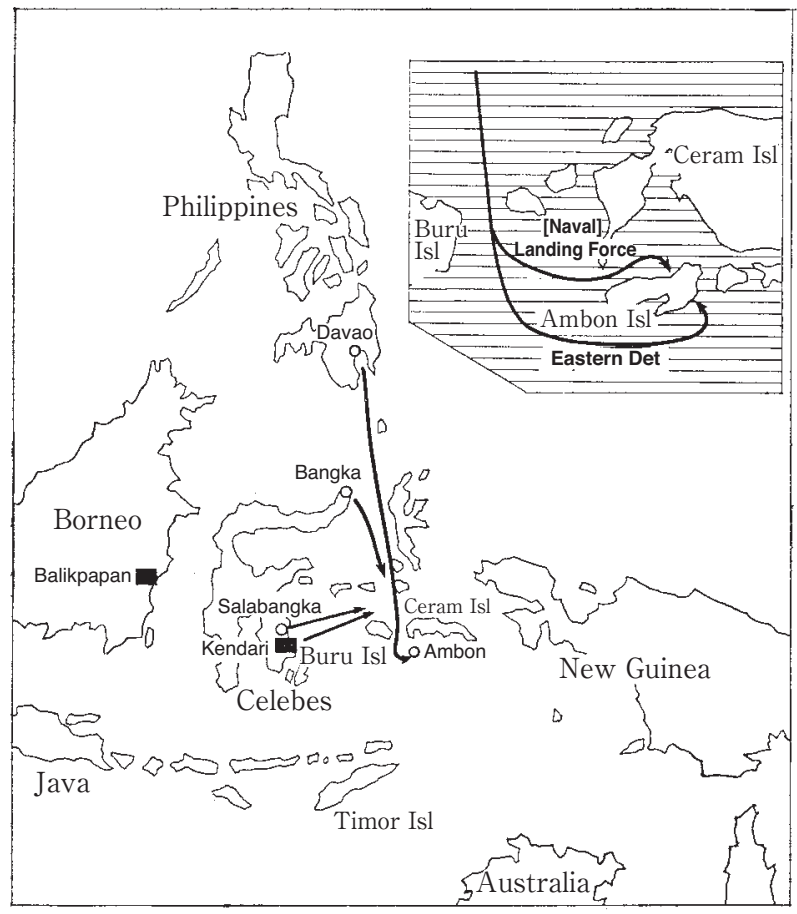

Illustration No. 35 - The Invasion of Ambon Wakabayashi Unit experienced considerable difficulties due to the fact that the jungle was denser than expected, but all reached the airfield in safety at noon today." (117) The fact was that the [enemy] garrison in Laha had raised the white flag because the main force of the Wakabayashi Company had charged into the airfield from the rear, but the ranking commanders of the Army did not talk much about it [in order to avoid disputes with the Navy].

The right attack unit had moved from Halong [to the airfield] in rapid night marches, but it was 0800 when it [finally] reached Suakodo east of Laha. By then the [enemy] garrison at the Laha airfield had already surrendered. ${ }^{(76)}$ The garrison at the Laha airfield was made up of some four hundred Australian and Dutch troops. ${ }^{(76)}$ Major Kimura reincorporated the Wakabayashi Company and in conjunction with the [naval] landing force mopped up [the enemy] in the vicinity, after which he returned to Halong at 0045 on 6 February. ${ }^{(76)}$

After continuously attacking, the left attack unit ([consisting of] the main force of the 228th Infantry Regiment) seized Highland 514, the peninsula's strategic point, and got close to the southern tip of the peninsula on the 3d. At 1530 [on the 3d], the Australian main force (including indigenous troops), consisting of Lieutenant Colonel Scott and his men, some 1,500 troops in total, surrendered at last. ${ }^{(76)}$

After the surrender of the main force of the Dutch and Australian forces near the Laha airfield and on the southeastern peninsula, the Eastern Detachment assumed the task of mopping up [the enemy] on the whole island and of implementing a military administration. However, as the [Navy] 24th Special Base Force ([with] R. Adm. Hatakeyama Kōichirō as commander) was organized on 5 February, ${ }^{(127)}$ [the Eastern Detachment] transferred this task to the latter as of that day and started preparing for the next operation to capture Timor. ${ }^{(76,}$ 127) Due to the delay in the minesweeping of Ambon Bay, it was not until 8 February that the 


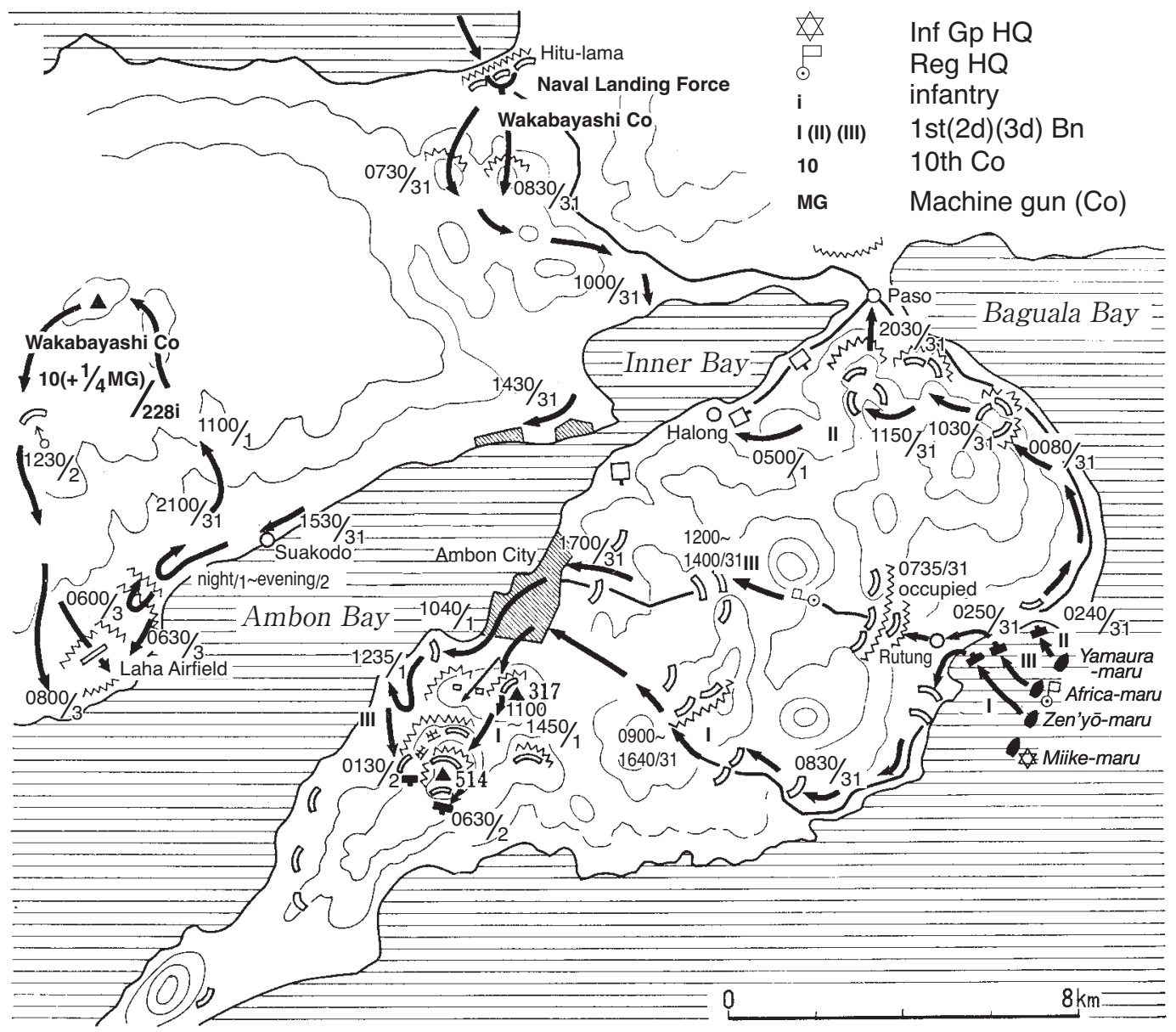

Illustration No. 36 - The Operation to Capture Ambon

five transport ships of the Eastern Detachment, which had been drifting off the coast of Rutung, were able to enter the port of Ambon. ${ }^{(117)}$

The number of allied troops the Eastern Detachment had engaged was about 3,000 ([consisting of] some 1,200 Australian troops, some 400 Dutch troops, and some 1,400 indigenous troops). The loss the detachment had sustained was fifty-five killed in action (including five officers), 135 wounded in action (including five officers), one horse killed, and four wounded. The military gains were as follows: ${ }^{(76)}$

Abandoned dead bodies (confirmed): 340

Prisoners of war: 2,182 (782 Australian troops, 334 Dutch troops, and 1,066 indigenous troops) Seized [weaponry, vehicles and aircraft]: two bombers, three flying boats, one 24-cm. howitzer, four 15-cm. guns, eight field guns ([with] 1,520 shells), two mountain guns ([with] 1,240 shells), six armored cars, two antitank rifles ([with] 235 bullets), four antiaircraft guns ([with] 168 shells), two tank guns ([with] 108 shells), five mortars ([with] 4,904 shells), six antiaircraft machine guns ([with] 13,990 shells), thirty-one machine guns ([with] 1,085,844 bullets), 261 light machine guns ([with] 31,900 bullets), 2,365 rifles ([with] $3,662,000$ bullets), 128 motor vehicles, and others. 


\section{The Capture of Banjarmasin, Makassar, Bali and Timor}

\section{(1) Politico-Strategic Issues and Phase-Three Operations of the Navy}

On 31 January, the Twenty-fifth Army advanced to the Johor Strait, landed on Singapore [Island] on the night of 8 February, and forced its surrender on the 15th. The day before (the 14th), the 1st [Paratroop] Raiding Group had conducted its drop on Palembang, while the 38th Division launched its landing operation on Sumatra on the 15th and seized Tanjungkarang on the 20th. Meanwhile, in the east the Eastern Detachment landed on Ambon on 31 January, the Yamamoto Unit (a powerful element of the Sakaguchi Detachment), which had left Balikpapan on 30 January, seized Banjarmasin on 10 February, and the Naval unit, which left Kendari on 6 February, seized Makassar on the 9th. Then, on 17 and 18 February the Eastern Detachment left Ambon and landed in Kupang and Dili on Timor Island on the 20th, while the Kanemura Detachment ([consisting of] one battalion of the 48th Division as the core) left Makassar on 18 February and landed on Bali on the 19th. [In the meantime] on the 19th, the Carrier Task Force (i.e. the First Air Fleet) conducted an air strike on Port Darwin in northwestern Australia. After that, on the 25th the main force of the Southern Task Force (directly led by the commander in chief of the Second Fleet) and the Carrier Task Force left Staring Bay and advanced into the sea south of Java. The Sixteenth Army carried out the Java landing operation on 1 March with the support of the Dutch East Indies Unit (i.e. the Third Fleet) and the air unit (i.e. the Eleventh Air Fleet), and the cooperation of the Malaya Unit (i.e. the First Southern Expeditionary Fleet). The capture of these key locations in the east took place against the following political and strategic background.

\section{The Strategic Background and the Major Strategic and Tactical Issues}

The major strategic and tactical changes in the plans to capture key areas east of Borneo and their implementation were in [chronological] outline as follows:

1. On 6 January, IGHQ replied to a question [by the Emperor] about the conduct of the phase-two operations by stating: "The matter of isolating Australia from the United States and the operations in the Indian Ocean are still being studied." (10) On 10 January, concerning the immediate measures against Australia and New Zealand, the Liaison Conference between IGHQ and the Government decided: "To strive to cut Australia loose from its ties with the United States and Britain, while intensifying the pressure on Australia through the progress of the southern operation and the cutting-off of its communications with the United States and Britain." (3)

On 8 January, the main force of the Carrier Task Force (which had returned on 24 December to the Inland Sea after the air strikes on Hawaii) left the Inland Sea in order to support the Rabaul and the Kavieng landing operations, which were to be conducted both by the South Seas Detachment and the South Seas [Pacific Islands] Unit (i.e. the Fourth Fleet) in conjunction. Only the $2 \mathrm{~d}$ Carrier Division (with the aircraft carriers Sōryū and Hiry $\bar{u})$ headed for Ambon. ${ }^{(53,103)}$

2. At the Manila [conference] from 21 to 23 January, the Southern Task Force requested a ten to fourteen day postponement of the operation to capture the Dutch East Indies, but the Southern Army only approved a five day postponement for the western Java 
[operation] and a seven day postponement for the eastern Java [operation]. ${ }^{(23)}$ At that time, the 21st and the 23d Air Flotillas were heading southward along Celebes and the east coast of Borneo respectively, and the $2 \mathrm{~d}$ Carrier Division, which was additionally deployed above and beyond the [original] plan, was sailing southward towards Ambon. At that time, as the Southern Task Force (the Dutch East Indies Unit in particular) was painfully aware of the shortage of escort ships due to the shortened invasion schedule, it was informally agreed that the capture of Banjarmasin by both the Army and the Navy in conjunction should be cancelled, and that the Bali airfield should be seized right before the Java landing operation [instead]. ${ }^{(23)}$

3. On receiving a report of the above-mentioned draft agreement, the Army Department of IGHQ, which considered the plan of the Southern Army and the Southern Task Force to be risky, repeatedly wired the Southern Army from the 24th onwards to request the capture of Banjarmasin prior [to the Java operation] and [also] asked the Navy Department to let the Carrier Task Force cooperate in [the operation to] capture Java. ${ }^{(23)}$

4. However, the Combined Fleet had already turned its interest to the northeastern part of Australia. On the 25th, on learning the views on subsequent operations from the Fourth Fleet, which had conducted the operations to land in Rabaul and Kavieng on 23 January, and the Carrier Task Force, which had supported these operations, the Combined Fleet approved of their views. On the 26th, [the Fleet] presented the plan "to have the Fourth Fleet capture Lae, Salamaua and Port Moresby in conjunction with the South Seas Detachment and have the Carrier Task Force carry out operations on the eastern part of Australia while cooperating in the [above operations]." (100, etc.)

After completing the support for the landing operations in Rabaul and Kavieng, the Carrier Task Force returned to Truk on the 27th and set about preparing for the subsequent operation, expecting that "the next operation [would be] the implementation of the operation against the eastern part of Australia in mid-February." (123) On the 29th, the Shōkaku, an aircraft carrier of the 5th Carrier Division, left Truk for the mainland to replenish its aircraft. ${ }^{(116)}$

5. On the 29th, having approved the plan of the Combined Fleet regarding the capture of key locations in the southeastern area, the Navy Department of IGHQ issued IGHQ Navy Department Instruction No. 47, in which it gave directions "to capture Lae and Salamaua in eastern New Guinea, and Tulagi in the Solomon Archipelago, with a force [consisting of] the Fourth Fleet as the core, in conjunction with the South Seas Detachment and, if possible, [also] capture Port Moresby in southeastern New Guinea."(1)

6. Although the Navy Department of IGHQ had given clear directions as to the employment of the Fourth Fleet, as in the above-mentioned IGHQ Navy Department Instruction of the 29th, at that time another employment plan for the Carrier Task Force emerged at the Navy Department of IGHQ, which was different from the Combined Fleet's view of the 26th. This plan was partly the result of the previously described [IGHQ] Army Department's request for the [Navy's] cooperation in the Java operation and partly the result of the $2 \mathrm{~d}$ Carrier Division's proposal that the Carrier Task Force should conduct an operation against Port Darwin. Other considerations were that the landing operation on Bali, which was within a stone's throw from Surabaya, was risky [if only] under the cover of the Eleventh Air Fleet, whose losses would not have been 
sufficiently replenished; that the military gains for the Carrier Task Force might be bigger if it participated in the operation to capture Java; and that on 24 January a detailed report had been received on the sinking of the U.S. aircraft carrier Lexington, [which was regarded as certain, and which diminished the need for the Task Force's presence in the southeastern area]. ${ }^{(100,108)}$

7. On 28 January, the Army Department of IGHQ wired the Southern Army, saying: "Although there were various arguments about the seizure of Banjarmasin, we learned from OsAmu [Sixteenth Army] Operation Order A, No. 119 that the army planned to seize the airfield on its own and make it ready for use by early February. Since it became clear to us that you also intended to attach great importance to the place for the Java operation, we approved everything."(23) [Editor's note: The quotations on p. 226 and p. 389 in the Japanese text have slightly different redactions.] It was at this juncture that the policy inside the Navy Department of IGHQ as to the employment of the Carrier Task Force came to a turning point. ${ }^{(147)}$

On the next day, the 29th, the Carrier Task Force, with the operations against the eastern part of Australia in mid-February in mind, sent the aircraft carrier Shōkaku from Truk to the mainland to replenish its aircraft, ${ }^{(123)}$ but the order which the Navy Department of IGHQ issued on that day (the 29th) regarding the operations in the southeastern area was only an order for the unit [consisting of] the Fourth Fleet as the core [and not for the Carrier Task Force]. ${ }^{(1)}$

Notes:

As we have seen, on receiving a telegram from the Southern Army that the capture of Banjarmasin would be omitted, the Army Department of IGHQ wired back on 24 January, saying, "we are deeply concerned about ... in a situation where the cooperation of the aircraft carriers cannot necessarily be expected," and again sent another [reply] telegram to the Southern Army on the 26th, "we have also been negotiating about the cooperation from aircraft carriers in the Java operation. However, at present it cannot be expected for sure, as the Navy is extremely cautious about sending them to a dangerous sea where the enemy air force is [still] strong." [Editor's note: In Army General Staff Telegram No. 591, cited on p. 217 , the word "dangerous" is absent.]

We have already explained the power of the B-17s, which raided Menado at that time, and the fact that the Southern Army had to give priority to the Palembang airfield in the paradrop operation for fear of the B-17s. According to the action report of the 44th Field Antiaircraft Artillery Battalion, B-17 super heavy bombers with a flying range of 1,680 kilometers raided Balikpapan on 24 January in four waves of seven, two, nine and three aircraft at a time (twenty-one aircraft in total). After dropping some forty bombs, all of them flew away in no hurry. [So,] in one view one could argue that "[the Navy] has to be cautious about sending the Carrier Task Force because the sea where the [enemy] B-17 [bombers] had command of the air was dangerous," but on the other hand, one could argue the view that "Port Darwin has to be attacked with the Carrier Task Force in order to contain the power of the B-17s."

8. By the morning of the next day, the 30th, the Army and Navy Departments of IGHQ had prepared the groundwork, so that Chief of the Army General Staff Sugiyama and Chief of the Navy General Staff Nagano could meet and the former could make the request which will be mentioned later. ${ }^{(147)}$ 
On that day (the 30th), Kusaka Ryūnosuke, chief of staff of the First Air Fleet (i.e. the Carrier Task Force), who had been summoned from Truk (accompanied by Staff Officer Genda Minoru), held talks with the staff officers of the Navy Department of IGHQ and those of the Combined Fleet. [Editor's note: According to Vol. 80, p. 170, they just happened to be there.] As a result, it was decided that the entire force of the Carrier Task Force and one element of the Submarine Fleet (i.e. the Sixth Fleet) should participate in the Java operation. ${ }^{(108)}$

As described previously, on that day (the 30th), Chief of the Army General Staff Sugiyama met with Chief of the Navy General Staff Nagano. Chief of the Army General Staff Sugiyama requested the cooperation [from the Navy] in the Burma operation and in the following words asked for cooperation in the Java operation as well, while [also] giving his view on the future conduct of the war: ${ }^{(2)}$

\section{Request to Chief of Navy General Staff Nagano (30 [January])}

(First part omitted by the author)

Needless to say, the Java operation is very difficult. [In fact,] in the light of the results of previous studies such as war games and others, the operations against Malaya and Java were deemed the most difficult. This can be said in particular about the air operations. As it is, in the Malaya operation, owing to divine aid and the close cooperation between the Army and the Navy, we were able to achieve brilliant military gains by conducting a surprise attack on the enemy. However, as for the Java operation that we will conduct shortly, we must expect that it will be extremely difficult compared to the Malaya operation, owing to the facts that the enemy has rapidly been reinforcing its defense in the area these days, that it is more difficult to make a surprise attack on Java than on Malaya, and that the enemy is getting familiar with our ways of conducting landing operations, and so on. In view of these characteristics of the Java operation, the Army is determined to accomplish the operation after thorough preparations. We sincerely hope that the Navy will also closely cooperate [with the Army] in various operations, in air operations in particular, so that we can fully demonstrate the essence of cooperation between the Army and the Navy in the final stage of the southern operation. [Editor's note: This paragraph was also quoted on p. 127 in a slightly different redaction. We have kept to the redaction given on $\mathrm{p}$. 127]

The cutting-off of U.S. and British reinforcements

The situation of U.S. and British reinforcements [for the allied forces] in East Asia is as shown in the separate table and the sketch map on the separate sheet; we may assume that the greater part will be transported by ship and a part by air. We consider it most advantageous if it is possible to catch and destroy them in the middle of their transport. Although the Navy has [also] been paying attention to it and has allocated some submarines and other forces, we hope you will pay as much attention as before to the cutting-off of reinforcements to the enemy, particularly to its forces in the Burma and Java areas.

The conduct of the war after [the southern operation]

We are now studying the conduct of the war after [the southern operation.] When the southern operation is almost wrapped up, we shall of course make every effort to carry out the operations necessary to speed up the ending of the war. However, we must attach great importance particularly to increasing the flexibility of our defensive strength as well as to promptly establishing a condition in which we are self-sufficient and ready against all possible attacks. As for the places to be captured from now on, we think that for now we should take the above into account and give careful thought to the limits [of our expansion], so as 
not to bring about a disadvantageous war of attrition. Furthermore, we consider it extremely important to conduct the first stage, that is, the operation against the south, always with an eye on the situation in the north. Because among our war aims great importance is attached to the surrender of Britain, the operations against the Indian Ocean are especially critical. Moreover, considering the above-mentioned U.S. and British reinforcements, we particularly hope that the Navy will concentrate its strength in that area. We will make efforts to frankly exchange opinions with the Navy on the detailed measures for these issues as soon as possible, so that we can draw up a definite plan.

9. On the next day, the 31st, the Combined Fleet issued Telegraphic Operation Order No. 54, by which it assigned the entire force of the Carrier Task Force and one element of the Sixth Fleet to the Southern Task Force as of 3 February, and had the latter conduct carrier operations during the Java operation. ${ }^{(123)}$ It was the day when the Twenty-fifth Army had advanced to the Johor Strait, while the Eastern Detachment had landed in Ambon.

However, on the next day, 1 February, a U.S. Carrier Task Force raided the Marshall Islands. The Japanese Carrier Task Force immediately departed from Truk and headed eastward. However, judging that the U.S. Task Force had already gone far away, it turned around and headed for Palau before daybreak on the $3 \mathrm{~d}$, expecting to arrive there on the 8th [to join the Java operation]. ${ }^{(116)}$

The above-mentioned air raid on the Marshall Islands on the 1st was the first air strike by a U.S. Carrier Task Force that [the Japanese] had experienced since the opening of hostilities. The Combined Fleet was forced to change its policy. It issued Telegraphic Operation Order No. 63 on 5 February as a first step, by which it removed twenty-one aircraft of the Gaoxiong Air Group (which had returned from Jolo to Gaoxiong at that time) from the Southern Task Force and transferred them to the South Seas [Pacific Islands] Unit (i.e. the Fourth Fleet). Then, it decided to cancel the deployment of the entire force of the Carrier Task Force to the Java area, to reserve the 5th Carrier Division (the aircraft carriers Shōkaku and Zuikaku) in the mainland, and to assign the main force of the remaining force ([consisting of] the 1st Carrier Division, with the aircraft carriers Akagi and Kaga as the core) to the Southern Task Force [instead]. On 8 February, it issued Telegraphic Order No. 64, by which it revised the previous order, and ordered: "The Carrier Task Force (minus the 5th Carrier Division and the 2d Section of the 18th Destroyer Division) and the $2 \mathrm{~d}$ Submarine Squadron shall be transferred to the Southern Task Force." ${ }^{(116,123)}$

In the meantime, the air unit of the Southern Task Force (i.e. the Eleventh Air Fleet) had achieved great military gains in Operation Z (a large air campaign carried out from 3 through 5 February against eastern Java from Balikpapan and Kendari with the force of the $2 \mathrm{~d}$ Carrier Division and the 21st, and the 23d Air Flotilla) and destroyed allied aircraft and naval vessels in eastern Java.

10. The operation to capture Makassar by a Navy unit (which departed from Kendari on 6 February and landed in Makassar on the 9th) was conducted just after Operation Z, making use of the military gains of the latter.

11. The commander of the Southern Task Force, to which the Carrier Task Force had been transferred, brought the 2d Carrier Division (the Sōryū and the Hiry $\bar{u}$ ) back under the command of the latter. He gave an order to the Carrier Task Force to carry out air 
strikes on Port Darwin the day before the landing of the Eastern Detachment on Timor, and then to leave Staring Bay on the 25th after replenishing and advance into the sea south of Java to conduct carrier operations. Furthermore, he gave orders to the air unit (i.e. the Eleventh Air Fleet) and the Dutch East Indies Unit (i.e. the Third Fleet) to cooperate in the operations of the Carrier Task Force with part of their forces. ${ }^{(117)}$

While the Eastern Detachment left Ambon for Timor on 17 and 18 February, the 21st Air Flotilla headquarters (in Kendari) took up position in Ambon during the period from the 11th to the 17th to take charge of directing the air operations in this area. ${ }^{(134)}$ The Carrier Task Force had left Palau on the 15th to carry out air strikes on Port Darwin on the 19th. ${ }^{(116)}$ The Eastern Detachment went ashore on Timor on the next day, the 20th, with little interference from [enemy] air or naval [forces].

12. Although the air unit (the Eleventh Air Fleet) carried out air strikes (Operation Z) on eastern Java from 3 [through 5] February as mentioned previously, it could not make sufficient [military] gains due to bad weather and other reasons after Operation $Z$. The Kanemura Detachment of the 48th Division ([consisting of] one battalion as the core) had left Lingayen on 7 February, advanced to Makassar on the 14th [the 15th according to p. 400], and then left Makassar on the 18th under the escort of only a few naval vessels and launched the landing [operation] on Bali on the night of the 19th [actually at 0100 on the 19th, see p 401]. At that moment, a strong allied fleet raided [the anchorage] and created a situation that terrified the Dutch East Indies Unit headquarters.

As reasons [for the panic], the following issues concerning the invasion schedule have to be taken into account, apart from the insufficient results of the air operations and the shortage of escort vessels.

13. As we have seen, the unofficial agreement at the Manila Conference was officially concluded on the day when the Banjarmasin issue was settled, that is, 28 January, and [on that day] the Dutch East Indies Unit officially passed down the disposition of forces and the outline of the phase-three operations. Although the Combined Fleet and the Southern Task Force (i.e. the Second Fleet) had already passed down the shift to phasethree operations on 24 January, the Dutch East Indies Unit was not able to decide the disposition of its forces until the Banjarmasin issue was settled.

Consequently, the arrangement between the Dutch East Indies Unit and the Sixteenth Army, which had informally been made in Manila on 23 January, was [finally] concluded on the 30th. This agreement stipulated that "the landing on Bali [shall be made] no later than day I - 2." On the other hand, the agreement between the Southern Army and the Southern Task Force, concluded on 28 January, had stated [the landing] as "around day I - 2." Day I indicated the [scheduled] date of landing on eastern Java, which was day $x+77$ (23 February). At that time, the scheduled date of landing on western Java (day H) was day $x+75$ (i.e. 21 February, which was day I - 2). The idea then was to conduct the capture of Bali within the main flow of the Java landing operations.

However, as described earlier, the Malaya Unit requested postponement of [the day to conduct Operation] L for two days on 4 February and for another four days on the 6th. The Southern Task Force considered it inevitable to put off L ([scheduled for] day $x+64$ ) for six days in total, and consequently, a six-day postponement of [the day to conduct Operation] H ([scheduled for] day $x+75$ [to be carried out in] western 
Java). On 8 February, [the Southern Task Force] discussed these matters with the Southern Army, and upon the approval of the latter on that day, it transmitted at 2040 on the next day, the 9th, the following order by Telegraphic Order No. 96. ${ }^{(117)}$ [The text is given on p. 305.]

The following amendments were made in the target dates for the invasions in the Dutch East Indies operation:

1. Western Java: day $x+81$ (Note by the author: 27 February)

2. Eastern Java: no later than day $x+81$, depending on the arrangements between the commander in chief of the Third Fleet and the Sixteenth Army commander.

The Southern Task Force considered it regrettable that the Malaya Unit had requested the postponement of L. Therefore, as for Java, it decided to stick to the previous plan, and ordered that the landing on eastern Java [should be executed] no later than day $x$ +81 .

As we have seen, before the Southern Task Force transmitted the above order, the prospect of when the Kuantan airfield would be ready for use had become certain around noon on that day (the 9th), and the advance unit of the 38th Division had left Cam Ranh Bay in the evening of that day; as a result, L was advanced by one day. Based on this and the above-mentioned telegraphic order of the Southern Task Force, the Dutch East Indies Unit, which had made the arrangements with the Sixteenth Army, transmitted the following telegraphic order at 1150 on the 11th:

The schedule for the Dutch East Indies invasion shall be revised as follows:

(a) Batavia and Surabaya: 26 February

(b) Kupang and Dili: 20 February

(c) Bali: 18 February (as scheduled)

[This meant] that [the unit] advanced the date [stipulated in the telegraphic order of the Southern Task Force] from day $x+81$ to day $x+80$. Apart from this, [the order of the unit] had three remarkable points: First, it set the [scheduled] dates of landing on [both] eastern and western Java on the same day despite the intention of the telegraphic order of the Southern Task Force. This was because it was the fixed opinion of the Sixteenth Army to simultaneously conduct [the landing operations] in [both] eastern and western Java. Secondly, Dili was added [to the targets to capture,] which will be explained later. Thirdly, [the date of the landing operation on] "Bali [shall be] 18 February as scheduled." This means that the date of the landing on Bali, which had been changed from around day I - 2, set in the order of the Southern Task Force, to day I - 5 by the Dutch East Indies Unit, was [further] changed to day I - 8 this time. The reason [for this] will also be described later.

On the 16th, the [scheduled] date of the landing on Bali was postponed [again] for one day due to circumstances that will be described later. However, [in the meantime,] the [scheduled] date of landing on Java was postponed for two days on the $23 \mathrm{~d}$, and again for one more day on the 27th due to circumstances that will [also] be described later. In the end, the [scheduled] date of the landing on Bali, which had been set as 
around day I - 2, ended up as day I - 10, which eventually presented the allied forces with an opportunity to smash the Bali invasion units one by one.

14. Earlier, for the seizure of Makassar (on the 9th), the unit had left the Bangka anchorage (north of Celebes) on the $2 \mathrm{~d}$ and Kendari on the 6 th. It had crossed [the sea] north of the Lesser Sunda Islands right in front of the enemy.

The reasons why this course had been taken boiled down to the shortening of the schedule to capture Java and the shortage of naval escort vessels. To be precise, it was because the main force of the 4th Destroyer Squadron, which had been positioned in Balikpapan, had headed north for the Philippines to escort the 48th Division, and because it was further decided that the naval vessels that had participated in the operation to capture Ambon (the landing was launched on 31 January), would [afterwards] join to provide support [to the Makassar landing], leaving Ambon on the 4th.

15. The unit to capture Timor left Ambon on 17 and 18 February, while the unit to capture Bali left Makassar on 18 February. It (the 18th) was [also] the day when the unit to land in central western Java departed from Cam Ranh Bay. The 48th Division left Jolo and headed for eastern Java on the next day, the 19th.

\section{The Issue of Seizing Dili}

As mentioned previously, Dili was the seat of the governor-general of [Portuguese] Timor, a territory of neutral Portugal. On 7 February, IGHQ endorsed the seizure of the city, the details of which were as follows:

At the time of the opening of hostilities, Dutch Timor was included in the [invasion] plan as one of the areas to be captured, but how to deal with Portuguese Timor had not been decided. ${ }^{(1,23)}$ The stance of IGHQ was to avoid a [Japanese] advance into Portuguese Timor in every possible way, because [the advance] might make Portugal join the allied forces. ${ }^{(16)}$

At the beginning of January 1942, the Southern Army obtained information that a total of about 1,000 Dutch East Indies and Australian troops had intruded into Portuguese Timor. ${ }^{(23)}$ On 5 January, while giving the Sixteenth Army the order to capture Ambon and Kupang, as mentioned previously, the Southern Army, which regarded the issue as troublesome, wired IGHQ on the same day as follows:(23) "(1) In consequence of our order [to launch] the Kupang operation, we believe that it is a reasonable action in terms of both international law as well as our strategy that we will possibly conduct air and ground attacks as needed, if the enemy forces should use the Portuguese territory on Timor. (2) Further, we would like your consideration to strictly keep the launch of the landing [operation] secret because considerable difficulties are anticipated in conducting this landing operation. (3) We inform you in advance of these two matters just to make sure. [Also,] we would like you to kindly send us as soon as possible actual proof that the enemy forces are using Portuguese territory." [However, the Southern Army] did not receive a reply on this matter from IGHQ until early February. ${ }^{(23)}$ Meanwhile, the Dutch East Indies Unit, which had to provide an escort for the Eastern Detachment's advance to Kupang, was in a serious predicament. At the Manila Conference (from 21 to 23 January), the senior staff officer of the Third Fleet, Captain Yamaki, had earnestly explained the difficulties of the Kupang operation to Southern Army Staff Officer Ishii. According to him, "unlike many other landing operations, the Kupang operation will be extremely difficult because it is [necessary to] pass through the [Lesser] Sunda Islands, 
and advance out into the Indian Ocean to carry out [the operation]. Especially, if [our convoy] should sail to Kupang by way of the Ombai Strait, it would be passing through the sea off Portuguese Timor all day, which is bad if we want to keep our intentions secret. If it is unavoidable to go southward passing through [other] narrow channels, we would need considerable minesweeping as well as escorting forces." Captain Yamaki repeatedly insisted that simultaneous attacks on Kupang and on Dili would make the operation comparatively less difficult. ${ }^{(23)}$ The Southern Task Force, like the Southern Army, had also suggested to the Navy Department of IGHQ to attack Dili [along with Kupang]. ${ }^{(117)}$

As described previously, on 1 January, an agreement was reached between the Southern Army and the Southern Task Force to "capture Kupang around 11 February." Having received the above-mentioned Southern Army telegram on 5 January, Chief of the Army General Staff Sugiyama reported to the Emperor: "The landing in Kupang has to be made in the face of the enemy. If the enemy enters Portuguese territory, Portugal, as a neutral country, should rightfully demand their withdrawal, or disarmament. If Portugal neglects that and sabotages our operations, attack operations must be carried out [as well] against Portuguese territory." (4) After that, the Liaison Conference between IGHQ and the Government was held on 20 January. At the conference, Chief of the Army General Staff Sugiyama told Foreign Minister Tōgō: "This is the way the Army Department [of IGHQ] thinks about the Portuguese territory. I request you to make a study on the case of warning them. We will further inform you about when and how to warn them, etc." (4) Right after the statement of Chief of the Army General Staff Sugiyama, Chief of the Navy General Staff Nagano demanded: "Allied aircraft, if any, in the Portuguese territory will certainly attack our convoy at the time of our Kupang landing operation. Therefore, we must attack them before that. In order to avoid such a scenario, we would like you to give a warning."(4)

As a result of the study which had been made since then, the conclusion was reached that it was necessary to advance into Dili in Portuguese [Timor] as well as simultaneously into Kupang, because the Australian and Dutch forces had already entered Portuguese territory, and the neutrality of Portuguese Timor was violated. The [Japanese] government had no particular objection to this conclusion. However, on 24 January (the day when participants in the Manila Conference made their way back), a problem arose. ${ }^{(7)}$ While Prime Minister (and War Minister) Tōjō Hideki maintained that "troops shall be promptly withdrawn from Portuguese territory, once they have achieved the purpose of the operation against it," Chief of Navy General Staff Nagano insisted that "Portuguese Timor must be secured for operations against Australia, even after the mopping up [of the territory is over.]"(7) The intent of Prime Minister Tōjō was to strictly prevent the expansion of the number of countries against which [Japan] was waging war.

On 27 January, the following draft was drawn up between the chief staff [officers] in charge: ${ }^{(7)}$

\section{Measures to be taken against Portugal at the time of operations against Dutch Timor}

1. In carrying out the operations against Dutch Timor, it is possible that the Empire [of Japan] may conduct operations against Portuguese Timor for self-defensive purposes. However, after mopping up the British, Australian and Dutch forces on Portuguese territory,

(Plan A) the Imperial Japanese forces shall withdraw from the area concerned, as long as Portugal ensures its neutrality; or 
(Plan B) whether the Imperial Japanese forces will be withdrawn from the place or will continue their use [of the place] as an operational base shall be determined depending on the attitude of the Portuguese and other circumstances at the time.

2. From the viewpoint of keeping our intention secret, diplomatic measures, such as further requesting the Portuguese government in advance to have British, Australian and Dutch forces pull out of Portuguese Timor, shall not be taken.

3. Just before the entry of [Japanese] ground units into Portuguese Timor, a notice shall be timely given to the Portuguese side, and an offer shall be made that the sovereignty of Portuguese Timor will be respected, and that "[Japan] intends to promptly pull out its forces once its purpose of self-defense is achieved, as long as Portugal ensures its neutrality." The Imperial Japanese Government shall announce the above intent, just after the entry [of its units into the territory.]

Note 1. As long as Portugal maintains its neutral position, we will maintain our present attitude toward Macao.

2. We will timely issue a statement to Germany and Italy as needed.

3. In case the Imperial Japanese forces should enter Portuguese Timor, they shall make efforts in every possible way so as not to make an enemy of the Portuguese forces.

The next day, the 28th, the subject was brought up for discussion at the Liaison Conference between IGHQ and the Government, and all of a sudden the argument became heated. For about an hour, a heated discussion continued between Prime Minister Tōjō, who pressed to "choose plan A," and Chief of the Navy General Staff Nagano, who insisted to "choose plan $\mathrm{B}$, " but they failed to come to an agreement. $(3,4,7)$

The tenor of Chief of the Navy General Staff Nagano's argument was as follows:

- According to the talks held on 23 January at Lisbon between Minister Chiba and the vice foreign minister of Portugal (regarding the additional dispatch of Portuguese troops to Timor), and also in view of the actual confinement of Japanese [residents] in Portuguese Timor, it may surely be said that the rightful status of Japan has already been infringed in the territory of a [supposedly] neutral country. Under such circumstances, it is (1) necessary to secure Portuguese Timor, which is of great immediate value for operations against Port Darwin, in anticipation of a prolonged war from now on, in which U.S. and British forces, U.S. aircraft and submarines in particular, will gather in Australia; and (2) even though [Plan A] says that [the Japanese forces] shall withdraw [from the territory] as long as Portugal ensures the neutrality of Timor, it is highly doubtful whether [the territory] will be able to ensure its neutrality on its own in a situation where the territory has already been invaded. In short, I find it difficult to clearly state our withdrawal while the Portuguese attitude and the changes in the other circumstances are still far from clear. Therefore, I prefer to decide this matter after seeing what happens.

— Prime Minister Tōjō regards the Timor operation as a campaign in a limited area, but that is wrong. When a prolonged war is anticipated, [the territory] is extremely important to check Australia. Even if Portugal takes sides against the Axis, it will probably not make a big difference in the war situation in Europe. No matter how seriously we treat the country, if it is incapable of maintaining its neutrality, in the long run it will never be able to ensure the neutrality [of its territory] against the pressure of Britain and the United States. It is not necessary to decide upon our withdrawal now as in plan A.

- I do not agree with deciding at this point matters that are absolutely essential for the implementation of the Empire's military operations without seeing first how the situation develops, as for instance a withdrawal, only because it would be necessary for tactical political reasons. 
The officers in charge racked their brains after the conference was over, but with no success. On the 30th, the chiefs of the Military Affairs Bureau of the Ministry of War [Maj. Gen. Mutō Akira] and the Naval Affairs Bureau of the Navy Ministry [R. Adm. Oka Takazumi] set out to settle the issue and reached agreement on the 31st. ${ }^{(7)}$

On 2 February, the Liaison Conference between IGHQ and the Government made the following decision (as drawn up in the original draft). ${ }^{(3)}$ Chief of the Navy General Staff Nagano did not utter a single word that day. ${ }^{(7)}$

After mopping up the British, Australian, and Dutch forces on Portuguese territory, the Imperial Japanese forces shall withdraw from the area concerned, as long as Portugal ensures the neutrality [of the territory]. However, if it is inevitable in terms of the attitude of the Portuguese and the other circumstances of the entire operation, the [Japanese forces] can continue to use [the place] as a base for operations.

On 4 February, the IGHQ Army Department wired the Southern Army the following message by way of Army General Staff Telegram No. 741, which was received by the Southern Army on the 5 th: ${ }^{(23)}$

We were ordered to notify you of the measures to be taken against Portugal at the time of the operation against Dutch Timor, which were decided at the liaison conference yesterday, the $2 \mathrm{~d}$, in the following way. Concerning the implementation of [operations in conformity with] these measures, you will be separately instructed.

The measures [against Portugal]

1. In carrying out the operation against Dutch Timor, it is possible that the Empire [of Japan] may conduct operations in Portuguese Timor for self-defensive purposes. Then, after mopping up the British, Australian and Dutch forces on Portuguese territory, the Imperial [Japanese] forces shall withdraw from the area concerned, as long as Portugal ensures the neutrality [of the territory]. However, if it is inevitable in terms of the attitude of the Portuguese and the other circumstances of the entire operation, the [Japanese forces] can continue to use [the place] as a base for operations.

2. From the viewpoint of keeping our intentions secret, diplomatic measures, such as further requesting the Portuguese government in advance to have the British, Australian and Dutch forces pull out of Portuguese Timor, shall not be taken.

3. Just before the entry of [Japanese] ground units into Portuguese Timor, a notice shall timely be given to the Portuguese side and an offer shall be made that Japan respects the territorial integrity of Portuguese Timor and as long as Portugal strictly observes its neutrality, [Japan] intends to promptly pull out its forces once its purpose of self-defense is achieved. The Imperial Japanese Government shall announce the above intent just after the entry [of its units to the territory].

4. If it is unclear before our entry whether the British, [Australian] and Dutch forces have pulled out, operations shall be conducted as planned for the time being. If the pullout of British, [Australian] and Dutch forces is confirmed after our entry, matters shall be handled in accordance with Item No. 1.

Note 1. As long as Portugal maintains its neutral position, we will maintain our present attitude toward Macao.

2. Explanations shall timely be given to Germany and Italy.

3. Imperial Japanese forces entering Portuguese Timor shall make every effort so as not to make an enemy of the Portuguese forces. 
On 5 February (the day when it received the aforementioned Army General Staff Telegram No. 741), the Southern Army was stunned to unexpectedly receive a telegram sent by the Southern Task Force on the 4th, which read: "In view of the present situation where both Australian and Dutch East Indies forces have occupied Portuguese Timor, we would like to have an element of the Itō Detachment go ashore in Dili (under the escort of the Navy) [at the time of the operation] to capture Timor almost simultaneously with the landing in $\mathrm{Ku}-$ pang and seize the vicinity." (23) On the same day (the 5th), the Southern Army sent the Army Department of IGHQ the following telegram:(23)

We duly received Army General Staff Telegram No. 741.

1. As it is said that the operations against Dutch Timor are extremely difficult from the viewpoint of naval tactics, it would be highly advantageous if it were possible to conduct operations against Portuguese Timor simultaneously with those against Kupang. As we have received an advisory telegram from the Second Fleet as well, it would be highly appreciated if you could consider the above and give us instructions immediately.

2. When entering [into Portuguese territory] from the sea, we would appreciate it if you gave notice to the territory after our entry into the anchorage.

3. We would like [to be notified?] immediately of the time and date of implementation, when fixed, by telegrams from the fleet. (Note by the author: This item seems to contain some misinterpretations of the code.)

On the next day, the 6th, the Southern Army [further] sent the following telegram to the Army Department of IGHQ:(23)

1. We would like you to immediately provide instructions, on which to base our operations against every kind of action from Portuguese forces, before the units to carry out the operations against Timor depart from the assembly point. The departure of the above units from the assembly point shall be on 17 February.

2. Further, in view of the strategic value of the island, it is expected that even if the Portuguese Army does not put up resistance, we should make considerable demands concerning such matters as the stationing of troops, guarding and counterintelligence, for the purpose of the defense of the island. Therefore, we think it highly advantageous if we can immediately induce Portugal to declare the island a war zone just after the landing of our troops.

On the next day, 7 February, after receiving approval [of the Emperor], Chief of Army General Staff Sugiyama passed down the following order, and the concomitant instructions: ${ }^{(1)}$

IGHQ Army Department Order No. 597

Order

1. The commander in chief of the Southern Army can conduct, in conjunction with the Navy, operations against Portuguese Timor for the purpose of self-defense.

2. The chief of Army General Staff shall provide detailed instructions.

7 February, 1942

IGHQ Army Department Instruction No. 1101

Instructions

Based on IGHQ Army Department Order No. 597, the following instructions are given: 
1. The outline of the operations against Portuguese Timor shall be discussed and determined between the commanders in chief of the Southern Army and the Combined Fleet.

2. When conducting the operations against Portuguese Timor, its sovereignty shall be respected as much as possible, unless Portugal takes hostile action.

In the meantime, the movements of the naval units on site were as follows: As we have seen, in giving shape to its phase-three operations, the Dutch East Indies Unit had wished to [include operations to] capture Dili and Kupang simultaneously, but it gave up [the plan] because central command [the Navy Department of IGHQ] gave no directions. Meanwhile on 27 January at central command [IGHQ], the aforementioned policy on measures against Portugal was informally agreed and expected to be approved at the Liaison Conference between IGHQ and the Government on the 28th. At 1000 on that day, the 28th, the Southern Task Force wired the Dutch East Indies Unit and the unit to capture Timor (i.e. the Eastern Attack Unit, led by the 5th Cruiser Division commander): "If you have drawn up a plan to go ashore on Portuguese Timor (in Dili and vicinity) in the operation to capture Timor, we would like you to promptly inform us of the outline."(117) As already described, central command [IGHQ] failed to reach agreement at the liaison conference on the 28th. On 1 February, the Dutch East Indies Unit wired back to the Southern Task Force that for reasons of the airfield in Dili being poor with a runway of [a mere] 800 meters, and the construction squad having no extra strength to spare, "[the unit] has decided to concentrate its full force on Kupang, but [also] plans to take appropriate measures without an missing opportunity should the enemy take advantage of Dili." (117) It may look odd that this telegram was sent by the Dutch East Indies Unit, whose Senior Staff Officer Yamaki had so ardently appealed to Ishii, [senior] staff officer of the Southern Army, for capturing Dili simultaneously with Kupang. It seems that the main factor [in this change of heart] was that the unit had taken the views of the Sixteenth Army seriously. The Sixteenth Army felt it risky to disperse the strength of the Eastern Detachment in the operation to capture Timor, which was receiving reinforcements from Australian forces. ${ }^{(23)}$ Later, on 8 February, when Southern Army Staff Officer Ishii had just received approval to issue the Southern Army Order that "the Sixteenth Army commander shall conduct operations against Portuguese Timor in conjunction with the Navy, for the purpose of facilitating the operations against Dutch Timor," and was about to arrange the transmission of the order, Colonel Takashima, senior staff officer of Section 1 of the Sixteenth Army presented himself. On receiving an explanation about [the operation to] capture Dili from Staff Officer Ishii, [Takashima] expressed his disapproval and strongly insisted that the Sixteenth Army intended to concentrate as much of its power as possible in one place in view of the case of Ambon (where the unit heading from Hitu-lama for the Laha airfield separately [from the other troops] had faced an uphill battle). He would not yield and in the end Staff Officer Ishii had to go so far as saying that "it has already been sent to the Second Fleet in reply, and has [also] been approved by [the commander in chief of the Southern Army]," in order to overcome his opposition. ${ }^{(23)}$ However, on the $2 \mathrm{~d}$, the day after the Dutch East Indies Unit had sent the aforementioned reply [to the Southern Task Force], the policy on measures against Portugal was decided at central command [IGHQ], as mentioned previously. Learning about the decision, the Dutch East Indies Unit changed its mind [again], and sent the following telegram on the 4 th: ${ }^{(117)}$ 


\section{To Chief of Staff, Second Fleet}

From Chief of Staff, Third Fleet, sent at 1530 on 4 February

Regarding IGHQ Navy Department Classified Telegram No. 638, we would like you to negotiate with the [Southern] Army about occupying Dili with one element of the Itō Detachment (the naval landing forces have no extra strength to cooperate in this [operation]) simultaneously with [the operation] to capture Kupang. As the schedule [is drawing near], we are going to proceed with the preliminary negotiations with the Sixteenth Army, based on the above scheme.

The developments after that were as previously described.

On 17 and 18 February, the Eastern Detachment left Ambon under the escort of the Navy, and went ashore in Kupang and Dili on the 20th. [Also] on the 20th, the [Japanese] government issued the following statement: ${ }^{(3,13)}$

On 17 December last year, British and Dutch forces took the step to invade Portuguese Timor despite the refusal of the Governor-General of the territory [to let them in] and occupied it. Since then, negotiations for withdrawal have been started between Britain and Portugal, and although the Portuguese government seems to be making efforts to improve the situation, it has remained unchanged until today. Now, with the advance of our operations towards Dutch Timor, the Imperial Japanese Army has come to a point that it is compelled to drive off the British and Dutch forces in Portuguese Timor for the purpose of self-defense. As the Empire of Japan fully understands the position of Portugal, which came to be greatly troubled by the actions of Britain and the Netherlands in disregard of international good faith, the Imperial Japanese government will ensure the territorial integrity of Portuguese Timor. And as long as the Portuguese government maintains its neutral attitude, it shall promptly withdraw its forces after attaining its purpose of self-defense. The Empire of Japan hereby declares that it has no other intentions against Portugal.

\section{Phase-Three Operations of the Naval Units}

\section{The Southern Task Force}

On 24 January, the Combined Fleet had ordered the Southern Task Force to shift to phasethree dispositions, as mentioned previously. That was the day when the participants in the Manila Conference started on their way back, and when the landing operations in Balikpapan as well as in Kendari were carried out. It was also the day when the two ships to disembark [air units, fuel and ammunition] at Endau and the unit to occupy the Anambas Islands departed from the Gulf of Thailand sector. On the same day, the Southern Task Force transmitted an order to switch to phase-three operations with the current disposition of forces. ${ }^{(117)} \mathrm{An}$ outline of the phase-three operations of the Southern Task Force as of that day was roughly as follows:

1. [The Southern Task Force] shall continue the operations to capture Ambon, Makassar and Kupang with the Dutch East Indies Unit. If IGHQ approves, [the operation] to seize Banjarmasin shall be omitted, and [the operations to seize] Bali and Dili shall be included [instead].

2. Air campaigns against eastern Java from Balikpapan and Kendari shall be carried out as preliminary operations for the invasion of Java.

3. It shall conduct the operation to capture southern Sumatra with the Malaya Unit.

4. Just before the landings on Java, it shall capture Bali and advance air units there. 
5. It shall have the $2 \mathrm{~d}$ Carrier Division attack Port Darwin first in concert with [the operation to] capture Timor.

6. It shall have the Dutch East Indies Unit escort the main force of the Sixteenth Army to eastern and western Java. For this [operation], it shall transfer the necessary vessels to the Dutch East Indies Unit from the Malaya Unit and return the 22d Air Flotilla to its original control (the Eleventh Air Fleet).

7. It shall deploy submarine units in the sea near Java to provide support.

8. After the capture of Singapore, it shall prepare for the northern Sumatra operation.

On 28 January, the cancelation of the operation to capture Banjarmasin by way of the sea was [officially] decided, and [consequently] the new schedule for the invasion operations set at the Manila Conference was fixed on the same day. Around that time, through the good offices of the Combined Fleet, the Southern Task Force had made efforts to successively increase [the number of] destroyers of the Dutch East Indies Unit, as already described [p. 235].

On 31 January, [the Southern Task Force] received a telegraphic order from the Combined Fleet to transfer, as of 3 February, the entire force of the Carrier Task Force and one element of the Sixth Fleet to the Southern Task Force. ${ }^{(116)}$ However, [the order] was revised on 8 February, and on the same day, it [again] received a telegraphic order that "[the Combined Fleet] will transfer the Carrier Task Force (minus the 5th Carrier Division and the 2d Section of the 18th Destroyer Division) and the 2d Submarine Squadron to the Southern Task Force." ${ }^{\prime 116)}$ By this [order], the [aircraft carriers] Akagi and Kaga (of the 1st Carrier Division) were added to

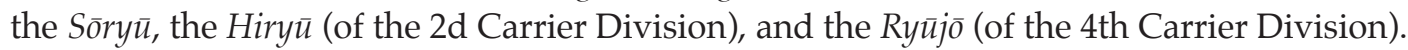
Also, the $2 d$ Submarine Squadron was added to the submarine unit [consisting] of the 4th, the 5th, and the 6th Submarine Squadrons, and the battleships Hiei and Kirishima (both of the 3d Battleship Division) were added to the battleships Kongō and Haruna.

On the next day, the 9th, the Southern Task Force drew up the outline of the carrier and submarine operations: ${ }^{(117)}$

1. The Carrier Task Force (which has brought back the $2 \mathrm{~d}$ Carrier Division under its command) shall depart from Palau, conduct a surprise attack on Port Darwin the day before [the operation to] capture Timor, and enter [the anchorage] at Staring Bay (this operation will be called the first carrier operation). After that, in concert with the Java operations, it will depart from Staring Bay and conduct carrier operations for five days against the area south of Java. (This will be called the second carrier operation.)

2. The Air Unit (i.e. the Eleventh Air Fleet) shall cooperate in the above operations in addition to its cooperation in the operations of the Dutch East Indies Unit.

3. Besides carrying out its predetermined operations, the Dutch East Indies Unit shall [also] cooperate in the operations of the Carrier Task Force by sending a force, consisting of the 5th Cruiser Division as the core, to the Banda Sea in the first carrier operation and to the southwest of Timor in the second carrier operation.

4. As for the submarine units, Submarine Unit A (the 4th and the 6th Submarine Squadrons) shall be in charge of the sea east of Java (including the island), Submarine Unit B (the 5th Submarine Squadron) of the sea west of Sumatra (including the island), and Submarine Unit C (the 2d Submarine Squadron) of the Java and the Lesser Sunda [Islands] areas.

5. The main force of the Southern Task Force shall leave Palau on 18 February and advance to the south of Java via Staring Bay. 
The air unit (the Eleventh Air Fleet) launched an air campaign against eastern Java on 3 February, and the Malaya Unit against western Java on 9 February. Makassar was seized on 9 February, and Banjarmasin on the 10th, and [the operation to] land in Bangka and Palembang was carried out on the 15th. On the 17th (the day before the departure of the main force of the Sixteenth Army from Cam Ranh Bay), the Southern Task Force issued an order to transfer one light cruiser, five destroyers and other ships from the Malaya Unit to the Dutch East Indies Unit. It also ordered the return of the 22d Air Flotilla from the Malaya Unit to the air unit (the Eleventh Air Fleet), etc.

\section{The Air Unit}

On 26 January, the air unit (the Eleventh Air Fleet) deployed nine carrier aircraft and twentyeight carrier aircraft of the $2 \mathrm{~d}$ Carrier Division ([consisting of] the aircraft carriers Sōry $\bar{u}$ and Hiry $\bar{u}$ ), which had completed attacks on Ambon (on 24 January), respectively in Balikpapan and Kendari. [Editor's note: Date and number of aircraft differ in the description in Vol. 26, p. 231.]

On 28 January, along with the cancellation of the operation to capture Banjarmasin by way of the sea, [the unit] changed its lines of operation as follows:(143)

The 1st Air Raid Unit (the 21st Air Flotilla)

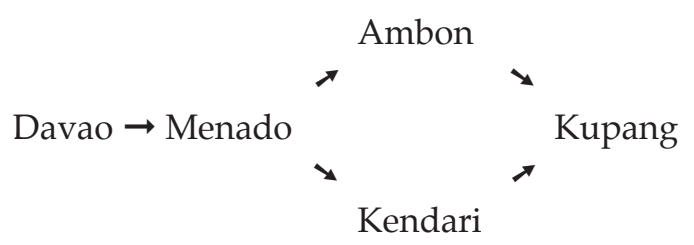

The 2d Air Raid Unit (the 23d Air Flotilla)

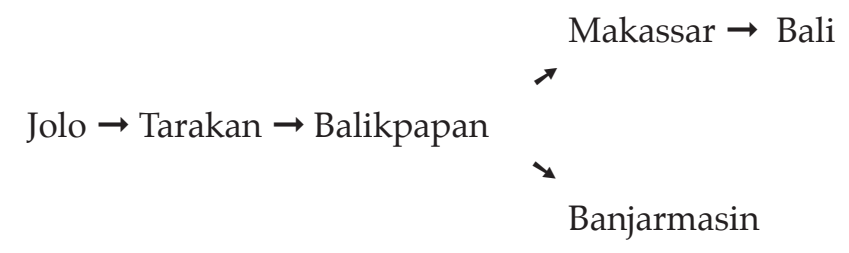

On 30 January the air unit (the Eleventh Air Fleet) passed down the order concerning the air campaign against eastern Java and conducted a massive air campaign from the bases in Kendari and Balikpapan from 3 through 5 February. ${ }^{(143)}$ On the 3d, thirty-seven land-based medium-sized attack planes and fifty-nine fighter planes carried out an air strike and reported a military gain of bringing down forty-eight [enemy] aircraft and destroying thirtysix. On the Japanese side, [the number of] aircraft which had crashed [themselves] on the enemy or did not return reached five. On the 4 th, the unit attacked four allied cruisers and seven destroyers off the coast of Java with sixty land-based medium-sized attack planes and reported a military gain of sinking two cruisers and causing substantial damage to the two other cruisers. $^{(100)}$ 
The $2 \mathrm{~d}$ Carrier Division returned to [the command of] the Carrier Task Force (the First Air Fleet) from the command of the Air Unit (the Eleventh Air Fleet) by the Southern Task Force order of 9 February. ${ }^{(117)}$

The 21st Air Flotilla headquarters (in Kendari) was positioned in Ambon from 12 through 17 February. ${ }^{(135)}$ (As already mentioned, on 15 February, the Carrier Task Force had left Palau to head southward.)

The 23d Air Flotilla headquarters advanced from Balikpapan to Bali on 26 February. ${ }^{(104)}$

Since 9 February, the 22d Air Flotilla had been launching an air campaign over western Java from Kuching with its main force under the command of the Malaya Unit. After that, it rapidly advanced into southern Sumatra, ${ }^{(104)}$ and returned to the direct control of the Air Unit (i.e. the Eleventh Air Fleet) on the 19th by the Southern Task Force order of 17 February. ${ }^{(120)}$ The air unit (the Eleventh Air Fleet) shifted its force to phase-three dispositions on and after that day (the 19th). ${ }^{(102)}$

The Eleventh Air Fleet headquarters advanced from Davao to Kendari on 21 February. ${ }^{(143)}$

\section{The Carrier Task Force}

The Carrier Task Force ([consisting of] the 1st and 2d Carrier Division, namely the aircraft carriers Akagi, Kaga, Sōryū, and Hiryū) left Palau on 15 February, carried out the air strike on Port Darwin on the 19th (the day before the landing of the Eastern Detachment on Timor), and entered the anchorage at Staring Bay on the 21st. ${ }^{(116)}$

The main force of the Southern Task Force, which had left Palau on 18 February, also arrived in Staring Bay on the same day (the 21st). ${ }^{(103)}$

Both of them were to leave Staring Bay on the 25th, to advance into the waters south of Java.

\section{The Dutch East Indies Unit}

As we have seen, after the Dutch East Indies Unit had made draft arrangements with the Sixteenth Army in Manila on 23 January, the Banjarmasin issue was settled on the 28th, and a new schedule for the Java operations was set on the same day. Further, in order to fill the shortage of escort forces of the Dutch East Indies Unit, the following units had been assigned or preliminarily assigned by then:

1. Orders [were given] to add the 21st Destroyer Division ([consisting of] four destroyers) [to the Dutch East Indies Unit] on 21 January, and [again] the 7th Destroyer Division (three destroyers) and the 1st Section of the 6th Destroyer Division (two destroyers) on the 28th. ${ }^{(114)}$

2. Informal arrangement to transfer the $2 \mathrm{~d}$ Section (two destroyers) [probably the 1st Section is meant, see p. 235] of the 6th Destroyer Division [to the Dutch East Indies Unit] from the air unit (the Eleventh Air Fleet) on the 30th.

3. Informal arrangement to transfer the light cruiser Yura, and the 11th Destroyer Division (three destroyers) and the 12th Destroyer Division (two destroyers) of the 3d Destroyer Squadron [to the Dutch East Indies Unit] from the Malaya Unit in tandem with the progress of the southern Sumatra operation.

Then, the commander of the Dutch East Indies Unit was able to determine the outline of the phase-three operations on the 28th and passed down Order No. 9 on the same day. ${ }^{(117)}$ 
The plan of the phase-three operations of the Dutch East Indies Unit was to capture Makassar, Bali and Kupang (and Dili, which was included on 7 February) with the Eastern Support Unit, the 2d Escort Unit and the 1st Base Unit, after the operation to capture Ambon (the landing on the island was executed on the 31st), as well as to escort the 48th Division (which was joined by the Sakaguchi Detachment on 16 February) to eastern Java with the 1st Escort Unit, the 1st Base Unit [2d Base Unit?], and the 2d Air Unit, and also to escort the main force of the Sixteenth Army to western Java with the 3d Escort Unit and the 1st Air Unit. The disposition of the forces was roughly as follows: ${ }^{(117,119,131)}$ [Editor's note: The author seems to have mixed up the "1st Base Unit" with the "2d Base Unit."]

Main Unit: [consisting of] the 16th Cruiser Division (minus the Nagara, so only the heavy cruiser Ashigara) and two destroyers, shall support the operations mainly in the Makassar Strait, Bali, and Surabaya areas from Davao.

1st Escort Unit: [consisting of] the main force of the 4th Destroyer Squadron (i.e. the light cruiser Naka, and a total of nine destroyers of the $2 \mathrm{~d}$, the 9th and the 24th Destroyer Divisions) as the core, shall escort the 48th Division (which was later joined by the Sakaguchi Detachment), to eastern Java after reversing course from Balikpapan. (However, one powerful element of the force shall first cooperate with the 1st Base Unit in its operation to capture Makassar and reverse course after that).

$2 \mathrm{~d}$ Base Unit: [shall conduct operations in] the Makassar Strait area from Balikpapan.

2d Air Unit: [consisting of] the 11th Seaplane Tender Division (with the seaplane tenders Mizuho and Chitose), shall first support [the operations] to capture Ambon, then Makassar, and [subsequently] for the most part cooperate with the 1st Escort Unit and the 2d Base Unit.

3d Escort Unit: [consisting of] the 5th Destroyer Squadron (the light cruiser Natori and a total of eight destroyers of the 5th and the 22d Destroyer Divisions) and [also] one section of the 6th Destroyer Division (two destroyers), which will later be joined by the light cruiser Yura and the 11th and 12th Destroyer Divisions (five destroyers in total) of the Malaya Unit, shall escort the main force of the Sixteenth Army to western Java.

1st Air Unit (the auxiliary seaplane tenders Kamikawa-maru and San'yō-maru): shall cooperate with the 3d Escort Unit.

Eastern Support Unit: [consisting of] the 5th Cruiser Division (the heavy cruisers Haguro and Nachi (note: the Myōkō was under repair in the mainland)), one section of the 6th Destroyer Division (two destroyers), and the 7th Destroyer Division (three destroyers), shall support the $2 \mathrm{~d}$ Escort Unit and the 1st Base Unit.

$2 d$ Escort Unit: [consisting of] the main force of the $2 d$ Destroyer Squadron (i.e. the light cruiser Jints $\bar{u}$ and a total of twelve destroyers of the 8th, the 15th and the 16th Destroyer Divisions), shall cooperate with the Eastern Detachment in its operations to capture Ambon, Kupang (and [also] Dili, which was included later).

1st Base Unit: [consisting of] the main force of the 1st Base Force, the light cruiser Nagara (which belonged to the 16th Cruiser Division), and four destroyers of the 21st Destroyer Division, which shall be joined by the 8th and the 15th Destroyer Divisions (eight destroyers in total) of the $2 \mathrm{~d}$ Destroyer Squadron at the time of the operation to capture Makassar, and by the 8th Destroyer Division (with four destroyers) at the time of the operation to capture Bali, shall support the operations to capture Makassar and Bali.

Special mention should be made of the following points concerning the operations of the Dutch East Indies Unit.

The first point is the previously mentioned clockwise route in [the operation to] capture Makassar. When the Dutch East Indies Unit ordered [the operation] on 28 January, the unit 
to capture Makassar was assembling in the Bangka anchorage, planning to sail counterclockwise [toward the city], while the Eastern Detachment had left Davao the day before (on the 27th) and was on its way to Ambon. On that day (the 28th), after confirming that the operation to capture Banjarmasin by sea was cancelled and that the new schedule set at the Manila Conference [was adopted], the Dutch East Indies Unit immediately ordered the main force of the 4th Destroyer Squadron to head northward to Luzon from Balikpapan (in order to make arrangements with the 48th Division, that is, to escort the transport of the division). [The Dutch East Indies Unit also] ordered the Makassar invasion unit to conduct the operation by a clockwise route, by which it intended to reinforce or support the Makassar invasion unit with the forces that were to be temporarily left in Balikpapan by the 4th Destroyer Squadron, and the forces that were to be diverted from the Eastern Attack Unit after its operation to capture Ambon (the landing on the island was scheduled for the 31st). ${ }^{(114,117)}$ At that time, the 21st Air Flotilla headquarters had advanced into Kendari the day before (on the 27th), ${ }^{(134)}$ while the 2d Carrier Division had carried out an air strike on Ambon on the 24th.

The second point is [the emergency situation during] the operation to capture Bali. At the time of the operation to capture Bali, the 1st Base Unit had the Nagara, and the 8th and the 21st Destroyer Divisions as its components, but due to various circumstances, merely two destroyers were in charge of the direct escort of the Kanemura Detachment. A number of allied cruisers and other vessels raided the anchorage. At that time, the commander of the Dutch East Indies Unit was in Balikpapan where he heard about the emergency and hurried southward with the main unit.

The third point is [the change in] the employment of the 5th Cruiser Division. As we have seen, before the Combined Fleet transmitted the order to transfer the Carrier Task Force [to the Southern Task Force] (on the 8th), the Air Unit (the Eleventh Air Fleet) had [already] carried out a massive air campaign on eastern Java (since 3 February). Therefore, along with the order concerning the operation of the Carrier Task Force on 9 February, the Southern Task Force had ordered that the 5th Cruiser Division should advance towards the sea southwest of Timor and cooperate with the Carrier Task Force in the second carrier operation. ${ }^{(117)}$ However, due to the weather and other factors, the Air Unit did not achieve satisfactory results, and when the convoy of the 48th Division entered the Java Sea, a powerful allied fleet was still very active in the Surabaya area. This brought about the necessity to resume the air attacks. Furthermore, the allied fleet came for an attack and the convoy of the 48th Division and the Sakaguchi Detachment were made to stand by at sea for three days. As a result, it was decided to cancel the cooperation of the 5th Cruiser Division with the Carrier Task Force, and to have the division take part in the battle off the coast of Surabaya [instead].

\section{(2) The Seizure of Banjarmasin (See Illustration No. 37)}

\section{Preparations for the Seizure}

When Detachment Commander Sakaguchi, who had landed in Balikpapan on 24 January and seized the city on the 25th, was implementing a military administration and was about to mop up the enemy in the areas of Samarinda and Sanga Sanga with a force [consisting of] the 1st Battalion as the core led by Lt. Col. Kume Motozō, he received the aforementioned Sixteenth Army order (of the 25th) regarding the seizure of Banjarmasin [p. 220]. 
As the Sakaguchi Detachment had been studying [the possibility of] an overland attack as well, the order came as no surprise. However, [the problem was that] the issue of an attack by sea [in conjunction with the Navy] was not settled until the 28th.

On the 28th, it was [finally] decided to cancel the joint Army-Navy operation to seize the city by sea. The next day, the 29th, the Dutch East Indies Unit ordered the commander of the 4th Destroyer Squadron to head for Manila [i.e. Lingayen]. He left Balikpapan on the 30th with the light cruiser Naka and the 2d Destroyer Division. ${ }^{(119)}$ On that day (the 30th), Detachment Commander Sakaguchi had the unit for the Banjarmasin operation depart from Balikpapan on the Ehime-maru and the Liverpool-maru.

Detachment Commander Sakaguchi planned to have the unit for the Banjarmasin operation rapidly advance toward the city with the main force by going ashore at Tanahgrogot and rushing toward the city overland, and one element by maneuvering from Balikpapan along the coast in small boats. The outline of his operation plan was as follows: ${ }^{(88)}$

\section{Mission}

(1) With the purpose of promptly seizing the airfield so that it can be used [in the operation to] capture Java, the unit shall make a surprise attack on the area of Banjarmasin and seize it, with its main force going by land after landing near Tanahgrogot and one element by landing in the area south of Banjarmasin after maneuvering along the coast in small boats.

(2) The transport of the troops and the maneuvering at sea shall be conducted only at night in order to keep the plan secret.

2. Disposition of forces

The overland task force

Commander: 146th Infantry Regiment Commander Col. Yamamoto Kyōhei

146th Infantry Regiment (minus the 1st and the 2d Battalions)

One artillery battery

One engineer company (minus one platoon)

One radio platoon

Medical unit

One transport company

The seaborne task force

One infantry company

One engineer platoon

One independent engineer platoon

3. Outline of Operations

(1) Operations of the overland task force

(a) The unit shall leave Balikpapan on the evening of 30 January, land in Tanahgrogot before daybreak of the 31st, and immediately make preparations for traversing the jungle and the mountains.

(b) When pushing its way through the jungle, the unit shall have one element of its force move ahead in the sector south of the main force in order to facilitate engagements after advancing into the Banjarmasin plain.

(c) Once emerging from the jungle, it shall start southward at once without waiting for the entire unit to gather. It shall rapidly advance, particularly in order to make it difficult for the enemy to destroy bridges while retreating.

(d) When seizing Banjarmasin, it shall make efforts to bring the seaborne task force [back] under its command.

(e) Provisions shall be procured on site as much as possible, but rations for nine days shall be carried along. 
(2) Operations of the seaborne task force

(a) The unit shall leave Balikpapan a few days earlier than the overland task force and seize Banjarmasin in close cooperation with the latter.

(b) It shall only use large and small motorized [landing] craft for the maneuver, and pay utmost attention to keeping the plan secret. [For that purpose,] no daytime actions are allowed until the end of the seaborne operation.

(c) When suspending operations during daylight, it shall go upriver at some distance from the mouth of rivers, moor the craft at the riverbank, and take a rest in the forest so as never to be spotted by [enemy] air reconnaissance.

(d) In order to make it safe to sail through the channel west of Laut Island, and facilitate the supply of provisions for the task force, it shall conduct a night raid on Kotabaru on the island to obtain supplies and collect information.

(e) After the landing, it shall rush toward the Martapura airfield.

(f) For provisions after landing, the unit shall depend on the resources on site.

(3) Operations after the seizure of Banjarmasin

(a) The commander of the overland task force shall bring the seaborne task force back under his command as soon as possible.

(b) It shall do its utmost to make the airfield ready while mopping up the remaining enemy.

(c) When the naval units arrive, it shall turn over the guarding, seized supplies and other matters to these units, and assemble in Banjarmasin.

\section{The Seizure}

The seaborne task force embarked on four large and two small motorized [landing] craft and left Balikpapan on the night of 30 January, loaded with fuel and ammunition from the Navy. It reached Tanahgrogot at daybreak on the 31st and continued its southward advance. A naval officer was attached as pilot. They sailed only at night; during the day they brought the craft into mangrove forests at the river mouths and camouflaged them. As they avoided using the radio, naval aircraft were sent to contact them, but every time these returned in vain without finding them. The unit operated in accordance with the orders, seized Kotabaru at the northern end of Laut Island on 10 February, further advanced, and went ashore at the coast southeast of Martapura. However, as the surprise attack of the overland task force had already scattered the enemy, they entered Martapura without a fight. ${ }^{(87,115)}$

The advance party of the overland task force had left Balikpapan on the morning of 31 January, reached Adang Bay at 2000 of the same day, and seized Tanahgrogot at 1030 on 1 February, while the main force left Balikpapan on the next day, the 2d, landed in Tanahgrogot on the $3 \mathrm{~d}$, and started its overland trek. There were no roads in the jungle, let alone bridges. [The unit] advanced and while being attacked by swarms of mosquitoes, land leeches and other insects, they clambered up steep mountains and threw temporary log bridges over deep gorges. They had abandoned their motor vehicles soon after departure. Although they [also] brought along 600 bicycles, only one soldier of the engineer unit carried his all the way through with an indomitable spirit. Just after they narrowly managed to make their way through the jungle-covered mountain range, they came across a Dutch East Indies army unit moving northward, which the Yamamoto (Kyōhei) Unit drove off after a minor battle. The Yamamoto Unit tried to hotly pursue the [enemy] unit toward Martapura, but it was not easy to assemble the entire unit and make it advance due to the fatigue from making its way through the jungle. However, the advance company led by Captain Kataoka, vying with the 


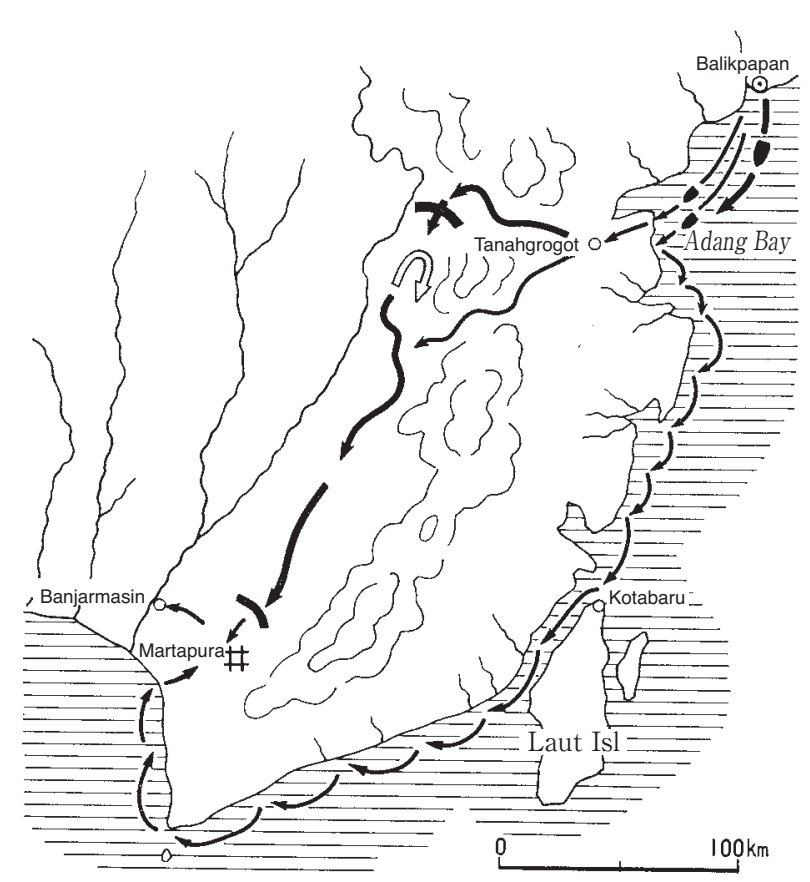

Illustration No. 37 - The Operation to Seize Banjarmasin

engineer company to be the first, chased [the enemy]. As the unit advanced, it gained more cooperation of the indigenous people. While obtaining bicycles, vehicles and provisions, the unit rushed forward and at 0900 on 10 February, the engineer company and the advance company seized the Martapura airfield..$^{(87)}$

The overland travel distance in this operation was some 400 kilometers, of which the jungle covered some 100 kilometers. The loss sustained in this operation was nine men killed by malaria. About $80 \%$ of the officers and men of the overland task force caught malaria. ${ }^{(87)}$

A unit in fishing boats loaded with the base matériel of the Eleventh Air Fleet left Balikpapan on 9 February and arrived at the Martapura airfield around 20 February. ${ }^{(139)}$ On 25 February, one element of the $23 \mathrm{~d}$ Air Flotilla advanced to the airfield, ${ }^{(104)}$ which was used as a relay base for the naval aircraft to advance to Bali.

\section{(3) The Seizure of Makassar (See Illustration No. 38)}

We have described the strategic significance of Makassar. The operation to seize Makassar was to be executed solely by the Navy and the date was [at first] arranged as day $x+45$ on 10 November. However, it was rescheduled for day $x+53$ on 1 January, due to the delay in the capture of Davao, [again] postponed to day $x+60$ on 6 January due to the delay in preparations for launching the Dutch East Indies operation, and [further] postponed to day $x+63$ (9 February) on 28 January due to the delay in making the Tarakan airfield ready and other reasons.

The seizure of Makassar was carried out by sailing from Kendari and crossing in front of the Lesser Sunda Islands, in front of the enemy. This came about because of the following circumstances.

Shortly before the Manila Conference (from 21 to 23 January), the Dutch East Indies Unit had the idea that it would have a ten-day-or-more postponement of the date of the Java landing operations approved, and that [then] the 1st Base Force, which was to [conduct the operation] to seize Kendari on 24 January, would [also] seize Makassar around 8 to 9 February, by sailing counterclockwise via Bangka and the Makassar Strait, along with the Sasebo Combined Special Landing Force, the 21st Destroyer Division, which would be transferred from the Combined Fleet, and one destroyer division, which would be brought in after the capture of Ambon (scheduled for 31 January). The 4th Destroyer Squadron would then conduct [the 
operation to] seize Balikpapan on 24 January and escort with its main force ([consisting of] two destroyer divisions) "a force [consisting of] one battalion of the Sakaguchi Detachment as the core to carry out the landing [operation] in Banjarmasin around 11 and 12 February." [Meanwhile,] the main unit of the Dutch East Indies Unit would then support and direct this operation from the Makassar Strait with the other forces in the areas of Davao and the Makassar Strait (including part of the 4th Destroyer Squadron, which would not participate in [the operation to] seize Banjarmasin). The Eastern Attack Unit ([consisting of] the 5th Cruiser Division and the $2 \mathrm{~d}$ Destroyer Squadron) would then act in concert with [this operation], while preparing for the coming [operation to] capture Timor. ${ }^{(117)}$

However, only a seven-day postponement was approved for the Java landing operation as a result of the Manila Conference, and the main force of the 4th Destroyer Squadron had to head northward for Luzon earlier to escort the transport of the 48th Division. Therefore, [the operation to] seize Banjarmasin by sea [in conjunction with the Navy] was cancelled. These matters were decided on 28 January, and the Southern Task Force transmitted order(s) concerning them on the same day. Then, based on the order of the Southern Task Force, the Dutch East Indies Unit sent a telegram at 1930 on the same day to change the operation to seize Makassar so as to be carried out by sailing clockwise. ${ }^{(114)}$ Because at that time, the unit [for the operation] to seize Makassar had already left Kendari the day before and had started northward for Bangka ${ }^{(117,124)}$ to seize Makassar by sailing counterclockwise, it ended up by having to turn around at Bangka to conduct the operation by sailing clockwise. On 29 January, the Dutch East Indies Unit ordered the 4th Destroyer Squadron commander to leave Balikpapan for Manila [i.e. Lingayen] with one destroyer division. ${ }^{(119)}$ It was [also] decided that the remaining forces of the squadron, which were left in Balikpapan, should sail northward for Jolo to escort the 48th Division, after cooperating in the Makassar [operation]. Further, on the same day, [the Dutch East Indies Unit] gave order(s) to increase the force to be diverted to the Makassar operation from Ambon after the capture of the island to two destroyer divisions by adding one more destroyer division. ${ }^{(119)}$

On 31 January, the Eastern Attack Unit launched the Ambon landing operation. As it was not until [later] on 4 February that the previously mentioned issue of a postponement of [Operation] L arose, a postponement of the [invasion] schedule was at that time as yet unthinkable. On receiving a report on the success of the Ambon landing [operation], the commander of the Dutch East Indies Unit, who felt sorry that the landing on eastern Java was scheduled for 23 February whereas that on western Java was scheduled for 21 February, immediately (on the same day) requested the Eastern Attack Unit to bring forward the Makassar operation. And on the next day (1 February), learning that the Eastern Attack Unit had no objections, the commander of the Dutch East Indies Unit passed down an order to advance the schedule by one day. ${ }^{(114)}$ However, as we have seen, the capture of Ambon and the minesweeping [of the bay] were confronted with unexpected difficulties. The next day, the $2 \mathrm{~d}$, the Dutch East Indies Unit withdrew the above order of the previous day and the date of [the operation to seize Makassar] was restored to 9 February as in the [previous] plan.

The units of the 1st Base Unit, which had left Kendari and had headed northward to Bangka since 27 January based on the original plan of the Dutch East Indies Unit to seize [Makassar by sailing] counterclockwise, made a U-turn and left Bangka on 2 February for Kendari at the change [to the new operation plan] to seize [Makassar by sailing] clockwise. Including the reinforcements [diverted] from the Ambon area, they left Kendari on 6 Febru- 
ary, conducted the Makassar landing operation on 9 February, and seized the city on the same day. ${ }^{(124)}$

The disposition of forces of the Eastern Attack Unit (commander: the 5th Cruiser Division commander) was in outline as follows: ${ }^{(14)}$

Eastern Attack Unit

Support Unit: [consisting of] the 5th Cruiser Division (with the heavy cruisers Haguro and Nachi (note: the Myōkō was still under repair in the mainland)), and the Akebono of the 7th Destroyer Division shall provide support, leaving Davao on 6 February.

1st Base Unit: [consisting of] the light cruiser Nagara ([of] the 16th Cruiser Division, shall leave Bangka on 2 February and [then] Kendari on the 6th); the 21st Destroyer Division (the Wak$a b a$, the Nenohi, and the Hatsushimo shall operate in the same way as the Nagara); the 15th Destroyer Division (the Natsushio, the Kuroshio, the Hayashio, and the Oyashio shall arrive in Kendari on the 4th from Ambon and leave there on the 6th); the 8th Destroyer Division (the Arashio, the Michishio, the Asashio, and the Ōshio shall arrive in Kendari on the 5th from Ambon and leave there on the 6th); the auxiliary seaplane tender Sanuki-maru (which had been damaged and was positioned in Balikpapan, and which was transferred to the 1st Base Force to use her seaplanes), and the main force of the Sasebo Combined Special Landing Force (shall leave Bangka on the 2d, arrive in Kendari on the 4th, and leave there on the 6th), shall [carry out the operation to] seize Makassar on the 9th, leaving Kendari on the 6th, under the command of the 1st Base Force commander.

2d Escort Unit: [consisting of] the light cruiser Jintsū, the 16th Destroyer Division (the Hatsukaze, the Amatsukaze, the Tokitsukaze, and the Yukikaze), and the main force of the 7th Destroyer Division (the Sazanami and the Ushio; this division was transferred by the Combined Fleet order of the 28th to the Dutch East Indies Unit as of 31 January) under the command of the 2d Destroyer Squadron commander, shall support the operation to seize Makassar, while continuing the Ambon operation.

2d Air Unit: [consisting of] the seaplane tenders Mizuho and Chitose of the 11th Seaplane Tender Division, shall support [the operation to] seize Makassar by winding up its support for the Ambon operation and advance westward toward the area southeast of Makassar.

While the operation to seize Makassar was conducted by the Eastern Attack Unit, the tasks of the units which had formerly belonged to the Western Attack Unit (under the command of the Dutch East Indies Unit commander), such as cooperating with the 48th Division and with the operation [to seize] Banjarmasin and Makassar, were in outline as follows:

The main unit of the Dutch East Indies Unit: [consisting of] the heavy cruiser Ashigara (of the 16th Cruiser Division), and the 1st [2d?] Section of the 24th Destroyer Division (the Suzukaze and the Yamakaze), shall support from Davao.

The 4th Destroyer Squadron commander shall leave Balikpapan on 30 January for Manila [Lingayen] with the light cruiser Naka and the 2d Destroyer Division (the Harusame, the Murasame, the Samidare and the Yüdachi).

The $2 \mathrm{~d}$ Base Force commander shall assume command of the force, which was left in Balikpapan by the 4th Destroyer Squadron, as well, and:

1. Transport base personnel and matériel of the Eleventh Air Fleet from Balikpapan to Banjarmasin by fishing boats, and

2. Leave Balikpapan on 8 February with the 9th Destroyer Division (the Natsugumo, the Minegumo, and the Asagumo; the Yamagumo was under repair at Lingayen Gulf) and the 1st Section of the 24th Destroyer Division (the Umikaze and the Kawakaze), and advance 
off the coast of Makassar on the 9th to support [the operation to] seize Makassar, after which he shall head northward to Jolo to join the escort of the 48th Division.

Note: Of the 1st Air Unit (i.e. the auxiliary seaplane tenders San'yō-maru and Sanuki-maru), which had taken part in the seizure of Balikpapan, the San'yō-maru was diverted toward Cam Ranh Bay to escort the main force of the Sixteenth Army. The Sanuki-maru was deployed as mentioned above.

The organization of the $2 \mathrm{~d}$ and 4 th Destroyer Squadrons was as follows:

The $2 \mathrm{~d}$ Destroyer Squadron: the light cruiser Jintsu and the 8th, the 15th and the 16th Destroyer

Divisions. (The 18th Destroyer Division had been transferred to the Carrier Task Force since before the opening of hostilities.)

The 4th Destroyer Squadron: the light cruiser Naka and the 2d, the 9th and the 24th Destroyer Divisions. (The 4th Destroyer Division had been transferred to the main force of the Southern Task Force since before the opening of hostilities, but was [temporarily re-transferred] to the 2d Carrier Division during early February.)

The unit [for the operation] to seize Makassar departed from Kendari on 6 February. ${ }^{(124)}$ Each unit concerned operated as planned. ${ }^{(14)}$ The air unit (i.e. the Eleventh Air Fleet) had launched a massive air campaign against eastern Java since 3 February, as mentioned previously. There was [almost] no interference [by the enemy] in the air as well as at sea, except some by allied submarines. Although some 1,000 Dutch East Indies troops were said to be [stationed] in Makassar, [the Japanese] easily seized the city on 9 February. ${ }^{(102,114,124)}$

The only loss sustained was the destroyer Natsushio, which was torpedoed and sunk on 9 February.

After the successful landing in Makassar (on the 9th), each unit operated in the following way: $(114,117,119,124)$

1. The 15th Destroyer Division and the seaplane tender Mizuho turned around for the coming operation to capture Timor.

2. The seaplane tender Chitose headed for Jolo to escort the 48th Division.

3. The 8th Destroyer Division headed for Jolo to escort the unit for [the operation to] capture Bali (the Kanemura Detachment).

4. The Nagara and the 21st Destroyer Division made preparations for the coming [operation to] capture Bali while taking charge of maintaining stability in Makassar and the vicinity.

5. The 9th Destroyer Division and the 1st Section of the 24th Destroyer Division, which had departed from Balikpapan, turned around on the 10th and headed northward for Jolo to escort the 48th Division.

6. The 5th Cruiser Division (which had left Davao on the 6th) entered Staring Bay on the 10th to make preparations to support the coming operation to capture Timor.

\section{(4) The Capture of Bali (See Illustration No. 39)}

We have seen that [the operation] to occupy Bali, which had been agreed on at the Iwakuni Conference for the first time, automatically disappeared [from the plans] after the Cam Ranh Agreement due to the moved-up schedule of the Java operation, but that it [again] came up for discussion in connection with the Banjarmasin issue at the Manila Conference; that in the middle of that conference, the chief of staff of the 48th Division, Kawagoe Moriji, visited the Eleventh Air Fleet headquarters in Davao and made arrangements [for the operation]; that 


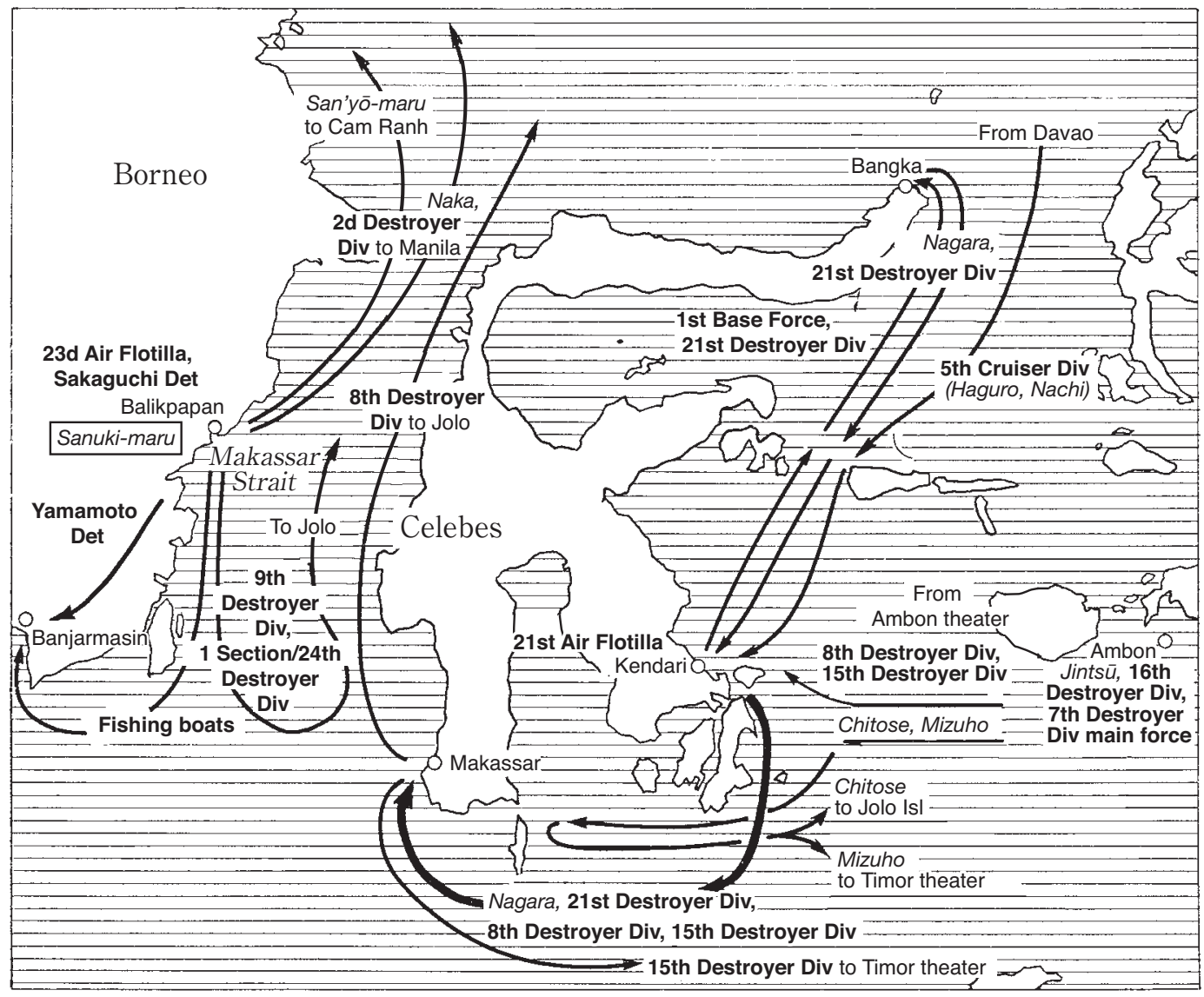

Illustration No. 38 - Overview of the Operation to Seize Makassar

in the draft arrangements between the Sixteenth Army and the Dutch East Indies Unit on 23 January, it was agreed to schedule it no later than day I - 2, and that on the 25th, the Southern Task Force sent the Southern Army a telegram to propose a date around day $x+75$ (day $x+$ 75 was [at that time] equivalent to day I -2 , that is, 21 February); and that although the execution of [the operation to] capture Bali and the schedule (around day $x+75$ ) was [finally] decided on 28 January, the Sixteenth Army had already passed down an order to capture Bali to the 48th Division earlier on 24 January.

As soon as capture of Bali was [officially] decided on 28 January, the commander of the Dutch East Indies Unit in Davao made up his mind to have the 1st Base Force commander conduct the Bali operation on the heels of [the operation to] capture Makassar, employing a force [consisting of] the Nagara (a light cruiser of the 16th Cruiser Division) and the 8th and the 21st Destroyer Divisions. On the same day, he ordered the 8th Destroyer Division (which was at that time sailing southward, escorting the Eastern Detachment for the operation to capture Ambon) to go to Jolo by 10 or 11 February in the wake of the capture of Ambon (on the 31st) and the capture of Makassar (on 9 February) and [then again] sail southward to escort the Kanemura Detachment. ${ }^{(117)}$

On 30 January, Commander in Chief of the Eleventh Air Fleet Tsukahara passed down order(s) in Davao concerning Operation Z (the massive air campaign over eastern Java to be 
launched from 3 February onwards). ${ }^{(143)}$ We have already related how surprised Chief of Staff Kawagoe of the 48th Division was about the great enthusiasm of Commander in Chief Tsukahara, when he previously (on the 23d) visited him in Davao, but at that time, the morale of the Eleventh Air Fleet was indeed sky-high. ${ }^{(136)}$ In line with the enthusiasm of the air fleet, Commander in Chief of the Third Fleet Takahashi, in Davao, decided to bring forward the operation to capture Bali by three days and ordered the 1st Base Force commander to [conduct the operation] on 18 February (day I - 5); (the latter was at the Bangka anchorage at that time, directing the clockwise change [in the operation] to capture Makassar). ${ }^{(117)}$

As previously related, in contrast to the order of Third Fleet Commander in Chief Takahashi to bring forward the [operation to capture] Bali by three days, Ozawa, commander in chief of the First Southern Expeditionary Fleet, proposed a postponement of [Operation] L for two days on 4 February and for another four days on the 6th (six days in total). Consequently, [the operation to] capture Bali became a stand-alone operation, separated from the Java landing operations in terms of schedule, which ended up increasing the risks, along with the bad weather (which hindered a satisfactory air campaign).

As previously related, on the 30th, Commander in Chief Takahashi gave orders to launch the operation "to capture Bali on the 18th [of February]," and at the same time he [also] gave instructions to advance [the operation] to seize Makassar. [Editor's note: Actually, the orders for Makassar were issued on 1 February.] As of that day [the 30th], the Combined Fleet had not yet issued orders to have the Carrier Task Force take part in the Java operation.

On 3 February, the air unit (i.e. the Eleventh Air Fleet) launched a massive air campaign over eastern Java (Operation Z). ${ }^{(134)}$ On that day, the Nagara and the 21st Destroyer Division under the command of the 1st Base Force commander were sailing southward to Kendari from Bangka to seize Makassar by a clockwise route, and the 8th Destroyer Division was still in the middle of the operation to capture Ambon. ${ }^{(117,124)}$ On that day (the 3d), Maj. Kanemura Matabē, commander of the $3 \mathrm{~d}$ Battalion of the 1st Taiwan Infantry Regiment, received in Manila the 48th Division's order concerning [the operation to] capture Bali, which was in outline as follows: ${ }^{(85)}$

The force consisting of the 3d Battalion (minus one company) of the 1st Taiwan Infantry Regiment, one mountain artillery section, and one independent engineer platoon as the core, led by Major Kanemura, commander of the battalion, shall be called the Kanemura Detachment.

The Kanemura Detachment shall leave Lingayen on the 5th, and assemble in Jolo on the 8th, where it shall make arrangements with the Navy and embark naval air [units'] matériel. [Then it shall] leave Jolo on the 13th, arrive in Makassar on the 15th, and go ashore on the coast east of Denpasar in Bali at midnight of the 18th, after which it shall seize the Kuta airfield (four kilometers southwest of Denpasar) and make it ready for use. It shall send out the empty ships on the night of the 19th and transfer the personnel and matériel of the independent engineer unit to the convoy of the main force of the division at the Makassar Strait.

At that time, Battalion Commander Kanemura had obtained the following information: There was about one battalion (some 600 troops) in Bali under the command of the eastern Java territorial commander, of which the main force was stationed in Singaraja, while one infantry company with armored cars was stationed in Denpasar and was guarding the Kuta airfield there. [Editor's note: There were no Dutch East Indies Army units stationed on Bali. The garrison consisted of local Balinese auxiliary troops led by a few European officers.] Four fortress 


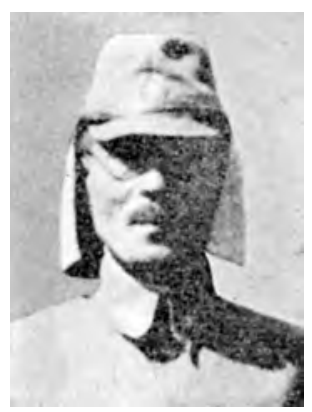

Commander of the $3 \mathrm{~d}$ Battalion of the 1st Taiwan Infantry Regiment, Maj. Kanemura Matabē

guns were deployed along the Lombok Strait. Mountains stretched close to the shorelines, and many petrified reefs and narrow channels made it difficult to carry out landing [operations] on Bali, but Sanur beach in the southeastern part of the island was sandy and suitable for the operation. Even then, the current in the Lombok Strait was so strong that it could reach five knots at its fastest. Although palm forests, dense forests and paddy fields were all around Denpasar and Kuta, the roads were well developed, etc. ${ }^{(85)}$

On the 7th, the fast ships Sasako-maru and Sagami-maru (how they were selected and brought around [for this operation] has been previously described) with the Kanemura Detachment on board left Lingayen plowing the waves and arrived in Jolo as early as on the 10th. ${ }^{(85)}$

The 8th Destroyer Division, which had left Ambon on the 4th and took part in the Makassar landing operations on the 9th, [also] arrived in Jolo at 1600 on the 10th. ${ }^{(117)}$

On the next day, the 11th, the Dutch East Indies Unit ordered the 1st Base Force to have the 21st Destroyer Division escort the transport ships loaded with matériel required for the Bali airfield and the like from Balikpapan and to have them arrive in Bali by the 24th. ${ }^{(117)}$ Accordingly, on the 13th, the 1st Base Force commander issued the following order: $(102,114,124)$

\section{1st [phase]: Raiding Operation}

The attack unit ([consisting of] the 8th Destroyer Division) shall leave Makassar on the 17th, escort the Kanemura Detachment (the Sasako-maru and the Sagami-maru), put [the detachment] ashore on Bali on the 18th, and leave Bali on the 19th to head back. After escorting the Sasakomaru and the Sagami-maru to Makassar, the 8th Destroyer Division shall return to its original unit (i.e. the $2 \mathrm{~d}$ Destroyer Squadron).

The support unit ([consisting of] the Nagara and (three destroyers of) the 21st Destroyer Division) shall leave Makassar on the 17th and take timely action to provide support.

2d [phase]: Transport Operation

The transport ships shall leave Balikpapan on the 20th and arrive in Makassar on the 22d under the escort of submarine chasers. The Nagara and the 21st Destroyer Division (three destroyers) shall leave Makassar on the evening of the 22d accompanying the transport ships and arrive in Bali on the 24th.

On that day (the 13th), the Kanemura Detachment and the 8th Destroyer Division left Jolo and advanced to Makassar on the 15th to stand by. ${ }^{(14,124)}$ On that day (the 15th), the Nagara, which had returned to Staring Bay after [the operation to] seize Makassar, left the bay and advanced to Makassar on the 16th. ${ }^{(124)}$

As previously related, on 3 February the air unit (the Eleventh Air Fleet) had launched Operation Z. However, the weather had been bad since 10 February. The attacks had not yet caused major damage to the allied air and naval forces, the surface forces in particular, in and around the Greater and Lesser Sunda Islands, and [what is more], the [real] situation was totally unknown due to the bad weather. On the 14th, the commander of the Eastern Attack Unit (i.e. the 5th Cruiser Division commander) expressed concern about [the situation] and requested to carry out an adequate air campaign in advance. ${ }^{(114)}$ The Dutch East Indies Unit commander agreed and on the 15th requested the air unit (the Eleventh Air Fleet) to do 
so. ${ }^{(114)}$ [However,] the weather still remained bad. On the 16th, the Dutch East Indies Unit commander passed down the order to postpone [the operation to] capture Bali by one day. ${ }^{(114)}$ On that day, the 21st Destroyer Division left Makassar for Balikpapan for replenishment. ${ }^{(24)}$

The next day, the 17th, the weather was still bad. The main unit of the Dutch East Indies Unit (the heavy cruiser Ashigara and the destroyer Yamakaze), which had left Davao on the 13th and advanced to Jolo on the 14th, left Jolo on that day to advance southward. ${ }^{(103)}$ The support unit of the Eastern Attack Unit (the heavy cruisers Haguro and Nachi and the destroyer Akebono), which had been positioned in Staring Bay since 10 February, left the bay on that day (the 17th) to support the Eastern Detachment in [its operation to] capture Timor. ${ }^{(114)}$

At 0100 on the next day, the 18th, the 8th Destroyer Division and the Kanemura Detachment ([on board] the Sasako-maru and the Sagami-maru) left Makassar for Bali. ${ }^{(102)}$ Ten minutes before [departure], the Dutch East Indies Unit commander wired: "[The detachment shall] turn back if the 1st Base Force commander judges the weather on the early morning of the 18th to be not suitable [for navy aircraft] to make a flight. In such a case, the Bali operation shall be postponed for another day." (114) However, the 1st Base Force commander decided to push ahead [regardless of the weather]. ${ }^{(114)}$ Fortunately the weather improved. The seaplanes of the Sanuki-maru in Makassar and the fighter plane unit of the 3d [Naval] Air Group of the 23d Air Flotilla from Balikpapan provided cover for the convoy. Twenty-seven land-based attack planes and eight Type-0 fighter planes of the air unit advanced over Surabaya, and conducted attacks on six destroyers, more than a dozen transport ships and other [vessels of the enemy] in port while engaging twenty [enemy] planes [in the air]. ${ }^{(100)}$ On that day, the Kanemura Detachment, which was only approached by one [enemy] flying boat coming for reconnaissance, sailed at high speed without being attacked by other enemy aircraft or vessels at all, entered the Sanur anchorage at 0015 on the 19th, and successfully went ashore at 0100. (102) $^{(102}$

Upon landing, the Kanemura Detachment headed westward, taking advantage of the darkness of the night and the heavy rain, seized the Denpasar barracks in a surprise attack, and [also] seized the Kuta airfield at 1130, clearing away resistance from a Dutch East Indies unit. ${ }^{(85)}$

On that day (the 19th), allied aircraft began a relentless bombardment [on the anchorage] from daybreak onwards, and their attacks lasted into the evening. ${ }^{(117)}$ The bombardment caused the Sagami-maru so much damage that she could only navigate with one screw, and it also caused some damage to the Sasako-maru. ${ }^{(117)}$ The disembarkation was continued amid the bombardment and submarine torpedo attacks. ${ }^{(117)}$ After completing the disembarkation, the Sagami-maru left the anchorage at 1725 , and started on her way back under the escort of the $2 \mathrm{~d}$ Section (the Michishio and the Arashio) [of the 8th Destroyer Division]. ${ }^{(117)}$ The Sasakomaru stayed at [the anchorage] under the escort of the 1st Section (the Öshio and the Asashio) to collect the [landing] craft. After the completion of collecting and loading the craft at 2350, she was about to start on her way back ${ }^{(117)}$ when allied naval vessels came for a raid, and an engagement began at 0000.(117) The allied fleet came in for an attack one after another. The destroyers Ōshio and Asashio bravely fought with the dominant allied naval vessels four times in some three hours* and sank one Dutch destroyer. ${ }^{(117)}$

${ }^{*}$ Note: According to U.S. and Dutch military history books, the first engagement [was with] two Dutch cruisers, one Dutch destroyer and two U.S. destroyers; the second through the 4th engagement [were with] one Dutch cruiser and four U.S. destroyers. 


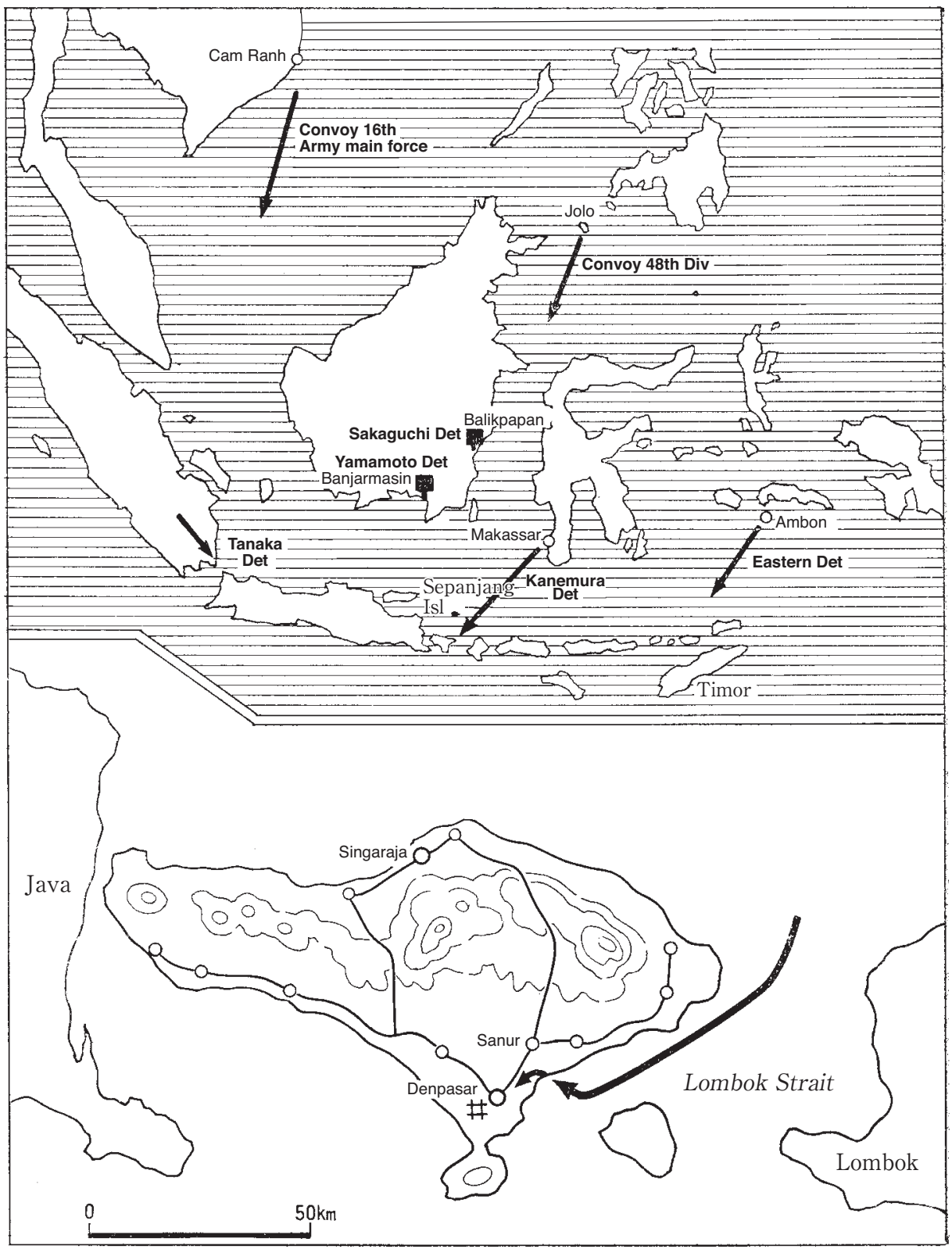

Illustration No. 39 - The Situation at the Time of the Operation to Capture Bali The Operation to Capture Bali

Later in the engagement, the $2 \mathrm{~d}$ Section (the Michishio and the Arashio) came across allied naval vessels at the east end of the [Badung] strait and for an instant fought with them. In the fight, the Michishio was hit in the engine room and got stalled at sea. ${ }^{(117)}$

The light cruiser Nagara and the 21st Destroyer Division (the Wakaba, the Nenohi and the Hatsushimo), which were standing by for support on the sea east of Sepanjang Island, hurried to the battle area, but the allied naval vessels had already gone. Also the main unit of the Dutch East Indies Unit ([consisting of] the heavy cruiser Ashigara and the destroyers Kawakaze 
and Yamakaze, which had left Jolo on the 17th and advanced to Balikpapan on the 18th) learned about the emergency, left Balikpapan at 0300 on the 20th, and sailed southward at full speed, but as a matter of course they were too late. The Nagara, the 21st and the 8th Destroyer Division (of which the Michishio was towed by the Arashio) headed back, beating off attacks by allied aircraft, and returned to Makassar on the night of the 21st. The main unit of the Dutch East Indies Unit left for Staring Bay. ${ }^{(102,117)}$

After seizing the Kuta airfield and while guarding and making it ready for use, the Kanemura Detachment [also] seized Singaraja on the 27th. ${ }^{\left({ }^{85}\right)}$

Considering the situation during the first [phase] of the raiding operation, the Dutch East Indies Unit commander revised the former order concerning the transport and landing operations in the second [phase]. ${ }^{(117)}$ On the $23 \mathrm{~d}$, five transport ships carrying personnel and matériel related to the [naval] air [units] left Makassar and debarked them at Bali on the night of the 24th [editor's note: actually the morning of the 25th, see Vol. 26, pp. 335-337] under escort of the Nagara and the 8th Destroyer Division (the Asashio and the Arashio) and the 21st Destroyer Division (the Wakaba, the Nenohi and the Hatsushimo). ${ }^{(102)}$ The main unit of the Dutch East Indies Unit (the heavy cruiser Ashigara and the destroyers Kawakaze and Yamakaze) left Staring Bay on the 23d to support the above [operation]. ${ }^{(103)}$ At that time, the 48th Division, which was to land on eastern Java (and had left Jolo on 19 February), was in the southern part of the Makassar Strait.

Thirty aircraft of the 23d Air Flotilla advanced to the Denpasar (Kuta) airfield as early as on the 20th, the day when the Kanemura Detachment had seized it, and the 23d Air Flotilla headquarters also advanced to Bali from Balikpapan on the 26th. ${ }^{(103)}$

The landing on Java, which had been scheduled for 26 February, was changed on the $23 \mathrm{~d}$ to the 28th and again changed on the 27th to 1 March and carried out on that day.

\section{(5) The Capture of Timor (See Illustrations No. 40 and No. 41)}

\section{Preparations for the Operation}

We have seen that in the plan before the opening of hostilities, Kupang was to be seized by the South Seas Detachment at the first opportunity; that after the opening of hostilities the desire grew to take advantage of the general war situation and concretely plan operations in the Banda Sea area, which led to the additional dispatch of the $2 \mathrm{~d}$ Carrier Division; that on 1 January it was agreed that the Eastern Detachment would seize Kupang on 11 February in the wake of the capture of Ambon; that on 5 January the Southern Army issued an order to seize Kupang, while proposing IGHQ to seize Dili; that on 28 January the date [to carry out the operation to] seize Kupang was postponed to 20 February; that the Southern Army, which had received no reply about Dili from IGHQ yet, suddenly received instead a telegram on 5 February from the Southern Task Force proposing [an operation against Dili], and after referring the matter to IGHQ, [finally] received the IGHQ Army Department Order of 7 February [approving the operation against Portuguese Timor]; and that on the next day, the 8th, the Southern Army gave an order to seize Dili as well, turning down the view of the Sixteenth Army [which wanted to concentrate on Kupang].

The order passed down by the Southern Army on 8 February was as follows: ${ }^{(23)}$ 
Southern Army Operation Order A, No. 54

\section{Southern Army Order}

Saigon, 8 February

1. The Sixteenth Army commander shall conduct operations against Portuguese Timor in conjunction with the Navy for the purpose of facilitating the Dutch Timor operation. The agreement between the Southern Army and the Second Fleet is as shown on the separate sheet.

2. If Portugal does not take hostile action or ceases such action at the time of the above operations [of ours], its sovereignty shall be respected as much as possible unless it affects the operations. In such a case, the measures which we will demand Portugal takes in defending Timor shall be given in a separate order. However, matters urgently required in terms of the operations can be demanded from Portugal, according to circumstances.

Separate Sheet

In view of the current situation where Australian and Dutch East Indies troops have occupied Portuguese Timor, one element of the Itō Detachment shall land in Dili when invading Timor (under the escort of the Navy) and seize the airfield in the vicinity almost simultaneously with the landing in Kupang.

As mentioned previously, the Southern Army had on 5 February received a telegram from the Second Fleet proposing the aforementioned agreement and wired back its approval on the 7th upon receiving the IGHQ Army Department Instructions. ${ }^{(23)}$

[Meanwhile,] the Navy Department of IGHQ gave directions to the Combined Fleet on the same day as the Army (on the 7th) with IGHQ Navy Department Order No. 14 and IGHQ Navy Department Instructions No. 51 that "operations can be conducted in Portuguese Timor." At 1120 on the same day (the 7th), the Dutch East Indies Unit (i.e. the Third Fleet) wired the Sixteenth Army the following proposal:(117)

Based on the instructions of central command and the commander of the Southern Task Force, we would like to discuss the following items regarding the operation to capture Timor:

1. Almost simultaneously with [the operation to] seize Kupang, one element of the Itō Detachment (for which adequate escort shall be provided) shall be put ashore in Dili and vicinity in Portuguese territory in order to seize the city (with seizing the airfield as the main purpose).

2. Depending on the situation after seizing Kupang, the Itō Detachment shall seize the Kolbano airfield (note by the author: presumably the Penfui airfield, which will be mentioned later) and make it ready for use.

Details shall be decided after consultation between Detachment Commander Itō and the $2 \mathrm{~d}$ Destroyer Squadron commander.

In response to the telegram, the Sixteenth Army wired back on 11 February that it had no objections. ${ }^{(114)}$ On the same day (the 11th), the Dutch East Indies Unit ordered the commanders of the 5th Cruiser Division and the 2d Destroyer Squadron to make arrangements with Detachment Commander Itō and the 21st Air Flotilla commander, and carry out the Dili and Kupang landing operations before daybreak on the 20th. ${ }^{(114)}$

On 13 February, Detachment Commander Itō discussed the arrangements with the Navy side in Ambon and concluded them on 14 February. ${ }^{(117)}$ He decided to have a force [consisting of] one battalion as the core led by Col. Doi Sadashichi, commander of the 228th Infantry Regiment, land in Dili, while he himself would land in Kupang leading the remaining forces. ${ }^{(78)}$

Around that time, the Navy side was dealing with the following problems: 
First of all, there was the issue of [a shortage of] destroyers. The destroyer divisions, which the Eastern Attack Unit was able to employ in the operation to seize Kendari, were the 8th, the 15th and the 16th Destroyer Divisions. The Combined Fleet and the Southern Task Force took various measures to help the Dutch East Indies Unit, which was suffering from a shortage of destroyers. The Combined Fleet added the 21st Destroyer Division, which the Dutch East Indies Unit and the Eastern Attack Unit employed for the Kendari [operation]. As the Eastern Attack Unit had to carry out in an extremely short period of time the operations to seize Kendari (on 24 January), then Ambon, then Makassar, and then again Timor, the Southern Task Force landed the carrier aircraft of the $2 \mathrm{~d}$ Carrier Division (with the carriers Sōryu and Hiry $\bar{u}$ ), which had returned to Davao on the 27th [according to Vol. 26, p. 231, the 25th] after conducting air strikes on Ambon on 24 January, onto land bases (in Kendari and Balikpapan), suspended the carrier operations, and added the 7th Destroyer Division, which had been attached to the $2 \mathrm{~d}$ Carrier Division, to the Dutch East Indies Unit. It was decided that the 21st Destroyer Division would prepare for [the operation to] seize Makassar while operating off eastern Celebes; whereas the 8th, the 15th, the 16th and the 7th Destroyer Divisions would take part in [the operation to] capture Ambon (on 31 January). [Meanwhile] on 28 January, [the operation to] capture Bali was newly included. [Accordingly,] the Eastern Attack Unit assigned the 21st Destroyer Division in Celebes to the operations to seize Makassar, and then Bali, from Kendari. It also arranged that among the destroyer divisions which had participated in the Ambon [operation], the 8th Destroyer Division would [further] take part in [the operation to] seize Makassar and then Bali, that the 15th Destroyer Division would reverse course [for the operation to] capture Timor after taking part in the Makassar [operation], and that the 7th and the 16th Destroyer Divisions would prepare in Ambon for [the operation to] capture Timor. However, the Southern Task Force decided to have the $2 \mathrm{~d}$ Carrier Division (with aircraft carriers) conduct an air strike on Port Darwin prior to [the operation to] capture Timor, and issued an order on 5 February that the 7th Destroyer Division should return to the 2d Carrier Division. ${ }^{(112)}$ The Eastern Attack Unit was perplexed; it immediately wired [to the Southern Task Force] the request to let it continuously employ the 7th Destroyer Division. ${ }^{(112)}$ Just at that time (on 7 February), the unit was ordered to further [carry out the operation to] seize Dili as well, which made the situation even more serious. The Eastern Attack Unit and the Dutch East Indies Unit repeatedly wired requests [to the Southern Task Force to keep the 7th Destroyer Division]. On 12 February, the Southern Task Force sent a reply that the employment [of the 7th destroyer division] could be continued. ${ }^{(112)}$ [It was because] before that, on 9 February, the Southern Task Force had dropped the idea of carrying out the air strike on Port Darwin solely with the $2 \mathrm{~d}$ Carrier Division, and issued an order to have the $2 \mathrm{~d}$ Carrier Division return to the Carrier Task Force.

The second problem was the order of the Combined Fleet to additionally deploy the Carrier Task Force (the First Air Fleet) [to the southern operation]. On 31 January, the Combined Fleet had issued an order to transfer the entire force of the Carrier Task Force [to the Southern Task Force] but revised it on 8 February so that the 5th Carrier Division was excluded. ${ }^{(116,123)}$ [As such] it was helpful for the Timor invasion units that the Carrier Task Force would attack the Port Darwin area. However, it meant that the 5th Cruiser Division got the additional task of cooperating in the operations of the Carrier Task Force, as mentioned previously.

The third problem was [the deployment of] the seaplane tenders Chitose and Mizuho. Both had participated in the operation to seize Makassar after the Ambon operation, and the for- 
mer had headed for Jolo to escort the 48th Division, while the latter was in Staring Bay, anticipating possible participation in the eastern Java operation. The units concerned [now] requested the participation of the Mizuho [in the operations against Timor], insisting it would be necessary to have a seaplane tender to accompany and escort the convoy. [As a result,] on 16 February the Dutch East Indies Unit issued an order to have the Mizuho join in [the operation to capture] Timor. ${ }^{(114,117)}$

The fourth problem was the deployment of the 21st Air Flotilla. Its deployment was affected by that of the $2 \mathrm{~d}$ Carrier Division and of the Carrier Task Force, the cancellation of [the operation to] capture Banjarmasin by sea [by the Navy in conjunction with the Army], and other [factors]. The 21st Air Flotilla commander, who had his headquarters in Kendari, was positioned in Ambon between 12 to 17 February and while directing air operations against this area, made arrangements for the Timor operation. ${ }^{(143)}$

The fifth problem was the [issue of] naval units to be employed for ground operations. It was decided not to use them for Dili, because the strength of the landing force would not be sufficient. [Instead,] it was decided that the main force of the 3d Yokosuka Special Landing Force (a paratrooper unit), whose paradrop operation on Balikpapan had been called off, would conduct a parachuting operation in the Kupang area, and the [remaining] element of the force and two platoons of the Sasebo Combined Special Landing Force ([stationed in] Makassar) would conduct landing operations against Kupang along with the Itō Detachment. ${ }^{(14,117)}$

[Sorting out] these problems, the Navy made decisions on the major issues by 16 February, and its plan was in outline as follows. ${ }^{(113,117)}$ At that time, the 1st Base Force was preparing for [the operation to] capture Bali along with the light cruiser Nagara and the 8th and the 21st Destroyer Divisions, in conjunction with the [Army] Kanemura Detachment, as already described. Meanwhile, the Carrier Task Force, which had left Palau the day before (on the 15th), was sailing southward to attack Port Darwin. In the western [theater of the Dutch East Indies operation], the Bangka and Palembang landing operations were conducted on the 15th.

The Support Unit, [of the Dutch East Indies Unit, consisting of] the 5th Cruiser Division (the heavy cruisers Haguro and Nachi) and the destroyers Akebono and Ikazuchi (the former from the 7th Destroyer Division and the latter from the 6th) shall support [the operation to] capture Timor as well as to cooperate with the Carrier Task Force, by leaving Staring Bay on the 17th (the 18th for the Ikazuchi) and sailing southeastward.

The 2d Escort Unit (led by the 2d Destroyer Squadron commander)

The Main Force, [consisting of] the light cruiser Jintsu and the destroyer Hatsukaze, shall leave Ambon for the Kupang area on the 17th and support all operations.

The Cover Unit, [consisting of] the 15th Destroyer Division (the Kuroshio, the Hayashio and the Asashio [Oyashio?]), shall leave Ambon on the 17th and cover the Kupang area.

The 1st Detachment, [consisting of] the 16th Destroyer Division (minus the Hatsukaze, that is, the Yukikaze, the Tokitsukaze and the Amatsukaze), is to leave Ambon on the 17th and escort the Kupang landing units.

The $2 \mathrm{~d}$ Detachment ([consisting of] the 1st section (the Ushio and the Sazanami) of the 7th Destroyer Division) shall leave Ambon on the 18th and escort the unit for seizing Dili.

Two platoons of the Sasebo Combined Special Landing Force shall be assigned to the Kupang area.

The Mizuho (seaplane tender) shall move to the Kupang area, leaving Staring Bay on the 17th. 
The 3d Yokosuka Special Landing Force (under the command of the 21st Air Flotilla) shall parachute down in the Kupang area on the 20th and the 21st.

It was decided that the main force of the Eastern Detachment, directly led by Detachment Commander Major General Itō, would leave Ambon on the 17th, and one element of the detachment, led by Regimental Commander Doi, would leave Ambon on the 18th, and land in Kupang and Dili respectively before daybreak on the 20th. ${ }^{(76)}$ The [information on] the situation obtained before departure and the operation plan will be described later.

\section{The Carrier Task Force's Air Strike on Port Darwin}

As already mentioned, the commander of the Southern Task Force (he had been positioned in Palau since 18 January) received on 8 February the Combined Fleet's order concerning the transfer of the Carrier Task Force to his command and on the same day issued his orders regarding the advance of the Carrier Task Force to Palau, the 2d Carrier Division's return to the Carrier Task Force (from Davao, from the command of the Eleventh Air Fleet), and others. On the next day, the 9th, he [also] gave orders regarding the first carrier operation (the attack on Port Darwin just before the landing [operation] on Timor), and the second carrier operation (the operations in the Indian Ocean at the time of the Java landing operations). On that day (the 9th), the enemy position was judged to be as follows: ${ }^{(117)}$

Through our air raids at the beginning of February, the enemy based on Java has lost most of its air and naval forces, and as our invasion operations progress, it is highly likely that the remaining forces will attempt to escape to Australia, India and South Africa; it is also quite likely that British, U.S., Dutch and Australian naval forces will appear in the eastern part of the Indian Ocean to pick them up. Further, it seems that part of the enemy forces have already escaped to Port Darwin and vicinity; there is information that part of the U.S. air reinforcements have been operating in concert with part of British and Australian forces, using [Port Darwin] as a base.

The plan was that the Carrier Task Force (commander, V. Adm. Nagumo Chūichi, commander in chief of the First Air Fleet) would depart from Palau on 15 February, return to Staring Bay after the first carrier operation, and [then] launch the second carrier operation; the main unit of the Southern Task Force would leave Palau on 18 February, advance into Staring Bay, and launch the second carrier operation. The forces, which had assembled in Palau by the 15 th, were in outline as follows: ${ }^{(103,116,123)}$

The aircraft carriers Akagi and Kaga of the 1st Carrier Division.

The aircraft carriers Sōry $\bar{u}$ and Hiryū of the $2 \mathrm{~d}$ Carrier Division.

The battleships Hiei, Kirishima, Kongō and Haruna of the 3d Battleship Division.

The heavy cruisers Maya, Takao and Atago of the 4th Cruiser Division (note: the Atago was the flagship of the Southern Task Force, and the Chōkai of this division was the flagship of the Malaya Unit).

The heavy cruisers Tone and Chikuma of the 8th Cruiser Division.

The light cruiser Abukuma, the 17th Destroyer Division, and the 2d Section of the 27th Destroyer Division of the 1st Destroyer Squadron.

The 4th Destroyer Division (of the 4th Destroyer Squadron), the 18th Destroyer Division (minus two destroyers), and the Akigumo. 
Of the above, the Atago, the 3d Battleship Division and the 4th Destroyer Division (the Arashi, the Nowaki, the Hagikaze and the Maikaze) were to leave Palau for Staring Bay on the 18th as the main force of the Southern Task Force, while the others left Palau on that day (the 15th) as the Strike Force for the attack on Port Darwin. ${ }^{(103,116,123)}$ In the western [theater of the Dutch East Indies operation], the Bangka and Palembang landing operations were carried out on the same day, while the Malaya Unit was engaging an allied fleet that [attempted] a counterattack in a sea battle.

On the 19th (the day before the Timor landing operations), the Carrier Task Force reached the waters about 220 nautical miles north-northwest of Port Darwin and launched an attack on Port Darwin with the full force of its aircraft (namely, thirty-six fighter planes, seventy-one car-

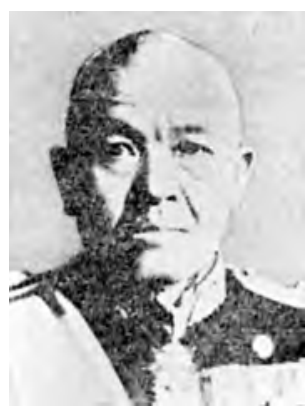

Commander in Chief of the First Air Fleet V. Adm. Nagumo Chūichi rier-based bombers, and eighty-one carrier-based attack planes). On that day, in concert [with this attack], the 21st Air Flotilla, [then] based in Kendari and Ambon, also attacked Port Darwin with the full force of its land-based attack planes. They reported the military gain of bringing down ten small and one large [enemy] aircraft in the air and sinking two destroyers and ten transport ships at sea, and that the allied forces in Port Darwin were wiped out. ${ }^{(103,}$ $116,123)$

\section{The Seizure of Kupang}

On the same day, the Eastern Detachment was approaching Kupang and Dili.

That is, the Miike-maru (with Detachment Commander Itō on board), the Africa-maru, the Ryōyo-maru, and the Zen'yo-maru carrying the main force of the Eastern Detachment, which had left Ambon at 0500 on the 17th and had passed through the Alor Strait on the night of the 18th, were making a detour at sea west of Timor on that day [the 19th] to sail toward the south of Kupang. Meanwhile, the Yamaura-maru carrying Regimental Commander Doi and his men, who were to [conduct the operation to] seize Dili, had left Ambon at 0230 on the 18th and was approaching Dili on that day [the 19th]. The Navy was escorting the convoys, operating as in the previously described plan.

The Eastern Detachment commander was only provided with maps on a scale of 1:2,000,000 for Timor and aerial photographs of Kupang and the vicinity. He understood that some 3,000 troops were stationed near Kupang and some 1,000 near Dili. He had also heard that there were entrenched positions and gun batteries near Kupang, that mines were laid in the coastal waters, and that most of the allied aircraft in Kupang had been destroyed. ${ }^{(78)}$

As for the Kupang area, the Eastern Detachment planned to seize the city from the south after landing on the south coast, where the defenses were considered weak. At this time, one element of the force was to advance northeastward to cut off the road that ran eastward from Kupang; another element of the force was to cooperate with the naval paratrooper unit in seizing the Penfui airfield, and yet another element of the force was to seize the coastal batteries. ${ }^{(78)}$ The Navy planned to have some 300 paratroopers of the $3 \mathrm{~d}$ Yokosuka Special Landing Force, carried by twenty-eight transport aircraft, seize the Penfui airfield by parachuting at 1030 on the 20th onto a pasture four kilometers northeast of Babau, [then] to have reinforcements parachute in on the 21st in the same way as on the 20th, and to have the remaining 118 men of the landing force and two platoons of the Sasebo Combined Special Landing Force 
go ashore with the main force of the Eastern Detachment and advance toward the Penfui airfield. ${ }^{(102,103)}$

The Eastern Detachment, assuming that the main force would land in the Kupang area and one element of the force in the Dili area before daybreak on the 20th, planned its operations as follows: ${ }^{(76,78)}$

\section{Main force of the detachment}

Right Attack Unit [consisting of] the 2d Company, one machine gun platoon, a battalion gun platoon (with one gun), one radio squad, and one element of the medical unit, led by the $2 \mathrm{~d}$ Company Commander 1st Lt. Kambe Masaji, after landing on the coast east of Cape Benini, shall promptly advance to Oesau and vicinity by way of the road connecting Baun - Oekahiti - Oesau and while defeating the enemy along [the road], it shall secure the neighborhood of the location and cut off the escape route of the enemy. During the advance up to Baun, it shall generally position itself behind the advance company of the center attack unit.

Center Attack Unit [consisting of] the 3d Battalion, one antitank gun company, and one mountain artillery battery (minus one section) as the core, led by the $3 \mathrm{~d}$ Battalion Commander Maj. Nishiyama Haruka, shall land on the coast between Cape Benini and Cape Mali, advance from Baun to the area southeast of Kupang by way of the road connecting Highland 385 - Kupang and while defeating the enemy along [the road], prepare for the subsequent attack on Kupang. It shall seize the Penfui airfield with one element of its force.

Left Attack Unit [consisting of] the 1st Battalion (minus two companies, one machine gun platoon, and the main force of the battalion artillery), a light-armored car company, one antitank gun platoon and one mountain artillery battery as the core, led by 1st Battalion Commander Maj. Hayakawa Kikuo, shall land on the coast northwest of Cape Mali, promptly seize the battery near Oilalus, advance into the area south of Kupang by way of the road connecting Cape Mali - Oilalus - Kupang, and while defeating the enemy along [the road], prepare for the subsequent attack on Kupang.

Artillery Unit [consisting of] the 2d Battalion of the 38th Mountain Artillery Regiment (minus two batteries), shall land on the coast east of Cape Mali, follow the rear of the center attack unit, and cooperate in the operations of the latter as needed.

Reserve Unit [consisting of] one company of the 1st Battalion, shall land on the east coast of Cape Mali following the main units and operate along with the detachment headquarters.

The detachment headquarters shall land on the coast east of Cape Mali and proceed at the rear of the center attack unit.

2. Dili attack unit [consisting of] the $2 \mathrm{~d}$ Battalion as the core, led by 228th Infantry Regiment Commander Col. Doi Sadashichi, shall land on the coast west of Dili and promptly seize the airfield.

The unit for seizing Kupang sailed without being attacked by allied air or naval forces. Its right, center and left attack units went ashore on the coast east and west of Cape Mali between 0235 and 0315 on the 20th and immediately started their advance. On that day, while the right and center attack units advanced to Highland 363 and Highland 385 respectively, the left attack unit rushed into Kupang as early as at 1900. [Also] on that day, the commander of the Yokosuka Special Landing Force and his men, a total of 308 paratroopers, parachuted down onto a pasture four kilometers northeast of Babau at 1045 meeting with no resistance and seized Babau by evening. ${ }^{(76,103)}$

On the next day, the 21st, the right attack unit advanced into Oesau at 1730, eliminating weak resistance, and set about occupying the position so as to cut off the eastward escape route of the allied units. On that day, the center attack unit entered Kupang at 0900, elimi- 
nating weak resistance. The 9th Company of the center attack unit had separated [from the main unit] at Highland 385, seized the Penfui airfield at 1400 on that day and handed over [the airfield] to the already-mentioned navy unit that had landed east of Cape Mali and followed [the army units]. At 1015 on that day, 323 men of the 2d Paratroop Unit of the Yokosuka Special Landing Force parachuted down onto the aforementioned pasture. The unit which had parachuted down the day before was not yet able to reach the Penfui airfield on that day due to destroyed bridges and obstruction by allied units. [In the meantime,] the detachment headquarters entered Kupang at 1700.(76,103)

On the next day, the 22d, the paratrooper unit of the Yokosuka Special Landing Force [finally] got to the Penfui airfield at $0600 .^{(102,103)}$

On that day (the 22d), Detachment Commander Itō, who was [positioned] in the city of Kupang, learned around 1030 that the right attack unit in Oesau had come under attack of some 1,000 allied troops trying to envelop them from the west with more than a dozen guns and armored cars. The detachment commander immediately dispatched the Murase Unit (a unit [consisting of] the 9th Company, the main force of the machine gun company, and one antitank gun platoon as the core, led by Capt. Murase Jishichirō, commander of the $3 \mathrm{~d}$ Machine Gun Company) from Pasir Panjang (about twenty-two kilometers west-southwest of Oesau) and requested the cooperation of naval aircraft. [Editor's note: The text has "Keshiru," which could not be identified. Based on the location, it was most likely Pasir (Panjang).] Then he [also] sent the Hayakawa Unit ([consisting of] the main force of the 1st Battalion of the 228th Infantry Regiment, two batteries and a light-armored car company, led by 1st Battalion Commander Maj. Hayakawa Kikuo). The Murase Unit left Pasir Panjang at 1200, and the Hayakawa Unit left Kupang by motor vehicles at 1430. The main force of the $3 \mathrm{~d}$ Battalion was assigned to guard the Kupang area. ${ }^{(76,14)}$

Since around 0700 on that day, the right attack unit, led by First Lieutenant Kambe (a total of 206 men at the Oesau position; see the previous description for its formation) had been under attack from the above-mentioned allied unit. By 1430, the ammunition of its grenade launchers ran out and only ten shells were left for the battalion gun. Losses were incurred one after another, and First Lieutenant Kambe also got injured at 1600. However, around 1700 a naval aircraft unit in a nine-plane formation dropped bombs at the rear of the allied unit, and around 1800 artillery was [also] heard from the rear of the allied unit. [It was] the Murase Unit, which had arrived there and started attacking the enemy from the rear. Then, the Hayakawa Unit [also] arrived and launched attacks, taking the Murase Unit under its command. The allied unit fiercely intensified its attacks, trying to break through the position of the Kambe Unit and escape eastward. By around 1830, the platoon positions in the right front line (north of the main road) and in the left rear were overrun, and only the position in the left front line remained. The ammunition ran out. The allied unit picked up the dead and the injured, broke through the [road] blocks at the east end of Oesau, and left eastward in over a hundred motor trucks. It was judged that their total strength was 1,500 troops and the number of casualties 500. As for the Kambe Unit, sixty-seven men were killed, and thirtyfour were wounded in the battle. Seeing the allied unit retreat, First Lieutenant Kambe followed, leading the remaining troops from the platoon positions in the left front line and in the left rear, but they constituted only nine men. ${ }^{(76,14)}$

After that, Major Hayakawa, bringing the right attack unit under his command as well, started pursuing the enemy, caught them in the area east of Naibonak at daybreak of the 23d, 


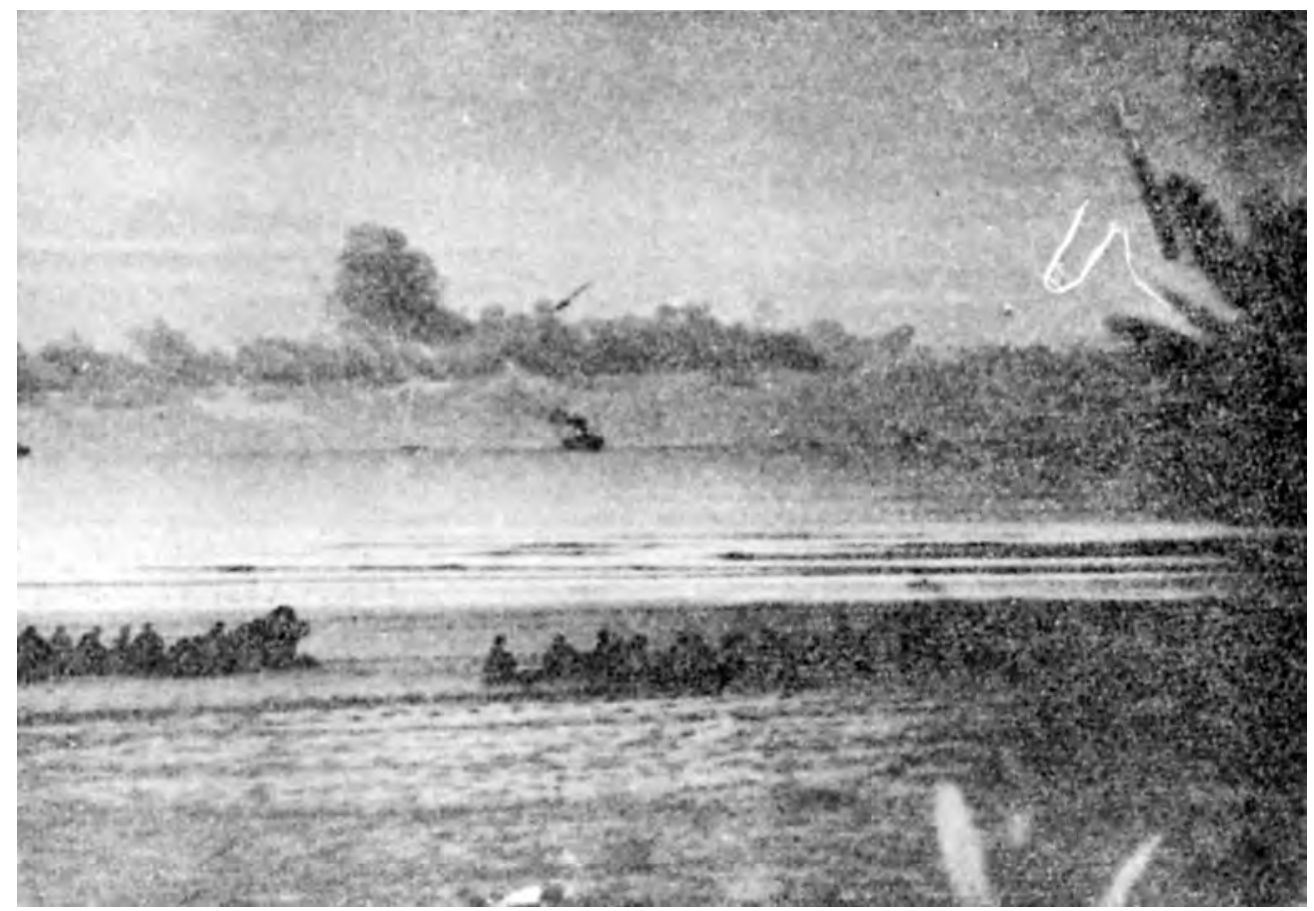

Landing in Kupang in the face of the enemy (20 February)

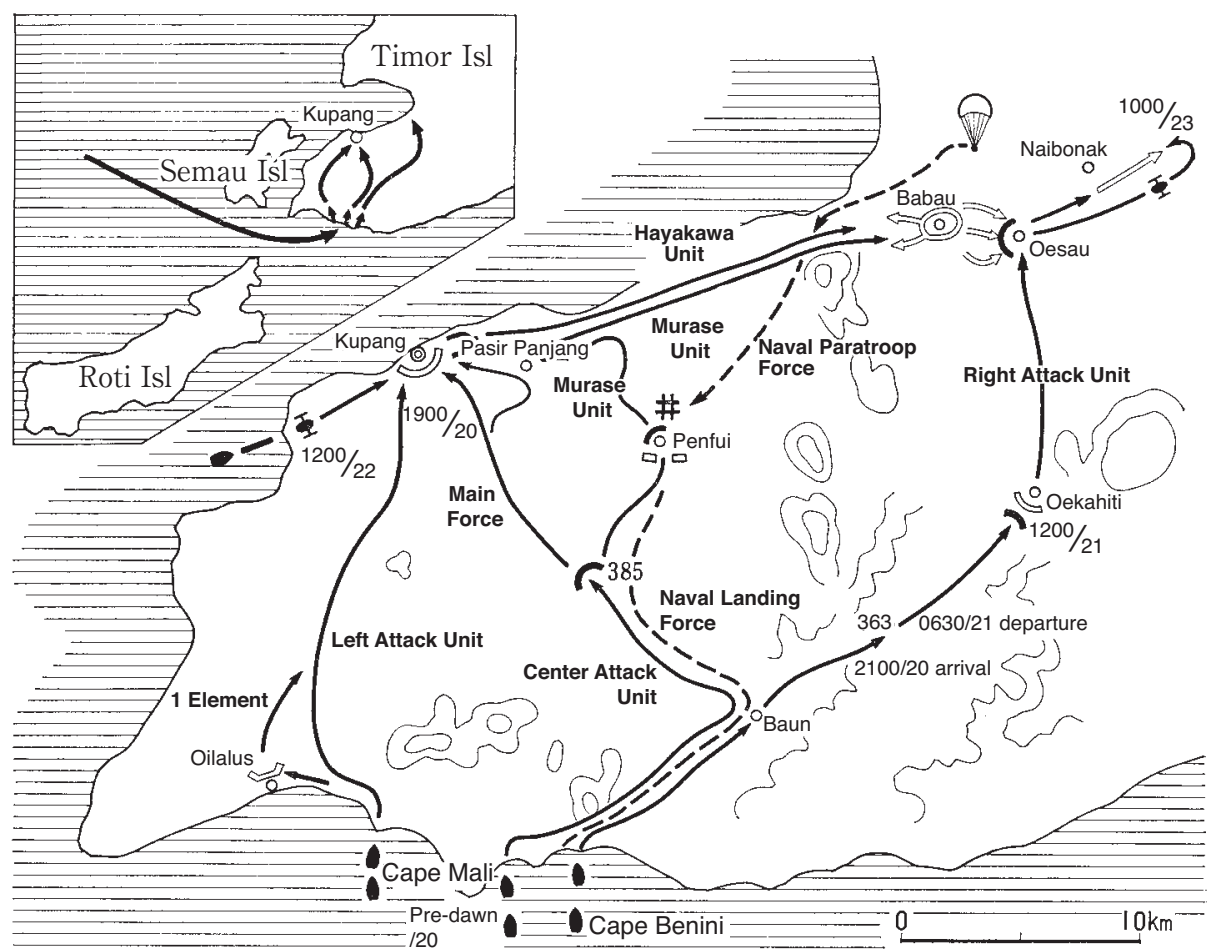

Illustration No. 40 - The Operation to Seize Kupang 
and at 1000 on the same day, he finally made some 1,000 troops (with about 100 light-armored cars and other vehicles) surrender. ${ }^{(76,14)}$

According to a later study by the Eastern Detachment, the main force of the allied unit, which was positioned near Kupang at the beginning, started its retreat eastward before the advance of the main force of the Eastern Detachment into Kupang and [further] retreated by breaking through the positions of the right attack unit in Oesau. The [allied] force, which fought with the Eastern Detachment in the Kupang area consisted of about 1,940 troops (some 1,500 Australian troops (including some 150 British), some 240 Dutch East Indies troops and some 200 indigenous troops); 296 abandoned bodies were confirmed, and 1,136 men (179 British, 934 Australian and 23 Dutch) were taken prisoner.

The detachment sustained a loss of sixty-seven men killed and fifty-six wounded in action. However, it seized seven tanks, five armored cars, two 15-cm. cannon (with 287 shells), eight mortars (with 3,000 shells), four antitank guns, six 37- $\mathrm{mm}$. antiaircraft automatic guns (with 3,282 shells), eighteen 13-mm. antiaircraft machine guns, forty-five heavy machine guns (with 47,100 bullets), thirty-six [semi-]automatic rifles (with 4,400 bullets), 756 rifles (379,760 bullets), and others. ${ }^{(76)}$

[Later] on 10 May, [Sixteenth] Army Commander Imamura conferred a citation of merit on the $2 \mathrm{~d}$ Company of the 228th Infantry Regiment and the units attached to it, led by the company commander, First Lieutenant Kambe, and proclaimed their distinguished military service to the entire army. It read: "You landed in the face of the enemy on the coast at the southwestern end of Timor on 20 February, forced your way through mountains and the jungle and while everywhere destroying the enemy, advanced into Oesau and vicinity on the 21 st and cut off the escape route of the enemy in Kupang and vicinity. Then on the next day, the $22 \mathrm{~d}$, at the attack of over 1,000 enemy troops with mechanized units, you first fought back the relentlessly repeated attacks by a group of tanks, held your position well with a small force by charging again and again toward all fronts against the enemy, which stormed into your position with tanks at the head while gradually enveloping [the position], and finally enabled the main force of the detachment to catch the enemy on the next day, the 23d." (14)

Eleven aircraft of the 21st Air Flotilla advanced into the Kupang (Penfui) airfield as early as on the $23 \mathrm{~d} .{ }^{(103)}$

Minesweeping of the sea near Kupang was relatively easy. Transport ships changed their anchorage [first] to one in the northwest, another in the north, and then another in the east [approaching Kupang], and disembarked most of the munitions at the city of Kupang.(117)

As mentioned previously, although no allied fleets were seen in Timor, strong fleet(s) still remained in the Surabaya area. [Consequently,] the 5th Cruiser Division's cooperation in the second carrier operation was canceled. It was decided that only the 15th Destroyer Division would take part in the second carrier operation, and that all the other ships would hurry westward to cooperate in the eastern Java landing operation of the 48th Division and the Sakaguchi Detachment.

\section{The Seizure of Dili (See Illustration No. 41)}

The strength of the unit to seize Dili consisted of the 228th Infantry Regiment (minus the 1st and the $3 \mathrm{~d}$ Battalions and the main force of the signal company), one independent engineer 
platoon (minus two squads), and one element from each of the divisional signal, transport, and medical and other units, led by Regimental Commander Colonel Doi. ${ }^{(76)}$

The mission of the unit to seize Dili was to go ashore in the area west of Dili, advance eastward and seize the Dili airfield. ${ }^{(76,77,78)}$

The situation in Dili and vicinity was almost unknown. There were many issues to be considered, such as the whereabouts of some 1,000 British, Australian and Dutch troops, which had reportedly entered Portuguese territory, whether [the unit] should also attack Portuguese forces if they should put up resistance, and how to identify friend or foe in the darkness after the night landing. ${ }^{(77)}$

The time of the landing of the unit was set for 0000 on the 20th. It entered the anchorage (one kilometer northwest of Dili) under escort of the Ushio and the Sazanami ([of] the 7th Destroyer Division) and started shifting to [landing] craft, when it came under the fierce fire of artillery and machine guns. [In response to] the inquiry from the Ushio about whether to provide cover fire, Regimental Commander Doi requested to give it. The Ushio and the Sazanami opened fire. Avoiding the gunfire, the unit moved the craft westward and went ashore at the mouth of the Comoro River at $0218 .{ }^{(77,117)}$

The unit headed eastward, groping in the dark and being obstructed in places by walls of cactuses as high as the height of the troops, it made an attack on a position, [guarded] with a couple of lines of barbed wire entanglements and landmines. After that, it seized the airfield and the city of Dili by around 1300 and rescued thirty Japanese [residents] kept in confinement. ${ }^{(77)}$

The number of the allied troops who put up resistance was about 1,300 men (some 300 Australian, some 400 Dutch East Indies and some 600 indigenous troops). Most of them escaped into the mountains except thirty-three who were captured. The loss sustained [by the Japanese] was seven men killed in action. The unit seized thirteen mountain guns (with 348 shells), one machine gun (with 5,000 bullets), 1,804 rifles (with 3,000 bullets) and others. ${ }^{(76)}$

The airfield had been destroyed to such a degree that ten days of restoration work was required before it could hold about twenty fighter planes. ${ }^{(17)}$ Only the Australian troops had offered resistance when the unit to seize Dili landed in the Dili area, whereas the Portuguese troops had not resisted. Furthermore, the Portuguese authorities had not evacuated [from Dili] and were [still] stationed in the city. The unit that seized Dili carefully respected [Portuguese] sovereignty by using the barracks of the Australian troops. ${ }^{(117)}$

After that, the Eastern Detachment gradually expanded the area to mop up the enemy from both Kupang and Dili and completed clearing almost the entire island in mid-April. ${ }^{(76)}$ 


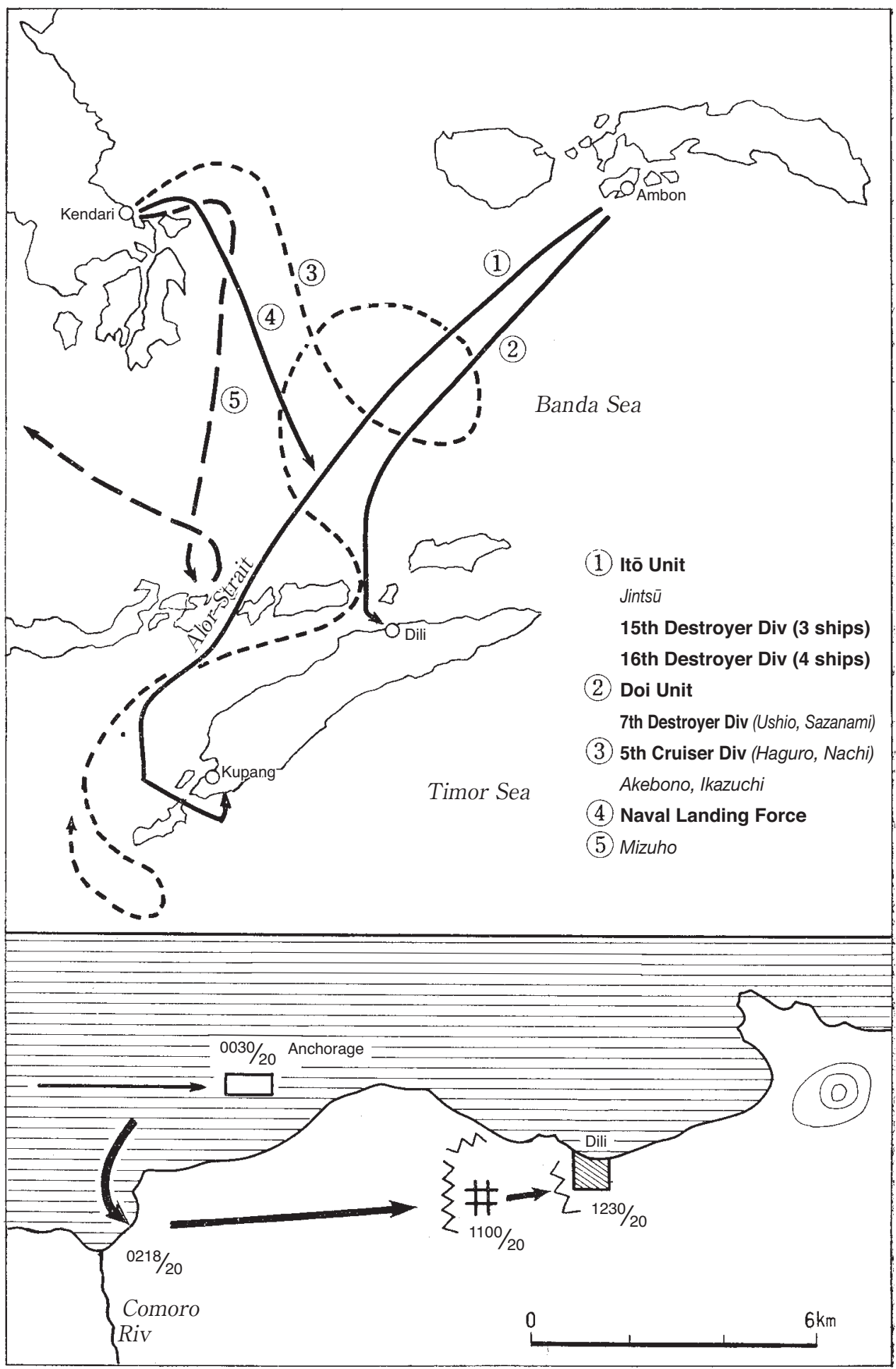

Illustration No. 41 - Overview of the Timor Invasion Operations Overview of the Operation to Seize Dili 


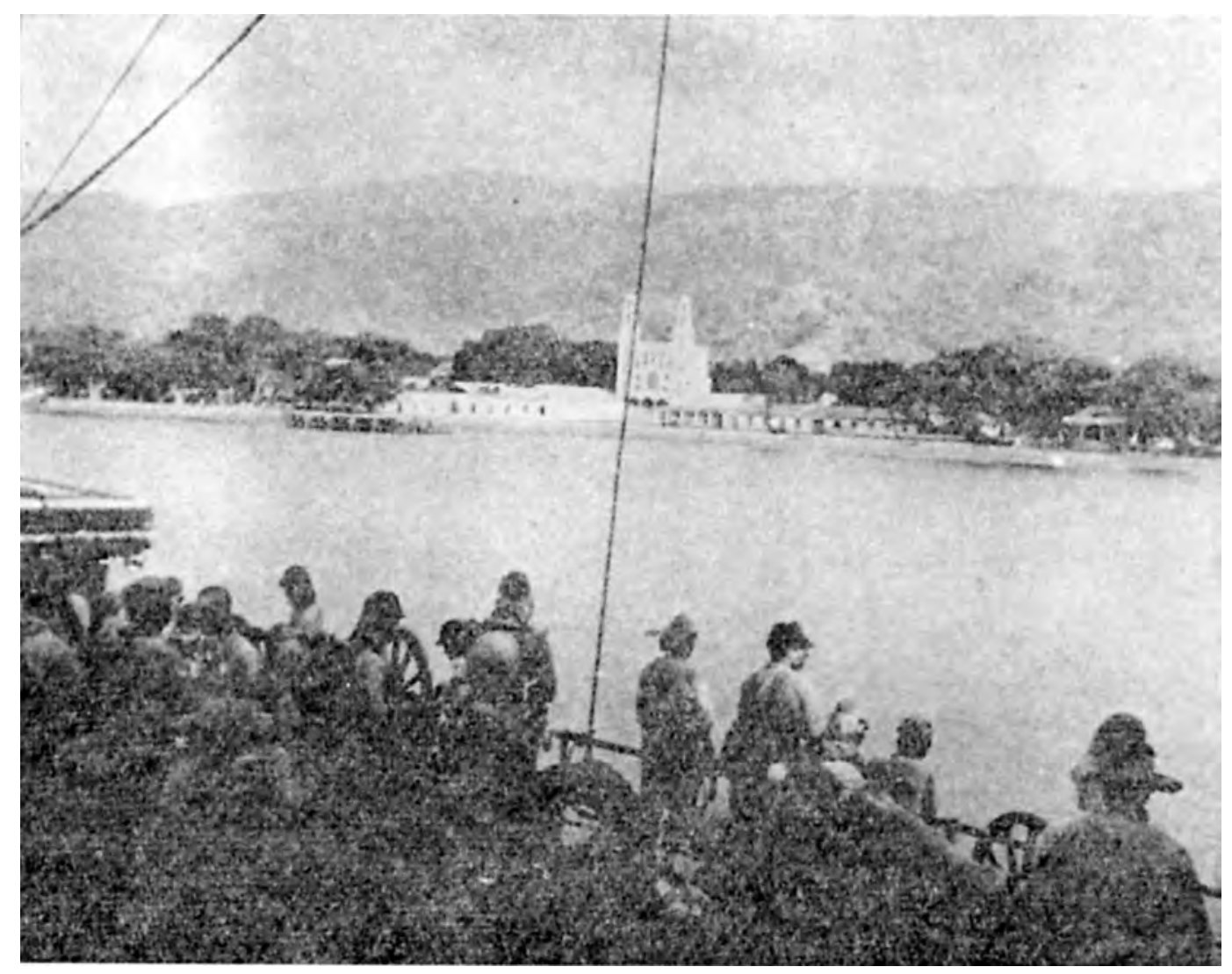

Viewing the City of Dili 

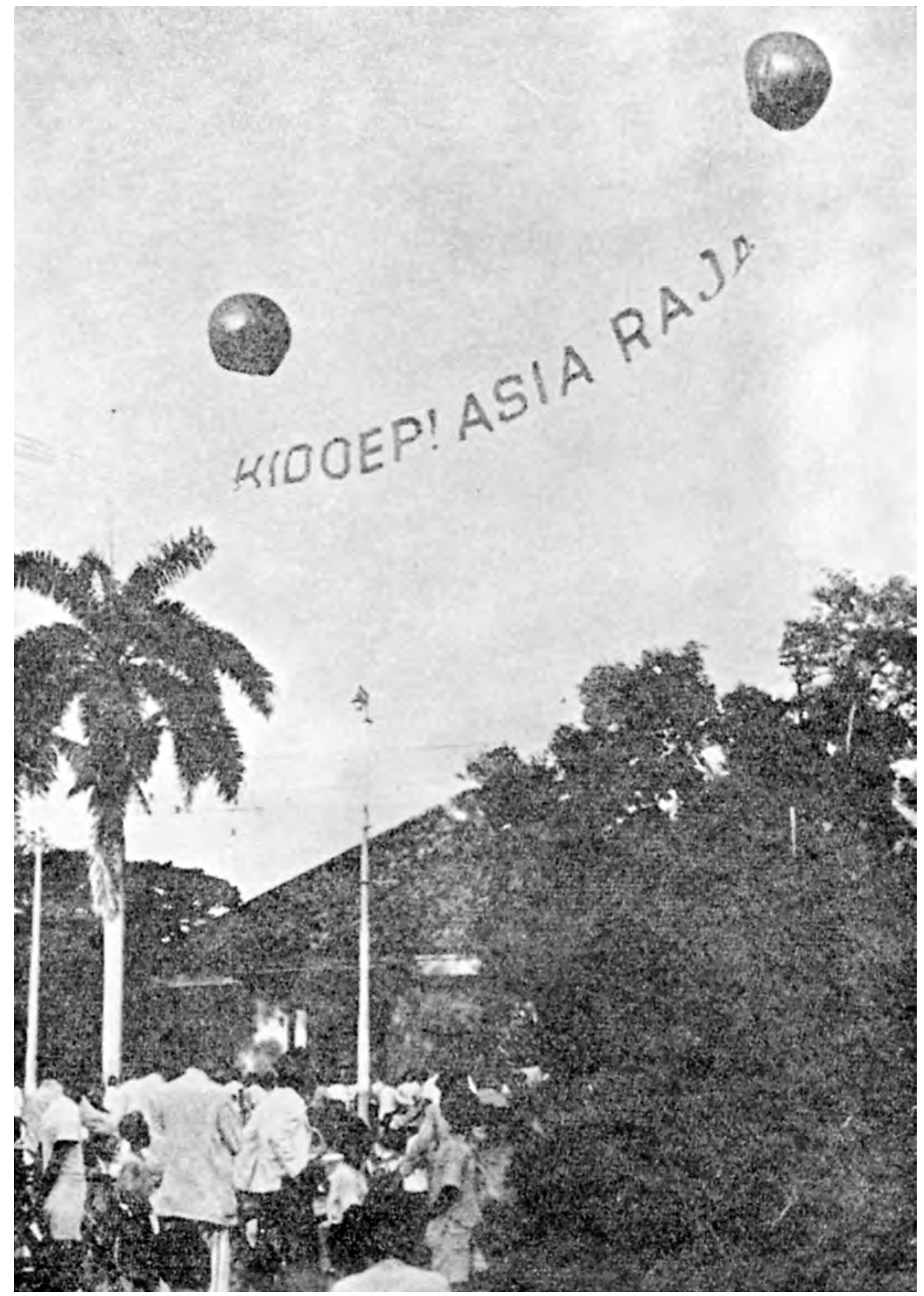

Balloons in the Sky over Batavia, Flown by the Propaganda Group at the Time of the Java Invasion The Brightly Colored Letters Read "Long Live Greater Asia!" 


\section{Chapter VIII The Invasion of Java}

\section{Progress of the Preparations for the Invasion of Java}

$\mathrm{T}$

hus were southern Sumatra, southern Borneo, southern Celebes and Bali captured, and Java was completely encircled. In the eastern [theater of the southern operation], Timor and, still further east, Rabaul were captured. In the western [theater], the Malay Peninsula was completely under [Japanese] control, and the advance on Rangoon had been set in motion.

In addition to such a strategically dominant position, [Japanese] air and naval forces were overwhelmingly superior [in number]. The air strength, which had been allotted to the Java invasion was 179 aircraft of the Third Air Force, 50 of the Dutch East Indies Unit and 190 of the Eleventh Air Fleet, which made a total of 419 aircraft. It was further increased by some 190 aircraft of the main force of the First Air Fleet led by Vice Admiral Nagumo, as well as by [the aircraft of] the 4th Carrier Division of the Malaya Unit, and others. The air power was overwhelming, and so was the power of the fleet. The [Japanese] naval vessels that operated against the moribund allied fleet in the Java area, which consisted of several light cruisers and lesser ships, were the battleships Hiei, Kirishima, Kongo and Haruna, the heavy cruisers Maya, Takao, Atago, Myōkō, Haguro, Nachi, Tone, Chikuma and Ashigara, and if we also count the light cruisers, destroyers, submarines and other vessels, we reach a truly large number of ships. What was more, in the middle of the operation to advance [on Java], the Malaya Unit had enough strength to spare to not only make a grand triumphal entry into the port of Singapore with the heavy cruiser Chōkai and other ships, but also to send the heavy cruisers Kumano, Suzuya, Mikuma and Mogami, and other ships to support the advance [on Java].

However, due to [the appearance of] an allied fleet, the unit to land in western Java, which had left Cam Ranh Bay on the 18th, and the unit to land in eastern Java, which had left Jolo on the 19th, temporarily reversed course on the 22d [and the next day] (which delayed the scheduled date of landing by two days) and again on the 27th (which delayed the date by another day). Furthermore, things reached such a state that the ship carrying [Sixteenth] Army Commander Imamura was sunk on the day of landing and he had to be rescued from the water. [The situation looked so serious that] during the course reversal, the Sixteenth Army staff officers even seriously discussed a plan to go ashore in Sumatra and then land on Java from Sumatra using [landing] craft.

I will describe the progress of the preparations for the invasion of Java below, focusing on how things came to this pass. 


\section{The General Situation Until Mid-February}

On 1 January, the Southern Army, which sought to bring forward the Java operation, made agreements with the Southern Task Force and settled on 10 January for the landings on Menado and Tarakan, on 20 January for Kendari and Balikpapan, on 25 January for Ambon, on 30 January for Makassar and Banjarmasin, on around 6 February for Bangka and Palembang, on around 11 February for Kupang, and on around 16 February for Java. ${ }^{(23)}$

On 5 January, the Southern Army ordered the Sixteenth Army to seize Bangka, Palembang, Ambon and Kupang. ${ }^{(23)}$ The seizure of Tarakan, Balikpapan and Banjarmasin had already been ordered to the Sixteenth Army before the opening of hostilities. ${ }^{(23)}$

[As for the Navy,] the Dutch East Indies Unit and the Air unit (the Eleventh Air Fleet) [ordered] the shift to phase-two operations respectively on 28 December $^{(117)}$ and 2 January, ${ }^{(117)}$ but due to the delay in capturing Davao and Jolo, and because of the shortened schedule, the shift was not easy. After making arrangements with the Sixteenth Army on 6 January, the Dutch East Indies Unit postponed the [above] dates by one day each. ${ }^{(117)}$

Although the landings on Tarakan and Menado were carried out on 11 January, ${ }^{(117,}{ }^{119)}$ it was not easy to sweep the mines in Tarakan and make the airfield ready. In addition, an impending attack by quite a number of [allied] submarines from the direction of Ambon was reported. On 15 January, the Dutch East Indies Unit issued an order to postpone [the operation to] seize Kendari and Ambon until 24 and 29 January respectively, ${ }^{(114)}$ and on the next day, the 16th, it issued another order to postpone [the operation to] seize Balikpapan until 24 January as well. ${ }^{(119)}$

By 20 January, the Dutch East Indies Unit and the Air Unit (the Eleventh Air Fleet) made a request to postpone the [entire] schedule for about two weeks, and the Malaya Unit also requested a two-week postponement, emphasizing the difficulty of [readying] the Kuching and the Ledo airfields. ${ }^{(23)}$

Although the Southern Army was aware of these requests, it [nevertheless] issued on 20 January an order to the Sixteenth Army to "capture Java in accordance with the agreement of 1 January," and held talks with the Navy side in Manila from the next day, the 21st, through the 23d. ${ }^{(23)}$

The draft of the Manila Agreement was concluded on 28 January, ${ }^{(119)}$ and it was decided that Banjarmasin was to be seized by land, and that the operation to capture Bali was to be newly included. ${ }^{(23)}$ It was also agreed to set the invasion dates for Makassar on 9 February, for Bangka and Palembang on 10 February, for Kupang on 20 February, for Bali on 21 February, for western Java on the same day (the 21st), and for eastern Java on 23 February. ${ }^{(23)}$

In the meantime:

1. Due to the circumstances in the Molucca Sea area, the Dutch East Indies Unit made arrangements on 19 January with the Sixteenth Army to postpone the date to launch the Ambon [operation] by another two days till 31 January. ${ }^{(117)}$

2. The $2 d$ Carrier Division, which was newly added [to the Southern Task Force] on 8 January, conducted an air raid on Ambon on 23 January. ${ }^{(103)}$

3. Landing operations were conducted in Balikpapan and Kendari on 24 January. In Balikpapan, four allied destroyers raided [the anchorage] and caused damage to the Japanese ships. Kendari could easily be seized, and it turned out to have a large airfield. ${ }^{(117,119)}$ 
4. With the progress in the transport operations in the Malaya area, the Southern Task Force gave the order to "switch to phase-three operations with the current disposition of forces" on 24 January. ${ }^{(117)}$

5. On the 26th, the Malaya Unit carried out the disembarkation at Endau and the occupation of the Anambas [Islands]. ${ }^{(118,126)}$

6. On the 27th, the Kawaguchi Detachment seized the Ledo airfield. ${ }^{(23)}$

Late in January, the Twenty-fifth Army was closing in on the Johor Strait. The next major operations were the Twenty-fifth Army's operation to seize Singapore, and the Sixteenth Army's southern Sumatra and Java operations.

Regarding the operation to capture southern Sumatra, preliminary arrangements were made between the Sixteenth Army and the Malaya Unit on 12 January ${ }^{(32,120)}$ and they were concluded on the 15th. However, they were reconsidered at the Manila Conference. On 28 January, preliminary arrangements were made between the Sixteenth Army, the Malaya Unit and the Third Air Force, ${ }^{(34)}$ and the arrangements were concluded on the 30th. ${ }^{(135)}$ It was decided that the air force to be employed would consist of 176 naval aircraft and 138 army aircraft, which made a total of 314 aircraft. ${ }^{(96)}$

As for the Java invasion operation, preliminary arrangements were made between the Sixteenth Army, the Third Air Force and the relevant naval units at the Manila Conference on 23 January, ${ }^{(32)}$ and they were concluded on 30 January. ${ }^{(135)}$ The air force to be employed consisted of a total of 419 aircraft, with the following breakdown: ${ }^{(96)}$

Eleventh Air Fleet: 115 land-based attack planes, 70 Type-0 fighter planes, and 5 landbased reconnaissance planes.

Third Fleet: 50 reconnaissance seaplanes.

Third Air Force: 15 command reconnaissance planes, 4 army reconnaissance planes, 90 fighter planes, 20 assault planes, 20 light bombers, and 30 heavy bombers.

At that time (the end of January), the Southern Army judged the enemy position to be in outline as follows: ${ }^{(23)}$ [See also pp. 256-257.]

1. Burma area

Apart from reinforcements of at least one division and other technical units of the [British] Indian Army, also Chiang [Kai-shek]'s Sixth Army has moved up close to the border, of which two corps have [already] entered Burma for certain. It appears that the remainder is also taking the route to enter [Burma].

It appears that the air force has been reinforced by some fifty aircraft.

2. Malaya area

An increase of one brigade of Indian troops [is known] for sure, apart from [this, ] an increase of about one division of Indian troops as well as elements of British and Australian troops must be assumed.

Further, the increase in air [forces] should be over two hundred aircraft (however, a part [of them] must have been deployed in Sumatra).

3. Dutch East Indies area

Apart from a reinforcement of an estimated two ([or] three) battalions to Sumatra, [the detailed situation] is still unknown. However, up to now the arrival of large troop numbers is unthinkable. 
Further, as for air force units, U.S. equipment and training personnel must have arrived in considerable numbers, but [details] remain unknown. However, the current number of aircraft is estimated to have reached about five hundred.

This information is based on the following:

1. Three thousand U.S. air personnel arrived in Java (information of 28 January and Cheng Jiemin report, degree of certainty $\mathrm{C}$ ).

2. According to a statement of a Dutch East Indies POW pilot, the current number of aircraft in the Dutch East Indies is some seven hundred, and they are dispersed over every airfield (degree of certainty C).

The previously-mentioned Manila Conference was held from 21 to 23 January, and at that time both the Army and the Navy Departments of IGHQ and the Combined Fleet were of the same opinion as the Southern Army that a postponement [in the operation schedule] would allow Java to receive reinforcements, which would make the defense [of the island] all the stronger. The Navy Department of IGHQ and the Combined Fleet requested the Southern Task Force to not postpone the [invasion] date. ${ }^{(23)}$ The Southern Task Force, which held the same view on the situation as the Southern Army, and which also felt responsible as a signee of the agreement of 1 January with the Southern Army, did not want to postpone the schedule either. ${ }^{(23)}$ As we have seen, the two-week postponement requested by the Dutch East Indies Unit, the Malaya Unit, and the Air Unit (i.e. the Eleventh Air Fleet) eventually resulted in a postponement of [merely] five days for the operation against western Java and seven days for the operation against eastern Java. ${ }^{(23)}$

Since 18 January, when the above issue of the request for a two-week postponement arose, the Southern Task Force had done everything possible, seeking to reinforce the Dutch East Indies Unit. So had the Combined Fleet; on 19 January it issued an order to add [to the unit] the 21st Destroyer Division, ${ }^{(114)}$ which ([consisting of] four destroyers) was employed on the Kendari - Makassar - Bali line [of operations]. During the Manila Conference, the Southern Task Force informally decided to later on transfer the Yura, the 11th Destroyer Division (three destroyers), and the 12th Destroyer Division (two destroyers) to the Dutch East Indies Unit [as well]. ${ }^{(96)}$ It also moved the carrier aircraft of the $2 \mathrm{~d}$ Carrier Division onto land bases as soon as the division returned to Davao on the 25th after completing the air strike on Ambon on 24 January, and issued an order on the 28th to add the 7th Destroyer Division (three destroyers [of the Carrier Division]) [to the Dutch East Indies Unit as well]. ${ }^{(114)}$ This destroyer division joined the Ambon - Kupang line [of operations]. On the same day, it also issued an order to transfer the 1st Section (two destroyers) of the 6th Destroyer Division of the Air Unit (the Eleventh Air Fleet). ${ }^{(120)}$ This section joined the Cam Ranh Bay - western Java line [of operations].

As mentioned previously, on 28 January it was decided to cancel [the operation to] seize Banjarmasin by sea, but to seize Bali [instead], and a new schedule was fixed on the same day. ${ }^{(119)}$ For the Navy, which had believed and before the opening of hostilities had all the time insisted that [the operation to] capture Java by a clockwise route would be quicker than that by a counterclockwise route, it was unbearable to conduct the landing [operation] on eastern Java two days later than the landing on western Java, even though the current situation was the inevitable consequence of circumstances from the time right before the war. ${ }^{(136)}$ Especially for the Dutch East Indies Unit, which had been urged on and additionally been provided with quite a number of destroyer divisions etc. by higher headquarters, and which, 
moreover, had [the operation to] seize Banjarmasin by sea called off, it was intolerable. ${ }^{(136)}$ Although [the operation against] Bali [was included] instead of that against Banjarmasin, it was to be conducted on the same day as the landing on western Java, so it was just a part of the operations to capture Java. ${ }^{(136)}$

The Dutch East Indies Unit made efforts to bring forward the date [of the landing operation on] eastern Java to the same day as that on western Java. In concert with the Dutch East Indies Unit, the Eleventh Air Fleet also studied [the possibility of] advancing the operation. On 28 January, the Dutch East Indies Unit issued an order to change the Makassar operation to a clockwise route. On 31 January it requested the 5th Cruiser Division to bring forward the date of the Makassar [operation]. ${ }^{(114)}$ On 1 February, the Dutch East Indies Unit ordered to conduct [the operation to] seize Makassar on 8 February by advancing it by one day, ${ }^{(114)}$ and [the operation to] capture Bali on 18 February by moving it up by three days. ${ }^{(119)}$ [The unit thought that] these changes would enable it to carry out the landing [operation] on eastern Java on the same day as that on western Java (21 February).

In the meantime, the landing [operation] in Ambon was carried out on 31 January. ${ }^{(117)}$ Also, the Combined Fleet passed down the order to transfer the Carrier Task Force to the Southern Task Force on the same day (the 31st). ${ }^{(116,123)}$

The day before the Combined Fleet issued the order to transfer the Carrier Task Force (that is, the 30th), the Air Unit (the Eleventh Air Fleet) issued the order for Operation Z and launched a full-scale air campaign on eastern Java from 3 February onwards. ${ }^{(143)}$ It was six days before the Malaya Unit's air campaign on western Java. As of 1 February, the forces that the Air Unit (the Eleventh Air Fleet) deployed in the front line were 138 aircraft in Kendari, thirty-three in Balikpapan and seventeen in Menado. ${ }^{(143,134)}$

On 4 February, the second day of Operation Z, the Air Unit (the Eleventh Air Fleet) made an attack on an enemy fleet in the Java Sea and reported to "have attacked an enemy fleet of seven cruisers and five destroyers and sunk three cruisers." $(134,143)$

However, on that day, an ironical reversal [of the situation] occurred. For on that day, while the Dutch East Indies Unit and the Air Unit (the Eleventh Air Fleet), which regretted that "the landing [operation] on eastern Java was to be conducted two days later [than that on western Java]," had revised their plans and were steadily achieving results [in advancing their schedule], the Malaya Unit actually proposed a two-day postponement of L (the Bangka and Palembang operation). ${ }^{(23)}$ [Sixteenth] Army Commander Imamura, who had arrived in Cam Ranh from Gaoxiong on that day (the 4th), held talks with [First Expeditionary Fleet] Commander in Chief Ozawa, accepted the latter's request, and sent Staff Officers Takashima, Kitamura and Oda, and Navy Staff Officer Wakatsuki [seconded to the Sixteenth Army] to the [Southern Army] headquarters to have them request a two-day postponement of [Operation] L. ${ }^{(23,32,34)}$

On 6 February, again a postponement of [Operation] L by another four days was requested. ${ }^{(23)}$ Chief of Staff Sawada and Staff Officer Tomari of the Malaya Unit, Sixteenth Army [Senior] Staff Officer Takashima, and others visited the [Southern Army] headquarters to make the request. ${ }^{(23)}$ The last time the issue was the Ledo airfield, but this time it was the Kuantan airfield. ${ }^{(23)}$

A postponement of L by a total of six days would inevitably lead to a postponement of [the operation against] western $\mathrm{H}$ (Java). Because the airfields were in such [bad] condition, the Malaya Unit had yet to launch its air campaign against Java. For the Air Unit (the 
Eleventh Air Fleet), which had conducted Operation $\mathrm{Z}$ from the $3 \mathrm{~d}$ through that day (the 6th), and the Dutch East Indies Unit, which on that day had dispatched from Kendari the unit to seize Makassar, the postponement could only have been totally unexpected. The Air Unit (the Eleventh Air Fleet) decided to shift the focus of its air campaign to the Banda Sea area. ${ }^{(143)}$

On 8 February, the Combined Fleet revised its previous order (for the already-mentioned reasons) and passed down a [new] order to transfer the Carrier Task Force (minus the 5th Carrier Division) and the $2 \mathrm{~d}$ Submarine Squadron to the Southern Task Force. ${ }^{(116,123)}$

Before that, on 5 February, the Southern Task Force had presented a plan to have the $2 \mathrm{~d}$ Carrier Division conduct an air strike on Port Darwin on 17 February (the first carrier operation) and have the Carrier Task Force leave Palau on 18 February and then Staring Bay on the $23 \mathrm{~d}$ to conduct a carrier operation in the Indian Ocean and to return to Staring Bay on 3 March after a five-day operation on the high seas (the second carrier operation), and it ordered a study of its feasibility. ${ }^{(116)}$ At that time, the postponement of [Operation] L was expected to be two days, and thus [the landing on] western $\mathrm{H}$ [Java] was also expected to be postponed by two days (that is, [the landing operations against] both eastern and western [Java] would be on the 23d.)

On receiving the aforementioned order of the Combined Fleet on 8 February, the Southern Task Force issued an order on the 9th, changing its former plan. ${ }^{(117)}$ By that time, it was assumed that in consequence of the request of the Malaya Unit (on the 6th) to postpone [Operation] L by another four days (six days in total), [Operation] $\mathrm{H}$ would inevitably be postponed by six days as well. In this order, the plan was that the entire Carrier Task Force (including the $2 \mathrm{~d}$ Carrier Division) should be employed for the carrier operations from the beginning; that as the first carrier operation, an air strike on Port Darwin should be conducted on 19 February; and that the second carrier operation should be a five-day carrier operation in the Indian Ocean to be conducted by leaving Staring Bay at the right moment. On the day before (the 8th), based on the request of the Malaya Unit (on the 6th) to postpone L by a total of six days, the Southern Task Force had sent the Southern Army a telegram to propose to "conduct [Operation] L on day $x+70$ (16 February), [the landing operation on] western Java on day $x+81$ (27 February), and that on eastern Java no later than day $x+81$, all depending upon the deliberations between the Third Fleet and the Sixteenth Army." (23)

The Southern Army had no option but to wire back its consent. ${ }^{(23)}$ In this way, the [temporary] situation in which a counterclockwise advance had been quicker [to reach Java] was restored to [the original] situation in which the clockwise route was quicker. The reasons for this reversal were as already described respectively in terms of the Malaya Unit, the Dutch East Indies Unit and the Air Unit (the Eleventh Air Fleet).

On the night of the 9th (the day when it passed down the orders on the carrier operations), the Southern Task Force issued the following order by telegram: ${ }^{(117)}$ [See pp. 305 and 379.]

\section{Southern Task Force Telegraphic Order No. 96}

2040, 9 February

The following amendments were made in the target dates for the invasions in the Dutch East Indies operation:

1. Western Java: day $x+81$.

2. Eastern Java: no later than day $x+81$, depending on the arrangements between the commander in chief of the Third Fleet and the Sixteenth Army commander. 
However, in the afternoon of that day (the 9th), before the telegraphic order was transmitted, the prospects for the preparation of the bases and deployment of its aircraft became clear for the Malaya Unit, and it issued an order to set [Operation] L for 15 February. [Accordingly, the units to land in southern Sumatra left Cam Ranh Bay on that evening. ${ }^{(118)}$ The Third Air Force had [already] launched its air operations [for Operation] L on 6 February. ${ }^{(96)}$ On that day (the 9th), the air unit of the Malaya Unit launched its air operations [for Operation] L, including [air] assaults on western Java. ${ }^{(104)}$

On the 10th, the units to land in western Java completed their assembly in Cam Ranh Bay. ${ }^{(120)}$ On that day, the Sakaguchi Detachment seized Banjarmasin. ${ }^{(87)}$ Makassar (its capture date was rescheduled on 2 Febru-

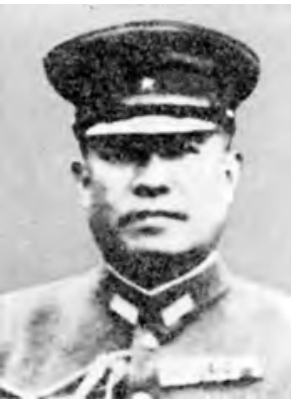

Chief of the 1st Bureau, Army General Staff Office, Lt. Gen. Tanaka Shin'ichi ary to the 9th), had been seized the day before (the 9th). ${ }^{(124)}$ The 48 th Division was under sail and scheduled to arrive in Jolo on the 12th. ${ }^{(119)}$

The Dutch East Indies Unit, which had made arrangements with the Sixteenth Army based on the telegraphic order of the Southern Task Force, transmitted the following order on the 11th: ${ }^{(117)}$ [See p. 379.]

Third Fleet Classified Telegram No. 272 sent at 1150 on the 11th

1. The schedule for the Dutch East Indies invasion shall be revised as follows:

1. Batavia and Surabaya: 26 February.

2. Kupang and Dili: 20 February.

3. Bali: 18 February (as scheduled).

2. Each unit shall conduct operations in line with the outline given in the Dutch East Indies Unit Classified Order No. 9 (note by the author: the order issued on 28 January), so as to meet the above schedule.

Three days earlier, Lt. Gen. Tanaka Shin'ichi, chief of the 1st Bureau (Operations Bureau) of the Army Department of IGHQ, had sent the following telegram from Saigon:(22)

\section{To: Vice Chief, Army General Staff}

From: Chief, 1st Bureau (sent on 8 February)

1. The Sixteenth Army has completed the preparations for its plans and has an extremely high morale, which, along with the consideration of our military power as well as the enemy's shown in the engagements in the early stages of the war, has made the army highly confident about Operation $\mathrm{H}$.

2. The Banjarmasin operation is progressing so smoothly that it is expected to achieve its aim by the 12th (note by the author: it was achieved on the 10th). [Banjarmasin] shall almost certainly be available as an air base by the time of $\mathrm{H}$.

3. The seizure of Tanjungkarang in southern Sumatra is planned around five days before [Operation] $\mathrm{H}$, and it is also expected that the aim will be achieved concerning Bali. Combined with the seizure of Banjarmasin, these will greatly facilitate the air operations,.

4. In the end, L was set on day $x+70, \mathrm{H}$ on day $\mathrm{x}+81$ for both the eastern and western parts, and Bali around day $x+76$ (note by the author: 22 February). 
That is to say, despite the telegram of the Southern Task Force on 9 February, which said "Western Java on the 27th [i.e. $x+81$ ] and eastern Java no later than the 27th," the Dutch East Indies Unit fixed [the date for the landing operation] on western Java for the 26th, according to the moving up of [Operation] L by one day, and also fixed [the date for the landing operation] on eastern Java for the 26th, endorsing the opinion of the Army, the Sixteenth Army in particular, that simultaneous landings on the eastern and western parts would be appropriate in terms of strategy.

The noteworthy points here are (1) that although the Army considered on 8 February that "[Operation] $\mathrm{H}$ [should be launched] on day $\mathrm{x}+81$ for both the eastern and western parts of Java," the Southern Task Force ordered on the next day, the 9th, that "[the operation on] the eastern part of $\mathrm{H}$ [should be launched] no later than day $\mathrm{x}+81$, ; $^{\prime \prime}(2)$ that although the Army also considered that [the landing operations on] Bali [should be conducted] around the 22d, the Dutch East Indies Unit fixed [the landing operations on Bali] "on 18 [February] as scheduled." This indicated the Navy's good faith. [However, because of that,] the operation to capture Bali became detached from the Java invasion operations in terms of timing, which ended up increasing the risks.

The reasons why the Dutch East Indies Unit decided [that the landing operations on Bali should be conducted] "on 18 [February] as scheduled" might have arisen from the circumstances that [the seizure of the Bali airfield] had been encouraged since 18 January, that the unit was reluctant to change an already issued order, or that in response to the eagerness of the Air Unit (the Eleventh Air Fleet), it hoped to enable the air unit to use the Bali airfield sooner and more effectively. Apart from that, it seems that [the Dutch East Indies Unit] had a [false] sense of security that it would be able to capture the island as easily as Makassar, overestimating the military gains of Operation Z. ${ }^{(136)}$

On the 9th (the day of the seizure of Makassar), the Southern Task Force issued an order concerning the operations of the Carrier Task Force, as mentioned previously. The order contained the following information: ${ }^{(117)}$ [See also p. 407. A minor difference in redaction has been ignored.]

Through our air raids at the beginning of February, the enemy based on Java has lost most of its air and naval forces, and as our invasion operations progress, it is highly likely that the remaining forces will attempt to escape to Australia, India and South Africa; it is also quite likely that British, U.S., Dutch and Australian naval forces will appear in the eastern part of the Indian Ocean to pick them up.

Note: It was reported that the air operations off the coast of Java on 4 February had produced a [military] gain of sinking three cruisers. However, according to allied military history sources, no ships were sunk.

On 10 February, the Navy Department of IGHQ transmitted the following telegram to each fleet, ${ }^{(117)}$ but [despite this telegram] the units on site did not pay much attention to [the situation in] Java itself. ${ }^{(136)}$

From: Chief, 1st Bureau, Navy Department, IGHQ (received at 1920 on the 10th)

JC (Bandung) sent the following report to Chongqing (sent on 6 February): [Editor's note: Unclear whether this refers to a report from the ABDA Joint Command in Bandung, or to something else, which was intercepted by the Japanese.] 
1. Allied air force

(1) Singapore: One squadron of British pursuit aircraft.

(2) Southern Sumatra: Four squadrons of British bombers and three Hurricane squadrons.

(3) Java: Forty Dutch East Indies bombers and two squadrons of pursuit aircraft, two U.S. squadrons of flying fortresses and two squadrons of pursuit aircraft; thirty reconnaissance aircraft and fifteen transport aircraft.

(4) One squadron consists of eighteen aircraft.

(5) Total: 190 bombers and 200 pursuit aircraft.

(6) Reinforcements: Two bombers [fly in] every day, and two squadrons of pursuit aircraft fly in every week after having been serviced in Australia.

2. One element of the Australian forces to be transferred to Java from the Middle East has already arrived and started reconnaissance of the terrain; the main force is expected to arrive within three or four weeks.

[However,] the attention of the [naval] units on site had mostly shifted to the Timor area. ${ }^{(136)}$ On the 11th, the Dutch East Indies Unit passed down order(s) concerning the outline of the Timor and the Bali operations. ${ }^{(114)}$ On the 12th, the 21st Air Flotilla headquarters moved eastward to Ambon from Kendari. ${ }^{(143)}$ The Carrier Task Force led by Vice Admiral Nagumo, commander in chief of the First Air Fleet, was to leave Palau on the 15th to sail southward to conduct an air strike on Port Darwin. The Eastern Detachment was to leave Ambon for Timor from the 17th onwards.

It was not until 14 February that the Dutch East Indies Unit and the Eleventh Air Fleet finally shifted their focus to Java. It (the 14th) was the day when the 1st [Paratroop] Raiding Group parachuted down in Palembang. It was inevitable that if the [Japanese] seized Palembang and Bangka (scheduled for the 15th), the allied aircraft that operated in Malaya and Sumatra would retreat to Java. [Nevertheless,] the stand-alone landing operation on Bali, which is separated from Java by just a narrow strait, would [still] be conducted on the 18th. On this day (the 14th), the 5th Cruiser Division commander wired the Dutch East Indies Unit the following request:(114)

As the Surabaya operation was rescheduled to the 26th, while the Bali operation is supposed to be conducted as scheduled, the interval between them has increased; and as the tasks of the transport of the construction squad, base personnel and others, and the guarding of these units on Bali have also been added, it means that during this period an extremely small force ([consisting of merely] two destroyers and three submarine chasers) will be exposed right in front of a major base of the enemy. Therefore, we would by all means like to request an arrangement that before the Bali invasion on the 18th the enemy naval vessels in Surabaya shall be searched for and attacked, and that the enemy bases on Bali, Lombok, Sumbawa, and in the neighboring areas shall be attacked as well.

On the 15th, the Dutch East Indies Unit sent the following request to the Air Unit (the Eleventh Air Fleet):(114)

[We] would like your cooperation in the implementation [of the request contained in] the 5th Cruiser Division Classified Telegram No. 717, to search for and attack the enemy naval vessels in the Surabaya area, and to attack key places in the neighboring areas before the [scheduled] surprise attack on Bali. 
It (the 15th) was the day when the Bangka and Palembang landing operations were carried out and also the day when the Malaya Unit had deployed for a naval and air engagement with an allied fleet that had sailed northward through the Gaspar Strait.

On the next day, the 16th, the allied fleet, which had reversed its course and left on the previous day, showed no intention to counterattack. The Tanaka Detachment had already landed in Bangka and Palembang on the 15th, and the convoy of the main force of the 38th Division reached the mouth of the Musi River on that day (the 16th). On that day, the Malaya Unit reported [to the Southern Task Force]: “We have no objections if from the 21st onwards the Yura, the 11th and the 12th Destroyer Division and others will be transferred to the Java invasion operation." (120) [Also] on that day, the Air Unit (the Eleventh Air Fleet) tried to conduct an air raid on eastern Java, responding to the telegraphic request of the day before, but without success due to bad weather. [Also on that day,] the order for the Sakaguchi Detachment to participate in the Java operation was issued.

On the next day, the 17th, the unit of the Eastern Detachment to land in Kupang left the port of Ambon. The Carrier Task Force led by Vice Admiral Nagumo was sailing south, scheduled to attack Port Darwin on the 19th. On the previous day (the 16th), the Dutch East Indies Unit had ordered the postponement of the Bali invasion by one day, because it had been impossible to provide air support on the 16th. ${ }^{(114)}$ Accordingly, the unit for capturing Bali was scheduled to leave the port of Makassar the next day, the 18th.

However, the weather remained bad on that day (the 17th). Besides, the 21st Air Flotilla headquarters returned on that day from Ambon to Kendari. ${ }^{(103,134)}$

The convoy of the main force of the Sixteenth Army was to leave Cam Ranh for western Java on the following day, the 18th. [Sixteenth] Army Commander Imamura had left Saigon on that day (the 17th), reached Cam Ranh Bay, and embarked on the Ryūjō-maru. ${ }^{(32)}$

However, the progress of the advance of the aircraft of the Third Air Force to the Palembang airfield was [slow,] as [seen] below:(135)

By the previous day, the 16th: twenty Type-97 fighter planes

By this day, the 17th: twenty Type-97 fighter planes, seven Type-1 fighter planes, and two command reconnaissance aircraft

The air unit of the Malaya Unit (the 22d Air Flotilla) was in [an even worse] situation: the Ledo airfield was not fit for use, the poor condition of the Kuching airfield allowed the aircraft to load [only] half a tank of fuel on take off, while the air groups stationed far behind at the bases in Kuantan and Thủ Dâu Một in French Indochina were far too far away to be effectively employed.

As we have seen, the air unit (the Eleventh Air Fleet) had shifted its focus to the eastern [theater] after conducting Operation Z (from 3 through 5 February), and the air unit of the Malaya Unit had launched an air campaign against western Java on 9 February. The situation of the air campaign against [both eastern and western] Java from 9 February onwards was as follows: ${ }^{(104)}$

\section{February}

Eastern Java: Seventeen land-based attack planes of the 23d Air Flotilla conducted a raid on Malang from Balikpapan. 
Western Java: Sixteen fighter planes and two land-based reconnaissance aircraft of the $22 \mathrm{~d}$ Air Flotilla conducted a raid on Batavia and also reconnoitered the city from Kuching.

10 February: No [air] raids were conducted.

11 February

Eastern Java: No [air] raids were conducted.

Western Java: Twenty-seven land-based attack planes of the 22d Air Flotilla took off from Kuantan with the intention to conduct a raid on Batavia, but they attacked [enemy] warships in Bangka [instead].

12-14 February: No [air] raids were conducted.

15 February

Eastern Java: The 23d Air Flotilla conducted a weather reconnaissance and searched for the enemy from Balikpapan.

Western Java: The full force of the 22d Air Flotilla from the Kuching, the Kuantan and the Thủ Dâu Một [airfields] attacked an allied fleet, which launched a counterattack, in the 16 February northern part of the Gaspar Strait.

Eastern Java: The 23d Air Flotilla conducted a weather reconnaissance from Balikpapan.

Western Java: No [air] raids were conducted.

17 February

Eastern Java: Twenty-five land-based attack planes of the 23d Air Flotilla took off from Balikpapan with the intention to conduct a raid on Surabaya, but they returned due to bad weather.

Western Java: No [air] raids were conducted. Land-based attack planes of the 22d Air Flotilla attacked an [enemy] fleet on the sea south of Bangka [Island] off southern Sumatra from Kuching.

[Sixteenth] Army Commander Imamura, who had boarded [the Rȳ̄j $\bar{o}-m a r u$ ] on that day, had the following conversation with the chief of the 1st Bureau of the Army Department of IGHQ, Lt. Gen. Tanaka Shin'ichi, before embarkation: ${ }^{(35)}$ [See also p. 100.]

[Tanaka] "I wonder whether it is possible to dispose of the entire Java invasion [operation] within fourteen days (two weeks)?"

[Imamura] "At this moment, we have not yet departed [from port], and I cannot tell how many ships will be able to arrive and disembark while braving enemy torpedoes. What makes you think that we can complete [the operation] within two weeks?"

"A campaign needs to be ended quickly."

"I wish in my mind that we can make the enemy surrender within a month, but my conscience does not allow me to declare that we can [promise to] make it happen."

"I see. But please, finish it by 'Shunki-kōreisai' [the vernal equinox, when the Imperial ceremony of ancestor worship is held] on 21 March."

"I will make efforts to end it at the earliest possible date. This is all I can say [now]."

At 1840 on that day (the 17th), the Southern Task Force sent the following telegraphic order to the Malaya Unit: ${ }^{(120)}$

1. As of 21 February, the disposition of forces shall be changed as follows:

(1) The Yura, the 11th and the 12th Destroyer Divisions, the 1st Minesweeper Division, the Kamikawa-maru, two auxiliary submarine chasers, two fishing boats, and the Tsurumi [shall be transferred] from the Malaya Unit to the Dutch East Indies Unit. 
(2) The 22d Air Flotilla (minus the Mihoro Air Group), a detachment from the 21st Air Flotilla, and a detachment (minus Type-96 carrier aircraft) from the 23d Air Flotilla [shall be transferred] from the Malaya Unit to the air unit.

2. The Malaya Unit shall cooperate in the western Java invasion operation, while staying engaged in its own mission.

By this order, the strength of the escort of the convoy of the main force of the Sixteenth Army, which was to leave Cam Ranh Bay the next day, the 18th, became two light cruisers, fifteen destroyers and two auxiliary seaplane tenders from the 21st onwards. Furthermore, the order let the Air Unit (the Eleventh Air Fleet) employ the air flotillas [originally under its command] (the 21st, the $22 \mathrm{~d}$ and the $23 \mathrm{~d}$ Air Flotillas) together for the Java operation from the 21st onwards.

Although the convoy of the main force of the Sixteenth Army left Cam Ranh Bay on the 18th, the Mentok airfield was not yet available, and neither the airfield in Tanjungkarang nor in Bali had been seized. Also, the capacity of the Palembang airfield was limited. There was no prospect yet of advancing naval aircraft to southern Sumatra. The Third Air Force was still directly cooperating in the Sumatra operation and had not yet launched the air campaign against Java.

The convoy took its departure neither "after gaining command of the air" nor "when the deployment of the air force was completed." It was "a departure taken prior to the seizure and preparation of air bases." It meant that both allied aircraft and naval vessels in Java were still operational at the time of the departure of the convoy.

On the 18th, 5th Destroyer Squadron Commander Rear Admiral Hara left Cam Ranh Bay escorting a large convoy of fifty-six ships carrying the main force of the Sixteenth Army with one light cruiser and ten destroyers. He wired the Malaya Unit (Vice Admiral Ozawa) on the same day a request to launch air attacks on enemy naval surface vessels as well as enemy aircraft on the sea west of Java. ${ }^{(120)}$

\section{The Advance of the Assembly Points}

The unit to land in western Java (the main force of the [Sixteenth] Army with the 2d Division and the Shōji Detachment as the core) and the unit to land in eastern Java ([consisting of] the 48th Division as the core) had advanced their assembly points respectively from Gaoxiong to Cam Ranh Bay, and from Luzon to Jolo, which had been carried out roughly in the following way:

\section{The Western Java Landing Unit}

On completing arrangements with the Dutch East Indies Unit (i.e. the Third Fleet) in Manila on 23 January, [Sixteenth] Army Commander Imamura passed down his orders to the 48th Division on the next day, the 24th. He returned from Manila to Gaoxiong on the same day, where, along with the 2d Division commander, Detachment Commander Shōji, and others he made arrangements with the 5th Destroyer Squadron commander on the 27th, and passed down his orders to the main force of the [Sixteenth] Army on the 30th. On 3 February, he left Gaoxiong, flew into Cam Ranh on the 4th, and arrived in Saigon on the same day. ${ }^{(31,32,33)}$ 
Of the 5th Destroyer Squadron, which was ordered to return to the Dutch East Indies Unit from the Malaya Unit for the Java operation, the Natori and the 22d Destroyer Division left Singora on 9 January and arrived in Magong on the 16th, and the 5th Destroyer Division left Singora on the 12th and arrived in Magong on the 18th. ${ }^{(120)}$

The advance of the assembly point of the main force of the Sixteenth Army ([with] the 2d Division and the Shōji Detachment as the core) from Gaoxiong to Cam Ranh Bay was carried out under escort of the 5th Destroyer Squadron ([with] one light cruiser and eight destroyers) in the following way: ${ }^{(120)}$

First group: twelve transport ships under escort of the Nagatsuki and the Minazuki of the $22 \mathrm{~d}$ Destroyer Division

Departed at 1200 on 1 February and arrived at 0900 on the 6th.

Second group: seventeen transport ships under escort of the Harukaze and the Hatakaze of the 5th Destroyer Division

Departed at 1200 on 3 February and arrived at 0900 on the 8th.

Third group: eighteen transport ships under escort of the Fumizuki and the Satsuki of the 22d Destroyer Division Departed at 1000 on 5 February and arrived at 0900 on the 10th.

Fourth group: eight transport ships under escort of the Asakaze and the Matsukaze of the 5th Destroyer Division, a high speed convoy Departed at 1200 on 6 February and arrived at 0900 on the 10th.

The plan based on the agreement between the Southern Army and the Southern Task Force on 1 January was to leave Gaoxiong on 6 February, sail nonstop to Java and land there on the 16th. However, as a result of the Manila Conference, it was changed to advance [first] to Cam Ranh as described above, depart from the bay on the 13th, and land in Java on the 21st. ${ }^{(23,96)}$

\section{The Eastern Java Landing Unit}

In the plan based on the agreement between the Southern Army and the Southern Task Force of 1 January, the unit [consisting of] the 48th Division as the core was to leave Manila on 8 February and sail nonstop to eastern Java and land there on the 16 th. ${ }^{(23)}$ However, as a result of the Manila Conference, the plan was changed so that [the unit] should leave Lingayen on the 8 th, arrive in Jolo on the 12th, leave Jolo on the 16th, and land on eastern Java on the 23d. ${ }^{(96)}$ The reason for the change [of the point of departure] from Manila to Lingayen was that the Bataan Peninsula, Corregidor Island and other locations had not been seized yet. Unlike Manila, loading and embarkation were extremely difficult in Lingayen, but there was no other choice.

As for the 4th Destroyer Squadron and the 2d Base Unit, which had been preparing for [the operation to] seize Banjarmasin after the seizure of Balikpapan, it was decided that with the decision to cancel [the operation to] seize Banjarmasin by sea and with the Dutch East Indies Unit's shift to phase-three operations, the 4th Destroyer Squadron commander should sail to Lingayen with the flagship Naka and the $2 \mathrm{~d}$ Destroyer Division (i.e. the Murasame, the Samidare, the Y $\bar{u}$ dachi and the Harusame) and escort the unit to capture eastern Java from Lingayen to Jolo, but that the $2 \mathrm{~d}$ Base Force commander [R. Adm. Hirose Sueto] should first support the operation to seize Makassar leading the 9th Destroyer Division (i.e. the Asagumo, 
the Natsugumo and the Minegumo) and the 1st Section of the 24th Destroyer Division (i.e. the Umikaze and the Kawakaze), and then sail to Jolo to rejoin the 4th Destroyer Squadron. ${ }^{(119)}$

Rear Admiral Nishimura, commander of the 4th Destroyer Squadron (aboard the Naka), left Balikpapan on 30 January, arrived in Lingayen on 2 February (the Harusame arrived from Davao [later] on the $3 \mathrm{~d}$ ), and made the previously mentioned arrangements with the 48th Division commander in Manila on the 4th. ${ }^{(119)}$ [See pp. 237-240.]

On 8 January, the 48th Division had been relieved on the Bataan front by the 65 th Brigade and was assembling in Manila. Then, on 24 January, the division received the above-mentioned order of the Sixteenth Army commander concerning the Java operation, started moving from Manila to Lingayen Gulf on 26 January, and set about embarking from 30 January onwards. ${ }^{(31,79)}$ On 4 February, [48th] Division Commander Tsuchihashi made arrangements with 4th Destroyer Squadron Commander Nishimura in Manila, left the city on the 5th, embarked on the Arizona-maru at Damortis that evening, and passed down his orders concerning the division's Java operations on the 6 th. ${ }^{(79,119)}$

Note: When transferring troops and war matériel [of the division] from Manila to Lingayen by shuttle motor vehicles, [48th] Division Commander Tsuchihashi transported war matériel of the Third Southern Expeditionary Fleet ([assigned to] the Philippines) from Lingayen to Manila by loading them on the empty return vehicles, which earned him the gratitude of the Navy.

On the next day, the 7th, the Kanemura Detachment, assigned to [the operation to] capture Bali, left Lingayen Gulf in the faster ships, the Sasako-maru and the Sagami-maru. ${ }^{(79)}$ As we have seen, the detachment sailed to Makassar and [further] headed for Bali under the escort of the 8th Destroyer Division, which had come to Jolo [for the escort] after participating in the Makassar landing operation in the wake of escorting the Eastern Detachment from Hong Kong to Ambon by way of Davao.

The convoy of the main force of the 48th Division (its distribution has been given before [see pp. 237-238]) left Lingayen Gulf on 8 February and arrived in Jolo on the 12th (one ship lagged behind and arrived on the 13th) under the escort of the light cruiser Naka and the $2 \mathrm{~d}$ Destroyer Division (four destroyers) led by Rear Admiral Nishimura. ${ }^{(119)}$ The Kuma of the Third Southern Expeditionary Fleet also temporarily (from the 8th through the 12th) joined in the escort [of the convoy] on the way. ${ }^{(119)}$ At Jolo, the 48th Division made the final supplementary preparations for the operations. Although its departure from Jolo had been scheduled for the 16th, on the 11th, it was rescheduled for the 19th. ${ }^{(119)}$

\section{The Decision to Include the Sakaguchi Detachment, the Change in the Oper- ation Plan of the [Sixteenth] Army, and the Paradrop [Operation] Issue}

[Sixteenth] Army Commander Imamura advanced to Saigon on 4 February, the main force of the army completed its assembly in Cam Ranh Bay on the 10th, and the main force of the 48th Division advanced to Jolo on the 12th. During this period (on 10 February), the Sakaguchi Detachment seized Banjarmasin.

At that time, the Sakaguchi Detachment was implementing a military administration, stationing its headquarters and the Kanauji Battalion (the 2d Battalion) in the Balikpapan area and the Kume Battalion (the 1st Battalion) in the Sanga Sanga and the Samarinda area, while conducting the Banjarmasin operation with the Matsumoto Battalion (the 3d Battalion) led 
by the commander of the 146th Infantry Regiment, Colonel Yamamoto. ${ }^{(88)}$ On 5 February, while keeping the Ehime-maru and the Liverpool-maru, which had carried out the transport to Tanahgrogot for the Banjarmasin operation, Detachment Commander Sakaguchi sent the other ships (i.e. the Nichiai-maru, the Havana-maru, the Hankow-maru, the Teiry $\bar{u}$-maru and the Nissho-maru [Hiteru-maru]) to Palau under the command of the commander of the 44th Field Antiaircraft Artillery Battalion, Maj. Takagi Takeo. He ordered Major Takagi to load on the Teiryū-maru and the Nisshō-maru [Hiteru-maru] at Palau the remaining troops, horses, and materiel of the detachment, which had been left there, and lead them back to Balikpapan. ${ }^{(88)}$

Around the time when the convoy led by Major Takagi departed, Detachment Commander Sakaguchi learned that a decision had been made to put the Navy in charge of the military administration in Dutch Borneo. ${ }^{(87)}$ The news came as a surprise, as the Sakaguchi Detachment, which had been specifically requested to implement a proper military administration by Maj. Gen. Satō Kenryō, Chief of the Military Affairs Bureau of the War Ministry before its departure from the mainland, and which [accordingly] had made every kind of preparation for it, was putting its heart and soul into the implementation of a military administration. ${ }^{(87)}$ [Editor's note: At that time, Major General Satō was still Chief of the Military Affairs Section.] At that time, the convoys for the Java invasion of the Sixteenth Army, to which the detachment belonged, were sailing southward one after another from Gaoxiong and Lingayen. Detachment Commander Sakaguchi immediately wired the Sixteenth Army a request for participation of his detachment in the Java operation. ${ }^{(87)}$

The Sixteenth Army headquarters in Saigon received the telegram, but [ignored it because] it was still closely watching the progress of the Banjarmasin operation. On 10 February, the report of the seizure of Banjarmasin arrived. The Sixteenth Army immediately (on the same day) completed a draft order for the Sakaguchi Detachment to participate in the Java operation and sent (a) staff officer to the Southern Army headquarters to ask for the latter's approval. [However,] the 1st Section of the Staff Department of the Southern Army did not approve. ${ }^{(36)}$ Then, Chief of Staff Okazaki [of the Sixteenth Army] visited Vice Chief of Staff Aoki [of the Southern Army] to make a [direct] appeal, [but] Vice Chief of Staff Aoki rejected it, insisting that the 56th Mixed Infantry Group had to be returned to the 56th Division for the Burma invasion operation and should not incur damage. ${ }^{(36)}$ Chief of Staff Okazaki sought approval by saying that the Burma invasion operation was to come after the Java invasion, and that the main force of the Sixteenth Army would [also] take part in the Burma invasion when the Java invasion was completed. [Even then,] Vice Chief of Staff Aoki was reluctant to approve it. ${ }^{(36)}$ Whether [the Southern Army] should let the Sakaguchi Detachment participate in the Java operation or not was not just a matter of whether to comply with the Sakaguchi Detachment's wish. Whereas the Sixteenth Army hoped that the powerful Sakaguchi Detachment would participate in the Java operation, the Southern Army had to consider the views of IGHQ as well as [the availability of] ships.

It was on 15 February (three days before the departure of the convoy of the main force of the Sixteenth Army from Cam Ranh Bay) that the Southern Army finally approved it. On the 16th, Major Takagi (who had left Balikpapan on the 5th and arrived in Palau on the 12th, leading the convoy [which had been used by the Sakaguchi Detachment]) received a telegraphic order from Detachment Commander Sakaguchi in Palau, which said: "Try to return to Balikpapan by the 21st at the latest with two of the ships, the Teiry $\bar{u}$-maru and the Nisshomaru [Hiteru-maru]. ${ }^{(88)}$ On the 16th, the Sixteenth Army sent the following telegram: ${ }^{(119)}$ 


\section{From: Chief of Staff, Sixteenth Army}

\section{To: Chiefs of Staff, Third Fleet, Eleventh Air Fleet, 48th Division, and Commander, 4th Destroyer Squadron}

Sixteenth Army Classified Telegram No. 316, 2100, 16 February

Conform to the purport of Sixteenth Army Telegram No. 297, we would like to have the main force of the Sakaguchi Detachment assigned to the 48th Division as follows, and have it join the Dutch East Indies operation roughly in the following manner:

1. The detachment headquarters and about one infantry battalion shall embark in transport ships at Balikpapan on the 18th, leave the port on the night of the 21st, join the convoy of the 48th Division off Pamanukan under escort of the Navy, and go ashore in or near Kragan.

2. When the disembarkation of the above unit is completed (around the 27th), the said transport ships shall immediately be sent to Banjarmasin under escort of the Navy, and embark a unit [consisting of] about one and a half infantry battalions as the core, and put it ashore in Kragan.

3. The following units shall be left in Borneo for guarding:

The Samarinda area: [A unit consisting of] one infantry battalion (minus two companies) as the core.

The Balikpapan area: [A unit consisting of] about one infantry company as the core. In the current state, the above units will be sufficient for maintaining public order.

4. We would like to have the 48th Division commander give directions concerning the escort of the Sakaguchi Detachment under sail, the outline of the latter's landing [operation], and the like. If [all of] you will approve the above, from now on we would like the 48 th Division commander to directly make arrangements with the 4th Destroyer Squadron commander.

5. Our headquarters shall leave Saigon on the morning of tomorrow, the 17th, and be on board the Ryūjo-maru from the afternoon of that day onwards.

The participation of the Sakaguchi Detachment in the Java operation was brought about after having gone through the above-described process. The order for its participation, however, was issued with the 10th as date (note: see the previously description) and read as follows: ${ }^{(31)}$

\section{Sixteenth Army Order (summary)}

1. The 48th Division shall land near Kragan before daybreak on day H.

2. The Sakaguchi Detachment shall go ashore near Kragan in the manner described below, charge toward Cilacap through the area west of a line which largely connects Mount Lasem (about twenty kilometers east of Rembang) and Mount Lawu (about forty kilometers east of Surakarta). It shall seize the city and cut off the enemy's escape route.

(1) The detachment headquarters and a unit [consisting of] one infantry battalion as the core shall embark at Balikpapan, and start landing near Kragan around daybreak of day H under escort of the Navy (if possible, after joining the convoy of the 48th Division off Balikpapan).

(2) Then, it shall immediately send the transport ships to Banjarmasin under escort of the Navy, and bring the unit [consisting of] about one and a half infantry battalions as the core to Kragan.

(3) After assembling its force in or near Kragan and making the necessary preparations for the raid, the detachment shall start its operation, charge toward Cilacap all at once, and seize the city.

3. The 48th Division commander shall make the necessary revisions in the arrangements with the 4th Destroyer Squadron regarding the participation of the Sakaguchi Detachment in the opera- 
tion, and give directions about the escort of the latter under sail, the outline of the latter's landing [operation] (landing point(s), the anchorage, and the air defense), and the like. [However,] the division commander may let Detachment Commander Sakaguchi make the necessary arrangements directly with the relevant naval units concerning the embarkation at Balikpapan, the navigation to the landing point(s), and the move of the Banjarmasin unit.

The 48th Division commander and the 4th Destroyer Squadron commander, who had entered [the anchorage] at Jolo on 12 February, received the above telegram on the 16th, held talks and made arrangements on the 17th. ${ }^{(119)}$ Fortunately, the commander of the Dutch East Indies Unit had left Davao on the 13th with his main unit (the heavy cruiser Ashigara and the destroyer Yamakaze), arrived in Jolo on the 14th, and was preparing for departure (scheduled for the 17th) for the support of the operation to capture Bali. The $2 \mathrm{~d}$ Base Force commander, who had supported the operation to seize Makassar (on the 9th), had also arrived in Jolo on the 13th. ${ }^{(119)}$ That was why the following decision could be made immediately (on the 17th)::

1. The [transport ships] which the Sakaguchi Detachment will board at Balikpapan shall be the Ehime-maru and the Liverpool-maru, which are [kept] there now. They shall join the convoy of the 48th Division in the Makassar Strait. The destroyer Kawakaze and the submarine chaser No. 4 shall provide the escort.

2. Regardless of the Sixteenth Army's order to send the Ehime-maru and the Liverpool-maru back [to Banjarmasin after disembarkation at Kragan], the faster ships Sasako-maru and Sagami-maru, which are employed in the Kanemura Detachment's landing [operation] on Bali on the 19th, shall be brought to Banjarmasin via Makassar by some time around the 24th, to take the unit there to Kragan by some time around the $27 \mathrm{th}$. The escort shall be provided by an element of the $2 \mathrm{~d}$ Base Unit.

On that day (the 17th), Major Takagi left Palau for Balikpapan, leading the Teiryu-maru and the Nisshō-maru [Hiteru-maru]. ${ }^{(88)}$

On the next day, the 18th, Detachment Commander Sakaguchi sent a telegraphic order to Major Takagi under sail: "The detachment will leave Balikpapan on the evening of the 21st and join the convoy of the 48th Division on the 22d. The Teiryu-maru and the Nisshō-maru [Hiteru-maru] shall catch up with it without calling at Balikpapan." ${ }^{(88)}$ It (the 18th) was the day when the convoy of the main force of the Sixteenth Army departed from Cam Ranh Bay.

\section{Revision of the Sixteenth Army's Operation Plan}

The operation plan of the Sixteenth Army, which had been drawn up in late December, was [once] revised in early January due to the moving-up of the Java operation, the return of the South Seas Detachment [to central command], and other factors. In this revised plan, the Kanemura Detachment was removed in late January from the eastern Java operation forces in the part on the Java operation, but now it was decided to include the Sakaguchi Detachment [instead]. In the beginning of mid-February, the Sixteenth Army's Java operation plan (including Bali) was revised [again] in the following general way: ${ }^{(36,40)}$ 


\section{Mission}

The [Sixteenth] Army shall land on [both] eastern and western Java before daybreak on 26 February under cover of the Navy and the Third Air Force and occupy the entire island in a short period of time.

\section{Directives}

1. The 48th Division shall land in or near Kragan under cover of the Navy and seize Surabaya. The Kanemura Detachment shall capture Bali prior to the landing [operation] of the main force.

2. The Sakaguchi Detachment shall land in or near Kragan almost simultaneously with [the landing of] the 48th Division, charge toward Cilacap, and seize the city.

3. The $2 \mathrm{~d}$ Division shall land at Bantam Bay with its main force and in or near Merak with one element. It shall have a powerful element charge toward Buitenzorg and seize the city, while having the main force advance toward Batavia and seize the city.

4. The Shōji Detachment shall land in or near Eretan, secure the Kalijati airfield in a surprise attack, while operating in concert with the main force of the $2 \mathrm{~d}$ Division.

5. After the seizure of Batavia, the main force of the $2 \mathrm{~d}$ Division and the Shōji Detachment shall attack the Bandung stronghold, lining up side by side to its north.

6. Depending on the circumstances, the detachment charging toward Buitenzorg and the Shōji Detachment shall seize Bandung at one fell swoop.

\section{The Issue of the Employment of the Paratroop Unit [for the Operation] Against Cilacap}

Once Bali and southern Sumatra were seized, Cilacap was the [only] port where the allied forces on Java could receive reinforcements or from where they could retreat. The Sixteenth Army, of course, had noticed this and so had the Southern Army.

The Southern Army studied [the possibility of] a plan to have the 1st [Paratroop] Raiding Group parachute down in Cilacap and asked for the opinion of the unit that was to execute it.

As we have seen, the 1st [Paratroop] Raiding Group had carried out the paradrop operation against Palembang on 14 February. Sixteenth Army Staff Officer Lieutenant Colonel Itoda, who had descended in Palembang along with the 1st [Paratroop] Raiding Group ([consisting of] the group headquarters and the 2d [Paratroop] Raiding Regiment), had offered, as already described, his opinion from Palembang on 17 February that [the group] should not be used for [the operation against] Cilacap. ${ }^{(23)}$

As described previously, the 38th Division commander had landed in Palembang at 1435 on that day (the 17th). At that very moment, the 1st [Paratroop] Raiding Group had come under the command of the Sixteenth Army (the 38th Division). Accordingly, the above-mentioned opinion had been offered to the Sixteenth Army commander, but was also sent to the Southern Army by telegram.

On that day (the 17th), the Southern Army was conducting a study on Cilacap, Sabang (northwest of Sumatra), the Andaman Islands (north of Sabang), and Yenangyaung (an oil field in Burma) as [prospective] subsequent drop spots for the 1st [Paratroop] Raiding Group. On that day, the Third Air Force urged the Southern Army to decide the next drop spot as soon as possible. ${ }^{(23,30,97)}$

On 20 February, the 1st [Paratroop] Raiding Group reported to the Southern Army its views on Cilacap, Sabang, Pangkalan Brandan (an oil field in northwestern Sumatra) and 
the Andamans. Its opinion was that (1) unless it was to be employed in the [operation against] Cilacap, it could be employed in [the operations against] Sabang, the Andamans, Pangkalan Brandan and other areas, but [only] on different days; that (2) if it was to be employed in [the operation against] the Cilacap stronghold, [the operation] would require the employment of the full force of the current raiding group and the group could [then] not be employed in other areas.

On the same day, IGHQ conveyed to the Southern Army its view that the group should be employed to seize oil resources. On the 24th, the Southern Army decided to employ the group in [an operation against] the Pangkalan Brandan oil field. However, after [this decision], it turned out that about $80 \%$ of the oil field had been destroyed, so on the 27th-28th the decision was changed to employ the unit in Burma. ${ }^{(23,30,97)}$

In the meantime, the 1st [Paratroop] Raiding Group had returned under the command of the Third Air Force by the Southern Army order of the 22d, and then, on 1 March, it was returned to the direct control of the Southern Army, as previously described.

\section{The Sailing [of the Convoys]}

\section{The Situation of the Enemy as Assessed Just Before the Sailing}

The main force of the Sixteenth Army and the 48th Division respectively departed from Cam Ranh Bay and Jolo on 18 and 19 February and headed for Java. The situation of the enemy as known at that time was in outline as follows:

\section{Air force}

At the end of January (when the Twenty-fifth Army advanced to the shore opposite Singapore), the air force in the Dutch East Indies (mainly on Java and Sumatra) was estimated to be five hundred aircraft. (See the previous descriptions.) [pp. 256-257, 419-420.]

On 10 February, the Southern Army estimated that "the Dutch East Indies forces [deployed] a total of about four hundred aircraft." (23) On the same day, [the Navy Department of] IGHQ notified that "according to enemy telegrams, the enemy air force in Singapore, Sumatra and Java consists of 190 bombers and 200 pursuit aircraft as of the 6th, and they are being reinforced by two bombers every day and thirty-six pursuit aircraft every week."(117)

Although [the Japanese forces] had seized the Palembang airfield on 14 February, the Lesser Sunda Islands were still under the control of the allied forces as of 18 February, and the judgment was that the [enemy] losses were being replenished.

2. Fleet

In the eastern Java area, the whereabouts of the allied fleet, which was [considered to] have retreated after having three of its cruisers sunk ([according to the Japanese] judgment at that time) out of seven cruisers and nine destroyers in the sea engagement off Java on 4 February, were unknown. ${ }^{(102)}$ Bad weather had hindered aerial reconnaissance. ${ }^{(102)}$

In the western Java area, the three cruisers and five destroyers, which had retreated after assuming a posture of counterattack at the Gaspar Strait at the time of the southern Sumatra landing operation on 15 February, were considered to be near Batavia. ${ }^{(102)}$ On 9 February, the Southern Task Force wired that "through our air raids at the beginning of February, the enemy based on Java has lost most of its air and naval forces, and as our invasion operations progress, it is highly likely that the remaining forces will attempt to escape to Australia, India and South Africa."(117) [See pp. 407, 424.] However, the units assigned to capture Bali and those departing for western Java were concerned because of the above-mentioned counterattacks on 15 February, the day- 


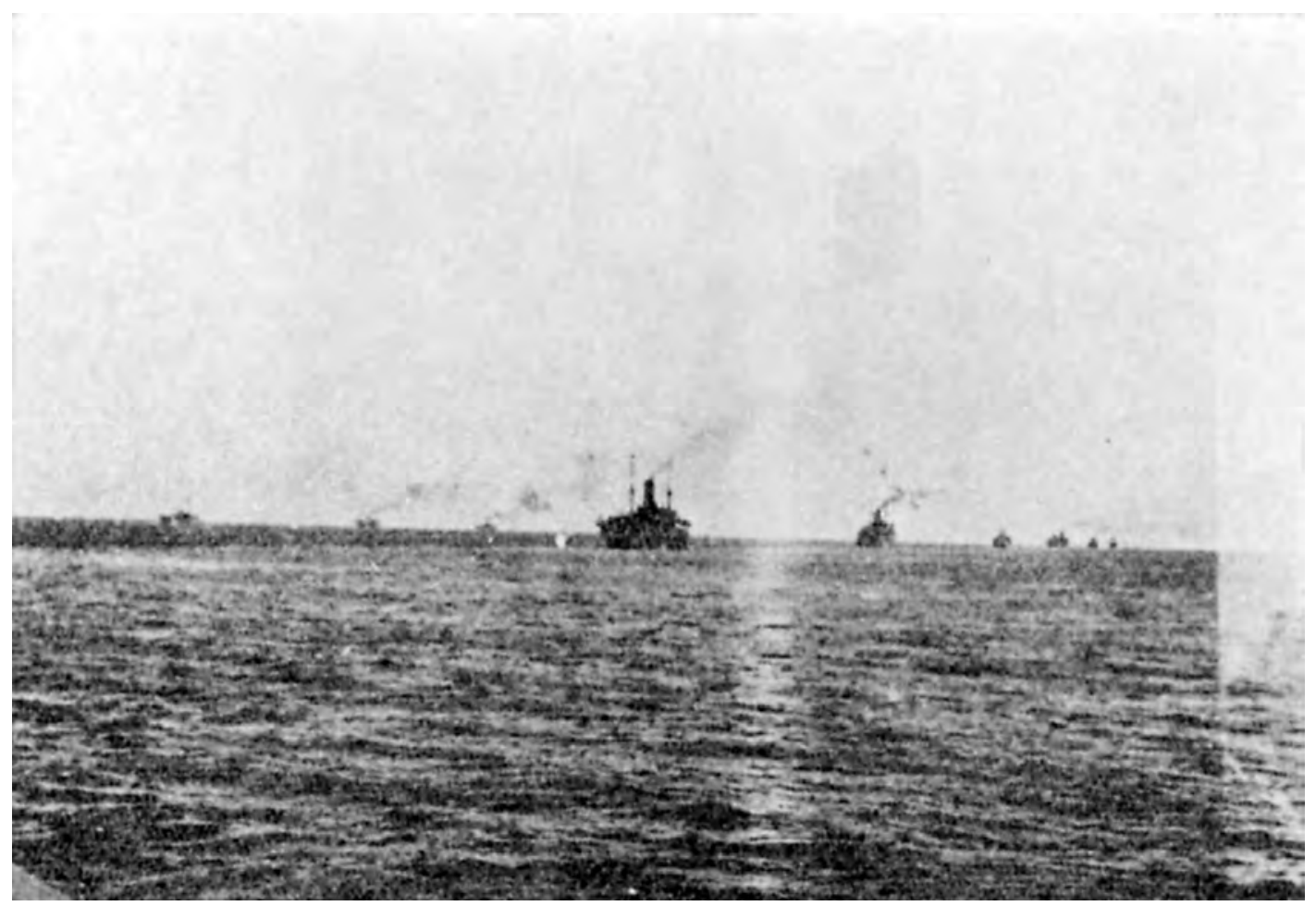

The Sailing of the Convoy of the Main Force of the Sixteenth Army

in-day-out bad weather in the eastern Java area, the unfinished operations to capture southern Sumatra, and other reasons. ${ }^{(14)}$

As mentioned previously, the units involved [in the operation to] capture Bali requested the Eleventh Air Fleet to search for the enemy and attack them, and on the 18th (the day of departure from Cam Ranh Bay) the commander of the 5th Destroyer Squadron, Rear Admiral Hara, also requested the commander of the Malaya Unit, Vice Admiral Ozawa, to launch an air attack on the allied fleets in the waters west of Java, to have the 7th Cruiser Division accompany the convoy of transport ships, and to have the aircraft carrier Ryujjō sail along with them as well if possible. ${ }^{(120)}$

3. The army

The strength known in 1941 was as follows: $:^{(2,23)}$

Time the information was known: End of September Beginning of November 10 November Java: 50,000

Dutch East Indies in total: $\quad 70,000$

85,000

100,000

The breakdown of the above 100,000 troops was known to be 75,000 regular troops, 15,000 volunteer soldiers and 10,000 policemen and indigenous units, while the ratios of white men in the regular troops, the volunteer troops and the police force were $20 \%, 95 \%$ and $10 \%$ respectively. The army strength on Java was known to consist of two divisions as the core. ${ }^{(2,23)}$

After the opening of hostilities, the Dutch East Indies Army staff officer who was taken prisoner in the [Japanese] capture of Tarakan (11 January) stated that one division had been added in central Java, which increased the troops in Java to three divisions as the core, and that their disposition on Java was: ${ }^{(24)}$ 
Army headquarters: Bandung.

Eastern Java: One division ([one unit consisting of] three infantry battalions as the core in Malang, and [one unit consisting of] one infantry battalion as the core in Surabaya).

Central Java: One division ([one unit consisting of] three infantry battalions as the core in Magelang and [one unit consisting of] one infantry battalion in Surakarta and Cilacap each).

Western Java: One division ([one unit consisting of] three infantry battalions as the core in Bandung, and [another unit consisting of] three infantry battalions as the core in Batavia).

Along with the progress of [the operation to] seize key areas outside Java, the information on the [enemy] disposition known by the end of January and by 10 February was as shown in Illustrations No. 42 and No. 43. ${ }^{(23)}$ However, it was information on the Dutch East Indies Army [only]. After the opening of hostilities, the American-British-Dutch-Australian (ABDA) Command was established, and it was beyond doubt that Supreme Commander General Wavell (Britain) had set up his general headquarters near Bandung.(23) There was [also] information that two or three battalions of the British and Australian armies were additionally sent to Sumatra by the end of January. ${ }^{(23)}$ How many [allied] troops would retreat to Java from Singapore and Sumatra with the operations against southern Sumatra in progress, and how many [allied] troops had been or would be additionally sent to Java from other countries, was [also] a matter of concern.

\section{The Start of the Sailing and a Two-Day Postponement of the Landings}

(See Illustrations No. 44 and No. 45)

The large convoy of the main force of the Sixteenth Army [consisting] of fifty-six ships departed from Cam Ranh Bay at 1000 on the 18th, ${ }^{(120)}$ while the convoy of the 48th Division [consisting] of thirty-eight ships departed from Jolo at 0800 on the 19th. ${ }^{(119)}$

As of the 19th, the Tanaka Detachment was heading southward from Palembang for Tanjungkarang in southern Sumatra. In the Lesser Sunda Islands, the Kanemura Detachment was from that morning in the middle of its landing [operation] on Bali, while the Eastern Detachment was approaching Timor for its landing operation scheduled for the following morning. The Carrier Task Force (the First Air Fleet) under the command of Vice Admiral Nagumo was carrying out an air raid on Port Darwin in full force on that day.

On that day (the 19th), the Southern Task Force was escorting the transport of the Sixteenth Army units, and operated roughly as follows:

Main force of the Southern Task Force with the flagship Atago (a heavy cruiser) [and consisting of] the 3d Battleship Division (the battleships Hiei, Kirishima, Kongo and Haruna) and the 4th Destroyer Division (the Arashi, the Nowaki, the Hagikaze and the Maikaze) had left Palau on the day before, the 18th, and was first advancing toward Staring Bay (southeast Celebes) with the aim of conducting operations in the waters south of Java at the time of the Java landing operation (on the 26th). ${ }^{(116)}$

Carrier Task Force [consisting of] the aircraft carriers Akagi and Kaga (the 1st Carrier Division), and the aircraft carriers Sōry $\bar{u}$ and Hiry $\bar{u}$ (the 2d Carrier Division), the heavy cruisers Maya and Takao ([of] the 4th Cruiser Division), Tone and Chikuma ([of] the 8th Cruiser Division), the 1st Destroyer Squadron (the light cruiser Abukuma, the 17th Destroyer Division, and the 2d Section of the 27th Destroyer Division), the 18th Destroyer Division (minus two destroyers), and the Akigumo, was in the middle of the air raid on Port Darwin. It was scheduled to 

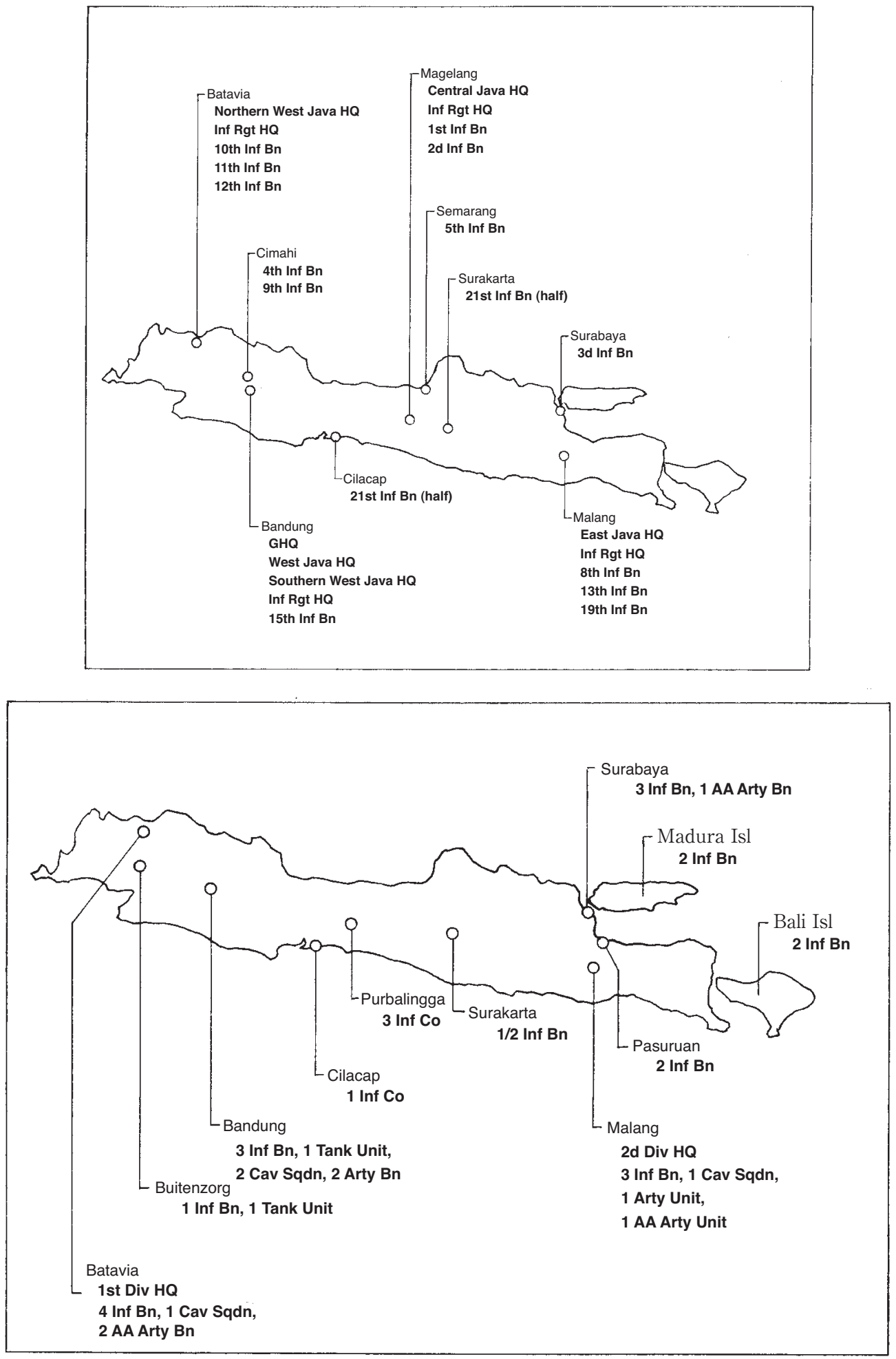

Illustration No. 42 - The [Enemy] Disposition as Known by the End of January Illustration No. 43 - The [Enemy] Disposition as Known by 10 February 
return to Staring Bay on the 21st and then conduct carrier operations on the waters south of Java. ${ }^{(116,123)}$

Malaya Unit:

On the 16th, judging that the escort operations in [Operation] $\mathrm{L}$ were for the most part completed, [First Southern Expeditionary Fleet] Commander in Chief Ozawa had switched the main force to its next operation. However, on that day, the 19th, the convoy of the main force of the 38th Division had not yet reached Palembang, and its river-ascending operation was still going on. [Nevertheless,] the flagship Chōkai (a heavy cruiser), the aircraft carrier Ryūjōo, and the destroyers Shikinami and Isonami returned to Cap Saint Jacques on that day, the 19th.

The light cruiser Yura, the 11th Destroyer Division (the Hatsuyuki, the Shirayuki and the Fubuki), the 12th Destroyer Division (the Shirakumo and the Murakumo), and the auxiliary seaplane tender Kamikawa-maru, which were to be transferred to the Dutch East Indies Unit (the 3d Escort Unit) on the 21st, completed assembly in the Anambas Islands by that day [the 19th].

The 7th Cruiser Division (the heavy cruisers Kumano, Suzuya, Mikuma and Mogami), which was to support the Java landing operation of the main force of the Sixteenth Army ([escorted by] the 5th Destroyer Squadron), had entered the anchorage in the Anambas Islands on the 17 th, and was standing by there.

The 3d Destroyer Squadron commander was continuing Operation L, leading the light cruiser Sendai (the flagship), a few destroyers and lesser ships. ${ }^{(103,115,118,130)}$

The 22d Air Flotilla returned under the command of the commander in chief of the Eleventh Air Fleet on this day (the 19th) ahead of schedule and became the 3d Air Raid Unit. ${ }^{(104,135)}$

Dutch East Indies Unit:

Main Unit, the flagship Ashigara (a heavy cruiser) and the destroyer Yamakaze (accompanied by the Kawakaze as well) left Jolo on the 17th and advanced to Balikpapan to support the operation to capture Bali (the Kawakaze was for escorting the Sakaguchi Detachment). ${ }^{(103)}$ The Bali Invasion [Support] Unit, [consisting of] the light cruiser Nagara and the 8th Destroyer Division (the Ōshio, the Asashio, the Michishio and the Arashio) was in the middle of supporting the landing [operation] on Bali, which had started that morning. ${ }^{(124)}$

The Timor Invasion [Support] Unit, [consisting of] the heavy cruisers Haguro and Nachi of the 5th Cruiser Division, and the auxiliary seaplane tender Mizuho, the flagship light cruiser Jintsū of the $2 \mathrm{~d}$ Destroyer Squadron, the destroyers Oyashio, Hayashio and Kuroshio (of the 15th Destroyer Division), the Yukikaze, the Tokitsukaze, the Amatsukaze, and the Hatsukaze (of the 16th Destroyer Division), the Ushio, the Sazanami and the Akebono (of the 7th Destroyer Division), and the Ikazuchi (of the 6th Destroyer Division) was supporting the landing operation on Timor to be conducted on the next day, the 20th. ${ }^{(14,117)}$

The unit to escort the 48th Division, [consisting of] the light cruiser Naka, flagship of the 4th Destroyer Squadron commander, the 2d Destroyer Division (the Murasame, the Samidare, the Yüdachi and the Harusame), both of which had escorted the division from Lingayen Gulf, the 9th Destroyer Division (the Asagumo, the Natsugumo and the Minegumo), the 24th Destroyer Division (only the Umikaze; the Kawakaze had departed with the main unit [of the Dutch East Indies Unit] earlier), the [mine]layer Itsukushima, flagship of the $2 \mathrm{~d}$ Base Force commander, the seaplane tender Chitose, all of which had sailed north to Jolo after supporting the Makassar operation, escorted the convoy of the 48th Division [consisting] of thirty-eight ships (apart from the Satsuma-maru which departed later) from Jolo. ${ }^{(119)}$

The unit to escort the main force of the Sixteenth Army, [consisting of] the light cruiser Natori, flagship of the 5th Destroyer Squadron commander, the 5th Destroyer Division (the Harukaze, the Hatakaze, the Asakaze and the Matsukaze) and the 22d Destroyer Division (the Nagatsuki, 
the Minazuki, the Fumizuki and the Satsuki), all of which had escorted the force from Gaoxiong, the 1st Section of the 6th Destroyer Division (the Akatsuki and the Hibiki, which came from Davao to Cam Ranh), and the auxiliary seaplane tender San'yō-maru (which had been diverted to Cam Ranh after the Balikpapan operation) had departed from Cam Ranh on the day before, the 18th (on the 17th for the San'yō-maru), and was sailing southward, escorting the convoy of fifty-six ships carrying the main force of the Sixteenth Army. They were notified that they would be joined by the previously-mentioned 11th Destroyer Division (the Hatsuyuki, the Shirayuki and the Fubuki), the 12th Destroyer Division (the Shirakumo and the Murakumo), the light cruiser Yura, and the auxiliary seaplane tender Kamikawa-maru at the Anambas Islands on the 21st, and that they would be provided with the cooperation of the 7th Cruiser Division ([consisting of] four heavy cruisers).. ${ }^{(120)}$

Submarine Unit, [consisting of] Submarine Unit A (the 4th and the 6th Submarine Squadrons), B (the 5th Submarine Squadron) and C (the 2d Submarine Squadron) was advancing respectively towards the seas southeast, west, and south of Java. ${ }^{(117)}$

Air Unit (the Eleventh Air Fleet):

On that day, the 19th, the force under the command of the 22d Air Flotilla commander was returned from the Malaya Unit. Vice Admiral Tsukahara (with his headquarters in Davao) [ordered] the shift to phase-three operations with the disposition of the 1st Air Raid Unit ([consisting of] the 21st Air Flotilla as the core, whose headquarters had returned from Ambon to Kendari on the 17th), the 2d Air Raid Unit ([consisting of] the 23d Air Flotilla with its headquarters in Balikpapan), and the 3d Air Raid Unit ([consisting of] the 22d Air Flotilla with its headquarters in Kuching). ${ }^{(135)}$

Note: The Southern Task Force had issued an order on 18 February and brought forward the date of transfer of the force under the command of the 22d Air Flotilla commander from the 21st to the 19th. ${ }^{(135)}$

On that day (the 19th), the [Army] Third Air Force launched an air assault on western Java from Palembang.

On the next day, the 20th, the convoy [of the units for the operation] to capture Java steadily sailed south. As we have seen, allied cruisers and destroyers raided the disembarkation point at Bali before daybreak. The 8th Destroyer Division fought a fierce battle, and the main unit of the Dutch East Indies Unit (the Ashigara, the Kawakaze, and the Yamakaze) rushed southward on this day, having left Balikpapan at 0300 before daybreak. Fortunately, the sea battle ended in Japanese favor, and twenty-seven aircraft of the $2 \mathrm{~d}$ Air Raid Unit advanced to the Bali airfield as early as that day. In the western [theater], Tanjungkarang was seized on that day, the 20th, and in the eastern [theater], the landing [operation] on Timor was successfully carried out on the same day.

On the next day, the 21 st, the convoy kept steadily sailing southward. That morning the convoy of the 48th Division reached the north end of the Makassar Strait and was sailing southward off Samarinda in the evening. The commander of the Dutch East Indies Unit transferred the 8th Destroyer Division, which had engaged in a fierce battle off Bali, to the main unit on that day and ordered the division to stand by in Makassar. ${ }^{(117)}$ He [also ordered] the seaplane tender Mizuho, which was in the middle of the Timor operation, to sail westward. ${ }^{(117)}$ The main unit of the Southern Task Force, which had sailed south from Palau, and the Carrier Task Force, which had carried out the air raid on Port Darwin, both entered the anchorage at Staring Bay on that day. ${ }^{(102)}$ The commander of the Southern Task Force issued the following order on that day:(119) 


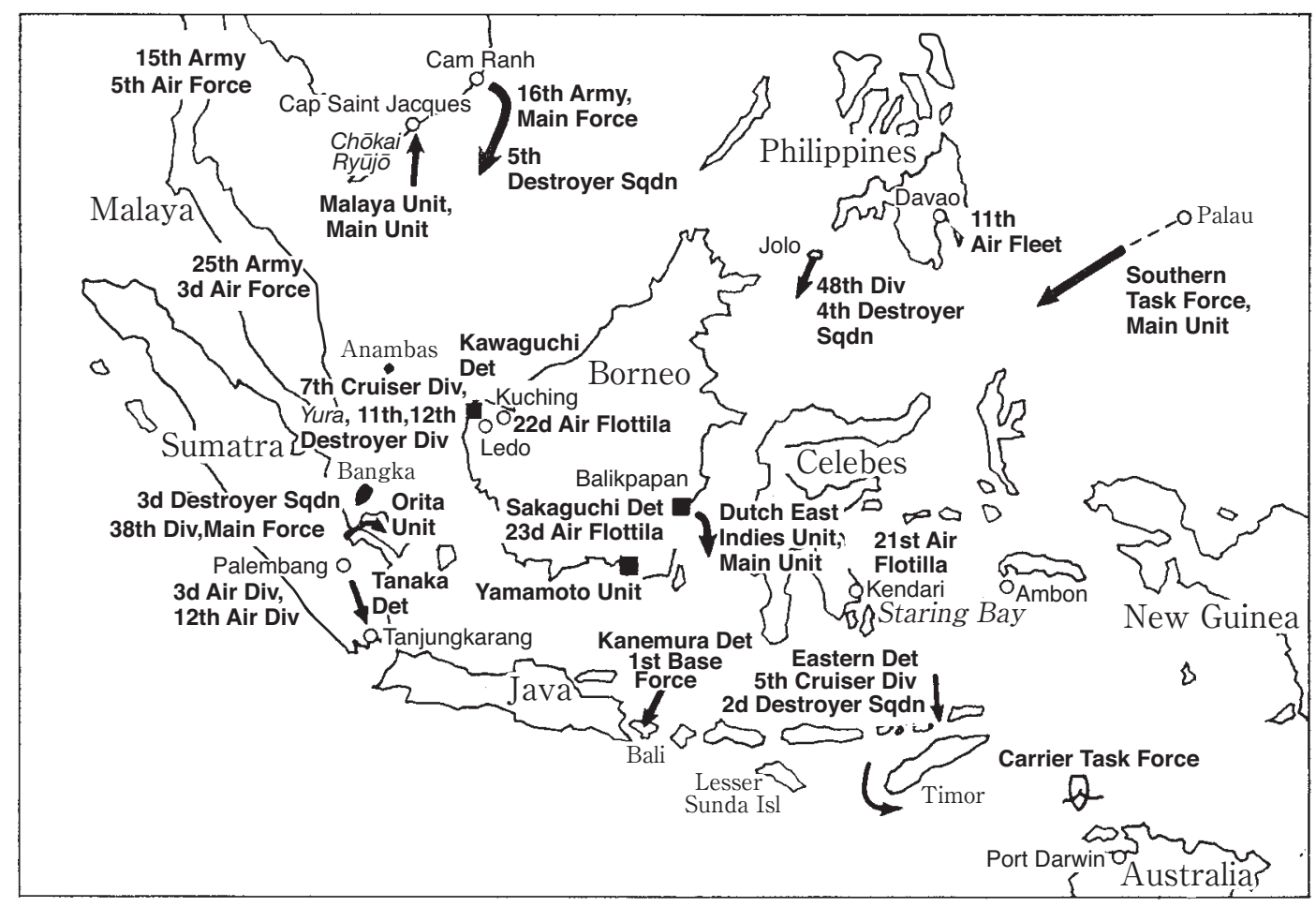

Illustration No. 44 - Situation [of Japanese Forces] on 19 February

Day $\mathrm{Z}$ shall be set as the base date of the operation and shall be applied to the Southern Task Force and the Southern Army as a whole. Day Z shall be 26 February.

In the western [theater], the Yura, and the 11th and the 12th Destroyer Divisions, which had been transferred to the command of the 5th Destroyer Squadron commander from the Malaya Unit, joined the convoy of the main force of the Sixteenth Army in the waters about 100 nautical miles north of the Anambas Islands at 0800 on that day. This increased the escort of the convoy of the main force of the Sixteenth Army to two cruisers and fifteen destroyers. Apart from those, the San'yo-maru (which had left Cam Ranh on the 17th and arrived in the Anambas Islands on the 19th) and the Kamikawa-maru (which had been in Anambas since [the execution of] Operation L) had been providing direct escort with their seaplanes. ${ }^{(120,130,131)}$ (See Illustration No. 45)

On the next day, the $22 \mathrm{~d}$, the convoy was still steadily sailing southward. However, around 1500 when it reached the waters at the latitude and longitude of $1^{\circ} 24^{\prime} \mathrm{N} 107^{\circ} 55^{\prime} \mathrm{E}$, the convoy of the main force of the Sixteenth Army reversed its course and began to sail northward. ${ }^{(130)}$ This was because according to a signal from the Natori, the flagship of the 5th Destroyer Squadron, "[due to] a powerful enemy fleet spotted in the Java Sea, day H has been postponed by two days, and the landing [operation] has been changed to the 28th." (36) The convoy's sailing in reverse direction still continued on the morning of the $23 \mathrm{~d}$. At the time of departure from Cam Ranh, [Sixteenth] Army Commander Imamura had given the order that "should anything happen to me, [2d] Divisional Commander Maruyama should take command, and if anything should happen to Divisional Commander Maruyama, Chief 
of Staff Okazaki [of the Sixteenth Army] should take command." ${ }^{(35,47)}$ On the Ryujjo-maru carrying the army headquarters, some staff officers of the army started saying: "Shouldn't we land on southern Sumatra and then land on Java by maneuvering [landing] craft [from there]?."(44) Others complained that it was a fine kettle of fish that the Chokki, the flagship of the Malaya Unit, and the aircraft carrier Ryūjō had stayed at Cap Saint Jacques to prepare for a triumphal entry into the port of Singapore on the 27th. ${ }^{(36)}$ Around 1400 (on the 23d), the convoy finally reversed course and resumed its southward sailing. The Dutch East Indies Unit officially proposed the army to reschedule day $\mathrm{H}(\mathrm{Z})$ for the 28th. The [Sixteenth] Army commander wired back his approval and transmitted it to all the transport ships. Sometime after 1600, allied submarine(s) were spotted, but the convoy continued sailing southward on a zigzag course.

In the meantime (on the $22 \mathrm{~d}$ and the $23 \mathrm{~d}$ ), the general situation had changed roughly in the following way:

1. The air operations had progressed in the following way since 18 February: ${ }^{(96,99,100,104)}$

18 [February]

Eastern Java: Twenty-three land-based attack planes and fifteen fighter planes of the $2 \mathrm{~d}$ Air Raid Unit conducted an [air] raid on Surabaya from Balikpapan. Six [enemy] destroyers and sixteen transport ships were spotted in the port.

Western Java: It was impossible to conduct [air] attacks.

19 [February]

It was the day when the Air Unit (the Eleventh Air Fleet) shifted to phase-three dispositions, and when the force under the command of the 22d Air Flotilla commander became the $3 d$ Air Raid Unit. [It was also the day] when the [Army] Third Air Force launched an air campaign against Java.

Eastern Java: Although eighteen land-based attack planes and twenty-four fighter planes of the 2d Air Raid Unit took off from Balikpapan to conduct an [air] attack on Surabaya, they could not enter [over the city] due to bad weather and attacked Bawean Island and other locations [instead].

Western Java: The [Navy] 3d Air Raid Unit conducted a reconnaissance of Batavia from Kuching with [a] land-based reconnaissance aircraft. One ship, which was apparently an [enemy] aircraft carrier, three cruisers and ten transport ships were spotted. The [Army] Third Air Force carried out an [air] assault on Bandung, Buitenzorg and other cities from Palembang with a [mixed] force of some sixty fighter planes and bombers, and engaged with some thirty or more allied planes.

20 [February]

Eastern Java: Twenty-seven fighter planes and three land-based reconnaissance aircraft of the [Navy] 2d Air Raid Unit advanced into Bali. Twenty-two fighter planes of the 23d Air Flotilla conducted a raid on Surabaya and Malang.

Western Java: The land-based attack planes of the [Naval] 3d Air Raid Unit searched for the enemy in Batavia from Kuching and spotted five cruisers, eight destroyers, fifty or more transport ships, ten flying boats and three reconnaissance seaplanes in Batavia. The [Army] Third Air Force carried out a raid on Kalijati from Palembang with a [mixed] force of some fifty fighter planes and bombers.

21 [February]

Eastern Java: Thirteen fighter planes of the 23d Air Flotilla conducted a raid on Surabaya and vicinity from Bali and Balikpapan. Twenty-one land-based attack planes of the 23d 
Air Flotilla conducted a raid on Surabaya from Balikpapan. One [enemy] cruiser and thirteen destroyers were spotted in the port.

Western Java: A [mixed] force of some thirty fighter planes and bombers of the [Army] Third Air Force conducted a raid on Kalijati and Bandung from Palembang.

2. The main unit of the Dutch East Indies Unit, which had rushed south from Balikpapan on the 20th at the report of a naval engagement near the landing point on Bali, entered the anchorage of Staring Bay on the morning of the $22 \mathrm{~d}$ and joined the main force of the Southern Task Force and the Carrier Task Force, which had advanced into the bay the day before.

The commanders of the Southern Task Force, the Dutch East Indies Unit and the Carrier Task Force held talks, examined [the situation], and decided that the air campaign that had started on the 18th (for eastern Java) and the 19th (for western Java) was not sufficient, and that there seemed to remain five to seven [enemy] cruisers and some ten destroyers in Batavia and two cruisers and about five destroyers in Surabaya.

They also judged that it was necessary to intensify the air campaigns and reinforce the surface units in the Java Sea area, which would necessitate a two-day postponement of the date of the landings. ${ }^{(117)}$

Accordingly, telegrams [to propose] a two-day postponement of the date of the landings, etc. were sent around 1200 on the $22 \mathrm{~d}$ to the Sixteenth Army and the Southern Army. Also, the orders to reverse course for the convoys were transmitted, and by evening directions were given about the concentration of surface forces into the Java Sea, etc.

The Dutch East Indies Unit issued the following order concerning the course reversal of the convoys: $:^{(117)}$

\section{Third Fleet Classified Telegram No. 445}

1200, 22 February

The dates to launch the landing of Operation $S u$ and Ya shall be postponed until 28 February. The unit for Operation $S u$ shall stand by near Balikpapan. The unit for Operation Ya shall act at the right moment as designated by the commander.

Note: $S u$ indicated eastern Java, and Ya western Java.

The proposal wired by the Dutch East Indies Unit to the Sixteenth Army regarding the postponement of the schedule read: "In view of the activities of naval vessels and aircraft of the enemy in the Java area as well as the results of our air campaigns, we propose a postponement of the date to start landing by two days until 28 February." At the same time, the Southern Task Force sent a telegram to the same effect to the Southern Army, and also requested it to cooperate in the naval air unit(s)' advance into the Gelumbang base so that they could destroy [enemy] naval vessels in the western Java area. ${ }^{(24)}$ The Sixteenth Army wired back its approval on the 23d. ${ }^{(32)}$ On the $23 \mathrm{~d}$, the Southern Army replied to the Southern Task Force: "While requesting no further postponements other than the above days, we will [provide] ample support to make the Gelumbang airfield ready for the Navy," and sent the following telegram to the 38th Division. ${ }^{(23,24)}$ The reason why it sent the telegram directly to the 38th Division was that it thought that the Sixteenth Army had sealed off its radio communications. 


\section{From: Chief of Staff [Southern Army]}

To: 38th Division commander [in] Palembang (sent on the 23d)

Southern Army Staff Section 1 Telegram No. 95

1. [This] is to the highest extent relevant to the landing [operation] of the main force for [Operation] $\mathrm{H}$. We would like you to immediately provide the Navy with ample support to make the Gelumbang airfield ready ([by] transporting fuel and ammunition, etc.).

2. Gelumbang is located about fifty kilometers southwest of Palembang.

3. The warship Shumushu and the Kōchō-maru [probably a misprint for Kōryū-maru] are in charge of readying the Navy's airfield and are now in port in Palembang.

As for the concentration of surface forces into the Java Sea and other issues, the Southern Task Force and the Dutch East Indies Unit decided the following and gave directions by the night of the $22 \mathrm{~d}:^{(117)}$

1. The main force of the Southern Task Force and the Carrier Task Force shall leave Staring Bay on the 25th and advance to the sea south of Java as formerly planned. The 5th Cruiser Division's advance into the Indian Ocean shall be canceled.

2. The main unit of the Dutch East Indies Unit (the Ashigara, the Ikazuchi and the Akebono the Yamakaze and the Kawakaze were replaced by the Ikazuchi and the Akebono) shall leave Staring Bay on the morning of the 23d, first support the second disembarkation operation at Bali (on the 25th), and then support the unit to land in eastern Java.

3. The Eastern Support Unit ([of the Dutch East Indies Unit, consisting of] the 5th Cruiser Division, the Ikazuchi and the Akebono, which had returned to Staring Bay on the 22d after supporting the Timor landing operation) shall be reorganized into the 5th Cruiser Division Unit, which will be made up of the 5th Cruiser Division (the Nachi and the Haguro), the Yamakaze the Kawakaze, and the 1st Section of the 7th Destroyer Division (the Ushio and the Sazanami, which were [at that time] in the middle of the Timor operation). [The unit] shall timely operate around the rear of the 1st Escort Unit (which, with the 4th Destroyer Squadron as the core, is escorting the unit for the landing in eastern Java), support the unit, and catch and destroy allied naval vessels. In this operation, the 5 th Cruiser Division commander may give directions to the 4 th and the $2 \mathrm{~d}$ Destroyer Squadron commanders (the latter of whom is conducting the Timor operation, but is supposed to hurry to join [the operation]). The advance of the 5 th Cruiser Division to the Indian Ocean shall be canceled.

4. The Nagara, the 8th Destroyer Division (the Asashio and the Arashio), and the 21st Destroyer Division (the Wakaba, the Nenohi, and the Hatsushimo) under the command of the 1st Base Force commander, shall leave Makassar on the 23d and cover the second disembarkation operation on Bali on the 25th.

5. The $2 \mathrm{~d}$ Escort Unit (which is covering the landing [operation] on Timor) shall be disbanded at 1800 on the 24th. The Jints $\bar{u}$ and the 16th Destroyer Division (the Yukikaze, the Tokitsukaze, the Amatsukaze and the Hatsukaze), under the command of the 2d Destroyer Squadron commander, shall advance to the waters south of Cape Selatan around 1600 on the 26th from Timor by way of Makassar. The 15th Destroyer Division (the Oyashio, the Hayashio, the Kuroshio and the Natsushio [editor's note: the last-mentioned ship had actually been sunk on 9 February, see p. 397] shall participate in the carrier operation of the Carrier Task Force and the main force of the Southern Task Force in the Indian Ocean from Timor. The 1st Section of the 7th Destroyer Division (the Ushio and the Sazanami) shall sail westward from Timor to come under the command of the 5 th Cruiser Division commander.

6. The Tomozuru shall leave Makassar, escorting the Sasako-maru (which had returned to Makassar after disembarking the Kanemura Detachment at Bali), embark Regimental Commander 


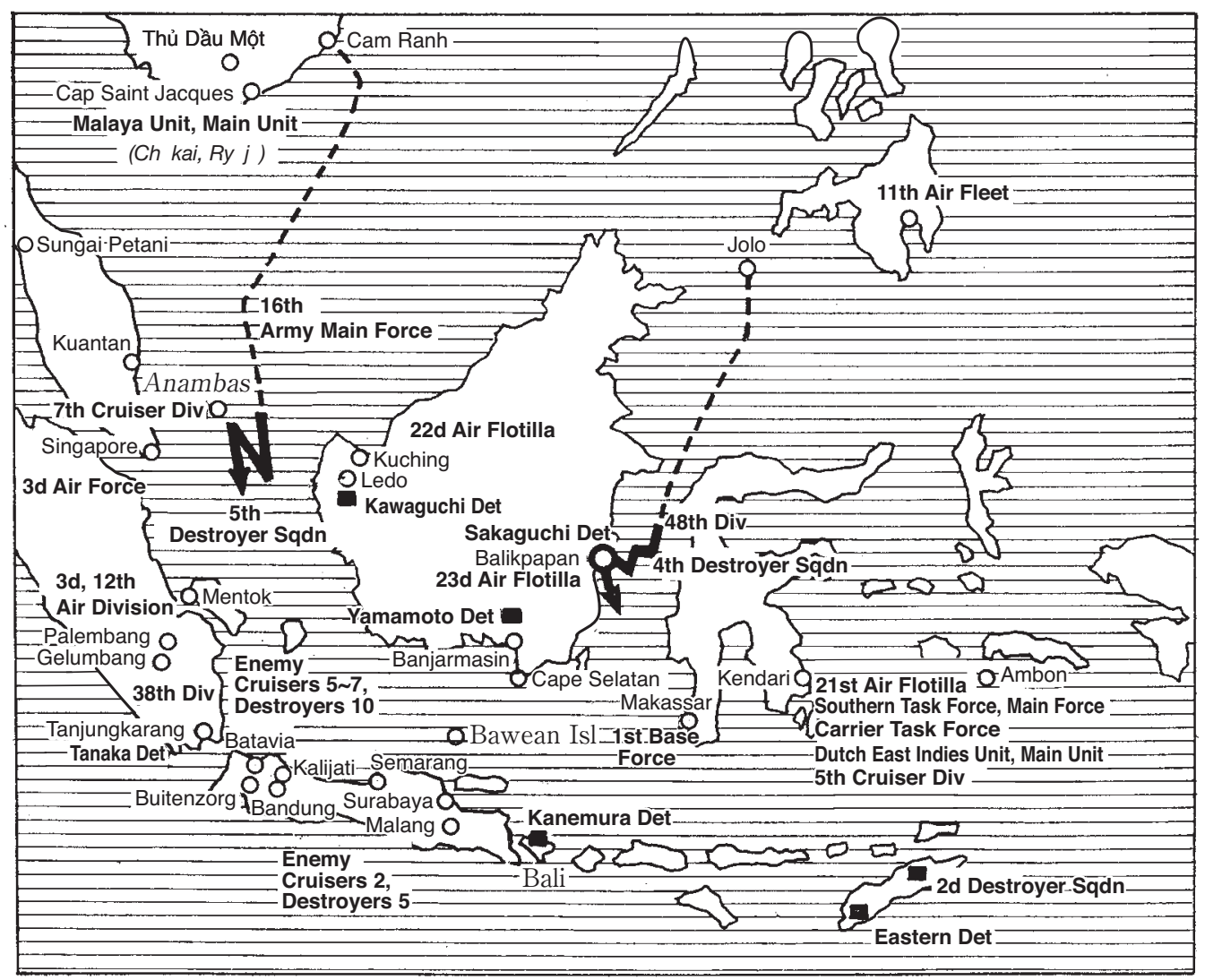

Illustration No. 45 - The Situation on 22 and 23 February

Yamamoto and his men on the Sasako-maru at Banjarmasin and then let the latter join the convoy [of the units to] land on eastern Java on the sea south of Cape Selatan around 1200 on the 26th.

3. The Ehime-maru and the Liverpool-maru carrying the main force of the Sakaguchi Detachment left Balikpapan at 0800 on the $22 \mathrm{~d}$ and took up their position at the rear of the convoy of the 48th Division north of Aru Bank at 1200 on the same day. ${ }^{(119)}$ The 1st Escort Unit (i.e. the 4th Destroyer Squadron), which had passed through the waterway of Aru Bank at 1220 escorting the 48th Division and the Sakaguchi Detachment, received the previously mentioned telegraphic order around 1345, reversed the course of the convoy at 1400, and temporarily anchored at a spot thirteen nautical miles southwest of Balikpapan. ${ }^{(119)}$ The Teiry ū-maru and the Nisshō-maru [Hiteru-maru] under the command of [Army] Major Takagi, which had hurriedly sailed from Palau, had arrived in Balikpapan before noon on that day. They had sailed night and day in such a hurry that five stokers had collapsed on the way. On arrival in Balikpapan, [Army Major Takagi] had drawn a sigh of disappointment when Detachment Commander Kume told him: "The Sakaguchi Detachment has [already] departed this morning." However, luckily for him, he learned the next day, the $23 \mathrm{~d}$, that the convoy had reversed course, as previously mentioned, and he [was able 
to] join [the convoy] on the same day. ${ }^{(88)}$ [Editor's note: There is some confusion about the date and time he joined the convoy. See pp. 450, 537.]

4. The Southern Army had wired that ample support should be immediately provided to make the Gelumbang airfield ready. The Gelumbang issue had gone through the following twists and turns.

In eastern Java, the aircraft of the $2 \mathrm{~d}$ Air Raid Unit, which had advanced into Bali from the 20th onwards, conducted a raid over Semarang and other locations from Bali with six fighter planes on the $22 \mathrm{~d}$ for two days running (which was mentioned earlier). It also conducted a raid on Malang from Bali with fourteen fighter planes on the $23 \mathrm{~d}$ and was freely carrying out its air campaign. Against western Java, however, the 3d Air Raid Unit had not been able to launch air attacks [yet]. ${ }^{(104)}$

The air operation against western Java was [planned and conducted] roughly in the following way.

On 28 January, an arrangement had been concluded for the [air operation in] Operation L between the Army and the Navy [pp. 265-267], which was in outline that (1) the [Navy] Malaya Unit and the Army should employ respectively about 176 and about 137 aircraft; (2) that when the Ledo [airfield] was fit for use, the Malaya Unit should use the Ledo, the Kuching, the Kuantan and the Sungai Petani [airfields]; (3) that the Malaya Unit should attack [the area] east of the line connecting Mentok and Palembang; and (4) that after the landing in L [i.e. Bangka and Palembang], the airfield on Bangka should be shared by the Army and the Navy with thirty aircraft each, whereas Palembang should be used exclusively by the Army. ${ }^{(96)}$ However, the Ledo airfield was not fit for use, and even though the Malaya Unit had launched its air operation [in Operation] L on 9 February, it was not able to conduct a sufficient air campaign against western Java.

The next day, 10 February, a revised version of the "Memorandum of the Arrangements for Operation $\mathrm{H}$ between the Sixteenth Army, the Third Air Force, the Third Fleet and the Eleventh Air Fleet" was concluded. The original arrangement had preliminarily been agreed at the Manila Conference and concluded on 30 January, based on the assumption that the 22d Air Flotilla should return to the Eleventh Air Fleet. [So,] its distinctive feature was the exclusion of the Malaya Unit (the First Southern Expeditionary Fleet). ${ }^{(96)}$ In this arrangement, it was agreed (1) that the forces to be employed should be about 190 aircraft of the Eleventh Air Fleet, about 50 reconnaissance seaplanes of the Third Fleet, and about 179 aircraft of the [Army] Third Air Force; (2) that the Army should mainly use the Palembang [airfield], while the Mentok [airfield] should be shared by the Army and the Navy (with thirty aircraft each); that when the Tanjungkarang [airfield] was fit for use for the Army, the Mentok [airfield] would be [handed over] to the Navy for its exclusive use; that the Army might use the Ledo [airfield] for some command reconnaissance aircraft; that in addition to the Ledo [airfield], the Navy might partially use the Palembang [airfield] and share the Mentok [airfield with the Army] (to return to its exclusive use later); and (3) that the Navy should conduct its raids on [the area] to the east of $108^{\circ}$ east. ${ }^{(96)}$ (See the previous description.)

On 14 February (the day when the [Paratroop] Raiding Group descended on Palembang), the Third Air Force drew up an outline for the air operation [in Operation] $\mathrm{H} .{ }^{(96)}$ At that time, the Fifteenth Army was charging toward Rangoon in Burma, and the [Army] Fifth Air Force was supporting this operation. The Twenty-fifth Army was in the middle 
of its attack on Singapore, and its subsequent operations included the northern Sumatra invasion operation. For this reason, the [Army] Third Air Force ([consisting of] the 3d, the 7th and the 12th Air Divisions, the 81st Air Group, and the 15th Independent Air Unit), which had to cooperate with [both] the Twenty-fifth and the Sixteenth Armies, set down in summary the following points in the outline of the air operations [in Operation] $\mathrm{H}:{ }^{(96)}$

1. In conjunction with the Navy, we shall swiftly destroy [enemy] air power in the western Java area in the wake of Operation L and [also] closely support the Sixteenth Army in the latter's operations in western Java.

2. As the airfields in Palembang and Tanjungkarang are seized and made ready for use, we shall first destroy the enemy air power in western Java (to the west of $108^{\circ}$ east).

3. From the day before the landing [operation] of the main force of the Sixteenth Army ( 25 February), we shall provide cover for the convoy of the main force of the $2 \mathrm{~d}$ Division under sail and the air defense at its anchorage, as well as directly support the main force of the Sixteenth Army in its ground combat.

4. Forces to be employed for Operation $\mathrm{H}$ and their operations are as follows:

81st Air Group: shall search [for the enemy].

12th Air Division (a fighter air division; [consisting of] one squadron of the 1st Air Group and the 11th Air Group):

Shall destroy [enemy] air power, cover the convoy and its anchorage, and [provide] air defense.

3d Air Division:

Headquarters

15th Independent Air Unit (the headquarters, the 50th and the 52d Independent Squadron - command reconnaissance aircraft)

59th Air Group (fighter planes)

64th Air Group (fighter planes)

27th Air Group (minus one squadron; assault planes)

90th Air Group (light bombers)

75th Air Group (light bombers):

Shall destroy [enemy] air power, directly support ground operations and cover the convoy as needed.

On that day (the 14th) the paratroop unit seized the Palembang airfield, and on the next day, the 15th, the aircraft of the $3 \mathrm{~d}$ and the 12th Air Divisions started their advance into the Palembang [airfield]. On the same day, the Tanaka Detachment landed in Mentok and Palembang.

On the next day, the 16th, the 12th Air division headquarters also advanced to the Palembang [airfield] to which twenty army aircraft had advanced by that day. ${ }^{(135)}$

On the next day, the 17th, the $3 \mathrm{~d}$ Air Division headquarters also advanced into Palembang, which increased the number of the army aircraft advanced to the airfield by this day to twenty-nine. ${ }^{(98,135)}$ About the situation of both the Mentok and the Ledo airfields, however, one could only be pessimistic. Although a total of 8,091 men had been employed [for readying] the Ledo airfield during a total period of twenty-one days by that day, the condition of the airfield as of that day was as previously described [p. 306]..(23) Although on that day the Malaya Unit passed down an order to the 22d Air Flotilla to advance its aircraft to the Ledo airfield for the first time, it was just a pitiful order that [only] one squadron should be advanced to Ledo as soon as possible from the 19th onwards. ${ }^{(135)} \mathrm{A}$ 
hurried preparation was also going on at the Mentok airfield, but for the time being it could not be put to use. Out of necessity, the Malaya Unit on that day requested the [Army] Third Air Force to allow twenty naval aircraft to advance to the Palembang [airfield]. ${ }^{(135)}$

However, on the next day, the 18th, the Third Air Force rejected the request. ${ }^{(135)}$ The Palembang airfield was not large enough either, and neither the convoy nor the necessary materiel had reached Palembang (the former arrived on the afternoon of the 20th). The situation of the units for [Operation] $\mathrm{H}$ of the [Army] Third Air Force was that [finally] all but the 75th Air Group managed to advance there by that day. ${ }^{(96)}$ The situation at the Mentok airfield as of that night was that "for the present [a runway of] seventy meters wide and seven hundred meters long has been completed, and its extension to one thousand meters in length is expected to be completed in several days, [but] the ground is quite bumpy." (118) It meant that the airfield would remain unavailable for the time being.

On the next day, the 19th, the [Army] Third Air Force launched its air operation [in Operation] $\mathrm{H}$ from Palembang. A total of twenty-four aircraft of the 59th, the 64th and the 90th Air Groups conducted a raid on Buitenzorg [Bogor] in the morning, and [a total of] thirty-seven aircraft on Bandung in the afternoon. They reported a military gain of bringing down nineteen [enemy] aircraft in total (three of which uncertain), and nine [enemy] aircraft destroyed by fire; one [of the Japanese] aircraft did not return. ${ }^{(96)}$ On that day, the [Army] Third Air Force discovered the Gelumbang airfield and reported it to the Eleventh Air Fleet. ${ }^{(135)}$ It was the day when the Air Unit (i.e. the Eleventh Air Fleet) took over the command of the 22d Air Flotilla and started giving directions to it as the [Navy] 3d Air Raid Unit. ${ }^{(135)}$

On the next day, the 20th, the 3d Air Raid Unit was still at its bases in Kuching, Kuantan and Thủ Dâu Một (in French Indochina). The Navy side had become extremely worried. On that day, the 22d Air Flotilla wired a request to the Eleventh Air Fleet: "As for the Ledo [airfield], we have made efforts to accumulate fuel and ammunition both by sea and by land, but we barely managed to accumulate [enough] fuel and ammunition for a single sortie of twenty-seven land-based attack planes; there is no prospect of progress in the accumulation [of fuel and ammunition] in the future, and the airfield is in no good condition either; furthermore, it is unlikely that fuel and ammunition can be transported to Gelumbang in time; we request [you to take measures] so that we can make use of the Palembang [airfield]." (135) Unable to remain indifferent to the 22d Air Flotilla's predicament, Cdr. Naitō Takeshi, a staff officer of the Malaya Unit, on that day visited the Southern Army to request that the Navy share the Palembang [airfield]. ${ }^{(24)}$ However, the Army rejected this, saying, "The Palembang [airfield] has no capacity to spare [for the Navy]. We would like you to make the Gelumbang [airfield] ready and use it, for which the Army shall provide cooperation." (24) [Also] on that day, the Tanaka Detachment seized Tanjungkarang. The preparation work was [still] going on at the Mentok [airfield]. On that day as well, the [Army] Third Air Force conducted a raid on Kalijati from Palembang with a total of thirty aircraft of the 59th, the 64th and the 90th Air Groups, and reported a military gain of eight [enemy] aircraft destroyed by fire. ${ }^{(96)}$

On the next day, the 21st, the Eleventh Air Fleet again wired to the [Army] Third Air Force, requesting: "It is difficult to have the entire force of the [Navy] Kanoya Air Group use the Ledo [airfield]. Despite the absolute necessity to launch an air campaign on the 
25th for the sake of the Java landing [operation] scheduled for the 26th, the [accumulation of] fuel and ammunition is far from ready at the Gelumbang [airfield]. We would like your reconsideration of sharing the Palembang [airfield]." (135) However, the [Army] Third Air Force could not afford to accept this. On that day, the 22d Air Flotilla sent an aircraft to survey the Palembang and the Gelumbang [airfields]; (it returned on the 23d). ${ }^{(135)}$ The Mentok [airfield] was still in the process of preparation. On this day as well, Staff Officer Itoda found the Tanjungkarang airfield, but it turned out to have [a runway of] no more than 700 meters in length. ${ }^{(39)}$ Also on that day, the Third Air Force carried out a raid on Kalijati and Bandung from Palembang with a total of forty-four aircraft of the 59th, the 64th and the 90th Air Groups, and reported a military gain of six [enemy] aircraft destroyed by fire and [also] the loss of one [Japanese] aircraft. ${ }^{(96)}$

On the next day, the 22d, the commanders of the Southern Task Force and the Dutch East Indies Unit held talks at Staring Bay. ${ }^{(117)}$ The convoys were sailing straight to the south aiming to land the Sixteenth Army on Java on the night of the 25th. However, it was reported that there remained five to seven allied cruisers and about ten destroyers in Batavia and two cruisers and about five destroyers in Surabaya. ${ }^{(17)}$ Accordingly, Southern Task Force Commander Vice Admiral Kondō proposed to Southern Army Commander in Chief Terauchi a two-day postponement of the landing schedule and requested the latter's cooperation in making the Gelumbang [airfield] ready. ${ }^{(17)}$ On that day, the [Army] Third Air Force carried out a raid on Batavia and Buitenzorg from Palembang with a total of forty-one aircraft of the 59th, the 64th and the 90th Air Groups, and reported a military gain of four [enemy] aircraft destroyed by fire. ${ }^{(96)}$ The Mentok and the Tanjungkarang airfields were [still] in the process of being readied.

On the next day, the $23 \mathrm{~d}$, the Southern Army sent a telegram to the 38th Division and ordered the latter to provide the Navy with ample support in making the Gelumbang airfield ready, as mentioned previously. The convoys, which had reversed their course the day before, resumed their course southward on that day. ${ }^{(130)}$ On that day as well, the $3 \mathrm{~d}$ Air Raid Unit was [finally] able to advance eighteen aircraft to the Mentok [airfield] for the first time. ${ }^{(104)}$ The [Army] Third Air Force [only] conducted reconnaissance and serviced its aircraft on that day. ${ }^{(96)}$ The [Army] Third Air Force had not yet completed the advance of its entire force into the Palembang [airfield]. The Tanaka Detachment was concentrating all its efforts into making the Tanjungkarang [airfield] ready.

That was the situation on the $22 \mathrm{~d}$ and the $23 \mathrm{~d}$ when some of the Sixteenth Army staff officers proposed: "Shouldn't we land on southern Sumatra and then land on Java by maneuvering [landing] craft [from there]?"

On the next day, the 24th, the convoy of the main force of the Sixteenth Army kept sailing straight to the south.

On that day (the 24th), in the eastern Java area, the 1st and the 2d Air Raid Units attacked Surabaya with a total of fifty-one land-based attack planes from Kendari, Balikpapan, and Bali, along with nine fighter planes from Bali. ${ }^{(104)}$

At 0800 on that day, the convoy carrying the 48th Division and the Sakaguchi Detachment, and the 1st Escort Unit (the 4th Destroyer Squadron) departed from the temporary anchorage south of Balikpapan and sailed southward. ${ }^{(119)}$ [Also] at 0800, the Tomozuru and the Sasakomaru left Makassar for Banjarmasin. ${ }^{(119)}$ The Teiryū-maru and the Nisshō-maru [Hiteru-maru] 
led by [Army] Major Takagi joined [the convoy of the 48th Division] at $1600,{ }^{\left({ }^{(8)}\right)}$ which increased the convoy to forty-two ships in total. The main unit of the Dutch East Indies Unit and the 1st Base Unit were taking up positions for the $2 \mathrm{~d}$ Bali disembarkation operation (on the 25th). On that day (the 24th), the 5th Destroyer Squadron unit departed from Staring Bay at 1200, the 1st Section of the 7th Destroyer Division from the sea off the coast of Dili at 0830, and the Jintsu $\bar{u}$ and the 16th Destroyer Division, which were directly led by the $2 \mathrm{~d}$ Destroyer Squadron commander, from Kupang at 1200, and sailed westward. ${ }^{(117)}$ On that day as well, Vice Admiral Takahashi, commander of the Dutch East Indies Unit, specifically sent telegrams to the commanders of the 5th Cruiser Division and the $2 \mathrm{~d}$ Destroyer Squadron to instruct them to quickly advance into the Java Sea. ${ }^{(114,117)}$

In the western Java area, the 3d Escort Unit (the 5th Destroyer Squadron) was sailing south, while [simultaneously] refueling ([with fuel brought] from the Anambas Islands) and escorting the main force of the Sixteenth Army. ${ }^{(120)}$ Although allied submarine(s) appeared, no damage was incurred. The 7th Cruiser Division (the heavy cruisers Kumano, Suzuya, Mikuma and Mogami) and the 19th Destroyer Division (the Uranami, the Isonami and the Shikinami) left the Anambas Islands at 1800 and sailed south in order to support the 3d Escort Unit. ${ }^{(115)}$ They were under the command of Malaya Unit Commander Vice Admiral Ozawa. On that day (the 24th), the Third Air Force carried out an attack on Bandung and Kalijati from Palembang with a total of sixty aircraft of the 59th, the 64th, the 75th and the 90th Air Groups in the morning, and on Batavia and Cililitan from Palembang with fifty-nine aircraft in the afternoon, and reported a military gain of bringing down eleven [enemy] aircraft (three of which uncertain) and twenty [enemy] aircraft destroyed by fire. ${ }^{\left({ }^{96}\right)}$ That morning Vice Admiral Kondō, commander in chief of the Southern Task Force, requested the commander in chief of the Eleventh Air Fleet and the commander of the Malaya Unit to accelerate [the work to] make the Gelumbang base ready and to let the Mihoro Air Group (which had been kept under the command of the Malaya Unit) participate in the air operation against Java as follows. On that day, the $3 \mathrm{~d}$ Air Raid Unit was able to advance thirty-nine aircraft to Gelumbang for the first time. ${ }^{(135)}$

\title{
From: Chief of Staff, Second Fleet
}

sent at 1030 on the 24th

\begin{abstract}
Now the date of the landings on Java is approaching. If we do not get an opportunity to destroy the enemy surface forces in the Java Sea area, it will have a great impact on the conduct of the landing operations. Therefore, [adequate] military gains are keenly desired from the air operations in these few days. In view of the fact that the Army has offered its cooperation and taking into account the situation of the Gelumbang base as well, I would like you to be determined to promptly destroy the [enemy] naval vessels and aircraft in the area prior to the execution of the landings, while accelerating the preparation of the base as much as possible and making use of it. Further, as the transport convoy is now under sail and the landing date has already been postponed by two days in order to intensify the air operation, we are in a situation where no further postponement shall be allowed. Therefore, I would like you to see to it that the Mihoro Air Group will conduct [air] attacks on the enemy naval vessels in the western Java area with its full force.
\end{abstract}

On the next day, the 25th, one large cruiser, three light cruisers, five destroyers, several smaller naval vessels of the enemy and thirty or more commercial ships were spotted in Surabaya, and one cruiser and more than a dozen commercial ships were spotted in Batavia. ${ }^{(117)}$ 
In the eastern Java area, twenty-two land-based attack planes and nine fighter planes conducted a raid on Surabaya respectively from Balikpapan and Bali on that day (the 25th). At 0800 the 1st Base Unit reached Bali and started the second disembarkation. ${ }^{(124)}$ After supporting this [operation], the main unit of the Dutch East Indies Unit returned to Makassar in the evening. ${ }^{(103)}$ The convoy carrying the 48th Division and the main force of the Sakaguchi Detachment, and the 1st Escort Unit continued sailing southward and entered the Java Sea through the waters between the islands of Moresses and Matasiri (See Illustration No. 46) around 2200 that night. ${ }^{(19)}$ The Sasako-maru, which was escorted by the Tomozuru, arrived at the anchorage south of Banjarmasin at 0900 on that day, and the Yamamoto Regiment started its embarkation. ${ }^{(119)}$ The 5th Cruiser Division (the Nachi and the Haguro), the Yamakaze and the Kawakaze entered the Java Sea. ${ }^{(114)}$ The Jints $\bar{u}$ of the $2 \mathrm{~d}$ Destroyer Squadron, the 16th Destroyer Division and the 1st Section of the 7th Destroyer Division arrived in Makassar in the afternoon and left the port at 1900 after replenishing to sail westward. ${ }^{(117)}$ On that day, the Carrier Task Force, the 2d Submarine Squadron, and the main force of the Southern Task Force left Staring Bay for the sea south of Java. ${ }^{(103)}$

In the western Java area, the convoy of the main force of the Sixteenth Army and the $3 \mathrm{~d}$ Escort Unit passed through the Karimata Strait around 1600 and entered the Java Sea on that day (the 25th). ${ }^{(120)}$ The 7th Cruiser Division and the 19th Destroyer Division (the Shikinami, the Uranami and the Isonami) were sailing south behind them. ${ }^{(115)}$ On that day, a reconnaissance aircraft of the 22d Air Flotilla reported: "[Spotted] one Type-A cruiser, two Type-B cruisers, and five destroyers in the Batavia port at 1105. [Spotted] one Type-B cruiser and one gunboat sailing northward through the Sunda Strait at 1130."(115) On that day, the [Army] Third Air Force carried out a raid on Kalijati from Palembang with a total of twenty-eight aircraft of the 64th and the 75th Air Groups, and again with a total of twenty-eight aircraft of the 59th and the 90th Air Groups, and reported a military gain of seven [enemy] planes in total destroyed by fire. ${ }^{(96)}$ The [Army] Third Air Force reported that its military gains from 19 to 25 February aggregated to bringing down thirty-three planes, damaging or destroying by fire fifty-three planes, and half or lightly damaging 125 planes. ${ }^{(96)}$ On that day, one squadron of the 11th Air Group advanced to the Tanjungkarang [airfield] for the first time. ${ }^{(99)}$ [Also] on that day, forty-four aircraft and fifteen aircraft of the 3d Air Raid Unit reconnoitered and attacked Batavia respectively from Gelumbang and Mentok. ${ }^{(104)}$ On that day, the commander in chief of the Eleventh Air Fleet sent telegrams of appreciation to the [Army] Third Air Force and the 38th Division for their cooperation in the preparation of the Gelumbang [airfield]. ${ }^{(135)}$

In the early morning of the next day, the 26th, the Air Unit (i.e. the Eleventh Air Fleet) judged: "the air campaign on eastern Java since 18 February has brought down forty-three [enemy] planes (eleven of which uncertain) and damaged or destroyed by fire forty-eight [enemy] planes." ${ }^{(117)}$ The military gains of the [Army] Third Air Force since the 19th were as previously mentioned, and that morning the [Army] Third Air Force judged: "the number of aircraft left in western Java are between twenty and thirty aircraft," ${ }^{(96)}$ whereas the [Navy] Air Unit (the Eleventh Air Fleet) the same morning judged:"the remaining [enemy] aircraft in Java are about fifty fighter planes, about forty bombers, and about twenty flying boats, and they have started using guerrilla tactics." ${ }^{(117)}$ The Air Unit (the Eleventh Air Fleet) further advanced thirty aircraft of the main unit of the $3 \mathrm{~d}$ [Naval] Air Group into Bali that day, the 26th, the intention of which was to rapidly clear and destroy the [remaining] allied aircraft. ${ }^{(117)}$ Accordingly, the headquarters of the 23d Air Flotilla also advanced into Bali on that day, the 
26th. ${ }^{(104)}$ On that day, twenty-six land-based attack planes and eight fighter planes carried out a raid on Surabaya respectively from Makassar and Bali. ${ }^{(104)}$ Around noon, the Sasakomaru (which had sailed from Banjarmasin carrying the Yamamoto Regiment escorted by the Tomozuru) joined the convoy of the 48th Division and the Sakaguchi Detachment (under escort of the 1st Escort Unit), ${ }^{(19)}$ which increased the number of transport ships [in the convoy] to forty-three. Around 1950 the convoy reached a spot 150 nautical miles north of Surabaya. ${ }^{(119)}$ The 5th Cruiser Division unit and the 2d Destroyer Squadron unit joined the convoy respectively in the morning and in the evening of the 26th. ${ }^{(114,117)}$ That morning as well, the main unit of the Dutch East Indies Unit left Makassar and sailed westward. ${ }^{(103)} \mathrm{Al}-$ though [air] raids on Surabaya had been frequently conducted as previously described, one [enemy] heavy cruiser, two light cruisers, several destroyers and several torpedo boats were spotted anchored outside the port of Surabaya, and also two ships, which appeared to be [enemy] destroyers, were spotted sailing eastward at the north end of Surabaya [port] at 1630 on that day (the 26th). ${ }^{(119)}$ [Also] on that day, allied flying boat(s) approached the 1st Escort Unit and the 2d Destroyer Squadron unit from 1245 onwards for reconnoitering, which indicated a possible counterattack by the allied fleet. ${ }^{(119)}$

On that day (the 26th) in the western Java area, the convoy of the main force of the Sixteenth Army (under escort of the 3d Escort Unit) was sailing southward about 215 nautical miles northeast of Batavia at 0800, but changed course to 270 degrees (due west) around noon. The 7th Cruiser Division unit was supporting [the convoy] at a visible distance. ${ }^{(115,120)}$ At 1300 the convoy of the main force of the Sixteenth Army was also approached by [reconnoitering] allied flying boats. ${ }^{(115)}$ On that day, the [Army] Third Air Force did not conduct its air campaign. ${ }^{(96)}$ The [Navy] 3d Air Raid Unit covered the convoy from the Gelumbang [airfield] on that day. The 3d Air Raid Unit aircraft spotted two commercial ships and a ship which appeared to be an [enemy] destroyer to the northeast of Batavia on that day. ${ }^{(103,135)}$

\section{Another One-Day Postponement of the Date of Landing and Naval Engage- ments (See Illustration No. 46)}

The main force of the Sixteenth Army was scheduled to enter the anchorage and conduct the landing [operation] on the night of the next day, 27 February.

As we have seen, the presence of [enemy] cruisers and lesser ships in [the ports of] Batavia and Surabaya had often been reported in the last few days. In the eastern Java area, the [air] base had been advanced as far as Bali from the 20th onwards and the aircraft of the Air Unit (the Eleventh Air Fleet) were repeatedly conducting attacks, but there were no reports of the sinking of [enemy] naval vessels. As for the western Java area, the [Army] Third Air Force had started its attacks from the 19th onwards, but the attacks were limited to aerial engagements. The [Navy] 3d Air Raid Unit was [not only] late in its advance [toward the south], [but] it [also] had to cover the convoy. [So,] no sinking of [enemy] vessels was reported from this area, either. Considering this situation, the Southern Task Force (which was on the sea south of Java) decided to have the aircraft carrier Ryujjo (of the 4th Carrier Division), anchored at Cap Saint Jacques after participating in Operation L, provide support. At 0850 on that day, the 27th, it transmitted the order that "the Malaya Unit shall have the 4th Carrier Division (minus the $2 \mathrm{~d}$ Section) promptly advance into the Java Sea area and support the operations of the Dutch East Indies Unit," ${ }^{\prime(20)}$ which was passed down by the Malaya Unit to the 4th 
Carrier Division at 1150. [However,] it was issued too late. At that moment, the convoy of the main force of the Sixteenth Army was reversing its course, avoiding the appearance of an allied fleet, which led to the situation that the date of landing had to be postponed by another day.

\section{The Appearance of the Allied Fleet and Another One-Day Postponement of the Landing Schedule on Western Java}

At 0530 on the 27th, the convoy of the main force of the Sixteenth Army reached the separating point (about 140 nautical miles north of Batavia). The convoy separated into the main force (the [Sixteenth] Army headquarters and a unit [consisting of] the 2d Division as the core in forty-nine ships) and a [separate] element (the Shōji Detachment), and each headed for its landing point. ${ }^{(120)}$ However, on a report that an allied fleet consisting of one heavy cruiser, two light cruisers and two destroyers was sailing northward, the convoy of the main force and that of the Shōji Detachment again started reversing their courses respectively at 1028 and $1045,{ }^{(115,120)}$ which continued respectively until 1500 and $1800 .{ }^{(115,120)}$ In the meantime, at the [Sixteenth] Army headquarters the concern grew that [the convoy] might run out of coal and water, and the feeling spread that it was unacceptable that the [Navy] Malaya Unit was conducting a triumphal entry into the port of Singapore on that very day. ${ }^{(36,44)}$

At 0900 a report was sent that "one large enemy cruiser, two light cruisers, and two destroyers have been spotted sailing southeast," which was followed by another report at 0935 that "the enemy fleet has turned around and is heading toward us." At that time, the situation on the [Japanese] side was as follows: ${ }^{(115,120,130,131,103)}$

The Shōji Detachment (in seven ships): [under escort of] the light cruiser Yura, the 1st Section of the 6th Destroyer Division (the Akatsuki and the Hibiki), and the 2d Section of the 22d Destroyer Division (the Nagatsuki and the Minazuki).

The convoy of the [Sixteenth] Army headquarters and the 2d Division (in forty-nine ships): [under the escort of] the light cruiser Natori, the 1st Section of the 22d Destroyer Division (the Fumizuki and the Satsuki), the 5th Destroyer Division (the Harukaze, the Hatakaze, the Asakaze and the Matsukaze), the 11th Destroyer Division (the Hatsuyuki, the Shirayuki and the Fubuki), and the 12th Destroyer Division (the Shirakumo and the Murakumo).

The 7th Cruiser Division unit, [provided by] the Malaya Unit for support: the 7th Cruiser Division ([consisting of] the heavy cruisers Kumano, Suzuya, Mikuma and Mogami), the 19th Destroyer Division (the Uranami, the Shikinami and the Isonami) on the sea south of the convoy

The Auxiliary Seaplane Tenders Kamikawa-maru and San'yō-maru: [in] the Anambas Islands.

The aircraft carrier Rȳjjō: at Cap Saint Jacques (scheduled to depart in the evening).

Rear Admiral Hara, commander of the 3d Escort Unit (and commander of the 5th Destroyer Squadron), assembled the flagship Natori, the light cruiser Yura, and the 5th, the 11th and the 12th Destroyer Divisions, and rushed toward the allied fleet in an attempt to destroy it in cooperation with the 7th Cruiser Division unit of the Malaya Unit. ${ }^{(120)}$ He left six destroyers [as escort for] the convoy and had [the convoy] reverse its course. ${ }^{(120)}$ However, the allied fleet began to sail southwestward from around 1443 onwards and then sailed away in the direction of Batavia. The Japanese pursued it, but discontinued the pursuit around 1500. ${ }^{(115,120)}$ In the meantime, the 5th Destroyer Squadron commander wired the Sixteenth Army commander [Imamura] at 1320 that "considering the enemy's current movements, we would like to first 
destroy the enemy surface vessels before conducting the landing operations. [Accordingly, we would like to postpone the landing date by another day." ${ }^{\prime 120)}$ As we have seen from the description of the convoy's movements, it meant that the landing date ended up being postponed by one more day. ${ }^{(32,120)}$

A unified command of the surface forces in this area was considered necessary, and based on the warning of the Combined Fleet issued at 1430, the telegraphic order of the Southern Task Force sent at 1600, and the Dutch East Indies Unit order given at 1800, the 7th Cruiser Division unit and the 4th Carrier Division (the Ryūjo and the Shiokaze) were incorporated into the Batavia invasion unit; the 7th Cruiser Division commander [R. Adm. Kurita Takeo] was assigned to command this unit. ${ }^{(115,120)}$

On that day, the 12th Air Division of the [Army] Third Air Force covered the convoy. The $3 \mathrm{~d}$ Air Division also covered the convoy, and the aircraft of the 75th and the 90th Air Groups carried out attacks on [enemy] naval vessels as well. ${ }^{(96)}$ On that day the [Navy] 3d Air Raid Unit conducted patrols to search for the enemy from the Mentok and the Gelumbang [airfield]. ${ }^{(104)}$

\section{Naval Engagements off Surabaya, and a One-day Postponement of the Landing [Opera- tion] on Eastern Java as well}

The convoy carrying the 48th Division and the Sakaguchi Detachment had been sailing westward along the southern coast of Borneo after entering the Java Sea. At 0700 on that day (the 27th), just as it advanced into the waters south of the central part of Borneo (immediately north of Kragan), it changed its course and headed due south (in the direction of Kragan).(119) [The convoy] was scheduled to enter the anchorage and land in Kragan on the night of the 27th. However, an aircraft reported that it had spotted "five enemy cruisers and six destroyers on the sea sixty-three nautical miles at 310 degrees (note by the author: northwest) of Surabaya, heading toward 80 degrees (note by the author: east-northeast) at a speed of twelve knots at 1150," which was followed by two engagements in the afternoon and another two in the night, ${ }^{(119)}$ and the convoy ended up repeatedly sailing back and forth ([according to] [48th] Division Commander Tsuchihashi's diary). In the end, that night (to be precise, at 0450 on the 28th), the Dutch East Indies Unit commander decided to postpone the landing [operation] by one day (to be carried out on the night of the 28th). ${ }^{(119)}$

The situation of the [Japanese] fleet in the eastern Java Sea area at the time of spotting the allied fleet was roughly as follows: ${ }^{(102,103,114,117,119,124)}$

The 1st Escort Unit, [consisting of] the light cruiser Naka, the 2d Destroyer Division (the Murasame, the Samidare, the Harusame and the Yüdachi), the 9th Destroyer Division (the Asagumo, the Minegumo and the Natsugumo), and the Umikaze of the 24th Destroyer Division, under the command of the 4th Destroyer Squadron commander, was escorting the convoy.

The 5th Cruiser Division unit, [consisting of] the 5th Cruiser Division ([with] the heavy cruisers Nachi and Haguro), the Ushio and the Sazanami of the 7th Destroyer Division, and the Yamakaze and the Kawakaze of the 24th Destroyer Division, kept its position near the convoy, prepared for support.

The $2 \mathrm{~d}$ Destroyer Squadron unit, [consisting of] the light cruiser Jints $\bar{u}$ and the 16th Destroyer Division (the Yukikaze, the Tokitsukaze, the Amatsukaze and the Hatsukaze), [also] kept its position near the convoy, prepared for support. 
The Main Unit of the Dutch East Indies Unit, [consisting of] the heavy cruiser Ashigara and the destroyers Ikazuchi and Akebono, had left Makassar on the 26th, and was in the sea north of the Kangean Islands. The heavy cruiser Myōkō (which belonged to the 5th Cruiser Division, but had just returned to the southern [front] after having the damage incurred at Davao repaired on the mainland) left Makassar on the morning of the 27th after replenishing there, and was following the unit (joining the unit in the evening).

The 1st Base Unit, [consisting of] the light cruisers Nagara and Kinu ([the latter of which] was the flagship of the 4th Submarine Squadron, and which had joined the unit on the 26th), the 8th Destroyer Division (the Asashio and the Arashio), and the 21st Destroyer Division (the Wakaba, the Nenohi and the Hatsushimo) was covering the second disembarkation [operation] on Bali.

The seaplane tenders Mizuho (was sailing west from Timor), and Chitose (was sailing south from Jolo), and the auxiliary seaplane tender Sanuki-maru (had been damaged and anchored at Balikpapan, but its seaplanes were stationed in Makassar).

From 1230 onwards, the full force of the 5th Cruiser Division unit ([consisting of] two heavy cruisers and four destroyers), the full force of the $2 \mathrm{~d}$ Destroyer Squadron unit ([consisting of] one light cruiser and four destroyers), and the main force of the 4th Destroyer Squadron unit ([consisting of] one light cruiser and six destroyers) headed for the allied fleet to make an attack. The allied fleet was made up of two heavy cruisers, three light cruisers and eight or nine destroyers, and it was superior [to the Japanese forces] in terms of cruiser strength. At 1300, the convoy [carrying the eastern Java landing unit] changed its course to the west. As an aircraft report sent at 1455 said that the allied fleet seemed to be sailing away toward Surabaya, the convoy resumed its course for the landing point in Kragan at 1500. However, the allied fleet [again started] sailing north from 1523 onwards, and was approaching the convoy. At 1745, the first daytime engagement began with a naval gun duel. The 5 th Cruiser Division commander, who was leading all the units under his unified command, planned to lure the allied fleet into a night engagement in order to destroy it at a stroke by displaying his torpedo strength, because the [Japanese] naval gun strength was inferior. However, around 1830, the distance between the convoy and the [allied] fleet was reduced to about twenty nautical miles. About 1834, the 4th Destroyer Squadron commander ordered the convoy to sail westward. At 1837, the 5th Cruiser Division Commander ordered: “All, Charge!" At 1839, the [Japanese] fleet all at once took a left turn and commenced the attack, which was the beginning of the second daytime engagement. The allied fleet was thrown into disorder. The [Japanese] units pursued them, while firing and launching torpedo attacks. At 2005, [the Japanese units] stopped the pursuit, judging that it was dangerous to come close to the area near Surabaya where mines had been laid and because night came on. During this engagement, three allied destroyers were sunk. Meanwhile after shifting to the attack, the 4th Destroyer Squadron commander had the convoy sail south [again] by ordering at 1903: "We have sunk three enemy destroyers and are in the middle of pursuit. The convoy shall sail toward the predetermined landing point." The allied fleet turned around again as night fell; about 2100, naval gun fire was exchanged for a short period, but the [Japanese units] let them slip away (the first night engagement). At 0033, the silhouettes of four warships were spotted. [The Japanese units] sank one ship, caused a large fire on another, and attacked and pursued the other two, but the units became sure by 0245 that they had let the [allied] ships slip away (the second night engagement). Due to the occurrence of these night engagements, the con- 
voy, which had resumed its southward sailing at 1903, again reversed its course and was heading northward. ${ }^{(114,117,119)}$

During these engagements, the Dutch East Indies Unit commander ordered the unit that was in the middle of the second Bali disembarkation operation to send its forces [to support the Java landing operation], while he himself sailed westward leading his main unit. From the Bali operation unit, the light cruiser Kinu and the 8th Destroyer Division (the Asashio and the Arashio) sailed westward. ${ }^{(103,124)}$

At 0310, the 5th Cruiser Division commander, who had fought a total of four naval battles [two] during the day and [two] at night, commanding the 2d and 4th Destroyer Squadrons as well, offered as his opinion to the Dutch East Indies Unit commander: "Considering the remaining enemy surface forces, I judge it better to postpone the starting date of the landing [operation] by one day. [Our] convoy seems to be still up north evading [the battles]." [According to Vol. 26, p. 460, the suggestion was made by Rear Admiral Nishimura, commander of the 4th Destroyer Squadron.] At 0450, a "no objections" reply was sent. Thus, the landing [operation] on eastern Java was postponed by one day, just like that on western Java. ${ }^{(114,117,119)}$

The Carrier Task Force ([consisting of] the aircraft carriers Akagi, Kaga, Sōryū and Hiryū, the battleships Hiei and Kirishima, the heavy cruisers Tone and Chikuma, the light cruiser Abukuma, and the destroyers Tanikaze, Isokaze, Hamakaze, Urakaze, Shiranui, Kasumi, Ariake and Y $\bar{u}$ gure), which had left Staring Bay at 0830 on the 25th, and the main force of the Southern Task Force (the battleships Kongō, and Haruna, the heavy cruisers Atago and Takao, and the destroyers Arashi, Nowaki and Hayashio; in addition, the Oyashio, the Hayashio and the Kuroshio had joined the force from Timor), which had left the bay following the fleet, had already advanced into the waters southeast of Java on that day. [Editor's note: There seem to be some mix-ups in this list, compared to the data in Volume 26.] At 1200 on that day (the 27th), the 2d Air Raid Unit sent a telegram, which said: "According to an aircraft report, one [enemy] light cruiser, six destroyers, and about forty commercial ships were spotted in the port of Cilacap, and one commercial ship and three destroyers outside the port as of 1130. . $^{\prime}(103,116,123)$

On that day (the 27th), the 1st and 2d Air Raid Units provided the escort for the convoy of the unit to capture eastern Java as well as the escort for the $2 \mathrm{~d}$ Bali disembarkation unit, and [also] conducted search and attack missions on the enemy in eastern Java, the Indian Ocean, etc., from Banjarmasin, Bali, Kupang and other bases. They spotted the aircraft carrier Langley (with thirty-two P-40 aircraft on its flight deck) in the sea south of Java at 1315 and sank it at $1340 .^{(103)}$

In the naval engagements on that day, the 27th (the naval engagement off Surabaya), the loss that the allied forces sustained was the Dutch cruisers HNLMS De Ruyter and HNLMS Java, the British destroyer HMS Electra, and the Dutch destroyer HNLMS Kortenaer, which were sunk, and the British cruiser HMS Exeter, which was damaged.

\section{Entry into the Anchorage, Start of the Landings and Naval Engagements (See Illustration No. 46)}

\section{The Western Java Area}

At 0120 on the 28th, the 5th Destroyer Squadron commander sent a telegraphic order: "The Yura shall return to its original unit. Each unit shall operate as scheduled." The Natori and other ships joined the unit for Area No. 1 (Bantam Bay and Merak) at 0415 and the Yura joined 
the unit for Area No.2 (Patrol) at 0500, and they headed for the landing points. The aircraft of the $3 \mathrm{~d}$ Air Raid Unit reconnoitered the Batavia port in the morning and spotted only fifteen large commercial ships. It was judged that the [enemy] cruisers and lesser ships of the day before had escaped. However at 1200, one cruiser and one destroyer (according to allied military history materials, they were the U.S. heavy cruiser USS Houston and the Australian light cruiser HMAS Perth, which had participated in the naval battles off Surabaya the day before) were spotted sailing westward on the waters forty-eight nautical miles south of the [Japanese] heavy cruisers Kumano and Suzuya. The Kumano and the Suzuya hurried toward them at full speed, but receiving an aircraft report at 1417, which said "one Glasgow-Type and one light cruiser stopped at a spot ten nautical miles at 20 degrees (note by the author: north-northeast) of Batavia," they judged that the allied fleet had already entered the anchorage of Batavia, and reversed their course toward north at 1450. At 1700, the 7th Cruiser Division commander wired: "One [enemy] heavy cruiser and one light cruiser are [spotted] anchored outside the Batavia port, and one light cruiser (note: according to a later study, a destroyer) inside the port." $(115,120)$

At 2020, the Area No.1 unit was separated into [sections for] Sectors A (south side of Merak), B (north side of Merak) and C (Bantam Bay), and headed for the waters off the coast of their respective sectors. At 2245, air reconnaissance of the Batavia area as of 2000 reported: "(1) one large [enemy] cruiser moored at the wharf, one light cruiser anchored inside the breakwater, and other than these, three flying boats; (2) one [enemy] gunboat and two patrol boats patrolling at the mouth of the bay; (3) one [enemy] destroyer and one large transport ship sailing westward through the channel north of Cape Kait, and (4) one [enemy] submarine going eastward [also] through the above channel."(115, 120)

The Area No.2 unit was approached and bombed by two allied aircraft at a point about thirty nautical miles north of Patrol around 2120, but having sustained no damage, it continued sailing south. ${ }^{(120)}$

At 0000 on 1 March, the convoy of [the units to land in] the Bantam Bay area entered the anchorage and the 1st landing unit started landing at 0030. [The convoy of the units to land in] the Merak area entered the anchorage at 0000 and succeeded in landing at 0145 . [The convoy of the units to land in] the Patrol area entered the anchorage at 0140 and succeeded in landing at 0400. ${ }^{(115,120)}$

When the Bantam Bay area convoy was executing the landing operation, the Fubuki, which was in its patrol area north of Bantam Bay, spotted two allied cruisers (the U.S. heavy cruiser USS Houston and the Australian light cruiser HMAS Perth) at 0015. The [Japanese] heavy cruisers Mikuma and Mogami, the light cruisers Natori and Yura, and the destroyers Harukaze, Hatakaze, Asakaze, Fubuki, Shirayuki, Shirakumo, Murakumo and others intercepted them, and the naval battle off Batavia began. [The Japanese] sank both cruisers and, in addition, sank the Dutch destroyer HNLMS Evertsen at a point west of Sebuku Island on the same day. The loss sustained on the Japanese side was one minesweeper and one transport ship sunk, several transport ships running aground and heavily damaged, and other minor damage. ${ }^{(115,120)}$

On the 28th, the [Army] Third Air Force covered the convoy with the 3d and the 12th Air Divisions. On that day (the 28th), Sixteenth Army Staff Officer Itoda requested from Tanjungkarang that the Southern Army temporarily assign three aircraft to the direct support [of the operations of the Sixteenth Army], but the Southern Army rejected it on 1 March, saying that it had no extra strength to spare. ${ }^{(96,99)}$ 
On the 28th, the [Navy] 3d Air Raid Unit searched for the enemy. At 0900 on 1 March, due to the bad weather and the bad condition of the airfield in Kuching, the unit requested the [Army] Third Air Force to provide the guarding of the sky over the anchorage of the Shōji Detachment, only to receive a reply that it wanted to [just] carry out the tasks as agreed in the arrangements, because it had no extra strength to spare after being day after day in action. ${ }^{(135)}$

\section{The Eastern Java Area and the Sea South of Java}

The 4th Destroyer Squadron continued sailing northward while positioning itself southeast of the convoy which carried the 48th Division and the Sakaguchi Detachment, and guarding it. Then, about 0500 on the 28th, it received the telegram from the Dutch East Indies Unit, saying: "No objection to postpone the landing [operation] by one day." It passed down its order to the transport convoy: "Move so as to reach at 1200 today, the 28th, [the spot] you were at 1200 on the 27th." [Then] it approached the convoy, and returned to the [original] escort formation at 0750. The main unit of the Dutch East Indies Unit (the heavy cruisers Ashigara and Myōkō, and the destroyers Ikazuchi and Akebono) joined the 5th Cruiser Division and the $2 d$ Destroyer Squadron at 0730. The light cruiser Kinu (the flagship of the 4th Submarine Squadron) and the 8th Destroyer Division (the Asashio), which both had shifted their positions from the support of the second Bali disembarkation operation [to the Java landing operation], joined the escort of the convoy at 1330 and sailed south along with the convoy and the 4th Destroyer Squadron unit. Despite the persistent approach of allied flying boats from 1640 to 1810, the convoy continued sailing south, changed into the formation to enter the anchorage at 2010, and kept going further south. ${ }^{(114,117,119)}$

From 0145 on 1 March onwards, the convoy came under persistent bombardment from about ten dive-bombers. The Tokushima-maru ran aground on the coast due to flooding caused by a hit at close range, while the Johore-maru, which took a direct hit and sustained a loss of some 150 casualties and other damage, had no [serious] damage to its hull and engine and continued sailing; it entered the anchorage at Kragan at 0235 as scheduled. Even after entering the anchorage, allied aircraft kept repeatedly bombing [the convoy] while dropping flares, and three [enemy] torpedo boats [also] invaded the anchorage (one of which was sunk and the other two were destroyed). [Then] after daybreak, [enemy] fighter planes came strafing [the convoy]. However, the 1st landing unit of the 48th Division successfully landed at 0400. ${ }^{(114,117,119)}$

In the meantime, on the evening of the 28th, an aircraft report came, saying: "At 1640, two enemy light cruisers were [spotted] at the northern entrance of [the port of] Surabaya, sailing in northeastern direction." The report made the 5th Cruiser Division and the 2d Destroyer Squadron unit take positions to intercept [a possible attack], but they returned to the

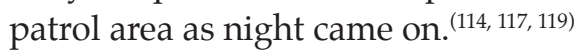

At 1103 on 1 March, the 5th Cruiser Division unit spotted the allied cruisers and destroyers. The 5th Cruiser Division unit ([consisting of] the heavy cruisers Nachi and Haguro, and the destroyers Yamakaze and Kawakaze) and the main unit of the Dutch East Indies Unit (the heavy cruisers Ashigara and Myōkō, and the destroyers Ikazuchi and Akebono) made a pincer attack and sank all of them. That is, the British Type-A cruiser HMS Exeter was sunk at 1250, the British destroyer HMS Encounter at 1330, and the U.S. destroyer USS Pope at 1540..$^{(103,114)}$ 


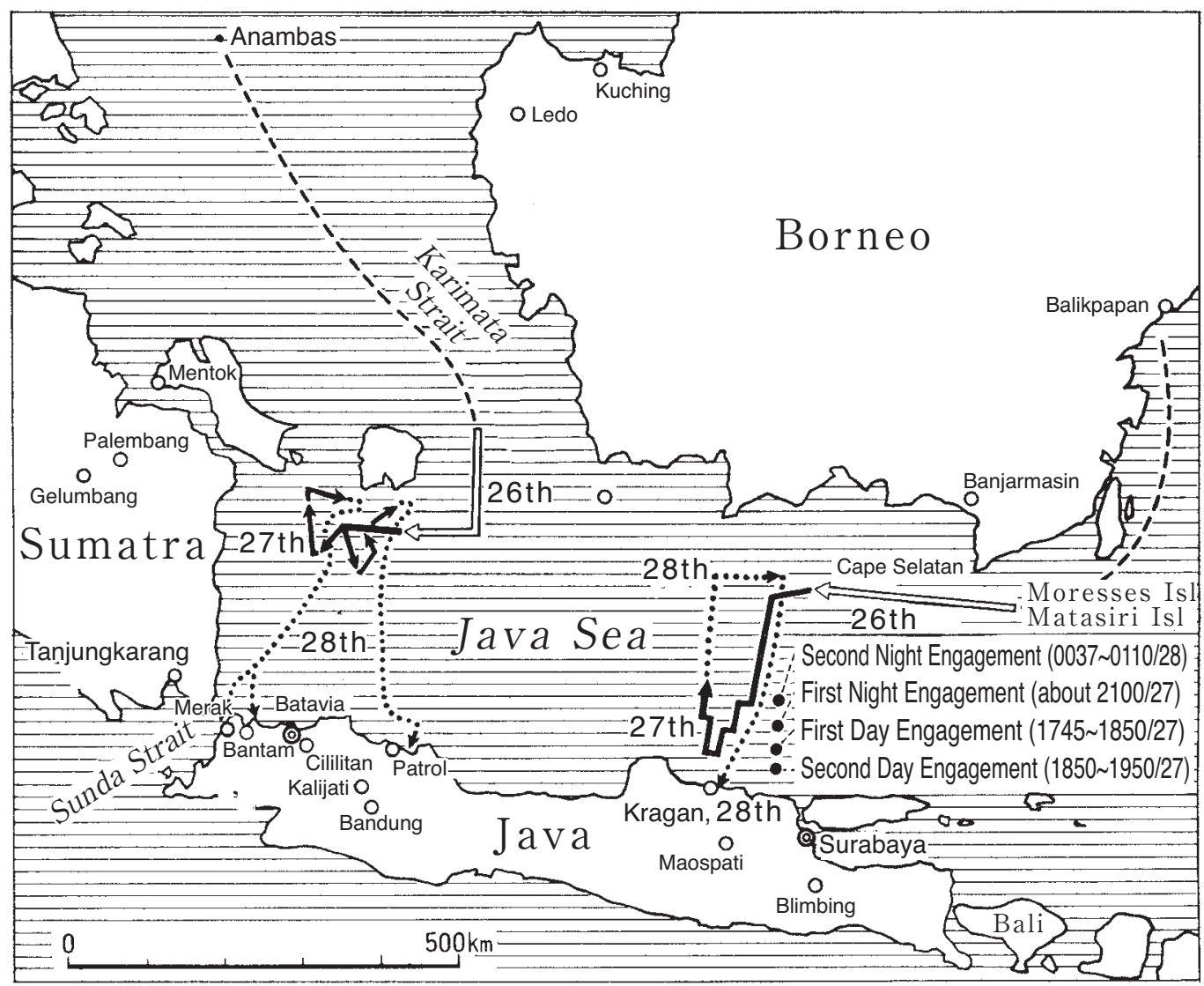

Illustration No. 46 - The Situation From 26 Through 28 February

On the 28th, in addition to covering the convoy as well as the Bali base and searching for the enemy, the [Navy] 2d Air Raid Unit conducted an air raid on the Maospati airfield with thirteen aircraft, the Blimbing and the Surabaya airfield with sixteen aircraft, and the Tanjung Priok airfield with nine aircraft from the Bali base. ${ }^{(104)}$

The Carrier Task Force and the main force of the Southern Task Force (whose strengths were already described) caught allied warships escaping from Cilacap in the area south of Java from 1 through 4 March and reported a military gain of sinking one British destroyer, two U.S. destroyers, one U.S. gunboat, one British minesweeper and eleven transport ships, and seizing four transport ships. ${ }^{(102)}$

\section{Operations of the Main Force of the [Sixteenth] Army}

\section{(1) The Operation Plans}

\section{The Operation Plan of the [Sixteenth] Army (See Illustrations No. 47 and No. 48)}

The distances between the landing points of the Sixteenth Army were great: as the crow flies, about two hundred kilometers between the landing point of the main force of the [Sixteenth] Army and that of the Shōji Detachment, and about four hundred kilometers between that of 
the Shōji Detachment and that of the 48th Division and the Sakaguchi Detachment. So were the distances between their respective targets: the distance between the target of the main force of the [Sixteenth] Army (Bandung) and that of the Sakaguchi Detachment (Cilacap) was about 180 kilometers, and [the distance between] the target of the Sakaguchi Detachment and that of the 48th Division (Surabaya) was about four hundred kilometers. Therefore, the Sixteenth Army anticipated that after the landings it would be difficult to manage the units in a unified manner (in particular the Sakaguchi Detachment and the 48th Division), or to provide timely and proper operation instructions. ${ }^{(35,36)}$ For this reason, measures were taken in order to provide the independently operating corps and detachment with units and equipment adapted to the needs of their mission, to provide them with specific operational directives, and assign [dedicated] staff officers to them. ${ }^{(35,36)}$ [The Sixteenth Army] Operations Staff Officer Yamashita was attached to the Shōji Detachment, which would operate in close connection with the main force of the [Sixteenth] Army (i.e. the 2d Division), and Intelligence Staff Officer Kuriya and Line-of-Communication Staff Officer Nishiura [of the Sixteenth Army] were attached to the 48 th Division. ${ }^{(35,36)}$ No staff officer [of the Sixteenth Army] was attached to the Sakaguchi Detachment, because the detachment, which consisted of just two battalions as the core, already had its trusted Staff Officer Yano.

As we have seen previously, the operations of the Sixteenth Army had been planned in outline as follows: ${ }^{(35,36,96)}$

1. According to the plan, the 48th Division should land in Kragan, seize the crossing point over the Solo River, the Cepu oil field and Rembang, after which [the division] should send one element eastward along the coastal area to contain the allied forces in the Surabaya area, while having its main force make a long detour far to the south, divide [the enemy forces in] Malang and Surabaya, and seize Surabaya.

The Surabaya stronghold was considered quite strong. [It was known that] there were fortifications in Porong, which was midway between Malang, a garrison town and the seat of the eastern Java territorial headquarters of the Dutch East Indies Army, and Surabaya. The concerns were, among others, how [the operations] would be affected by these [factors], and what would happen if the allied forces took offensive action.

2. According to the plan, the Sakaguchi Detachment ([consisting of] two infantry battalions as the core) would land in Kragan, charge toward Cilacap, and seize the city.

It was judged certain that a central Java territorial headquarters (a divisional headquarters) of the Dutch East Indies Army was newly established in Magelang. However, it was expected that the Sakaguchi Detachment, though small in number of troops, was powerful enough to travel the long distance of three hundred and some tens of kilometers, while defeating the allied forces along the way. The point of concern was Cilacap. It was not only an important port and the one and only rear gate of Java, it was also located close to Bandung, the [enemy] base of operations in Java, and it was connected to the United States, Britain and Australia by sea.

3. According to the plan, the main force of the [Sixteenth] Army (the 2d Division and the Shōji Detachment) should capture western Java, the base and center of the allied forces. Its targets were Batavia, the capital [of the Dutch East Indies], and Bandung, the military headquarters of Java. It was considered certain that Bandung would come to serve as both the military and political center when the [Japanese] operations progressed. It was considered a matter of course to seize first Batavia and then Bandung. It was also thought not unlikely that a decisive battle might occur ahead of [the operation to] seize Batavia.

In the Batavia and the Bandung operations, Buitenzorg [Bogor] and Kalijati were strategically significant. Buitenzorg [Bogor] was a key location that would enable [the Japanese] to di- 
vide [the allied forces in] Batavia and Bandung in case they attached importance to Batavia. Further, regardless of whether they attached importance to Batavia or not, it was [still] vital because it could not only be used in attacking [both] Bandung and Batavia, but it would also, and in particular, enable [the Japanese army] to launch a coup de main against Bandung from the west. Kalijati was a strategic point which would enable [the Japanese] to command the communication route between Bandung and Batavia at the north of the Bandung stronghold. It would [also] enable [the Japanese] to advance a large number of aircraft at an early stage. In addition, it was a strategic point that would facilitate the preparations to seize the Bandung stronghold from the north. In order to completely cut off the road between Bandung and Batavia, it was necessary to seize the crossing point over the Citarum River.

The main concerns about the plans of the allied forces were how many U.S., British and Australian reinforcements had been or would be received through Cilacap, how many troops had retreated to western Java from Singapore, Sumatra and other areas, and what operations [the allied forces] would launch, taking advantage of the moment when the $2 \mathrm{~d}$ Division and the Shōji Detachment were [still] far from each other just after the landing.

Considering these matters, the operations in the area of the main force of the [Sixteenth] Army were planned in outline as follows:

(1) The Shōji Detachment shall land in Eretan, seize the Kalijati airfield all at once and secure [the airfield], while seizing the crossing point over the Citarum River to cut off the road connecting Batavia and Bandung. Depending on the circumstances, it shall act in concert with the 2d Division in seizing Batavia.

(2) The 2d Division shall have one powerful unit led by the infantry group commander charge toward Buitenzorg and seize it to cut off the road connecting Bandung and Batavia, while having its main force advance into the area southwest of Batavia by heading eastward through the flatlands, and then seize Batavia.

(3) After the seizure of Batavia, the main force of the 2d Division and the Shōji Detachment shall line up side by side north of the Bandung stronghold and attack the city.

(4) Depending on the circumstances, the unit to seize Buitenzorg and the Shōji Detachment shall charge toward Bandung.

The tentative dates for [the operations to] seize Kalijati, Buitenzorg and Batavia were set respectively on the first, the fourth and the fifth day after the landings. ${ }^{(96)}$

The [Sixteenth] Army commander should designate one battalion of the 2d Division as the army reserve and advance with it in the rear of the main force of the $2 \mathrm{~d}$ Division. The [Sixteenth] Army headquarters should land at Bantam Bay before daybreak on the first day of the landings, after which it would first advance its command post to Serang. ${ }^{(96)}$

4. The landings of the [Sixteenth] Army are planned as follows. ${ }^{(96)}$ [The plan] indicates that [the operations to] seize Surabaya and Bandung were expected to meet with considerable difficulties, and take much time.

The area of the main force of the [Sixteenth] Army

The first landing

Fifty-four transport ships.

Day H: Start of the landing.

Day $\mathrm{H}+4$ : Completion of the disembarkation of the Shōji Detachment and the Merak landing unit of the $2 \mathrm{~d}$ Division.

Day H +6 : Completion of the disembarkation at Bantam Bay of the main force of the

2d Division and the unit under the direct control of the [Sixteenth] Army.

The second landing

Twenty-five transport ships.

Day H + 22: Start of the disembarkation at Bantam Bay (if possible, in Batavia). 
The third landing

About twenty transport ships (some 100,000 tons).

No records were found about the starting date of the disembarkation, but probably it was started around Day $\mathrm{H}+28$ or later.

The 48th Division

The first landing

Thirty-nine transport ships.

Day H: Start of the landing.

Day $\mathrm{H}+4$ : Completion of the disembarkation.

The second landing

About ten transport ships (some 50,000 tons).

No records were found about the starting date of the disembarkation.

Note: This was the plan as of 10 February. However, from that moment onwards the participation of the Carrier Task Force became a realistic possibility, which seems to have led to a slowdown and a natural disappearance of the preparations for the third landing of the main force of the [Sixteenth] Army and the second landing of the 48th Division.

As we have seen, the plan was that 179 aircraft of the [Army] Third Air Force, 50 of the Dutch East Indies Unit, 190 of the Eleventh Air Fleet and about 190 of the First Air Fleet (Carrier Task Force) should cooperate in the Java invasion operation of the Sixteenth Army, and that the ground operations of the main force of the Sixteenth Army should directly be supported by the [Army] Third Air Force, and those of the 48th Division by naval aircraft only. ${ }^{(96)}$

\section{The Operation Plan of the Shōji Detachment}

The Shōji Detachment consisted of the 230th Infantry Regiment (minus one battalion), one tank squadron, one antitank gun battalion (minus two companies), one mountain artillery battalion (minus one battery), one engineer company (minus two platoons), and one antiaircraft artillery battery as the core. ${ }^{(73,74)}$

An outline of the operations of the Shōji Detachment was as follows: ${ }^{(96)}$

\section{Operation Outline of the Shōji Detachment}

1. Mission

(1) The detachment shall land near Patrol and promptly seize the Kalijati airfield, and also gain control of the crossing point over the Citarum River in order to divide the enemy in the Bandung and the Batavia areas.

(2) After that, the detachment shall attack Bandung from the area northeast [of the city] in concert with the 2d Division.

2. Directives

(3) The detachment shall land in or near Patrol before daybreak on Day H and promptly seize the Kalijati airfield with one element and at the same time advance to Krawang and vicinity to divide the enemy in the Bandung and the Batavia areas.

(4) After that, [the detachment shall] seize strategic points such as Subang, Purwakarta and Cikampek, etc. one after another, and prepare for the subsequent [operation to] seize Bandung. Depending on the circumstances, it shall have one element participate in [the operation to] seize Batavia. 
(5) Hand in hand with the advance of the main force of the $2 d$ Division, the detachment shall advance to the area southeast of Subang, head for the area east of Bandung from the Cikramas area, and attack the enemy so as to cut off its escape route.

(6) Depending on the circumstances, the detachment may [launch an operation to] seize Bandung in concert with the unit advancing from the Cianjur area before the arrival of the main force of the $2 \mathrm{~d}$ Division.

(7) After the seizure of Bandung, the detachment shall be assigned to mop up the enemy all over Java in cooperation with the $2 \mathrm{~d}$ and the 48 th Divisions.

This was the operation outline that the Sixteenth Army had shown to Detachment Commander Shōji as of 10 February. The [Sixteenth] Army attached [more] importance to the operations in Batavia and vicinity. However, as will be described later, Detachment Commander Shōji gave [more] careful consideration to [the operation against] Bandung, which was the headquarters of the allied forces. He [also] selected Eretan as the landing point, where the road ran closest to the coastline, and the tanks and motor vehicles to be used in the raid against Kalijati could be advanced more quickly. ${ }^{(41)}$ Changing the landing point to Eretan meant nothing more than landing at a point slightly to the east, but the 5th Destroyer Squadron at first objected to it, because [the change would put the landing point] closer to Surabaya. ${ }^{(44)}$

The [transport] ships carrying the Shōji Detachment were the Yae-maru, the Toyofuku-maru [Hoffuku-maru], the Calcutta-maru, the Glasgow-maru, the Suwa-maru, the Uchide-maru and the Yamazuki-maru [Yamatsuki-maru], a total of seven ships. [Editor's note: three of the ships are different from the list given on p. 242.] The [landing] craft allocated to the detachment were two extra large, seventeen large and fifteen small motorized [landing] craft. ${ }^{(96)}$

Note: The standard capacity of the extra large, large and small motorized [landing] craft was respectively 120 men, 80 men and 35 men in mild weather, and 80 men, 60 men and 25 men in rough weather. ${ }^{(73)}$

The detachment commander made the following disposition of his units and assigned them their tasks based on the plan that "we shall land near Eretan before daybreak of Day H, promptly secure the Kalijati airfield, and at the same time have one element seize the crossing point over the Citarum River near Kedunggede to cut off the enemy [in] the direction of Batavia." ${ }^{(73)}$

Wakamatsu Raiding Unit (with the following core units):

$2 \mathrm{~d}$ Battalion of the 230th Infantry Regiment (minus the 6th Company and one machine gun platoon)

One regimental artillery squad

One antitank gun platoon

1st Squadron of the 4th Tank Regiment (minus one troop)

One engineer company (minus two platoons)

Upon landing, the unit shall have one element push forward toward Pamanukan without missing an opportunity and secure the town as well as the river crossing point to the east of the town. [The unit shall] have its main force promptly advance to the Kalijati airfield along the Patrol - Pamanukan - Subang road, secure the airfield, and help the ground unit of the air unit in making the airfield ready, while guarding it. The unit to seize Pamanukan shall leave one platoon [in the town] until the reserve unit advances [there].

Egashira Raiding Unit (with the following core units): 
1st Battalion of the 230th Infantry Regiment (minus the 4th Company and one machine gun platoon)

One antitank gun company (minus one platoon)

One tank troop

One mountain artillery battery

One independent engineer platoon

Following the departure of the Wakamatsu Raiding Unit, the unit shall promptly advance to Kedunggede along the Batavia road, seize the bridge there to cut off the escape route of the enemy in Batavia, while securing a point for the main force of the [Sixteenth] Army to advance. [The unit] shall [also] make preparations so as to subsequently act in concert with the main force of the [Sixteenth] Army to seize Batavia. In addition, the unit shall have one element seize Cikampek and guard the rear [of the Japanese forces] facing Bandung, while cutting off the escape route of the enemy in Cilamaya and vicinity.

Artillery Unit:

3d Battalion of the 38th Mountain Artillery Regiment (minus two batteries)

The unit shall depart following the Egashira Battalion to catch up with the Wakamatsu Raiding Unit. At least one section of the unit shall accompany the Wakamatsu Raiding Unit.

Antiaircraft Artillery Unit (one battery).

Disembarkation Working Unit ([consisting of] one independent engineer company (minus one platoon) led by Major Watanabe of the 40th Anchorage headquarters as the core)

Signal Communication Unit (omitted by the author).

Motor Transport Unit (two companies (minus one platoon)).

The main force shall transport the Wakamatsu Raiding Unit, and one element the Egashira Raiding Unit.

Ōno Unit:

Commander: Lt. Col. Ōno Takeo, commander of the 2d Independent Antitank Gun Battalion

2d Independent Antitank Gun Battalion headquarters

6th Company of the 230th Infantry Regiment

One machine gun platoon

One regimental artillery squad

Upon landing, one element shall promptly seize Eretan and cover the left side of the landing point, while the main force shall work on the tasks at the landing point.

Reserve Corps:

Infantry Artillery Unit (minus two squads) of the 230th Infantry Regiment, led by 1st Lt.

Wada Toshimichi, commander of the unit

4th Company

One machine gun platoon

It shall assemble in Patrol.

The detachment commander shall go ashore along with the $2 \mathrm{~d}$ landing unit. [He shall] first go to Patrol and then to Pamanukan. After that, he is scheduled to advance to Kalijati.

Airfield Unit (under the direction [of the detachment]):

24th Airfield Battalion (minus one element) led by the battalion commander

One element of the 28th Airfield Battalion

One element of the 1st Air Signal Regiment

One meteorological observation detail of the 4th Meteorological Company

One motor transport platoon

One ground duty platoon

Following on the advance of the Wakamatsu Raiding Unit, the unit shall promptly advance to the Kalijati airfield. After that, [the unit] shall operate following the orders of the air divi- 
sion. The unit shall directly make arrangements with Raiding Unit Commander Wakamatsu for [the latter's] assistance in readying the airfield.

\section{The Operation Plan of the 2d Division}

The operation outline of the $2 \mathrm{~d}$ Division that the Sixteenth Army showed to it was as follows: ${ }^{(96)}$

\section{Operation Outline of the 2d Division}

1. Mission

(1) The division shall land on western Java and promptly seize Batavia, while defeating the enemy.

(2) After that, the division shall promptly seize Bandung with its main force via Purwakarta, Subang and the area east of these cities, and with one element via Cianjur and the area south [of this town].

2. Directives

(3) The division shall have its main force land near Bojonegara and one element in the areas north and south of Merak before daybreak on Day $\mathrm{H}$ and promptly secure the crossing points near Rangkasbitung and Kragilan with one element. At the same time it shall have one powerful element rush to Buitenzorg [Bogor], divide the enemy in the Batavia and the Bandung areas, cut off their escape routes and block reinforcements, after which it shall gain a footing as forward as possible for the subsequent operation of the army to seize Bandung.

(4) The main force of the division shall promptly advance to Serang and vicinity first without waiting for the completion of the landing [operation]. Then, it shall rush toward Batavia and the area south of [the city] through the areas along the Serang - Tangerang - Batavia road and promptly seize the city.

The Shōji Detachment shall promptly advance to the crossing point over the Citarum River and vicinity (Krawang) and divide the enemy in the Bandung and the Batavia areas, while making preparations for the subsequent [operation to] seize Batavia.

(5) When Batavia is seized, the division shall promptly seize Bandung with its main force from the direction of Purwakarta and Subang and with one element from the direction of Cianjur. Depending on the circumstances, the element advancing from the direction of Cianjur may seize Bandung in concert with the Shōji Detachment before the arrival of the main force of the division.

(6) The division shall subsequently mop up the enemy all over Java in concert with the 48th Division.

The $2 \mathrm{~d}$ Division had to leave the $3 \mathrm{~d}$ Battalion of the $2 \mathrm{~d}$ Field Artillery Regiment in the homeland due to the [limited] availability of ships caused by the moving up of the Java operation and have the battalion catch up later. ${ }^{(31,53)}$ [The division] was [also specifically] instructed to put the 1st Battalion of the 16th Infantry Regiment at the disposal of the [Sixteenth] Army as its reserve. ${ }^{(53)}$

On 27 January, the division, along with the [Sixteenth] Army headquarters and the Shōji Detachment, made arrangements with the 5th Destroyer Squadron in Gaoxiong [pp. 241244]. [The division] received the already-described order of the Sixteenth Army [p. 245], and the previously-mentioned operation outline on the 30th, and passed down its [own] divisional order concerning the landing [operation] the next day, the 31 st. $^{(31,120,59)}$ 
In this divisional order, the disposition of the forces was shown in outline in the following way, based on the plan that [the division] should make a surprise landing on the western coast of Bantam Bay (Sector C) with its main force, and with one element on Merak Island and the coast north of Merak (not included) (Sector B), and on the coast south of Merak (Sector A) before daybreak on Day $\mathrm{H}$, and advance without waiting for the completion of the landing [operation], and that it should carry out a forced landing if day broke after the beginning of the landing [operation], or if the enemy had sensed its plans.

Merak area

Nasu Detachment (with the following core units) $)^{(96)}$

Commander: Maj. Gen. Nasu Yumio, commander of the $2 \mathrm{~d}$ Infantry Group

$2 d$ Infantry Group headquarters

16th Infantry Regiment (minus the 1st Battalion)

2d Reconnaissance Regiment

1st Battalion of the 2d Field Artillery Regiment (minus the 1st Battery)

1st Company of the $2 \mathrm{~d}$ Engineer Regiment

One tank squadron

One antitank gun company

Motorbike unit

One antiaircraft artillery battery

Accompanied by Staff Officer Satō Hidehiko

On completion of the preparations for the landing, [the detachment] shall promptly land in Sector A and have one element rush to Rangkasbitung and Kragilan to secure the crossing points over the Ciujung River. At the same time, it shall have its main force first promptly advance to the right bank area of the Ciujung River near Rangkasbitung, [by pushing] along the Cilegon - Serang - Buitenzorg road, and then rush to Buitenzorg and vicinity, get control of narrow paths in the neighborhood, and cut off the Bandung Batavia road. ${ }^{(31,64,65)}$

Fukushima Detachment

Commander: Col. Fukushima Kyūsaku, commander of the 4th Infantry Regiment 4th Infantry Regiment (minus the 3d Battalion)

5th Independent Antitank Gun Battalion

2d Battalion of the 2d Field Artillery Regiment

2d Battery of the 16th Antiaircraft Artillery Regiment

$2 \mathrm{~d}$ Company of the $2 \mathrm{~d}$ Engineer Regiment

One-third of the medical unit

Water Supply and Purification Department ${ }^{(96)}$

[The detachment] shall land in Sector B, and first advance into Serang and vicinity along the Sekong - Cilegon - Serang road, following the Nasu Detachment. [Then,] it shall prepare for the advance toward the area southwest of Batavia (inference by the author).

Bantam Bay area

Unit to seize Panjang Island

The Kawamura Platoon of the 9th Company of the 4th Infantry Regiment (including one machine gun squad with a radio unit ${ }^{(59)}$ )

The unit shall make a surprise landing on Panjang Island, seize it, and facilitate the landing of the main force of the [Sixteenth] Army at Bantam Bay. ${ }^{(59)}$

Satō Detachment (with the following core units) ${ }^{(96)}$

Commander: Col. Satō Hanshichi, commander of the 29th Infantry Regiment 29th Infantry Regiment 
2d Tank Regiment (minus three squadrons)

One antitank gun company

$2 \mathrm{~d}$ Engineer Regiment (minus the 1st and the 2d Company)

The detachment shall land in Sector C, and first advance to the left bank area of the Ciujung River, along the Trate - Bantam - Kragilan - Tangerang road. [Then,] it shall prepare for the advance toward the area west of Batavia (inference by the author).

Artillery Unit

Commander: Col. Ishizaki Masuo, commander of the 2d Field Artillery Regiment

2d Field Artillery Regiment (minus two and a half battalions)

One field heavy artillery battalion (minus one battery) ${ }^{(96)}$

Engineer Unit

Commander: Col. Oda Yoshishige, commander of the 1st Independent Engineer Regiment

Main force of the 1st Independent Engineer Regiment

4th Independent Engineer Company

One independent motor transport platoon

Two river-crossing material companies (minus one element) ${ }^{(96)}$

Air Defense Unit

Main force of the 16th Antiaircraft Artillery Regiment ${ }^{(96)}$

Reserve Corps

3d Battalion of the 4th Infantry Regiment (minus one platoon) ${ }^{(96)}$

Note: The 1st Battalion of the 16th Infantry Regiment was the reserve unit of the [Sixteenth]

Army.

\section{The Operation Plan of the Third Air Force}

In the previously-mentioned "Arrangements for Operation $\mathrm{H}$ between the Sixteenth Army, the Third Air Force, the Third Fleet and the Eleventh Air Fleet" (preliminarily agreed on 23 January and revised on 10 February) [pp. 226-233], and the "Outline for the Air Operations [in Operation] H of the Third Air Force" (14 February), the support for the ground operations in Java was planned as follows: ${ }^{(96)}$

1. The support for the ground operations was arranged as follows:

The area of the main force of the Sixteenth Army

(1) The Army shall be in charge of the direct support of the ground operations.

(2) The Navy shall be in charge of cutting off the transport [routes] of the enemy in the Cilacap area. It shall [also] be in charge of attacking enemy reinforcements or forces in retreat when requested by the Army.

The area of the 48 th Division

The Third Fleet shall be in charge of the direct support of the ground operations, and the Eleventh Air Fleet shall appropriately provide support at the request of the Army. The Army shall join in [the direct support] if possible.

2. It was arranged that the Army should allocate about fifteen command reconnaissance planes, about four army reconnaissance planes, about ninety fighter planes, about twenty assault planes, about twenty light bombers and about thirty heavy bombers. Based on this [arrangement], the Third Air Force commander organized the Operation H Unit with the following units, and deployed the air division of fighter planes (the 12th Air Division) in Tanjungkarang and the other units and the headquarters of the Air Force in Palembang (he had advanced into Palembang on 21 February). ${ }^{(96)}$

Unit under the direct control: the 81st Air Group (command reconnaissance aircraft) 


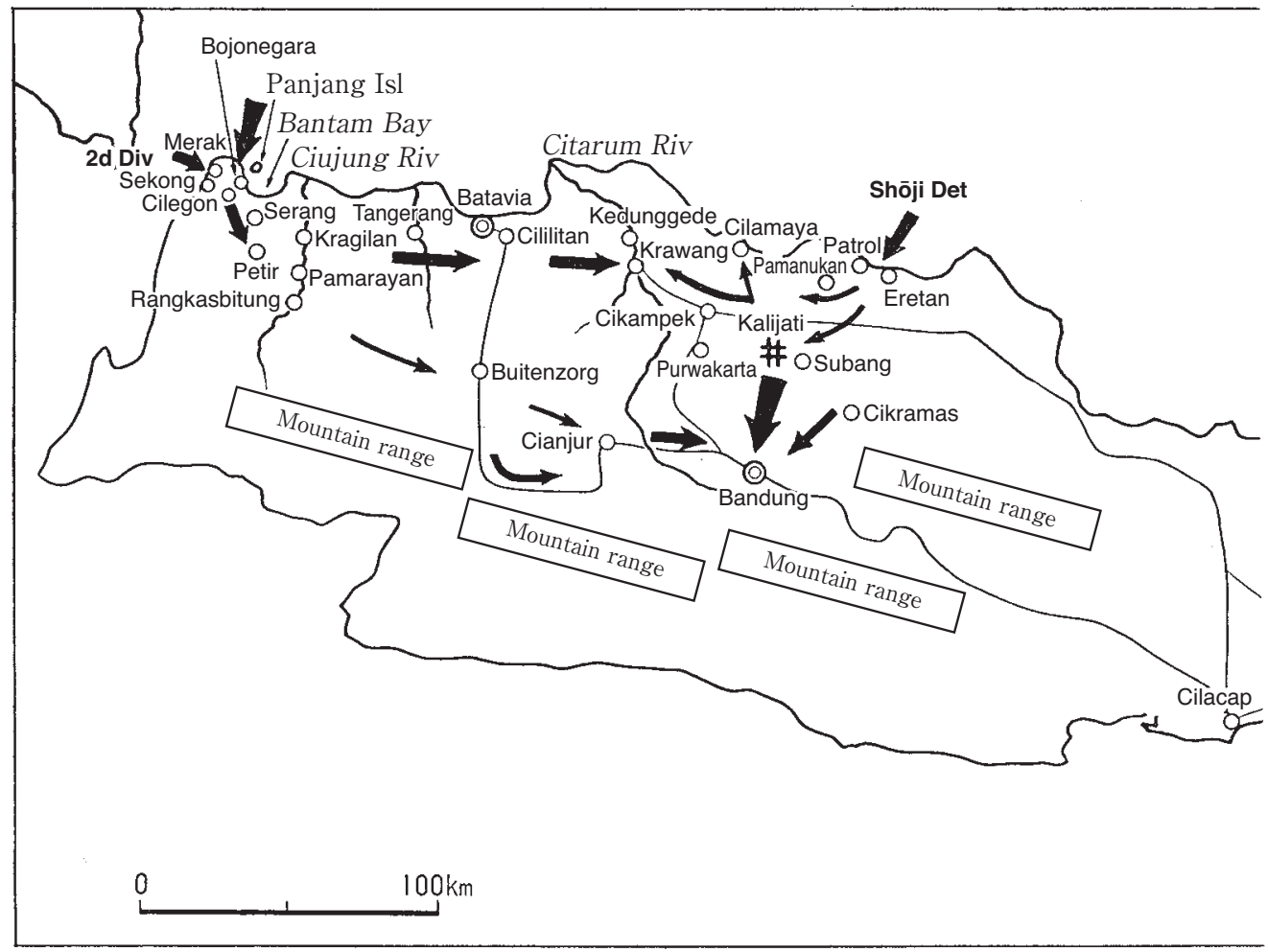

Illustration No. 47 - Overview of the Operation Plan of the Sixteenth Army

12th Air Division

One squadron of the 1st Air Group (fighter planes)

11th Air Group (fighter planes)

3d Air Division

15th Independent Air Unit (its headquarters, and the 50th and the 52d Independent

Squadron) (command reconnaissance aircraft).

59th Air Group (fighter planes)

64th Air Group (fighter planes)

27th Air Group (minus one squadron) (assault planes)

75th Air Group (light bombers)

90th Air Group (light bombers)

The convoy cover assigned to the Third Air Force was [limited to] the cover for the main force of the [Sixteenth] Army (excluding the Shōji Detachment) after the latter had separated from the main force of the Sixteenth Army. ${ }^{(96)}$

Concerning the guarding of the anchorage assigned to the Army, it was arranged that a continuous guarding in the sky over the anchorage should be provided until sunset each day in the Bantam and the Merak areas respectively until Day $\mathrm{H}+2$ and Day $\mathrm{H}+1$, and after that, air cover should be provided as needed depending on the circumstances. ${ }^{(96)}$

3. The use of airfields in Java was arranged roughly in the following way:(96)

(1) The Batavia and the Cililitan airfields should be readied by the Army and shared by the Army and the Navy (with about thirty-five and about sixty-three aircraft respectively). 


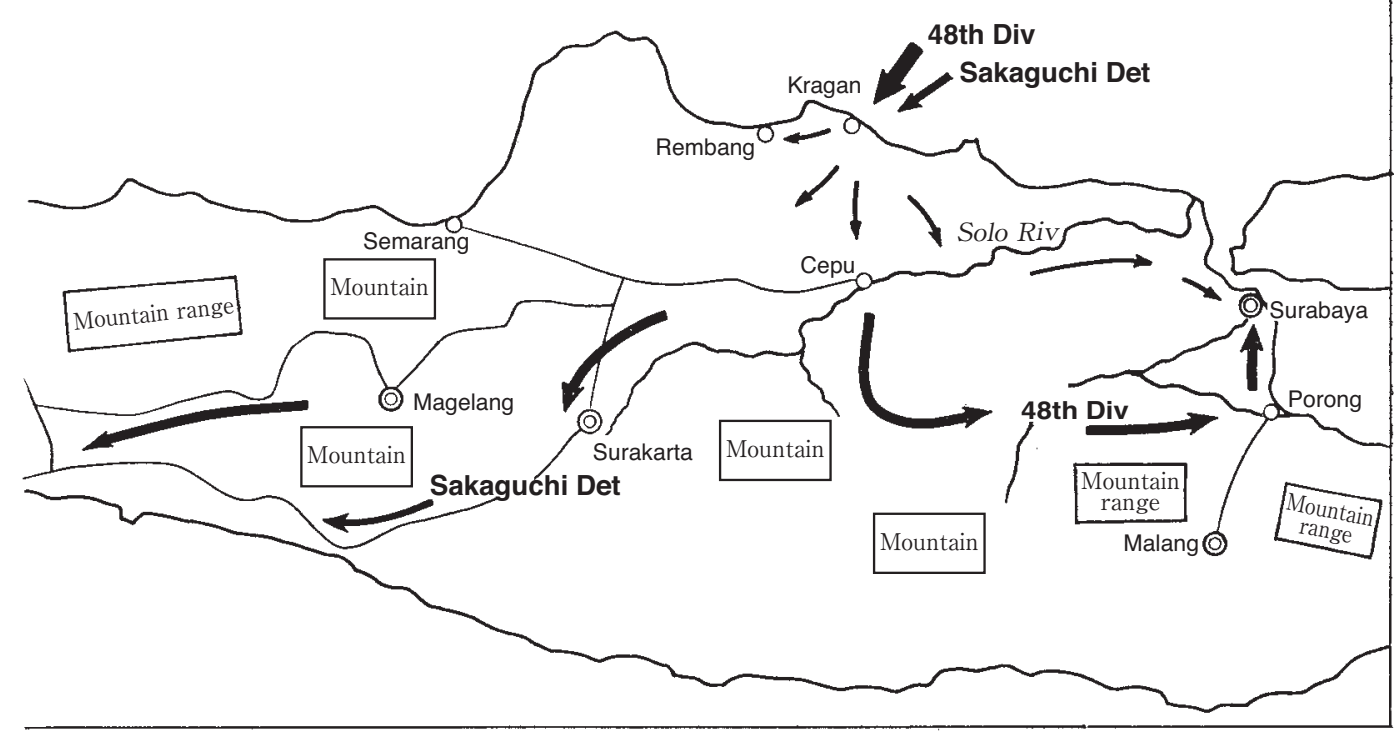

(2) The Buitenzorg [Bogor] and the Kalijati airfields would be used by the Army. The Navy might advance about twenty-seven aircraft to the Kalijati airfield.

4. The Sixteenth Army was to have the ground units of the air unit which had been brought under its control by the Southern Army Order of 15 January [p. 156] advance to a position very close to the front line units of the $2 \mathrm{~d}$ Division and the Shōji Detachment, and promptly make the airfields ready. [The Army] had disposed them in the following way. Furthermore, the plan was that the [Army] Third Air Force should rapidly advance [to these airfields], when their preparation would for the most part be completed. ${ }^{(23,73,96)}$

(1) Units to accompany the Shōji Detachment and make the Kalijati airfield ready (expected [to enable] air units to advance there on Day $\mathrm{H}$ ).

24th Airfield Battalion (minus one element)

One element of the 28th Airfield Battalion

One squad of the 1st Air Signal Regiment

One meteorological observation detail of the 4th Meteorological Company

One platoon of the 298th Independent Motor Transport Company

One platoon of the 123d Ground Duty Company

(2) Units to accompany the 2d Division, and make the Buitenzorg and the Batavia airfield ready (expected [to enable] air units to advance into the Buitenzorg airfield on Day $\mathrm{H}+3$ and into the Batavia airfield on Day $\mathrm{H}+4)$.

4th Air Ground Support Headquarters

One element of the 24th Airfield Battalion

28th Airfield Battalion (minus one element)

Two squads of the 1st Air Signal Regiment

9th Field Airfield Construction Unit

One element of 9th Field Aircraft Repair Depot 
4th Meteorological Company (minus one element)

298th Independent Motor Transport Company (minus one platoon)

123d Ground Duty Company (minus one platoon)

(2) The Operations in the Sector of the 2d Division; the Operational Direction by the [Sixteenth] Army

Landing; the Ship with the [Sixteenth] Army Headquarters Torpedoed

(See Illustrations No. 48, No. 49, and No. 50)

\section{Naval Engagements; [the Ship carrying the Sixteenth Army Headquarters] Torpedoed}

As we have seen, the eight transport ships carrying the unit of the $2 \mathrm{~d}$ Infantry Group Commander Nasu and his men, which was to land to the south of Merak, the seven transport ships carrying the unit of the 4th Infantry Regiment Commander Fukushima and his men, which was to land to the north of Merak, and the thirty-two transport ships carrying the unit of [Sixteenth] Army Commander Imamura and others, which was to land at Bantam Bay, had separated from the transport convoy ([of] seven ships) of the Shōji Detachment at a point about 140 nautical miles north of Batavia at 0530 on the 27th. ${ }^{(120)}$ From this point (Point J), the [Army] Third Air Force assumed the task of escorting the convoy (except the Shōji Detachment). ${ }^{(96)}$ On that day, [the convoy] reversed its course at the report of the appearance of an allied fleet (one heavy cruiser, two light cruisers and two destroyers). The landing date was postponed by another day, and the convoy separately advanced toward southern and northern Merak, and Bantam [at last] at 2020 on the 28th. ${ }^{(120)}$ (See the previous description.)

The thirty-two ships of the convoy heading for Bantam Bay reached the bay at 2230.(120) Despite the almost full moon, the sky was not very clear. ${ }^{(31)}$ Just before the convoy's entry into the anchorage, allied aircraft came reconnoitering but flew away. ${ }^{(120)}$ Just after the convoy's entry into the anchorage, two [enemy] patrol boats were spotted. [Editor's note: According to Vol. 26, p. 436, there was only one patrol boat.] Our pilot ship [the destroyer Harukaze, in concert with the Fubuki] fired at them, drove them off, and made them run aground. ${ }^{(120)}$ [The convoy] started dropping anchor around 2345 and completed its entry into the anchorage by 0000 on 1 March. ${ }^{(120)}$

At 0030, the 1st landing unit departed. It was followed by a coded message that the left wing unit had successfully landed as early as at 0033 , which was immediately transmitted to Saigon and Tokyo. ${ }^{(34)}$ However, around 0037, the convoy came under attack from the sky as well as from the sea, and it launched an antiaircraft barrage while the fleet engaged the enemy at sea. ${ }^{(120)}$

The attacking allied forces consisted of six aircraft and the U.S. heavy cruiser USS Houston and the Australian light cruiser HMAS Perth. ${ }^{(120)}$ These two cruisers drove back the (six) [Japanese] destroyers with their huge guns and approached to a point five kilometers off the anchorage at 0100. ${ }^{(120)}$ After ordering: "All, Charge" at 0045, Rear Admiral Hara, commander of the 5th Destroyer Squadron, rushed [toward them], leading the light cruiser Natori and two destroyers. However, at that time (0100), he was still about fifteen kilometers away from the anchorage and these two cruisers. ${ }^{(120)}$ Prior to that, Rear Admiral Hara had ordered: "The transport ships shall go into the bay and evade [the engagements] all together." ${ }^{\prime(20)}$ However, it was feared that mines were laid in the bay, and Maj. Gen. Itō Shinobu, commander of the disembarkation group, ordered the ships to shift anchor to a point closer to the coast where 
all of them could be run aground. ${ }^{(94)}$ Fortunately, a smoke screen created by a [Japanese] destroyer hid the convoy from the U.S. and Australian cruisers. ${ }^{(120)}$ Around 0100, the Natori and the other ships started to engage the enemy and were joined by the heavy cruisers Mikuma and Mogami of the 7th Cruiser Division around 0118. During the engagement, the battle site shifted to the north. At 0140, HMAS Perth was sunk, followed by USS Houston at 0206. ${ }^{(115,120)}$

At the Bantam anchorage, one crisis followed another. Shortly after USS Houston and HMAS Perth had passed five kilometers off the anchorage, allied high-speed torpedo boats rushed in. ${ }^{(34)}$ It was just when the Mikuma, the Mogami and the other ships were engaged in a gun

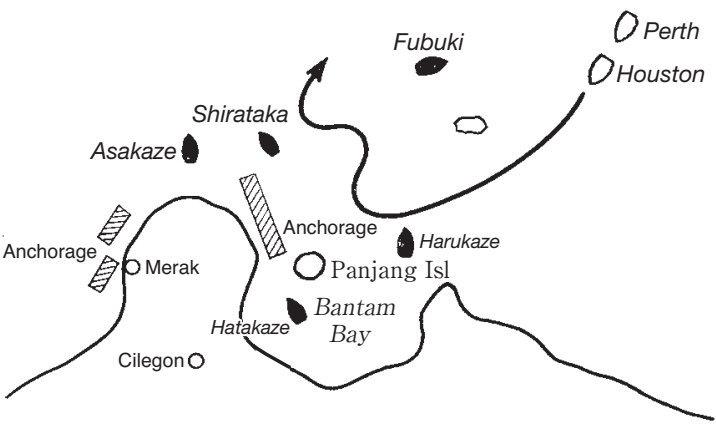

Illustration No. 48 - The Position of [the Japanese Naval] Forces Immediately After the Appearance of the Enemy Ships, and the Latter's Movements battle and launching their torpedoes; enemy as well as Japanese torpedoes crisscrossed [the waters]. The hospital ship Hōrai-maru, which was shifting her anchor, was hit by a torpedo, blew up, and listed. ${ }^{(27)}$ She was followed by the Ryujjō-maru, with [Sixteenth] Army Commander Imamura on board, which was [also] blown up by a torpedo. ${ }^{(27)}$ Then, the Sakuramaru was torpedoed and sunk, and the Tatsuno-maru was also torpedoed and heavily damaged. ${ }^{(27)}$ As they were [still] shifting anchors, [the loss was that] the Sakura-maru was sunk, and that the heavily damaged Rȳjī̄-maru, Hōrai-maru, and Tatsuno-maru ran aground and listed. ${ }^{(27)}$ [Editor's note: Dutch sources make no mention at all of the presence of allied high-speed torpedo boats; it appears that the Japanese ships were all hit by friendly fire. Vol. 26, p. 490 admits as much.]

The Ryuj $\bar{j} \overline{-}-m a r u$ and the Sakura-maru were carrying the [Sixteenth] Army headquarters. ${ }^{(35}$. ${ }^{36)}$ Maj. Gen. Itō Shinobu, the disembarkation group commander, put all the strength of the [crew of the] Atsuta-maru, which he was on, into the rescue operation. ${ }^{(94)}$ These four ships were sunk or destroyed in the middle of the second landing, but the disembarkation [operation] was continued. The Ryujjo-maru was shot through at the fuel oil tank, which caused the fuel oil to spill out into the waters all around. ${ }^{(94)}$ [Sixteenth] Army Commander Imamura, aged fifty-five and armed, swam around in the oil-covered waters floating in his life jacket until he was [finally] rescued around 0430. His watch had stopped at 0200.(35)

Due to the shipwreck of the two ships carrying the [Sixteenth] Army headquarters (the Ryujjo-maru and the Sakura-maru), radio sets, code books, a war chest of six million yen and other equipment was lost. ${ }^{(27)}$ In the shipwreck of a total of four ships, one large and five small motorized [landing] craft, one small steamboat and two boats with Yanmar engines were lost as well. ${ }^{(27)}$

An irrecoverable loss was the sinking in the sea of the radio sets and the code books, which ended up causing difficulties in the command of the [Sixteenth] Army during the most important first days of the landing operations. The thirty-two ships of the convoy [of the 


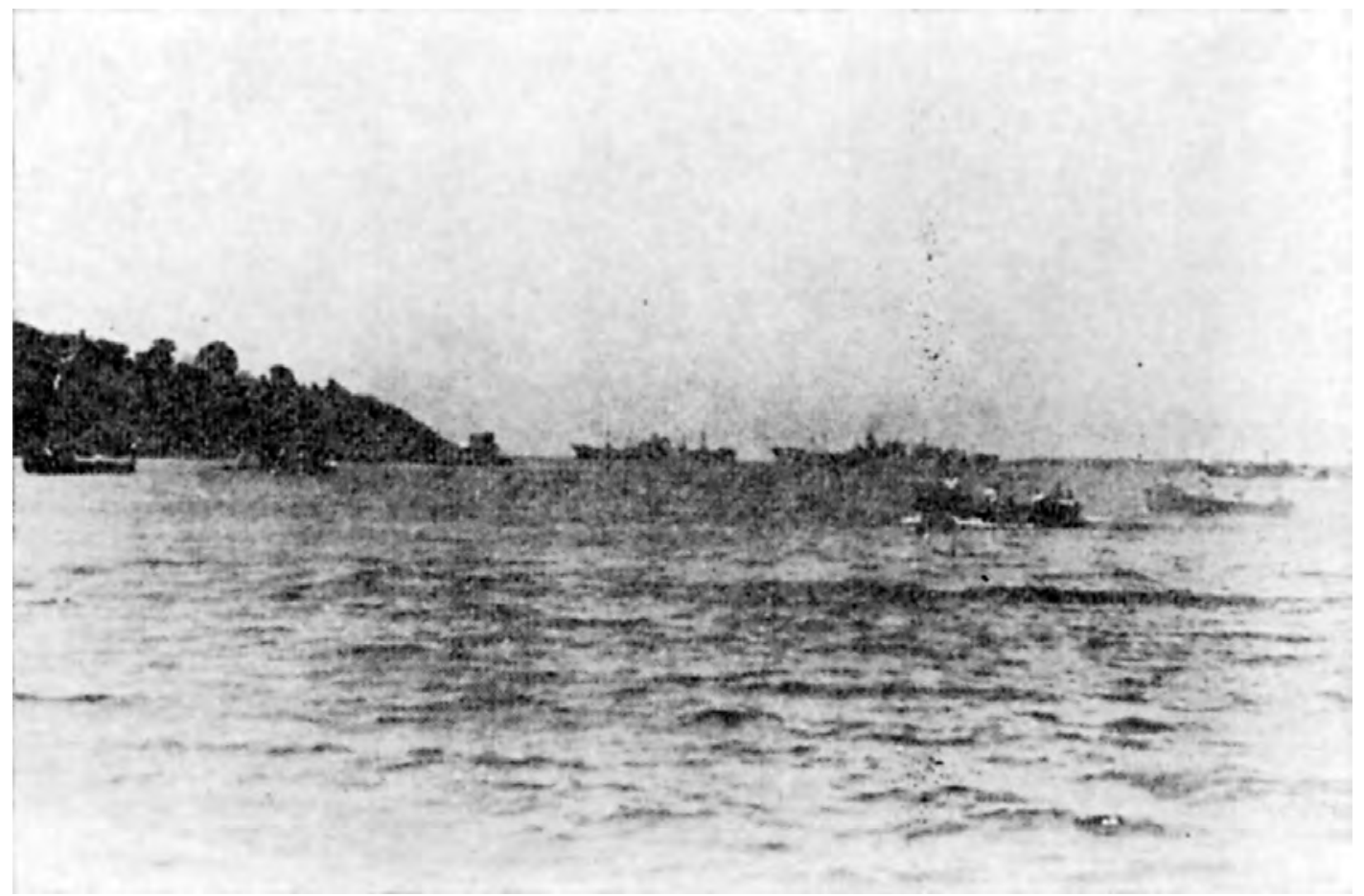

The Landing [Operation] of the Main Force of the Sixteenth Army at Bantam Bay

units to] land in Bantam [Bay] were divided into six sections, of which the Ryūjō-maru belonged to the $2 \mathrm{~d}$ Section, the Tatsuno-maru and the Horrai-maru to the 1st Section, and the

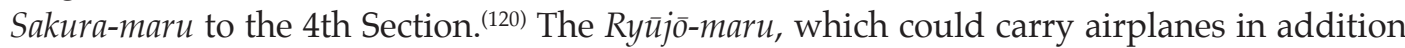
to thirty to forty large motorized [landing] craft and a great many small ones, had a peculiar appearance and, as we have seen, it had been an issue whether the [Sixteenth] Army commander ([and] the army headquarters) should board [this ship].

Note: The sinking of the radio sets of the Sakura-maru was reported as follows: ${ }^{(147)}$

SHŌSEN (note by the author: the abbreviation for the Saigon command post of the Shipping Transport Command) Staff Telegram No.2459 (sent at 1800, 3 March)

From: Captain General of the Shipping Transport Command [at] Saigon

To: War Minister, and Inspector General of Logistics

[This is] to report that I received a report to the effect that among the radio sets loaded on the Sakura-maru, the following (including accessories), kept by the signal regiment, have been lost at the time of the sinking of the ship off the coast of Java on 1 March.

1. One 2-kilowatt shortwave radio set

2. One 500-watt medium-wave and shortwave marine radio set

3. Two Type-94 Mark-3A radio sets

4. One Type-94 radio set

5. Eleven Type-96 Mark-7 radio sets

\section{The Operational Direction by the Sixteenth Army on the 1st [of March]}

[The chief of the] Signal Communication Staff of the Sixteenth Army, Lieutenant Colonel Saiki, had been positioned in the communications room of the Ryujjo-maru from the moment the convoy was about to enter the Bantam anchorage. Upon receiving the report of the suc- 


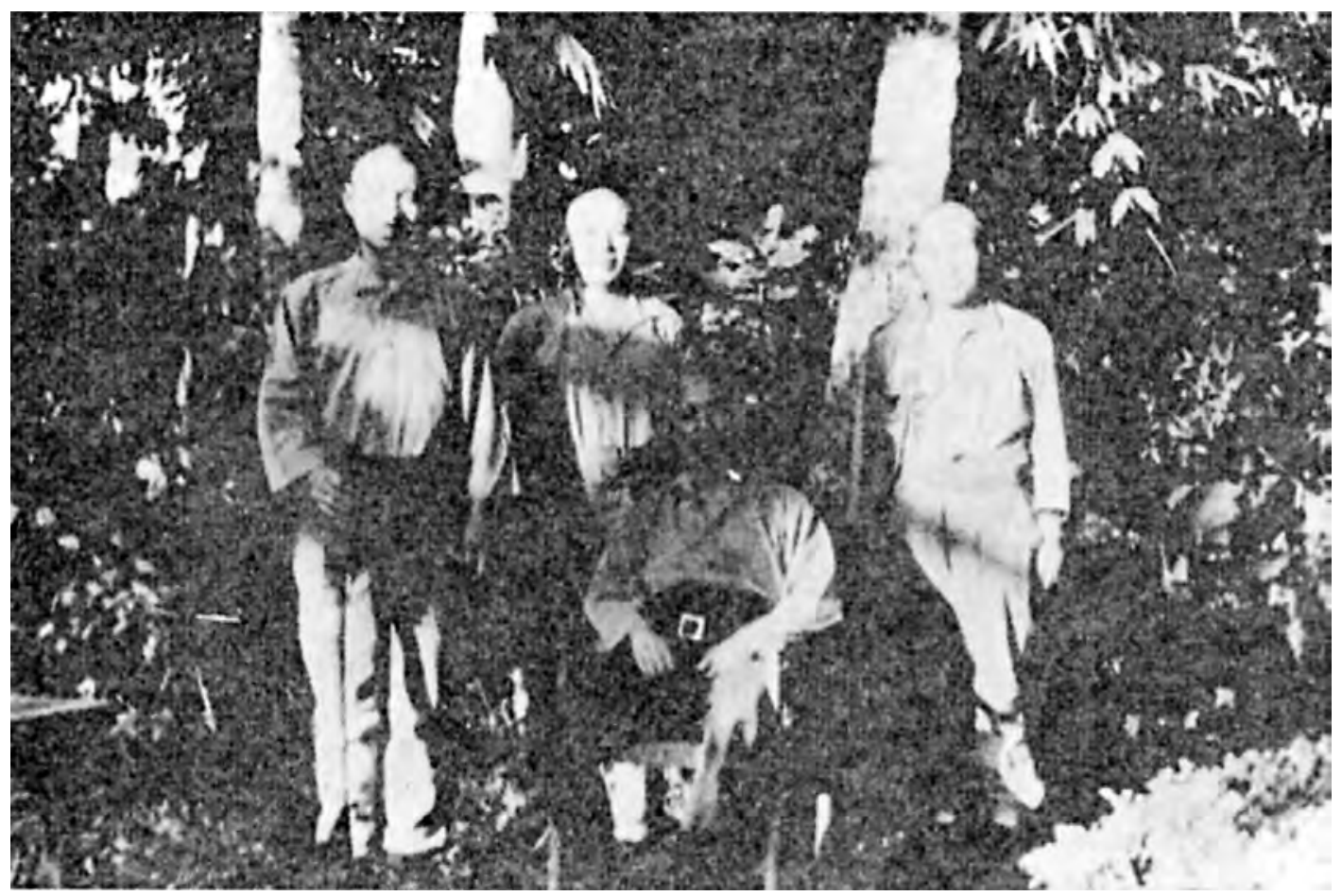

Army Commander Imamura and his Staff Officers Just After Landing out of the Oil-Covered Waters

(From the left in the back row, Chief of Staff [Okazaki], Staff Officer Kitamura, and Staff Officer Okamura)

cessful landing at 0033, he immediately transmitted the report. A little after 0130, Staff Officer Saiki left the Ryūjo-maru by motorized landing craft along with personnel to set up the command post of the [Sixteenth] Army. ${ }^{(34)}$ The gunfire of the naval engagement with the U.S. and Australian cruisers was heard less and less. They landed on the coral coast, looked [back] at the sea, and saw high-speed [enemy] torpedo boats spotlighting the [Japanese] transport ships and firing at them. ${ }^{(34)}$ They saw the Ryuj $\bar{j} \overline{0}$-maru listing, hit by a torpedo. As they feared that the coast might come under fire, they left the landing point around 0300, worrying about the safety of the army commander and the others, reached the village of Ragas and set up the command post there. ${ }^{(34)}$ Staff Officer Saiki was accompanied by only a radio platoon with a Mark-3 radio set, which enabled him to communicate with the $2 \mathrm{~d}$ Division and the Atsutamaru (disembarkation group commander Itō), but it was impossible to communicate with the Shōji Detachment, the Sakaguchi Detachment, the 48th Division and others, which were beyond the communication range of a Mark-3 radio set. ${ }^{(34)}$ From around daybreak, the [Sixteenth] Army commander and others, who were soaked black with fuel oil, arrived one after another. Senior Staff of Section 1, Takashima, was hospitalized. Frustrated, Staff Officer Saiki tried hard to communicate with the Shōji Detachment and other corps in distant places, as well as the Southern Army, but without success. The first thing to do was to request the Southern Army to provide [the command post] with communication equipment and code books. He tried to send a telegram to the Southern Army by asking a naval signal unit to transmit it via the Natori, the flagship of the 5th Destroyer Squadron, only to fail. Then he asked [the unit] to transmit it via the Eleventh Air Fleet, but it was unknown whether it reached [the Southern Army] or not. ${ }^{(34)}$ Around 1500, he was able to get hold of two fixed 
wireless units at last. He tried to make contact with all units concerned other than the $2 \mathrm{~d}$ Division by employing all the radio sets, but in the end he could not establish contact on 1 March. The amount of equipment brought ashore was very small, and it took much time to set it up, due to the fact that it was long-distance radio sets and that the [signal] unit was inexperienced [in handling these]. The radio contact with the Southern Army was [finally] established at 1000 on the next day, the $2 \mathrm{~d}$, and radio contact with the others followed. However, in disregard of the communications situation, a huge amount of transmissions poured in, and because there were only a small number of communication sets and code books, communications became unmanageable.

On that day (the 1st), [radio] contact with the Shōji Detachment, the Sakaguchi Detachment and the 48th Division could not be established all day. ${ }^{(34)}$ However, [the command post] was informed by the Navy that those landing [operations] were going well. ${ }^{(36)}$ Communications with the $2 \mathrm{~d}$ Division were maintained. ${ }^{(36)}$ Whereas the war situation seemed favorable in the Merak area (the Nasu and the Fukushima Detachment), in the area where the main force of the $2 \mathrm{~d}$ Division [had landed], the only road through the paddy fields about one kilometer south of the [Sixteenth] Army headquarters was blasted, and it was not expected to be repaired for the time being, which forced the unit to make a detour through the jungle. On top of that, the road south of the blast point was blocked with huge cut-down or blasteddown roadside trees, presumed to be 300 years old, due to which the unit had a very hard time going southward while carrying their bicycles on their shoulders. It seemed out of the question to capture the entire island by 'Shunki-kōreisai' (the Imperial ceremony of ancestor worship on the vernal equinox day, 21 March). ${ }^{(35,36,59)}$

In the evening, Staff Officer Wakatsuki (Staff Officer of the Third Fleet seconded to the Sixteenth Army) wired to the Southern Task Force and others through the naval communication system the following:(131)

The military situation on land of [Operation] $\mathrm{H}$ on 1 March is as follows:

1. The main force has landed at Bantam Bay and the detachment has landed at Merak; the front line has already reached Serang. The [Sixteenth] Army headquarters is positioned near the landing point and is scheduled to advance to Serang tomorrow morning. The enemy has put up a stubborn resistance and thoroughly destroyed the roads.

2. The military situation is developing smoothly in the areas of the 48th Division and the Shōji Detachment, but details are unknown.

The next day it turned out that the road barricade with roadside trees before the main force of the $2 \mathrm{~d}$ Division continued for ten kilometers to Serdang. ${ }^{(35,36)}$ On that evening (the 1st), however, even though the advance of the main force of the $2 \mathrm{~d}$ Division was still hampered, the [Sixteenth] Army headquarters finally felt greatly relieved to receive a telegram that the operations in the Merak area were going well and that the advance party of the Nasu Detachment in pursuit of the enemy had broken through Serang, and rushed even further to secure one of the bridges over the Ciujung River, to which all the time great importance had been attached, just before it was going to be blown up. ${ }^{(36)}$ 


\section{The Leadership of the Southern Army on the 1st [of March]}

The Southern Army headquarters ([in] Saigon) had received the telegram from the Ryūjōmaru before its shipwreck that "the main force of the [Sixteenth] Army [had] completed its entry into the anchorage at 2350 on the 28th and succeeded in landing near Cape Awuran in the morning of today, the 1st." (24) On that day, the Southern Army wired back as follows:(23,24)

We offer our sincere congratulations on your successful landing. We hope that you will destroy the base of the enemy at once and swiftly complete your mission.

By saying that it hoped [that the Sixteenth Army would] "destroy the base of the enemy at once," the Southern Army expressed its view that [the Sixteenth Army] should make Bandung the primary target, contrary to the latter which had made Batavia the primary target and considered Bandung as the secondary target in its operation plan as well as in its operation orders. ${ }^{(23,24)}$

Learning about the accident to [Sixteenth] Army Commander Imamura and his men, the war minister and the chief of the general staff sent telegrams expressing their sympathy. ${ }^{(17)}$ However, the Southern Army sent no expressions of sympathy. It was beyond doubt that the Southern Army sympathized with the ship-wrecked [Sixteenth] Army headquarters, but it felt that it was something that could happen to soldiers, and that the success or failure of the landing held the key to the success of Operation H. Now that [the Sixteenth Army] had succeeded in landing, [the Sixteenth Army] should go straight for Bandung, putting Batavia aside, and by sending only the previously-mentioned telegram it meant to boost the morale of the Sixteenth Army. ${ }^{(23)}$

\section{[The Operations] of the Nasu Detachment on the 1st [of March]}

The Nasu Detachment, which was assigned to land in Sector A of Merak (note: at the right front) and rush toward Buitenzorg, was organized for transportation by motor vehicle. ${ }^{(55)}$

Detachment Commander Nasu had divided the landing (disembarkation) of his men and motor vehicles into eleven sections, and he further divided the first section into two transports. He planned to have the unit that was to seize the coastal area ([consisting only of] men) land in the first transport of the first section and to have the raiding unit ([consisting of] men and motor vehicles) land in the second transport of the first section and have it charge ahead. The remaining units were to land (disembark) after that. ${ }^{(64,65)}$

Planning "to make a surprise landing in Sector A at 0200, advance all at once into the area on the right bank of the Ciujung River near Rangkasbitung and make preparations for the subsequent advance" on the first day of landing, Detachment Commander Nasu disposed [his unit] roughly as follows: ${ }^{(64,65)}$

K Raiding Unit ([consisting of] the 3d Company of the $2 \mathrm{~d}$ Reconnaissance Regiment as the core): The unit shall land in the second transport of the first section, promptly charge toward Kragilan along the Cilegon - Serang road and secure the bridge over the Ciujung River. When one element of the Satō Detachment arrives [there], the unit shall turn over [the defense of] the bridge [to it] and return to the Noguchi Echelon.

Noguchi Echelon (with the following core units):

Main force of the $2 \mathrm{~d}$ Reconnaissance Regiment 


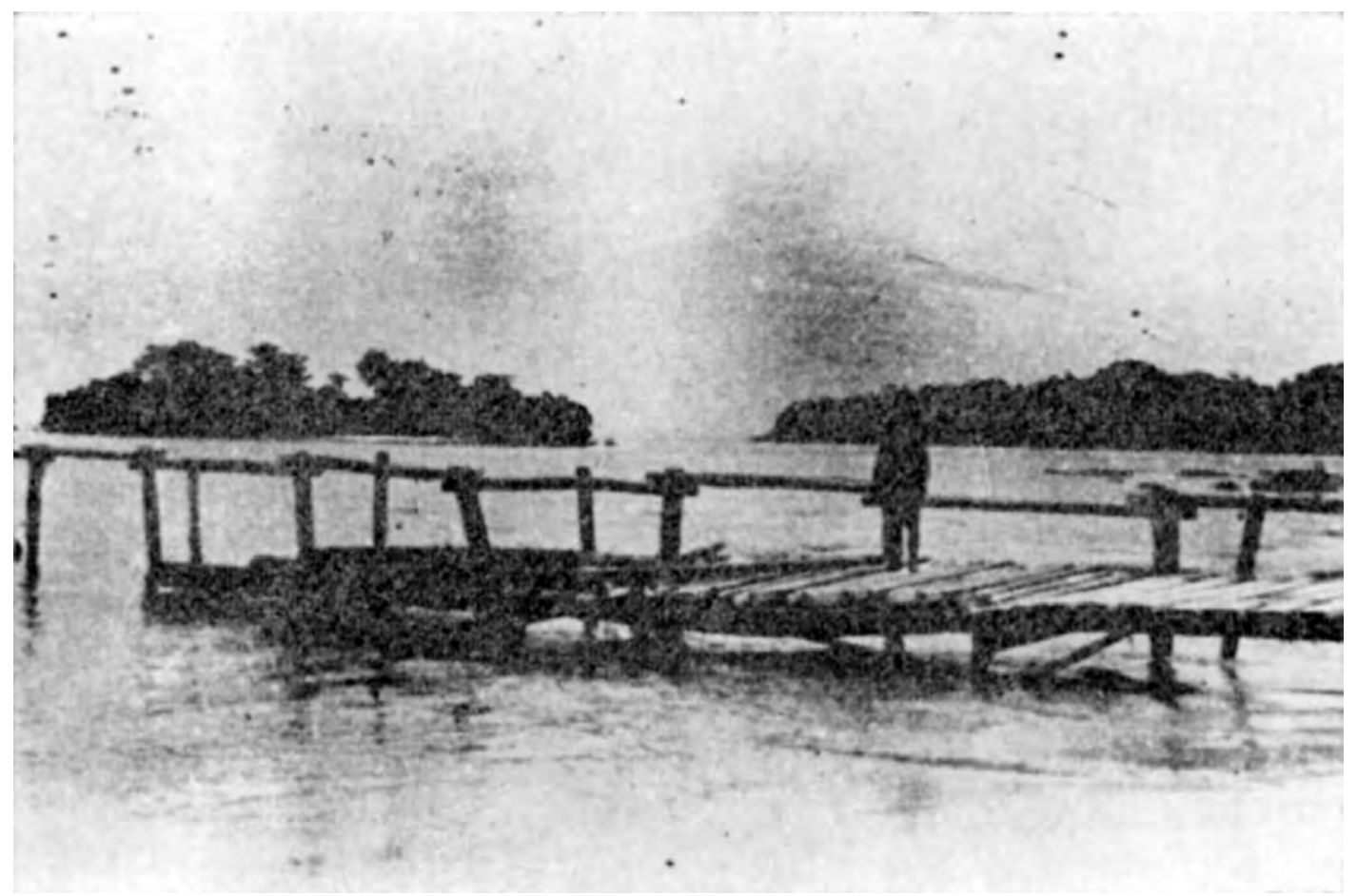

The Coast of Merak After the Landing of the Nasu Detachment

Motorbike unit

One field artillery battery (minus one section)

One divisional engineer platoon

One independent engineer platoon

One independent antitank gun company (minus one platoon)

The echelon shall start landing in the second transport of the first section following the unit of the Hiroyasu Echelon that shall land in the first transport of the section, charge toward Rangkasbitung without engaging the enemy and try to secure the bridge there while making preparations for advancing toward Buitenzorg. When one element of the Fukushima Detachment arrives, the echelon shall turn over the defense of the bridge to them.

Hiroyasu Echelon (with the following core units):

16th Infantry Regiment (minus the 1st Battalion, the 10th Company, and one regimental gun platoon)

1st Battalion of the 2d Field Artillery Regiment ([minus?] one battery and one section)

One engineer company (minus one platoon)

One bridge building material platoon

39th Independent Motor Transport Battalion (minus the $3 \mathrm{~d}$ and the 4th Company)

While focusing its attention on its right flank, the echelon shall land on the coast between a point about one kilometer west of Mt. Kamuning and the southern end of Merak. While having one element mop up possible [enemy] firing positions on its flank near the landing coast, it shall have its main force first of all promptly charge to Cilegon along the Merak Serang road, further rush through the area along the Serang - Tunjung Ketuk road without waiting for the disembarkation of motor vehicles and guns, cross the Ciujung River in the area north of Rangkasbitung, advance into the eastern area of the city, and make preparations for the subsequent advance.

Remaining units: 
Shall follow the Hiroyasu Echelon.

The convoy of the Nasu Detachment (the Kōyō-maru, the Hokumei-maru, the Shinshu-maru, the Columbia-maru, the Atlas-maru, the Ryūnan-maru and the Akitsu-maru, a total of seven ships) [editor's note: the names and number of ships differ from the list in the agreement given on p. 242] entered the anchorage at 0000 on 1 March, dropped anchor at 0030, and conducted the vessel-launching (note: the launching of landing craft onto the waters from transport ships) around 0130. ${ }^{(58,64,120)}$

Both front-line battalions of the Hiroyasu Echelon that were to land in the first transport of the first section (at the right front line the $2 \mathrm{~d}$ Battalion commanded by Maj. Onoguchi Satoru and at the left front line the 3d Battalion commanded by Maj. Morozumi Yoshikazu) came ashore at 0200. Although there was about one Dutch East Indies Army company in Merak and vicinity, they retreated without putting up much resistance. After landing, the Hiroyasu Echelon immediately started advancing on foot, drove away a Dutch East Indies Army unit consisting of some 200 men in Cilegon in the early morning, commandeered a few motor vehicles in the city (one motor vehicle for the Morozumi Battalion in the rear), and continued its advance. ${ }^{(61,62)}$

The K Raiding Unit and the Noguchi Echelon landed following both front-line battalions of the Hiroyasu Echelon and charged ahead, overtaking [both battalions]. ${ }^{(64,65)}$

Echelon Commander Noguchi (2d Reconnaissance Regiment Commander Lt. Col. Noguchi Kin'ichi) had divided his unit into three advance parties and the main body ([consisting of] three echelons). He had disposed his unit roughly in the following way, planning to have [the unit] land in the order of the advance parties and the main body, and while having the advance parties immediately charge toward the bridge over the Ciujung River, have the main body rush toward Rangkasbitung after lining up the echelons one after another in a column on the right side of the main road near Grogol. On arrival in Rangkasbitung, the unit should make preparations for the subsequent advance. ${ }^{(64,65)}$

Right advance party (the main force of the 4th Company): to the Rangkasbitung bridge.

Left advance party (two platoon of the 3d Company): to the Pamarayan bridge.

Shishido advance party (motorbike unit): shall charge to Serang, secure the Serang bridge, and rush toward Rangkasbitung when the first echelon arrives. After that, it shall make preparations for advancing toward Lawangtaji.

Main body and the order of the accompanying units:

First echelon (led by Captain Takase; [consisting of] the 2d Company, the regimental headquarters, and others): After forming a column with its head at Grogol, the echelon shall rush to Rangkasbitung. After that, it shall make preparations for advancing toward Leuwiliang. It shall have one element take over the defense of the Rangkasbitung bridge from the right advance party and turn it over to the Fukushima Detachment when the latter arrives.

Second echelon (led by Captain Sakurai; [consisting of] the main force of the 1st Company, the main force of the independent antitank gun company, and others): shall follow the first echelon.

Third echelon (led by 1st Lt. Watanabe Kōichi; [consisting of] the 3d Battery of the 2d Field Artillery Regiment (minus one section) as the core): shall follow the $2 \mathrm{~d}$ Echelon. 
The K Raiding Unit as well as the right, the left and the Shishido advance parties overtook the Hiroyasu Echelon, charged into Serang at 0700, and further rushed to reach the line of the Ciujung River by $1400 .{ }^{(64,65)}$

The Kragilan bridge had already been destroyed. ${ }^{(55)}$

The advance party to seize Rangkasbitung was accompanied by $2 \mathrm{~d}$ Division Staff Officer Maj. Satō Hidehiko. When the advance party reached Pandeglang, it encountered about one company of the British / Australian Army, which had retreated from the Labuhan coast, caught some of the enemy and heavily pursued the enemy by having the prisoners of war drive the commandeered motor vehicles. Just when the party was approaching the front of the Rangkasbitung bridge at 1230, the allied unit managed by a hair's breadth to demolish the bridge but, fortunately, half of the bridge remained. ${ }^{(54)}$

The unit sent to the Pamarayan bridge engaged on the east side of the bridge the allied unit that had rushed to the bridge to destroy it and narrowly managed to secure it. ${ }^{(31)}$

On advancing into Rangkasbitung, Echelon Commander Noguchi issued an order there at 1500 to deploy his unit so as to have one element [consisting of] the $2 \mathrm{~d}$ Company as the core head for Leuwiliang as an advance party by leaving the town at 1630, and have the main force leave at $1730 .{ }^{(64,65)}$

The Hiroyasu Echelon arrived in Serang one after another from a little before noon onwards. ${ }^{(64)}$

Detachment Commander Nasu reached Serang at 1300. By evening, he learned that the advance of the main force of the division had been delayed, that the Sato Detachment was [at last] advancing into Serdang, and that the Fukushima Detachment was advancing into the area about one kilometer northwest of Serdang. He decided to assemble his detachment in Rangkasbitung and vicinity the night of the same day, the 1st, to make preparations for advancing on the next day, the $2 \mathrm{~d}$, and issued his orders for the detachment in Serang at 1810. That is, the commander deployed his unit so as to position the Noguchi Echelon (with the K Raiding Unit returned) in Jasinga and the Hiroyasu Echelon in the area east of Rangkasbitung that night to prepare for the subsequent engagements, and have the remaining units advance toward Rangkasbitung one by one. ${ }^{(64)}$

Despite the independent motor transport battalion (two companies) being assigned to the detachment and the presence of the 1st Battalion of the 2d Field Artillery Regiment, which was the only battalion in the regiment equipped with motor vehicles, the mobility of the Nasu Detachment was not sufficient. The disembarkation was scheduled to take [as long as] seven days. The Hiroyasu Echelon came under attack from one allied aircraft in Serang, but sustained no damage. [The Echelon] got hold of bicycles, which arrived while it was standing by there, and left Serang for Rangkasbitung at 1900, using commandeered motor vehicles as well. Of the Morozumi Battalion (i.e. the 3d Battalion), which departed from Serang, the battalion headquarters and the 9th Company advanced by bicycle, the machine gun company marched on foot while pulling two-wheeled carts. Motor vehicles were available only for the guns, gunners and superiors of the battalion gun platoon; all the other companies marched on foot. On that day, with a temperature of 31 degrees Celsius and no wind, the summer heat was hard on the officers and men of this regiment from Shibata in Niigata, a cold region. [The heat] was followed by torrential rain in the evening. ${ }^{(61,62,64)}$

The Nasu Detachment headquarters arrived in Serang in the afternoon, and left there for Rangkasbitung at 2100. ${ }^{(59,64)}$ 
The indigenous people greeted the [Japanese] units with cheers and helped them everywhere. ${ }^{(55)}$

\section{[The Operations of] the Fukushima Detachment on the 1st [of March]}

The convoy ([consisting of] the Akitsu-maru, the Momoyama-maru, the Pacific-maru, the Kizanmaru, the Reiyo-maru, the Tsuyama-maru and the Sydney-maru) of the Fukushima Detachment (led by Col. Fukushima Kyūsaku, commander of the 4th Infantry Regiment), which was to land in Sector B of Merak (the left front), completed its entry into the anchorage at 0045 on 1 March. ${ }^{(120)}$ [Editor's note: The list of ships agrees with that on p. 242. However, the Akitsumaru was on p. 477 also assigned to the Nasu Detachment. The actual situation is unclear.]

At 0145 , the ships launched the landing [operation] all at once and [the troops] successfully landed without loss. Detachment Commander [Fukushima] went ashore along with the second [transport] group, and advanced to the southern end of Lebak Gede. Lt. Col. Ikuta Tōichi, commander of the 1st Battalion on the right front line, immediately sent the $2 \mathrm{~d}$ Company to attack the Dutch East Indies Army on Mt. Merak, while having one element of the company charge toward the station and vicinity. At the same time, he also had the engineer platoon assigned [to his unit] rush along the coastal road to search for and attack enemy pillboxes. The [Japanese] units destroyed several lines of obstacles and in combination with the outflanking attack via the top of the Mt. Merak they put the Dutch East Indies Army to flight into the jungle to the southeast, giving it no time to put up resistance. Furthermore, the unit to seize Merak Island, led by 1st Lt. Inoue Kanji, commander of the 1st Company, [managed to] land on the island under fierce [direct] fire of machine gun(s) from the direction of the Merak [railway] station and completed clearing the island. In their shift to Pulau Merak [not the island, but the suburb south of Merak across from the island], they took thirty-five white sailors prisoner, castaways from the warship(s) [USS Houston and/or HMAS Perth] sunk in the naval engagement in the Bay off Batavia [i.e. Bantam]. ${ }^{(58)}$

The [Fukushima] Detachment did not wait for the completion of the landing of the entire unit; the 1 st and the $2 \mathrm{~d}$ echelon left Sekong and Lebak Gede at 0530 and at 0730 respectively, and advanced along the Sekong - Cilegon - Serang - Petir road toward the right bank of the Ciujung River near Pamarayan. The detachment commander passed through Serang around 2300. The $3 \mathrm{~d}$ echelon and succeeding units also followed one after another after their landing. ${ }^{(58)}$

\section{[The Operations in] the Sector of the Main Force of the 2d Division on the 1st [of March]}

The Satō Detachment (commander, 29th Infantry Regiment Commander Col. Satō Hanshichi) launched the [landing] craft of the first transport at 0000 on 1 March and landed at 0045 . All fronts met with no resistance at all. The detachment commander landed at a point one kilometer west of Cape Kapo [?] at 0245. The 1st Battalion (commander, Lt. Col. Endō Shigesuke), the $2 \mathrm{~d}$ Battalion (commander, Lt. Col. Watanabe Katsutoshi) and the $3 \mathrm{~d}$ Battalion (raiding unit; commander, Maj. Yoshii Tadao) departed respectively at 0320, 0600 and 0630 without waiting for [the completion of] the assembly [of each unit]. They pushed along the coastal road, which was only passable with extreme difficulty due to felled roadside trees and destroyed bridges, but the heads of each battalion reached Trate respectively at 0900, 1200 and 1500. Detachment Commander [Satō] reached Trate at 1030. Then, the detachment left the 
town at 1700, heading along the Trate - Bantam - Ciruas - Kragilan road toward the right bank of the Ciujung River; they reached Bantam at 2100, where they encamped. ${ }^{(63,120)}$

The [2d] Division command post, which had been positioned in Bojonegara [following] the advance of the Satō Detachment after the landing, left the town at 1500 to move to Serdang. ${ }^{(59)}$

Taking the situation of the detachments into account, the [2d] division commander instructed each of the detachments to send one element ahead to seize the crossing points on the Cidurian River, while urging them to [quickly] advance to the right bank of the Ciujung River. At the same time, he tried to stay in [overall] control of his units. ${ }^{(31)}$

The divisional reserve unit ([consisting of] the $3 \mathrm{~d}$ Battalion of the 4 th Infantry Regiment led by Maj. Sasaki Mori'e) completed landing at 0520. While having one platoon clear the road along the north coast of the peninsula up to Merak, he headed southward with the main force (one company by bicycle and the others on foot) and reached Bojonegara at 1530 and Serdang at 2200. ${ }^{(59)}$

\section{The situation on 2 March}

The [Sixteenth] Army headquarters greeted the morning of the $2 \mathrm{~d}$ in Ragas. Radio contact with the Shōji Detachment, the 48th Division and others was yet to be established. ${ }^{(34,36)}$

While the [Navy] 1st Air Unit ([consisting of] the auxiliary seaplane tenders Kamikawamaru and San'yo-maru), which supported the 3d Escort Unit (under the command of the 5th Destroyer Squadron commander), was still positioned in the Anambas Islands, two planes of each ship had advanced to the Patrol base at noon of the previous day (the 1st), and two of them shifted from the Patrol base to the Bantam base that evening. The 1st Base Force had set up the Bantam Base with one element. ${ }^{(130,131)}$ [Editor's note: This is a somewhat garbled account of the events. See Vol. 26, pp. 516-517.]

The bombings of its anchorage by allied aircraft on the previous night, along with the appearance of [allied] submarines, had caused tension in the [Sixteenth] Army headquarters. Just then, two telegrams arrived that morning (of the $2 \mathrm{~d}$ ) via the previously mentioned naval unit. ${ }^{(36)}$

One was from the Shōji Detachment, which contained the message that "the Shōji Detachment seized the Kalijati airfield at noon on the 1st and obtained an immense amount of spoils. One element of the detachment is [now] advancing toward the Krawang bridge. This morning (of the $2 \mathrm{~d}$ ), the disembarkation point at Eretan is under the attack of 400 to 500 enemy [troops] with armored cars." ${ }^{\prime 17,36)}$

The other telegram was from the 48th Division, which contained the message that "according to the statement of the captain of a British destroyer, who was taken prisoner as a consequence of the naval engagement off Surabaya, two divisions of the Australian Army had completed their landing on Java at Cilacap several days ago." $(17,36)$

The [Sixteenth] Army headquarters grew agitated. The Shōji Detachment, consisting of only two battalions, had gone inland, split up into units for Kalijati and Krawang, while its disembarkation point, which was in the middle of the disembarkation operation, was said to be under the attack of allied forces that morning. The situation of the detachments in the inland was unknown. On top of that, two divisions of the Australian Army were said to have landed recently. If it had been Dutch East Indies Army divisions, it would have been no problem, but the Australian Army could not be treated lightly. The entire staff of the headquarters 


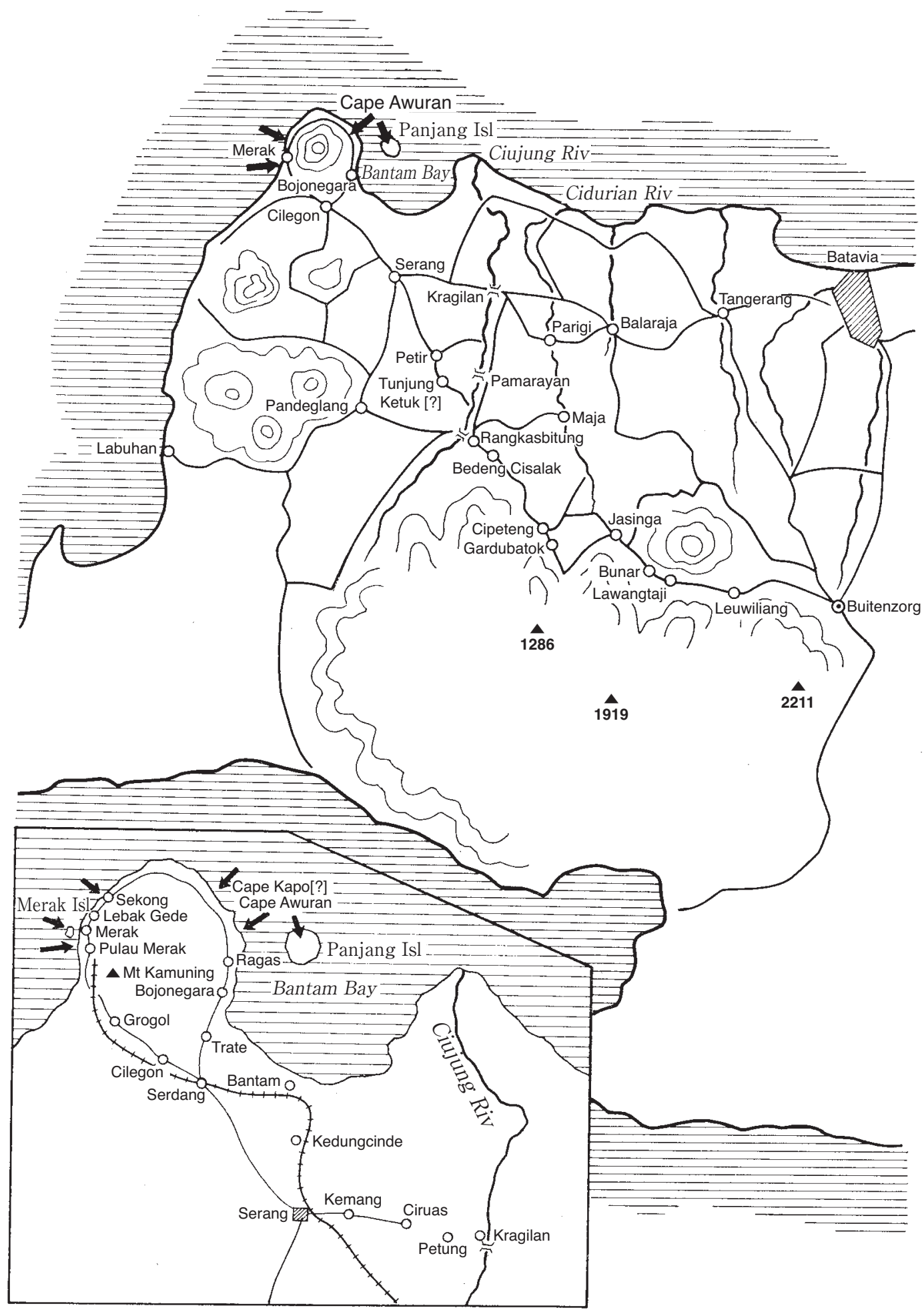

Illustration No. 49 - The Sector of the Main Force of the [Sixteenth] Army: The Terrain and Landing Points 
became more and more anxious, but the chief of staff, Major General Okazaki, asserted: "The information of the landing of the Australian Army is a lie," and assured the staff that "judging from the recent operations of our aircraft, submarines and other units, as well as from the strategic positions of the enemy and ours, it is absolutely unthinkable."(17,36)

Note: The matter of the two divisions of the Australian Army will be described later in section 6: "The Conclusion of the Java Invasion Operation and the Operations of the Allied Forces."

It was inconvenient to give commands and establish contact from Ragas. The Army Commander [Imamura] left Ragas with the personnel of the command post at 1500. After going southward halfway along the coastal road [obstructed] with felled roadside trees, they used [landing] craft to land [again] at the southwestern part of Bantam Bay and arrived in Serang at 2000 on the $2 \mathrm{~d}$ in the motor vehicles that had come from Merak to pick them up. ${ }^{(31,32,35)}$

In the area of the Nasu Detachment, Echelon Commander Noguchi, who had left Rangkasbitung for Leuwiliang at 1730 on the 1st, reached Cipeteng (about twenty kilometers southeast of Rangkasbitung) at 1845 and learned that the advance party was in the middle of an engagement with an Australian Army [unit] equipped with machine guns there. He immediately deployed his unit, and drove off [the enemy]. As the allied forces had set antitank obstacles on a concave road in Cipeteng, he decided to pursue the enemy toward Gardubatok (departure scheduled at 2030) after removing the obstacles and made the necessary [changes in the] disposition of his units at 1930. The echelon resumed its advance at 2030 and continued its march while removing obstacles on the road. On the $2 \mathrm{~d}$ at 1800 , it arrived at the position of the advance company in Lawangtaji and encamped in the area between Lawangtaji and Bunar on the night of the $2 \mathrm{~d}$, while removing antitank obstacles and landmines near the Lawangtaji bridge. ${ }^{(64,65)}$

The Hiroyasu Echelon (led by 16th Infantry Regimental Commander Col. Hiroyasu Jurō) of the Nasu Detachment advanced by marching through the night from Serang and reached Bedeng Cisalak (its destination), located four kilometers east of Rangkasbitung, around 0800 on the $2 \mathrm{~d}$. Echelon Commander Hiroyasu decided to assemble his force near Bedeng Cisalak to [have his unit] prepare for the subsequent advance. At 0830, he arranged that the units following behind and the goods left in Serang be brought to the present location by shuttle transport [provided] by the motor transport unit. Then at 1820, having decided to advance [his units] toward Leuwiliang via Jasinga by leaving Bedeng Cisalak the next day, the $3 \mathrm{~d}$, he issued the relevant orders. ${ }^{(61,64,65)}$

As we have seen, the Fukushima Detachment had passed through Serang the night before, and continued its rush toward Pamarayan on the $2 \mathrm{~d}$. From the afternoon of the $2 \mathrm{~d}$ onwards, motor vehicles became available for the transport [of the detachment] as well, which enabled the detachment to assemble most of the separated units near the Pamarayan bridge at midnight. ${ }^{(58)}$

The Satō Detachment left the southern end of Bantam at 0100 on the $2 \mathrm{~d}$ to advance toward Kragilan. It reached Kedungcinde at 0730, Kemang at 1230, and Ciruas at 1900; the 1st Battalion and the main force of the detachment encamped respectively in Petung and Ciruas. On this day, the $2 \mathrm{~d}$, the raiding unit (i.e. the $3 \mathrm{~d}$ Battalion led by Maj. Yoshii Tadao) rushed toward Kragilan, getting ahead of the main force at 0200, reached the town at 1040, and took 
over the defense [of the town] from the K Raiding Unit of the Nasu Detachment, which had seized the town. ${ }^{(31,63)}$

The $2 \mathrm{~d}$ Division command post had left Serdang around 0400 on the $2 d$, reached Serang, from which it departed [again] at 2000, and advanced to Petir. ${ }^{(59)}$

The divisional reserve unit had [also] left Serdang at 0400 on the $2 \mathrm{~d}$ and reached Serang at 1030, where it encamped. ${ }^{(59)}$

The reserve unit of the [Sixteenth] Army ([consisting of] the 1st Battalion of the 16th Infantry Regiment, commanded by Lt. Col. Minamoto Shirō) was positioned in the area northwest of Serang.

\section{Shifting Priority to the \\ Buitenzorg Road \\ (See Illustrations No. 51, No. \\ 52 and No. 53)}

\section{The Operational Direction of the Sixteenth Army on the 3d [of March]}

The [Sixteenth] Army command post greeted the morning of the $3 d$ in Serang. ${ }^{(34)}$ Senior Staff Officer Colonel Takashima of the 1st Section was [still] in hospital and the [Sixteenth] Army headquar-

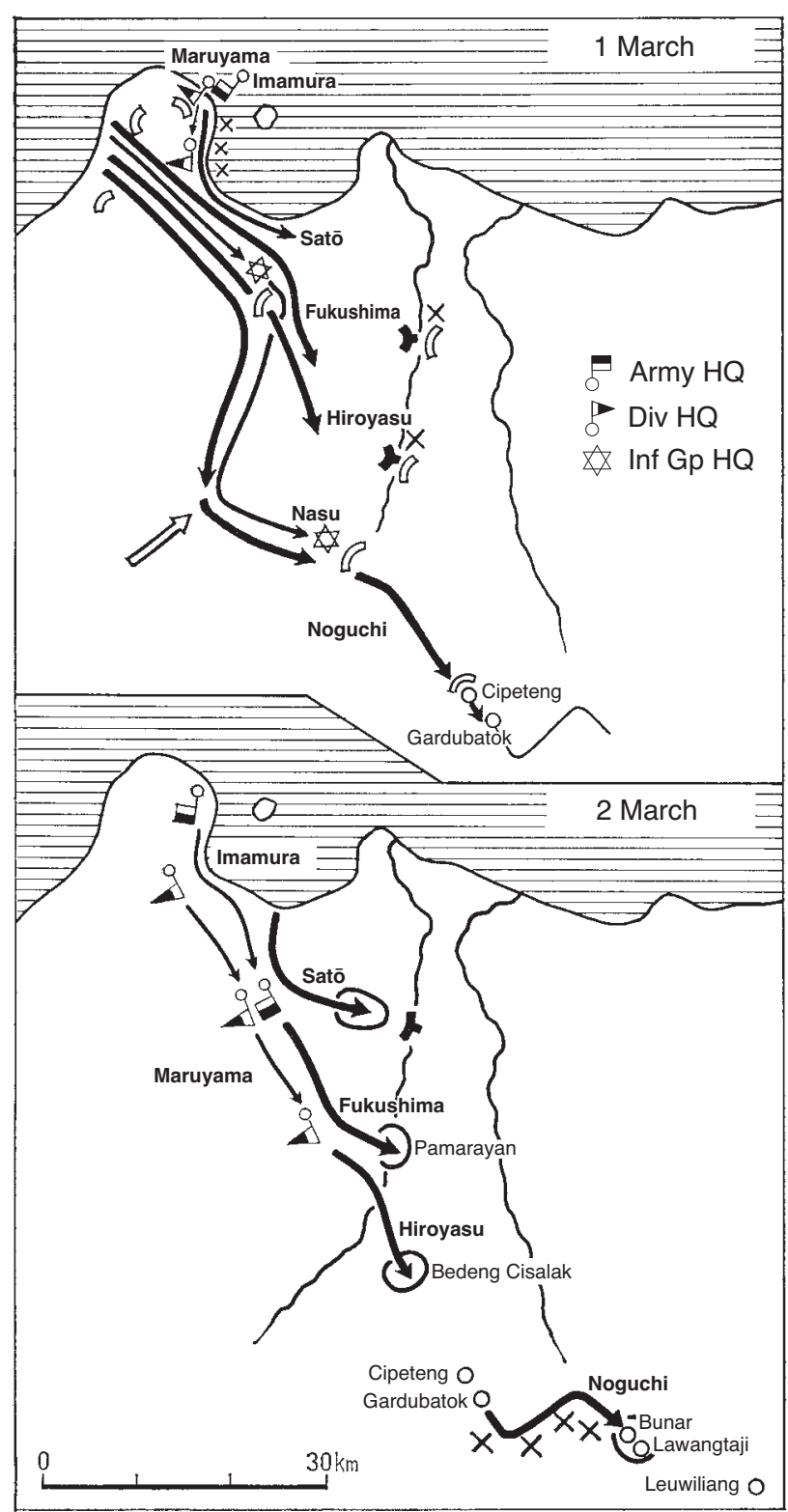

Illustration No. 50 - [Advances on] 1 and 2 March ters was still positioned in Ragas. ${ }^{(34)}$ So were [Chief] Signal Communication Staff Lieutenant Colonel Saiki and the army signal unit. The situation was [tough:] the bridge to the north of Bojonegara had not yet been repaired, and one element of the $2 \mathrm{~d}$ Division reserve unit was still at the landing point. ${ }^{(59)}$

The situation of the $2 \mathrm{~d}$ Division before daybreak on the $3 \mathrm{~d}$ was that the Nasu Detachment was advancing smoothly in general, that both the Fukushima and the Sato Detachment had managed to reach the west bank of the Ciujung River at last and were preparing to cross the river, while sending one element of their force ahead to try to seize the bridges over the Cidurian River. ${ }^{(58,61,63)}$ 
The situation of the Shōji Detachment was a matter of concern. Because destroyed bridges, blocked roads and heavy rainfall had seriously delayed the advance of the main force of the 2d Division, the Shōji Detachment would remain isolated for an even longer period. [Sixteenth Army Chief of Staff Okazaki] had suppressed the agitation among the staff officers, asserting that the statement of the captain of an allied destroyer that two divisions of the Australian Army had landed was a lie, but he had no solid grounds. As a matter of fact, the units that put up resistance against the Nasu Detachment one after another were units of the Australian Army.

In the morning, Chief of Staff Okazaki left the [Sixteenth Army] command post in Serang to visit the $2 \mathrm{~d}$ Division headquarters in Petir. The $2 \mathrm{~d}$ Division Commander Maruyama told him that the division had not been able to advance as it had expected due to destroyed bridges, that the engineers had difficulty in bridging the rivers because the rivers were deep and had high banks; moreover, every day heavy squalls in the afternoon instantly swelled the rivers. Chief of Staff Okazaki went on toward the Kragilan bridge by car. ${ }^{(36)}$

At noon, 2d Division Commander Maruyama decided to advance the [divisional] headquarters to Rangkasbitung to urge his units onward. He [also] decided to have the divisional reserve unit secure the Pamarayan bridge (which had not been destroyed) after the Fukushima Detachment had passed through the bridge eastward, [and] issued the following order: ${ }^{(59)}$ [Editor's note: The Pamarayan "bridge" also functioned as a flood-control dam. The Japanese had caught the Dutch East Indies Army unit while it was setting the demolition charges.]

\section{2d Division Order}

Petir, 1200, 3 March

1. This afternoon, the main force of the Fukushima Detachment shall leave Pamarayan and [start] its advance.

2. The divisional reserve unit shall have its main force advance to Pamarayan within today and keep guard mainly against the direction of Parigi. It shall have one element accompany the divisional command post as before.

3. I am at the present location and shall advance to Rangkasbitung via Pamarayan tomorrow, the 4th.

2d Division Commander Maruyama Masao

[Sixteenth] Army Chief of Staff Major General Okazaki had left the 2d Division headquarters in Petir before this divisional order was passed down and was inspecting Kragilan. The situation of the swollen river, the destroyed bridge, the preparations for bridging, the present attempts to use various materials to cross the river, etc., was entirely deplorable. Seeing that the slow performance of the unit in this area did not fit what the situation required, Chief of Staff Okazaki encouraged the Satō Detachment. Then, he hurried back to the [Sixteenth] Army command post in Serang, reported [the situation] to Army Commander Imamura and offered his opinion. ${ }^{(36)}$

[As a result,] a [Sixteenth] Army order was issued to the effect that "the [Sixteenth] Army Ordnance Department Director Maj. Gen. Yamada Hisamatsu shall immediately bridge the river in Kragilan by taking unified command of the engineer units and other units assigned [to the task]."(36) 


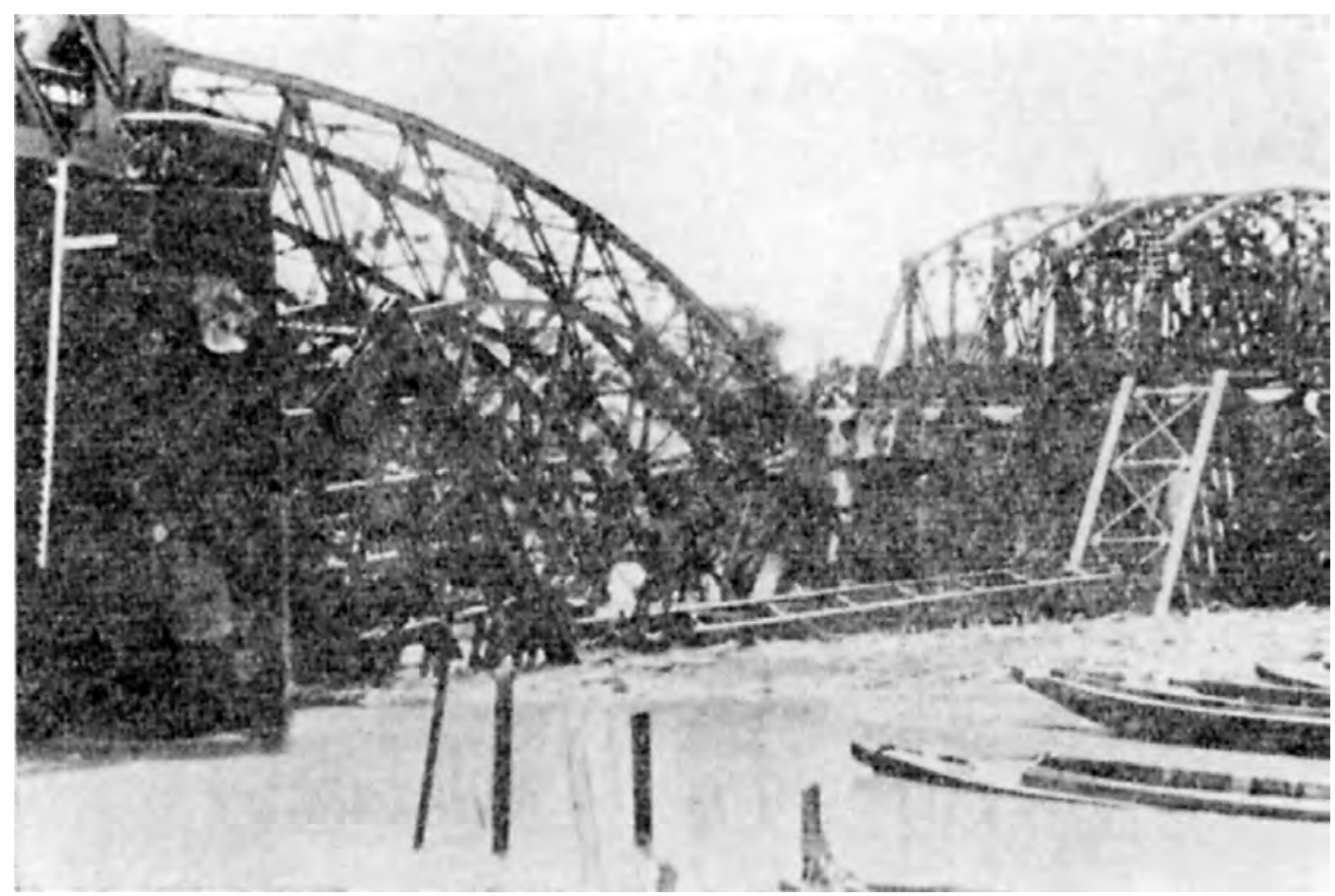

The Destroyed Bridge at Kragilan

[Another Sixteenth] Army order was passed down to the 2d Division to the effect that "it shall speed up as much as possible the operations in the sectors of the Nasu and the Fukushima Detachment." (36) One motor transport company was added to the 2d Division. ${ }^{(34)}$

At 1200 on the 3d, Lieutenant Colonel Saiki, [chief] signal communication staff of the [Sixteenth] Army, left Ragas along with the main force of the army signal unit. As the bridge three kilometers north of Bojonegara had not yet been repaired, they made a detour along the north coast of the peninsula and arrived at the [Sixteenth] Army command post in Serang via Merak at 1500. The strength brought there was one wire company and two wireless platoons. ${ }^{(34)}$ [However,] also on that day, telegrams from the Shōji Detachment, the 48th Division, etc. could not yet be submitted [to the army headquarters] through the [Sixteenth] Army signal unit. (36)

\section{The situation of the $2 \mathrm{~d}$ Division on the $3 \mathrm{~d}$ [of March]}

On the early morning of the $3 \mathrm{~d}$, the Noguchi Echelon of the Nasu Detachment ([consisting of] the $2 \mathrm{~d}$ Reconnaissance Regiment as the core, led by regimental commander Lt. Col. Noguchi Kin'ichi) left the area of Lawangtaji and Bunar where it was encamped the night before. The advance company advanced into Leuwiliang at 1330 and went into battle with the units of the Australian Army positioned on the east bank of the city. Echelon Commander Noguchi caught up with [the company] at 1400 and decided to make a night raid that night. ${ }^{(64,65)}$

The Hiroyasu Echelon of the Nasu Detachment was encamped near Bedeng Cisalak the night before. At 0840 on the $3 \mathrm{~d}$, the echelon left Bedeng Cisalak, transported in motor vehicles in the order of the 1st echelon ([consisting of] the Morozumi 3d Battalion as the core), the $2 \mathrm{~d}$ echelon (the regimental headquarters and artillery units) and the $3 \mathrm{~d}$ echelon ([consisting of] 
the Onoguchi 2d Battalion as the core). Both battalions had the support of one company of the 39th Independent Motor Transport Battalion each. It was decided that upon arrival of its advance company at Leuwiliang around 1630, the echelon should join in the battle there. ${ }^{(61,62,64)}$

The Fukushima Detachment, which had assembled near Pamarayan in the middle of the previous night, came under attack from allied planes three times before and after daybreak on the $3 \mathrm{~d}$, but it sustained no losses. It left Pamarayan at 1200 and advanced toward Maja via Rangkasbitung by motor vehicle and bicycle. Its advance party, under the command of 5th Company Commander 1st Lt. Onodera Yoshimi, rushed toward the bridge east of Maja early in the morning and reached Maja at 1600, where it reconnoitered the enemy's movements as well as the terrain. The allied units had already retreated after destroying the bridge over the Cidurian River. In addition, anything like a road was hardly seen on the right bank of the river. ${ }^{(58)}$

The raiding unit of the Satō Detachment (the 3d Battalion under the command of the Battalion Commander Maj. Yoshii Tadao) left Kragilan in the early morning of the $3 \mathrm{~d}$, seized the Parigi bridge at 0930, and then advanced into Balaraja at 1530, but the bridge there had already been destroyed. The main force of the Satō Detachment advanced, crossing the Ciujung River at $1100 .{ }^{(63)}$

The divisional reserve unit left Serang at 1800 on that day and arrived in Petir at 2200. Further, one company of the unit reached Pamarayan at 2300 and took over the defense of the bridge there from the Fukushima Detachment. ${ }^{(59)}$

The $2 \mathrm{~d}$ Division commander was still in Petir. On learning that there were no eastward roads from Maja, the division commander gave an order to the Fukushima Detachment to shift its position to the rear of the Nasu Detachment. The [Fukushima] Detachment made preparations for the shift all through the night. ${ }^{(55,58)}$

\section{The Worries of the [Sixteenth] Army Headquarters}

(See Illustrations No. 51, No. 52 and No.53)

The [Sixteenth] Army headquarters greeted the morning of day four after the landing (4 March) in Serang. ${ }^{(36)}$

In the sector of the Nasu Detachment, the advance company of the reconnaissance regiment had reached Leuwiliang in the early afternoon of the previous day where its light-armored car was pierced by enemy fire; the main force of the reconnaissance regiment had caught up, but the enemy was an Australian Army [unit], which had several guns and was entrenched in pillboxes; the Hiroyasu Regiment had also caught up and they had decided to conduct a night attack together with the reconnaissance regiment; their current situation, however, was unknown; the Fukushima Detachment had been shifted to the rear of the Nasu Detachment because there were no [eastward] roads [from where they were]; in the sector of the Satō Detachment, the Kragilan bridge had not been (re)built yet, and [what was more,] it turned out that the Balaraja bridge was also destroyed.

Although it was the fourth day after the landing, no telegrams from the Shōji Detachment, the Sakaguchi Detachment and the 48th Division had been submitted to the [Sixteenth] Army headquarters through the army signal unit. ${ }^{(35,36)}$ [The unit] was short of radio sets and code books. It still had a pile of telegrams to be radioed; as much as eighty telegrams which should have been sent to the Southern Army had remained unsent at the army headquarters in 
Ragas. ${ }^{(34)}$ Staff Officer Saiki arranged that they would be transmitted through the ship signal system (by way of the Ayatosan-maru and the Shipping Transport Command in Saigon). ${ }^{(34)}$ Such was the situation with the telegrams to the Southern Army, even though they had been given priority to other [telegrams] at Ragas as well as at Serang. The situation of the wire communications was also [bad]: It was not until that day, the 4th, that telephone connections were [finally] established between the [army] command post in Serang and the 2d Division headquarters in Rangkasbitung and between the [army] command post in Serang and the Serang airfield. ${ }^{(34)}$

As we have seen, in contrast to the views of the Southern Army [which gave priority to Bandung], the Sixteenth Army attached greater importance to Batavia and was also on the alert for an offensive of the allied forces in the area west of Batavia. At the same time, it had reached the conclusion that the allied forces were planning to hold out in the area to the west of Batavia up to the west coast [of Java] and in the meantime destroy the Shōji Detachment. As a matter of fact, the current situation was as mentioned above. Imagining the difficulties of the Shōji Detachment, which had charged [both] to Kalijati and Krawang [only] with the strength of two battalions, the army headquarters was deeply concerned. Putting it ahead of all other telegrams, the army commander [Imamura] sent the following telegram to the Southern Army: ${ }^{(23)}$

\section{Sixteenth Army Field Telegram No. 128 (4 March)}

Considering the military situation in the sector of the Shōji Detachment, the [Sixteenth] Army intends to further secure its strategic superiority by reinforcing the strength in this sector. For this purpose, it requests, based on the prearranged plan, your approval to employ about thirty transport aircraft for sending in one element of the 38th Division ([consisting of] about two infantry companies as the core) to the Kalijati airfield from Palembang by air. [Sixteenth Army] Staff Officer Itoda in Palembang has communicated the details to the person in charge [at the Southern Army].

What [Commander Imamura] really meant was that he wanted two companies to be brought by air from Palembang to the relief of the Shōji Detachment, but since he could not help toning it down, he sent the telegram as phrased above. At that time, [the army headquarters] had lost contact with Staff Officer Itoda who had landed in Palembang ahead [of the Java landings] together with the [paratroop] raiding unit. It caused the army headquarters a great deal of worry that the whereabouts of its [chief] aviation staff were unknown precisely at a time when his active involvement was most counted on. The fact was that after his bellylanding in Palembang, Lieutenant Colonel Itoda had dealt with the issue over the employment of the paratroop unit in Cilacap, discovered the Tanjungkarang airfield, directed its preparation, and made efforts so that the army reconnaissance planes could be deployed there (all of which has been described earlier). Then, he had flown to Kalijati to direct the air support for the Shōji Detachment. The [Sixteenth] Army headquarters knew nothing about it, because its radio communications were in the previously described state. Consequently, the army headquarters also did not know that the issue of the employment of the paratroop unit in Cilacap had changed in the already described way.

When the army headquarters sent the previously mentioned telegram and was impatiently waiting for the reply from the Southern Army, the entire staff at the headquarters was 
surprised to see Staff Officer [Itoda] come to the headquarters out of nowhere. He reported: "I have returned via the Kalijati and the Serang airfields; the Shōji Detachment headquarters is positioned in Subang and the Wakamatsu Battalion in Kalijati; the Egashira Battalion is said to be heading for Krawang; the Endō Air Division has advanced to the Kalijati [airfield] since the 2d; the Shōji Detachment is under concentrated attacks from the enemy from all directions; yesterday, the $3 \mathrm{~d}$, twenty-five enemy tanks and one hundred motor vehicle came for an attack on Subang; at 0730, twenty enemy armored vehicles came for an assault on Kalijati, and a large column of an enemy mechanized unit followed from Purwakarta in the afternoon; the Wakamatsu Battalion fought back with the support of the Endo Air Division and seized Purwakarta this morning; fortunately, the detachment headquarters in Subang also drove off the enemy after a hard fight; Detachment Commander Shōji said, 'I do not think that the 2d Division can be expected to come soon; I hear that there are 30,000 enemy [troops] in Bandung; if I stay in level country in such a situation, I will be defeated, and I am planning to cling to a corner in the mountains north of Bandung.'"

Just then, a report came from the $2 \mathrm{~d}$ Division, which said: "The Hiroyasu 16th Infantry Regiment and the Noguchi 2d Reconnaissance Regiment made a night raid on the [enemy] position in Leuwiliang before daybreak on the 4th, and Regimental Commander Hiroyasu is currently missing." (64)

The atmosphere of the army headquarters became graver than ever. At that moment, information came in that "the enemy in the Batavia and the Buitenzorg [Bogor] area are retreating." (31) It was known that there were zones with pillbox positions near Leuwiliang, Tangerang, Buitenzorg and Batavia. The [Sixteenth] Army headquarters drew the conclusion that "the enemy plans to put up a drawn-out struggle along the line connecting Tangerang and Leuwiliang, and the line connecting Batavia and Buitenzorg, and that during that period it will divert forces which can be extracted from Buitenzorg and Batavia for the time being to the front of the Shōji Detachment and try to defeat the units of the detachment one by one."(36)

The army headquarters anxiously waited for the reply from the Southern Army with deepening concerns. In the afternoon, the following reply came at last: ${ }^{(23)}$

\section{To: Chief of Staff, Sixteenth Army}

\section{From: Chief of Staff, Southern Army,}

sent on 4 March

Replying to Sixteenth Army Field Telegram No. 128.

The [paratroop] raiding air unit has already returned to Phnom Penh (note by the author: French Indochina). Moreover, taking the present considerable loss and damage of equipment of the transport air unit and the requirements for the execution of subsequent air operations into account, I would like you to understand that unfortunately I won't be able to fulfill your wishes.

When the Southern Army read Field Telegram No. 128, it did not understand what the Sixteenth Army really meant and read it as "the war is going so well that it is intending to expand the advantageous military situation." (23) Moreover, as told above, because the subsequent deployment of the [paratroop] raiding unit had already been decided, meaning that it should not press additional operations on the transport unit due to the necessity of maintenance, the Southern Army thought that it should by all means avoid a spur-of-the-moment operation that had not been in the plans. ${ }^{(23)}$ 
Receiving this reply from the Southern Army, the Sixteenth Army realized that it had no choice but to have the $2 \mathrm{~d}$ Division break through Leuwiliang and rush [to the help of the Shōji Detachment]. ${ }^{(36)}$ At that time, the $2 \mathrm{~d}$ Division deployed five battalions of infantry (two Hiroyasu battalions, two Fukushima battalions and one reserve battalion) on the Leuwiliang front, three battalions along the Tangerang - Batavia road, and one battalion as the army reserve.

The Sixteenth Army decided to rouse the $2 \mathrm{~d}$ Division to action, have it focus all out on Leuwiliang, and charge toward Bandung through Buitenzorg.

In order to rouse the $2 \mathrm{~d}$ Division to action, [the Sixteenth Army] pointed out the following concerning the situation of both sides: ${ }^{(59)}$

The enemy in the areas of Batavia and Buitenzorg are retreating one after another into the Bandung stronghold.

The Shōji Detachment has seized Purwakarta at 0700 today, the 4th.

It was decided that the $2 \mathrm{~d}$ Division should divert one battalion from the Satō Detachment to the sector of the Nasu Detachment, which meant increasing the battalions in the Leuwiliang sector to six, and reducing those along the coastal road to two (one battalion was the army reserve). It was [also] decided to divert the $2 \mathrm{~d}$ Tank Regiment.

The order and the operational directions, which the Sixteenth Army gave at this time, caused unexpected misunderstandings and errors between the Sixteenth Army and the 2d Division afterwards, but these will be described later.

How the 2d Division interpreted the [Sixteenth] Army order and disposed its units can be seen in the following order: ${ }^{(59)}$

IsAmu Operation Order A, No. 60(59)

\section{2d Division Order}

Rangkasbitung, 1700, 4 March

1. The enemy in the Batavia and the Buitenzorg area are retreating one after another into the Bandung stronghold. The Shōji Detachment has seized Purwakarta at 0700 today, the 4 th.

2. The division intends to promptly seize Buitenzorg to cut off the escape route of the enemy.

3. The Satō Detachment shall attack the enemy it is facing and advance into the area south of Batavia as soon as possible.

4. I shall advance first toward Leuwiliang tomorrow, the 5th.

2d Division Commander

Maruyama Masao

RYŪSA Operation Order No. 30(59)

\section{3d Battalion Order}

Wirana, 2200, 4 March

1. [As] the enemy in the Batavia and the Buitenzorg area are retreating one after another into the Bandung stronghold, the division plans to promptly seize Buitenzorg to cut off the escape route of the enemy. The Nasu Detachment (to which the Fukushima Detachment and the 2d Battalion of the 29th Infantry Regiment have newly been attached) is expected to advance to Buitenzorg, cut off the escape route of the enemy, and immediately follow them in hot pursuit toward Bandung. The Shōji Detachment has seized Purwakarta at 0700 today, on the 4th.

2. The battalion plans to defend Pamarayan with one element, while advancing its main force to Rangkasbitung and then assemble in or near Leuwiliang. For this purpose, [the battalion] shall 
come under the direction of Detachment Commander Fukushima concerning the advance from Rangkasbitung to Leuwiliang. (The rest omitted by the author.)

Note: RYưsA indicates the Sasaki Battalion of the Sendai Regiment. It is an order of the $3 \mathrm{~d}$ Battalion of the 4 th Infantry Regiment (the divisional reserve unit at that time).

Wirana is located four kilometers south of Pamarayan.

\section{The Battle of Leuwiliang (See Illustrations No. 51 and No. 52)}

The battle in Leuwiliang had begun in the early afternoon of the previous day (the 3d).

At 1330 on the $3 d$, the advance company of the Noguchi Echelon

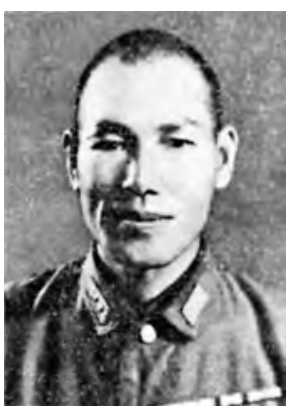

2d Reconnaissance Regiment Commander, Lt. Col. Noguchi Kin'ichi ([consisting of] the $2 \mathrm{~d}$ Reconnaissance Regiment as the core) of the Nasu Detachment came to the bridge in Leuwiliang. However, the bridge had been destroyed. All of a sudden, [the company] came under concentrated fire from [enemy] antitank rifles and machine guns from the opposite bank, which destroyed the light-armored car at the head of the company. ${ }^{(54,65)}$

The echelon commander (2d Reconnaissance Regiment Commander Lt. Col. Noguchi Kin'ichi), who had caught up with the advance company responding to the [enemy] fire, decided to cross the Cianten River with his main force on the night of the $3 \mathrm{~d}$ and conduct a night attack on [the enemy position(s) on] Mt. Galuga from the left rear of the enemy positions, while containing the enemy at the front with one element. He gave the order at Leuwiliang at 1400 , and deployed his units roughly as follows: ${ }^{(64,65)}$

1. From the right, the $2 \mathrm{~d}$ Company (to which one element of engineers shall be assigned) and the 1st Company (minus one platoon; one element of engineers shall also be assigned to it) shall form the front line. Each of them shall cross the Cianten River in or near Bantarkaret, about three kilometers upstream from the bridge, and advance to Cibungbulang and vicinity (note by the author: location unclear, presumably near Cibatok). [Editor's note: Probably Cibungbulang.] After that, the $2 \mathrm{~d}$ Company shall conduct a surprise attack on the enemy position(s) on Mt. Galuga from the area on the north side of the main road, and the 1st Company on the enemy positions at the east end of the bridge from the area along the main road. They shall depart at 1900 , cross the river at 2200, and charge at 2400 .

2. The engineer company shall start repairing the bridge when the night raids are successfully carried out.

3. The battery shall fire at the enemy from the front during the daytime so as to contain them [there].

4. The independent antitank gun company shall fire at the enemy from the front so as to contain them [there].

5. The $3 \mathrm{~d}$ and the 4 th Companies shall be positioned at the present location as reserve units.

The enemy [the echelon was facing] was an Australian Army unit. It was known that that it had blown up the Leuwiliang bridge and reinforced the zone of existing pillboxes on the right bank [of the river] with field positions, and that it had two guns. ${ }^{(64,65)}$

At 1730, the battery ([consisting of] the $3 \mathrm{~d}$ Battery of the $2 \mathrm{~d}$ Field Artillery Regiment (minus one section), led by Commander 1st Lt. Watanabe Kōichi), opened fire at the lookout post at the top of Mt. Galuga with all its firepower (two guns) and then fired at the pill- 
boxes. ${ }^{(65)}$

In the meantime, the advance company of the Hiroyasu Echelon ([consisting of] the $2 \mathrm{~d}$ and the $3 \mathrm{~d}$ Battalions of the 16th Infantry Regiment led by Regimental Commander Col. Hiroyasu Jurō) had reached Leuwiliang around 1630. ${ }^{(64)}$

Echelon Commander Hiroyasu and Detachment Commander Nasu [also] arrived in Leuwiliang one after another.

Echelon Commander Noguchi reported the enemy's movements, the terrain, his plan, the current situation, etc. to Detachment Commander Nasu. Staff Officer Maj. Satō Hidehiko of the 2d Division was [also] present. He had accompanied the advance party (the advance company) of the Noguchi Echelon from the time of its landing in order to collect in-

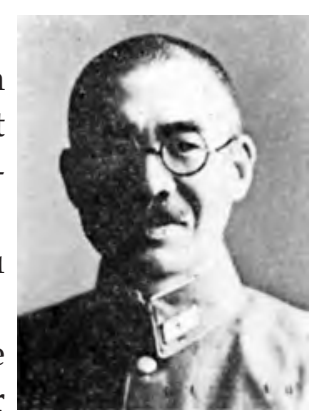

2d Infantry Group Commander, Maj. Gen. Nasu Yumio formation. Recently he had advanced [along with the company] in the light-armored car that had been hit in front of the [enemy] position, but he had safely gotten out of the car and retreated. After that, he had been together with Echelon Commander Noguchi. ${ }^{(54)}$

Then, the selection of the unit to conduct the night raid became an issue. A night raid was the specialty of the infantry, and that meant here the 16th [Infantry] Regiment, i.e. the Hiroyasu Echelon, which prided itself on its tradition [established at] Gongchangling [in the RussoJapanese War]. However, it had just arrived and did not have enough time to make preparations. Major General Nasu asked Staff Officer Satō's views. Staff Officer Satō, who trusted Lieutenant Colonel Noguchi's ability to find opportunities and get things done, said, "I judge the enemy positions at the front to be forward positions. I think that we should not give time to the enemy." In brief, Staff Officer Sato thought that the Noguchi Echelon should do it as planned. However, Major General Nasu, who was the commander of the $2 \mathrm{~d}$ Infantry Group as well as of the detachment, decided to employ the 16th Infantry Regiment [instead]. His decision was also based on the fact that he made allowances for the hardship of the Noguchi Echelon, which had been in the forefront all the time since the landing, and because he saw that the Hiroyasu Echelon was impatiently waiting to display its ability. ${ }^{(54)}$

Around 1800, Detachment Commander Nasu passed down his orders. He ordered the Noguchi Echelon to "stop the preparations for the night raid; just continue the gunfire to contain the enemy and make preparations for the subsequent operations," whereas he ordered the Hiroyasu Echelon to "attack the enemy in front with one element from the left rear [of the enemy positions] at dusk." $(63,64)$

Based on the detachment order, Echelon Commander Hiroyasu decided to cross the Cianten River at an area south of Leuwiliang with his main force and then attack the enemy in front of him with one element. He ordered the $3 \mathrm{~d}$ Battalion to

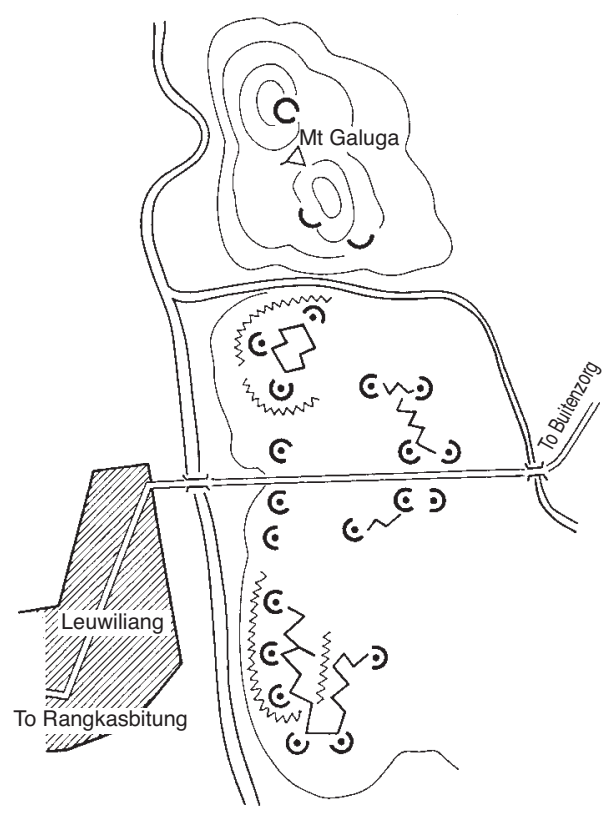

Illustration No. 51 - The [Enemy] Positions at the Leuwiliang Front 
cross the Cianten River at a point about three kilometers south of Leuwiliang, seize the enemy positions on the plateau east of Leuwiliang that night and advance to Cibatok and vicinity. He [also] ordered the regimental gun and antitank gun companies to follow the $3 \mathrm{~d}$ Battalion and seize the positions on the plateau on the right bank of the Cianten River to support the attack of the $3 \mathrm{~d}$ Battalion. He [further] ordered the $2 \mathrm{~d}$ Battalion to follow them as the reserve unit. ${ }^{(62,64,65)}$

At that time, the advance company of the $3 \mathrm{~d}$ Battalion had already moved forward to the right flank of the Noguchi Echelon and was attacking the allied positions in front of them. Based on the regimental order, $3 \mathrm{~d}$ Battalion Commander Maj. Morozumi Yoshikazu sent the advance guard to the crossing point and vicinity and had them reconnoiter the enemy movements and the terrain and, at the same time, he himself left Leuwiliang at 1900 along with the regimental commander to reconnoiter the crossing point about three kilometers south of Leuwiliang after which he returned to Leuwiliang at 2200.

The battalion left Leuwiliang at 0000 on the 4th and reached the crossing point about three kilometers south of the town. The Cianten River was swollen because of the squall the previous evening. It was about thirty meters wide and about 130 centimeters deep but flowed fast, due to which it took an unexpectedly long time to cross. ${ }^{(62)}$

At 0530 on the 4 th, two companies had for the most part finished crossing the river. At the crossing point, the battalion commander learned that an allied unit, the strength of which was unknown but considered not to be large, had occupied positions in Bojongneros and vicinity, which was about 1500 meters east of the Cianten River, and that the neighborhood consisted of easily passable paddy fields all around. So he had the 9th Company (Commander: Capt. Itō Kesatake) and the 11th Company (Commander: 1st Lt. Shigeno Masami) charge forward to seize the said positions, respectively as the first line attack unit and the second line attack unit. (See Illustration No. 52.) Battalion Commander Morozumi and Regimental Commander Hiroyasu were advancing at the head of the 11th Company, and no sooner had the 9th Company driven away an allied unit, apparently a lookout unit, which had fired at the company by surprise, and charged in column along a road of about four meters wide [toward the enemy position], than the regimental commander followed immediately in its rear. All of a sudden, the 9th company and the regimental commander came under rapid fire from the whole front of the plateau ahead of them, which completely pinned them down and made them unable to move. Commander Captain Itō of the 9th Company and others were killed, while the regimental commander and others were injured. Battalion Commander Morozumi [increased the strength by] adding the

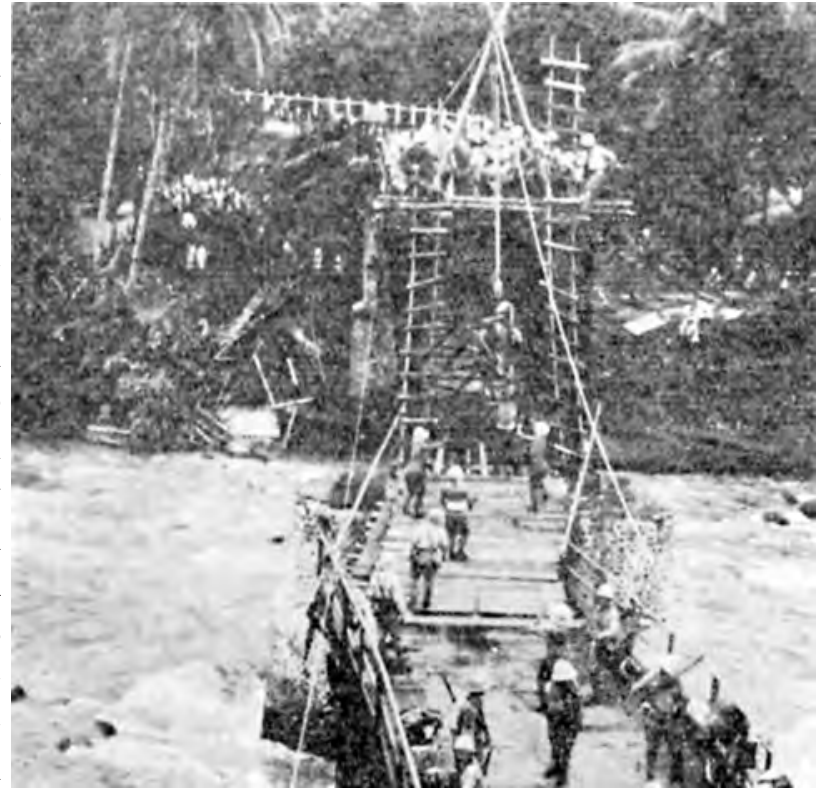

Bridging Work at Leuwiliang in the $2 d$ Division Sector 
11th Company, the second line attack unit, to the left of the 9th Company, but they could not beat off the enemy. He [also] had the 10th Company (Commander: 1st Lt. Nakayama Yoshio), which had caught up around 0800, attack and advance so as to envelop the right flank of the enemy in the position ahead, but they could not drive back the enemy yet. Around 1000, the main force of the 3d Machine Gun Company (Commander: 1st Lt. Kameoka Takao) caught up with them and joined the firing line. ${ }^{(62)}$

The artillery unit of the Nasu Detachment consisted of the 1st Battalion of the 2d Field Artillery Regiment (minus the 1st Battery) with Maj. Suwabe Jirō as battalion commander. The $3 \mathrm{~d}$ Battery (minus one section) (Commander: 1st Lt. Watanabe Kōichi) was assigned to the Noguchi Ech-

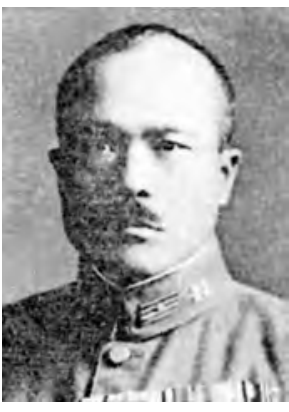
Commander of the $3 \mathrm{~d}$ Battalion of the 16th Infantry Regiment, Maj. Morozumi Yoshikazu elon, and the rest of the main force to the Hiroyasu Echelon. Both of them occupied positions to the west of Leuwiliang. Battalion Commander Suwabe had separated from Echelon Commander Hiroyasu at 2330 on the $3 \mathrm{~d}$ and from the morning of the 4th onwards tried to keep contact with him, while firing only at Mt. Galuga so as not to harm the Hiroyasu Unit. At 0920 the liaison officer assigned [to the Hiroyasu Unit] reported: "[I] tried to catch up with the echelon commander along with the colors and Captain Yamada but lost sight of him. [I] asked the noncommissioned officer who had accompanied the echelon commander, but he did not know. [We can] catch glimpses of the enemy two hundred meters ahead." At 1020, the Suwabe Battalion finally managed to locate the echelon commander's whereabouts and received his orders. At 1100, the whole artillery unit was brought under the direct command of Detachment Commander Nasu by order of the detachment. ${ }^{(64,45)}$

The 3d Battalion Gun Platoon of the Morozumi Battalion caught up around 1500. Around that time, about three hundred allied troops newly came forward so as to envelop the right flank of the Morozumi Battalion (the 9th Company). The Regimental Commander [Hiroyasu] deployed the 2d Battalion (Commander: Maj. Onoguchi Satoru), which had successively arrived, to the right of the Morozumi Battalion to have it deal with this new enemy. The Onoguchi Battalion completed its deployment in the evening. ${ }^{(62)}$

In the meantime, the Suwabe Artillery Battalion (eight guns) was firing at the [enemy] positions on Mt. Galuga and key sites in Cibatok. At 1600 an allied artillery [unit] ([with] two guns?) appeared on the east side of Mt. Galuga, which the battalion counterattacked and silenced at 1640. After that [the battalion] put its efforts into searching for the allied artillery. A report said that the allied artillery had about two guns in Ciaruten (about one kilometer northeast of Cibatok) and that, apart from these, six [guns] were being brought in as reinforcement. ${ }^{(64,65)}$

When the deployment of the Onoguchi Battalion was completed, Echelon Commander Hiroyasu gave orders around 1600, determined to seize the [enemy] positions in front in a night raid with both battalions and subsequently seize the highland of Galuga (one kilometer northeast of Leuwiliang) and Cibatok. A squall with drenching rain started around 1930. Taking advantage of it, the regiment charged [toward the enemy positions], braving the gunfire of heavy weapons, seized the position around 2100, and advanced into Cibatok and vicinity. ${ }^{(62,64,65)}$

Before that, on learning about the Hiroyasu Regiment's plan to conduct a night attack on Galuga and Cibatok, Detachment Commander Nasu decided to seize key sites on the right 
bank of the Cianten River on the night of the 5th and prepare for the next sally forward. At 2010, he issued an order to the Noguchi Echelon to promptly catch up with the unit advancing to the vicinity of the river junction to the northeast of Leuwiliang with its main force and seize the highland north of Gunung Jatake (about five kilometers northeast of Leuwiliang) by daybreak on the next day, the 5th, to facilitate the subsequent operations of the detachment. ${ }^{(64)}$

Before that, around 1800, Detachment Commander Nasu had learned that the $3 \mathrm{~d}$ Battalion of the 29th Infantry Regiment and the main force of the $2 \mathrm{~d}$ Tank Regiment had been diverted from the Sato Detachment to the sector of his detachment. [Editor's note: Correctly the $2 \mathrm{~d}$ Batalion, i.e. the Watanabe Battalion. See pp. 480, 496.] Then, he learned that the Fukushima Detachment ([consisting of] two infantry battalions as the core) and the previously mentioned Watanabe Battalion had been added to his detachment. At 0200 on the 5th, Detachment Commander Nasu issued the following order: ${ }^{(64)}$

\section{Nasu Detachment Order}

Leuwiliang, 02005 March

1. The enemy in the Batavia area has started retreating and is fleeing to the Bandung stronghold. The Hiroyasu Unit successfully conducted a night attack and seized Cibatok and the highland of Galuga (one kilometer northeast of Leuwiliang). The situation of the Noguchi Unit is still unknown. The Fukushima Detachment and the Watanabe Battalion shall newly be brought under my command.

2. The detachment shall pursue the enemy in its front, advance toward the line connecting Semplak (four kilometers northwest of Buitenzorg) - Dramaga (five kilometers northwest of Buitenzorg) to prepare for the subsequent attack on Buitenzorg.

3. The Hiroyasu Unit shall pursue [the enemy] toward Dramaga along the Leuwiliang - Cibatok (three kilometers east of Leuwiliang) - Dramaga road.

4. The Noguchi Unit shall pursue [the enemy] toward Semplak along the road from Ciampea (seven kilometers northeast of Leuwiliang) that runs on the right bank of the Cisadane [River], while having one element destroy the railway [facility] near Deanpungu [?] (five kilometers north of Buitenzorg) (note by the author: Jampungu [?]). [Editor's note: Probably Jambudipa.]

5. The Watanabe Battalion shall immediately cross the Cianten River, and advance toward Kaum (one kilometer north of Semplak) in the rear of the Noguchi Unit.

6. The Fukushima Detachment shall assemble its strength in or near its present location, and prepare for the next advance. (The rest omitted by the author.)

Staff Officer Satō of the 2d Division had accompanied the Nasu Detachment just for collecting information. However, as the strength and the responsibility of the Nasu Detachment had gained ever-greater importance in the last few days, he had been serving like a staff officer assigned to the detachment on his own initiative. Staff Officer Satō and Detachment Commander Nasu had heard that there were considerably strong positions in the Buitenzorg area. And they judged that the enemy planned to assemble its strength in the Buitenzorg area for a counterattack. After studying plans for either a pursuit or a controlled advance, the policy of a "tactical pursuit while keeping close to the line of control" was decided upon, and the previously mentioned order was passed down. Detachment Commander Nasu and Staff Officer Sato had the same view of the situation. ${ }^{(54)}$

In the battle of Leuwiliang, the loss the Hiroyasu Reigment sustained was twenty-eight men including 9th Company Commander Capt. Itō Kesatake killed, and twenty-one including Regimental Commander Hiroyasu wounded. Although wounded in the head, Regimen- 


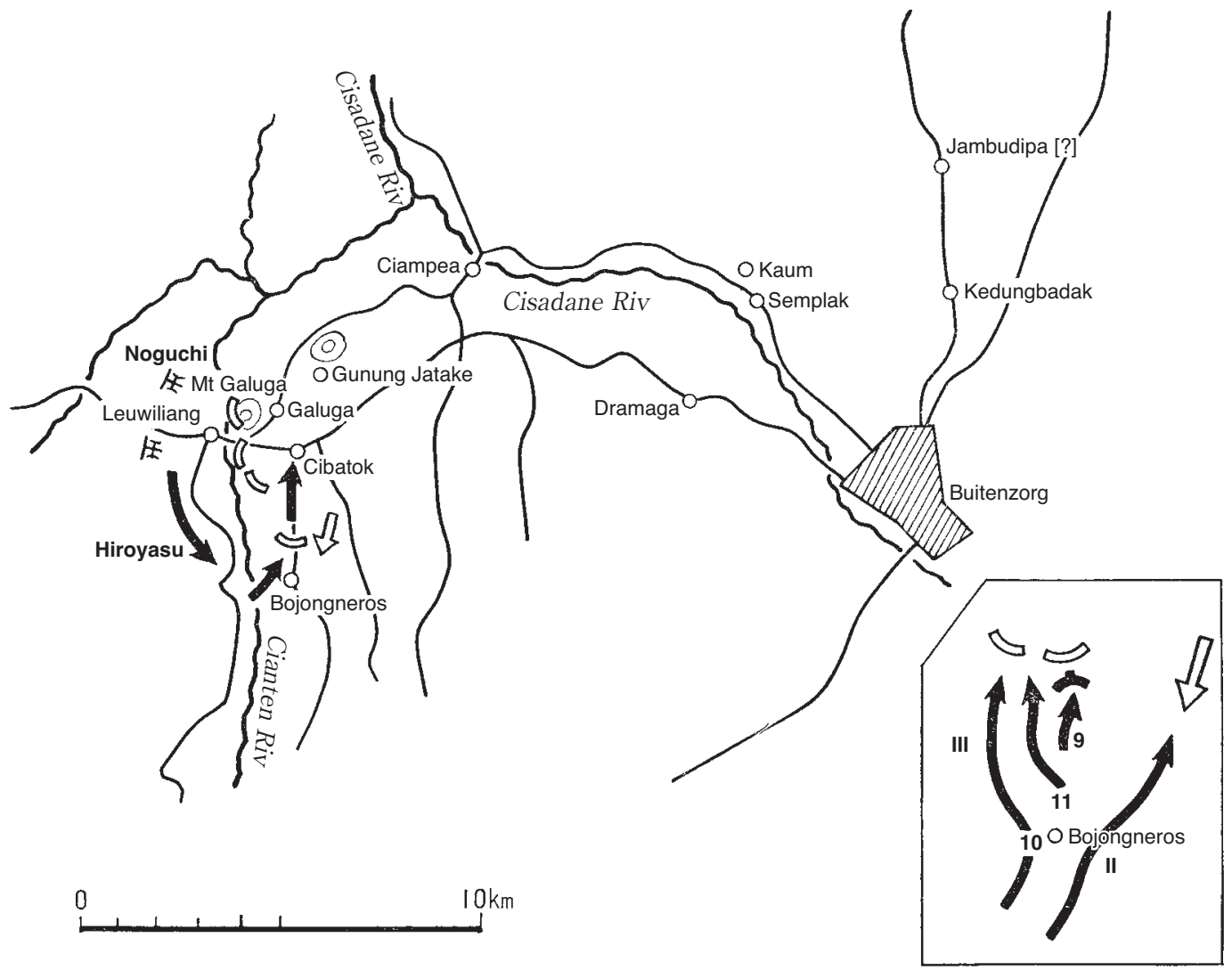

Illustration No. 52 - The Battle at Leuwiliang

tal Commander Hiroyasu continued commanding his unit. The Suwabe Artillery Battalion (eight guns) fired 379 shells. ${ }^{(62,64)}$

\section{A Favorable Turn Followed by Setbacks (See Illustrations No. 54 and No. 55)}

\section{The Situation of the Units on the 4th [of March]}

The situation of the units on the 4th was roughly as follows:

1. The [Sixteenth] Army headquarters (in Serang) had made a request to the Southern Army for an airlift [of troops], but it was not approved. Learning that the allied units in Batavia and Buitenzorg showed signs of retreating, the Army headquarters issued orders to strengthen the sector of the Nasu Detachment and have it rapidly advance in the direction of Buitenzorg and Bandung. ${ }^{(23,59)}$

2. The $2 \mathrm{~d}$ Division headquarters left Petir on the 4 th before daybreak and advanced to Rangkasbitung via Pamarayan. The previous evening the division commander had ordered the Fukushima Detachment to prepare for the shift. Then, on receiving the previously mentioned army order, he transferred (assigned) the Watanabe Battalion and the Fukushima Detachment to the Nasu Detachment, and redeployed the 2d Tank Regiment as well. ${ }^{(59)}$ 
3. The Nasu Detachment, which had not succeeded in its night attack during the previous night, continued its attack on Leuwiliang on the 4th throughout the day and night. ${ }^{(62,64,65)}$

4. The Fukushima Detachment was successively transferred by motor vehicles from the morning of the 4 th onwards. Passing through Rangkasbitung with the head of its advance party at 1400, it headed eastward and reached Jasinga at 1800 . It further continued its advance while repairing the road and assembled at a point about four kilometers west of Leuwiliang at midnight. ${ }^{(58,59,64)}$

5. The Watanabe Battalion, which was transferred from

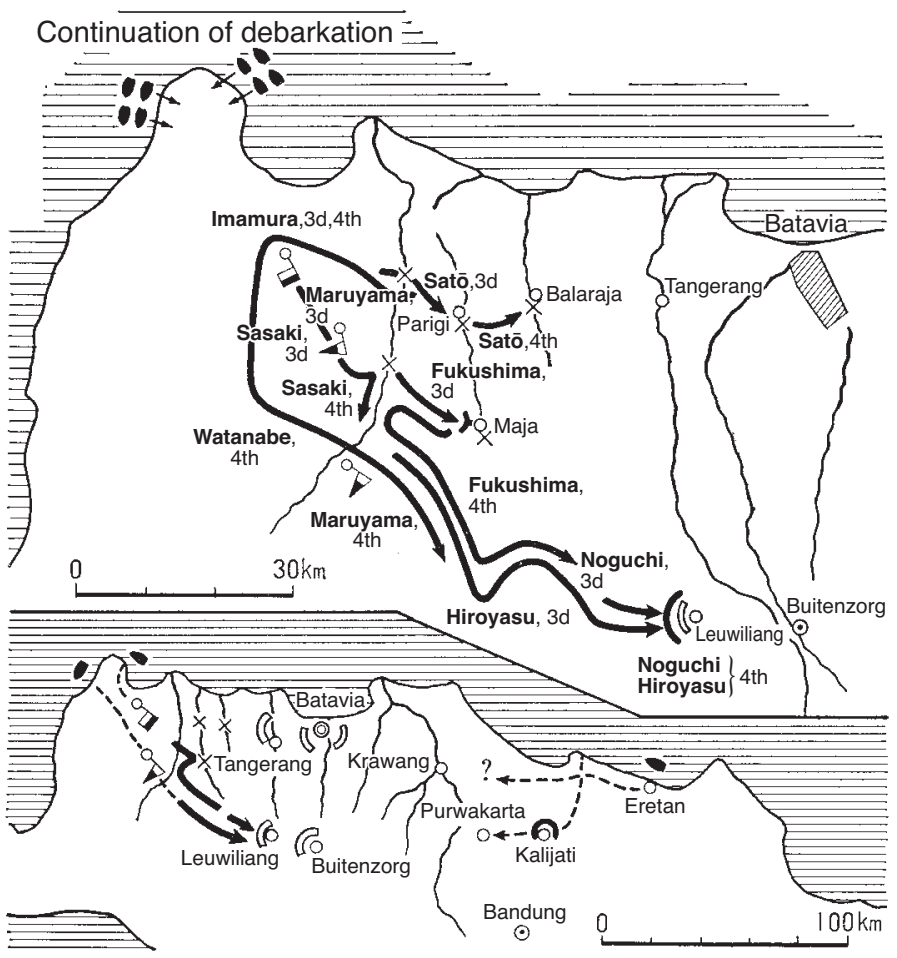

Illustration No. 53 - [The Main Force of the Sixteenth Army on] 3 and 4 March the Satō Detachment, also arrived [there] around the same time. It was decided that the Watanabe Battalion should advance first the next day, the 5th. ${ }^{(64,65)}$

6. The divisional reserve unit (the Sasaki Battalion) had left Petir at midnight of the $3 \mathrm{~d}$, reached Pamarayan at 1010 on the 4th and provided cover for the shift of the Fukushima Detachment and the Watanabe Battalion by keeping guard against the Parigi area. After that, it left Pamarayan with its main force at 2000 on the same day (the 4th), advanced toward Rangkasbitung under the direction of Detachment Commander Fukushima and arrived there at 0220 on the 5 th. ${ }^{(59)}$

7. The Satō Detachment assembled its force in Balaraja around 1700 on the 4 th and prepared for its subsequent advance. ${ }^{(63)}$

8. The disembarkation at the Merak anchorage progressed smoothly. The fourteen transport ships at the anchorage completed disembarkation on the 4th and headed back under the escort of two destroyers. The situation at the Bantam anchorage was bad and it was decided to bring the transport ships at the anchorage around to Merak for disembarkation. ${ }^{(130)}$

\section{A Favorable Turn, the Seizure of Batavia, and Again a Change of Focus by the [Sixteenth] Army (See Illustration No. 55)}

On the morning of 5 March (day five of the landing), the [Sixteenth] Army headquarters (in Serang) judged that the Nasu Detachment would seize the positions in Leuwiliang and vicinity that day, the 5th, and successively advance to the front of Buitenzorg, and that the Sato 
Detachment ([consisting of] two battalions) would run up against the [enemy] positions in Tangerang. Since before leaving the mainland [of Japan], it had been known that there were pillbox zones in the Buitenzorg, the Batavia and the Tangerang sectors. ${ }^{(36)}$ The [Sixteenth] Army headquarters could not expect much from the Sato Detachment with its reduced strength and pinned its hopes solely on the Nasu Detachment for progress in the military situation.

However, [the situation did not progress as expected:] Although Detachment Commander Nasu had issued his already-mentioned order at 0200 on the 5 th to advance toward the line connecting Semplak and Dramaga and prepare for the subsequent attack on Buitenzorg, it was not easy to reorganize [the units] after the night raid. It was not until 0930 that the Morozumi Battalion, the van of the Hiroyasu Regiment, left the east end of Cibatok. After starting its advance, it encountered an [enemy] unit with armored cars, which it attacked, and it was not until 1530 that the Morozumi Battalion advanced into Dramaga. ${ }^{(62,64)}$

While worrying about the difficulties ahead, the [Sixteenth] Army headquarters entered the night. [However,] late at night, it received a totally unexpected telegram. It was a telegram informing it that the Satō Detachment had entered Batavia. ${ }^{(34)}$

The Satō Detachment had left Balaraja at 0800 on the 5th. While it was advancing, planning to cross the river at Serpong and attack the pillbox zone in Tangerang from there, it received a report that "the enemy is retreating," and it first advanced toward Tangerang. After passing down the order at 1630 to pursue [the enemy] toward Batavia, [the detachment] rushed [toward the city] and one element of it entered Batavia at 2130. At 2230, the detachment commander triumphantly entered Batavia without casualties. ${ }^{(63)}$

A shout of joy arose at the [Sixteenth] Army headquarters. Just then, [Chief] Shipping Staff Sendō appeared, and reported that the convoy at the Merak anchorage had completed its disembarkation and left the port. [He also added] that the convoy at the Bantam anchorage would be brought around to Merak to speed up the progress of disembarkation, etc. ${ }^{(34,44)}$

The seizure of Batavia was thought to have saved the critical situation of the Shōji Detachment and the operation plan was [again] drastically changed so as to expand the military gains from the direction of Batavia and the Shōji Detachment. The [new] operation plan was decided roughly in the following way: ${ }^{(34)}$

1. The [Sixteenth] Army shall attack Bandung from the direction of the Buitenzorg - Bandung road with one element and from Kalijati with its main force.

2. For this purpose:

(1) After seizing Buitenzorg, the Nasu Detachment shall come under the direct command of the [Sixteenth] Army and attack Bandung directly from Buitenzorg. The main force of the $2 \mathrm{~d}$ Division shall shift its position to Subang. Further, the Satō Detachment of the 2d Division shall rush to Subang straight from Batavia.

(2) The main force of the 2d Division and the Shōji Detachment shall be united to attack the Bandung stronghold, directing their main attack on Bandung from Subang.

(3) The attack shall be launched on 14 March.

(4) The [Sixteenth] Army headquarters shall be positioned in Batavia and the army command post in Kalijati.

Without delay, [Sixteenth] Army [Chief] Signal Communication Staff Lieutenant Colonel Saiki unofficially gave a summary [of the plan] to the army signal unit commander and had 


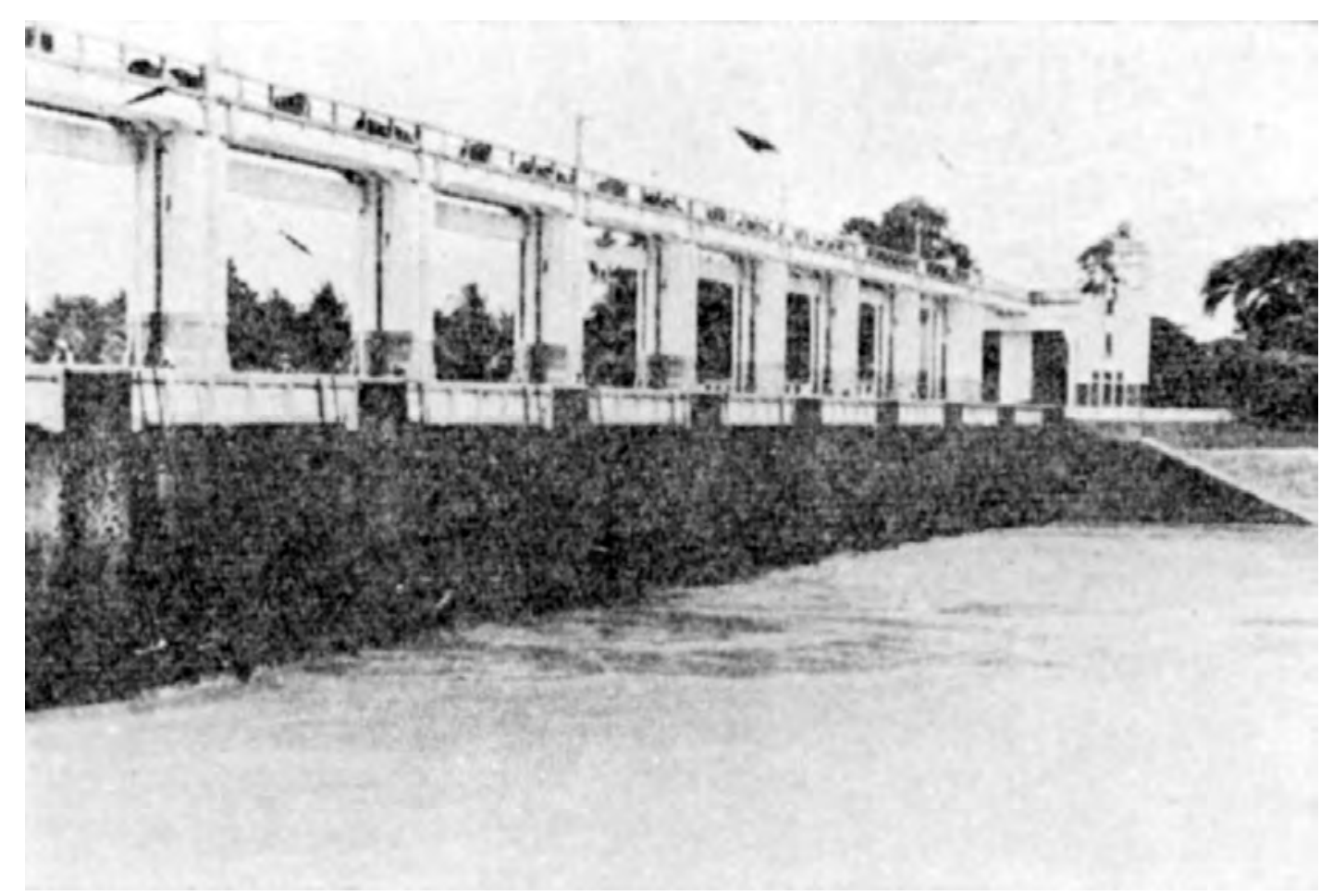

An Undestroyed Railway Bridge in Batavia [Editor's note: The photograph is actually a picture of the Cisadane Floodgates in Tangerang. It had no railroad.]

him prepare the setting up of the subsequent communication networks. ${ }^{(34)}$ The staff office was bustling with activity. ${ }^{(34)}$

\section{Again a Setback}

In the middle of the night (around 0100 on the 6th), just after Staff Officer Saiki had gone to bed, he was woken up by a messenger from Chief of Operations Oda, who passed the message: "Come right away." (34) He went there and was told: "Go immediately [to the Satō Detachment] and [pass] the instruction that the detachment must rush to Kalijati." ${ }^{(34)}$ The reason [for the sudden order] was that for the first time a telegram had been submitted from the Shōji Detachment, whose telegrams had not even once been submitted [to the army headquarters] by the army signal unit since the landing and [what is more,] that the telegram contained a description that the Shōji Detachment on its own had launched an attack on the Bandung stronghold line. [Editor's note: Actually, it was the second telegram from the Shōji Detachment. On the day of landing it had submitted a telegram through the navy. See p. 480.] The telegram is no [longer] extant, but [the attack] is [also] known from the following telegram, ${ }^{(131)}$ which was sent by [Navy] Commander Wakatsuki, staff officer of the Third Fleet seconded to the Sixteenth Army (who served at the army headquarters), at 1030 on the 6th. 


\section{From: Staff Officer Wakatsuki}

To: Kamikawa-maru; Commander, [Navy] Southern Task Force; Commander, [Navy] Carrier Task Force; Chief, 1st Bureau, Navy Department, IGHQ; and Staff Officer Ishihara [of the Second Fleet seconded to the Southern Army]

The military situation on the 5th was as follows:

1. The Satō Detachment seized Batavia at 2130 and continues to head eastward for Bandung.

2. The Shōji Detachment advanced to six kilometers northeast of ... (ten kilometers from Lembang) at 1840 and is engaging the enemy. (Note by the author: Some errors in decryption are apparent.)

3. The Sakaguchi Detachment seized Surakarta at 0500 and was scheduled to attack Magelang the same day.

4. The 48th Division reached an area ten kilometers west of Jombang at 1200. [This telegram was] sent at 1030 .

[The news] raised [a storm of] criticism: Didn't we have Major Yamashita, assistant operation staff officer of the [Sixteenth] Army [specifically] assigned to have the Shōji Detachment operate in close coordination with the main force of the army? And what is all this to engage the enemy on your own with a small force of two battalions and attack the Bandung stronghold line when the main force of the army is not ready yet? However, it was too late to do anything about it. What could be done was to have the Sato Detachment rapidly advance from Batavia and to request the Southern Army to airlift troops. ${ }^{(36,40)}$

[So,] the [Sixteenth] Army headquarters (in Serang) woke up Staff Officer Saiki to rush him off to the Satō Detachment ${ }^{(34)}$ and wired the following request to the Southern Army: ${ }^{(23)}$

\section{Sixteenth Army Field Telegram No. 166 (sent on 6 March)}

1. The tank unit of the Shōji Detachment crossed the watershed to the southwest of Ciater at 1500 on the 5th and charged into a corner of the Bandung stronghold.

2. We believe that it will be extremely significant in terms of a swift conclusion of our operations to obtain a decisive military gain at a stroke by taking advantage of this opportunity and additionally sending in a more powerful unit to reinforce [the detachment] in the area.

3. However, as it will take considerable time to divert the other force, the $2 \mathrm{~d}$ Division, due to the difficulties of the terrain in the area where it is [positioned], we earnestly hope that about one infantry battalion, which has currently assembled in Palembang, be airlifted to the Kalijati airfield.

Therefore we would like to again request your urgent consideration of the above issue.

At that time, the Sixteenth Army never even imagined that on the basis of the general situation, the Shōji Detachment would think that there was something that could be gained from its operational situation by engaging the enemy. From the report from Staff Officer Itoda, who had returned [to the headquarters] on the 4th, the army had concluded: "Detachment Commander Shojji thinks that there is no chance of an early arrival of the $2 \mathrm{~d}$ Division, that his detachment will be annihilated by concentrated attacks of the enemy if he stays in level country, and that he wants to somehow seize a corner of the mountains and use that as a base. Staking the survival or annihilation [of his detachment], he is now attacking one of the hillocks in the mountains south of Ciater." Therefore, the true feeling of the Sixteenth Army 
was to beg the Southern Army to airlift troops, but since it could not show any faintheartedness in the text, it phrased the telegram in the way above.

On receiving this telegram, the Southern Army again [wrongly] took it that the telegram was sent under a favorable military situation and wired back as follows: ${ }^{(23)}$

\section{Reply to Sixteenth Army Field Telegram No. 166}

Airlifting the unit in Palembang is considered highly disadvantageous for exercising our air power in the Java area. In addition to the situation shown in the Southern Army Staff Section 1 Telegram No. 72, the current enemy air [operations] in Kalijati and vicinity [would put us in a situation where] most of the strength of the $3 \mathrm{~d}$ Air Division would have to be allocated to the cover of the above airlift. [Therefore,] we would like you to depend on transportation by ship or [landing] craft this time.

This telegram from the Southern Army not only disappointed the Sixteenth Army by rejecting the airlift but also gave the latter the impression that [Japanese] air power had no strength to spare. The situation was [indeed] that the front of the $2 \mathrm{~d}$ Division had been provided with no air support at all.

\section{The Situation at the Satō Detachment and the Unexpected Telegram from the $2 \mathrm{~d}$ Division}

While the above telegrams were exchanged, Staff Officer Saiki and the Satō Detachment found themselves in the following situation: ${ }^{(34)}$

Staff Officer Saiki left Serang by motor vehicle (loaded with three bicycles) with two guards at 0200 (on the 6th). At 0400, they had to switch to bicycles near Pamarayan due to the bad road. They rode bicycles for about two kilometers when they happened upon three motor vehicles of the 39th Independent Motor Transort Battalion. Using one of them (also loading it with their bicycles), they reached Tangerang. At 0800, they borrowed there another bicycle (for the driver) from Col. Takahashi Takuzō, commander of the $2 \mathrm{~d}$ Engineer Regiment. The four of them, riding and pushing their bicycles, arrived in Batavia a little after 1000 and heard that the Satō Detachment, which had made an around-the-clock forced march the day before, the 5th, was taking a rest and was scheduled to leave on the morning of the next day, the 7th. Staff Officer Saiki explained the urgency of the situation, and requested the immediate dispatch of a unit even if it were small. At 1330, one platoon managed to get ready. Staff Officer Saiki was empowered to take command of the platoon and departed without delay in order to reconnoiter the crossing point over the Citarum River and promptly contact the Shōji Detachment. The bridge had been destroyed. Staff Officer Saiki ordered the platoon commander and his men, a total of ten men, to advance by bicycle and he himself returned to the Satō Detachment headquarters and told the detachment commander that "it would probably be better to send a company ahead first, even if it were just a bicycle company, and have the motor vehicle [unit] take a detour." The detachment commander answered that since the motor vehicle unit was loaded with bicycles, he would use bicycles from the destroyed point onwards. At 1800 Staff Officer Saiki left Batavia along with the detachment headquarters. The local people lining the roadside saw them off cheering and waving. At 1900, Detachment Commander Satō, in the middle of the advance, received the following order from the $2 \mathrm{~d}$ Division Commander: ${ }^{(34)}$ 
The Shōji Detachment is not in danger. The Satō Detachment shall stop its advance.

Staff Officer Saiki found the order hard to understand, but it was a strict division order. He concluded that he was compelled to follow it. The Sato Detachment stopped. Staff Officer Saiki took steps to promptly report the situation to the [Sixteenth] Army headquarters in Serang. ${ }^{(34)}$

\section{The Seizure of Buitenzorg (See Illustration No. 54)}

During the above period, the Nasu Detachment had seized Buitenzorg. As mentioned previously, the Morozumi Battalion, the van of the Hiroyasu Regiment, had advanced to Dramaga, the target of the detachment, at 1530 on the 5 th. Around the same time, one element of the Noguchi Reconnaissance Regiment drove off an allied unit on the right bank of the Cisadane River north of Ciampea. At that time, the allied units [stationed] in Batavia were retreating to Buitenzorg. ${ }^{(62)}$

After advancing to the line connecting Semplak and Dramaga, Staff Officer Satō's judgment of the situation was that "[the detachment should] engage the enemy one after another, and carry out a night attack," whereas Detachment Commander Nasu's judgment was that "[the detachment should first] search [for the enemy], reconnoiter, and conduct a night raid after the enemy's situation and the terrain had become clear." However, soon after that, Detachment Commander Nasu agreed to Staff Officer Satō's plan, considering that "it would be a blunder if the enemy had [indeed] retreated."(54)

Detachment Commander Nasu decided to have the units which were successively advancing to the line connecting Dramaga, Semplak and Kaum continue their move and take a large detour widely and deeply so as to advance separately to both rear sides of Buitenzorg. He assigned the Watanabe Battalion and the Fukushima Detachment to advance from Kaum to Kedungbadak and vicinity and then move southward from the area east of the Batavia Buitenzorg road. He assigned the Hiroyasu Regiment to charge toward Buitenzorg along the Dramaga - Cilubang - Petir - Kuripan - Pangkalandalem - Warungloa - Pasireurih - Kabandungan Udik - Buitenzorg road. ${ }^{(64,65)}$

The 10th Company (Commander, 1st Lt. Nakayama Yoshio) of the Hiroyasu Regiment, which was positioned in front of Buitenzorg and assigned to provide cover for the detour operation of the regiment while containing the allied units, noticed signs that the allied units were retreating and charged into Buitenzorg at 0200 on the 6th. ${ }^{(31)}$ At that time, the other units were taking a long night detour through unknown areas. The Morozumi Battalion of the Hiroyasu Regiment passed through Bab Gadog around 0500 and Kabandungan Udik around 0800, and advanced into Buitenzorg at 1100. ${ }^{(62)}$

The Fukushima Detachment advanced crossing the Leuwiliang bridge and reached Kaum at 2200. ${ }^{(58)}$ In the meantime, the Ikuta raiding party (i.e. the 1st Battalion) of the Fukushima Detachment had one element seize the Kedungbadak bridge in a surprise attack and reconnoiter the movements of the enemy as well as the terrain, while making preparations for a night attack. [The raiding party] departed at 0200 with its main force, and advanced along the Kaum - Kedungbadak - Buitenzorg road. As set in its orders, it charged into Buitenzorg at 0500 , mopped up [the enemy in] the city meeting with no resistance and assembled near the residence of the governor-general at $0800 .{ }^{(31,58)}$ 
On seizing Buitenzorg, Detachment Commander Nasu immediately had one infantry company hotly pursue [the enemy] in the direction of the Puncak Pass (about twenty-five kilometers southeast of Buitenzorg). ${ }^{(31)}$

\section{A Further Setback}

The situation described above can be summarized as follows: responding to the telegram from the Shōji Detachment that it was attacking the Bandung stronghold line, [which was read] around 0100 on 6 March, [the Sixteenth Army] wired the Southern Army to request an airlift [of troops]; at 0200 one element of the Hiroyasu Regiment charged into Buitenzorg while simultaneously Staff Officer Saiki left Serang for the Satō Detachment; at

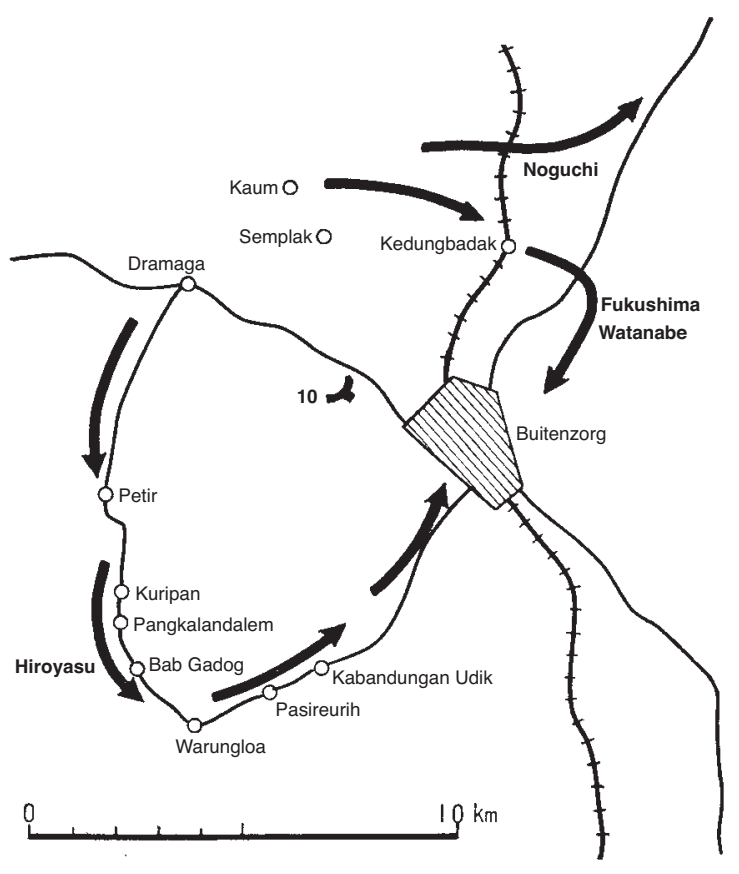
0500 the battalion at the head of the Fukushima Detachment charged into Illustration No. 54 - The Attack on Buitenzorg [Bogor] Buitenzorg, followed by the battalion at the head of the Hiroyasu Regiment, which charged [into the city] at 1100; at 1800 the Satō Detachment left Batavia, but received at 1900 an order from the $2 \mathrm{~d}$ Division to stop [its advance].

At that time, the Satō Detachment consisted of [just] two battalions, while the area between Buitenzorg and Rangkasbitung was overflowing with the strength of six infantry battalions, [one] reconnaissance regiment, [one] tank regiment, [one] field artillery regiment and others. The divisional reserve corps, the Sasaki Battalion, was to depart from Rangkasbitung the next day, the 7th, with its officers and men traveling by motor vehicle, while the horses followed on foot. ${ }^{(59)}$

As mentioned previously, [Chief] Signal Communication Staff Lieutenant Colonel Saiki, had left for Batavia after only unofficially informing the army signal unit that "the full-scale attack on Bandung will be launched on 14 March," so that it could get ready. Believing that as a first step the Satō Detachment would hurry [toward the Shōji Detachment], the [Sixteenth] Army headquarters was trying to grasp the situation of the main force of the $2 \mathrm{~d}$ Division and waiting for the reply from the Southern Army. Although the [Sixteenth] Army headquarters had decided on the policy of diverting the main force of the $2 \mathrm{~d}$ Division to the Kalijati area after seizing Buitenzorg, it had not yet shown [the plan] to the $2 \mathrm{~d}$ Division.

The $2 \mathrm{~d}$ Division had taken the already-mentioned order of the [Sixteenth] Army on 4 March, that "[as] the enemy is retreating into the Bandung stronghold one after another and the Shōji Detachment has already seized even Purwakarta at 0700 on the 4 th despite its small strength, the $2 \mathrm{~d}$ Division shall directly attack Bandung after completing the seizure of Buitenzorg," literally. That was the reason why it passed down the order: "The Shōji Detachment is not in danger. The Satō Detachment shall stop its advance." Reading this order, Staff Officer 
Saiki "had his doubts [about the order], but had [the Detachment] stop the advance, as it was a divisional order," and he took steps to report the situation [to the Sixteenth Army]. ${ }^{(34)}$

The telegram with the report of Staff Officer Saiki did not reach [the army]. [However,] a reply came from the Southern Army that rejected the request for an airlift [of troops]. Just then (on the night of the 6th), another serious telegram came from the Shōji Detachment, which roughly contained the following message:(35)

As of this morning, the 6th, the enemy tank unit that launched attacks against us from the Bandung stronghold has sustained great damage by the joint counterattacks of our ground and air forces and has retreated, leaving several tanks behind. Taking advantage of this opportunity, the detachment is going to break through the line on the top of the stronghold.

The contents were serious even if just taken at face value. It could be much more serious if [Detachment Commander Shōji had sent] this telegram in the same sentiment, hiding his nervousness, as the [Sixteenth] Army had done when it had sent the telegram requesting the airlift from the Southern Army. Army Commander [Imamura], who had known Colonel Shōji's character very well for a long time, felt that the message of this telegram was extremely serious.

Army Commander Imamura immediately decided to rapidly advance with the army reserve unit (the 1st Battalion of the 16th Infantry Regiment led by Lt. Col. Minamoto Shirō), and made the following arrangements: ${ }^{(35)}$

1. He wired Detachment Commander Shōji: "I am greatly impressed by the brave fight your detachment has fought. In view of the steep and difficult terrain in the area west of the stronghold, I have changed the prearranged attack plan and decided to add the main force of the $2 \mathrm{~d}$ Division to your detachment's front, have it reach the area by the 8 th, and on the 9th, under my command, charge into the stronghold to defeat the enemy. Therefore, your detachment shall secure the front line of the stronghold, the line on the top of the mountains, and wait for the arrival of the main force of the army. The detachment must not [try to] single-handedly break through the stronghold." (35)

2. He decided to have Chief of Staff Okazaki rush to $2 \mathrm{~d}$ Division Commander Maruyama by car after daybreak (on the morning of the 7th) to convey the message: "I have changed the prearranged attack plan and decided to conduct an attack so as to expand the military gains of the Shōji Detachment. Therefore, the 2d Division shall have one element contain the enemy from the west front, and shift two or more regiments of the main force so that they will reach the area of the Shōji Detachment by the 8th," and gave him instructions concerning it. ${ }^{(35)}$

3. He ordered the Army headquarters and the army reserve unit to depart from Serang after daybreak (on the morning of the 7 th) to advance to Batavia. ${ }^{(35)}$

\section{Report of an Offer of Surrender by the Bandung Garrison}

It was decided that Chief of Staff Okazaki would accompany the Army Commander [Imamura] up to Batavia and travel separately from there onwards.

The [Sixteenth] Army command post departed from Serang in the early morning of the 7th. Local people greeted them with cheers everywhere along the road. The pill box positions and obstacles in Tangerang looked very substantial, which made the entire staff exchange looks and wonder how [difficult the attack] would have been if the allied forces had put up 


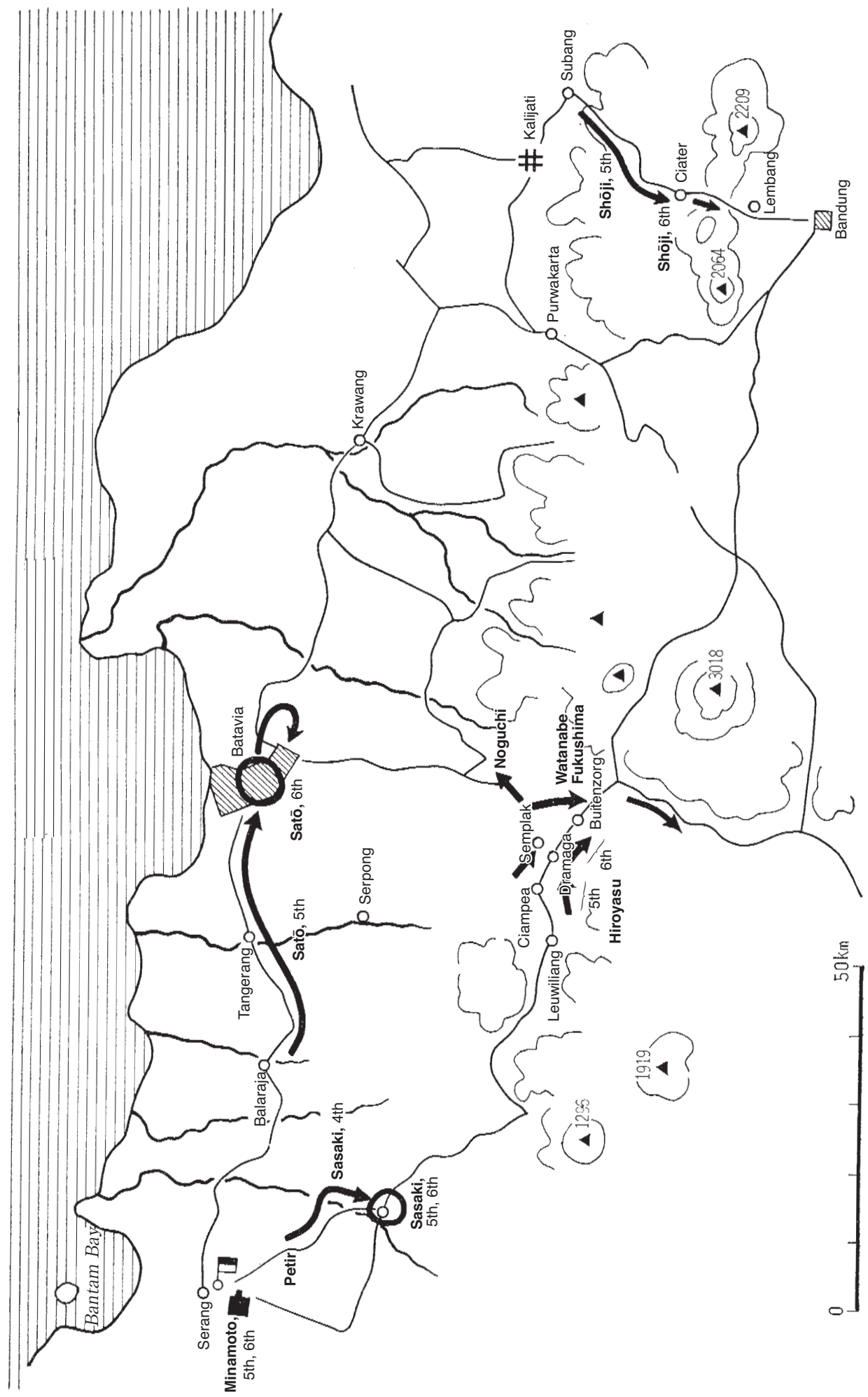

Illustration No. 55 - [The Japanese Units in western Java on] 5 and 6 March 
some real resistance. Of the bridges in Batavia, those for people and vehicles had been destroyed, but the railway bridges remained [intact]. They arrived in Batavia around $1700 .{ }^{(34,35,36)}$

Because of the already-mentioned circumstances, the Satō Detachment was still in Batavia. Army Commander Imamura called Detachment Commander Satō and gave him a direct order to depart immediately. At 2300, the report came that the Satō Detachment had departed in motor vehicles, taking a detour. ${ }^{(34,35,36)}$

Chief of Staff Okazaki arrived in Buitenzorg from Batavia together with [Chief of] Operations Lieutenant Colonel Oda. Commander Maruyama of the 2d Division had not advanced [there] yet. Chief of Staff Okazaki waited for Division Commander Maruyama's arrival in Buitenzorg and handed him the army order, summarized as follows, and explained what the army commander intended to do. ${ }^{(36)}$

\section{Sixteenth Army Order (summary)}

1. The [Sixteenth] Army shall attack Bandung from the direction of the Buitenzorg - Bandung road with one element, and from the direction of Kalijati with its main force.

2. The $2 \mathrm{~d}$ Division shall put the Nasu Detachment ([consisting of] three infantry battalions as the core) under the direct command of the [Sixteenth] Army from now on, and have the detachment continue its pursuit of the enemy in the direction of Bandung. The main force of the division shall promptly advance into Kalijati and vicinity and prepare for the attack on Bandung, to be conducted from the north.

Army Commander Imamura established the command post in the barracks of the Dutch Army in the suburbs of Batavia. Traveling by night, Chief of Staff Okazaki returned and reported the situation in Buitenzorg. After hearing the report, the army commander went to bed around 2300. ${ }^{(35,36)}$

Soon [Chief of] Operations Oda visited the army commander's bedroom and reported the arrival of a telegram that said: "An enemy staff officer has come to the Shōji Detachment with an offer that the Dutch Army Commander is ready to propose a cease-fire to the Japanese Army Commander. We would like you to give your directions about what to do." It was in the middle of the night on the 7th (a little after 0000 a.m. on the 8th). ${ }^{(35)}$

[Meanwhile,] Capt. Yanagawa Motoshige, attached to the Sixteenth Army headquarters, who had rushed along with the advance party of the Nasu Detachment since its landing in Merak before daybreak on 1 March, had gone ahead alone on a reconnaissance mission along side roads from the night of the 1st onwards and around that time had infiltrated into Bandung via Buitenzorg. ${ }^{(47)}$

\section{(3) The Operations of the Shōji Detachment}

The convoy (the Taigen-maru No. 3, the Naples-maru, the Calcutta-maru, the Glasgow-maru, the Suwa-maru, the Kōzan-maru and the Yamazuki-maru [Yamatsuki-maru], a total of seven ships) of the Shōji Detachment ([consisting of] the 1st and the 2d Battalions of the 230th Infantry Regiment as the core) separated from the convoy of the $2 \mathrm{~d}$ Division at a point about 140 nautical miles north of Batavia (Point J) at 0530 on 27 February, after which it advanced under the escort of the light cruiser Yura, the 1st Section of the 6th Destroyer Division (the Akatsuki and the Hibiki) and the $2 \mathrm{~d}$ Section of the $22 \mathrm{~d}$ Destroyer Division (the Nagatsuki and the Minazuki). The Navy was still in charge of the air cover of the Shōji Detachment. As the date [to 
launch] the landing operation was postponed by one day, [the convoy] entered the anchorage off Eretan at 0140 on 1 March. ${ }^{(96,120)}$ [Editor's note: The list of ships of the convoy agrees with the list given on p. 242, but differs from that on p. 463.]

As we have seen, the tasks assigned to the Shōji Detachment were (1) to rapidly secure the Kalijati airfield and seize the crossing point over the Citarum River, (2) depending on the situation, to be ready for having one element join [the operation to] capture Batavia, and (3) to help [the ground unit of] the air unit in readying the airfield. ${ }^{(96)}$ As mentioned previously, Sixteenth Army Staff Officer Yamashita was assigned to the Shōji Detachment, and Lt. Col. Ōno Takeo, commander of the 2d Independent Antitank Gun Battalion, was added to the detachment as well. It was also additionally equipped with motor vehicles. ${ }^{(36)}$ Although Patrol was designated as its disembarkation point, it had chosen Eretan instead, because this place was closer to the road that its motor vehicles needed to travel for the sudden attack on the [Kalijati] airfield. ${ }^{(41)}$

The fighting strength of the Shōji Detachment consisted of two infantry battalions (with four infantry companies each), a regimental infantry gun unit, one tank squadron, one independent antitank gun company, two mountain artillery batteries and one antiaircraft artillery battery. ${ }^{(73)}$

The commander of the 1st Battalion was Maj. Egashira Masaru (graduate of the $42 \mathrm{~d}$ class of the Imperial Japanese Military Academy) and the commander of the 2d Battalion was Maj. Wakamatsu Minoru (38th class). Major Wakamatsu, who was from Saga prefecture and had grown a long beard, had a reputation for holding a deep affection for his men, but training them hard and thoroughly, for being indifferent to praise or criticism, and for being a crack soldier. $^{(41,75)}$

Detachment Commander Shōji decided to have the battalion under the senior officer, Major Wakamatsu, charge toward Kalijati and the battalion under Major Egashira head for the bridge over the Citarum River; however, he removed one company and one machine gun platoon each from both battalions to organize the disembarkation point covering unit and the detachment reserve corps. ${ }^{(73)}$

Further, he decided to assign one regimental gun squad, one antitank gun platoon and one tank squadron (minus one troop) to the Wakamatsu Battalion, and one antitank gun company (minus one platoon), one tank troop and one mountain artillery battery to the Egashira Battalion. He also decided to use the motor transport company assigned to the detachment for the swift move of the Wakamatsu Unit. ${ }^{(73)}$

Ignoring the general rule for landing in the face of the enemy, he decided the order of disembarkation in such a way that tanks and trucks to be used for dashing forward to seize Kalijati would be disembarked first and then the general infantry. ${ }^{(41)}$

As we have seen, the Southern Army, the Sixteenth Army, as well as the [Army] Third Air Force had planned that the units, [consisting of] the 4th Air Ground Support headquarters and the 24th and the 28th Airfield Battalions as the core, assigned to the Sixteenth Army, should follow the front line units of the $2 \mathrm{~d}$ Division and the Shōji Detachment, and prepare the Buitenzorg, the Batavia and the Kalijati airfields, to which the units of the Third Air Force would rapidly advance when the preparations were for the most part over. In the plan, these airfield preparation units would be split between the 2d Division and the Shōji Detachment, while the 4 th Air Ground Support headquarters was to advance along with the $2 \mathrm{~d}$ Division. ${ }^{(96)}$ 
However, in view of the fact that the scheduled dates for the air units to advance into the Kalijati, the Buitenzorg, and the Batavia [airfields] were set respectively as Day $\mathrm{H}$, Day $\mathrm{H}+3$ and Day $\mathrm{H}+4$, and in view of the significance of the location and the capacity of the Kalijati [airfield], it was decided that 4th Air Ground Support Commander Lt. Col. Sugimura Takayoshi should advance along with the Shōji Detachment. ${ }^{(73,75,96)}$

Thus, the disposition after the landing was decided as follows, the details of which are as mentioned previously [see pp. 463-465]:(73,74)

Wakamatsu Raiding Unit: Major Wakamatsu and his men, [advance] to Kalijati

Egashira Raiding Unit: Major Egashira and his men, [advance] to the bridge

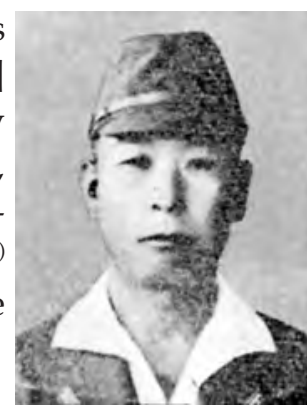

230th Infantry Regiment Commander, Col. Shōji Toshishige over the Citarum River

Artillery [unit]: [advance] to the sector of the Wakamatsu Raiding Unit

Antiaircraft Artillery [unit]: air defense of the disembarkation point

Disembarkation Working Unit: Major Watanabe of the 40th Anchorage Headquarters and others Signal Unit: First Lieutenant Suzuki, commander of the regimental signal unit, and others

Motor Transport Unit: Captain Asami and others

Ōno Unit: Lieutenant Colonel Ōno, commander of the 2d Independent Antitank Gun Battalion, and others, cover for the disembarkation point

Reserve Corps: First Lieutenant Wada, commander of the regimental infantry artillery unit, and others

Airfield Unit: 4th Air Ground Support Commander Lieutenant Colonel Sugimura, and others

Detachment Commander Shōji planned to have a report center set up in Subang after the advance of the Wakamatsu Raiding Unit, and have Staff Officer Yamashita take command [of the center]. Also, he himself planned to advance to Subang with the reserve unit when the disembarkation [operation] progressed..$^{(73,75)}$ Subang was a strategic point where the road going north from Bandung branched into two, one leading to the disembarkation area in Eretan and another to the Kalijati airfield. Although, as already told, the operation outline provided by the [Sixteenth] Army attached more importance to Batavia, Detachment Commander Shōji gave more careful consideration to Bandung.

\section{The Seizure of the Airfield on Day One of the Landing and the Enemy's Assault on the Disembarkation Point}

(See Illustration No.56)

The Shōji Detachment knew that there were about 35,000 allied troops in the Bandung stronghold area. ${ }^{(75)}$

Before entering the anchorage, [the convoy] came under attack from some allied aircraft but sustained no losses. ${ }^{(120)}$ At 0330 (on 1 March), the 1st landing unit successfully landed in Eretan meeting with no resistance, ${ }^{(120)}$ and then it acted based on the plan. Detachment Commander [Shōji] landed along with the $2 \mathrm{~d}$ landing unit at 0430 and took position at the west end of the village of Eretan. ${ }^{(75)}$

At daybreak, allied aircraft fiercely strafed and bombed [the detachment] from a very low altitude, which caused about a hundred casualties at the landing point and on the ships. 
Meanwhile, two seaplanes of the auxiliary seaplane tender San'yo-maru (at Anambas Islands) advanced around 1130 and two planes of the auxiliary seaplane tender Kamikawa-maru ([also] at Anambas Islands) at 1230 to cover the landing point. Of these planes, the two planes of the Kamikawa-maru were attacked by allied aircraft after having landed on the water at 1605; one went up in flames and the other became unable to fly. The two seaplanes of the San'yō-maru retreated to Bantam Bay in the evening. ${ }^{(130,131)}$

In order to seize the Kalijati airfield, the Ōsawa advance party ([consisting of] thirty-six men, two machine guns, one battalion gun, one antitank gun and two trucks under the command of 7th Company Commander 1st Lt. Ōsawa Shigeru) of the Wakamatsu Raiding Unit left the landing point at 0610 and rushed [toward the airfield]. At 1030, it encountered at a point one kilometer west of Subang about one hundred troops of a Dutch East Indies Army unit heading eastward, and went into battle. (A later investigation showed that this unit of the Dutch East Indies

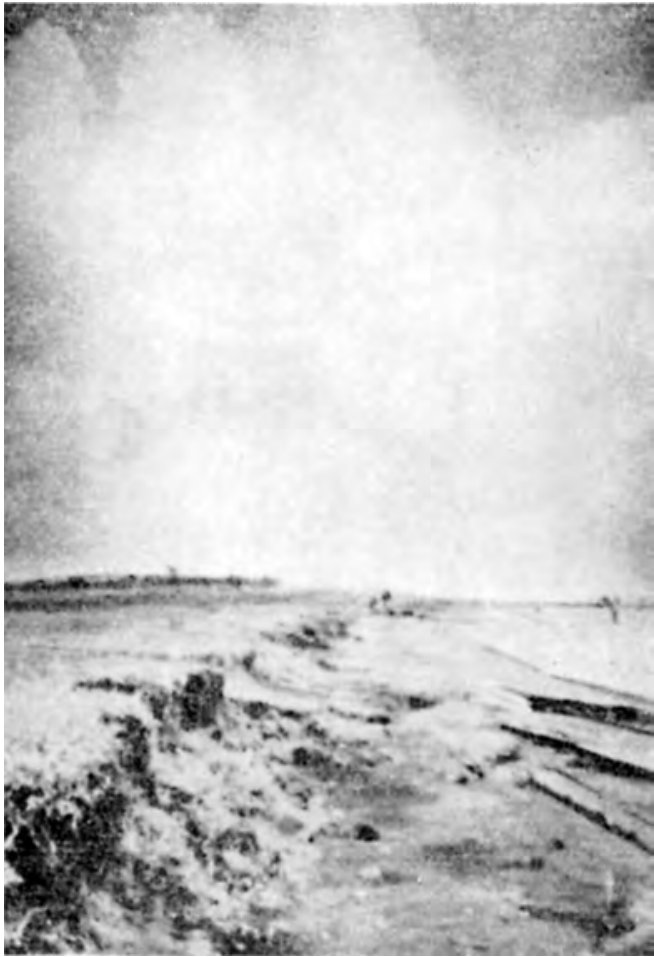

The Landing Point at Eretan Army was heading eastward to destroy the Pamanukan bridge.)

At 0800, Battalion Commander Wakamatsu left the landing point by motor vehicles, leading only the units that had finished landing by then. He caught up [with the Ôsawa advance party] at the battlefront at 1045, brought the advance party under his command as well, drove off the Dutch East Indies Army unit, and rushed straight [for Kalijati]. He ran into Dutch East Indies Army units one after another. Four times he forestalled them, drove them off each time, and [continued] his dash. At 1200, he charged into the target, the Kalijati airfield, and completely seized it at 1230 . The airfield was fit for use right away. [Commander Wakamatsu] took steps to immediately send a report, but the wireless could not get through. ${ }^{(13,31,75)}$

The Egashira Raiding Unit left the landing point at 0540, heading for the Krawang bridge as its target. One company traveled by bicycle and the others on foot. The main force of the raiding unit was strafed and bombed several times by allied fighter plane units consisting of more than a dozen aircraft and sustained forty to fifty casualties including Second Lieutenant Masuda. Since he could not advance as much as he expected, [Commander Egashira] assembled his force in Pamanukan at nightfall. ${ }^{(31,75)}$

At the landing point, 400 to 500 troops of a Dutch East Indies Army unit in armored vehicles attacked from the east around 1130. The disembarkation point covering unit ([consisting of] the 6th Company, one machine gun platoon, and one regimental gun squad), commanded by Lieutenant Colonel Ōno, drove them off after a hard fight. ${ }^{(73,75)}$

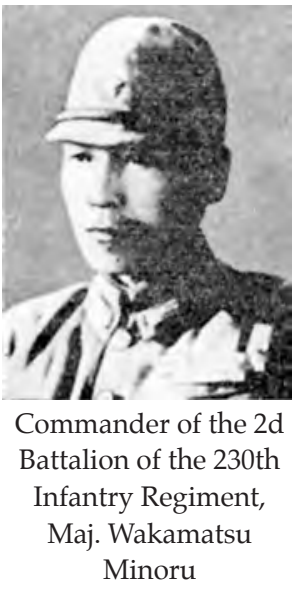


Positioned in Eretan, Detachment Commander Shōji waited for a report [on the seizure of the airfield] while giving directions concerning the disembarkation and the engagements. At 1630, a bicycle messenger sent by Staff Officer Yamashita (who had departed along with the Ōsawa advance party and set up the report center in Subang) arrived and reported the seizure of Kalijati. Commander [Shōji] immediately arranged to send the report. On that day, he could not make contact with the Wakamatsu Raiding Unit. ${ }^{(75)}$

The 2d [of March]: The Detachment Headquarters Overrun and the Advance of the Air Units [of the 3d Air Division] (See Illustration No. 57)

At 0400 on the next day, the 2d, Detachment Commander Shōji departed from Eretan by motor vehicle along with the company bearing the colors (the 4th Company) and arrived at the report center in Subang at 0500. Staff Officer Yamashita reported: "No [new] reports

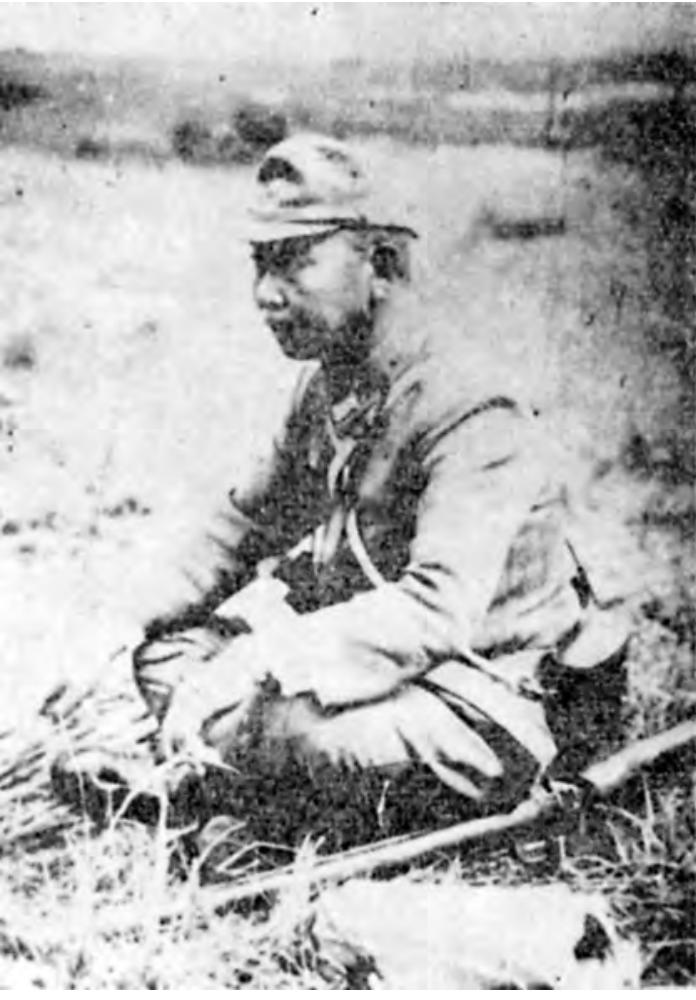

Colonel Shōji at Eretan at Noon on the First Day of Landing have come from the Wakamatsu Raiding Unit since, but I don't think we need to worry, because succeeding units have headed for Kalijati via Subang one after another." The detachment headquarters was placed in Subang. A couple of allied aircraft strafed and bombed around 0900, but fortunately there were no casualties. At 1100, the alarm came that "a mechanized enemy unit is coming in for an assault." A total of about twenty-five enemy light tanks and armored vehicles came fiercely rushing in from the road to the Bandung stronghold. The personnel positioned in Subang consisted of a total of about one hundred men including Detachment Commander [Shōji], Staff Officer Yamashita, 1st Lt. Wada Toshimichi (commander of the reserve unit and the regimental infantry artillery unit), and 1st Lt. Sugii Jirō, commander of the 4th Company (the company bearing the colors). The heavy weapons they had were just one mountain gun, one antitank gun and two machine guns. They destroyed the two [enemy] vehicles at the front, but the allied tanks and armored vehicles drove into the [Japanese] position in spite of that and freely ran about the place. Even the colors were in danger. After a battle of one and a half hours, they destroyed a total of twelve [enemy] vehicles [and tanks] by frantic shooting and attacks at close quarters and were finally able to make them retreat with the loss of some twenty-odd casualties. ${ }^{(13,31,75)}$

In the evening, another 300 to 400 troops of a Dutch East Indies Army unit in trucks attacked [the Japanese position] in Subang from the road to the Bandung stronghold. The company bearing the colors fought bravely and drove them off. ${ }^{(31,75)}$ 


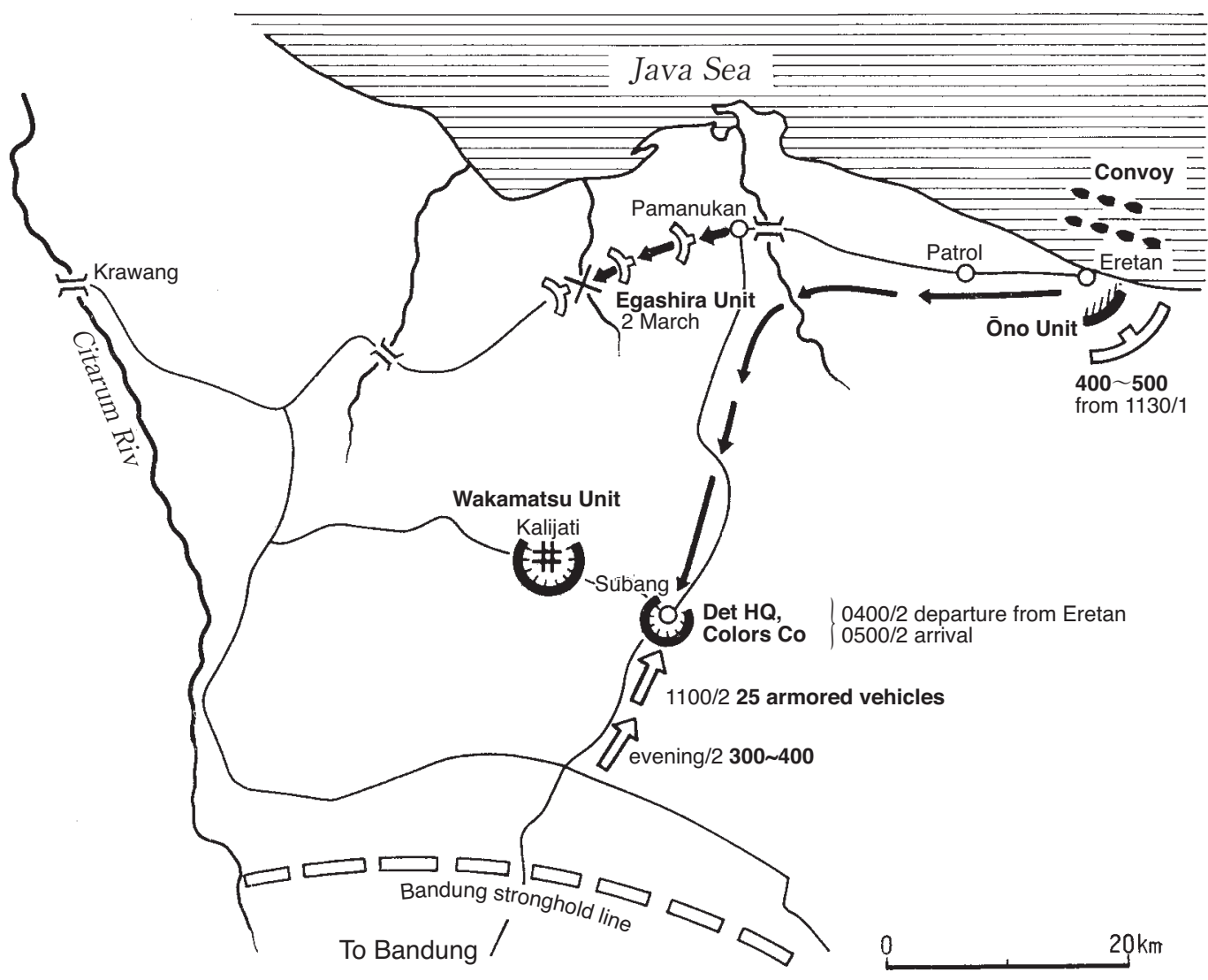

Illustration No. 56 - The Shōji Detachment on 2 March

On that day, the Egashira Raiding Unit continued its rush toward the Krawang bridge, but its advance was seriously hindered because all the bridges had been destroyed and also because several times Dutch East Indies Army units put up resistance. ${ }^{(31,75)}$

Fortunately, on that day, the aircraft of the 3d Air Division began to advance into the Kalijati [airfield]. Two aircraft landed at 1400, followed by the main force of the 27th Air Group (assault planes) and three planes of the 59th Air Group (fighter planes) (both of which had left Palembang at 1600). ${ }^{(91,96)}$

Sixteenth Army Staff Officer Lieutenant Colonel Itoda also flew in. ${ }^{(39)}$

\section{The 3d [of March]: [Enemy] Counterattacks at All Fronts (See Illustration No. 58)}

At the landing point, disembarkation was being continued. The Ōno Unit ([consisting of] one infantry company) was [still] confronting the Dutch East Indies Army in the area east of Eretan. The light cruiser Yura and the destroyers Akatsuki, Hibiki, Nagatsuki and Minazuki were continuously guarding the sea. The auxiliary seaplane tenders Kamikawa-maru and San'yō-maru had left the Anambas base for Bantam Bay the day before, the $2 \mathrm{~d}$. At the landing point in Eretan, a total of five planes of the Kamikawa-maru and a total of six planes of the San'yo-maru had provided [cover for the disembarkation] on the day before, the $2 \mathrm{~d} .{ }^{(130,131)}$ 


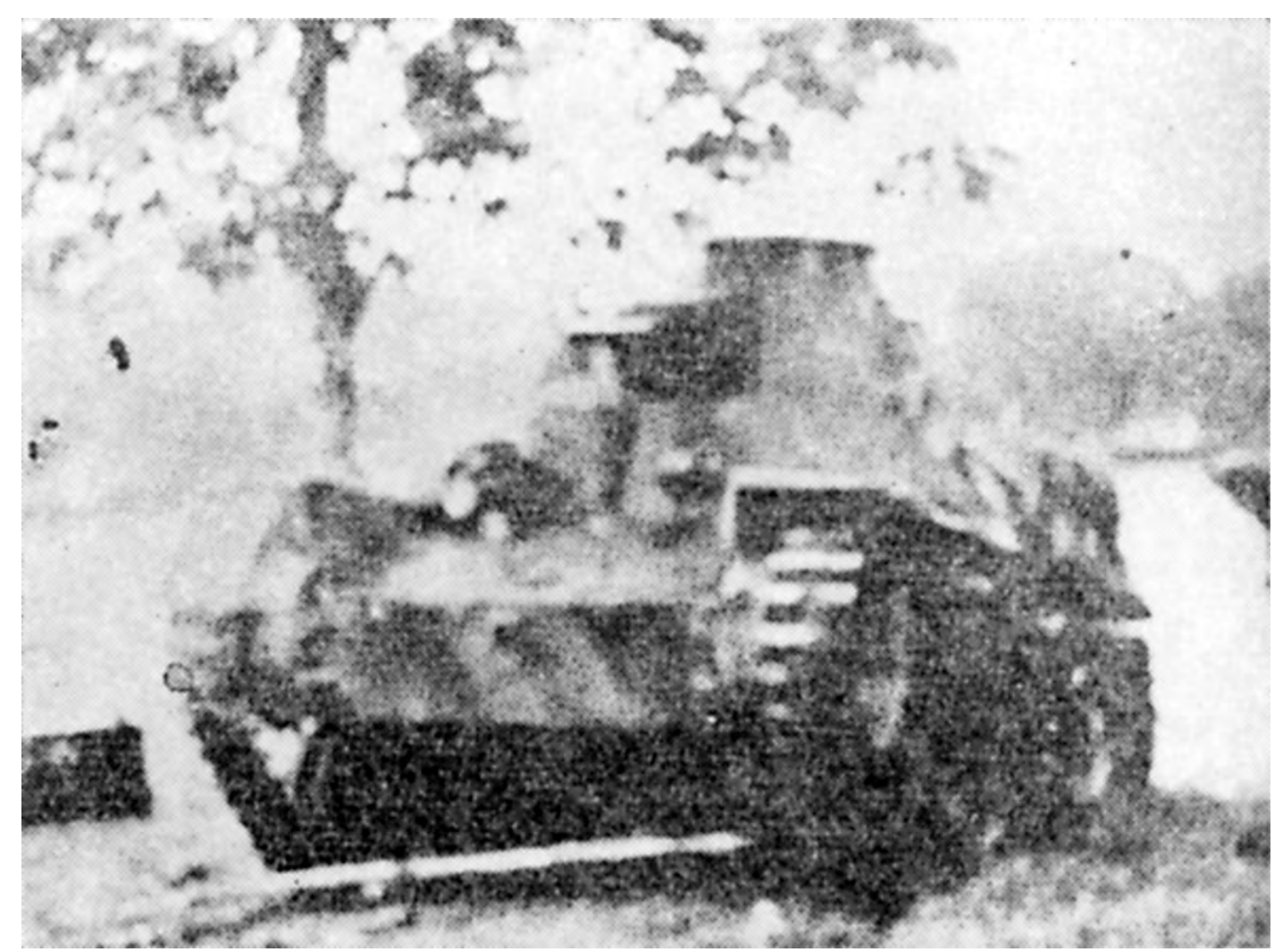

A Tank of the Dutch East Indies Army that Attacked [the Japanese Position in] Subang

At the Kalijati airfield on that day, the $3 \mathrm{~d}$, about twenty [enemy] armored vehicles attacked from the west around 0730, against which the Wakamatsu Battalion and the Sugimura Airfield Unit put up a defensive fight. At 0800, five allied aircraft raided and strafed the airfield, after which one B-17 bomber dropped huge bombs. One of the Japanese heavy bombers went up in flames, and 300 mountain gun shells exploded. At 0830, a Hurricane raided [the airfield] as well. The Wakamatsu Battalion drove off the [enemy] unit after destroying one of the armored vehicles and capturing five of them. ${ }^{(96,99)}$

As soon as the melee calmed down, Sixteenth Army Staff Officer Itoda hurried to the Shōji Detachment headquarters in Subang by car. He handed over a congratulatory telegram from 3d Air Division Commander Maj. Gen. Endō Saburō addressed to Detachment Commander Shōji and expressed his appreciation for the hard fighting of the Wakamatsu Battalion. ${ }^{(39,75)}$

Colonel Shōji, whose detachment headquarters had been overrun the day before, the $2 \mathrm{~d}$, learned that the Wakamatsu Battalion had been under a counterattack since the morning of the $3 \mathrm{~d}$. Although the Egashira Battalion was advancing to the front of Jatisari at last, its subsequent progress was doubtful. The allied units to the east of the disembarkation point seemed to be increasing, and it could not be predicted when the main force of the allied forces in the Bandung stronghold would attack in full force. Colonel Shōji deeply thought about what he had been told by General Hishikari Takashi long ago when he was young: "Don't stay in level country. Secure a mountain." However, fuel and ammunition for aircraft, and others were [still] being disembarked in Eretan at that moment. Colonel Shōji deliberately 
started speaking, and told the following [to Staff officer Itoda]: ${ }^{(75)}$

The successful landing this time was a result of the [excellent] direction of the [Sixteenth] Army headquarters and the support of the air and naval forces, especially the cooperation of the Endō Air Division. I am deeply grateful for that, and I would like to request your further continuous cooperation and support. The enemy, which is very much superior in power, has been enveloping our detachment. In addition, the landing and advance of the main force of the Sixteenth Army is falling behind schedule. Taking a defensive attitude out of hesitation and doing nothing will necessarily invite destruction. Therefore, I am considering assembling my whole force as soon as the disembarkation is for the most part complete and to break through a corner of the Bandung stronghold. I would like to request the unstinting support of the Endō Air Division, and on that occasion, I would appreciate it if I am [also] allowed to have the main force of the Wakamatsu Unit returned to my command, except for only one element to be left at the airfield.

Colonel Shōji said that he was considering "to

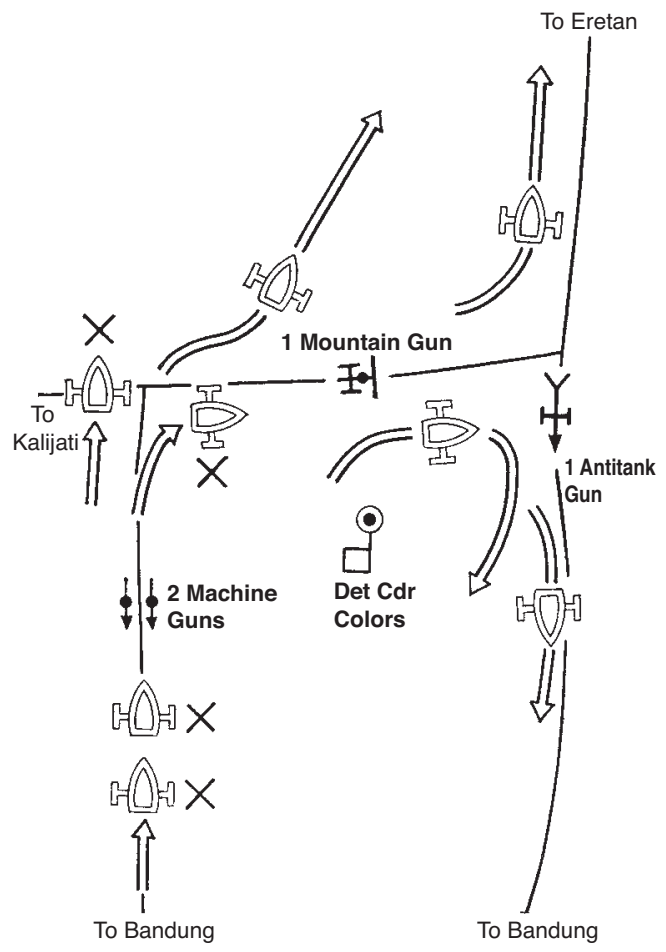

Illustration No. 57 - The Defensive Fight in Subang [on] 2 March (from 1100 to 1230) break through a corner of the Bandung stronghold," but his true feeling was, "[my detachment] will be crushed if we stay in level country. I wish we could occupy any one of the hillocks of the Bandung highlands and hang on to it." (75)

Staff Officer Itoda answered: "[3d] Air Division Commander Endō intends to support the Shōji Detachment with all his might. The air - ground communication squad under Major Kuboki is expected to be dispatched shortly for communications." After that, Staff Officer Itoda had lunch with Colonel Shōji and told him all about the Palembang paradrop operation of the [paratroop] raiding group, the Palembang operation of the Tanaka advance party, and the southern Sumatra operation of the 38th Division. It was stories about how the raiding group and the advance group had overcome difficulties, about the brave fighting of the Tanaka Regiment, his fellow unit, which at the beginning had been planned to be employed for seizing the Kalijati sector (until [Sixteenth] Army Commander Imamura had changed the plan) and about the 38th Division to which his [detachment] belonged. [These stories] happened to come up in the conversation at lunch because Staff Officer Itoda had been [in Sumatra] until then, and because the Shōji Regiment was a regiment of the 38th Division. ${ }^{(75)}$

Later, when Chief of the Army General Staff Sugiyama came on an inspection tour and asked Colonel Shōji, "What was your estimate of the strength of the enemy?" he answered, "I estimated the enemy strength to be 35,000, as I had heard from the Sixteenth Army. I was 
afraid that we would be enveloped and annihilated by the enemy if we were slow and hesitant. So I advanced toward the lines of the stronghold, prepared to die after seizing one corner of the stronghold." (75)

At 1130, while Staff Officer Itoda and Colonel Shōji had their talk together, 3d Air Division Commander Major General Endō (who had left Palembang at 1015) landed on the Kalijati airfield. The 59th Air Group (fighter planes) and the 75th Air Group (light bombers) also advanced there. ${ }^{(96,98,99)}$

At 1200, while Colonel Shōji and Lieutenant Colonel Itoda were having lunch, the Egashira Unit finally advanced in front of the Jatisari bridge. The bridge had been destroyed and there was a powerful Dutch East Indies Army unit on the opposite bank. At that time, the disposition of [Shōji's] force was: three companies in Kalijati, one in Subang, one in Eretan, and three in Jatisari. Detachment Commander Shōji decided to re-route the Egashira Unit to Krawang by way of Subang and Kalijati and ordered it to reverse course. At 2000 the battalion began to reverse course by motor vehicle. ${ }^{(31,75)}$

In the meantime (from noontime on the $3 \mathrm{~d}$ ), serious [enemy] counterattacks were launched at all areas [of the detachment] as follows: ${ }^{(31,75,99)}$

1. An infantry-tank combined unit consisting of more than a dozen tanks and sixty to a hundred trucks was closing in on Subang ([where] the Shōji Detachment headquarters and one company [were positioned]) from Bandung (heading northward, after passing at 1130 through Jalancagak, about twenty-seven kilometers north of Bandung.)

2. One hundred and several tens of tanks and trucks were approaching Kalijati ([where] the Wakamatsu unit [consisting of] three companies [was stationed]) from the southwest. Around 1400, the head [of the convoy] was spotted at ten-odd kilometers west of the airfield.

3. In the afternoon, about two thousand troops with guns came to attack the disembarkation point at Eretan ([where] one company under Lieutenant Colonel Ōno [was stationed]) from the direction of Cirebon (east of Eretan).

4. The allied unit on the Jatisari front ([where] the Egashira Unit [consisting of] three companies [was stationed]) was also picking up in activity.

The Endō Air Division flew six missions with a total of twenty-four aircraft against the [enemy] armored unit approaching Subang from Bandung, sent fourteen vehicles up in flames, and wrecked seventeen. Nevertheless, the [enemy] armored unit further continued its advance and one element [of the unit] appeared in front of the [Japanese] position in Subang in the evening. Detachment Commander Shōji drove it off. ${ }^{(31,75,99)}$

The Endo Air Division [also] flew six missions with a total of twenty-seven aircraft between 1430 and 1800 against the [enemy] vehicles approaching Kalijati in column from the southwest. It pinned down the large column of vehicles by first blowing up the vehicle at the head (at sixteen kilometers west of the airfield) then another at the tail, so it could not move from the road and then repeatedly strafed and bombed them. It achieved a large military gain of sending up in flames or destroying a total of 158 vehicles (10 tanks, 44 armored vehicles, and 104 trucks). ${ }^{(99)}$

The wreckage of the vehicles of the Dutch East Indies Army unit stretched out for over twenty kilometers from a point sixteen kilometers west of Kalijati to the south of Purwakarta. However, the troops on those vehicles quickly got out of them. Major Wakamatsu aiming to 
"destroy the enemy while they are demoralized," proposed and asked the detachment commander's permission to launch an attack, which Colonel Shōji in Subang approved. ${ }^{(75)}$

Around that time (at 2000), the Egashira Battalion started its U-turn from Jatisari. ${ }^{(31,75)}$

Around the same time, Lieutenant Colonel Ōno, commander of the disembarkation point covering unit, was trying to judge the situation of the Dutch East Indies Army unit on his front (east of Eretan), consisting of 2,000 troops (with four tanks and eight heavy guns), feeling that he should meet the expectations of Chief of Staff Okazaki and Colonel Shōji. (As mentioned previously, Sixteenth Army Chief of Staff Major General Okazaki had specifically assigned him [to command the disembarkation point]. Although he was the commander of the $2 \mathrm{~d}$ Independent Antitank Gun Battalion, all three companies under his command had been assigned to other areas, which left no antitank guns under his command. [Instead,] he was [now] commanding the 6th [Infantry] Company, one machine gun platoon and one regimental gun squad of the Shōji Regiment.) At night, Lieutenant Colonel Ōno ventured an attack on the assembly point of the Dutch East Indies Army unit in Kandanghaur and seized it at $2400 .{ }^{(31,75)}$

\section{The 4th [of March]: Disembarkation Completed (See Illustration No. 58)}

On the next day, 4 March (day four of the landing), the Wakamatsu Battalion, which had been heading westward, destroying the Dutch East Indies Army units everywhere on its way since the night before, seized Purwakarta at 0700. ${ }^{(59,31,75)}$

Staff Officer Itoda asked [3d] Air Division Commander Endō to look after things, left Kalijati and returned to the [Sixteenth] Army headquarters via the Serang airfield. At that time, the Army headquarters had no idea of the whereabouts of Staff Officer Itoda. Worried, it was waiting for a reply from the Southern Army to its telegram requesting an airlift [of troops]. We have seen how the words of the report of Staff Officer Itoda that "[the Shōji Detachment] seized Purwakarta at 0700 this morning" caused subtly different reactions [on the part of the Southern Army, the Sixteenth Army and the 2d Division] until the night of the 7th.

In the middle of the previous night (at 0000 on the 4th), the Wakamatsu Battalion had left Kalijati by motor vehicles. At 0040, it encountered about one hundred troops of a Dutch East Indies Army unit equipped with tanks and antitank guns at a point sixteen kilometers west of the town. It defeated the latter after an engagement of some thirty-minutes and headed westward. Subsequently, it encountered units of the Dutch East Indies Army twice, continued its westward advance after defeating them, and seized Purwakarta at $0700 .{ }^{(59,31,75)}$

The Egashira Battalion, which had been ordered to make a U-turn, [next] headed westward in motor vehicles via Subang and Kalijati, and then headed further northwestward. It attacked a powerful Dutch East Indies Army unit and entered Cikampek around 1400 on that day (the 4th). As the Dutch East Indies Army unit there (about 500 troops) had already retreated, the Egashira Battalion continued its advance toward Kedunggede. It entered Krawang at 1830, defeated the Dutch East Indies Army unit there, hotly pursued it, and arrived in Kedunggede at 1910, but the bridge over the Citarum River there had already been destroyed. ${ }^{(31,75)}$

After seizing Purwakarta, the Wakamatsu Battalion had been carefully watching the progress of the Egashira Battalion's northwestward advance. Having ascertained that the 


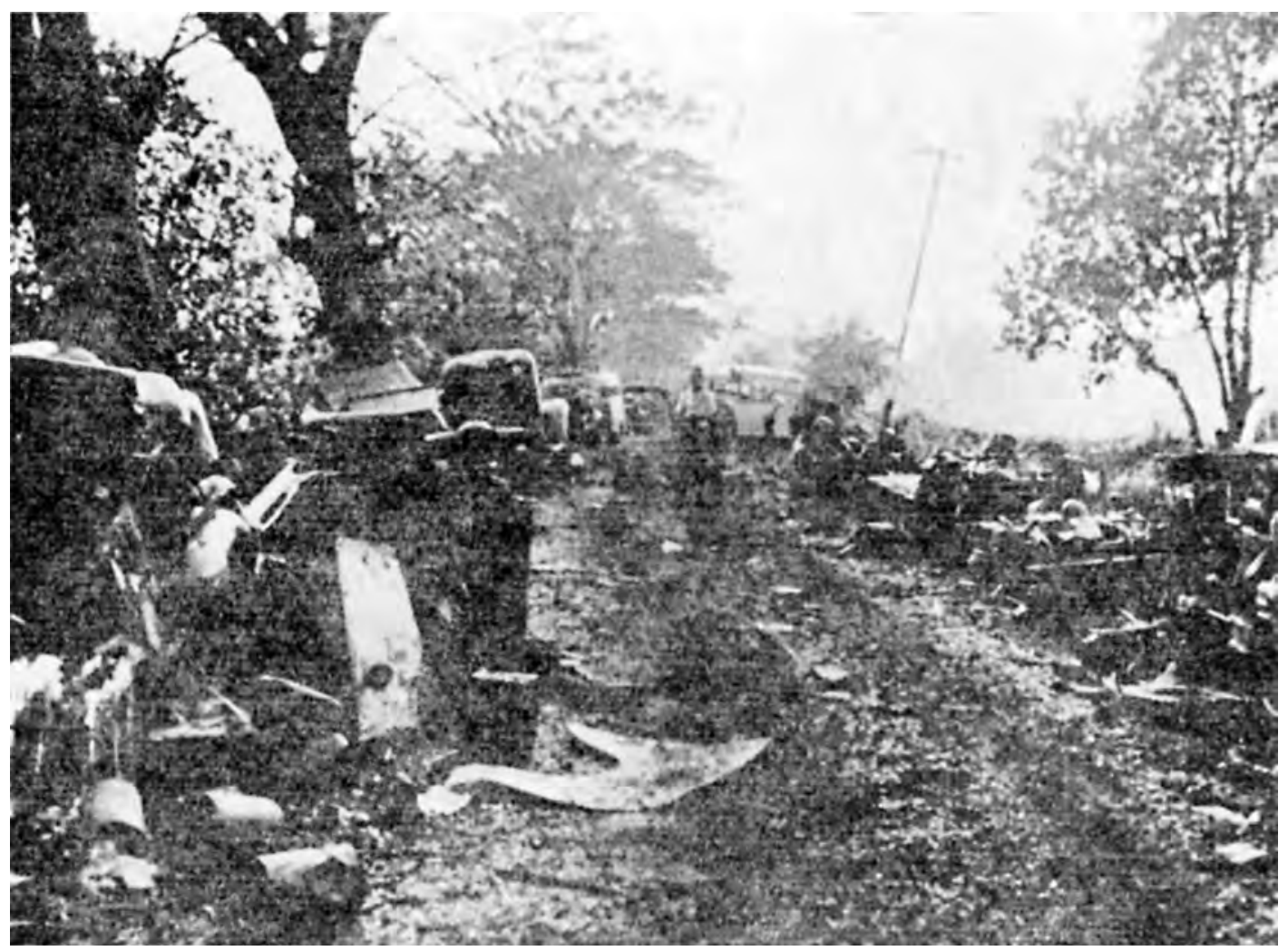

The Mobile Unit of the Dutch East Indies Army Destroyed in its Attack from Purwakarta on Kalijati

Egashira Battalion was advancing in the direction of Cikampek without difficulty, [the Wakamatsu Battalion] returned to Kalijati around 1400..$^{(31,75)}$

On that day (the 4th), Third Air Force Commander Lieutenant General Sugawara flew into the Kalijati airfield around 1400 and took off for Singapore (already renamed Shōnan) after an inspection of about one hour. On that day, three allied aircraft attacked the Kalijati airfield at 0820 and seven at 1030. The aircraft of the 75th and the 90th Air Groups of the 3d Air Division launched an attack on Bandung from the airfield on that day. ${ }^{(97,98,99)}$

The Kamikawa-maru and the San'yō-maru, which had left the Anambas Islands on the 2d, were under sail for Bantam Bay (they arrived at Bantam Bay on the 5th) and their reconnaissance seaplanes, which had advanced to the Bantam and Patrol (Eretan) bases since the 1st, covered the disembarkation [operation] and supported the fighting of the Ono Unit with a total of thirteen aircraft on the $3 \mathrm{~d}$ and a total of eleven aircraft on the 4 th. ${ }^{(130,131)}$

On that day, the 4th, the convoy completed disembarkation and the transport ships left [the anchorage] off Eretan under the escort of the light cruiser Yura and others in the afternoon. ${ }^{(120)}$

\section{Third Air Division Commander [Endō] and Detachment Commander Shōji's Change of Mind}

A subtle change had occurred in [3d] Air Division Commander Endō and Detachment Commander Shōji's judgment of the situation. 
Major General Endō had concluded: "The focus of the operations has shifted to this area now; we should give all our support to the Shōji Detachment in this area, and put the support for the operations of the main force of the Sixteenth Army second." Instead of thinking: "[My detachment] will undoubtedly be annihilated if it stays in level country," and "We should seize one of the hillocks on the ridgeline of the [Bandung] stronghold, cling to it, and die a glorious death [while trying to hold on to it]," Detachment Commander Shōji now felt: "the detachment has completed its initial mission, having crushed every counterattack of the enemy as well as the presumed main counterattack on 3 March," and "since I have heard nothing from the [Sixteenth] Army at all, I want to try to take the initiative on my own authority, counting on the Endō Air Division."

[Third] Air Division Commander Endō and Detachment Commander Shōji's judgment of the situation had started to change on the morning of the 3d when Staff Officer Itoda had handed over the telegram from Major General Endō to Colonel Shōji. [The change] had developed rapidly when, contacted by Staff Officer [Itoda] that afternoon, Major General Endō had declared that he would "fully support the Shōji Detachment," and [the Shōji Detachment] had defeated the counterattacks of the Dutch East Indies Army from every direction. [The change] became firmly established on the 4 th, when [one element of the detachment] reached the bank of Citarum River, and the disembarkation at Eretan was completed.

On the night of the 4th, [3d] Air Division Commander Endō deplored that "the ground operations of the main force of the Sixteenth Army are making little progress," and that "in enthusiasm they totally differ from those of the Twenty-fifth Army (on the Malay Peninsula)." ${ }^{(98)}$ [In other words, ] he was ready to immediately burst into action once Colonel Shōji would set him off.

[Meanwhile] on the evening of the 4th (in Subang), Detachment Commander Shōji's judgment of the movements of the enemy was that "about 2,000 troops are in the area of Cirebon (east of Eretan), about 20,000 in the Bandung area, and about 3,000 in the Purwakarta area, while the numbers in these areas seem to be gradually increasing," and that "the enemy must be concentrating and integrating more of its force to attack Subang and Kalijati." (75) Based on the above judgment and the current situation, particularly the fact that no contact had yet been established with the [Sixteenth] Army, and that he had completed his initial mission, Colonel Shōji determined: "We need to preemptively seize the Bandung stronghold, before the enemy concentrates and integrates [its forces] and attacks us."(75)

Staff Officer Yamashita of the Sixteenth Army, who enjoyed the confidence of Army Commander Imamura and had been assigned to the Shōji Detachment for [just] such a situation, was facing a serious problem. Staff Officer Yamashita's judgment of the movements of the enemy was as follows: ${ }^{(31,41)}$

1. The vigorous offensive of the enemy from 2 to 4 March shows that from the beginning the enemy clearly had no intention to put up a defense [just] relying on existing positions. But although they did attempt a coastal thrust, it may be considered as having been generally [too] weak and ill-timed.

2. Therefore, there are signs that the enemy, having its attacks at the front of the detachment frustrated, is now successively withdrawing its forces in all areas and gathering them in Bandung to shift to a defense using existing positions. 


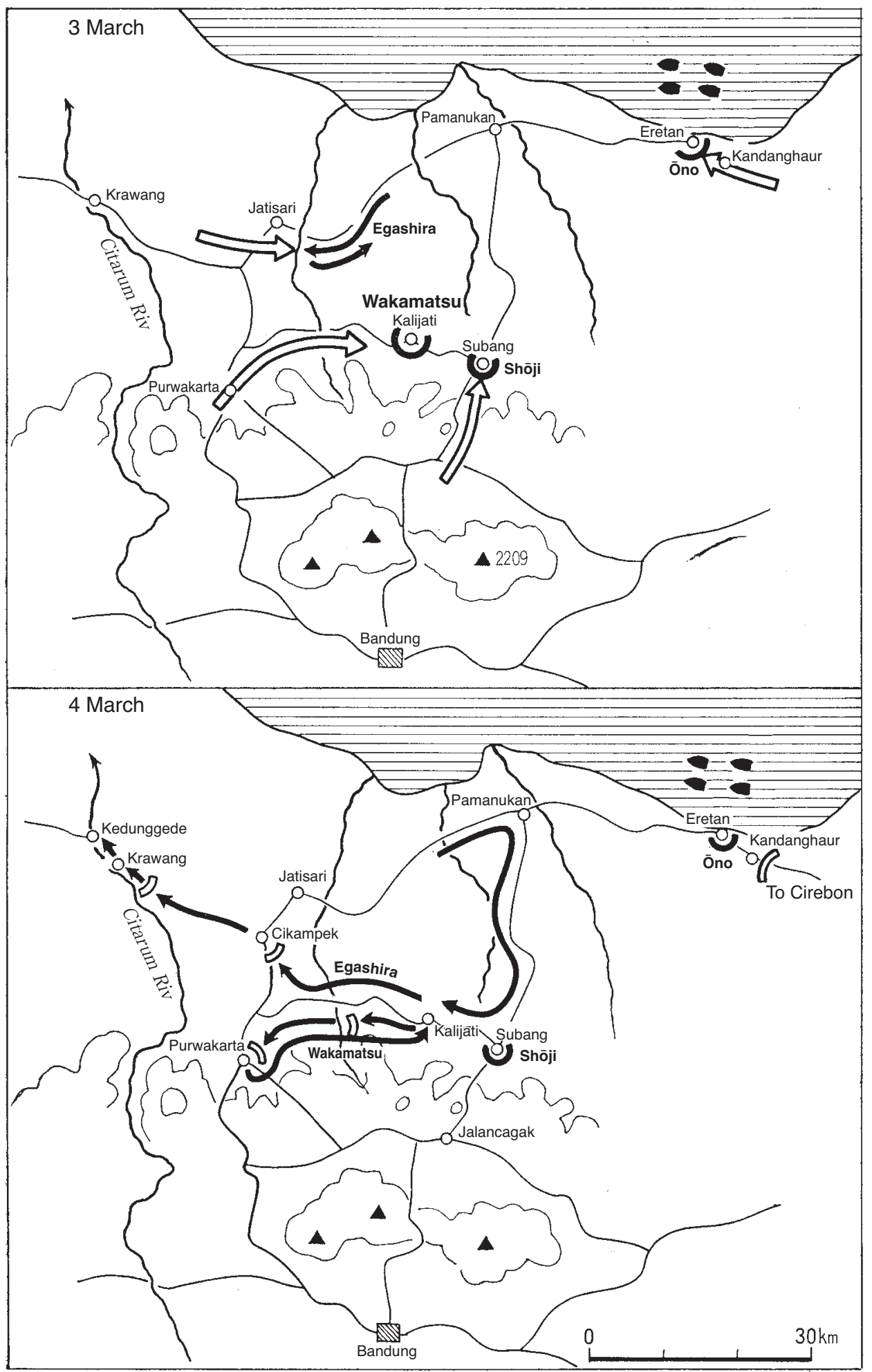

Illustration No. 58 - [The Shōji Detachment] on 3 and 4 of March 
Staff Officer Yamashita's judgment of the enemy movements was far more confident than Detachment Commander Shōji's, but in his judgment of the situation [and what to do], he was more timid. [So,] Staff Officer Yamashita proposed to the detachment commander: "How about conducting a reconnaissance in force?"(41) This proposal reflected Staff Officer Yamashita's dilemma as a staff officer, to be precise, as the [assistant] operations staff officer of the Sixteenth Army.

Colonel Shōji, however, regarded young Staff Officer Yamashita [simply] as a staff officer assigned to his detachment, that is, as a staff officer under his command.(75)

In the end, Colonel Shōji decided that "[the detachment] should preemptively seize the Bandung stronghold." (75) He informed [3d] Air Division Commander Endō of his decision and asked for support. ${ }^{(75)}$ In no time, Major General Endō replied: "Go ahead. We will support you with all our might."(75)

Colonel Shōji immediately passed down the following orders. ${ }^{(75)}$ When giving orders, he had made it a habit to draft them himself without getting assistance from staff officers and to give oral instructions. ${ }^{(75)}$

1. The Wakamatsu unit shall promptly assemble its force and leave Subang at 1100 tomorrow, the 5 th. As the advance party for seizing Bandung, it shall advance first to Ciater and vicinity along the Subang - Bandung road and reconnoiter the situation of the area, particularly the situation of the enemy positions and the terrain on the north side of Bandung.

At the Kalijati airfield, [the Wakamatsu unit] shall leave behind the troops requested by [3d] Air Division Commander Endō and leave them under his command. These troops are scheduled to catch up [with the unit] when they are later replaced by troops of the Egashira unit.

Staff Officer Yamashita, Adjutant Sekiya and [other] necessary [staff of] the headquarters shall accompany [the unit].

2. The Egashira unit shall promptly pull out of Cikampek. It shall assemble all its force in Subang, so as to leave Subang in the early morning of the 6th and advance toward Bandung. Further, when it passes the Kalijati airfield, it shall leave the same number of troops as those left by the Wakamatsu unit, replace the latter, and put them under the command of [3d] Air Division Commander Endō.

3. Unit Commander Ōno shall take command of all the units in the rear. (A minimal infantry force shall be assigned.)

\section{The Third Air Force's Support of the Ground Operations}

As we have seen above, on the night of the 4th (when the Nasu Detachment was conducting its second night attack on the [enemy] positions in Leuwiliang and when the Satō Detachment was about to advance to the front of the defensive zone in Tangerang on the next day, the 5th), Detachment Commander Shōji gave the order to advance to the front lines of the Bandung stronghold and it was settled that the $3 \mathrm{~d}$ Air Division would support this operation. I will describe below how the [Army] Third Air Force had supported the ground operations of the Sixteenth Army until then and how it conducted the support thereafter.

As described previously, for the maintenance of the airfields to be performed by the air ground support unit assigned to the army, the Sixteenth Army had allocated [a unit] consisting of the 24th Airfield Battalion as the core to the Kalijati [airfield] and another consisting of the 28th Airfield Battalion as the core to the Buitenzorg and the Batavia [airfields]. The Third Air Force had instructed the units concerned to be ready, assuming that flight units 
would be able to advance to the Kalijati airfield on Day $\mathrm{H}$ (the starting date of the Java landing [operation]), the Buitenzorg airfield on Day $\mathrm{H}+3$, and the Batavia airfield on Day $\mathrm{H}+$ 4. $(23,96)$

In addition, as we have seen, the Third Air Force had [also] stated that it would employ the $3 \mathrm{~d}$ and the 12th Air Divisions, and the 81st Air Group for the Java operations, and [also] one element of the 7th Air Division depending on the circumstances. [The Third Air Force] had disposed its forces and their tasks roughly in the following way: ${ }^{(96)}$

81st Air Group: Reconnaissance of enemy airfields, the location of the convoys, photography of the landing points, and other general scouting.

12th Air Division ([consisting of] one squadron of the 1st Air Group (fighter planes), and the 11th Air Group (fighter planes)): shall destroy [the enemy] air power, cover [the Japanese] convoys under sail and provide air defense at their anchorages, as well as the air defense of key locations as needed.

3d Air Division ([consisting of] the 15th Independent Air Unit (its headquarters and the 50th and the 52d Independent Squadrons; command reconnaissance aircraft), the 27th Air Group (minus one squadron; assault planes), the 59th Air Group (fighter planes), the 64th Air Group (fighter planes), the 75th Air Group (light bombers), and the 90th Air Group (light bombers)): shall destroy [the enemy] air power, give direct support to ground operations, and cover the [Japanese] convoys as needed.

It meant that out of the force of the [Army] Third Air Force consisting of three air divisions as the core, it employed the $3 \mathrm{~d}$ Air Division (reinforced) for the direct support of the Java ground operations. Further, it had circumscribed its direct support of the ground operations as follows: ${ }^{(96)}$

After the landing of the main force of the Sixteenth Army, [the Army Third Air Force] shall promptly advance its base when the enemy airfields in western Java are seized and made ready for use. Simultaneously, it shall [also] anticipate that the air ground unit belonging to the Sixteenth Army may be assigned to it.

After the landing of the Sixteenth Army, it shall directly support the army in its ground operations.

Depending on the circumstances, direct support of the 48th Division in its operations in eastern Java may be called for.

The Third Air Force had launched a campaign to destroy [the enemy] air power [in the sector] from $108^{\circ} \mathrm{E}$ westwards, and subsequently provided cover for the convoy of the main force of the Sixteenth Army after the convoy of the Shōji Detachment had separated and gone its own way. On the day before the landing operation of the Sixteenth Army (28 February), it issued the following order: ${ }^{(96)}$

1. The outlines of Operation $\mathrm{H}$ of the $2 \mathrm{~d}$ Division and that of the Shōji Detachment are respectively as shown in Separate Sheet No. 1 and No. 2 (omitted by the author).

2. The $3 \mathrm{~d}$ Air Division commander shall provide direct support mainly for the operations of the main force of the 2d Division and the Shōji Detachment from tomorrow, 1 March, onwards.

3. The 12th Air Division commander shall continue his current tasks.

4. The 81st Air Group commander shall be relieved of his tasks to cooperate with the 12th Air Division. 
At that time, the 12th Air Division was stationed in Tanjungkarang, and the 3d Air Division and the 81st Air Group in Palembang. The [Third] Air Force commander had [also] been positioned in Palembang since 21 February. As soon as [he was informed that the Sixteenth Army had successfully landed, he issued the following order in Palembang at 1200 on 1 March:(96)

1. The Sixteenth Army has successfully landed on $\mathrm{H}$; one element of the army is attacking and advancing in the sector east of Serang at 1030.

2. The [Third] Air Force intends to advance part of its force to Java to support the Sixteenth Army in its operations.

3. The 3d Air Division commander shall successively advance his force to a group of airfields in western Java after those airfields have been seized and readied and continue his current tasks. However, the 64th and the 90th Air Groups, the 94th and the 91st Airfield Battalions, and the 7th Airfield Company shall still use Palembang as their base. When the 15th Independent Air Unit (minus the 51st Independent Squadron), the 27th Air Group and the 36th and the 93d Airfield Battalions are advanced, the [number of] personnel and equipment [to be advanced] shall be minimized, taking subsequent redeployments into account.

4. The 81st Air Group commander shall have his main force prepare for advance to western Java, leaving the 1st Squadron behind in Malaya.

5. The 12th Air Division commander shall continue his tasks at his current base until ordered otherwise. (Rest omitted by the author.)

As already told, on 25 February, the Third Air Force had judged that "the campaign to destroy [the enemy] air power in Java is for the most part completed today," and on 26 [February] that "the remaining enemy aircraft in western Java are between twenty to thirty." It had provided cover for the convoy of the main force of the Sixteenth Army on the 27th and the 28th, and shifted to cover for the landing [operations] and support of the ground operations from the next day, 1 March, onwards. [Its operations] with a focus on its support of the operations in the sectors of the $2 \mathrm{~d}$ Division and the Shōji Detachment may be summarized as follows:

\section{March}

The 12th Air Division provided cover for the anchorage of the disembarkation point of the $2 \mathrm{~d}$ Division from the early morning. ${ }^{(96)}$

As for the 3d Air Division, in the morning, the commander and others went into action to support the landing operations in the sector of the $2 \mathrm{~d}$ Division. However, the landing was performed boldly without problems, and after their landing, the units were advancing amid welcoming cheers of the inhabitants, who looked up and just waved their hands at the aircraft [of the division]. As they never ran off even if the aircraft flew above them, the division returned, considering that "there is no place [for the aircraft] to drop bombs." (98, 99)

At 1200 the [Third] Air Force commander passed down the already-mentioned order to advance [to Java]. ${ }^{(96)}$

In the afternoon, a telegram about the sector of the Shōji Detachment came from the [Navy] 3d Air Raid Unit, which said: "Enemy aircraft attacked ten times, taking advantage of the moonlight. Please step up the campaign to destroy [the enemy] air power." But [the Third Air Force] replied as described in the section "Entry into the Anchorage, Start of the Landings, and Naval Engagements." [See p. 458.] The [Third] Air Force did not launch attacks either on the airfields or at the front of the Shōji Detachment. ${ }^{(99)}$ 


\section{March}

Learning that Kalijati was seized, the 3d Air Division advanced three aircraft of the 59th Air Group and the main force of the 27th Air Group to the Kalijati [airfield] on that day. These aircraft immediately took care of the air defense and conducted attacks on the Bandung airfield. Receiving information that twenty-nine allied aircraft had been spotted on the Bandung airfield, [3d] Air Division Commander [Endō] sent the 59th, the 64th, the 75th and the 90th Air Groups for an attack from Palembang, all of which returned to Palembang. No direct support for the $2 \mathrm{~d}$ Division was provided. ${ }^{(98,99)}$

The 12th Air Division continued its task to cover the anchorage of the 2d Division. ${ }^{(96)}$

\section{March}

On this day, the commander and the 59th and the 75th Air Groups of the 3d Air Division advanced to the Kalijati [airfield] and along with the 27th Air Group, which had advanced the day before, conducted the campaign to crush the counterattacks of the allied mechanized units. The 64th and the 90th Air Groups attacked the Bandung airfield from Palembang and returned to Palembang. On this day, the battle in Leuwiliang started in the afternoon, but no direct support for the 2d Division was provided. ${ }^{(98,99)}$

\section{March}

Of the 3d Air Division, the commander and the 27th, the 59th and the 75th Air Groups were stationed on the Kalijati [airfield], while the 64th and the 90th Air Group were on the Palembang [airfield]. The previous afternoon, Staff Officer Itoda of the Sixteenth Army, who had returned from the Shōji Detachment headquarters, had asked Air Division Commander [Endō] for air support for the Shōji Detachment. This morning, the engagements since the previous evening in the area west of Kalijati were continued, while the Wakamatsu unit was heading for Purwakarta, and the Egashira Battalion, which had made a U-turn [from Jatisari], was heading in the direction of Krawang via Kalijati, while attacking Dutch East Indies Army units [on its way]. Accordingly, support for these units became the main operation of the division this morning (which was conducted by twelve aircraft for six times). Meanwhile, in Kalijati a total of eleven allied aircraft attacked three times, which caused a loss of one aircraft sent up in flames and six heavily or partly damaged. Consequently, a joint attack on the Bandung airfield by fighter planes and bombers became the main operation of the $3 \mathrm{~d}$ Air Division on this afternoon. ${ }^{(98,99)}$

[Also] on this day, Third Air Force Commander Lieutenant General Sugawara flew to the Kalijati [airfield] at 1400 and left at 1500 after an inspection tour. ${ }^{(97,98)}$ On this day, too, the Nasu Detachment of the $2 \mathrm{~d}$ Division vigorously attacked [the enemy] position in Leuwiliang all day, and the Sixteenth Army was asking the Southern Army to airlift [troops] to Kalijati.

Due to its subsequent operations, the Third Air Force had committed only the 3d Air Division to the direct support for the Sixteenth Army in the ground operations. But the military situation at the $3 \mathrm{~d}$ Air Division did not allow it much leeway to support the $2 \mathrm{~d}$ Division. It could not smoothly contact the latter, either. Although it had sent its aircraft also to the sector of the $2 \mathrm{~d}$ Division, only the column on the march could be spotted. The military situation at the front line remained unclear.

The self-confidence of the $3 \mathrm{~d}$ Air Division, which had increased since the evening of the $3 \mathrm{~d}$, became solid on the morning of the 4th. On the 4th, $3 \mathrm{~d}$ Air Division Commander Endō, who had known about the Detachment Commander Shōji's request since the afternoon of the 3d, became irritated at the [slow] advance of the $2 \mathrm{~d}$ Division. As soon as he received from Detachment Commander Shōji, who was a kindred spirit on the same battlefield, the message that he in- 
tended to advance toward the Bandung stronghold, he decided to support the latter with all his might. ${ }^{(98)}$

\section{The 5th [of March]: Heading for the Bandung Stronghold}

(See Illustrations No. 59 and No. 60)

At 0900 on the 5th, after paying respects to Air Division Commander Endō, the Wakamatsu Battalion departed from the Kalijati airfield. ${ }^{(98)}$

At 1100 on the 5th, the Wakamatsu Unit ([consisting of] three infantry companies as the core, with the same attached units as before and joined by the main force of the mountain artillery battalion (two batteries)) left Subang and headed south. Staff Officer Yamashita Yutaka, Regimental Adjutant Capt. Sekiya Eiji, and others accompanied the unit. On its way, the Wakamatsu Unit pursued southward about one infantry company of the Dutch East Indies Army equipped with light-armored vehicles and heavy guns, which was retreating due to the bombardment by the Endō Air Division. Around 1600, the tank at the head of the [Wakamatsu] Unit unexpectedly came upon [enemy] pillbox positions in the area south of Ciater and went into battle. Battalion Commander Wakamatsu immediately ordered [the unit] to deploy and attack. Fortunately, hindered by the many trees, the field of fire of the pillboxes was limited. The battalion seized the pillbox positions with barbed wire entanglements on the front line, then attacked similar pillbox positions on the second line, and [finally] took five pillboxes in total. Battalion Commander Wakamatsu decided to continue the attack again the next morning, the 6th [of March]. ${ }^{(31,41,75)}$

Sixteenth Army Staff Officer Major Yamashita (the staff officer assigned to the Shōji Detachment), who accompanied the battalion, at first thought that the battalion should better withdraw at night, but came to hold the same view as Battalion Commander Wakamatsu because the military situation was so overly favorable. ${ }^{(41)}$

Note: Staff Officer Yamashita had the following recollection of the events:

I accompanied Battalion Commander Wakamatsu and went southward from Subang, positioned at the head of the main force of the battalion. On the way, we spotted blown-up enemy armored vehicles and motor vehicles on the road. We went southward without delay. Tanks (one troop, as I recall) were at the head, which were followed by the advance company. It seems that both the tanks and the advance company headed southward without engaging [the enemy]. (Note by the author: According to the historical records of Kanzaki Kiyoshi, staff officer of the $3 \mathrm{~d}$ Air Division, twenty-four aircraft of the Endō Air Division had bombed the whole length and breadth [of an enemy column] on the road between Jalancagak and Ciater from 1130 onwards. It seems that this bombardment by the Endō Air Division had blown to pieces about one company of a Dutch East Indies Army mechanized unit equipped with armored vehicles and heavy guns, and made it retreat.) When we advanced to the edge of the plateau north of Jalancagak (note by the author: according to the records of Staff Officer Kanzaki, it seems to have been at 1258) and observed the area to the south, I saw mountains completely covered with trees stretching to the south of Ciater, and no [enemy] positions at the foot of the mountains. As there was no fire pointed at us, we continued going southward. When we passed through Ciater (note by the author: around 1530 according to Kanzaki's records) and reached the foot of a mountain, the tank at the head suddenly came under [enemy] fire. There were [enemy] positions with antitank obstacles consisting of [pieces of] railroad rail stuck in the ground, barbed wire entanglements and pillboxes. Battalion Commander Wakamatsu deployed the battalion and ordered an attack. I spotted five pillboxes, three of which covered the main road with their guns. Other pill- 
box positions stretched in a row on both sides of them, but the details were not clear. Fortunately, the place was rugged and had many trees. The front line company approached [the three pillboxes] by skillfully taking advantage of the terrain and the natural objects and seized them. I went southward along the main road, having small talk with the battalion commander, and advanced onto the high ground of those pillboxes. When we advanced onto the high ground, all of a sudden we were fired upon from pillbox positions (a second line of pillbox positions at a distance of 400 to 500 meters) on another plateau across a stream, which killed two and wounded several men. Just then, several enemy tanks (with no accompanying infantry) sallied forth and forced their way onto our high ground. The battalion drove them off. The front line company continued its attack and seized two pillboxes of the pillbox positions in the second line, after which Battalion Commander Wakamatsu advanced toward the high ground of the second line of pillbox positions. I stayed behind. After taking steps to report [the situation] to the detachment commander, I left the high ground of the first line of pillbox positions and advanced along with Detachment Adjutant Captain Sekiya to catch up with the battalion headquarters. [First] we advanced along the main road, turned right after crossing the high ground of the second line of pillbox positions, and advanced through the forest, when suddenly at point-blank range we were fired upon by enemy stragglers with a semi-automatic rifle, which wounded Adjutant Sekiya. It happened at dusk. After making arrangements to send Adjutant Sekiya back to the rear, I continued advancing and joined the battalion headquarters. The battalion stayed up all night, keeping strict guard.

That evening, Detachment Commander Shōji (in Subang) received [Yamashita's] report, which said: "The Wakamatsu Unit reached Ciater, pursuing on its way about one thousand enemy [troops] equipped with guns, who were retreating due to the bombardment by the Endō Air Division." However, he heard nothing [from the unit] after nightfall. ${ }^{(75)}$

On that day, the Egashira Battalion was waiting in the Krawang and Kedunggede sector for motor vehicles to be brought around. ${ }^{(31,75)}$

On that day (the 5th), a total of two allied aircraft attacked the Kalijati airfield twice in the early morning, but there were no attacks afterwards. At 0800, when [3d] Air Division Commander Endō was sending off a combined unit of fighter planes and bombers to attack airfield(s) in the Bandung area, Battalion Commander Wakamatsu [had come and] paid his respect to him at 0900, saying, "I'm departing for the Bandung stronghold front. Please take care of things after I'm gone." Air Division Commander Endō was glad that the defensive until yesterday had from this day [finally] turned into an offensive. He encouraged [the battalion commander], saying, "Please don't mind the cover for the airfield. I want you to quickly capture [Bandung]. Our air division will support you with all its power," and he immediately gave his air groups their assignments. On that day, the Endō Air Division sent a total of forty-eight aircraft from the 27th, the 75th and the 90th Air Groups on sorties to directly support the Shōji Detachment. ${ }^{(96,98,99)}$

\section{The 6th [of March]: Attack on the [Enemy's] Main Position and Seizure of the Mountaintop (See Illustration No. 60)}

On the morning of the 6th, Adjutant Sekiya and more than a dozen wounded men were brought back to the Shōji Detachment headquarters. The detachment commander, who had lost contact with the Wakamatsu Unit since the previous evening and who was worrying about it, for the first time learned about the previously described state of affairs. ${ }^{(75)}$ 
Around 0900, Detachment Commander Shōji left Subang to catch up with the Wakamatsu Unit, leading the whole body of his headquarters. He ordered the Egashira Battalion to hurry. That morning (of the 6th), the Egashira Battalion [finally] started its U-turn from the Krawang and Kedunggede area. ${ }^{(31,75)}$

Around 1400, Detachment Commander Shōji caught up with the Wakamatsu Unit, met Battalion Commander Wakamatsu and Staff Officer Yamashita, and received a report saying: "The enemy positions on the north side of Bandung are guarded with pillboxes, barbed wire entanglements, and the like, and are considerably strong. They seem to be equipped with more than a dozen guns and defended by some 3,000 troops. The Dutch East Indies Army [there] is gradually increasing [its troops]. There are cliffs here and there in front of the positions, which seem to make it difficult to pass through, and both sides of the positions are covered with jungle, which also seem to make it difficult to pass through." (Note: From the recollections of the detachment commander.) Detachment Commander [Shōji] ordered Battalion Commander Wakamatsu to "seize more of these outpost-like positions of the Dutch East Indies Army and continue to reconnoiter the situation of the main position," and he gave orders to the artillery battalion commander to cooperate in the task [as well]. Colonel Shōji judged that the positions which the Wakamatsu Unit had seized the previous evening were forward positions, that the positions with pillboxes just in front of the unit were something like outposts [of the main position], and that there [must be] a main position on the ridgeline in the rear. Around that time, the shift of Egashira Battalion was delayed due to motor vehicle trouble. On that day, the Endō Air Division supported the detachment again from morning onwards. ${ }^{(75)}$

That morning, before the arrival of Colonel Shōji, Unit Commander Wakamatsu had unexpectedly run into and engaged a[n enemy] mechanized unit, which had counterattacked from the direction of Bandung. When Detachment Commander Shōji left after his talk with Battalion Commander Wakamatsu, the questioning of the prisoners of war of the Dutch East Indies Army who had been taken in the engagement in the morning was in progress. ${ }^{(31)}$

Note: Staff Officer Yamashita had the following recollection of the events:

I hailed the morning of the 6th in the same trench as Battalion Commander Wakamatsu. Since that morning, the enemy artillery had been firing [at us]. Battalion Commander Wakamatsu said: "The enemy artillery doesn't amount to much. Moreover, all the shells are falling behind us, passing high over our heads. It is not worth fearing." Just then, an enemy [unit] came counterattacking from the direction of Bandung. The enemy, attacking in front of my position, was about one company. The battalion engaged the enemy in this unexpected encounter in the forest and the engagement lasted till about noon. The enemy was defeated. We were able to take thirty to forty prisoners.

From the statement of a prisoner of war, it turned out that the artillery in front was a Dutch East Indies Army artillery [unit] consisting of about one battery only, that the force defending the positions was [also] Dutch East Indies Army troops, but few in number, that there was a detour in the jungle to the west, and the like. Guided by this prisoner of war, the Wakamatsu unit advanced along the byway through the jungle and headed to the west of the position that the detachment commander had indicated as "something like an outpost," and came to a col to the west of the position. The place that [Detachment Commander Shōji] had considered as "something like an outpost" was [in fact] the main position (the Cicenang position) 


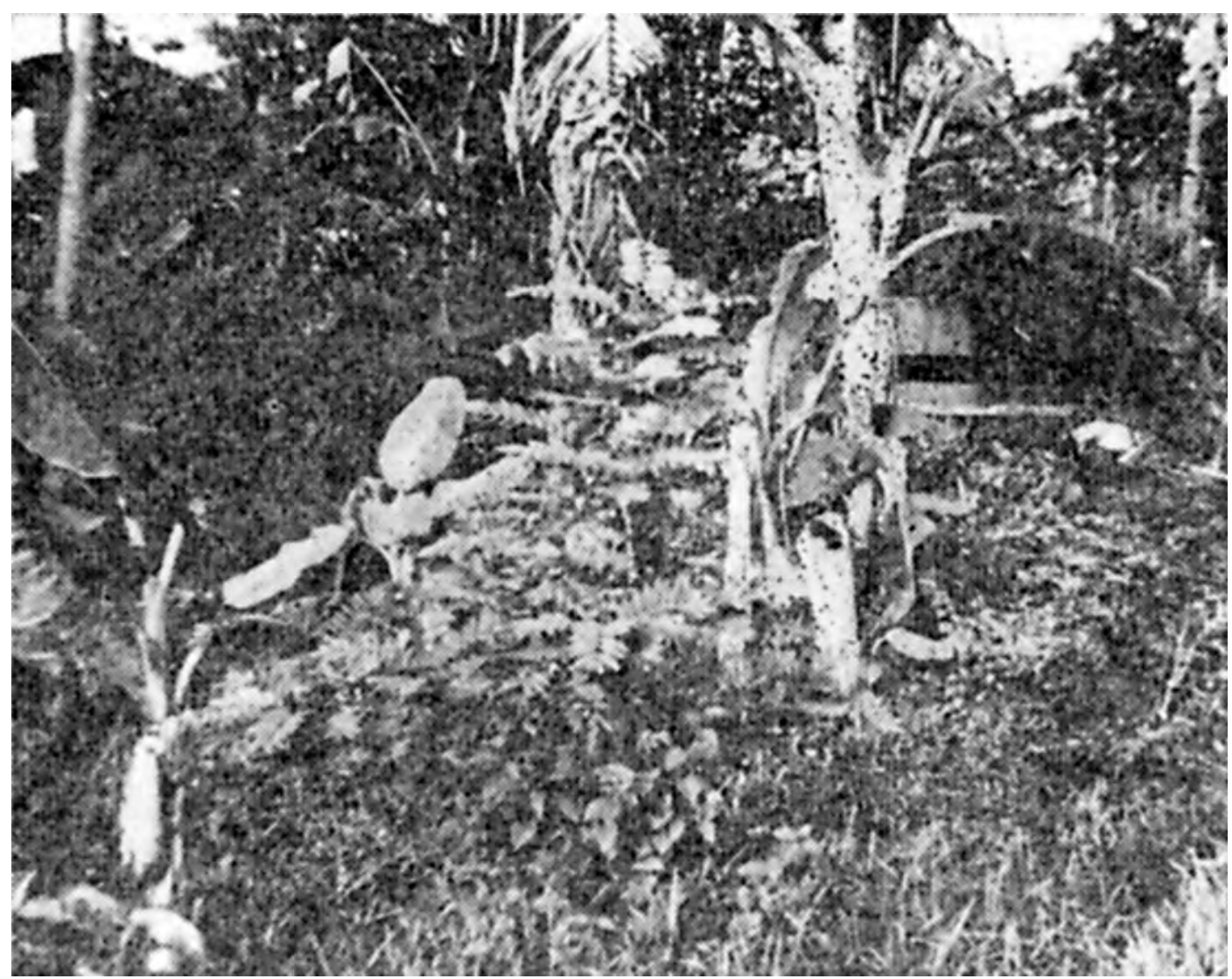

A Pillbox Position of the Bandung Stronghold

on the ridgeline. There was a thick fog. Taking advantage of the thick fog, Battalion Commander Wakamatsu quickly deployed the battalion and prepared for an attack. When the fog cleared away, the battalion charged all at once. The Dutch East Indies Army unit was totally taken by surprise; it fled in a rout to the hillock behind the position. The hillock in the rear was a reserve position for the main position and had not yet been completed. There was another position on the southeast side of the main road. Both of these positions were by far inferior to the one just seized. Seeing the Dutch East Indies Army retreating in utter confusion toward the above-mentioned reserve position, Staff Officer Yamashita suggested to Battalion Commander Wakamatsu: "Let's pursue them." The commander, however, did not agree. Battalion Commander Wakamatsu believed that he had taken complete control of the Bandung stronghold line by occupying the present position. Of course, he knew that he ought to pursue them. He [also] believed that he could "easily enter Bandung in pursuit of the defeated enemy." Nevertheless, out of friendship for Battalion Commander Egashira, who was four years his junior [at the academy] and who was hurrying up from the rear to catch up, he did not try to seek the honor. Battalion Commander Wakamatsu ordered the battalion to secure the present position. At this time, it was gradually getting dark.

Staff Officer Yamashita was about to descend the mountain to report the situation to the detachment headquarters, but judging that Detachment Commander [Shōji] must be on his 
way to catch up and afraid that they would cross each other, he reversed course and returned to the trench where Battalion Commander Wakamatsu was positioned.

In this period, the detachment headquarters was positioned to the south of Ciater (near the previously mentioned second line of pillbox positions). ${ }^{(75)}$

The Endō Air Division supported the Wakamatsu Unit in the attack on the stronghold with almost all its strength the whole day on the 6th as well. The fighter plane unit launched seven times a total of twenty aircraft in support. Its air groups of assault planes and light bombers (i.e. the 27th, the 75th and the 90th Air Groups) supported the operations with a total of seventy aircraft. On that day, one antiaircraft artillery battery arrived for the air defense at the Kalijati airfield, but Air Division Commander Endō sent this antiaircraft artillery battery to the stronghold line, saying: "This battery should be employed for the artillery of the Shōji Detachment because the detachment does not have sufficient artillery." On that day, there were no attacks by allied aircraft on the Kalijati airfield. On that day, Air Division Commander Endō [also] sent a total of nine light bombers to support the $2 \mathrm{~d}$ Division, which had seized Batavia on the night of the 5 th and Buitenzorg on the morning of the 6 th. ${ }^{(98,99)}$

\section{The 7th [of March]: The Bandung Garrison Offers to Surrender}

As we have seen, [the Wakamatsu Unit] had seized the most important position on the ridgeline (the highland on the west side of the main road) on the evening of the 6th. At daybreak on the 7th, the Wakamatsu Battalion, which had stayed up all night securing the position, started mopping up [the enemy] at all positions near the road on the ridgeline. To be precise, it [first] mopped up with one powerful element [the enemy] at the reserve position (an uncompleted position on the west side of the main road) behind the Cicenang [position] on the morning of the 7th, and then [mopped up] those at the position southeast of the Cicenang position from the rear. While keeping his main force on the west side of the main road, Battalion Commander Wakamatsu deployed one element on the col above the main road. It was out of consideration for the Egashira Battalion, i.e. on the arrival of the battalion, by letting it use the main road (a motor road), he would let it be the first to enter Bandung. ${ }^{(41)}$

At the detachment headquarters positioned to the south of Ciater (near the previously mentioned second line of pillbox positions), Detachment Commander Shōji was worried about the Wakamatsu Unit because contact with the unit had been lost since the evening of the 6th. Around 0630 (on the morning of the 7th) Deputy Regimental Adjutant Nakajo returned to the headquarters and reported that the Wakamatsu Unit had seized last evening "the position that had been taken for something like an outpost," but that it had turned out to be the main and most important position, and that since daybreak of that day, the 7th, the unit had been mopping up the enemy at the line of positions across the mountain ridge. The detachment commander immediately rushed to the scene by car, met Battalion Commander Wakamatsu around 0700 to learn that the latter had completed seizing the positions across the mountain ridge, and congratulated him on his success. ${ }^{(75)}$

Staff Officer Yamashita offered his opinion that [the detachment] should carry out the pursuit. Colonel Shōji accepted this opinion, but he [also] accepted Battalion Commander Wakamatsu's opinion regarding the disposition of forces to be employed in the pursuit. The detachment commander decided to wait for the Egashira Battalion and in the pursuit of the defeated enemy first advance to the edge of the plateau. He deployed his troops in such a 


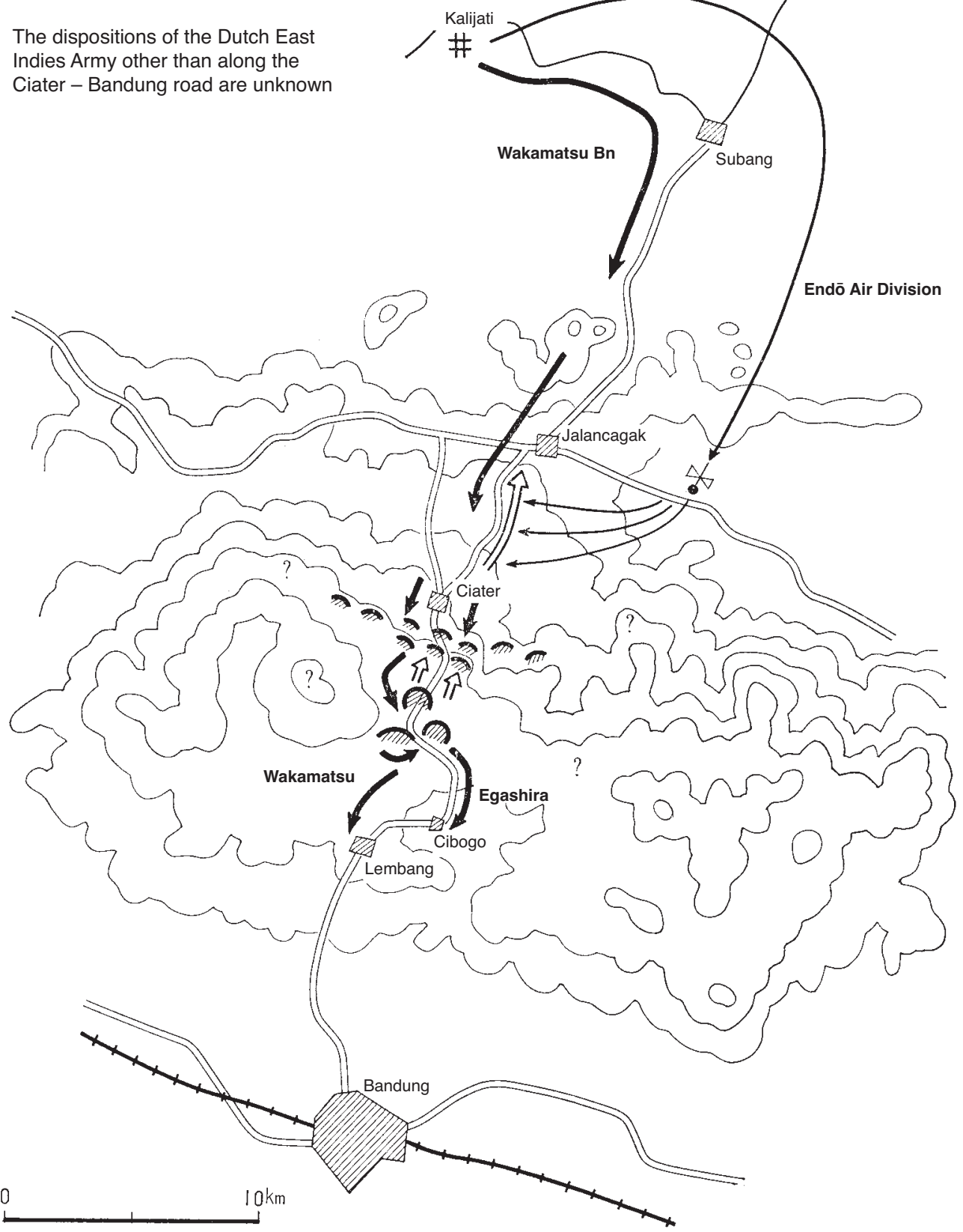

Illustration No. 59 - [The Military Situation Between] 5 and 7 March

way that the Wakamatsu Unit as the right pursuit unit to the west of the main road and the Egashira Battalion (minus two companies) as the left pursuit unit in the sector of the main road would respectively attack the enemy still there and first of all pursue them to the edge of the plateau. ${ }^{(41,75)}$

As the Egashira Battalion was late due to motor vehicle trouble, the detachment commander had the Wakamatsu Battalion depart at 1300 before the arrival of the Egashira Battal- 


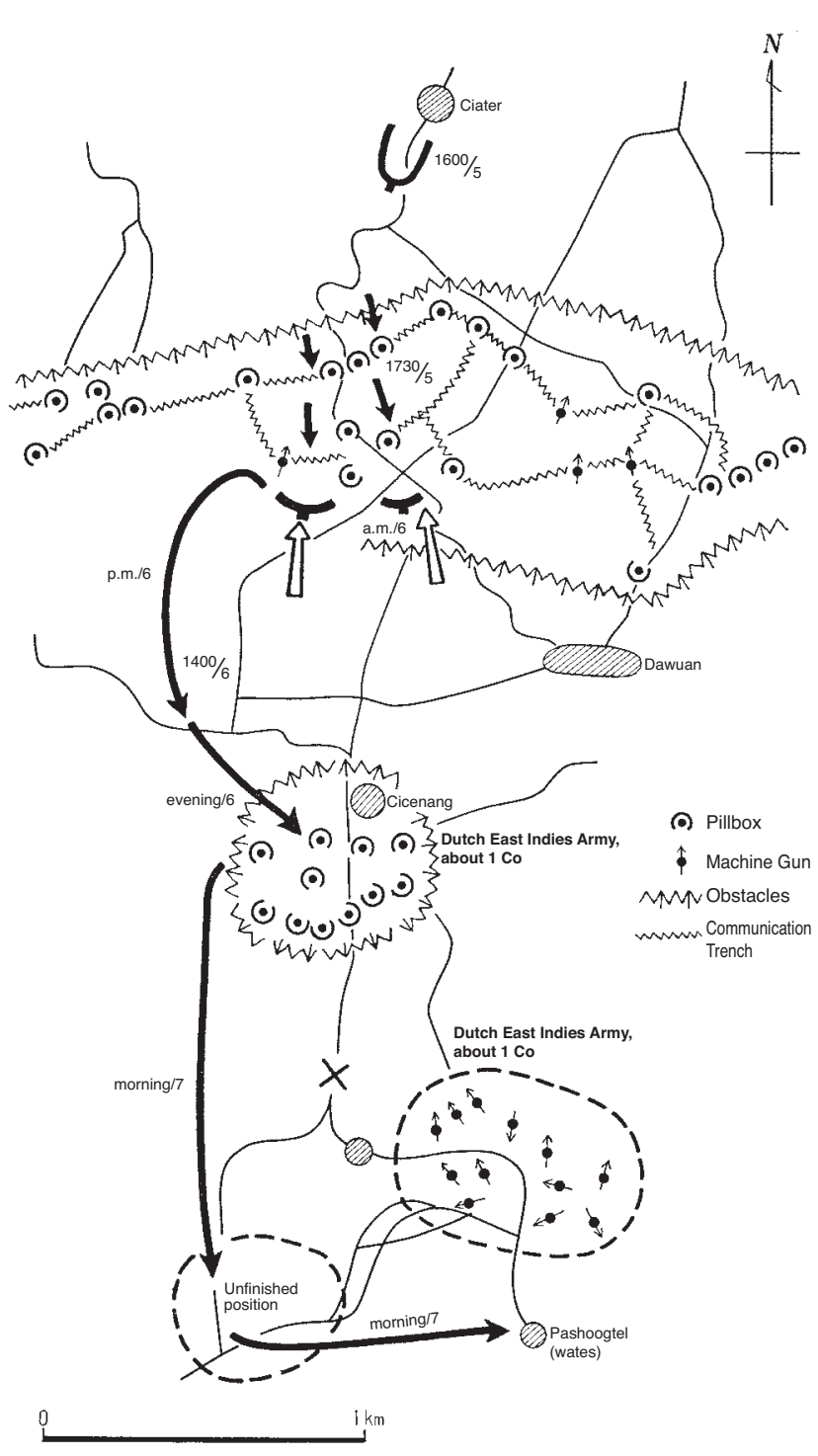

ion. He wanted to show an ardor for advance [on the part of the Japanese troops], so as not to give the enemy time to gather its strength and get ready [to fight back]. The Egashira Battalion got to the pass at 1500, and continued its advance southward. ${ }^{(31,}$ 41,75)

Although due to a squall and the bombardment by the Endō Air Division the road was muddy and the bridges had been destroyed, the Wakamatsu Battalion entered Lembang at 2000, then advanced to the plateau south of the city, and took up a position that overlooked Bandung below. The detachment commander decided to maintain all night this posture of readiness and kept on concentrating his force. ${ }^{(31,41,75)}$

Around 2100, Unit Commander Egashira (whose battalion had stopped at Cibogo, located northeast of Lembang, because the bridge there had been destroyed) reported that a bearer of a flag of truce had come to the front of the $3 \mathrm{~d}$ Company. [The detachment commander] immediately had the bearer escorted to him and received him. The bearer (a Dutch captain) said: "I have come as envoy of Bandung Garrison Commander Major General Pesman. As

Illustration No. 60 - The Attacks of the Wakamatsu Battalion of he has the intention to surrender, he the Shoji Detachment from Ciater to the Pass

would like the attack on Bandung to be suspended." Colonel Shōji said: “I

will send Staff Officer Yamashita and others to the Isola Hotel in the suburbs of Bandung at 1000 tomorrow, the 8 th, for negotiations." The bearer wore an expression as if convinced that [Twenty-fifth] Army Commander Yamashita, who had captured Malaya, had come to this front. But realizing that it was Staff Officer Yamashita, he took his leave with a perplexed look. ${ }^{(75)}$

Colonel Shōji immediately wired Army Commander [Imamura] to ask for instructions. ${ }^{(75)}$

Before daybreak on that day (the 7th), allied aircraft had raided the Kalijati airfield, which had caused more than twenty casualties. [3d] Air Division Commander Endō conducted a retaliatory strike with sixteen aircraft at dawn and destroyed ten-odd aircraft at the Tasik- 
malaya airfield (eighty kilometers southeast of Bandung). On that day, a total of twenty-five aircraft of the fighter plane unit and a total of sixty-five aircraft of the assault plane and the light bomber units of the Endō Air Division directly supported the Shōji Detachment, and a total of fourteen aircraft of the light bomber unit attacked Bandung. On that day (the 7th), when the Shōji Detachment pursued [the Bandung Garrison] from the ridgeline of the Bandung stronghold to the city of Bandung with the support of the Endo Air Division and made the Bandung Garrison surrender, Air Division Commander Endō received a telegram from the Sixteenth Army, saying: "Because the Sixteenth Army will rapidly divert the 2d Division and attack the Bandung stronghold with the 2d Division and the Shōji Detachment together, it requests on that occasion an air strike on Bandung on 10 March." $(96,98,99)$

\section{(4) The Surrender of the Dutch East Indies Army}

\section{The Meeting with the Governor-General and His Party}

Late at night on the 7th (after 0000 on the 8th), the [Sixteenth] Army headquarters in Batavia learned that "at 2230 on the 7th, an offer of surrender [was made] to the Shōji Detachment." It immediately wired to Detachment Commander Shōji, saying: "(1) The meeting shall be held at the Isola Hotel in Bandung at 1000 on the 8th; (2) See to it that not only Major General Pesman but also Governor-General [Tjarda van] Starkenborgh [Stachouwer], and Lieutenant General Ter Poorten, commander of the Dutch East Indies Army (chief of the Dutch East Indies Army Department) attend the meeting." But soon after that, [the army headquarters] changed it, and wired [again] that [the detachment] should pass the message that (1) the time and venue of the meeting should be changed to 1400 on the 8th at Kalijati, and that (2) if the governor-general of the Dutch East Indies and the Dutch East Indies Army commander would come to the said place at the said time accompanied by the necessary staff officers and meet the commander of the Japanese Army to directly offer a cease-fire, [they would be] instantly [informed of] the decision of whether it would be accepted or not, and that their safety on the way [to Kalijati] and back within the area occupied by [the Japanese] would be guaranteed. ${ }^{(35,98)}$

Army Commander Imamura planned to steer the offer of surrender from the commander of the Bandung sector to the surrender of all the allied forces in the Dutch East Indies. He gave a direct order to Staff Officer Saiki to depart and convey to $2 \mathrm{~d}$ Division Commander Maruyama the message that "the enemy is starting to lose its fighting spirit," and that "the shift of the $2 \mathrm{~d}$ Division needs to be carried out as quickly as possible in order to take advantage of this opportunity," while he himself decided to advance to Kalijati with Staff Officer Okazaki and the other staff by $1400 \cdot{ }^{(34,35)}$

At 0800, Staff Officer Saiki left Batavia, arrived in Buitenzorg at 0900, and delivered the message to $2 \mathrm{~d}$ Division Commander Maruyama. ${ }^{(34)}$ At that time, the situation of the $2 \mathrm{~d}$ Division was as follows:

1. The $2 \mathrm{~d}$ Division, which had seized Buitenzorg on the morning of the 6th and received [Sixteenth] Army order(s) that evening to shift to the northern front of the Bandung stronghold with its main force, decided to [first] shift to the Purwakarta area with its main force. It gave order(s) to the Nasu Detachment (from which the reconnaissance regiment, the Fukushima Regiment and the Endō Battalion were removed, and to which the main force of the Sasaki Battalion was newly added at 0800 on the 7 th) to pursue the enemy at its front while advancing toward the direction of Bandung and gain a footing as widely as possible so as to have an advantage in subsequent 
engagements. [Editor's note: On p. 496 the Endō Battalion is called the Watanabe Battalion.] To the Satō Detachment (to which the Endō [Watanabe?] Battalion would be returned from the Nasu Detachment) it gave orders to prepare in Batavia and vicinity for the advance toward Purwakarta; to the Noguchi Detachment (whose assignment to the Nasu Detachment was lifted, and to which one element of the Sasaki Battalion was added at 0800 on the 7th) it gave orders to prepare in Buitenzorg for the advance toward Purwakarta. It [further] gave order(s) to the Fukushima Detachment (whose assignment to the Nasu Detachment would be lifted) to prepare in the area between Buitenzorg and Leuwiliang for the advance toward Purwakarta. ${ }^{(59)}$

2. The Nasu Detachment (which had seized Buitenzorg on the morning of the 6th) had sent one company in advance, leaving Buitenzorg at 1700 on the 6th for Cipayung and vicinity, which was located about ten kilometers southeast of Buitenzorg. It [also] separately had one platoon rush along the Buitenzorg - Cibadak - Sukabumi road (a national road) to secure the railway, and then had the $2 \mathrm{~d}$ Battalion of the regiment (the Hiroyasu Regiment) pursue [the enemy] along this area that night. However, the advance party encountered an allied unit in Cibadak and vicinity (some thirty kilometers south of Buitenzorg), and sustained many casualties. This [incident], along with the destroyed bridges, made [the detachment] give up the pursuit from this direction and have [the advance party and the battalion] reverse course. The main force of the detachment (which was reorganized and became [a unit of] a total of three battalions as the core, consisting of the Onoguchi 2d Battalion and the Morozumi 3d Battalion of the Hiroyasu Regiment, and the main force of the Sasaki Battalion, which had been the divisional reserve), left Buitenzorg at 2100 on the 7th, and was advancing toward Ciranjang along the Puncak Pass (some twenty-five kilometers southeast of Buitenzorg) - Ciranjang (forty kilometers west of Bandung) road. ${ }^{(31,61)}$

3. The Endō [Watanabe?] Battalion was returned to the Satō Detachment by the divisional order of the 6th. The Fukushima Detachment had the Ikuta 1st Battalion leave Buitenzorg toward Batavia by rail at 1330 on the 7 th, while having its main force stand by in Buitenzorg. ${ }^{(58,63)}$

Staff Officer Saiki told Division Commander Maruyama: “Army Commander Imamura has strongly demanded that the $2 \mathrm{~d}$ Division should complete its advance into the area north of the Bandung stronghold within twenty-four hours." (34)

At that time, Army Commander Imamura had left Batavia and was heading for Kalijati. [Meanwhile,] Air Division Commander Endō in Kalijati had received a telegram with the "request to suspend the bombing" at 0800, after which he learned that an offer of surrender had been made to the Shōji Detachment on the previous night, and that a meeting between the Sixteenth Army and the allied forces would be held at the Isola Hotel in Bandung at 1000 that day. Detachment Commander Shōji had dispatched Staff Officer Yamashita to the Isola Hotel as military envoy. ${ }^{(75,98)}$

Staff Officer Saiki, who had delivered the message to Divisional Commander Maruyama at 0900, immediately reversed course and rushed to the Krawang bridge. Because the bridge had been destroyed, there was an endless column of motor vehicles that had come to a standstill [before the bridge]. He caught up with Army Commander [Imamura] at the crossing point in Krawang. The army commander was trying to build a raft with iron pontoons to ferry the motor vehicles across the river. ${ }^{(34)}$

At that time, having learned that the venue of the meeting had been changed and that the army commander had left Batavia, Air Divisional Commander Endō in Kalijati offered a car to pick up the commander. ${ }^{(98)}$

In the meantime, Staff Officer Yamashita was negotiating with the Dutch East Indies side at the Isola Hotel in Bandung. The Dutch East Indies side was reluctant to send the gover- 
nor-general and the other officials to Kalijati but agreed to it at last. ${ }^{(41,75)}$

In the early afternoon, the governor-general of the Dutch East Indies and his party visited in Lembang the headquarters of Shōji Detachment, which stood ready for combat, paid their respects to Detachment Commander Shōji and headed for Kalijati. ${ }^{(75)}$

Around 1500, the governor-general of the Dutch East Indies and his party arrived in Kalijati. [3d] Air Division Commander Endō received them, saying: “We have accepted your offer of a cease-fire in conformity with the Japanese code of the warrior. The commander of our ground forces is due to arrive later. After conferring with him, we probably will make demands. If you accept them, we will agree to a cease-fire; otherwise, we will probably bomb Bandung right away with our aircraft, which are ready to be launched, as you can see." Then he let them wait. ${ }^{(98)}$ After a while at 1600, [Sixteenth] Army Commander Imamura, Chief of Staff Okazaki, and the other staff arrived. . $^{(33)}$

At 1800, Army Commander Imamura started the meeting. ${ }^{(33)}$

With Army Commander Imamura at the center, Chief of Staff Okazaki was seated at his right and Air Division Commander Endō at his left; Bandung Area Garrison Commander Major General Pesman, Governor-General Tjarda [van Starkenborgh Stachouwer], Army Department Chief Lieutenant General Ter Poorten and Army Chief of Staff Major General Bakkers were seated from right to left across the table. Staff Officer Okamura Masayuki of [the Army Department of] IGHQ, who had accompanied [the Sixteenth Army] since the convoy left Cam Ranh Bay, [Sixteenth Army Senior] Staff Takashima Tatsuhiko, who was [just] out of hospital on the 7th, and other staff were at the side near Chief of Staff Okazaki, while Miyoshi Shunkichirō, attached to the Military Administration Department (who later became consul), was at the side near Air Division Commander Endō as interpreter together with the interpreter of the Dutch East Indies side. ${ }^{(13)}$

Army Commander Imamura asked the governor-general: "Do you represent all the forces, officials, and people in the Dutch East Indies in the capacity of governor-general of the Dutch East Indies?" "Yes," the governor-general answered. Army Commander Imamura asked: "In that case, can you, as you sit here, declare surrender or continuation of the war?" The governor-general blanched, looked down, and after a while answered: "No, I cannot." "Why?" Army Commander Imamura asked. The governor-general answered: “As governor-general of the Dutch East Indies, I had until recently the supreme command of the armed forces [of the Dutch East Indies]. But when General Wavell became supreme commander of the allied forces, I was simultaneously deprived of that prerogative by the order of the Queen." [Then] Army Commander Imamura turned to Army Commander Ter Poorten and asked: "How about you?" The latter answered: "I don't have such authority, either." Army Commander Imamura kept on asking: "In that case, what do you do as the chief of the Dutch East Indies Army Department?" [Commander Ter Poorten] inconsistently answered: "I can command the army." (13)

Army Commander Imamura asked the governor-general and his party: "In that case, why on earth did you gentlemen come here?" "We did not come of ourselves; you invited us," the governor-general answered. Army Commander Imamura asked: "If so, for what reason did you offer a cease-fire by sending a bearer of a flag of truce yesterday, the 7th?" "We offered a cease-fire to surrender the Bandung stronghold, because it is unbearable to further expose Bandung to the devastations of the war," the governor-general answered. Army Commander Imamura continued, "Then, what do you think about surrendering the entire Dutch 


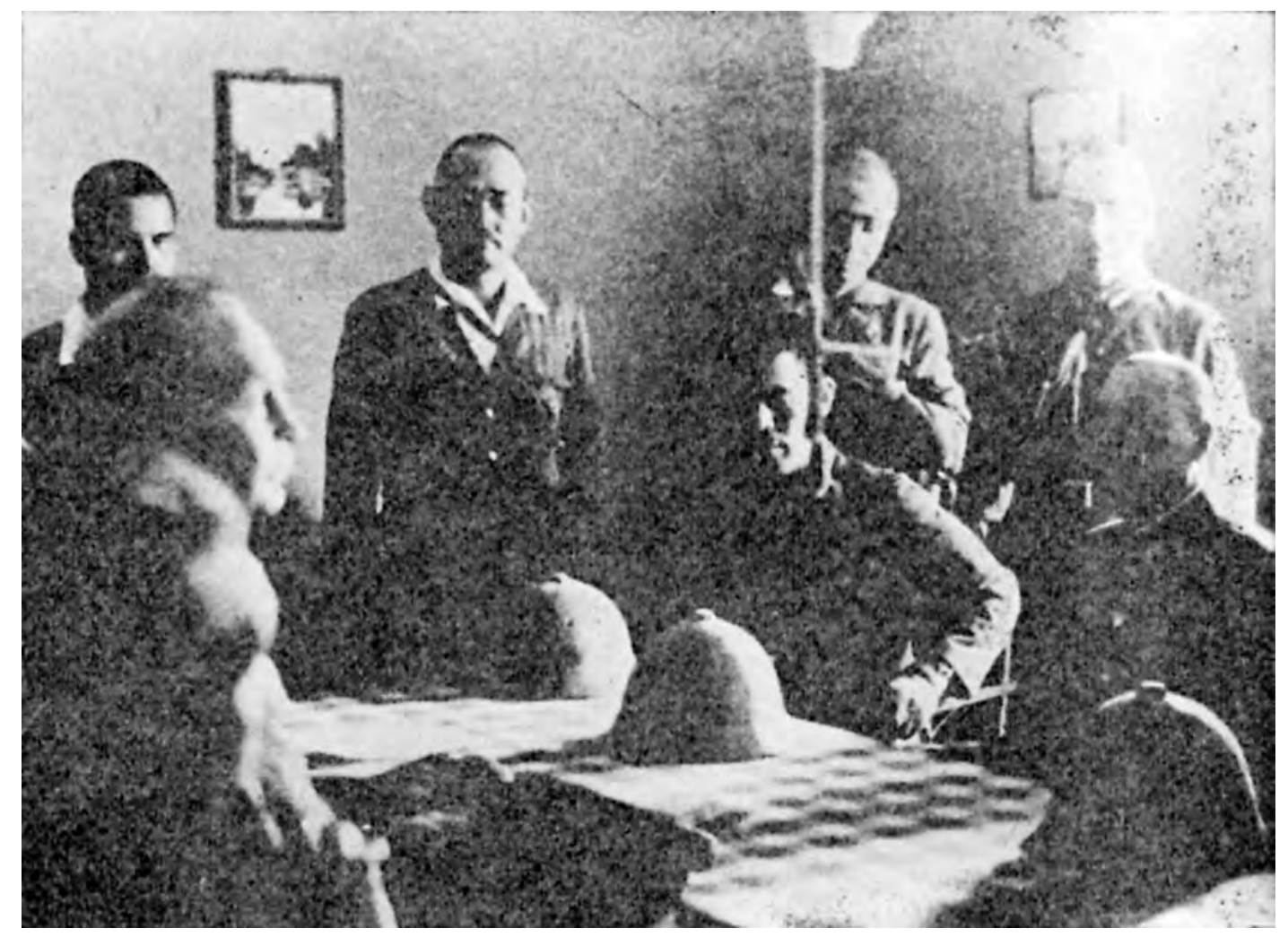

The Surrender Talks at Kalijati

East Indies?" "That is impossible, because I don't have such authority," the governor-general answered. Army Commander Imamura went on: “Do you mean you can make war but cannot surrender?"

The governor-general answered: "Only the Queen can decide surrender. As we have no means of communication to petition the Queen for permission to surrender, we can do nothing." Army Commander Imamura said, "We are at war with each other at the moment. This is not a place to conduct diplomatic negotiations. We are here only to discuss a capitulation or the continuation of the war. In such a discussion, we cannot deal with you," and sent all non-military persons out of the room. ${ }^{(13)}$

After the governor-general had left the room, Army Commander Imamura asked Army Commander Ter Poorten: "Do you surrender, even if the governor-general disapproves?" Army Commander Ter Poorten said: "The state of Bandung and vicinity is too pitiful to look at. Bandung has become completely defenseless and the army has as good as disbanded. It is utterly unbearable to force the citizens into the horrors of war any further. I will surrender a considerably wide area of Bandung. Will you accept that?" Army Commander Imamura said: "The surrender of Bandung does not matter to the Japanese Army. Just seizing Bandung is quite easy for the elite troops of the Japanese Army. If surrendering is that impossible for you, it is futile to parley any further. I will make it clear to you once again for the last time. The Japanese Army demands your overall and unconditional surrender. If you cannot accept 
it, leave now, and we shall promptly reopen hostilities and resort to force until the Dutch East Indies Army is destroyed. If you should have the intention to surrender totally and unconditionally, you must personally [address] the whole Dutch East Indies Army [through the radio] at the Bandung broadcasting station at 1200 tomorrow, the 9th, and give an order that the army shall stop all resistance after 1200 and that each regional unit shall surrender to the Japanese Army in its area. Our demands shall be read out to you now. You had better memorize them accurately and think them over." [Sixteenth] Army Chief of Staff Okazaki read out the demands. Army Commander Ter Poorten wrote his signature on the [Japanese] demands. It was 1950. Then, Army Commander Imamura continued: “For your reference, I will give you this [list of] our demands regarding the cease-fire. If you decide on an unconditional surrender, come here again, after broadcasting [the order of] cessation of hostilities to the whole Dutch East Indies Army tomorrow, to conclude the arrangements and agreements concerning the surrender." "What time should I come tomorrow?" Army Commander Ter Poorten asked. Army Commander Imamura answered: "We shall meet again at 1520. Just to make sure: if we cannot hear your radio address from Bandung here at 1200, it will mean that the Japanese Army will resume the attacks and the bombardments by the air units will also be resumed. If you understand what I mean, please go back to Bandung for the time being. We will safely show you to the first line of the stronghold." (13)

Thus, the first talks were over. The governor-general and his party took their leave at 2000.

That night, the Shōji Detachment still stayed up all night in Lembang and vicinity in a position of combat-readiness. ${ }^{(75)}$ The Nasu Detachment ([consisting of] three battalions as the core) rushed and advanced into Cimahi (eight kilometers west-northwest of Bandung) late at night (at 0200 on the 9th). At that time, the Sasaki Battalion, at the rearmost end of the detachment, was still midway between Buitenzorg and Leuwiliang. It was decided that the Nasu Detachment should prepare and be ready to attack Bandung, while gathering its strength in Cimahi. ${ }^{(59,61)}$ In the sector of the main force of the $2 \mathrm{~d}$ Division, there was no prospect [yet] for the reconstruction of the bridge at Krawang, and many motor vehicles remained at a standstill. Particularly, because the Satō Detachment, which had commandeered many motor vehicles (including passenger cars) in Batavia, was at the head of the column, it blocked the road. The detachment remained [stuck] west of Krawang along the Batavia Krawang road (until 0100 on the 10th). ${ }^{(63)}$ The Fukushima Detachment had the 1st Battalion leave Buitenzorg for Batavia by rail at 1300 on the 7 th, while the main force followed the battalion by rail [leaving] at 0930 on the 8 th. It got off at the Manggarai Station (south of Batavia) at 1130, and advanced in commandeered automobiles and on bicycles along the BataviaCibarusa (about thirty-five kilometers southeast of Batavia) - Krawang road, ${ }^{(58)}$ (and arrived in Krawang at 1400 on the 9th).

\section{Broadcast of the Surrender and the Second Meeting}

On the 9th, Air Division Commander Endō had intimidation flights conducted from the morning onwards. ${ }^{(98)}$ The Sixteenth Army command post in Kalijati grew tired of waiting for the advance of the commander of the $2 \mathrm{~d}$ Division. Before noon, the $2 \mathrm{~d}$ Division commander arrived [at last]. At 1200, the Dutch East Indies side made the following broadcast: 
The Japanese Army succeeded in breaking through into the intermountain area of Bandung. It has taken complete command of the air, which made it impossible for us to put up resistance for long in the intermountain area of Bandung. Therefore, we had no choice but to hold ceasefire negotiations.

The Japanese Army demanded prompt talks with our governor-general and me. In these talks, the Japanese Army commander made the following demands on 8 March:

1. Our overall surrender.

2. A prompt discontinuance of all hostilities.

3. The raising of white flags as a proof of our overall surrender.

4. All forces shall be disarmed and handed over. For this purpose, after disarmament, units in positions shall assemble at clearly visible places, and other units in barracks. Collected weapons and ammunition shall be gathered and put under supervision.

5. The demands stated in Items 1 to 4 shall be completed by 1200 on 9 March.

6. Bodies identified as Japanese military, goods of [Japanese] prisoners of war, and deceased and living Japanese residents shall be promptly handed over.

7. Any kind of destruction is prohibited. For example, the destruction of war materials, weapons, ammunition, roads or traffic structures is forbidden.

8. Communication with foreign countries is prohibited.

9. The operations of the Japanese Army shall be continued.

10. If the above demands are not met, attacks will be immediately resumed. In order to ensure [compliance with] the demands, armed patrol units necessary to maintain public order shall be formed and provided with a certain amount of weapons and ammunition. These patrol units need to be supervised by officers as much as possible. The patrol units shall be made distinguishable by a white armband and a white flag.

After due consideration, I finally had no option but to meet these stipulated demands. I order you to suspend the current hostilities and obey the above-mentioned demands.

When you have received this order, or when you have been contacted by the Japanese Army commander, I ask you to communicate or broadcast [this] through the available radio communication facilities and broadcasting stations, on every whole hour and every thirty minutes starting at 0900 until 1200.

This order applies also to the Navy and all directors of customs.

Major General Pesman, on behalf of the Chief of the Dutch East Indies Army Department

[Editor's note: Item 6 of the above is unclear. One would expect it to read: "prisoners of war and their goods ..." The introduction and ending of the broadcast were apparently translated from the Dutch broadcast into Japanese. There are some differences, which I have indicated in italics below:

After due consideration and with deep regret, I finally had no option but to meet these stipulated demands for the sake of land and people [of the Dutch East Indies]. I order you to suspend the current hostilities, obey the above-mentioned demands, and contact the highest Japanese commander in or near your sector.

I ask you, starting at 0900 Java time and thereafter every whole and half hour until 1200, to communicate by means of the available radio, telegraph, or broadcasting facilities the reception of this order and when you have established contact with the highest Japanese commander [in or near your sector].

This order applies also to the Royal Navy, the Dutch East Indies Navy, and all harbor masters.]

At that time, the positions of the [Japanese] units were as follows: ${ }^{(53)}$

Shōji Detachment: in Lembang (since the evening of the 7th) 
Nasu Detachment: in Cimahi (since 0200 on the 9th)

2d Division commander: in Kalijati (since before noon of the 9th)

Satō Detachment: in Krawang (since the night of the 7th)

Fukushima Detachment: near Cibarusa, about thirty kilometers southwest of Krawang (marching toward Krawang)

At 1430 (on the 9th), earlier than demanded, Army Commander (Army Department Chief) Ter Poorten and his party showed up at Kalijati again. The talks were resumed at 1440 . It was felt that Lieutenant General Ter Poorten was faithfully implementing the cease-fire process. At 1450, the signing of the instruments of surrender was completed. Army Commander Imamura permitted him to keep wearing his sword. Lieutenant General Ter Poorten left Kalijati accompanied by 2d Division Commander Maruyama. ${ }^{(33,34,98)}$.

Around 1800, Army Commander Imamura left Kalijati, and arrived in Lembang around 2100, where he established his command post. ${ }^{(34)}$

\section{Triumphal Entry into Bandung and Citations of Merit}

On the early morning of the 9th, the Sixteenth Army had decided on a plan that it would let the $2 \mathrm{~d}$ Division commander make a triumphal entry into Bandung together with and leading the Shōji Detachment. However, as the $2 \mathrm{~d}$ Division commander arrived late in Kalijati as previously mentioned, Detachment Commander Shōji entered Bandung by the order of Army Commander Imamura at 1500 on the 9th (the time when the second meeting at Kalijati was over) and began the work of requisitioning. ${ }^{(75)}$ When the $2 \mathrm{~d}$ Division commander, who left Kalijati around the same time, arrived in Bandung, the Shōji Detachment had already entered the city of Bandung. On the morning of the 10th, the $2 \mathrm{~d}$ Division commander told Detachment Commander Shōji that the detachment had been put under the command of the division at 1200 on the 9th, and had the main force of the detachment withdrawn from the city of Bandung, except for one battalion that was left behind. ${ }^{(75)}$ Then, the $2 \mathrm{~d}$ Division commander had one battalion of the Nasu Detachment enter [the city] at 1600. Detachment Commander Satō arrived in Lembang at 2400 that day (the 10th), and Detachment Commander Fukushima arrived in Subang at 1700 that day (the 10th). ${ }^{(31,53)}$

[Sixteenth] Army Commander Imamura, who had been positioned in Lembang the night before, left Lembang at 1630 that day (the 10th), entered Bandung at 1700, had a meeting with the $2 \mathrm{~d}$ Division commander, and then attended dinner at the mess. ${ }^{(34)}$ Staff Officer Yano of the Sakaguchi Detachment, whom he had not seen since they had parted in Moji, was [also] present at the mess, and reported on the capture of Davao, Jolo, Balikpapan and Banjarmasin, the landing in Kragan, and the progress of the seizure of Cilacap. ${ }^{(87)}$

Army Commander Imamura presented the following citation of merit to the Shōji Detachment:(13)

\section{Citation of Merit}

The Shōji Unit, the units attached to it and those posted to it

The above units landed in the face of the enemy in Eretan and vicinity in March 1942, several times crushed persistent enemy attacks conducted by air and land, unremittingly pursued the enemy, and seized the Kalijati airfield and the surrounding area as early as noon on the same day, and thus enabled [the army] to gain command of the air. They also cut off the communica- 
tion between Batavia and Bandung, broke through a corner of the Bandung stronghold with the support of the Endo Air Unit on the afternoon of the 5th, and thus provided a prime factor in the overall surrender of the enemy. The above operations were courageous, resourceful and extremely opportune; their military merit is outstanding. We present here this citation of merit and proclaim it to the whole army.

21 March, 1942

Imamura Hitoshi, Commander of the Army in the Dutch East Indies Theater

The [Army] Third Air Force Commander Sugawara presented the Endō Air Division with the following citation of merit, and proclaimed its distinguished military service. ${ }^{(13)}$

\section{Citation of Merit}

The 3d Air Division and the units attached to the division With the Palembang airfield as their base, the $3 \mathrm{~d}$ Air Division and the units attached to it, under the command of the $3 \mathrm{~d}$ Air Division commander, destroyed the superior enemy air power in western Java with a small force, overcoming every kind of difficulty. In the landing [operations] of the Sixteenth Army in western Java, they willingly took charge of attacking enemy warships, covered the convoy of the main force of the army and thus facilitated the landing. Upon the seizure of the Kalijati airfield by the Shōji Unit, they fearlessly advanced their base there without missing opportunities, eliminated the persistent enemy counterattacks by air and land, and boldly and actively secured the dominant position all the time by destroying the remaining enemy aircraft and supporting the ground forces in their advance, which completely shattered the enemy's will to put up resistance, and eventually led to the overall surrender of the Dutch East Indies in a very short period. Of course, their military gains were great, but their achievements, which contributed to the operational direction of the entire army, were indeed even greater; their military merit is outstanding. Therefore, we here award this citation of merit.

12 March 1942

[Army] Third Air Force Commander Sugawara Michiō 


\section{The Operations of the Sakaguchi Detachment}

\section{Operation Plan (See Illustration No. 61)}

Of the Sakaguchi Detachment, which had seized Banjarmasin on 10 February and whose participation in the Java operation had been approved on the 15th, [the unit consisting of] the 3d Battalion (commander, Lt. Col. Matsumoto Tadasu) as the core and led by Col. Yamamoto Kyōhei, commander of the 146th Infantry Regiment, was positioned at that time in Banjarmasin; the detachment headquarters and [the unit consisting of] the $2 \mathrm{~d}$ Battalion (commander, Maj. Kanauji Ken'ichi) as the core was in Balikpapan; and [the unit consisting of] the 1st Battalion (commander, Lt. Col. Kume Motozō) was in the Samarinda area, while of its ships the Ehime-maru and the Liverpool-maru were at Balikpapan, and the others at Palau. ${ }^{(88)}$

On the 16th, the detachment commander passed down his orders concerning the participation in the Java operation and embarked along with the 1st echelon ([the unit] consisting of the headquarters, the $2 \mathrm{~d}$ Battalion, the armored vehicle unit and the main force of the field artillery battalion as the core) on the Ehime-maru and the Liverpool-maru. At 0700 on the 22d, he left Balikpapan to join the convoy of the 48th Division. ${ }^{(88)}$ [Editor's note: On p. 445 the departure time mentioned was 0800.] The Teiryū-maru and the Nisshō-maru [Hiteru-maru] under the command of [Army] Maj. Takagi Takeo (the commander of the 44th Field Antiaircraft Artillery Battalion), which carried the personnel and goods left in Palau, arrived in Balikpapan at 1100 on the $22 \mathrm{~d}$, then departed from the port at 0600 on the $24 \mathrm{th}$, and joined the convoy at 0800 that day. ${ }^{(88)}$ [Editor's note: There is some confusion about when these ships joined the convoy. Based on the same original sources, the $23 \mathrm{~d}$ is given as the date on pp. 445-446, while on pp. 449-450 the 24th is given as the date and 1600 as the time.] [The unit, consisting of] the 146th Infantry Regiment (minus the 1st Battalion (minus one company) and the 2d Battalion) and one field artillery battery as the core, under the command of Colonel Yamamoto, was to catch up as the $2 \mathrm{~d}$ echelon on the Sagami-maru and the Sasako-maru, which would be brought around after the Bali operation, but because only the Sasako-maru came, [the unit] left Banjarmasin on this ship on the 26th, and joined the convoy that day. ${ }^{(119)}$ [Editor's note: The Sagami-maru had been severely damaged in the Bali operation. See p. 401.] Because the date of the landing on Java was postponed twice, these units could fortunately each time still join the convoy. However, the Sasako-maru, which had sustained damage in the Bali operation, was not so fast as to be called a high-speed ship anymore. With her speed decreased to five knots, she could not keep up [with the other ships] during their rapid progress on the 28th and arrived in Kragan one day behind. ${ }^{(88,119)}$

As we have seen, the mission of the Sakaguchi Detachment was to land in Kragan under the direction of the 48th Division commander, charge toward Cilacap through the sector west of [the line connecting] Mt. Lasem and Mt. Lawu, and seize the city. After securing the beachhead, the 48th Division was expected to seize Rembang and Ngawi in the sector of the Sakaguchi Detachment, and take over Blora from the Sakaguchi Detachment.

Located between Kragan and Cilacap were Surakarta, the capital of the principality of Solo, and Yogyakarta, the capital of the principality of Yogya; the area north of Surakarta was an extensive plain with the Solo River flowing northeastward and the Serang River northwestward. Semarang was a strategic port, and Magelang was the garrison city of the central territorial command of the Dutch East Indies. 
It seemed highly unlikely that the allied forces would counterattack the landing point in Kragan with their main force. Blora was suitable as a jumping-off base to be used after Kragan. Purwodadi was located at a pivotal point to fan out from between Semarang, Magelang and Surakarta.

Having left the Kume Detachment in Borneo ([to be precise] leaving one infantry company with one gun in Tenggarong and vicinity, one infantry company in Banjarmasin, and the main force in Balikpapan under the command of 1st Battalion Commander Lt. Col. Kume Motozō), the Sakaguchi Detachment was to conduct the Java operation only with the remaining force of slightly more than two battalions. ${ }^{\left({ }^{88}\right)}$ [To hide its true size,] the detachment hit upon the idea to (1) make its strength for the Java operation look like one division, and for that purpose divide the detachment into three echelons, each with a strength of a little less than three companies, and make each [echelon] look like a regiment; (2) make it a point to charge ahead by motor vehicle; and (3) safely secure the various facilities. ${ }^{(87)}$ And thus it planned its operations roughly in the following way: ${ }^{(88)}$

\section{Outline of the Sakaguchi Detachment's [operation to] seize central Java (23 February)}

\section{Mission}

(1) The Detachment shall land in the area east of Kragan along with the 48th Division, then assemble in Blora and vicinity and in a rapid attack by way of Surakarta, Yogyakarta, Magelang, Wonosobo and the southern foot of Mt. Slamet, seize Cilacap by storm and cut off the escape route of the enemy from the direction of Batavia and Bandung.

(2) After that, the detachment shall mop up the remaining enemy and clean up the key areas in central Java in concert with the divisions in the adjacent sectors [i.e. the $2 \mathrm{~d}$ Division in western Java and the 48th Division in eastern Java]. Depending on the situation, it may participate in [the operation to] seize Bandung.

II. Directives

\section{First Phase}

(3) The 1st echelon shall depart from Balikpapan and the 2d echelon from Banjarmasin, and each of them shall land in Kragan under the direction of the 48th Division commander.

(4) After landing in Kragan and vicinity, the detachment shall promptly seize Blora with the unit consisting of the Kanauji Echelon as the core, and have [the echelon] gather information and secure an advance base. The detachment shall promptly advance the detachment command post there. The 48th Division shall seize Rembang and Ngawi with one element.

(5) After having essentially finished assembling in Blora and vicinity (scheduled for day three after the landing), the main force of the detachment, with the Matsumoto Echelon at the head and followed by the Yamamoto and the Kanauji Echelons in that order, shall rush toward Surakarta along the Blora - Purwodadi - Surakarta road and seize the city. As the seizure of Surakarta will be the first [major] engagement on the main island of Java for the detachment, it shall put particular emphasis on the total elimination of the enemy. For this purpose, it shall keep focused on the area west of the road and carry out the attack with great speed so as to cut off the escape routes of the enemy.

(6) After seizing Surakarta, the detachment shall have one element (the Kanauji Echelon) swiftly advance in the direction of Yogyakarta, while having the main force destroy the [enemy] position at the northern foot of Mt. Merbabu in a sudden attack from the south without missing an opportunity, then reverse course to seize Yogyakarta, and then at one go seize the [enemy] barracks in Magelang from the south. In this [attack on Magelang], the detachment shall have one element of the Matsumoto Echelon contain the 


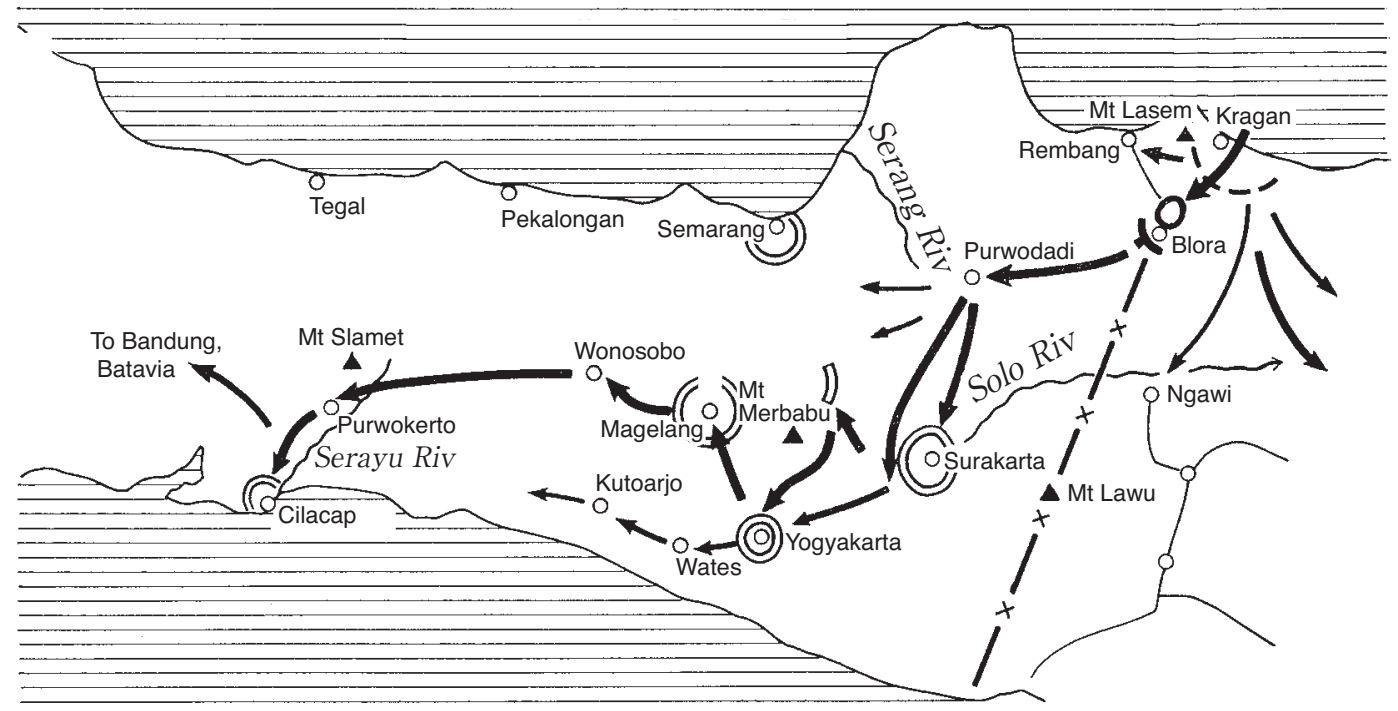

Illustration No. 61 - Overview of the Operation Plan of the Sakaguchi Detachment

enemy in Magelang from the north and the east. Depending on the situation, the detachment shall seize Magelang without attacking the [enemy] position at the northern foot of Mt. Merbabu. Magelang shall be seized on day six after the landing. After seizing Yogyakarta, the detachment shall have one element closely pursue the enemy via Wates toward Kutoarjo.

(7) After seizing Magelang, the detachment shall leave one element (one infantry company) there, advance via Wonosobo to the southern foot of Mt. Slamet and Purwokerto and vicinity by crossing the Serayu River as far upriver as possible, and expel the enemy from the highland to the north of Cilacap. After seizing the area, the detachment shall seize an opportunity to charge into Cilacap and secure the city. In this [action], [the detachment] shall also seize and secure the enemy battery on the cape south of Cilacap with one element by using [landing] craft. The seizure of Cilacap is scheduled on day ten after the landing at the latest.

(8) Disembarked military supplies shall successively be accumulated in Magelang via Surakarta and Yogyakarta.

(9) During the operations of this phase, support by one element of the naval air unit is expected.

(10) The theater of operations of the detachment is the area west of [the line connecting] Mt. Lasem and Mt. Lawu.

\section{Second Phase}

(11) After seizing Cilacap and eliminating the enemy escaping from Bandung and Batavia, the detachment shall promptly shift its main force to Magelang and vicinity, successively seize the key coastal areas of Java, such as Semarang, Pekalongan and Tegal, and mop up [the enemy] there in a timely manner.

(12) Depending on the progress of [the operation] of the main force of the [Sixteenth] Army to seize Bandung, [the detachment] shall anticipate sending a powerful unit to that area, and prepare for it.

3. Disposition of forces

Kanauji Echelon (Commander: Maj. Kanauji Ken'ichi) 
$2 \mathrm{~d}$ Battalion (minus one company and one platoon) of the 146th Infantry Regiment

One regimental gun platoon (minus one squad)

One antitank gun squad

Two mortars

3d Field Artillery Battery (two guns), as the core

Eight trucks

Matsumoto Echelon (Commander: Lt. Col. Matsumoto Tadasu)

$3 \mathrm{~d}$ Battalion (minus one company and one platoon) of the 146th Infantry Regiment

One regimental gun squad

One antitank gun platoon (minus one squad)

Two mortars

1st Field Artillery Battery (two guns), as the core

Eight trucks

Yamamoto Echelon (Commander: Col. Yamamoto Kyōhei)

Headquarters and three companies of the 146th Infantry Regiment

Regimental gun company (minus one section)

Antitank gun company (minus one platoon)

Field artillery battalion headquarters and one field artillery section, as the core

Seven trucks

Unit under the direct command of the headquarters

Headquarters

One infantry platoon

Armored vehicle unit

Transport company

Line-of-communication motor transport company, as the core

\section{Implementation of the Operation (See Illustration No. 62)}

The 1st Echelon [Kanauji], being at the rear of the 48th Division, beat off persistent attacks by allied aircraft from the night of 28 February onwards and entered the anchorage at 0230 on 1 March. It started landing at a point six kilometers southeast of Kragan (to the left of the 48th Division) at 0700. ${ }^{(88)}$ The Kanauji Echelon departed [from the landing point] without delay and seized Blora at 2000, from where about one battalion of the Dutch East Indies Army had just retreated, and began to gather information. The 2d Echelon (the Sasako-maru) entered the anchorage one day behind. The Yamamoto and the Matsumoto Echelon landed at 1230 on the $2 \mathrm{~d}$, departed at 2200, and reached Blora before dawn on the $3 \mathrm{~d}$. Meanwhile, the detachment commander had landed on the afternoon of the 1st and immediately advanced to Blora. The Kanauji Echelon turned over [the guarding of] Blora to the 48th Division on the 2d, departed [from the town] at 1500, drove away twenty to thirty troops of the Dutch East Indies Army in Ngawen and seized Purwodadi at 0330 on the $3 \mathrm{~d}$. The detachment commander decided to advance his force to Purwodadi in succession and assemble them there in preparation for the seizure of Surakarta. After giving orders at 0800 on the $3 \mathrm{~d}$ in Blora to the Matsumoto and the Yamamoto Echelon to depart [from the town] in that order, he left Blora at 1300 on the same day, and advanced to Purwodadi. ${ }^{(31,88)}$

Detachment Commander [Sakaguchi] concluded in Purwodadi that the allied units in Semarang and Magelang had no intention to take the offensive toward Bugel [Godong] and Salatiga, and decided to attack the allied units in Surakarta and vicinity the next day, the 4th, to capture and eliminate them. At 1500 on the 3d, he ordered to the Kanauji Echelon (to which 
an armored vehicle unit was attached up to its arrival in Bugel [Godong] and the 2d Transport Company from there onwards) to quickly advance to Bugel [Godong], and after containing the allied units ([consisting of] about 600 [troops]) in the Semarang area, leave Bugel [Godong] at 0900 on the 4th and advance to the sector east of Klaten via the Juwangi - Karanggede Boyolali road to cut off the escape route [of the enemy]. [Then,] he gave orders to the Matsumoto Echelon (to which an armored vehicle unit was attached) to leave Purwodadi at 1200 on the 4 th to attack the allied unit in Surakarta via the Purwodadi-Surakarta road. Also, he ordered the Yamamoto Echelon to assemble in Purwodadi as swiftly as possible on the next day, the 4 th. ${ }^{(87,88)}$

The Kanauji Echelon left Purwodadi at 1850 on the 3d and seized Bugel [Godong] at 1950, driving away about thirty troops of the Dutch East Indies Army. After containing the allied unit in the Semarang area, it left [Bugel/Godong] at 0800 on the 4th to head southwestward. The Matsumoto Echelon left Blora at 0300 on the 4th, reached Purwodadi at 0600, and left the town at 1200, to head south. ${ }^{(31)}$ At 0900 on the 4th in Purwodadi, Detachment Commander [Sakaguchi] ordered the Yamamoto Echelon to depart after 1400, advance along the Purwodadi - Surakarta road to the west of Surakarta and cut off the escape routes [of the enemy]. He also ordered the echelon to take over the armored vehicle unit from the Matsumoto Echelon after advancing to Kalioso, and to bring the Kanauji Echelon under its command as well after advancing to the west of Surakarta. ${ }^{(88)}$ The detachment commander was going to leave Purwodadi for Surakarta at 1700. ${ }^{(88)}$

However, the Matsumoto Echelon's southward advance was fraught with difficulties because the road and bridges along the Purwodadi - Surakarta road had been destroyed at many places. At 1500 (on the 4th) in Purwodadi, Detachment Commander [Sakaguchi] changed his mind and had the main force of the detachment advance at the rear of the Kanauji Echelon [instead of the Matsumoto Echelon] to the west of Surakarta to capture and crush the allied units in the vicinity. [So,] he ordered that the Yamamoto Echelon should advance at the rear of the Kanauji Echelon to the west of Surakarta to cut off the escape route(s) [of the enemy], but that the previous order concerning the command of the Kanauji Echelon should stay as it was, and that the headquarters should head for Boyolali, [also] following the course of the Kanauji Echelon. ${ }^{(87,88)}$

At 1830 on the 4th, the Yamamoto Echelon left Purwodadi. ${ }^{(31)}$ The Matsumoto Echelon went southward beyond the (two) bridges destroyed by the allied unit. It drove away a Dutch East Indies Army unit consisting of twenty to thirty men accompanied by armored vehicles north of Surakarta at 0055 on the 5th, advanced to the front of an [enemy] position to the north of Surakarta ([guarded by] 200 to 300 troops) at 0135, launched a charge at 0615 on the 5th, and seized Surakarta ([guarded by] a Dutch East Indies Army unit totaling 700 to 800 troops). ${ }^{(31)}$

The road and bridges on the route of the Kanauji Echelon, which headed southwestward to the west of the Matsumoto Echelon, had been destroyed everywhere, while felled trees also blocked the road. In spite of these difficulties, the echelon advanced and seized Boyolali at 1130 on the 5th, driving away about one hundred troops of a Dutch East Indies Army unit. $^{(31,87)}$

The detachment headquarters, which was following the Kanauji Echelon, spotted a small number of Dutch East Indies troops heading westward from Surakarta in total disarray. The headquarters changed its plan without delay, decided to seize Yogyakarta at a stroke, and 
ordered the Kanauji Echelon to charge toward Yogyakarta, taking a short cut. The echelon left Boyolali at 1230 and rushed ahead. The detachment headquarters followed it traveled at a speed of over 100 kilometers per hour and rushed into Yogyakarta at 1730. The charge took place when the garrison commander of the Dutch East Indies Army there was just about to give orders concerning the defense [of the city] to the 700 men under him, all of whom were taken prisoner. ${ }^{(31,87)}$

The effective strength of the allied forces had become clear. This was the opportunity to take the offensive. Detachment Commander Sakaguchi (assisted by Staff Officer Yano) changed the operation plan, decided to closely pursue the enemy by covering the long distance along the coastal road to Cilacap at one go with the main force led by Regimental Commander Yamamoto, while he himself, leading one element, would subdue Magelang, the garrison city of the central territorial command. He passed down the following order: ${ }^{(88)}$

SAKA [Sakaguchi Detachment] Operation Order A, No. 37

\section{Sakaguchi Detachment Order}

Yogyakarta, 2100, 5 March

1. The enemy in Yogyakarta has surrendered unconditionally. The defeated enemy is retreating to the west and the north without restraint.

2. The detachment shall closely pursue the defeated enemy and promptly seize Cilacap and Magelang.

3. Echelon Commander Yamamoto shall hotly pursue the defeated enemy, promptly seize Cilacap, and cut off the escape route of the enemy. He shall take command of the Kanauji Echelon as decided before.

The armored vehicle unit and one platoon of the 259th Independent Motor Transport Company shall be removed [from the echelon]. They shall promptly be sent to Surakarta.

4. The Matsumoto Echelon shall leave Surakarta on the morning of tomorrow, the 6th, and promptly seize Magelang by way of Yogyakarta, while hotly pursuing the enemy.

The armored vehicle unit and one platoon of the 259th Independent Motor Transport Company shall be attached to the echelon at Surakarta.

5. - 7. (Omitted by the author.)

8. I am in Yogyakarta. I will advance toward Surakarta at 2300 today.

\section{Detachment Commander Sakaguchi Shizuo}

It was decided to let only a captain, a noncommissioned officer and one private deal with the 700 prisoners in Yogyakarta. ${ }^{\left({ }^{8}\right)}$ Detachment commander [Sakaguchi] waited for Regimental Commander Yamamoto to report, but since the latter did not show up, the detachment commander left Yogyakarta at 2300 as scheduled and made a U-turn to Surakarta ${ }^{(87)}$ in order to give instructions concerning Surakarta after its seizure as well as to send the Matsumoto Echelon to Magelang. He arrived in Surakarta after a long drive at night to find the Yamamoto Echelon busy preparing in their mess tins two meals, one for that evening and the other for the next day. The echelon explained that it had acted as previously ordered and that it had arrived in Surakarta at 1730. ${ }^{(87)}$ The detachment commander ordered [the echelon] to immediately start [for Cilacap]. The Yamamoto Echelon left Surakarta in the middle of the night (at 0100 on the 6th). ${ }^{(31)}$

The Yamamoto Echelon reached Yogyakarta at 0600 on the 6th, and left there without a break to follow the Kanauji Echelon. 
[The echelon] charged ahead while driving away about one hundred troops of a Dutch East Indies Army unit in Purworejo at 1230, about one hundred in Kebumen at 1620, and another one hundred in Gombong, and advanced into Maos in the evening, where it stopped because the bridge [there] had been destroyed. On that day, the 6th, the distances that the Kanauji and the Yamamoto Echelon covered were respectively about 170 kilometers and about 220 kilometers. The Kanauji Echelon had traveled about one hundred kilometers on average day in and day out since the landing. The drivers alternately stood and sat behind the wheel and some crashed their cars on a straight road. It was because driving without rest or sleep day after day dazed their eyes, and when the car ahead suddenly loomed straight in front, they cut the steering wheel in panic [and crashed]. Many drivers got sweat rashes because they gripped their steering wheels too tightly to wipe off their sweat. In that way, on that evening (the 6th) they reached the Serayu River, where Cilacap was seen at a calling distance. Unfortunately, the bridge had been destroyed, which meant that they had to set about preparing to cross the river. ${ }^{(31,87)}$

The Matsumoto Echelon, which was to head for Magelang, left Surakarta that morning (of the 6th), and via Yogyakarta advanced to the front of the [enemy] position in Magelang in the evening. Accompanied by the detachment headquarters, [the echelon] started its attack at 1715, against which an allied unit fought back with fierce gunfire. The Matsumoto Echelon had prepared itself for a hard battle all the more because Magelang was a garrison town. [However,] before long, the gunfire of the allied unit ceased abruptly. From a precedent at Tarakan, Staff Officer Yano judged that it meant surrender, and headed for the town of Magelang with three men in a single captured armored vehicle. They kept advancing in spite of a heavy squall, which struck them just then, and all of a sudden they came upon an envoy of the garrison army (a lieutenant colonel), who was approaching them holding a white flag. The lieutenant colonel asked them to stop the attack because the garrison army was surrendering. They put him in the armored car and entered Magelang. Before long, [Infantry] Group Commander Sakaguchi also arrived. Having been told that the troops of the Japanese Army sent to this front were just one element and that the main force was advancing toward Semarang and Ambarawa, the garrison commander said that he would see to it that the Dutch East Indies Army in those areas would also surrender. In reality, there were no [Japanese] troops heading for those areas. Without delay, the detachment commander hurriedly sent one platoon to those areas along with an officer of the Dutch East Indies Army. In this way, [the detachment commander] was able to have within that night 1,700 officers and men including Colonel Fleischer of the Dutch East Indies Army in the city of Magelang, 600 in Semarang, 200 in Salatiga, 160 in Ambarawa, and 70 in Temanggung surrender. ${ }^{(31,87)}$ At 1900, the detachment commander gave the following order: ${ }^{(88)}$

SAKA [Sakaguchi Detachment] Operation Order A, No. 38

\section{Sakaguchi Detachment Order}

Magelang, 1900, 6 March

1. The enemy has surrendered unconditionally.

2. The detachment shall push all the harder to capture [the remaining areas].

3. The Matsumoto Echelon shall park at the car assembly point at the north end of Magelang and after finishing refitting the vehicles of the unit, at one go secure the bridge in Banjarnegara.

4. I shall advance at the rear of the Matsumoto Echelon. 
At daybreak (on the morning of the 7th), the Matsumoto Echelon resumed its rapid advance. It drove away fifty troops of a Dutch East Indies Army unit in Wonosobo, then attacked 160 troops in the evening, and entered Banjarnegara at night. It left the town on the morning of the next day, the 8 th, passed through Bukateja, where the bridge had been destroyed, at 1045, and reached Purbalingga at 1215. The bridge [there] had been destroyed [as well]. There the detachment commander learned that [his detachment] had successfully seized Cilacap at 1240 on that day, the 8 th. ${ }^{(31,87)}$

On the evening of the 6th, the Kanauji Echelon, which had advanced to Maos at the bank of the Serayu River, defeated some 150 troops of a Dutch East Indies Army unit equipped with armored vehicles, and reconnoitered the area of Maos along the upper and the lower reaches of the Serayu River, [only] to find that all the bridges had been destroyed. [Consequently,] it made preparations to cross the river from the evening of the 6th to the evening of the 7th, crossed the river at 2000 on the 7 th, and charged into Cilacap at 0340 on the 8th. The Yamamoto Echelon, which had followed the above echelon, also arrived in Cilacap at 1500 on the same day (the 8th). ${ }^{(87)}$

In the evening (the evening of the 8th), Detachment Commander [Sakaguchi] issued the following order in Purbalingga: ${ }^{(88)}$

SAKA [Sakaguchi Detachment] Operation Order A, No. 39

\section{Sakaguchi Detachment Order}

Purbalingga, 1710, 8 March

1. The Yamamoto Echelon has seized Cilacap at 1240 today, the 8th. It seems that the enemy has destroyed all bridges and retreated to the west.

2. The detachment shall closely pursue the enemy.

3. The Yamamoto Echelon (to which the Kanauji Echelon is attached) shall promptly seize Banjar (seventy kilometers northwest of Cilacap) and vicinity to eliminate the enemy retreating from the Bandung area, while leaving in Cilacap a minimal element necessary to maintain the public order there.

4. I am in Purbalingga and will advance toward Purwokerto.

On having finished crossing the river in Purbalingga, the Matsumoto Echelon left the town at 1950 (on the 8th) and advanced to Purwokerto at 2300. Bridges [there] had also been destroyed. $^{(31,87)}$ The detachment commander caught up with the echelon and issued the following order there at noon on the 9 th: ${ }^{(88)}$

SAKA [Sakaguchi Detachment] Operation Order A, No. 40

\section{Sakaguchi Detachment Order}

Purwokerto, 1200, 9 March

1. It seems that the enemy has practically lost its fighting spirit and is escaping to the west.

2. The detachment shall cut off the escape routes of the enemy with one element and eliminate the defeated enemy.

3. The Matsumoto Echelon shall be positioned in Kranggan and vicinity and catch and destroy the enemy retreating from the direction of Batavia. The armored vehicle unit shall be put under my direct control from now on.

4. - 5. (Omitted by the author.)

6. I will leave Purwokerto at 1300 and go to Cilacap. 
However, one hour later (at 1300), an envoy of Major General Cox came from Wangon to the Yamamoto Echelon and offered to surrender. ${ }^{(31,87)}$ As we have seen, the surrender [of the Dutch East Indies Army] was broadcast from Bandung at 1200 on that day. Echelon Commander Yamamoto instructed the envoy to go to the detachment headquarters. ${ }^{(31,}$ ${ }^{87)}$ Detachment Commander Sakaguchi issued the following order: ${ }^{(88)}$

SAKA [Sakaguchi Detachment] Operation Order A, No. 41

Sakaguchi Detachment Order Purwokerto, 2000, 9 March

1. The enemy commander of central Java has offered to surrender.

2. The detachment shall maintain its readiness to attack in order to have the upper hand when disarming the enemy.

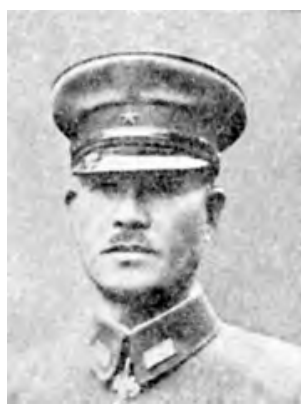

56th Mixed Infantry Group Commander Maj. Gen. Sakaguchi Shizuo

3. The Matsumoto Echelon shall assemble its main force in Ajibarang and vicinity and take charge of maintaining public order around there, while holding one element ready to attack the enemy at the bridge and its vicinity south of Ajibarang.

4. I am in Purwokerto.

Detachment Commander Sakaguchi Shizuo

At 1100 on the 10th, Detachment Commander [Sakaguchi] met Major General Cox at the residence of the Dutch East Indies Resident in Purwokerto and accepted his surrender. ${ }^{(31,87)}$ At 1200, the detachment commander passed down [the detachment] Operation Order A, No. 42 in Purwokerto. He ordered the Yamamoto Echelon (including the Kanauji Echelon) to promptly advance to Tasikmalaya and vicinity to monitor the disarmament. He [further] ordered the Matsumoto Echelon to assemble its main force in Ajibarang and vicinity and have it monitor the disarmament of the Dutch East Indies Army units north of Wangon (not included), while assigning one element to maintain the public order in the Tegal and Pekalongan area. ${ }^{(8)}$ In Wangon and vicinity, 2,000 troops under Major General Cox surrendered. ${ }^{(31)}$

Although the detachment commander remained positioned in Purwokerto, Staff Officer Yano immediately departed after the order was passed down and presented himself at the mess dinner (already described) with [Sixteenth] Army Commander Imamura and others that night (the night of the 10th) in Bandung. ${ }^{(87)}$ While everyone gave him an incredulous look, Staff Officer Yano reported that [the Sakaguchi Detachment] had subdued all the strategically important places from Semarang to Tegal on the north coast, from the south of Surakarta to the west of Cilacap on the south coast, and from Blora westward to Tasikmalaya in the central part. ${ }^{(87)}$

[Sixteenth] Army Commander Imamura presented the following citation of merit to the Sakaguchi Detachment, and proclaimed its distinguished military service to the whole army. ${ }^{(13)}$

\section{Citation of Merit}

The Sakaguchi [Infantry] Group and the units attached to it Going ahead of the army, the above expeditionary force drove deep into enemy territory and successively fought battles in the Philippine Islands and Dutch Borneo. Five times they carried out landings in the face of the enemy, fought hard, defeated a stubborn enemy and seized strate- 


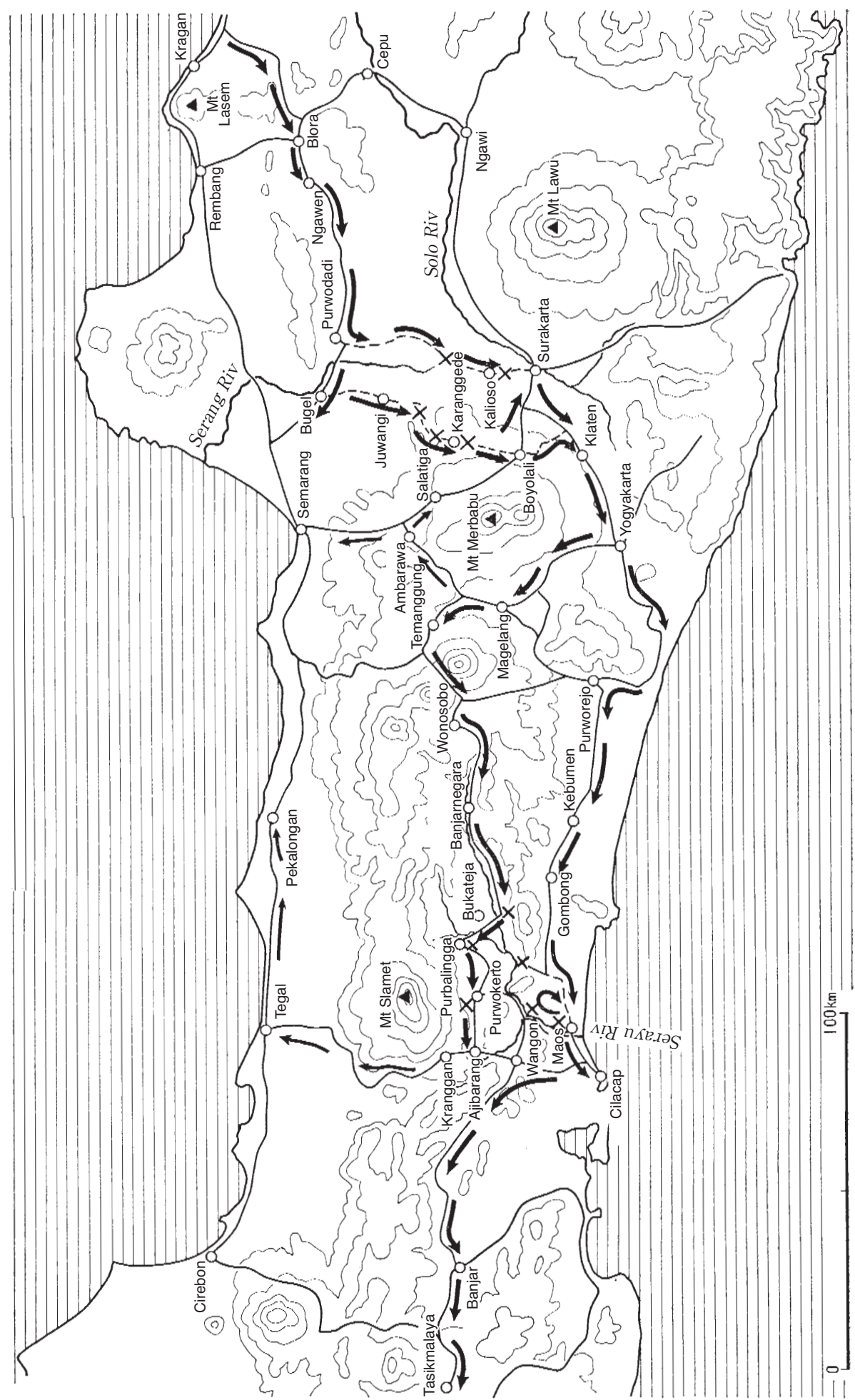

Illustration No. 62 - The Operation of the Sakaguchi Detachment 
gic points without missing opportunities, thereby turning the entire invasion operation of the East Indies to our favor.

In the operations of the main force of the [Sixteenth] Army against Java, the group landed in Kragan and vicinity and with great speed broke through all places [of resistance] in central Java. After the landing, they dashed forward to seize Cilacap in less than a week and cut off the escape route of the entire enemy army in Java, which dealt the enemy a fatal blow, and [thus] critically contributed to the unconditional surrender of the enemy. Their military merit is truly outstanding. We present here this citation of merit and proclaim it to the whole army.

21 March, 1942

Imamura Hitoshi, Commander in Chief of the Army in the Dutch East Indies Theater

Of the 16th Army only the Sakaguchi Detachment and the Shōji Detachment received a citation of merit in the Java invasion operation. 


\section{The Operations of the 48th Division}

\section{Terrain and Operation Plan (See Illustration No. 63)}

In eastern Java, the Serang River runs from Surakarta to the northeast of Semarang and the Solo River flows into the Madura Strait via Ngawi, Cepu, Bojonegoro and Babad. To the southeast of the Solo River, the Brantas River flows through Mojokerto via Kediri and Kertosono; its lower part branches into the Kalimas River, which flows [into the sea] at Surabaya, and the Porong River, which flows through Porong. Paddy fields cover the areas along these rivers, but the areas between the north coast and the Solo River and those between the Solo River and the Brantas River, and between [the Solo River and] the Widas River are hilly, while high conical mountains range from east to west in the entire area south of the Widas and the Brantas River. Many [drainage and irrigation] channels and ditches run through the coastal areas that face the Madura Strait and the Madura Sea.

As for the situation of the enemy, it had been known since before the opening of hostilities that there were batteries, pillbox positions and strongholds with three lines of barbed-wire entanglements at the military port of Surabaya (in the areas of Gresik, Surabaya, and Piring); that the eastern territorial (divisional) headquarters [of the Dutch East Indies Army] was located in Malang; that in Porong, which is situated in between [Surabaya and Malang], there was a V-shaped position (a position open at the front from where the enemy attack is expected and designed to squeeze and trap the enemy within its narrowing wings, resting on natural obstacles) with two-storied pillboxes and barbed-wire entanglements; that there was a position with batteries in Semarang as well; and that there were barracks in Magelang, etc. After the opening of the hostilities, it was also learned that a central territorial (divisional) command was newly established in Magelang. The information on the disposition of the allied forces was rather diverse, but for the area from Magelang to the east it may be roughly [summarized] as follows: ${ }^{(23)}$

Magelang: a divisional headquarters and [a unit consisting of] two battalions as the core Semarang: [a unit consisting of] one battalion as the core

Surakarta: [a unit consisting of] half a battalion as the core

Surabaya (including the island of Madura): [a unit consisting of] five battalions as the core

Pasuruan and Porong: [a unit consisting of] two battalions as the core

Malang: a divisional headquarters and [a unit consisting of] three battalions as the core

As we have seen, the initial operation plan of IGHQ, the Southern Army and the Sixteenth Army was that [a force consisting of] the $2 \mathrm{~d}$ Division and three battalions of the 38th Division as the core should capture western Java, the 48th Division eastern Java, while the South Seas Detachment should land in Cirebon and seize Cilacap. At that time, the sector which the 48th Division was supposed to capture was roughly determined as the area from Semarang and Magelang to the east, while its landing points were set at three points between Kragan and vicinity and Semarang. ${ }^{(80)}$ As a matter of course, its main target was Surabaya.

After the decision to give up the employment of the South Seas Detachment, the Sixteenth Army's [revised] operation plan reduced the number of landing points by one point to two. The plan had [the division] seize Semarang and Magelang in the west, and seize Surabaya 
in the east from the direction of the coastal road and via the road along the Solo River valley (in other words, from the northwest), while Cilacap was to be seized at an appropriate time. ${ }^{(80)}$ It was a plan in which a unit under the command of Col. Imai Kazufumi, commander of the 1st Taiwan Infantry Regiment, should land at the Serang River valley in six transport ships and head for Semarang and Magelang, while [a unit on] nineteen transport ships directly led by Divisional Commander Lt. Gen. Tsuchihashi Yūitsu, should disembark at Kragan and head for Surabaya along the coast as well as the road along the Solo River valley. ${ }^{(96)}$ (See the previously described arrangement between the Sixteenth Army and the Third Fleet [p. 226 ff.].) Apart from this, it was planned to have a unit [consisting of] one battalion as the core land on Bali using two high-speed ships. ${ }^{(80)}$

Against this Sixteenth Army plan, the 48th Division offered its opinion and at two points the plan was revised.

The first point was that in view of the bitter precedent in the landing [operation] on northern Luzon, the landing points were reduced to [just] one point, which enabled a better guard against submarines. Along the whole northern coast [of Java], there were shoreline positions and obstacles, but fortunately these were not spotted along the coast of Kragan. Moreover, with a sandy shoal (of fifteen meters deep) stretching far into the sea, the coast had the advantage [of providing protection] against attacks on the anchorage by [enemy] submarines. It was decided to set the landing point of the 48th Division only at Kragan and have the landing point covered from the air by three layers of naval fighter planes. ${ }^{\left({ }^{(0)}\right.}$

The second point was to fully demonstrate the mobile strength [of the division] by concentrating its strength on the allied forces in one area and defeat them, while reducing the allied forces in other areas to passivity. As mentioned previously, the division had originally been organized as a motorized division (that is, it had motor vehicles sufficient for one third of the personnel of its infantry regiments). After the capture of Manila, [the division had commandeered so many motor vehicles that] the entire division could be transported all at the same time by motor vehicles. The division commander revised the plan in such a way that after the landing in Kragan, he would have [the division] seize the lower reaches of the Serang River, Cepu (oil fields and bridges), and Bojonegoro (bridges), and in particular make a demonstration of heading southwestward. As the landing progressed, he would have the main force charge toward the Widas River and the Brantas River, defeat the allied units, and seize Porong. Having cut the line of communication between Surabaya and Malang, he would then attack the Surabaya stronghold. Prior to the attack on the Surabaya stronghold, he would have the unit that had advanced to the lower reaches of the Serang River at the beginning [of the operation] seize Magelang, while the attack on Cilacap would be conducted depending on the situation. The order that the Sixteenth Army had given to the 48th Division on 24 January was in outline: (1) [the division] should have a unit [consisting of] one battalion as the core land in Bali no later than day I - 2; (2) the division should land at Kragan on day I, promptly secure the crossing points over the Solo River and the oil resources in Cepu with one element, and then defeat the enemy to promptly seize Surabaya, and have a powerful element dash to Cilacap at a favorable opportunity to cut off the escape route of the enemy; (3) after that, the division should mop up the enemy in eastern Java in concert with the main force of the [Sixteenth] Army. (See the previous description. [pp. 236-237]) The landing plan, for which the 48th Division made arrangements with the 4th Destroyer Squadron on 4 February, was as follows (See the previous description. [pp. 237-240]): 


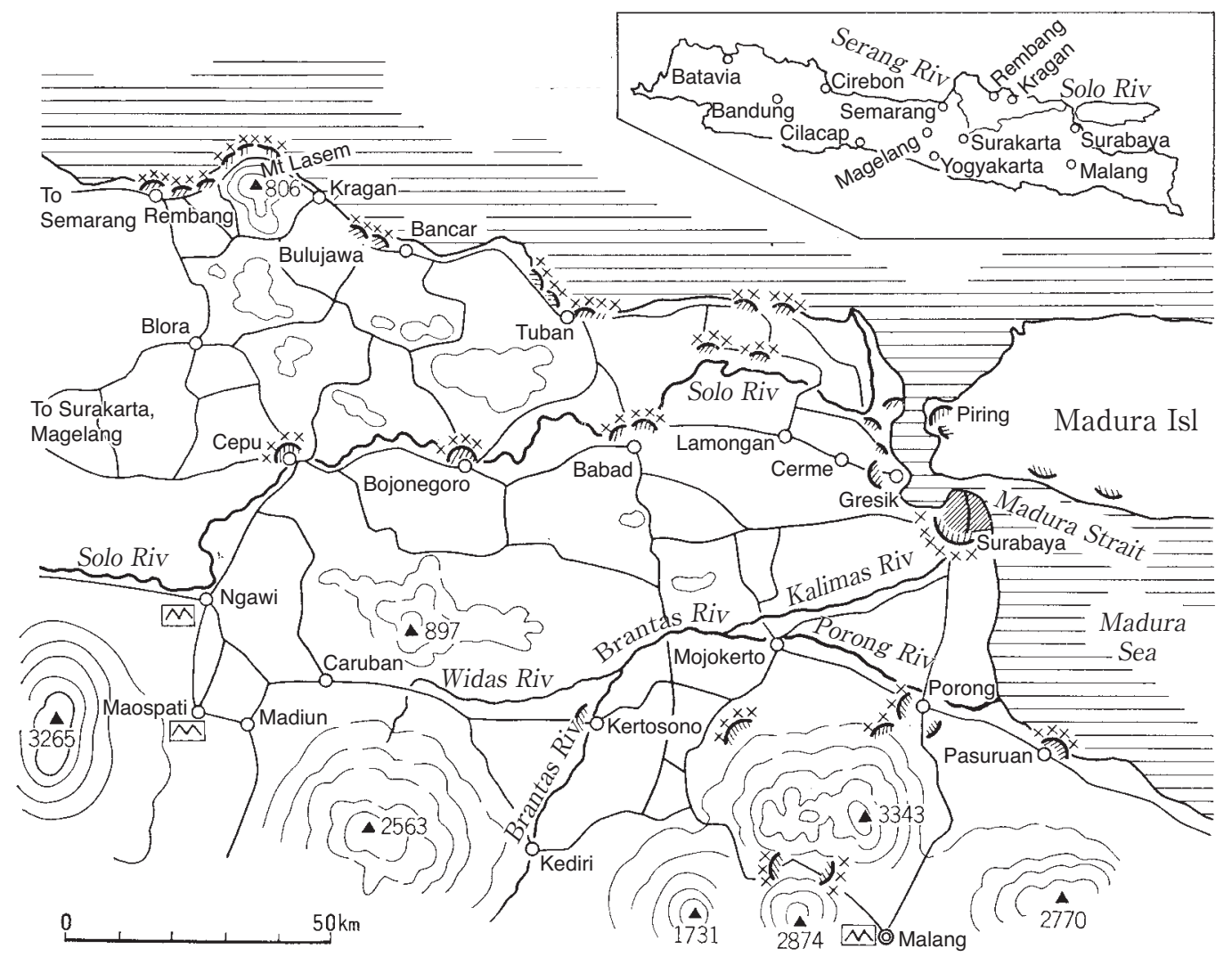

Illustration No. 63 - The Terrain and the Known Position of the Enemy in Eastern Java

Imai Unit ([consisting of] two infantry battalions and one mountain artillery battalion as the core under the command of the 1st Taiwan Infantry Regiment commander): shall come ashore in Sector B in Kragan and advance to Serang (Magelang). [Editor's note: Possibly a misreading for Sedan and Semarang. See p. 238.]

Kitamura Unit (48th Reconnaissance Regiment): shall come ashore at the same landing point as the above and advance to Bojonegoro.

Abe Unit ([consisting of] three infantry battalions, two tank squadrons and two mountain artillery battalions as the core, under the command of the infantry group commander): shall come ashore in Sector A in Kragan and advance to Ponjūru. [Editor's note: The map on p. 575 in the Japanese edition has a "Ponjūru" and a "Ponjoru," both of which are unidentifiable. The most likely candidates are "Bulujawa," "Boncong" and "Bancar." The latter might locally be pronounced as "Boncor."]

Tanaka Unit ([consisting of] two infantry battalions and one mountain artillery battalion as the core under the command of the 2d Taiwan Infantry Regiment commander): shall come ashore at the same landing point as the above and advance to Cepu.

In mid February, it was decided that the Sakaguchi Detachment would [also] land in Kragan and head for Cilacap. It was further decided that the Imai Unit and the Abe Unit ([consisting of] the 47th Infantry Regiment as its core) should come ashore respectively as the right wing 
unit and the left wing unit, and secure a beachhead that stretched from Mt. Lasem to a line eight kilometers south of Kragan to cover the landing. The Imai Unit should further seize Rembang and the Kanauji Battalion of the Sakaguchi Detachment should rush beyond the beachhead to seize Blora ([the guarding of] which would later be taken over by the Imai Unit), while the Tanaka Unit should rush beyond the beachhead to seize Cepu and Ngawi. The Kitamura Unit should rush beyond the beachhead to seize Bojonegoro (and seize Tuban with one element). After the landing of the Matsumoto and the Yamamoto Echelon, the Sakaguchi Detachment should then leave Blora for Cilacap, whereas in progress with the landing, the 48th Division should head for the area east of the Brantas River with the Abe Unit as the 1st echelon, the Tanaka Unit as the $2 \mathrm{~d}$, and the Imai Unit as the $3 \mathrm{~d}$ echelon, while having the Kitamura Unit head eastward from Bojonegoro to Surabaya to contain the allied units, and so gain the upper hand for the decisive battle of the division that was expected to occur on the bank of the Brantas River. ${ }^{(79,80)}$

\section{Operational Preparations}

As mentioned previously, the 48th Division had been preparing for the Malaya [invasion] operation, when in August 1941 the [operation] plan was changed in such a way that it would join the Philippines and Java [invasion] operations instead. It then mainly focused on the preparations for the operation against the Philippines. However, right after the departure of the units that were to land in Aparri and Vigan, it turned out that a member of the sultan's family of the Principality of Yogyakarta was teaching at Gaoxiong Commercial School in Taiwan, and the main force of the division took him along to the Philippines. This helped [the division] to know the details [of the situation] in eastern Java. ${ }^{(80)}$ Just before the seizure of Manila, Divisional Commander Tsuchihashi learned that it had been decided to move up the Java operation and that IGHQ and the Southern Army considered that the division's assignment in the Philippines had been completed. However, Division Commander Tsuchihashi could not allow himself to overlook the U.S.-Filipino Army's retreat into Bataan and decided to head for Bataan for a limited period of one week to ten days at most. On 8 January, the division turned over the battle front of Bataan to the 65th Brigade, assembled in the suburbs of Manila, and started the preparations for the Java operation. When Vice Chief of Staff Aoki of the Southern Army had visited [the division] before, it had particularly requested heavy artillery units (at least one $10-\mathrm{cm}$. gun and one $15-\mathrm{cm}$. howitzer battalion each) to be assigned [to the division] for the attack on the Surabaya stronghold. However, the Southern Army had informally decided not to transfer [heavy artillery units] from the Fourteenth Army, which was to capture Bataan and Corregidor, but to transfer instead units which belonged to the Twenty-fifth Army, and which were to be sent later. As a result, no heavy artillery units were included in the twenty-one units [on the list] to be transferred by the order of the Southern Army on 15 January, although tanks (the 4 th Regiment) were included. ${ }^{(23,24)}$ Lieutenant General Tsuchihashi wired to the chief of staff of the Southern Army, saying, "I'm not complaining, but I heard that Surabaya has a stronghold, while my corps is equipped only with mountain guns. When we fire at the enemy stronghold and the shells bounce back with a clang, who will take responsibility? I would like to ask you a favor to at least allocate [a unit of] 15-cm. howitzers." Only one 15-cm. howitzer battery of the 17th Field Heavy Artillery 
Regiment was sent from Lüshun [Port Arthur] and joined the division at Lingayen just before embarkation. ${ }^{(79)}$

The main preparation for the [Java] operation done in Manila was the maintenance of the motor vehicles. As mentioned previously, the division had equipped itself so that the entire division could move all together in motor vehicles. ${ }^{\left({ }^{80}\right)} \mathrm{Col}$. Yanagi Isamu, the 47 th Infantry Regiment commander, procured about 3,000 pairs of pliers in Manila to demolish the three lines of barbed-wire entanglements of the Surabaya stronghold. ${ }^{(84)}$

As we have seen, [the division commander] made arrangements with the 4th Destroyer Squadron commander in Manila on 4 February and embarked on 5 February. On the 7th, the Kanemura Detachment departed from Lingayen [for Bali], and the convoy of the main force (thirty-nine ships) left the gulf on the 8th, then made supplementary preparations for the operation in Jolo, and sailed southward after making a change in its operation plan to include the Sakaguchi Detachment's participation [in the operation]. ${ }^{(79)}$

\section{Landing, and Seizure of Rembang and the Bridges over the Solo River (See Illustration No. 64)}

The convoy, which had reversed course from a point about seventy kilometers north of Kragan at 2040 on the 27th, sailed northward all through the night, turned eastward around 0500 on the 28th, and resumed sailing southward around 0800 on the same day. Despite allied planes approaching it that evening, it safely sailed southward after that. From around 0030 on 1 March, Mt. Lasem was distantly visible in the dim moonlight of an almost full moon. The Arizona-maru with the division commander aboard dropped anchor at 0130 and [the convoy] completed entering the anchorage at 0235 . Although [the convoy] was attacked several times from around 0300 and sustained a loss of one ship sunk, one stranded, sixty-two men killed and 210 wounded, the right and left wing units succeeded in landing respectively at 0345 and 0400. [Editor's note: The description on p. 458 differs.] The allied unit facing them consisted of about one Dutch East Indies Army company with a small number of armored vehicles and sidecars; it retreated after only firing randomly some shells from a trench mor$\operatorname{tar} .(31,79,119)$

The first landing units of the right wing unit (the 1st Taiwan Infantry Regiment led by Col. Imai Kazufumi) and the left wing unit (the 47th Infantry Regiment (with Col. Yanagi Isamu as regimental commander) led by Maj. Gen. Abe Kōichi, commander of the 48th Infantry Group) immediately advanced to the line connecting Mt. Lasem, Sedan and Ponjūru [? Bancar] (about eight kilometers from the landing point in Kragan), and took positions to cover the landing. On landing, the main force of the Imai Unit (the second and the subsequent landing units) made preparations for charging toward Rembang, the Tanaka Regiment (the 2d Taiwan Infantry Regiment led by Col. Tanaka Tōru) for charging toward Cepu, the Kitamura Unit (the 48th Reconnaissance Regiment led by Lt. Col. Kitamura Kurō) for charging toward Bojonegoro (one element toward Tuban), and the Kanauji Echelon of the Sakaguchi Detachment for charging toward Blora. When leaving the mother ship in a large motorized [landing] craft at 0730, the division commander was strafed by four or five allied planes, but safely came ashore in Kragan at 0830. The Kanauji Echelon (which had started landing at 0700) seized Blora at 2000, and the Tanaka Unit and the Kitamura Unit left respectively for Cepu and Bojonegoro (one element of the latter for Tuban) around 1500 and around 1700. 
The main force of the Imai Unit departed around 1900 and headed for Rembang, separating into a group that went along the road north and a group that went along the road south of Mt. Lasem. The $2 \mathrm{~d}$ Battalion [of the Imai Unit], which had taken the coastal road, attacked an allied unit at 2330 northwest of Mt. Lasem. Thus, by midnight on the first day of landing, the 48th Division (including the Sakaguchi Detachment) had established a foothold of about seventy to eighty kilometers wide and about forty kilometers deep, and continued expanding it. Detachment Commander Sakaguchi bid farewell to the division commander and left for Blora. ${ }^{(31,79,119)}$

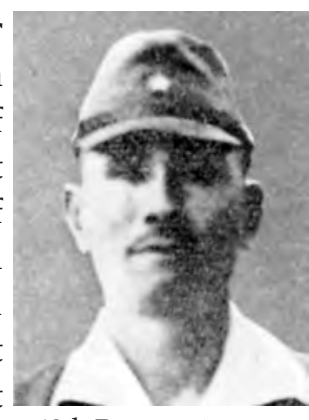

48th Reconnaissance Regiment Commander, Lt. Col. Kitamura Kurō

The landing point was really favorable; the condition of the coast was perfect, and about 700 indigenous men helped with the disembarkation from just after [the start of] the landing. ${ }^{(27)}$

On 2 March, the Imai Unit charged into Rembang at 0340. The advance of the Tanaka Unit was delayed because the road north of Cepu was barricaded with trees over a long distance, but the unit advanced into Cepu at 1530, drove away a small unit of the Dutch East Indies Army on the south bank of the Solo River, and seized the whole area at 1800. The bridges in Cepu had been destroyed. The Kitamura Unit finally managed to get to the north bank [of the Solo River] in Bojonegoro in the evening, due to the loss of a number of its officers at the time of landing, which was followed by a series of motor vehicle trouble. The Abe Unit (Yanagi Unit) successively shifted to the assembling of its strength. The Sasako-maru, which

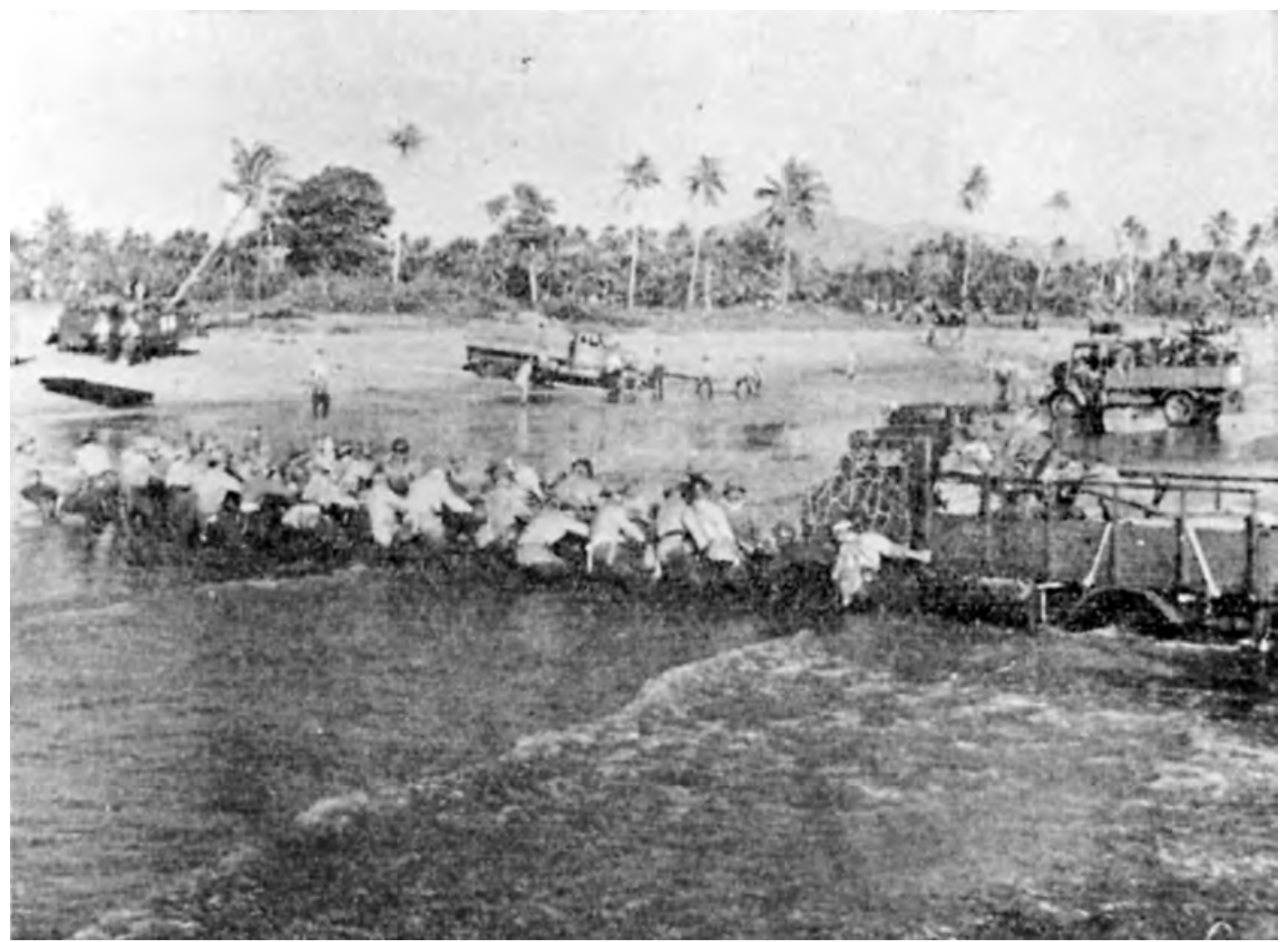

The Landing in Kragan 


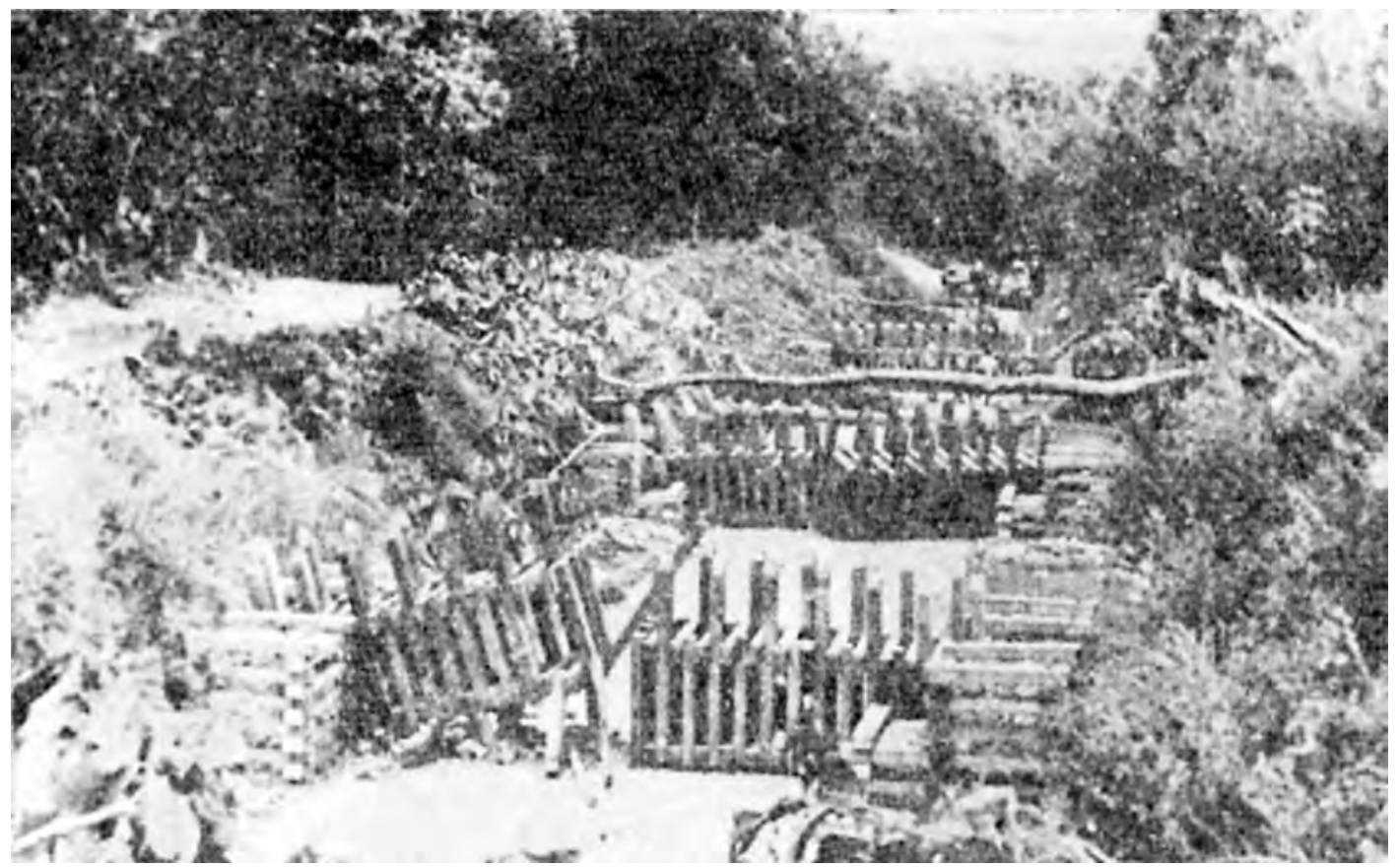

Barricades on the Blora-Cepu road

had enjoyed fame as a high-speed ship, was [no longer] able to sail at a speed faster than five knots due to the damage she sustained in the Bali operation. She entered the anchorage on that day and started the disembarkation of the Yamamoto and the Matsumoto Echelons. In the evening, Division Commander Tsuchihashi ordered the Imai Unit and the Abe Unit to send their advance units respectively to Blora and the three-forked junction east of the town for the purpose of their subsequent advance. However, soon after that, he learned that the bridges over the Solo River in Cepu, Bojonegoro and Babad were all destroyed, and gave orders to the 48th Engineer Regiment and the 3d Independent Engineer Regiment to rapidly advance to bridge the river. ${ }^{(31,79,84,88)}$

\section{Meeting Engagements at the Banks of the Brantas River \\ (See Illustrations No. 65 and No. 66)}

The next day, the 3d [of March], was the [Japanese] Girl's Festival [and seasonally cold in Japan], but it was hot. A report came from the Kitamura Unit, saying: "Today the 3d at 0600, we have crossed the Solo River and seized Bojonegoro, from where a Dutch East Indies Army unit had retreated last night." On that day, the Imai Unit first of all dispatched its bicycle unit from Rembang to Blora. The Abe Unit assembled its force and made preparations for advancing southward. Division Commander [Tsuchihashi] left Kragan at 1600, and advanced to Cepu at 1910. He had departed as soon as he had heard that the barricades on the road to Cepu had been cleared. The road had been barricaded in places for several hundred meters with felled teak trees brought from the large forests, which made [the divisional commander] think of the trouble of the removal work. The oil wells in Cepu were burning and the oil refinery had also been destroyed. ${ }^{(31,79)}$ 
On the next day, the 4th, the division commander waited for the bridging in Cepu to be completed and the assembly of his units. The division commander's plan was to [first] carry out at one go after the landing a rapid advance up to the seizure of Rembang and the crossing points of the Solo River (including the oil fields in Cepu), then have his force assemble on the line of the Solo River, and on completion of the assembling, launch with lightning speed an all-out war of movement. On that day (the 4th), the Abe Unit started its advance at 0600 and had [already] arrived in Cepu at 1100. The Imai Unit (other than those who had departed by bicycle the day before) also left Rembang at 0900 on that day (the 4th) in motor vehicles and caught up with the rear of the Abe Unit via Blora. The bridging [of the Solo River] in Cepu was all they had been

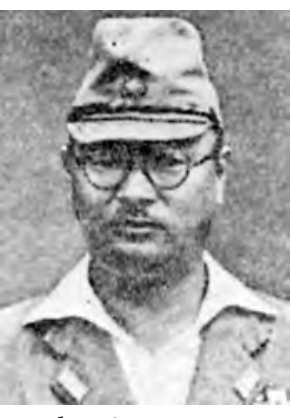

48th Infantry Group Commander Maj. Gen. Abe Kōichi waiting for. It was to be completed by noon on that day (the 4th) but was delayed because part of the bridge had been carried away by the river swollen with the squall of the previous night and had to be rebuilt. Receiving a report in the middle of the night that "the bridging has been completed at 2100 and the crossing of the river has started," the divisional commander felt finally relieved and took a nap. ${ }^{(31,79)}$

On the next day, the 5th, Divisional Commander Tsuchihashi waited for a report on the situation, while going over his operational directives for the meeting engagements expected to take place at the banks of the Brantas River that day, the 5th. The Abe Unit was supposed to have started its advance in the dead of night and be charging toward the front of the Porong stronghold, while the Kitamura Unit (reconnaissance regiment) was supposed to have advanced from Bojonegoro toward Surabaya and contained the allied units. The division commander himself planned to advance at the head of the Tanaka Unit (the $2 \mathrm{~d}$ echelon), while having the Imai Unit (the $3 \mathrm{~d}$ echelon) depart following the Tanaka Unit. He also planned to have the Tanaka Unit on its way mop up [the enemy in] Ngawi and Maospati with one element. He considered that it was highly probable that a meeting engagement would take place at the banks of the Brantas River, particularly in the area somewhere between Kertosono and Mojokerto. As the bridge at Kediri south of Kertosono would be especially important if [his units] should engage the enemy at the Brantas River, the divisional commander had instructed Unit Commander Abe and the staff officer up front to preemptively seize [the bridge]. ${ }^{(79)}$

When the divisional commander was thinking about winning a decisive victory in a field battle on that day, the 5th, a staff officer came to him and reported: "The leading echelon, the Abe Unit, has for the most part completed crossing the river around 0600 in spite of some confusion. But when the 4th Tank Regiment at the tail of the Abe Unit crossed the bridge, it began to move a medium-sized U.S. tank that had been captured in the Philippines onto the bridge ignoring the bridge monitoring squad's calls to stop, as a result part of the bridge was destroyed." Divisional Commander Tsuchihashi lost his temper, saying, "What on earth is it that no staff officers kept an eye on it?" He stamped with frustration, but there was no chance to temporarily fix it in time [for the expected meeting engagement]. Having no choice, he decided to have pontoon rafts prepared to paddle across the river. It was not until 1300 that the divisional commander, who had planned to closely follow in the rear of the Abe Unit, managed to cross the Solo River. He judged that the Abe Unit should [now] be in the middle of a fierce battle. ${ }^{(79)}$ 


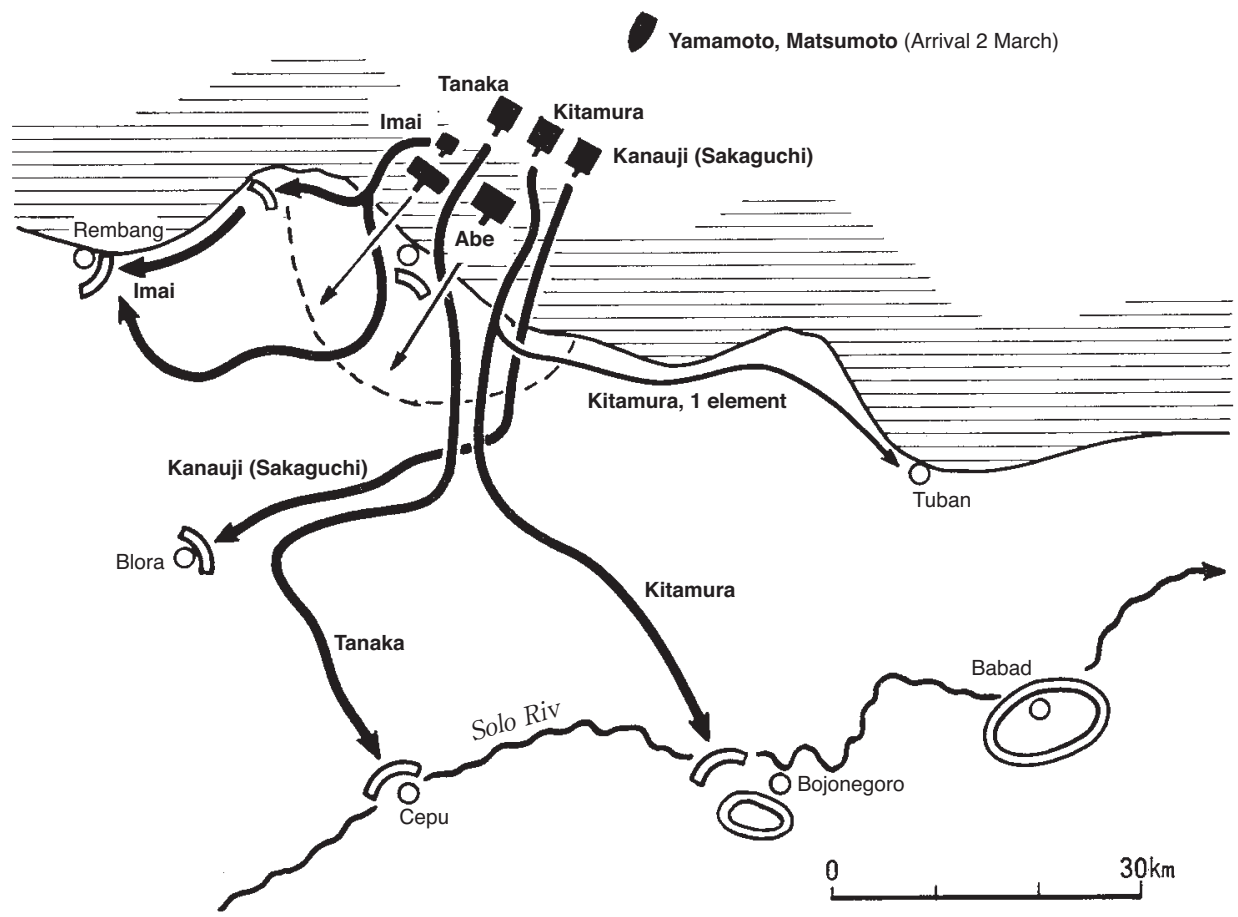

Illustration No. 64 - [the 48th Division] on 1 and 2 March

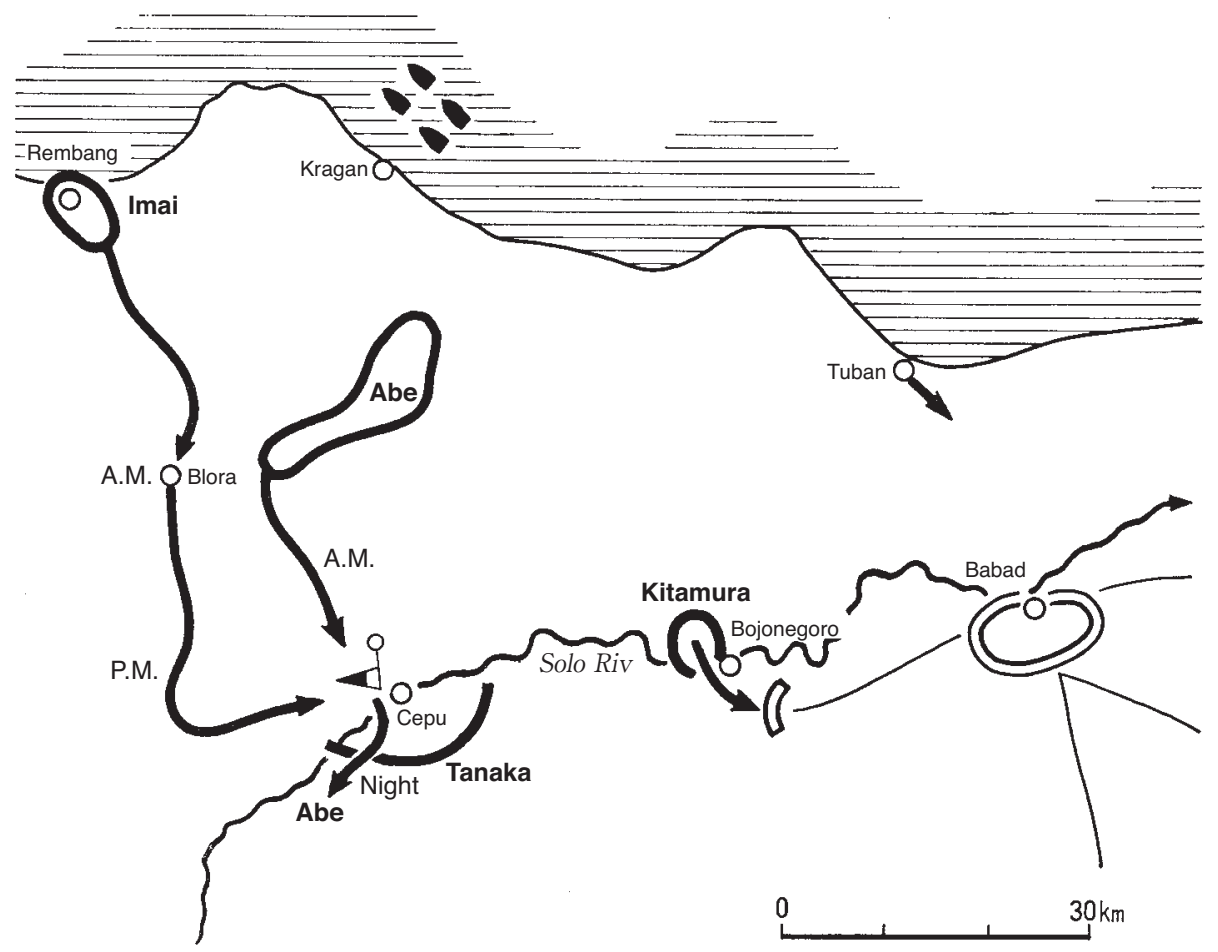

Illustration No. 65 - [The 48th Division] on 4 March 
Well, what was the situation of the Abe Unit during that time? The Abe Unit, whose strength consisted of the infantry group headquarters, the 47th Infantry Regiment, the 4th Tank Regiment, the main force of the 48th Mountain Artillery Regiment and the main force of the 48th Engineer Regiment as the core, was assigned to advance toward Mojokerto along the Caruban - Nganjuk - Kertosono - Porong road. Unit Commander Abe designated the 2d Battalion (commander, Maj. Baba Asanoshin) of the 47th Infantry Regiment as the core led by Colonel Yanagi, commander of the regiment, as the advance guard. In the evening of the $4 \mathrm{th}$, Colonel Yanagi sent eight camouflaged reconnaissance raiding teams ahead to seize the bridges between Cepu and Mojokerto, while the advance guard left Cepu in the middle of the night on

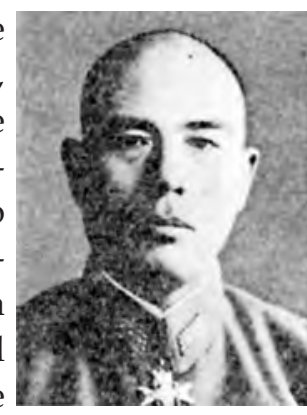
47th Infantry Regiment Commander, Col. Yanagi Isamu the 4 th. Although the reconnaissance raiding teams were intercepted by 200 to 300 troops of a Dutch East Indies Army unit at a point about four kilometers northwest of Caruban at 0130 on the 5th, they broke through and advanced. They again encountered a Dutch East Indies Army unit at 0450 in the town of Caruban and went into a fierce fight. The advance guard led by Colonel Yanagi joined up with the reconnaissance teams, who were in the middle of a fierce fight in Caruban, immediately dealt a heavy blow to the Dutch East Indies Army unit facing it and drove it back. [Colonel Yanagi] disbanded the reconnaissance raiding teams and then followed [the enemy] in hot pursuit. In Wilangan [the advance guard] was intercepted by a Dutch East Indies Army unit of about 200 troops, but broke through. Then it met and engaged a Dutch East Indies Army unit of about 1,000 troops equipped with guns, tanks, and armored vehicles in Kertosono. It defeated them and charged into Kertosono at 1315 (almost at the same time as the divisional commander crossed the [Solo] River in Cepu). The Dutch East Indies Army unit hurriedly [tried to] blow up the bridge at the east end of Kertosono. Although they had set explosives to blow up all segments of the bridge, fortunately [for the Japanese army], the bridge dropped only at one of its central segments to the point that the water barely flowed over the surface of the bridge without it sinking to the bottom of the river. ${ }^{(31,80,82,84)}$

Divisional Commander [Tsuchihashi], who had crossed the Solo River at 1300, arrived in Caruban at 1515 and temporarily stopped off there. A report came that "the Abe Unit is attacking a powerful enemy [unit] in Kertosono," and the divisional commander immediately asked in return, "Has [the unit] already seized Kediri?" Staff Officer Nakahara Makoto rushed out by car right away [to find out]. He hurried to Nganjuk and asked the local people. Although Staff Officer Akatsuka Kazuo, who accompanied the advance guard, should have sent one company separately from Nganjuk to seize the bridge at Kediri, there were no signs that one company had indeed separated from the advance guard there. Staff Officer Nakahara requested Major General Abe to take steps to quickly dispatch a unit. Without delay, the major general sent the $3 \mathrm{~d}$ Battalion (commander, Maj. Miyaji Ikuzō) of the 47th Infantry Regiment of the main force, which had [already] advanced to Kertosono, south along the road on a bank of the Brantas River toward Kediri. Not only Infantry Group Commander [Abe] and Staff Officer Akatsuka, but also the company commander, who had unofficially been informed beforehand [about the separate advance to Kediri], had totally forgotten all about it due to the war situation facing them. ${ }^{(79,80)}$ 
The division commander (in Caruban) obtained the following [information on] the situation by the evening:(79)

1. The Abe Unit had driven back about 500 enemy troops with four guns in Kertosono around 1300. However, as the enemy had destroyed the bridge at the east end of the city, the unit was crossing the river in small boats. [According to the Abe Unit,] the Miyaji Battalion had left for the bridge at Kediri.

2. The Tanaka Unit, which had left Cepu following the Abe Unit, had seized the airfield in Maospati with one element at 1130. The Yanagi Battalion (the 2d [1st?] Battalion of the 2d Taiwan Infantry Regiment under Commander Maj. Yanagi Hiroshi) of the Tanaka Unit had charged into [the enemy] barracks in Ngawi around 1330, taken 150 men prisoner, and rescued thirty-two Japanese women and children who had been confined there. [Sixteenth Army] Staff Officer Kuriya Tsugunori was with this battalion.

3. The Imai Unit, which had left Cepu last, had continued its advance, overtaking the Tanaka Unit.

4. The Kitamura Unit had seized a position west of Babad at 1700.

5. The Tanaka Unit was assembling at Caruban in the evening.

6. According to reconnaissance by [a] naval plane, powerful units of the enemy, which had been positioned in the sector northwest of Surabaya, were in quick succession advancing toward Mojokerto along the Lamongan - Surabaya - Mojokerto road. No enemy was spotted moving along the road connecting Malang and Kediri or the road connecting Malang and Surabaya.

Now it became clear that the corps of the eastern territorial headquarters of the Dutch East Indies Army was positioned [in the area] from the banks of the Brantas River to the northwest of Surabaya and that the forces to the northwest of Surabaya were being transferred toward the banks of the Brantas River. It was considered inevitable that a large meeting engagement would occur by the Brantas River. Divisional Commander [Tsuchihashi] decided to immediately send the Kitamura Unit south toward Mojokerto and seize the three bridges near Mojokerto and vicinity, and passed down his order. ${ }^{(79,80)}$

The night of the 5 th fell. The greatest concern of Divisional Commander Tsuchihashi was the Kediri bridge, to which he had called the attention of his men in the Philippines and again on the ship, and about which he had once again reminded [his men] after the landing. Immediately on getting up in the morning of the 6th, the divisional commander [once again] asked: "Have they seized Kediri?" The reply was: "We have received no reports yet." The divisional commander lost his temper for the second time after the landing, curtly telling his staff officers, "Go and find out right now." (79)

Soon a report came that the Abe Unit had crossed the Brantas River around 1530 on the previous day, the 5th, driven away the Dutch East Indies Army west of Jombang, and sat the night out there, and that the Miyaji Battalion had seized the bridge in Kediri intact around 1730 on the previous day, the 5 th. ${ }^{(79)}$

The advance company of the Miyaji Battalion had rushed to the Kediri bridge at full speed; while crossing the bridge, it had encountered at 1700 (on the 5th) a Dutch East Indies Army unit, which [also] came rushing from the direction of Jombang; it had repulsed the latter at 1730 , and seized the bridge. ${ }^{(31)}$

[Meanwhile,] the advance guard had successively advanced to the right bank of the Brantas River from Kertosono from around 1600 (on the 5th) onwards. At that time, the footbridge was still hanging there in its [almost] destroyed state and was barely passable for personnel. The railway bridge, however, was still there. As soon as the engineer unit had finished setting 


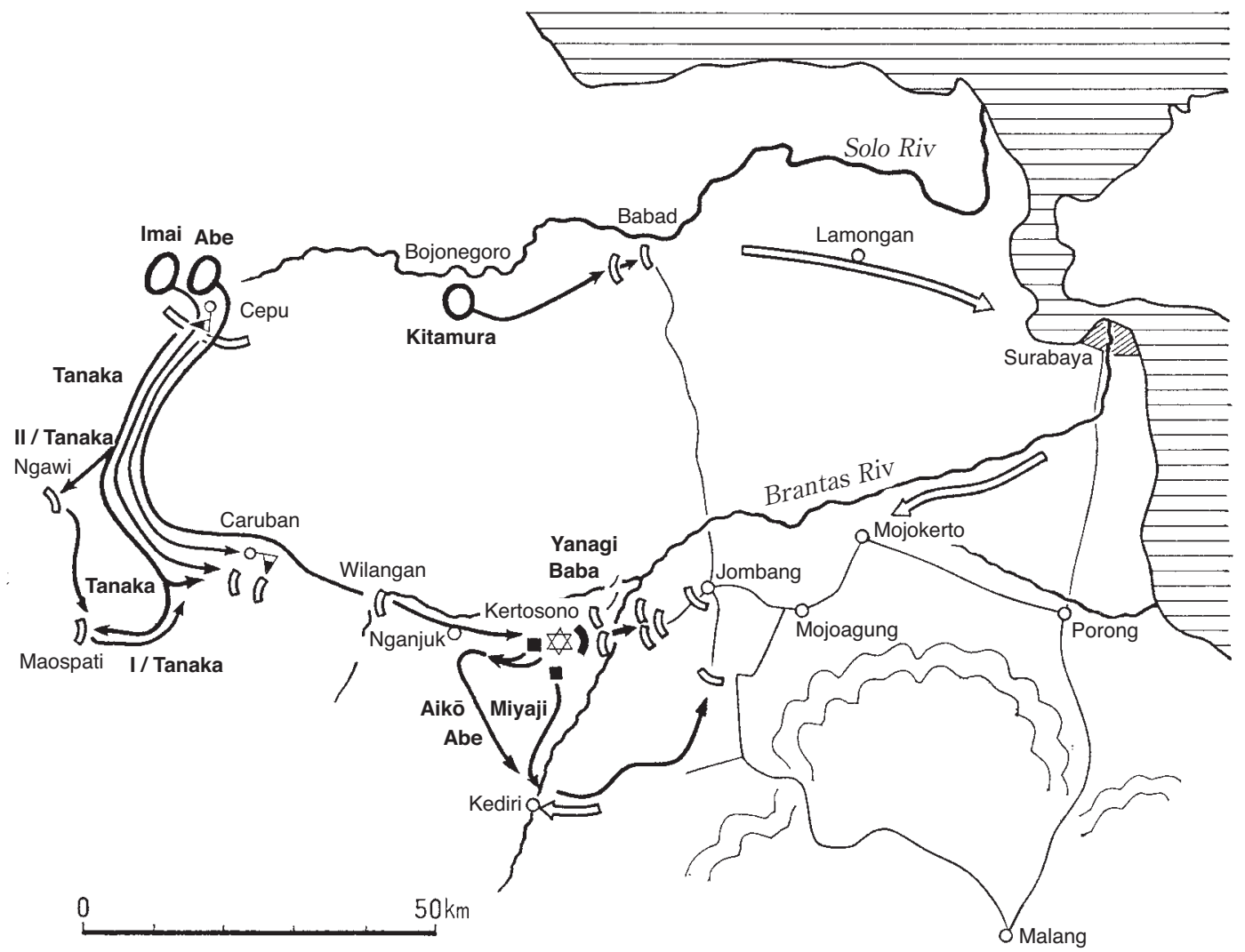

Illustration No. 66 - [The 48th Division on] 5 March

up equipment to cross the railway bridge, the vehicles had been sent across the bridge in succession at midnight. The main force of the remainder of the 1st Echelon (the unit [consisting of] the Aikō Battalion as the core under the command of Major General Abe) had made a U-turn at Kertosono and was heading for Kediri by way of Nganjuk. On learning that the Miyaji Battalion had seized Kediri, the battalion was sent onwards toward Jombang, while the main force had followed immediately in their rear. ${ }^{(82,83,84)}$

On that day (the 5th), the Kitamura Unit had left Bojonegoro at 1100, and attacked [enemy] positions west of Babad from 1330 onwards, which caused the unit a loss of four officers and two noncommissioned officers killed. However, it had seized the positions at 1715 and launched a night attack on the town of Babad at 2000. . $31,79,86)$

On the morning of the 6th, on learning of the "successful seizure of the Kediri bridge last evening," Divisional Commander Tsuchihashi left Caruban at 0730 at the head of the Imai and the Tanaka Units to head for Jombang via the Kediri bridge. ${ }^{(31,79)}$

In the meantime, the advance guard ([consisting of] the Baba Battalion as the core led by Colonel Yanagi [Isamu]), which had crossed the [Brantas] River at a point near Kertosono from the previous evening onwards, had shifted to the pursuit [of the enemy] in motor vehicles when the assembly of the main force was completed around 0500 on the 6 th, and charged into the city of Jombang at daybreak. [The advance guard] continued its charge and met resistance from a Dutch East Indies Army unit of about 200 troops equipped with guns at 0820 near Mojoagung. It defeated [the enemy troops], further advanced, and was in the 


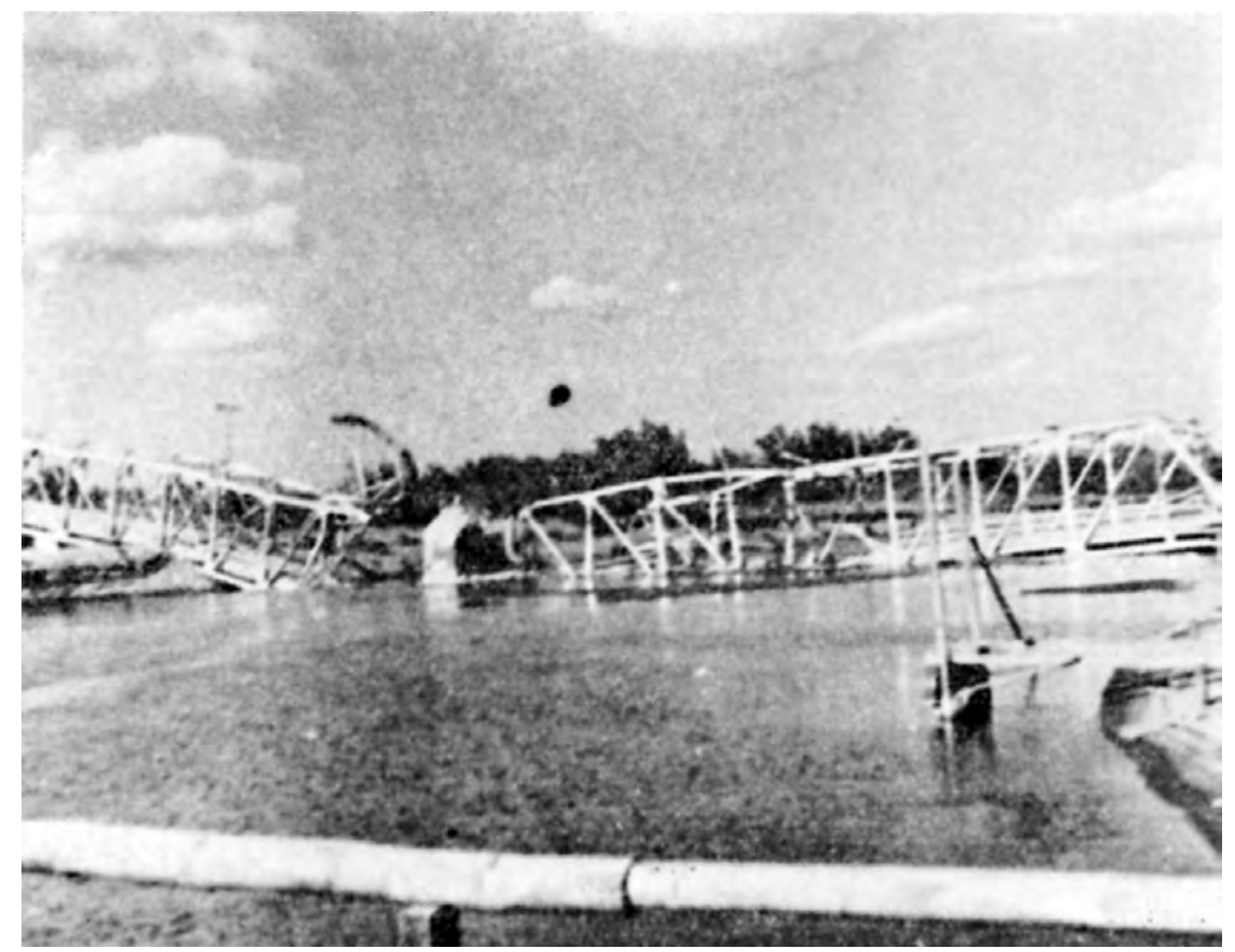

The Destroyed Bridge at Kertosono

middle of attacking a Dutch East Indies Army unit in Mojokerto. The main force of the Abe Unit ([consisting of] the Miyaji and the Aikō Battalions — [advancing] via the Kediri bridge) was following immediately in its rear. ${ }^{(31,79,83)}$

Divisional Commander [Tsuchihashi] advanced to Jombang at 1040, moving at the head of the Imai and the Tanaka Unit, and set up his headquarters there. Before noon, he learned that the advance guard of the Abe Unit (i.e. the Yanagi Unit) had charged into Mojokerto around 1100, seized the town, further defeated with one element about one hundred troops of a Dutch East Indies Army unit near the bridge at the north end of Mojokerto and secured the bridge, and that the advance guard had continued its advance toward Porong.

Then, he learned that the Kitamura Unit had conducted a night attack on Babad at 2000 the previous night, seized the town at 0300 on the 6 th, and started its southward advance toward Mojokerto, leaving Babad around 1100. He [also] learned that a Dutch East Indies Army unit, which had retreated from Babad toward Surabaya, was returning to Babad. Considering the fact that the Yanagi Unit had already seized the bridges in Mojokerto and also judging that the rear of the Kitamura Unit was not secured, Divisional Commander [Tsuchihashi] gave orders to the Kitamura Unit to stop its southward advance and return to its original assignment. ${ }^{(31,79)}$

The divisional commander left Jombang at 1520 and advanced to Mojokerto at 1600 . The Imai and the Tanaka Units, in this order, followed immediately in his rear. ${ }^{(31,79)}$ 
When the divisional commander advanced to Mojokerto (around 1600 on the 6th), he received a report from a naval plane that "the enemy is assembling into Porong from the west and the south and that there is a hint that they are retreating in Surabaya." (79)

Note: Of the [Sixteenth] Army staff officers assigned [to the division], Staff Officer Kuriya directed the rescue of the Japanese [residents confined] in Ngawi as described previously, and Staff Officer Nishiura was in charge of reconnaissance and communications by using naval reconnaissance seaplanes. ${ }^{(42,45)}$

The divisional commander instantly made a decision, dictated the following orders separately as direct orders, and had [the orders] delivered by motorbike, intending not to let the Dutch East Indies Army units use the Porong stronghold as their base as well as to keep them away from the Surabaya stronghold. ${ }^{(79)}$

- The Abe Unit shall break through the Porong [stronghold] and advance to the line along the canal in Kedungrejo.

- The Imai Unit shall head northward from Mojosari, charge toward Sidoarjo to approach the rear of the enemy. It shall cooperate with the Abe Unit as needed.

- The Tanaka Unit shall head northward along the west bank sector of the Kalimas River, seize the bridge north of Krijan and the highland on its northwest side, and reconnoiter the enemy position.

\section{The Seizure of Porong (See Illustrations No. 67 and No. 68)}

When Divisional Commander [Tsuchihashi] gave the previously mentioned orders, Colonel Yanagi [Isamu], commander of the advance guard of the Abe Unit, had already seized Porong.

As we have seen, it was said that in Porong, there were midway defense works between the garrison town of Malang and the Surabaya stronghold, a stronghold with a number of two-storied pillboxes and barbed wire entanglements, and a V-shaped position with narrowing sides, which made the 48th Division give it a careful consideration. Based on the division order, Unit Commander Abe showed [his unit] that "the division intends to seize the Porong stronghold and that [accordingly] the Abe Unit will advance to [a line] about eight kilometers northwest of the Porong stronghold, and while reconnoitering the enemy's situation and the terrain, cover the deployment of the division," and gave orders to the advance guard to move up to the line. ${ }^{(82)}$

After seizing the bridges and the urban area of Mojokerto, Colonel Yanagi had headed eastward with an advance company [consisting of] one infantry company, one tank troop and one mountain artillery battery as the core, while keeping [the remaining] three infantry companies as the core under his direct command. He had one element advance separately from Mojosari to secure the two bridges over the Porong River, while he himself continued heading eastward. While advancing, he had received information by a communication cylinder dropped from a [Japanese] naval plane, which said: "The enemy is now shifting its force from the direction of the cities of Malang and Surabaya to the Porong stronghold to deploy them there." The colonel instantly decided on his own judgment to seize the Porong stronghold and immediately gave an order to attack it. The troops, which came from the Oita Regimental District in northern Kyūshū, charged boldly. Lt. Col. Kumagai Shōji, commander of the 4th Tank Regiment, and Lt. Col. Yamaguchi Kayoshi, commander of the 48th Mountain Artillery Regiment, who accompanied Colonel Yanagi, quickly deployed their own units and 


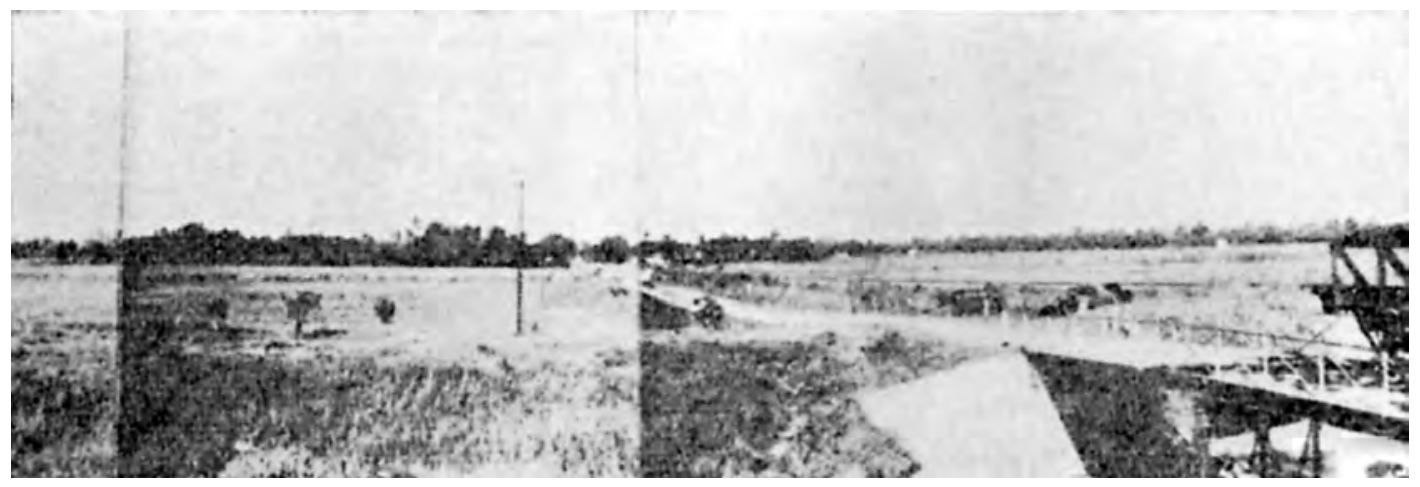

The Battlefield Near the Porong Stronghold

along with naval planes supported [the charge]. They broke through part of the Porong Position at 1520 and advanced to the line of a stream on the west side of Kejapanan at 1530. In Kejapanan and vicinity, 1,200 to 1,300 troops of a Dutch East Indies Army unit had assembled and part of them fought back. At 1550, [the Japanese] launched a fierce attack on Kejapanan with infantry, tanks and artillery in close coordination, broke at a stroke through [the defense of] the city and cut off the road connecting Surabaya and Malang. One element rapidly advanced to the bridges in Porong, and secured them. The Baba Battalion was the only infantry [battalion] that fought from the beginning to the end. It had already seized the city before the Miyaji and Aikō Battalion of the main force of the Abe Unit joined the battle. ${ }^{(83,84)}$

Divisional Commander [Tsuchihashi] was very pleased to learn that Colonel Yanagi had quickly seized Porong on his own judgment. He advanced his headquarters from Mojokerto to Mojosari in the evening. ${ }^{(79)}$ That is to say, on the 6th, the division headquarters advanced from Caruban to Jombang, then to Mojokerto, and further to Mojosari in [just] one day.

\section{Preparations for Seizing the Surabaya Stronghold (See Illustration No. 69)}

By the previously described division order of around 1600 on the 6th and the division order that followed the seizure of Porong, the units moved during the night of the 6th and advanced to the sectors south and southwest of the Surabaya stronghold. It was decided to let Infantry Group Commander Abe take command of the Yanagi (the 47th Infantry) and the Imai (the 1st Taiwan Infantry) Regiments together. Colonel Yanagi employed the $3 \mathrm{~d}$ Battalion (the Miyaji Battalion), which was returned from Major General Abe, [instead] as the van, left the Porong sector at 2100 on the 6th, and advanced to an area about four kilometers south of Surabaya at 0300 on the 7 th, where he began to reconnoiter the position of the enemy and the terrain. By the morning of the 7th, the Imai Regiment had advanced to the front west of and level with [Colonel Yanagi], and the Tanaka (the 2d Taiwan Infantry) Regiment to the area northwest of Imai (i.e. southwest of the Surabaya stronghold) and began reconnoitering the position of the enemy and the terrain. ${ }^{(79,83)}$

On the previous day (the 6th) while in pursuit of the enemy toward Mojokerto after the engagement in Mojoagung, the advance guard had [found and] obtained a detailed [enemy] "deployment plan of Surabaya" in an abandoned car. Taking a look at it, Colonel Yanagi had felt, "this gives me confidence in a sure victory."(84) Divisional Commander Tsuchihashi, who had advanced to Mojokerto at 1600 on the same day (the 6th), looked at the plan and felt: "The defense of Surabaya seems considerably [strong], but I wonder whether it is actually 


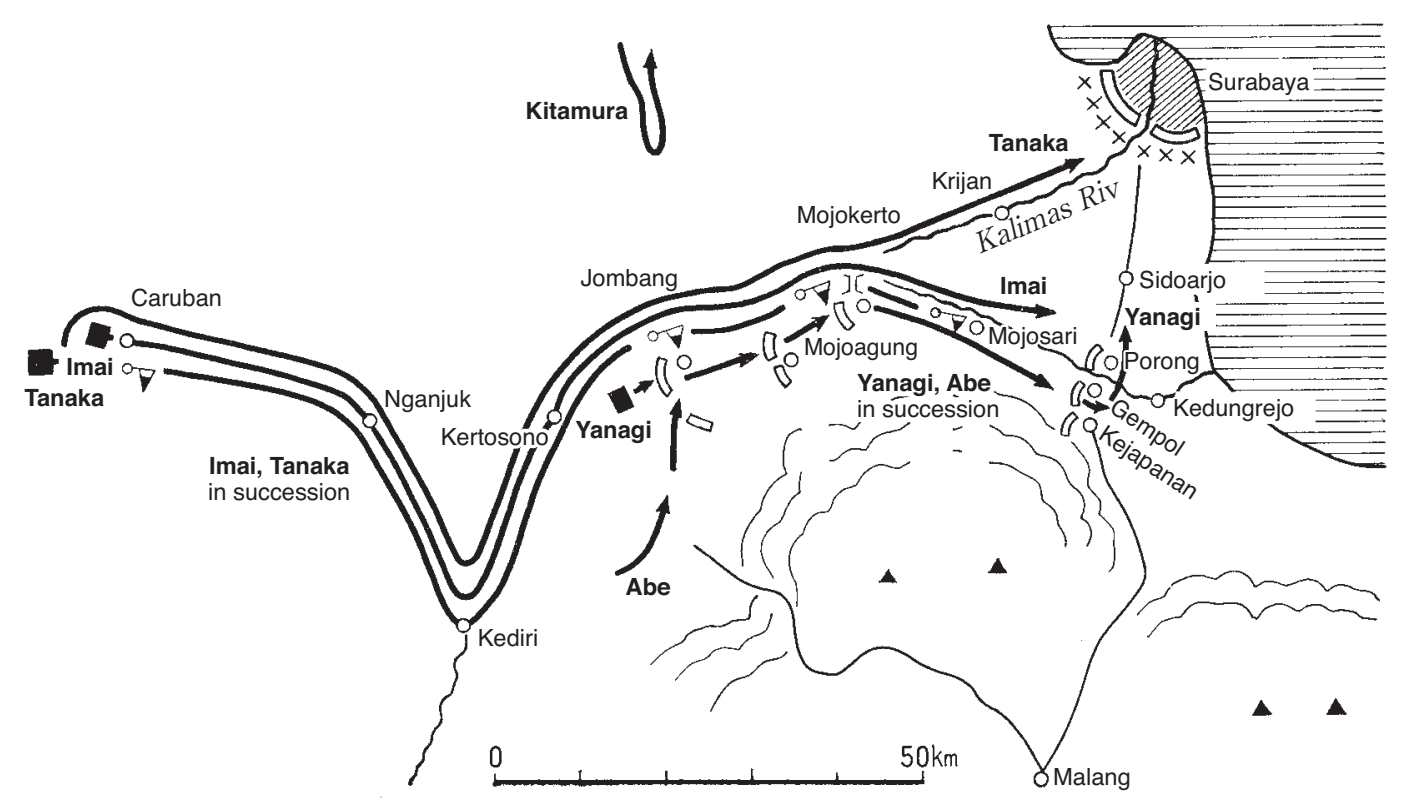

Illustration No. 67 - [The 48th Division on] 6 March

so. In any case, we should avoid a reckless attack to minimize loss and tactfully seize the city." (79) When asked by an embedded war correspondent: "Are you going to enter Surabaya on the Army Day (10 March)?" the divisional commander had answered: "We will seize Surabaya when the prospects for an attack are promising. We do not carry out an unreasonable attack at the risk of causing [many] casualties." (79) Giving detailed orders concerning reconnaissance, the division commander planned to gather [more] materials for his attack plan. ${ }^{(79)}$

Before noon on that day (the 7th), the divisional commander advanced his command post from Mojosari to Sidoarjo. ${ }^{(79)}$

Right after that (around noon on the 7th), a report came from the front line unit, which said: "There are signs of flooding. The river is rising inch by inch." The divisional commander recalled what Sixteenth Army Staff Officer Major Kuriya had told him on the transport ship and immediately sent for him at the front line. The staff officer rushed to the branching point on the Brantas River and operated the water gate in such a way that the water flow, which had been set to flow into the Kalimas River, went into the direction of the Porong River. ${ }^{(79)}$

On the next day, 8 March, the change of the flow at the water gate showed effect and the level of the river started to fall. ${ }^{(79)}$

The divisional commander learned that the Kitamura Unit had seized Lamongan (halfway between Babad and Gresik) after a minor engagement around 1730 on the previous day, the 7th. ${ }^{(79)}$

By that morning (of the 8th), the divisional commander had come to the conclusion that the Surabaya position was not so strong. He decided to attack from the evening of the next day, the 9 th, onwards and passed down the following attack order at 0800 on that day (the 8th): ${ }^{(79)}$

1. Launch of the attack: at 2030 after sunset on the 9 th 


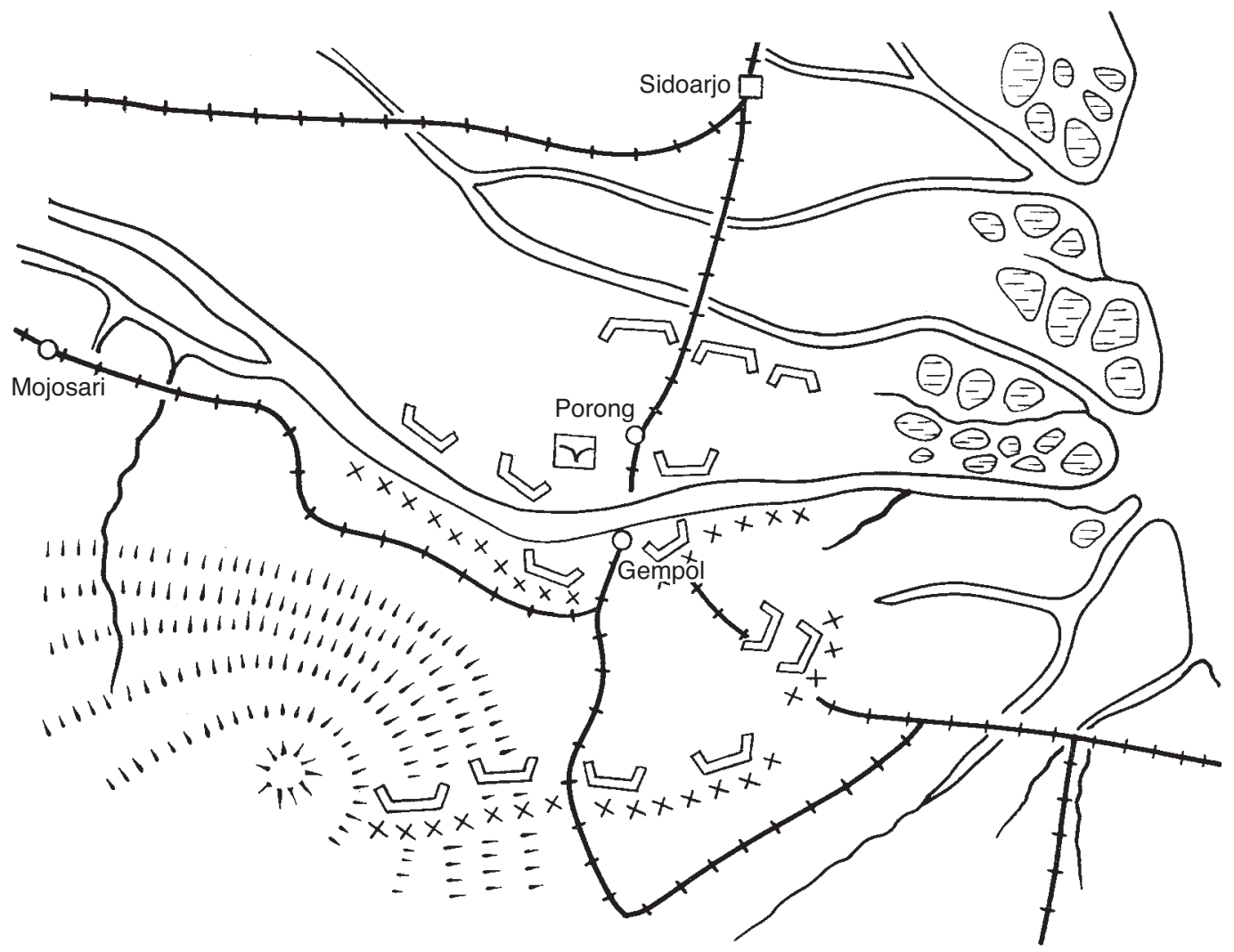

Illustration No. 68 - The Situation of the Porong Stronghold as Was Known Just After the Landing

2. Main attack: [from] the south front (the front of the Abe Unit)

3. The unit [consisting of] both the Imai and the Yanagi Regiments as the core under the command of Major General Abe shall cross the canal of Wonokromo by surprise, storm the enemy artillery position in the east sector of Surabaya, then turn its front by 90 degrees, dribble through Surabaya and attack the positions of the enemy from behind.

4. After seizing the southwest corner, the Tanaka Unit shall upset the [enemy] position with tanks and overrun the artillery position.

5. The Kitamura Unit shall just hold down the west front and prevent the enemy from escaping. The $3 \mathrm{~d}$ Battalion of the $2 \mathrm{~d}$ Taiwan Infantry Regiment shall be assigned to it.

6. Artillery fire: shall be conducted from 1400 to 1600 and from 1830 to 2000 on the 8 th, and from 1400 to 1600 on the 9th.

[The unit shall first] destroy the southwest corner position of the enemy, [halt the fire] and resume the fire at 1630 [1830?].

7. At some time on the 8 th and the 9th, the [most] important points of the [enemy] positions as well as the artillery positions shall be bombarded.

\section{Surrender of the Eastern Corps of the Dutch East Indies Army}

The units had assiduously been reconnoitering the position of the enemy and the terrain. After obtaining approval from Divisional Commander [Tsuchihashi], Regimental Commander Yanagi selected one company out of each battalion and let them carry out a recon- 


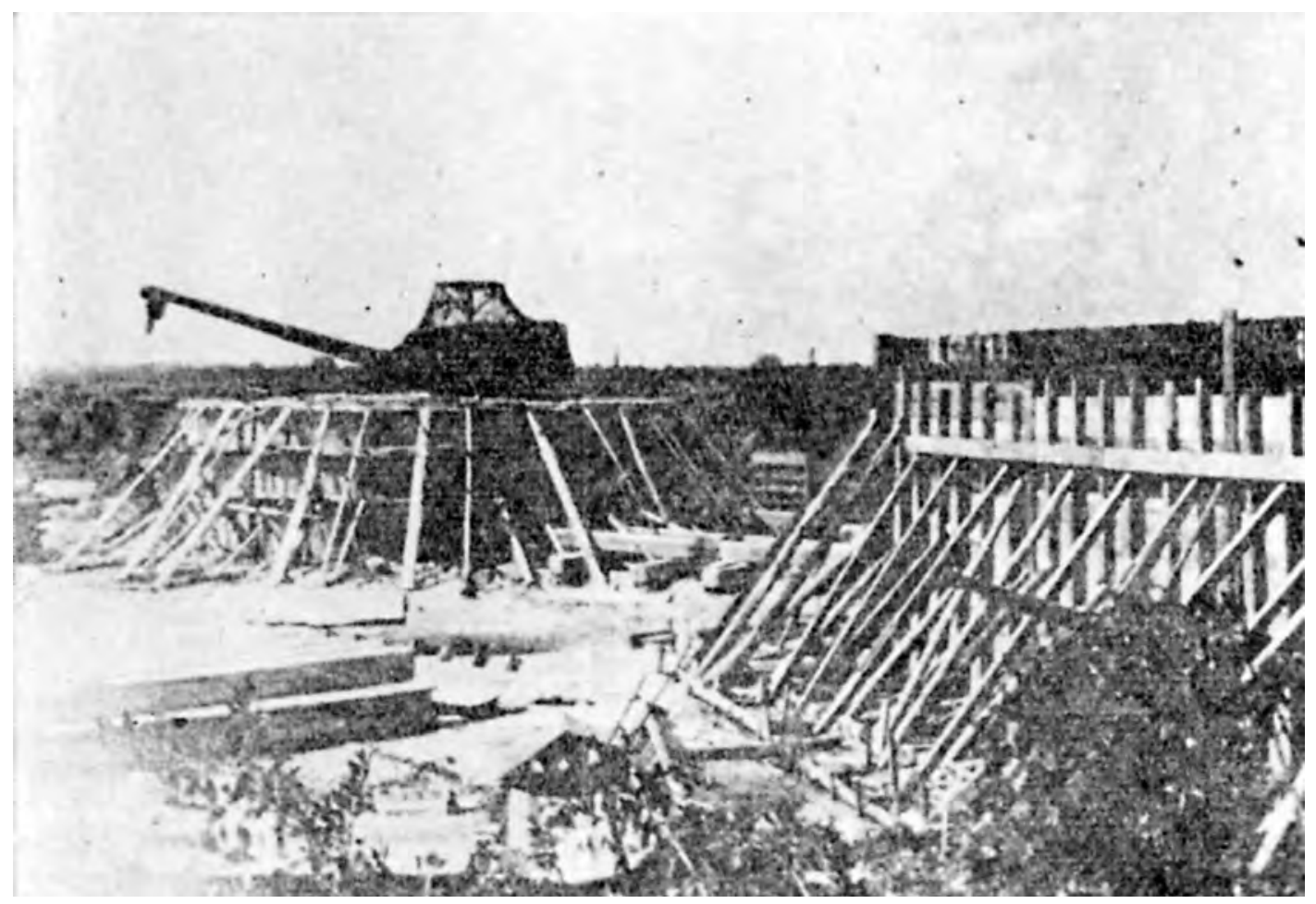

The Modung Battery on the Island of Madura (Under Construction at that Time)

naissance in force. These companies entered the city of Surabaya from the east at 1000 on the 8th, but no Dutch East Indies Army units were spotted. ${ }^{(31)}$

Note: Ninety-three pillbox positions were spotted north of the Wonokromo canal in the front of the Yanagi Regiment. ${ }^{(84)}$

Around 1000, the divisional commander received an aircraft report saying that a white flag was flying on the bridge of Wonokromo (the southern entrance to Surabaya) and immediately sent Staff Officer Kuriya to Surabaya to bring the persons in charge back with him. ${ }^{(79)}$

Then at 1030, a report came from the Tanaka Unit: "We will send the military envoy, who has come to the unit, to division headquarters." (79)

The divisional commander waited well into the afternoon for Staff Officer Kuriya to return, but he was long in coming back. With the first artillery bombardment scheduled to start at 1400 on the 8 th, [the divisional commander] hesitated whether he should open fire as scheduled, but in the end, he decided to cancel the bombardment plan and gave orders to that effect at 1330. For the 15-cm. Howitzer Battery of the 17th Field Heavy Artillery Regiment, which had come in high spirits from Manchuria, the Java operation ended with firing not a single gunshot. ${ }^{(79)}$

At 1420, Staff Officer Kuriya returned, accompanied by the governor of East Java, the mayor of Surabaya and the commander of the garrison army in Surabaya (an artillery lieutenant colonel) but, needless to say, none of them held the supreme command of the entire Dutch East Indies Army in East Java. Considering it impossible to hold ceasefire [talks] with them, Divisional Commander [Tsuchihashi] showed the following demands to them and canceled the talks. ${ }^{(79)}$ 


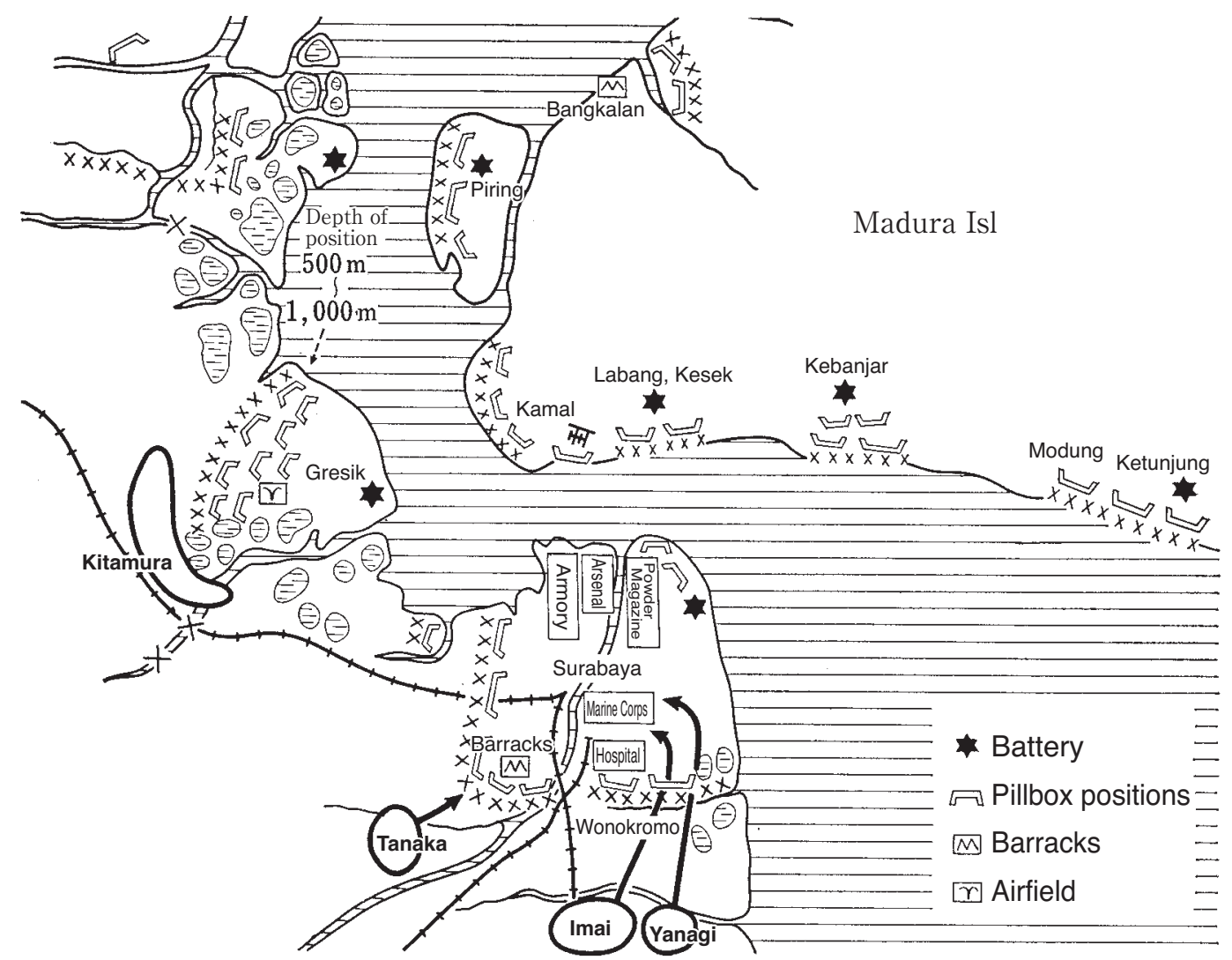

Illustration No. 69 - The Known Situation of the Surabaya Stronghold and the Attack Plan

1. As the Japanese Army would immediately be brought into Surabaya, they should promptly and thoroughly inform the army, police and civilians [there] so that no unforeseen and unfortunate incidents would occur.

2. They should not destroy weapons and ammunition, or other military materiél, facilities, and resources.

3. They should have the commanders of Gresik and Madura present themselves to the commander of the 48th Division as soon as possible.

After that, the divisional commander passed down orders that the reconnaissance teams should go into Surabaya immediately, and the [other] units by 1700, and that the Yanagi and the Imai Regiments should guard respectively the northern and the southern halves of the city of Surabaya. ${ }^{(79)}$

Communications with the Sixteenth Army headquarters had not yet been established since the landing, and they failed to be established that day, too. ${ }^{(79)}$

On the next day, 9 March, in view of the importance of Malang, the division commander assigned Major General Abe to take command of a unit [consisting of] the 2d Taiwan Infantry Regiment as the core, seize the city and guard it. The unit arrived in Malang around 1130, seized it without a hitch, and took charge of the guarding of the city. ${ }^{(79)}$ 
Then, learning that the Kitamura Unit had advanced into Cerme (about ten kilometers southwest of Gresik) that morning, the divisional commander urged it to promptly advance to Gresik. He also sent Staff Officer Nakahara Makoto to Surabaya to have him study how to send troops to [the island of] Madura. ${ }^{(79)}$

At 1330 (on the 9th), by a communications cylinder dropped from a [Japanese] plane, the divisional commander learned for the first time about the complete surrender of the Dutch East Indies Army as well as the surrender terms, which the [Sixteenth] Army headquarters had let the Dutch East Indies side sign. This message was the first communication that the division had received from the army headquarters since its landing on Java. ${ }^{(79)}$

Then, at the report from Major General Abe that Major General Ilgen, the eastern territorial commander and commander of the 3d Division, had presented himself to Major General Abe, the division commander immediately ordered [Abe] to send [Major General Ilgen] to the divisional headquarters in Sidoarjo. Major General Ilgen arrived [there] at 2030. Simultaneously, the commander of the garrison army on Madura also presented himself. ${ }^{(79)}$

The divisional commander immediately held the surrender ceremony. Major General Ilgen (who was accompanied by the Madura garrison army commander and four other people) said that he had the authority to surrender, and signed a surrender document presented by the divisional commander. After that, Major General Ilgen accepted Division Commander Tsuchihashi's demand to "go to Surabaya right now and tell over the radio that all your men shall assemble and surrender," and left. ${ }^{(79)}$

At 1400 on that day (the 9th), the Kitamura Unit entered Gresik, while one company of the 47th Infantry Regiment went ashore in Kamal on the island of Madura. ${ }^{(79)}$

The next morning, on the 10th, Major General Ilgen broadcast the announcement as promised. The divisional commander sent Major General Ilgen to Major General Abe in Malang to be sent to an internment camp. Meanwhile, the divisional commander left Sidoarjo at 1000 on that day (the 10th) and moved his command post to Surabaya at 1400. ${ }^{(79)}$

\section{Conclusion of the Java Invasion Operation and the Operations of the Allied Forces}

\section{The Troop Strength [Involved in] the Operation and the Military Gains}

As of 20 December 1941, the troop strength scheduled to be employed by the Sixteenth Army (excluding air and shipping units) was 97,800 men. ${ }^{(5)}$ However, the [actual] number of troops that landed on the island of Java in the first [transport] for the invasion [operation] (i.e. the troop strength that landed during the first ten days of March, including airfield duty units and shipping units) was about 55,000. ${ }^{(6)}$

The capitulation of the allied forces on Java was completed when the 8,000 troops of the British and Australian Army which had been positioned in the mountain range east of Bandung surrendered on 12 March. ${ }^{(32,33)}$

When the Dutch East Indies Army surrendered on 9 March, the following numbers were reported from the Dutch East Indies side concerning its entire army: ${ }^{(13)}$

Prisoners of war: $\quad 93,000$ (including about 2,000 officers)

Breakdown: Units on Java $\quad 60,000$ 


$$
\begin{array}{ll}
\text { Units outside Java } & 18,000 \\
\text { Volunteers } & 15,000
\end{array}
$$

Captured weaponry:

152 aircraft (breakdown: 24 bombers, 45 fighter planes, and 83 other planes)

367 tanks (including armored vehicles)

732 guns

1,567 machine guns (mainly for aircraft)

97,384 firearms

4,105 bombs

120,000 boxes of explosives

$30,000,000$ shells of various kinds

34,000 hand grenades

$72,317,100$ bullets of various kinds

The military gains achieved on Java by 25 March were as follows:(14)

Prisoners of war: $\quad 82,618$ in total

Breakdown Dutch East Indies Armed Forces 66,219

Australian Armed Forces $\quad 4,890$

British Armed Forces $\quad 10,626$

U.S. Armed Forces 883

Captured weaponry:

177 aircraft

940 guns in total (breakdown: 108 heavy guns, 161 field or mountain guns, 83 antiaircraft guns and 588 [other] guns such as autocannons, antitank guns, trench mortars in total)

4,228 heavy or light machine guns

80,778 rifles and pistols

5, 153 antiaircraft searchlights

$1,728,585$ rounds of gun ammunition

$89,071,820$ cartridges for machine guns and rifles

36,000 bombs

1,059 vehicles in total [consisting of] vehicles, tanks, armored vehicles, and special vehicles

9,500 motor vehicles

7,108 railway carriages

About one year's supply of medicines for 100,000 people

The loss of personnel that the Sixteenth Army sustained was as follows:

1. From the day of the opening of the hostilities to 31 January

35 men killed (including 7 officers), 21 men died of wounds, 0 men died from a disease contracted at the front, 130 men wounded, 6 men contracted a disease at the front

2. The loss it sustained during the Java Operation: 


\begin{tabular}{lrrrr} 
& \multicolumn{2}{c}{1 March } & \multicolumn{2}{c}{$2-5$ March } \\
& killed & wounded & killed & wounded \\
Shōji Detachment & 63 & 165 & 19 & 26 \\
Sakaguchi Detachment & 1 & 18 & 2 & 28 \\
2d Division & 15 & 10 & 64 & 180 \\
48th Division & 91 & 254 & 0 & 21 \\
In total & 170 & 447 & 85 & 255
\end{tabular}

Of the convoys of the first transport of the Java invasion operation, the convoy of the Shoji Detachment completed disembarkation on 4 March, and the convoy of the Sakaguchi Detachment and the 48th Division on 6 March. As for the main force of the Sixteenth Army, after the seizure of Batavia, the ships were brought to that port for disembarkation, and the final convoy started its return [to its original port] from that port on $14 \mathrm{March}$. As we have seen, the transport of the Java invasion units was to be carried out in three transports (1st transport: 560,000 tons, $2 \mathrm{~d}$ transport: 150,000 tons, 3d transport: 100,000 tons; 810,000 tons in total). The convoy of the $2 \mathrm{~d}$ transport departed from Sakaide, Ujina, Moji, Dalian, Qingdao, Shanghai, Gaoxiong and Lingayen, respectively carrying the $3 \mathrm{~d}$ Battalion of the $2 \mathrm{~d}$ Field Artillery Regiment and other units to be carried in the $2 \mathrm{~d}$ transport in the following ships, which assembled in Cam Ranh Bay between 9 and 20 March, and operated on a schedule to land in Java on 29 March: ${ }^{(27,94)}$

England-maru, France-maru, Kamoi-maru [Shin'i-maru], Shunkō-maru, Rashin-maru, Manshū-maru, London-maru, Akiura-maru, Chile-maru, Nichiren-maru, Kamo-maru, Tamahoko-maru and Delagoamaru

However, the Java invasion operation was completed as early as 9 March. [As a result,] it was decided to transport only such necessary units as the field artillery battalion of the $2 \mathrm{~d}$ Division [to Java] and redeploy the other units to other areas or send them back home. ${ }^{(27,36)}$

On 10 March, the Emperor called the chiefs of the Army and the Navy General Staff to his presence and bestowed an Imperial Rescript on the Commanders in Chief of the Southern Army and the Combined Fleet, which read as follows: ${ }^{(13)}$

\section{Imperial Rescript}

The units of the Army and the Navy which executed operations in the East Indies area have in close and effective cooperation covered a long distance, overcome many difficulties, and skillfully destroyed the enemy air power as well as its naval vessels. At the same time, the units resolutely carried out extremely difficult landing operations in various areas and while crushing the formidable enemy everywhere, thoroughly destroyed all the enemy key bases with great speed and boldness, and have swept away the power of the enemy.

We have the greatest respect for them.

On 12 March, various ceremonies of the second celebration day of the war victory were held in the homeland. ${ }^{(13)}$ 


\section{The Operations of the Allied Forces (See Illustration No. 70)}

According to the published war history of Britain and the statements of Lieutenant General Ter Poorten and other generals of the Dutch East Indies Army, the operations of the allied forces were carried out in outline as follows: ${ }^{(50,51)}$

On 3 January, the American-British-Dutch-Australian [ABDA] Command was formed and its Supreme Commander General Wavell arrived in Java on 10 January. On the 18th, he set up his general headquarters in Lembang but left Java after disbanding it on 25 Febru$\operatorname{ary} .^{(51)}$

Earlier on 2 January, Britain had decided to reinforce the Dutch East Indies with two divisions from the Middle East. At the end of January, when Singapore had become isolated, General Wavell made the decision to employ the Australian division that was expected to arrive at the end of February for Sumatra and the Australian division and armored brigade that were scheduled to arrive in March for Java. However, as the situation became critical, he requested Lieutenant General Ter Poorten on 5 February to divert a total of two battalions from Batavia and Cimahi on Java to Sumatra. In the middle of February, when [the Japanese] conducted the Bangka and Palembang operations, the total troop strength of the Dutch East Indies Army in Sumatra was seven battalions, of which one battalion was stationed in Palembang and another battalion on the islands of Bangka and Belitung. These two battalions were the above-mentioned force that had been diverted from Java. The bulk of these two battalions and an advance party of the Australian Army, which had been arriving in southern Sumatra at that time, retreated to Java one after another. ${ }^{(50,51)}$ Right after [the Japanese] carried out the landing on Bali (on 20 February), the decision was made to call off the additional deployment of the two Australian Army divisions to the Dutch East Indies (their destination was changed to Burma and India [instead]). ${ }^{(51)}$

When [the Japanese] launched the Java landing operations, the troop strength on Java consisted of about 65,000 Dutch East Indies Army troops and about 16,000 U.S., British and Australian Army troops, totaling about 81,000 troops. ${ }^{(51)}$

Of the troops of the Dutch East Indies Army, about 25,000 troops belonged to regular units, which consisted of four infantry regiments (with three battalions each) as the core. There were three divisional headquarters, and apart from these, there was the Bandung Sector Garrison Army headquarters. The main force of the U.S., British and Australian Army was called the "Black Force" and consisted of two infantry battalions as its core. ${ }^{(51)}$ [Editor's note: The "Black Force" was named after its commander Brig. Gen. A.S. Blackburn.]

The disposition of the main regular units [of the Dutch East Indies Army] at the time when [the Japanese] launched the Java landing operation was in outline as follows: ${ }^{(50)}$

Army headquarters (Lieutenant General Ter Poorten): Bandung

Western Java Corps ([led by] 1st Division Commander, Major General Schilling)

Headquarters: Batavia

1st Infantry Regiment: Batavia, Tangerang sector

2d Infantry Regiment: Buitenzorg sector

Black Force: Buitenzorg sector

Bandung Area Garrison Army Corps (Major General Pesman)

Headquarters: Bandung 
4th Infantry Regiment: the area stretching from Cirebon and vicinity in the east to Krawang and vicinity in the west, with its center in Bandung

Central Java Corps (2d Division Commander, Major General Cox)

Headquarters: Magelang

No regular infantry regiments

Eastern Java Corps (3d Division Commander, Major General Ilgen)

Headquarters: Surabaya area (primarily in Malang)

3d Infantry Regiment: with its main force in the area of Babad and Bojonegoro, and one element in the area of Cepu and Kertosono

Lieutenant General Ter Poorten had judged that the Japanese army would be able to employ six to seven divisions for the invasion of Java and that the Japanese would have their main force land in western Java. Because of this, he had transferred the $2 \mathrm{~d}$ Infantry Regiment from Bandung to the Western Java Corps, and the 4th Infantry Regiment from the Central Java Corps to the newly established Bandung Area Garrison Army Corps at the end of February. ${ }^{(50)}$

Lieutenant General Ter Poorten had given orders to the Eastern Java Corps to hold on to the Surabaya stronghold as long as possible, and to the Central Java Corps to conduct a protracted struggle, while putting on a show that its strength was greater than it was, and retreat in the end towards Cilacap and Bandung. He had [also] ordered the Western Java Corps to aggressively make counterattacks. He had judged that even if the Japanese landed at the coast north of Bandung (western central Java), it would be just for establishing a beachhead in Cirebon. ${ }^{(50)}$

On the morning of 1 March, at the start of the landing of the Japanese troops, the Western Java Corps began to move westwards in order to counterattack the Maruyama Division on the line connecting Tangerang and Leuwiliang. The Black Force headed for Leuwiliang. The Bandung Area Garrison Army Corps launched a counterattack against the Shōji Detachment ([landing at] Eretan) via a coastal road with the battalion from Cirebon. In the afternoon, it turned out that Kalijati had been taken. In the late afternoon of the 1st, Lieutenant General Ter Poorten passed down orders to the Western Java Corps to divert the 2d Infantry Regiment (as one of its battalions had not yet returned from [its assignment in] West Sumatra, its actual strength was [only] two battalions), one battalion of the 1st Infantry Regiment and the Black Force ([consisting of] two battalions as its core) to be put under the command of the Bandung Area Garrison Army Corps for [a counterattack] to destroy the Shōji Detachment. ${ }^{(50)}$

On 2 March, Bandung Area Garrison Army Commander Major General Pesman carried out a counterattack with the [Japanese] landing point at Eretan as the general target. The battalion in Cirebon moved westward, while twenty-five tanks as well as one infantry battalion from the Bandung stronghold headed northward by way of Subang, and one battalion of the 1st Infantry Regiment in Batavia moved eastward, following a route close to the coast. However, [the counterattack] ended up in failure. On that day, the 2d Infantry Regiment ([consisting of] two battalions) arrived in the sector west of Bandung. The Black Force, having expressed its [negative] opinion on the plan, did not shift its position. ${ }^{(50,51)}$

On 3 March, with the 2d Infantry Regiment ([consisting of] two battalions) added to the strength of the previous day, [Major General Pesman] launched a counterattack with Kalijati as the primary target. Although the $2 \mathrm{~d}$ Infantry Regiment was bombed by the Endo Air Di- 
vision when it was moving forward via Purwakarta, it engaged with the Wakamatsu Battalion until the morning of the following day, the 4th. One battalion of the 1st Infantry Regiment, which was moving east from Batavia, engaged on the morning of the 4th the Egashira Battalion, which had moved via Subang and Kalijati [to Cikampek]. On that day (the 3d), the Black Force ([consisting of] two battalions) started to engage the Nasu Detachment at Leuwiliang. [Also] on that day (the 3d), the main force of one of the battalions, which had been sent earlier to southern Sumatra, came [back] ashore in Wijnkoopsbaai on the southwest coast [of Java] and started its advance towards Bandung. Further, one semi-regular battalion was diverted from the Central Java Corps to Bandung. ${ }^{(50)}$

On the morning of 4 March, engagements went on in Cikampek (with the Egashira Battalion), Purwakarta (with the Wakamatsu Battalion) and Leuwiliang (with the Nasu Detachment). Before noon, Lieutenant General Ter Poorten gave orders to the units in Batavia and Buitenzorg area to assemble in the Bandung stronghold. [He also] ordered the Black Force to retreat to Sukabumi. ${ }^{(50,51)}$

Around noon on 5 March, the units in Batavia had finished their retreat. In the afternoon, the Black Force withdrew from its rear positions around Buitenzorg and vicinity. It was [newly] assigned to take charge of the eastern sector of the Bandung defense line. ${ }^{(50,51)}$

On 6 March, the Shōji Detachment attacked the positions south of Ciater. Lieutenant General Ter Poorten decided to make the position at Lembang ([with the unit consisting of] one regular battalion as its core) his main position, and made up his mind that he would surrender Bandung if this position should be seized.

On the afternoon of 7 March, Lembang was taken. Thus, he sent a military envoy to the Shōji Detachment with an offer to surrender. ${ }^{(50)}$

As we have seen, the Central Java Corps did not have a regular regiment. Major General Cox, the commander of the $2 \mathrm{~d}$ Division, tried to block the advance of the Sakaguchi Detachment at vital positions with militia units, as well as the deployment of a cavalry unit. [In the meantime,] he moved its headquarters from Magelang to Wangon. ${ }^{(50)}$

Major General Ilgen, commander of the Eastern Java Corps (and commander of the $3 \mathrm{~d}$ Division) had intended to launch an aggressive counterattack from the direction of the Solo River. He had positioned the 8th Battalion of the $3 \mathrm{~d}$ Infantry Regiment in Bojonegoro and the 13th Battalion in Babad, and the 3d Battalion on the island of Madura (the Surabaya stronghold area), while positioning the semi-regular 19th Battalion in the Cepu and the Kertosono areas. As soon as Bojonegoro and Cepu were taken, the commander changed the disposition: [while leaving] the 13th Battalion in Babad (as before), he shifted the 8th Battalion to Sukorame, south [of Babad], the semi-regular 19th Battalion to Kertosono and the 3d Battalion to Surabaya. When Major General Ilgen learned that despite the fierce engagement that occured in Kertosono, the Japanese presence in the Babad area consisted of nothing more than a reconnaissance regiment (the Kitamura Unit), he had the 3d Battalion in Surabaya move to Mojokerto to have it cover the retreat [of other troops], and [in the meantime] had the 8th and the 13th Battalions retreat respectively to Porong and Gempol, and the semi-regular 19th Battalion to Pandakan, after which he had the 3d Battalion retreat to Gempol. Then when the Porong sector was broken through [by the Japanese], Major General Ilgen had the 13th and the semi-regular 19th Battalions retreat to the east of Malang, and the $3 \mathrm{~d}$ and 8th Battalion respectively to Jember and Lumajang, while having his headquarters pull back to 


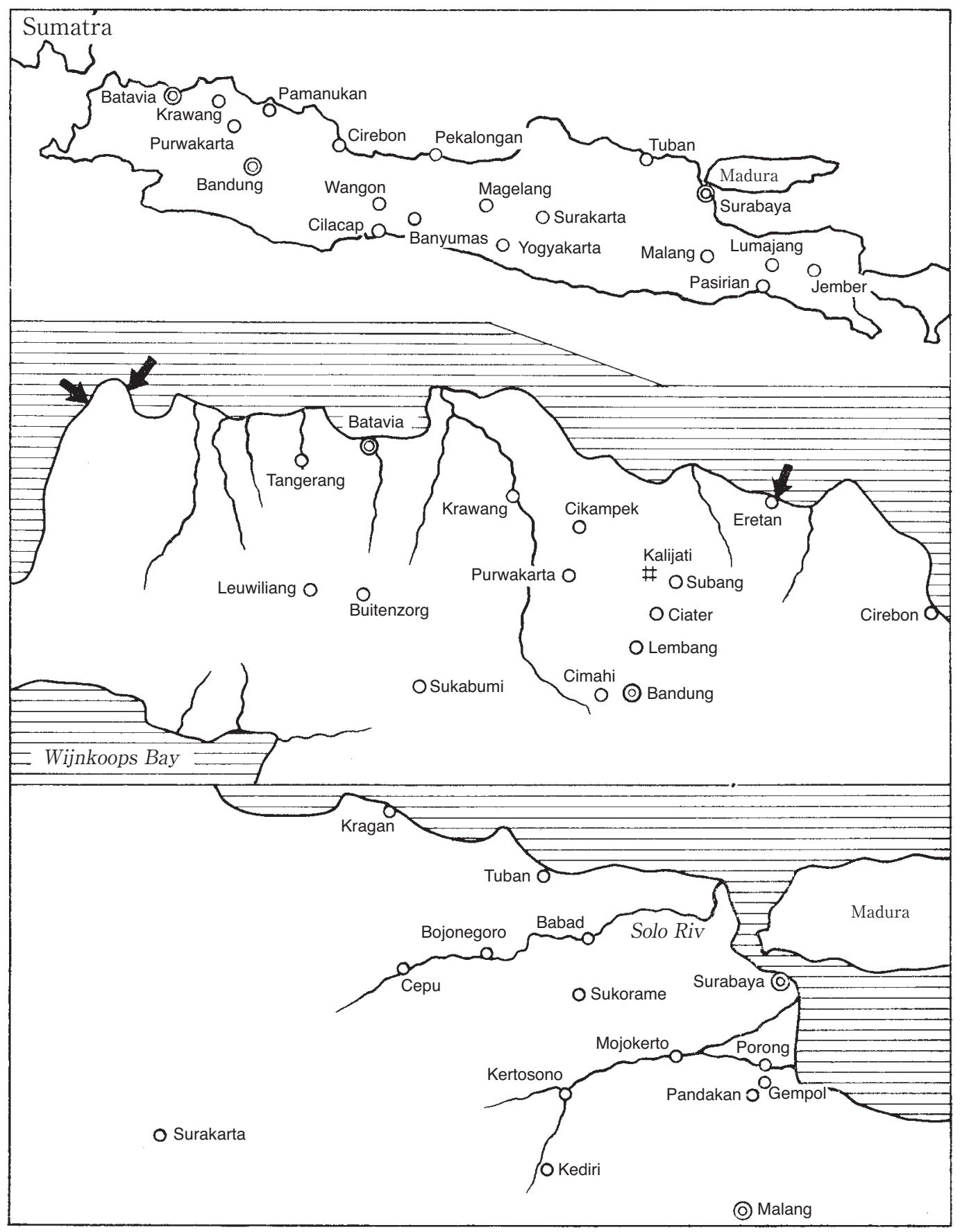

Illustration No. 70 - Locations Relevant to the Operations of the Allied Forces

Pasirian from the Porong area. After hearing the surrender broadcast from Bandung, Major General Ilgen also offered his surrender. ${ }^{(50)}$ 


\section{The Black Clandestine Broadcasts by the Southern Army}

One of the causes that swiftly brought the Java [invasion] operation to a conclusion was [Japanese] black clandestine broadcasting aimed at Java. According to the "Report on the Progress of Black Clandestine Broadcasts toward Java" of the headquarters of the Southern Army and the recollections by Captain Tarōra Sadao, the black clandestine broadcasts were conducted in the following way:

\section{Decision to Broadcast}

At the beginning of February 1942, a large number of NHK [Japan Broadcasting Corporation] broadcasters and press reporters had assembled at Staff Section 2 of the headquarters of the Southern Army (at Saigon) to prepare for the reopening of broadcasting stations after the seizure of the stations at Singapore, Rangoon, Bandung, etc. When the work of the intelligence staff calmed down after the fall of Singapore on 15 February, the reporters of the various news agencies working at the Publicity Department as well as at Section 2, the representatives dispatched from the Ministry of Foreign Affairs, and the intelligence officers made a joint study at Section 2 with Captain Tarōra Sadao as the central figure. They drew up a plan to deliver black clandestine broadcasts toward Java in close coordination with the Java invasion operation of the Sixteenth Army in order to quickly conclude the Java [invasion] operation as well as to prevent scorched-earth tactics from happening in Java. Their plan received the approval of Commander in Chief Terauchi.

\section{The Broadcasting Situation in Java}

In Java, the Dutch East Indies had so far set up large broadcasting stations operating with a power of one to ten kilowatts in Surabaya, Bandung, Tanjung Priok [and other cities] to cover every region, and about twenty-eight smaller broadcasting stations in each region for broadcasts within the provinces and local regions; each [station] transmitted broadcasts to individual antennas. It seemed that in order to strengthen the air defense and to intensify propaganda and guidance by radio after the outbreak of the Greater East Asia War, the broadcasting stations had been brought under government control with the Bandung broadcasting station acting as the center, while the broadcasts from the Tanjung Priok station were essentially suspended. Programs were broadcast from the station at Bandung with 1.5 kilowatts of power on three frequencies, 15,310, 11,000 and 10,260 kilocycles, and the station called itself Batavia Station or Bandung Station as the occasion demanded.

At that time, in view of the past example when clever German use of black clandestine radio [broadcasts] had led the Netherlands and Poland to make numerous mistakes, the Dutch East Indies were extremely on guard against radio waves of dubious origin. As a defense against such broadcasts, apart from implementing various technical measures, it did not shut down the emission of radio signals after the sign-off. Furthermore, following the examples of other countries, it particularly attached importance to domestic propaganda radio programs. Not to mention public notices or announcements of the government or the army authorities, it communicated at times [even] orders and official notices such as mobilization and assembly orders, or orders for subordinate units, using common language, abbreviations and secret language. As a matter of course, control and censorship of the news were strictly implemented. 


\section{The Situation at the Saigon Broadcasting Station}

The broadcasting station of Saigon available to the Southern Army had [the equipment, which could broadcast] with 12 kilowatts of power on the frequency of 10,240 and 6,180 kilocycles, and with 3 kilowatts of power on the frequency of 10,150 kilocycles. The Southern Army provided and also censored the news broadcast in Dutch and Malay by French Indochina on the frequency of 10,240 kilocycles. However, the army kept itself in the background and just let French Indochina put these programs on the air. As a result, the addresses from Saigon to the Dutch East Indies remained very passive.

\section{Preparations for Broadcasting by the Southern Army}

In order not to expose the [Japanese] intentions, the Southern Army planned to transmit, during the Java invasion operation and in close coordination with the operations, the necessary deceptive broadcasts from the Saigon broadcasting station by using the name of the Dutch East Indies authorities and switching the original signal sent with 12 kilowatt of power on the frequency of 10,240 kilocycles to a signal on the frequency of 10,260 kilocycles on the same wavelength as the broadcasting station of Bandung, hoping that it would lead the Dutch East Indies Army to make the wrong judgments about the [Japanese Army's] intentions and its strength. [The Southern Army] also planned to swiftly obtain a full surrender through the demoralization of the Dutch East Indies by stressing the irresponsible attitude of the United States and Britain regarding the defense of Java, and started its preparations for the black clandestine broadcasts.

The use of the broadcasting station at Saigon, the frequency changes, and its long-term overall use in particular, were considered quite difficult because of the complexity of the international relationship between Japan and France. However, after the official submission of the request to the government of French Indochina on 23 February and all sorts of negotiations, the [Japanese] request was accepted. The Southern Army provided the Saigon Broadcasting Station with crystals with a frequency of 10,260 kilocycles and adjusted [the equipment] so as to be able to timely switch [its frequency] from 10,240 kilocycles [to 10,260 kilocycles].

In order to conduct the black clandestine broadcasts, the Southern Army organized a special broadcasting detail in the following way:

\section{Organization of the Special Broadcasting Detail}

General supervisor:

Editing staff:

Translators (including broadcasters):

Technicians (including monitor staff):

External relations staff:

In total:

\section{1 company officer}

1 company officer and 2 army-drafted personnel 1 embassy vice-consul (Dutch language), 1 officer cadet (Dutch language), 4 army-drafted personnel (1 for the Malay and 3 for the Dutch language), 2 Malays, 1 Indonesian and 1 Dutchman 5 army-drafted personnel (interception [of broadcasts] in the Dutch language only)

1 company officer and 2 army-drafted personnel 18

[Editor's note: The numbers do not add up, unless the foreign nationals are not included.] 


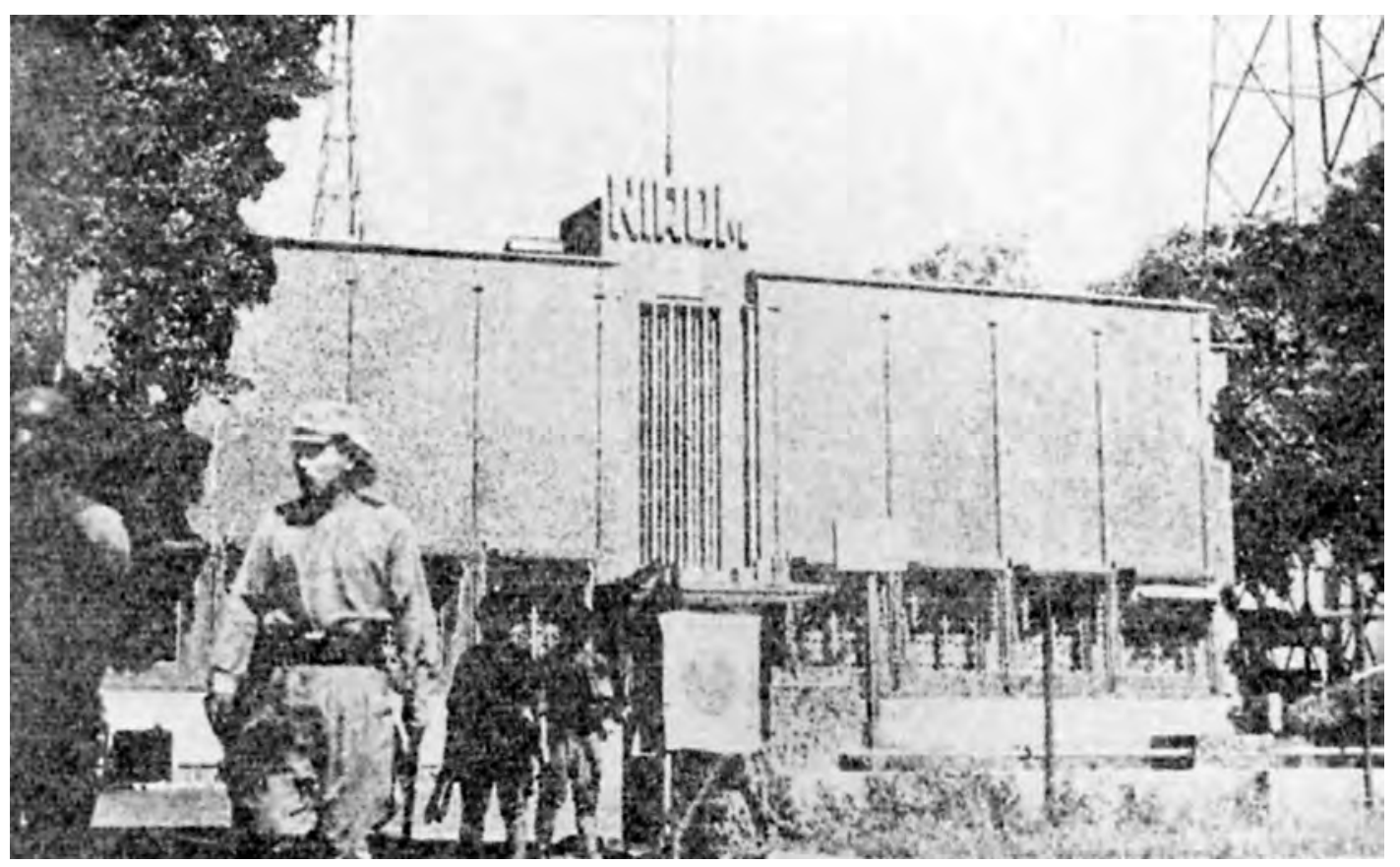

The NIROM Broadcasting Station in Bandung

From 25 to 28 February, the Special Broadcasting Detail intercepted broadcasts by the NIROM [Nederlandsch-Indische Radio Omroep Maatschappij: Dutch East Indies Radio Broadcasting Corporation] (at Bandung) and monitored the signals night and day. With the broadcasts of the Saigon station still on the air as usual so as to conceal its intentions, the detail monitored the NIROM signal around the clock day after day, trying to find out agitation on the Dutch East Indies side during the day, and carefully seeking the moment when transmissions would be suspended at night. The Dutch East Indies side did not suspend the emission of the signal all night but transmitted instead the sound of a bell every fifteen seconds, as if they were on guard against sham broadcasts.

\section{Broadcasting}

On 27 February, the Special Broadcasting Detail had finished its preparations.

On 27 and 28 February, the Dutch East Indies broadcasts were as confident as ever, with no admission of anything out of the ordinary.

At 0000 on 1 March (the day of the landing of the Sixteenth Army), with the sudden [broadcast of] an air-raid alarm siren, the tumult in Java was on the air, and lasted for about two hours. At 0630, the signal of the Dutch East Indies broadcasting station, which [normally] was never suspended all day long, was interrupted. [The Special Broadcasting Detail] monitored the situation of the Dutch East Indies station for a while and prepared itself to start its black clandestine broadcast at 0800, when the Dutch East Indies station resumed its transmission at 0805 . However, it only briefly reported the landing of the Japanese Army on the north coast of Java, and then as usual it only leisurely broadcast news from overseas as well as music until the end of the program of that day. 
At 0730 on 2 March, the signal of the Dutch East Indies was [again] interrupted as on the day before. Without missing an opportunity, the Special Broadcasting Detail immediately started putting Dutch music on the air from the Saigon station at the frequency of 10,260 kilocycles, modulated the signal, and was about to switch to the real broadcast, when at 0800 the Dutch East Indies station again resumed its broadcast. The Special Broadcasting Detail had no choice but to abort its transmission and decided to wait until the morning of the $3 \mathrm{~d}$. Originally, the start of the black clandestine broadcasts was planned in such a way that simultaneously with the start of the landings of the Sixteenth Army in Java the Endō 3d Air Division would destroy the Bandung broadcasting station. As soon as the station had gone off the air, the Special Broacasting Detail would assume the identity of the Bandung broadcasting station at the right moment and start broadcasting from the Saigon broadcasting station with the message: "A short while ago, our broadcast from the Bandung broadcasting station was interrupted due to a bombardment, but as the damage has been fixed, we are resuming our broadcast." However, judging from the condition of the air defense facilities of the Bandung broadcasting station, the chances of success of a bombing raid by the $3 \mathrm{~d}$ Air Division were deemed small. Therefore, it was decided to start the black clandestine broadcasts from 3 March onwards, regardless of the situation of the signal of the Dutch East Indies broadcasting station, and get hold of the listeners through technical manipulation.

From 0730 on 3 March onwards, the Special Broadcasting Detail began its black clandestine broadcasts as scheduled from the Saigon broadcasting station, using the name of the Bandung broadcasting station. That is to say, the detail aired a black clandestine broadcast for about thirty minutes from 0730, before the morning newscast of the NIROM, and another black clandestine broadcast in Dutch and Malay after the evening newscast of the NIROM was over. The main topics of the broadcasts were as follows:

1. The Japanese army has been reinforced. Its troop strength already runs to 100,000 men and the Dutch East Indies Army is caught in a desperate battle. Reinforcements from Britain, the United States and Australia have not arrived yet.

2. Due to the powerful and swift advance of the Japanese troops and the half-hearted attitude of the British, U.S. and Australian forces, the Dutch East Indies forces are caught in a lost battle that is beyond control.

3. Large forces of the Japanese army are rapidly advancing. The destiny of Java is likely to be decided within a few days. A responsible authority said: "The defense of Java was not as important to the Allies as that of Australia."

4. Large formations of Japanese air units once again carried out fierce airstrikes on Port Moresby and Port Darwin.

5. The failure of the [allied] operation on Java has shaken Churchill's position.

6. The U.S.-Filipino Army on the Bataan Peninsula is running short of provisions and is facing a most difficult condition.

7. The Japanese troops in Burma have been reinforced. They stormed Rangoon, which left the British Indian Army no choice but to give up the city.

8. German submarines are intensily active off the coast of the Atlantic Ocean.

9. Those who are in possession of motor vehicles or motor bicycles and live in or around Bandung are required to assemble immediately. Those who have been called up for service and have been requested to present themselves at the Navy Department in Surabaya today do not need to be enlisted [anymore]. 
10. The Japanese troops, which landed at the bay of Indramayu, are now approaching a point thirty kilometers north of Bandung.

11. According to stories of eyewitnesses to the horrors of war, the Japanese army has meted out severe punishments to those who engaged in scorched-earth tactics.

That day (3 March), was the day when the Nasu Detachment advanced to the front of the Leuwiliang position and large-scale counterattacks from all sides were launched against the Shōji Detachment. The reactions to and the success of the aforementioned broadcasts, however, were observed as follows:

1. At the beginning of the [Japanese] landings on the island of Java, radio communications in all countries hardly mentioned the Japanese troop strength that had landed on the island. However, from 5 March onwards, such articles as "the strength of the Japanese army that has landed on Java is estimated at 70,000 to 100,000 troops," started to be seen in Arip [the semiofficial French Indochinese news agency] and other media, after which the Dutch East Indies came to overestimate the Japanese troop strength.

2. [The topics on] the airstrikes on Australia and New Guinea were broadcast roughly one day later.

3. The coverage of the instability of Churchill's cabinet started to appear in succession in overseas news from around 5 to 6 March. On 6 March, the [Japanese] Dōmei News Agency even started reporting as news from Washington that "Howard [Stafford?] Cripps is the successor." It was observed that this news might to a certain degree have been derived from the black clandestine broadcast.

The Bandung broadcast on that day (3 March) was as usual; it only briefly touched on the war situation on the island, with no admission of anything out of the ordinary.

The next day, 4 March, was the day when the Nasu Detachment attacked the Leuwiliang position all day, the Wakamatsu Battalion of the Shōji Detachment returned to Kalijati after seizing Purwakarta to the west in the morning, and the Egashira Battalion advanced to the bridge over the Citarum River. On that day, the Special Broadcasting Detail delivered black clandestine broadcasts for about thirty minutes three times in the morning and [again] three times in the afternoon in Dutch and Malay from the Saigon broadcasting station, calling itself the Bandung broadcasting station. The broadcast topics were in outline as follows:

1. Japanese air forces bombed Sydney as well as key locations on Java, yesterday 3 March.

2. Due to a shortage of troops and the irresponsible retreat of U.S., British and Australian forces, the Dutch East Indies Army has been forced into an overall retreat. We, the people of the Dutch East Indies should have second thoughts about the position of the Dutch East Indies.

3. Prime Minister Churchill and President Roosevelt have promised specific support to Australia in a joint statement.

4. General Wavell has fled to India.

5. The Dutch East Indies government and army will put off the implementation of matters they have already publicly announced.

6. The people of the Dutch East Indies must stop destroying basic facilities for daily life and calmly wait and see.

7. The information the government had provided the people with was incorrect. The Japanese army is powerful but has a warm heart.

8. Under fierce attacks from the air as well as by land, Bandung is on the verge of a crisis. 
9. Van Mook has raised strong protests against Britain and the United States.

10. U.S. government circles are giving a sharp retort to the slander on Lieutenant General MacArthur in a London broadcast.

11. A large Japanese army unit has crossed the Sittang River, which is putting pressure on Britain to provide support for Burma.

12. The Japanese air power deserves close attention and the United States is going all out to investigate the true state of things.

13. The Dutch people in the home country under German occupation are worried whether the Dutch East Indies will adopt destruction tactics for Java.

14. The island of Java is about to be split into three by the Japanese army. All residents must give up their dependence on other countries.

On that day (the 4th), the Dutch East Indies broadcasting station aired its programs as usual. The war situation in Java was only briefly broadcast, with no admission of anything out of the ordinary. Nevertheless, the [black clandestine] broadcast on that day was considered to have had the following effect:

1. It seemed that the [Japanese] broadcast, which had hinted at the shortage of strength of the Dutch East Indies Army, especially the news that the Japanese troops were being continuously reinforced, had caused considerable anxiety on the Dutch East Indies side. On the night of the 5th, the NIROM station broadcast that: "The Japanese troops are more numerous than ours and we are at a disadvantage in every aspect." The NIROM station repeated a similar broadcast on the 8th.

2. Apart from broadcasting the general war situation, the fact that [the Japanese clandestine broadcast] clearly mentioned the seized locations in particular apparently had a great effect on attracting people to the black clandestine broadcasts. As a result, from the 5th onwards, the NIROM station all of a sudden changed its former attitude of providing only brief and abstract reports; moreover the contents of its releases became pessimistic.

The next day, 5 March, was the day when the Nasu Detachment seized the Leuwiliang position in the morning and advanced to the front of Buitenzorg in the evening, the Sato Detachment entered Batavia at night, and the Shōji Detachment moved southward from Subang and seized the pillbox positions at Ciater in the evening. On that day, the Special Broadcasting Detail, as on the preceding day, delivered its broadcasts [this time] for about one hour once in the morning and [again] three times in the afternoon in Dutch and Malay from the Saigon broadcasting station, calling itself the Bandung broadcasting station. The contents of the broadcasts were as follows:

1. The Japanese Army has again landed large units on the north coast of Java as well as on several locations on the south coast.

2. Van Mook is reproaching Britain and the United States.

3. In order to arrest persons engaging in scorched-earth tactics, the Japanese Army is using fifth column units.

4. On 3 March, the Japanese Army carried out an intensive bombardment on Sydney and key locations in the periphery of Java.

5. People must stop destroying basic facilities for daily life and calmly wait and see.

6. Bandung is facing a total crisis due to fierce attacks by the Japanese air force. 
7. A large Japanese army unit has crossed the Sittang River, which is putting pressure on the British Armed Forces to provide support for Burma.

8. The United States is paying close attention to the Japanese air power and is going all out to investigate the true state of things.

9. The Dutch people in the home country under German occupation are worried whether the people in Java will carry out scorched-earth tactics.

10. The island of Java is about to be split into three by the Japanese army. All residents must give up their dependence on the United States, Britain and Australia.

11. The garrison of Batavia has offered a cease-fire to the Japanese.

12. General Wavell, who has returned to India, said that he had gained a new appreciation of the Japanese forces and stressed the necessity of intensive training for his own troops.

13. The British House of Commons is debating the issue of a shortage of troops as well as of labor in Australia.

14. The whole north coast and west coast of Australia is frightened by the Japanese air strikes.

15. The lines of communication of our army have been cut off. People must not engage in hasty acts of destruction.

16. Van Mook's protests against Britain and the United States are creating a great sensation among the allied nations.

17. The residents in the areas along Bantam Bay occupied by the Japanese army are living a normal life.

18. The Japanese Army is using fifth column [units] to arrest saboteurs.

19. At an Allied War Council, the Australian representative requested reinforcements from Britain and the United States.

20. The Japanese Army landed at Wijnkoopsbaai as well as east of Probolinggo on the 5th.

21. All listeners are asked to beware of false rumors [spread by] news from unidentified broadcasting stations.

22. Honolulu, which has been shaking from massive explosions of an unknown origin, came under a large Japanese airstrike on the 5th.

23. Germany made a mocking remark about the removal of General Wavell and the Dutch people in the home country are delighted about it.

The Bandung broadcasting station maintained its broadcasts in the same manner as it had on the previous day until the evening of that day (the 5th). However, all of a sudden at 2015, the station started to show its reaction to [the Japanese] broadcasts. That is to say, the Bandung station started with a public announcement warning that "in order to obstruct our military leadership, the enemy (Japan) is sending clandestine broadcasts from a certain broadcasting station. Listeners must mark the difference by the voice of the announcers and not be swayed by these [fake broadcasts]." Then, the station aired all at once all the discouraging topics that had been concealed so far: such as the situation of defeat in Java, the anxiety in political circles, the conflict between Britain and the United States over the failure to defend Java, the protest by the Dutch East Indies authorities to Britain and the United States, the search for who was to blame for the defeat, etc. After that, the Dutch East Indies side lost control over its propaganda and the station began to give reactions that were induced by the Japanese broadcasts. It seemed that the propaganda policy of the Dutch East Indies had basically collapsed. Particularly, when the [Japanese] Special Broadcasting Detail aired on that day that "Van Mook has raised a fierce protest against Britain and the United States about General Wavell's retreat to India," the Dutch East Indies side, as if making some kind of excuse, broadcast several times on the 6th as well as on the 7th, a recording of Van Mook's ad- 
dress at the People's Council of 5 March, which was very unfavorable for the Dutch East Indies. It provided the Japanese with materials to decide on conducting a broadcast to advise the Dutch East Indies to surrender.

The main results gained in the response to the broadcast on that day ( $5 \mathrm{March}$ ) were in outline as follows:

1. Alarmed at the news of "further landings of large units of the Japanese Army" in the [Japanese] clandestine broadcasts, the Dutch East Indies side believed it and aired a report at 2300 on 6 March from the NIROM station that "the Japanese Army is conducting further landings at Tegal, Cilacap, Probolinggo and the island of Madura."

[The fact was that] the Japanese Army had conducted no landings at all at the aforementioned locations. However, the broadcast of the Special Broadcasting Detail deceived the broadcasting station of the Dutch East Indies, which in turn misled the Dutch East Indies Army, and eventually IGHQ and the Sakaguchi Detachment were [also] misled.

The chief of the Special Broadcasting Detail, Captain Tarōra, recollected it as follows:

After the completion of the operation, survey squads were immediately dispatched to the field. In all the areas where we conducted on-site surveys, the people as well as officials were obeying the instructions from Saigon and had no doubts whatsoever even after the surrender. The chief of operations of the Dutch East Indies Army headquarters stated: "As information on [further] landings [of the Japanese] in Cilacap was repeatedly received, I sent one of our two heavy artillery batteries that had been kept in reserve down south, but up to now I still have my doubts about the source of this information." It was only much later, when the staff officers involved presented themselves at IGHQ, and were asked, "Who had ordered the landing in Cilacap," and answered, "That was just a fabrication," that [IGHQ] saw the funny side of it.

Staff Officer Yano of the Sakaguchi Detachment recalled it as follows:

As we had information that "Japanese forces are landing in Cilacap and vicinity," we had no doubt that the Navy was trying to distinguish itself by stealing a march on us, and we furiously charged toward Cilacap.

2. The aforementioned broadcast of "further landings of the Japanese Army" by the NIROM also reached countries abroad at face value, and a broadcast in San Francisco aired [a report of] "further landings of 50,000 Japanese reinforcements" on the 6th.

3. Against the black clandestine broadcast of the Special Broadcasting Detail that "Van Mook has raised protests against Britain and the United States," the NIROM aired a recording of Van Mook's address at the People's Council on the previous day. The recorded speech contained the following passage: "If the Dutch East Indies had not participated in the war, we would now be like Thailand and French Indochina." These words were carefully scrutinized for possible hidden meanings. But then again, the recorded speech was interpreted as nothing but an excuse to the people. This speech became valuable material in the decision to broadcast an advice to surrender.

4. It was observed that topic No. 3 (the use of fifth column units to arrest those who engaged in scorched-earth tactics) and No. 5 (stop the destruction and calmly wait and see) of [the Japanese] broadcast caused considerable confusion at the Dutch East Indies side. The Dutch East Indies announced through the NIROM broadcast that, "a specially-formed military police shall be created to control groundless rumors." We then followed this up in a clandestine broadcast by saying that "People must beware of fake police authorities, as they are everywhere."

5. Struggling with the fact that the Japanese clandestine broadcasts were widely listened to by the people in Java, the NIROM at 2015 on 5 March repeatedly transmitted instructions to "listen to the voice of the announcers to tell the difference and avoid being deceived by these fake broadcasts." [Against this,] the Special Broadcasting Detail aired that "You will know which news 
tells the truth if you compare the news and the facts," by which the detail seized upon the NIROM's weakness that it had until now not dealt so much with domestic news. From then on, the NIROM suddenly started covering domestic news or the attitudes of Britain or the United States, and the content of the broadcasts reflected gloomier views.

6. Beginning with the flight of General Wavell, a number of broadcasts aired on that day with the intention of alienating the Dutch East Indies from Britain and the United States reached overseas countries, and [the report] that "not only Britain but also the United States have come to abandon the Dutch East Indies" started to appear in the news worldwide.

The next day, 6 March, was the day when the Nasu Detachment seized Buitenzorg in the morning, the Sixteenth Army again submitted a request for the air lift [of troops from Palembang] to support the Shōji Detachment, and the latter detachment repulsed the counterattack of the enemy in the morning and seized one vital area of the positions across the mountain ridge in the evening. That night, the Dutch East Indies decided to make the Lembang position its main position, and [also] made up its mind to surrender Bandung should this position be taken.

On that day (the 6th), the Special Broadcasting Detail broadcast once in the morning (for about one hour) and three times in the afternoon (for about two and a half hours [in total]) in Dutch and Malay. A noteworthy [feature] of the broadcast on that day was that the detail had started airing broadcasts with the advice to surrender. Having heard the recorded speech of Van Mook, which the NIROM had broadcasted that morning, the Southern Army judged that the Dutch East Indies was considering surrender. At 1930 and again at 2145 on that day, the detail broadcast Commander in Chief Terauchi's message advising surrender on the wavelength used in French Indochina, while in close coordination with this, putting the black clandestine broadcast on the air on the wavelength used in the Dutch East Indies. The broadcast emphasized Britain's and the United States' abandonment of the Dutch East Indies, the situation of the Dutch East Indies Army losing the war, the crisis in the Churchill administration, the people's yearning for peace, the opinions [exchanged] between the [Dutch East Indies] army and government concerning surrender, the dispute between Britain and the United States on the failure of defending Java, etc.

The main topics that the Special Broadcasting Detail broadcast on that day (6 March) were in outline as follows:

1. The advance of the Japanese Army in Burma is furious; it caused the abandonment of Rangoon. Chiang Kai-Shek's troops are withdrawing to the north.

2. The garrison in Batavia has surrendered. Its citizens are fully protected by the Japanese Army.

3. The total defeat in Java made Prime Minister Churchill decide on the resignation of his cabinet en masse.

4. The people [in Java] must remain calm and composed like the citizens of Batavia. They must not vainly provoke the Japanese Army.

5. Prime Minister Churchill declared brazenly that he bore no responsibility for the [failed] defense of Java.

6. People must beware of fake police authorities, as they are everywhere.

7. A Dutch East Indies tank unit that was heading to attack the Kalijati airfield has not been heard of.

8. The Japanese air force has bombed Australia and the [Lesser] Sunda Islands.

9. The leader of a U.S. mission to India has been chosen. 
10. Our units are fiercely engaging with a powerful mechanized unit of the enemy (Japanese Army) in Lembang and vicinity.

11. The home country of the Netherlands is delighted about the broadcast of [the address of] Van Mook, who has come to his senses concerning Britain and the United States.

12. In order to maintain public peace and order, people in the areas occupied by the Japanese Army must obey the army's orders.

13. The Japanese Army is passing through Surakarta and Yogyakarta from the morning of the 6th onwards.

The next day, 7 March, was the day when [Siteenth] Army Commander Imamura advanced from Serang to Batavia, the Shōji Detachment left the mountain ridge line in the afternoon to advance into the Lembang sector in the evening.

On that day (the 7th), the Special Broadcasting Detail [again] broadcast once in the morning (for about one hour) and three times in the afternoon (for about two and a half hours [in total]) in Dutch and Malay. Furthermore, at 1930 and again at 2145 as it had done on the previous day, the detail broadcast the message of the commander in chief [of the Southern Army] advising surrender (note: four times in total since the previous day). On that day, the signal of the NIROM went all the time on and off again from around 1300 onwards, and went completely silent at last by 2220 . The main topics of the [Japanese] clandestine broadcasts aired on that day were as follows:

1. The Dutch East Indies Army is caught in an uphill battle accross [the island]. The government is likely to decide on surrender so as not to make the same mistake as Poland and Belgium. Everyone must according to his own judgment appropriately deal with the Japanese Army's advice to surrender.

2. The rapid attack by the Japanese Army has already decided the outcome. The present result came from the irresponsible retreat of the U.S., British and Australian forces. In order to bring an end to this disadvantageous battle, the government is initiating every possible form of negotiations with Japan.

3. The government and the top-level officers of the army will hold an important meeting today on the 7th concerning the Japanese Army's advice to surrender.

4. The Japanese Fleet has made its appearance in the Indian Ocean.

5. Bennett is urging the people to be ready, saying that it is only a matter of weeks before a Japanese attack on Australia takes place.

6. The Australian government officially announced that men would be made to perform military duty or serve in the military industry.

7. The Japanese forces have carried out the sixth and the seventh bombardments of Port Moresby.

8. There are people who do not observe the suspension of scorched-earth tactics. Close watch is required.

9. Signs of lack of military discipline are seen in all areas. All commanders must take the necessary steps.

10. Fierce engagements are occurring on the highlands in the vicinity of Bandung.

11. Although Bandung's fate is being sealed, the citizens must remain calm. They must not leave their post.

12. Japanese reinforcement units are under sail to Java.

13. The Japanese Army stormed into a corner of Rangoon on the afternoon of the 7th.

14. Labor disputes in the United States are causing casualties.

The reactions of the Dutch East Indies side on that day (the 7th) were as follows: 
1. Concerning the aforementioned topic No. 1 of the [Japanese] clandestine broadcast (i.e. Everyone must according to his own judgment appropriately deal with the Japanese Army's advice to surrender), the NIROM in no time aired as an official notice, "the special military police can be recognized by a white scarf around their necks. You must be careful; they are not soldiers who have surrendered."

2. At 2220 at night, the NIROM fell completely silent.

3. At 2330 at night, a military envoy of the Bandung garrison army commander came to the Shōji Detachment to offer a local cease-fire.

The next day, 8 March, was the day when Governor-General Tjarda [van Starkenborgh Stachouwer] and the chief of the Dutch East Indies Army Department, Ter Poorten, came to Kalijati in the afternoon for the meeting with [Sixteenth] Army Commander Imamura.

It was not until the morning of that day (the 8th) that the Special Broadcasting Detail in Saigon learned that "on the previous night, the Bandung garrison army commander offered a local cease-fire to the Shōji Detachment."

When the Special Broadcasting Detail received this news, it did not let the opportunity slip to steer this toward a total surrender and aired instructions and annoucements directed to the entire Dutch East Indies Army, all the administrative officials, and the people at large on the assumption of the absolute superiority of the Japanese Army and pretending as if an agreement for a total surrender was being concluded in Bandung. In this way, it tried to bring about a feeling of defeat on the Dutch East Indies side and put the Sixteenth Army in an advantageous position in the negotiations. Then, as soon as it learned that the Dutch East Indies Governor-General and his party would arrive in Kalijati at 1550, the Special Broadcasting Detail figured that the total surrender of the Dutch East Indies had become a foregone conclusion. After that, the detail only aired discreet broadcasts using news from overseas so as not to hamper this process, while preparing to close down the clandestine broadcasts.

On that day (the 8th), the Special Broadcasting Detail successively broadcasted in Dutch and Malay from 0730 to 1800 , except for the hours when the Saigon station aired its news programs. Further, the detail decided to remain on the air for forty-eight consecutive hours from 1935, successively broadcasting in Dutch and Malay. The number of broadcasts on this day [the 8th] amounted to nine Dutch and Malay broadcasts each in the morning as well as in the afternoon. The main topics the Special Broadcast Squad aired on that day as clandestine broadcasts were in outline as follows:

1. The Japanese Army has entered Bandung.

2. [The Dutch East Indies] offered a cease-fire to the Japanese Army and is negotiating about the particulars.

3. All the people [on Java] must follow the proclamation of the supreme commander [of the Dutch East Indies army], and refrain from taking reckless, rash actions.

4. The Dutch East Indies Army has done its utter best, but due to the betrayal of the United States, Britain and Australia, it had no choice but to make the ultimate decision and accept the message of the Japanese Army Commander sent on the radio advising a cease-fire.

5. The Japanese Army accepted our offer of a cease-fire. At present, talks with the Japanese Army are being held at the Isola Hotel in Bandung.

6. The reports of a Dutch East Indies cease-fire have caused emotional conflict between the British government and the Dutch government in exile. 
7. Britain is much concerned about a sudden increase of pressure of the Japanese Army on Australia and Burma as a consequence of the cease-fire with the Dutch East Indies Army, and is asking the United States for support.

8. Port Darwin was again bombed by the Japanese air force on the 7 th.

9. It seems that Prime Minister [Luang] Pibulsonggram will be nominated to head the incoming cabinet of Thailand.

10. As a result of the negotiations with the Japanese Army, the Dutch East Indies Army has decided to suspend all hostilities.

11. The Japanese Army completely captured Rangoon on the morning of the 8th.

12. Reports on the cease-fire of the Dutch East Indies Army and the fall of Rangoon have greatly upset the Australian government.

13. On the 8th, the government of the Dutch East Indies decided to surrender to the Japanese Army. Each administrative official must follow the instructions given by the Japanese Army. Particulars will be given as soon as they have been decided upon.

14. The Army as well as the government have decided to completely surrender to the Japanese Army. All forces must surrender. Public officials and civilians alike must exert themselves to maintain public order, following the instructions of the Japanese Army.

The next day, 9 March, was the day when the Dutch East Indies broadcast its unconditional surrender in the afternoon. On that day, the Special Broadcasting Detail in Saigon started its broadcast at 0730, aired the clandestine broadcasts in Dutch and Malay until 1805, except for the hours when the Saigon station aired its news programs. The broadcasts on that day were aired twice in the morning and three times in the afternoon both in Dutch and Malay. The topics aired on that day were in outline as follows:

1. The Dutch East Indies government is still holding talks with the Japanese Army at Kalijati. Its army, government officials and civilians must trust in the chivalrous (Bushidō) spirit of the Japanese Army.

2. Australia is intensifying its guard. The Japanese air force is [still] actively operating in the South Pacific, even after the offer of a cease-fire by the Dutch East Indies.

3. The war situation in Burma has developed and General Wavell is in the middle of negotiations with Chiang Kai-shek's army.

4. Peace has returned to the city of Batavia. The Japanese Army has established a military administration over the city.

As the Dutch East Indies officially accepted a total and unconditional surrender at 1500 on that day and announced a joint statement by the Dutch East Indies government and the Dutch East Indies Army regarding their total surrender from the Bandung station [starting] from 2030, the Southern Army (i.e. the Special Broadcasting Detail) immediately stopped its clandestine broadcasts.

\section{The Shift to the Military Administration}

The main characteristic of the Java operation was that the inhabitants welcomed [the Japanese troops] with cheers and wholeheartedly actively cooperated. There was no need to watch out for [hostile] indigenous people wherever on the island of Java [the Japanese troops] went during the operation. ${ }^{(36)}$ 
[Sixteenth] Army Commander Imamura, who made his entry into Batavia at 1500 on 7 March, simultaneously proclaimed Military Government Decree No. 1, installed the Military Administration Department, [consisting of] Vice Chief of Staff Major General Harada and his men, in Batavia, and immediately set them to work. Article 1 of the aforementioned Military Government Decree No. 1 read as follows: ${ }^{(13)}$

Article 1. With the intention of promoting the welfare of the people of the East Indies, with whom we share a common ancestry, and determined to ensure [a state of] coexistence and coprosperity with the local population based on the principle of a joint defense of Greater East Asia, the Imperial Japanese Army shall for the present implement a military administration in the area of the East Indies in order to establish peace and order within the East Indies and swiftly let the people live and work in peace and quiet.

\section{[Changes in] the Disposition of the Units}

On the day when the Dutch East Indies Army surrendered (9 March), the Southern Army passed down orders in which it designated the entire island of Sumatra as the operational area of the Twenty-fifth Army from 12 March onwards and ordered the units currently present in the area to be transferred to that army as of that date. ${ }^{(23)}$ It was anticipated that the Shōji Detachment would return to the 38th Division operating in Sumatra, to which it had [originally] belonged. Also, as previously decided, the Sakaguchi Detachment would return to the 56th Division [currently] in Burma, to which it had [originally] belonged. [Apart from these,] special consideration was needed for the two principalities on Java, Surakarta and Yogyakarta.

Taking these factors into account, on 10 March, the Sixteenth Army made the following disposition of its units and passed down orders for the mopping up of remnants of the enemy, the maintenance of public order, and the requisitioning as well as the securement of all facilities and resources. ${ }^{(88)}$

[Sixteenth] Army headquarters: Batavia

Shōji Detachment:

Shall be stationed in Batavia, scheduled to be put under the direct control of the [Sixteenth] Army and be in charge of the maintenance of public order in the Batavia residency.

Sakaguchi Detachment: Shall assemble without delay in Batavia

2d Division:

Shall take charge of western Java and the residencies of Pekalongan and Banyumas with headquarters in Bandung.

48th Division:

Shall take charge of central Java, and eastern Java and Madura (with the exception of the principalities of Surakarta and Yogyakarta as well as the Pekalongan and the Banyumas residencies) with headquarters in Surabaya.

The two principalities of Surakarta and Yogyakarta shall be put under the direct control of the Army. For this purpose, the $2 \mathrm{~d}$ Division and the 48th Division shall each send half a battalion of infantry as the core respectively to Yogyakarta and Surakarta by $15 \mathrm{March}$, and put these units under the direct control of the Sixteenth Army. 


\section{Conclusion}

$\mathrm{B}$ efore the opening of hostilities, the landing on Java in the Dutch East Indies invasion operation was expected around the 103d day and the surrender of the Dutch East Indies around the 120th day from the opening of hostilities, assuming that the southern operation could be carried out smoothly. However, [the operation was] concluded [ahead of time] with the landing on Java on the 84th day, the surrender offer by the Dutch East Indies Army on the 90th day, and the surrender of the army on the 92d day.

Here, I will look back on the execution of the plan and give consideration to some principal matters.

1. As factors that enabled the Dutch East Indies operation to be completed in a shorter period, the following can be considered:

(1) The success in the surprise attack on Hawaii and the decisive military gains in the sea battles off Malaya.

The former not only removed the threat from the Pacific Ocean but also enabled [the Navy] to send reinforcements to the Southern Task Force. The latter facilitated the progress of the operations in the Malaya theater and also led to Britain's abandonment of the idea to deploy its main fleet.

(2) The success in the attack right at the opening of hostilities to destroy the enemy air power as well as the success in the surprise landings in the Philippines and Malaya.

(3) The Southern Army's operational leadership to make the most of the initial military gains and to keep on pursuing the enemy.

(4) The excellent cooperation between the Army and the Navy, which in particular enabled the rapid advance of air bases.

(5) The complete isolation of Java before the landing of the Sixteenth Army, the defection of the indigenous people from the Dutch side, and also the success in the black clandestine broadcasts.

(6) The Shōji Detachment's attack on Bandung, the main base of the Dutch East Indies Army, with the support of the Endō Air Division, and the Sakaguchi Detachiment's seizure of Cilacap, carried out by a sustained pursuit over a long distance at one go.

2. The distinctive characteristics of the leadership of the Sixteenth Army and of the way each corps operated.

(1) The planning and conduct of the operations by the Sixteenth Army was cautious.

(2) The operational conduct of the 2d Division was hindered at the time of its advance by the fact that it was under the direct instruction of the aforementioned Sixteenth Army as its main corps, that the division was organized as a horse-carried [unit], and that many of the bridges [on its way] were destroyed. 
(3) The Shōji Detachment and the Sakaguchi Detachment carried out bold charges in their Java operations.

The Sakaguchi Detachment conducted six operations [in total] (i.e. operations at six places) from the opening of hostilities. In every operation, it carried out the operation with imagination and full of energy.

(4) The 48th Division commander conducted the operations [of the division] with great attention to control and mobility. Especially in the operations east of the Solo River, the advance guard [commander] achieved decisive military gains by acting on his own judgment.

(5) The main force of the 38th Division carried out its assignment with careful planning and bold execution of the operation.

(6) The Eastern Detachment carried out its assignment in close cooperation with the Navy, and it was [also] able to smoothly carry out the capture of Dili in Portuguese [Timor.]

(7) Although the 1st Paratroop Raiding Group had to employ the 2d [Paratroop] Raiding Regiment, which came behind and had not been trained sufficiently, for the operations both against the airport and the oil refineries, it boldly engaged in battle and lived up to the expectations of the entire Army.

3. The cooperation from the indigenous people.

The indigenous people defected from the Dutch side and cooperated with the Japanese. The following reasons can be thought of:

(1) The Dutch East Indies government and the Dutch people were removed from the indigenous people.

(2) Of old, there had been exchanges between the Japanese and the Indonesians, and the indigenous people felt an affinity with the Japanese for having common ancestors and being of the same race. Also, a legend had been widely handed down from olden times that a savior (Topi merah) would come to Indonesia to free them; the people felt that the Japanese advance this time was it.

(3) The propaganda of the Japanese Army had been effective.

\section{Oil}

We have seen that the main issue that caused the Greater East Asia War was the oil issue, and that the Southern Army as well as the Sixteenth Army went to all kinds of great pains to obtain the oil.

On 2 March 1942, the Liaison Conference between IGHQ and the Government could hold the following bright prospect: ${ }^{(3)}$

The current estimate of the amount of oil obtained is as follows:

Fiscal Year 1941

British Borneo

1,400 kiloliter

The Tarakan area

2,000 kiloliter

Fiscal Year 1942

British Borneo $\quad 700,000$ kiloliter

The Tarakan area 250,000 kiloliter

The Sanga Sanga area 300,000 kiloliter

Southern Sumatra $\quad 500,000$ kiloliter

In total $\quad 1,750,000$ kiloliter 
After that on 9 March, the following rosy decisions were made in the Liaison Conference between IGHQ and the Government. ${ }^{(3)}$

1. The amount of oil for private use for the fiscal year 1942, which was set at 1.4 million tons just before the opening of hostilities, shall now be revised to 1.9 million tons.

2. The Separate Oil [Categories] A and B (note by the author: the separate oil [categories] for the Army and the Navy) to be used on site shall also be incorporated in the plan for the mobilization of materials.

3. To implement the above, the amount of oil to be aquired in the Southern areas is decided at 1.7 million tons.

In this way, abundant oil resources were secured. The amount of oil to be acquired from the Dutch East Indies in the first year of the war had been estimated at 300,000 tons before the opening of hostilities, but now it was estimated to be 1.7 million tons.

However, with its tankers necessary for the transport destroyed or sunk one after another by the allied forces, submarines in particular, Japan ended up continuing the war, again suffering from an extreme shortage of fuel. 



\section{Notes}

1. Tairikumei-tsuzuri (大陸命綴 [The files of IGHQ Army Department Orders]), Daikaireitsuzuri (大海令綴 [The files of IGHQ Navy Department Orders]), Tairikushi-tsuzuri (大陸 指綴 [The files of IGHQ Army Department Instructions]), and Daikaishi-tsuzuri (大海指綴 [The files of IGHQ Navy Department Instructions]); these files contain the orders passed down by the Army or the Navy Department of IGHQ, and the instructions (given by the chief of general staff of the Army or the Navy based respectively on the orders of the Army Department or the Navy Department of IGHQ).

2. Sakusen Kankei Jūyō Shorui-tsuzuri (作戦関係重要書類綴 [Files of important documents concerning operations]). These files include documents [related to] the reports to the Emperor concerning operations, and documents [kept] at Section 2 (Operations Section) of IGHQ.

3. Daihon'ei - Seifu Renraku Kaigi Gijiroku (大本営政府連絡会議議事録 [The minutes of the Liaison Conferences between IGHQ and the Government]), [made by] the Army Department of IGHQ.

4. Sugiyama Memo (杉山メモ [Sugiyama Memoranda]). These are the memoranda of the deliberations at the liaison meetings and conferences from January to May 1942, taken by Chief of Army General Staff Sugiyama; they were [subsequently] sorted out and turned into a clean copy by the War Direction Group (Section).

5. Riku-a-mitsu-tsuzuri (陸亜密綴 [Files of classified documents concerning the Greater East Asia War at the War Ministry]). These files contain classified documents [including circular notices issued] at the War Ministry concerning the Greater East Asia War.

6. Sanada Jōichirō Taisa Nikki (真田穣一郎大佐日記 [Diary of Col. Sanada Jōichirō]), then chief of the Army Affairs Section of the Military Affairs Bureau of the Ministry of War.

7. Daihon'ei Kimitsu Sensō Nisshi (大本営機密戦争日誌 [The classified war journal of IGHQ]), kept every day as the group (section) journal of Group 20 (Section 15) at the Army General Staff Office. It should not be considered the official classified war journal of IGHQ; nevertheless it is of great value as material for the history of the war.

8. Kondō Dempachi Shōsa Nikki (近藤傳八少佐日記 [Diary of Maj. Kondō Dempachi]), then staff of Section 2 of the Army Department of IGHQ.

9. Imoto Kumao Chūsa Nikki (井本熊男中佐日記 [Diary of Lt. Col. Imoto Kumao]), then staff of Section 2 of the Army Department of IGHQ.

10. Tanaka Shin'ichi Chūjō no Nisshi ni motozuku Shuki (田中新一中将の日誌に基づく手記 [A personal account of Lt. Gen. Tanaka Shin'ichi based on his journal]), then chief of the 1st Bureau (Operations Bureau) of the Army Department of IGHQ.

11. Gunji Nenkan (『軍事年鑑』[Military Yearbook]), compiled by Zaidan Hōjin Gunjin Kaikan Toshobu (財団法人軍人会館図書部編 [Publication Department of Gunjin Kaikan [Military Center]]).

12. Nippon Gaikō Nempyō narabini Shuyō Bunsho (『日本外交年表並主要文書』[Chronology of Japanese Diplomacy and major documents]), compiled by the Ministry of Foreign Affairs.

13. Newspapers, mainly the Asahi Shimbun (『朝日新聞』), along with other contemporary newspapers. 
14. Kaikōsha-kiji (『偕行社記事』[Bulletin of the Kaikōsha]), edited by the Kaikōsha (偕行社 [The Association of Army Officers; http:/ / en.wikipedia.org/wiki/Kaikosha]).

15. Daitōa Senki (『大東亜戦記』Rikugun Hōdō-bu-hen陸軍報道部編, [Chronicle of the Greater East Asia War, edited by the Army Information Department]).

16. Hattori Takushirō Taisa Kaisō (服部卓四郎大佐回想 [Recollections of Col. Hattori Takushirō]), then chief of Section 2 of the Army Department of IGHQ.

17. Okamura Masayuki Shōsa Kaisō (岡村誠之少佐回想 [Recollections of Maj. Okamura Masayuki]), then staff of Section 2 of the Army Department of IGHQ.

18. Sejima Ryūzō Shōsa Kaisō (瀬島龍三少佐回想 [Recollections of Maj. Sejima Ryūzō]), then staff of Section 2 of the Army Department of IGHQ.

19. Sugita Ichiji Chūsa Kaisō (杉田一次中佐回想 [Recollections of Lt. Col. Sugita Ichiji]), then staff of the 2d Bureau (Intelligence Bureau) of the Army Department of IGHQ.

20. Shiho Kenkichi Shōsa Kaisō (志甫健吉少佐回想 [Recollections of Maj. Shiho Kenkichi]), then staff of Section 3 (Organization Section) of the Army Department of IGHQ.

21. Compiled from Tōnan-Ajiya Bunkaken-shi (『東南アジヤ文化圈史』船越康壽著 [History of the Southeast Asian cultural area, by Funakoshi Yasuju]); Zusetsu Nampō Kyōei-ken (『圖説南方共 栄圈』同盟通信社編 [The Southern Co-prosperity Sphere, edited by the Dōmei News Agency]), Ranryō Indo Nōgyō Seisaku-shi (『蘭領印度農業政策史』關嘉彦著 [History of agricultural policies in the Dutch East Indies, by Seki Yoshihiko]), Ran'in Seikatsu Nijūnen『蘭印生活二十年』和田 民治著 [Twenty years in Dutch East Indies, by Wada Tamiji]), Rikugunshō Gummu-ka Ōnishi Hajime Chūsa Shuki (陸軍省軍務課大西一中佐手記 [A personal account by Lt. Col. Ōnishi Hajime, staff of Military Affairs Section of the Ministry of War]), Nampō Keizai Shigen Sōran (『南方経済資源総覧』細田秀造著 [Economic resources of Borneo, Celebes and New Guinea: A complete guide to the economic resources in the South, vol. 11, by Hosoda Hidezō]), etc.

22. Nampō-gun Dempō Tsuzuri (南方軍電報経 [File of the telegrams of the Southern Army]), received by the Army Department of IGHQ.

23. Ishii Shiryō (石井資料 [The Ishii Documents]), the documents in the possession of Col. Ishii Masayoshi, [then] senior staff of Section 1 of the Southern Army, and such documents as various plans, orders, instructions and agreements related to the Southern Army, which he obtained from the demobilization offices after the war. He sorted them out and also added his descriptions on the operational directives of the Southern Army and others.

24. Nampō-sōgun no Tōsui (南方総軍の統帥) [The supreme command of the Southern Army]), the journal in which Lt. Col. Arao Okikatsu, chief of operations staff of the Southern Army, recorded in detail the classified matters on the supreme command of the Southern Army from the time of the preparation of the operations by the army to the completion of most of the southern invasion operation.

25. Tanikawa Kazuo Taisa Nikki (谷川一男大佐日記 [Diary of Col. Tanikawa Kazuo]), then senior staff of Section 4 (Aviation Section) of the staff department of the Southern Army.

26. Ishii Akiho Taisa Nikki (石井秋穂大佐日記 [The diary of Col. Ishii Akiho]), then senior staff of Section 3 of the staff department of the Southern Army.

27. Taiheiyō Sensō ni okeru Sempaku Yusō no Kenkyū (太平洋戦争に於ける船舶輸送の研究 [A Study of Shipping Transport in the Pacific War]), written by Lt. Col. Ueno Shigeru, [then] shipping transportation staff, based on contemporary materials.

28. Arao Okikatsu Chūsa Kaisō (荒尾興功中佐回想 [Recollections of Lt. Col. Arao Okikatsu]), then chief of operations staff of the Southern Army.

29. Mabuchi Shinji Shōsa Kaisō (馬淵新治少佐回想 [Recollections of Maj. Mabuchi Shinji]), then shipping transportation staff.

30. Matsumae Misoo Chūsa Nikki (松前未曾雄中佐日記 [Diary of Lt. Col. Matsumae Misoo]), then staff of Section 4 of the staff department of the Southern Army. 
31. Jawa Sakusen Kiroku (爪哇作戦記録 [Records of the Java Operations]), written by Lt. Col. Oda Akimitsu, [then] chief of operations staff of the Sixteenth Army, based on the materials in his possession right after the war and the materials kept at the demobilization offices. Edited by the Demobilization Bureau.

32. Okazaki Seizaburō Shōshō Nikki (岡崎清三郎少将日記 [Diary of Maj. Gen. Okazaki Seizaburō]), then chief of staff of the Sixteenth Army.

33. Takashima Tatsuhiko Taisa Nikki (高嶋辰彦大佐日記 [Diary of Col. Takashima Tatsuhiko]), then senior staff of Section 1 of the staff department of the Sixteenth Army.

34. Saiki Ikuzō Chūsa Nikki (斎木郁三中佐日記 [Diary of Lt. Col. Saiki Ikuzō]), then Staff of Section 2 (Chief Signal Communication Staff) of the staff department of the Sixteenth Army.

35. Imamura Hitoshi Chūjō Kaisō (今村均中将回想 [Recollections of Lt. Gen. Imamura Hitoshi]), then commander of the Sixteenth Army, including the "memoir" he wrote in prison camp right after the war with the materials in his possession.

36. Okazaki Seizaburō Shōshō Kaisō (岡崎清三郎少将回想 [Recollections of Maj. Gen. Okazaki Seizaburō]), then chief of staff of the Sixteenth Army; including "Tengoku kara Jigoku" (天 国から地獄 [From Heaven to Hell]) he wrote after the war, based on the diary he had kept.

37. Harada Yoshikazu Shōshō Kaisō (原田義和少将回想 [Recollections of Maj. Gen. Harada Yoshikazu]), [who had] accompanied the Yoshizawa Delegation at the time of the negotiation between Japan and the Netherlands. He [later] served as vice chief of staff of the Sixteenth Army at the time of [Java] invasion operation.

38. Takashima Tatsuhiko Taisa Kaisō (高嶋辰彦大佐回想 [Recollections of Col. Takashima Tatsuhiko], then senior staff of Section 1 of the staff department of the Sixteenth Army.

39. Itoda Isamu Chūsa Kaisō (井戸田勇中佐回想 [Recollections of Lt. Col. Itoda Isamu]), then staff of Section 1 (Aviation) of the staff department of the Sixteenth Army.

40. Oda Akimitsu Chūsa Kaisō (於田秋光中佐回想 [Recollections of Lt. Col. Oda Akimitsu]), then chief of operations staff of the staff department of the Sixteenth Army.

41. Yamashita Yutaka Shōsa Kaisō (山下豊少佐回想 [Recollections of Maj. Yamashita Yutaka]), then staff of Section 1 (Operations) of the staff department of the Sixteenth Army.

42. Kuriya Tsugunori Shōsa Kaisō (厨次則少佐回想 [Recollections of Maj. Kuriya Tsugunori]), [who had been] assigned in Java at the time of the negotiation between Japan and the Netherlands, and who later became staff of Section 1 (Intelligence) of the staff department of the Sixteenth Army.

43. Kitamura Yoshifuto Taisa Kaisō (北村可大大佐回想 [Recollections of Col. Kitamura Yoshifuto]), then senior staff of Section 2 of the staff department of the Sixteenth Army.

44. Sendō Shunzō Chūsa Kaisō (仙頭俊三中佐回想 [Recollections of Lt. Col. Sendō Shunzō]), then staff of Section 2 (Shipping) of the staff department of the Sixteenth Army; including the article (「蘭印作戦の回想」[“Memoirs of the Dutch East Indies operation”]) which he contributed to the March 1944 [issue of] Kaikōsha-kiji (『偕行社記事』[Bulletin of the Kaikōsha]).

45. Nishiura Setsuzō Shōsa Kaisō (西浦節三少佐回想 [Recollections of Maj. Nishiura Setsuzō]), then staff of Section 2 (Line of Communication) of the staff department of the Sixteenth Army.

46. Nakayama Yasuto Taisa Kaisō (中山寧人大佐回想 [Recollections of Col. Nakayama Yasuto]), who accompanied the [Yoshizawa] Delegation at the time of the negotiations between Japan and the Netherlands; later he was attached to the headquarters of the Sixteenth Army ([for] the military administration).

47. Yanagawa Motoshige Taii Kaisō (柳川宗成大尉回想 [Recollections of Capt. Yanagawa Motoshige]), then attached to the staff department of the Sixteenth Army.

48. Machida Keiji Chūsa Kaisō (町田敬二中佐回想 [Recollections of Lt. Col. Machida Keiji]), then head of the propaganda group.

49. Ōkubo Tōru Shōsa Kaisō (大久保亨少佐回想 [Recollections of Maj. Ōkubo Tōru]), then attached to the oil drilling squad of the 21st Field Ordnance Depot. 
50. Daitōa Sensō Teki Furyo no Shuki (『大東亜戦争敵俘虜の手記』[Personal accounts of enemy prisoners of war in the Greater East Asia War]), edited by Daitō Kenkyū-jo (大東研究所編), which contains the personal accounts of allied army commanders and division commanders [http: / / kindai.ndl.go.jp/info:ndljp/pid/1041980].

51. Igirisu Kōkan Senshi “Tainichi-sen” (英公刊戦史「対日戦」) [War against Japan, S. Woodburn Kirby et al, London: HMSO.]

52. Butai Chōsa-hyō (部隊調查票 [Data charts of units]), covering the organization, the numbers of personnel, horses and vehicles, etc. of each unit, prepared by the Military Preparedness Section of the Ministry of War.

53. Butai Shiryō (部隊資料 [Data of units]), compiled data of fragmented information on organizations, formations, staff, and actions, arranged according to units.

54. Satō Hidehiko Shōsa Kaisō (佐藤英彦少佐回想 [Recollections of Maj. Satō Hidehiko], then chief intelligence staff of the 2d Division.

55. Taguchi Kazuo Taii Kaisō (田口和夫大尉回想 [Recollections of Capt. Taguchi Kazuo]), then staff of the 2d Division.

56. Takano Sōsuke Taii Kaisō (高野左右助大尉回想 [Recollections of Capt. Takano Sōsuke]), then officer at the Intendance Department of the $2 \mathrm{~d}$ Division.

57. Inamura Ryōhei Taii Kaisō (稲村良平大尉回想 [Recollections of Capt. Inamura Ryōhei]), then adjutant to the $2 \mathrm{~d}$ Division.

58. Hohei Dai-yon Rentai Rekishi (歩兵第四聯隊歴史 [History of the 4th Infantry Regiment]).

59. Hohei Dai-yon Rentai Dai-san Daitai Kōdō Shōhō (歩兵第四聯隊第三大隊行動詳報 [Action report of the 3d Battalion of the 4th Infantry Regiment]), prepared by the battalion in March 1942.

60. Sasaki Mori'e Shōsa Nikki (佐々木盛衛少佐日記 [Diary of Maj. Sasaki Mori'e]), then commander of the 3d Battalion of the 4th Infantry Regiment.

61. Hohei Dai-jūroku Rentai Ryakureki (歩兵第十六聯隊略歴 [Brief history of the 16th Infantry Regiment]).

62. Morozumi Yoshikazu Shōsa Kaisō (諸角善一少佐回想 [Recollections of Maj. Morozumi Yoshikazu]), then commander of the 3d Battalion of the 16th Infantry Regiment; he wrote this based on his diary of that time and [other] materials.

63. Hohei Dai-nijūku Rentai Ryakureki (歩兵第二十九聯隊略歴 [Brief history of the 29th Infantry Regiment]).

64. Yahōhei Dai-ni Rentai Dai-ichi Daitai Sentō Shōhō (野砲兵第二聯隊第一大隊戦闘詳報 [Action report of the 1st Battalion of the 2d Field Artillery Regiment]).

65. Yahōhei Dai-ni Rentai Dai-san Chūtai Sentō Shōhō (野砲兵第二聯隊第三中隊戦闘詳報 [Action report of the $3 \mathrm{~d}$ Battery of the 2d Field Artillery Regiment]).

66. Abe Yoshimitsu Taisa Kaisō (阿部芳光大佐回想 [Recollections of Col. Abe Yoshimitsu]), then chief of staff of the 38th Division; including the "Bangka, Palembang Sakusen Kiroku" (「バンカ、パレンバン作戦記録」復員局調整 [“Records of the Bangka and Palembang operation," prepared by the Demobilization Bureau]), which he wrote after the war based on materials in his possession and those kept at demobilization offices.

67. Oyadomari Chōsei Chūsa Shuki (親泊朝省中佐手記 [A personal account of Lt. Col. Oyadomari Chōsei]), then chief of operations staff of the 38th Division; his contribution "Sumatra Sakusen Obo'egaki” (「スマトラ作戦覚書」[“Memorandum on the Sumatra operation,” included in the article "Hong Kong, Sumatra, Ga-tō Sakusen Dampen" (『香港、スマトラ、ガ 島作戦断片』[“Snippets of Hong Kong, Sumatra, and Guadalcanal operations”] was written for the December 1943 [issue of] the Kaikōsha-kiji (『偕行社記事』[Bulletin of the Kaikōsha]).

68. Tanaka Ryōsaburō Taisa Kaisō (田中良三郎大佐回想 [Recollections of Col. Tanaka Ryōsaburō]), then commander of the 229th Infantry Regiment. 
69. Dokuritsu Kōhei Dai-nijūroku Rentai Dai-ni Chūtai Dai-ichi Shōtai Sentō Shōhō (独立工兵 第二十六聯隊第二中隊第一小隊戦闘詳報 [Action report of the 1st Platoon of the $2 \mathrm{~d}$ Company of the 26th Independent Engineer Regiment]).

70. Ogawa Yukio Chūi Nikki (小川行男中尉日記 [Diary of 1st Lt. Ogawa Yukio]), then commander of the 1st Supply Platoon of the Regimental Train of the 4th Tank Regiment.

71. Doi Masanobu Chūi Kaisō (土肥正信中尉回想 [Recollections of 1st Lt. Doi Masanobu]), then attached to the 38th Mountain Artillery Regiment headquarters.

72. Ōneda Yasuhei Shōsa Kaisō (大根田安平少佐回想 [Recollections of Maj. Ōneda Yasuhei]), then commander of the 3d Battalion of the 230th Infantry Regiment.

73. Shōji Shitai Jōriku Keikaku (東海林支隊上陸計画 [Landing operation plan of the Shōji Detachment]), prepared on 3 February 1942.

74. Shōji Shitai Yōriku Sagyō Keikaku (東海林支隊揚陸作業計画 [Debarkation work plan of the Shōji Detachment]), prepared on 6 February 1942.

75. Shōji Toshishige Taisa Kaisō (東海林俊成大佐回想 [Recollections of Col. Shōji Toshishige], then commander of the 230th Infantry Regiment, including [an account] he wrote in prison camp right after the war.

76. Tōhō Shitai Senji Geppō (東方支隊戦時月報 [Monthly war report of the Eastern Detachment]).

77. Doi Sadashichi Taisa Kaisō (土井定七大佐回想 [Recollections of Col. Doi Sadashichi]), then commander of the 228th Infantry Regiment.

78. Tosaka Susumu Shōsa Kaisō（登坂進少佐回想） [The recollections by Maj. Tosaka Susumu], then staff of the 38th Division.

79. Tsuchihashi Yūitsu Chūjō Nikki (土橋勇逸中将日記 [Diary of Lt. Gen. Tsuchihashi Yūitsu]), then commander of the 48th Division.

80. Kawagoe Moriji Taisa Kaisō (川越守二大佐回想 [Recollections of Col. Kawagoe Moriji]), then chief of staff of the 48th Division; including his postwar personal account Dai-yonjūhachi Shidan no Jawa Kōryaku-sen (第四十八師団のジャワ攻略戦 [The Java invasion operation of the 48th Division]), and his contribution to Mikata Kangaekata (『見方考方方』[Way of viewing and thinking], Vol. 12.

81. Indō Kimio Taii Nikki (犬童己未男大尉日記 [Diary of Capt. Indō Kimio]), then adjutant of the 48th Division.

82. Abe Kōichi Shōshō Kaisō (安部孝一少将回想 [Recollections of Maj. Gen. Abe Kōichi]), then commander of the 48th Infantry Group.

83. Hohei Dai-yonjūnana Rentai Ryakureki (歩兵第四十七聯隊略歴 [Brief history of the 47th Infantry Regiment]).

84. Yanagi Isamu Taisa Kaisō (柳勇大佐回想 [Recollections of Col. Yanagi Isamu]), then commander of the 47th Infantry Regiment.

85. Kanemura Matabē Shōsa Kaisō (金村亦兵衛少佐回想 [Recollections of Maj. Kanemura Matabē]), then commander of the 3d Battalion of the 1st Taiwan Infantry Regiment.

86. Kitamura Kurō Chūsa Kaisō (北村九郎中佐回想 [Recollections of Lt. Col. Kitamura Kurō]), then commander of the 48th Reconnaissance Regiment.

87. Yano Tsuneo Chūsa Kaisō (矢野常雄中佐回想 [Recollections of Lt. Col. Yano Tsuneo]), then staff of the Sakaguchi Detachment, including his war-time contribution to Daitōa Senki (『大 東亜戦記』[Chronicle of the Greater East Asia War]), and his Tarakan Kōryaku ni kansuru Ken (タラカン攻略に関する件 [The invasion of Tarakan]), Balikpapan Kōryaku ni kansuru Ken (バリクパパン攻略に関する件 [The invasion of Balikpapan]), and Bajarmasin Kōryaku ni kansuru Ken (バンジェルマシン攻略に関する件 [The invasion of Banjarmasin]), all of which were written by him after the war based on materials in his possession as well as those kept at demobilization offices (all of which were prepared by the Demobilization Bureau). 
88. Yasen Kōshahō Dai-yonjūyon Daitai Sentō Shōhō (野戦高射砲第四十四大隊戦闘詳報 [Action report of the 44th Field Antiaircraft Artillery Battalion]).

89. Dokuritsu Jidōsha Dai-nihyakurokujū Chūtai Dai-ni Shōtai Sentō Shōhō (独立自動車第二 百六十中隊第二小隊戦闘詳報 [Action report of the 2d Platoon of the 260th Independent Motor Transport Company]).

90. Kōhei Dai-jūroku Rentai Dai-san Chūtai Dai-ichi Shōtai Sentō Shōhō (工兵第十六聯隊第三 中隊第一小隊戦闘詳報 [Action report of the 1st Platoon of the 3d Company of the 16th Engineer Regiment]).

91. Borneo Sakusen Kiroku (ボルネオ作戦記録 [Records of the Borneo operation]), which were compiled after the war based on materials in the possession of the [then] adjutant of the Kawaguchi Detachment as well as on those kept at demobilization offices, and prepared by the Demobilization Bureau.

92. Kawaguchi Kiyotake Shōshō Kaisō (川口清健少将回想 [Recollections of Maj. Gen. Kawaguchi Kiyotake]), then commander of the 35th Infantry Brigade of the 18th Division, including his Kaisōroku (回想録 [Memoirs]).

93. Compiled from: Dai-ichi Teishindan-zuki Kinoshita Hideaki Chūsa Kaisō (第一挺進団付木 下秀明中佐回想 [Recollections of Lt. Col. Kinoshita Hideaki, attached to the 1st [Paratroop] Raiding Group]); Daitōa Senki (『大東栜戦記』[pp. 155-168, http:/ / dl.ndl.go.jp/info:ndljp/ pid/1460291] Rikugun-shō kanshū陸軍省監修, Rikugun Kōkū-hombu hen 陸軍航空本部編 [Chronicle of the Greater East Asia War, supervised by the Ministry of War and [a chapter written] by the Army Aviation Department]); the June 1942 [issue of] Kaikōsha-kiji (『偕行社記事』 [Bulletin of the Kaikōsha] (an article contributed by 1st. Lt. Tokunaga, and another by the Army Aviation Department); Teishin Dai-ni Rentai Dai-yon Chūtai Dai-ichi Shōtai-chō Ōki Takashi Chūi Shiryō (挺進第二聯隊第四中隊第一小隊長大城隆中尉資料 [Materials in possession of 1st Lt. Ōki Takashi, commander of the 1st Platoon of the 4th Company of the 2d [Paratroop] Raiding Regiment]); and Kanjō Shūroku (感状輯録 [Compiled records of citations of merit]).

94. Itō Shinobu Shōshō Kaisō (伊藤忍少将回想 [The recollections by the Maj. Gen. Itō Shinobu]), then commander of the 1st Disembarkation Group, including his personal account Daitōa Sensōkan no Sempaku Sakusen ni tsuite (大東亜戦争間の船舶作戦について [On the shipping operations during the Greater East Asia War]), which he wrote right after the war.

95. Malay Senki (馬来戦記 [Records of war in Malaya]), kept by Maj. Kunitake Teruhito, then staff of the Twenty-fifth Army.

96. Ran'in Kōkū Sakusen Kiroku (蘭印航空作戦記録 [Records of the Dutch East Indies air operation]), compiled by Lt. Col. Miyashi Minoru, chief of operations staff of the Third Air Force based on contemporary materials.

97. Sugawara Michiō Chūjō Nikki (菅原道大中将日記 [Diary of Lt. Gen. Sugawara Michiō]), then commander of the Third Air Force.

98. Endō Saburō Shōshō Nikki (遠藤三郎少将日記 [日誌] [Diary of Maj. Gen. Endō Saburō]), then commander of the $3 \mathrm{~d}$ Air Division.

99. Chōsho (調書 [Records] of Army air units).

100. Gunreibu Nisshi (軍令部日誌 [Journal of the Navy General Staff Office]), a diary kept by Cdr. Sanagi Sadamu, then staff of Section 1 of the Navy General Staff.

101. Kantai Hensei, Kaigun Senji Hensei Kaitei Kiroku (艦隊編制、海軍戦時編制改定記録 [Records of revisions of fleet organizations, and the wartime organization of the Navy]).

102. Sakusen Kenkyū Shiryō (作戦研究資料 [Operation reviews]), compiled from action reports of Navy units by the Navy Achievement Appraisal Department.

103. Kōdō Chōsho (行動調書 [Action records]), records of actions of Naval units summarized at the Navy Achievement Appraisal Department. 
104. Hikōki-tai Sentō Kōdō Chōsho (飛行機隊戦闘行動調書 [Action records of air units]), a summary of actions of Naval air units.

105. Tomioka Sadatoshi Taisa Kaisō (富岡定俊大佐回想 [Recollections of Capt. Tomioka Sadatoshi]), then chief of Section 1 of the Navy General Staff.

106. Miyo Tatsukichi Chūsa Kaisō (三代辰吉中佐回想 [Recollections of Cdr. Miyo Tatsukichi]), then staff of Section 1 of the Navy General Staff.

107. Rengō Kantai Meirei-tsuzuri (聯合艦隊命令綴 [Files of the Combined Fleet orders]).

108. Ugaki Matome Chūjō Nikki (宇垣䌕中将日記 [Diary of V. Adm. Ugaki Matome]), then chief of staff of the Combined Fleet, [originally titled by himself as] Sen-sō-roku (戦藻録).

109. Nampō Butai Sentō Gaihō (南方部隊戦闘概報 [Summary report of the actions of the Southern Task Force]).

110. Matsudaira Nagayoshi Kikan Taii Shiryō (松平永芳機関大尉資料 [Documents of Lieutenant of Engineering Matsudaira Nagayoshi]), then chief engineer of the Destroyer Inazuma, excerpts of essential matters concerning operations made by him.

111. Kuroshima Kameto Taisa Kaisō (黒島亀人大佐回想 [Recollections of Capt. Kuroshima Kameto]), then senior staff of the Combined Fleet.

112. Fujita Masamichi Chūsa Kaisō (藤田正路中佐回想 [Recollections of Cdr. Fujita Masamichi]), then operations staff of the Second Fleet.

113. Yamaki Akira Taisa Kaisō (矢牧章大佐回想 [Recollections of Capt. Yamaki Akira]), then senior staff of the Third Fleet.

114. Dai-go Sentai Senji Nisshi, Sentō Shōhō (第五戦隊戦時日誌、戦闘詳報 [War journal and action report of the 5th Cruiser Division]).

115. Dai-nana Sentai Senji Nisshi, Sentō Shōhō (第七戦隊戦時日誌、戦闘詳報 [War journal and action report of the 7th Cruiser Division]).

116. Dai-ichi Suirai Sentai Senji Nisshi, Sentō Shōhō (第一水雷戦隊戦時日誌、戦闘詳報 [War journal / action report of the 1st Destroyer Squadron]).

117. Dai-ni Suirai Sentai Senji Nisshi, Sentō Shōhō (第二水雷戦隊戦時日誌、戦闘詳報 [War journal/action report of the $2 \mathrm{~d}$ Destroyer Squadron]).

118. Dai-san Suirai Sentai Senji Nisshi, Sentō Shōhō (第三水雷戦隊戦時日誌、戦闘詳報 [War journal/action report of the 3d Destroyer Squadron]).

119. Dai-yon Suirai Sentai Senji Nisshi, Sentō Shōhō (第四水雷戦隊戦時日誌、戦闘詳報 [War journal/action report of the 4th Destroyer Squadron]).

120. Dai-go Suirai Sentai Senji Nisshi, Sentō Shōhō (第五水雷戦隊戦時日誌、戦闘詳報 [War journal/action report of the 5th Destroyer Squadron]).

121. Dai-roku Suirai Sentai Senji Nisshi, Sentō Shōhō (第六水雷戦隊戦時日誌、戦闘詳報 [War journal/action report of the 6th Destroyer Squadron]).

122. Dai-yon Sensui Sentai Senji Nisshi, Sentō Shōhō (第四潜水戦隊戦時日誌、戦闘詳報 [War journal/action report of the 4th Submarine Squadron]).

123. Dai-go Kōkū Sentai Senji Nisshi, Sentō Shōhō (第五航空戦隊戦時日誌、戦闘詳報 [War journal/action report of the 5th Carrier Division]).

124. Dai-ichi Konkyochi-tai Senji Nisshi, Sentō Shōhō (第一根拠地隊戦時日誌、戦闘詳報 [War journal/action report of the 1st Base Force]).

125. Dai-ni Konkyochi-tai Senji Nisshi, Sentō Shōhō (第二根拠地隊戦時日誌、戦闘詳報 [War journal and action report of the 2d Base Force]).

126. Dai-kyū Konkyochi-tai Senji Nisshi, Sentō Shōhō (第九根拠地隊戦時日誌、戦闘詳報 [War journal / action report of the 9th Base Force]).

127. Dai-nijūyon Tokubetsu Konkyochi-tai Senji Nisshi, Sentō Shōhō (第二十四特別根拠地隊戦 時日誌、戦闘詳報 [War journal/action report of the 24th Special Base Force]). 
128. Kure Dai-ichi Tokubetsu Rikusen-tai Senji Nisshi, Sentō Shōhō (與第一特別陸戦隊戦時日 誌、戦闘詳報 [War journal/action report of the 1st Kure Special Landing Force]).

129. Chinkai Keibi-fu Senji Nisshi, Sentō Shōhō (鎮海警備府戦時日誌、戦闘詳報 [War journal/action report of the Chinkai Guard District]).

130. Kamikawa-maru Senji Nisshi, Sentō Shōhō (神川丸戦時日誌、戦闘詳報 [War journal/action report of the Kamikawa-maru]).

131. San'yō-maru Senji Nisshi, Sentō Shōhō (山陽丸戦時日誌、戦闘詳報 [War journal/action report of the $\left.\left.S_{a n}^{\prime} y \bar{o}-m a r u\right]\right)$.

132. Sanuki-maru Senji Nisshi, Sentō Shōhō (讃岐丸戦時日誌、戦闘詳報 [War journal/action report of the Sanuki-maru].

133. Sagara-maru Senji Nisshi, Sentō Shōhō (相良丸戦時日誌、戦闘詳報 [War journal/action report of the Sagara-maru].

134. Daiichi Kūshū Butai Sentō Gaihō (第一空襲部隊戦闘概報 [Summary report of the actions of the [Navy] 1st Air Raid Unit]).

135. Sampa-tsū-kiroku (三派通記録 [Records of the Navy 3d Detached Signal Unit]).

136. Takahashi Chihaya Taisa Kaisō (高橋千隼大佐回想 [Recollections of Capt. Takahashi Chihaya]), then senior staff of the Eleventh Air Fleet.

137. Shimada Kōichi Shōsa Kaisō (島田航一少佐回想 [Recollections of Lt. Cdr. Shimada Kōichi]), then staff of the Eleventh Air Fleet.

138. Yoshikawa Shūkichi Chūsa Kaisō (由川周吉中佐回想 [Recollections of Cdr. Yoshikawa Shūkichi]), then senior staff of the 5th Destroyer Squadron.

139. Imazato Yoshimitsu Chūsa Shuki (今里義光中佐手記 [A personal account of Cdr. Imazato Yoshimitsu]), then senior staff of the $2 \mathrm{~d}$ Base Force.

140. Yasunobu Takeo Chūsa Kaisō (安延多計夫中佐回想 [Recollections of Cdr. Yasunobu Takeo]), then senior staff of the 23d Air Flotilla.

141. Shibata Bunzō Chūsa Nikki (柴田文三中佐日記 [Diary of Cdr. Shibata Bunzō]), then senior staff of the 21st Air Flotilla.

142. Matsumoto Makoto Shōsa Shiryō (松本眞實少佐史料 [Materials in possession of Lt. Cdr. Matsumoto Makoto]), then aviation officer of the [Naval] 1st Air Group.

143. [A compilation of] Senkun (戦訓 [Lessons [learned in] combat]), issued by the Naval Committee for Researching Lessons in Combats.

144. Yokosuka Tokubetsu Dai-ichi Rikusentai Sentō Shōhō (横須賀特別第一陸戦隊戦闘詳報 [Action report of the 1st Yokosuka Special Landing Force]).

145. Kōseki Binran (功績便覧 [Records of Achievements]), a list of assignments and outline of services and military gains of each unit made by the Navy Achievement Appraisal Department.

146. Dainikki (大日記 [Document Files]), files of official incoming and outgoing letters of the War Ministry.

147. Imoto Kumao Chūsa Kaisō (井本熊男中佐回想 [Recollections of Lt. Col. Imoto Kumao]), then staff of Section 2 of the Army Department of IGHQ. 


\section{Appendix}

\section{List of Units in the Order of Battle of the Sixteenth Army (from 6 November 1941 to 1 March 1942)}

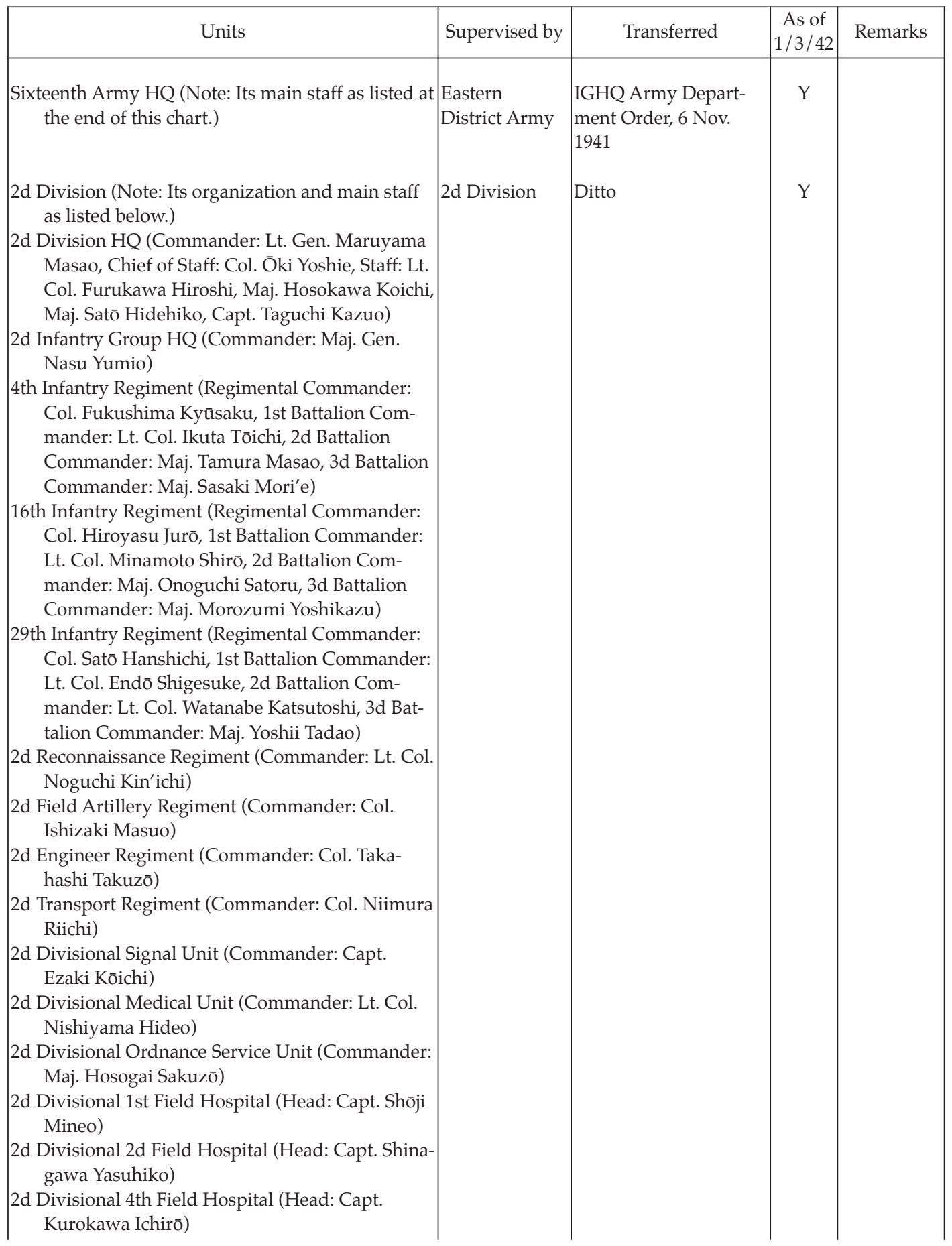


2d Divisional Water Supply and Purification Department (Commander: Capt. Numasawa Tamotsu)

2d Divisional Sick Horse Depot (Commander: Maj. Satō Tadanobu)

38th Division (Note: Its organization and main staff 38th Division as listed below)

38th Division HQ (Commander: Lt. Gen. Sano Tadayoshi, Chief of Staff: Col. Abe Yoshimitsu, Staff: Maj. Oyadomari Chōsei, Maj. Tosaka Susumu, Maj. Hosokawa Naonori)

38th Infantry Group HQ (Commander: Maj. Gen. Itō Takeo)

228th Infantry Regiment (Regimental Commander: Col. Doi Sadashichi, 1st Battalion Commander: Maj. Hayakawa Kikuo, 2d Battalion Commander: Maj. Kimura Eijirō, 3d Battalion Commander: Maj. Nishiyama Haruka)

229th Infantry Regiment (Regimental Commander: Col. Tanaka Ryōsaburō, 1st Battalion Commander: Capt. Orita Masaru, 2d Battalion Commander: Maj. Miyazawa Shigezō, 3d Battalion Commander: Maj. Kemmotsu Heishichi)

230th Infantry Regiment (Regimental Commander: Col. Shōji Toshishige, 1st Battalion Commander: Maj. Egashira Masaru, 2d Battalion Commander: Maj. Wakamatsu Minoru, 3d Battalion Commander: Maj. Ōneda Yasuhei)

38th Mountain Artillery Regiment (Commander: Col. Kanki Takekichi)

38th Engineer Regiment (Commander: Lt. Col. Iwabuchi Tsuneo)

38th Transport Regiment (Commander: Lt. Col. Yabuta Hidekazu)

38th Divisional Signal Unit (Commander: Maj. Itō Ryōichi)

38th Divisional Ordnance Service Unit (Commander: Capt. Koide Sadaharu)

38th Divisional Medical Unit (Commander: Lt. Col. Hattori Otokazu)

38th Divisional 1st Field Hospital (Head: Maj. Suzuki Toshimi)

38th Divisional 2d Field Hospital (Head: Maj. Itō Takuzō)

38th Divisional Sick Horse Depot (Commander: Maj. Hayashi Jirō)

48th Division (Note: Its organization and main staff 48 th Division as listed below)

48th Division HQ (Commander: Lt. Gen. Tsuchihashi Yūitsu, Chief of Staff: Col. Kawagoe Moriji, Staff: Maj. Nakahara Makoto, Maj. Akatsuka Kazuo, Maj. Tanabe Masaki)

48th Infantry Group HQ (Commander: Maj. Gen. Abe Kōichi)

From the Twenty-third Army in southern China; IGHQ Army Department Order, 4 Jan. 1942
From the Fourteenth Army on the Philippines; IGHQ Army Department Order, 14 Jan. 1942 
1st Taiwan Infantry Regiment (Regimental Commander: Col. Imai Kazufumi, 1st Battalion Commander: Maj. Sazawa Toshiteru, 2d Battalion Commander: Maj. Kobayashi Masao, 3d Battalion Commander: Maj. Kanemura Matabē)

2d Taiwan Infantry Regiment (Regimental Commander: Col. Tanaka Tōru, 1st Battalion Commander: Maj. Yanagi Hiroshi, 2d Battalion Commander: Maj. Takizawa Shichijūrō, 3d Battalion Commander: Maj. Kanno Zenkichi)

47th Infantry Regiment (Regimental Commander: Col. Yanagi Isamu, 1st Battalion Commander: Maj. Aikō Satoshi, 2d Battalion Commander: Maj. Baba Asanoshin, 3d Battalion Commander: Maj. Miyaji Ikuzō)

48th Reconnaissance Regiment (Commander: Lt. Col. Kitamura Kurō)

48th Mountain Artillery Regiment (Commander: Lt. Col. Yamaguchi Kayoshi)

48th Engineer Regiment (Commander: Lt. Col. Yanagi Toshio)

48th Divisional Signal Unit (Commander: Maj. Ikemoto Yoshiyuki)

48th Transport Regiment (Commander: Lt. Col. Tasaka Satoshi)

48th Divisional Ordnance Service Unit (Commander: Maj. Shimizu)

48th Divisional Medical Unit (Commander: Lt. Col. Manabe)

48th Divisional 1st Field Hospital (Head: Maj. Harada Sumitaka)

48th Divisional 4th Field Hospital (Head: Maj. Watanabe)

56th Mixed Infantry Group (Note: Its organization and main staff as listed below)

56th Infantry Group HQ (Commander: Maj. Gen. Sakaguchi Shizuo, Chief of Staff: Lt. Col. Yano Tsuneo)

146th Infantry Regiment (Regimental Commander: Col. Yamamoto Kyōhei, 1st Battalion Commander: Lt. Col. Kume Motozō, 2d Battalion Commander: Maj. Kanauji Ken'ichi, 3d Battalion Commander: Lt. Col. Matsumoto Tadasu)

56th Infantry Group Armored Car Unit

56th Field Artillery Regiment 1st Battalion

56th Engineer Regiment 1st Company

56th Transport Regiment 2d Company

56th Infantry Group Medical Unit

56th Divisional 1st Field Hospital

South Seas Detachment

Commander: Maj. Gen. Horii Tomitarō (55th In-

55th Division

From northern 


\begin{tabular}{|c|c|c|c|c|}
\hline \begin{tabular}{|l} 
144th Infantry Regiment \\
55th Cavalry Regiment 3d Squadron (minus one el- \\
ement) \\
One antitank gun squad of the above regiment \\
55th Mountain Artillery Regiment 1st Battalion \\
55th Engineer Regiment 1st Company and one ele- \\
ment of equipment platoon \\
One element of 55th Divisional Signal Unit \\
55th Transport Regiment 2d Company \\
One element of 55th Divisional Medical Unit \\
55th Divisional 1st Field Hospital \\
One element of 55th Divisional Sick Horse Depot \\
One element of 55th Divisional Water Supply and \\
Purification Department
\end{tabular} & & & & \\
\hline 8th Tank Regiment & $\begin{array}{l}\text { Eastern District } \\
\text { Army }\end{array}$ & $\begin{array}{l}\text { From the Kwantung } \\
\text { Army in Manchuria; } \\
\text { IGHQ Army Depart- } \\
\text { ment Order, } 6 \text { Nov. } \\
1941\end{array}$ & - & $\begin{array}{l}\text { To the } \\
\text { Kwantung } \\
\text { Army } \\
\text { [IGHQ } \\
\text { Army de- } \\
\text { partment } \\
\text { Order,] } 29 \\
\text { Jan. } 1942\end{array}$ \\
\hline $\begin{array}{l}\text { 2d Tank Regiment (minus [one] light tank } \\
\text { squadron) (Commander: Col. Mori Iwao) }\end{array}$ & $\begin{array}{l}\text { Imperial Guard } \\
\text { Depot Division }\end{array}$ & $\begin{array}{l}\text { From the Twenty-fifth } \\
\text { Army in Malaya; } \\
\text { IGHQ Army Depart- } \\
\text { ment Order, 29 Jan. } \\
1942\end{array}$ & Y & \\
\hline $\begin{array}{l}\text { 4th Tank Regiment (Commander: Lt. Col. Kumagai } \\
\text { Shōji) }\end{array}$ & Fifth Army & $\begin{array}{l}\text { From the Fourteenth } \\
\text { Army on the Philip- } \\
\text { pines; IGHQ Army De- } \\
\text { partment Order, 29 Jan. } \\
1942\end{array}$ & Y & \\
\hline 17th Field Heavy Artillery Regiment (A) & $\begin{array}{l}\text { 61st Infantry } \\
\text { Group }\end{array}$ & $\begin{array}{l}\text { From the Kwantung } \\
\text { Army in Manchuria; } \\
\text { IGHQ Army Depart- } \\
\text { ment Order, } 6 \text { Nov. } \\
1941\end{array}$ & Y & \\
\hline 2d Independent Antitank Gun Battalion & 3d Division & $\begin{array}{l}\text { From the Twenty-third } \\
\text { Army in southern } \\
\text { China; IGHQ Army } \\
\text { Department order, } 4 \\
\text { Jan. } 1942\end{array}$ & Y & \\
\hline 5th Independent Antitank Gun Battalion & 16th Division & Ditto & Y & \\
\hline $\begin{array}{l}\text { 8th Independent Antitank Gun Company (Comman- } \\
\text { der: Capt. Nakaoka) }\end{array}$ & Ditto & $\begin{array}{l}\text { From the Fourteenth } \\
\text { Army on the Philip- } \\
\text { pines; IGHQ Army De- } \\
\text { partment Order, 29 Jan. } \\
1942\end{array}$ & Y & \\
\hline $\begin{array}{l}\text { 10th Independent Antitank Gun Company (Com- } \\
\text { mander: Capt. Miyaji) }\end{array}$ & $\begin{array}{l}\text { 4th Depot Di- } \\
\text { vision }\end{array}$ & Ditto & Y & \\
\hline 18th Field Antiaircraft Defense Unit HQ & 56th Division & $\begin{array}{l}\text { From Kurume Divi- } \\
\text { sional District; IGHQ } \\
\text { Army Department } \\
\text { Order, } 6 \text { Nov. } 1941\end{array}$ & Y & \\
\hline
\end{tabular}




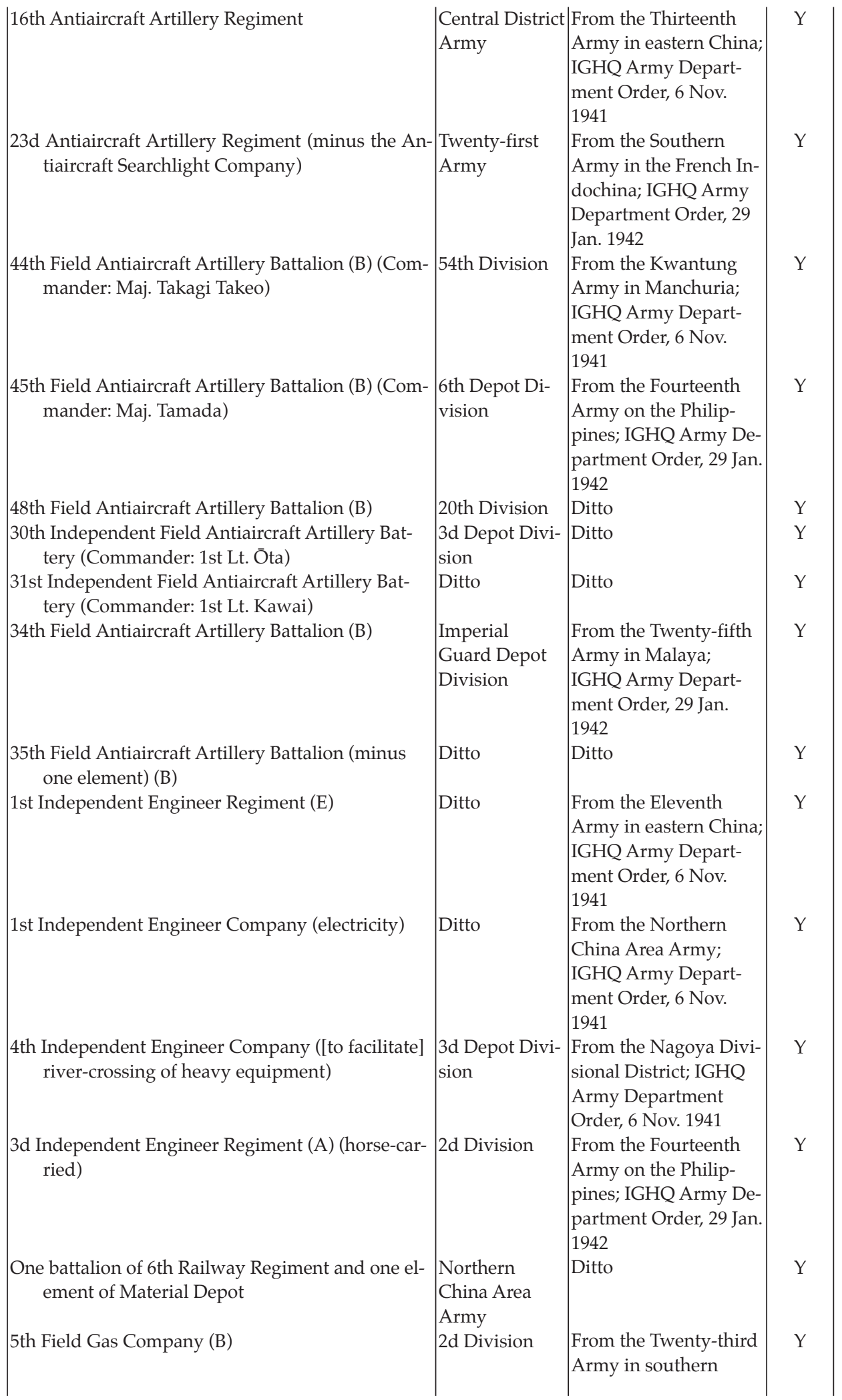




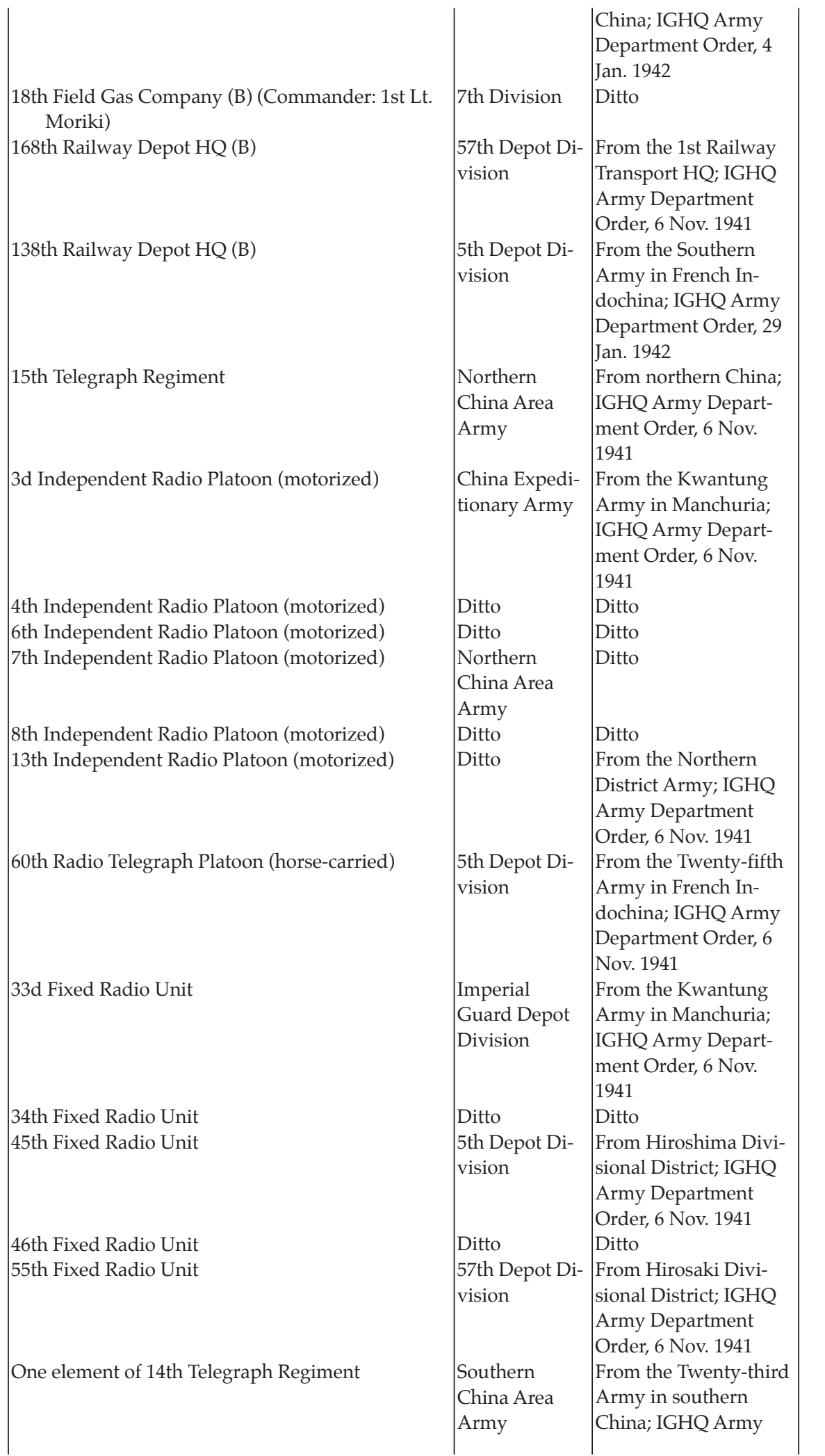




\begin{tabular}{|c|c|c|}
\hline & & $\begin{array}{l}\text { Department Order, } 4 \\
\text { Jan. } 1942\end{array}$ \\
\hline 5th Independent Radio Platoon (motorized) & $\begin{array}{l}\text { China Expedi- } \\
\text { tionary Army }\end{array}$ & $\begin{array}{l}\text { From the Fourteenth } \\
\text { Army on the Philip- } \\
\text { pines; IGHQ Army De- } \\
\text { partment Order, } 29 \text { Jan. } \\
1942\end{array}$ \\
\hline 51st Independent Radio Platoon (motorized) & $\begin{array}{l}\text { 5th Depot Di- } \\
\text { vision }\end{array}$ & Ditto \\
\hline 52d Independent Radio Platoon (motorized) & Ditto & Ditto \\
\hline 40th Fixed Radio Unit & Ditto & Ditto \\
\hline 5th Fixed Radio Unit & $\begin{array}{l}\text { Northern Dis- } \\
\text { trict Army }\end{array}$ & $\begin{array}{l}\text { From the Northern } \\
\text { District Army; IGHQ } \\
\text { Army Department } \\
\text { Order, } 16 \text { Feb. } 1942\end{array}$ \\
\hline 29th Bridge Building Material Company & $\begin{array}{l}\text { 5th Depot Di- } \\
\text { vision }\end{array}$ & $\begin{array}{l}\text { From the Kwantung } \\
\text { Army in Manchuria; } \\
\text { IGHQ Army Depart- } \\
\text { ment Order, } 6 \text { Nov. } \\
1941\end{array}$ \\
\hline 6th Division Bridge Building Material Company & $\begin{array}{l}\text { 6th Depot Di- } \\
\text { vision }\end{array}$ & $\begin{array}{l}\text { From the Eleventh } \\
\text { Army in eastern China; } \\
\text { IGHQ Army Depart- } \\
\text { ment Order, } 6 \text { Nov. } \\
1941\end{array}$ \\
\hline $\begin{array}{l}\text { Imperial Guard Division River-crossing Material } \\
\text { Company }\end{array}$ & $\begin{array}{l}\text { Imperial } \\
\text { Guard Depot } \\
\text { Division }\end{array}$ & Ditto \\
\hline $\begin{array}{l}\text { 26th Bridge Building Material Company (Com- } \\
\text { mander: 1st Lt. Kuwahara) }\end{array}$ & $\begin{array}{l}\text { 3d Depot Divi- } \\
\text { sion }\end{array}$ & $\begin{array}{l}\text { From the Fourteenth } \\
\text { Army on the Philip- } \\
\text { pines; IGHQ Army De- } \\
\text { partment Order, } 29 \text { Jan. } \\
1942\end{array}$ \\
\hline 13th River-crossing Material Company & $\begin{array}{l}\text { 51st Depot Di- } \\
\text { vision }\end{array}$ & Ditto \\
\hline 14th River-crossing Material Company & 53d Division & Ditto \\
\hline 3d Field Military Police Unit & $\begin{array}{l}\text { Kwantung } \\
\text { Army }\end{array}$ & $\begin{array}{l}\text { From the Kwantung } \\
\text { Army in Manchuria; } \\
\text { IGHQ Army Depart- } \\
\text { ment Order, } 6 \text { Nov. } \\
1941\end{array}$ \\
\hline 43d Line-of-Communication Area Unit & 2d Division & $\begin{array}{l}\text { From the Kwantung } \\
\text { Army in Manchuria; } \\
\text { IGHQ Army Depart- } \\
\text { ment Order, } 6 \text { Nov. } \\
1941\end{array}$ \\
\hline 48th Line-of-Communication Area Unit & 52d Division & Ditto \\
\hline 2d Field Transport HQ & $\begin{array}{l}\text { 61st Infantry } \\
\text { Group }\end{array}$ & $\begin{array}{l}\text { From the Kwantung } \\
\text { Army in Manchuria; } \\
\text { IGHQ Army Depart- } \\
\text { ment Order, } 6 \text { Nov. } \\
1941\end{array}$ \\
\hline 39th Independent Motor Transport Battalion & 52d Division & $\begin{array}{l}\text { From Kanazawa Divi- } \\
\text { sional District; IGHQ } \\
\text { Army Department } \\
\text { Order, } 6 \text { Nov. } 1941\end{array}$ \\
\hline
\end{tabular}




\begin{tabular}{|c|c|c|}
\hline 261st Independent Motor Transport Company & $\begin{array}{l}4 \text { th Depot Di- } \\
\text { vision }\end{array}$ & Ditto \\
\hline 102d Independent Motor Transport Battalion & $\begin{array}{l}\text { 61st Infantry } \\
\text { Group }\end{array}$ & $\begin{array}{l}\text { From Tokyo Divisional } \\
\text { District; IGHQ Army } \\
\text { Department Order, } 27 \\
\text { Nov. } 1941\end{array}$ \\
\hline $\begin{array}{l}\text { 209th Independent Motor Transport Company } \\
\text { (Commander: 1st Lt. Arai) }\end{array}$ & $\begin{array}{l}\text { Imperial } \\
\text { Guard Depot } \\
\text { Division }\end{array}$ & $\begin{array}{l}\text { From the Fourteenth } \\
\text { Army on Philippines; } \\
\text { IGHQ Army Depart- } \\
\text { ment Order, 29 Jan. } \\
1942\end{array}$ \\
\hline $\begin{array}{l}\text { 258th Independent Motor Transport Company } \\
\text { (Commander: 1st Lt. Hiradōri) }\end{array}$ & $\begin{array}{l}\text { 4th Depot Di- } \\
\text { vision }\end{array}$ & Ditto \\
\hline $\begin{array}{l}\text { 259th Independent Motor Transport Company } \\
\text { (Commander: 1st Lt. Tomura) }\end{array}$ & Ditto & Ditto \\
\hline 28th Motor Transport Regiment & $\begin{array}{l}\text { 51st Depot Di- } \\
\text { vision }\end{array}$ & $\begin{array}{l}\text { From the Twenty-fifth } \\
\text { Army in Malaya; } \\
\text { IGHQ Army Depart- } \\
\text { ment Order, 29 Jan. } \\
1942\end{array}$ \\
\hline 45th Independent Motor Transport Battalion & $\begin{array}{l}\text { 3d Depot Divi- } \\
\text { sion }\end{array}$ & Ditto \\
\hline 212th Independent Motor Transport Company & $\begin{array}{l}\text { Imperial } \\
\text { Guard Depot } \\
\text { Division }\end{array}$ & Ditto \\
\hline 307th Independent Motor Transport Company & Taiwan Army & Ditto \\
\hline 308th Independent Motor Transport Company & Ditto & Ditto \\
\hline 42d Field Road Unit & 56th Division & $\begin{array}{l}\text { From the Kwantung } \\
\text { Army in Manchuria; } \\
\text { IGHQ Army Depart- } \\
\text { ment Order, } 6 \text { Nov. } \\
1941\end{array}$ \\
\hline 44th Field Road Unit & $\begin{array}{l}\text { 57th Depot Di- } \\
\text { vision }\end{array}$ & Ditto \\
\hline 5th Field Well-drilling Company & $\begin{array}{l}\text { Imperial } \\
\text { Guard Depot } \\
\text { Division }\end{array}$ & $\begin{array}{l}\text { From Tokyo Divisional } \\
\text { District; IGHQ Army } \\
\text { Department Order, } 6 \\
\text { Nov. } 1941\end{array}$ \\
\hline 16th Field Well-drilling Company & 52d Division & $\begin{array}{l}\text { From the Kwantung } \\
\text { Army in Manchuria; } \\
\text { IGHQ Army Depart- } \\
\text { ment Order, } 6 \text { Nov. } \\
1941\end{array}$ \\
\hline 14th Field Duty Unit HQ & 55th Division & $\begin{array}{l}\text { From Zentsūji Divi- } \\
\text { sional District; IGHQ }\end{array}$ \\
\hline
\end{tabular}

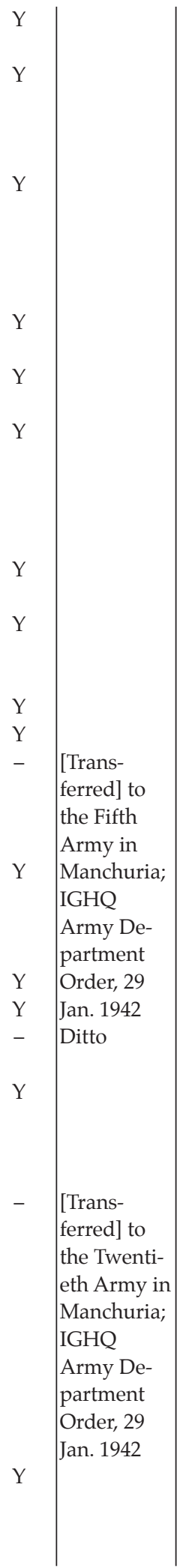


107th Shore Duty Company 108th Shore Duty Company

45th Sea Duty Company

Ditto

54th Division

61st Construction Duty Company

55th Division

Army Department

Order, 6 Nov. 1941

Ditto

Ditto

From Himeji Divi-

sional District; IGHQ

Army Department

Order, 6 Nov. 1941

From Zentsūji Divi-

sional District; IGHQ

Army Department

Order, 6 Nov. 1941

62d Construction Duty Company

Ditto

Ditto

18th Field Postal Unit

6th Depot Di-

vision

From Kumamoto Divi-

sional District; IGHQ

Army Department

Order, 6 Nov. 1941

18th Line-of-Communication Medical Unit HQ

55th Division

From Zentsūji Divi-

sional District; IGHQ

Army Department

Order, 6 Nov. 1941

67th Line-of-Communication Hospital

Imperial

From the Kwantung

Guard Depot

Division

Army in Manchuria;

IGHQ Army Department Order, 6 Nov. 1941

115th Line-of-Communication Hospital

56th Division

From Kurume Divi-

sional District; IGHQ

Army Department

Order, 6 Nov. 1941

116th Line-of-Communication Hospital

Ditto Ditto

121st Line-of-Communication Hospital

7th Division

From Asahikawa Divisional District; IGHQ

Army Department

Order, 6 Nov. 1941

56th Division

From Kurume Divi-

sional District; IGHQ

Army Department

Order, 6 Nov. 1941

65th Patient Transport Platoon

Ditto

Ditto

Ditto

68th Patient Transport Platoon

7th Division

38th Patient Transport Platoon (Commander: 1st

2d Division

Lt. Masui)

22d Field Water Supply and Purification Depart-

Kwantung

Ditto

From Asahikawa Divisional District; IGHQ

Army Department

Order, 6 Nov. 1941

From the Fourteenth

Army on the Philip-

pines; IGHQ Army De-

partment Order, 29 Jan. 1942

ment (B)

Army

From the Kwantung

Army in Manchuria;

IGHQ Army Department Order, 6 Nov. 
8th Water Supply and Purification Department (Head: Capt. Takeuchi)

17th Water Supply and Purification Department

13th Line-of-Communication Sick Horse Depot

19th Veterinary Quarantine Depot (B)

24th Field Ordnance Depot

24th Field Motor Transport Depot

24th Field Freight Depot

\begin{tabular}{|c|c|}
\hline 1st Division & $\begin{array}{l}\text { From the Fourteenth } \\
\text { Army on the Philip- } \\
\text { pines; IGHQ Army De- } \\
\text { partment Order, 29 Jan. } \\
1942\end{array}$ \\
\hline Ditto & $\begin{array}{l}\text { From the Twenty-third } \\
\text { Army in southern } \\
\text { China; IGHQ Army } \\
\text { Department Order, } 4 \\
\text { Jan. } 1942\end{array}$ \\
\hline 52d Division & $\begin{array}{l}\text { From Kanazawa Divi- } \\
\text { sional District; IGHQ } \\
\text { Army Department } \\
\text { Order, } 6 \text { Nov. } 1941\end{array}$ \\
\hline $\begin{array}{l}57 \text { th Depot Di- } \\
\text { vision }\end{array}$ & $\begin{array}{l}\text { From Hirosaki Divi- } \\
\text { sional District; IGHQ } \\
\text { Army Department } \\
\text { Order, 6 Nov. } 1941\end{array}$ \\
\hline Imperial & From Tokyo Divisional \\
\hline Guard Depot & District; IGHQ Army \\
\hline Division & $\begin{array}{l}\text { Department Order, } 6 \\
\text { Nov. } 1941\end{array}$ \\
\hline $\begin{array}{l}\text { 4th Depot Di- } \\
\text { vision }\end{array}$ & $\begin{array}{l}\text { From Osaka Divisional } \\
\text { District; IGHQ Army } \\
\text { Department Order, } 6 \\
\text { Nov. } 1941\end{array}$ \\
\hline Imperial & From Tokyo Divisional \\
\hline Guard Depot & District; IGHQ Army \\
\hline Division & $\begin{array}{l}\text { Department Order, } 6 \\
\text { Nov. } 1941\end{array}$ \\
\hline
\end{tabular}

Remarks:

1. "Supervised by" indicates the Army, Division or other unit that administered the mobilization or the organization of the unit. "Transferred" indicates the order that put the unit under the command of the Sixteenth Army. "As of $1 / 3 / 42$ " indicates whether the unit was still under the command of the Sixteenth Army as of 1 March 1942.

2. [Concerns the original Japanese text. Not relevant to the translation. Omitted by the editor.]

3. For example, the last-mentioned 24th Field Freight Depot was organized under the supervision of the depot division of the Imperial Guard Division, put in the order of battle of the Sixteenth Army by IGHQ Army Department Order of 6 November 1941 from the Tokyo Divisional District, and was still under the command of the Sixteenth Army as of 1 March 1942.

Main staff of the Sixteenth Army Headquarters

Army Commander: Lt. Gen. Imamura Hitoshi

Chief of Staff: Maj. Gen. Okazaki Seizaburō

Vice Chief of Staff: Maj. Gen. Harada Yoshikazu

Staff of Section 1: Col. Takashima Tatsuhiko (Senior Staff), Lt. Col. [Col.] Murakami Kimisuke (Intelligence), Lt. Col. Itoda Isamu (Aviation), Lt. Col. Oda Akimitsu (Operations), Maj. Kuriya Tsugunori (Intelligence), Maj. Yamashita Yutaka (Operations).

Staff of Section 2: Col. Kitamura Yoshifuto (Senior Staff), Lt. Col. Saiki Ikuzō (Signal Communications), Lt. Col. Sendō Shunzō (Shipping), Maj. Takahashi Mitsuzō (Line of Communication), Maj. Nishiura Setsuzō (Line of Communication).

Attached to the Army Headquarters: Col. Nakayama Yasuto (Military Administration) 


\section{Glossary}

\section{Army}

15-cm Howitzer Battery

1st Bureau (Operations Bureau),

[Army Department of IGHQ]

1st Disembarkation Group

2d Bureau (Intelligence Bureau),

[Army Department of IGHQ]

air division

[Numbered] Air Force

air ground support unit

air ground support headquarters

[Army] air group

air signal regiment

air signal unit

air transport company

airfield battalion/ company

airfield duty unit

anchorage headquarters

antiaircraft artillery regiment/battalion

antiaircraft searchlight company

[numbered] Army

Army Aviation Headquarters

Army Department of IGHQ

Army Flying School,

Baichengzi/Hamamatsu

army railway unit

battalion artillery section

bridge building material company

cavalry regiment

Central Distirct Army

Central Shipping Transport,

[Ministry of War]

China Expeditionary Army

construction duty company

detachment

disembarkation working unit

division

division headquarters

divisional district

\begin{tabular}{|c|c|}
\hline \multirow{2}{*}{$\begin{array}{l}\text { jūgo-ryū chūtai } \\
\text { Dai-ichi-bu (Sakusen-bu) }\end{array}$} & 十五榴中隊 \\
\hline & 第一部 (作戦部) \\
\hline Dai-ichi Yōriku Dan & 第一揚陸団 \\
\hline Dai-ni-bu (Jōhō-bu) & 第二部 (情報部) \\
\hline hikō dan & 飛行団 \\
\hline Hikō Shūdan & 飛行集団 \\
\hline kōkū chiku butai & 航空地区部隊 \\
\hline kōkū chiku shirei-bu & 航空地区司令部 \\
\hline hikō sentai & 飛行戦隊 \\
\hline kōkū tsūshin rentai & 航空通信聯隊 \\
\hline kōkū tsūshin tai & 航空通信隊 \\
\hline yusō hikō chūtai & 輸送飛行中隊 \\
\hline hikō-jō daitai / chūtai & 飛行場大隊/ 中隊 \\
\hline hikō-jō kimmu butai & 飛行場勤務部隊 \\
\hline teihaku-jō shirei-bu & 碇泊場司令部 \\
\hline kōshahō rentai / daitai & 高射砲聯隊/ 大隊 \\
\hline shōkū chūtai & 照空中隊 \\
\hline Gun & 軍 \\
\hline Rikugun Kōkū Hombu & 陸軍航空本部 \\
\hline Daihon'ei Rikugun-bu & 大本営陸軍部 \\
\hline Hakujōshi /Hamamatsu & 白城子/浜松 \\
\hline Rikugun Hikō-gakkō & 陸軍飛行学校 \\
\hline gun tetsudō butai & (第16)軍鉄道部隊 \\
\hline daitaihō shōtai & 大隊砲小隊 \\
\hline kakyō zairyō chūtai & 架橋材料中隊 \\
\hline kihei rentai & 騎兵聯隊 \\
\hline Chūbu Gun & 中部軍 \\
\hline Un'yu-bu & 運輸部 \\
\hline Shina-haken Gun & 支那派遣軍 \\
\hline kenchiku kimmu chūtai & 建築勤務中隊 \\
\hline shitai & 支隊 \\
\hline yōriku sagyō tai & 揚陸作業隊 \\
\hline shidan & 師団 \\
\hline shidan shirei-bu & 師団司令部 \\
\hline - & . \\
\hline
\end{tabular}


Eastern District Army

Economic Mobilization Bureau,

[Ministry of War]

engineer regiment

equipment platoon

field aircraft repair depot

field airfield construction unit

field antiaircraft defense unit headquarters

field artillery regiment

field duty unit headquarters

field freight depot

field gas company

field heavy artillery regiment

field hospital

(field) meteorological company

field military police unit

field motor transport depot

field ordnance depot

field postal unit

field road unit

field transport headquarters

field well-drilling company

fixed radio unit

ground duty company [Army aviation]

Imperial Guard Division

Imperial Japanese Military Academy

independent air unit

independent antitank gun

battalion/company

independent engineer company

(electricity)/ ([to facilitate] river-crossing

of heavy equipment)

independent field antiaircraft artillery

battery (horse-carried)

independent motor transport

battalion/company

independent radio platoon

independent squadron

[of Army Air Forces]

infantry artillery unit

infantry group

infantry regiment/battalion/

company/platoon

Information Department,

[Ministry of War]

Inspectorate General of [Army] Aviation

Inspectorate General of

Line of Communication

Inspectorate General of Military Training
Tōbu Gun

Seibi-kyoku

kōhei rentai

kizai shōtai

yasen kōkū shūri-shō

yasen hikō-jō settei tai

yasen bōkū tai shirei-bu

yahōhei rentai

yasen kimmu tai hombu

yasen kamotsu-shō

yasen gasu chūtai

yasen jūhōhei rentai

yasen byōin

(yasen) kishō chūtai

yasen kempei tai

yasen jidōsha-shō

yasen heiki-shō

yasen yūbin tai

yasen dōro tai

yasen yusō shirei-bu

yasen sakusei chūtai

kotei musen tai

rikujō kimmu chūtai

Kono'e Shidan

Rikugun Shikan-gakkō

dokuritsu hikō tai

dokuritsu sokushahō daitai / chūtai

dokuritsu kōhei chūtai

$$
\text { (denki)/ (jūtoga) }
$$

dokuritsu yasen kōshahō chūtai (daba)

dokuritsu jidōsha daitai/chūtai

dokuritsu musen shōtai

dokuritsu hikō chūtai

hoheihō tai

hohei dan

hohei rentai/daitai/ chūtai/shōtai

Hōdō-bu

Kōkū Sōkan-bu

Heitan Sōkan-bu

Kyōiku Sōkan-bu
東部軍

整備局

工兵聯隊

器材小隊

野戦航空修理廠

野戦飛行場設定隊

野戦防空隊司令部

野砲兵聯隊

野戦勤務隊本部

野戦貨物廠

野戦瓦斯中隊

野戦重砲兵聯隊

野戦病院

(野戦)気象中隊

野戦憲兵隊

野戦自動車廠

野戦兵器廠

野戦郵便隊

野戦道路隊

野戦輸送司令部

野戦作井中隊

固定無線隊

陸上勤務中隊

近衛師団

陸軍士官学校

独立飛行隊

独立速射砲

大隊/中隊

独立工兵中隊

(電気) / (重渡河)

独立野戦高射砲

中隊 (駄)

独立自動車

大隊/中隊

独立無線小隊

独立飛行中隊

歩兵砲隊

歩兵団

歩兵聯隊/大隊/

中隊/小隊

報道部

航空総監部

兵站総監部

教育総監部 
intendance department director

Kwantung Army

legal department director

light-armored car unit

line-of-communication sick horse depot

line-of-communication area unit

line-of-communication

hospital/medical unit

machine gun company

Mark-3 radio squad

material depot

medical department director

medical unit

meteorological observation detail

military administration department

Military Affairs Bureau,

[Ministry of War]

Ministry of War

mixed brigade

motor transport squad

motorcycle unit

mountain artillery regiment

Northern China Area Army

Northern District Army

Office of Army General Staff

on-board antiaircraft artillery regiment

ordnance department director

ordnance service unit

patient transport unit HQ/

platoon

press corps

Propaganda Group

radio telegraph platoon

raiding air group, [paratroop]

Raiding Group, [1st Paratroop]

raiding regiment, [paratroop]

railway depot headquarters

railway regiment

reconnaissance regiment

regimental artillery section

Resource section, [Ministry of War]

river-crossing material company

sea duty company

sea transport supervisory unit

Section 2 (Operations Section),

[Army Department of IGHQ]

Section 3 (Organization and

Mobilization Section),

[Army Department of IGHQ]

$\begin{array}{ll}\text { keiri-buchō } & \text { 経理部長 } \\ \text { Kantō Gun } & \text { 関東軍 } \\ \text { hōmu-buchō } & \text { 法務部長 } \\ \text { kei-sōkōsha tai } & \text { 軽装甲車隊 } \\ \text { heitan byōba-shō } & \text { 兵站病馬廠 } \\ \text { heitan chiku tai } & \text { 兵站地区隊 } \\ \text { heitan } & \text { 兵站 }\end{array}$

\begin{tabular}{ll}
\multicolumn{1}{c}{ byōin/eisei tai } & \multicolumn{1}{c}{ 病院/衛生隊 } \\
kikanjū chūtai & 機関銃中隊 \\
San-gō-musen buntai & 3号無線 分隊 \\
zairyō-shō & 材料廠 \\
gun'i-buchō & 軍医部長 \\
eisei tai & 衛生隊 \\
sokkō han & 測候班 \\
gunsei-bu & 軍政部 \\
Gummu-kyoku & 軍務局
\end{tabular}

Rikugun-shō 陸軍省

konsei ryodan 混成旅団

jidōsha han 自動車班

jidō-nirinsha tai 自動二輪車隊

sampōhei rentai 山砲兵聯隊

Kita-shina-hōmen Gun 北支那方面軍

Hokubu Gun 北部軍

Sambō Hombu参謀本部

sempaku kōshahō rentai 船舶高射砲聯隊

heiki-buchō 兵器部長

heiki kimmu tai 兵器勤務隊

kan'ja yusō tai hombu / 患者輸送隊本部/

小隊

報道班

宣伝班

無線電信小隊

挺進飛行戦隊

[第一]挺進団

挺進聯隊

停車場司令部

鉄道聯隊

捜索聯隊

聯隊砲小隊

資源課

渡河材料中隊

水上勤務中隊

海上輸送監視隊

$\begin{array}{ll}\text { Dai-ni-ka (Sakusen-ka) } & \text { 第二課 (作戦課) }\end{array}$

Dai-san-ka 第三課

(Hensei, Dōin-ka）（編成・動員課） 
ship repair depot

shipping engineer

shipping signal regiment

Shipping Transport Command

shore duty company

signal unit

sick horse depot

Soutern Army

Southern China Area Army

Southern Group,

[Army Department of IGHQ]

Special Broadcasting Detail

squad

squad for collecting cast-off articles

squadron, [Army air group]

supply platoon of the train [of regiment]

Taiwan Army

tank regiment

telegraph regiment

transport regiment

Transport section, [Ministry of War]

unit

unit under direct control of

the [Sixteenth] Army

vessel launching unit

veterinary department director

veterinary quarantine depot

War College

War Preparation Section, [Ministry of War]

water supply and purification department

weather observation detail

wire company

\begin{tabular}{|c|c|}
\hline sempaku kōsaku-shō & 船舶工作廠 \\
\hline sempaku kōhei & 船舶工兵 \\
\hline sempaku tsūshin rentai & 船舶通信聯隊 \\
\hline Sempaku Yusō Shirei-bu & 船舶輸送司令部 \\
\hline rikujō kimmu chūtai & 陸上勤務中隊 \\
\hline tsūshin tai & 通信隊 \\
\hline byōba-shō & 病馬廠 \\
\hline Nampō Gun & 南方軍 \\
\hline Minami-shina-hōmen Gun & 南支那方面軍 \\
\hline Nampō Han & 南方班 \\
\hline Tokushu Hōsō Han & 特殊放送班 \\
\hline buntai & 分隊 \\
\hline ikibutsu shūshū han & 遺棄物収集班 \\
\hline hikō chūtai & 飛行中隊 \\
\hline rentai danretsu hokyū shōta & ai 聯隊段列補給小隊 \\
\hline Taiwan Gun & 台湾軍 \\
\hline sensha rentai & 戦車聯隊 \\
\hline denshin rentai & 電信聯隊 \\
\hline shichō rentai & 輕重聯隊 \\
\hline Kōtsū-ka & 交通課 \\
\hline tai/butai & 隊/部隊 \\
\hline $\begin{array}{l}\text { (Jūroku-)gun-chokuzoku } \\
\text { butai }\end{array}$ & (第16)軍直属部隊 \\
\hline hensui sagyō tai & 泛水作業隊 \\
\hline jūi-buchō & 獣医部長 \\
\hline gumba bōeki-shō & 軍馬防疫廠 \\
\hline Rikugun Daigakkō & 陸軍大学校 \\
\hline Sembi-ka & 戦備課 \\
\hline bōeki kyūsui-bu & 防疫給水部 \\
\hline kansoku han & 観測班 \\
\hline yūsen chūtai & 有線中隊 \\
\hline
\end{tabular}




\section{Navy}

1001 [Paratroop] Unit

Air Fleet, [First, Eleventh]

Air Flotilla,

[21st, 22d, 23d]

[Naval] Air Group,

[3d, Gaoxiong, Genzan,

Kanoya, Mihoro]

auxiliary

(special) base force

Battleship Division, [3d]

Carrier Division,

[1st, 2d, 4th, 5th]

[Carrier] Task Force / [Carrier] Strike Force

China Area Fleet

Chinkai Guard District

Combined Fleet

construction squad

Cruiser Division

[4th, 5th, 7th, 8th, 9th, 16th]

destroyer division

Destroyer Squadron,

[1st, 2d, 3d, 4th, 5th, 6th]

Dutch East Indies Unit

Eastern Support Unit

explosives sweeper unit

Fleet, [First, Second, Third,

Fourth, Fifth, Sixth]

guard unit

Iwakuni Navy Air Unit

land-based [naval] air unit/fleet

land-based attack plane unit

(special) landing force

main force

main unit

Malaya Unit

Minelayer Division, [17th]

minesweeper division

Naval Affairs Bureau [Navy Ministry]

Naval College
1001 Butai

1001部隊

Kantai, [Dai-ichi,

[第1, 11] 航空艦隊

Dai-jū-ichi]

Kōkū Sentai,

[第21，22，23] 航空戦隊

[Dai-nijū-ichi,

Dai-nijū-ni, Dai-nijū-san]

Kōkūtai,

航空隊

[Dai-san, Takao, Genzan, [第3, 高雄, 元山,

Kanoya, Mihoro]

tokusetsu

鹿屋, 美幌]

特設

(tokubetsu) konkyochi tai (特別)根拠地隊

Sentai, [Dai-san]

Kōkū Sentai,

[第 3] 戦隊

[第1, 2, 4, 5] 航空戦隊

[Dai-ichi, Dai-ni,

Dai-yon, Dai-go]

Kidō Butai

機動部隊

Shina-hōmen Kantai

支那方面艦隊

Chinkai Keibi-fu

鎮海警備府

Rengō Kantai

聯合艦隊

設営班

setsuei han

[第4, 5, 7, 8, 9, 16] 戦隊

[Dai-yon, Dai-go,

Dai-nana, Dai-hachi,

Dai-kyū, Dai-jū-roku]

kuchiku tai

Suirai Sentai,

[Dai-ichi, Dai-ni,

Dai-san, Dai-yon,

Dai-go, Dai-roku]

Ran'in Butai

蘭印部隊

Tōhō-shien tai

(南方部隊) 東方支援隊

掃爆隊

sōbaku tai

[第1，2，3，4，5，6] 艦隊

Dai-san, Dai-yon,

Dai-go, Dai-roku]

keibi tai

警備隊

Iwakuni Kaigun Kōkū tai

岩國海軍航空隊

kichi kōkū butai/kantai

基地航空部隊/艦隊

rikkō tai

陸攻隊

(tokubetsu) rikusen tai (特別)陸戦隊

hontai

本隊

shutai

主隊

Marei Butai

馬来部隊

Sentai, [Dai-jū-nana]

[第17] 戦隊

sōkai tai

掃海隊

Gummu-kyoku

軍務局

Kaigun Daigakkō

海軍大学校 
Naval Engineering College

naval station

Navy Department of IGHQ

Navy Ministry

Northern Task Force

Office of Navy General Staff

paratroop unit

Philippines Unit

Seaplane Tender Division,

[11th, 12th]

Second China Expeditionary Fleet

signal unit

South Seas [Pacific Islands] Unit

Southern Expeditionary Fleet,

[First, Third]

Southern Philippines Area Task Force,

[Philippines Unit]

Southern Task Force

strategic port

subchaser division

Submarine Squadron,

[2d, 4th, 5th, 6th]
Kaigun Kikangakkō

Chinju-fu

Daihon'ei Kaigun-bu

Kaigun-shō

Hoppō Butai

Gunrei-bu

Kūtei butai

Hi-tō (Philippines) Butai

Kōkū Sentai,

[Dai-jū-ichi, Dai-jū-ni]

Dai-ni Kenshi Kantai

tsūshin tai

Nan'yō Butai

Nanken Kantai,

[Dai-ichi, Dai-san]

Nan-hi-/Nam-pi- shien tai 南比支援隊

Nampō Butai

yōkō

kusen tai

Sensui Sentai,

[Dai-ni, Dai-yon,

Dai-go, Dai-roku]
海軍機関学校

鎮守府

大本営海軍部

海軍省

北方部隊

軍令部

空挺部隊

比島部隊

[第11，12] 航空戦隊

第2遣支艦隊

通信隊

南洋部隊

[第1,3]南遣艦隊

南方部隊

要港

駆潜隊

[第2, 4, 5, 6] 潜水戦隊 


\section{Index of Personal Names}

The characters used in Japanese names can often be read in more than one way. We have tried to ascertain the correct readings based on several outside sources (see Editor's Note). Here we have added a question mark behind the family and/or personal name whenever the reading remains open to interpretation.

Abe Kōichi (安部孝一), Maj Gen, 48th Inf Gp cdr, IJA, 238, 550-55, 557-62, 564, 566-67, 600

Abe Tomoji (阿部知二), [Novelist, translator and scholar of English literature], 102

Abe Yoshimitsu (阿部芳光), Col, Ch of staff, 38th Div, IJA, 162, 342-43, 600

Aikō Satoshi [Tetsu? Akira?] (愛甲哲), Maj, 47th Inf Rgt 1st Bn cdr, IJA, 559, 560, 562, 601

Akatsuka Kazuo (赤塚一雄), Maj, 48th Div staff, IJA, 185, 223, 236, 557, 600

Aoki Shigemasa（青木重誠), Lt Gen, V Ch of staff, Southern Army, IJA, 152-54, 171, 431, 551

Arai（荒井), 1st Lt, 209th Independent Motor Transport Co cdr, IJA, 600

Araki（荒木), Press Corps, IJA, 324

Arao Okikatsu（荒尾興功）, Lt Col, Ch of opns staff, Southern Army, IJA, 100, 115, 209, 253, $272,274,292,301,321$

Arita Hachirō (有田八郎), [former] Foreign Minister of Japan, 2

Asami (浅見), Capt, Shōji Det Motor Transport Unit [cdr], IJA, 507

Asano Akira（浅野晃), [Poet and scholar of Japanese literature], 102

Baba Asanoshin (馬場浅之進), Maj, 47th Inf Rgt 2d Bn cdr, IJA, 557, 559, 562, 601

Bakkers, [Rudolph] (バッカス), Maj Gen, Ch of Gen Staff, KNIL, 531

Bennett, [Henry Gordon] (ベネット), Maj Gen, AU Army, 583

Cheng Jiemin [?]（鄭介民) , 257, 420
Chiang Kai-shek, [Jiang Jieshi] (蒋介石) , 17, 256, 257, 419, 582, 585

Chiba (千葉), Japanese Minister in Portugal, 382 Churchill, [Sir Winston] (チャーチル) , 578, 582

Colijn, [Anton Hendrikus] (コーレン), Capt, BPM manager and Tarakan garrison army adjutant, KNIL, 350, 354

Cox, [Pierre A] (コックス), Maj Gen, 2d Div cdr (Central Java), KNIL, 545, 571-72

Cripps, Howard [Sir Richard Stafford Cripps?] (クリップス,ハワード), 578

Doi Sadashichi（土井定七), Col, 228th Inf Rgt cdr, IJA, 369, 370, 404, 407-09, 413, 600

Egashira Masaru（江頭多) , Maj, 230th Inf Rgt 1st Bn cdr, IJA, 463, 488, 506-11, 513-15, 518, 521, 523-24, 525-28, 572, 578, 600

Emperor (天皇) , 24, 26, 32, 40, 41, 56-58, 69, 88, $128,138,215-16,296,373,381,384,569$

Endō (遠藤), Lt Col, 38th Div (Opn L: the Gin'yōmaru Transport cdr), IJA, 312

Endō Saburō（遠藤三郎）, Maj Gen, 3d Air Div cdr, IJA, 189, 322, 488, 511-16, 518, 521-24, $526,528-31,533,536,571,577,587$

Endō Shigesuke [?] (遠藤重助), Lt Col, 29th Inf Rgt 1st Bn cdr, IJA, 480, 530, 599

Ezaki [Esaki?] (江崎) , [56th Rgt] Engr Co cdr, IJA, 109

Ezaki [Esaki?] Kōichi [Takakazu?] (江崎孝一), Capt, 2d Div Signal Unit cdr, IJA, 599

Fleischer, [J. A.] (フライヒュー), Col, [Magelang garrison cdr], KNIL, 543

Fujimoto (藤本), Lt Col, 38th Div (Opn L: the Sado-maru Transport cdr), IJA, 312 
Fujita Masamichi（藤田正路), Cdr, 2d Fleet gunnery staff ofcr and opns staff, IJN, 210

Fukushima Kyūsaku (福島久作), Col, 4th Inf Rgt cdr, IJA, 242, 466, 470, 474, 476-79, 482-86, 489, 490, 494-496, 501-02, 529-30, 533, 535, 599

Furukawa Hiroshi（古川浩）, Lt Col, 2d Div HQ staff, IJA, 606

Furuki Shigeyuki（古木重之), Lt Col, Staff, Dept 2 (Intel Bureau), Army Gen Staff Office/ IGHQ, IJA, 19

Furushō（古荘), Lt Col, 38th Div (Opn L: the Lima-maru Transport cdr), IJA, 312

Gamō (蒲生)，1st Lt, 2d [Paratroop] Raiding Rgt 2d Co Plt cdr, IJA, 328-29

Genda Minoru（源田實)，Cdr, 1st Air Fleet staff, IJN, 376

Hada Jūichi（波田重一), former Taiwan Mixed Bde cdr, IJA, 23

Hara Kenzaburō (原顕三郎), R Adm, 5th Destroyer Sqdn cdr, IJN, 163-64, 187, 224, 244, $428,436,453,471$

Harada Sumitaka（原田純隆）, Maj, Head, 48th Div 1st Field Hospital, IJA, 601

Harada Yoshikazu（原田義和）, Col, Staff, Army Dept of IGHQ; [Later] Maj Gen, V Ch of staff, Director of L of C Dept, 16th Army, and Director of Mil Administration Dept, 16th Army, IJA, 18, 21, 71, 73, 99, 101-03, 110, 161, $163,189,252,348,586,608$

Hart, [Thomas, C.] (ハート), Adm, C in C, US Asiatic Fleet, US Navy, 218

Hasebe Masayoshi [?]（長谷部正義)，Maj, 2d [Paratroop] Raiding Rgt Plt cdr, IJA, 324, 32930

Hashida Sei [?]（橋田精)，Maj, Staff, Dept 2 (Intel Bureau), Army Gen Staff Office/IGHQ, IJA, 19

Hashimoto Shintarō（橋本信太郎）, R Adm, 3d Destroyer Sqdn cdr, IJN, 187, 279, 313

Hatakeyama Kōichirō [?] (畠山耕一郎), R Adm, 24th Special Base Force cdr, IJN, 371
Hattori Otokazu [Otoichi?]（服部乙一), Lt Col 38th Div Medical Unit cdr, IJA, 600

Hattori Takushirō (服部卓四郎), Col, Ch of opns (Section 2), Army Dept of IGHQ, IJA, 118-19, 121, 125, 165

Hayakawa Kikuo (早川菊夫) , Maj, 228th Inf Rgt 1st Bn cdr, IJA, 370, 409, 410, 600

Hayashi Jirō (林次郎), Maj, 38th Div Sick Horse Depot cdr, IJA, 600

Hiradōri [Hiratōri?] (平通), 1st Lt, 258th Independent Motor Transport Co cdr, IJA

Hirano (平野), 1st Lt, 38th Div (Opn L: the Meigen-maru Transport cdr), IJA, 312

Hiraoka Kumeichi (平岡条一), R Adm, 9th Base Force cdr, IJN, 279, 280

Hirose Nobutaka（廣瀬信隆)，1st Lt, 2d [Paratroop] Raiding Rgt 2d Co cdr, IJA, 318, 324, 327-28

Hirose Sueto（廣瀬末人), R Adm, 2d Base Force cdr, IJN, 430

Hiroyasu Jurō [Toshirō?]（廣安壽郎)， Col, 16th Inf Rgt cdr, IJA, 476-78, 482, 485-86, 488-89, 491-95, 497, 501-02, 530, 601

Hishikari Takashi (菱刈隆), Gen, IJA, 511

Hoffmann, [Carl, Adolf, Maximilian] (ホフマン), 219

Homma Masaharu（本間雅晴），Lt Gen, 14th Army cdr, IJA, 51, 601

Hoogenband, [Cornelis van den] (オーハンバン ツ), Lt Col, Balikpapan garrison cdr, KNIL, 351

Horii Tomitarō（掘井富太郎）, Maj Gen, 55th Inf Gp cdr and Horii Det cdr, IJA, 26, 51

Hosogai Sakuzō（細貝作藏）, Maj, 2d Div Ordnance Service Unit cdr, IJA, 599

Hosokawa Koichi [Shōichi? Saitsu? Saichi?]（細 川小一), Maj, 2d Div HQ staff, IJA, 599

Hosokawa Naonori (細川直知), Maj, 38th Div staff, IJA, 283, 600

Ieki Kōnosuke [?] (家木幸之輔)，Cdr, 1st Kure Special Landing Force cdr, IJN, 370 
Iguchi [Inoguchi, Inokuchi?] Kaneo（井口兼夫）,

Lt Cdr, Liaison staff ofcr with 3d Air Force, IJN, 210

Iida Nobuo（飯田信夫), [Composer and conductor], 102

Iida Shōjirō（飯田祥二郎）, Lt Gen, 15th Army cdr, IJA, 51, 62

Ikemoto Yoshiyuki [?] (池本好行), Maj, 48th Div Signal Unit cdr, IJA, 601

Ikeno（池野), Corporal, 2d [Paratroop] Raiding Rgt, IJA, 330

Ikuta Tōichi [?] (生田藤一), Lt Col, 4th Inf Rgt 1st Bn cdr, IJA, 479, 501, 530, 599

Ilgen, [Gustav, Adolf] (イルヘン), Maj Gen, 3d Div (and eastern territorial) cdr, KNIL, 567, 571-73

Imai Kazufumi (今井一二三), Col, 1st Taiwan Inf Rgt cdr, IJA, 237-38, 549-55, 558-62, 564, 566, 601

Imamura Hitoshi (今村均), Lt Gen, Deputy Ch of Inspectorate Gen of Mil Training; [Later] 23d Army cdr, [and then] 16th Army cdr, IJA, 19, 20, 51, 69-71, 73, 76, 81-82, 90-91, 100-101, 132, 142, 161-64, 170-71, 185, 188-89, 192-93, 195, 197, 199, 210, 212, 214, 219, 235-36, 240, $242,244,246-47,251-54,265,276,292,363-64$, 412, 417, 421, 426-28, 430, 441, 453, 470-71, $475,482,485,487,503,505,512,516,528-33$, $535-36,545,547,583-84,586,608$

Imoto Kumao（井本熊男), Lt Col, Staff, Section 2 (Opns Section), Army Dept of IGHQ, IJA, 26 Inagaki (稲垣), 2d Lt, Engr, Southern Army, IJA, 298

Inagaki (稲垣) , [1st [Paratroop] Raiding Gp] Adjutant, IJA, 324

Inoue Kanji [?] (井上幹次), 1st Lt, 4th Inf Rgt 1st Co cdr, IJA, 479

Irifune Naosaburō (入船直三郎)，R Adm, 32d [Special] Base Force cdr, IJN, 110

Isayama Haruki (諌山春樹), Maj Gen, Ch of Staff, 15th Army, IJA, 31
Ishihara Itsu (石原聿), Capt, 2d Fleet staff ofcr seconded to Southern Army, IJN, 190-91, 204, 209, 212, 499

Ishii Masayoshi [Masami?] (石井正美), Col, Senior staff, Section 1 (Opns Section), Southern Army, IJA, 115, 190-91, 199, 204, 209, 210-12, 214, 220-21, 259, 292-94, 297, 301-02, 380, 385 Ishikawa Susumu (石川晋), Lt Col, Dept 2 (Intel Bureau), Army Gen Staff Office, IJA, 19

Ishimoto Itsuo (石本五雄), Col, Ch, Resource Section, Ministry of War, 17, 18

Ishimoto Tōkichi (石本統吉), [Film director, producer, and businessman], 102

Ishizaki [Ishisaki?] Masuo (石崎益雄), Col, 2d Field Arty Rgt cdr, IJA, 467, 599

Itō Kesatake [?] [Kesatsune? Kesanobu? Kesamichi?]（伊藤今朝長)， Capt, 16th Inf Rgt 9th Co cdr, IJA, 492, 494

Itō Ryōichi (伊藤遼一) , Maj, 38th Div Signal Unit cdr, IJA, 600

Itō Shinobu（伊藤忍）, Maj Gen, 1st Disembarkation Gp cdr, IJA, 152, 252, 470-71, 473

Itō Takeo (伊東武夫), Maj Gen, 38th Inf Gp cdr and Eastern Det cdr, IJA, 36, 38, 93-96, 162, 164, 187-88, 363-70, 384, 386, 404, 406-08, 410, 600

Itō Takuzō (伊藤卓藏), Maj, Head, 38th Div 2d Field Hospital, IJA, 600

Itoda Isamu (井戸田勇) , Lt Col, Inspectorate Gen of Army Avn; [Later] Ch avn staff, Section 1, 16th Army, IJA, 24, 28, 73, 94, 101, 161, 165, 252-53, 259, 265, 272, 275, 324, 339, 340, 434, $449,458,487,488,499,510-14,516,521,608$

Iwabuchi [Iwafuchi?] Tsuneo (岩淵經夫) , Lt Col, 38th Engr Rgt cdr, IJA, 270, 279, 280, 312, 335, 600

Kadomatsu Shōichi（門松正一), Lt Col, Staff, Dept 2 (Intel Bureau), Army Dept of IGHQ, IJA, 19 
Kambe [Kōbe? Kamito? Kando?] Masaji [Masatsugu? Seiji?] (神戸政次) , 1st Lt, 228th Inf Reg 2d Co cdr, IJA, 409, 410, 412

Kameoka Takao (亀岡高夫), 1st Lt, 3d Machine Gun Co cdr, IJA, 493

Kanauji [Kaneuji?] Ken'ichi（金氏堅一），Maj, 146th Inf Rgt 2d Bn cdr, IJA, 107, 175, 352, 354-55, 357, 359, 430, 537-45, 551-52, 601

Kanemura [Kanamura?] Matabē (金村亦兵衛)， Maj, 1st Taiwan Inf Rgt 3d Bn cdr, IJA, 235, 304, 373, 378, 391, 397-401, 403, 406, 430, 433$34,437,444,552$

Kanki Takekichi（神吉武吉), Col, 38th Mountain Arty Rgt cdr, IJA, 312, 334, 342-43, 600

Kanno [Sugano? Sugeno?] Zenkichi（菅野善吉）, Maj, 2d Taiwan Inf Rgt 3d Bn cdr, IJA, 79, 105, 123,601

Kanzaki Kiyoshi（神崎清), 3d Air Div staff, IJA, 522

Kapitz, [Joseph] (カーピス), Lt Col, Ambon Garrison cdr, KNIL, 369

Kashiwabara [Kashiwara? Kashihara? Kasehara?] (柏原)， Maj, 38th Div (Opn L: the Tsushimamaru Transport cdr), IJA, 312

Katano Saburō (形野三郎) , Sr Pvt, [2d Paratroop Raiding Rgt], IJA, 333

Kataoka (片岡), Capt, 146th Inf Rgt Co cdr, IJA, 393

Katō Shunji [Toshitsugu?] (加藤俊二 [rightly: 俊 次]), Maj, attached to oil-drilling unit, IJA, 284

Katō Tsukasa (加藤長), Maj, Economic Mobilization Bureau, Ministry of War, IJA, 16

Katsuyama (勝山) , [civilian], 173

Kawagoe Moriji (川越守二), Col, Ch of staff, 48th Div, IJA, 211, 222-23, 236, 249, 250, 397, 399, 600

Kawaguchi Kiyotake (川口清健), Maj Gen, 18th Div 35th Inf Bde cdr and Kawaguchi Det cdr, IJA, 5, 52, 61-63, 69, 77, 78, 106, 116-17, 12122, 124, 126, 133-34, 142-43, 156, 165, 185, 190 ,
192, 197-204, 220, 254, 284, 294-96, 298-300, 302, 306-07, 419

Kawahara Masao (川原正雄), Sgt, [2d Paratroop Raiding Rgt], IJA, 333

Kawai（河合)，1st Lt, 31st Independent Field Antiaircraft Arty Battery cdr, IJA, 603

Kawamura (川村) , 4th Inf Rgt 9th Co Plt cdr, IJA， 467

Kemmotsu Heishichi（監物平七）, Maj, 229th Inf Rgt 3d Bn cdr, IJA, 312, 338, 600

Kikuchi Kiyoji [Kiyoharu?]（菊地喜代治）Sgt Maj, Paymaster, 2d [Paratroop] Raiding Rgt, IJA, 333

Kimura (木村), [16th Div 33d Inf Reg] Kimura Det cdr, IJA, 57, 79, 90, 104, 105

Kimura Eijirō (木村栄次郎), Maj, 228th Inf Rgt 2d Bn cdr, IJA, 369-71, 600

Kimura Kenji (木村健二), Cdr, 12th Seaplane Tender Div senior staff (to be transferred and attached to 3d Fleet HQ), IJN, 210

Kinoshita Hideaki (木下秀明), Lt Col, attached to the 1st [Paratroop] Raiding Gp, IJA, 146, 258

Kishi Fukuji（岸福治)，R Adm, 9th Cruiser Div cdr, IJN, 224

Kitahara Takeo (北原武夫) , [Novelist], 102

Kitamura Kurō (北村九郎)，Lt Col, 48th Reconnaissance Rgt cdr, IJA, 238, 550-55, 558-60, 563-64, 567, 572, 601

Kitamura Yoshifuto (北村可大), Col, War College; [Later], senior staff, Section 2, 16th Army, IJA, 28, 31, 73, 164-65, 188-89, 252-53, 292, 364, 421, 608

Kobayashi Ichizō (小林一三), Japanese Minister of Commerce and Industry and special envoy to the Dutch East Indies, 3, 17, 18, 73

Kobayashi Masao (小林正夫), Maj, 1st Taiwan Inf Rgt 2d Bn cdr, IJA, 601

Koide Sadaharu（小出貞治) , Capt, 38th Div Ordnance Service Unit cdr, IJA, 312, 609 
Kōma Masayoshi（高馬正義), Cdr, 22d Air Flotilla staff, IJN, 301

Komaki [Omaki?] (小牧), 1st Lt, [2d Paratroop Raiding Rgt], IJA, 328

Kōmura Takeo（甲村武雄), Maj, 2d [Paratroop] Raiding Rgt cdr, IJA, 146, 286, 318, 324, 32729

Kondō Dempachi（近藤傳八）, Maj, Staff, Section 2, Army Dept of IGHQ, IJA, 18, 22, 31, 117

Kondō Nobutake (近藤信竹) , V Adm, C in C of the Navy in the Southern Area, cdr of Navy Southern Task Force and C in C, 2d Fleet, IJN, 56, 57, 60, 70, 76, 118, 127, 129, 195, 197, 208, $210,3346,449,450$

Kōno Takashi（河野鷹思), [Graphic designer, editorial designer], 102

Konoe Fumimaro (近衛文麿), Prime Minister of Japan, 35

Kubo Kyūji (久保九次), R Adm, 1st Base Force cdr, IJN, 226

Kuboki (久保木), Maj, Air-ground communication squad [cdr], IJA, 512

Kumagai [Kumagaya? Kumatani?] Shōji (熊谷庄 治), Lt Col, 4th Tank Rgt cdr, IJA, 561, 602

Kume Motozō [Honzō?] (久米本三), Lt Col, 146th Inf Rgt 1st Bn cdr, IJA, 352, 357-59, 391, 430, 445, 537-38, 601

Kume Seiichi (久米精一), Col, 1st [Paratroop] Raiding Gp cdr, IJA, 95, 100, 146, 258-59, 275, 285-86, 316, 324, 331-32, 337, 340

Kumon Aribumi [Arifumi?]（久門有文)，Staff， Army Dept of IGHQ, IJA, 33, 117

Kurata Fumindo (倉田文人) , [Film director, producer and scriptwriter], 102

Kuribayashi Tadamichi (栗林忠道), Maj Gen, Ch of staff, 23d Army, IJA, 189

Kurita Takeo（栗田健男), R Adm, 7th Cruiser Div cdr, IJN, 454

Kuriya Tsugunori (㕑次則), Maj, Army Gen Staff Office staff; [Later] Staff Intel, 16th Army, IJA,
$18,21,73,100,161,165,247,252,460,558,561$, $463,565,608$

Kurokawa Ichirō (黒川一郎), Capt, Head, 2 d Div 4th Field Hospital, IJA, 599

Kurokawa Sanjirō (黒川三治郎), Col, Veterinary Dept Director, 16th Army, IJA, 73

Kusaka Ryūnosuke（草鹿龍之介）, R Adm, Ch of staff, 1st Air Fleet, IJN, 376

Kusakabe (日下部), Capt, 38th Div (Opn L: the Makassar-maru Transport cdr), IJA, 312

Kuwahara [Kuwabara?] (桑 原), 1st Lt, 26th Bridge Building Material Co cdr, IJA, 605

Mabuchi Shinji（馬淵新治), Maj [?], Staff, Shipping Transport Cmd, IJA, 132

MacArthur, Douglas（マックアーサー,マッカー サー) , Lt Gen, US Army Forces in the Far East (USAFFE) cdr, 218, 579

Machida Keiji (町田敬二)，Lt Col, Head, Propaganda Gp, 16th Army, IJA, 101

Maeda Masami（前田正實), Lt Gen, Ch of staff, 14th Army, IJA, 90, 152

Makiuchi Tadao (牧内忠雄), Cdr, 2d Kure Special Landing Force cdr, IJN, 176

Manabe (真鍋), Lt Col, 48th Div Medical Unit cdr, IJA, 601

Manaki Takanobu（馬奈木敬信)，[Col] attached to Mil Affairs Bureau, Ministry of War; [Later] Maj Gen, V Ch of staff, 25th Army, IJA, 27, 31

Maruyama Masao（丸山政男)，Lt Gen, 2d Div cdr, IJA, 71, 74, 101, 242, 252, 441, 484, 489, $503,505,529,530,535,571,599$

Masuda（増田）, 2d Lt, 230th Inf Rgt 1st Bn, IJA， 508

Masui (増井), 1st Lt, 38th Patient Transport Plt cdr, IJA

Matsui Suisei (松井翠声), [Narrator and comic storyteller], 101

Matsumae Misoo (松前未曾雄), Lt Col, Staff, Section 4 (Avn Section), Southern Army, IJA, 253, 272,292 
Matsumoto Tadasu (松本治), Lt Col, 146th Inf

Rgt 3d Bn cdr, IJA, 84, 104, 106-10, 113-14, 126, 179, 349, 352, 430, 537-38, 540-45, 551, 554,601

Matsunaga Sadaichi (松永貞市), R Adm, 22d Air Flotilla cdr, IJN, 306

Matsuoka Yōsuke（松岡洋右), Foreign Minister of Japan, 20

Minami Masayoshi（南政善), [Painter], 102

Minamoto Shirō (源紫郎), Lt Col, 16th Inf Reg 1st Bn cdr, IJA, 483, 503, 599

Mitani [Mitsuya? Mitsutani?] Hirotarō? [Kōtarō?] (三谷博太郎)，1st Lt, 2d [Paratroop] Raiding Rgt 4th Co cdr, IJA, 324, 327-28

Mitsuoka (光岡), 4th Tank Rgt unit cdr, IJA, 284

Miura Toshio (三浦俊雄), Lt Col, attached to 16th Div 33d Inf Rgt, Miura Det cdr, IJA, 57, 79, 83, 90, 93, 103-04, 106-10

Miyaji [Miyachi?] (宮地), Capt, 10th Independent Antitank Gun Co cdr, IJA, 602

Miyaji [Miyachi?] Ikuzō (宮地育三), Maj, 47th Inf Rgt 3d Bn cdr, IJA, 557-62, 601

Miyashi [Miyako?] Minoru (宮子實), Lt Col, Ch of opns staff, 3d Air Force, IJA, 209

Miyazawa Shigezō [Jūzō?] (宮澤重藏)，Maj, 229th Inf Rgt 2d Bn cdr, IJA, 270, 279, 280, 312, $335,339,341,600$

Miyoshi Shunkichirō (三好俊吉郎), attached to Mil Administration Dept, 16th Army [Later] consul, 531

Miyoshi Teruhiko (三好輝彦), Capt, the Cruiser Yura captain, IJN, 280

Mook, [Hubertus, Johannes] van (ファンモーク)， 579-83

Mori Iwao (森嚴), Col, 2d Tank Rgt cdr, IJA Moriki（森木)，中尉，野戦瓦斯第18中隊（乙）長 1st Lt, 18th Field Gas Co (B) cdr, IJA

Morimoto (森本), Lt Col, Opn L: Debarkation Opn Unit, IJA, 280

Morisawa (森澤) , 1st Lt, 2d [Paratroop] Raiding Rgt 3d Co cdr, IJA, 319, 324, 331
Morozumi Yoshikazu（諸角善一), Maj, 16th Rgt 3d Bn cdr, IJA, 477-78, 485, 492-93, 497, 501, 530, 599

Mukai Kinjirō [Kanejirō?]（向井金次郎）, Maj Gen, 16th Army Intendance Dept Director, IJA, 73

Murakami Kimisuke (村上公亮)，Lt Col, Head， Southern Gp, Dept 2 [Intel Bureau], Army Gen Staff Office / IGHQ; [Later] Information Dept, Ministry of War, and then [Col,] Ch Intel staff, 16th Army, IJA, 19, 28, 31, 73, 161, $165,295,299,608$

Murase Jishichirō [?]（村瀬治七郎）, Capt, 3d Machine Gun Co cdr, IJA, 410

Mutaguchi Ren'ya（牟田口廉也），Lt Gen, 18th Div cdr, IJA, 194, 205

Mutō Akira (武藤章), Maj Gen, Ch, Mil Affairs Bureau, Ministry of War, IJA, 383

Nagahata Yoshinobu [Tadanobu? Setsutan?] (永 幡節誕)，Lt Col, Oil-drilling Gp cdr, IJA, 284， 312,342

Nagano Osami（永野修身)，Adm, Ch of Navy Gen Staff, IJN, 33, 40, 55, 127, 375-76, 381-83

Nagaoka Harukazu（長岡春一), Japanese diplomat and ambassador to Batavia, 1

Nagumo Chūichi（南雲忠一), V Adm, C in C, 1st Air Fleet and Carrier Task Force cdr, IJN, 407, 417, 425-26, 437

Naitō Takeshi (内藤雄), Cdr, Southern Expeditionary Fleet/Malaya Unit staff, IJN, 448

Nakahama Gosuke（中濱吾祐），Lt Col, 15th Independent Air Unit cdr, IJA, 331

Nakahara Makoto (中原信), Maj, 48th Div staff, IJA, 557, 567, 600

Nakahara Yoshimasa（中原義正), Capt, IJN, 17

Nakajima [Nakashima?] Haruhiko（中島（嶌）晴 彦) , Maj Gen, 16th Army Medical Dept Director, IJA, 73

Nakajō [Chūjō?] (中條), [230 Inf Rgt] adjutant, IJA, 526 
Nakao (中尾), 1st Lt, 2d [Paratroop] Raiding Rgt 1st Co cdr, IJA, 324, 329

Nakaoka (中岡), Capt, 8th Independent Antitank Gun Co cdr, IJA, 602

Nakasuji Tōichi（中筋藤一) , Lt Cdr of Engring, IJN, 17

Nakayama Yasuto（中山寧人) , Lt Col [Col from Mar 1941], Ch, Section 3, Gen Affairs Dept, Army Avn HQ, IJA; [Later] atatched to [16th] Army HQ and Head, Mil Administration Dept, 16th Army, 17, 18, 73, 102, 608

Nakayama Yoshio (中山芳男), 1st Lt, 16th Inf Rgt 10th Co cdr, IJA, 493, 501

Namekata Shōichi (行方正一), Lt Col, 56th Field Arty Rgt 1st Bn cdr, IJA, 178

Narihira（成平)，1st Lt, 38th Div (Opn L: the Kenzui-maru Transport cdr), IJA, 312

Nasu Yumio (那須弓雄), Maj Gen, $2 d$ Inf Gp cdr, IJA, 242, 466, 470, 474-75, 477-79, 482-86, 48991, 493-97, 501-02, 505, 518, 521, 529-30, 533, $535,572,578-79,582,599$

Niihara [Niibara? Shimbara? Shinhara? Niibaru? Shimbaru?] Sueto [Tokito?] (新原季人 [in the text:"新原秀人"]) ) , Maj, [Paratroop] Raiding Air Unit cdr, IJA, 146, 319

Niimura Riichi（新村理市), Col, 2d Transport Rgt cdr, IJA, 599

Nishimura Shōji（西村祥治), R Adm, 4th Destroyer Sqdn cdr, IJN, 86, 170-71, 173-74, 178, 237, 348-49, 356-58, 430

Nishiura Setsuzō (西浦節三), Maj, Staff, Section 3, Army Dept of IGHQ; [Later] Staff L of C, Section 2, 16th Army, IJA, 21, 73, 165, 188-89, $247,252,364,460,561,608$

Nishiyama Haruka (西山遼), Maj, 228th Inf Rgt 3d Bn cdr, IJA, 370, 409, 600

Nishiyama Hideo (西山秀雄), Lt Col, 2d Div Medical Unit cdr, IJA, 599

Niwa [?] (丹羽) , Sgt Maj, 2d [Paratroop] Raiding Rgt Plt, IJA, 330
Noguchi Kin'ichi（野口欽一), Lt Col, 2d Reconnaissance Rgt cdr, IJA, 96, 475, 477-78, 482, 485-86, 488, 490-94, 501, 530, 599

Numasawa [Numazawa?] Tamotsu [Yasushi?] (沼澤保) , Capt, 2d Div Water Supply and Purification Dept cdr, IJA, 600

Obata [Ohata? Kobata? Kohata?] (小畑) , [230th Inf Rgt 3d Bn] Plt cdr, IJA, 342-43

Obata [Ohata?] Hideyoshi（小畑英良）, Lt Gen, 5th Air Force cdr, IJA, 51

Ōchi Hiroshi (大智浩), [Graphic designer], 102

Oda [Orita?] Yoshishige [?]（織田義重), Col, 1st Independent Engr Rgt cdr, IJA, 467

Oda Akimitsu（於田秋光), Instructor, War College; [Later] Lt Col, Northern District Army staff and [from Nov, '41] Ch of opns staff, 16th Army, IJA, 27, 73, 101, 120, 132, 160, 162, 164 $65,185,188,210,252-53,292,421,498,505,608$

Ōe Kenji (大江賢次), [Novelist], 102

Ogawa (小川) , 2d [Paratroop] Raiding Rgt 1st Co [?] squad cdr, IJA, 329

Oka Akinosuke（岡明之助), Col, 124th Inf Rgt cdr, IJA, 198-99, 204, 294, 296, 297, 306

Oka Takazumi (岡敬純), R Adm, Ch, Naval Affairs Bureau, Navy Ministry, IJN, 383

Okada（岡田), 1st Lt, 38th Div (Opn L: the Alpenmaru [Argun-maru?] Transport cdr), IJA, 312

Okamura Masayuki (岡村誠之), Maj, staff, Section 2 (Opns Section), Army Gen Staff Office/ IGHQ, IJA, 16, 18, 21, 22, 121-22, 531

Okazaki Seizaburō (岡崎清三郎), Maj Gen, Ch of Gen Affairs Dept, Inspectorate Gen of Mil Training; [Later] Ch of staff, 16th Army, IJA, $19,27,67,69,70-71,73,142,173,185,188-89$, 210, 247, 251-52, 431, 442, 482, 484-85, 503, $505,514,529,531,533,608$

Ōki [Ōgi?] Yoshi'e (大木良枝), Col, Ch of staff, 2d Div, 599

Ōki Atsuo (大木惊夫), [Poet and translator], 102 Ōki Takashi (大城隆), 1st Lieutemant, 2d [Paratroop] Raiding Rgt 4th Co 1st Plt cdr, IJA, 328 
Ōkubo Tōru [?] (大久保亨), Maj, attached to 21st Field Ordnance Depot Oil-drilling squad, IJA, 284

Okumoto Minoru (奥本實), 1st Lt, 2d [Paratroop] Raiding Rgt 4th Co 2d Plt cdr, IJA, 32728,333

Okuzaki [Okusaki?] (奥崎 ), Lt Col, 38th Div (Opn L: the Hirokawa-maru Transport cdr), IJA, 312

Ōneda Yasuhei (大根田安平), Maj, 230th Inf Rgt 3d Bn cdr, IJA, 312, 342

Ōnishi Takijirō (大西瀧治郎) , R Adm, Ch of staff, 11th Air Fleet, IJN, 223

Ono Saseo (小野佐世男) , [Cartoonist, painter, essayist, and novelist], 102

Ōno Takeo (大野武夫), Lt Col, 2d Independent Antitank Gun Bn cdr, IJA, 247, 464, 506-08, 510, 513-15, 518

Onodera Yoshimi (小野寺義實), 1st Lt, 4th Inf Rgt 5th Co cdr, IJA, 486

Onoguchi Satoru (小野口知) , Maj, 16th Rgt 2d Bn cdr, IJA, 477, 486, 493-94, 530, 599

Orita Masaru（折田優), Capt, 229 Inf Rgt 1st Bn cdr, IJA, 270, 272, 279, 280, 312, 333-36, 338, $342-43,600$

Ōsaka Junji (大坂順次) , Lt Col, 98th Air Combat Gp cdr, IJA, 319

Ōsawa Shigeru [?] (大澤重) , 1st Lt, 230 Inf Rgt 2d Bn 7th Co cdr, IJA, 508-09

Ōta (太田) , 1st Lt, 30th Independent Field Antiaircraft Arty Battery cdr, IJA, 603

Ōya Sōichi (大宅壮一), [Journalist and Non-fiction writer], 101

Oyadomari Chōsei（親泊朝省）, Maj, Ch of opns staff, 38th Div, IJA, 162, 185, 338-39, 343

Ozawa Jisaburō (小澤治三郎), V Adm, C in C, Southern Expeditionary Fleet and Malaya Unit cdr, IJN, 58, 164, 188, 195, 214, 253, 263, 265, 276, 278, 313-14, 334, 337, 341, 399, 421, $428,436,439,450$
Pesman, [Jacob, J.] (ベスマン), Maj Gen, Bandung area garrison [army] cdr, KNIL, 528-29, 531-33, 535, 570-72, 584

Pibulsonggram, [Luang] (ピプン), Prime Minister of Thailand, 585

Poorten, [Hein] ter (テルポーテン), Lt Gen, Dutch East Indies Army cdr and Ch of the Dutch East Indies Army Dept, KNIL, 246, 529, 531-33, 535, 570-72, 584

Queen [Wilhelmina] [ウ价汁]女王)，2，531-32

Reinderhoff, [Gerard, Leonard] (レンデルボ), Capt, Tarakan garrison army staff, KNIL, 350, 354

Roosevelt, [Franklin Delano] ルーズベルト, 578

Saeki Bunrō（佐伯文郎），Lt Gen, Ch, Central Shipping Transport; [Later] Capt Gen of Shipping Transport Cmd, IJA, 133-34, 146, 149, 151

Saiki Ikuzō（斎木郁三)，Lt Col, Signal Communication Section, Army Gen Staff Office; [Later] Staff, Section 2 (Ch Signal Communication staff), 16th Army, IJA, 28, 73, 161, 165, 188, 253, 265, 272, 292, 364, 472-73, 483, 485, $487,497-503,529-30,608$

Saitō (斎藤), Interpreter, 324

Saitō Tomoo (斎藤朋雄), Southern Army staff, IJA, 264, 275

Sakaguchi Shizuo（坂口静夫), Maj Gen, 56th Mixed Inf Gp cdr and Sakaguchi Det cdr, IJA, $5,26,30,36,38,52,56,57,61,71,72,75,79,80$ $83,85,86,88,90-93,95,96,98,101,103-04$, 106-10, 115, 118, 126, 135, 137-38, 159, 162-63, $67,169,170-74,176-79,182,185,187,207,215$, 220-23, 225, 234-35, 237, 240-41, 244, 246, 304, $325,346,348-60,365,373,390-92,395,412$, 423, 426, 430-34, 439, 445, 449, 451-52, 454, $458,460,473-74,486,499,535,537-45,547$, $550-53,569,572,581,586-88,601$

Sakaguchi Yoshitarō (阪口芳太郎), V Ch of staff, Southern Army, IJA, 325 
Sakai Takashi (酒井隆), Lt Gen, 23d Army cdr, IJA, 69

Sakurai (桜井), Capt, 2d Reconnaissance Rgt [1st Co], IJA, 478

Sano Tadayoshi（佐野忠義), Lt Gen, 38th Div cdr, IJA, 75, 188, 251, 253, 268, 280, 282, 284, $337,341-43,363,600$

Sasaki Mori'e (佐々木盛衛), Maj, 4th Inf Rgt 3d Bn cdr, IJA, 480, 490, 496, 502, 529-30, 533, 599 Satō (佐藤), Lt Col, 38th Div (Opn L: the Manseimaru Transport cdr), IJA, 312

Satō Hanshichi (佐藤半七), Col, 29th Inf Rgt cdr, IJA, 243, 466, 475, 478-80, 482-84, 486, 489, 494, 496-502, 505, 518, 530, 533, 535, 579, 599

Satō Hidehiko (佐藤英彦) , Maj, Ch Intel staff, $2 \mathrm{~d}$ Div, IJA, 466, 478, 491, 491, 501, 599

Satō Hiroo (佐藤裕雄) , Southern Army staff, IJA, 198, 344

Satō Kenryō (佐藤賢了), Maj Gen, Ch of Mil Affairs Bureau [Section?] of War Ministry, IJA, 431

Satō Tadanobu（佐藤忠信 ), Maj, 2d Div Sick Horse Depot cdr, IJA, 600

Sawada Torao（澤田虎夫), R Adm, Ch of staff, 1st Southern Expeditionary Fleet/Malay Unit, IJN, 300, 301, 310, 421

Sazawa Toshiteru [Toshiki?] (佐澤利輝), Maj, 1st Taiwan Inf Rgt 1st Bn cdr, IJA, 600

Schilling, [Wijbrandus] (ヒスリング), Maj Gen, Western Java Corps 1st Div cdr, KNIL, 570

Scott [W. J. R.] (スコット) , Lt Col, cdr, AU Army (Ambon), 571

Sejima Ryūzō (瀬島龍三), Maj, Staff, Section 2, Army Dept of IGHQ, IJA, 162

Sekiya Eiji（関谷栄治), Capt, [230th Inf] Rgt Adjutant (Shōji Det), IJA, 518, 522-23

Sendō Shunzō [Toshizō?]（仙頭俊三), Lt Col, Transport Section, Economic Mobilization Bureau, Ministry of War; [Later] Ch Shipping staff, 16th Army, IJA, 19, 28, 73, 163, 214, 226, $249,252,497,608$
Shigeno Masami [Masayoshi?] (滋野正美) , 1st Lt, 16th Inf Rgt 11th Co cdr, IJA, 492

Shigeno Nobuo (重野誠雄), Maj, Staff, Section 2, Army Dept of IGHQ, IJA, 21

Shiho Kenkichi（志甫健吉), Maj, Head, Resources and Materials Gp, Section 3 (Organization and Mobilization Section), Army Gen Staff Office, IJA, 16

Shimizu (清水), Maj, 48th Div Ordnance Service Unit cdr, IJA, 601

Shimizu Hitoshi（清水齊）, [Head, Propaganda Section [?] of Propaganda Gp], 102

Shinagawa Yasuhiko (品川安彦), Capt, Head, 2d Div 2d Field Hospital, IJA, 599

Shiraishi Kazutaka (白石萬隆), R Adm, Ch of staff, 2d Fleet, IJN, 212

Shiraishi Michinori (白石通教) , Maj, [Kawaguchi Det] staff, 18th Div, IJA, 198-99, 201, 204-05, 294-95, 298

Shishido (宍戸), Motorbike unit [cdr], advance party [to land in Merak with Noguchi 2d Reconnaissance Rgt], IJA, 477-78

Shōji [Sōshi? Sōji? ] Mineo (荘子峰男), Capt, Head, 2d Div 1st Field Hospital, IJA, 599

Shōji Toshishige (東海林俊成), Col, 230th Inf Rgt cdr and Shōji Det cdr, IJA, 147-48, 189, 214, 224, 226, 231, 236, 241-45, 247, 251-52, 267-68, 304, 428-29, 434, 453, 458-63, 465-66, 468-70, 473-74, 480, 482, 484-89, 497-503, 505-07, 509 511-516, 518-26, 528-31, 533, 535-36, 547, 569, $571-72,578-79,582-84,586-88,600$

Sugawara Michiō（菅原道大)， Lt Gen, 3d Air Force cdr, IJA, 51, 256, 259, 265, 286-87, 321, $325,331,333,515,521,536$

Sugii Jirō (杉井二郎), 1st Lt, 230 Inf Rgt 4th Co cdr, IJA, 509

Sugimura Takayoshi (椙村隆良), Lt Col, 4th Air Ground Support cdr, IJA, 507, 511

Sugiyama Gen (杉山元) , Gen, Ch of Army Gen Staff, IJA, 24-26, 32, 40, 41, 52, 127-28, 133, $138,375-76,381,384,512$ 
Sultan [Ahmad Tajuddin] of Brunei（ブルネイ 王), 198

Sumihara（住原), Cap, 38th Div (Opn L: the Alaska-maru Transport cdr), IJA, 312

Suwabe Jirō (諏訪部次郎)， Maj, 2d Field Arty Rgt 1st Bn cdr, IJA, 493, 495

Suzuki（鈴木) , 1st Lt, 230 Inf Rgt Signal Unit cdr, IJA, 507

Suzuki Sōsaku（鈴木宗作), Lt Gen, Ch of staff, 25th Army, IJA, 193

Suzuki Toshimi [?]（鈴木敏美）, Maj, Head, 38th Div 1st Field Hospital, IJA, 600

Tada Takeo (多田武雄), R Adm, 21st Air Flotilla cdr, IJN, 172

Taguchi Kazuo（田口和夫), Capt, 2d Div staff, IJA, 599

Tajima Toshitsugu [Hisatsugu?]（田嶋壽嗣）, Capt, cdr, Gp for collecting cast-off articles, IJA, 175

Takagi Takeo（高木武雄), R Adm, 5th Cruiser Div cdr, IJN, 105-06, 108, 207, 361, 367

Takagi Takeo（高木猛雄), Maj, 44th Field Antiaircraft Arty Bn (B) cdr, IJA, 92, 350, 431, 433, $445,450,537,603$

Takahashi Chihaya（高橋千隼）, Capt, Senior staff, 11th Air Fleet, IJN, 208, 210, 212

Takahashi Ibō (高橋伊望), V Adm, C in C, 3d Fleet and the Philippines ([and later] the Dutch East Indies) Unit cdr, IJN, 57, 81, 82, 92, 105-06, 127, 158, 163, 169, 170-72, 206-07, 346, $349,364,399,450$

Takahashi Mitsuzō [Manzō? Michizō?]（高橋満 藏), Maj, War Preparation Section, Ministry of War; [Later] Staff, L of C, Section 2, 16th Army, IJA, 28, 73, 189, 608

Takahashi Takuzō (高橋卓三) , Col, 2d Engr Rgt cdr, IJA, 500, 599

Takase (高瀬), Capt, [2d Reconnaissance Rgt 2d Co cdr?], IJA, 477

Takashima Tatsuhiko (高嶋辰彦), Col, Senior staff, Section 1, 16th Army, IJA, 73, 100, 110,
164-65, 188-89, 210, 252-53, 292, 301-02, 364, $385,421,474,483,531,608$

Takayama Shinobu (高山信武), Staff, Army Dept of IGHQ, IJA, 267

Takeda Rintarō（武田麟太郎）, [Novelist], 102 Takeda Takeo（武田丈夫)，Maj, 1st [Paratroop Raiding] Rgt cdr, IJA, 146

Takeda-no-miya Tsuneyoshiō, [Prince]（竹田宮 恒徳王), Maj, Staff, Army Gen Staff Office, IJA, 22, 23, 33

Takeuchi（竹内), 229 Inf Rgt 1st Bn 1st Co cdr, IJA, 335

Takeuchi (竹内), Capt, Head, 8th Water Supply and Purification Dept, IJA, 608

Takizawa Shichijūrō [Nanajūrō?]（瀧澤七十郎）, Maj, 2d Taiwan Inf Rgt 2d Bn cdr, IJA

Takumi Hiroshi（佗美浩), Maj Gen, Takumi Det (18D) cdr, IJA, 78, 115, 118, 120, 126, 142, 156, 165,192

Tamada (玉田), Maj, 45th Field Antiaircraft Arty Bn (B) cdr, IJA, 603

Tamura Masao（田村昌雄), Maj, 4th Inf Rgt 2d Bn cdr, IJA, 599

Tanabe Masaki（田邊正樹), Maj, 48th Div HQ staff, IJA, 250, 600

Tanabe Moritake（田辺盛武)，Lt Gen, V Ch of Army Gen Staff, IJA, 133

Tanabe Suketomo（田辺助友）, Maj Gen, 2d Debarkation Gp cdr, IJA, 150

Tanaka Raizō（田中頼三), R Adm, 2d Destroyer Sqdn cdr, IJN, 84, 105-06, 108, 110, 113, 171, 366, 370-71

Tanaka Ryōsaburō [Ryōzaburō?]（田中良三郎）, Col, 229th Inf Rgt cdr, IJA, 270, 279, 280, 312, $316,318,332$, 334-39, 341-43, 426, 437, 447-49, 512,600

Tanaka Shin'ichi（田中新一), Lt Gen, Ch, Opns Bureau (1st Bureau), Army Dept of IGHQ, IJA, 100, 423, 427 
Tanaka Tōru（田中透）, Col, 2d Taiwan Inf Rgt cdr, IJA, [79, 105, 120, 123???] 238, 550-53, 555, 558-62, 564-65, 601

Tanikawa [Tanigawa?] Kazuo (谷川一男), Col, Senior staff, Section 4 (Avn staff), Southern Army, IJA, 190-91, 204, 209, 210, 218-19, 30103, 305

Tarōra Sadao（太郎良定夫), Capt, Ch of Special Broadcasting Detail, Section 2, Southern Army HQ, IJA, 574, 581

Tasaka [Tazaka?] Satoshi（田坂敏), Lt Col, 48th Transport Rgt cdr, IJA, 601

Terasaki Takaji (寺崎隆治)，1st Southern Expeditionary Fleet staff, IJN, 298

Terauchi Hisaichi (寺内 壽一), Gen, C in C, Southern Army, IJA, 51, 56, 57, 60, 62, 69, 70, 76, 127, 129, 142, 152, 155, 164, 188, 205, 219, $269,272,296,298,321,332,449,574$

Tjarda van Starkenborgh Stachouwer, [Jonkheer Alidius, Warmoldus, Lambertus] (スタルケ ンボルグ,チャルダー), Governor-Gen, Dutch East Indies, 529, 531, 584

Tōgō Shigenori（東郷茂徳）, Foreign Minister of Japan, 381

Tōjō Hideki (東條英機, 東条英機), War Minister and Prime Minister of Japan, 33, 35, 36, 69, 381-82

Tokunaga (徳永), 1st Lt, 2d [Paratroop] Raiding Rgt 1st Co Plt cdr, IJA, 329

Tomari Mitsuyoshi（泊満義), Capt, Senior staff, 1st Southern Expeditionary Fleet / Malaya Unit, IJN, 209, 210, 212, 294, 297, 300, 301, 310, 421

Tomizawa Uio（富沢有為男), [Author and painter], 102

Tomura [Komura?] (戸村), 1st Lt, 259th Independent Motor Transport Co cdr, IJA, 606

Tosaka [Tozaka, Noborizaka, Noborisaka, Tōban, Tōsaka?] Susumu (登坂進), Maj, 38th Div staff, IJA, 162, 364, 600
Tsuchihashi [Tsuchibashi?] Yūitsu [Yūichi?]（土 橋勇逸)，Lt Gen, 48th Div cdr, IJA, 75, 236-37， 250, 430, 549, 551, 554-55, 557-62, 564-65, 600

Tsukada Osamu（塚田攻）, Lt Gen, V Ch, Army Gen Staff; [Later] Ch of staff, Southern Army, IJA, 24, 26, 164, 217

Tsukahara Nishizō（塚原二四三）, V Adm, C in C, 11th Air Fleet, IJN, 57, 58, 106, 170, 172, 183, 223, 348, 398-99, 440

Tsumura Mikizō [Kanzō?] (津村幹三) , Col, Legal Dept Director, 16th Army, IJA, 73

Tsunoda [Kadota? Kakuta? Sumida? Sumita?] Isamu [Isao? Isami?]（角田勇), Maj, 33d Inf Rgt 1st Bn cdr, IJA, 107, 110

Tsushima Shūsuke（對馬周助), Senior Pvt, [2d Paratroop Raiding Rgt], IJA, 333

Ueda（上田)，大尉 (通信) Capt, Signal communications [2d Paratroop Raiding Rgt?], IJA, 324

Ueno Shigeru (上野滋), Col [Lt Col], Shipping Transport Cmd staff, IJA, 132, 214

Ugaki Matome（宇垣緾）, R Adm, Ch of staff, Combined Fleet, IJN, 157

Waal, S. de, Lt Col, Tarakan garrison cdr, 177

Wada Toshimichi（和田敏道), 1st Lt 230th Inf Rgt Inf Arty Unit cdr, IJA, 464, 507, 509

Wakabayashi Tōichi (若林東一), 1st Lt, 228th Inf Rgt 10th Co cdr, IJA, 366, 369, 369-71

Wakamatsu Minoru [Mitsunori?]（若松満則）, Maj, 230th Inf Rgt 2d Bn cdr, IJA, 463-65, 488, 506-09, 511-15, 518, 521-27, 572, 578, 600

Wakatsuki Ryōzō [Ryūzō?]（若槻龍三) , Cdr, 3d Fleet staff ofcr seconded to 16th Army, IJN, 253, 292, 300, 421, 474, 499

Watanabe [Watabe?] (渡邊), Maj, 40th Anchorage $\mathrm{HQ}$, IJA, 464, 507

Watanabe [Watabe?] (渡邊) , Maj, Head, 48th Div 4th Field Hospital, IJA, 601

Watanabe [Watabe?] Kōichi [Hirokazu?] (渡部 弘一) , 1st Lt, 2d Field Arty Rgt 3d Battery cdr, IJA, 477, 490, 493 
Watanabe [Watabe?] Katsutoshi [?] (渡邊勝利), Lt Col, 29th Inf Rgt 2d Bn cdr, IJA, 479, 49496, 501, 530, 599

Watanabe [Watabe?] Tarō (渡邊太郎), Southern Army staff, IJA, 298-300

Wavell, [Archibald, P.]（ウェーベル）, Gen, Supreme cdr, ABDACOM, 437, 531, 570, 578, $580,582,585$

Yabuta Hidekazu [Shūichi?]（薮田秀一)，Lt Col， 38th Transport Rgt cdr, IJA, 312, 600

Yamada（山田）, Capt, [Hiroyasu Echelon], IJA, 493

Yamada（山田), [Cdr?] Yamada [Air] Unit cdr, IJN, 306, 309, 310

Yamada Hisamatsu（山田久松）, Maj Gen, Ordnance Dept Director, 16th Army, IJA, 73, 484

Yamaguchi Kayoshi (山口嘉良), Lt Col, 48th Mountain Arty Rgt cdr, IJA, 561, 601

Yamaki Akira (矢牧章), Capt, Senior staff, $3 \mathrm{~d}$ Fleet, IJN, 171, 208, 210, 212, 380-81, 385

Yamamoto (山本), Cdr, Navy Dept of IGHQ, IJN, 121

Yamamoto (山本), Adjutant, 38th Div, IJA, 338

Yamamoto Isoroku（山本五十六), Adm, C in C, Combined Fleet, IJN, 55-57, 60, 70, 76

Yamamoto Kenji (山本健兒), Maj Gen, 7th Air Div cdr, IJA, 286

Yamamoto Kyōhei (山本恭平) , Col, 146th Inf Rgt cdr, IJA, 175, 178, 350, 352, 357-58, 373, 392 93, 431, 445, 451-52, 537-38, 540-45, 551, 554, 601

Yamashita (山下), Pvt 1st Class, IJA, 330

Yamashita Tomoyuki（山下奉文)，Lt Gen, 25th Army cdr, IJA, 51, 62, 528

Yamashita Yutaka (山下豊), Maj, Appointments and Assignment Section, [Personnel Bureau], Ministry of War; [Later] Assistant opns staff, Section 1, 16th Army, IJA, 28, 73, 100, 189, 247, $252,460,499,506-07,509,516,518,522,524$ $26,528,530,608$
Yanagawa Motoshige（柳川宗成，Capt, attached to 16th Army HQ, IJA, 505

Yanagi Hiroshi (築木宏), Maj, 2d Taiwan Inf Rgt 1st [OOB]/ 2d Bn cdr, IJA, 558, 601

Yanagi Isamu (柳勇)， Col, 47th Inf Rgt cdr, IJA, 552-53, 557, 559-62, 564-66, 601

Yanagi Toshio（柳敏雄），Lt Col, 48th Engr Rgt cdr, IJA, 601

Yanagisawa Kuranosuke（柳澤藏之助）, Capt, Senior staff, 2d Fleet, IJN, 210-12, 220

Yano Tsuneo (矢野常雄), Lt Col, Staff, 56th Inf Gp and Sakaguchi Det, IJA, 81, 91, 106, 173, 179 , 207, 240, 248, 349, 350, 460, 535, 542-43, $545,581,601$

Yokoyama Ryūichi（横山隆一), [Cartoonist and animation creator], 102

Yoshii Tadao (吉井忠雄), Maj, 29th Inf Rgt 3d Bn cdr, IJA, 479, 482, 486, 599

Yoshikawa Shūkichi（由川周吉), Cdr, Senior staff, 5th Destroyer Sqdn, IJN, 210

Yoshimoto Teiichi (吉本貞一), Lt Gen, Former 2d Div cdr, IJA, 20

Yoshimura（吉村 ), Col, [Shipping Transport Cmd] Ujina, IJA, 150

Yoshinaga (吉永) , Sgt Maj, 2d [Paratroop] Raiding Rgt 2d Co Plt, IJA, 329

Yoshioka（吉岡），2d [Paratroop] Raiding Rgt [1st Co?] squad cdr, IJA, 329

Yoshizawa Kenkichi（芳澤謙吉), Ambassador, and special envoy, 3, 18, 20, 21, 71, 73 


\section{Index of Place Names}

See also Editor's Note. The katakana spellings given here are not official spellings, but the spellings as they are found in the original Japanese text.

Abab, [Talang] Abab (アバブ), 271, 282, 338

Aceh (アチェー, アチエ), 112, 47

Adang Bay (アダン湾), 393

Adat Reef (アダットリーフ), 175, 176

Ajibarang (アジバラン), 545

Akeno (明野), 161

Aleutians, Aleutian Islands (アリューシャン,ア リューシャン列島), 50, 59

Alor Setar (アロルスター), 115, 145, 254

Alor Strait (アロール水道), 408

Amal, Shore, River (アマル, 海岸, 河), 17577,179

Amami Ōshima (奄美大島), 61, 79, 124

Ambarawa (アンバラワ), 543

Ambon, Ｉsland, Bay (アンボン, 島, ＼cjkstart湾), 4, 5, $11,13,28,29,30,32,33,36,46,59,61,62,66$, $79,80,82,93,94,95,96,98,100,121-23,125$, $128,130,132,134-35,142,155,156,159,160$, $162,165,170-72,187,206-08,212,215,218$, $223,225,234-35,241,252,254,304,346,361-$ 63, 365-74, 377-78, 380, 385-86, 388-89, 39091, 394-96, 398-400, 403-08, 418, 420-21, 425-26, 430, 440

Anambas, base, Anambas Islands (アナンバス ～基地), 186, 204, 214, 235, 243，255，263-64， 272, 295, 296-97, 309, 313-14, 322, 386, 419, 439-41, 450, 453, 480, 508, 510, 515

Andamans, Andaman Islands (アンダマン，〜諸 島, 群島， 列島)，59，259，285，434-35

Anyer-Lor (アニエールロール), 96, 99 Aoyama (青山), 71, 73 Aparri (アパリ), 30, 31, 45, 58, 60, 92, 105, 120, 123, 131,551
Apo [Reef] Channel (アポ水道), 239

Aru Bank, waterway of (アルバンク水道), 445

Atlantic Ocean (大西洋), 577

Australia (豪州, 濠州, オーストラリア) , 4, 7, 13, $26,41,42,59,66,80,122,125,127,158,160$, 186, 191, 218, 233, 248, 257, 274, 358, 373-75, $381-82,407,424-25,435,460,577-78,580$, $582-$ 85

Austria (オーストリア), 1

Awuran, Cape (アウラン), 475

Ayer Tawar (アエルタワル), 145, 285

Bab Gadog (バブガト), 501

Babakappa [?] (ババカッパ), 203

Babang, [Jagui]babang (パパン), 200, 201

Babad (ババト), 548, 554, 558-60, 563, 571-72

Babau (バパウ), 408, 409

Badung Strait ([バダン] 海峡), 402

Baguala Bay (バゴアラ湾), 366

Baichengzi (白城子), 23, 32

Bakri (バクリ), 255

Balaraja (パララジャ,バララジャ), 486, 496, 497

Bali, Bali Island (バリー,バリー島), 10, 79-83, 88， $93,95,103,117,135,159-60,209-16,218$, $222-$ 26, 233-36, 238, 252, 304, 346, 373-74, 378-80, 386, 388-91, 394, 397401, 403, 405-06, 417-18, 420-21, 423-26, 428, 430, 433-37, 439-40, 442$44,446,449-52,455-56,458-59,537,549,552$, 554,570

Balikpapan (バリクパパン,バリックパパン), 4, 5, 11, 30, 33, 46, 59, 61, 66, 69, 79-83, 87-88, 91, $93,95,100,103,123,135,155,159,162,170$, $172,175-76,187,206-07,209-15,220-23,225$, 234, 236-37, 240-41, 246, 275, 304, 346, 348-56, 
358-62, 365, 368, 371, 373, 375, 377, 380, 386, 388-97, 400-01, 403, 405-06, 418, 421, 426-27, 429-33, 439-40, 442-43, 445, 449, 451, 455, 535, 537-38

Ban Don (バンドン [Thailand]), 45 Bancar (ポンジョル), 238, 550, 552

Banda Sea (バンダ海), 158-59, 387, 403, 422

Bandung (バンドン), 16, 24, 47, 94-96, 98, 155, 167, 205, 245-47, 424, 434, 437, 442-43, 448-50, 460-66, 475, 487-89, 494-95, 497-99, 502-03, 505, 507, 509, 511-13, 515-16, 518, 521-26, 528$36,538-39,544-45,567,570-80,582-87$

Bangka, anchorage (バンカ, 〜泊地 [N of Menado]), 160, 182, 361, 365, 368, 380, 391, 394-96, 399

Bangka ( Island) (バンカ, 〜島 [near Sumatra]), $12,33,47,62,94-95,117,119,122,127-28,134$, 136, 142-44, 155, 162, 163, 171, 186, 189, 190, 193, 195-96, 201, 204-05, 211-13, 215, 219, 236, $241,251-54,256,259,260,265,271,274,276$, 278-79, 282-83, 311, 333-35, 337, 342-43, 363, 388, 406, 408, 418, 421, 425-27, 446, 570

Bangkok (バンコック，バンコク，磐谷)，47，137， 185-87, 196, 225

Banjar (パンジャル), 544

Banjarmasin (バンジェルマシン), 4, 5, 30, 33, 46, $59,61,66,69,79,80-83,88,91,93-95,103,135$, $159,162,170,187,190,208-11,213-22,224-25$, 233-35, 240-41, 244, 252, 304, 349, 351, 359, $363,373-75,378,386-89$, 391-93, 395-97, 406, 418, 420-21, 423, 429-33, 445, 449, 451-52, 456, 535, 537-38

Banjarnegara (バンジャルナガラ), 543-44

Bantam, Bay, ranchorage [Banten] (バンタム, パンタム, 湾, 〜泊地), 226, 231, 242-44, 434, 456-57, 461, 466-68, 470-72, 474, 479-80, 482, 496-97, 508, 510, 515, 580

Bantarkaret (ベニアカレツ), 490

Banyumas (バンユマス), 586

Bara (バラ), 126, 197

Baru (バルー), 88, 348
Basra (バスラ), 257

Bataan Peninsula (バタン半島,バタアン半島), 128-29, 152-53, 223, 429-30, 551, 609

Batan Island (バタン島), 45, 58, 79, 93

Batavia (Jakarta) (バタビア, バタビヤ), 1, 3, 4, 10, $11,13,18,21,24,47,94-96,98-99,136,155$, $159,160,162-63,187-88,205,226,230-31,244$ $47,257,267,311,379,423,427,434-35,437$, 442-43, 449-54, 457, 460-70, 475, 479, 487-89, 494-97, 499-503, 505-07, 518-19, 526, 529-36, 538-39, 544, 569-72, 574, 579-80, 582-83, 58586

Batu Ampar (パトアンバル) 359

Batu, Cape (バツー岬), 85, 87, 159, 175-76, 178

Batu Dua (パットドア), 85, 176

Batu Pahat (バトパハ), 145, 255, 260, 262, 266, 323, 325

Bau (バム), 199

Baun (バウン), 409

Bawean Island (バウエアン島), 442

Bedeng Cisalak (ペテンチサラク), 482, 485

Belgium (ベルギー) 583

Belitung, Belitung Island (ビリトン,ビリトン島), 12,570

Bendo, Cape (ペント岬), 238-39

Bengkayang (ペンカヤン), 126, 143, 197-200, 203, 298-99, 307

Bengkulu (ベンクレン), 12, 334, 341-43

Benini, Cape (ベニニ岬), 409

Bintan Island (ビンタン島), 12

Bismarck Archipelago (ビスマルク島, ビスマル ク諸島), 32, 44-46, 50, 129

Blimbing (ブリンピン), 459

Blora (プロラ), 537-38, 540-41, 545, 551-55

Bojonegara (ポジョネゴロ [Bantam Bay]), 245， $465,480,483,485$

Bojonegoro (ポジョネゴロ[between Babad and Cepu]), 238, 548-55, 559, 571-72

Bojongneros (ボジョネロス), 492

Boncong (ポンジュール), 550

Borang Island (ブルン島), 341, 345 
Borneo [Kalimantan] (ボルネオ), 9,10, 11, 12, 28， $30,33,36,44,54,55,64,117-18,125-26,134$ 35, 141, 143-44, 146, 165, 170, 190, 192, 197, 200-03, 220, 222, 230, 246, 261, 276, 278-79, $284,299,305,373-74,417,432,454,538$

Boyolali (ボョラリ,ポヨラリ), 541-42

Brantas River (ブランタス河), 548-49, 551, 554$55,557-59,563$

Britain (英国), 1, 2, 3，7，16-21，24，40，42，44，49，50， $55,64,70,105,168-69,192,233,358,373,377$, $382,386,437,460,570,575,577,579-85$

British Borneo (英領ボルネオ) , 4, 5, 6, 9, 11, 25, $32,33,44,46,49,52,54,58,60,63-66,77,78$, $106,118,123,124,155,165,186,201,298-99$, 588

British Malaya (英領(の)マレー, 英領馬来)，4，42， $44-47,49,56,58,64-66$

Brunei (ブルネイ), 198

Bugel [Godong] (ブゲル), 540, 544

Buitenzorg [Bogor] (ボイテンゾルグ), 96, 98, 99, 167, 230, 245, 434, 442, 448-49, 460-61, 465-66, $469,475-76,483,488-89,494-97$, 501-02, 50507, 518-19, 526, 529-30, 533, 570, 572, 579, 582

Bukateja (プカラジャ), 544

Bula (ブル), 11, 12

Bulujowo (ブルージャク), 238, 550

Bunar (ブナール), 482, 485

Bungo Channel (豊後水道), 208, 365, 368

Buntu, [Kampong Sungai] Buntu (ブンツ), 195

Burma (ビルマ，緬甸)，5，25，26，31，32，40-42，44， $45,47,50,52,54,56,64-66,69,118-19,128-29$, $135,137,143-45,152,165,185,191,218,256$, $259,275,285,376,419,431,434-35,446,570$, $577,580,582,585-86$

Cabanatuan (カバナツアン), 152

Cam Ranh, Bay (カムラン, 湾), 36-38, 52, 78, 80-82, 93, 100, 118-20, 122, 124, 127, 129, 133, $168,137,140,142,146-47,150,154,156-57$, 160-61, 164-65, 172, 185-89, 192-97, 204, 205, $208,209,211,213,214,223,227,235,236,241-$ $45,247,248,251-55,259,262-65,267,269,270$,
272, 278-80, 282-84, 287, 292-94, 297, 299, 300, 304-06, 309-10, 312-15, 321-22, 325, 346, 365, $379,380,388,397,417,420,421,423,426,428-$ $31,433,435-37,440-41,531,569$

Cap Saint Jacques (サンジャック), 120, 126, 156, 214, 272, 299, 300, 310, 439, 442, 452-53

Carita (チャリタ), 96, 99

Caruban (チャルバン, チャルパン), 557-59, 562

Celebes [Sulawesi] (セレベス), 4, 6, 9, 10-12, 30$32,44,49,66,94,144,146,158-59,164,170$, 184, 206, 214, 218, 222, 234-35, 246, 274, 374, $380,405,417,437$

Cepu (チェプー), 11, 12, 99, 236, 238, 460, 548-49, 550-55, 557-58, 571-72

Ceram (セラム島), 11, 12

Cerme (チェルメ), 567

Cheju Island (済州島), 161

China (中国，支那，支，中)，1，3，19，24，26，31，42， $48-50,60,61,72,75,129,136-37,156,161$, 249, 250

Chongqing (重慶), 218, 424

Ciampea (チャムペア, タンペラア), 494, 501

Cianjur (チャンジュール), 463, 465

Cianten River (チャンテン河, チアンテン河), 490-92, 494

Ciaruten (チアルト), 493

Ciater (チャテル), 499, 518, 522-23, 526, 572, 579

Cibadak (チバタク), 530

Cibarusa (チバルサ), 533, 535

Cibatok (チバトク), 490, 492-94, 497

Cibogo (チボフ), 528

Cibungbulang (チュムバン), 490

Cicenang (チチェナン), 525-26

Cidurian River (チドリアン河), 480, 483, 486

Cikampek (チカンベック,チカベック), 96, 462, 464, 514-15, 518, 572

Cikramas (チクラマス), 463

Cilacap (チラチャップ), 11, 12, 94, 98-99, 167, 231, 237, 246-47, 340, 432, 434-35, 437, 456, 459, 460-61, 467, 480, 487, 535, 537-39, 542-45, $547-51,571,581,588$ 
Cilamaya (チラマヤ), 96, 99, 464

Cilegon (チレゴン), 466, 475-77, 479

Cililitan (チリリタン), 230, 450, 468

Cilubang (チルバン), 501

Cimahi (チマヒ), 533, 535, 570

Cipayung (チバヤン), 530

Cipeteng (チャペテン), 482

Ciranjang (チランヂャン), 530

Cirebon (チェリボン), 94, 98, 99, 513, 516, 548, 571

Ciruas (チルアス), 480, 482

Cisadane, Cisandane River (チサダネ,チサダネ 河), 494, 501

Citarum River (チタルム河), 245, 247, 461-63, $465,500,506-07,514,516,578$

Ciujung River (チジュン河), 245, 466, 474-80, 483， 486

Comoro River (コロモ河), 413

Corregidor (コレヒドール), 218, 429, 551

Cotabato (コタバト), 104

Czechoslovakia (チェコスロバキア), 1

Dagu [Ta-ku] (太沽), 250

Daingapic Point (ダインガピック岬), 113

Dalian (大連), 133, 250, 569

Daliao (ダリアオ,ダリヤオ), 109, 171, 174-76

Damortis (ダモルテス), 430

Dan'jo Archipelago (男女列島), 248

Datu, Cape (ダツウ岬), 203, 204

Davao (ダバオ), 4-6, 27, 29-33, 35, 45, 52, 54, 56, $58,66,67,69,71,78-85,88,90,91,93,95,101$, 103-10, 113-16, 118-19, 123-24, 126, 134-35, $137,141,146-47,157-60,162-63,165,170-76$, 182-83, 185, 187, 189, 206-08, 223, 225, 234 236, 241, 346, 348, 351, 360-61, 363-68, 388-91, 394-99, 401, 405, 407, 418, 420, 430, 433, 440, 455,535

Deanpungu [Jambudipa ?] (デアンプング, ジャ ンプング), 494

Denmark (デンマーク), 2

Denpasar (デンパッサル), 399, 400, 401, 403

Dili (デリー), 11, 373, 379-81, 384-86, 390, 403-09, $412-13,423,450,488$
Dobare [Tebarau?] (ドバレ), 202

Dramaga (ドラマガ), 494, 497, 501

Dunkirk (ダンケルク), 2, 16

Dutch Borneo (蘭領ボルネオ), 4, 11, 31，32, 38, 44, 49, 64, 65, 143, 175, 198, 200, 202, 204, 299, 307, $353,431,545$

Dutch East Indies (蘭印, オランダ領東インド諸 島, 蘭領印度), 1-7, 10-14, 16-19, 21-32, 35, 40$46,49,52,54,56,58-61,63,65,66,70,77,80$, $93,101,105,117,120,123,124,127,128,135$, $137,158,159,168,169,174,177,184,186,169$, 174, 177, 184, 186, 189, 190-92, 197, 206, 218, $246,248,257,273,274,282,333,350,365,373$, $420,423,435,436,461,529,531,532,534,536-$ $37,576,578-85,587,589$

Dutch Timor (蘭領チモール), 11, 44, 380-81, 38385,404

East Indies (東印度), 361

Eastern China (中支), 19, 22, 70, 137, 185

Egypt (エジプト), 218, 257

Endau (エンダウ), 118, 120, 137, 141-42, 150, 156$57,166,192-93,195-97,204,252,255,259,262-$ 64, 292, 295-97, 302, 362, 386, 419

English Channel (英仏海峡), 2

Eretan (エレタン), 434, 461，463-64，480, 506-07, 509-511, 513-16, 536, 571

Fiji (フィジー), 59

France (フランス, 仏国), 1, 2, 575

French Indochina (仏印，仏領インドシナ), 3-5, 17-22, 24, 25, 31, 32, 40, 42, 44, 48, 50, 52, 56, $82,118,124,137-38,154,156-57,165,252-53$, 258, 285, 298-99, 300, 306, 310, 322, 426, 448, $488,575,581,582$

Fuji (富士), 71, 101，224， 247

Fukuyama (福山), 26

Fuzhou (福州), 22, 23, 36

Galuga (カヴウガ), 493-94

Galuga [?], Mt. (ガボング山), 490-91, 493

Gaoxiong [Takao] (高雄), 58, 72, 79, 133, 136-37, $147-48,150,152$, 154, 157, 160-65, 170-72, 187$90,193,195,197,210,220,224-25,234-36,240-$ 
42, 247-52, 292, 304, 348, 377, 421, 428-29, 431, $440,466,551,569$

Gardubatok (ガルトヘトク,ガドルベク), 482

Gaspar Strait (ガスパル海峡), 314, 426-27, 435

Gelumbang (ゲルンバン), 343-44, 443-44, 446, 448-52, 454

Gemas (ゲマス), 115, 193, 196, 255, 264

Gempol (ゲムボル, ゲンポル), 572

Germany (ドイツ,独), 1-3, 13, 16, 20, 382, 383, 580

Gombong (ゴムボン), 543

Gongchangling (弓張嶺), 20, 24, 491

Gotemba (御殿場), 247

Gotō Islands (五島列島), 248

Gresik [Grissee] (グリッセ), 94, 548, 563, 566-67

Grogol (グロゴール), 477

Guadalcanal (ガダルカナル), 369

Guam, Guam Island (グァム, 瓦無，島), 1, 25, 26, 28-32, 36, 40, 44-46, 50, 52, 55, 58, 61, 72, 76, $80,95,116,121,139$

Guangdong [Canton] (広東), 18, 48, 69, 70, 78, $126,137,150,156,162,165,170,188,258,268$, 285,363

Gunung Cangkol (ゴンチャンコール,ブーンチ ヤンコル), 176, 177

Gunung Jatake (ガンノアンジャタッケ), 494

Hainan Island (海南島)， 3, 18, 21，23，52，188，25253,285

Haiphong (海防, ハイフオン), 132, 137, 258

Halong, Sea[plane] Base (ハロン, ハロング, 水 上基地), 366, 369, 370-71

Hashirajima (柱島), 121, 303

Hawaii, Hawaiian Islands (ハワイ，布哇，群，島 ), 4-7, 24, 25, 27-29, 32, 33, 50, 55, 56, 58, 105, $121,123,172,305,362,373,587$

Hiroshima (広島), 247-48

Hitokappu Bay (単冠湾), 56

Hitu-lama, anchorage (ヒトラマ, 泊地), 366, $368-69,385$

Holland, Netherlands (オランダ, 蘭), 1-3, 13, 16$21,24,40,42,49,50,55,64,70,105,168-69$, $358,386,574,583$
Hong Kong, Hong Kong Island (香港, 香港島), 1, $5,7,16,22,23,25,30-32,35-38,40,42-46,52$, $54,61,62,72,75,77,79,82,93,95,100,116$, $117,119,121,128,133,135-38,146-47,150$, 152, 162, 164-66, 185-90, 193, 195, 201, 208, $223,241,251-52,254,267-68,362-65,369,430$ Honolulu (ホノルル), 2, 580 Humen (虎門), 120, 142, 185 India (インド, 印度), 7, 26, 28, 41，42，185，218，407， $424,435,570,578,580,582$

Indian Ocean (印度洋，インド洋)，28，50，66，77， 98, 115, 120, 125, 192, 224, 226, 373, 377, 381, $407,422,424,444,456,583$

Indochina (印度支那), 44, 46-48, 51，64， 65 Indramayu, bay of (インドラマユ， 湾), 578 Inuyama (犬山), 101 Ipoh (イポー), 144-45, 185, 254, 266 Iraq (イラク), 257

Ishinomaki (coast of ) (石巻海岸), 247 Isola Hotel (イゾラホテル), 528-31, 584 Italy (イタリア, 伊), 2, 3, 20, 257, 382-83 Iwakuni (岩國), 57, 67, 70, 76, 77, 79, 81，90-93，95， $96,103,110,123,135,214,397$ Jabung, Cape (ジャブン岬), 256 Jakarta (ジャカルタ) 1, 3, 4, 10, 13, 18, 21 Jalancagak (ジャランチガル), 513, 522 Jambi (ジャンビー), 256, 258, 268, 285, 316, 318， 327, 334, 342-44

Jang, Cape (ジャン角), 314

Janpungu [Jambudipa ?] (ジャンプングーデアン プング), 494

Jasinga (ジャシンガ), 478, 482, 496

Jatisari (ジャチサリ), 511，513-14, 521

Java (ジャワ，爪哇， 島)，3-13，16-18，20-33，36， $38,44,47,49,50,54,59,62,64-66,70,71,73-$ 76, 79-83, 93-96, 98-101, 115-22, 124-25, 12728, 132-47, 149, 154-55, 158-159 162, 164-67, 171, 186-87, 189-91, 193, 195-98, 201, 203, 205, 208-11, 213-25, 227, 230, 233-38, 240-41, 24446, 248, 250, 252, 254, 256-57, 259-63, 266-67, $269,274-76,278-79,304-05,307,311,334,338$, 
340, 344-46, 356, 373-80, 386-92, 394-95, 39799, 403, 406-07, 412, 417-37, 439-47, 449-63, $465,467,469,472,480,487,500,519-21,534$ $39,545,547-49,551-52,565,567-72,574-87$, 588

Java Sea (ジャワ海), 29, 125, 158, 234, 244, 356, 391, 421, 441, 443-44, 450-51, 453-54

Jember (ジャンベル), 572

Jesselton [Kota Kinabalu] (ジェツセルトン, ジェ ッセルトン), 198, 201

Jitra, line (ジットラ, ライン), 115, 235

Johor, S Strait (ジョホール， 水道), 144, 193，255，

263-64, 269, 305, 308, 373, 377, 419

Johor Bahru (ジョホールバール, ジョホールバル), $116,139,255,311$

Jolo (ホロ，島)， 4, 5, 27, 32, 36, 45, 54, 58, 61-63， $66,69,79,81-84,88,90,93,95,103-04,106$, 108-10, 113-14, 118, 123-24, 126-27, 134-35, $137,146,157-58,163,170-72,174-76,179,181$, 208, 227, 236-40, 348-49, 351-52, 358, 377, 380, $388,395,397-401,403,406,417-18,423,428-$ $30,433,435,437,439,455,535,552$

Jombang (ジョンバン), 499, 558-60, 562

Juwangi (ビジュワン), 541

Juwata (ジョワタ,ヂュワタ), 176-77

Kabandungan Udik (カバンドンガンウヂィク), 501

Kaganjan/Kaganjuan (カガンヂャン,カガンジュ アン), 104

Kahang (カハン), 144-45, 196, 211, 213, 260, 26566, 287-89, 297, 301-03, 308-10, 313, 317-18, $322-23,325,331$

Kait, Cape (カイト角), 457

Kakamigahara (各務原), 163

Kakas (カカス), 183

Kalijati (カリジャチイ,カリヂャチイ,カリヂャ チー), 38, 94, 96, 189, 230, 245, 247, 251, 434, 442-43, 448-51, 460-64, 469, 480, 482, 487-88, 497-500, 502, 505-16, 518-19, 521-23, 526, 528-31, 533, 535-36, 571-72, 578, 582, 584-85
Kalimas River (カリマス河，マース河), 548, 561, 563

Kalioso (カリオソ), 541

Kalipang (カリバン), 240

Kamal (カマル), 567

Kampar (カンパル), 255

Kamuning, Mt. (カムニン山), 477

Kanamarugahara [Kanamaruhara] (金丸ケ原), 19

Kandanghaur (カンダンハウエル), 514

Kangean Islands (カンゲアン島), 455

Kanoya (鹿屋), 32, 33, 279, 297, 306-07, 310, 448

Kapo [?], Cape (カポ岬), 480

Karanggede (カランゲド), 541

Karatsu (唐津), 19

Karimata Strait (カリマタ海峡), 244, 451

Karungan, River (カルンガン, カロンガン, 川), $85,87,173,175,178-79$

Kaum (カウム), 494, 501-02

Kaunayan (カウナヤン), 113

Kavieng (カビエン), 373-74

Kebumen (クブメン), 543

Kediri (ケデリ), 548, 555, 557-60

Kedungbadak (キデングバタク), 501-02

Kedungcinde (ケドンチント), 482

Kedunggede (ケドンゲテ), 463-64, 514, 523-24

Kedungrejo (ケドングレジョ), 561

Keelung [Jilong] (基隆), 79

Kejapanan (ケジャパナン), 562

Kema (ケマ), 182-83

Kemang (ケマン), 483

Kendari (ケンダリー)，4，6，11，30，33，46，59，66， $123,159,160,170,206-07,210,223,225,234$ $35,241,304,346,348,358,361-62,365-66,368$, $373,377-78,380,386,388-89,391,394-97,399$, $405,406,408,418,420-22,425-26,440,449$

Kertosono (ケルトソノ), 548, 555, 557-59, 571-72 Ketil (ケチル), 145, 254, 266, 286

Klaten (クラチン), 541

Kluang (クルアン), 116, 144-45, 196, 211, 213, 255, $260,262,264,266,285-89,293,303,308-09$, $317-18,322-23,325$ 
Kolbano airfield [?] (コルバノ飛行場), 404

Korea (朝鮮), 3, 10, 21, 42, 70, 136, 156, 161, 249

Korowelang, Cape (コロエラン岬), 239

Kota Bharu (コタバル [Malay Peninsula]), 78, 115, 118, 126, 192, 266, 276, 297, 301

Kotabaru (コタバル [Laut Island near Borneo]), 393

Kowloon Peninsula (九竜半島), 46, 116, 267

Kragan (クラガン), 226, 231, 236-40, 432-34, 454$55,458,460,535,537-38,540,547-52,554$

Kragilan (クラギラン), 465-67, 475, 478, 480, 482， 484, 486

Kranggan (クランガン), 544

Krawang (クラワン), 463, 465, 480, 482, 487-88, 508. 510, 513, 515, 521, 523-24, 530, 533, 535, 571

Krijan (クリジャン), 561

Kuala Lumpur (クアラルンプール), 115, 145, 185, 193, 264

Kuantan (クワンタン), 78, 116-20, 126, 141-42, 144, 156-57, 165-66, 185-86, 192, 265, 292, 297, 301-03, 306, 310, 313-14, 322, 379, 421, 426-27, 446,448

Kuching (クチン), 4, 5, 29-31, 33, 46, 52, 66, 69, 94, 117-18, 122, 124, 126, 143, 156, 186, 197-204, 211, 261, 265, 275, 294-97, 299-301, 303, 30506, 309-10, 313-14, 389, 418, 426-27, 440, 442, $446,448,458$

Kunming (昆明), 48, 101

Kupang (クーパン), 4, 5, 11, 28-30, 32, 33, 36, 46, $59,62,66,79,80,82,93-96,98,122-23,128$, $135,142,159-60,162,165,171,187,211,213$, $215,225,234,252,254,346,361,363,373,379$, 380-81, 384-86, 388, 390, 403-04, 406-10, 412$13,418,420,423,426,450,456$

Kure (呉), 172

Kuripan (クリバン), 501

Kurume (久留米) , 24, 26, 55, 92

Kuta airfield (ゴータ飛行場), 399, 400-01, 403

Kuto River (クタ河), 239

Kutoarjo (クタルジョ), 539
Kutoraja [Kotabumi ?] (クトラジャ), 339

Kyūshū (九州), 4, 11, 19, 22, 23, 32, 36, 51, 69, 110， 116, 137, 267, 501

Labis (ラビス), 255

Labuan (ラブアン), 198

Labuha (ラブハ), 206

Labuhan coast (ラブハン海岸), 478

Lae (ラエ), 374

Laha (ラハ), 96, 366, 369, 370-71, 385

Lahat (ラハト), 268, 334, 339, 341-42

Lamon Bay (ラモン湾), 5, 30, 45, 79, 90, 106, 116, 124, 127, 136, 138, 157

Lamongan (ラモンガン), 558, 563

Lampang (ランパン), 285

Lampung Bay (ランプン湾), 282, 338, 343

Lanang (ラナン), 108

Langoan (ランゴアン), 182-83

Laoag (ラオアグ), 30, 31, 45, 58

Lasem, Mt. (ラセム山), 238, 432, 537, 539, 551-53

Laut Island (ラウト島), 393

Lawangtaji (ラワングダテ), 477, 482, 485

Lawu, Mt. (ラウ山), 432, 537, 539

Lebak Gede (レバックゲテ), 479

Ledo (レド), 121, 126, 134-35, 142-43, 185-86, 190, 197-205, 211-13, 215, 230, 253-54, 261, 265, 275, 292-303, 305-07, 309-10, 313, 418-19, 421, 426, 446-48

Legaspi (レガスピー)，5，30-33，35，45，52，54，56， $58,78,79,90,93,104-06,123,170,172,207$

Lembang (レンバン), 499, 528, 531, 533, 535, 570, $572,582-83$

Leuwiliang (ルウイリアン), 94, 477-78, 482, 486, 488-94, 496, 501, 518, 521, 530, 533, 571-72, 578-79

Limau (リマウ), 271, 282, 338

Lingayen, Ｇulf (リンガエン , 湾), 5, 30, 45, 79, $81,106,116,118,120$, 123-24, 127, 133, 136-38, $148,152,156-57,170,210,214,222,234,236-$ 37, 239, 249, 250, 304, 378, 392, 395-96, 399, $400,429,430-31,439,552,569$

Lingga Island (リンガ島), 313-14 
Lingkas (リンカス), 85, 87, 93, 173-79, 181

Lisbon (リスボン), 382

Lombok, Island, Strait (ロンボック,〜島, 〜海 峡), 10, 400, 425

London (ロンドン), 1, 2, 579

Lubuklinggau (ルブクリンガウ), 268, 342-43

Lüshun [Port Arthur] (旅順), 552

Lumajang (ルマジャン), 572

Luzon, Luzon Island (ルソン, 呂宋, 〜島), 5, 27, 33, $45,48,54,92,93,104,106,124,136,139,152$, $391,395,428,549$

Macao (マカオ，澳門), 382-83

Madura ( Island, Strait, Sea (マヅラ ( 島, 〜海 峡, 海), 10, 13, 94, 240, 548, 566-67, 572, 581, 586

Magelang (マゲラン), 238, 246, 437, 460, 499, 53740, 542-43, 548-50, 571-72

Magelang ? Semarang ? (マゼラン $\rightarrow$ スマラン?), 238

Magong (馬公), 6, 67, 79, 92-93, 104, 120, 122, 124， $127,137,157-58,160,171,187-88,195,208$, $225,241,248,251,257,364-65,429$

Maja (マジャ), 486

Makassar (マカッサル)，4，6，11，30，33，46，59，66， 159, 160, 164, 170, 190, 209, 210-11, 213, 215, 225-26, 234-35, 237, 241, 304, 367-68, 373, 377$78,380,386,388,390-91,394-401,403,405-06$, $418,420-24,426,429-30,433,439-40,444,449$, 451-52, 455

Makassar Strait (マカッサル海峡), 26，32，158-59， 165, 225, 234, 238, 356, 390, 394-95, 399, 403, 433,440

Malacca, Ｓtrait (マラッカ, ～海峡), 47, 125, 256, 260,334

Malagos (マラゴス), 107

Malalag, Bay (マララグ, 湾), 105, 107, 159, 176

Malang (マラン), 94, 246, 426, 437, 442, 446, 460, $548-49,558,561-62,566-67,571-72$

Malay Peninsula (マレー半島, 馬来半島), 19, 31， $32,47,75,116-17,197,285,417,516$
Malaya (馬来, マレー), 4, 6, 7, 9, 12, 13, 16-23, 25$33,35,36,38,40-49,52,54,56,58-60,63-66$, $69,72,77,78,98,100-01,104-05,115,117-23$, $125,127-28,135-37,141,143-146,155-57,162$, 165-66, 185-86, 191-96, 201, 208, 211-13, 215, 218-19, 233, 246, 254-57, 260, 262, 274, 276, 278-79, 286, 292-93, 297, 301, 305, 325, 333, $340,362,376,419,425,520,529,551,587$

Mali, Cape (マリー岬), 409-10

Manchu(ria) (満州), 20, 23, 32, 41, 48, 60, 70, 72, $92,98,136,139,140,153,156,249,565$

Manchuria and Korea (満鮮), 3, 21, 161

Mandah (マンダ), 339

Mangalis Point (マンガリス岬), 113

Manggar River (マンガル河), 353

Manggarai Station (マンガラリリ駅), 533

Manila, Bay (マニラ, 馬尼刺, 湾), 4, 5, 7, 22, 23, $27,30-32,35,38,43,45,52,61,62,65,69,75$, $80-82,127-28,138,143,152-53,163,174,188$ 89, 190-91, 204, 209, 210, 212, 215, 220, 221, $223,226,228,235-37,240-41,259,264,362$, $378,389,392,395-96,399,418,428-30,549$, $551-52$

Maos (マオス), 543-44

Maospati (マオスバチ, マオスパチ), 459, 555, 558

Marshall Islands (マーシャル), 377

Martapura (マルタプラ [Sumatra]), 268, 271, 282$83,333,335,337-40,342$

Martapura (マルタプラ [Borneo]), 393-94

Matasiri Island (マタシリ島), 451

Matina Hill (マチナ台), 109

Matsushima (松島), 247

Mauk (マウク), 96, 99

Medan (メダン), 10, 47, 121, 186, 254

Mempawah (マンバワ), 298-99

Menado (メナド), 4, 6, 11, 27, 30-33, 46, 59, 66, 81, $82,87,91,92,122-23,125,127,134-35,154$, 158-60, 168-73, 182-84, 187, 206, 208, 225, 27374, 346, 348, 361, 365, 368, 375, 388, 418, 421 Mengacu, Battery, 〜Channel (メンガチュ, 砲 台， 水道), 173, 178 
Mentok (ムントク), 94, 96, 145, 165, 189, 230, 254, 265-67, 270-72, 277-78, 280-83, 308, 314-15, $322,325,333-38,341-44,428,446-49,451,454$

Merak (メラク), 96, 98, 99, 226, 231, 242, 245, 434, 456-57, 461, 465-66, 469-80, 482, 485, 496-97, 505

Merak Island (メラク島), 466, 479

Merak, Mt. (メラク山), 479

Merbabu, Mt. (メルバブ山, メルバボ山), 538-39

Mersing (メルシン), 78, 116-18, 120, 137, 141-42, 150, 156-57, 166, 185-87, 190, 192, 195-97, 252, 254-55, 262-64, 292, 362

Middle East (中東), 425,570

Midway (ミッドウェー), 59, 94, 460

Mindanao (ミンダナオ), 4, 110, 124, 127, 157, 171， 215

Mintal (ミンタル), 109

Miri (ミリ), 4, 5, 11, 28-33, 46, 52, 66, 69, 116-17, 124, 156, 198-201, 284, 298

Miyakezaka (三宅坂), 73

Modung, Battery (モドン, ～砲台), 565

Moji (門司), 36, 55-57, 69-72, 90-92, 101, 103, 121， $137,146,186,188,224,258,285,535,569$

Mojoagung (モジャウン), 559, 562

Mojokerto (モジョケルト), 548, 555, 557-58, 56062,572

Mojosari (モジョサリ),561-63

Molucca Sea (モルッカ海), 106, 158, 207, 225, 234, $348,362,368,418$

Moluccas [Maluku], Moluccan Islands (モルッカ ～諸島，～群島)，10，11，32，44，49，54，64，65，361

Momong (モモング), 306

Monterado (モンテラド), 299

Moresses Island (モラセス島), 451

Moulmein (モールメン), 47, 129, 166

Mudanjiang (牡丹江), 92

Murozumi (室積), 32

Musi River (ムシ河), 94, 96, 189, 268, 270-72, 278$83,314,323,325,331,333,335-39,341,426$

Naibonak (ゲイボナ), 410

Nakhon (ナコン), 45
Nanning (南寧), 276

Narashino (習志野), 71, 101, 161, 224

New Britain (ニューブリテン), 59

New Guinea (ニューギニア), 10-12, 59, 374, 578

New Zealand (ニュージーランド), 26, 41, 373

Nganjuk (ンガンジョク), 557, 559

Ngawen (ンガエン), 540

Ngawi (ヌガウイ), 537-38, 548, 551，555，558, 561

Nha Trang (ナトラン), 253

Niigata (新潟), 478

North Africa (北阿), 218

Northern China (北支), 5, 47, 70, 137

Norway (ノルウェー), 2

Nyūtabaru (新田原), 146

Oekahiti (カピチ), 409

Oesau (デサウ), 409, 410, 412

Ogasawara Islands (小笠原諸島，小笠原群島)，36， $50,52,55$

Oilalus (アルス), 409

Ombai Strait (オンバイ海峡), 381

Ōmura (大村), 36, 110

Osaka (大阪), 136, 148

Pacific (太平洋), 2, 50, 587

Pacific Islands, [equatorial] Pacific Islands (南洋 群島, 南洋), 1, 5, 46, 50, 51, 58, 373, 377

Padang (バダン), 257

Palau (パラオ), 2, 6, 27, 33, 35, 36, 45, 46, 52, 54, $56,57,61,62,66.69,71,76,79-84,86,90,92$, 93, 101, 103-06, 108, 110, 113-14, 116, 118, 122, 124, 126-27, 135, 157, 158, 165, 171, 173, 195, 197, 208, 210, 212, 346, 348, 365, 377-78, 387, 389, 406-08, 422, 425, 431, 433, 437, 440, 445, 537

Palembang (パレンバン), 4, 5, 10, 12, 22-24, 28 30, 47, 94-96, 98, 100, 117, 121-22, 127-28, 134, 136, 143, 145, 157, 163, 165, 171, 184, 186-87, 189-90, 193, 195-96, 201, 204-05, 211-15, 219, 230, 236, 241, 251-54, 258-60, 262, 265-99, 306, 308-09, 311-14, 316-18, 322-23, 325-28, 331$45,363,373,375,388,406,408,418,421,425-$ $26,428,434-35,437,439-40,442-44,446-51$, 
$467,487,499,500,510,512-13,520-21,536$, 570,582

Pamanukan (パマンカン, パマヌカン), 432, 46364, 508

Pamarayan (パマラヤン), 477-79, 482-84, 486, 489-90, 495-96, 500

Pamusian (ペムシャン), 175-76

Panacan, River, $\sim$ Bridge (パナカン, 〜河, 〜橋), 107,110

Pandakan (バンダカン), 572

Pandeglang (パンデグラン), 478

Pangkalan Brandan (バンカランブランタン, パ ンカランブランタン), 259, 434-35

Pangkalan Susu (バンカランスス), 259

Pangkalandalem (バンカランジュン), 501

Pangkalpinang (バンカルピナン), 282, 335

Panjang Island (パンジャン島), 243, 466-67

Parigi (パリギ), 484, 486, 496

Pasir Panjang [?] (ケシル), 410

Pasireurih (パシレルヒ), 501

Pasirian (パシリアン), 573

Paso (パソ), 369, 370

Pasuruan (パスルアン), 548

Pata, anchorage (バタ, 泊地), 227, 236

Patrol (パトロール), 224, 226, 243-45, 457, 462-64， 480, 506, 515

Pattani (パタニ), 45, 78

Pegah River (ペガ河), 88

Pegu (ペグー), 129

Pekalongan (ペカロンガン), 539, 545, 586

Pekanbaru (パカンバル), 186, 254, 258, 261, 285, 288

Peleliu (ペリリュー), 170

Pemangkat (パマンカット), 200, 203, 294-96, 29899, 300, 307, 310

Penal Colony, [Davao] Penal Colony (ベルナ・コ ロニー), 109

Penang (ペナン), 31, 65, 117, 125, 193, 264

Penfui airfield (プトン 飛行場), 404, 408-10, 412

Penghu Islands (Pescadores) (澎湖島), 52

Perak River (ペラク河), 192, 255
Petir (プチル [south of Serang]), 479, 483-84, 486, 495

Petir (ペチル [west of Buitenzorg/Bogor]), 501

Petokol, Cape (ペトコル岬), 239

Petung (ペトン), 483

Philippines (フィリピン，比律賓，比島，菲律賓)， $1,4,6,7,9,13,16,17,20-28,30,32,33,36,38$, $40-47,49,52,54,56,59-62,64-67,69,70,72$, $75,77-79,88,98,100,104-05,116,124,128$, 136-39, 144, 152-53, 155-58, 188-89, 191, 218, 222, 225-26, 133, 236, 246, 250, 267, 274, 346, $380,430,551,555,558,587$

Phnom Penh (プノンペン), 146, 285-87, 488

Piring (ビリン), 548

Plaju [?] (ウヨヂラフ), 268

Poland (ポーランド), 1, 574, 583

Pontianak (ポンチャナック), 121, 126, 197, 199, 200, 201, 296, 298-300, 307

Porong, River (ボロン, 河), 94, 460, 548-49, 555, 557, 560-63, 572-73

Port Darwin (ポートダーウィン), 373-75, 378， 382 , 387, 389, 405-08, 422, 425-26, 437, 440, 577,585

Port Moresby (ポートモレスビー), 374, 577, 583

Portugal (ポルトガル), 380-86, 404

Portuguese Timor (葡領チモール), 11, 380-86, 404

Prabumulih (プラムプリ), 342

Probolinggo (プロポリンゴ), 229, 580-81

Pulau Merak (ポロメラク), 479

Puncak Pass (ブンチャック峠), 502, 530

Puolo Condore (プロコンドル諸島), 263, 297

Purbalingga (プルポリンゴ), 544

Purwakarta (プルワカルタ), 98, 463, 465, 488-89, 502, 513, 514, 516, 521, 529-30, 572, 578

Purwodadi (プルワダチィ), 538, 540-41

Purwokerto (プルオケルト), 539, 544-45

Purworejo (プルワルジョ), 543

Qingdao (青島), 137, 569 
Rabaul (ラバウル), 24, 26, 28-30, 32, 36-38, 46, 52, $55,58,61,72,76,80,93,95,100,116,121,127$, $139,233,373-74,417$

Ragas (ラガス), 473, 480, 482, 484-85, 487

Rangkasbitung (ランカスピドン), 465-66, 47578, 482, 484, 486-87, 489-90, 495-96, 502

Rangoon (ラングーン,ラングン、蘭貢), 185, 417, $446,474,477,582-83,585$

Rembang (レンバン), 96, 99, 432, 460, 537-38, 551-55

Risau (リソウ), 201

Rutung (ローテン), 368, 372

Sabang (Sabang Island) (サバン,サバン島), 47， 259, 285, 434-35

Sadau (Sadau Island) (サドウ,サドウ島), 86, 87， 177

Saigon (サイゴン，西貢)，57，58，77-79, 99, 100， $101,115,117-18,120-22,128,132-33,138,141-$ $43,146,148-53,155,160-65,171,185,188-89$, 192-93, 195, 199, 204-05, 209-12, 227, 236, 246, 249, 253, 259, 263, 272-73, 284, 292, 294-95, 299, 300, 302-03, 307, 310, 404, 423, 426, 428, 430-32, 470, 472, 475, 487, 574-79, 581, 584-85

Sakaide (坂出), 36, 55, 569

Sakhalin (樺太), 10

Salabangka Channel (サラバンガ水道), 361, 366, 368

Salamaua (サラモア), 374

Salatiga (サラチガ), 540, 543

Saleh River (サレ河), 268, 270-71, 278, 280-83, 333,335

Salween River (サルウイン河), 129

Samal Island (サマール島), 104, 106, 108

Samarinda (サマリンダ), 83, 88, 103, 221, 346, 354-56, 359, 391, 430, 432, 440, 537

Sambas (サンバス), 203-04, 294, 296, 299, 300, 307

Samboja (スンボジア), 352-53, 355, 359

Samoa (サモア), 59

San Francisco (サンフランシスコ), 581

Sandakan (サンダカン), 201
Sanga Sanga (サンガサンガ), 11, 12, 88, 221, 346, $354,359,391,430,588$

Sanggau [Sanggan] (サンゴウ), 203, 296, 299, 300, 306-07

Santa Cruz (サンタクルーズ), 104

Sanur, beach, anchorage (サマール，海岸， ～泊地), 400, 401

Sanya (三亜), 3, 66, 78, 188, 252, 285

Sarawak River (サラワク川), 200

Sasa Airfield (ササ飛行場), 107

Sasebo (佐世保), 19

Sebuku Island (スポーコー島), 457

Sedan (セダン), 238, 244, 550, 552

Sekayu (スカユ), 268, 342-43

Sekong (セコン), 466, 479

Selatan, Cape (セラタン), 444, 445

Semangka Bay (スマンカ湾), 271, 282, 343

Semarang (スマラン), 12, 94, 238-39, 446, 537-41, $543,545,548-50$

Semplak (セムプラル, センプラル), 494, 497, 501 Sendai (仙台), 22, 26, 71, 101, 251, 490

Sepanjang Island (セバチャン島), 402 Sepuluh (スプールー), 88, 348

Serang (セラン), 99, 245, 461, 465-66, 474-79, 48288, 496, 499, 500-503, 505, 514, 520, 583

Serang River (セラン 河), 238, 537, 548-50

Serayu River (スラユ河, セラヤブ河?), 539, 54344

Serdang (セルダン, セダン), 244, 474, 478, 480, 483

Seria (セリヤ,セリア), 69, 198, 284, 298

Serpong (セルボン), 497

Shanghai (上海), 18, 69, 91, 133, 161, 170, 250, 569

Shantou [Swatow] (汕頭, スワトウ), 18

Shibata (新発田), 101, 478

Shikoku (四国), 11, 36, 55

Shimonoseki (下関), 248

Shōnan (昭南), = Singapore

Sidoarjo (シドアルジョ), 561, 563, 567 
Siluas (シルアス,シリアス), 186, 199, 200, 201, 203, 295-96

Singapore (シンガポール，ポ，新嘉坡，昭南)，1，3，

$4,7,18-21,23,28-32,35,44-47,50,61,64-66$, $69,75,115,117,119,121-22,125-26,128,134-$ $35,138,141,143-144,147,185-86,189-90,192-$ 97, 201, 204-05, 218, 255-57, 259-64, 269, 274-76, 280, 284, 287, 293, 304-08, 311-14, 321$22,325,334-35,373,387,417,419,425,435$, $437,442,447,453,461,515,570,574$

Singaraja (シンガラジヤ), 399, 403

Singkawang (シンカワン), 126, 185, 197, 200, 201， 203-04, 296, 298-99, 300, 307

Singkep Island (シンケップ島), 12

Singora (シンゴラ), 45, 78, 116-17, 119-20, 122,

126, 137, 150, 156, 187-88, 192-93, 196, 205,

214, 225, 241, 255, 262-63, 276, 297, 362, 429

Sintang (シンタン), 307

Sittang (セダン河 [シッタン河]), 579, 580

Slamet, Mt. (スラメット山), 538, 539

Slim (スリム), 185, 255

Solo, P Principality (ソロ王国), 13, 537

Solo River (ソロ河), 236, 460, 537, 548-49, 552-55, $557,572,588$

Solomon(s), Solomon Archipelago (ソロモン, 群島), 374

Sorong (ソロン), 59

South (南方), 18, 20, 27，32，35，44，48-51，56-57， 63-64, 66, 76, 120, 125, 132, 144, 146, 212-13, 220

South Africa (南阿, 南アフリカ), 407, 424, 435

South China Sea (南シナ海), 6, 29, 104, 158, 209， 225, 234, 358

Southern China (南支，南支那)，4，22，23，48，51， $61,98,120,122,137,139,142,162,185,258$, 276, 285,

South Pacific (南太平洋), 50

Southern Kuril Islands (南千島, 列島), 56

Southwest Islands (南西諸島), 51, 52

Soviet Union (ソ, 蘇, ソ連, 蘇国), 1, 16, 75
Staring Bay (スターリング湾), 373, 378, 387, 389, 397, 400-403, 406-08, 422, 437, 439-40, 443-44, $449-50$

Suakodo (スウアコド), 371

Subang (スバン), 98, 463-65, 488, 497, 507-11, 513-14, 516, 518, 522-24, 535, 571-72, 579

Sukabumi (スカブミ), 530, 572

Sukorame (スコラメ), 572

Sula Islands (スラ島), 206

Sumatra (スマトラ), 4-6, 8-10, 12-13, 21-22, 28$33,36,38,44,49-50,54,59,62,64-66,78,93-$ 96, 99, 117, 119-23, 134-35, 142-45, 154-55, 162, 184, 186, 191, 193-94, 197, 201, 230, 246, 252, 254-61, 263-68, 273, 276-79, 282, 284-85, $305,308,311,325,333-34,337,344,373,386$,$87,389,417,419,423,425,427-28,434-37,442$, $447,449,461,513,570-72,586,588$

Sumbawa (スンバワ), 425

Sumber River (サンバニ河), 355

Sunda Islands, [Lesser] Sunda Islands (スンダ列 島), 4, 10，145，276，380，394，400，435，437，582 Sunda Strait (スンダ海峡), 189, 451

Sungai Penuh (スンゲイペニュ), 299

Sungai Petani (スンゲイパタニ)，192-93，254， 265-66, 286-87, 297, 301, 317-18, 322-23, 325, 446

Sungaigerong (スンゲイゲロン), 268

Surabaya (スラバヤ), 10, 11, 18, 23, 24, 47, 80, 94 96, 98-99, 136, 155, 159, 163, 188, 205, 210, 212, 218, 224-26, 229, 231, 234, 237, 240, 245-46, 257, 358, 374, 379, 390-91, 401, 412, 423, 425, 427, 434, 437, 442-43, 449, 451-52, 454-61, 463, 480, 548-49, 551-52, 555, 558, 560-67, 571-72, $574,577,586$

Surakarta (スラカルタ)，13，246，432，437，499， $537-43,545,548,583,586$

Switzerland (スイス), 169

Sydney (シドニー), 578-79

Tai Mo Shan [Dàmàoshān] (大帽山), 116

Taipei [Taihoku] (台北)，69，82，161-63，170，189， 251 
Taiping (タイピン), 285

Taiwan (台湾) , 5, 6, 10, 23, 27, 32, 33, 35, 36, 38, 42， $45,47,48,51,52,54,58,61,62,66,78,80,82$, $83,93,113,118,122,124,127,137-38,150,153$, $156,161,163,164,170-71,188,210,235,251$, 253, 364, 429, 551

Takanabe (高鍋), 23, 32, 33, 146

Talang Jimar (タランジュール油田), 339

Talomo, Bay, River (夕口モ, 湾, ～河), 103， 106-10

Tanahgrogot (タナゴロコッド), 392-93, 431

Tangerang (タンゲラン), 94, 99, 245-46, 465, 467， 488-89, 497, 500, 503, 518, 570-71

Tanjung Priok (タンジョンプリオク), 94, 96, 98, $99,246,459,574$

Tanjungkarang (タンジュンカラン), 94, 96, 145, 230, 260, 262, 268, 271, 282-83, 333, 335, 33740, 342-43, 373, 423, 428, 437, 440, 446-49, 451, $458,468,487,520$

Tannenberg (タンネルベルヒ), 219

Tarakan, Tarakan Island (タラカン, タラカン島), $4-5,11-12,27,30,33,46,59,61-63,66,69$, 79, 80-83, 85, 87-88, 90-93, 95, 103, 114, 122-25, 127, 134-35, 154-55, 158-59, 162-64, 168-77, 179-82, 185, 187, 190, 205-09, 220, 223, 225, 246, 275, 346, 348-49, 350-56, 358, 360, 365, 368, 388, 394, 418, 436, 543, 588

Tasikmalaya (タシクマラヤ,タシクラマヤ), 529， 545

Tavoy (タヴオイ), 285

Tawau (タワオ), 299

Tebatagung (テバタグン), 268

Tegal (テガル), 539, 545, 581

Telang River (テラ河), 268, 270-71, 278, 280-83, 333,335

Telukbetung (テロックペトン), 189, 268, 339, 343

Temanggung (テマンゴン), 543

Tenggarong (テンガロン), 354, 538

Terashima-suidō [Channel] (寺島水道), 57, 92

Thai(land), Gulf of (タイ,タイランド, 泰, 泰国, ～湾), 4-5, 18-21, 25-26, 29, 31-32, 40, 44-48，
50, 54, 56, 58, 63-65, 69, 78, 106, 137, 143, 144, 153, 165, 364, 386, 581, 585

Thủ Dâu Một (ツダウム), 306, 310, 313-14, 322, 426-27, 448

Tibungco, coast of (チブンコ海岸), 107

Timor, Timor Island (チモール, チモール島)，4， 10-11, 30, 32, 42, 44, 49, 64-65, 123, 190, 235, $274,304,358,368,371,373,378,380,382,384$ $85,387,389,391,395,397,401,403-08,412$, $417,425,437,439-40,444,455-56$

Tokyo, Bay (東京, 湾), 3, 17-18, 38, 63, 69-71, 76, 101, 117, 120-21, 127, 132, 161, 165, 170, $189,212,214-15,224,246,270$

Tourane [Da Nang] (ツーラン), 162

Toyohashi (豊橋), 19, 71, 101, 224

Trate (トラーテ), 467, 479-80

Truk (トラック), 26, 374-77

Tuban (ツバン), 240, 551-52

Tulagi (ツラギ), 374

Tunang (ツナン), 299

Tunjung Ketuk (トンゲコング), 477

U.S.-ruled Philippines (米領フィリピン), 4

Ubin Island (ビュローウビン島), 308

Ujina (宇品), 36, 132-33, 147, 150, 152, 224, 24748,569

United States (米国), 1-3, 16-21, 24, 26, 35, 40, 42, $44,49-50,55-56,64,70,80,105,168-69,191-$ $92,218,233,358,373,382,460,575,577,579$ 85

Victoria Point (ヴイクトリヤポイント), 47

Vigan (ビガン), 30-31, 45, 58, 79, 93, 105, 123, 551

Wain River (ワイン河), 353, 359

Wakamatsu (若松), 101

Wake, Wake Island (ウエーク，ウエーク島), 50,

58, 95, 116-17, 121, 127, 172

Wangon (ワンゴン), 545, 572

Warungloa (ワルナカ), 501

Washington (ワシントン), 1, 578

Wates (ワテス), 539

West Pacific (西太平洋), 115

Widas River (ウイダス河), 548-49 
Wijnkoopsbaai, coast of (ウェインコープス湾),

527,580

Wilangan (ウイラガン), 557

Wirana (ウイラナ), 490

Wonokromo (ウオノコロモ), 94, 564-65

Wonosobo (ウオノソボ), 538-39, 544

Wusong (呉淞 (ウースン)), 91

Yamaguchi (prefecture) (山口県), 32, 57

Yangtze Kiang [Yangzi, Chang Jiang] (揚子江), 49

Yenangyaung (エナンジョン), 259, 285, 434

Yogyakarta (ジョクジャカルタ), 13, 537-39, 541-

43,583

Yogyakarta, Principality (ジョグジャ王国), 13，

$537,551,586$

Yong Peng (ヨンペン), 255

Yukasuka [?] (ユカスカ), 342

Zentsūji (善通寺), 24, 26 